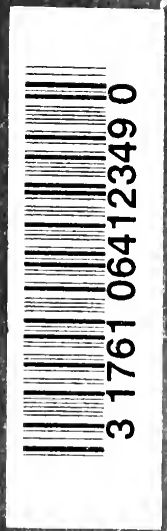

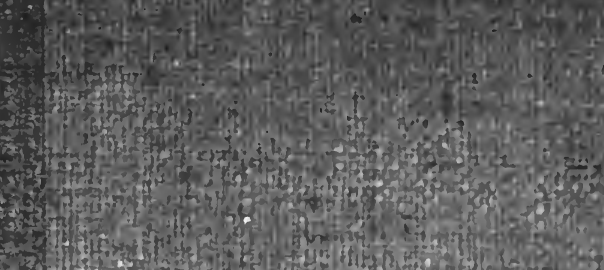

(3)
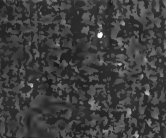

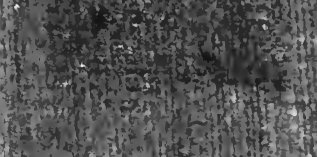
Hon

4.

(⿻)

intwing

Whing

(5)

9.

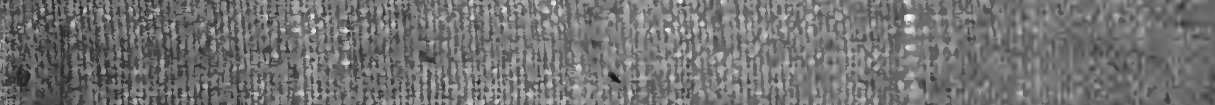
3.

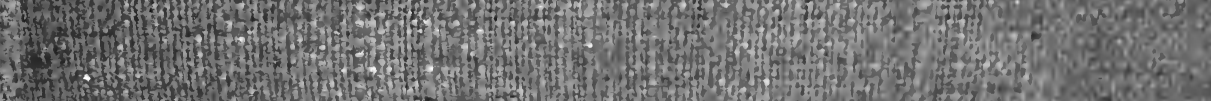
S. 
or 


\section{HISTORY OF THE I'TALIAN REPUBIICS}


Digitized by the Internet Archive in 2007 with funding from Microsoft Corporation 


\title{
HISTORY
}

OF THE

\section{ITALIAN REPUBLICS}

\section{IN THE MIDDLE AGES}

\author{
BY \\ J. C. L. SISMONDI
}

ENTIRELY RECAST AND SUPPLEMENTED IN THE LIGHT OF SUBSEQUENT HISTORICAL RESEARCH WITH A MEMOIR OF THE AUTHOR

BY

WILLIAM BOULTING

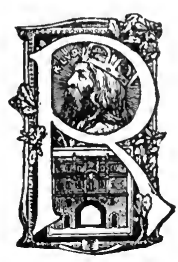

LONDON

GEORGE ROUTLEDGE \& SONS, Limited NEW YORK : E. P. DUTTON \& CO. 


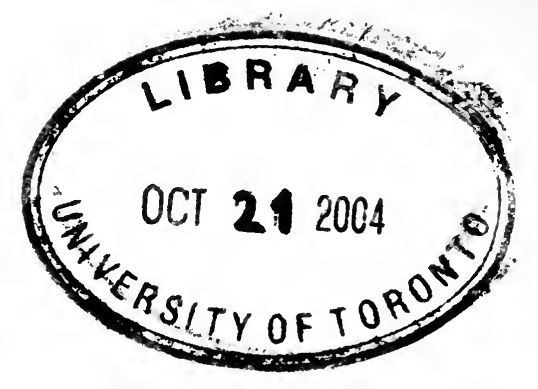




\section{P R E F A C E}

WhEN, in the early part of the eighteenth century, Italy was in measure released from Spanish subjection, the immediate revival of letters and scholarship gave evidence that the natural force and genius of the people had, indeed, been silenced by oppression, but were still quick. Giambattista Vico and others investigated the laws of progress; Ludovico Antonio Muratori, aided by Scipione Maffei of Verona and Apostolo Zeno of Venice, examined original sources of information, and their stupendous labours issued in a multitude of ponderous tomes that remain the preciouis possessions of the scholar, and furnish him, not merely with a vast body of authentic fact, but even with the beginnings of explanation. These Italians concerned themselves with the mediaval records of their country; then, as when Italy became united, the first effort of her sons was to discover and reconstruct her history. Building on the foundation thus raised, Jean Charles Simonde de Sismondi ransacked archives and studied documents to which Muratori had no access, and carried on the work of explanation a stage further. Nearly a hundred years ago there appeared in Zurich the first of the many volumes that contain the fruit of Sismiondi's labours. The exact scholarship, comprehensive grasp, and clear flowing statement of the "Histoire des Républiques Italiennes" gained it immediate success; and it has taken rank as the classic account of the remote memories of Mediæval Italy, and the remarkable phenomena of the Renaissance. In our own time brilliant historians, such as Professor Pasquale Villari and François Perrens, give evidence of their indebtedness to this renowned work. Muratori and Sismondi, alone of great historians, traverse the entire field of Mediæeval Italy; and, apart from Muratori's edition of original authorities, Sismondi, as Hallam observed, replaced Muratori.

$\mathrm{Bu}$ t Muratori and Sismondi, though the first and greatest surveyors of Mediæval Italy, were ignorant of vast storehouses of wealth that have since been examined; nor did they possess the methods which reveal in fullest measure the true significance of what they exhibited. Their successors have discovered precious stone after precious stone of the ancient edifice, and have laboriously placed them. in conjunction, sometimes with certainty, sometimes in conjecture, until they are beginning to really reconstruct the past history of Italian States, but 
always on the foundations which Muratori and Sismondi builded, wiser than they knew.

Archives, then, are accessible to-day which were unknown to Sismondi: The industry of modern scholars in ransacking and diligently investigating the records of the past has furnished the world with a body of knowledge which, properly interpreted, throws a new light on history and invests it with a new meaning. Rich, vital significance has been extracted from what once appeared to be barely intelligible rubbish-heaps of fact. The discovery of fresh facts, too, has often given new interpretation; new questions have presented themselves, and some have received an answer. Doubtless the modern scholar has his own prejudices; but though Sismondi's misjudgments are singularly few, the widening of human thought removes us far from the religious and political prepossessions of his time. We are not now engaged in seeking every opportunity to cast stones at the Popes, nor are we ready to render uncritical worship directly the resounding, but often empty, name of Liberty is mentioned. Nor is this all. During the last half of the last century we have accustomed ourselves to recognise that human societies are organic, but interdependent, wholes, which develop by natural law, and can only be understood by the application of scientific methods. This conception was present to the mind of Machiavelli, the Florentine historian, but was imperfectly appreciated by him and his successors. To the later nineteenth century it came with the force of a revelation, and has had an effect on the historical mind which can only be compared to that of the revolutionary conceptions of Copernicus or Darwin on the scientific investigator. And, again, we have learned to recognise economic factors as great determining forces in history. The germinal icleas of the latter half of the century from which we have just emerged, and the labours of its scholars in tracing the roots of the past, are fructifying, and the result will be that all history will have to be rewritten in a profounder and more penetrative spirit.

This is the age of specialization in all sciences: each investigator cultivates his own narrow field of allotted labour. Hence Sismondi remains the last great encyclopædist who dared to take all Italian history as his province. But the vast amount of material disinterred from dusty, forgotten chests, and the revealing light that the modern scientific spirit has thrown on them, forbid translation of his great work as it stands. To-day a mind of no extraordinary perception may, by the aid of other investigators, often by its own unaided powers even, interpret events and explain character in a way to which Sismondi was a stranger. Yet, while men such as Villari, Lanzoni, 
Perrens, Cipolla, and many others have penetrated many departments of buried knowledge in a truly scientific spirit, Sismondi alone, utilizing Muratori, has presented us with the whole picture; he alone has treated the entire subject with an approach to philosophic temper and a near hit at unfailing accuracy. Hence the present work aims at a complete reconstruction of his history, leaving out nothing of essential value which it contains, but winnowing, revising, and enriching it by the results of subsequent investigators and the interpretations of an age more instructed in scientific procedure than his. The reconstruction which follows aspires, then, with all due reverence for a great historian, to render the "phantoms of a mistier day" in some degree more real and vital by the application of modern methods and by the explanations which these have rendered possible. The author is fully conscious of how defective this result of his labours must be ; but he has been comforted in the prosecution of his task by the remark of Pascal that "the pigmy on the shoulders of a giant may see farther than the giant." 



\section{CONTENTS}

MEMOIR OF SisMoNdi

P'AGF - xvii

BOOK I.-THE DARK AGES AND THE DAWN OF THE MEDIAVAL WORLD : THE RISE OF THE COMMUNES, A.D. 476-II54

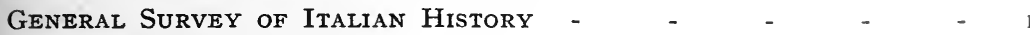

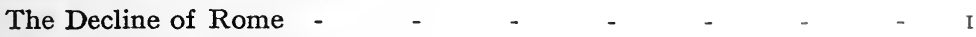

Internal Condition of Roman Italy - $\quad-\quad-\quad-\quad-\quad-\quad-\quad 2$

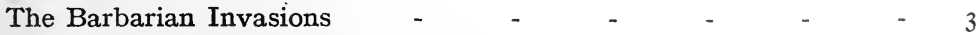

Byzantine, Lombard, and Papal Italy - $\quad-\quad-\quad-\quad-\quad-7$

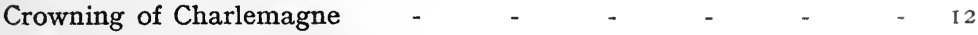

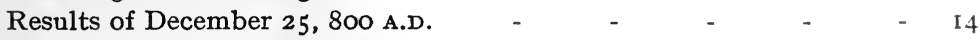

The Times of the Carolingian Emperors - _ - $\quad$ - $\quad$ - 16

Italy from the Deposition of Charles the Fat ( 887 A.D.) to the Imperial

Coronation of Otho the Great (962 A.D.) - _ - _ - $\quad$ - 23

The Age of the Saxon Emperors (962-1024) - $\quad$ - $\quad-\quad$ - 27

The Age of the First Franconian Emperors: Henry III. and the

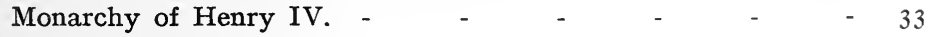

Growing Power and Pretensions of the Papacy - _ - _ _ - $\quad$ - 40

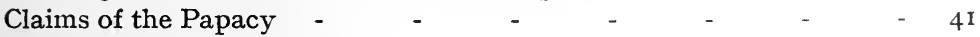

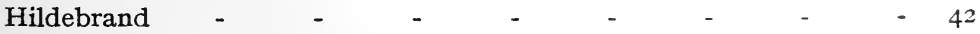

The Contest as to Investitures from the Death of Gregory VII. (1085)

to the Concordat of Worms (I122) - - - - - 47

The Reigns of the Emperors Lothiar III. and Conrad III. (I I25-II 52) - 50

The Norman Monarchy in South Italy - - - - - $\quad-\quad 52$

Northern Italy in the First Half of the Twelfth Century - - $\quad 56$

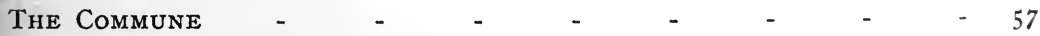

Was the Commune a Continuation of the Roman Municipality ? - 57

The Revival of the Maritime Cities and Rome - _ - - $\quad 58$

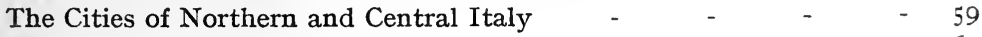

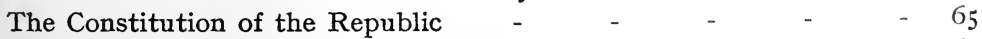

The Cities and the Wars of Investiture - $\quad-\quad-\quad-\quad-\quad-\quad-67$

ROME

Mediæval History to IrI8 A.D. - - - - $\quad-\quad-\quad$ - 7 I

The Republic of Rome and its Relations with the Papacy and Empire

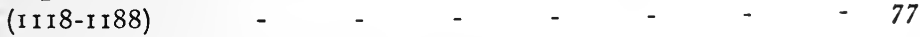

Milan and the Cities of the Great Plain - - - - $\quad$ - 80

VENICE -

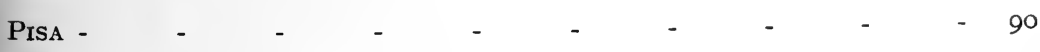

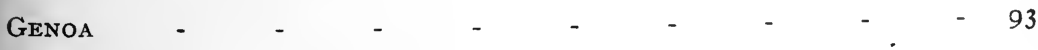

FlORENCE -

SIENA 
Life, Literature, ANd Art

Transformation of Latin into Italian : Literature of the Dark Ages - 99

The Characteristics of the Dark Ages - $\quad$ - $\quad$ - $\quad$ - $\quad$ - IOI

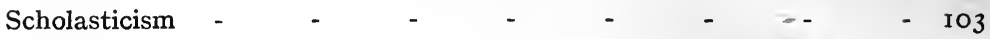

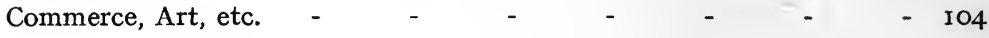

BOOK II.-THE AGE OF THE COMMUNES : FROM THE DESCENT INTO ITALY OF BARBAROSSA TO THE DEATH OF THE EMPEROR FREDERICK II., II 54-I250

General Survey of Italian History $\quad-\quad$ - $\quad$ - $\quad$ - $\quad$ - . 107

The Struggle of the Free Cities against the Empire - - _ - 107

Guelph and Ghibelline - $\quad$ - $\quad$ - $\quad$ - $\quad$ - $\quad$ - $\quad$ - 132

The Conflict of Civil with Ecclesiastical Government, and the Endeavour to institute Universal Monarchy - . - _ - 136

The Communes after the War with Barbarossa - - $\quad$ - I56

Further Evolution of the Commune - - - - - $\quad$ - 156

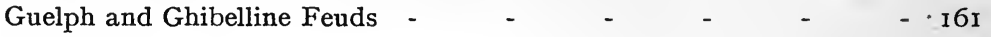

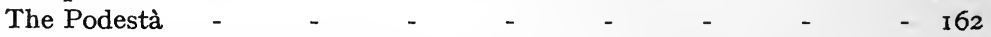

The Continued Contest of Rival Families for Dominance - - - 163

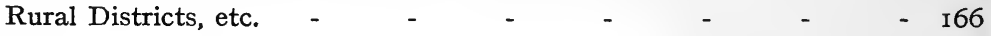

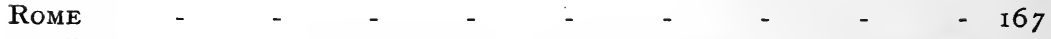

From the Ascent of Barbarossa (I I52) to the Concordia with Clement

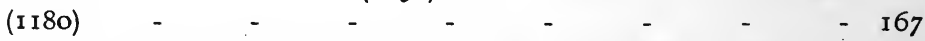

From the Concordia with Clement III. (I 188 ) to the Death of Frederick II. (1250) -

Milan and the Cities of the Great Plain - $\quad$ - $\quad-\quad$ - 173

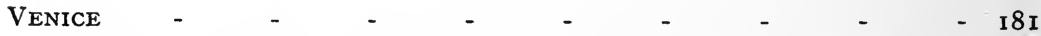

Venice and Barbarossa : The Fourth Crusade : Taking of Constantinople by the Latins

From the Taking of Constantinople (1204) to the Death of Frederick II. (1250)

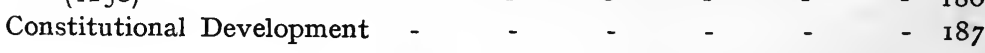

PISA -

GENOA

Florence

SIENA

Life, Literature, AND ARt

Life

Religion and Heresy -

Education: The Foundation of Universities

- 189

The Development of Literature in Provence: Its Translation into

Italy : Origin of Romantic Love : Sicilian Literature - - 2II Architecture 
BOOK III.-THE CENTRAL MEDIÆVAL PERIOD.-THE INSTITUTION

IN MOST COMMUNES OF DICTATORSHIP.-FRON THE DEATH OF

FREDERICK II. TO THAT OF HENRY VII., I $250-1313$

General Survey of Italian History -

The Angevin Predominance -

The Deterioration of the Papacy - - 215

The Expedition of Henry VII. (I 3 IO-I 3 I3)

The Commune -

The Republics nominate "Lords" -

Treatment of Subject Populations

The Structure of the Trade Associations and the Rise of Capitalism

Rour

From the Arrival of Brancaleone (1252) to the Reinstitution of Dem

cratic Government by the Papacy (I3IO) - - - - $\quad$ - 245

Milan and the Communes of the Great Plain - $\quad$ - $\quad$ - 247

Milan from the Death of Frederick II. (I250) to the Establishment of the Visconti (1277) - $\quad$ - $\quad$ - $\quad$ - $\quad$ - $\quad$ - $\quad$ - 247

From the Coming of the Visconti to their Restoration (I3IO) - - $25 \mathrm{I}$

The Failure of Self-government in the Northern Communes - $\quad-255$

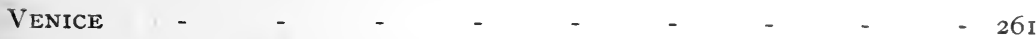

Eastern Troubles and Rivalry with Genoa to the Peace of I299 - 261

Constitutional Development to the Closing of the Grand Council and

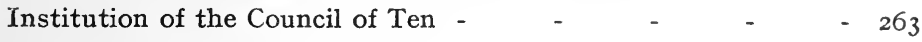

The Final Struggle between Genoa and Pisa - - $\quad$ - 265

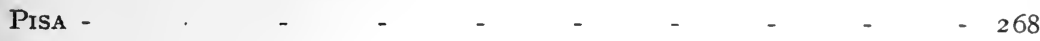

GENOA -

The State of Genoa from the Death of Frederick II. to the Signory of

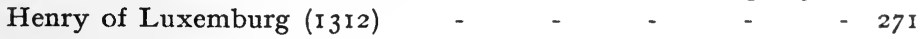

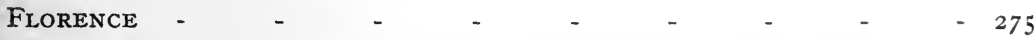

From the Death of Frederick to the Restoration of the Guelphs (1267) 275

From the Restoration of the Guelphs (1267) to the Full Establishment of the Signoria (1282) - $\quad-\quad$ - $\quad-\quad$ -

From the Establishment of the Constitution (1282) to the Death of the Emperor Henry of Luxemburg (I3I3) - $\quad$ - $\quad$ - $\quad-284$

SIENA

Life, Literature, ANd Art

Life and Religion

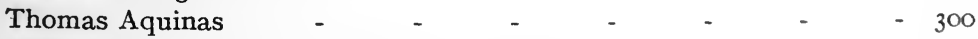

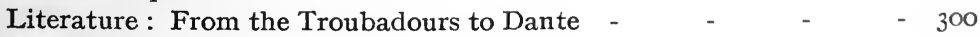

Art

Travel

Science . 
BOOK IV. - THE DAWN OF THE RENAISSANCE.-THE COMMUNES UNDER DICTATORS.-FROM THE DEATH OF HENRY VII. TO THE COMMENCEMENT OF THE GREAT SCHISM, I3I3-I378

General Survey of Italian History -

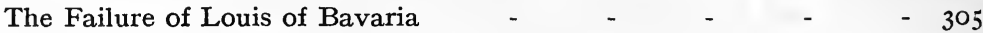

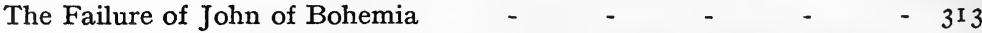

The Early Struggle between Tyrants and Republics, the Decay of the

Kingdom, and the Recovery of Romagna by the Pope - - 316

The Expeditions of Charles IV. (I354-1369) - - - - - 32 I

The Condition of Italy from the Attempted Restoration of the Empire to the Great Schism (1312-1378) - - - - - $\quad 326$

The Attempt of the Avignon Popes to recover Temporal Power.

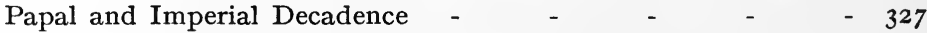

Rome

From the Coronation of Henry VII. (1312) to the Death of Cola di Rienzi (r 354)

From the Death of Rienzi to the Return of Gregory XI.

North Italy: The Despots of Northern Italy and the Formation of Small States -

The General Character of the Tyrannies established in Northern Italy

The Visconti, Scaligeri, and their Neighbours -

The Declension and Fall of Bologna

The First Attempts to found a Continental Empire - $\quad$ - $\quad-369$

Venice and World-commerce in the Fourteenth Century - - 370

The Great Naval War with Genoa (1350-1355) - - - $\quad$ - 372

From the Loss of Dalmatia ( 1358 ) to the Beginning of the Last Great

Struggle with Genoa (1 378)

Genoa

From the Death of Henry VII. (I 3 I 3) to the Election of a Doge (1 339)

The Struggle with Venice (1 348 ) to the Proctectorate and Expulsion of the Visconti (1356)

The Commercial Element rules in Genoa : Feuds of Rival Houses

From the Death of Henry VII. ( $13 \mathrm{I}_{3}$ ) to the Conquest of Lucca (1342)

From the Conquest of Lucca ( 1342 ) to the Peace of Pescia ( 1364 )

The Overthrow of the Doge Agnello and the Recovery of her Independence by Pisa (1368-1 370)

Florence -

From the Death of Henry VII. (I $\left.3 I_{3}\right)$ to the Expulsion of the Duke of Athens (1 343)

From the Expulsion of the Duke of Athens (1343) to the Peace with Pisa (1 364) -

- From the Peace with Pisa to the Peace with the Pope (1364-r 378) 
Life

Religion

Morals

The New Spirit -

Literature

Art

BOOK V.-THE FORMATION OF STATES : FROM THE COMMENCEMENT OF THE GREAT SCHISM TO THE ESTABLISHMENT OF SFORZA IN MILAN.-THE CONDOTTIERI, I378-I450

General Survey of Italian History -

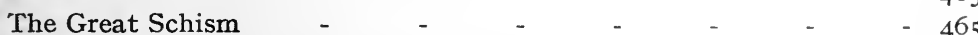

Italian Politics during the Great Schism - $\quad$ - $\quad$ - $\quad-468$

Italian Politics from the Council of Constance to the Dissolution of the Council of Basel (I4I6-I449) - $\quad$ - $\quad$ - $\quad$ - $\quad$ - 47 I

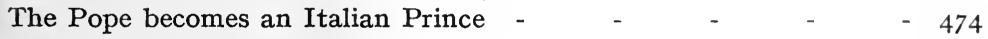

The Last Coronations at Rome - $\quad$ - $\quad$ - $\quad$ - $\quad 480$

The Condottieri -

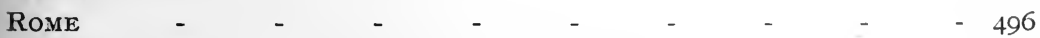

The Extinction of the Republic by the Popes - - - - $\quad$ - 496

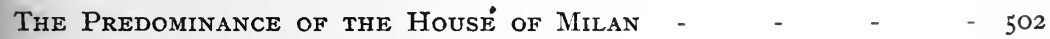

The Visconti - $\quad$ - $\quad$ - $\quad$ - $\quad$ - $\quad$ - $\quad$ - $\quad$ - 502

The Re-establishment of the Milanese Republic, its Overthrow by Francesco Sforza, and the War with Venice to the Peace of Lodi

\begin{tabular}{lllllllll}
$(\mathrm{I} 447-\mathrm{I} 454)$ & - & - & - & - & - & - & & \\
\hline
\end{tabular}

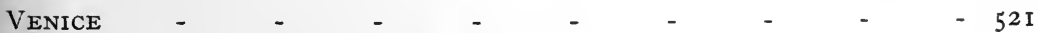

The Life and Death Struggle with Genoa - - - - $\quad 52 \mathrm{I}$

From the Peace of Turin to the Establishment of the Republic on the

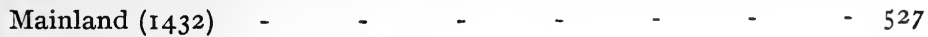

The Wars with Milan to the Peace of Lodi (1455) - - - $\quad$ - 539

The Reign of Francesco Foscari (1423-1457) - - - - - 546

GENOA

PISA -

From the Recall of Pietro Gambacorti ( 1368 ) to the Conquest of Pisa

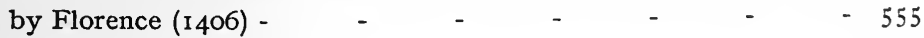

FLORENCE

The Revolt of the Ciompi (1378) and the Rule of the Lesser Arts $\begin{array}{llllllll}(1378-1382) & - & - & - & - & - & - & \end{array}$

The Recovery of Power by the Oligarchy - - - - - 570

The Rule of the Albizzi from the Fall of the Lesser Arts from Power

(I 382 ) to the Death of Gian Galeazzo Visconti (I402) - - 575

The Subjugation of Pisa (I406) and the Danger from Naples (I408-14I4) 58I

From the Death of Ladislaus (I4I4) to the Recall of Cosimo dei Medici

(1434) - $\quad$ - $\quad$ - $\quad$ - $\quad$ - $\quad$ - $\quad$ - $\quad 587$

The Manipulation of Public Affairs by Cosimo dei Medici - - - 597 
BOOK VI.-THE PERIOD OF BALANCED POWER. - THE FULL RENAISSANCE, I 450-I 494

General Survey of Italian History -

The Italy of Princely Houses -

The Temporalization of the Holy See -

PAGE

- 6ri

- 6II

MILAN

- 613

\section{VENICE}

The War with Mohammed II. (1463-I 479)

The War of Ferrara

Genoa

FLorence

The Last Years of Cosimo

Florence under Piero dei Medici (1464-I469)

Florence under Lorenzo dei Medici (I 469-I 492) -

SiENA

- 618

- 622

- 622

- 639

- 639

- 647

- 647

- 649

- 652

- $66 \mathrm{r}$

BOOK VII. - THE INVASIONS OF ITALY BY THE GREAT POWERS -THE LATE RENAISSANCE, 'I494-I 530

General Survey of Italian History

The Papacy and the Foreign Invaders -

The Invasion of Charles VIII.

The Invasion of Louis XII.

The Conquests of Cesare Borgia

Julius II. and the League of Cambrai

Julius II. and the Holy League

The Struggle between France and the Empire

Charles V. and Clement ViI.

The Emperor Charles V. supreme in Italy -

VENICE

The Turkish War and the League of Cambrai -

\section{FLORENCE}

The Expulsion of the Medici

Savonarola

The Downfall of the Republic -

Rebellion against Florence

Life, Literature, and Art from the Close of the Fourteenth to Life the Commencement of the Sixteenth Century

Literature

Architecture

Sculpture

Painting 
BOOK VIII.-THE FOREIGN DOMINATION.-REVIVAL OF ITALIAN SPIRIT.-UNITED FREE ITALY, I 530-I870

General Survey of Italian History.-The Close of the Mage Ages.-Subjugated Italy.-Italy Free - - $\quad-758$

From the Coronation of Charles V. (1530) to his Abdication (1554) - 758

The Last Struggle

Italy under Spanish, Austrian, and Bourbon Rule _ _ _ _ 765

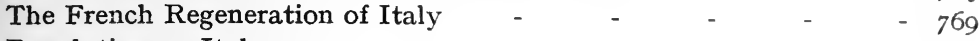

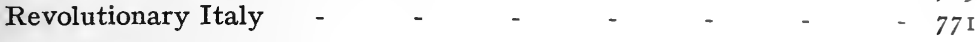

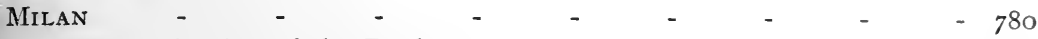

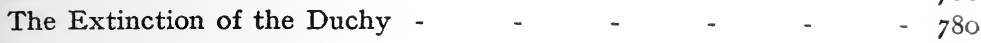

GenoA

The Oligarchical Constitution-Ephemeral Republics - - $78 \mathrm{I}$

Siena

VENICE

Life, Literature, and ARt

Life

The "Cicisbeatura"

Literature

Fine Art

Sculpture, etc. -

Music -

BIBLIOGRAPHY

$-800$

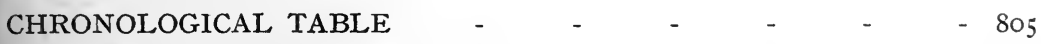

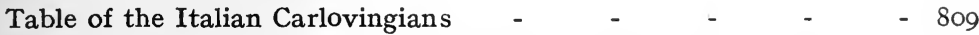

Table of Italian Kings from the Deposition of Charles the Fat to the

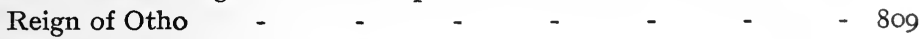

Table of the Popes and Crowned Emperors, and their Expeditions into Italy, from Charlemagne to Charles V. - - - - $\quad$ - 809

INDEX 



\section{MEMOIR OF SISMONDI}

Jean Charles Léonard Simonde de Sismondi first saw the light at Geneva on May 9, I773. His father, a wealthy Protestant minister, knew nothing of the descent of the family from an old patrician and Ghibelline stock, the Sismondi of Pisa; but a Sismondi had been ennobled by Otho the Red, and the family had been one of considerable importance. When Pisa, after regaining her liberty for a time, finally fell to Florentine arms, the Sismondi, with many other noble Pisans, sought shelter in France. They found a home amid the stern mountains of Dauphiny, but, having adopted the Reformed Faith, they migrated, after the revocation of the Edict of Nantes, to Switzerland, and settled in the metropolis of severe Protestantism, the beautiful city on the shore that was already famous and that was destined to become so rich in literary memories-Geneva. "Sismondi" had been Frenchified into "Simonde," and our author was the first to add "de Sismondi" to the altered family name. The good-natured world was amused thereat, laughed, and accepted the title. Jean Charles was proud of his origin and vain enough to emphasize it: he burned to announce his origin as "de Sismondi," and "de Sismondi" he became; all the more easily that his family, though evil days had fallen on them, had once been wealthy and still took rank among the Genevese aristocracy. Jean Charles passed his first happy years at La Châtelaine, a country house which belonged to his father, and which was not far from Geneva. But the elder Simonde believed so firmly in the ability of the great Swiss financier, Necker, that he placed all his wealth in French funds, and when the crash came, he found himself bereft of almost all that he had possessed. Happily, the future historian had by this time made good progress in his classical studies, first at college and subsequently at L'Auditoire de Genève. He was placed as clerk in the house of Eynard at Lyons, and was reputed to be an ardent and painstaking worker (1792). But the political thunderstorm became so severe at Lyons as to suspend all business, and young Simonde returned to Geneva, only to find the principles of the Revolution also in full ferment in that city. The elder Simonde, who supported the oligarchical government of the Republic, was condemned to pay a heavy fine, and spent some little time in prison. Directly he was released he sought safety in the great asylum for political refugees, our own country (1793), carrying 
his family with him; and for a year and a half young Simonde was fully occupied in the study of legislation, banking, and commerce. He soon acquired English, for he had a natural aptitude for picking up languages, and was vastly interested in our literature and insular peculiarities. But the family purse soon ran out, and the entire household was obliged to return to Geneva (I794). Geneva was no sanctuary in those days for republicans of oligarchic tendencies. The family was generous and imprudent enough to give shelter to a French emigrant. He was torn from them and shot, and the Simondes, father and son, were kept under arrest for awhile. Simonde père now sold what little property remained to him of his once considerable fortune, and the family crossed the Alps and returned to the land of their forefathers. They settled in the Val Chiusa in Tuscany, and devoted themselves to agriculture. The soil of their farm was very good, and consequently the labour requisite to till it was not great. Jean Charles had plenty of time both to think and read; he pondered on agricultural and economic conditions, and became too free of utterance to suit the taste of the Grand Duke of Tuscany (Ferdinand III.) and his myrmidons. Three times he was cast into prison, and even his life was considered to be in jeopardy. Yet nobody was more moderate and evenly balanced in his political views. He was so impartial, had already acquired by mental discipline so much critical faculty, such $\sigma \omega \phi \rho o \sigma v v \eta \eta$, that, as is invariably the case with those who have the unfortunate habit of "looking too precisely on the event " and considering it from more sides than one, he incurred the displeasure of all with a prejudice-that is to say, of everybody. Jean Charles had blamed alike the blind fatuous egotism of the monarch, and the "fool-fury of the Seine." The result was that the populace set him down as an Austrian, the aristocrats as a Jacobin. As so often happens in a family where young people are rash enough to cast doubts on the prejudices of their elders, Jean Charles found himself at variance with his mother. Conservative by nature, Madame Simonde had seen her nearest and dearest suffer through the advance of Idea, and, like a true woman, she threw passionate sympathies on the opposite aristocratic and Austrian side : she execrated the very name of liberty. "Do you still rail at the generous liberty of England ?" Jean Charles wrote to his mother from his prison cell-"at her habeas corpus, the jury system, and her simple and intelligible legislation? That wretched French copy, even, would have saved us from the wrongs we are suffering had we now been in France."

Suddenly, Napoleon left Geneva and crossed the Alps, and the 
decisive victory of Marengo struck another blow at the fetters of Europe (I80o). Peace fell for a time on the troubled waters; and the Simondes returned to Geneva. But their yearly income was reduced to a pittance; the entire family. now had but 4,000 francs ( $f$ r6o) a year coming in.

Jean Charles had spent his leisure time in Tuscany in the pursuit of letters, in investigations into economical science, and in studying the histories of both Italy and France. He had formed an opinion very inimical to the monarchical system, and he was very much impressed by the manner in which industry in Italy had risen, as from the dead, directly the serf was emancipated and the commune firmly established in the eleventh and twelfth centuries. It was an expression of these views that had attracted the inconvenient attentions of the Austrian police. The obscure and perplexed problems of the "clismal science" now began to weigh heavily on the young thinker. He was stimulated by the study of past industrial development and by the series of economical changes taking place with such rapidity in his own time. The generous, sympathetic mind of the youth, not yet rendered insensitive by familiarity, took shock at the seamy side of competition, and Jean Charles was genuinely pained by the condition of the worker. In I8or he sprang all at once into fame as an economist through the publication of his "Tableau de l'Agriculture" ("Delineation of Agriculture"), and two years later his position as a thinker was established by his work "De la Richesse Commerciale, Genève, I8o3," 2 vols., 8vo. ("Concerning Commercial Wealth"). But these volumes exhibit Simonde as still a devoted, undeviating follower in the footsteps of Adam Smith. The fame which he acquired through these thoughtful works soon spread far beyond Geneva, and brought him into contact with the most brilliant minds of his time. Nor were offers of advancement lacking. Alexander I., Emperor of Russia, had recently restored the University of Vilna, and he offered Simonde the Chair of Economics there at a salary of 6,000 francs. But Simonde refused, preferring his independence. He was invited to Chateau Coppet, whither Necker had returned with his illustrious daughter, Madame de Staël. At the Court of that most distinguished of the intellectual ladies of the period, Simonde made the acquaintance of many illustrious Frenchmen ; and he was so far advanced in the good graces of the literary Queen that she twice "commanded" him to accompany her to Italy as one of her Court. His journey, much as he and Madame de Staël were attached to one another, was not wholly pleasant; and Simonde took a great dislike to A. W. Schlegel, who was of the party. He made the acquaintance of Louisa of Stolberg, 
Dowager Countess of Albany, on this tour ; and the lady, though now too old to exert the feminine magnetism which had captured the senses of so many distinguished men, was able to draw Simonde into an intimacy of a chaster, but sincerer, and of more lasting character. Meanwhile his little income was derived from his office as Secretary of Commerce to the Department of Léman; for Geneva was now united to France and had become one of its departmental capitals. He exhibited independence by his fearless insistence on Genevese rights as against the interference of the Government : he wrote a series of protests, which he sent straight to headquarters. But he devoted all his spare time to historical study and research; and in I 805 he had the happiness to discover that his family belonged to the ancient House of Sismondi.

So constant was his application, and so capable was he of collecting and concentrating all his intellectual powers into a focus, that by 1807 he was able to issue the first two volumes of his magnum opus, "L'Histoire des Républiques Italiennes au Moyen Âge" (" History of the Italian Republics in the Middle Ages"). They were published at Zurich. The subject expanded under his hands until it embraced the history, not merely of the communes, but of Italy ; for he was led on by the tangled web of Italian politics to treat of much more than was absolutely necessary to his immediate purpose. The work was not finished for fourteen years, volumes iii. and iv. appearing in 1808 ; volumes v.-viii. at Paris, in I809; and volumes ix.-xvi. at Paris, in I8I8. In the early part of the nineteenth century it is true that the great published collections of Muratori and Struvius and others were to be found in most public and some private libraries; but many secrets of the archives were only to be discovered in the archives themselves. It was not possible then to write a great history in the quiet seclusion of a country rectory, as Bishop Creighton did three generations later. Simonde visited Italy nine times in order to prepare his work. He searched the libraries and monasteries, not only of Italy, but of Germany, for material, and spent a small fortune in securing the rare and costly books that he found necessary to his purpose.

Sismondi, as we must now and henceforward call Jean Charles Léonard, at once took a vastly higher position as an historian than he had done as an economist, though that was by no means other than a veritable niche in the temple of honour. Many editions of the work followed each other in rapid succession, and the volumes remain as indispensable as ever to any serious student of the great stretch of time from Charles the Great to Charles the Fifth. Yet, either because Sismondi had overburdened his work with detail and moral reflections, 
or from some occasional defects of style that were offensive to the Parisian ear, the "Institut" refused its crown, in spite of the solicitations of intellectual Europe. The two Schlegels, Jean de Müller, Cuvier, Saussure, Boettiger, and many more hammered at the gate in vain on behalf of Sismondi : he was never admitted past that sacred and exclusive portal.

Sismondi still remained attached to the apron-strings of the great literary Queen. It was while staying with Madame de Staël and her suite of "intellectuals" at Vienna that he published his treatise on Austrian paper-money (" Mémoire sur le Papier Monnaie dans les États Autrichiennes et les Moyens de le Supprimer," Weimar, i8 Io, 8vo.). The success that his works attained had by this time rendered his circumstances less straitened; but he was glad to increase his income by giving a course of lectures, which he afterwards expanded and published as "The Literature of the South" ("La Littérature du Midi de l'Europe, 1819-29," 4 vols., 8vo.), and he refused a lucrative professoriate at Geneva rather than submit to the least restraint on intellectual freedom.

Paris, ever the brain and soul of France, drew Sismondi to her (1813). He was warmly welcomed by Madame de Staël and Benjamin Constant; and, owing to his intimacy with the Countess d'Albany, the severely exclusive and aristocratic salons of the legitimist remnant gave him a very gracious welcome. His correspondence with the frail but famous Countess is full of interest and charm. Sismondi was a sort of French Whig. He was by no means opposed to the retention of a certain measure of authority and power by the aristocracy, though he was of opinion that the haute bourgeoisie, the upper middle class, as the brain and heart of the nation, constituting its best and most cultivated workers, should be entrusted with political supremacy. The French Revolution had been diverted: the combined rebellion of the middle classes and the rising proletariat had issued in the re-establishment of authority vested in the middle class alone. This exaltation of the bourgeoisie was, in no small measure, a movement partly directed and partly supported by Bonaparte; and it is not therefore surprising to find Sismondi very shrewd to detect the ineptitude of the Bourbons when the Emperor fell, and quick to hail his return from Elba as that of the restorer of liberal ideas and the true representative of the Revolution. He had received shocks which to many were a rude awakening; but he still continued to dream that the Empire might be induced to become more liberal, and that popular liberty might be preserved by constitutional guarantees. And when Napoleon desired to see him (1815), he walked an hour with the 
throne-shaker beneath the may-blossoms of the Elysée, and gave him his views on pressing questions of statecraft and high policy. Next morning Napoleon sent him the patent of the Legion of Honour. Sismondi refused it: his independence, like the honour of Cesar's wife, might suffer no reproach, no taint of suspicion.

Meanwhile a gradual change had been taking place in Sismondi's economic views, and to these he had given inadequate expression in the "Edinburgh Encyclopadia." He therefore published in 18 r9 his "New Principles of Political Economy; or, Wealth Regarded in its Bearing on the Population" ("Nouveaux Principes d'Économie Politique, ou de la Richesse dans ses Rapports avec la Population"). It "attacked an orthodoxy - an enterprise no less dangerous in philosophy than in religion." Sismondi was the first writer on political economy to point out that that science had directed its attention almost wholly to the increase of wealth, while it had ignored the question of righteous distribution. He was the first to express disapprobation of those current cloctrines of laissez-faire which lasted down to our own day, and he exposed the moral defects of the modern competitive and industrial system. Of course he incurred the contempt of Bastiat and the "scientific" school, who remained serenely self-satisfied in a position which they deemed it sheer idiocy even to question and insanity to attack. And yet Sismondi, who had more bowels of compassion than the orthodox economist, had done nothing more than point out the vice; he proposed no real remedy; he deemed the evil to be fixed in the nature of things; like the priest and Levite of the parable, "he came and looked, and passed by on the other side." This was not due to indifference, however, but to genuine conviction that there was no help to be given. In spite of living in the age before Charles Darwin, like another Copernicus, had inverted the "great order" for us-in the age when men believed in clearing the board and reconstructing society by sheer force of intelligence-Sismondi gave it as his deliberate judgment that the execution of economic justice is beyond human power. And yet the very first words that he had written in the introduction to his "Republics" were that " one of the most important conclusions that one can draw from historical study is that the most powerful cause of the character of peoples rests in their government; that national virtues or vices, energy or idleness, talent, intelligence, or ignorance, scarcely ever result from climate or are the attributes of race, but are the effects of laws; that everything was given to all by Nature, whilst government fosters or clestroys in its subjects the qualities which are naturally the common heritage of the race." Different, indeed, is this 
attitude of mind from that of the Darwinists and Weissmannites of to-day, who never get weary of proclaiming how little we owe to nurture and how much to nature and heredity! Yet, in spite of his avowed doctrine as to the potency of laws to make and mar, Sismondi felt himself powerless in the presence of the great problem, and declared it insoluble. On the whole, he was deprived by Nature of that indiscreet, perfervid imagination, that alert originality of mind, which opens up new vistas to human intelligence, but is so rarely associated with a spirit of wisclom and prudence. He was needlewitted enough to become conscious, in advance of other thinkers, of the importance of questions of distribution; he became so at a time when the world thought pretty well all the problems of economics were embraced in questions of production; his sensitive mind was keenly aware of the opposition of ethics to current economical theory and the actual constitution of society; but he regarded the opposition as an antinomy in the nature of things. His mind had the natural limitations that pertain to good balance of judgment; he was no constructive dreamer-was impotent to transcend in thought the limiting conditions of his own day, and unable to soar to the conception of a radically different social order. Unwillingly, he found himself compelled to declare any fundamental alteration of the economic conditions of life to be impossible; while he still called on Government to regulate the progress of wealth and protect the vanquished in an immoral struggle to the best of its limited ability.

Sismondi now revisited London, and married a lady named Jessie Allen, the sister-in-law of his friend Sir James Mackintosh, the statesman and historian; and with her he appears to have enjoyed what neither authors nor their wives seem commonly to find-domestic felicity. He was engaged at the time in preparing his huge "Histoire des Français," which was the main interest of his remaining years. It was planned on a vaster scale than the "History of the Italian Republics" even, and it exhibits the same minute thoroughness and accuracy; but the Academy did not deign to notice the work. Sismondi was next offered a chair at the College of France, which he declined. He left England, however, and settled in Geneva. Here he took an active part in the political life of the city, and his judicial and doctrinaire liberalism wore somewhat threadbare in that circumscribed political arena. By the Treaty of Paris, Geneva had become a Swiss canton; all its citizens were declared equal (on parchment), but the franchise was limited, and the so-called representative government was in the hands of eighteen families, who kept themselves in power by co-opting each other. To Sismondi this appeared 
to be an ideal constitution : the very kind of constitution he had denounced in his history he now supported; he fought tooth and nail against growing discontent. His liberalism, indeed, while bitterly opposed to Popes and Kings, had confined itself to a bourgeois idealto the substitution of a commercial oligarchy for monarchy and the Court. A weakness for this kind of aristocratic distinction, derived from his father and conspicuous in his Italian history, was deeply rooted in Sismondi's nature; and the man at whom the world smiled when he added "de Sismondi" to his name felt outraged when a certain M. Grenus, a fellow-citizen and also an historian, ventured to assume the distinction of nobility as a member of the extinct Holy Roman Empire. Sismondi fulminated against the new noble in the Paris journals, and refused to apologize. The irate gentlemen proceeded to exchange shots; the result was not mortal; nevertheless, honour was vindicated (I829).

Thus the preparation of the "History of the French" did not absorb all Sismondi's energies. A most voluminous writer--never, as he tells us, working fewer than eight hours a day-Sismondi poured forth histories of the "Reawakening of Liberty in Italy" (1832), of the "Fall of the Roman Empire" (I835), an "Abridgment of the History of the French" (I839), and a vast amount of pamphlets and small books, chiefly on political topics. He had even tried his hand at historical romance, writing a novel concerned with the manners of Roman Gaul, and entitled "Julia Severa, ou l'An 492" (I822). His facility in acquiring languages enabled him to re-write in a condensed form his "History of the Italian Republics" in English for Lardner's "Cabinet Cyclopædia" (I832). The work found great favour, but the statement is so terse and condensed as to be confusing to the reader, and the style, though sometimes quite readable, often becomes jerky.

In $\mathrm{r} 84 \mathrm{I}$ Sismondi at last consented to receive the decoration of the Légion d'Honneur, and was elected to a seat in the Legislative Assembly of Geneva. Much to his digust, popular discontent and a public demonstration soon afterwards obliged the little oligarchy to accede to an enlargement of this representative council, while the executive power was still retained by a smaller body. The measure staved off radical reform for a time; but five years later the populace forced a remodelling of the constitution on a democratic basis. Sismondi held faith in one form of government only-namely, that of a Liberal aristocracy, and this he did with all the assured fervour of a doctrinaire; happily, he did not live to see the opening of the floodgates. He had been intrepid in his opposition to the reform of $184 \mathrm{I}$; he became so rancorous in his protests against what had been done, 
that even his own personal friends of his own party did not venture to support him. That he was suffering agonies from cancer of the stomach all the time will excuse much of the violence of this uncompromising temper. And, after all, his favourite fetish had been mutilated, and its fate still trembled in the scales. His physician, who must have been both astute and wise, ordained silence. The indefatigable scholar, with heroic self-command, used up the lees of life on his unfinished "Histoire des Français," pushed it on with might and main, and corrected the proofs until a few days before the end. He died, leaving no issue, June $\mathbf{2 5}, \mathrm{I} 842$, aged sixty-nine years. He was distinguished among his contemporaries as one of those rare men who earn no less esteem for excellence of moral character than admiration for intellectual eminence. Few have excelled Sismondi in the scrupulous avoidance of every worldly advantage that might limit perfect freedom ; no scholar has made a more stupendous exercise of great gifts to imperishable ends. He had a fault that is often more endearing than a virtue-an artless, childlike vanity in the qualities of his literary style, and in that gratifying lineage from a family of merchant nobles which he had discovered for himself. 



\title{
H I S T O R Y
}

OF

\section{THE ITALIAN REPUBLICS}

\section{BOOK .I}

\author{
THE DARK AGES AND THE DAWN OF THE MEDIEVAL \\ WORLD : THE RISE OF THE COMMUNES, \\ A.D. 476 -I I 54
}

\section{GENERAL SURVEY OF ITALIAN HISTORY}

\section{The Decline of Rome}

IN the Middle Ages Italy was occupied by a vast number of political communities, some large, others very small, some self-governing, some under despotic rule. These small states were for over contending with each other, often to the death, for independence, or increase of territory, or control of trade-routes, or preponderance. They frequently grouped themselves in unstable alliance to meet some common peril or gratify some common greed. And the domestic politics of Italy were further subject to perturbation, owing to the presence of an authoritative and aspiring Papacy within her gates, and the temptations that the fair land offered to the rapacity of the foreigner without.

Several of the self-governing communities of Italy achieved imperishable lustre and distinction. The eldest children of liberty, they became the mighty mothers of the art, the literature, the commerce, and the civilization of the modern world. To each of the more illustrious of these republics detailed attention will be given in due course. But their relations with surrounding communities were subject to protean transformations and interpenetrating complexities that cannot be adequately comprehended without first surveying the continuous development of the Peninsula as a whole-the higher unfolding of a process which contained and conditioned the life of each individual state. That process begins with the period when the progressive decay of the Roman world led to its disintegration, when Italy experienced successive shocks of invasion by races of barbarians or semi-civilized peoples, some of whom settled on the disorganized land and ruled it ; it embraces the struggle of Pope, Lombard, and the Greek representatives of the Roman Empire for supremacy; it includes the occupation of the fairest portion of the country by colonistsoldiers from Mohammedan shores, and its subjugation by Norman adventurers from the fields of Cotentin; it proceeds to the great struggle between the resuscitated empire in the grasp of German Cæsars, and the illimitable ambition of the spiritual sovereigns of Europe; it concerns itself with the degeneracy of the Pontiff into an Italian princelet, with the coalescence of the independent communes into larger states, with the 
foreign interference which their quarrels caused them to evoke, and with the subjugation of the petty despotisms and enfeebled republics of the Peninsula alike, by the unsuspected power of the great monarchies beyond the Alps ; it ends with the diversion and expansion of the main stream of European thought and life from Italy to the North; carrying with it the precious and immortal results of the vigour and vitality of Italian character and intellect.

Imperial Rome had imposed her yoke on the Western World. Corrupted by the increase of wealth that accrued, her citizens supported by the corn of conquered countries, and emasculated by pleasures provided for by the public treasury, she became unfitted either for administration or defence. The decentralization of the Empire by Diocletian, followed by the founding of New Rome in the Orient by Constantine, and the partition of the Roman world into executive and administrative halves by Theodosius, tended towards the isolation of Italy. Constantinople, Alexandria, and Trier became the rivals of Rome, and the establishment of the Court at Milan, the great city that guarded the ingress of the North through the barriers of the Alps, or at Ravenna, surrounded by waterways that rendered her impregnable, dealt heavy blows at the prestige and supremacy of the metropolis, and were a stepping-stone to the disintegration of Italy itself. Hordes of barbarians, pressed forward by the onslaught of wild Mongolian tribes from the steppes of Asia, threatened the northern frontiers. Enfeebled Italy no longer grew a sufficiency of crops to feed a large population, there were no men to repel the invaders, and in A.D. 370 Valentinian I. established colonies of barbarians to cultivate the forsaken plain of Lombardy. The migrating mercenaries that were engaged to defend the country had neither a common language nor a common religion; there was nothing to inspire pride in the legion or secure its sincere attachment to the Emperor, and the hearts of its men were set on booty. And the poorer classes of Italy had been replaced by slaves on the great estates which the great nobles had gathered together, while the squirearchy had fallen into decay.

\section{InTERNAL CONDITION OF Roman ItALy}

From a very early time, when Rome was a small republic, the poorer citizens had been oppressed by the State. In the frequent wars which ravaged the republic the farmers were called forth to fight, and, beyond precarious booty, they got no redress for the burning of their homesteads or the spoiling of their crops. The cruel law of debt also had tended to the extinction of a middle class. Farming was further rendered unremunerative by the competition in food-supplies that came from conquered countries beyond the seas. Large estates grew at the expense of small holdings, wealth accumulated and men decayed, and slaves replaced a population of freemen. Hence, ultimately, the supply of soldiers ran short. After the second Punic War, B.C. 202, even Italy was characterized by a large slave population, with no interest in its defence, and a turbulent, pauperized, and pampered proletariat, kept quiet by "panem et circenses "for the comfort and security of a dissolute and degenerate nobility. In the time of the Empire famine further reduced the population, and the State was incessantly weakened by the wars of contending aspirants to 
the purple. Side by side with the Imperial Government, local selfgovernment had been highly developed by means of the "curia," a term still preserved in the Roman Church. The curia consisted of " decurions," corresponding to our "esquires," who, under the earlier emperors, exhibited an honourable emulation in the service of the community, and contributed largely from their private purse to public works and their adornment. But the greed of the Emperors and Cæsars (who since the time of Diocletian had been multiplied), and still more of their households, together with the requirements of a large bureaucracy, imposed such burdens on the curia that its members gradually became the bondslaves of the Court, compelled to minister to its necessities, and provided with no loophole for escape. The free-will offerings once applied to the public service were converted into a grinding tax, which, by the ruin of one decurion after another, became still more ruinous to the rest. Further, Christianity competed with the curia, and benevolence built churches instead of aqueducts and baths. Inconceivably bad finance impoverishod the Empire by taking an excessive share of produce from the cultivators of the soil, and by farming out taxes to the hated " publicans." There was no remission granted, but as the agriculturalists were ruined one by one the burthen of taxation became heavier to the survivors in geometrical progression. The old Roman spirit died with the Pagan faith, the ideal city of God replaced the cementing force of belief in the city of the seven hills, and jealousy between the divisions of the Empire prevented either section from helping the other (Hodgkin, Italy and her Invaders, Book II., Chap. IX.). But Rome, deprived of political supremacy, clung to her position as the metropolis whence Christianity had interpenetrated the Roman world, and as the seat of a long line of bishops that claimed to inherit from St. Peter, and that, through the prestige and erewhile predominance of the ancient mistress of the world, took a natural precedence in the Church. The decay of her imperial prerogative favoured a "vita nuova," a rebirth of Roman claims to supremacy no longer supported by the thunder of the legions, but defended by a Divine panoply and a wielding of the sword of the Spirit. Rome underwent a slow, strange metamorphosis, but retained her ascendency. She aspired to bocome the spiritual mistress of the Western World.

\section{The Barbarian InVasions}

From time to time the barbarians who menaced the Empire were bought off both by the Emperor at Constantinople and his co-ruler in Italy. They were seduced by liberal pay to defend territory which was no longer capable of self-defence. The enemies of the State thus became its defenders against the ravages of the savage Hun and their own brethren across the mountains. Thus a debased copy of Roman civilization naturally got transmitted, by the intercourse of the legionaries with their brethren, to distant nations, and awakened their interest in, and even reverence for, the ancient Mother, while Christian missionaries were successful in converting whole tribes of these heathen to the faith that was now the official religion of the Roman State. The mercenary peoples that defended the Empire felt the blood-ties that bound them to the barbarians of the North as being closer than the allegiance they owed to an Emperor 
whom they often accused of exhibiting bad faith toward them. The "fœederati " of Italy at last had the audacity to claim one-third of the land they defended, and they raised Odovacar (Odoacer), a soldier of fortune, on the shield, and hailed him as their King (A.D. 476). He was wise enough to secure the reality of power by affecting allegiance and subordination to the Eastern Emperor, while he deposed the puppet who reigned in Italy. Hence the Peninsula remained, nominally, an integral part of the Roman Empire, and was, in theory, ruled by authority delegated from the new Rome on the Bosphorus. The Eastern Emperor, impotent to stem the adverse current, bestowed on Odovacar the modest title of Patrician, and one-third of the lands and slaves of Italy were now at the mercy of her so-called defenders. The new protectors were not strong enough to oppose a great nation that, tricked and mismanaged by the Romans of Constantinople, now came pouring across the Eastern passesmen, women, and children, and their belongings, in all 200,000 strong (A.D. 489). Theodoric, the commander of these Ostrogoths, conquered the Peninsula in four years, and showed himself no less firm yet conciliatory as a ruler than brave and capable as a general. He applied himself to the statesman-like task of fusing the barbarian invaders with the old Roman population, and his government was marked by complete religious toleration. The presence of two buildings at Ravenna--the Arian baptistery of the invaders and the Catholic baptistery of the Roman worshippers-bears witness to-day to the prudence of his administration. But Theodoric's successors were less able and less fortunate. A now Emperor, fond of splendour and renown, ascended the throne at Constantinople. Justinian found a full treasury and an able staff, and he was supported by lavish ministers and great generals. He expended the resources of the Empire, and ground down his people by taxation, in the attempt to recover the lost possessions of Rome. First, the famous warrior Belisarius, and then the crafty strategist Narses, the eunuch, were despatched to Italy, and a sanguinary conflict lasting for eightoon years onded in the complete overthrow of the Goths. Procopius tells us that for six weeks Rome was left desolate without a single inhabitant, and the proud city was three times besieged and twice taken by the Northern barbarians. At last the defeated Goths, preferring the precarious freedom of the wild and uninviting North to the ease of servitude, wended their way back over the mountains, and Italy, from the Alps to Sicily, was again united to the Roman Empire (553 A.D.). In the midst of these troubles, Benedict, a noble Roman who had assumed the garb of a monk, retired to Monte Cassino. With a rare knowledge of the requirements of the human heart, he founded the religious Order that still bears his name, and gave it its rules. Through ages of bloodshed and rapine Benedict's monastery, with varying fortunes, remained an abode of religious meditation and a centre of serviceable work ; his community survived the passing of empires and the crash of conflicting races that aspired to rule the South ; it not merely enregistered the hagiology of the period, but it gave peaceful refuge to what of learning retained a precarious vitality through the long lethargy of the dark ages. Through the intercourse of the monks with Constantinople the traditions of Byzantine art and learning passed into the Western Church, and it would seem that even the lore of the far East may have been welcomed by the recluses of 
Monte Cassino (vide Gay, L'Italie méridionale et l'empire byzantine. Paris, 1904, pp. 597, 598).

The Visigoth, the Hun, the Vandal, and the Ostrogoth had swept over the land and devastated it. Their presence had destroyed all the luxurious culture and nearly every social vestige of the proud old Roman days ; but they had failed to reconstruct-they left no permanent memorial of their sway. But now, in the great movement of peoples that had been started by Mongolian pressure, there was creeping along the valleys of the Eastern Alps a rude and violent horde of barbarians, whose forefathers hailed from the foggy fens of the lower Elbe, and who had never received the least tincture of polish or refinement from contact or intercourse with Rome. "Everything about them," says Hodgkin, " even for many years after they have entered upon the sacred soil of Italy, speaks of mere savage delight in bloodshed and the rudest forms of sensual indulgence; they are the anarchists of the Völkerwanderung, whose delight is only in destruction and who seem incapable of culture. Yet this is the race from which, in the fulness of time, under the transmuting power of the old Italian civilization, were to spring Anselm and Lanfranc, Hildebrand and Dante Alighieri." Mingled with the Lombards were Saxons, conquered Gepidæ, Bulgarians, and Sclavs. Not merely did the presence of so many different tribes tend to disorder, but the Lombards themselves had but a feeble impulse to obey central authority. The motley horde marched in regiments, each of a thousand men, led by a duke, subdivided into companies of a hundred officered by sculdahis, and all conducted by Alboin the King. They came to a land enfeebled by the miseries of a series of foreign invasions that had been witnessed by six successive generations ; they met only with the resistance of a weakened people, and the Eastern power that had been exhausted by the boundless ambition, the reckless extravagance, and the crushing taxation of Justinian. The Lombards occupied Venetia in 568 A.D. By 572 they were in possession of Pavia and Lombardy, and had, it is believed, laid the foundations of their rule in Central and Southern Italy. But, an inland people, unaccustomed to maritime enterprise, they were unable to cope with the degenerate "Romans" of Constantinople, who held the coast and the great waterways without fear of dislodgment. Ravenna and the five cities round it, known as the Pentapolis-in other phraseology, the "Exarchate"-still maintained obedience to the Emperor, as did the maritime cities around Naples, the extreme South, and Genoa, as well as the people who dwelt on the melancholy sandbanks of the Venetian lagoons. Rome, and some other cities situated on navigable rivers, also continued to owe allegiance to Constantinople. The ruthless Lombard ravaged the Peninsula; he had lived by war, and for him warfare alone gave dignity and zest to life. He drove the inhabitants before him like sheep, or slew the land-owners, and reduced the masses to servitude, and, following the example of previous conquerors, he demanded one-third of the produce of the lands that he did not seize. Unlike the Germanic tribes who had preceded him, the Lombards settled in the cities that still retained some remnants of the old civilization; and even when matters had begun to improve, Pope Gregory wrote that " the condition of this country does not forebode the end of the world; it realizes it." The uncompliant, unsubmissive character of the Lombards is shown in the fact that they renounced the authority of their King, and 
split up into thirty-six separate governments under dukes, whereof the Duchies of Friuli and Trient in the North, and Benevento and Spoleto in the South, were the most important. Not merely was their power enfeebled by this centrifugal tendency, but by the fact that the great duchies of the South were separated by the Apennines from the duchies of the "waveless plain," and liable to be cut off by expeditions from Ravenna. They had to defend their acquisitions against other Lombard hordes who attempted to pierce the Western Alps, and they were unable to capture Naples, or make serious headway against the Greeks who held the " toe " of Italy. Finally, Maurice, the Eastern Emperor, bent on the recovery of the Peninsula, subsidized the Franks to invade it, and the fear of external foes, and, perhaps, the presence of internal danger, compelled the Lombard dukes again to choose a monarch. Authari, the son of the last King was elected by common consent. The unquenchable influence of Rome was beginning to bear on the barbarian; he desired to legitimatize his position, and Authari called himself " Flavius," from some nebulous tradition of the distant glory that surrounds the great Flavian line. The loosely aggregated body of Lombard States had, however, small notion of obedience and little respect for authority ; revolt was the rule, and the great duchies seized on every opportunity favourable to their independence. Yet the dangers and disasters due to the division of authority among the conquerors were not disadvantageous to the vanquished. Tho Roman cultivator of the ground was, indeed, tied to a master and to the soil he tilled, but he was granted protection against the arbitrary increase of rent, nor could he be sold as a slave, while he was allowed to apply the old Roman law to his own affairs (Hodgkin, VI., C.xiv). Nor was this all. The presence of so many centres of government in Lombard Italy, of great ports, like Amalfi and Gonoa, that had acquired practical autonomy under the enfeebled headship of Constantinople, and, lastly, the continuance of the great Roman tradition under the altered form of a Supreme Bishop, elected, not merely by the clergy, but by the clergy conjoined with the senate and people of Rome, introduced a principle of struggle and therefore of vitality into the Peninsula, and prepared the way to the peculiar development of its subsequent history.

The position of Rome, with the duchy of Spoleto between it and the Exarchate, was perilous in the extreme. In 592 the throne of St. Peter was occupied by a man who has not only the great distinction of having been, perhaps, the ablest of the most capable line of monarchs the world has ever scen, but the far more exceptional fame of being possessed by as great holiness as he was remarkable for power. St. Gregory was Pope when the Lombard Duke of Spoleto threatened Rome. Gregory contrived to secure a separate peace with the invader, and so incurred the wrath of his overlord the Emperor. Soldiers were sent from Ravenna against the Lombards, and their success roused the wrath of all the nation, and brought their King before the walls of Rome (593). Gregory was compelled to abandon the seclusion of his study and his meditations on Holy Writ, in order to superintend the defences of the city of which he was first magistrate. He received the invader on the steps of the basilica of St. Peter's, which was without the walls, and is said to have wholly vanquished the truculent Lombard by his serene and saintly presence. (Codex Haoniensis, quoted by Hodgkin, V., 37I). The Lombard King 
withdrew his army, and Rome was saved. The Papacy was by this time possessed of much landed property around Rome, in Southern Italy and Sicily, in Illyria and Gaul, called the Patrimony of St. Peter, and derived from bequests by the faithful. The Pope had become a vast landed proprietor, but he still owed allegiance to the Emperor at Constantinople. But communications between the Pope and the Exarch, the Imperial representative at Ravenna, or intercourse with the Imperial Duke of Naples, were liable to be cut off, and were becoming increasingly difficult. Whatever his views might be on the matter, circumstances were forcing the spiritual pastor into temporal sovereignty; and Gregory himself began to question whether his function as Roman Bishop was that of spiritual shepherd or worldly prince. Gregory insisted on the universal supremacy of the bishopric that had been the fortress of Catholicism against the Arian and other heresies; a supremacy threatened by the Patriarch of Constantinople, and even by the Bishop of Ravenna, now that Rome had become a distant provincial town of the Empire of the Orient. He assumed the role of protector of the Italians by defending the inhabitants of Southern Italy against the oppressions of their Greek rulers ; and, by his skill as a diplomatist, he became the arbitrator between the Lombard kingdom and the Empire, and laid the foundations of Rome as an independent state; he was unwearied in the conversion of the Lombards to the Catholic form of faith, and died leaving Rome not merely still free from Lombard rule, but demanding deference and consideration from her nominal overlord, and possessed of supreme influence over the nations of the West.

Consequently, when the Fapacy insisted on the celibacy of the clergy, Pope Sergius was able to refuse to accept the decrees of Justinian II. (A.D. 692); and the populace showed their contempt for the Imperial authority by rejecting the Imperial coinage and treading the Imperial likeness under their feet. When the stress of the spread of Islamism was felt in Constantinople, and the manner in which its emphatically spiritual conception of the Deity appealed to the Oriental mind (so deeply persuaded, from of old time, of the opposition of spirit to matter) was recognised there, the Emperor, Leo the Isaurian, prohibited the worship of images throughout the Empire, and the Exarch tried to execute his orders (7 15). The Romans, armed in the name of the Pope, called their Pontiff the Father of the Roman Republic, and obliged the Imperial officer to retire from the city. A council, assembled at Rome, excommunicated the iconoclasts ; the Papacy threw off the yoke of the East, and resolved to secure itself against any attempt to reimpose it ; and the Greek fugitives from the monasteries of the South, bearing their mosaics and paintings with them, were received in Rome. Splendour of pigment and glittering gold gave adornment meet to the Metropolis of Catholic Christianity.

\section{Byzantine, Lombard, and Papal Italy}

The iconoclastic controversy was a signal of revolt to discontented cities. The Lombards were becoming civilized, and, on the whole, their rule was just. Masons of Como raised churches in the North ; enfranchisement was made easy to the serf. Bologna and other towns withdrew their allegiance from Constantinople and bestowed it on Luitprand, the 
Lombard King, on condition of keeping their own Roman law. The two peoples, possessing a common faith and common interests, became almost fused, all the more readily that conqueror and conquered had come to speak the same language. The Lombards, with the adaptability of their northern blood, imitated Italian refinement; they allowed Catholic Bishops to rule side by side with their own Arian Prelates; and although Catholicism was the profession of an inferior race, it was not long before they became fervently Catholic themselves.

The monarchy was elective, but the Lombards chose their King from certain families; and to the Crown belonged all lands not in private possession and the confiscated property of traitors. The King, when crowned at Pavia, the capital, with the famous iron crown of Lombardy, 1 became the chief representative of the States, the president of their select councils and tribunals, and supreme guardian of all the states and of all their inhabitants. The Lombard dukedoms, like the kingship, tended to become hereditary. It would seem, at first, difficult to understand why the rulers of the Lombard states were styled " dukes," for the Roman count ranked higher than the duke, and the latter title literally means "companion" of the chief ruler. But the difficulty disappears when we remember how mixed was the horde that accompanied the Lombards into Italy and the prior victories of the Lombards over the Gepidæ and other tribes : the duke $(d u x)$ was often a subjugated chief, always a princelet, either by heredity or election; and although subordinate to the King, he did not represent him, as did the Roman count. The dukes of Spoleto and Benevento, separated from Pavia by the Apennines, and constantly threatened by Imperial troops along the Flaminian Way, were practically independent sovereigns. Below the duke was the gastald, who administered the royal domain situate in the dukedom; the sculdahis appears to have been the chief man in each little town, entrusted with the duties of justice of the peace. Very little is known of the condition of the indigenous Italians; but they probably bore a similar relation to their Lombard masters that the rayah does to his Turkish conqueror. And, while most Italians were half-free aldii, or tenants, tied to the soil under superior (Lombard) holders, this state of things must have presented many exceptions, especially in remote districts and where the Lombards were few in number.

There is no hatred so intense as the hatred of a civilized people for their barbarian conquerors, who often surpass them as much in manliness as they are inferior to them in manners. Hence, in spite of the severity of Italian accounts, it is better to judge of the Lombards from their legislation, and it is clear, from the code of King Rothari, published A.D. 643 , and the laws passed by the yearly assemblies under King Luitprand (A.D. 7I2-744), that there was a sincere desire on their part to govern equitably and impartially. While the Roman retained his own code for his own purposes, Lombard laws were sensibly modified by Roman legislature. In order to understand the position of the aldii and the serf,

1 The iron crown, now carefully preserved at Monza, is a gold circlet set with jewels and enamels, and bears on its inner side an iron band, popularly believed to have been made of a nail of the cross, and brought from Jerusalem by Helena, the mother of Constantine the Great. But this story cannot be traced back more than four centuries, and Muratori disposed of it nearly two centuries ago. 
we must go back to the condition of the people in Imperial times (Hegel, C., Geschichte der Städteverfassung von Italien-Hodgkin, Italy and her Invaders, vol. vi.).

Quite apart from and before the introduction of Christianity, moral ideas began to operate in favour of the slave. These ideas were intensified when Christianity became a power in the state; and some measure of legal protection was given to the slave class. When the Empire had ceased to expand and began to decay, there was no fresh importation of slaves by conquest: the slave-market being thus closed, slaves became of more value, and although bound to their master, were not usually sold by him; and, owing to the same cause, free labour became more and more employed. Diocletian commenced an organization of the Empire, not unlike the caste-system of modern India. Everyone was treated as the servant of the State; for he had to give of his labour, or of his means, or of both; and professions became fixed in families. Thus, public servants could not marry out of the collegium to which they belonged; the members of the curia were bound to their posts ; and the responsibility of the individual was transmitted to his family. By these means the public coffers were maintained: the State was organized against invasion at the expense of personal freedom. But the difference between the freeman and the slave was conspicuously lessened thereby. In the country, too, many leaseholders who could not pay their rent, and poor men who wished for an assured living, as well as captives or immigrants, became attached to the soil, yielding a portion of their produce to their master, but remaining personally free. It was found that slaves worked better on the same conditions. These changes took place with great rapidity in the fourth century after Christ, and it is safe to say that by the seventh century there was very little practical difference between serfs and slaves. In fact, the freemen had fallen and the slaves had risen to the condition of serfs. In cities serfs were converted into freemen by the operation of several causes. Many men purchased their freedom out of their savings; other slaves worked so ill that they were not worth their salt ; freemen were found to work better than serfs, and were needed for the defence of the city; for a freeman who has something of his own to defend will always fight better than a slave; the Church exercised its influence in getting masters to manumit their bondsmen; often by a public ceremony they gave freedom to their helots, to come into effect at their death; or they bequeathed a portion of their property to the Church, with the provisio that their bondsmen should become freemen and have a small allotment given to them out of the land thus bequeathed for their support; or they simply handed them over with estates to the Church. But the Church retarded as well as advanced manumission: it was unable to release, being a legal body, bound by acceptance; at all events, the Church found it convenient to retain its serf on this or any excuse, for, as St. Thomas Aquinas teaches, slavery is natural to some men and ordained by God. This, then, was the condition of the people at the time of the Lombard Conquest; and during the Lombard occupation the same processes went on. The fact that master and slave were equally subject to the conqueror had a tendency to obliterate the distinction between bond and free. But, since the lords hated paying widrigild, or fined compensation for injury, and preferred private warfare. 
at which they were adepts, and in which they were eternally engaged, they depended on their vassals during their frequent absence on the war-path ; and this, together with the advantages of free-labour manifested by neighbouring towns and the absence of the lords from their estates (for they resided partly in towns), tended to liberate or improve the condition of the country serf, though he was to be found in Italy even in the fifteenth century.

The Papacy now found itself confronted by a relatively strong monarchy at the very time when the Eastern power, which it had lukewarmly supported and even opposed, was enfeebled by the results of the great contest concerning images. Weary of religious strife and the puritanism of iconoclasts, religion was replaced in the East by hypocrisy, and the earnestness of both parties by the reaction of indifference and laxity of morals. The series of Exarchs of Ravenna, who were entrusted with regal power, was corrupt; they thought only of squeezing a fortune out of their subjects and returning with it to Constantinople. The Duke of Naples held almost independent rule over Gaeta, Naples, Calabria, and Otranto, territories separated from each other by lands that formed part of the great Lombard duchy of Benevento. Sicily, oppressed for her adherence to the Papal side during the iconoclastic disputes, was mulcted by increased taxation. There was an increasing tendency on the part of provincial governors to assume independent powers ; and the great trading ports, such as Amalfi, were practically autonomous. The connection between the component parts of the Empire was one of sentiment, and, while the possessions of Constantinople in South Italy were in the position of Crown Colonies, the tie that bound them to her was hardly stronger than that which binds the French of Montreal to the English King : they looked to the Emperor for what small defence he could supply ; they were content with a light yoke, and proud of the Roman name so long as they were let alone.

The sway of the Eastern Empire over Italy had been focussed at Ravenna, whence the Ostrogoths had been expelled some years after the able and tolerant reign of its conqueror, the great Goth, Theodoric. Admirably situated for communication with Constantinople, the city was defended on the land side by almost impassable marshes. The natural features of Ravenna remind us of that later Queen of the Adriatic-Venice. It was, indeed, the Venice of its time, though the original harbour had been silted up, and was now transferred to Classis, some little distance off. But there was still a water-way up to the city. The Exarch, representing the Imperial authority, delegated his powers to the governors of Rome, Naples, and those of Southern Italy. Ravenna was resplendent with fine churches and baptisteries adorned with those sumptuous mosaics which still feast the eye of the Italian traveller. Shortly after the middle of the sixth century the Lombards succeeded in establishing themselves in Spoleto, thus cutting off the direct communication between Ravenna and Rome; and, with a view to the acquisition of Naples, they took Benevento, which became the capital of a great duchy.

The historian is often supplied with full accounts of unimportant periods, while great events remain unrecorded or barely registered or the chronicles that reported them have disappeared. Such unwelcome ignorance is all that the ages have spared us concerning the fall of Ravenna. 
From the bare chronicles we only know that this last transformed remnant of ancient Roman power north of the Apennines fell to Aistulf the Lombard in A.D. 75I, fourteen hundred years after the traditional building of Rome. The meagre chronicles suffice to

\section{"shroud a ruin, and, below, The rotting bones of dead antiquity."}

The fall of the Exarchate, and the decay of the Imperial power in Southern Italy, left the Pope at the mercy of Lombardy. But, as always happened in times of dire extremity, a strong man then sat in the chair of St. Peter. Pope Stephen II. was resolved to defend his patrimony in and about Rome from trespass; and, as true representative of the city of Rome, he claimed the inheritance that had dropped from the grasp of the Emperor. Aistulf's reply was an invasion of Roman territory. He demanded the overlordship of the city and the fruits of a poll-tax to be levied therein. With all hope of aid from the East torn away, the Pope, in his extremity, had recourse to that fatal policy which his successors so frequently followed to the ruin of Italy. He called in a Sovereign of the West to redress the balance; he cried to Pepin, lord of the Franks, for aid ; he crossed the Alps, and to purchase assistance, consecrated and legitimatized the crown which Pepin had won by ability. In return, Pepin, with the title of Patrician, promised to defend the Pope, and crossed over Mont Cenis at the head of an army. Aistulf submitted, but his submission was insincere. He besieged Rome (A.D. 756), and Pepin, at the Pope's summons, again appeared, and handed the Exarchate over to Stephen. Henceforth the Pope claims this temporality by a double title-as successor to the Imperial representative of the ancient Roman power, and by a deed which the conqueror compelled Aistulf to execute. But the Lombards, though defeated, still continued to intrigue and threaten, and Charles, the son of Pepin, known to history as Charlemagne, crossed the mountains from Geneva. Desiderius, the Lombard King, had failed to win the affections of his people; there was, as usual, a fatal want of cohesion between the Lombard states, and the antipathy of the Roman aldus to his arrogant master prevented him, perhaps, from giving his sovereign right soldierly support. Pavia fell (A.D. 774), and the reign of the Lombard in Italy, which had lasted for two centuries, came to an end. Charles took the title of "King of the Lombards and Patrician of the Romans "; but he adopted the statesman-like policy of interfering as little as possible with his new people. He left the laws practically unaltered, and he put their administration mainly in Lombard hands. But he replaced the great authority of semi-independent dukes by that of counts, men who either were Franks or those Lombards on whose good faith he could rely. To these he delegated his kingly authority. The Lombard chieftains fretted under the light curb, and Charles found it desirable to place the iron crown on the head of his son, Pepin (781). The authority of the Frank extended over the north of the Peninsula only ; and, indeed, it did not embrace the whole of that region ; for Venice, never subdued by the Lombards, and theoretically a part of the Empire, still kept her independence. Across the Apennines the great Lombard duchy of Benevento, protected by the mountain masses of the Abruzzi, still remained free, though later she allowed the effigies of the King to 
appear on her coinage. Sicily and the extreme South were still integral parts of the Eastern or Byzantine Empire, governed by the Patrician of Sicily, but over Naples, Gaeta, and Amalfi the Eastern Empire exercised only the shadow of authority, and while loyal to their overlord, these cities, with their territories, enjoyed practical autonomy. Italy was thus politically divided into three great regions-Frankish Italy, the Italy which still remained practically Lombard (Benevento, and, to a less extent, Spoleto), and Byzantine Italy, to which must be added the Pontifical State, under the protection of the Frankish power. In vain did the Greeks attempt to recover their hold of the Peninsula: the wise and generous policy of Charles had prevailed, and the united armies of the Franks and Lombards, aided by the troops of Benevento, repelled them (788).

\section{Crowning of Charlemagne, A.D. 800}

In A.D. 799 a momentous event occurred in Rome, an event that has bound Italy and the North together for weal and woe, that was the exciting cause of the reconstitution of the Roman Empire of the West under a Teutonic Sovereign, and that originated the great political theory which occupied the imaginations of thinkers and influenced the practice of statesmen through the whole course of the Middle Ages. The slight source whence flowed so great a change in the speculation and polity of the world was a disturbance in Rome. Already the Popes had come to loggerheads with the turbulent nobility of the city of which they claimed to be First Magistrates. A sudden and brutal attack was made on the Pope, Leo III. The Romans tore out his tongue, an attempt was made to blind him, and he was confined in a monastery. Thence he contrived to escape, and took refuge across the Alps in the camp of Charles. The shock of such an outrage to the Vicar of Christ made it clear that Rome must be firmly governed; that Charles must be clad with an authority more awe-inspiring, and must assume a dignity commensurate with his power. In Constantinople the Empress Irene had seized, deposed, and blinded the Emperor Constantine, her own son ; and this deed of wickedness, shocked even the callous inured Constantinopolitans and roused the indignation of Western Christendom. Alcuin and the learned men of the West and North were full of what had been retained of the literature of Rome and the traditions of the great past; they bemoaned that the Eastern fragment of the Empire had fallen into the hands of a wily, ambitious, and criminal woman. Milan, Trier, Ravenna, once capitals of the Empire, were now ruled by Charles, and was he not the protector of its heart-Rome itself ? Alcuin wrote to Charles, pointing out that hitherto three people in the world had had station higher than all othersthe Apostolic Sublimity, the Imperial Dignity and power of the second Rome, now deposed, and the Royal Dignity of Charles himself, more powerful, wise and sublime than the other twain; on him now reposed the whole salvation of the Churches of Christ (Alcuin, Ep. I 20). The times were ripe for the assumption of the Imperial title by the man who possessed its power; who ruled so many of the lands comprised in the Western Empire; and who was monarch of a country never visited by Cæsar's eagles ; one, moreover, who was the loyal defender of orthodox Christianity, and a friend to the Holy See. The age was ready for the 
consolidation, under temporal and spiritual headships, of the new social order that had grown up from the introduction of Christianity and the movement of the Teutonic races into the enfeebled Empire of the West; those ruins could be repaired and reconstructed into a temple fairer than before, so men thought, because consecrated to the service of a God that the great race of early Emperors, Augustus and Trajan and Hadrian and the Antonines, had never known. Leo, and afterwards Charles, returned to Rome, the first in 799, Charles in 800 A.D. ; both were received by the great dignitaries of Rome, civil and ecclesiastical, by the body that called itself the Senate, by the militia and the members of religious houses, by the guilds of Franks, Frisians, English, and Lombards resident in the city, with waving of banners and singing of psalms. The keys of Calvary and the Holy Sepulchre and the banner of Jerusalem were sent by Haroun al Raschid to the great King ; for there was an " entente cordiale " between the Saracens of the East and the Frank as opposed to a similar understanding between the Emir at Cordova and Constantinople. " "It was in a certain sense a recognition that the holiest place in Christendom was under the protection of the great monarch of the West, and in so far it helped to prepare men's minds for the impending revolution" (Hodgkin).

It was the fourth visit of Charlemagne to Rome. On Christmas morning (A.D. 800) Charles proceeded to worship in the basilica of St. Peter's. Around him were gathered his son Pepin, his daughters, the chivalry of the North, the native nobles that boasted their descent from Roman senators, the great ecclesiastics, and no small sprinkling of the leading spirits of a realm that extended from the Atlantic to the Baltic, from the Oder to the Ebro. Mass was said, and at the moment of Sacrifice, the Pope approached the commanding martial figure of the great warrior and placed a golden crown on his brow. The Roman citizens hailed Charles with shouts of "Augustus, Emperor of the Romans, crowned by the hand of God !" The momentous link between the Middle Ages and the ancient world had been forged.

It is possible that, as Hodgkin suggests, Charles, before taking the great step, like Julius Cæsar, like Cromwell, experienced much swaying of mind and many misgivings. For since, in theory, the Empire remained one and indivisible, his assumption of the title of Emperor was a challenge to the ruler of the New Rome. Constantinople still claimed the authority it was powerless to enforce. While the Empire came to be considered as a resuscitation of that of Romulus Augustulus, this may not have entered into the mind of the practical Charles. It was repudiated as soon as formulated by the Byzantine monarchs. So great a statesman must have been aware of the unsupportable offence that the Imperial assumption would give to the Eastern Court; he would foresee how dangerous a precedent the bestowal of the Imperial crown by the Church would institute. ${ }^{2}$ On the other hand, he must have realized the need of

1 A carved elephant's horn, presented by the great Caliph to the great Frank, is still preserved in that most magnificent repository of mediæval art, the sacristy of Aachen.

2 It is significant that the Emperor was careful to avoid the presidency of any Bishop when he nominated his son, Louis the Pious, as his successor, and admitted him to share his Imperial office. 
re-establishing the fundamental principles of the Roman administration in Rome, its disorganized centre, and that the authority of the actual monarch would be supported by his bearing the Imperial name. Moreover, it was desirable to weld and cement power that spread over such a wide area, over such diverse races, and that had been so recently acquired. From this deed of Leo III. arose the political ideas and ideal of so many centuries, that it is necessary to suspend our narrative while we consider the results of the scene that was enacted in the gloom of the apsidal tribune, above the reputed tomb of Rome's first Pope, St. Peter, on that fateful December morning.

\section{Results of December 25, A.D. 800}

I. The advent of the barbarian hosts brought fresh and disturbing elements both of blood and organization into Italy. The great work attempted by Charlemagne was to reduce his Empire to some measure of systematized government. Early Teutonic society was markedly individualistic: individualism is the dominating characteristic of the Germanic temperament. The early political organization of the Northern barbarians was personal in character: every free man had his alod or freehold; occupation gave him his arable share, not necessarily an equal share, in the lands of the tribe, with rights of forest and pasture ; the only obligations he owed were service in war and presence at the tribal council. But become conquerors, this primitive organization no longer served; personal became changed inot a territorial constitution ; individual liberty was modified; tribal autonomy disappeared. Charlemagne gathered up the growing tendencies of his time and systematized them; divided his Empire into districts which he placed under counts; made these responsible for the good government of their countries; placed Margraves on the Marches, or borders, with troops to defend them ; and sent inspectors, clerical and lay (missi dominici), all over the Empire to supervise and tighten the constituent elements of his realm. It is a proof of how effective this system of Charlemagne's was, that, disorganized and dissolved as the Empire became in the hands of his heirs, Otho I. was called in by Italy to re-establish the old order a century and a half after Charles's time.

But the feudal system thus initiated by Charlemagne rooted that spirit of individualism characteristic of the Northern tribes ; neither Otho nor the Church succeeded in quelling the results of the discord that reigned in Italy before and after Charlemagne. The old Latin spirit was different ; it was a spirit of association. We shall find in our examination of the Italian communes or republics the resuscitation of Latin race and Latin traditions in the cities; we shall find them taking the first place in feudal Italy, because their spirit of association enabled them to take advantage of anarchy due to the importation of individualism from beyond the Alps; but we shall also find that individualistic spirit has entered within the walls of the commune itself, and between the several communes. Charlemagne introduced a clever compromise-which, however, only endured for a short season-between these two opposed principles of individualism and association. These two forces will be discovered maintaining themselves and acting in perpetual opposition. 
2. The crowning of Charlemagne increased the influence and power of the Church. From it flowed the pretentions of the Papacy to the homage and obedience of the Imperial Crown and of all Christian Princes. The great political concept of the Middle Ages derives from "this one ceremony wherein the first Emperor received his crown from the hand of the Roman Pope" (Dahn, Bausteine). This concept is that of the Two Swords-one the Pope's : he is the spiritual head of Christendom ; the other the Emperor's : he administers and maintains temporal justice. It was an ideal which, in its regulative results, was of vast service. For it was in some measure a restraint on the barbarian forces of Europe ; it helped towards a common civilization; it required of all a common fealty to State and Church. On the other hand, it deluged Italy in blood; and, could it have been realized, it would have rendered Europe as unprogressive as China in her long trance. Happily, the passions of Pope and Emperor and the constant quarrellings in a feudalism wholly incompatible with its ideal compelled this concept to remain a dream, though a dream not without a very real and marked effect.

3. This great event gave birth to the notion that the Imperial dignity necessitated sovereignty over the citizens of Rome, and could hardly bc lawfully assumed except in Rome. Italians, and still more Germans, perishing, either by the sword or by the fatal fevers of the South, bore fell witness to the calamitous results of this theory.

4. It followed from the concept of the State, thus inaugurated, that Latin should become the language of the State, of the school, and of commerce, as it already was of the Church. The unity and solidarity of peoples was fostered thereby ; and the relics of a perished and superior civilization were thus rendered accessible. Nevertheless, the advantage thus gained exhibited attendant defects. The development of national languages and literatures was retarded. And the ancient world came to be considered as sacro-sanct, the only authoritative voice besides the Church, the sole foundation of all human knowledge. Not merely was antiquity regarded as a Divinely appointed harbinger, but there was held to be absolute organic continuity between it and existent Christendom. For God prepared the world for the Empire (which still existed), and through the Empire for the Church. Thus it happened that the Middle Age, while ever diverging more and more from the spirit of ancient Rome, was so convinced of its identity with the Roman Empire that, even far on in the Renaissance, it never occurred to poct or painter to treat the ancients as other than a feudal people. Yet the spirit of ancient Rome had been wholly lost for centuries, and it was rediscovered and reabsorbed in a transmuted form by the Renaissance.

5. Later on, when Roman Law came to be studied, it was adopted on account of unquestioned belief in the legitimate unity and continuity of the new German with the old Roman Empire. He who would comprehend this must remember that, to the mediæval mind, at once subtle and crude, directly philosophy began, abstract conceptions were held to have a real existence ; and while there was little search for causes, there was an unwearied examination of properties. The Church, mankind, and other general notions, were, by most thinkers, held to be in themselves real, and only embodied in this or that individual. Hence arose the demand that Church and State, as the twofold expression of God's 
reign on earth, should have an outward bond of form corresponding to its real being. Perhaps even more remarkable than the power of associating our ideas is the facility with which we yield to their dissociation, and with no insincerity of aim permit the separation of practice from theory in a manner grotesquely unconscious. Hence we shall not be surprised to find that mediæval man, unable, as all uneducated and halfeducated people are, to rise far above the concrete, was perfectly contented to violate every ideal and regulative principle of his confession, provided that his faith was duly honoured and unquestioningly acknowledged.

5. The advent of Charlemagne and his acceptance of the Imperial power had a very noteworthy consequence to Italy. She had never forgotten the world-wide dominion of Rome. The Northern nations were greatly indebted to the Roman civilization: it influenced their civilization and their laws, but it did not enthral them ; it was dead before their birth; and between it and them there was no real historic continuity. Italy, on the contrary, was conscious of her vital connection with Rome. Hence, while the peoples north of the Alps worked out their own salvation in their own way, Italy was ever held in check by the dead hand of her past. She dreamed a dream of the vital presence and indestructible authority of the vanished Empire; and she was dominated by the illusion of its real existence when she leaned on the support of the Augustus of an alien people. Not once, but many times, in the history of the Holy Roman Empire we find the Italian cities seeking for support outside themselves. Incapable of Federal Government, a principle that appears in far more modern times, the hundreds of small states in Italy relied on the substantial reality of what was only a phantom of the past. Over and over again they were disillusioned; over and over again a new generation dreamed the old dream afresh, and awaited its feudal Cæsar ; yet once more to have its hopes and fallacies dispelled. Too often the alien eagle brought no healing on its wings, nor was its power sufficient even to establish the shadow of justice and rectitude among warring municipalities. Intercivic anarchy remained untouched; for the pax Romana, once established by veteran legions, was now supported solely by the ephemeral feudal armies of aliens, bound to short service only, that vanished like snow before Italian pestilence, or were soon recalled over the mountains by feudal quarrels at home.

6. Not merely was the sovereignty thus established by the Emperor of the Franks fatal to any Italian unity, but it prevented Germany herself from becoming a strong, compact kingdom. The constant descents which the lawless confusion of Italian affairs demanded drained the Teuton of his resources ; and the frequent absence of the supreme ruler encouraged disaffection among native princes, who were never remarkable for constant and regular compliance with Imperial demands.

\section{The Times of the Carolingian Emperors}

In the year of grace 800 A.D. the most prescient statesmen foresaw nothing of this great theory and the unfolding of the great drama that was to follow the first scene. The greatest among them was a practical man of affairs, wholly occupied in dealing with the pressing problems of 
the hour. He desired to be accepted by the Lombard nation as its head, and he was careful not to institute any violent change in its government. But he appointed Royal Commissioners (missi dominici) with general powers, and introduced a jury system, whereby scabini, appointed sometimes by the count and people conjointly, sometimes by the Commissioners, decided questions, not of fact alone, but also of law. The prestige of the Church was immensely increased by the coronation of Charlemagne, and he added to her power by augmenting that of the bishops in cities. 'To these he gave conjoint jurisdiction with the counts; doubtless as a check on the centrifugal tendency of those great officers. He instituted schools, and issued an eightfold ban, six articles of which were in defence of women and the poor. The legislation of the Lombards had already been marked by progressive liberality and mildness : the husband of a wife seduced by her master was set free ; the right of sanctuary, so valuable in lawless times, was endorsed; regulated penalties were substituted for arbitrary punishment ; and the mild influence of Christian teaching on the rough Lombard is exhibited in the words of King Aistulf: "It seems to us of the greatest advantage that slaves should be led forth from bondage to liberty, forasmuch as our Redeemer Himself became a slave that He might grant us our freedom."

Pepin, King of the Lombards, was his father's right hand in Italy. He brought the Duke of Benevento to his knees, drove the Saracen from the neighbouring islands of Sardinia and Corsica, and then turned his conquering arms to the lagoons of Venetia, where the inhabitants were already busy in manufacturing the wools of his father's kingdom into cloth for the merchants of Bagdad and the thriving valleys of the Euphrates and the Tigris, and transporting the ostrich feathers of the Sahara, the furs of the Euxine, and the pearls of the Orient, to adorn the fair chatelaines of rude castles of Rhône and Rhine. There was, in Venetia, a proFrankish as well as a pro-Byzantine party; and by 806 , however it may have happened, Venetia and Dalmatia werc added by Pepin to the new Empire. They were transitory possessions.

Charles was bent on appeasing the indignation and vanquishing the opposition of the Fastern Crown. He secured peace by relinquishing the lagoons and Dalmatia to Byzantium (A.D. 8II); but the astute Venetians, perceiving what was adrift, had already transferred their capital to Rialto-a position accessible to a trader, but impenetrable to a foe-and there they laid the foundations of that mighty and beautiful city, that, secure on the waters, owed allegiance to neither West nor East, escaped the anarchy of feudalism and the more peaceful but debasing rule of the despot, achieved her own destiny, and succeeded in maintaining her own independence for a whole millennium.

As Hodgkin remarks, " that feudal anarchy, which, with unintentional irony, has been called the feudal system," was deep rooted in Teutonic nature. Charlemagne was obliged, in his capitularies, to sanction the practice of private hostilities carried on by force of arms; benefices were held of Church or King by doing service ; the lord had his followers, and even the word vassal is used. But Italy, under his wise and beneficent administration, depopulated as it had been by slavery under the Roman Empire, by incursions of rude barbarians, and by intestinal warfare, began to flourish once again; once more the "waveless plain of 
Lombardy" responded to the diligence of the farmer, and began to be stocked with homesteads and herds. By 825 A.D. Verona, Milan, Parma, Siena, and Rome were provided with schools of instruction, and the trade of the cities revived. Charlemagne was followed by successors of far feebler character than their great sire-men unable to contend against the disruptive forces of their time. Pascal I. took care not to wait for the Imperial consent before ascending the pontifical throne ; and Lothaire, on his death-bed, enforced nine famous constitutions on the Papacy, and extracted an oath from the new Pope to be loyal to the Emperor. Under the degenerate descendants of Charlemagne public spirit decayed, personal violence increased; jealousy, defiance, and disdain rendered even neighbouring villages hostile to each other; it became dangerous to sow the fields; the crops were subject to plunder or destruction; and wayside robbery was the rule. For, in the quarrels of the royal line, the contending monarchs were obliged to purchase the help of their subjects by concessions that were fatal to their own authority. The result was such disintegration, that, throughout the vast territory, it would have been difficult to find a province, city, or town where the kingly power was not held in contempt, nor where duke or marquis, bishop or count, had not really usurped it. The decay and disintegration of the Empire caused by the wars of the descendants of Charlemagne brought the unity of the Church into bold relief, and increased the authority of the Roman Pontiff : the Papacy became, not merely the strongest temporal power in Italy, but the strongest moral influence throughout the West. This was the period that expressed its bias and desire in the famous fiction of the "false decretals"; it saw a Pope again dispense with the Imperial sanction. The Saracens were not slow to take advantage of the weakness of Europe. The Moors of Africa sailed for Sicily at a time when Constantinople was enfeebled by political strife : in 83I they took Messina, and when, in 832, Palermo fell after an heroic defence, they were still fighting their way through the island. Meanwhile other Saracens had captured Bari and overrun a great part of the duchy of Benevento. Pillaging hordes of unbelievers pushed up to the very walls of Rome and ransacked the basilica of St. Peter. The eldest son of Lothaire the Emperor, Louis, King of the Lombards, drove the Saracens back as far as Gaeta, and then met with a reverse, wherein a large part of his army perished. Thereupon the Saracens sailed a fleet up the Tiber and desecrated the churches of the Apostles St. Peter and St. Paul, but were in insufficient force to carry the walls or besiege the city. They retreated to reinforce; and it looked as if the Koran would shortly replace the Missal in the capital of Latin Christianity. But Leo IV. (847-855), a Pontiff chosen, during these days of anxiety, from among the stout nobility of the Campagna, repaired the walls, disciplined the militia, summoned aid from Naples and Gaeta, and succeeded in daunting the invading host, which reset their sails to the south. Sicily was now almost wholly under the heel of the Saracen; Arab corsairs from Spain and Morocco had pillaged the harbours of the South, and had even occupied for a time the port of Naples; the shores of Calabria were periodically ravaged by corsairs from Palormo, and marauders from every part of the Mediterranean threatened the entire coast-line of the Peninsula. A league of the cities of the South had sent opportune help to Leo in his hour of danger; 
and for the complete comprehension of the political condition of Italy it becomes necessary to turn our attention to the evolution of events in the South.

It will be remembered that the Lombards, during their conquest of Italy, had pushed south, and, probably with designs on Naples, had established the great duchy of Benevento, which isolated Rome from the arrival of Greek aid from the South, as the duchy of Spoleto isolated it from the support of the Exarch of Ravenna. Betwoen 67I and 678 they conquered Brindisi and Taranto, and, later, Otranto fell to their arms. They extended their sway down to the coast at several points, so that the possessions that owed allegiance to Constantinople were but patches of territory isolated from all communication with each other, save by sea. The toe and heel of Italy still remained Greek; so did the duchies of Gaeta and Naples. Gaeta, strongly fortified, occupied an almost impregnable position on a bare sea-cliff, and commanded a region of sub-tropical luxuriance lying between the vineries of Mount Cæcubum and Mount Massicum, so familiar to lovers of Horace. Naples, a day's journey to the south, was also well defended against attack ; and smiling Sorrento, included in that duchy, was almost unapproachable save by sea; while round the promontory lay the town of Amalfi, renowned for its commercial enterprise and prosperity, with villages around, some nestling in the rocky recesses of the coast, others perched like eyries on the mountain cliffs above; all half-hidden by olive and orange and the foliage of the South ; to the south Salerno, an important city, was close to the Lombard confines ; but a few miles off was Pæstum, so celebrated in classic times for its " twice-blooming roses," now a malarious plain dotted with a little fortified town and deserted temples. All these places owed allegiance to the Empire. But the cities, while they owned Greek supremacy, were allowed no small measure of municipal freedom ; they elected their own magistrates, their own local taxes were self-imposed ; and in the enfeebled condition of the Empire, they defended their own walls by a militia of disciplined citizens. When Ravenna fell into the hands of the Franks, these Greek towns were placed under the Patrician of Sicily, to whom the military governor of Naples was subordinate. In spite of the loose hold of the Empire over its Italian possessions, the presence of the barbarian at their gates kept these loyal to Byzantium ; and in liturgy, and even in language, they were becoming more Greek than Latin. And though the endeavours of Leo the Isaurian to suppress image-worship in the beginning of the eighth century caused revolt, the Eastern Crown, which had lost Ravenna in the same dispute, had the wisdom to give way. A great part of the South owed a double loyalty; politically to Constantinople ; ecclesiastically to Rome. Obliged to rely on self-defence, and divided from each other by the foe, the provinces tended towards autonomy. Towards the end of the eighth century we find a Duke, who was also the Bishop, ruling Naples; the duchy, which became dynastic, extended from Cumæ to Salerno (Capasso, Monument. ad Neap. duc. hist. pert. Naples, I88I-I 893). The independence of this territory was often threatened by the Lombards of Benevento; Naples was frequently besieged and compelled to furnish contributions, and for twerty years $(820-840)$ she only avoided occupation by becoming tributary to her powerful neighbour. Thus, harassed by Lombard and Saracen alike, 
and unsupported by the nerveless hand of her own Emperor, Naples repeatedly sought the aid of the successors of Charlemagne.

The duchy of Benevento, practically independent of the Lombard Kings, though promised by Charlemagne to the Pope, remained an independent sovereign power that comprised the greater part of Southern Italy. Yet, though protected from invasion by the mountain-fastnesses of the Abruzzi, the geographical character, which was the defence of the country, lent itself to the insubordination of local chieftains; and the energies of the Duke were mainly absorbed in quelling insurrection and gathering taxes by armed force from the more distant provinces of his state. Benevento had, however, no satisfactory ports, though Salerno had been an early acquisition; and, in 836 , the unhappy inhabitants of Amalfi were transported to Salerno, with the object of clearing the way to the conquest of Naples. Sicard, the reigning Duke at this time, forced the Amalfitans into marriage with his own subjects, in order to "Lombardize" them, and he endeavoured still further to secure their allegiance by conferring on them the same rights that were possessed by the Lombards themselves. But, at the news of his assassination, the patriotic Amalfitans rushed to the port, seized and manned the vessels lying there, and sailed back in triumph to their old home, which they reoccupied and fortified (839). Meanwhile the threatened Neapolitans had been compelled to call in Saracen aid, an example which later on was only too freely followed. ${ }^{1}$ The independence of certain coast towns, such as Gaeta and Amalfi, which were practically independent of Naples-an independence of the predominant Lombard preserved for more than two centurieswas due to the bad military organization of the duchy alone. The duke was constantly at war with disobedient vassals, who instituted little dynasties more or less defiant of the central authority, that could not gather the whole of the forces which, theoretically, were at its disposition. The duchy was now feeling the effect of the hostilities of many generations, and Salerno, in an admirable position both for trade and defence, outstripped Benevento, which had only military importance-that of commanding the route from north to south and from sea to sea. The rivalry between two cities having opposed interests led to a series of civil wars, in which Saracens were employed, but at last a partition was arranged, whereby the Adriatic provinces fell to Benevento and the Mediterranean to Salerno. Even this did not end the strife, and in the dissolution of the State, the Duke of Benevento was left with his capital only. During these disastrous wars colonies of Saracens got firm hold of the mouth of the Garigliano, Cumæ, Agripoli, and Misena, and in 846 Gaeta was besieged by them. Naples, Amalfi, and Sorrento now formed a league, fought many sea-battles, delivered the city, and, reinforced by its militia, proceeded to relieve Rome from the same danger.

The little territory of Amalfi, protected by surrounding hills which furnished the material for shipbuilding, had become famous for its com-

1 The text of the treaty between Sicard, the Duke of Benevento, and the Bishop, Military Commander, and Republic of Naples is still preserved. It is interesting to note the pre-eminence of the Bishop as defender of the city; it will be remembered that Charlemagne gave bishops conjoint authority with his counts ; and a little later on we shall find the Bishops of Lombardy emancipating their cities from external control. 
mercial enterprise. Its overhanging cliffs and rugged coast bred a hardy and adventurous race; and in the middle of the ninth century the little community rivalled, if it did not eclipse, Naples in maritime success. Naples had called in the Saracen to aid her, but the danger from Benevento was becoming less, and that from the Mohammedan greater day by day, and Amalfi joined hands with Naples, Sorrento, and Gacta against the common foe.

From 849 to 866 Apulia was in the hands of the Saracens. They formed an autonomous government at Bari, defeated Louis, the Emperor, and his Franks and Lombards that the monks of Monte Cassino summoned on more than one occasion, devastated the environs of Naples, and raided the upper valley of the Volturno. The Government at Byzantium had been unable to keep the Moslem out of Sicily. The descendant of Charlcmagne, weakened by quarrels with the other princes of his house, was further paralyzed by Pope Nicholas I., who haughtily bade monarchs obey pontifical direction, and refused to admit the authority of Louis in the Pontifical States. For the Pope's example was followed by almost every feudatory throughout Italy, and even the smallest squires built and fortified castles under the pretext of repelling the ravaging bands of the heathen. These strongholds were nothing but centres of offence to their neighbours and shelters for raiders. The great Duchy of Benevento, that should have been the first line of defence, was in a chronic state of dissolution, and it seemed as if Italy must share the fate of Spain. In these straits Louis entered into negotiations with Constantinople, and by a stupendous effort with inadequate forces took Bari, the stronghold of the Saracens in the peninsula (870).

Directly the great centre of Saracen power was captured questions of authority and ecclesiastical jurisdiction arose between the two Emperors, of whom one affected to regard the other as a usurper. And the conduct of the Franks on their return to Benevento caused a rising, during which the Emperor and Empress were kept for forty days imprisoned in a tower by the vassal duke. The natural result of this division in the Christian camp was the renewal of Saracen hopes; but these proved fruitless, and Louis, after a brilliant victory over the Saracen army near Capua, took advantage of the lull that followed to try to reassert his authority. Benevento thereupon entered into close relations with Constantinople, and Louis, disheartened and disillusioned, withdrew to Brescia to die (874).

The citizens of that new Rome of Constantine which replaced the old Greek city, Byzantium, resembled some noble race, degenerate indeed, but conscious of a great tradition, wherein ever and anon the ashes of sires long dead would appear to glow once again with life in their descendants, and where some happy admixture with a ruder stock seems sometimes to impart new vigour to their enfeebled vitality. For 800 years Constantinople, or Byzantium, was the safeguard of the East against the Moslem, and at this period, under the strong, resolute rule of the Macedonian dynasty, she resumed her role of protectress of the West. Driven inch by inch out of Sicily the Greeks re-established themselves, only the more firmly, in Calabria. They occupied Bari and Taranto, and prepared to re-establish their ancient predominance in Italy. By 880 , after a campaign by land and a prolonged naval contest, the grip of Constantinople was firmly fixed along the Gulf of Taranto; but, now that the Saracens were no longer at their gates, 
Capua, Salerno, Gaeta, Naples, and Amalfi came to an understanding with the Mohammedan. The trading communities of the western littoral preferred trade to warfare. Friendly relations with the Saracen gave them easier access to the products of the East, they were not reluctant to accept their share of the spoils of war, and their neighbouring rivals and enemies were the sufferers in the contest. On the personal intercession of the Pope, Capua and Salerno detached themselves from the Moslem alliance, but Naples, under its bishop-duke, and Amalfi continued a philoSaracenic policy.

Meanwhile, in the North, dissensions in the royal house reduced the wearers of the purple to be none other than the helpless puppets of intrigue. The designated successor of Louis was rejected by Pope John VIII., whose assumption of the right of bestowing the Imperial crown led to fierce contest between the rival branches of the Carolingian House. Once again the Saracens, taking advantage of Christian anarchy and weakness, sent a piratical horde to Rome, and made the head of Christendom tributary to the witnesses of Islam. The rivalries of the Carolingians remained unabated, and were, indeed, supported by the discord in the Church. For Lombard Milan had a ritual of its own, and always strove for independence of Latin Rome, and there was chronic antagonism between the two sees. The Archbishop of Milan maintained that the Lombard crown, carrying with it the kingship of Italy and the Imperial office, were distinct, and that the first belonged to Milan, the second to Rome. Each prelate supported his own candidate, but at last the Pope, still menaced by the Saracens, gave way, and Italy, overrun by the Moslem, Germany by the Slav, and France by the fierce pirates of the North, became united under the unsubstantial rule and feeble administration of Charles the Fat. It was not long before the incompetency of Charles. led to his deposition; the last of the phantasms that closed the line of the first great Emperor disappeared into the silence of the cloister, and the shadow of empire dissolved in the reality of feudal strife (887).

It was a time when strong centralized authority seemed more needed than ever. The most striking feature of this age of dissolution is the Moslem advance. While the princes of Italy were tearing each other to pieces the Saracens were masters of the Mediterranean ; Sicily and Calabria, were in their hands; the waves of Moslem advance showed a rising tide. John VIII. wrote in a vain appeal to Charles the Bald: "If all the trees of the forest became tongues they could not describe the ravages of these impious pagans ; the devout people of God are destroyed by continuous slaughter; he who escapes fire and sword is taken into slavery. Cities, castles, villages, are wasted, and are without a living soul ; bishops wander and get their bread as beggars, or flee to Rome as their only place of refuge " (Ad Carol. Calv. Imp. apud Bouquet, p. 47I). And again': "All Campania is a desert." Indeed the capital of Christianity was in danger of falling into the hands of the infidel and becoming a little Moslem town. 
Italy from the Deposition of Charles the Fat (887 A.D.) to the Imperial Coronation of Otho the Great (962 A.D.)

The decay of Carolingian authority in Northern Italy was, however, followed by the restoration of Byzantine power in the South. The Moor, indeed, remained dislodged in Sicily, and made that island a base whence he repeatedly invaded the mainland, harried the countryside, and destroyed the great Lombard monasteries. Even in the face of common danger the rival ambitions and discords of the Lombards continued, and gave opportunity to the Greek to intervene; he took Salerno under his protection, and contrived to get his ancient overlordship acknowledged by Gaeta and Naples, where, indeed, some sort of control was imperatively necessary. One of the many militant bishops of the latter town, wherein ecclesiastical power predominated (as it tended to do in all free cities), a man remarkable for culture and learning in a city which was far more polished than Rome, had manifested no hesitation in allying himself with the Moslem (Gay, L'Italie Merid. et l'Emp. Byz., Paris, 1904, p. 137). After a long contest, marked by the fluctuations of fortune, the Greeks and their allies achieved a crowning victory at the mouth of the Garigliano, and subsequently succeeded in expelling the last Moorish settlers from the Peninsula (915).

But Sicily was already irretrievably lost, and had passed into Moslem hands. And though the Greek founded "themes" of Calabria and Lombardy, his control of Lombard territory was rather nominal than real, while even in Naples, in spite of old Imperial tradition and eager acceptance of Byzantine culture, the schism which divided, and was ultimately to separate, the Eastern and Western Churches was felt. Naples clung to autonomy and the authority of her own Pontiff-warriors. Amalfi, too, was inspired by passionate local patriotism. Towards the middle of the ninth century we find her governed by one, and sometimes by two, magistrates, and M. Gay is of opinion that these represented certain leading opulent families which divided authority between them. But towards the close of the century the headship of the little republic was already tending to become an hereditary office. The merchants of that illustrious little commune traversed the Mediterranean and had relations with Antioch ; they had a footing in the ports of Syria, and carried on an extensive commerce with the Saracens of Sicily (Gay, pp. 248, 249).

In the North the deposition of Charles left the country in the possession of certain great lords and ecclesiastics, and of a multitude of smallor nobility. The great duchies of the Lombards had become diminished in number by absorption at the hands of some feudal lords and by the subdivision of the lands of others. The Marquis of Ivrea was charged with the defence of the Western passes, and the Duke of Friuli with that of the defiles of the Julian Alps. The ancient cities of Verona, Milan, Pavia, and Turin either preserved the relics or had acquired the germs of freedom under ecclesiastical rule, while two seaports that had been unsubdued by the sea-hating Lombard-Venice on the east, protected by her lagoons, and Genoa on the west, separated from the great plain by the Apennines-enjoyed municipal institutions and complete freedom. Pisa had been favoured by the Lombards as a warder from Byzantine attack, and 
possessed semi-independence; but Tuscany was under Lombard rule, and Umbria and the surrounding country were dominated by the Marquis of Spoleto. ${ }^{1}$ In central Italy the Pope administered his patrimony, and had apparently control of the commune of Rome; but, no longer supported by the Empire, he was already confronted with the insubordination of neighbouring barons.

The fall of the Carolingians brought the old antagonism between the Archbishop of Milan and the Pope to the front. Milan desired to give the iron crown of Lombardy to a Lombard; the Pope to the Duke of Spoleto, now ruler of a part of Benevento, a prince powerful enough to protect him against the pretensions of the North and the Saracen and Greek of the South. Berenger, the Lombard, relied on the Germans, the Duke on the French, and terrible and protracted wars followed, which corrupted the Papacy and weakened the Crown. Receiving the royal insignia from one Pope, Guido of Spoleto found himself opposed by the next, whom, desirous of founding a line, he had compelled to crown his son. The Pope in question, Formosus, resented the presence, so near to the Tiber, of a protector who would assuredly become a master, and appealed to Eerenger, who in his turn summoned the aid of the German King, Arnolph. Arnolph accepted the invitation, and descended into Italy, accompanied by a cruel and brutish army. No sooner was he crowned than Berenger and the Duke of Spoleto came to terms, and divided the country between them. Berenger aspired to the Imperial crown, and the Marquis of Tuscany opposed Louis of Provence, a member of the old Carolingian line, in his pretensions. Directly Louis was crowned, the Marquis, to preserve his independence, sent to Berenger, who was in exile, to return, and an arrangement was made whereby Berenger reigned in Pavia over truncated territory. In 9 5 Berenger was crowned as Emperor, and his foes summoned the Duke of Burgundy to attack him. Reduced to extremities, Berenger invited the Magyars to his aid, opened the passes of the Alps to them, and saw Pavia burned and North Italy ravaged on his behalf. Then came the assassin's dagger, and ended the stormy life of Berenger I. (924).

Nor were these the only horrors that mark this debased and bloody period. The Hungarians or Magyars invaded Italy (A.D.900). They defeated Berenger, who then opposed them, they overran Lombardy, infested Central Italy, threatened Rome, and established themselves in Southern Italy, where we hear of them as being at Otranto half a century after their first appearance (Ann. Benevent, 947). Consisting of small companies of light cavalry, these heathen were able to slip behind the clumsy, heavilyarmed horsemen and the slow militia of the towns; and the great feudatories were for years occupied in chasing an enemy that they never could come up to. These Turanian pillagers never mingled with the Italians, nor influenced them in any permanent way. Liguria, too, was ravaged by the Saracen riffraff of Spain, a race that penetrated even into the recesses of the Alps, and gave names to more than one snowy member of that noble chain. The opposite coast of Italy was also subject to piratical raids by Slavs from Dalmatia.

The crown was now offered to Hugh of Provence, and became the cause

1 The designations "Duke" and "Marquis" seem to have indicated equality of rank. The mark indicated the limits (marches) of territory. 
of incredible and infamous intrigues only possible in an incredible and infamous age. The object of so much desire is the name of authority without the fact, the liberty to command vassals, who, withdrawn from the towns, had built them each his castle on his own point of vantage in his own domain, to attempt to coerce contumacious and walled cities, ruled by uncompliant priests, or jealous equals, to whose divisions the monarch owed his crown, and by the maintenance of whose antagonisms he alone could preserve it! It is commonly accepted that feudalism never took root in Italy. The reverse is the case. Italy is the country whore feudalism, in its essence, most flourished and longest survived. The essence of feudalism lay in the delegation of authority, on condition of support, by a central Power, unable of its own force to exact the obedience it claimed, or to execute the justice it imposed. The natural issue was a perpetual state of warfare-a struggle for existence, wherein, elsewhere, the strong lord acquired and consolidated true monarchical power. In Italy alone, owing to a variety of interfering forces, the disorders attendant on the weakness of central authority continued throughout the Middle Ages, and if the peculiar constitution of feudalism there was less marked than elsewhere, its real nature was more agile, and it endured for a longer time.

In the anarchical struggle for power or bare existence in the tenth century the Papacy became debased to its lowest ebb, and the scandals of a later age were forestalled. The fascination of female favour was exerted in the papal court no less than in the feudal, and women of high birth, strong character, and disreputable life raised their lovers or their sons to the tiara. The Chair of St. Peter almost became the appanage of the Counts of Tusculum. The Iron Crown only continued to exist because it afforded a rallying cry to a party. Torn by anarchy at home, and threatened by heathen from across the mountains and the seas, sharing with the rest of Europe in the evils of dissolving society and heathen incursions, it is not surprising that the century should have believed in the approaching end of all things.

Hugh of Provence, recipient of the Iron Crown-married to Marozia, who, with her mother Theodora, had held the keys of St. Peter's attached to her chatelaine-appeared likely to attain the Imperial crown. The powerful Marquis of Tuscany was his brother; a son-in-law was Pope. But his overbearing conduct to another son-in-law, Alberic, and to the Romans, led to his expulsion from the city. He bore himself bravely against Saracen corsairs, and then transplanted a colony of them to Friuli as a sort of little standing army (940), and lost thereby the support of his feudatories. Berenger II., Marquis of Ivrea, who had suffered injustice at Hugh's hands, escaped by the aid of Lothair, Hugh's son, to the Court of Otho of Germany, where he was well received, and where he gathered some of his discontented countrymen around him. At the head of a small but ever-increasing army he reached Milan, and convoled the states of the kingdom (945). As Liutprand observes, the Italians preferred to serve two masters in order that either might be restrained by fear of the other. So they put Lothair, the son of Hugh, on the throne, and appointed Berenger general administrator of the kingdom. It is difficult to extract the truth from prejudiced and partisan chroniclers, but it appears that Lothair was not disliked, and his wife Adelaide was adored. They say 
that Berenger, finding his power decrease daily, caused the death of the young King by poison, and manœuvred so that he himself was crowned. But he became possessed of little more than a title; he was really powerless to restore order among ungovernable bishops, defiant vassals, and contemptuous and contending factions. To restore order was wholly impossible ; he stood alone against anarchy. Berenger, in order to legitimatize his own position and secure the throne to his son, endeavoured to marry the latter to Adelaide, the widow of Lothair. But Adelaide was unwilling, and her objection received the support of the Church, to which she was a great benefactress, while the feudatories disliked the completely fixed establishment of one of themselves, and the Milanese objected to the Archbishop that Berenger had presented to their seo in order to reward services (he had been Bishop of Pavia, and Pavia and Milan were always hostile to one another). There was a general appeal to Otho of Germany, the victor in many a fight against the barbarian hordes that ravaged Europe, a prince closely related to the royal family of France, and practically protector of that kingdom-one who might be regarded as successor to the Carolingian line. Otho probably foresaw his way to the resuscitation of the Empire in his own person. He accepted the invitation, and was joyfully received by a people weary of perpetual strife. He wooed and married Adelaide, the widow of the late King, but allowed Berenger to retain his crown on condition of becoming his vassal, and gave him the territory below the Brenner and the Julian Alps-that is to say, he secured to himself the keys of Italy. But the spirit of anarchy remained strong in Italy. Berenger and his lords were perpetually at feud, and the Pope complained of an attack made on his own possessions. For the second time Otho was summoned, and crossed the Alps with an army officered by the princes and nobles of Germany and warlike prelates of the Church. He received the Iron Crown at Milan, and overcame the sturdy resistance which Berenger, followed by a faithful few, made in Romagna. Berenger was taken prisoner and sent to Bamberg, while his son fled to Greece. Then Otho marched on Rome, and the Church once again bestowed the Imperial crown on a Teutonic Prince, restored the Empire, and manifested the spiritual power that, though degenerate and dishonoured, the successor of St. Peter still retained over the Western world. The new Emperor guaranteed its territorial possessions to the Papacy, while the Church engaged that Papal elections should take place in the presence of representatives of the Emperor. Weary of turmoil, exhausted Italy clutched at the resuscitated Empire as the last stay for despair.

The dissolution of the house of Charlemagne and the anarchy that followed ; the great struggles of rival princes; the incessant wars of their feudatories with each other, and the swarms of barbarians that roved over the country, had led to the withdrawal of the Lombard aristocracies to keep and eyrie difficult of assault; while the defenceless inhabitants of the cities were permitted by their overlords or encouraged by their bishops to rebuild the city walls. Large towns of many thousand inhabitants had often been obliged to ransom themselves from quite small bands; but now, secure from outrage and every kind of attack save siege, which in those days of undeveloped warfare meant much preparation, and was frequently unattended by success, the citizens applied themselves to the acquisition of wealth, and learned how to defend the 
wealth they acquired. Every village soon had walls, or a strong tower to which the inhabitants might retire with their valuables in case of attack. The haughty nobility, disliking the new warlike and independent spirit of the citizens, whom they had been wont to dominate, withdrew to the country, and each land-owner, desiring to increase his retinue of defenders, hastened to enfranchise the serfs on his domain in order to gain their affections and train them to efficiency in the use of arms. The result was that, in spite of all the horrors of the time, the cities increased in wealth and importance, and the liberated agricultural classes multiplied rapidly and brought vast tracts of abandoned soil under culitvation.

Throughout this period of anarchy we observe an unceasing attempt on the part of inferior orders to emancipate themselves from the rule of the greater. And now that the central power is re-established, we shall find the greater feudatories again endeavouring to emancipate themselves from its control. The lowest classes are the descendants of the conquered; where they are gathered into commercial centres they gain wealth and power ; they help the smaller feudatories, and receive privileges from the central authority for their aid against rebels; then, the communes thus privileged, use the small feudatories in their private wars to the subjugation of neighbouring villages and rival small towns. In a state of society where there is always rebellion going on, where all are adversaries, the communes first use one feudatory against another, and then turn against the very men who have led them to battle; out of the war of opposed interests they contrive to secure their own advancement. The central authority begins to support the bishops of the towns in order to check the centrifugal tendency of the big feudatories, and this converts the towns into the most important feudatories of the Empire; then we shall observe the citizens taking advantage of quarrels between Empire and Church to overthrow episcopal domination without submitting to the authority of the Crown. There is a universal reign of violence; each feudatory entrenches himself in his strong castle, and the citizens strengthen their walls, discipline their militia, maintain their independence, and develop their greatness by reason of the very divisions and general instability of these unhappy times.

\section{The Age of the SAxon Emperors: 962-IO24}

No sooner was Otho's back turned than Pope John XII. secretly intrigued with the small party that still adhered to Berenger. Otho also received complaints of the Pope's licentious cruelty; so he retraced his steps, assembled a council, and deposed him. But directly the Emperor left the city John re-entered it, and secured so much support among the clergy and the factions and unstable nobles of Rome that he was able to drive the new Pope Leo into exile. John died in 964, and the Roman clergy, disregarding the Imperial appointment, refused to have anything to do with Leo, and elected a new Pope. This brought Otho back to Rome yet once again. He banished the clerical nominee and reinstated Leo ; but a year after Leo died, and a new Pope, John XIII., was elected with Otho's consent. Then the turbulent Romans ejected the new Pope, whereupon Otho re-entered Rome and hanged the ringleaders of this opposition to his Imperial authority. At this time it is clear that the 
duchy of Rome was considered to belong to the Crown, and Liutprand stoutly justifies Otho's action in the matter. In the year 967 Otho advanced his son, Otho II., to share the Imperial dignity, and had him crowned at Rome. These coronations were attended with some pretence at the pomp that adorned the illustrious ascensions of the great Cæasars of antiquity. The Emperor and Empress-elect were conducted to chambers that bore the classic names of Augustus and of Livia ; a pretorian prefect bore before them the naked blade of justice. The standards that had figured on the road to the capitol in glorious triumphs, or copies of them, were carried before the half-barbarian successors of the polished masters of the world. The new Sovereign parodied the sacerdotal office of pontificatus maximus by being installed in a Christian canonry of St. Peter's, and his name was added to the illustrious list of Augusti that had conferred distinction even on ancient Rome. Men weary of the universal insecurity and confusion of the times remembered the faint tradition of the Roman peace, and hoped that its orderly and impressive grandeur might be not dead but asleep, and could be awakened.

Before the monarch took the Imperial crown at the hands of the Pope, he received the Iron Crown of Lombardy at the hands of the feudatories. At one time, indeed, this had become an hereditary possession of the house of Charlemagne, but, since the deposition of Charles the Fat, the nation had resumed its rights, and, indeed, had exercised them sufficiently often to reconstitute a title, had such been required. When the throne was vacant, the National Assembly met, either at Pavia or Milan (later on, on the plain of Roncaglia). The aspirant, whether he claimed the crown by right of sword or by petition of the people, convoked all freemen to the assembly to confirm him by acclamation. This done, he received the crown.

The Emperors brought big armies with them to Italy; but they were feudal armies; the barons were only bound to serve for a limited period, and each man, when the specific service for which he was called out was finished, had a right to retire to his own hearth. The persistent power of ideas over the human mind is nowhere better illustrated than in this restoration of the Empire to the hands of mediæval barbarians. Henceforth Italy had German princes, whose German subjects were so turbulent that the monarch could only exercise effective authority, south of the Alps, spasmodically and at long intervals. Italy was left more and more to herself, but in spite of disillusion perpetually repeated, in spite of the ineffectiveness of her Cæsars, of the bitter and bloody results of their coming, she still clung to men who only shared the name of Augustus Imperator with the true descendants of Octavian.

Otho I. came, indeed, as a conqueror, but he ruled in accordance with law and usage. He did not even find it necessary to send Germans, as Charlemagne had sent Franks, to supervise the government; but was content, since the Italians accepted his right to command, to enforce obedience when he was present, and to allow it to lapse when he had recrossed the Alps, relying on the might of the Imperial name to reinstitute his authority when he should reappear. But Italy, with the natural boundaries of the Alps between Germany and herself, disintegrated by the internal barriers of the Apennines, which are spread so irregularly over the peninsula; and vexed with the confusion which resulted from 
the admixture of so many races of conquerors, could give no firm foothold to the Northern Power, crippled as it was by domestic difficulty. The rejuvenated Empire was, however, full of hope. Southern Italy, indeed, was wanting to round off the possessions of Otho; and he attempted to get his Imperial position recognised by Byzantium in the marriage of his son to a Greek princess, dowered with the gift of Greek Italy. The projected marriage was first favoured and then rejected by the Eastern monarch; whereupon Otho attacked and ravaged the Greek possessions of the South, until the Emperor of the East was glad to accord the hand of the Princess Theophano to the younger Otho. In order to consolidate his power in Northern Italy, Otho entrusted the marquisate of Friuli and the defence of the eastern portion of the plain and the passes from Germany to his brother, and created the marquisates of Montferret, Este, and South Lombardy, which he entrusted to.Germans or Italians on whose fidelity he could rely. These new feudatories were regarded with suspicion and jealousy by their neighbours ; they sought security in their country castles; and the towns, left more to themselves than ever, usurped municipal privileges, which Otho, perceiving the value of urban support, quietly favoured.

Otho II. found himself confronted on his accession by troubles at home, and was for years unable to visit Italy. The anarchy that ensued drove the Popes to infeodate their dominions in order to retain them, at the expense of a permanent weakening of their authority. The Archbishop of Ravenna, in spite of Papal opposition, did the same thing, and the prelates of Lombardy supplanted the power of the nobles in the cities by inducing the burghers to place themselves under their protection. A centrifugal tendency was soon manifested by Otho's feudatories, and, when he was able to descend into Italy (980), he gave charters to the towns, under the lordship of their militant bishops, in order to restrain baronial pretensions. He received the Iron Crown at Pavia, and, proceeding to Rome, caused the massacre of several turbulent barons who were insubordinate to his creature, Pope Benedict VII. Yet, in his own way - a way marked at the same time by asperity and circumventionOtho II. appears to have endeavoured to introduce some sort of order into the chronic confusion of Italian affairs. Southern Italy was at this time in a very disturbed condition, and Otho determined to assert his claim to the whole peninsula, and secure order in the domains and tributary states which the Eastern Emperor was unable to govern. The history of what followed it is almost impossible to unravel, so perplexing and contradictory are the obscure and muddled records of this dark and distant age. The rising sea-port of Pisa inaugurated her long series of services to the Imperial cause by lending him her galleys. He found the Lombard princes intriguing against each other, and opposing his claim to supremacy, and he pushed on into Apulia in the hope of an insurrection in his favour. He met with resistance, though his wife Theophano was well received at Rossano, where she remained guarding the Imperial treasure. We learn that he advanced to meet a new invading host of Saracens and defeated them; but a little later he fell into a trap, and the Moslem, descending from their mountain covert, surrounded the Christian army that was exhausted by a tedious march under a scorching sun. The Bishop of Augsburg, the Abbot of Fulda, the most distinguished of the 
chiefs and warriors of the Christians lay dead on the field, or were led away captive by the Moslem. Then follows a story which might have adorned the legendary chronicles of Novalesa or inspired the chaunters of the cycle of Charlemagne. Otho escaped with difficulty and fled along the sea-shore. Perceiving two Greek vessels skirting the coast, he rode his horse into the waves and shouted for help. One of the vessels sheered off, but the other rowed towards him and he was takon on board. Otho, finding himself on a ship that had fought against him at Taranto, concealed his identity, which was recognised only by a sailor who had once bcen in his service, and who kept the secret. The captain, with a view to the ransom that a person obviously of high rank would command, set sail for Constantinople ; but Otho succeeded in corrupting him, promising him a large sum if he would take him on to Rossano. The sailor in the secret was the first to disembark; and he returned to the port witn Theophano, the Bishop of Metz, and a little escort bearing concealed armis. Mules heavily laden with treasure were led in the rear. The Bishop embarked with his men and sailed towards the Greek galley; and the Greeks, their greed inflamed by the sight of the weighted mules, at once rowed nearer the shore and let down anchor. If perchance they surmised that an Emperor was their prisoner, they had no dread of his oscape ; they were accustomed to a Basileus who never walked, even, without the ceremonious assistance of eunuchs. Suddenly Otho jumped overboard, swam for the shore and gained it, protected by the Bishop's boat. The befooled Greek captain lost one of his men, who, attempting to follow Otho, was killed by the disguised German soldiery, and he sailed away, enlightened as to the character of barbarian royalty (Chron. Venez.-Mon. Germ. Sc. Thietmari Chron.-Gest. Episc. Camer. I. id.-Arnulphi. Hist. Med.). The victory of the Saracens had lost them their leader. They retired to Sicily, and Otho, too feeble to reduce the Lombard princes to submission, retired to Verona, where he assembled a diet, and had his young son by Theophano proclaimed King of Italy. Assembling a new army, he again marched southwards, but the death of the Pope recalled him to Rome, where he died (983). It is interesting to note that in a diploma by which Otho II. confirms the privileges of Venice, the Exarchate and Pentapolis are expressly mentioned in a manner contradictory of tho claim of the Papal See to those territories through a grant of Otho I.

The long minority of Otho III. kept Germany in a ferment, and the absence of the monarch allowed the provinces of Italy to augment their independence. The spirit of organization and good administration showed some signs of vigour in North Italy. The feudatories, lay and clerical, issued ordinances; the cities elected consuls and pretors, published municipal regulations, organized elective councils and prepared for defence; each citizen became a soldier; and the provincial signors established local courts of justice. Venice extended her sway over Dalmatia and put down piracy on the Adriatic ; and Crescentius re-established an oligarchical republic in Rome; while the Greeks in Southern Italy, harassed still by Saracens, but relieved, by the absence of German interference, from the oscillating policy of the Lombard states which had played off one Empire against the other, placed a Catapan of the theme of Italy at Bari, and maintained a close connection between their coasts on both sides of the Adriatic. 
Grandson of the pious and reverential Adelaide, and son of a Greek princess on one side, and of the bold, brave, and capable house of Saxony on the other, instructed by Gerbert, the most learned man of his century, who had studied among the most cultivated people of the age-the Moors of Spain-Otho developed a large stretch of imagination, vivid confidence in his own powers, resolute will, and soaring ambition. $\mathrm{He}$ is said to have visited Venice incognito, attended by a few courtiers only, and to have excused that city from the annual tribute that it paid to the Lombard Crown. He deemed himself born to achieve the restoration of the ancient Roman Empire to its pristine splendour. In 996 he entered Italy. The bishops welcomed him with joy, Crescentius withdrew from Rome at his approach, the Pope resumed his authority, and, on the death of John XV., Otho appointed his own cousin to the Holy See, and received the Imperial crown at his hands. It was evident that the new Cæsar might be a dreamer, but that he was a man of steel, tenacious, and resolute in his dreams. The German Pope endeavoured to clench his power by surrounding himself with Germans and appointing his fellow-countrymen to judicial posts. When Otho was away from Rome this policy led to an insurrection of the national party, led by Crescentius; the Pope was deposed, and the general opinion was that the insurrectionists intended to place themselves under the protection of Byzantium (Avnulfi, Gest. arch. Mediol.). If it were so, there is no proof of Greek intrigue in the matter (Gay, p. 393). Otho swiftly returned, and besieged Crescentius in St. Angelo. Crescentius capitulated after making heroic resistance, and, violating a pledge of grace, Otho or his subordinates had him cast from the battlements. The mailed fist of the Emperor was heavily felt in the Peninsula. Gerbert, Otho's old preceptor, who had already been appointed Archbishop of Ravenna, was elevated to the Papacy, and his splendid imagination is reputed to have inspired Otho with dreams of reviving the ancient Empire to its pristine boundaries. ${ }^{1}$ The Marquis of Ivrea, the most powerful feudatory in North Italy, was put to tho ban of the Empire, and the great marquisate of Tuscany was infeodated to a German; the Sovereign imitated the magnificence of the Oriental Court; he announced himself as "Otho, Roman, Saxon, and Italian, servant of the Apostles, by the grace of God August Emperor of the Roman world "; born of a Greek mother, he demanded the hand of a Greek Princess, and she had already arrived at Bari when she heard the news of the premature death of the young Emperor. The dazzling prospect of a restored Empire was condemned by the Fates to remain the deceptive lure of a visionary age ; and the young Cæsar, who aspired to the command of the world, was unable to control the turbulent militia of the dismantled and dilapidated city he had designated for his capital ; he had been compelled to escape by stealth, in the dead of night, from the Aventine palace, where his subjects were besieging him, and he died while awaitiug the arrival of fresh troops from Germany (1002).

The death of the third Otho extinguished that imperial line, and led

1 A letter was discovered among the Leyden MS. wherein Sylvester calls on the warriors of the West to the recovery of Jerusalem, "the light of the Western World." This letter, regarded by most authorities as spurious, certainly dates from a period anterior to the first crusade, which proves that the idea of recovering the Holy City was in the Christian mind before the Council of Clermont. 
to a civil war in Germany between contending forces for the vacant throne. Each disturbance struck a fresh blow at the effective power of the Emperor in Italy - a power already weakened by long and frequently repeated absences of the monarch ; while the election of a stranger, related indeed to the Royal House, but very distantly, seemed to absolve the cities from the debt of gratitude which they owed to the Othos. Italy was, in essence, a collocation of manifold and clashing interests ; and, even in the presence of the Emperor, the individual had little protection other than that afforded by his immediate lord or the bishop and magistrates of his particular city; different laws, different usages prevailed in different places; and the affection we now feel for our country the citizen then bore to his town. Every fresh disturbance weakened the notion of feudal obligation, and helped the estrangement from each other of the various members of the State. On the death of Otho III., Ardoin, Marquis of Ivrea, whom he had placed under his ban, convoked a diet at Pavia, and, in the hope of reviving the national monarchy, the prelates and lords present elected that powerful baron to the throne. The patriotism exhibited in Pavia was enough to excite the jealousy of the rival city, and Arnulph, Bishop of Milan, who had returned from an embassy too late to be present at the diet, declared the election illegal, since he, the premier ecclesiastical prince of Lombardy, had had no voice in it. Arnulph convoked a fresh diet at Roncaglia, and the pro-German and Milanese party recognised the new Emperor of the Germans as their King. Civil war followed, but Ardoin was defeated, and the descent of Henry II. into Italy met with no resistance. He received the Iron Crown at Pavia, the late centre of disaffection; but on the very day of coronation, drunken Germans insulted the citizens, and the latter besieged their new monarch in his palace. His army, encamped without the walls, fired the city, released their Sovereign, and then beat a hasty retreat. Pavia, almost burned to the ground, was hastily rebuilt, and civil war recommenced. Ardoin kept to the mountains, and Henry was called back to strife in Germany, while Milan and Pavia fought on. Italy had now two crowned monarchs and no ruler; Rome was in anarchy; and throughout the great plain and the slopes of the Alps, feudatories, in the names of the rivals, fought for their own establishment. At last, in IOI3, Henry was able to return to Italy, and succeeded in getting crowned in Rome and restoring some degree of order. He riveted the allegiance of his faithful adherents - the bishops of the city-by giving them lay power equal to that of the great lords around, rights of coinage, of executing justice, and of levying taxes. As far as lay in his power, Henry, called the Saint by a grateful Church, converted lay into ecclesiastical feudalities.

Meanwhile, internal troubles in Sicily diverted the attention of the Saracens to home affairs ; and the Greeks took advantage of the diminution of danger from that source to fortify the northern frontier and make the authority of Basil II. recognised over the whole South as far as the Papal States. The Catapan founded a new city, Troia, in a commanding situation, and captured and occupied a fortress on the Garigliano, which was a direct menace to Rome. It became incumbent on Henry, who was now in Germany, to listen to the solicitations of the Pope and recross the Alps. According to certain German chronicles, Henry took Troia 
(Ann. Sangall, I., 82.-Casuum S. Galli cont., II., I55); but Gay is of opinion that he achieved a less unqualified success (Gay, L'Italie mérid. et l'empire byz., Paris, 1904, 419-425), though he succeeded in establishing the county of Camino as a barrier state (1022). He associated with its defence a. band of Norman adventurers, who, under the guise of pilgrims, were traversing the South of Italy at this period, and finding it "a land flowing with milk and honey," were attracting their fellows thither. The Normans began to act as condottieri in the quarrels of the Lombard princelets. Henry now returned to Germany, where he died (IO24).

\section{The Age of the First Franconian Emperors: Henry iII. AND THE Minority of Henry IV.}

During the many years before he received the Imperial crown, Henry II. had styled himself King of the Romans in order to assert his title to the Empire, and Conrad II., elected by German nobles, also assumed it. Conrad of Franconia was a descendant of the great Otho, but on the spindle side: hence he was called the "Salic," and the great lords of Northern Italy again seized an opportunity, which they regarded as favourable, to free themselves from the domination of Germany. The King of France and the Duke of Aquitaine prudently refused the proffered honour of the Iron Crown, and Heribert, Archbishop of Milan, who directed these intrigues, then went to Germany to conciliate Conrad, who, following a usage which was beginning to establish itself, sent deputies to the cities announcing his approach, and requiring their oath of fealty, feederum, or provisions for himself and army or their value in money, parata, or a sum to repair the roads and bridges of the route, and mansionatum, or the expenses of quartering the court and army.

The diet was held at Roncaglia, a waste plain ncar Piacenza, which became the customary rendezvous on such occasions. Habitations, surrounded by a wall, arose as if by magic. Merchants assembled from all parts of Italy, and pitched their booths outside the enclosure, so that the scene was a combination of martial display with the bustle and gaicty of a fair. In the centre of the camp rose the royal pavilion, and this was guarded by feudatories, summoned in turn by a herald. The ceremony of watching their arms through the night served the purpose of a roll-call, and those who did not present themselves were liable to be deprived of their fiefs. First, the monarch adjudicated on private causes; then he received the delegates of the towns, regulated their relations with theCrown, and settled their disputes ; afterwards he disposed of questions of fief.

Pavia and Ravenna alone withheld their oath of obedience, and were duly punished, and Conrad marched on to Rome, where he received the Imperial crown in the presence of Canute, the monarch of Denmark and England, and of Rudolph of Burgundy; while a fracas between the soldiery and the Romans, which recurred on these occasions with the regularity of the more harmless town and gown riots of modern times, mocked the sacred dignity of the investiture, and the magnificence of the pageantry which accompanied it. Conrad despoiled the marquisate of Verona to the gain of the Patriarch of Aquileia, confided the Brenner Pass to the keeping of the Bishop of Brixen, gave vice-regal powers to the Archbishop of Milan, and then recrossed the Alps. 
The great bishops had become invested with too much power. The burghers of the cities and the country nobles drew together, while the town populace, oppressed by the rich traders, supported the episcopal autocrats. Heribert of Milan, who, according to his contemporaries, had but to nod and Italy obeyed, led the militant bishops and the small burghers to battle, and met with unexpected defeat at Campo Malo. In mediæval Italy the devastating forces of anarchy, like the subterranean fires of its volcanoes, were ever ready to burst the weakened trammel and spread terror and desolation through the land. From everywhere a cry went forth for the Emperor. Conrad responded to the appeal, and marched down to Italy (I036). "The thirst of the Italian for law shall be assuaged," he said. Among other things he granted municipal constitutions to the towns.

Heribert and the ecclesiastical party were pro-German so long as the German Sovereign extended their local sway; they made a volte face directly their privileges and authority in the towns were menaced. A diet was convoked, not at Milan, but at the city that hitherto had been anti-imperialistic-at Pavia. Heribert refused to appear and answer an accusation of injustice brought against him by certain of his vassals. Conrad replied to his contumacy by seizing and imprisoning him and several other bishops. Straightway Heribert becomes a popular hero; he is the national champion against the brutal Teuton. The big burgher is now on the side of the Archbishop, and Conrad fails to take Milan. The conflagration spreads like wildfire throughout Northern and Central Italy, and the Teuton is on the verge of expulsion.

One clever stroke saved the Empire. Conrad convoked a diet, and declared all military holdings hereditary to male issue; he annulled the right of lords, lay and clerical, to dispossess their vassals of their fiefs. The same law of inheritance which gratified the family ambition of the great noble was, with indisputable logic, applied to the smallest peasantholder, and gave him security of tenure. An axe was laid at the root of episcopal power, and in spite of the rivalries of neighbouring cities and the hostile elements shut up within the selfsame walls, the seeds of Italian freedom were sown.

It was in the struggle against Conrad that Heribert introduced the famous caroccio of Milan, copied by Italian cities, used as their standard, the prize of battle, the object of attack, the centre of defence, round which the contest was ever wont to wage fiercest. Supposed to imitate the ark of the covenant, it was drawn by the swift-paced bullocks of the South, adorned with red coverlets; from its centre rose a pole bearing the flag of the city with a figure of Christ on the cross below it. In front the caroccio bore a platform for the brave men ready to die in its defence ; behind were trumpeters. The Host was consecrated on the caroccio before its departure for battle, and a chaplain often accompanied it to the field. Its loss was felt as the deepest ignominy that could befall a city, and the flower of the citizen army was selected to be its guard.

Having settled the affairs of Lombardy, Conrad turned his attention to the South. In spite of perpetual war with the Saracen the Greeks had consolidated their empire in Apulia ; the Lombards, divided among themselves into little principalities, were under the preponderating influence of the Prince of Capua, and the Prince of Capua, bent on destroying the 
privileges of the monks of Casino that had been guaranteed by Imperial charters, and on forcing the Lombard South to submission to his will, was the determined foe of Germanic influence, and had allied himself with the Catapan. Conrad marched his army to Troia, received its submission, and, getting help from the Prince of Salerno and the Norman colonists and condottieri, it needed a mere military promenade to break the power of Capua and transfer it to Salerno. Salerno, nominally the vassal of Germany, was now the real sovereign of Campania. The success of Conrad was largely aided by a handful of the most courageous, even if not the most physically powerful, people in Europe-heathen buccaneers, who, sailing from Scandinavia, had in three generations conquered Normandy, transformed themselves into Christians, exhibited a natural aptitude for eloquence and the ingenious subtleties of law, absorbed a civilization superior to their own, and endowed it with a new vitality, and, retaining the predatory instinct, the adventurous daring, and the unquenchable curiosity of their sires, had acquired an intemperate reverence for holy places, and directed their energies to visiting them. Pilgrims of this race, so well described by Geoffrey Malaterra, their contemporary, as accomplished (with the accomplishment of those times) yet cunning, grasping to have, but lavish to spend, enduring, yet given to pleasure, traversed France and Italy en route for Palestine, quite prepared to obtain by the right of the sword what was not accorded by religious benevolence. Monte Cassino was then the abode of learning, the seat of miracle, and the resort of the poorer pilgrim. The history of the first appearance of these Northmen in Southern Italy is mingled with legend, and is more than obscure, but it is clear that they were keenly sensitive to the soft attractions of that enchanted land, laden with grain and flower and fruit, while they disdained its languid, timid inhabitants. Band after band arrived, their numbers increased steadily, and in Ior 7 they ravaged Apulia with even more ferocity than Saracen pirates or the light horse of the Hun. Defeated in a bloody battle by the Catapan and his Byzantine troops (IOI8), the scattered remnant had taken service under the various Lombard chiefs, and been granted small patches of territory and points of vantage at Aversa, near Naples, and elsewhere.

The corruption of the Church at this period and the clash of conflicting claims was accompanied by increased vigour of municipal life and renewal of the Christian spirit. The feudatories desired admission to the cities .that had become powerful by reason of the security their walls afforded, the tranquillity of municipal administration, and the presence of an organized militia. They requested the cities to protect them and their fiefs; and the presence of skilled warriors gave increased powers of resistance to the cities, and acted as a counterpoise to episcopal sway. In the Church the old orders were being reformed and new orders founded, and Peter Damian, Peter the Lombard, and Lanfranc denounced the disorders and degeneracy of the Church, and urged a return to the simplicity of its early principles. A true reformation was afoot, not opposed to Catholic authority, but bent on restoring to it the spirit of its founder, while, at its seat, three rival Pontiffs divided the revenues of the Church, and issued Papal curses at each other from three Holy Chairs at the Vatican, the Lateran, and S. Maria Maggiore. It was clearly the duty of Henry III., the son and successor of Conrad (who died in A.D. IO39) to descend into 
Italy and reform the Papacy as he had already reformed the German Church, as well as to establish his authority over the towns of the fertile plain, the fertility of which now emancipated a large proportion of the growing population from agriculture, and permitted them to supply the markets of Germany with goods of their own manufacture and exotic luxuries, which their proximity to the passes of the Alps and the seaports of the Mediterranean enabled them to transmit. Henry deposed the rival Pontiffs, and appointed the first of a series of devout and capable German Popes, whom he held in strict subjection to the Empire, little conscious that he was establishing a rival power that would become its mightiest and bitterest foe. For the first Pope was content with a subordinate position; he recognised the overlordship of the "Vicar of God," whom he anointed, and while he and his immediate successors restored the dignity and authority of the Pope in his sacerdotal functions, the Emperor, a man of upright character and a firm ruler, was now practically the Head of the Church, and appointed the bishops of Italy and the Empire at his will.

It had now become an Imperial tradition that the Emperor should proceed from Rome to exercise his authority in Southern Italy. Henry III., therefore, marched his army southwards, where he tried to establish some balance of power among the Lombard princes, and recognised the Norman counts by granting them the Imperial investiture of the lands they had acquired-lands gotten by playing off Lombard against Lombard, Greek against Greek, and Lombard against Greek, by taking and changing service with the indifference, but without even the scruples, of a Dugald Dalgetty. For first we find some of the increasing numbers of these adventurers aiding Maniakes the Greek general, in his attempt, at first successful and afterwards disastrous, to re-establish Byzantine rule round the slopes of Etna ; and then, complaining of the smallness of their share of the booty, returning to Campania. The heavy levies of troops and contributions made during the Sicilian War caused a revolt of the towns of Apulia, and the Norman chieftains, finding the numbers of their ranks increasing day by day, joined their forces with an intriguing Lombard of Milan in the Greek service, who favoured the insurrection, and lent their aid to the insurrectionary movement. They even arranged beforehand the division among themselves and Ardouin, this Lombard adventurer, of the territories they intended to rule. The Greeks were defeated in successive battles (IO4I) and their commander captured. Bari and other towns concluded treaties with the Normans, become masters of Melfi, assuming independent power in order to preserve their territory from ravage; while Argiros, a local chieftain, was proclaimed Duke and Prince of Italy, usurped the position and powers of Catapan, and acknowledged the status of the Norman "counts." Back came Maniakes, and the presence of that ruthless but capable Greek boded ill to the Norman arms. Then came news to the Greek camp of a new Emperor at Constantinople and the ascendancy there of Maniakes' bitterest foe. Maniakes, foreseeing ruin, seduced his soldiery and took the insignia of royalty, whereupon Argiros bought the favour of the Eastern government by submission; and, by a quick change of parts, it is now Argiros who bears the authority of Constantinople and restrains his Normans on behalf of the Eastern Empire, while Maniakes, the Greek 
general, takes up the role of revolt. Many of the Normans, finding their career checked by the volte face of Argiros, now chose one of the famous House of Hauteville as their leader, and in order to legitimatize their position they offered their services to the Prince of Salerno, who received their homage for the territory they had acquired. Their warlike instinct had led them to the occupation of positions very distant from each other, indeed, but commanding all the routes that led to the Adriatic. When Henry III. admitted the Normans as feudatories of the Empire they signalized the new honour, and took advantage of the weakness of all the Powers of the South by occupying the patrimonies of St. Peter, ravaging the countryside, and waylaying the pligrims even (John of Fécamp, Migne, cxliii., 798). The condition of the South, lay and ecclesiastical, compelled the frequent personal presence of the Pope, and Leo IX. regarded the defence of Imperial and ecclesiastical rights as one and inseparable. He set out at the head of a small army of very poor quality, for German troops were for the most part occupied in their own country. There was a complete understanding between the Pope and Argirosboth Empires were to unite to put an end to the reign of terror of those "Saracen Christians," the Normans. But Argiros was soon disposed of by the Normans, who then encountered the Pope, defeated him near Civitate, and besieged him in that town, to which he had retreated. It was impossible to hold Civitate, and the Pope came forth, clad in his pontifical robes, at the head of a procession of his clergy, and we witness the strange scene of the hardened warriors, still flushed with victory, grovelling in the dust, and demanding the forgiveness of the man who had come to attack them. They did him homage, and swore to be faithful to him, and doubtless, in spite of the rising wave of religious emotion, an understanding of some practical nature was arrived at. Under the guise of a guard of honour the Pope was conveyed to Benevento, and kept as a hostage for six months. Henceforward we find the Normans taking up a new political role. Under the cover of devoted service to the Holy See they seek every opportunity of disuniting their foes, securing their own advancement, and pushing their own advantage in both the present and the future life.

In 1054 the Pope smote the Greek Church with anathema for holding that the Holy Spirit proceeded from the Father alone. An estrangement between the two great branches of the Christian Church had lasted for six centuries with temporary reconciliations, but political considerations were always mingled with theological prejudices, and, in spite of the resumption of intercourse on more than one occasion, the subsequent brutality of the Norman allies of the Church and the Latin seizure of Constantinople, prevented any real healing of the breach, which now became final.

Henry died in ro56, and the Empress ruled on behalf of her young son Henry, now but six years of age. The long minority gave the Papacy an opportunity, not merely of affirming its independence, and under the direction of the great Hildebrand, the Pope-maker, of reforming the Church, but of establishing the spiritual supremacy of Rome over the temporal power of the Empire. Nicholas II. got it decreed that henceforward the cardinalate, or curates of the parish churches of Rome, should alone have the right to elect the Pope, saving the honour and respect due to the Empire. The Imperial authority itself was undermined, and the 
rights of the Roman citizens destroyed, and the Romans rose in revolt; but a band of the Pope's faithful Normans soon restored order to the city, for, since it was found impossible to break the Norman power in the South, it became the policy of the Papacy to enlist its services, while the Normans were acute enough to perceive that the reforming party in the Church would have quite enough to do without opposing their advance.

The inner reason of this close alliance was that the Papacy had to re-establish the authority of the Western Church in Southern Italy, where there were many Greek monasteries to be dealt with, and ancient patrimonies of St. Peter to be recovered, and the decrees of the Church could only be made effective by the aid of Norman arms. If these devout adventurers had, on the one hand, an ungracious instinct for spoliation, they were not wholly beyond the pale of redemption, for they enriched the Holy Church with lands and monasteries that remained equally devoted to their benefactors and the Holy See (vide Aims, ystoive di li Normant.-Gay, p. 5I7). Robert Guiscard, one of the sons of the House of Hauteville in Cotentin, was present with Hildebrand and Nicholas II. at the Council of Melfi (I058), and in return for his oath of support he was entitled " Duke of Apulia and Calabria, by the grace of God and St. Peter, and with their aid future Duke of Sicily." It is evident that the astute policy of the Holy See foresaw the great role that was to be played by the Norman in the South. Reviving the theory that the Chair of St. Peter was the representative of ancient Rome, Pope Nicholas II. and his great adviser, Hildebrand, usurped powers which, on their own theory, they had delegated to the Emperor. They gave the Normans the sanction of religion, and thereby endowed them with great force, and for seven centuries after this memorable investiture the kingdom of Naples remained a fief of St. Peter. But the immediate effect was to stir the Greeks to obstinate resistance, and for years Robert's band of Normans, strengthened by Sclavs from Dalmatia and ruffians of all kinds, occupied mountain-fastnesses and maintained themselves by a life of plunder. Their incessant raids on the countryside and assaults on the towns gradually brought the country to submission, while Constantinople remained paralyzed by domestic disorder, and unable to put forth her full power. At last Bari, the stronghold of Greek influence, and its military and naval metropolis in Italy, fell to Robert Guiscard (I07I), and allowed him to send reinforcements to his brother Roger, who was across the Straits of Messina winning, bit by bit, the freedom of the Christian rayah of Sicily from Moslem masters, a task in which he was aided by their dissensions.

During the restoration of Greek power in the land of which New Rome had never relinquished its grasp, though it was often compelled by internal troubles to relax it, the cities, one by one, recognised the supremacy of the Empire of which they still theoretically remained a part. The last city to come under effective control was Amalfi, and the reason of the reluctance of Amalfi and Naples to welcome the restoration of Eastern authority is to be found in their commerce and friendly relations with the Moslem. Constantinople allowed Naples to retain its autonomy under the native dukes, and that city was defended by a separate military caste. The gradual evolution of the little state being through the leadership of the bishop towards an aristocratic form of government, the "Duke " got 
more and more monarchical power, transmitting it to members of his own family. Finally, this monarchy became weakened, and power gradually passed to an aristocracy. At Gaeta the ducal authority was never so strong as at Naples, and that state also became, in essence, an oligarchy in the latter half of the eleventh century. Bari and all the important and flourishing ports along both eastern and western littorals appear to have been governed by Imperial delegates from Constantinople, but the rulers of the smaller towns belonged for the most part to native families, and " boni homines," natives of position, formed boards of arbitration for the settlement of trifling matters. At Gaeta and Naples the "boni homines" appear to have had a share in the government. Fidelity in troublous times brought an increase of autonomous privilege, and in the period nearing the extinction of the Greek domination the cities were in the hands of local wealthy families. Ultimately, the stress of Saracen and Norman invasions compelled the Catapan to leave the cities to themselves. The dissensions of the Lombards were also favourable to the emancipation of the towns under their control, and we find from the annals of Benevento that there was a rudimentary municipal organization there in the beginning of the eleventh century (Dina, Il com. benevent nel mille, Milan, 1898). It must not be forgotten that the tradition of the municipal life of the past was probably never wholly lost in Southern Italy, and in times of Greek weakness cities attacked by the Saracen made separate treaties quite independently of the concurrence of central authority. Each city learned to rely on itself more and more, and we find them filled with the same spirit of local patriotism and mutual jealousy which we shall observe to grow up in the towns of the North. 'Their inhabitants appear to have acted collectively in the names of their chief dignitaries (Gay, Chap. VII.). Rivalry of politically opposed parties developed in the South, some relying on the aid of Constantinople, while others proposed to seek succour from the Lombards or the revived Western Empire. When the Normans conquered the land, they were obliged to respect that municipal autonomy of the towns which was, indeed, the chief factor that had retarded their success. Indeed, the decline of Greek domination enhanced the freedom of the towns, and Amalfi in particular then reached the acme of her commercial prosperity. The brazen gates of her episcopal palace commanded the admiration of Didier, the friend of Hildebrand. William of Apulia describes her as being " unsurpassed in wealth, in gold and silver and merchandise, full of mariners, as wise in the knowledge of the stars as expert in the ways of the sea, her sailors bringing the wares of Alexandria and Antioch to their homes, and familiar with Arab and Indian, and the peoples of Sicily and Africa." Unfortunately, we are in complete ignorance as to the municipal organization of Amalfi or any of the communes of Southern Italy and Sicily, and quite erroneous deductions have been drawn from the occurrence of the term " consul," which was often applied to any functionary, irrespective of the derivation of the authority he exercised. Monte Cassino, the oldest of monasteries, founded by the saintly Benedict in the troublous times that attended the break-up of the Empire of the West (529), maintained relations with both Rome and Constantinople, was adorned with the refinements of art, and its library sheltered the manuscripts of culture and superstition. The neighbouring city of Capua became a centre for study, and Naples was renowned for its, 
translators of Greek legends of the saints. Salerno produced an historian who was at pains to consult the local archives, and journeys were made from beyond the Alps to consult its physicians.

In Southern Italy and Sicily, that "rich jewel of the South," the Normans found themselves possessed of the fairest lands and ruling the most polished races of Europe. By the end of the century Roger Guiscard had Sicily at his feet, while to Robert Guiscard, aided by Amalfi, Salerno, the last of the Lombard possessions, fell in 1077, five centuries after the advent of Alboin and his Lombards, and three centuries after the Frankish overthrow of the great kingdom they established in the North. The Amalfitans made Robert their Duke, with the stipulation that their territory was to remain inviolate to Norman troops, and that they should continue to enjoy their ancient rights and liberties. By ro8o the last vestiges of Greek domination had disappeared, though from the ancient colonization of the land by the Hellenes much Greek blood remained, with some of the Sclav and other races that made up the mixed population of Constantinople; and there were also Sclavonian colonies from Dalmatia near the Adriatic littoral. Of the Saracen there remained little trace in Apulia and Calabria. In I08I restless ambition, combined with enthusiasm for the Roman Church, his benefactor, and the calculations of a "forward" policy, led Robert Guiscard to attack the Greeks in Illyria. He defeated Alexius Comnenus, who had arrived to raise the siege of Durazzo, but was recalled by his overlord, Pope Gregory VII., to deliver him from the hands of Henry IV., who hastily evacuated Rome at his advance. The needy adventurer had become a powerful prince, and could boast of having made both Emperors of the Roman world flee from his formidable presence. Become masters, the Norman banditti exhibited admirable administrative qualities. As soldiers they had learned the value of discipline and cohesion; they were excellent organizers, and, as Freeman remarks, even in their lawlessness they displayed their inclination for law, for they delighted in defending themselves by elaborate reasoning. In Sicily they became admirable and tolerant rulers of a population mixed in race and professing antagonistic creeds, and it is quite possible that perception of the adaptability and the latent powers of administration that lay within them may have weighed with the Papacy and its astute advisers among those considerations which induced it to bestow its favours on such apparent foes of order and tranquillity. The Papal defeat at Civitate made the Pontiff supreme lord of the South; it gave the successor of St. Peter more power than any victory, and his captivity enabled Leo to acquire sovereignty which the most intrepid of his predecessors would not have dared to attempt.

\section{Growing Power and Pretensions of the Papacy}

The honest, praiseworthy attempt of Henry III. to reform the Church by placing strong men of indisputable piety in the Chair of St. Peter led to results of which he little dreamed; it led to pretensions of theocratic character, to a prolonged and bloody contest, which finally enfeebled both the contesting powers and witnessed the humiliation of Popes and the yet deeper abasement of Emperors. Reform of the Church appeared to its statesmen to remain impossible so long as the Church depended on 
Imperial support, and the Pope owed his position to Imperial patronage; so long as the great sees were the traffic of the great lords, and the nomination to benefices in their hands; so long as the Church was restricted from an unfettered rule of her own house, and those who should give the Holy Spirit unconditional and unconstrained devotion remained the timeserving partners or adherents of the sons of men.

\section{Claims of the Papacy}

It is worth while to note that from an early period in the Middle Ages the Papacy had been persistently and insidiously intent on the prosecution of two great claims-namely, that of temporal power (which developed into the assertion of universal dominion) and that of spiritual supremacy.

I. Claim to Temporal Power.-At the time when the Byzantine dominion in Italy was waning and the kingdom of the Lombards was in decay, the Pope desired to shake off the authority of the East and become an independent ruler. Some Roman cleric forged the famous donation of Constantine, which set forth that Constantine the Great, in gratitude for having been miraculously cured of leprosy at the hands of Pope Sylvester I., had retired to the Bosphorus, and delegated the rule of the Western capital and Italy to the Pontifical Chair. Stephen II. appointed Pepin, the father of Charlemagne, Patrician of Rome and defender of the City and the Church. The author of the life of Stephen says that Pepin executed a deed of gift, ceding certain cities to all the Popes, and that this document was extant in his time (ninth century). No trace of it has been discovered, but it probably referred to the Exarchate. This donation is said to have been confirmed by Charlemagne (vita Adriani), who further bestowed on the Pope Venice, Istria, Benevento, and other provinces (which he had never conquered, and which consequently it was not in his power to give). This document has also disappeared, and was probably a forgery (if it ever existed). As to the policy of these Papal claims, it must be acknowledged that, while on the one hand they have delayed the union of Italy and diverted the Church from its spiritual functions, yet, on the other hand, had it not been for the persistent claim of the Pope to independence he would probably have become a creature of the protecting Power, as did the Popes in exile. The Roman Catholic Church might easily have sunk far below the servile level of Avignon; it might have occupied a similar dependency on the State to that which has characterized the Greek Church, or have become subordinate to the civil power, like the Church of England.

II. Claim to Spiritual Authority.-From the very earliest times the Popes, as successors to Peter and as metropolitan bishops, claimed seniority and ultimately authority over the other bishops of the Christian Church. But a Frankish ecclesiastic, who styled himself Isidorus Mercator (840-860), in order to protect the Frankish bishops from the oppressions of princes and ecclesiastical councils, antedated certain documents, and gathered up the prevailing tendencies of the time into forged documents, the contents of which shifted the control of their order to the Pope (False Decretals). 


\section{HILDEBRAND}

The claims of the Church found their greatest exponent in the person of Gregory VII. Hildebrand, the son of a Tuscan carpenter, entered the great Church, which then offered the only career open to merit independently of rank, and became a monk of the famous Benedictine House of Cluny. He achieved no less a reputation for holiness of life than for ripeness of learning, and accompanied Bruno, Bishop of Toul and a relative of the Emperor Henry III., to Rome. It was through the influence of Hildebrand that Bruno became Pope, as Leo IX., in ro49. Hildebrand became a sort of "Mayor of the Palace," and was the mainspring of the complex combinations of Papal policy. He was the intimate councillor, and directed the statesmanship of Bruno and his four successors in the Holy Chair. Elected to the Papacy in 1073, he was politic enough to request the approval of Henry IV., who readily confirmed him in the Pontificate. But, as he wrote to his friend, the Abbot of Cluny, it was his fixed desire to effect a total purging of the Church from its foulness, and especially from the guilt of simony. Now Henry, in spite of many manly and wholesome qualities, was dissolute, wilful, at war with his barons, desirous of superiority in honour and power, and ever in want of money. Consequently, when he had grown up and entered into his heritage, he sold benefices to incapable and even to corrupt men, and the clergy of Germany, already sufficiently vicious, strengthened in their unclerical quality by the accession of these unworthy pastors, were the ready supporters of the Imperial project to checkmate the growing pretensions of Rome, and subordinate the Church to a kind of feudal dependence on the royal will. Gregory began by reproving Henry mildly but resolutely. He then sent legates to Germany to exhibit there the authority of the Church, but in vain. Then in I074 and 1075 he summoned councils at Rome to condemn and anathematize priests guilty of concubinage, and persons guilty of simony, and in the latter council kings and princes were for the first time forbidden to give the ring and crosier, a custom which had been followed since Carolingian times. The issues were now clear. The Emperor strove to make the Church a feudal dependency; the Pope to render the Church, with all its temporalities, independent of the State. Technically, the consecration of a bishop by his metropolitan was the real spiritual investiture. But Gregory was not the man to be caught in a legal trap, and he made no distinction between this spiritual act and the temporal gift with which it was associated. His was that fine union of the speculative with the practical intellect that can recognise distinctions and penetrate beneath them to the essential factors of a question. Declarations of "Deposition" on the one side, and "Excommunication with deposition" on the other side followed. The German lords, either in rebellion or ripe for it, were not slow to avail themselves of this bold act of Gregory, and Henry was forced to a dramatic penitence at the gates of the castle of the great Countess Matilda, which, after eight centuries had passed, still rankled in the mind of the strongest of Prussian statesmen. Germany was about to transfer the crown to Rudolph of Swabia, and so desperate had the situation become that Henry had to make his escape from his enemies, and cross the Alps in mid-winter, accompanied only by 
his wife, his child, and a few faithful retainers. The lords of Lombardy were not altogether indisposed to take up his cause, because, among other reasons, the See of Milan was striving to keep its independence of Rome. It had been attacked on the question of the celibacy of the clergy, which it failed to preserve, and the traditional policy of Lombardy was to adopt the weaker side. But the attitude of his feudatories in Germany was so menacing that Henry hurried on to the Apennines, where Gregory was staying with that obedient and devoted daughter of Rome, his faithful friend and supporter Matilda, the powerful Countess of Tuscany and the broad lands on either side. Gregory was preparing to pass on to Germany, when the Marquis of Este, the Abbot of Cluny, and the chief lords and ecclesiastics of Italy, implored him to grant Henry absolution. A contemporary writer, Lambert of Aschaffenberg, relates the famous dramatic events that took place at the mountain stronghold of Canossa.

"The Pope stood out a long while," says he, "but at length, persuaded by the entreaties and position of the supplicants, he replied, "If, indeed, he be truly repentant of his misdoing, let him divest himself of his crown and all the insignia of royalty, and place them in my hands as evidence of heartfelt and sincere contrition, and let him proclaim that his culpable contumacy has rendered him unworthy to occupy regal dignity and bear the royal name.'

"These conditions appeared too merciless to the delegates; they importuned the Pope to modify his decision and not to bruise the broken reed. At last Gregory yielded grudgingly to their earnest appeals, and he assented to Henry's coming to him to make reparation as a penitent for the affront which he had offered the Holy See in disobeying its decrees. Henry fulfilled the command, and came, and the castle being girdled by a triple wall he was admitted into the enclosure within the second wall, all his following being kept without in the first court. He had divested him of his royal robes; nothing betokened the ruler, nothing indicated his rank; his feet were bare, and he remained fasting from the morning till eventide vainly awaiting the sentence of the Roman Pontiff. The second and the third days passed in like manner; on the fourth he was admitted, and in the presence of everybody, after prolonged discussion, the sentence of excommunication was removed, but under condition-namely, that he should hold himself ready to answer to a diet of German princes concerning the charges made against him at the place and time which the Pope should dictate; further, that the Pope should be his judge and determine the cause, and that if Henry could prove his innocence he might retain his sovereignty, but if not he should be deprived of it, and subjected to the penalty laid down by ecclesiastical law. . . . And until judgment was pronounced he should neither bear the insignia of royalty nor assume any public function" (Lambertus Schafnaburgensis, de Rebus German). Donizo, the chaplain of the great Countess, says that the winter was bitterly cold (Vit. Comit. Mat.); the high ground of the Apennines would be covered with snow. Yet the bitter penance, which sent a thrill of awe through the Western World, and will continue to impress its imagination throughout the ages, did not suffice to appease the indignation or complete the policy of the last of that series of great Pontiffs who had raised the Papacy from its deepest degradation to fullest princedom. Gregory was bent on securing a true priesthood to the Church, on firmly fixing the 
Church Catholic in its true character of sanctuary to the weak, succour and support of lowly merit, asylum of letters, no respecter of persons, a bond of unity between past and present, ruling and restraining the tumultuous conflicting elements of the world, and bringing all men into the brotherhood of Christ. The Pope-statesman, it will be noted, was not content with the penitential garb, the satisfaction made for contumacy, the abasement of the princely, or the exaltation of the pontifical office; his pronouncement struck a still deeper blow at Imperial supremacy when he ordered Henry to present himself for trial before his peers at the Papal mandate.

In order fully to appreciate the bold self-confidence of Hildebrand's action, it should be noted that the quarrel had been brought to a crisis by insubordination within the Church itself. The quasi-independent See of Milan had been occupied by a protégé of Hildebrand who had been driven from the archiepiscopal throne, and filled by Henry at the solicitation of the diocese. And the man who claimed the obedience of the sovereigns of Europe was so little master in his own house that the nobles of Rome, headed by Cenci, a former prefect of the City, attacked the Pope, and cast him into prison, whence he was only rescued by fear of the "people who were devoted to him. Now, however, Gregory seemed to be complete victor. Impressed by the personality and under the influence of the great Pope, the Countess Matilda gave the succession to her broad domain to the Papacy at the time of the great scene at Canossa (I077). Gregory declared the ecclesiastics who supported the Emperor to be excommunicated and deposed (1078). He was not afraid of his Norman supporters even, and visited them with the penalties of the Church; while his authority ran from Sicily to Denmark and from Hungary to France. Councils were held, monarchs and bishops deposed, and reform effected. But Henry, victor in Germany, nursed his revenge, and the struggle between the Papacy and the Empire soon recommenced. The contentions of rival bishops weakened the political power of the Lombard episcopacy over their cities, and burghers profited by the bickerings of prelates to administer their cities themselves. Barely four years after Canossa (I080), Henry, more advanced in manhood and experienced in arms, and with a deeper insight into political issues, recrossed the Alps. Pope and Emperor launched fiats of deposition against one another. Henry was welcomed by the municipalities of Lombardy, and received the royal crown. Wealthy Pisa, Lucca, and Siena, seeking the grant of privileges, gave him every aid, and paralyzed the power of the great Countess. Henry marched on to Rome, and Gregory, placed in deadly jeopardy, removed anathema from the Normans, whom he had excommunicated for their aggressions, invested them with their conquests, and sent a despairing cry to Robert Guiscard for help. Three times did Henry invest Rome, three times he was compelled to withdraw, but at last the fickle populace, weary of the sacrifice they were perpetually renewing for their indomitable master, admitted the Emperor into the city. Gregory escaped to the Castle of St. Angelo, and was besieged by Henry and by the Romans themselves, now irritated through the sufferings they had undergone from that inflexible will. The wheel had gone full circle, and Gregory, pent up in St. Angelo, might hear the shouts that attended the crowning of the Emperor and the installation of a new Pope. For Henry called a parlia- 
ment of the Romans and the nobles and bishops of the camp. Gregory was finally summoned, and, failing to appear, the Archbishop of Ravenna was installed as Clement III. Then followed the coronation of Henry. But the Pope still held out in St. Angelo, and Robert Guiscard, who had retired from a campaign in Dalmatia at the Pope's call, accompanied by a body of formidable warriors, advanced to his relief. Henry, whose feudal following was much diminished by disease or the ending of the term of service to which it was bound, found himself in one of those enfeebled situations that were regularly recurrent under the feudal military system. He was compelled to slink ignominiously out of one gate as Guiscard's horse arrived at another. Rome was stormed and taken. The adventurers who " had defeated the army of the Emperor of the East in Albania, had put to flight the Emperor of the West, now replaced the greatest of the Popes on the throne of Christendom. Gregory VII., standing beside his preserver Guiscard, presents a spectacle so remarkable as seldom to be met with in history".(Gregorovi:us). The city was given over to slaughter, sack, and fire, and under the escort of Norman bandits and Saracen unbelievers the Great Visionary retired from the city to which he had brought ruin. He appears to have made no effort to save the city, as Leo I. is reputed to have done when it was menaced by Attila and his hordes. Prolonged contention had produced its usual result in embittering the temper and disturbing the judgment of a great spirit. $\mathrm{He}$ died at Salerno the following year, I085. Surveying his long and stormy career he had the satisfaction of being able to judge of himself in terms which few of the swift successors of frail humanity dare use, though they were completed by an utterance of bitter pessimism. "I have loved justice and hated iniquity, and therefore I die in exile," is said to have been the last word of the strenuous and lofty-souled Hildebrand.

His ambition was of no ignoble order. He aspired to make the Papacy the guide and controller of the Western nations, and the Church the worthy keeper of the Christian conscience. In order to do so it was necessary to reform the Church itself, to isolate it from all family ties, and to vindicate its independence of feudal influence and feudal interference. These two objects required (I) the submission of the clergy to a rule of life, not indeed new, but never rigidly enforced; and (2) the maintenance of the prerogatives of the clergy against lay authority. In the first of these two objects he succeeded, in the second he met with but partial success, and the quarrel Gregory bequeathed has been continued down to our own time.

The doctrine of a celibate clergy appeared very early in the history of the Church, at first tentatively and as a counsel of perfection, and afterwards it was enforced as indispensable. The Council of Elvira, which sat early in the fourth century, ordered married priests to live apart from their wives ; at the Council of Nice (A.D. 325) all but readers were excluded from marriage, and a whole string of Popes before Gregory had issued decrees commanding celibacy. When it is realized that, in the unsettled society of the Middle Ages, marriage was essentially a matter of family barter and arrangement, wherein the increase of the sway and power of the contracting families was a prime consideration, it is obvious that the claims of alliance might prove a serious and disturbing factor in a married career. The great lords, too, had commenced to intermarry their children with those of priests, especially in North Italy, where the 
great Heribert had been a married man. Since the Emperor had so many bishoprics in his gift, and, naturally, gave them to his own countrymen, this meant an increase of the Imperial power in Italy. And apart from political considerations it is generally conceded that the constraining force of marital and paternal duty often gravely hinders the fulfilment of high and strenuous purpose. A strong case can certainly be made out for Hildebrand, for, in his time, the stringent laws of celibacy were relaxed or had become a dead letter, and the richest benefices were assigned for family reasons. The Councils of 1074 and 1075 rigorously and decisively confirmed the condemnation of the marriage of Churchmen, and also of investiture at lay hands, which Hildebrand, as the power behind the throne, had previously prohibited through Victor II., Stephen IX., Nicholas II., and Alexander III., Pontiffs that, since he had contrived to secure the support of the senate and Roman people as well as the confidence of the clergy, owed their election to his authority. Nor was it only marriage that he attacked; he penalized sexual impurity in the priesthood. His great aim was to secure the spiritual power of the priestly order by isolating it from all temporal control and temporal influences. It must, however, be conceded that the austere Pope, who rose to fame and power by the sanctity then attributed to bodily self-mortification, was perhaps too ready to assume that the severe distinction of rigorous chastity, laborious to the unconsecrated natural man, would be rigidly observed by the consecrated clergy, even though that body was selected, invested, and sustained by spiritual control.

Investiture was a natural issue of feudalism. For though in the early Church priests were elected by the people, kings and nobles, in enriching the Church, naturally retained the right of presentation to the livings which they had endowed. Quite early the Carolingian monarchs conceived that they had a right to nominate bishops. If ecclesiastics held feudal lands it was illogical that they should be excused from feudal duty. When the Sovereign invested the priest with temporal benefits, the latter by the ordinary system of tenure should become his man. But, on the other hand, no result could have been more indecorous and inconsequent than for the servants of the Prince of Peace to lead troops, join in combat, and occupy themselves with worldly cares even more incompatible with their profession than those attaching to wedlock. Questions of privilege and right, of coinage and toll, not to speak of the seductions of field sports and worldly display, obscured those peculiar and distinctive spiritual qualities which should adorn a priesthood. The Church was fully equipped with the world, the flesh, and the devil, and every prominent person, if a Churchman, endeavoured to secure these ecclesiastical advantages for himself, if a layman for some member of his family.

Many spiritually-minded reformers, like Arnold of Brescia, have wished to relieve the Church of all temporalities except tithes; but Hildebrand was convinced that the Spiritual Arbitress of the world required temporal power to maintain her position and enforce her decrees. The revenues of the Church could be collected and administered by organized authority. Just as Cæsar and Augustus saw the necessity of consolidating and unifying the disorganized Republic by gathering all its forces under one head capable of purging the State of its vices, so Hildebrand perceived the need of a centralized command which might correct the 
corruptions and maintain the vigour and authority of the Church. $\mathrm{He}$ claimed, moreover, the right of the representative of the spiritual unity of Europe to the vassalage of the West, and to interfere in the name of God, of justice, and of right-doing, with the turbulent injustices and anarchical antagonisms of Feudal Europe. To the infallibility of the Pope when fulfilling his spiritual office, only formally adopted by the most œcumenical of all Councils in 1870 , he would fain have added the office of the Dictatorship of Peace to the Western World. Though he was not unopposed in his own Church, the long minority of the Emperor favoured his purpose. He thus was able to meet Henry's fiat of deposition with anathema, and the contrition of disturbed and exhausted Germany led to the triumph of Canossa.

Much as we are compelled to admire Gregory's persistent energy, his comprehensive views, his lofty ambition, and his pure motives; much as we are compelled to sympathize with his magnificent conceptions of a purified and triumphant Church, and his unwearied efforts to realize his aim, there are few who will not agree that, as the tyranny of the multitude is greater than that of the autocrat, so, but far more terrible even, would have been the tyranny of a Spiritual Power, established with an admitted claim to absolute obedience. From the tyranny of a Church which compels the conscience, as well as controls the destinies of its subjects, there is no possibility of revolt, no opportunity of escape.

Gregory was entirely successful in rescuing his Church from any serious menace of the State. From his time no Pope ever dreamed of awaiting the Imperial sanction to his appointment. On the other hand, he, and only he, could confer the Imperial crown, and since the monarchy was not hereditary, and was sometimes in abeyance, Gregory's successors were able to claim and sometimes to establish their suzerainty.

Gregory instituted a search in the archives of the Papacy, and believed that he had discovered unanswerable evidence that the kingdoms of the world were the fiefs of the Church. He believed, moreover, that all human institutions were a consequence of, and corrupted by, the fall of man; and, although this doctrine was subsequently rejected by St. Thomas Aquinas, that authoritative Catholic writer states that the actual directing presence of Divine Government resides in the Church; the Church alone constitutes the Livine mouthpiece before whose mandate civil government must bow. However the doctrine may be compelled to silence or disguise by circumstance or policy, this is the inextinguishable, immutable, and fundamental view of Rome, more strongly fixed in her deepest and most private thoughts in our twentieth century than in the eleventh; and it is an instinctive and obscure perception of this fact that has commonly rallied the friends of liberty in opposition to her.

\section{The Contest as to Investitures from the Death of Gregory VII.} (I085) TO THE CONCORDAT OF WORMS (I I22)

Gregory established the mediæval Papacy as a moral court of appeal in Europe, with the prerogative of excommunicating even Emperors. Whatever its lapses, and they were both many and serious, it.remained the embodied conscience of Europe, the symbol of the supremacy of the soul. The Pontiffs who succeeded him-Victor III., Urban II., Paschal II. 
and Gelasius II.-were animated by something of the same spirit as himself, while the antipope Clement III. was, of course, upheld by the Emperor.

Indeed, the mantle of Hildebrand almost appeared to have fallen on Urban II. Though he lived by the charity of the faithful, he nevertheless issued Bull after Eull against his foes, and, by the aid of the Norman "faithful" drove Clement III. from Rome and made him swear never to return. He restored the waning power of Matilda, the great countess, by inducing her, in spite of her chaste repugnance, to marry Wölf of Bavaria, the bitter enemy of Henry IV. Henry's answer was a descent into Italy. He took Mantua, Parma, and Piacenza, and so humbled Matilda and frightened the Guelph or Papal party that Urban II. evacuated Rome, and a large number of his bishops recommended Matilda to recognise the antipope. But an enthusiastic hermit, one John, reanimated the failing hopes of Urban's party; and Urban struck a serious blow at the Imperial power, not yet recovered from the effects of the struggle with Hildebrand, by supporting Conrad, Henry's son, in his rebellion against his father. Conrad got the good-will of Italy by promising to confirm the liberties of the Lombard towns, and Matilda accompanied him to Milan, where he was crowned King of Italy. Lombardy and the great possessions of Matilda in Central Italy were enthusiastic on his behalf. The Pope, Sicily, Matilda, and the free towns were thus arrayed against Henry, and when the Pope preached the first crusade and all the chivalry and religious enthusiasm of Europe leaped into fearless adventure at the Papal call, it seemed as if the power and authority of the Holy See were indeed clinched. But it was by no means the intention of the Guelph party to substitute Conrad for Henry IV., for Conrad was not docile. He died at Florence, and the Papal party then aided Henry, afterwards Henry V., in an infamous insurrection against his father. Five years after the death of the latter, Henry descended into Italy, to find Milan at war with Lodi, and a general demand on the part of the towns of Matilda's territory for concessions, which the great countess refused them. Paschal II. seized the opportunity of Henry's application for the crown to attempt to compel the bishops to surrender their Imperial fiefs.

If the great Gregory was unequal to such a task as this, the smaller man may well have remained impotent to effect it. Henry's reply was to seize and imprison him, but the Romans, skilled in revolt, effected his release. Paschal gave way in prison, but retracted the oath he swore directly the Emperor had recrossed the Alps. The struggle, signalized by war and excommunication, went on with wavering fortunes. In III5 the great Countess Matilda died. She appears to have been one of those high-strung women, so little understood in their own day, and so common in every age, who are enthusiastic but ill-balanced. There can be little doubt that she was under what one may almost call the hypnotic influence of her spiritual adviser, who again, received his directions from Gregory. "Suggestion" resulted in the bequeathal of her vast estates, which included Tuscany, Liguria, part of Lombardy, Modena, and Ferrara, to the Pontificate, thus casting down an apple of discord which later on induced a prolonged tussle between Emperor and Pope. The Papacy did not dare, indeed, to possess itself of these Imperial fiefs at the moment, but it knew how to wait. Nevertheless, the Tuscan cities, which already 
possessed republican constitutions, remained throughout free from Papal claim: Throughout the war of investitures the great rulers were in sympathy with the Emperors, for they recognised in the Papal Pretension a power capable of dethroning the mightiest and proudest amongst them ; but the German princes naturally tended to support the Pope, for by enfeebling their liege lord they had the opportunity of securing and enlarging their own authority and enjoying its unrestrained exercise.

In II2I the Imperial Antipope Burdinus (Gregory VIII.), who had been elected at a time when the Imperialist party had turned Paschal out of Rome, was captured at Sutri by the Papal troops. The Roman populace was indulged with a new form of triumphal procession; Burdinus was led through the streets strapped to a camel with his face to the tail. By this time the Emperor, wearied of war, and finding his power in Germany menaced by its continuance, approached the Pope, and the result was a Diet which sat at Worms and came to an agreement. This Diet produced two imposing State Documents which distinguished between Church claims and State claims. Feudal duty was recognised, but so was Church right. Each of the rival powers was endowed with the prerogatives consonant with its own particular character. But the problem of the relation of Church to State was by no means definitively settled in I I22. The burning question of the bequest of the Great Countess remained undecided. Could a woman bequeath her property without the consent of her suzerain ? Was no distinction to be made between freehold property and fiefs of the Empire? The Concordat of Worms was a truce produced by the weariness and exhaustion of the antagonists ; it was no cessation of their strife. The only gainers by the bloody and protracted struggle were the city communes. Privileges granted them by the Papacy in order to gain their allegiance were confirmed by the monarchical party in order to transfer it. And the communes had learned how to work the game. Almost all the towns of Lombardy, and many of Tuscany, had exacted or been granted rights from the bishops of one party or the other, and confirmed by their respective Sovereigns, or by both of them, as the wheel of Fortune revolved her course.

The most remarkable result of the struggles for investiture was the increased independence of the towns. Each side had been compelled to bid for their support, and the shrewd burghers had been able to effect a diminution of the authority of their bishops or snatch it from them on the one hand, and on the other to get their rights confirmed and their immunities extended from the Imperial side. Before long the municipalities had practically become self-governing republics, and almost all the cities of Lombardy and most of the Tuscan towns enjoyed similar liberty to the ancient freedom of Genoa and Venice. The political power of the bishops, attacked by the Emperor, was destroyed by the action of the Holy See in opposing him, and the Emperor confirmed by charter what the towns had wrested from their prelates. The long wars had produced indifference towards the contending parties. The enfranchised citizen began to take a keener interest in questions of commerce and toll, of roadway and waterway, than in the contest of the Empire and Papacy. Each city of the Lombard plain tried to extend its own commerce by ruining that of its neighbour, war waged fiercely between the little 
communes, and the chief occupation of the towns of Tuscany was to secure for themselves the tolls which they had refused to Matilda.

Thus the Concordat of Worms saw a multitude of small self-governing republics established, owing little more than a nominal fealty to the Empire, and almost emancipated from the episcopal power. The dissensions of the Church itself played no small part in their emancipation, for both Empire, and to a less extent the Church, were too often houses divided against themselves.

\section{The Reigns of the Emperors Lothatr III. and Conrad III.}

$$
\text { (I I } 25-I I 52 \text { ) }
$$

Henry V. died without issue in I I 25, three years after the Concordat of Worms. The last four Emperors, descended on the female side, through Conrad the Salic, from Otho the Great, and hence called the Salic House, were also dukes in Franconia. Now, Conrad the Salic had come from a castle called Weiblingen, which in its Italianized form gave rise to the word Ghibelline. There was also a conspicuous family which occupied the ducal throne of Bavaria in the tenth and eleventh centuries. Its sons bore the name of Welf. It is interesting to note in passing that the heiress of the last of the House intermarried with a younger scion of the House of Este, and became the progenitress of the House of Brunswick, and so of our own later Guelph monarchs. A diet, convoked at Mainz to elect a new Emperor, hastily chose Lothair, Duke of Saxony. Now, the Franconian line was represented by the Counts of Hohenstaufen, on whom, in I08c, Henry IV. had bestowed the dukedom of Swabia, and the Swabian family was naturally disappointed at the loss of what it had come to regard as a family holding. The Bavarian or Welf family was closely related to the new Emperor, and a feud seems to have now arisen between the two houses of Weiblingen (Ghibelline) and Welf (Guelf). Throughout the wars of investiture the Welfs had supported the Papal pretensions, and it was at the suggestion of the Archbishop of Mainz that Lothair was proclaimed Emperor to the exclusion of Frederick of Hohenstaufen, Duke of Swabia, who was a nephew of the deceased monarch, and who inherited the greater part of his estates. Lothair immediately after his election marked his inclination towards the Welf by giving the hand of his daughter and his own dukedom of Saxony to the chief of that house. The next year Frederick rebelled, and in II27 he was reinforced by his brother Conrad, who had returned from the Holy Land, and who crossed the Alps with the object of forestalling Lothair and securing Lombard support, not for Henry, but for himself, for, with his brother's consent, he was to represent their House as the successor of Henry V.

The Milanese received Conrad with great state. A parliament of clergy and laity assembled in the Piazza, and acclaimed him as the legitimate successor of Henry, and he was crowned both at Monza and in the basilica of St. Ambrogio at Milan ( I I 28). The Pope, Honorius, none the less gave an impartial judgment in favour of Lothair. Forthwith the " heather was on fire." Pavia, Cremona, Novara, Brescia, and Piacenza convoked a diet at Pavia, and their bishops excommunicated the Archbishop of Milan, who had crowned Conrad. But they gave Conrad no effective support, and sought nothing but the gratification of their own passions, so that 
Conrad, who was meditating a march on Rome, had to make an enforced halt at Parma. Contrariwise Lothair had been unable to do anything very effective in Germany (for Frederick held a strong position in Swabia and Alsace), and when he entered Italy in the following year (I I 32) his army was so ridiculously small that it was unable to besiege Milan, and arrived by a circuitous march at Roncaglia, an object of derision to the Italians. Meanwhile Conrad, who had been supported at the charges of Milan and Parma, quietly and unobtrusively stole back again over the Alpine passes. Both candidates for the purple had made a ridiculous and humiliating début, and the respect due to the Imperial power did not gain thereby. Lothair advanced to Rome, but had to be content with receiving the crown in the church of St. John Lateran, for St. Peter's was occupied by the Antipope Anaclete and the soldiers of Roger I. of Sicily. So the Emperor returned to Germany with all speed. There the two Hohenstaufen brothers made submission to him, and in I I 36 Conrad shared the command with Lothair in his second journey to Italy. Lombardy gave them a good reception, and they succeeded in dislodging the Antipope, and in forcing Roger to raise the siege of Naples. But in the following year (II37) Lothair died in the Trentino. His son-in-law, Henry the Proud, Duke of Saxony and Bavaria and Marquis of Tuscany, aspired to succeed him, but his arrogance disgusted the electors, who somewhat precipitately, and in a manner not too regular, disappointed his hopes by choosing Conrad. The Saxons and Welfs rebelled, and Germany was so ravaged by war between Conrad and Henry that the former was never able to leave the country to be crowned. He died in I I 52, and during the fourteen years of his reign Italy had little cause to complain of Imperial intervention.

The heavy hand of the Empire on the growing republics had become enfeebled by the intestinal feuds of Germany, and Milan perhaps had grown somewhat sceptical of its power to interfere. The republic was mistaken. The electors chose Frederick, Duke of Swabia, who, like our own Henry VII., united the pretensions of the rival houses. The grandson of Henry V. and of a Duke of Bavaria, he had been nominated by the dying Conrad. During his long reign the rival houses observed a truce ; he was a strong, capable man, in the flower of youth, and both able and willing to bring the restored might of Germany to bear on Italian questions. Both nations had become veterans in warfare, and a struggle between Imperial order and authority on the one hand, and civic independence and new-born enfranchisement on the other hand, was inevitable. A new Italy had arisen. The dukes, marquises, counts, bishops, and abbots, had lost their ancient jurisdiction and even their influence. Lothair had acquired the broad lands of Matilda by doing homage to the Pope for them, but he subinfeodated them to Henry Welf of Bavaria, and Welf of Bavaria was an absentee in Germany, and incapable of arresting the disintegration of his property and the usurpations of his towns. The Count of Maurienne, by his marriage with the heiress of the Marquis of Susa (thus uniting Piedmont with Savoy), and the Marquis of Montferrat were the only powerful lords in Northern Italy, the only relics of the old order. 


\section{The Norman Monarchy in Southern Italy}

While Northern Italy was in process of disintegration, and a number of communes or republics were developing principles of freedom under the liberating conditions of a contest of great powers, in Southern Italy a strong monarchical power was establishing itself on the ruins of the Greek Empire and the Lombard duchies, and subduing the ancient independence of the cities of the littoral. The strange spectacle is witnessed of barbarians that hailed from the fir forests of Scandinavia imposing the monarchical and feudal principles of the North on the subjects of the Basileus of Constantinople and the Caliph of Kairwan.

Robert Guiscard, sprung from the obscure family of Hauteville, a Scandinavian house that had turned farmers in Cotentin, was a man, as Anna Comnena, the Byzantine Princess, remarks, "who united marvellous astuteness with immense ambition . . . whose whole desire was to attain to the wealth and power of the greatest living men, extremely tenacious of his designs, and most wise in finding means to attain his ends ... who naturally hated the idea of service, and would not be subject to any man, for such are those natures which are born too great for their surroundings " (Alexiad). He died, master of Southern Italy, in 1085, at Cephalonia, where he was still warring against the Greek Empire. His brother Roger, " the Great Count," who exhibited the same bravery, greed, craft, ambition, and prowess that characterized all the other members of his house, subdued Sicily, not without some opposition on the part of certain Christians who preferred King Log to King Stork. The failure of the line of Robert united the "Two Sicilies," as Southern Italy and the great island got to be called, under the son of Roger.

The descendants of obscure buccaneers and petty farmers became princes remarkable for the just tolerance of their administration. They protected all races and creeds alike. Greek, Saracen, Lombard, Jew, and Norman of France or England, formed strange and discordant elements requiring the strong hand, and not permitting of the development of local institutions or of national life.

In the quarrels of the Empire and the Papacy the monarch of the South naturally took the weaker and anti-Imperial side. Hence he was crowned by the authority of the Antipope, Anaclete II., " King of Sicily and Italy," and later, on the triumph of Innocent II., King Roger, who had been his most uncompromising foe, effected a reconciliation with him, and was granted the title of "King of Sicily and of the Duchy of Apulia, and Principality of Capua." The monarch, directly he became authorized by the Antipope to declare himself one of the crowned Kings of Europe, was not long in demanding of the Amalfitans that they should resign the privileges of their commune, on the ground that these were contrary to monarchical prerogatives. The courageous little republic refused, but Roger took its fortresses one by one, and brought the citizens to submission (II3I). He turned his arms against the Greek heretics, won Corfu, and transplanted the silk-workers of Thebes and the Peloponnesus to initiate a new industry in Sicily. Many of his barons, feeling the oppression of his yoke, refused to aid him against the "legitimate" Pope, rose under Robert, Lord of Capua, and allied themselves with Naples, the last of the independent towns. Capua fell, and Naples sought the succour of Pisa against 
a King who was about to destroy the liberty of their ancient ally, and who oppressed the Church by forcing it to receive an Antipope.

The Pisans, ever on the side of the Empire, had taken up the cause of Innocent II. with ardour; they equipped a fleet and 8,000 men, but demanded expenses. The Neapolitans forthwith spared not, but gave even to the silver of their churches. The militia of Amalfi were forced by the Normans to intercept all communication by land, and the Amalfitan fleet was joined with that of Sicily, so that the coast was left defenceless. The Pisan Consuls, who commanded forty-six sail, seized the opportunity of injuring a rival commercial city, and surprised and pillaged Amalfi. Here they found a copy of the Pandects of Justinian, which they bore back with them. But the Pisans were surprised in their turn while besieging the Castle of Fratta; 1,500 men were killed or taken prisoners, including one of their Consuls; they retreated to their ships, and precipitately made for home (I 135). The commander of Naples and the Prince of Capua renewed their appeal to Pisa. But the Pisans, who had had a prolonged contest with Genoa, and were weary of war, especially since the disaster of Fratta, refused to fight any longer in a quarrel which was not their own. The Neapolitans had more success with the Emperor Lothair, for St. Bernard had urged him with his usual vehemence to put down the only Prince who prolonged the schism. Lothair set out for Italy before the end of the winter of I 36 ; but as he had to make a perpetual series of halts either to reform the administration or recover his rights, Robert of Capua went on in front of him, and solicited the Pisans anew. With their aid he filled five vessels full with provisions, and, escaping the blockading fleet, brought them into the harbour of Naples, which was completely beleaguered by the Normans and at famine-point. Robert then returned to the Emperor, who was encamped hard by at Cremona in Lombardy, and urged him to hasten on. Naples was, indeed, at the last extremity; but, as Falco of Benevento, who was himself shut up in the famished city, tells us, though women, children, and aged people were dying of hunger in the public streets, "yet Sergius, the commander, and the citizens who had the custody of public liberty, and who maintained the ancient manners of their fathers, preferred to die of want rather than to bow the neck under the hated yoke of kings " (Falco, Benevent. Chron.). At length the Emperor advanced, and forced the Normans to rajse the siege. Meanwhile the Pisans, taking heart of grace, had penetrated the defences of the harbour with a fleet of 100 vessels. Then they turned their prows towards Amalfi. Many Amalfitans received them gladly, but the two castles of Scala and Scalella, which resisted, were taken and sacked. From this time forth Amalfi fell into gradual decay. The vestiges of its republican institutions lasted up to $\mathrm{I} 35 \mathrm{O}$. To-day a picturesque fishing village, lying half concealed in one of the most enchanting districts of a beautiful coast, represents the commercial centre that once despatched its merchantmen to Syria and Greece, and established its counting-houses throughout the Orient.

This little centre of exchange and enterprise was perhaps the most distinguished among the few isolated nuclei that bore the feeble flame of liberty and conserved the arts and refinements of life through the dark ages : it carried on traditions of international trade and intercourse; it was a link in the Western world, connecting the civilization of a past age with the culture of modern times. Amalfi is popularly credited with 
the honour of the invention of the compass and the preservation of the Pandects of Justinian. A copy of the Pandects was certainly secured by the Pisans when they took Amalfi in I 35 ; but whether the Western world was then acquainted with that great work of legislation is unimportant, for at the opening of the twelfth century one Irnerius was lecturing at Bologna on the Institutes and Codes, and by I 35 the principles of Roman law were being taught throughout Italy. The compass is said to have been given to the world by an Amalfitan two centuries later, but Guiot de Provens, a poet who lived certainly not later than St. Louis, gives an unmistakable description of it, as do Guido Guinicelli, an Italian poet, and James of Vitry, bishop in the Holy Land, both living in the early part of the thirteenth century. They do not speak of it as a new invention. Probably the use of the compass was derived from the Saracens, and many scholars are of opinion that they, in turn, derived it from China, where it was certainly in use a considerable time before the Christian era. To Amalfi, however, belongs the honour of the foundation of the famous order of Knights-Hospitallers. Certain of its merchants, whom commerce drew to the East and devotion to Jerusalem, obtained in the year I02 3 permission from the Caliph to erect at Jerusalem a hospital for such among them as were sick, and for sick pilgrims. They also erected two convents. These they dedicated to St. John, and the establishments were kept up by the citizens of Amalfi. But the new institutions did so much good work among the sick pilgrims that their fame spread and their wealth was increased by free offerings, while many knights joined the fraternity. Hence, in I I 8 it was converted, without difficulty, into a military as well as a charitable order, sworn to the defence of the cross. These Knights of St. John of Jerusalem, driven from Palestine, captured Rhodes, and after their expulsion thence by the advancing Turk, were given the island of Malta by Charles V., where they re-established themselves and continued their distinguished career.

The Amalfitans framed regulations of the nature of sea laws (Tabula Amalfitana), which are said, though on unsatisfactory evidence, to have acquired the same acceptance throughout the Mediterranean basin as was accorded to those of Rhodes in classic times (Freccia de subfeudatione apud Giannone ist. civil del regno di Napoli). Their coinage, under the name of tari, was current wherever they went, and even as late as the eighteenth century Neapolitans were accustomed to count in tari. It was a gold coin weighing about twelve grains.

Naples did not long enjoy independence after the subjugation of Amalfi. When Salerno was taken by the Emperor, the Pisans, always apt to fire up, bridled because the terms of capitulation had been signed without their consent, although their fleet had commanded success. Innocent II. also claimed, one knows not on what grounds, that Salerno was an estate of the Holy See. So the Pisans reset their sails for Tuscany, the Emperor marched back again to Germany, and the Pope resumed his Pontifical functions in Rome. Roger, relieved from the presence of any serious foe, advanced; Salerno opened her gates; he subdued Nocera, burned Capua, and reconquered the country as rapidly as he had lost it. Innocent II., left single-handed by the Emperor's departure, tried to terminate the schism and the war by debate. Three of his cardinals discussed with three of Anaclete's cardinals as to the right occupancy 
of St. Peter's chair. Of course each party remained unconvinced, and a wordy war of anathema was fulminated against each other by the rival Pontiffs, who took good heed to keep out of the way themselves, each having learned discretion by experience of bad faith. The schism was closed by the death of Anaclete, for his successor was not superior to a bribe, and abdicated in favour of Innocent. Next year (II38) Innocent renewed his excommunication of Roger, and, untaught by the fate of a previous Pope, he even ventured to lead a little army against him. The Papal forces were surprised and surrounded and the Pope was led a prisoner to the King's camp in Sicily. Innocent, in order to become a free man again, despoiled his unhappy friend Roger of Capua of his rights and bestowed them on Roger of Sicily, and he entrusted to his care the "honour of Naples and its dependencies"- that is to say, he granted his captor the sovereignty of a city that had remained faithful to himself. Naples, having sost Sergius on the battlefield, and seeing no shadow of hope, submitted to the inevitable; it sent deputies to Benevento to offer Roger the ducal crown, and became a part of the new monarchy. The King, who up to this point had treated his revolted subjects with incredible severity, was more gracious to the Neapolitans. He preserved their municipal rights and whatever was consonant with the kingly power. Their quasi-independence lasted yet nearly another century, but though Naples became the capital of the kingdom, its commerce and prosperity suffered, chiefly by reason of the debased coin which the King of the Two Sicilies put into circulation.

Once firmly seated on the throne, Roger proved himself to be as able in administration as he had been brilliant in battle. He appointed justiciaries in the provinces and bailiffs in the towns to execute justice and collect the royal taxes. Under a constable, he appointed a baron for each district, gave the baron rule over the smaller nobility, and thus equipped himself with well-organized feudal support. He encouraged commerce, so that his marine excited the envy and jealousy of Venice and Constantinople. We have said that under Norman rule there was established a religious tolerance new to the world, and which has only been rivalled in our own times. Magnificent churches of Romanists, built by Saracens and embellished with mosaics by Greeks, adorned the cities of Sicily with a unique and delightful beauty. The mulberry was introduced with the silkworm from the East, and Sicily became the home of a novel and lucrative industry. A kingdom was consolidated which, in spite of the ringing changes of time-though it passed from Norman to German, and from Frenchman to Spaniard, though the fairest gem of the Mediterranean and the fruitful olive-yards of Campania were the prize for the bloody contention of aliens, though the people were debased by the vilest misgovernment-yet, so firmly was the bit and bridle adjusted that, from the times of its robber conquerors, it remained a compact and subdued state. Henceforward, save so far as the southern monarchy interferes with Italy by political interaction, it hardly enters into the imperishable glory that attaches to the unfolding of the Italian spirit. The kingdom of the Two Sicilies contained no germinal principle of freedom, it took little share in the brilliant achievements of the Renaissance, it accepted the gilded fetters of despotic peace, and its development was limited and stunted by that vicious restraint. 


\section{Northern Italy in the First Half of the Twelfth Century}

The war of investitures had given wing to the spirit of liberty throughout all the municipalities of Lombardy, Piedmont, Venetia, Romagna, and Tuscany. The cities, encircled by massive walls, defended by citizen militia led by the country squires that had been compelled or had desired to become burghers, developed wise constitutions, zealous magistrates, and a spirit of local patriotism and liberty. They accumulated wealth, and the more powerful sought to secure, by force of arms, the military obedience of their weaker neighbours, or even the ruin of their trade rivals. Two great towns in Lombardy surpassed the others in wealth and power-Milan and Pavia-and these invariably took opposite sides in the disputes between Church and Empire which divided the units of Italy into two great parties, not yet known as Guelph, or Papal, and Ghibelline, or Imperial. The cities changed sides from time to time, but Milan was, on the whole, Papal and Pavia Imperial in tendency. Milan had subdued Lodi and Como, and was supported by Tortona, Crema, Bergamo, Brescia, Piacenza and Parma. Cremona and Novara were adherents to Pavia. Turin was the most important of the towns of Piedmont, and contested the authority of the Imperial Vicar, the Count of Savoy. The city of Asti was more powerful than the Marquis of Monferrat, the family of the defenders of the Veronese marches was extinct, and the old Roman cities of Verona, Padua, Vicenza, Treviso, and Mantua were independent and of nearly equal power. South of the Po, Bologna held the first rank for wealth and military power, its school of jurisprudence was already famous, and students flocked to it from all parts of Italy and from beyond the Alps, while it was a formidable neighbour to Modena and Reggio on the one side, and Ferrara, Ravenna, Imola, Faenza, Forli and Rimini on the other. Florence was becoming the chief power in Tuscany, but Pistoja, Arezzo, San Niniato, Volterra, Lucca, Cortona, Perugia, Siena, and many other towns were independent communes ; as were the small towns of hilly Umbria, freed by the extinction of the great house of Spoleto. The crusades had given an impetus to the trade of Pisa, Genoa, and Venice. The first was mistress of the Maremma, of Sardinia and the-Balearics, which she had taken from the Saracen; but Genoa, predominant in the Riviera, disputed the sovereignty of Corsica with her; Venice, preserved from the hurly-burly of Italian politics by her lagoons, had developed a stable oligarchic constitution, and subdued the maritime cities of Illyria. All three commercial states had depots in the East, which led to an intense rivalry that had already lighted the fires of war between the two ports of the Tyrrhenian Sea. The spirit of freedom had penetrated to the Papal See, and schism enabled the Romans to revolt and complete the municipal enfranchisement of Italy. From the Alps to the confines of the Northern Kingdom every little city rejoiced in its own republican government, and exhibited a narrow, and too often a selfish, local patriotism.

For almost a generation no Cæsar had crossed the Alps; but the great tradition of the Empire still held the imaginations and affections of Italy, and all parties were prepared to acclaim his presence. So the discontented, the Pope, the bishops, certain feudatories, and little cities oppressed 
by their more powerful rivals, entreated the young Emperor Frederick (Redbeard), the first illustrious son of the great Hohenstaufen line, to come and set his house in order. Italy recognised him as her arbiter and sovereign, and Frederick, one of the greatest of German sovereigns, descended into Italy (I I 54), his intellect, perchance, prejudiced, but his will fortified by strong prepossessions, taking Charlemagne, it may be, for his model, possessed by similar lofty ambition and magnanimous aims, but convinced of the sacred rights of the Imperial Crown, and regarding the independence of Italy as a subtle revolt against the overlordship of Germany and the Imperial office-a revolt which it was his first duty to overpower. The struggle of the Empire with the Papacy now became complicated by the attack of the former on the Lombard towns, which were aided in the struggle by the support and moral authority of the Pope.

\section{THE COMMUNE}

\section{Was the Commune a Continuation of the Roman Municipality?}

THERE are two opposed schools of opinion as to the origin of the Italian communes. One holds, with Savigny, that the Republics derive from Rome ; the other, led by Troya and Hegel, maintains that they were selforiginated, or were the result of contact with Germanic freedom. Hodgkin thinks that the question can be reduced to its simplest form by considering the Exarchate, which formed a part of the Eastern Empire, and never really fell under Lombard domination. From the Exarchate we can therefore exclude Teutonic influence. Savigny admits that the higher magistracy disappeared in the course of the two centuries during which the Exarchate endured. The question, therefore, narrows itself into that of the survival of the curiæ, and if they survived, whether they retained their powers. In the East they were abolished by Leo VI. (890). They certainly existed in Italy at the end of the sixth century, and there is an almost continuous series of documents in the archives of Ravenna, which show that the curia still existed as a court of registration, and that the appellations of its officers were retained, little or not at all changed, up to that date. But there is no documentary evidence that these "subscribing witnesses" retained any real power. Hodgkin concludes that they were merely like our courts-baron or courts-leet. "If we can imagine these faint survivals becoming once more great and powerful realities, or rather becoming greater and more powerful than ever they were in the noonday of the Feudal System, if we can imagine them making and unmaking ministries and determining the destiny of England, then, as it seems to me, we may also imagine the Commune of Florence or Siena descending from the curiæ of the Imperial age " (Hodgkin, Vol. VI., p. 56). Nothing is more certain than that similar conditions give rise to similar institutions, and municipal communes may well have originated de novo in an environment favouring their genesis and development.

But there is probably some measure of truth in the contention of the Italian as opposed to the German school of critics. The Italian school would derive the mediæval municipalities directly from the municipalities 
of the old Roman world, and though patriotism and the renown of the Roman name has influenced that school, evidence has been set forth which would seem to indicate that the spirit of municipal life at least remained in the form of tradition; nay, that this spirit was always active, and that it gave the breath of life to the new institutions that came into being with the new world that unfolded itself when fresh and vigorous growths arose, intermingling their leafage with the old, pollarded, almost up-rooted, but still vital relics of the ancient world. Whatever may have been the case in the Eastern Empire, Majorian (457-46r) strengthened the municipalities of the West when the central authority was on the wane, and as that authority decreased, as communication became interrupted by invasion, it is natural to suppose that organization would consolidate in provincial centres. Leo VI. (886-9II) reigned at a time when the cities of Lombardy certainly possessed the germs of the Commune, and up to that time changes in the Exarchate were probably of a superficial character, for the old Roman tradition was not interrupted. Theodoric the Ostrogoth, who reigned at Ravenna, had been brought up in the Court of Constantinople, and respected Roman institutions. When the Lombards came they were only I30,000 strong, and they are not likely to have completely overthrown native institutions ; moreover, they soon became amalgamated with the conquered peoples, which, at least, means the permanence of old tradition and probably of old forms. The organization of the Roman Church, moreover, corresponded with the ancient Imperial organization, and it continued to represent, feebly indeed, the ancient culture. The Pope was elected by the senate, the people, and the clergy of Rome; it had militia organized for its defence, and the cities of the Pentapolis-Ancona, Fano, Pesaro, Rimini, and Senigaglia-formed a confederacy against the Lombard. Moreover, the Lombards, who had become Catholic, did not oppose the Pope as their Spiritual Head, but as the head of the Roman municipality, who stood in the way of conquest. The Roman law remained in use among the Latin population of Italy throughout the centuries of barbarian rule, and Lanzani asks the pertinent question, How could the law have persisted without some authority to maintain it? Moreover, during Lombard times the famous builders of Como retained a communal organization of Roman origin; industries still went on, and had corporations derived from those of an older time, and even if these organizations copied the schola militium, it is difficult to believe that the schila militium had not a Roman model. It may fairly be concluded, then, that the spirit of the Roman municipality remained as a vital principle, never quite extinct, and capable of bursting forth afresh into the manifestation of new and vigorous forms under favourable conditions.

\section{The Revival of the Maritime Cities and Rome}

The first towns to develop self-government and achieve independence were the Maritime Cities that were subject to the nominal overlordship of the Eastern Empire. Naples, Gaeta, and Amalfi became practically free states during the decline of Byzantine power, and although they willingly submitted to the restoration of the Imperial authority in the eighth century, the bitter difference of opinion between the Eastern and Western 
Churches concerning the veneration of images, a controversy in which they took the Roman side, facilitated their emancipation when the Greek power began again to decline. The neighbourhood of the great Lombard state of Benevento obliged the cities of the South to provide for their own defence, and Amalfi, as we have seen, became a true republic. All these cities were subject to Saracen as well as Lombard attack, but they always preferred trade arrangements rather than fight with the Moslem. The Lombard invasions drove the inhabitants of the mainland of Venetia to the lagoons, where during previous invasions they had found a temporary asylum. In 726 we find Orso, the third doge, assailing Ravenna, taking the nephew of the Lombard King prisoner, and reclaiming the city for the Eastern Empire, which shows that that republic was already powerful enough not to dread the Lombard, and by 837 the Venetians were able to add sixty ships to the Greek navy. For a long time Venice owed a nominal obedience to the Eastern power, but her situation gave her a unique history among Italian states of which we shall treat separately. Genoa, on the opposite coast, also was, in name, a portion of the Greek Empire ; she was separated from Lombardy by a chain of mountains, and the Lombards were never maritime in their tendencies. She was, indeed, incorporated by the Franks in the Empire, but in 888 we find her provided with her own consuls, senate, and popular assembly, and she was recognised as a state by Berenger II. (958). Pisa was incorporated by the resuscitated Western Empire in the margravate of Tuscany, and she favoured the Western Empire just as Venice did the Eastern, and, getting numerous privileges thereby, thus commenced that career of steadfast devotion to the Imperial cause which is so remarkable in her subsequent history. Rome, abandoned by the Exarch when he was beset by the Lombard powers of Benevento and Spoleto, became a refuge for the oppressed Latins around. The Pope, whose authority was delegated to him by the city and its clergy, who had never forgotten that he remained the foundation of a great Empire, disturbed indeed but not overthrown, was unwearied in his efforts to become the head of the Church and to secure autonomy, an effort which was greatly aided by the Iconoclastic rift between East and West. Rome had been nominally subject in matters temporal to Constantinople, but in 7 I 5-73 I the people, under Pope Gregory II., resisted Greek authority, and in 726 we find the Republic of Rome headed by Pope, Patrician, and Consuls.

\section{The Cities of Northern and Central Italy}

The early history of the towns has, for the most part, to be constructed from dry, bare, and incomplete annals, foreign chronicles, and monastic archives. Even of the more striking incidents of court and field, the glitter of the court, the shock of arms where princely issues were at stake, we get but a few bare bones of fact, robbed of the breathing life, the strong passions, the throes of hope and of despair, the motives to action, that characterize and animate human affairs.

" Darkly, as by some gloomèd mirror glassed, Herein, at times, the brooding eye beholds The great scarred visage of the pompous Past ; But oftener only the embroidered folds And soiled regality of his rent robe." 
If so little is said of kings and leaders of men it may be gathered how scanty and incidental are the references of the chroniclers to the towns.

We gather that in Lombard and Carolingian times the country was divided into the gau, consisting of the privileged order of the conquerors, and the civitas of the conquered. The gau (pagus, vicus, comitatus, contado) was ruled by a duke, or, in the case of border and incompletely occupied districts, by the margrave, under whom were the "big vassals" that represented his authority (vassales majores, capitanei, cattani). Freeholders, or hereditary possessors of their own land (alloduim), were the only real freemen (edelinge), and below these were the arimanni (ehrenmänner), those compelled to give service or tribute to the freeholders, whence the minor orders of Italian nobility or gentry were derived. The arimanni were the small freeholders who, in the decomposition of society caused by barbarian invasions, put themselves under the protection of bigger people; they were vavassores minores, or vavasors (Lanzani, $F$. Storia dei comunidal origini, Milano, I88I). The indigenous population were villeins, owing military service. On the other hand, the civitas was composed of the conquered, wherever these had preserved property, and the corporations of the towns if they had any constitution of their own, certainly of the trade-guilds. These guilds possessed a considerable amount of home rule, they regulated themselves and gave themselves their own laws ; and hence, there being no such centralization of authority as existed before and since, the trade-associations were the basis whereupon the organization of the town was built. All municipal institutions were of a military nature, for the invasion of the Huns and other barbarians necessitated the defence of the towns as a prime necessity. German and Scythian hated fortified towns, and regarded them as so many prisons. The Lombards, though they occupied towns, built their defences on points of vantage in the country, the walls of cities were razed, and their reconstruction was forbidden without the express consent of the King, to whom the defence of the kingdom appertained. It was always in virtue of some regal or Imperial charter that the walls were rebuilt, and these charters, at first granted with reluctance, became so needful when, in the ninth and tenth centuries, Saracens and Huns marauded the country, that not only every town but almost every monastery, village, and country seat had to be strongly fortified. This power of self-defence added greatly to the self-reliance of the towns and prepared the way for their emancipation. The Capitularies are silent as to the municipal trade-associations ; it is evident that the dominant people were above taking an interest in commerce ; their power was territorial, and they allowed an organization injurious to their interests to develop without perceiving its significance.

The whole land was subject to the King of Lombardy or the Emperor ; the feudal system grew up out of the acquisition of foreign lands, which were held by the partition and subdivision of authority. Under the Carolingians minor counts were subject to greater counts, the minor count ruling a city and its district. Thus Florence, Lucca, and Siena were ruled by counts subject to the Margrave of Tuscany, and the minor count was assisted by decurions or judices. When the Franks came the exaction of the counts was past bearing, and in order to remedy this, and also to institute a check on the centrifugal tendency of the great nobles, the Carolingians gave the bishops increased power. This increase of 
episcopal power and immunity led towards the sovereign sway of the bishop; the clerics were not slow to take advantage of general oppression ; they frequently appealed to the Imperial authority. At the time when the Papacy was at its nadir of degradation the bishop was prominent in the civitas; as the gau diminished in importance the civitas increased, and the commune, which had never entirely forgotten its ancient dignity, was emancipated from the worst forms of feudalism. After Charlemagne's reform the bishops came rapidly to the front; their votes, especially in Lombardy, turned the balance in the bestowal of the Iron Crown, and the elected Sovereign naturally favoured the party that had brought him into power. Thus Berenger I. gives his permission, not to counts, but to the Bishops of Bergamo, Pavia, and Reggio to fortify their cities against the Huns. Throughout mediæval history we find states within states, and as the city still increases in power and importance the gau still continues to diminish, and we find the bishop possessed of more and more land, with advocati to administer and protect his rights, as the count has his scabini for the same office. There is a perpetual tendency of the count to fix his authority and wealth by the oppression of the masses on the one hand, and by emancipating himself from sovereign control on the other; hence the Sovereign favours the bishop as against the other big feudatories; the vavasors, also oppressed, support the ecclesiastical power; and the trade-associations naturally support the ecclesiastic identified with their town and with a venerable Church of which the authority runs side by side with and even beyond that of the Emperor, and against the condemnation and curse of which the mightiest are unable to escape. The gau itself becomes divided into pro-episcopal and procount, democratic and aristocratic parties. Otho I. neither deposed the counts nor formally limited their prerogatives, but he divided and subdivided the great principalities, and, in order to weaken the power of the nobles still further, he encouraged the towns which were becoming able to check their pretensions. Thus the count, powerless to compel an armed population, found himself on the horns of a dilemma; he had to choose between relaxing his privileges or invoking the authority of a monarch who was extremely unlikely to support him. The bishop, rich in vassals, lands, and wealth, finally won all control of the city, the easier that its population was concentrated and organized. The only appeal open to the count was the sword or the diet of the monarch, and in both he was more likely to fail than to succeed. The count is, indeed, still supreme in the contado in the country amongst his vassals, great and small ; but the bishop heads the city in war, rules it in peace, judges its malefactors, and represents what has become a distinct political unit. But while the bishops thus unwittingly laid the foundation-stones of the Italian republics, they also, by supporting central authority, bound Italy to Germany, and made her vassal to a foreign monarch under the specious form of the restored Empire of Rome.

The importance of the count having diminished, the arimanni resist his authority; when successful they become his peers, when defeated they sink again into vassalage. The jealous neighbours of the count give no aid, but the city, ruled by its bishop, profits by these divisions in the enemies' camp, and the secular vicar of the bishop, presiding over'a council of scabini of the country and "good men and true" (buomiomini) of the 
towns, calls all the minor nobles before his court. The towns, in a measure left to themselves, quietly set up municipal government without any charter; they see little of the greater aristocracy, who shut themselves up in their castles and rule the land around them. The nobles, nevertheless, have acquired a taste for luxury, and so the city thrives ; but, as the bourgeoisie increase in wealth, the lowest class of invaders sink into penury. Among citizens are dependants of the Church and those that had been dependants of the lords. Otho I., in order to rule by dividing, gives freedom to many cities, such as Acqui, Bologna, Cremona, Florence, Iodi, Novara, Parma, and these cities, flourishing under this period of episcopal supremacy, form a militia, led by "captains " who are the greater vassals, officered by minor vassals (of whom there are a large number bound now to the Church), and recruited by the citizens themselves.

The natural tendency of the bishop was now to constitute himself absolute ruler of his district. The attempt was invariably followed by the revolt of his vassals. The summit of episcopal power is already reached at the end of the tenth century, and the first half of the eleventh century witnesses a reaction. Thus, when Heribert, the great Archbishop of Milan, despoiled a vassal of the Church, disaffection commenced in the city, a fray ensued, and numbers of vassals were expelled. These descendants of the conquerors, vassals residing in the city and outside, collect; are supported by the vassals of the bishops of other cities under the name of "Motta," and by Conrad the Fmperor, who now opposed the bishops for the same reason that the sovereign authority had formerly opposed the counts-he could not allow his feudatories to become so powerful as to increase the chances of successful rebellion. Bloody battles were fought between the vassals and the militia of the towns, and obliged Conrad II. to descend into Italy. To release the vassals from oppression, he declared all fiefs to be hereditary, and that feudatories could only be dispossessed by judgment of their peers or by Imperial decision. The exact date of this edict is uncertain, but it laid low all episcopal domination over the vassals of the Church as well as the power of the big feudatories. When the war was over the smaller nobles returned to their cities, only to find that the people recognised them as a breed no less rapacious than the upper nobles; their position was by no means improved. The bishops, too, who were of foreign descent and noble birth, abandoned by the small gentry, turned to the citizens for support. Conrad returned to Italy (1036), having succeeded in setting up the smaller nobles against the power of the bishops, though these were aided by the militia of the now very important cities. But the vassals, quite secure in their privileges by Conrad's edict, perceived that it had now become necessary to defend themselves not merely against internal foes in the cities to which they belonged, but also to help defend the cities against rival powers, and even against the Emperor, formidable by his army and capable of imposing severe legal restraint. Heribert, the Archbishop of Milan, was summoned to the diet at Pavia; he disobeyed, was seized, imprisoned, and released by his own party. He re-entered Milan and became a national hero. The Italian populace defended their bishop against the might of the Empire ; all are of one mind for the nonce ; trade corporations are organized into military companies ; every quarter 
of the city (a feudal division for administrative purposes) has its own captain and standard-bearer, who are small nobles; the heads of the trade corporations and the corporations themselves become soldiers; the militia includes all the artisans of the city. To withstand the shock of cavalry Heribert hit on a device. For he was the author of the caroccio, adopted by every Italian municipality. This "ark of the covenant" was the rallying point of the army; Mass was celebrated on it when it left the city, and often a priest accompanied it; the fiercest battle waged round it; it gave weight, confidence, steadiness to an army, brave indeed, but ill-disciplined; it could not be saved in a hasty retreat; to leave it on the field was a shame worse than the last indignity of death. Thus, defended by a valorous and patriotic people, Milan withstood Conrad. $\mathrm{He}$ had to raise the siege.

The question will arise how, in the incessant changes and incurable instability of the times, the towns nevertheless made uninterrupted progress in trade, civilization, and power? Such centralized authority as was established had a two-fold origin. The town was divided into municipal districts under a centralized command, the nature of which we shall presently set forth. This, as we have said, was a feudal arrangement. But the organization of the town in the main proceeded from the trade associations as a basis, and this was not an imported and adopted arrangement but in spirit, at least, of ancient derivation and of spontaneous, natural, and native development. The municipal institutions, as such, were chiefly of a military nature ; they preserved order and administered justice in grave cases. The various associations were responsible for everything else.

Quite early we come across the ancient name of Consul, which gets a very definite signification. Otho III. in 998 calls himself Imperator Consul, and bishops sometimes assume the title. But Consuls having other functions than those of merely governing are found in Fano and other places in 883 ; in Rome in 901 ; Orvieto, 975 ; Ravenna, 990 ; Ferrara, IOI 5 ; Pisa and Genoa, I IOO; Florence, Iror. Naturally, the most prominent members of the trade-associations would meet together in cases of emergency or of some common danger threatening their city. Gradually the cities grew more and more organized by the efforts of the citizens themselves.

It is now the turn of the bishop, whose power is reduced by the edict of Conrad, to concede privilege, and the independence of the people is more and more secured. The bishop has to rely on the citizens. Yet the gau, though shaken, is by no means overthrown. A portion of the privileged orders is predominant in the country, and the bishop is always of that class, though self-interest may have led him to oppose its pretensions. But the Italian people have already entered the political arena, and the Italian cities, through their bishops, are integral and even predominating factors in feudal society. Whenever there was a struggle between count and bishop, or between the greater and smaller nobility there would be a tendency for representative citizens to make themselves felt; and we have now arrived at a period when ecclesiastical reform was in the air, when more than one Pope claimed to be the successor of St. Peter, and when two bishops belonging to different parties claimed the same see. The rule of faction was almost the only sort of rule known in Italy, and as, when a see was contested, neither bishop could properly perform his 
functions, the bishop's representatives commenced to exercise the power that properly belonged to him. Religious reform was inextricably interwoven, as is nearly, if not always, the case, with political movements ; heresy is often the banner under which economic or social forces assert their claims. Lombardy was honeycombed with heresy, and within the Church rival bishops were supported by rival factions, whereby the citizens got more influence and more power into their own hands. The big lord, in order to oust the episcopal power, gives the city privileges, especially in times of danger to himself ; and then, fear of the big lord with his vassals without the walls and his castles that command the routes traversed by trade, determines the burghers to support the smaller nobles. The big burghers become equal in wealth and power to the smaller nobility, and frequently they begin the struggle. Bishop and count are not so strong as they were ; both are deprived of their natural allies, while the citizens are ready to take arms at the least offence now that they are organized and have tasted the sweets of power. Let anyone be attacked by a noble, and the guilds take up his cause, which is theirs ; probably the man belongs to a guild, is associated with trade; then the reason is the stronger. The arrogant bigger nobles who have taken up residence in the city are in their turn ejected from it, warred against. As often as not it is the bishop himself who has to go. In IO4I a noble beat a plebeian in Milan, and another noble, Lanzone, with all his vassals, took up the popular cause, for the citizens always required some man born to arms and command to lead them. They made Lanzone chief of the Council of Credenza, the council of the big burghers; they besieged the fortified houses in the city, which the nobles, introducing their right of private war within the walls, had built for themselves, and razed them to the ground; finally, they compelled the nobles to leave the city. The Emperor was about to intervene and reassert his authority over Milan, when Lanzone, with admirable address and practical wisdom saved the situation. The nobles, masters of the routes and cornlands were perhaps able to reduce Milan by famine. Lanzone had been obliged to appeal to the Emperor, and liberty would certainly have been lost had that appeal been followed, as was required, by the admission of Imperial cavalry into the city. Like a wise patriot Lanzone effected a peace, whereby half the government of the city was to remain in aristocratic, half in purely citizen, hands.

But the men of the various cities had learned how to oppose cavalry by massing themselves round the caroccio. They were joined by the smaller nobles, or gentry, who were allowed to remain within the walls, whence, as almost everywhere, the big nobles were expelled. And when the nobles return everything is changed for them as it was for the vassals during their war. There are no longer two opposed classes of aristocrats, originally of foreign extraction, and people; for the smaller gentry that have suffered from the arrogance of those above them, or have begun to trade, are with the people; the nobles, individually powerful, are not wholly preponderant as a class ; the bishop is no longer quasi-absolute, he must respect freedom, any infringement of liberty will turn to his detriment, if he exercises his old power he is met by rebellion, and he is always liable to Imperial ban; the bigger nobles find the city intolerable, and retire from the delights of city life to their fastnesses in the country where they have real subordinates. 


\section{The Constitution of the Republic}

The fall of episcopal power enables the spirit of association, inherited by the people through tradition, and, perhaps, by the presence of some actual remnants of ancient life, to manifest itself in a united municipality, freed from the dominance of count and priest and greater nobility that have departed. All classes of citizens assemble in Parlamento consiglio grande, or general assembly. This includes all who possess bread and wine of their own; but the gathering is unmanageable, and the big burghers who direct the trade and policy of the city take care that the numbers who possess the franchise are reduced. In Milan the numbers were after a while limited to 2,000 , then to $\mathrm{I}, 500$, then to 800 . The gathering, summoned by bell, proceeded to elect authorities representing the ancient powers of count and bishop, and taking command of the army and control of police and other forms of jurisdiction. These reproductions of the ancient duumviri are called consuls, and, just as the duumviri were aided by decurions and the count and bishop by scabini, so are the consuls supported by a consiglio di credenza, or private council, also elected at the general assembly. The members of this council are called councillors, judges, wise men; they are experts in the laws of the people or of the various trade associations (Lanzani, L. ii., c. ii., § 5). Such a popular assembly certainly met in Milan in 1045. The chief representatives are nobles who have taken the popular side and have remained in the city; but these no longer form a distinct people, they have become a class, and their position as leaders of the commune is not a matter of privilege, but of the free choice of electors whom they represent. Career is open to talent, and industrious and astute citizens can, by the purchase of land, become the equals of the gentry. But the bishop and the count still try to regain their lost position; and the big nobles will not allow goods to pass through their domains without excessive taxation or sheer robbery. The count, the bishop, and the expelled heads of the city, often make common cause against the republic which has expelled them, and rival cities have to be contended against, for, in the municipal constitutions accorded by Otho I. and his successors, the right of private war, once the right of every free Teuton, was accorded to the cities. Efficiency in administration, policy, and military preparedness was a necessity to existence in such strenuous times.

Ultimately the government of the city assumes something of this form. The consuls, besides being civil and military administrators, convoked and presided over the councils. They could be re-elected, and varied in number from two to twenty. The Secret Council acted as a check on the consular power, and dealt with foreign affairs and finance. But there was usually another body, composed of a hundred members or more, and named in different cities Senate, Grand Council, Special Council, or Popular Council. This body prepared the resolutions to be put to the sovereign people in parliament assembled. The people were summoned not merely for election but for consultation on questions of high importance; but propositions were never submitted to them before they had passed both councils. The towns were divided into four or six quarters, corresponding to as many gates or chief churches. Each ward was 
responsible for the defence of its own gate, and came in a short time to have a separate consul exercising both civil and military functions; each provided a separate military troop, indicated by a special ensign; the tradeassociations had also ensigns and formed companies. The consuls were selected from among the richest citizens, and, when the nobles again became burghers, from among the nobles. The soldiers of the quarter consisted of one or two companies of armed horse, twice that number of cross-bowmen, and twice their number of infantry, armed with lance, buckler, and helmet; the remaining citizens, also in companies, carried swords, and were obliged to assemble in the "place d'armes" of their quarter at the tocsin's call. The age of service was from eighteen to sixty. The captains of the quarters were subordinate to the consul; each had a standard-bearer, and each company was led by a sub-captain. There were no petty officers; every man was left to his own initiative so long as he kept his colours in sight. The horse were all of the smaller nobility, and as they constituted the most effective arm of the service, we can understand the anxiety of the burghers, who had no opportunities of becoming cavalry, to secure the services of the signorial class. The towns as well as the feudal nobility not merely possessed but exercised the privilege of private war; nay, their wars were envenomed by jealous rivalries and marked by a spirit more nearly national than juridical.

Specially early in development were Rome, Orvieto, and Verona. We discover communal institutions as early as the tenth century. Genoa, Pisa, and Ferrara also have well-defined institutions in the eleventh century.

The antagonism of the city and the surrounding country nobility was favoured by the lands belonging to the cities being interlocked with that of small domains. As the civic population increased, it was exposed to starvation by a signorial league. At the best of times, indeed, the nobles were wont to sally forth from their strongholds and rob the passing merchants and travellers, or devastate the city lands right up to the very walls.

For a short period internal concord seems to reign in all the cities. The arch-enemies of the burghers, the high nobles of the gau, do not trouble them ; the smaller nobles, or, as we should say, gentry, have had their teeth drawn, and form a cavalry useful for attack; for the citizens are no longer content to defend their walls, but march out with their caroc.io to put an end to the depredations of their foes. There is, indeed, a constant vendetta going on between the city and the remaining part of the gan, and bit by bit the citizens reduce the castles immediately surrounding the city and make their lords their vassals. The city is, moreover, an asylum for fugitive slaves and all rebels, and the country nobles are obliged to give their slaves freedom, in order that they may have a sufficiency of fighting men against the city, and keep these dependents contented. The little villages are either given privileges similar to those of the city by their lords, or they assume freedom and are protected by the cities. As the citizens take castle after castle, they compel the owners to become their vassals. In fact, the perpetual vendetta and every accommodation of peace are absolutely feudal in character, and go on under the feudal overlordship of the Crown, of which the city is now directly a vassal. Every year it grows more important by the number of villages and their lords that it makes its own vassals. The commune has already almost 
entirely replaced the greater lords ; it is now the overlord of a vast proportion of their vassaldom, but it is hampered in its march of conquest by the fact that its soldiers are burghers and artisans, and cannot remain away too long a time from their business. Hence, directly the campaign is over the nobles collect again, burn the crops and harry the lands of the commune, and the contest begins afresh.

\section{The Cities and the Wars of Investiture}

The Contest of Investiture in Italy covered many other issues than that of Feudal v. Ecclesiastical rights. Within the Church itself it gave an opportunity to the ecclesiastical nobility to rebel against Papal supremacy, and to the lower clergy to oppose the ecclesiastical aristocracy; it gave a chance to the great feudatories to throw off the tightening Imperial chain, and to the centrifugal forces of Lombardy to oppose Teutonic dictation; it brought into relief the antagonisms of the Empire, of the people of Northern Italy to the aggressive Norman, dominating the South, and his alliance with the Pope ; it enabled the minor orders of feudality to oppose margraves and other great lords; and, above all, it gave opportunity to the cities to assert and increase their independence, and to be the protagonists of the Latin population resurgent from the bondage of the descendants of its conquerers, of native as opposed to barbarian law and custom, of the ancient principle of association as opposed by the innovation of a social system of foreign origin. That social system was an arrangement wherein privilege and subordination of rank were a compromise whereby the rank individualism of the Teuton was enabled to assert itself under the forms of legality (vide Lanzani, Storia dei Com. It., r882, p. 177).

In ro59 there began a long struggle between the Papacy and the Church of Milan, which had up to that time been almost independent of Rome. Milan had a liturgy peculiar to itself, and derived its discipline from St. Ambrose. Married men were allowed to take orders, though an unmarried priest could not marry after ordination. There was, however, a good deal of protest, accompanied by tumult, against this Ambrosian practice before the time of Hildebrand. Pope Alexander II. sent a legate to Milan in 1063 to enforce the decree of celibacy, and serious disturbances accompanied his advent. A Bull of excommunication was launched against the city, but the people rose and drove out the Fapal agents. Faction fights continued for some years, and in 1076 the Papal legate was killed in one of these riots. The Fapacy replied by removing its suffragans from the jurisdiction of the Archbishop, to whom the people, for the most part, loyally adhered. Gregory VII. finally succeeded in extinguishing the independence of the Ambrosian Church (Verri, Storia di Milano, Chap. V.). But the effect of this was that, during the War of Investiture, the cities at first took the side of the nobles. By-and-by, however, the Imperial authority was found to be weakened, and Milan and the other Lombard cities allied themselves to Matilda, the great countess, who firmly supported the Papal claims. By doing this they contrived to get rid of the Imperial vicars, and really to establish their communal independence. It was then that they were enabled to fix firmly something like a communal constitution, for the power of the 
Archbishop of Milan had been seriously weakened by the detachment of his suffragans from his authority; the Church generally had lost much of its power in Lombardy during the time that the people sided with the nobles and the Imperial cause. The bishops had occasionally lost authority by Papal nominations which were not recognised, and finally, when the towns allied themselves with Matilda, the Imperial authority was at a discount.

The opposition of the episcopal nobles to Papal pretensions aroused, then, at first, some spirit of Lombard nationalism, and hence the militia went with the Emperor. But there was an undercurrent of suspicion of a Sovereign Power that, indeed, had favoured the communes solely to abate the big nobles and exalt itself. If rebellion against the crown implied Imperial ban, it removed Papal interdict. The defection of Ferrara, Lucca, and Siena prevented Matilda, the great Margravine of Tuscany, from employing her military resources to the full, and the Lombard towns were not slow to take advantage of the situation. In the whole vast domain of the Margravine the gentry were rebellious, and the bishops and greater nobles had to secure the support of the citizens; for the cities were now as strategically important as the castles. On both sides there ensued a bid for the support of the city, of which the importance gave dignity to its overlord, as its defences and militia gave him strength. Each side tried to excel the other in extending liberal privileges as to toll, customs, rights of coinage, questions of food-supply, extension of territory, etc., all duly set forth and ratified by charter. The gratitude of the cities consisted in a lively sense of favours to come from the other side. We find Iucca on the Papal side in 1064; for the Emperor in 108r. In 1098 Matilda gave Crema to Cremona; in 1204 Cremona obtained a new charter from Henry V. Privilege and dominance were the restraining forces of the feudal system, whereby it was preserved from sheer individualistic anarchy, and it will be noted how completely submissive the spirit of association in the towns was to this exotic importation. The commune is still nothing but a plexus of associations which, in the troublous times of the Wars of Investiture strives to get particular privileges for itself ; the individual profits thereby and is ready to fight in order to obtain what he wants or defend what he has obtained. At the head of the commune are men of Teutonic descent and tradition, saturated with the feudal spirit, and this, and the national tendency of the richer classes to dominate, gives a direction to the state whereby the privileges thus obtained are enjoyed by a few, who gradually form themselves into orders possessed of privileges from which the many are excluded.

During the Wars of Investiture the smallest grievance against a bishop or against its neighbours was an opportunity seized by the commune and turned to its advantage. The townsmen had learned how to put on pressure by revolt; and ambition to extend their territory, jealousy of a neighbour, commercial greed, and the policy of capturing the trade of a neighbouring town were causes which helped towards communal independence. For in every town there was an Imperial as well as an ecclesiastical party, and where these were nearly balanced, the less eager partisans would probably turn the balance in favour of whichever side was likely to procure more advantage to the common weal. Ill-informed as to the real merits of the dispute, its adhesion to Pope or Emperor would 
soon come to depend on what would bring most advantage to the tow $n$ itself. The communes were, of course, of little vital service to either party, but their miserable little quarrels were an aid, for, since the towns were so militant, the one that was a foe to-day might become a friend to-morrow. They were allowed to pursue their own course in order to

- retain or to procure their aid for as much as it was worth. For the most part, for example, the towns contrived to get the election of their bishops practically into their own hands.

While the spirit of association prevailed within the commune, it must be remembered that each little republic had only a very few miles of territory, and each existed quite in and for itself, and not at all for its neighbours. Each petty town or village was like a great modern state, purely selfish and grasping in its policy. All beyond the narrow domain was foreign. "In fact," says Lanzani, " hardly is the commune constituted than we find its spirit identical with that of the feudal man in his relations with his subjects and equals : it demands onerous services; its citizens will do to others what they had endured-death, rather than submit to themselves."

Questions of pasturage, cattle, boundaries, were constantly arising, the more so as the estates of the nobles were interlocked with those of the towns. A series of private injuries become a public wrong which it is necessary to suppress. The town is found constantly asserting its rights, which was not so perilous as it would have been had the aggressors been united ; but, as a rule, like the Gow Chrom, every man fought for his own hand. When negotiation failed, an attack was made on the transgressors. The towns, if they found their forces too feeble, sought for allies; these allies, whether smaller towns or feudatories, tended to become tributary. The communes soon learned method in their policy; they became aggressive on the occurrence of anything that would serve as a pretext for attacking their weaker neighbours first.

Both the Papal and Imperial authorities were acknowledged; but they were antagonistic, and one was foreign and usually distant. The law of reprisals allowed an injured man to force restitution from the first man of the community to which the offender belonged, and each commune was nothing but a big family, with its own family dissensions; but all of its members were ready to rise and resent an injury offered to one. The first use made of increased privilege was to extend territory; the War of Investiture was utilized by the cities to their own private ends; they adopted a standard in order to call all citizens together to assail a neighbour. Often a feeble commune sought the protection of a more powerful city against an aggressive neighbour. Thus, we find Crema placing herself under Milan to escape Cremona. Leagues were formed which simply implied a convenient concentration of forces for the pursuit of quite diverse interests : they were ephemeral; a city protests against the absorption of territory near, and whilom friends are converted into bitter antagonists. The foreign policy of the commune plays into the hands of the nobility that had remained in the city or of the wealthy burghers. These classes are sometimes antagonistic, sometimes united, and the internal policy of the republic is disturbed by faction.

This seething turmoil wherein there is perpetual strife of interests, the reactions of municipal association and municipal organization and 
feudalism, the contest of city with city, bring into prominence the courage, the intelligence, the idiosyncrasies of the individual. The struggle endows the citizen with just pride and concentrated patriotism ; it emancipates him from the thraldom of antique ideas, and is the commencement of the reaction of the individual spirit against the fetters of mediæval conceptions and mediæval forms. Yet the Emperor, with his double claim to obedience as King of Lombardy and Head of the renewed Empire, is still acknowledged, and the movement of the communes is, as yet, only the undercurrent of the returning tide.

The war against the nobles was almost perpetual. Even the little villages learned to desert their lord, until the lord, in order to preserve even the shadow of power, petitioned to re-enter the city, became its vassal, and swore to observe its statutes. The city now took entirely the position once held by the great vassals who received their fiefs directly from the Crown. The nobles discovered, when it was too late, that they were isolated one from another in holdings too feeble for them to hold, or even to reside in, with safety. Often they gave their castles into the hands of the Church; oftener they were compelled to surrender them to the town and reside in it as hostages. The citizens, by reason of their daily occupation, were incapable of prolonged warfare; nor was attack sufficiently developed to admit of their carrying strongholds by assault; indeed, a few retainers could usually hold them against a numerous force until subdued by famine. Hence the republics endeavoured to conciliate the rural counts by admitting them to citizenship. Moreover, the citizens were ill-fitted to command, and they had not the valuable connections and large acquaintance with the world that the nobles possessed. Most of the nobles accepted burghership, hoping to regain within the city the predominance they had lost on the countryside. Further, the towns were much livelier residences for the nobles and their families than the dreary country, and gave them plenty of employment in warfare. Moreover, they had the diversion of feuds among themselves, and this bellicose spirit unhappily spread to the citizen-population. Each family or clan of the aristocracy inhabited a high tower, to which their houses gave access, and into which they could retire when they were not on speaking terms with their acquaintance. Here they could defy their foes in safety, and rain down missives from the lofty battlements. In Florence there were five hundred of these towers, some I 50 feet high, surmounted by wooden balconies, whence missives could be discharged on assailants below. Visitors to the little Tuscan town of San Gimignano, the " city of the beautiful towers," will recall its bristling appearance on the summit of the hill, yet only one-sixth of its towers are still standing. The lofty leaning towers of Bologna are other examples of this kind of street-fortress. The nobles kept up a constant state of domestic squabbling, elucidated by the argument of the naked blade. These contests in the narrow thoroughfares appear to have caused as little concern to the citizens as an ordinary street fight does to-day. When they were weary of slaughtering one another, the nobles not uncommonly applied to the tribunals of the town, and this tended to give dignity and power to the citizens. For, at first, nobles were independent of the consular authority. Often they were extravagant, or found war a losing game, and sought admission to the burgher class; and when the burghers had 
become of importance by reason of their increasing wealth, this loss of caste carried but little humiliation with it. The nobles were often chosen to civic offices, since these so often implied military duties; and this was not done sparingly by the burghers, for they had a certain security in the fact that the tenure was for short periods of time, and that the offices were eagerly competed for. Hence the real civic power came to be vested in a few great noble families and a larger number of rich burghers that included the smaller nobles or gentry. Nevertheless, these two orders were hostile to one another, and, in Lombardy, the nobles often preferred to become the vassals of the Church rather than of the town. Of northern extraction, the feudal aristocracy loved horses, sport, and the great game of war, and despised the folk who could not fight on horseback. Their ideal was the maintenance of honour; that of the burgher the exercise of prudence. There was no serfdom within the town walls; free labour was necessary to its increasing trade.' Christian ideas, too, helped emancipation. The serfs became burghers, and often rose in the social scale ; so in the communes, as always, commerce, until it became gathered into the hands of a few, tended to the abasement of the mighty and the raising of them of low degree. But a number of serfs were still to be found in the country, and there, right up to the fifteenth century, we find leaseholders tied to the soll. The science of law was in the utmost confusion. Roman, Lombard, Feudal, and Canon law were coexistent. The Italians had kept some fragments of their old judiciary system; the Teutons had introduced theirs, and each nation had administered its own laws in its own way. The towns and trade-associations formed their own statutes; but, with the revival of the study of Roman law, some systematization of laws and their subordination to principles began to take place. This study had its effect on the communal statutes, though these were of quite native origin, and were devised to meet the practical needs of the towns. In spite of the difficulty of protracted warfare, the communes resented exaction, and were wont to take the matter up and carry it through. If, as happened sometimes, the nobles achieved almost exclusive possession of the offices of the city, others of their order, relying on their protection, were wont to conduct themselves arrogantly towards the inferior classes. Then war arose within the walls.

\section{ROME}

\section{Medieval History to i i 8 A.d.}

Rome aspired to be the Metropolis of Christianity, the centre of both the Imperial and Papal authorities. At the same time the Roman citizens were unwilling to submit either to the Empire or the Church. The Popes, in order to strengthen their position or reward their friends, granted these fiefs in the contado. Hence the history of mediæval Rome is a history of revolutionary wars-wars of the people against the nobles, of the nobles against each other, of nobles or of people, or of both combined, against the Pope or the Emperor. 
How far the old municipal constitution of Rome decayed we cannot tell. There was a shadowy Senate in the period of Byzantine rule, and an army under a magister militum commanded the troops, and received his orders from the Exarch of Ravenna. Yet this authority was not foreign ; here the Goths did not claim one-third of the produce of the land ; and if the glory of Rome were faded, the Exarch was still a Roman official representing the authority of the New Rome on the Bosphorus. The invasion of the Longobards brought the wagister militum to the front : the prefect of the city becomes an unimportant person. Rome had to organize herself and fight for her own hand, and Pope and people drew together against the barbarians and against the Eastern Emperor that no longer exercised direct authority.

The fluctuations of Papal power and its relations on the one hand to Imperial power, and on the other hand to the city of Rome, can only be considered together.

The Roman republic will be found to bear a general resemblance to that of the other communes of Italy, both in its constitution in the Middle Ages, and in its manner of development. But its chequered history is less brilliant and much more fluctuating, and this is due to the overpowering presence of the great spiritual Head of the Church, to his contest with the Imperial power, and to the fact that, being surrounded by the desolate Campagna, trade remained undeveloped, and the burgher class was unable either to absorb or to eject the contending factions of nobles. Wild waves of strife, the flux and reflux of unbridled contention, were ever lashing round those "wrecks of Ancient Time" that were nearly all that remained.

We have said that during the invasions of the Lombards the Roman populace were in close alliance with the Popes. For the seat of Empire lay far away on the Bosphorus, and little aid could come from the nominal suzerain; while the Lombards thundered at the gates. The Pope, too, was engaged in combating the Eastern doctrine as to the twofold nature of Christ, and in resisting the iconoclastic edicts of Leo the Isaurian. So Pope and people were at one in avoiding an absolute rupture with either power lest they should have to depend on the other, and in defending their common interests against both.

The city was governed by a duke, whom the people endeavoured to elect, but who was the representative of Constantinople. He largely extended the limits of his duchy, and was supported by an army, at first consisting of nobles and landed proprietors, but including, in the tenth century, all the inhabitants except Churchmen, women, and slaves. The senate disappears from the records for a time. There is silence about it from the sixth to the eighth century, and again from the eighth until the twelfth century; but it is possible that the ancient senate had been gradually converted into a new body of nobles, assembling at irregular intervals, or only on emergency, before the summoning of the general popular assembly. But the Pope was the administrator of enormous revenues, and possessed of spiritual authority over the whole of Western Christendom. When the suzerainty of the East was disavowed, he seems to have come to regard the duchy of Rome as the appanage of the Church. To avoid becoming the subject of the Lombard, he called in the Frank. Even Gregory II. (7I5-73I) had accepted the allegiance of other towns 
in the name of the Republic, and Pepin received the title of King of the Franks and Defender of the Church, in return for which Pepin granted to the Pope the usufruct of Ravenna and the Pentapolis. The Pope now regarded himself as the head of the Republic and the Empire. The new ideas found expression in the famous forgery of the donation of Constantine, which merely expresses the firm conviction of the Church party, who, as is human, came to believe what they wished to believe, that the donation of Pepin was of the nature of a restitution; and, in A.D. 800, we find the Pope conferring temporal sovereignty over the severed and scarcely recognisable members of Ancient Empire to Pepin's son Charlemagne. The Pope now became a temporal Sovereign. The warfare which this temporal power caused in Rome, the schisms within the Church, and the ultimate rule of Italy by the foreigner, date from the grant of Pepin. In 767 the nobles set up an Antipope, and faction fighting was common in the public streets of Rome. The duke, the militia, and the people now became subordinate to the bishop of the city, who was also the bishop of all bishops, and who claimed, now that the connection with Constantinople was severed, to represent the Empire. But neither Emperor nor Roman people admitted the usurped authority of the Pontiff. The Romans were, it is true, greatly benefited by the riches that poured into their city on account of the presence there of the Head of Christendom ; indeed, other sources of wealth had they none. But no man is a prophet in his own country: the citizens lived too close to the Pope to respect him ; they were indisposed to be ruled by him; they could ncither live with him nor without him. The Popes also infeodated their lands to their relations or friends in order to render it of real military service in defence against barbarian hosts and other foes ; the same causes undermined their feudal authority as diminished the strength of all great rulers at this period; and as the Papacy was not hereditary, but there was a constant succession of holders of the office, each of whom did the best for himself and his kin, there arose in Roman territory far more than the ordinary degree of jealousy and disagreement among the members of the class thus enriched and ennobled. The result was that one faction or another of the nobles was ever engaged in plotting against the Pope, appealing to the militia for support, and fighting among themselves. When once anarchy is established in a state, history teaches us that it is an evil weed difficult to uproot; and the history of medirval Rome is preeminently a history of anarchy.

When Leo III. sent Charlemagne the banner of Rome, he came near to losing his life at the hands of the infuriated multitude (799). In fact, it was a very statesmanlike move on the part of Leo to establish the German Empire of the West, as he had now reconstituted authority and an effective force to fall back on. When the Carolingian empire declined, ecclesiastics to whom the Imperial administration had been given became the real sovereigns of Italy. It was dextrous circumspection on the part of the great lords to place their younger sons in the Church; these young men had the usual military training; many deposed kings and nobles were forced to receive the tonsure, and in the ninth and tenth centuries the bulk of the clergy was appointed from unspiritual motive and from a body of men entirely worldly. The Church feil into an incredible state of moral decrepitude and decay. The fall of the Frankish 
Empire left Italy in unspeakable disorder; Huns descended the mountains and ravaged the land, and robber bands of marauding Saracens put their prows into almost every creek, and wandered from Calabria to the Alps and from sea to sea. No Imperial legates appeared in the land, and the aristocracy of Rome overpowered the Pope and his clergy; thus this turbulent oligarchy held Rome and the Papacy in the hollow of its hand, when it was not divided in private hate. But these feudal nobles still claimed to be the "patricians" of Rome. "A consul of the Romans, who seems to have borne the title of Senator, was elected as Princeps of the nobility from their midst, confirmed by the Pope, and placed as Patricius at the head of the jurisdiction and administration of the city " (Gregorovius).

Roman ladies in the tenth century were not less beautiful, if more illiterate, than in ancient days, and were quite as dissolute. The Papacy was in the hands of the nobles, for the Papal electorate consisted of them and of clerics who, for the most part, were also nobles. What wonder, then, that other than a saintly disposition qualified for the Papacy, or that the seductive charms of well-born women had power to sway the fortunes of the city and the Church ? Theodora, said to have been the concubine of John X., was able to raise him to the Papal throne (9I4). From that time she and her daughter Marozia, women endowed with ability, courage, beauty, and concupiscence, disposed of the tiara.

Marozia imprisoned the Pontiff that her mother had made in her castle of St. Angelo, once the tomb of Hadrian (928), and in 93I she caused the election of her own son to the Papal chair as John XI. She took for her third husband Hugo, Duke of Provence, who aspired to the Imperial crown. Hugo was ill-advised enough to box the ears of Alberic, Marozia's son by a former marriage. Alberic's reply was a call to arms. He rushed to the street and summoned the people to shake off the yoke of women and of the barbarians who of yore had been the slaves and not the masters of Rome. The gates were shut to prevent the entry of Hugo's troops; the King fled, and Marozia was imprisoned. The Pope, Alberic's brother, was relieved from temporal cares and confined to strictly ecclesiastical. duty in the Lateran (932). The citizens thus released at once from the yoke of women, Pope, and King, believed that they had recovered the liberty of ancient Rome. Alberic received the title of Princeps atque omnium Romanorum Senator. He gave the name of Octavian to his son, and here, as always, we see the notion of the preservation or revival of old Roman forms by mediæval Italians. Alberic's power depended on the aristocracy, more especially on those of his own family, and on the militia. He secured himself by paying and reorganizing the militia; the coinage bore his name; and the magistrates met in his house. For twenty-two years he ruled the city with great ability. During the administration of Alberic the rights of the people were recognised, and the army became his defence against the overbearing assumption of the nobility. He made the nobles swear to elect his son Octavian to the Papacy. Soon after he died, and they kept their oath, but they appointed a prefect, annual consuls, and twelve tribunes. Octavian, who took the title of John XII., inherited the vices of his female ancestors without their intelligence. He was little more than a boy, and the nobles once again found themselves without a master. John was unable to cope with 
Berenger, who held the neighbouring Exarchate, and he therefore revived the Empire by calling in Otho I. (962). John soon discovered that he had a master, and conspired with the nobles and Berenger. But the next year Otho reappeared in Rome, and exacted an oath from the clergy and nobles that they would never elect a Pope without the Imperial consent. He then convoked and presided over a council which deposed John and elected Leo VIII., a Roman noble, in his place. In this council the plebeians were officially represented, which shows their growing importance. Indeed, shortly afterwards (January, 96t) they united with the nobles and attacked the Emperor, but were repulsed by his followers. This was the first of the encounters between the Romans and the German followers of the Emperor, which became as time-honoured a tradition of Rome as town and gown riots at Oxford. The moment Otho departed from Rome the citizens recalled John and deposed Leo, and on John's death elected a new Pope, whereupon Otho returned, besieged and reduced the city, reinstated Leo, and sent the Antipope a prisoner to Germany. There was again a revolt against the Emperor's next Pope in 965 , which led to a sack of the city at Otho's hands; he executed the twelve chiefs of the twelve "regions" of the city. About this time there is evidence that the Roman populace took advantage of divisions among the nobles, and were advancing to greater power in the state. The army had become democratic, and was under the leadership of the captains of the regions (decarconi), while the nobles were headed by the prefect. But the two parties still made common cause against the Emperor, they also strangled one Pope and exiled others. In fact, the Popes were constantly being chased out of Rome by the Romans and brought back again by the Emperor, or deposed by the Emperor and restored by the city. When Otho I. was crowned the old reverence for the Imperial institution, which had been diminished by the feebleness and disunion of Charlemagne's successors, revived, and a strong man manipulated the tradition. But Otho I. was succeeded by his son, a youth of eighteen. The turmoils of Rome recommenced with his reign. Giovanni Crescenzio, the Patrician, attempted to imitate Alberic ; but the third Emperor of the Saxon line, though a lad, was supported by a party opposed to Crescenzio, and overcame him. Otho III., the son of a German father and a Greek mother, possessed that plastic brain capable of vivid conception and fervid imagination and all the contradictions of character that so often mark admixture of race. He dreamed of making Rome once again the seat of a Universal Empire. He surrounded himself with the splendours of the Eastern Court, which he paraded in his palace on the Palatine. When he elevated his cousin Bruno to the Papacy as Gregory V. (996), the new Pope surrounded himself by his countrymen and advanced them to important posts. Crescenzio expelled the Pope and his creatures, reconstituted the commune, and created a new Pope. But Otho came to Rome, and there was an Imperial party in the city ready to open the gates to his forces. Crescenzio was besieged in S. Angelo, and forced to capitulate on honourable terms. His life was the forfeit of his reliance ; the Imperial word was basely violated, and he was tortured and slain. Crescenzio, as opponent of both King and Pope, embodies the Roman revolutionary spirit. It was during the reign of Otho that the feudal system was firmly established in the Church, and that bishops were encouraged by 
Sylvester II. to become the counts of lands and cities, thus giving rise to the dispute as to investitures, which was destined to widen that breach between Church and State of which we can discern symptoms even in the time of the first Otho. On the death of the third Otho, while Ardoin of Ivrea was endeavouring to constitute Italy into a kingdom for himself, another Giovanni Crescenzio was elected patrician, and restored the old form of the republic. Consuls, senators, and assemblies of the people appear (IOIO), and a relative of Giovanni presides as prefect over the administration of justice. Giovanni made a new Pope (IOO3), but after his death, the descendants of Alberic gained the upper hand in Rome. They practically nominated the Pope, and Henry II. was obliged to humble himself in order to secure his crown, much as an aristocratic member of Parliament condescends to-day in order to secure his seat.

A strange and inconsequent mingling of the elements of grandeur and feebleness in the Roman character manifests itself at this and every period. High impulse is followed by collapse, and a tempestuous spirit of liberty subsides into debased servitude. As Hallam observes, "There still remained enough in the wreck of that vast inheritance to swell the bosoms of her citizens with a consciousness of their own dignity. They bore the venerable name, they contemplated the monuments of art and empire, and forgot, in the illusions of national pride, that the tutelar gods of the building were departed for ever."

Three descendants of Marozia and the elder Alberic now sat on the Papal throne-namely, Benedict VIII. in IoI2, John XIX., his brother, who was not even a priest, in 1024, and their nephew, Benedict IX., a mere child, in r033. The election of the last two was secured by simony and electoral corruption, and the Papal dignity seemed to have become hereditary. " I dread to repeat," writes Pope Victor III., at that time Benedict's subject and afterwards his successor, " how shameful, corrupt, and execrable was the life of Benedict when he was consecrated; and I speak only of afterwards. After he had long tormented the Roman people with pillage, murder, and abominations, the citizens, unable to endure his villainy any longer, mustered, and ejected him both from the city and the Papal chair. They replaced him, but by receiving payment and thinking scorn of the sacred canons. John, Bishop of Sabina, thus elected only occupied the chair three months. Benedjct, who sprang from Roman consuls, and who was supported by all their power, overran the city with soldiers and forced the bishop to return to his diocese. Benedict resumed the tiara, but did not change his morals. Finding at last that the clergy and people detested his evil deeds, and that his vices were on everybody's tongue, since he was devoted to voluptuousness, and wished to live rather as an epicure than as a Pope, he contrived to sell the Pontificate at a good price to a certain archbishop who passed for a highly religious priest, and who, taking the style of Gregory VI., governed the Church two years and eight months, until the arrival of Henry of Germany." (Chron. Mont. Cassin, L. II., B. iv., p. 396). Gregory VI. gave himself up to recovering Papal possessions, and, as he was absolutely unlettered and ignorant, the Roman people gave him a colleague to attend to his official duties whilst he was in the field fighting. So when Henry arrived at the gates of Rome, which he, prudently, was not clesirous of entering, he found Benedict enthroned at St. John's Lateran, Gregory at St. Maria Maggiore, and Sylvester 
at St. Peter's. He convened a council to depose the trio, and nominated the Bishop of Bamberg, who took the style of Clement II. : he also took the title of patrician, and thus became complete master of the Church no less than of the State. Henry, taking advantage of the gratitude of the new Pope and of the obloquy which the last schism had thrown on popular election, compelled the Roman people to renounce their right of presentation in his favour. He appointed four short-lived Popes of German birth, who were pious reformers of the Church. But during the minority of Henry IV. the Roman nobles again began to assert their power, and Hildebrand, the master-mind of his age, got Nicholas II., whose election was due to his statesmanship, to entrust the cardinals with the election of all future Popes, who were to be drawn from their ranks. The assent of the Emperor, the clergy, and the people was to be purely formal. He had the support of the piously inclined Normans of the South, who struck off the heads of those of the Roman nobility that opposed his measures. Among the Roman nobles there had been for a long time a cleavage on Imperial and Papal lines, and Hildebrand certainly had fierce opponents in one, if not in both of these parties. But fear of popular wrath prevented them from becoming the masters of Gregory VII., even though they were the masters of Rome. By Hildebrand, as Gregorovius says, the deep sleep of the Middle Ages was disturbed. In the Wars of Investiture the Popes were at the mercy of the nobles of Rome, who, however, were divided by faction, and the Pope was obliged to truckle now to one side and now to the other. His power was least effective in his own city. Right up to the Papal palace the nobles of Rome were divided, by a far deeper cleavage than ever, into the party of the Emperor and the party of the Pope. Did he leave Rome, the Pope could not re-enter unless his Norman allies forced the way for him; did he desire to influence an election, the Imperialists carried the day, and compelled him to seek security in the fortress-tomb of Hadrian. And yet an aristocratic government of some sort goes on under an elective senate and consuls. Moreover, the people increased in power and importance, because in Rome, as elsewhere, neither of the aristocratic factions could gain the upper hand without their aid. It was a case of thieves quarrelling and honest men coming by their own.

\section{The Republic of Rome and its Relations with the Papacy AND EMPiRe (III8-II88)}

During the Wars of Investiture the great movement for communal freedom spread throughout Italy. Rome felt the impulse, but the nobles here were stronger than elsewhere. Two great parties cloaked their mutual jealousies and petty quarrels under the guise of Imperial and anti-Imperial factions; they set up rival Popes, and the Pontiff who chanced to be the stronger for the moment, had to strengthen his faction or detach his foes by yielding more and more power. The nobles of Rome had nearly excluded all the nobles of the Campagna from municipal power. The two leading families were the Pierleoni and the Frangipanni, who had taken opposite sides in the Papal election of II I 8 -an election which resulted in the establishment of rival Popes. The Pierleoni were the descendants of Jewish usurers who had adopted Christianity, and this time their candidate was recognised as the legitimate Pope. Though 
the trade of Rome was small, as the abode of Papacy, it become a centre of finance, and there consequently arose a new aristocracy of wealth. Since so many of the nobility were the recent creations of the series of short-lived Popes, the barons of Rome were less exclusive than elsewhere, and the " new men " rapidly attained to great power, which they increased by taking up the cause of the people and getting the support of its strong militia. In I I 30 a hurried election placed Innocent II. on the Papal throne, but the Frangipanni and a majority of cardinals elected one of the Pierleoni. Innocent for a time lurked in one after another of the ancient triumphal arches of Rome, now converted into fortresses by the Frangipanni, but finding himself unable to stand against the popular party, he fled to France and Germany, where he was acknowledged as lawful Pope, and he induced Lothair to come to Rome to be crowned, with the hope of seating himself at St. Peter's by the Imperial aid. But Roger of Sicily and the other Pope occupied the city, and Innocent had to content himself with crowning the Emperor in St. John's Lateran, which the Frangipanni still held (II33). In I 36 the Imperial troops ejected Anaclete from the Vatican; and although Innocent was taken prisoner by Roger in I I 39, he got himself released and re-established by that astute monarch, in the manner already related. It need hardly be said that scandalous disorder attended these contests of the rival claimants to the Apostolic See, and the Romans were not slow to take advantage thereby. Now, little Tivoli had become a republic and annexed some territory, and Innocent got the help of Roman soldiery to bring it into obedience. But the men of Tivoli defeated the men of Rome, and pursued them right up to their own gates (II4I). Indignant that the mistress of the world should be thus repulsed by one of her earliest and smallest conquests, her sons marched a bigger army on Tivoli and took it. But the defenders yielded to the Pope, and came to an understanding with him, whereupon the Romans demanded that submission should be made to them, the sovereign Roman people, and that the walls of Tivoli should be destroyed and its citizens dispersed. Innocent refused, and the result was that the people rose against him ( I I43), excluded nearly all the nobles from government, abolished the sovereignty of the Pope, and reorganized the senate. In I I 44 Lucius II. tried to suppress revolt by the aid of the Normans, but this only increased the violence of the movement. $\mathrm{He}$ was called upon to resign all temporalia except tithes and donations, and the Romans elected Giordano dei Pierleoni as their patrician. Lucius was killed in a street fight, and his successor driven from the city because he refused to subscribe to the demands of the people. Rome, like Tivoli, was excited by the success of the Northern towns in establishing their independence, but the conditions were very different. The Roman burgher depended on the wealth brought in by pilgrims; the nobles were constituted by tenure, and formed no very well-defined caste. There were, indeed, a few patricians who boasted their descent from those of ancient Rome, but they were of little account. The lesser nobility joined the burghers, and the revolution spread throughout the domain of the Church. The towns declared their independence, and the nobles of the Campagna set themselves up as little sovereigns. But the authority of the Emperor was still recognised, and the senate addressed Conrad III. in pompous terms, which have been preserved for us by Otho of Frisingen. "By God's grace the 
Senate has been re-established. By the force of the Senate and of the Roman people Constantine and Justinian gloriously reigned over the undivided Empire; we strive and would fain that you should rule as they did. ... Once again have we laid the foundations of that ancient order, for we maintain peace and justice for those that love them ; we have made ourselves masters of the towers, fortresses, and houses of the nobles, who, in concert with the Sicilian and the Pope, resisted your authority; some we hold in your name; others we have razed to the ground. Let your wisdom recall all the mischief that the Papal court and the nobles of whom we speak have done to your predecessors. In concord with the Sicilian they prepare evils yet greater" (Otto Fris., De gestis Frid I.). Conrad justly estimated the value of the loyalty professed, and did not reply either to this or other missives. There arrived at Rome at this time Arnold of Brescia, the great reforming and revolutionary spirit of his age.

Arnold had been a pupil of Abelard, one of the most brilliant, if not one of the profoundest, of the schoolmen. Impassioned, manly, clear in thought and eloquent in word, the corruption of his brother clergy weighed on his mind; the contest between the Church and the Empire roused his disgust. He yearned for the pristine purity and simplicity of the Christian life, and his penetrative insight detected the incompatibility of an ecclesiastical hierarchy sharing temporal responsibilities with the civil power. He vindicated the authority of the State in its own sphere, and taught that Christ's was a spiritual and not a temporal kingdom; he held that the clergy, like the Apostles sent forth by the Lord Himself, should obey His command and be satisfied with the free offerings of the faithful, or at least with their tithes. Like his friend Abelard, he held mystical notions concerning the mystery of the Trinity, which gave the Church a handle. By preaching against the wealth and temporal power of the Church he had so excited the Brescians that they expelled their bishop. Otho of Frisingen and other authors say that he was condemned with other heretics by a Lateran council held in II 39 , but his name does not occur in the canons of the council. He was an exile from Italy for some years, pursued, like Abelard, by the pious and unrelenting enmity of St. Bernard, until, learning of the insurrection in Rome, he repaired thither, and gave his services to the movement with the most perfect disinterestedness.

The senate was drawn from the burghers and smaller nobles. It consisted of a smaller consiglio di credenza for consultation with the heads of the Republic on secret and urgent affairs, and of the greater council, constituted by the whole senate, as well as a judiciary, composed of senators and jurisconsults. There was a patrician or gonfalonier, and later, a prefect or kind of podesta at the head of affairs. The Pope was anxious to return from exile ; the Romans were the poorer for the absence of the Pope. So in II 45 Eugenius III., who had been elected to the Papacy partly because no one was particularly desirous of the Holy Office at this juncture, and partly because he was a pupil of St. Bernard, and therefore a stout champion of the Temporal Power, made terms with the republic, and re-entered Rome at Christmastide. But in two years time he discovered that the republic was too strong for him, and he left for France. Giordano Pierleoni was at the head of the government, 
and engaged in razing Tivoli and resisting other cities of the state, that made the same demands on Rome which the Romans had made for themselves. But one may presume that, unlike certain latter-day transcendental theorists, the Romans of the twelfth century were hard to convince that they would be quite free to follow their own lines of development if they were subjected to the conflicting interests of perfectly free neighbours, who, after the manner of human nature, would be sure to attempt to impose their will on each other and on Rome. Moreover, the Romans regarded themselves as the veritable descendants of those who had established the Pax Romana, and they proceeded in a manner perfectly orthodox and in order in those days. Meanwhile Arnold, supported by the sympathetic body of the poorer clergy, was busy preaching his doctrines as to temporalities, and strenuous in reviving the sense of civic duty in Rome.

\section{MILAN AND THE CITIES OF THE GREAT PLAIN}

Among the cities of the great plain, Milan, a former capital of the Empire. remained the most important, and preserved most memories of classic times. Pavia was the capital of the Lombard King, but Milan became superior to Pavia in trade and importance; and, in the fact that one city represented barbarian authority, the other Roman tradition and national life, we find the germs of their future rivalry and antagonism. The archbishopric of Milan was the oldest in Lombardy; the Milanese Church had a separate ritual - that of its patron St. Ambrose--and a separate government. The Archbishop presided over the national diet; he was the richest ecclesiastic and his city the wealthiest and largest in Italy, and as early as the close of the ninth century we find him exercising juridical rights and fortifying his town. From an early period the congregation of St. Ambrose aspired to be a national Church, and was antagonistic to Papal claims, and by the beginning of the eleventh century the city contained over 300,000 inhabitants, was a manufacturing centre of wool, armour, and jewellery, and had considerable trade relations with the Orient (A. Amati, Il risorgim. del com. di Milano, P. I., c. 3). As early as the close of the tenth century the Archbishop had displaced the count, and nominated citizen-magistrates. In the struggle between Ardoin and Henry II., the Archbishop took the Imperial side against the Lombard pretender and his feudal following. The most famous of the great Archbishops was Heribert, elected in Ior 8 by the citizens, and invested by the Emperor. He supported Conrad against the league of Lombard nobles, fighting Pavia in the quarrel, as a matter of course, and he gave the world the rare spectacle of following the Emperor across the Alps against his rebellious vassals. This self-reliant, warlike, ambitious and able prelate, of whom his contemporaries said that he could dispose of all Italy by a nod, subdued Lodi and Cremona either for ecclesiastical reasons or under an ecclesiastical pretext, and then was so masterful and oppressive in his dealings with his vassals that they rebelled (I035). The vassals (vavasors) formed a league or Motta, while the Archbishop called a general levy of 
the citizens, and a great battle was fought, called "Campomalo," from the great numbers that were slain. The Archbishop's forces were defeated, and the vavasors returned to the city. So many complaints from so many quarters, from cities as well as feudatories, were made against the bishops that many of them were arrested. Thereupon the Milanese, grateful to Heribert for having in the main executed justice, put down the tyrannies of the petty feudatories and enforced the truce "of God," 1 opposed Conrad, and compelled him to abandon his attempt to capture the city by siege. The growing spirit of independence among the people is evidenced by the war against the nobles, wherein Lanzone, a leader among the great feudatories, took the popular side, and after withstanding three years of siege (IO42-IO44) cleverly contrived to prevent Imperial interference and domination, by effecting a reconciliation and re-admitting the feudatories to the city. With this war episcopal absolutism practically comes to an end. Next year (1045) the great Heribert died. Even in the period of full episcopal domination there existed the "parlamento," the council, and some executive authority, which latter power ultimately evolved into the consulate, then into the podestate, and finally into the captaincy of the people.

When Otho III. made German Popes, the Papacy lost prestige and the Italians were dissatisfied. The feeling was that of pride of race; it was not yet a national sentiment, nor did it become so for centuries, but the towns began to have something less of respect for the Papal power, something more of opposition to and contempt for the rough hordes of the North, some increased feeling of unconstraint. In the archiepiscopal See of Milan this was intensified by the semi-independence of the Ambrosian Church. Hostile feelings, however, characterized neighbouring cities : the Roman population of Mediolanum had had a rooted antipathy to the Lombard garrison of Pavia ; and when, on the death of Otho III., the Lombards chose Ardoin of Ivrea to occupy the vacant throne, we find Milan siding with the Germans, because the Milanese were associative in feeling, opposed to feudality, and their archbishop was naturally jealous of the feudatories whose rights he had usurped. Moreover, Pavia is but twenty miles from Milan; between the two cities-nay, throughout the great Italian plain, south of the Alps and north of the Apennines-there is no natural boundary. The land is watered by innumerable runnels, and questions of water-supply, of limits, of trespass, must have arisen perpetually among its countless little cities. To stop aggression, a law of reprisals had been established. Almost throughout Italy if a citizen of any city were attacked or otherwise injured by the citizen of some other territory, and redress were not given, he was at liberty, after certain formalities, to enter the country of his adversary, and recover from the first man that he met, at his owa hazard, recompense to the value of that which he had suffered or lo.st (Muratori, Antiq. Ital., vol. iv.). This doctrine of reprisals was hardly calculated to conduce to concord among the cities. When the cities threw off the authority of the bishops this state of things did not cease. They claimed all the territory their former governors had held, and conceived themselves to be quite justified in suppressing the little com-

1 The "truce of God" preached by the Bishops of Arles and Lyons limited private war to three days in the week. It was never well observed in Italy. 
munities within the ancient territory, that had copied the metropolis in instituting self-government. Occasionally, too, they purchased certain feudal overlordships, and, confounding the rights of property with those of control, made effective use of their own superior strength.

It is not, then, difficult to see what countless causes of offence must have arisen, and how readily a chronic state of warfare and antagonism would be established. The most irrational view that historian or politician can possibly take is that mankind is chiefly amenable to reason, or likely to adapt his course to its dictates. Jealousy, the desire of power, the vainglory of conquest, all the evil and verminous passions that Swift satirized in his immortal Gulliver, were excited by these conditions, and fanned the flame of hate. What was taking place all over Italy began to assume larger proportions on the stage of Lombardy, and the two chief actors of the picce were Milan and Pavia. It is obvious that the natural and only way of escape from these evils was for the stronger to attack and swallow up the weaker towns, to garrison and convert them from dangers into sources of strength. Pavia and Milan did not directly attack one another at the outset. They first warred against their feebler neighbours, and the whole of Lombardy became divided into two leagues, headed by these two cities. Cremona, the third city in importance, conquered Crema, its neighbour, in I Ioo. Pavia, seven years later, attacked Tortona, and Milan assailed Lodi and Novara. Each fearful town sought succour of the great city of which it had least apprehension. Crema and Tortona sought the protection of Milan; Pavia, Cremona, Lodi, and Novara allied themselves in opposition ; Brescia, the neighbour of Cremona joined Milan; Asti, hostile to Tortona, confederated with Pavia. Of cities at a greater distance, Parma and Modena were usually to be found on the side of Milan; Piacenza and Reggio on the opposite side. The wars of the cities usually commenced in some fray during harvest time, and each plundered its neighbours of their crops; when ill-feeling became pronounced, the opposed towns would send mutual defiance, and at a fixed time and place on the frontier all able-bodied citizens would gather, armed, round their caroccio and march to give battle. Bravery was their only science, and a campaign, and often a war, ceased with the victory of one of the opposing sides. The foes sought triumph above all things, and were sometimes satisfied with the renown of victory. In I Io8, the Milanese, having made a great number of Pavians prisoners, conducted them to their great piazza, and fixing lighted torches to the least noble part of their persons, hooted them out of the open gates. But every war had not so farcical and inconsequent a result. The Milanese territories were compressed by those of seven other republics-Como, Novara, Pavia, Lodi, Cremona, Crema, and Bergamo. Of these cities the farthest off was but forty miles distant from Milan. Crema was the least powerful, and was under the protection of Milan. The others were united by the tie of a danger common to all, but there was no solid stable pact, and a victory or a treaty sufficed to divide them. Milan, having found an opportunity in their disunion, attacked Lodi ( I IO7). This war lasted four years. Lodi is said to have gained some battles, but part of the harvest was seized and the Milanese came up to the walls in order to insult the Lodesi. In those days the art of siege was not developed, and the object was to draw the besieged force into the open field; otherwise the artisans 
who formed the rank and file of the assailants, and who received no pay, had to return to their work. Every year the Milanese renewed the war, burning or carrying off the harvest, in spite of the aid sent to Lodi by Cremona and Pavia. At last the town was carried by assault, the walls were levelled, the houses destroyed, the inhabitants distributed among six villages and severely dragooned, and not until forty-seven years later was the town rebuilt.

More important was the war against Como, undertaken in I I 8 , and sung by a local bard, who compares himself to Homer, and the siege to that of Troy (Cumanus, seu de bells Comensi anonymum poema). Homer sometimes nods ; the Comasque poet does little else ; but, truly, the siege of Como, like that of Troy, lasted ten years, and all the republics of Lombardy arrayed themselves against the unhappy town. It was the first big thing at which the cities tried their prentice hand, and the struggle with hardy mountaineers was no bad training for the militia that had presently to face the forces of Frederick Barbarossa. The war between Milan and Como had its proximate cause in an ecclesiastical dispute. Whilst Lombardy, as a whole, sided with the Imperial party, Como supported the Papal party, and had received a bishop at the hands of the legitimate Pope, who had become popular with the citizens. The Imperialist and rival Pope, Burdino, had intended to present the see to a Milanese of noble birth, who took advantage of the presence of Henry V. in Italy to occupy the castle of San Giorgio, whence he intrigued against the Bishop de facto. But one night the Bishop of Como and its Consuls contrived to surprise the fortress, took the candidate of the Antipope prisoner, and slew several of his relations and abettors. Some of the defenders of the castle, however, contrived to escape, bearing the bloody clothes of the slain with them, and appealed to Milan for redress, according to Landolf the younger, in a very dramatic way; for the men laid out the stained garments in the Piazza, and sat in silence, while the weeping widows and orphans of the slain appealed to the populace to avenge them. It happened to be the hour of service, and the Archbishop ordered the portals of the church to be closed, and stood beneath the portico at the head of his clergy, refusing admission to all who would not vow to avenge this insult to Mother Church and their city. The Milanese took up the quarrel with ardour. They defied the Comascines by herald, and advanced against the city with all the pomp of war. The two armies encountered and fought until nightfall without either side having gained any marked advantage. But during the night, and while the Comascincs were encamped at the foot of a hill, the Milanese crept up the dry bed of a torrent, and, forcing the undefended gates, set the town ablaze. In the early morning the Comascines, finding their enemies gone, marched back again to their city, and beheld it all aflame. They charged down the hills with fury, fell on the Milanese, who were occupied in plundering the burning city, and put them, not without severe slaughter, to an ignominious and speedy departure. Now, Como had a number of dependencies, small, but rich and powerful communities, occupying the flanks of the mountains. Some of these found their subordination irksome, and one, the little lake-republic of Isola, revolted to the side of Milan. It engaged Como on the lake (I I I9), but its little fleet had to retire before the boatmen of Como. It is said-but the statement is subject to some 
doubt-that Milan secured the co-operation of several of the cities of the plain. The war lasted until I I27, when the Comascines, weakened by the defection of their little dependencies, and unable to defend their city any longer, withdrew by night to a fortress near. The Milanese, unwilling to undertake a new siege, sent an embassy of clergy, offering to respect their rights in consideration of their subscribing to military service, to certain imposts, and to the destruction of fortifications. The Comascines accepted the terms, and remained subservient to Milan until they took the side of Barbarossa in the intestinal conflict which took place under his reign.

The constant wars of the towns with each other was undoubtedly aggravated by the noblemen, or landed proprietors, who, absorbed into the civic constitution, directed their ambition towards the conduct of municipal affairs and, by reason of their military inheritance, towards the aggrandisement of the cities with which they now identified themselves. Excepting the families of Montferrat, Savoy, Este, and Malaspina, there were perhaps no noblemen who had not accepted citizenship. But this introduced a strong " jingo" element into city life, only restrained by the obligation that the civic militia was under to earn its own bread. Sometimes the cities adopted a wiser policy, however. They would extend their privileges to settlers ; they even, occasionally, were unconscious imitators of their Ancient Mother, and granted their own privileges to a friendly community.

The Concordat of Worms (II22) was nothing but a temporary compromise. The Papacy still claimed a supremacy which was antagonistic to the Empire, and proved intolerable. The Concordat was a truce which had become a necessity to the Imperial power. Not merely was it an impossible task to subdue foreign revolt with the forces of the state weakened by dissensions at home, but the cities were freeing themselves from subservience, were fully armed, and were engaged in anarchical rivalries with each other. Venice cannot be considered to have belonged to the Empire. She was a free republic, owing a shadowy and nominal lomage to the Empire of the East. But Pisa and Genoa, while noninally belonging to the Empirc, by virtue of their maritime position and their fleets, had acquired an ill-defined but very real independence. Of the inland cities, Milan was the eldest daughter of Rome, and, whilom, the capital of the decaying Empire. During the continuance, for forty-seven years, of the Wars of Investiture, she and the other cities took advantage of the biddings of the rival powers for aid, and had become, to all intents and purposes, autonomous. Like all the cities, she improved the occasion, supplanting the importance and power of the Bishop by that of the civic magistracy. Everywhere the consuls obtained clear and definite authority ; they presided over and represented the community; they conducted the affairs of the state with its neighbours. The population of the towns had increased by leaps and bounds. Under the apparent rule of the democracy, the true rulers, the oligarchy of the gran consiglio, which would appear to be the popolo of contemporary writers, supported by a. vital and vigorous public spirit, made roads, built public edifices, constructed harbours, and raised adequate defences. The proud descent from Rome manifested itself in the people in the names of their officers, in the study of Roman law, which they encouraged, in their antagonism 
to the Teuton. South of the Apennines Pisa built her 1)uomo; northern Milan watered her fields by a superb system of irrigation.

The communes fettered the free exercise of feudai authority, and the full control of the Teutonic power. The feudal principle was the only principle that gave order to Northern Europe, and the Emperor found himself liable to collision with a foreign people, animated by disorderly impulses; vitality and individuality were manifesting themselves in living germs, embedded in a.rigid feudal socety, and surrounded by an inexpansive, unprogressive, restrictive system. The cities respected the bearer of the Imperial name, but they resented any attempt to arrest their own development. Conflict was inevitable, and it was equally inevitable that the Church should draw the cities into its own quarrel with the Empire.

\section{VENICE}

The Brenta and a few smaller rivers, flowing into a crescentic bay, carry their silt into the Adriatic, and, in the slow passage of the ages, have deposited a huge but broken bar of islands (lidi), some miles from the mainland. A number of smaller islands, due to the same cause, lie between the lidi and the coast-line. They rise out of the shallow, placid salt-water lake, called the lagoon, which is half dry at low tide, and always protected by the lidi. The lagoon is navigable at lowest tide by narrow and tortuous channels that afford secure anchorage. In the frequent invasions that heralded the fall of Rome, the harassed inhabitants of the mainland found a safe asylum among the fisher-folk of these islands. In 452, when the furious Hun burned and ravaged Italy, the inhabitants of Aquila, Padua, and other neighbouring towns, took refuge here, and some came to remain. These colonies were at the outset governed from the citics of the shore. Owing, possibly, to each island having been colonizcd from a different city, brawls were very frequent; and in order to establish some control, their peoples assembled at Grado on the mainland, and elected twelve tribunes (466). Each of these tribunes represented a separate settlement. On the disruption of the Western Empire the community lived in amity with its near neighbour, Theodoric the Goth, who held his court at Ravenna ; and we learn something of these Venctians from his secretary, Cassiodorus. He tells us that they were chiefly occupied in fisheries and at salt-works, and that they were emphatically democratic, with equal rights (584). When Justinian sent Belisarius and Narses to recover Italy for the Empire, the mainland was again devastated. The quiet refuge was again resorted to by fresh fugitives, who swelled the population. The community must have become prosperous and important, for when the Paduans complained that the Venetians had taken to navigate their rivers and fortify their mouths, Narses seems to have taken care not to add to his difficulties by interference. It is possible that this little attempt to get a footing on the mainland may have been due to the insecurity of food-supplies-a factor which, centuries later, manifested itself in the career of Venice as a land-power. When the Lombards arrived (568), there was a fresh influx of refugees. 
All the barbarian conquerors of Italy were Arian Christians. It is difficult to conceive of untrained minds being capable of understanding the metaphysical subtleties of ípoov́ $\sigma \iota v$; and in the quarrels of Arians and Catholics and all the brawls of creeds in the decay of the Roman Empire, one is tempted to suspect that there, as so often is the case in history, religious differences served to disguise national, social, economical, and political antagonisms. But the effect of the particular form of Christianity affected by the Continent isolated the immigrant clergy, and contributed towards the independence of Venice. Probably intestinal commotions continued among the islanders, for in 584 we find the number of tribunes doubled. Twelve new magistrates were elected by the islanders as a whole, and given power over those already in existence. At this time Longinus tried to secure the adherence of the settlers to the Eastern Empire. They promised allegiance, but refused to confirm it by an oath, and informed him that their labours, and not Imperial administration, had made the place, and that it was naturally impregnable, save by sea. When the Lombard power became established, they feigned fidelity to the new suzerainty, for they did not desire to impair their commercial relations with the mainland, but they contrived to evade absorption either into the new kingdom or the Eastern State ; and in this they were befriended both by their relative insignificance and the tumultuous sweep of events in those times. But the state was still weak, owing to the continued brawlings of the different islands, and in 697 the Patriarch of Grado convoked an assembly of the inhabitants at Heraclea on the mainland, and succeeded in federating them under a doge or Duke. The duke's office was to be elective ; he was to hold it during life, and he was to be appointed by a general assembly or concio. The concio had power to treat with forcign powers, to declare war or determine peace; but the tribunes were to be designated by the Doge. Here we find the germ of that remarkable consolidation of the forces of the State which characterized the polity of Venice; but it was still open to the dangers which centuries later ruined the republics of the mainland: a weak Doge became the tool of faction; a strong Doge tended to become absolute ruler, and to found a dynasty. Bloody revolts ensued, and Doges were exiled, blinded, or executed. The Doge was invested with the power of selecting bishops, and he had the further sacerdotal duty of blessing the people in serious crises. To maintain her own independence by supporting the weaker of rival powers was ever the policy of Venice, as of our own country. Hence, in the attacks made by the Lombards on the Exarchate, the Venetians gave ardent support to the Eastern monarchy; for not merely did self-interest impel them, but they held the barbarians in contempt, and prided themselves on their Roman descent, and on the distinction of the Imperial name. In 805, Pepin, the son of Charlemagne, bent on the acquisition of Istria and Dalmatia, contrived to obtain the good-will of the doge. But the concio, assembled at Malamocco, one of the islands, repudiated his policy of submission to the new power. Pepin, established at Ravenna, forced his way into the lagoons; the Venetians retired to a central island called Riva Alta (Rialto), inveigled the heavy ships of the Franks on to the shoals, where they became stranded, attacked them with their light craft, and forced them to retire. Rialto is surrounded by the sixty islets on which Venice is built, and from this moment 
it became the metropolis of the little state. In 842 Venice secured a commercial treaty, together with a promise of neutrality from Lothair, if any attack were made on it. For, in the great movements of the Northern and Eastern hordes which accompanied the fall of the Empire, the Sclavs had followed in the wake of the other barbarians, and some had settled themselves on the Dalmatian coast, and taken up that ancient trade of piracy which was the wonted source of profit of that quarter. Ever since the times of Justinian the Sclavs had given the Venetians the opportunity of disciplining themselves in naval operations, and thus did the latter receive the training requisite to their future maritime supremacy. To these sea-robbers a new commercial pest was added: Saracen corsairs swept the Adriatic, and were only prevented by the dangerous navigation of the lagoon from establishing themselves in Venice itself. In 864 we meet with an early instance of the policy of Venice, steadily maintained throughout her history, of subordinating the authority of the Church to that of the State. The Doge had promoted to the See of Torcello, an island near Venice, a priest who was displeasing to his ecclesiastical superior, the Patriarch of Grado. The Pope interfered on behalf of the Patriarch, but the bishops of the lagoons, always independent, by reason of their early separation in the Arian times of the Lombards from spiritual communion with the mainland, took no notice of his interposition, and the result was the victory of the Doge.

During the whole of the ninth century the Republic witnessed internal dissensions. The new city was torn by the rivalries of powerful families and their factions. The leading families, too, tried to make the clogeship a family possession, and in this attempt they were aided by the customary nomination by the Doge of some relation as his coadjutor. This procedure had the advantage of giving the Doge the aid of one who was more likely to be trustworthy and better under command than a stranger. Happily, the political sagacity of the people thwarted every attempt to introduce a dynastic principle. "They had not sought refuge in the desolate lagoons," they said, "to submit themselves to a master." In 900 a new danger menaced the city; the Hungarians, who held the mainland, attacked it, but the Venetians defended themselves with so much courage and determination that the attempt was never renewed. At this time they were not enfeebled by faction as they had been during the Saracenic invasion. The genius of the city was commercial : it felt no scruple in supplying the Saracens with ships and arms. This is proved by the oath which they were compelled to give John Zimiskes, Emperor at Constantinople, when he meditated attacking these enemies. In $99 \mathrm{r}$ they received the privileges of the most favoured nation from the Emperor Basil, and, in return, placed their powerful squadrons at his disposal for purposes of transport. A few years previous to this an advantageous commercial treaty had been concluded with Otho the Great, the new Emperor of the West. The Venetians had learned the security of their position-that the difficult navigation of the lagoons preserved them from successful attack. So, being by disposition and environment disposed to enrich themselves by the methods of trade, which are naturally opposed to those of warfare, they next contrived to come to such an understanding with the Saracen that they obtained a 
commercial adjustment with the whole Moslem world. They took advantage of a quarrel with the Bishop of Belluno to secure the support of Otho III., and in 996 they got permission to erect factories on the mainland, and to open up trade with Germany and the North through the great dolomitic valley of the Piave. Venice had adopted the same pacific policy with regard to the Istrian pirates, but it took the form of payment of blackmail, and failed of its effect. The Eastern monarchy, unable to defend the towns of Istria and Dalmatia, had allowed them to defend themselves, and to enjoy civic liberty. But a Sclavonic settlement at Narentia was in the habit, not merely of preying on Venetian merchantmen, but on these, its neighbouring, towns. Unable to protect themselves effectually, these appealed to Venice for assistance. Owing to the bad faith of the pirates, a settlement was proved to be impossible. The whole of Istria and Dalmatia and all the islands of Illyria, save two, promised allegiance to Venice; but these unimportant exceptions took the Narentine side. Having reduced these islands, Venice visited the Narentines with blood and slaughter; she razed their city to the ground, and purged the high seas of their presence for ever. She had the moderation to leave the allies, who had offered her their homage, undisturbed in the enjoyment of their self-government, and only demanded a nominal tribute from them. Nevertheless, to mark the predominance of Venetian interests on that coast, the Doge then and thenceforward added the words "and of Dalmatia" to his title of "Doge of Venice" (I00o). Venice commemorated the day of great victory (Ascension Day) by an annual procession of her ships, which solemnly glided through the narrow channels of the lidi to the open waters. There a prayer was offered up for those at sea. While the strains of the chant, "Purge me with hyssop, and I shall be clean ; wash me, and I shall be whiter than snow," spread over the waters, the Doge was aspersed with due religious gravity, the cup was reversed, and the remainder of the holy water was cast into the sea. Possibly some heathen feeling of propitiating the mysterious and mutable genius of the ocean may have lurked beneath the sacred Christian rites, for, in the libation of the holy water, there is certainly some suggestion of propitiation. At least the ceremony was expressive of self-abasement ; but from the time that Barbarossa and Alexander selected Venice as their meeting-place, and made peace with one another in the atrium of St. Mark's, the function changed its character. It became sacramental and sumptuous. It developed into the famous "Sposalizio del Mar." The Doge dropped a consecrated ring into the waves, declaring "Deponsamus te, mare," and so asserted the maritime authority and supremacy of the Venetian State. In ro32 a further advance in the political development of Venice took place in a restriction of the ducal power. Wearied of faction and afraid of a dynasty, the Venetians excluded the family of the great Doge Orseolo, the conqueror of Narentia, from holding office in the state. They put a stop to the ducal nomination of a successor or a coadjutor; but they replaced the latter by two Ducal Counsellors, and the Doge was further obliged to invite important citizens to form a senate (pregadi) or sort of Privy Council.

Venice never ignored any fresh commercial opportunity. In Io7 I Alexius, the ruler at Constantinople, asked the aid of the city against the Norman adventurers, who had appeared in the Mediterranean and were besieging 
Durazzo. The Normans defeated the allies; but the Venetians were so far successful in a sea-fight fourteen years later that the Emperor granted them factories and lands at Constantinople, and ordered their rivals, the traders of Amalfi, who visited that city, to contribute towards the building of St. Mark's. For the supposed body of St. Mark, stolen from Alexandria disguised as pork, in 828 , believed to have been destroyed with the cathedral in a fire, was miraculously rediscovered, and the Venetians had commenced to enshrine it in a new church of sumptuous marble and glittering mosaic.

In 1096 the city was selected by the Crusaders as a port of embarkation. Venice furnished them with a fleet of 200 vessels. The Eastern Emperor had had his own troubles with the Crusaders, and the creation of the new Kingdom of Jerusalem was an infringement of his rights. He attempted to seduce the Venetians from their contract, but they remained firm. $\mathrm{He}$ then set their rivals, the Pisans, on to them, but these were ignominiously defeated off Rhodes. The antagonism between the Eastern Empire on the one hand, and the Northern Powers and Venice on the other, which led to the criminal perversion of the fourth crusade and the sack of Constantinople in $\mathbf{2} 204$, thus began with the very first crusade, a century earlier than the perpetration of that blunder. In $\mathrm{IIO}_{2}$ the Venetians pursued their commercial policy by obtaining colonial rights from the new King of Jerusalem in Sidon, and, during the short-lived rule of the Crusaders in Syria, they planted little offshoots of the mother city, with self-governing powers, right along its coast. But meanwhile the fleet was at sea. Just as Austria to-day needs an outlet to the sea and holds the same district, so the King of Hungary then experienced the same want and made use of the opportunity to capture many of the Dalmatian ports. For centuries this contest continued with varying fortuncs, until finally the province was obtained by Austria in 1797 .

In I I 8 the Doge was defeated and slain at Zara, one of the Dalmatian towns, and for a time the Venetians gave up the struggle. In I 48 the growing naval power of the Normans aroused Venetian jealousy, and, after their wonted policy, the Venetians aided the weaker power, receiving a restitution of their privileges which had been withdrawn from them when they stood firm by the Crusaders. But by this time the ill-will between the Greeks and Venetians had become very manifest, and the sailors could not be held in hand. The result was that, at the earliest opportunity, the Doge came to an understanding with the Normans, who promised not to molest Venetian territory in the Adriatic. Venice also had troubles on the mainland. The Paduans had cut a new channel for the Brenta, which caused silting of the lagoons. The Venetians beat them by means of hired troops or condottie $i$, thus introducing a system which was to prove most baneful to Italy.

Venice had now developed a life and strength of her own. She derived her blood from Italy, her culture from Byzantium. Seated in her lagoons, approachable only by narrow and tortuous channels, she was immune from invasion, while at the same time she was open to the commerce of the world. She had become a great distributing centre; she had acquired a great carrying trade; she defended her fleets by means of a powerful marine. Detached from Italy almost at the very commencement of her existence, she had developed herself in her own way, and there was nothing 
Italian about her, save some community of blood and an essential identity of speech. She was ever happier than Italian towns in that she had no exiled citizens hanging about her gates and waiting an opportunity to reinstate themselves by means of foreign invaders. She had discovered early the danger of falling into the snare of despotism, and was fast rendering such a disaster impossible. Her internal dissensions were mere family quarrels ; in times of difficulty and danger " none were for a party ; all were for the state." Venetians ever presented an unbroken front to the foe. The poor were the peculiar charge of the rich, and the citizens had not yet lost their democratic rights, while they had acquired stability of government and continuity of state-craft. Their Doge was yet elected by the people in parliament assembled, though, of course, the great divisions that attend commercial development had appeared. There was an upper, a middle, and a lower class (popoli maggiori, mediocri $e$ minori). Justice was publicly administered, nor did it linger, for the judges proceeded in circuit through the lagoons. Venetian trade was fostered by the guilds, the origin of which may belong to the lower empire, but is obscured by the mists of the dark ages. We find them mentioned in the ninth century in the Albion Chronicle, and in the eleventh we read of a Master of the Guild of Smiths in a document preserved in the Vatican ; it is an appeal to the Doge of a certain ironsmith who complains that the master had compelled him to do the gratuitous service which he owed to the state in a public place instead of in his own home, which he had a prescriptive right to do. The guilds of the Middle Ages were bodies politic within the state. The modern conception of individualism was unknown; to be loyal to his guild was the first duty of every true man ; he existed as a portion of the Church and of his trade-association first, then as a citizen, and last of all for himself as a private and unique personality. The Venetian guilds did unpaid service to the state. They passed on trade secrets from generation to generation, and the Venetians who belonged to the governing class, called anteriores, possibly because they descended from the first settlers, kept the higher kinds of handicrafts in their own order.

\section{PISA}

Авоuт the time when Venice began to lay the foundations of her power on the eastern coast of the Adriatic, two little cities of the Tyrrhenian Sca, destined to become her rivals, began to manifest their nascent greatness. Pisa was one of the first of the Italian cities to regain her independence. The Lombards, ever fearful of a Greek descent by the sea, were obliged to favour the development of the little navies of the Mediterranean ports. They were not a seafaring people and left the maritime communes pretty much to themselves. An anonymous monk of Salerno tells us that, in 871 , the Prince of Salerno entrusted the defence of that city to Tuscans, who, to the number of two thousand, were to be found within her gates; doubtless these Tuscans were Pisans. Pisa was less prosperous under Lombard and Frankish rule than it had been under Greek, though it flourished once again when it was ruled by the Marquis 
of Tuscany as representative of the Emperor. In 980 Otho II. demanded a fleet of the Pisans to aid him in carrying on his war in Southern Italy, and we find that the city already possessed self-government under consuls The commune was trained to warfare by incessant conflict with Greek, Norman, Saracen and the rival cities. A few miles away lay Lucca, between whom and the Pisans there was such persistent and invetcrate hatred that Dante speaks of the hill which separates them as serving to protect them from seeing one another. But Lucca lies inland. The most important rival of Pisa was a seaport that lay to the north (Genoa), possessed of a soil less fertile and of fewer citizens, but rejoicing in an incomparablc harbour. In 1003 Pisa and Lucca acquired, according to Muratori, the unenviable renown of being the first of the Italian townships to commence their long series of internecine conflicts. In IOO4 Arab marauders forced the harbour while the Pisan fleet was engaged in fighting their countrymen in Sicilian waters, and sacked a whole quarter in Pisa. In IOI I the insult was repeated, and allied with the rival city of Genoa, the most powerful fleet that had sailed the Mediterranean for centuries set forth for Sardinia and ejected the Moors who had conquered it. Now the results of the expedition were to be thus apportioned: the Pisans wcre to retain whatever conquests might be made, and the Genocse were to have all the plunder. But neither party had expected entirely to cxpel the Arabs. Hence jealousy of the Pisan power arose in the breasts of the Genoese, and from this dates the constant wars between the two states, which only ended when Pisa was absolutely crushed. The Arabs made attempts to recover Sardinia, and Pisa determined to carry war into the enemy's country. Her fleet forthwith coasted along the shores of Africa ; it menaced Carthage and took Bona, the Hippo of which St. Augustine had been bishop. But in 1050 Sardinia was again taken by the Moors of Africa and Spain, except the town of Cagliari which still held out for Pisa. The Pisans were on the point of losing courage, but the feudatory nobles urged bold action. The Republic felt insecure in the presence of these unwelcome neighbours, and its free way over the sea was barred. It listened to the advice of the feudatories, and prepared to reconquer Sardinia, the feudatories furnishing both men and ships. Genoa and various nobles, one from Spain, even, came to the support. The combined fleet was commanded by one Gualduccio of Pisa, a plebeian, but skilled in warfare. He led the flotilla to Cagliari, which still held out for Pisa but was besieged by the Moslem, landed his troops with consummate skill, and engaged the enemy on the beach. The Moors were led by Mogahid, the old Moorish chieftain who had conquered and ruled Sardinia, and who, although he is said to have been over eighty years of age, had not lost his ancient prowess; but, attacked at the same time by the charge of the Pisans, the cloud of arrows discharged from the ships, and the sorties of the beleagured garrison, the Moors fled in disorder. Mogahid, wounded in two places, fell from his horse and was captured. He was taken to Pisa, and died in chains, and the whole of Sardinia fell once again into Christian hands. Gualduccio, acting by authority of the republic, divided the island into fiefs, which were given to the allies, Pisa retaining the overlordship and Cagliari, with certain other territories (Annal. Laurent. Bonincontr Miniatens apud Murat. S. R. It.-Bernardo Marangoni Chron., p. 324). 
Pisa continued her warfare with the Moor, and in 1062 her flotilla returned from Palermo laden with booty. In recognition of this " crowning mercy" the famous cathedral, so far in advance of any building of the period, and a wonder of majesty and simplicity, was erected. Though the beautiful building is their true monument, the names of the architects, Boschetto and Rinaldo, ought not to be left unrecorded. The Cathedral was the first to be erected of the four buildings which occupy the Piazza del Duomo, and which together form, without dispute, the noblest architectural group in the world. The Cathedral is the best evidence possible of the degree of how far the Pisans of the eleventh century had advanced from a rude and barbarous state, though to-day it presents a heightened form. Pisa still owed allegiance to the Marquis of Tuscany, but it was an entirely self-governed city; it made treaties and sent envoys in the name of its Archbishop and consuls, and it had its own system of laws, approved by Pope Gregory VII. in I075 and confirmed by the Emperor Henry IV. six years later. It is in this document, which is of approved authority, that we find the first indisputable mention of the municipal consuls of Italy. The aristocrats took the most prominent position in public affairs, and especially, as one would naturally suppose, in warfare. In ro99 Pisa joined in the second crusade, as did her rivals, Genoa and Venice, and derived much commercial advantage from it, establishing business houses throughout the maritime East, and undoubtedly taking the commercial lead of the other two trading cities. In I I Io we learn that a six years' war with Lucca came to an end.

Three years later, on Easter Sunday, the Archbishop Peter elevated the cross at the door of the Duomo, and in stirring words urged the huge congregation to deliver the thousands of Christians held captive by the Moor in the Balearic Islands. Old men who had served in their youth against the Moslem, and taken part in the glorious victories of Cagliari and Bona, renewed their ancient fires, and told again in glowing accents the oft-repeated tale. The enthusiasm became strained to a high degree, nor did it abate until an expedition set sail. Unfortunately the Eastern coast of Spain was mistaken for the Balearics, and the error was not discovered until the lands of the good Christian peasants of Catalonia had been thoroughly devastated. Nevertheless, nothing daunted, the fleet set sail the following year, with the intrepid Archbishop in command. Its success was complete. It returned with a great multitude of released captives and the last living scion of the reigning house of the Moors of Majorca. Meanwhile the jealousy between the Genoese and Pisans had been fostered by their rival pretensions in Sardinia. An edict issued by Gelasius II., who was a Pisan, making Corsica suffragan to the metropolitan Church of Pisa, was received with great rejoicings by the citizens. This was as a spark to touchwood, and Genoa made war on Pisa the following year (I 20 ). The war continued for twelve years, when Innocent II., who had taken refuge in Pisa, re-established peace by rendering the Genoese Church independent of Milan, and raising the Bishop of Genoa to the dignity of Archbishop, with rights over a portion of Corsica, while Pisa received certain ecclesiastical compensations. In return the Pisans lent their aid to fight Innocent's foes, the recalcitrant Normans. They aided in the heroic defence of Naples, and destroyed for ever the prosperity of Amalfi, which they twice pillaged (I 135 and 
II37). By this time the neighbouring villages of the seashore had, either by force or by consent, confederated themselves with Pisa. They undertook not to fight among themselves, but to submit their quarrels to the arbitration of the Pisan consuls, and to place their militia under Pisan orders. The cessation of incessant aggressions and bloody reprisals among a horde of small communities was a great advance, though it involved them in the prolonged duel between Genoa and Pisa, and in the inveterate antagonism of Pisa and Lucca; it also, by strengthening the forces of the metropolis, increased security against mauraders. The Pisan supremacy extended along the coast-line from Lerici to Piombino, but the district was unhealthy, and the coterminous states of Florence and Lucca were a check on further aggrandisement. At this time Florence and Pisa were on friendly terms.

There are so many gaps in Pisan history that it is difficult to trace the development of its municipal self-government. The nobles were much more important people than those of Florence. There was a senate or council of the commune, but no consul in the time of Henry IV. This council appears to have consisted of aristocrats ; there was also a general assembly. Five aristocrats formed a board under the presidency of the Bishop, and these seemed to have exercised consular functions. Consuls are again mentioned in I094, and probably had duties similar to those of the other cities. The Countess Matilda enriched the Bishop by the presentation of several castles; and Donizo, in his life of the great Churchwoman, speaks of. Pisa as an important port, into which there flowed commerce from the Orient. Undoubtedly in Pisa, as in Milan, the Bishop took a large share in the government of the growing commune. Readers who have visited Pisa will wonder how it could ever have become an important port. In those days there existed a bay at Calambrone, which furnished the Pisans with a commodious harbour; now, it is completely silted up. It is interesting to note a curious resemblance between the account of the expedition to the Balearics in I I I 4, led by the Archbishop Pietro Moricone, and written by his secretary, Diaconus, and the "Gerusalemme" of Tasso; it seems extremely probable that the great Italian poet was acquainted with the earlier work.

\section{GENOA}

AlL that we can learn of the early progress of other Italian self-governing communities is gathered from the incidental observations of foreign annalists, or from the not always reliable accounts of subsequent historians. But Genoa had the advantage of maintaining a chronicle, kept by Caffaro, one of her magistrates, and presented yearly to the consuls, and consigned, after the approval of the senate, to the public archives. It begins with the year I IOI, and was continued by diverse hands until I294. This chronicle was evidently accommodated to flatter the magistrates and people, but in spite of its partiality it remains the most curious and instructive record of the age. Having secured from contending nobles the rights, privileges, and immunities of municipal freedom during the Lombard and Carolingian periods, we find that Genoa, like the other Italian towns, was ruled by 
consuls. During the early years of the twelfth century their number varied from four to six, and they remained in office three or four years.

In I 22 the consuls were annually elected, and in I 30 their functions were specialized into executive and legislative. The bodies thus constituted were severally called "Consuls of the Commune" and "Consuls of the Pleaders." The former, four to six in number, were elected annually, possessed executive power, and were specially charged with the maintenance of public order, foreign affairs, and the command of both land and sea forces. The latter were sometimes equal, sometimes considerably more in number than the officers of the executive, and were the judiciary of the republic. The city was divided into seven quarters, and each division chose its own judge, who served for a year. Later on, two courts were set up, one for the whole city and another for the quarter, and the defendant could compel the plaintiffs to prosecute in whichever court he preferred. On the request of the people, other officers were appointed to the number of twelve or fifteen, who had the function of revising the laws. Since the legislative body had usually nothing to do with administration, the state did not incur serious danger by this procedure, but it may be remarked that the Italians believed in entrusting legislation to specialists rather than amateurs. These jurisconsults were of course blind followers of the maxims of the school and the code of Justinian, and we always find them in Italian history the creatures of precedent and the supporters of despotic power.

A council or senate is mentioned two or three times, and was supposed to assist the consuls, but had it possessed important powers it would have been more en evidence. The consuls were nearly, or quite, all of noble rank. As the aristocratic order had declared itself the defender of the city against Imperial or other powerful aggression, a grateful people had accepted its guardianship, and we meet with illustrious names in the consular lists of this period-Spinola, Doria, etc. Like Pisa, Genoa was pillaged by Saracen marauders in 935, an event which she did not forget. We have told how, when the Saracens were established firmly in Sicily and the Balearics, and seemed likely to become settled in the near neighbourhood of Sardinia, the Genoese united with the Pisans in a successful expedition, which, however, led to subsequent rivalry and strife. But in 1087 they again co-operated in dislodging a Moslem pirate who had established himself near Tunis, and the allies, having defeated him, obtained the right of free trading along the coast as well as the release of his Christian captives. They traded with the Levant in the eleventh century, though the peril of capture from the Saracens of Sicily must have been great. When Sicily succumbed to the Normans much trade fell into the hands of both Pisa and Genoa ; interchange went on not merely with Sicily, but with the Levant, the route to which was now clear. And commerce was greatly fostered by the Crusades, for Pisa and Genoa transported the armies of the West, and intercourse with the East increased the demands for commodities. Meanwhile, rivalry with Pisa continued. One of many bloody wars lasted from III9 to II33, and was only terminated by the adroit interposition of Innocent II., as has been recorded in our account of Pisa. But the cities shared in the Crusading enthusiasm, and turned it, after the manner of trading communities, to practical advantage. Genoa sent twenty-eight galleys and six other ships to the 
Orient at the same time, or near it, that Pisa despatched one hundred and twenty ships (I IOO), and the next year we have detailed accounts of the siege of Cesarea (Caffaro. Ann. Gen.). Daimbert, the Archbishop of Pisa, who commanded the Pisan fleet, harangued the republican allies, and urged them to take the Holy Communion next morning, for, under the protection of that holy sacrament they could not fail to capture the city. He bade them not wait for engines of war but rely on their ships' ladders and assuredly they would gain the city. The audience was roused to enthusiasm. The next morning the city was furiously assailed, the Genoese consul was the first to reach the rampart-top, and fought singlehanded until his followers could join him. The city was taken and pillaged, and the booty, after Roman usage, was divided by the consuls. A fifteenth was set aside for the ships' guards, another portion was reserved to the magistrates and leaders, and the common soldier received forty-eight silver soldi and two pounds of pepper. ${ }^{1}$ A signal victory thus won, the republican fleets set sail for home. Genoa not merely got similar advantages to Venice and Pisa in the Holy Land, but she established herself in the Levant, on the shores of the Black Sea, along the banks of the Euphrates, and wrested seaports from the Saracen in Africa and Spain. This policy of expansion fanned the jealous flame that was smouldering in the heart of Pisa. In fact, the three republican confederates of the crusades became most jealous foes, and serious warfare between them was quite inevitable. The same process of confederation of seaports under the Genoese flag took place in the Riviera as did that of those of the Maremma under the Pisan; they contributed to its power, but retained their own free constitution in all but military and naval affairs.

In 1146 the Moorish settlements in Minorca fell to the victorious arms of the city, and in I 47 Almeria, in the Moorish kingdom of Grenada, was attacked by sixty-three galleys, one hundred and sixty-three transports, and twelve thousand troops. The booty was immense, and the following year, by aid of the Catalonians, Tortosa fell. The jealousy of the other two maritime communes of Italy was thereby excited, and before long they came to blows. We shall find the contest for supremacy rage first between the nearer neighbours, Genoa and Pisa, and on the crushing defeat of the latter, after two centuries of bloodshed, between the victor and Venice.

\section{FLORENCE}

ONE of the least considerable of Italian cities at an early period, but destined in the fulness of time to become by far the most important of the Italian republics, was that great city on the Arno, which her poct justly spoke of as "the most beautiful and renowned of the daughters of Rome" (Dante). Her gates open on to a fertile plain-fertile, even as Italians count fertility - and this is surrounded by smiling hills, whereof the hedgerows are rose-trees, and the yield, the finest oil and the daintiest wines; while the barrier mountains beyond enfold vast forests of sweet chestnut, the cultivation of which requires little labour, and yields more

1 Cesarea was a great centre of the spice-trade, and depot of Indian commerce. 
nourishment per acre than any other form of food. It will be our grateful task to follow the opening fortunes of the republic, because the motives which actuated the infant city and the methods she employed, as well as the story of her constitutional development, are typical of the motives, method, and evolution of every Italian town. Multiply Florentine drama a thousandfold, and you have a view of the full and troubled sea of life that was ever agitating Italy, its waves ceaselessly " poursuivrantes et poursuivries."

The mountains isolated most of the Tuscan towns from the world, and hence Florence and her neighbours were two or three centuries late in following the development of the cities of the great plain, and were still more in the rear of the maritime republics. While it was within the marquisate of Tuscany, there were no great nobles immediately round Florence, and so, unlike Siena and Pisa, it had no important aristocrats within its walls. The surrounding hills were peaked by many a small feudal turret, and these engaged the city in a number of petty wars; but in the longrun these minor feudatories could not hold their own, and, on account of the comparative unimportance of the city, she was not seriously interfered with during the earlier portion of her career. The spirit of independence that characterized her citizens, which later, "by faction dyed her lily a scarlet hue " (Dante), was early manifested. In 1063 Henry IV. sold her bishopric to one Mezzabarba, and imposed his nominee on the city. Street warfare ensued, and Alexander II. had to send Damien to try to quell the disturbance. The Florentines would not accept his temporizing policy, but obstinately refused the sacraments of Mezzabarba's clergy. A council had to be held, and the monks, who represented the popular party, demanded that curious ordeal by fire which seems to have been originally a pagan form of trial (cf. Soph. Anti,.,v. 264). Hildebrand espoused the popular cause, but would neither consent to the deposition of Mezzabarba nor to the proposed ordeal. Mezzabarba retorted by getting an order from the Imperial authority for the expulsion of the monks. Forthwith the little town was all ablaze. The men vowed that they would forsake their city rather than yield it to a heretic : the women beat their breasts and rolled in the mud, shouting "Christ drives thee out ; Simon Magus does not permit thee to dwell with us." Five years of disturbance followed. Then a monk is said to have traversed the fire unharmed, and Desiderius of Cassino informs us that the man himself told him that he had stopped midway in the flames to pick up his handkerchief. Alexander deposed Mezzabarba, and made the monk a bishop; but, as Perrens observes, it taught the magistrates that they could act against constituted authority, and the multitude that they could get their way if they were only sufficiently riotous. The Florentines inherited the religious impressionability as well as the artistic genius of their Etruscan forebears : religion was ever showing itself in forms of excitement. In I099, Pazzo dei Pazzi, a brave Crusader, brought back pieces of the Holy Sepulchre. All Florence turned out of doors, and, amid a scene of wild religious joy, the Bishop struck fire from the fragments, and lighted candles therewith, while the Gloria was sung with fervour ; then the whole populace, proceeding to the quarter where the Pazzi lived, repeated the procedure. This was the origin of the famous " festa della colombina della casa Pazzi," so well known to visitors to the 
city at Eastertide. The piety of Florence was well pleasing to the Great Countess, to whom her other towns gave chastening discipline; and, partly on this account, and partly by reason of its insignificance, Florence did not suffer seriously at the time of the wars concerning Investiture. The little town, thus let alone, began to thrive and develop its resources. The Florentines began to understand that they must secure the routes for their growing trade, and make them safe; and there were no important powers residing in or near the city to restrain them. The hegemony of Tuscany fell to Florence, because the stream of its power began so slowly and from so inconsiderable a source that nobody observed how it broadened and deepened. When Henry IV. sent his vicar to oppose the alienation of Matilda's heritage, Tuscany fell to pieces. Each town was opposed to the great country nobles, who represented the Empire and its claims ; and the smaller nobles often found it to their advantage to stand by the towns wherein they resided, and take the consulate in Matilda's name. But, since the office was often renewed and passed from one family to another, great discord arose. Obnoxious nobles had their towers burned down, and in III7 the Uberti, the forefathers of Farinata Uberti, were burned out of their quarter, and their towers, with which their houses communicated, were razed. The jealous nobles joined the populace on this occasion. The consuls were chosen from the great nobles, and represented the overlord, but this part of their duty was purely nominal; their real business was to keep the city in some sort of civil order, and to take military command. Some of the leaders of the city were descended from the people, but most were enfranchised nobles who maintained their intercourse with the nobility outside the city walls, and formed "societies of the towers" within them. These societies were often at war with each other. Villani says that one such contest lasted for two years, so that men would be feasting together one day and at each other's throats the next. The consuls of the city were sometimes also consuls of trade-associations. These guilds were the real governing powers of the city, for there was no centralized authority such as we are accustomed to in modern times. And great matters, whatever their nature might be, were entrusted to leading men : there was no specialization of political function. Florence began her career of conquest in Matilda's time. Pagna, in the Val d' Elsa, and a feudal fortress near Signa, on the road to Pisa, fell to her victorious arms. It was necessary for her to have an unimpeded route to Pisa, which was the nearest seaport ; and so trusted was the Florentine government, that Pisa confided the defence of her territory to it while she was engaged in her Balearic contest (I I I -I I I6) The Florentine leader forbade his soldiery to enter the town; one man disobeyed, and was straightway condemned to be hanged. In vain did the Pisans demand a pardon; then they implored that the execution might not take place on their territory. The Florentine reply was to quietly buy a piece of land from a Pisan and erect a gallows thereon. The Pisans recognised the faithful service of Florence by presenting her with a column of porphyry, taken from the Saracens, which the curious may still see adorning one of the porches of the baptistery. Florence now turned her attention to the robber-barons of the neighbourhood. First the Counts of Monte Cascioli fell (I I I9); then the nobles who had taken refuge in Fiesole were attacked, and that mountain fastness, so near and dangerous 
a neighbour, was conquered (II25). Then, after eight years of quiet preparation, the Count Guido Guerra, who, with the aid of Siena and Arezzo, had harassed Florence, was attacked in his own castle, which lay on the road to Siena, and the Florentines razed that fastness to the ground. Florence next turned her arms against the neighbouring cities, with which there was always some dispute as to the transit of goods, or boundaries, or the harbouring of exiles, or concerning alliances with robber-barons. Thus, Empoli fell into Florentine hands in II82. Siena had ambitions to be supreme in Tuscany; Arezzo had attached herself to the interest of Guido ; Pistoja was too near a neighbour. These cities, although small, were too feeble for little Florence to fight, but she attacked and subdued Prato and Pagna. A bitter enmity between Florence and Siena, evidences of which are to be found in the temper of their inhabitants towards one another even to-day, first arose in I08I, when, in the Wars of Investiture, the troops of Henry IV. besieged Florence and were provisioned by the Sienese. From that time forth, with rare and short intervals, there was either declared warfare between the two cities, or they seized every opportunity to vex and raid one another's territory.

\section{SIENA}

ON a Tuscan hill-top, where three long ridges run out from a slight central hollow, and straggle in different directions down to the valleys, rises " fair, soft Siena," the rival of Florence in dominion, commerce, and the arts-a city which, by its situation and adornment, is, perhaps, the most dignified and daintily winsome of all the graceful towns of Tuscany. As in the other cities of Italy, and when Siena was still a quite unimportant town, the bishop took the place of the count; and by the same process, which obtained elsewhere, his authority waned in turn, and was replaced by that of the commune, with consuls at its head. Each of the three separate hilly ridges or arms was a natural division of the city, and became a distinct ward. Each ward elected one or two consuls, who at first co-operated with the bishops in the rule of the city. Owing to the relative importance of her nobles, Siena enjoyed a continuance of Imperial favour; her natural tendency to Ghibellinism was thus increased, and still more so by the Guelph profession of rival cities, though she had ever a democratic Guelph party within her gates. She helped Henry IV. against Florence, but she was always discreet enough to render the Imperial power as little service as possible, though she invariably behaved respectfully, and gave the Crown all due honour. An example of her spirit was given later on : when Frederick II. visited Tuscany and required her to furnish troops, she replied that she would grant him a guard of honour ; but that if he sought more, it was meet that he should come personally and make his requests to her council. And her Imperialistic tendencies were not so assertive as to prevent her from becoming, like Florence, money-changer to the Pope.

At the head of the little republic stood five great families-the Malavolti, Piccolomini, Salimbeni, Saracini, and Tolomei-claiming descent from Latin forefathers, or from Frank and Lombard conquerors. The 
Sienese aristocracy, like that of city and country alike in Italy, was tempestuous ; their blood coursed fiercely through their veins, and the narrow lanes were disturbed, almost without cessation, by their bickerings. As usual, the weaker side in the quarrel sought the support of the people, who were not slow to profit thereby; and in I 147 we find them accorded one-third of the seats in the general council of 150 members. One by one the feudal lordships of the neighbourhood were purchased, taken, or menaced ; so that their inhabitants were compelled to become burghers, and reside within the city walls during a portion of the year.

\section{LIFE, LITERATURE, AND ART}

\section{LIFE}

WrTH the invasions of the barbarians the great day of Rome set in sombre gloom ; they ushered in a lugubrious period, during which, none the less, the great vital forces of Nature and man were preparing for a new impulsion of the human spirit, and were silently remodelling a people. The Latin race was for the most part reduced to half free-proprietors, or aldii, and serfs. A third of the land or of its produce had to be sacrificed to the conqueror, who, however, showed no tendency to further depress the conquered race, but allowed their personal laws to stand beside his own territorial ones, and administered justice fairly and impartially. The small body of Lombards could not permanently withstand the subtle, constraining influence exhibited by the children of Ancient Rome; after generations of antipathy the two races became Italian, though the rulers of the country remained of foreign descent, and even as late as the twelfth century, "Langobard" and " Roman" were used as terms of recrimination and reproach. Lombard law, which had coexisted with Roman law, each people being called upon to obey its own judiciary system, survived for a long time in Pavia and elsewhere. Under the Carolingians we have seen how the bishops acquired immunities which practically made them the sovereigns of the towns, and the municipalities organized themselves under episcopal protection, first of all as trusses of tradeassociations, then as true municipalities under consuls. The towns became self-reliant and even turbulent, ready for attack or defence, freed themselves from the count and the bishop, and emancipated the slaves that sought shelter within their walls. Trade flourished, and serfdom, both in town and country, rapidly began to disappear. The intermingling of races and the decay and transformation of the Roman tradition had by the tenth and eleventh centuries produced a.new people speaking a new language and leading a new life.

\section{Transformation of Latin into Italian-Literature of the DARK AGES}

In all probability, literary Latin had differed very considerably from the Latin of daily life. For in letters, as in so much else, the Roman was the scholar of the Greek, and his literature, based on the Greek model, not merely copied the artistic form, but was influenced by the linguistic 
felicities of Hellenic culture. But Latin possessed more stateliness and dignity, and Greek more subtleness and flexibility. Consequently, Latin literature was far from being solely imitative : it vitally transformed the culture which had brought it into life ; it was an organic assimilation which acquired a novel and virile dignity and force. None the less, the Latin known to us, being of foreign origin, was a literary tongue, differing in a measure from the speech of the home and the market. The divergence thus established between the written and the spoken tongue was aggravated by the corruptions of provincial speech, and by the differences of form and pronunciation adopted by alien peoples. The barbarians simplified the language by mutilating the inflections : the neuter gender vanished; articles, derived from ille and unus were used by the foreigner to make his broken speech intelligible; auxiliary verbs were introduced by the Teutonic conqueror, who had only two tenses in his own tongue; foreign words and Teutonic idioms were adopted; and the difficulties of pronouncing a foreign language hastened the phonetic changes which are natural to the life-history of every tongue. Consequently, the powerful Roman tongue became gradually transformed, not, indeed, into "soft bastard Latin," as Byron designates the Italian idiom, but into a rude and unpolished variety of rough dialects, which, nevertheless, contained the possibilities of the grace, flexibility, and elevation of Italian. The loss of literature implied the loss of a standard, both of pronunciation and of grammar. The Latin of the fifth century was already corrupt; the productions of that age show loss of inflection. By the ninth and tenth centuries even literary Latin had become barbarous, and references to classical writers are few. The council of 992 found that scarcely a single priest in Rome could read or write. The authors of the time were incompetent to write; and in reading them, especially those in metre, we suffer, not merely from the sterility of the subject-matter, but also from the clumsy ineptitude of the style-a style quite incapable of rendering the true mind of the writer, in spite of the license of barbaric idiom in which he indulged : their Latin is inconceivably debased. The literary innocence and absence of mental discipline displayed by these chroniclers is well-nigh incredible. Thus, Agnellus, Bishop of Ravenna, who flourished in the middle of the ninth century, says, in his Liber Pontificalis, that where he was unable to obtain information from inscription of the monuments, the conversation of the aged, or "other authentic source, in such a case, that there might be no break in the series, I have composed the life myself, with the help of God and the prayers of the Brethren "- a process which, at the hands of less candid writers, conceivably accounts for a good deal of venerable history! Liutprand, a canon of Pavia and ambassador of Berenger II. to the court of Constantine Porphyrogenitus in 946, afterwards Otho's ambassador in Rome, and sent by him again to Constantinople in the reign of Nicephorus Phocas, has higher claims; he is energetic and concise, varied and, occasionally, profound ; he is inconsequent and partial, but is not wholly unlearned, and when he becomes animated, he breaks out into verse of supportable quality. The license of his narrative, when one recollects his ecclesiastical calling, gives one an insight into the moral tone and manners of the aristocracy and court-life of the period. The anonymous writer of Salerno, Gaufred Malaterra, Alexander of Telessa, 
and Falco of Benevento, are not dull ; and the narrative poem of William of Apulia on the Norman conquests is far above the average verses of the time. But it must be remembered that William of Apulia was not an Italian, and Bartoli thinks that, owing to the continuity of their history, the Italians of this period were lacking in that spontaneity, in that " childlike state of mind and heart " which inspired the Northern races, and which only infused Italy with freshness, and then, surely, in a modified form, when the Renaissance began. The political ferment of municipal interests influenced the Italians in the direction of practical affairs rather than of belles-lettres. This tendency to pursue knowledge for use, then, is illustrated by the eminence in jurisprudence which Italy obtained by the end of the twelfth century, and by her literary deficiency and small devotion to the theological sciences. Her historical origin, and her lack of the freshness of mind that distinguished the North, accounts for the tenacity of the Latin language in Italy. Everybody wrote in Latin, though the dialects of the country had assumed some kind of fixity and grammatical shape. The great scholar Muratori was unable to discover a single document of the language which Italians spoke anterior to the end of the tenth century. The presence of two languages - a dialect of German spoken by the conquerors, and a debased Latin in vulgar usemust have kept up the antagonism of the two peoples. But the guttural German, so difficult to the Italian tongue and ear, could not prescrve itself. Though its usage was thrice reinforced, by the coming of Lombard, of Frank, and by the renewal of the Empire under the House of Saxony, the German children naturally spoke the tongue of the people; and, in two or three generations the mother-tongue was forgotten. The more the cities increased in wealth, population, and importance, the more the vulgar tongue came to the front and took precedence of Latin and German. By the twelfth century it had become completely victorious, and by the thirteenth century we shall find it polished and employed by poets and historians.

When Latin ceased to be a living language, and the invasions of the barbarians and their subsequent internecine warfare had destroyed the remnants of ancient culture, the people lost the arts of reading and writing. These were possessed by the clergy alone. The clergy were either interested in the acts of the saints or engaged in the practice of law: the knowledge of Latin became valued only as professional equipment, and a great part of the glorious body of Latin and Greek literature was lost, the valuable parchment that had preserved it being used for other achievements, chiefly by the wonder-loving monks for disordered, hare-brained records of miracle.

\section{The Characteristics of the Dark Ages}

The warm, kind world that Flaccus and Ovid knew became a world of ever-present fear and lugubrious portent. It was perpetual witness to human atrocity, and the haunt of horrific devildom, a cave of despair, wrecked by man and visited by fiends. When the Roman world tottered to its fall the saintly Benedict established a refuge for piety and learning on the picturesque heights of Monte Cassino; and, following his example, pious and unworldly men and women fled to secluded places 
for peace. In the quiet of the monastery men and women lived a community-life of devotion, of agriculture, and even of leisured learning. But the Church became corrupt and worldly. The end of the world was deemed to be near; the despair of the time expressed itself as of old: "Let us eat, drink, and be merry, for to-morrow we die." In 936 a youthful monk of Farfa, in the Sabine land, poisoned the abbot of his monastery, usurped his place, took a wife to himself, and the whole community ended by supporting themselves by brigandage and leading a life of pleasure. In 947 the Senator of Rome put these monks down by armed force, and a new abbot, from the reforming monastery of Cluny, was placed in command. ' In 952 he also was poisoned, and the old life was resumed and continued for thirty or forty years. For the most part religion was purely formal, and its practice consisted in the repetition, by clerics and laics alike, of stereotyped phrases. To these desiccated spirits only one remnant of Christianity really remained a truly potent article of faith, and that was a sure and certain belief in the reign and frequent appearance of His Satanic Majesty and his ministers (R. Glaber, Hist. Libr. V., Ed. Prou. Paris, Picard, I 886). Raoul Glaber, who travelled in Italy, tells us that Vilgardus of Ravenna (circa A.D. 1000) "studied grammar more assiduously than is usual, after the manner of those Italians who neglect all for letters. Swollen with pride and full of foolishness, he saw one night three devils jnder the form of Virgil, Horace, and Juvenal. These devils deceived him, and he taught doctrines contrary to our Holy Faith, for, according to him, one might believe all the words of these poets. Peter, bishop of the city, judged and condemned him as a heretic. At that time there were many in Italy who professed this pestilential belief, and who perished therefore by steel or fire." Three centuries later Virgil was to conduct the repentant steps of Dante to the summit of the sacred mount and the garden of the Lord.

All knowledge of natural science was lost ; reasoning was regarded with suspicion; the devil was seen behind every post ; miracle was so common, that the ordinary course of Nature would have been deemed miraculous had it been perceived; and thinkers fixed their attention on abstract words or what is obscure. Symbolism was almost the sole method of thought, but it disciplined the race; it led to the vision of Dante, the teaching of St. Francis, the frescoes of Raphael, the statuary of Michaelangelo, and, passing on to our own island and time, reproduced itself in the mystic conceptions of Watts.

The world was occupied with portent: the dread of the approaching end of the world was on all. An army marching under Otho I. was so terrified by an eclipse of the sun that, believing it to announce the passing of the earth, the soldiery fled in every direction. It was believed that the year A.D. I000 was the appointed time of the day of wrath. But at the Papal Court men knew better: the Council of Rome, held in A.D. 998, imposed a penance of seven years' duration on Robert of France.

When this almost universal dread was dissipated by the passing of the thousandth year without particular mishap, we find, under the constitutions which the Othos had given the towns, a remarkable outburst of republican energy. And the mediæval mind, which, even in the ninth century, had manifested a strange speculative power, began to investigate ultimate principles, and tried to discover some pathway to reality. 
But the popular and even the cultivated mind remained grossly superstitious, and though men travelled more than is usually supposed, and saw many natural phenomena, they regarded themselves as a corporate whole, bearing the sins of Adam and Eve, and meriting the direst Divine displeasure, which was indicated by comet and eclipse. A fire at St. Peter's in Rome was presaged by an eruption of Vesuvius. On June 29, I033, the sun was eclipsed, and men broke out into a cold sweat with fear; next day the barons of Rome tried to assassinate the Pope. A comet preceded the destruction of a great church; the terrible famines of days when there was little intercommunication and hardly any means of transit, and pest, favoured by an incredible disregard of sanitation, were regarded as visitations to punish the wicked. Insanity or learning were equally regarded as possession by devils. In certain monasteries, however, the Church, that has always been liberal of mind when she has not been actively opposed, allowed discussion of the freest kind, even as to the existence of an Almighty Being. Such discussions were, of course, of a purely academic character, and faith was not really questioned. Credo quia non intelligibile was, in the main, the fundamental basis of faith.

One of the most striking illustrations of the mingled credulity and brutality of the mediæval man is furnished by the children's crusade of I2II. Ninety thousand children set forth from Germany to convert the Saracen by their hymns and example. But when many reached Genoa, they were met by the practical difficulty of getting across the Mediterranean without galleys, and most of them dispersed. What became of these unfortunate, deluded little innocents is not clear ; 30,000 of them reached Marseilles, and were partly murdered or allowed to starve, and the rest were sold as slaves to the Saracen. Venice had an evil reputation for trading in Christian slaves.

\section{Scholasticism}

When, in the ninth century, the human mind began to arouse itself from its long lethargy, and found in the peace of the convent that leisure to think which was denied to it in the hurly-burly of the troubled world, monks began to ponder on the nature of general and particular ideas; and these logical problems led up to what is the pith and marrow of all human inqury - the questions Whence? Why? Whither? What? The discussion began with the relation of certain points in Aristotle's logic (which the monks obtained in a mutilated form through the Arabs) to the doctrines of their Church. The freest discussion appears to have taken place in the cloister. But the conclusions were predetermined by the necessity of reason arriving at a result concurrent with religion, and also by the dead weight of the great authority of Aristotle. Although the schoolmen exhibited a confusion of logic with ontology, and of both with theology, and misunderstood Aristotle, they debated, though very confusedly, all the fundamental difficulties of philosophy. Never has the world seen subtler or acuter thinkers; never have such delicate distinctions in thought been so finely discriminated. Two Italians stand out in the first rank of these thinkers, though Italy has contributed but few metaphysical thinkers, for her genius is mainly objective and even practical. One-St. Anselm 
of Aosta (1034-I 109)-became Archbishop of Canterbury; his proof of the existence of the Absolute presupposes the identification of the rational with the real, and however reformulated, or however criticised, his aperçu lies in the heart of nearly all really great speculative thinking. As is said of him by a living metaphysician, he is "among the few deep speculative thinkers who have opened new avenues for the human mind " (J. M. Rigg., St. Anselm). The other-St. Thomas of Aquino, in the kingdom of Naples (1227-1274)-is the officially recognised philosopher of the Roman Catholic Church. He held that we have two sources of knowledge-the revelation of God, which for us is ultimately a mystery, and that of human reason-but, since both are derived from one ultimate and absolute truth, they do not really contradict one another. By this subterfuge, human reason was, in measure, set free to pursue her own course. Much of the speculation of Anselm and Aquinas and of all the schoolmen is very barren. This was apparent even to themselves. John of Salisbury, writing in the twelfth century, speaks of "the ancient question in the solution of which the world has grown gray, and more time has been consumed than the Cæsars gave to the conquest of the world, more money spent than Crœsus counted in all his wealth." Yet the highest and best minds did not cease to be stung by the divine gadfly, nor were they able to withdraw themselves from the irresistible quest. They were assailed by

\section{"Obstinate questionings of sense and outward things ; Blank misgivings of a creature \\ Moving about in worlds not realised."}

Progress was impossible until other problems of life and knowledge had been settled, which, while they cannot solve metaphysical questions, nevertheless alter their enunciation and aspect. By the end of the fourteenth century scholasticism had perished of its own internal decay, and Italy, and, indeed, Europe, had awakened to new interests and fresh pursuits.

\section{Commerce, Art, etc.}

During the dark ages there was considerable intercourse with the Orient through the Byzantine Empire and Constantinople. Liutprand, who was sent by Otho I. on an embassy to Nicephorus Phocas, the Eastern Emperor, gave the Greeks great offence by telling them that the Lombards were as finely arrayed as they. They retorted that the illicit exportation of their stuffs by Venice and Amalfi should be prohibited. But it could only have been the feudatories and their ladies who donned the products of Eastern looms. The men and women of the trading classes were clad in quite another style than that of silk and fur-plain homespun or coarse woollen was their only wear. The country gentry spent their time like joyous beasts of the field, in eating and drinking, fighting, hunting, and hawking. Trade was fostered by the Crusades, in which the Italians had mainly, but not entirely, a commercial interest. For the Pisans brought many shiploads of soil from Calvary wherein their dead might repose (the Campo Santo). City life was unostentatious, but exciting; the streets mean, narrow, and unpaved.

The building art had suffered a great decline in the later days of the 
Roman Empire. The masons of Como kept architectural traditions alive, and built in that debased style which is known as Romanesque, and they are frequently referred to in the documents of the time. The circular apse, beneath which the bishop sat enthroned with his consistory on tiers, became usual, and was often employed at both ends of the building, and the plan adopted at Santa Sophia in Constantinople-of a less than semicircular dome with semi-domes or domes of smaller dimensions at either end-a plan due to the genius of Justinian's architect, was introduced into Venice. The arch, even in the third century, had begun to, displace the entablature, as is evidenced by Diocletian's palace at Spalato, and the dosseret, introduced to adjust differences of height in antique columns that were used again for new buildings, led to the decorated convex capitals of Ravenna and Torcello. San Vitale at Ravenna, which commanded the admiration of Charlemagne, and led him to copy the building in his famous church at Aachen, is an octagonal church with a central dome. The early Italian churches are for the most part derived from the Roman house that was used for worship. There is an atrium, or open court, leading to the church with its colonnaded triple aisle and semicircular apse, of which an excellent example is to be seen in San Ambrogio at Milan. Internally the Roman basilica, or law-court, was taken as a model. The Emperor had sat on a throne, surrounded by his senators, who occupied raised seats in semicircular tiers below him, and this apse was preserved, the bishop occupying the throne, surrounded by his clergy; thence he descended to the altar, which was now inside the building, instead of being outside, as in pagan times. The churches were decorated with mosaic-always the great glory of Italy-during the period of which we treat, though in the thirteenth century it began to be displaced by the great art of fresco-painting. Ruskin is quite wrong in speaking of Lombardic architecture. There was no special style peculiar to the Lombards, though they often made their columns rest on carved couchant beasts, which they selected as symbols, and which are probably there because, at first, they used up precious antique columns that were too short for their purpose. The older palaces of Venice have beautiful qualities peculiar to that city, and contain elements which the Venetians borrowed from the art of Constantinople and the Moslem world.

We have pointed out that in the great palace of Diocletian at Spalato in Dalmatia, we find the departure that issued in the Gothic style : the arch springs directly from the capital. Pisa, Lucca, and other places took the lead in buildings which are of peculiar beauty, owing to the use of the arch as a decoration. Their citizens employed tiers of arches, of which the tiers are the supports of the building, with small open galleries beneath the roof; the pillars of these frequently increase in height towards the apex of the cornice. The effect is that of a charming repose, and the style permitted of free play to the workman, who now begins to expitess his individual temperament. Charming decorative arcading was also used. The cathedral of Pisa was consecrated in I I I 8, but the delightful west front belongs to the thirteenth century; for, as an inscription tells us, the original building was then lengthened and raised. The baptistery was begun in II 53, though its present construction. is chiefly fourteenth - century work; its pulpit belongs to the first half of the thirteenth century. Classic tradition had never quite perished. The 
Pisans, who had a keen eye for the beautiful, collected Roman sculpture, and in the South there was an attempt to combine the tenderness and subtle sympathies of Christian feeling with the graceful reserve and dignity of Classic work. But for many generations sculpture remained the handmaiden of architecture, and no attempt was made to develop it as an independent art.

The Norman in Sicily employed Saracens and Greeks as well as Normans in the building and decoration of his churches and palaces. The result is an admixture of Roman, Byzantine, Saracenic, and Norman elements of strange and captivating beauty, of which excellent examples are to be seen in Palermo, Monreale, and Cefalu. The buildings belonging to the period of Norman rule in Sicily are decorated with beautiful wall-mosaics. The Romans had been not merely masters in the art of tessellated pavement, but they used glass mosaics for the niches of statues and fountains. But large mosaics for mural decoration is purely of Byzantine origin. Examples of fifth-century work remain in the orthodox baptistery and the tomb of Galla Placidia at Ravenna, as well as at Rome and Milan, and throughout Italy mosaics of conservative type are found, dating from A.D. 450 to the ninth century, becoming progressively inferior in conception and treatment until the art appears to have died out in the peninsula for two centuries. But in the twelfth century we have a glorious revival in Venice, Torcello, Murano, Rome, Palermo, Monreale, and the cities of the South-glorious in colour, and resplendent as jewels, but not superior to the work of the fifth century. In the thirteenth century the development of fresco-painting, allowing greater freedom, began to displace the necessarily conventional treatment used in the more enduring and more scintillant art.

The painting of Italy remained a poor copy of the fixed allegorical conventionalities of Byzantine art, regarded as sacred fixed types that had inspired the worship of Christ and the saints in dead forefathers, and that might not be meddled with without breaking some pious association of idea or committing some sacrilege.

At the beginning of the tenth century, Guido, a Benedictine monk of Arezzo, invented the principle of the stave and the $\mathrm{F}$ and $\mathrm{C}$ clefs, but not the four-lined stave itself; he is also believed to have set forth the principles of the Hexachord, Solonization, and the Harmonic Hand. He taught music at Arezzo, and, by the invitation of Benedict VIII. and John XIX., at Rome; after which he instructed the monks of an abbey near Ferrara. But he advanced principles which were inferior to those possessed by the Northern peoples; these sang tunes having different parts long before the Southern races. Indeed, until the time of Palestrina (sixteenth century), Italy was as far behind the Teutonic peoples in music as the Georgian and Victorian English were behind the Germans of their periud. 


\section{BOOK II}

\section{THE AGE OF THE COMMUNES : FROM THE DESCENT INTO ITALY OF BARBAROSSA TO THE DEATH OF THE EMPEROR FREDERICK II., I I54-I250}

\section{GENERAL SURVEY OF ITALIAN HISTORY}

The Struggle of the Free Cities of Lombardy against the Empire

FREDERICK I., surnamed Redbeard (Barbarossa) by his Italian subjects, gave a taste of his Imperial quality on the very day that he received the German crown. A noble who had incurred his displeasure, hoping to take advantage of so joyful an occasion, presented himself at Court, and, falling on his knees, craved Barbarossa's pardon. The peers and people endorsed his appeal ; there was a general cry for mercy. Frederick imposed silence on the clamorous throng, and at the very moment of inunction he announced in clear, severe accents that he had been actuated by no ignoble motive, but by the obligation of impartial rectitude, and that his judgment was irrevocable.

Italian barons, whether invited or not, took part in his election at Frankfort. . Forthwith he deputed a commission to investigate the affairs of Italy, and its members returned accompanied by delegates from the Pope, Eugenius III., who sought his aid against the insurgent Romans, led by Arnold of Brescia; and also by Robert of Capua and barons of Apulia, who had appealed against the usurpations of the Sicilian King. Frederick was young, eager for action, carried away by the chimerical notion, common to the age, of his Cæasarship, and determined to enforce order, by a policy of "Thorough" on his anarchical transalpine possessions. He regarded Italy as in a state of unjustifiable revolt, and the internecine wars and aggressions of its towns as so many acts of usurpation. That he was not opposed to municipal self-government, as such, is shown by the privileges which he extended to the cities of Germany, where he wished to hamper the power of the turbulent and rebellious aristocracy, and to strengthen his own authority by securing the support of growing, prosperous, and grateful communities. But in Northern and Central Italy there was no established feudal power. The barons had added the spirit of their native insubordination to the spirit of independence that characterized the towns of which they had become citizens; and these towns had become powerful, not by charter, but through the benevolent neutrality or the impotence of previous monarchs. Not merely did Barbarossa appear as the champion of rights that no one ventured to question, but he conceived that he was the apostle of order and the liberator of the oppressed. It was impossible for him to understand that in what appeared to be a mere dislike of control, fostered by the neglect and weakness of the Empire, there lay the germinal principle of free development and even of national sentiment, of civilization and emancipation of thought and life, which the rigid and austere conception of universal monarchy could never 
foster, and of the presence of which the republics, while they felt a vital instinct for freedom, were still profoundly unconscious. Frederick summoned all his vassals to get ready for the Italian expedition, and made them take oath to support him. In 1153 he presided at a diet held at Constance, when two citizens of Lodi made their way through the throng of princes, and, casting themselves weeping at his feet, adjured him to release their people from the tyranny of Milan. They bore no commission from their fellows, but Frederick immediately ordered one of his officials to carry an order to the Milanese to renounce their jurisdiction over the Lodesi, and to reinstate them. The Imperial messenger was first sent to acquaint the Lodesi with the nature of his mission ; in vain they regretted the inconsiderate rashness of the unauthorized appeal that had been made ; they dreaded lest the Milanese should reply to the haughty mandate by burning their houses and crops ; they pointed out that it would be at least a year before the Imperial troops could arrive to protect them; already they had endured their servitude for two generations. The envoy refused even to defer the delivery of the mandate. The Milanese consuls received him in a full meeting of the people. The crowd was carried away by the passion peculiar to such gatherings. They snatched the missive from the hands of its proclaimer, and trod it underfoot; they hurled imprecations and defiance at the Emperor, and his unfortunate servant escaped with difficulty from their fury. The Lodesi, in mortal terror, sought shelter in the woods, but the passions of a mob are soon cooled, and on calmer reflection the Milanese tried to appease Frederick by joining the other towns in sending delegates bearing the customary donation to the new Sovereign. But the envoys of Pavia and Cremona, Lombard towns loyal to the Emperor because they were jealous of the growing might of Latin Milan, improved the occasion by presenting complaints against the aggressions of their neighbour, whereupon Milan retaliated by re-invading the territories of Pavia and Cremona (II54). Lombardy was thus in an uproar when Frederick descended the valley of the Adige to open the Italian comitia at Roncaglia.

Here he was assailed by complaints from bishops and nobles against the towns ; the consuls of Pavia, Cremona, Como, and Lodi were loud in their denunciations of Milan, while those of Crema, Brescia, Piacenza, and Tortona defended the action of that city. Frederick appears to have exercised a very judicial spirit. $\mathrm{He}$ was smarting under the insolent treatment of his command. In that strange admixture of motives which determines human action, there was present to his mind the obvious policy of supporting the weaker of the two factions that disturbed Lombardy (Sire Raul). That faction was led by Pavia. Before giving judgment, Frederick announced his intention of judging for himself what the truth of the contention was. He set out for Novara, and commanded the consuls of Milan to supply the forage, food, and lodging which were the acknowledged dues of the Sovereign. Frederick traversed a district devastated by encounters between the Milanese and Pavians; and since the German soldiery seized pretty much what they wanted, the peasants fled before them, and the country was absolutely deserted. Hence, since all the provisions sent by Milan were consumed at a single distribution, and the rains caused delay, the army was half famished, and took its revenge when and where it could. Frederick ordered the Milanese to evacuate the little 
fortified town of Rosate in order that his army might obtain its stores. The Milanese consuls obeyed the order, and personally conducted the German army to the place, whereupon the women and children fled with justified terror to Milan, and by the time they reached the city they were in a pitiable condition. The garrison of Rosate retired, and the soldiery sacked and razed the place. The Milanese, enraged at the turn that events had taken, vented their wrath on the consuls, and destroyed the house of one of them-Gherardo Nero-who had the magnanimity to ignore this ungrateful outburst of the agitated populace, and continued to do his duty by the state with undiminished zeal and fidelity. When popular passion had again abated, emissaries were sent to Frederick; they dexterously represented the attack on the consul's house as an evidence of loyal attachment to the throne, and they offered a considerable tribute to retain possession of Lodi and Como. Frederick received the offer of a bribe with indignation; he gave over the fertile plain to the license of his soldiery; he crossed and then burned the bridges which the Milanese had constructed, and which were their means of communication with Novara, and he destroyed the two fortresses on the Novarese side which were held by Milan. and were considered to be the keys of the position. Meanwhile, Milan began to put itself into a better condition for defence, and cast about for allies.

Frederick treated Novara and Turin with consideration; but the inhabitants of Chieri and Asti fled at his approach, and their deserted houses were plundered and burned. He advanced towards Tortona, and ordered the city to abandon its league with Milan. The upper town had strong defences, and, trusting to these, the citizens, who had retreated thither, returned a refusal. Frederick occupied the lower town, and began to besiege the upper, but could not prevent the entrance of 200 fresh defenders, who were sent by Milan. At Eastertide Frederick ordered a four days' cessation of hostilities, to gratify God, refresh his own troops, and still further enfeeble the resisting powers of the now starving inhabitants. The clergy, to their eternal disgrace, took advantage of the truce, left the town in a body, and begged to be exempt from the punishment of a sinful populace, whom they abandoned to his just displeasure. Frederick, to his honour, refused to listen to their cowardly pleadings. He forced them back into the town, and renewed the attack (Otto Frisingens). For sixty-two days the brave citizens resisted the attacks of Frederick's formidable army, now increased by the arms of Pavia and the other towns that took the Imperial side. At last thirst effected what assault was unable to accomplish: want of water alone ended the heroic resistance of a handful of burghers against an empire (April, II 55). The Emperor allowed the burghers and their families to retire to Milan, taking with them what each could bear on his shoulders ; the soldiery took what remained, and the town was set on fire. The opulent burghers of Milan gave shelter and hospitality to the refugees, and Frederick marched on to Pavia, and received the Iron Crown of Lombardy. Thence he marched for Rome to assume the Golden Crown of the Empire.

The German army, notwithstanding the ardour with which it had undertaken this distant expedition, now began to pine for home, and pillage hardly appeared to compensate for tedious marches and the misadventures 
of war. The Emperor was obliged to avoid attacking the great towns on the route. Almost all the cities refused to admit the troops, though they furnished them with rations. Frederick had no small difficulty in maintaining the discipline of a body of rapacious men, beholding for the first time the luxuries of what to them was an advanced civilizationa difficulty which difference of language and race did not diminish. $\mathrm{He}$ passed by Piacenza, Parma, Bologna, and Florence. Rome did not receive him; his army occupied the suburb round St. Peter's; the troops had to hold the bridge of S. Angelo from the turbulent Romans to enable Adrian to perform the coronation ceremony.

Frederick marched his troops through the mountains the next day (II55); the dog-days were drawing near, and the army was suffering severely from fever. The republic of Spoleto owed the Emperor $£ 800$ (fode $e^{\circ}$ ), and had further incurred the royal displeasure by arresting a Tuscan nobleman who was returning to the army from embassy duty. It was a theory current in the Middle Ages, and not yet extinct among the military classes, thet severe reprisal and rigorous punishment is the humanest method of wrrfare, and that leniency and indulgence is the very way to protract strife. Men of that period had small compunction in their contests, nor was Frcderick in advance of his time. Spoleto was added to the list of cities put to the flames. The exiled barons of Apulia begged the Emperor to take :dvantage of the death of Roger and the revolt of Robert of Capua to reconquer the South ; but his forces were weakened by disease and battle, and were homesick withal. At Ancona he was obliged to disband a portion of his army, for many of his leaders had embarked from that town for Venice, while others had made across the passes of Savoy. He was no longer in a condition to prolong the war, though he was still in command of a considerable army. Verona refused to admit his troops. It had never been customary for Verona or any other city to admit the Imperial army within its walls. The Italians were ever wary of their monarch and his army ; they were accustomed to lodge even the Sovereign without the walls, though his lordship was not the ordinary regal rulership of places, but consisted of general authority over all men. But he came as a foreign conqueror, elected by a German diet to which Italians were not summoned, and wherein they had no effective voice, and he could not regard Italy as other than a subjugated land. All these causes led to a want of trust, and the foreign army had exhibited the usual license of campaigners in a hostile land. Otho of Frisingen says that the bridge built by the Veronese for the passage of the troops was very frail, and that it was plotted to launch enormous masses of tree-trunks into the swiftly-flowing Adige, so that these should break up the bridge at a critical moment by the momentum of their descent, but that the plot failed owing to a slight mistake in calcuiating the time. Frederick passed over the Alps, having failed to subdue Italy. He had not dared to attack the larger cities, and a year's campaign had dissipated a powerful army.

Ill as they comprehended the meaning of liberty, much as they abused its possession, the towns of Lombardy were penetrated by a vital and virile instinct for freedom; it inspired them with a sublime self-confidence ; it invigorated them to heroic effort and unquenchable hope. One by one we see them fall into line with Milan, their incoercible and heroic leader. Scarcely had Frederick left the ruins of Tortona when its citizens set to 
work to rebuild and refortify the town, repulsing the Pavians, who surprised them at their labours. Some of the fainter-hearted did indeed seek the shelter of the church, and the Milanese consuls marked their contempt for such timidity and despair of the commonweal by inscribing their names on its portals, to be bywords and a shame. Milan rebuilt the fortifications which commanded the territories of Novara, Pavia, and Montferrat, and alarmed the Pavians into accepting a humiliating peace. She took a score of castles in the valley of the Lugano, which had adhered to the Emperor; rebuilt and fortified bridges over the Adda; defeated the Cremonese ; compelled the people of Lodi to submit; and expended 50,000 silver marks on strengthening her own defences. The spirit she displayed was contagious, all Lombardy assumed a dark and lowering aspect for the Emperor, whose first expedition had gained for him nothing but hatred and disdain.

Nor had the Imperial prestige increased in Southern Italy. A year after the Imperial crown had been placed on the brows of Frederick, Adrian was compelled to forsake his own loyal adherents and confer possessions, of which Frederick claimed the right of investiture, on the growing Norman power (I I5). Adrian, strengthened by the support of the new dominion, now ventured to humiliate Frederick. Some German lords had arrested a Swedish Archbishop; the Pope sent his nuncios to the diet held at Besançon, and addressed Frederick with all the disdainful arrogance of a Hildebrand. "The Holy Pope Adrian," said they, "your father and ours, and the cardinals your brothers, send you greetings." Then followed the haughty statement: "We have invested you with the Imperial crown and the fulness of worldly honour ; we should not hesitate to confer on you offices (beneficium) still more imposing, were greater possible." Since Hildebrand no Pontiff had deemed it necessary to await the confirmation of the Emperor. Frederick had conveniently omitted the wonted ceremony of holding Adrian's stirrup as he mounted his steed, and the equivocal word "beneficium," which might be construed as fief, did violence to his proud spirit. His indignation was shared by every member of the diet; the legates were ordered to depart, and the missive was treated with silent disdain. But it became evident to Frederick that no time was to be lost, so he summoned his German feudatories to assemble at Ulm, and ordered those Italians who remained loyal to prepare for his coming. The Pope perceived that he had gone too far. He wrote to the Emperor explaining away the phrases he had used, and succeeded in reestablishing terms with him. This epistle is a masterpiece of clerical gloss. " By the word 'beneficium," " said he, "we implied that we were doing a congenial act, and not granting a fief; by conferring the crown, we meant that we had placed it on your brow; we never meant any other significations than these ; and you will not deny that we have ever acted in a friendly spirit." The truth was that the missive had been couched in terms so clevely ambiguous as to admit of an explanation quite contrary to their intended purport (Radevic Frising).

Meanwhile Milan prepared for the approaching conflict. She sought to secure the adhesion of Lodi ( I I 58). She asked for no hostages ; she garrisoned no point of vantage ; it is an evidence of the sincerity and good faith of Italy at this period that the Milanese simply demanded an oath of allegiance from every member of the community. But the Lodesi 
replied with scrupulous rectitude that they were willing to do so if the clause "saving the fidelity due to the Emperor" were added. The Milanese consuls, to enforce their demand, marched the militia against them, and impounded their goods. They gave them two days to consider, and then the troops again advanced, but the Lodesi, determined to resist Milan, had withdrawn to Pizzighettone. The Milanese set fire to their habitations.

Meanwhile Frederick's vassals, who regarded him as the restorer of order and the rights of the Empire, poured into Lombardy through all the Alpine passes. Frederick arrived in Brescian territory, which the pusillanimity of Brescia had opened to him, held a kind of diet, and promulgated certain rules of discipline, known as "The Prince's Peace," which throw considerable light on twelfth-century warfare. The first article is aimed at the putting down of private hostilities : on the satisfactory evidence of two witnesses, not being relations of the complainant, punishment is to be meted out in proportion to the gravity of the offence-confiscation of equipment, or corporal punishment, or close-cropping with branding, or execution; in the absence of witnesses, if free men, then the appeal by judicial combat was allowed, or, in the case of serfs, the proof by hot iron. Other articles are directed to the protection of non-combatants. Merchants were evidently specially favoured, for we find that "if a soldier robs a merchant he shall restore to him twofold, and take oath that he was ignorant of his calling." "Whoso burns a house shall be beaten with rods, shorn, and burned on the jaw." "Whoso shall discover wine-casks shall not destroy them; he may take the wine only." "On seizing a castle, the soldiery may sack, but not put it to fire, save by order of the marshal." "If a German shall have wounded an Italian, on the evidence of two competent witnesses that the latter had sworn peace, then the German shall be punished." All the twenty-four articles bear similar evidence of a rude and undisciplined time. To this diet the Milanese were summoned. The citation was loyally obeyed, and their deputies urged excuses for their conduct, and offered a considerable sum of money ; it was refused, and war was declared. After passing the Adda, Frederick presided over the laying of the foundation-stones of a new city for the Lodesi, which would serve as a key to Lombardy. This town, called Monteghezzone, situated four miles from the ancient Lodi (Lodi vecchio) is still existent. Frederick, who had now gathered an army of over I 5,000 horse and 100,000 foot, had no engines of war strong enough to break down formidable walls, and resolved to reduce Milan by famine. The worst barbarities of the siege seem to have been chargeable to the Cremonese and Pavians, who absolutely ruined the territory of the Milanese ; they razed houses, burned the vineyards and olive-yards, and cut the throats of those whom they could capture. Under these circumstances, one could hardly expect the youthful republics, hampered by the notion of the Imperial claim, and only confusedly conscious of the implications of freedom, to refuse fairly favourable terms. Their constitution was unrecognised by law; the oath of fidelity to the Emperor was held to be a sacred duty; they were accustomed to pay tribute to him. And now that the towns were strong enough to be independent, in some measure, of the support of their bishops, the latter took the Imperial side. "Your will alone"-it is thus we find the Archbishop of Milan addressing Frederick- " your will alone determines justice ; 
a missive, an edict, a word from you becomes law. Is it not reasonable that recompense should follow toil, and that he who bears the burthen of defence should enjoy the prerogative of control ?" The few independent vassals of the Crown that remained in Lombardy took a nobler line. They proceeded to the Imperial camp, and one of them - the Count of Blandrate -offered his services as mediator. He succeeded in securing terms which were not unfavourable to the Milanese : they engaged to pay 9,000 marks in silver, they were to acknowledge the Imperial rights, and to restore their independence to Lodi and Como. On the other hand, they were not obliged to admit the Emperor within their walls on his descent into Italy; they retained the right of electing their consuls, and their allies, the citizens of Tortona and Crema, were included in the treaty. (September, I I 58). Frederick, in granting an honourable capitulation, had no intention of abandoning any Imperial rights. He had no notion that the legislative authority of the diet of the kingdom was liable to question.

The second diet of his reign was held at Roncaglia in November, I I 58 , and it overthrew what the cities considered to be their most precious rights. In I I 53 the jurisconsults of Bologna had induced the burghers of that city to call in a foreigner, an inhabitant of the neighbouring little state of Faenza, to preside over their tribunals and keep the peace among the turbulent nobles and parties of the city. The office of "Podestà," thus originated, was adopted by the diet. With a view to public peace and prosperity, the administration of justice was taken away from the elected consuls of the cities, and given to a judge, not being a citizen of the town to which he was appointed, nominated and invested with his authority by the Emperor. The diet further deprived cities and feudatories alike of the right of making private war, and stretched the limits of Imperial right. All these innovations were honestly intended to preserve public peace and promote public prosperity. It is an evidence of the revival of learning and the increasing influence of the ancient civilization over the mediæval world that the diet was in the hands of men enthusiastic in their admiration for the laws of Justinian and the Imperial practice of the later Empire. The clergy naturally supported constituted authority. The Archbishop of Milan, who opened the discussion, declared the will of the monarch to be the law of his people. The jurisconsults were prepossessed on behalf of authority, and weighted by considerations of inapplicable precedent. The training for and exercise of both professions demonstrated that their most distinguished members were not concerned with root-principles, the appreciation of new ideas, or sympathy with new developments and nascent ideals. Both clergy and jurisconsults were on the Imperial side, and the latter strained their principles. The jurisconsults, trained first in the grammatical study of language, which is mainly an application of fixed rules, and secondly in the elucidation of established principles, who regarded the code of Justinian, like Holy Writ, as the very letter of reason itself, applied the maxims of his despotism to the new conditions of the twelfth century. They expounded the Imperial prerogatives with all the learned subtleties of the schools before a victorious prince at the head of a powerful army. The diet declared regalian rights to belong to the Emperor only, and these rights were to extend over duchies, marquisates, counties, coinage, tolls, fodero, tributes, pórts, mills, -fisheries, etc. ; moreover, the subjects of the Empire were to pay capitation- 
fees to its chief. Frederick did not make use of this vast admission; probably he did not darc. He made a show of munificent liberality; he confirmed everybody in rights in possession, subject to an annual fine as acknowledgment of his suzerainty, which added very materially to his income. But the cities had no sympathy with what was, on the whole, an honest attempt on the part of the diet to secure some kind of order and strengthen the established system of control. They regarded its provisions as perfidious violations of the treaty which had been signed between the Emperor and Milan. And the Papacy dreaded the extension of Imperial authority, for increased Imperial would carry with it diminished Papal power.

The immediate reason for the institution of the new functionary of the Empire, the Podestà, was that so many plaints were entered before Frederick at Roncaglia, that he declared that the devotion of a lifetime would not avail to determine them. To anticipate a little, it was soon found that the new functionary, though he was never selected from among the citizens of the diocese he was called upon to govern, was at variance with the Consuls. The Podestà stood by prerogative; the Consuls, elected by burghers, championed their liberties. Consequently, the Emperor ordered the Consuls to be entirely replaced by Podesti. This act was almost the sole cause of the wars which followed. Yet their respect for the "dead hand " of Cæsarism and ancient Rome prevented the cities from destroying the office. They had received it, after all, from their legitimate monarch, and perhaps they perceived that it was not wholly disadvantageous to possess a supreme magistrate, who, being a foreigner, was less flexible in the hands of party, and more disinterested than one of their own citizens. So they changed the Imperial Podestate into an elective office, and, finding the plan worked well, they retained it. But the habit of constant reliance on a single authority paved the way for the "tyrannies" which afterwards governed them.

The diet, after forbidding private war (a law which was generally approved), proceeded to pronounce on a quarrel of long standing between Cremona and Piacenza. The latter had been the ally of Milan; it was defortified.

Frederick had bent everything to his will; his ambition grew with his success. Corsica and Sardinia had once formed a part of the Roman Empire ; he ordered Pisa and Genoa to convey his commissioners thither. They filled their reply with excuses. The Genoese, further, referred him to their ancient exemptions from impost and service, which had been accorded on account of the sterility of their soil, and they pointed out that they had been at the charge of defending the Empire against the Saracen invaders. Meanwhile, they put their house in order ; Frederick accepted I,200 silver marks and let them alone. He was now of opinion that the Diet of Roncaglia had, by its decisions, released him from his confirmation of the authority of Milan over all its territory, save Lodi and Como. So he withdrew Monza from its jurisdiction, and soon after invested a noble with their counties of Martesana and Seprio. He put a German garrison into Trezzo, and ordered the destruction of the fortifications of Crema to gratify Cremona. He sent his Chancellor to Milan to replace its Consuls by his Podestà, an action which was contrary to the letter no less than to the spirit of his agreement with them. The reply 
of both Milan and Crema was to eject forcibly the Imperial envoys. Frederick's army was much diminished by now. Many nobles had returned to Germany after the submission of Milan. The subsequent approach of winter had also caused many to withdraw, and Frederick, with his reduced forces, was busily engaged near Bologna in giving effect to the recent decrees. Although the Milanese had no other allies than little Crema and Brescia-for Tortona was helpless to aid them, and Piacenza had been compelled to annul its alliance, and Como and Lodi were in arms for the Emperor-Frederick did not feel himself strong enough to attack so large a city, not even with the main keys to the position in his hands. He contented himself for the present by forays into Milanese territory, while the Cremonese, in hatred of Milan, aided his troops in the siege of the little city of Crema. A line of circumvallation was built, but the work was seriously interrupted by the gallant sorties of the little garrison, which had been reinforced both by Milan and Brescia. Frederick was so irritated by this that he hanged a number of prisoners in front of the walls. It was an age of swift, strong, and ungoverned passions. Men were earnest, vehement, resolute, alike in their loves and hates, and subject to frightful outbursts of passion. Our own Henry II. would fling himself on the ground and gnaw the rushes in one of his royal paroxysms of rage. But the result of this barbarity was that the Cremese retaliated in kind, and presently an equal number of German corpses swung from their battlements. The response of Frederick was to declare by herald that Crema had forfeited all hope of mercy, and to slay forty-six hostages, including the nephew of the Archbishop of Milan.

Other hostages still remained in the hands of Frederick. They were young children. He bound them to a moving tower, which he caused to be advanced to the attack. The besieged could not repel it without killing or wounding their own children. A cry of despair resounded along the walls of Crema. The wretched parents, all people of importance, implored death from their fellow-citizens to escape from witnessing the martyrdom of their children, but they cried to their children not to fear to die for their city (Radevic Frising). The assault was repelled, and the moving tower bore away nine young corpses in its retreat. Meanwhile, the country round Milan was ravaged, and Piacenza was put under the ban of the Empire for sending provisions to Milan and Crema. At the end of six months the Emperor contrived to seduce the chief engineer of the beleaguered city, who now directed the construction of engines, to advance against the place he had hitherto defended. He constructed new towers of attack, and advised Frederick to place his best cross-bow men on the high top stage to dominate the battlements. Below were the pick of the soldiery ready to fix their bridges. Around these movable towers the rank and file were prepared to sap or scale. The besieged sheltered themselves under mantlets, and sought to seize or overthrow the bridges of these movable castles by means of hooked battering-rams. They were, however, soon driven by these engines of attack to their second line of defence, and lost so many men that they opened negotiations with the Patriarch of Aquileia and the Duke of Bavaria, who had proved himself one of the bravest of their assailants. They represented that they had taken arms, not against Frederick, but against the Cremonese, who were 
resolved to prevent them from rendering free service either to God or the Emperor. They credited themselves with the proof that they preferred death to slavery. They had allied themselves with the Milanese to evade this lot, but in their present wretched condition they perceived the evidence of God's displeasure, and though they were destitute neither of arms nor provisions, they submitted to that judgment, and only begged the Emperor, whatever punishment he might see fit to inflict, to save them from the hands of those bitter enemies, the Cremonese. Frederick allowed them to carry away what they could on their shoulders, but the Milanese and Brescians among the defenders were deprived of their arms and kit. All were free to go where they chose, and they all chose to seek shelter in Milan (January, I I60).

Meanwhile events in Rome had given some dawn of hope to the Milanese. After the Diet of Roncaglia, Adrian IV., finding Frederick's army no longer quite so formidable, objected to the presence of Imperial deputies in Roman territory; he maintained that if ever there could be a question of fodero, that must be confined to the occasion of coronation; that Italian bishops owed a simple oath of fidelity and not homage to the Empire; that they were not obliged to lodge Imperial deputies; and that all the possessions of the Countess Matilda devolved to the Holy See, including the Isles of Sardinia and Corsica. The theory of two ruling planets in the Holy Roman Empire, now as always, was far removed from "l' amor che move il sole e l' altre stelle," but the death of Adrian delayed the development of the quarrel. The Roman senate, however, in the practical-minded Italian manner, forgot the severe snub with which the Emperor had received its pretensions at his coronation, and, ever at enmity with the Pope, sided with Barbarossa. Soon we shall see the strange spectacle of the Roman republic, struggling towards freedom, attaching itself to Imperial and autocratic interests, while the Pope, struggling with his persistent enemy, the Roman republic, befriends in Lombardy the very system of government and strife for emancipation to which he remains opposed at home. On the death of Adrian, rival parties elected separate Popes. Alexander III., determined by the Church to have been the legitimate Pontiff, had the greater following of cardinals. Victor III. was supported by the Roman Senate and nobility. Frederick, rejoicing to see the Papal power thus enfeebled, improved the occasion to summon both Popes to his presence, that he might decide on the question of legitimacy. Alexander, though a wanderer on earth, replied in the spirit of Hildebrand, that the legitimate successor of St. Peter was above the opinions of emperors and councils. Victor alone appeared before Frederick at Pavia, and got his election confirmed in a council held there, which excommunicated Alexander. Alexander retorted by launching the thunders of the Church at Frederick, and releasing his subjects from their allegiance (II60). But the Antipope died in the early part of I 64, and his successor, Paschal III., was not recognised by France or England, nor, altogether, by Frederick's own subjects in Germany. Clerical intrigue was also active in Rome, and Alexander III. was received with acclamation when he re-entered Rome (I 65). The Archbishopelect of Mainz, who was the Imperial representative in Tuscany, conquered Viterbo with German troops, but it was soon retaken by the Romans with the aid of the Norman power. In fact, the Normans found 
it politic to make common cause with the Eastern Empire, the Pope, and the free cities, against Frederick ( 1165 ).

The siege of Crema exhausted German patience. The soldiers of the age were unaccustomed to such protracted expeditions. The greater number of feudatories, whose term of service had long expired, went home, promising to reassemble. Frederick, with unshaken determination, remained, supported by the Ghibelline or Imperialist allies, and, placing himself at the head of the forces of Pavia, Cremona, and Novara, carried on a desultory war in which he exhibited great personal courage. His sole object was to destroy the crops and reduce Milan, the head of the hydra, by famine. In the summer of i 6 I a new army crossed the Alps, and Frederick found himself at the head of 100,000 men. The ferocity of the feudatories was excited by the continuance of what they regarded as perfidious rebellion. Frederick, clement in victory, was relentless during actual warfare. His severities increased with the prolongation of the struggle; he ordered prisoners to be executed or maimed : in a single day twenty-five peasants caught carrying stores to Milan, had their hands chopped off.

Frederick's great object was to reduce Milan by famine. The rich burghers had bought corn, and erected and filled public magazines with provisions; but these were partly exhausted, fresh supply was cut off, and an accidental fire consumed the stores that were left. For three years the Milanese had supported a terribly unequal contest; now (I 62 ) they were conquered by hunger, and compelled to surrender at discretion. Half the citizens marched before the sacred caroccio to Lodi, where the Emperor was ; its trumpeters sounded their last despairing note, and at the signal, the pole and flag fell quivering to the ground. One of the consuls made a piteous appeal to the magnanimity of the sovereign; the vast crowd, with cords round their necks, and holding the cross, after the manner of suppliants, fell with one accord to their knees, and entreated mercy. The Count of Blandrate, still their friend, though now a stalwart supporter of Frederick, took a cross from the hands of a suppliant, and, casting himself on his knees before the throne, implored the Imperial mercy. The courtiers, the rough soldiery, were agitated even to tears. Frederick alone remained unmoved. The scene was imposing; but seeing that the Empress, who was tender-hearted, had been forbidden to attend, it had probably been carefully prearranged. The Milanese, unable to appeal to her for succour, threw their crosses towards her pavilion. The only reply that Frederick deigned to make was an order for the gates to be pulled down, the battered walls to be razed, and the moats filled up. $\mathrm{He}$ obliged the entire population to take an oath of fidelity to his person, and removed the ban, but kept the city for ten days in mortal dread of the entry of his licentious soldiery. Then he marched his troops to Pavia, and, five days later, ordered the Milanese consuls to eject all their fellow-citizens. Men, women, and children crowded the roads to Lodi, Pavia, Bergamo, Como, and the other Lombard towns; the great city was silent. Nine days after this, the Emperor, at the head of his army, approached and proclaimed its fate. It was to be delivered over to absolute destruction at the hands of the men of Lodi, Pavia, Cremona, Como, and other towns ; each separate enemy of the city being appointed to the destruction of an entire ward. For six days the imperialists were 
employed on this work of destruction, and on the seventh, when there was scarcely one stone left upon another-it being the Day of Rest, and his work done-Barbarossa rode back to Pavia.

The cause seemed lost. Deputies, nobles, podesti, consuls, the representatives of the might and splendour of the Empire, gathered, a glittering throng, to see the Emperor resume the Imperial crown which he had been under vow not to wear until the rebellious city should be subdued. Brescia and Piacenza sought to appease him by submitting to his will. They dismantled their fortifications, accepted podesti, and paid enormous fines. It seemed as though rebellion were extinct-as though Imperial autocracy had been established once and for all. Barbarossa still allowed to Cremona, Pavia, and Lodi, the right of consular election ; but podesti were planted at Ferrara, Bologna, Faenza, Imola, Parma, Como, and Novara-towns that had given him their aid; and when he returned to Germany, his representative, Raymond, Chancellor of the Empire and Archbishop of Cologne, made the heavy hand of the Empire felt in every corner of Lombardy. The podesti cruelly misused their authority; they increased contributions and imposts sixfold; they took two-thirds of the crops from Milan and Crema. Otto Morena, an historian prejudiced in favour of the Emperor, says that there was no Lombard, who, remembering his ancient liberty, did not feel the shame of these exactions, and did not burn to avenge them. The Imperial lieutenants were of alien race, and obliged the citizens with the gifts of scorn, physical force, and exaction. From their decision an appeal to the Imperial power was practically impossible. But the fact that they were aliens raised them above the petty squabbles of local party, and guaranteed some measure of the fair administration of justice.

A common misfortune extinguished ancient enmities: hostile towns opened their gates to the Milanese refugees. When Barbarossa returned in I 63 , relying on the terror of his name alone, and unaccompanied by an army, it is true that Pavia contrived to secure permission to destroy Tortona, which the Milanese had rebuilt, but this was the last act of jealous injury on the part of the towns. They were soon to confederate against their common foe. Venice, ever alive to her own interest, was little desirous of the presence of so powerful a neighbour as Frederick; she attacked the nobles of the Veronese marches, who were opposed to the cities ; she expelled the most odious of the Imperial representatives. Whilst Frederick and the brilliant retinue that he had brought in lieu of an army believed that he could rely on the local soldiery of the Ghibelline towns to support him, and, after razing the walls of Tortona, directed his steps to Rome to support his schismatic Pontiff, Verona, Vicenza, Padua, and Treviso were pledging themselves to mutual support. The institution of Podesti nominated by the Emperor, had roused the spirit of liberty in the Ghibelline as well as in the Guelph cities. That they were permanent representatives of Imperialism was enough, though the Ghibelline cities were allowed to choose their own Podesti. Perhaps even these took advantage of their Imperial backing to assail what the citizens considered their liberties. Frederick returned to the North, only to find the support of Cremona, Novara, Lodi, Como, and even Pavia, become lukewarm.

He became thoroughly frightened at the evidences of gathering storm ; 
he could place no reliance on the Italian militia, and he incontinently fled over the mountains (I I64). All the cities were equally suspect, and as the rural nobility were their natural enemies, the rural fortresses received what German soldiery there were in Italy (vita Alex. III. a card. Avagon.). He returned with a fresh German army (I 66 ) by the Val Cammonica, for Veronese and Paduans had already possessed themselves by force of arms of the usual route.

The towns of the Veronese Marches beheld the Emperor pass quietly on to Rome ; he dared not attack them. They became bolder : they assembled a new diet, attended by the consuls of Bergamo, Brescia, Mantua, and Ferrara, as well as those of the Marches. Guelphs and Ghibellines were united. The deputies of the Cremonese (who had lent their aid in the destruction of Milan) now asked the confederated towns to rebuild the cify. The league of Lombardy was formed, and every consul took a solemn oath, and the burghers of the cities repeated it. The league of Lombardy was an alliance of the cities to endure for twenty years, during which every Lombard should unite with his fellow-countrymen to recover liberty, and should aid any cities that might suffer loss in repairing the damage they should have sustained. This clause was retrospective; and the soldiery of Bergamo, Brescia, Cremona, Mantua, Verona, and Treviso, aided by the inhabitants of the desolated country around, and the citizens, who had sought shelter in distant cities, assembled on the ruins of the great city, apportioned the work, and, in the course of a few weeks, had rebuilt and fortified Milan. Nothing could have been more moderate or legitimate than the demand of the communes. They insisted on a return to their ancient constitutions which they had enjoyed up to the accession of the present monarch.

The city of Pavia was so devotedly Imperialistic that there was no hope of its conversion to the popular cause ; but Lodi was of great importance to the league, for, in the possession of an enemy, it would threaten communications with the rebuilt city of Milan. So the allies sent deputies from Cremona-a city ever friendly to Lodi-to expound their principles, justify their rebellion, and urge Lodi to take her share in the vindication of Lombard honour, and in the re-instatement of ancient rights. The Lodesi replied that they would suffer death rather than desert the liberator who had rebuilt their walls. A second embassy received a like check; whereupon deputies from Milan, Bergamo, Brescia, and Mantua were convoked by the Cremonese. The confederates determined to employ force, but, while their militia was assembling, they appealed for the third time to Lodi to burst her bonds. Lodi replied by a touching appeal to the Cremonese, adjuring the men, who of their own free-will had lent ready hands to the rebuilding of their walls, by the ancient comradeship of the two towns, to cease asking them to violate an oath which they would keep at the cost of life and city. Lodi was besieged; the Emperor sent no help ; indeed, many Lodesi were serving in his expedition. Famine still further weakened its powers of resistance, and finally the citizens gave way and took the oath of confederacy. The Lombard army then besieged and took the castle of Trezzo, between Milan and Bergamo, which was garrisoned by German soldiery, and contained much of Frederick's valuables. The movement spread with great rapidity: even as far south as Bologna it took root. That city, only a little before, had given thirty 
hostages for good behaviour ; it now sent its podestà about his business, and joined the league. The feeling of duty to a legitimate King was becoming rapidly weakened. Loyalty remained as an abstract theory; there was no sentiment of devotion to a common country, but the warm affection which each citizen bore to his own particular commune was stimulated in a high degree, and each commune felt that its cause was the cause of all. Frederick had been hated only by the cities that he had oppressed; he had been worshipped by the cities that he favoured; he had allowed them to choose their own podesti, while revolted cities had to submit to those of his choosing; he was now regarded as the opponent of the liberties of all. Otho of Frisingen speaks with horror of the cruelties of the communes to each other (Otto Fris., lib. I., cap. 39); their mutual antagonisms were now converted into a common antagonism to one whom they regarded as an oppressor: for a time their bitter and fratricidal hatred was changed into a " union of hearts." But Frederick was the representative of law and order, and the supporter of claims which, in essence, were admitted by the Italians themselves. He was a strong, just man, and commanded the enthusiastic love and allegiance of his own nation. When once the bonds of discipline are relaxed, and a dependent nation has had a taste of the sweets of liberty, in however small a degree, history shows us how unsubmissive it becomes to mild measures, how unconquerable by severe. We can see now that there was right and wrong on both sides, and that the legal claims of the Emperor were beyond dispute; the real foundation for and justification of opposition lay in what neither side could perceive-that the fitful exercise of an authority, become antiquated and inconsistent with existing fact, was no remedy for the disorders of Italy. The cities believed in an Imperial theory, though they had never had any real attachment to the Empire ; but they had, up to this time, a very real hatred and fear of one another. They became friends for awhile by reason of a common danger; when the danger has passed away, we shall find them hating and fearing each other as before. Now, Piacenza, Parma, Modena, and Bologna joined the league, and even Venice, that ever pursued her own course, secure in her inviolable lagoons, began to take alarm at the mighty force that had crossed the Alps, and became one of the signatories. Nothing but interurban jealousy and local interest had hitherto kept the communes from combining against a foreign suzerain who called on them to be passive at his hands, who came to extort supplies for his armies, to rule them by his obnoxious viceregents, and to deprive them of that privilege of freefighting with one another which they so dearly cherished. Imola, Faenza, and Forli submitted to the German army.

Meanwhile, Frederick marched on towards Rome. The greater political interests of the Empire demanded his presence there; for his Antipope, Victor III., had died, and the successor whom he had caused to be nominated was still more strongly rejected by the Church. Alexander III., who had sought an asylum in France, had been able to return to the city, where the senate welcomed him as a defender of ancient privilege against the Imperial Antipope. He received the support of a monarch, naturally antagonistic to the Empire-William, the Norman King of the Two Sicilies. Frederick advanced by way of Ancona. Between this city and Constantinople there was considerable commercial intercourse; and the Eastern 
Emperor, jealous of the Western Crown, had contracted an alliance with Ancona, garrisoned and subsidized it. Isaac Angelus, the legitimate heir of the Cæsars, regarded Barbarossa as a pretentious parvenu, and spoke of him as the chief Prince in Germany; whereto Barbarossa had retorted that while he was "Emperor of the Romans," Isaac was but Emperor Romanicorum (alluding to his empire, diminished almost to Thrace). In spite of several assaults, the city was glad to compromise and purchase peace for a considerable sum, and Frederick was no less satisfied to be released for the settlement of more urgent matters in Rome.

The Romans dared not give combat in the open field. Frederick appealed to the animosity of Tusculum to Rome; he threw a large force into the Leonine city, dislodged the defenders of the Vatican by firing a neighbouring church, occupied the Vatican, and installed his creature the Antipope, Paschal, and was crowned anew by him, together with his consort, while Alexander fled in terror, and Rome reeked with blood and smoke. Master of Alexander, his great spiritual antagonist, with a large part of Italy at his feet, supported by a formidable army, and opposed only by the burghers of the North, it seemed as if no power on earth could effectively resist the resolute hostility of the great monarch. Yet, at this very time, when conquered Rome was taking the oath of submission, the sturdy burghers of Lombardy were rebuilding and refortifying Milan. But the triumph man would probably have been impotent to prevent was checked at the very moment of apparent victory by some subtle bane engendered in the rank foulness of the Campagna. A scourge of sickness fell on the army; the fell, invisible Death converted the camp into a cemetery ; in a few weeks the princes to whom Frederick was most attached, the captains in whom he had most confidence, were stricken or dead; the flower of German chivalry succumbed. Terror seized the army; Heaven seemed to have declared against the violator of the Holy See; the terrors of superstition mingled with violent agitations of conscience, and combined to speed the silent, fateful footsteps of plague. Frederick's forces were destroyed as by an unseen hand; little but his dauntless courage remained to the unfortunate monarch. Leaving the sick to the tender mercy of the Romans, from whom he demanded hostages to secure it, he led the scanty remnant northward, and made a vain attempt to summon the disobedient cities to a diet at Pavia. Brescian and Bergamesque cavalry blocked his way at Lodi; Parmesans and Cremonese at Piacenza. The communes had also summoned a diet with more success than the Emperor, whose star was manifestly in decline. Those of his soldiers who had escaped what they considered a just visitation of God were fast devoting themselves to the monastic life, and his only effective support lay in his faithful Pavia and the vassals of Montferrat. Suza barred the way of his retreat until he released the hostages whom he had taken with him, and so secretly was his retirement conducted, that not even the Lombards in his service were aware of it until he had left Italy. No sooner was he gone than the confederate forces took Blandrate, released the hostages confined therein, and razed it to the ground. Novara, Vercelli, Como, Asti, and Tortona, joined the league; and the Marquis Malaspina, who had anticipated the part of the Vicar of Bray, again turned his coat. Pavia and Montferrat still re- 
mained faithful to the losing cause, and the militia of Cremona, Milan and Piacenza were delegated to intercept communications between them. A scorched and shadeless plain in summer, but interpenetrated with streams at other seasons, and approachable with difficulty by an advancing army, seemed a natural situation for a fortified town. There the Lombards founded a new city, which still commemorates the heroic fight for what of freedom they knew. They named it Alessandria, after the father of the faithful and protagonist of their cause. To it they transported the inhabitants of the surrounding villages; they built them houses and fortifications; they induced the Pope to institute a new episcopate, and in the very first year of its existence the new commune possessed a republican constitution, and an army of fifteen thousand fighting men, ever ready to cut the communications between Montferrat and Pavia (Vita Alex. III., a card Aragon.-Otto de Sancto Blasio.-Benv. de S. Gengio, hist. Montf. Tristani Calchi hist. Patr.-Oberti Cancell. Ann. Genuens.).

The cities had commenced their revolt because they had become unused to the bit; they resented the reintroduction of heavier imposts than of yore-imposts which they supposed were obsolete, because they had not been enforced. But now they stood together for freedom and municipal rights. So little, however, did they understand the implications of liberty, that they were too prone to refuse to one another what each claimed for itself. But they felt the vitality of organic growth, so different from the mechanical restraints of a foreign rule, however benign, and, in the case of feudalism, so harsh and disturbed in its operation. They had secured the co-operation of the Pope, their natural ally, had received his blessing on their arms, and thus possessed the great advantage of being at peace with their own Church. Sicily and Constantinople, though mutually antagonistic, had both sent them material aid, and so had Genoa (II68), though she had not joined the league. The barons of Middle Italy had been called upon by the Pope to aid them, and, although there was no passion of nationality, the fact that their foe was alien in race and tongue could not but be felt. Some of the German bishops, also, took the side of Alexander. Now, if ever, there was an opportunity for confederation into a state. But at this period the idea was too remote, too abstract to be realized. Men ever find it difficult to pass far beyond the concrete : a flag, a personality is a great aid to the political imagination even now. Men who had only just reached the conception of municipal liberty were incapable of submerging it in the deliberations of a congress; they were incapable of renouncing their full rights of deciding for themselves on questions of peace, war, and finance-rights which they had only so recently come to enjoy. It never entered their minds to subordinate local to general interest, to share the control of their own destinies with the precarious interference of strangers. The fatal want of cohesion, of self-renunciation to the common good, which was ultimately the ruin of the most gifted race, except the ancient Greeks, the world has ever seen, and which ever menaces the great confederations of to-day, could not be expected of a half-civilized people in the twelfth century. A real federation of Lombard cities had been then as visionary and impossible as a united states of Europe would be to-day. And, besides, the revived study of civil law, acute, subtle, and imposing, declared that they still 
owed allegiance to the Emperor. They were never unwilling to yield him what they deemed to be his rights, though they opposed his exactions. Otho of Frisingen voices the general opinion not less than the learning of the time when he declares that "to the Emperor belongs the protection of the whole earth." But, not merely were the Emperors not slow to accept the position thus ascribed to them, they took undue advantage of it, in the opinion of the communes. Hence the struggle was never other than of a constitutional character. In this struggle, in the eloquent words of Symons, they "rose to an altitude of patriotic heroism. By suffering and daring, the citizens showed themselves sublime, devoted, and disinterested, winning the purest laurels which give lustre to Italian story."

For five years other matters which demanded the presence of the Emperor detained him north of the Alps. During this breathing-time the cities of Lombardy corrected their laws, refilled their treasuries, strengthened their fortifications, and drilled their burghers. The sword still menaced Italy; the German spear might at any moment be thrust into her heart. Frederick had not forgotten the rebellion. Christian, the Archbishop of Mainz, Archchancellor of the Empire, remained in Italy as vicar. To subdue Lombardy was hopeless; he marched to Tuscany, where the Ghibellines were still powerful. A college of "rectors," placed at the head of the Lombard league of freedom, gave it increased unity and better administration; even some of the podesti of Italian descent offered to defend the cities they governed against the Empcror that had nominated them; obnoxious podesti were ejected, and the institution being found not without value, the cities replaced them by men of their own temper of mind. Even the cities of Romagna entered the league, which was supported by all the commercial energy and wealth of Northern Italy, and a spirit which was rapidly becoming patriot:

"Let us cast the yoke of the Germans" from our shoulders, was the feeling produced by the authority of the foreign viceregents in the towns. We quote from the Milanese chronicle (Manip. Flor.). The oath of the league, as sworn in II 70 , is to the following effect: "In the name of God, amen. I swear on the Holy Gospels that I will make neither truce nor treaty with Frederick the Emperor, nor with his son, his wife, nor his house, either directly or indirectly. I will honestly use all means to prevent any German or other army, great or small, of the Emperors from crossing the mountains and entering Italy ; and, if any cross, I will wage fierce war against the Emperor until all his army leaves Italy, and I will cause my sons from the age of fourteen upwards to take the same oath." There was no stipulation as to the number of soldiers, or the amount of money to be contributed ; it was taken for granted that each town would do its very best. The League, called "concordia," was represented by the consuls and podesti of the respective towns, who met from time to time, and submitted their decisions to their various cities. Though towns of Romagna joined the league, they took no active part towards repelling the new invasion, which everybody felt was drawing near.

Frederick was isolated; he vainly and repeatedly endeavoured to detach the Pope, William of Sicily, the towns, in turn. Meanwhile, he was preparing to lead a new army into Lombardy. His vicar, the Archchancellor Christian, had found Tuscany divided by the rivalries of 
Genoa and Pisa. Lucca, too near to Pisa to be her ally, Siena, Pistoja, and Count Guido Guerra, the most powerful of the Tuscan feudatories, were on the side of Genoa. The natural enemies of these latter powers were Florence and Prato, the trade of which passed through Pisa to the sea. Florence had already begun to extend her territory and excite the jealousy of her neighbours; hence their adherence to Genoa; while Florence took good care to support Pisa as being the only maritime outlet for her trade, and a town too powerful, as yet, for her to nourish any hope of subduing. It was to the interest of the Archchancellor to conciliate a town so near Lombardy as Genoa, a town that had not joined the League. The Pisans, therefore, sent to Constantinople and entered into a commercial treaty with Manuel Comnenus, which was ratified by Greek envoys before the full "parliament" of Pisa. Christian now offered the services of his master to arbitrate between Pisa and Genoa, which were at war with one another, but the Pisans refused. The Archchancellor thereupon put them to the ban of the Empire, and prohibited them from coining money or exercising sovereignty in Sardinia (II72). But next year he pretended anxicty to re-establish peace between the rival cities of the shore; he removed the ban, and settled, in parliament assembled, the preliminaries of a peace. At this diet, held in Pisa, the consuls were present, but were unmolested; but at a subsequent diet held at San Ginasio, in the valley of the lower Arno, for the purpose of concluding the matter, Christian seized and imprisoned the consuls of both Pisa and Florence. Now, one of the terms of the treaty between Pisa and Constantinople had been the reception by the former of an annual subsidy, which would, of course, be available for the war-chest ; again, owing to the rivalry of the Eastern and Western powers, the German Empire was naturally jealous of alliances between its subjects and Constantinople. But the great point gained by this "diplomatic" dénouement was that the Ghibellines of Tuscany, Siena, Pistoja, and Lucca, as well as the nobles of Umbria and Romagna, were forced to take arms against the party of the Church, and to furnish Christian with a powerful army, with which he combated the forces of Florence. The campaign was indecisive, but it served as a training to the Imperial forces, and, strengthened by the German troops who had remained in Italy after the retreat of Frederick, Christian proceeded to a more important undertaking. Ancona was not a member of the Lombard League, but she was under the protection of the Empire of the East. This was the offence which Christian proceeded to requite; and his efforts were seconded by Venice, which, although she was a member of the League, had nothing really at heart, as usual, but her own commercial interests, and was jealous of the good harbour and growing Oriental trade of Ancona: to remain mistress of the Adriatic was her sole policy. She therefore attacked Ancona by sea, while Christian, with his army further strengthened by the feudatories of the marches, drew near by land. Boncompagni, who was not a contemporary writer, and who is distinctly biassed, says that the new levies, led to the relief of the city by Guglielmo Marcheselli, spread themselves out as much as possible, and descended the mountains by night, each soldier bearing several burning brands affixed to the point of his lance, and so deceived the enemy as to their real strength. Christian struck his tents during the night and marched for the duchy of Spoleto, and the Venetians also, 
finding themselves deserted, set sail. What is certain is that the siege was very effectively raised.

Meanwhile, Frederick had finished his preparations for war, and conducted a new army, no less powerful than the old, across the Mont Cénis Pass, in the autumn of II74. His first act was to wreak vengeance on the town of Susa, which had dared to humble his pride during his flight six years before. The strategy of the communes was to avoid the hazard of the open field, whereon the chances would be immensely in favour of Frederick, and to wear him out by compelling him to a succession of sieges. They therefore sent delegates to Asti, to stimulate the city to a courageous defence, and to promise that a Lombard army should advance to relieve it as soon as the danger should become pressing. But Asti was unnerved when she saw the formidable army, so largely composed of Flemings, whose barbaric valour was greatly dreaded, and she opened her gates to the Emperor. Frederick then marched his troops against the new city of Alessandria, not without difficulty, for the heavy soil, soddened with the wintry rainfall, greatly obstructed the progress of the army. The chief defence of the city lay, not in its hastily-constructed walls, nor even in its deep fosse, but in the indomitable courage of its men. Frederick employed every means then known to the art of siege in vain ; the elements fought against him with a fury almost as vehement as that of the citizens ; his soldiers began to desert, and at the end of four months no ground had been gained. Meanwhile a council of war, held at Modena, resolved that the time had come to raise the siege and revictual the town, and Frederick learned that the confederate forces were encamped at Tortona, only ten miles off. Frederick, who regarded the building of the new fortified city, which cut in twain the loyal territories of Pavia and Montferrat, as an insult to his Imperial dignity, could not stomach the possibility of failure. It is the one great blot on his character that he descended to the subterfuges of dishonour, and endeavoured to win by fraud what he was unable to secure by prowess. It was Lent, II75, and he proposed a truce for Holy Friday ; but he had secretly undermined the ramparts, and while the citizens were relying on his kingly word, in the first watches of the night he marched his soldiers along the excavated gallery, and they debouched on the public square. But the citizens, alarmed by their sentinels, ran to arms : they slaughtered the soldiers who had penetrated into the town, or forced them to leap from the battlements; they buried alive those who were still in the tunnel; and then, opening the gates, they made a furious sortie on the Imperial camp, routed the army, and triumphantly burned the instruments of siege. Repulsed by these heroic defenders, and threatened by the proximity of the Lombard army, Frederick set fire to his camp the following night, and, on Easter Sunday, advanced towards Pavia. But he found the road barred by an army more powerful than his own, and to offer battle would have been to court defeat. Frederick's army had orders not to attack and, in full view of the Lombard forces, it encamped. Frederick counted on the authority of the Imperial name; the Lombards fell into the trap; they were unwilling to commit an act of high treason against the Emperor by commencing an attack when he thus appeared to place himself in their hands and rely on their sense of honour and loyalty to the Empire of which they formed a part. The Empire was grounded on law and reverent 
sentiment, and not on force. Frederick had counted well. If he had once forgotten the maxims of "noblesse oblige" before Alessandria, if he had usurped the exercise of an authority to which the cities, at least, conceived that he possessed no legal claim, the confederated peoples were bound by a notion of loyalty as exalted as ever inspired the lofty deeds of chivalry; they remained quiet and motionless in their ranks. The solemn oath that they had taken to bar the way to Frederick, the disavowal of their fidelity, faded for the moment before the sentiment of faithful allegiance to the superstition of feudal authority, to the presence of the descendant of the Imperial Cæsars of Rome. A few nobles, who enjoyed the confidence of both sides, contrived to arrange for negotiations; Frederick and the Lombard captains agreed to disband their respective followers ; and, accompanied only by a personal escort and his family, Frederick rode off to his faithful city of Pavia. At the series of congresses held there it was necessary for him to come to terms with Holy Church. Alexander III. had returned triumphant, and had preached a crusade of independence ; and relations with the King of Sicily and the Emperor of the East had to be defined and arranged. Before the parliament of Pavia, constituted probably by the more considerable of the citizens, by assembling whom Frederick perhaps endeavoured to show that he respected municipal self-government when royal rights were conceded, the Emperor sat, surrounded by his princes. The Bishop of Ostia, who represented the Pope, bore himself with that inflexible severity which the Church knows so well how to assume; the Emperor answered with modesty and self-restraint. Then a series of private audiences were given to the Papal legates, and the delegates of the towns. The pretensions of the Papacy did not allow the ancient prerogatives which Frederick demanded as his due. It is evident that the Emperor considered the Church as his main antagonist; the question of the towns was a by-issue. The towns felt that the Church was their mainstay in the struggle. Presently negotiations, foredoomed to failure, ceased, and even while they were going on, Frederick was engaged in summoning a new army from Germany, and in authorizing Christian to attack the castle of San Cassiano, held by the Bolognese. When the congress broke up, the Lombards devastated the countryside of Pavia, Como, and the Imperial feudatories, while Frederick, accompanied by Italian militia, harassed Alessandria, but dared not attack it.

Next year (I I 75) Wicmann, Archbishop of Magdeburg, and Philip, Archbishop of Cologne, representing the feudal principle in Church politics, and all the princes and bishops of Germany, save Henry the Lion and his powerful following, marched by way of the Engadine and Chiavenna (for the Trentine route was closed by Verona), into the fair land already so fraught with disaster to the armies of the North. The Milanese, exposed to the first shock of invasion, had, with the other towns, renewed the solemn oath of the league, and had formed two cohorts of selected cavalry. One, called the "company of death," nine hundred strong, was sworn to death or victory ; the other, the " cohort of the caroccio," was, in like terms, sworn to its defence. Six regiments, comprising the armed force of the six quarters of the city, with the militia of Piacenza, and a few chosen soldiers from Verona, Brescia, Novara, and Vercelli, hastily marched against Frederick, who, they were informed, had joined his army 
and advanced to within fifteen miles of Milan. Seven hundred horse were sent forward to reconnoitre the enemy; they came across 300 Germans, whom they charged, but found themselves confronted with Frederick's main body; they thereupon retired towards the caroccio. The 900 young men, devoted to the care of the sacred car first knelt in prayer, and then advanced, bearing their ensign, against the German ranks. The Imperial troops almost broke the Italian lines, and the caroccio itself appeared to be in danger, but the "cohort of death," repeating their oath with all the enthusiasm of intense and zealous resolve, cast themslves against the serried ranks of the foe with so irresistible a shock that they succeeded in bearing off the royal ensign. Frederick, who fought in the foremost rank, was unhorsed, and the Germans fled, pursued by the Lombards for eight miles. Almost all the Comascines, who had forsaken the banner of liberty, were slain or taken prisoners; the camp was found to be filled with rich spoil, and it was rumoured that the Emperor was dead, and that his widow had already assumed mourning. Frederick, however, had succeeded in stealing away from the battlefield unperceived, and in a few days he contrived to creep into Pavia.

Twenty years before, Frederick had devastated, in his pride, the very country which he was now stealthily traversing, a fearful fugitive. Hc had believed that, as the inheritor of the Roman Empire, he was, by Divine right and appointment, the ruler of all the kingdoms of this world. He had claimed the prerogatives of his position, and the learned professor. of the newly-revived study of civil law had supported him in his claim; the cities had rebelled, and he had regarded it as his bounden duty to repress a dangerous spirit of defiance to his just authority, as well as the wanton insolences of the towns to himself and to one another. For him the Lombard malcontents had been traitors to God, cven, Who had appointed the Empire to which he had, therefore, recently affixed the title of "Holy." To repress anarchy, and to establish just authority, he had employed all the resources of his realm : seven times had he summoned the armies of the North across the Alpine barrier, and seven times had they melted away like the snows they traversed; half a million men in all had gleefully leaped to arms at his summons, and now he stood in his ancient capital of Lombardy, defeated, surrounded by his foes, and almost alone. $\mathrm{He}$, the representative of all the Cæsars, holding his authority from the German conquerors of Italy, had been vanquished by a handful of trading towns of a country which had no voice in the election of its own Emperor. The high-priests of his creed had called down on him the thunders of Heaven, and their appeal had been heard. The conquest of Italy would mean the disruption of Germany, even were that conquest now possible. With all sincerity and simplicity, traits in a bold and honest character, Barbarossa sought for peace, since the will of God had declared against him. He delegated the Archbishops of Magdeburg, Mainz, and Worms, to negotiate with Alexander. He abjured the Antipopes whom he had set up; and Alexander, like a wise statesman, received the recalcitrant clergy into Papal favour on their swearing solemn oaths of fidelity. Church and Emperor were reconciled for the nonce, and there was no difficulty in the reconciliation of Emperor and municipality. The communes acknowledged ancient Imperiảl rights, and tradition prevented them from prescribing for themselves the just 
claims of victory. Frederick was no longer their enemy; he remained their Sovereign: the nobles of every city were the natural defenders of Imperial authority, and the partisans of Frederick were not slow to fan the flames of ancient jealousies and break up the league. "Cremona, the old ally of Pavia and foe of Milan, had joined the league with a lukewarm passion, moved to it only by the burthen of distasteful exactions. Frederick detached the city by confirming its privileges, leaving to it the free election of its consuls, and conferring on it, in fact, everything for which the league had spent its blood. He was not opposed to municipal government as such. He had been a good friend to his own German towns; but he was opposed to all insubordination, and ever determined to maintain discipline in the Empire. The example set by Cremona was followed by Tortona, and their new ally promised to protect them from the vengeance of the league.

Venice had withdrawn from the league; in theory she was supposed to own the Emperor at Constantinople as her overlord. Her main interests were commercial : she might be regarded as a neutral city. The main points to settle were the reconciliation of the Emperor with the Church, and the termination of the schism; the restoration of peace between the two Empires and the King of Sicily; and the definition of the constitutional rights of the Emperor over his Italian cities. At first Venice kept the Emperor, whose presence she dreaded, at Ravenna, then at Chioggia, afterwards she ventured to admit him to her very heart. Here, in this neutral and scarcely Italian city, the great Pope met his great adversary; in the atrio of St. Mark's, sheeted with glistening gold, sheen of marble, and glitter of mosaic, the reconciliation was effected (June 24, II77). It is said that the Emperor, kneeling before the Pope, said: " Not to thee, but to Peter "; whereon the Pope replied: "But both to me and to Peter." Possibly the legend only expresses the irreconcilability of Imperial and Papal claims. Church and State each claimed an authority which the other would not tolerate : peace was patched, but the conditions of hostility remained unchanged. On July 6, a perpetual peace was sworn with the Church, a peace of sixteen years with the King of Sicily, and a six years' truce with the rebellious cities ; and each city appointed two arbitrators to determine differences between the two parties and keep the peace during the truce. During this period the Emperor renounced his right to exact an oath of fidelity from the members of the confederation. ${ }^{1}$

The essential struggle had been between the two swords that in theory were co-operant-between the conflicting claims of Cæsar and Pontiff to supremacy. The rebellion of the cities was a minor matter in Frederick's eyes. He dreamed of reintroducing the ancient Roman peace, and consolidating his government by the organization of beneficent control, and

1 It has sometimes been said that the Pope "sold" his Lombard allies, and pursued his own interests only at this congress. This notion is due to Sire Raul, who is the only contemporary Lombard historian, save one, we possess (Sive Raul, I 192, I 193). But Romuald of Salerno, who as ambassador of the King of Sicily, was present at the conferences, says that the Pope had to promise Frederick a fifteen years' lease of the heritage of Matilda before he could induce him to grant truce to the cities (Romuald Salern, p. 223). The other contemporary Lombard is silent, and scarcely speaks of the war at all. 
the reduction to order within his jurisdiction of what he regarded as a state of rebellious anarchy. On the other hand, the cities had associated themselves together in a common resistance to preserve the right of working out their own destinies in their own way; they had tasted the sweets of freedom, and resented the pretensions of any shadow of despotism, however benevolent its intentions. Although united to a common effort, they were as a discordant family, subduing private rancours for the nonce in face of a common foe ; and we shall shortly find them insisting on the right of settling their family disputes by the good old rule of warfare to which they had been habituated. The fight of the Lombard cities for freedom of action was the first clear note struck by that spirit of individualism which generated glorious performance, but contained within its womb seed of decay as well as principle of development, and ultimately issued in foreign occupation and a prolonged suppression of nearly every form of vigorous life in Italy.

The six years of truce were occupied by negotiations, during which the Emperor spared no pains to break up the League by coming to a separate understanding with individual cities. Scarcely had the truce been proclaimed, than he accepted a secret oath from some nobles of Treviso. The people learned this, armed themselves, and were about to inflict condign punishment, when the Trevisan consuls undertook to refer the matter to a diet of the League, which severely penalized the offenders and redoubled precautions. In I I 83 Frederick renewed and published a very fair treaty which he had made with Tortona; he reserved to himself, however, the right of nominating consuls. The object of the publication of this treaty was undoubtedly to invite other towns to follow suit, and so break up the confederation. He was also successful in detaching from the League Alessandria, the very town that owed it her being. $\mathrm{He}$ expressed himself as absolutely determined to raze her walls at the expiration of the truce; whereupon the citizens consented to gather outside the walls and receive an Imperial deputy, who led them back and renamed the town Cesarea. But Frederick allowed the rechristened city to elect her own consuls. Alexander was now dead, and was succeeded by a less aggressive Pope; the pretensions on both sides had abated; time had blunted the edge of resentment ; Henry, also, was anxious to be associated with his father in the crowns of Germany and Italy, and intervened. Finally, the famous peace of Constance, which for so long formed the basis of Italian public rights, was signed (II83). By this treaty the Emperor ceded to the towns all regalian rights within the walls, all rights which they had acquired over dependent districts, and fatal power to levy and employ troops : he granted leave to fortify and to exercise self-government. In all cases of contested regalia the bishop was to name two arbitrators, and if they could not agree, the Emperor was to receive 200 silver marks annually, which he might reduce at will. All infeoda. tions to the prejudice of the cities, constituted subsequent to the war, were invalidated, and confiscations were annulled. The Emperor promised not to remain long in any one territory, and he consented to the continuance of the league and its renewal. The towns were allowed to retain their consuls, with the powers of Imperial vicars, but they were to receive their charge through the bishop or an Imperial legate. The Emperor was authorized to establish a judge of appeal in each city for the trial of 
important civil actions. The old Imperial rights, which had never been disputed, were to be maintained. In fact, acquiescence with the new order of things was inevitable, and it is greatly to the credit of the sturdy old warrior that he possessed the sound and statesman-like judgment to yield.

Frederick seized on an opportunity of uniting the kingdom of the Two Sicilies with his Empire. The later Norman Kings were feeble monarchs, and the feudatories of Southern Italy would have become independent had it not been that their rivalries enmeshed them in the intrigues of the Court; the cities were insubordinate, but in no sense free; Sicily was governed despotically, but the Crown could no longer maintain order. The reigning monarch was unlikely to have issue; and Constance, the daughter of Roger, the first King of Sicily, was heiress to the throne. She was considerably older than Frederick's son Henry, but such a detail counted for little in royal and other important alliances, and Frederick perceived that by the marriage he would become virtual ruler of the South, and unite the Crown of the Two Sicilies with those of Lombardy and Germany. The House of Swabia would acquire a preponderance which neither the Papacy, the nobles, nor the free towns would be able to resist.

In spite of their sufferings during the war, the Lombard cities had so much confidence in the pledged word of the Emperor, that, when he and Henry visited them (I I 84), they strove to see which could do him most honour. The Milanese in particular endeavoured to secure his goodwill, and to show themselves loyal to him and the Empire. Frederick was astute enough to avail himself of the support of Milan and the cities of the League. He granted new privileges, and allowed the Milanese to rebuild the town of Crema, which he had destroyed twenty-four years before. The Cremonese had opposed its reconstruction when the Lombard League was in the fullest exercise of its power, and they were so offensively jealous of the sanction given to Milan, that Frederick, following the caroccio of the city, advanced into Cremonese territory and compelled an appeal to mercy. By this astute policy Frederick put himself at the head of the League that had opposed him, and vindicated the Imperial claim to be the Sovereign arbitrator of Italian quarrels and the maintainer of impartial justice among his subjects. The cities considered themselves as confederates of the Emperor, and regarded him as a party chief. And to the honour of the great House of Hohenstauffen, during the sixtyseven years that it continued to reign after the peace of Constance, it made no attempt to infringe the conditions of the compact it had accepted, though when the struggle was renewed between the Empire and the Papacy, the communes seconded by arms the policy of the Holy See. But, during his visit in I I 84, Frederick favoured the feudatories in Tuscany against the towns, which only offered a feeble copy of the Lombard spirit, for they did not yet possess the Lombard power. At Rome, on the other hand, he sustained the unsubmissive Senate against the pretensions of the Papacy to rule that insubordinate city; and when Pope Lucius III. retaliated by refusing to crown his son Henry, Frederick was powerful enough to banish him to Verona. The Popes were fully aware of the danger that menaced them from the union of the heirs of the Empire and the South, but the turbulence of Rome and Papal feudatories paralyzed a series of feeble but short-lived Popes. The Bishop of Aquileia 
crowned Henry at Naples, and all the Holy See could do was to suspend the ecclesiastics that were present.

In II 87 the heaviest blow that had yet fallen on the Crusaders was inflicted by the abilities of Saladin, the courageous, generous, and merciful Sultan of Egypt. At the head of 80,00o troops he shattered their forces, and, in spite of their desperate valour, took Jerusalem. The blow resounded through the West, and all Christendom answered the call to arms. Cremona was at war with Brescia, Parma with Piacenza, Milan and Pavia were preparing for a fresh struggle, but Gregory VIII. preached the peace of God, and the republics instantly laid down their arms, and quiet in Italy was secured for awhile by the departure of its most ardent and irrepressible spirits for the Third Crusade. At the head of 90,000 enthusiasts animated by religious fervour or the love of adventure, Frederick crossed over to Asia to do battle with Saladin, but he was seized with apoplexy while fording a small river in the Christian country of Armenia, and, falling from his horse, was drowned. The towns that had been most exposed to his vengeance were the first to acknowledge his good faith, emphasized by one solitary lapse; they could not but feel the absence of resentment from his character; they remembered his indomitable courage, his unshaken resolve under the most adverse circumstances, his magnanimity, alike in success and defeat; they had learned to respect their old enemy, and they deplored his loss. In his own land he became the hero of legend, like Charlemagne, whom he is said to have taken as his model. Confused, perhaps, with his brilliant grandson, Frederick II., the old Redbeard still sleeps in the bosom of a Thuringian mountain, awaiting the call to lead, yet once again, his German hosts to victory.

In the twelfth century treasure was lavished, blood poured forth like water, in a quarrel which eight centuries have by no means terminatedthe opposition of rights claimed by the body politic to rights claimed by the Church. But we are presented with the singular spectacle of political units seizing the opportunity afforded by the clash of rival demands to shield themselves behind the spiritual authority. We have said that the conflict between Pope and Emperor was the determining and vital core of that stubborn contest on the Lombard plain-a struggle fought by men of iron mould. The Papacy exhibited no less resoluteness and self-command than its heroic opponent. When Frederick found that his power was getting undermined at home, and that the conscience of Germany was turning against him, he sent Eberhard, the Bishop of Bamberg, to Alexander, with a commission to come to some private understanding. Alexander made a public reply. He told Eberhard that he was amazed at his simplicity in accepting a commission from one so crafty. The Papal cause had been judged by God's Church, and he (Alexander) was accepted by all the kings of Christendom save Frederick only. If Frederick wished to rejoin the Church, let him bow his head, let him vindicate rather than violate the liberties of that Church which had raised him to Empire, and maintain a filial attitude towards her. What vital energy decayed and degenerate Rome still retained was employed in driving its masters into exile, or resisting their authority. The Church itself was rent by schism, but the heroic self-possession of its chief bishops remained unshaken. One and all, in the firm, lofty 
accents of unquestionable right and fully-assured conviction, they reproduce on a higher, because less material, plane, the haughty self-confidence of ancient Rome. If his temper was that of disdain mingled with contempt, it was because the Pontiff cherished the flame of a high ideal. And though, like Barbarossa, he was willing to yield in small things, he knew that unshaken firmness in great matters is the secret of success.

(For the reign of Frederick, see Otto. ep. Freisingen.-Cont. Radevic.Otto Morena Lodi.-Cont. Acerb.-Aragon, Vita Alex. III. Also Milman, Hist. Lat. Christ.-Teste (1877).-Freeman, Hist. Essays, series I.Chevrier.-Von Raumer.-C. Vignati, Storia diplomatica della lega Lombarda, Milan, I866.)

\section{Guelph and Ghibelline}

Although the terms which designated them were not yet introduced, the opposed principles of Church and Empire had already effected a cleavage in Italian political life. Abandoning narrative for awhile, it is desirable to attempt to furnish a key to the perplexing maze of events that will occupy us for the next three centuries, though in doing so the reader will find himself not merely reviewing a tale already told, but projected into a period not yet unfolded.

No problems in history are more complicated in appearance than that of the nature of the opposition of Guelph to Ghibelline; few are really more simple to understand, when once the student has grasped underlying and essential tendencies and the factors which alter and perplex principles that abide, concealed in the tangled skein of Italian politics. For it is a mêlée, in the confused tussle of which it is often difficult to discern the motives that actuate the partisans, or the reasons why they so rapidly change sides, only to change again; or why, as is often the case, combatants should unite with opponents to attack those who bear their own banner. It must now be our attempt, not, indeed, to unravel the tangled threads-that can only be done in the details yet to be toldbut to give a general clue, which may help as a guide to the bewildering perplexities of contests in which these rallying calls served to distinguish between opposite factions, and enabled them to range themselves in adverse camps or ally themselves for mutual defence.

When the Popes called in the Franks, and subsequently, when they gave a Divine sanction to the Frankish Empire, they received in return the perpetual usufruct of the territory which had been governed from Byzantium by the legitimate representatives of the Roman Empire. This grant was renewed by Louis I. and Charles II., and acknowledged by Otho I. and Otho III.; but, by means of forged documents, the suzerainty of the Emperor was denied. In those ages it was a common practice of ecclesiastics who were convinced of the justice of their cause, and who had the almost exclusive monopoly of the pen, to embody their conviction in documents purporting to endorse it. There came into being a forgery which set forth that Constantine the Great, on retiring to Byzantium, had bequeathed the suzerainty of the Western Empire to the Roman Bishop ; and although this document conveniently disappeared, it was the basis of the later Papal claims to territorial supremacy. And, in the time of Gregory, the Great Countess Matilda bequeathed to the 
Church her possessions of Tuscany, Liguria, part of Lombardy, Modena, and Ferrara, the validity of which gift the Empire disputed on the ground that, the Emperor being Matilda's overlord, the bequest was contrary to feudal law. Moreover, the forgery of the false decretals supported a claim to the civil jurisdiction of the Pope over his clergy, which constituted a state within a state. The Church claimed that spiritual officers could not be subject to civil magistrates. Thus, in course of time, the Popes arrogated to themselves the power to appoint, or at least to confirm, and to depose, princes ; to become the arbitrators between Christian states; and to rule the Church and its temporalities independently of the State. The Empire and the civil governments of Europe naturally denied and resisted this usurpation of their powers and disturbing element to their administration. The Pope relied on his spiritual authority and on the disaffection and rebellion of the vassals of the Empire. Thus, Alexander III. found his mainstay in the insurgent towns of Lombardy; for his temporal power was weak, his possessions were in the occupation of uncontrollable feudatories, and his city was in a state of almost chronic revolt. On the other hand, the Emperor was too far off to bring effective resources against him ; he was weak at home by reason of perpetually recurring revolt and by competitors for the Empire; he was weak in Italy, because, having no army of his own, he was dependent on the loyalty of his subjects in response to the feudal call to arms. Thus, from the very commencement of the Holy Roman Empire, the germs of discord were present, and had to be mainly fought out by powers that were not principals in the dispute. From the Imperial point of view it was necessary that the Church should, as to temporalities, be subject to the Crown; from the point of view of the Church it was impossible to sever the "life of the soul from the life of the world," the Church militant from the Church triumphant, civil or military from Divine right. The Papacy feared the Empire, because the triumph of the Empire would mean the ruin of ecclesiastical authority. These opposite doctrines had been developed within an Empire, the theory of which was the existence of one universal authority, in which State and Church were coincident. The struggle was between Emperor and Church for the possession of this authority.

At first it seemed as if the Empire would win. A series of strong Emperors had the upper hand of weak and vicious Popes. Then Henry III. appointed a series of short-lived but pious Popes, and during the long minority of his son, Hildebrand made still further attempts to purify the Church, and used its increased spiritual reputation to fortify its power. Henry IV. and Henry V., the fierce opponents of the developed Papal doctrine, were also known by the name of Waiblingen, from a castle they occupied near Augsburg; and their opponents, many of whom bore the appellation of Wölf, came to bear this specific name. Hence the supporters of the Imperial doctrine came to be designated Ghibelline in Italy, and the adherents of the Papal cause, Guelph. But it soon ceased to be a question of mere doctrine. Those families or cities or states that found it to their advantage to side with the Pope were Guelphs; those who found profit in the Emperor's party were Ghibellines. Yet, at first, the terms distinguished two camps, opposed on very. easily distinguished principles. It is true that our own Puritans fought against an Established Church, while the Cavaliers supported it. But the Guelphs 
resembled the Puritans in this : that they fought for the independence of religion; they protested against the insolence and aggression of constituted military and civil authority; they professed strictness of life, if they were far from severe observance of their profession. But there was this difference between Italian Guelphs and English Puritans : the former were free from hypocrisy. Cant is the ensign of Northern religiosity ; more than anything else, it brought the Puritans into disrepute. Cant never had place with the quick, impulsive Italian. That halfunconscious insincerity, that strange admixture of conceit and self-interest. with glib outpourings of sanctimonious platitudes, which is so often a painful feature of our own islanders, has never been a foible of the passionate South.

As the head of the feudal system, for the most part bearing Teutonic names, and of remote Teutonic descent, the Ghibellines gathered round the Emperor. Iike the Cavaliers, they reflected the gay worldliness, the pomp, the luxury, the insolence, the insouciance, and the daring courage of the camp and the court. They were regardless and contemptuous of the claims of the classes below them to civic right, but they were not insensible to exalted conceptions of duty, nor wanting in the chivalrous self-devotion of a noble caste. The Ghibellines had the virtues of the aristocracy, the Guelphs inclined to those of the "bourgeoisie." After Alexander had found his first line of defence in the insurgent cities, we discover a pronounced change. Even before this, during the Wars of Investiture, it was the natural policy of the rising communes to lessen the restricting pressure of Imperial rule. At the same time they emancipated themselves from their bishops. Some towns found it politic to embrace the Imperial, other towns the Papal cause. Within the same towns there were two parties-the party of privilege, and the party of liberty. The nobles naturally stood by the King; the burghers by the Pope. Some nobles would find it to their advantage to take the popular side, as some burghers would find their most advantageous alliances with the nobles; so there were divisions within the towns, just as the towns themselves were by no means all arrayed under the same standard. Private interests and private animosities divided the same town between Guelph and Ghibelline parties.

In their early years the communes were perpetually struggling with the old feudal aristocracy of foreign descent that held strong places around them, that laid toll on their commerce, and were perpetually endeavouring to bring them into subjection; they were for ever expelling this aristocracy, taking their castles, subjecting them in vassalage to the commune. We shall find that the smaller gentry, holding of the greater lords, become vassals of the bishops of the cities, and after various struggles are absorbed in the commune, and with their absorption the distinction between the trading city and the occupation of the country by men of foreign descent disappears. The bishop gradually replaces the count; but his power is undermined in the Wars of Investiture, for he cannot stand without popular support; if he is on the Imperial side, he must conciliate the city to preserve himself ; if on the Papal side, he must still give way to popular rlemand, or the party in the city opposed to him will gain an advantage. Thus the commune becomes triumphant and free from episcopal control. It then turns against the greater nobles; it subdues them, and forces them 
to reside within the town as a pledge of good conduct. Compelled to become citizens, they regain their power by achieving the government and military direction of the city, quarrel among themselves, are expelled, recalled, expelled again. Finally, this struggle between grandi and popolo, which is synchronous and corresponds with the struggle between Empire and Church, is generalized as the struggle of Ghibellines versus Guelphs, and when that struggle is over, becomes in each commune a contest between two leading rival families. For in the life-history of the commune, which we shall investigate in a separate chapter, we find the struggle first concentrated into the contest of two parties in the same communethe party of existing privilege, and the party excluded from privilege, the latter often led by grandi and supported by the lower orders; then it is still further restricted and concentrated into the rivalry of leading houses. Guelph and Ghibelline are rallying cries under which class wars, private animosities, leagues made by the communes and the nobles for the advancement of their own interests and the suppression of their neighbours, were fought out. Every city contained factions representing opposed interests. The prevailing party exiled the other party. Party stood for interest, and interest prevailed over civic patriotism; the exiles found an asylum in the cities of their party ; they were for ever endeavouring, by the intrigue of their friends within the walls, or by the hostile combinations of their friends without the walls, to re-enter the city and resume their power.

Thus communal interests, geographical situation, the politics of rival and neighbouring towns, determined whether the majority in a city stood for Pope or Emperor. The tradition and interest of the commune or the family fixed its response to the one or the other rallying cry. The commune expelled the citizens who were of the weaker side; the exiles fled to more congenial refuges, and awaited their opportunity to wage war against their native home and effect a return thither. Incessant wars and conspiracies were the inevitable result. The interests of the Pope were now changed: they had been partly spiritual, partly temporal; they became of a purely temporal character. His great object was to keep Central and Southern Italy in close alliance with and dependence on the Papal See, and to establish a great number of small self-governing communities in the northern plains, that might serve as barrier states and keep the Emperor at bay. Owing to this alliance with communities rightly struggling to be free, the Guelph party became the party of progress. The Ghibellines were the party of privilege and authority; they were the good old crusted Tories of the Middle Ages. The Guelphs were the Whigs; they were supported by nobles of no less distinguished lineage than the Ghibelline nobles, but who maintained their power and increased their pelf by supporting the Guelph faction. Men ever aid their abstract conceptions by means of the concrete; a flag or a rallying cry serves to differentiate parties : it serves as a sign when it has ceased to be a symbol. A Guelph Emperor can now support a Ghibelline cause. The Guelphs in Tuscany, their stronghold, split up into white and black factions; the views of the former are expressed by Dante. He held that the Church is superior in dignity to the Empire, as the soul is superior to the bodyan opinion very similar to that held by Peter Damian (De Monarchia.Cipolla, Storia delle Signorie, p. 5). From this theoretical position prac- 
tical politics could easily be deduced. The black Guelphs, on the other hand, found their views set forward in first principles by Marsilio of Padua, who denied the spiritual power of the Pope, and put the Emperor in his place, even over the bishops (Defensor Fidei). The split in the Guelphic party was a reappearance of the old problems of the relation of Church to State, and of Privilege and Order as against Natural Right and Freedom. This division appeared half a century subsequent to the reign, of Frederick II. in some of the places where the Guelphs had achieved power; the Whites, consisting of certain nobles and the mass of the people, wished to extend the franchise and political power : they were Liberals; the Black Guelphs were the Conservatives of the period; the Radicals were yet to arrive. Finally, names survived principles ; it was convenient for a family or a small state to support feelings of rancour and actions of injustice, to open the way to aggression, and to exclude all possibility of mutual understanding and compromise by adopting a badge which was the emblem of centuries of hatred and strife. The Emperor was no longer an object of dread ; the Pope, sunk into a mere petty territorial Sovereign, was no longer a cementing bond in the brotherhood of mankind; the Ghibellines no longer cared for the universality of Empire nor for the determining of disputes by authority; the Guelphs were no longer the protagonists of self-government and the repression of the insolences of power. Whether they called themselves Guelph or Ghibelline, the cities and the dominant party in the city alike sought to maintain their own power, with no particular superstition as to the moral soundness of the means they employed; or they endeavoured to extend their power and authority over neighbouring states with an unscrupulous oppressiveness that was sublime because it was so wholly unconscious. And still the theory of the Holy Roman Empire remained undisputed-a hollow and unsubstantial mockery, a phantasm of Imperial Rome.

The Conflict of Civil with Ecclesiastical Government, and the ENDEAVOUR to Institute Universal Monarchy

The Papacy, with its wonted political acumen, perceived the menace to its power that the union of the heir to the German throne with the heiress of the Two Sicilies implied; but wretched squabbles with Rome rendered it powerless to interfere, and the Pope was more often than not wandering in exile from his see. In I I9I Henry entered Italy with a view of subduing the kingdom which Tancred, the natural son of Roger, who was the eldest son of the first King of Sicily, had usurped at the call of the Sicilians ; for these were far from welcoming the advent of a German stranger to their throne. In order to pass through Lombardy, he patted the cities on the back, and so reached Rome. Here he found Celestine III. and his Romans at war with Tusculum. He lost no time in conciliating them by advancing against that town, which he succeeded in burning and razing, leaving only a few folk in hovels built of evergreens, whence developed in time the little community of Frascati. Thence he advanced to Naples, which offered a stout resistance. The army was half drowned by heavy rains, and the country had become a bog. The expedition ended in distaster. Henry now realized that he could do nothing without a fleet; he therefore offered Pisa complete possession of Gaeta and Trapani, and half of the towns of 
Naples, Messina, and Palermo ; and to Genoa he promised Syracuse and fifty fiefs, if they would aid him. Palermo and Sicily yielded at once to the new army and the threatening fleets furnished by Pisa and Genoa. Tancred had died, and his son, an infant, was given up to Henry, who made a eunuch of him and shut him up in prison. Genoa and Pisa now found that their bargain was ignored; they had not actually fought, which gave Henry a convenient excuse to evade their claim ; indeed, he withdrew the trading privileges which they enjoyed in Sicily from them. Sicily began to groan beneath the heel of a tyrant. Italy, too, quickly began to feel his grasp tighten on her. He was known as the "merciless cyclops." There is this excuse for his action in Northern Italy: that the cities were at their wonted and prodigal pastime of private war. Henry gained over the counts of the commanding Tyrol and Apennines; made his brother Philip of Swabia his vicar in Tuscany, and appointed other Germans elsewhere ; while, by his connivance, the Roman senate obtained a charter which practically destroyed the temporal power. He was now Emperor of Germany, and ruled the whole of Italy and Sicily and a part of Provence. He dreamed of conquering the Greek Empire and restoring the sway and peace of ancient Rome ; and the world seemed perilously near to coming under the control of an ambitious, clear-headed, and persistent man, remorselessly brutal in his wrath, and coldly elusive of his plighted word.

" But the fair guerdon when we hope to find,

And think to burst out into sudden blaze,

Comes the blind Fury with the abhorred shears

And slits the thin-spun life."

He died unexpectedly in 1197 , and but a year afterwards his wife also died, leaving her little son of four years, afterwards to be spoken of by his contemporaries as "Stupor Mundi," to the guardianship of Pope Innocent III. There was now an opportunity for the Holy See to establish a theocracy, and govern the Western World with more than Imperial authority. Two rival aspirants to the Imperial crown were on the fieldPhilip of Swabia, the late monarch's brother, supported by Philip Augustus of France ; and Otho of Aquitaine, the son of Henry the Lion, aided by Philip's natural enemy, his great feudatory, Richard Cœur de Lion of Normandy and England. The College of Cardinals had elected as Pope one of the Roman nobles-a man that they could trust, in the prime of life, of large and penetrative insight, ambitious of power, high-minded and devoted to the interests of the Church, of appalling will-power, selfcontained, and possessing all the moral and intellectual qualities required for the monarchy of the Christian Church, as well as the statesmanship needful to establish that monarchy and render it secure. He had gained his experience in world-politics as legate. At this time Rome had adopted the practice of other cities, and a foreigner dwelling in the palace of the senate on the Capitol, under the name of Senator, concentrated the powers of the senate in his own person, and ruled the turbulent city with a firm hand. Obviously, the first step to the exercise of efficient control over Italy and Europe was to become master in his own city ; and although this could not be immediately effected, the circumstances were favourable, and Innocent was able to initiate his policy. For the citizens were beginning to gib at the unwonted restraint of their podestà ; also, with Italian 
shrewdness, they demanded money from the new Pontiff. Alexander, with still more astuteness, at once acceded to their request, but he made them swear an oath of allegiance of increased stringency; he also contrived to displace the unpopular Senator from his office, and to fill it with one of his own creatures, whom he bound by oath in very strict terms. Though not yet master of Rome, he now felt himself sufficiently secure to take advantage of the weakness of Germany, torn, as it was, by opposite factions. There was no possibility of an invasion of Italy occurring while the throne remained disputed. Now, the German feudatories appointed by Henry VI. to rule over the pretended gift of Constantine and the bequest of Matilda to the Church had abused their power, and were hated by the people; the towns of the disputed domain, smaller and feebler than those of Lombardy, had, for the most part, not developed full municipal self-government, which remained pretty much as it had been two centuries before; so Innocent lost no time in sending warrior-prelates forth to reconquer the Marches and the duchy of Spoleto. The people, hoping for more liberty under the government of the Church than they had experienced at the hands of foreign military control, threw open their gates and welcomed the Papal troops. Tuscany, however, had tasted the sweets of liberty ; its urban constitutions were already evolving; but while it had been faithful to the Emperor, it had suffered from exaction during the late reign. Innocent was far too wary to urge his rights, through Matilda, over powerful, self-governing urban communities. He sent his cardinals to Florence, Lucca, Siena, Prato, S. Miniato, and Volterra, to point out that their allegiance to the Empire was in abeyance, and that they should take the opportunity to insure that a new Emperor did not involve them in disputes wherein they might find their loyalty opposed to the duty which they owed to God. The issue of this was a Tuscan League, renewed half a century later, which engaged to submit to no sway without the express approbation of the Church, to aid it when called upon to do so, and to support the Pope in recovering his territories, save in so far as the allies themselves might be occupying them. Pisa, which had obtained all it wanted from the Empire, refused to enter the League, and, indeed, nearly always took the lead of the Ghibelline faction in Tuscany. The Two Sicilies were in Innocent's hands ; for though the Empire attempted to re-establish its power there, Innocent, who had not much material resources, nevertheless contrived to defend the rights of his ward by balancing opposed interests in the South with consummate address. He performed his duties as guardian to the young Frederick honestly and well. He appointed the Archbishops of Capua, Palermo, Monreale, and the Bishop of Troyes, to administer the kingdom, and he supervised them and directed them by a daily letter.

Innocent recognised no practical distinction between the moral conscience and the political conduct of Europe ; for him there was one Church, triumphant above and militant on earth, and the Church on earth he proceeded to govern and direct, outside and inside, and to purge from heresy. He ordered the Duke of Hungary to vex his brother no more with his presence, but to proceed forthwith to the Holy Land; he compelled the brother to wage war against Bosnia, because it sheltered heretics ; he sui ceeded in deposing the usurper of Norway, and in compelling the King of France to take back his wife; he constrained the Sovereigns of Castile and Portugal to seek peace with one another, and to make common cause 
against the Moor; and he forced the Kings of Portugal, Aragon, Poland, and England to declare themselves the vassals of Rome. As its Father in Christ, he saw Western Europe at his feet; he was at once its shepherd and its sovereign. By interdict and excommunication, by lofty resolve, unflinching system, judicious direction, and consummately able manipulation of the tendencies and agencies of his time, Innocent made every event, every movement of policy or of the human spirit contribute and conduce to the political influence, temporal power, and spiritual authority of the Holy See. He was quick to perceive the renewal of the spirit of Christ in the gentle fervour of Francis of Assisi, the depurating passion of Dominic. He annexed them and their followers, and employed them in the work of freshening and weeding the Church. The Franciscans' movement served as the velvet glove, the Dominicans' as the iron hand, by which he extirpated all heretical departure from that sacred Church that alone claimed the sole Divine guidance of the Holy Spirit Himself. The Franciscans allured heretics within the fold by their unpretentious and holy simplicity; the Dominicans excited popular wrath against them by their fierce denunciations ; and these " black dogs" of the Church were employed to nose out every suspicion of heresy, and bring it under the scrutiny of the Holy Office. Innocent was unwearied in writing letters of exhortation to the cities to expel the heretic that was within their walls, and in preaching crusades against schismatics, where, as in the case of the Albigenses, they were collected together in force. $\mathrm{He}$ and the men of his time were of robust faith ; they believed the directing presence of the Holy Ghost to constitute the Roman Church into the keystone of human society, without which morals would fall into ruinous confusion, and there would be no bridge of salvation ; they acted in strict conscientious and logical agreement with their belief. The Inquisition was in full force, and that craftilydevised expedient, the "secular arm," did its work well during this and the subsequent reigns of masterful Pontiffs. The blood of the separatists was shed like water; little was left to become the sced of schismatic Churches. Never was a Pope clad with so great authority; the stars in their course seemed to fight on his behalf. He was disobeyed by the Crusaders when they attacked Constantinople, and he rightly denounced and endeavoured to prevent that unrighteous scheme; but the establishment of a Latin kingdom there seemed to promise a subordination of the Greek to the Latin form of the Christian faith; and Innocent, with the astuteness of the statesman, quietly accepted the accomplished fact, and saw with satisfaction the establishment of a Roman Catholic patriarch in the see of his Byzantine rival. We have seen that, besides the favouring circumstances of his time, which he was so adroit in turning to account, Innocent was wise in employing the passion of religious enthusiasts so as to augment the spiritual power of the Holy See. Temporal sway was important, but in his view it was less important than spiritual command. The mendicant friars ousted the secular clergy from their psychical preponderance, and through them the voice of religion reached the conscience of peasant and of king. In favouring the new orders, he chained them to the Church, and later mendicant friars, like Thomas of Aquino, devoted their philosophic powers to its service, or rose through the College of Cardinals to the Holy Seat. He employed the canon law with the dexterity of a born lawyer, and the austerity and sincerity of his character obscured, to 
an uncritical age, the real character of many of the fictions that he employed.

The condition of Italy at this period exhibits the almost complete decay of the great feudal families in the North and Centre. Those who remained had lost all jurisdiction over their vassals, and there was no other organization than that produced by a spirit of party. As a rule, families powerful enough to defend themselves were attached by the Imperial party ; those whose castles were near great towns, or who were too feeble for resistance, had become citizens, dwelt in the towns a part of the year, took the principal share in their government and defence, and affected the Papal side. But every chain of hills was thick-set with fortress-habitations held by independent castellans that avowed their allegiance to their Emperor. Yet they also sought admission to citizenship, with a view to directing the counsels of the towns and maintaining their personal interests and those common to their order ; and as war was their only occupation, the burghers were glad to receive the services of such redoubtable captains. Accustomed to settle every question by the sword, these nobles and country squires were unsubmissive to urban law; they introduced wild scenes of warfare into the city lanes, which also were enlivened by fierce and frequent siege of the aristocratic fastnesses that lined them. Faction ruled ; family aversions became a family inheritance ; and the citizens were obliged to accept Frederick's institution, and elected their own podestà to preserve some semblance of order. Even so, before the close of the twelfth ceritury every Lombard city in succession had risen against and expelled its nobles, and then recalled them because their military qualities were indispensable. The house of Este, allied to the Welfs of Saxony and Bavaria, held several castles on

" many folded hills,

Those famous Euganean hills, which bear, As seen from Lido, through the harbour piles, The likeness of a clump of peakèd isles."

They joined and ultimately dominated the republic of Ferrara, and ardently espoused the Papal cause. Opposite, on a parallel chain of " hoar and aery Alps," rose the castles of Eccelin of Romano, whose family, enriched by the Emperors, fiercely Ghibelline, defended Verona and Vicenza, and were destined to become their tyrants. On the northern slopes of the chestnut-clad Apennines the fortresses of Imperialists lay scattered thick ; their lords excited revolutions in the republics of Piacenza, Parma, Reggio, and Modena. On their southern cliffs were the castles of other Ghibellines, who were by turn the citizens and foes of Arezzo, Florence, Lucca, and Pistoja. Commanding the lower valleys of the Po, and in the upper vale of Arno, were strongholds of the Guelphs.

Heresy added to the general confusion, and the sleuth-hounds of the Church, the Dominicans, tracked it through the lanes where it lurked; and policy accused noble families, suspected of disaffection to the Papal cause, of tolerating or entertaining Patarine opinions. Yet the industry, commerce, and wealth of the country made rapid strides. The sails of the maritime cities-Genoa, Pisa, and Venice-were spread throughout the Mediterranean; they transported the armies of the Crusades, and by the seizure of Constantinople one-fourth and a half of the Roman Empire of the East was adjudged to be the spoil of Venice. 
Innocent, who, in order to make his power felt abroad, adopted a liberal policy at home, was compelled to allow a republic to constitute itself under his own eyes at Rome, and abandon authority over it. Two German commanders, respectively raised by Henry VI. to the rank of Duke of Spoleto and Marquis of Ancona, ruled the provinces nearest Rome; but Papal legates revived the spirit of liberty among the pinched and scanty citizens of the mountain towns and the wealthier citizens of the coast and the plains. Two Guelph leagues threw off the German yoke : one comprehended the cities of Ancona, Fermo, Osimo, Camerino, Fano, Jesi, Sinigallia, and Pesaro ; the other, Spoleto, Rieti, Assisi, Foligno, Nocera, Perugia, Gobbio, Todi, and Citta di Castello. The cities which owed their liberation and protection to the Church afterwards submitted, without resistance, to its sovereignty. Other legates were sent to Tuscany, the heritage of Matilda, and convoked a diet at San Ginasio. Provincial diets were in the habit of assembling frequently to discuss, and sometimes even to settle, the differences that arose between cities, and they had succeeded in keeping. Tuscany fairly free from civil war during the great contest. But they had been presided over hitherto by an Imperial representative, and the castle where he resided is to this day called San Miniato al Tedesco. Pisa, which had been loaded with favours by the House of Hohenstauffen, and had been invested with sixty-four fortified towns on the Tuscan shore and the islands of Corsica, Elba, Capraia, and Pianosa, remained determinedly Ghibelline ; but the republics of Florence, Siena, Arezzo, Pistoja, and Lucca accepted Papal protection, and formed a Guelphic league.

When Otho IV., the next Emperor, after having effected a reconciliation between the rival houses of Romano and Este in North Italy, arrived in Rome, he received the Imperial crown while a considerable number of German soldiers were biting the dust in the inevitable turmoil that accompanied a coronation. Otho now refused to acknowledge the Pope's territorial claim, and cited his own oath to maintain the prerogatives of his Empire. Matters were beginning to look ominous when the representatives of the two incompatible powers separated, and Otho prepared himself for contest. He fomented discontent in Rome; favoured Pisa in order to get command of her fleet; claimed Apulia as a fief of the Empire ; put himself into communication with the German warriors who had settled in the kingdom of the South; gave the duchy of Spoleto, which Innocent had acquired, to one of them; deftly secured the adhesion of Milan, Parma, Bologna, and the great Houses of Romano and Este (save Azzo of Este, who forsook him, though he was of his own family); and recommenced war against his Ghibelline neighbours (I 209). Innocent was feebly supported by the Tuscan Ieague (it was hardly to its commercial advantage to quarrel with its port, Pisa, or to have the claimant to Matilda's heritage too strong a neighbour), but he was abetted by Genoa, the opponent of Pisa, and by Pavia and Cremona as opponents of Milan, and by the Marquis of Montferrat. In spite of excommunication, Otho overran Apulia and a great part of Calabria, and it seemed as if the "young king of priests," as Frederick was called, would be assailed in Palermo; he already had a galley moored beneath the palace windows for escape. But the bishops of Germany were taking advantage of Innocent's Bull of excommunication, and were plotting to transfer the crown from the line of Guelph to the house which Barbarossa had ren- 
dered immortal. They proposed to give his grandson, young Frederick, the crown, and great nobles, supported by Philip of France, declared Otho dethroned. The plot was engineered by the Papacy; it promised success, and Otho had to abandon his enterprise and recross the Alps in haste.

The Papacy had committed a great blunder. Out of hatred and fear of Otho it had restored the Hohenstauffen line; it had taken a course of action which committed the Church to the greatest struggle in which she was ever involved; she accepted the union of crowns that she had vainly attempted to keep separate, and that had only become disjointed again by the accident of an unforeseen death. The Papacy secured for itself what poor protection it could get in the guarantee that Sicily should pass to the infant son of Frederick, and that he should never wear both crowns. The Papal action caused strange confusion of parties. Most Ghibellines, as supporters of the Hohenstauffen, found themselves in alliance with the Pope, while whole-hearted Guelphs and those that had ties to Othohimself a Guelph-were arrayed against their sacerdotal head. Those communes of Lombardy that had been on the side of Frederick Barbarossa, more faithful to names and persons than to principles, were faithful to his young grandson, while the Guelph towns supported Otho, that had meditated violating Italian liberties. Frederick was detained three months at Genoa before he could traverse a hostile country, where Guelph and Ghibelline were ravaging one another's territory. Every day of delay was serious for Frederick's chances in Germany, and he only succeeded in reaching Cremona by the skin of his teeth; his Pavian guard was cut to pieces by the Milanese during its march back; but he succeeded in making the passage of the Trentino (1212). The defeat of Otho by Philip of France at Bouvinez, shortly afterwards, practically put Frederick in possession of Germany, and, in I 2 i 8, Otho died.

1. In I2I5 Innocent assembled the fourth Ecumenical Council held at the Lateran. This council condemned the rampant separatism and fermenting heterodoxy of the time, confirmed the pretensions of Frederick to the Empire, and compelled every true Catholic to confess himself to a priest at least once a year. The Papacy was in the zenith of its power. Next year, Innocent, while travelling to Tuscany to adjust the differences between the rival maritime powers-Genoa and Pisa-fell ill at Perugia, and died there. The new Pope, Honorius III., had been governor of Palermo and Frederick's tutor; but; though not a strong man, he was not the creature of Frederick, and in the interests of Italy and the Papacy, he ordered Frederick to resign the crown of Sicily to his little son, in order that it might not remain united with that of Germany.

Frederick, now twenty-four years of age, was unlike any other man of his time with whom we are acquainted; Matthew Paris calls him "Stupor mundis"; Nicholas of Jamsilla, who belongs to the next generation, says that he was " a great soul, but his magnanimity was tempered by prudence ; his actions were the result of reflection, and never of impulse. He was a zealot in matters of the mind; he cultivated his own intelligence, and established liberal learning throughout his realm. In Sicily he opened schools wherein the liberal arts and all kinds of knowledge were pursued-a thing unknown there beford his happy advent. He gathered his professors from afar, and not merely paid them, but, in order that 
no one should be prevented from study by reason of indigence, he supported the poorest scholars from his own private purse. He gave a proof of his own cultivation by writing a work on the nature and care of birds, for he was ever inclined towards natural history. He cherished justice, and any man might plead against him in the courts of law, and his advocate be sure of obtaining equity. And if he was just, he was also clement" (Nich. Jams. Hist. Convad et Manf.). And Villani the Florentine, also of the succeeding generation, writes : "He was very valorous and of high talent; he was naturally able, and he developed his abilities by study. He was a universal man; he spoke Latin, the vernacular, German, French, Greek, and Arabic. His good qualities were copious; he was generous, courteous, brave, and skilful in warfare, and a general much to be feared. But he was dissolute in the pursuit of pleasure, Saracenic in the number of his concubines; like the Moslem, he was served by slaves; he abandoned himself to every enjoyment of sense, and lived an epicurean life, believing in no existence beyond the grave" (Villani, G., Ist). Frederick possessed that brilliant, versatile, impressionable mind so often to be found in admixture of race; he inherited much of the practical wisdom and fixity of resolve of one grandfather, the Norman fincness and adaptability of mental structure of the other, and the vigour and courage of both. Brought up, not in a single community, but in the presence of several, he early achieved that emancipation from custom which is apt to confound so entirely the universality of ethical obligation with the localism of fixed usage; he had been educated in a school of clerical statesmen who were accustomed to substitute astuteness and mental reservation for more courageous weapons; and the inheritance of duplicity, which came with his Norman blood, improved the lesson, and enabled him to escape the snares laid by the Papacy by a facile compliance that concealed bad faith.

In spite of Pope Honorius having been a preceptor of Frederick, the deaths of Innocent III. and Otho broke the unnatural alliance between the Pope and the Ghibellines. The Milanese, excommunicated by Innocent for having fought against Frederick, continued to attack his partisans. They refused him the Iron Crown, and allied themselves with the Count of Savoy and the citizens of Crema, Piacenza, Lodi, Vercelli, Novara, Tortona, Como, and Alessandria to drive the Ghibellines out of Lombardy. The militia of Cremona, Parma, Reggio, and Modena defeated them in I218, and the beaten Guelphs turned on their nobles who had led them into family feuds and foreign interests. The power of the nobles in the city was reduced, and, in I22 I, they were expelled from Milan.

In 1220, Frederick, avoiding the contumacious towns in Lombardy, presented himself before the Pope, and having promised for the second time to proceed without delay to succour the Crusaders,. received the Imperial crown. The promise thus exacted, if kept, would have seriously hampered work that was Frederick's more immediate duty-namely, the restoration of order in Sicily. Less energetic and resolute than Innocent, Honorious only feebly urged the execution by Frederick of his promises ; and Frederick found it easy to plead the youth of his son and Sicilian and Apulian anarchy, which, arising from the insubordination of feudalism and a revolt of Saracens, and guerilla warfare in the mountains which was aided by their brethren in Africa, he had not completely rectuced to order. 
Frederick, by open warfare and statecraft, established himself in the South in absolute power. He subdued and bound feudalism in chains; relieved the bishops and abbots of the charge of castles, telling them that they would have more time for prayer if released from military duty; instituted good government ; put down a Saracen insurrection, and transported 20,000 insurgents to the mainland. Here he allowed the cathedral to be turned into the mosque, and converted troublesome marauders into the best soldiery in Europe, unrestrained by any inconvenient reverence for the Pope. While nursing projects of recovering as much as he could of the great Roman world, and placing it under just, firm, and beneficent sway, wherein peace, prosperity, and letters should dwell by compulsion, he allowed or induced the lords of Germany to crown his young son at Aachen, and thus arranged for the stability of his house in the broad domains of Empire which the Papacy had vainly attempted to divide, and which stretched from Aachen to Palermo, and included the petty states of the Church ; and he occupied his leisure in the pursuit of study, surrounded by a Court of learned Greeks, Arabs, and Jews, founding seats of learning, encouraging minstrels, and writing poetry, revising laws, and, the first of the moderns, putting an end to trial by battle, inquiring into everything, and tolerating the creeds. This was quite a new kind of authority exercised by a novel sort of man; and he soon made it felt in Northern Italy by placing a vicar in Lombardy, another in Romagna, and fooling the Pope by inventing excuses for remaining at home. Tuscany he left pretty much to itself; it was too independent to attack immediately. Lombardy became suspicious, and when he convoked a diet of Cremona to establish something like peace and order in the North, Milan, Bologna, and nine other towns answered the invitation to attend by establishing a "Societas Lombardorum " of their own. Henry, the King of the Romans, Frederick's young heir, was unable to respond to his father's call; the Alps were closed to him, and Honorius patched up a peace between the towns and the Emperor, who had narrowly escaped slaughter at Bologna. But the next Pope was of a character less temporizing. The mantle of Innocent fell on Gregory IX., a man subtle in the law, and of much acumen, but, as is sometimes the case with great lawyers, of a naturally violent and wilful temper, and this infirmity was, in his case, hardened by age. He ordered Frederick to take the cross. Frederick had now brought his kingdom to heel; moreover, he had taken as his second wife the heiress of the kingdom of Jerusalem, which was by now in Saracen hands; so he embarked to recover the rights that thus accrued to him, but was driven back by tempest and pestilence. The impatient, irrational, old Pope excommunicated Frederick for returning, and fulminated anathemas when he went. Frederick possessed his soul ; he secretly stirred up the nobles of Rome to give the Pope an unquiet time, and issued a protest to all the princes of Europe, while he commanded the clergy of the South to continue their offices. And then he went to fulfil his vow. Pursued by anathema and news of revolt, he nevertheless succeeded in securing a treaty with the Soldan of Egypt, whereby the Saracens obtained possession of the Jewish temple, which was on the site of that of Solomon, while the Holy Sepulchre, which was the main object of Christian veneration, became subject to Frederick. The obstinate, perverse old Pope chose to confound the two places, 
though it should have been clear to the Church that since Frederick was crowned King of Jerusalem in the Church of the Holy Sepulchre, the main object of the crusade was achieved.

Determined to rectify the blunder of Innocent, to break Frederick, to destroy the predominance of the Empire, and substitute the supremacy of the Vicar of God, the Pope entered into an alliance with the "Societas Lombardorum," the renewed Lombard league. It was constituted by the association of the republics of Milan, Bologna, Piacenza, Verona, Brescia, Faenza, Mantua, Vercelli, Lodi, Bergamo, Turin, Alessandria, Vicenza, Padua, and Treviso ; it was stipulated that it should last twentyfive years ; it engaged to defend the liberties of every city and the independence of the Court of Rome, and it sent active support to Gregory in the war that he made on Frederick's possessions during his absence in the East. Gregory took advantage of the alliance to get the towns to accept the Inquisition, which they had hitherto refused to introducs within their walls : allies of the Holy See could not be indulgent to its enemies. Apulia was invaded; emissaries were sent to rouse Germany to revolt (I 229).

Frederick had only to reappear, and all the insurrection in his kingdom which had been fomented by the Papacy in Southern Italy ceased; the bands of revolt were scattered to the winds; he received the felicitations of the Senate and people of Rome, and the Pope was obliged to receive him into the bosom of the Church, on condition that he issued a general pardon. The Lombard league, so necessary to the Papacy, was included in this treaty; it was, in fact, almost its last resource. For Frederick was a child of the South; secure in Germany, he was able to dwell at the gates of Rome, as it were, in his beloved Sicily.

\section{" Das Land wo die Citronen blühn \\ Im dunkeln Laub die goldorangen glühn Dahin, dahin !"}

Two or threc colonies of his faithful Saracens, hcedless of Papal invective and excommunication, were settled within three or four days' journey of Rome; and their lord, educated in the midst of political intrigue, was master of the game. Born in the land, Frederick had more Italian support than any Emperor before him, and the extinction of great houses had increased his power in the duchies of Tuscany, Spoleto, and Romagna, while in Lombardy he could count on the counter-league which the Ghibelline cities had formed.

There could be no prolonged peace between a Papacy consumed by frenzied desire to oust the Moslem from the East, to burn out heresy, and to establish ecclesiastical despotism, and the Cæasar who in his palace at trilingual Palermo, spent his leisure in quietly mocking at superstition to a brilliant and learned court, or in toying with the dark-eyed houri; of his harem, or twanging the one-stringed lyre to a chanson of his own composition. And, moreover, Frederick had a keen eye for character; he had surrounded himself by carefully selected advisers, and his intimate; were the ablest and most advanced thinkers of the time; he was himself a statesman and lawgiver of high merit, revolving the consolidation of his empire on lay and rational principles, relying on the support of a great body of trained Saracen troops. He had so little of narrow, fanatical 
temper, that he allowed the commercial welfare of his state, and even the claims of learning, to predominate over the passions excited by a bitter war. When Genoa and Venice joined the coalition against him, he gave strict orders that their merchants resident in his dominion should not be disturbed (Winckelmann Acta Imp. ined., p. 576); and when the canon law of Bologna was opposed by the civil law of his own university of Naples, and Bologna was the mainstay of Papal doctrines and among his bitterest foes, the advancement of learning outweighed all political animosity, and he sent to her jurisconsults a translation of Aristotle. Frederick's mind was that of the practical statesman, with imagination enough to grasp great ideas, and his fine balance of many mental powers allowed him to support the orthodoxy of the Church in Sicily, even while he was fighting her, so that, among other reasons, he might have the support of Christendom if his favourite and more civilized Moslem should grow troublesome and resistent. The opponents represented, in many respects, the mediæval and modern spirits, with many of the virtues and not without the serious defects of both : they could not dwell long together in the same planet without collision. But for the nonce both powers were in amity tempered by suspicion, and co-operated.

In a short time Frederick was able to turn his attention to Lombardy ; he had no intention of abrogating the concessions made by his grandfather, but he wished to make the cities members of the Empire. The cities instinctively felt that a consolidated Empire would mean the destruction of initiative and individuality and the dearly-prized right of quarrel and reprisal. Frederick's Saracen colonies of Nocera and Lucera supplied him with 30,000 Moslem troops, indifferent to the views of a people that spoke another language and worshipped a strange God; deaf to the persuasions or anathemas of Rome. He summoned a diet at Ravenna; he hoped to pacify Italy, and so disarm the Pope. He was so far successful, that the great house of Romano became his fast ally, an event fateful to the Veronese Marches, for Eccelino da Romano was ambitious, intrepid, ruthless, and endowed with great military talent. But, on the other hand, Azzo of Este and the Lombard League attacked Frederick's son, the King of Rome and his German followers, in spite of the opposition of the Pope, who had a deep sense of moral obligation, and was as stern to himself as to others. The new allies of Frederick had at least been connivers at heresy, and this strengthened their hands against the Guelph party, which had bought Papal support at the cost of lighting the fires of perescution within their gates. Yet Frederick, the astute politician, intrigued with and was friendly towards the Patarines of Tuscany, where Papal influence predominated, while he cast dust into the eyes of the Catholic world, suspicious of his orthodoxy, by persecuting them at home. ${ }^{1}$ The jealous antagonism of the Lombard towns to Frederick, though born of a spirit of freedom, did its best to strangle a new idea at its birth-the idea that lay in the mind of the Emperor, as inaugurative of the modern spirit as it was a reappearance of the ancient, the idea of a purely lay government based on law; and this idea was opposed to every instinct of the Papacy. The Lombard War, now coming on, might

1 Perhaps Frederick was acute enough to foresee that a bid for religious freedom would be the prelude to a leap for political freedom, and this influenced his policy towards heretics in his own State. 
have been avoided had it not been for the alliance of the cities with Rome, and their mutual jealousies and arrogant self-confidence. Milan, adopting the ancient Italian policy of always having two masters and setting one against the other, instigated Henry, crowned by his father King of Germany, to rebel ; he was promised the Iron Crown, which had been refused to his father and was jealously preserved at Monza.

The Emperor easily crushed his son's rebellion, but had to employ two years in restoring order in Germany. He arrived, August, 1236, at Verona, accompanied by a body of German cavalry. A senate of eighty members, Ghibelline nobles, then governed that republic, and Frederick, by his address, got Eccelino da Romano named captain of the people, thus securing him both the command of the militia and the judiciary; and since the minds of the Veronese were at high tension and occupied with the triumph of faction, the safeguarding of their liberty was forgotten, and Eccelino became possessed of almost sovereign power. Frederick, obliged to return to Germany for awhile, left Eccelino in the command of both German and Saracen troops. Eccelino, thus strengthened, made himself master of Verona, which he allowed to be ruthlessly pillaged, and, in I237, of Padua, the most powerful, democratic, and Guelphic city of the district. He secured obedience by seizing hostages from the richest and most distinguished families ; instituted a system of espionage, and maintained his authority by a reign of terror.

Frederick returned from Germany in a few months (1237). The adherence of Mantua and Ferrara to the Lombard league was uncertain, for there was a Ghibelline party in most, if not in all, of the communes, and the constitution of those of the marches was such that they were subject to the predominance of great nobles. Cremona, Parma, Modena, and Reggio were under the ascendancy of Eccelino, and were for the Emperor. Pavia held aloof out of fear of Milan. There remained two uncertain quantities-Ferrara and Mantua-and with these towns on his side, the league would be cut up into three districts with no direct and easy communication between them-namely (I) Milan with Brescia, Piacenza, and the less important towns of Piedmont; (2) Bologna with Romagna ; and (3) Padua with Treviso and Vicenza. Eccelino had control of the last-named cities, Ferrara was overshadowed by Salinguerra, a Ghibelline ; and Frederick, through the Ghibelline party in its neighbourhood and in the city itself, possessed himself of Mantua. Here I0,000 of his Apulian Saracens joined him, and he advanced into the territory of the Cremonese to attack the confederated Guelphic army, which was under the command of the consuls of Milan. The Lombards had no other military quality than bravery; they marched on in no sort of order, and singing songs as they went, ignorant that they were being watched and outflanked by an unseen and subtle foe. At last one of Frederick's warriors rode up to them on a white horse, and, in the generous spirit of knighthood, warned them to be ready. Suddenly the Emperor's troops burst from the cover of a wood like a tornado. The Milanese trooped to the defence of their sacred caroccio, and fought throughout the afternoon with stubborn bravery ; its captain hacked it to pieces with his own hands rather than see it fall to the foe. "Cæar himself," says Peter de Vinea, "smote all his foes with his own hand, the Germans dyed their swords, the glad chivalry of the kingdom fought fiercely beside 
their Prince; the soldiery of Pavia avenged themselves on Milan; loyal Cremona and other states cloyed their axes with gore; the quiver of the Saracen was empty. Never in any contest were there such piles of bodies; had not night swiftly overtaken him, not an enemy would have escaped Casar's hands ; it was marvellous how few of our men fell." The defeat of Cortenuova cost the Guelphs I0,000 men; the fugitives, though they fled by night up the course of the Oglio towards the Bergamesque mountains, would have fallen into Frederick's hands had not Pagano della Torre, the lord of Val Sassina, a Guelph noble, hastened to their assistance, opened the defiles guarded by his castles, and thus brought them back to Milan. The citizens of Milan never forgot this service, which ultimately led to the House of Della Torre dominating the republic.

The defeat broke the power of the Guelphs in Lombardy, and the greater number of the cities detached themselves from the League. But Frederick, who had not always the self-restraint and common-sense of his grandfather, now made two blunders : he presented the remains of the caroccio to the Roman senate, accompanied by a pompous epistle, to aggravate His Holiness; and he imprisoned and executed the Podestì of Milan, who had fallen into his hands, and who was a son of the doge of Venice. Venice joined the League against him.

Next year, I238, Frederick passed into Piedmont, and received the enthusiastic support of the cities which hitherto had held back through fear of incurring the wrath of Milan. Four cities alone now remained in opposition-Milan, Brescia, Piacenza, and Bologna-and even those were desirous of terms; but, as Frederick demanded unconditional submission to his authority, they sent him the spirited answer that they preferred to perish, sword in hand. Frederick, having increased by his presence the aristocratic, and therefore Ghibelline preponderance in the communal governments of Piedmont, believed that he was master of the situation. He had yet to be made fully acquainted with the firm texture of the Northern republics. Brescia resisted his repeated attacks for sixty-eight days, and finally obliged him to draw off his weakened and discouraged army.

Gregory, mcanwhile, had seen with alarm an Emperor, thorough master of Germany and the Two Sicilies, on the point of triumph in Upper Italy. The monarch's Saracen soldiers were perpetually passing and repassing through the states of the Church, and their lord would probably soon be master of the Church, towards which he evinced little respect, and the teachings of which he was accused of not believing. Gregory had recourse to Venice and Genoa, states occupied in Oriental conquest and commerce, and which seldom took any active part in the politics of Italy. He represented to them that they also would have their liberties threatened, and that the freedom of the seas would hardly avail them if the Emperor occupied their trade-routes and sat at their gates after destroying the liberty of Lombardy and annulling the championship of the Church. At last he obtained their promise to ally themselves with the four surviving cities of the 'Lombard League, and then he fulminated another excommunication against Frederick (1 239).

The excommunication produced a greater effect than Gregory had dared to hope. All that were interested in the fate of the Holy See, all that desired individual freedom or license, were at one with its policy of 
dividing the Two Sicilies from the huge Empire. Many of the Guelph nobles, who had been seduced by Court favours were distrusted by the Emperor, and were aware of the distrust. The Marquis of Este and the Count of San Bonifacio escaped from the Imperial camp; the principle of freedom again opposed itself to the principle of order, and the Guelph nobles en masse rose in opposition to Frederick, and gave the cities captains habituated to politics and arms.

Frederick had bound Eccelino to his interests by giving him his daughter in marriage; much of the Veronese marches, though partly hostile, and partly recovered by the Marquis of Este, was in strong hands for defence, and yet Frederick frittered away the time in unimportant sieges. Perhaps to the discouragement produced by the heroic defence of Brescia there was added some faint hope of coming to terms with Gregory; certainly we know that the Emperor's movements depended a great deal on the predictions of his astrologers (Rolandini, de fact in March Trev., L. $i v$., c. I 3 ). He finally arrived at Pisa, and secured the devotion of a republic ever Ghibelline and jealous of its rivals, Genoa and Venice, that had declared against him. He married his natural son Enzio to a rich heiress of Sardinia, whose former husband had supported the pretensions of the Pope there to the prejudice of Pisa, and made him titular King ; but he discreetly kept Enzio on the mainland, employed in military service, and confirmed the rights of Pisa in that island. Then he marched southward, and the Roman populace, hitherto on the side of Gregory, wavered, and showed signs of mutiny. The Pope, in extremity, appealed to their superstition or religious devotion. Preceded by a bit of the true cross and the heads of St. Peter and St. Paul, he advanced to his cathedral, accompanied by the cardinals, and blessed the crowd as he passed along. He fanned the little spark of enthusiasm that began to kindle at the oratory of the mendicant friars: he used them to preach a crusade against the Emperor. Frederick gave up hope of possessing himself of Rome, and retired to Apulia. All the land behind him was ablaze. Town fought against town-nay, party fought against party in the very streets of nearly every town near Rome. Gregory supported the people against their lords elsewhere, their lords against the people in his own domain. The result of the crusade he had preached was that, at Perugia, "fathers fought their sons, and sons drew their swords against their fathers, and Italy became pandemonium" (Zeller, Hist. d'Italie). Gregory had declared the Emperor dethroned. But the rulers of Europe had felt how heavy the hand of the Church could be, and Frederick's cause was their cause. Saint Louis himself, the devout King of France, replied in severe terms, and told Gregory that he tried to trample on every crown. Frederick had given the Pope tit for tat, and spoken of him as Antichrist; he expelled the Papal agents, the mendicant Orders, from Sicily, taxed the clergy, and forbad all intercourse with the Holy See. The Pope sought to strengthen his anathema by summoning a general council. A considerable number of French prelates embarked on Genoese galleys to be transported to the Council. The Pisans lay in wait for them at Meloria, attacked them, sunk three vessels, took nineteen, and carried the bishops to Pisa, where they languished in the Pisan Duomo. Though their chains were of silver, no such deadly insult had ever been offered to the Holy See. It broke the aged Pope, and ended the stormiest 
of Papal reigns; he died fourteen weeks after the battle of Meloria. The college of cardinals consisted now of but six or seven members, and as a Pope could only be elected by two-thirds of the votes, and as Frederick could turn half of them to account, the election lagged. And as Frederick very truly said, each cardinal was so near the throne, that it went to his very heart to give it to another. The blame of the delay was cast on Frederick; he spoke to the cardinals in terms in which no prince had ever addressed prelates before: "I speak to you, O sons of Belial," said he, "to you, sons of Ephraim, herd of perdition; your guilt is it that the whole world is in disturbance; on your head rests this world-wide scandal." He harassed them, threatened Rome, and only retired at their contrite prayer. At last (1243) the new Pope was elected. Up to that time, though he came from Genoa, his house had inclined to the Ghibelline side, and he was the intimate friend of the Emperor. But Frederick knew full well what would happen. "I have lost an active and ardent friend from the college of cardinals: I behold a new Pope who will become my bitterest foe!" he exclaimed. Nevertheless, he did all he could to set himself straight with the Church. He sent his High Chancellor, Peter de Vinea and Ansaldo de Mari, a member of a Ghibelline and Genoese house, to offer his congratulations and to express his desire to submit, while he proposed to marry the Pope's niece to Conrad, his own son and heir. The new Pope professed an ardent desire for peace, but demanded that Frederick should release his prisoners and restore his conquests. Frederick, on his side, required the Papacy to withdraw its protection from the Lombard towns, and to recall its legate, who was fulminating a crusade there against him. The negotiations dragged on, for, in spite of their protestations, neither side had come to put much faith in the other. Their relative strength stood thus: Frederick had been obliged to part with a portion of his forces, for Moslem cavalry had entered the duchy of Austria, and was threatening Vienna; the Papal party still held out in the north of Italy, but Frederick was master of the south, and was intriguing with the Roman nobles. The Pope dreaded lest he should be seized and carried off by the Imperial troops, so, disguised as a soldier, he rode by night to Civita Vecchia to the Podestà of Genoa, with whom he had been in correspondence, who was in command of a strong Genoese fleet. This conveyed him home. It was given out that 300 Tuscan horse had tried to seize him, but that he had evaded them, which is a story hardly consonant with the presence of the fleet. Innocent IV. showed himself to be a man of cunning, enterprise, and resource. It was evident that another strong man sat in St. Peter's chair. Frederick published to the world the fact that the mendicant friars had tried to corrupt his courtiers and take his life ; it is probable that he really intended to seize Innocent and confront him with the criminals (Petri de Vineis Epistola).

Innocent summoned a universal council. Such a council was really necessary. Christendom was losing ground both in Europe and in Asia. But Innocent IV. had a small nature and a vindictive spirit. "Let us slay the dragon," quoth he ; "we shall soon do away with the snakes." The council assembled at Lyons. Taddeus de Sassa and Peter de Vinea represented Frederick. The immutable silence of the eloquent Peter was ominously strange. Taddeus made a warm and stirring defence. 
He urged that Frederick only awaited the amity of the Papacy to place his person, his treasure, and his forces in its hands for the defence of the faith. "What guarantee do you give ?" asked Innocent. "The best that Christianity can afford," retorted Taddeus-" the Kings of France and England." "We do not want to place our friends in an invidious position," replied Innocent, "for it is the habit of your master to break his oath." The council then adjourned. At its next meeting Taddeus again took up the defence with more than his usual courage and skill; he debated the charges point by point, and finally declared that Frederick had already arrived at Turin on his way to appear in person. The Pope brooked no delay: twelve days was all the time he gave, and that only at the intercession of the English and French ambassadors. Frederick knew that condemnation was certain: he did not appear. In vain did Taddeus point out that the council was not fully representative, as it should have been. Innocent, without even consulting the council, read aloud to that awe-stricken auditory his solemn condemnation and excommunication. He said that the Emperor had been wanting in faithfulness to the Holy See, whose vassal as King of Sicily he was ; that he had violated the peace concluded with it more than once; that he had sacrilegiously imprisoned the cardinals and prelates who were going to council; that he had committed heresy in treating excommunication with contempt, and in allying himself with the paynim whose customs he had adopted. "We, therefore, who unworthy stand on earth in the place of our Lord Jesus Christ, We to whom have been addressed these words: 'What thou bindest on earth shall be bound in heaven,' We, having deliberated with our brothers the cardinalate, and the holy council, declare this prince unworthy of Empire, of his kingdoms, and of all honour and dignity. God rejects him, and will have him no longer to reign. It is for Us to denounce and declare only, that he is bound by his sins, rejected of God, deprived by the Lord; and We confirm it by Our sentence also. We discharge and absolve all that are bound to him by oath of obedience, and expressly forbid them to perform it. They who shall aid and abet him as Emperor or King, them also do We excommunicate, in the mere fact that they do so. Let a new Emperor be freely elected. As to the kingdom of Sicily, We and our cardinal brethren will deliberate." When the Pope had ceased, the cardinals, who held lighted torches, reversed and extinguished them; and Taddeus, beating his breast, went out crying aloud : "Day of anger, tribulation, and grief ! Heretics, pagans, be content! Saracens and Turks, attack without pity or fear !" "I have done my duty," replied the Pope; "with God be the rest."

When Frederick heard the news, he called for his crown and put it on before the assembled court. "It is still here," said he; "neither the attacks of the Pope nor the decrees of the council have sufficed to remove it ; and I will not resign it but at the cost of blood." He appealed to the princes of Europe. "How can you obey the sons of your subjects," he urged-" men who grow fat on alms, and then turn on the benefactors of their Church ? If I succumb, it will be all over with you."

The Pope had, indeed, unfastened the box of Pandora. Matthew Paris tells us that those present at the council heard the sentence with astonishment and dismay (Math. Parisius Hist. Ang. ad an. I245). An anti- 
emperor in Germany; the Italian towns, that needed no encouragement, egged on to warfare; Sicily, only kept in order by the strong hand, urged to revolt: what a witches' broth it meant! The men of letters, the jurisconsults, grammarians, and poets, the nobler of the nobles, all who inclined to freedom of thought, all those who had enjoyed the patronage and protection of Frederick, did not forsake him. The Papacy, however, was strong in its despotic rule. To achieve absolute power, it had abased the prelate and exalted the humble mendicant monk. "There was no longer an aristocracy in the Church powerful enough to disobey. It had, in fact, become a tyranny. The Papacy had employed the fervour of the Orders and the wave of religious enthusiasm which animated the masses and launched the crusades, to build up the theocracy and to arrest the advancing tide of speculation. The mendicant monks preached a crusade against the Ghibellines ; the Pope wrote to the Sicilian communes, telling them how much he loved them, and how truly paternal he was. "He feels for you nothing but pity ... he casts about to assuage your sufferings, or even to procure you the happiness of completely setting you free. Seek you, in your hearts, how you can shake off the chain of servitude, how you may make your community blossom in the liberty of peace. It is bruited among the nations, that as your kingdom is distinguished by its noble character and fertile soil, so, by Divine aid, it will unite the glory of an assured liberty to its other gifts." Was the issue of this appeal likely to be liberty or license ? Mendicant friars plotted with nobles to assassinate Frederick. Frederick declared that the Pope had instigated these conspiracies; that the priests had confessed that they had their orders from the Holy See, and he wrote indignant letters to all the princes in Christendom. He had lost all confidence in his High Chancellor, Peter de Vinea, since the council of Lyons. Peter had been a mendicant-scholar of Bologna, possessed of a passionate love of letters, and of no inconsiderable facility therein. Frederick had detected his ability and taken him up. He had made him his right hand in reforming the laws and encouraging learning, and had relied on him as his mouthpiece. Peter expressed Frederick's views in his own pure and persuasive style. Either Frederick became unjustly suspicious, or, as Matthew Paris says, Peter really attempted to poison his master. The subject is very obscure, and the accounts of it are contradictory. A generation later Dante believed him to have been innocent. Frederick condemned the chancellor to be blinded; and whether the sentence was just or unjust, he exclaimed, many times before he pronounced it: "Alas for me! What a man must I punish !" Peter committed suicide ; and readers of Dante will remember meeting the man "who held both keys of Frederick's heart," in the dismal wood of the self-murderers.

\section{"L'animo mio, per disdegnoso gusto Credendo, col morir, fuggir, disdegno Ingiusto fece me, contra me, giusto."}

(My spirit in disdaintul mood, thinking to escape disdain through death, forced me, though just, to be unjust to myself.)

Frederick confided Germany to his son Conrad, and the exclusive government of the Veronese marches to Eccelino. Eccelino imprisoned his foes, real or suspected, in loathsome dungeons; he put them to death by 
prolonged torture, or allowed them to perish by starvation. In the strong family feeling that existed in the Middle Ages each family was a unit and centre of moral control and political action, and bound to a common course of offence and defence. Eccelino converted the relatives and connections of his victims into foes ; these, also, he attacked, and the more foes he felled the more he was compelled to strike. Milan, Bergamo, Mantua, and Brescia became more firm than ever in their determination to resist an Emperor who had no thought of attacking them. Guelphs that had been expelled from Parma gathered together, while the preaching of monks in that city inflamed the Parmesans, and when the Parmesans were ordered to attack the exiles they turned round on the battlefield and joined them. The friends and relatives of Pope Innocent IV. re-entered Parma, and intercepted Frederick's lines of communication from Apulia to Pavia and the Mont Cenis, as well as to Verona and the Trientine Pass into Germany. Frederick was determined at any cost to recover Parma, and he sent one of his natural sons, Frederick, titular King of Antioch, with a large body of Saracens to the siege. The Lombard Ghibellines assembled under the command of another son, Enzio, the titular King of Sardinia, and Eccelino arrived with the militia of Padua, Vicenza, and Verona, and the soldiery of his hereditary fiefs. On the Guelphic side Milan led the way, followed by the militia of Mantua, Piacenza, and Ferrara, while the exiles of Reggio, Modena, and other Ghibelline towns went into the city to defend it (I 247).

The militia of Pavia saved the hostages given previous to the revolt; they declared that the sword of the Ghibelline soldiery and not the Emperor's hangman should secure his throne. Frederick vowed that ho would raze Parma to the ground, but his camp was surprised and pillaged, and his soldiers dispersed in a sortie while he was away hawking, and he was compelled to abandon the siege (I248). In Tuscany he had better fortune ; he sent the King of Antioch thither, accompanied by German cavalry ; and, by concert with the Uberti, the Ghibelline leaders in Florence, a city torn by faction, the King got possession, while the Ghibellines demolished the towers of their Guelph foes, expelled all Guelphs, and constrained the other cities of Tuscany to declare for the Emperor.

The check sustained at Parma drove Frederick back to his kingdom, though he left Enzio at Modena to continue the war, while the Pope sent his legate to urge the Guelph cities to pursue their victory and punish the Imperial party for its revolt against the Church. The democratic republic of Bologna, famous for its university and its wealth, undertook to sustain the Guelph cause ; it forced the cities of Romagna to declare for the Church, and then turned to the attack of Enzio's army. Enzio lost the battle, and being separated from his friends by the hurry of retreat and the obscurity of the night, was betrayed to the encmy by the sheen of his golden locks, and taken a prisoner to Bologna, where his release was stubbornly refused to his father. Here he remained, splendidly entertained, but strictly guarded, until his death many years later. Frederick had lost many of his wisest councillors and his nearest of kin by death or capture; his courage failed him ; he offered to divide his Empire among his children and to abdicate. But the Pope would have nothing to do with that "brood of vipers." Henry was a Hohenstauffen, and the Hohenstauffen were the enemies of the Church-that was enough. There was nothing to be done 
with the Church ; it had excommunicated Frederick because he would not go to the Holy Land; it excommunicated him when he went there ; it had refused all his efforts to compromise; it was inveterate in its policy of hate. Frederick's star was declining; fortune had turned against him ; he began to feel the terrible loneliness of the throne as well as that no less terrible loneliness that comes when the friends of our youth are departed and the illusions of life dispelled; he became morose, suspicious, even cruel. He called in more Saracens to revenge himself on Rome; he dreamed of calling in the Turk; he left North-east Lombardy to the tender mercies of Eccelino. But once more the brilliant diplomatist reappears in Frederick, and reminds us of the lustre of former years. Saint Louis was in Cyprus (1 249) and in want of provisions. He and Frederick, the pious King of the Middle Ages and the first King of the modern world, appear to have always had a regard for one another. Frederick was at war with Venice, but he not merely gave the Venetians a free pass to succour Louis but sent a convoy of stores himself, and expressed his regret that the Pope prevented him from joining in the crusade. Saint Louis and Queen Blanche implored the Pope to come to terms, but the Holy Chair was implacable, and ere long the defeat and captivity of Louis and the death of Frederick spared the Pope any further importunities ${ }^{1}$ ( I 250). Innocent IV.,

1 The intimate character of this, the most brilliant and fascinating figure of the Middle Ages, is very difficult to determine. He made a good Christian end with a philosophical reflection on the vanity of human desires, clad in Cistercian habit, and, after due confession, absolved by the Bishop of Palermo. Yet, if he had any Christian belief at all, it certainly was not the orthodox form demanded by the time. Among the infinite variety of his accomplishments he was acquainted, not merely with the scholastic philosophy, but with that of the Mohammedan world, and his recorded jests and observations on religious subjects show him to have been far from a good Churchman. His constant endeavour was to relieve the world from the yoke of Rome, while at the same time he tried to establish his own absolute power, the only way possible in these days to effect his object. In this, as in so many respects, he was born out of his due time, and he anticipated the later absolute sovereigns of Europe with far more culture and intelligence, if with like Oriental voluptuousness. M. HuillardBréholles was of opinion that he wished to become a pontiff-emperor, but there is nothing of the pious enthusiast in his character, nor was he a man who lived with his head in the clouds. He was an opportunist, not a theopath. The union of the two offices, of which Maximilian dreamed, would have been an idea alien to Frederick's age. In all probability he had a metaphysic of his own, and his final acceptance of Christian dogma was due to the usual rule that men who have just flirted with speculation, and who are disheartened in the quest for truth, or worn down by the cankerworm of care and the failure to find the heart's desire, turn in their last hours to the religious teaching that has fallen from the dear lips of those who first loved them and fostered and gave a bent to their young fresh impulses. Hence, by a psychological law, in spite of the superstructure of reflective thought, first impressions usually remain the bed-rock of our inmost being, which denudation may expose. Another problem partly discussed above is that of the severe laws and penalties that Frederick urged against heretics in his own immediate government, while he favoured them elsewhere; but it must be remembered that in the fourth Lateran Council (1215) it was decreed that rulers who did not aid in the extirpation of heresy were subject to excommunication and deposition. While, therefore, Frederick gave perfect toleration to Jew and Saracen, otherwise, he allowed the Church of Rome to pursue her own course 
who, if the Papacy had drawn Italy into a bloody quarrel, had at least saved her from Imperialism by his combined doggedness and craft and his uncompromising hostility to the sway of the Hohenstauffen, came back to Genoa in triumph (125I). Milan turned out its population en masse, and gave him an ovation; he held his court there as if he sat in the place of the dead Emperor; he gave the city a podestà, launched his thunders against Eccelino, reconciled the factions, and claimed Sicily for his. But when he arrived in his own special episcopal city of Rome there was no ovation, nor was he allowed to make his conditions before entering the gates. With anxious solicitude that the Father of the Church should not wander without homestead or fireside, the Senator of the city brought the Pope into the midst of his most faithful subjects, and treated him no otherwise than had been the immemorial usage of Roman sheep to their Pastor. And the arrogance with which Innocent treated Milan, a city that had emptied its treasury and then given its podestà carte-blanche to raise money for the Papal cause by any means he found possible, was never forgiven, and had no small influence in giving the Ghibelline party power in that city.

In the Middle Ages there was but one principle of unity common to the peoples of Western Europe-it was the Catholic Church, and its principles and sway were embodied in the Papacy. Yet, though Europe could be moved to passionate fervour or craven fear by the fiats of spiritual power, it would have been impossible for the Church to have existed as a merely spiritual dominion, as Arnold of Brescia and other reformers had dreamed. The Church was honeycombed by heresy, the Papal city was ever in a condition of disorderly agitation when it was not in violent revolt, and the condition of Rome was virtually the condition of the rest of Western Europe. The power of the spirit had to be sustained by the might of the sword. But the Holy Roman Empire, the "theory of the two swords," contained within itself a principle of perpetual discord. The functions of the Church could not be separated from those of the State ; the " two swords "were in perpetual clash and opposition. The Church would not submit to be a mere office of the State ; the Empire would not tolerate priestly dictation; neither Church nor Empire could exist in subserviency. Yet the Papacy was ineffective without the sword of the flesh as the auxiliary to its sword of the spirit. It was, therefore, compelled by astute statesmanship and diplomatic combinations to keep the balance of political power such that its fiats should determine the course of the nations.

with her own people. For his Christian subjects to remain Catholic was a means to the unification and strengthening of the State, a policy which, later, the Spanish monarchs also carried into effect, and Frederick made religious belief an engine to political ends. Too much importance has been assigned to certain curious phrases used by Frederick. It was the custom of this time, as it was of the Renaissance, to make constant scriptural and pagan applications to itself; thus Frederick speaks of Jesi, where he was born as "Bethleem nostra," and of his mother as "diva mater nostra" ; but it must be remembered that in the theory of the period the monarchy and the succession of St. Peter were both of Divine institution and associated rule. These particular phrases, then, indicate a precursor of the Renaissance, and the latter reminds one of the Christian Church at Rimini, remodelled in the fifteenth century to "diva Isotta," in imitation of the customary homage of Imperial Rome. 
"Divide et impera " was the motto of the Curia. But it also felt the need of some established basis of territorial authority ; it needed the solid factor of a sword of its own, which should enable it to smite effectively when it failed to manage dexterously, and accompany diplomacy with a show of force which it were prudent to respect. Hence when the Council of Lyons deposed Frederick II., the deposition extended to his heirs no less than to himself, and the Papacy thus hoped to come into possession of the Italian South. And when Innocent IV. entered Milan in triumph (I 25 I), he felt confident of success; he believed that he had fully established his authority; he therefore pronounced between the factions, appointed a podestà, excommunicated Eccelino, the cruel vicar of Frederick in the Trevisan marches, and, flushed by the enthusiasm that his presence had excited, presumed on his victory to a degree which was ruinous to his cause in the north. At present the future had a roseate hue. "Let the heavens rejoice and the earth make merry," wrote he, "for tempest and thunder are changed by this man's death into cooling breezes and reviving dews."

(Chief contemporary writers: M. Paris, Hist. Maj. Ang.-Salimbene Chron.-Aragon. Card, Vita Greg. IX.-Ann. Med.-R. S. German Chron. -Chron. Plac.-Chron. de rebus in It. gest.-Annales It. M. G. H. Modern writers: Winkelmann, Geschic te Kaiser F. II.-Huillard-B íholles.Milman.-Freeman, as above.)

\section{THE COMMUNES AFTER THE WAR WITH BARBAROSSA}

\section{Further Evolution of the Commune}

THE smaller cities soon became the vassals of the bigger ; and the exercise of oppressive powers not entrusted to them in their feudal capacity led to the interference of Frederick I. in his double character of King of Lombardy and Head of the Roman Empire. There was municipal war throughout Italy. Milan was the most powerful of the cities and the most grievous offender, and Barbarossa was determined to resume the Imperial power of the Monarchs of Ancient Rome, and restore some semblance of the ancient Roman peace.

During Barbarossa's War all the communes of Lombardy resisted and combined under the hegemony of the Pope to oppose this interference of the foreigner with the rights they had usurped. Yet the tradition of Ancient Rome was so strong, the theory of the Two Swords so generally accepted, the desire for settled order so powerfully felt, and the feudal principle so implanted as the only principle that was in the least preservative of anything like settled government, that Barbarossa, on the acceptance of peace, was at once treated as a legitimate master who had merely exceeded his authority and recognised his mistake, and the cities welcomed him once again as sovereign and friendly ruler. The principles of autonomy and that of the right of the cities to private war were reaffirmed.

No sooner was the war over than we find Bergamo, Cremona, Modena, Parma, Pavia, and Reggio allied against Asti, Alessandria, Brescia, Como, 
Milan, Novara, and Vercelli. In I 99 Cremona tries to subjugate Crema. In the very year following the victory of Legnano, seventeen cities, the great danger being over, return to the Imperial party. Of course the great lords came into this league, which thus contained heterogeneous and discordant elements. Shortly there is universal war again, and worse than before. Milan crosses swords with Pavia; the new-born city of Alessandria fights Asti. From north to south every city is at war with its neighbour. Brescia draws swords with Bergamo and Cremona, Cremona with Crema; there is war in the territory of every commune eastwards right up to and including Venice; there is war beyond the Po down to Faenza and Forli, Ravenna, Rimini, and Cesena. Across the Apennines Florence fights Siena; Pisa, Lucca; even Rome and its little neighbours are at bitter feud. All sorts of cross alliances are formed and dissolved, and are mixed up with the great contest between Innocent and Otho IV. All this was considered as legitimate. Barbarossa himself led the league against Cremona to save Crema from subjugation, while in I 203 Cremona vainly implored the Emperor to dissuade Bologna from attacking Modena. Parma disregarded the Imperial representative resident within her gates. And the great maritime republics were equally bent on each other's destruction. Genoa and Pisa warred together in II 87, I 195, I 196, and I205. Pisa seized Syracuse, promised by the Emperor to Genoa; the war spread into the settlements in Asia, and the Levant became the theatre of the contest.

But the principle of association, the instinct of freedom, none the less spread rapidly. All around the great cities little communities copied municipal institutions, the neighbouring gentry being the leaders and patrons of the infant republics, though in form they were often vassals of the free commune. The nobility residing in the city were allied by blood or marriage with the houses of those great lords who still remained independent, and who were the natural enemies of the commune. Such were the Marquises of Montferrat and Este, and the Count di San Bonifazio. The feuds of the cities, internal and external, simply played into the hands of the territorial nobility, who found profitable fishing in these troubled waters. This territorial nobility, now for the most part compelled to obey the magistrates, help the city in defence and attack, submit to taxation, and observe laws that had some regard to the equality of all before the tribunal of justice, found themselves for the first time collected together, capable of united action. But this danger to the commune was counteracted by their mutual jealousies and family feuds, and the presence of a nobility of wealth-people such as the Scaligeri, who became rulers of Verona, and were the descendants of traffickers in oil. The old and new nobility formed associations like the various trades of the city. Thus at Florence we find the territorial families led by the Uberti opposed to the civic families led by the Buondelmonti, and at Milan there is the organization called Motta, of Milan burghers, opposed to the Gagliardi of country squires.

Besides the territorial gentry and the "popolo" there were the tradespeople of inferior grade and occupation, and artisans (the arti minori), and the lowest classes. These had at first admission to the parliaments, but no voice in the government of the city, or in the nomination of its magistrates, or in the taxes which they were called upon to pay. They 
were descendants, for the most part, of those who had fled from feudal service to secure the freedom which entrance within the city-gates gave them. As Lanzani says, the mediæval commune, like infant Rome, was recruited from the lowest class of the people (Lanzani, Stor. dei com. It., p. 307). Soon, however, the number of voters at the parliaments of the growing city was reduced, and a struggle became inevitable between the "popolo minuto" and the "greater arts"- that is to say, between the disfranchised and enfranchised, as well as between the burghers and the squires. The latter, bringing their fierce habits and rough retainers into the city, were a very undesirable element, and would have been intolerable but for their service as cavalry. Civic right always stood between the wind and their nobility; it offended the haughty arrogant notions they had derived from Teuton forebears, and they were for ever introducing the spirit of the gau, of the contado into the civitas (Lanzani, p. 308). And from the last years of the twelfth century the city is the arena of perpetual family feud, and when the disturbers of the peace are ejected they carry on the quarrel outside the walls and through the countryside. In Milan the nobles even formed an organization, known as the Credenza dei Consoli, to keep political power in their own hands. The smaller gentry, descendants of the vassals of the great lords, had another society known as the Motta, organized like a commune or a trade-association; the rich burghers had another guild called Paratici, and the populace its Credenza di San Ambrogio. All these associations had statutes and judges, so that there were positively four organized communes within the Commune of Milan. At Piacenza the citizens were obliged to expel their nobles, and then had to go out and try to defeat them in battle on account of the manner in which they tyrannized the district (I 2 I 8 ). They returned in I 221 , and were soon expelled again. In Milan intestinal dissension continued throughout the period between the two Lombard leagues, and in 1221 the nobles and archbishop were expelled from the city, and there was civil war.

We have spoken of the importance of the Guild system to the mediæval town. During these tumultuous times the real principle of growth, of development, and even of continuity, lay in the increasing power of the trade-associations. These were the only really stable elements in the ferment of wars, great and private, of perpetual contest and internal feud. In the far-off days of the Roman emperors associations had been formed, which under stress of invasion had assumed a military character (schole militium); when times became a little more settled, schole artium, or associations of those practising the same trade appear side by side with the military organizations. Probably these quietly developed during the rule of the Lombards. In the twelfth century we find organizations existing in Rome of members of the same nation and also of the same trade. These associations, or guilds, in Lombardy contrived to obtain charters from the Imperial power when they were obscure and unimportant. The obtaining of these was discreetly managed in as unobtrusive a way as possible, especially during the struggles of the suzerain with his vassals, and of the Pope against the Emperor. It was necessary to be diplomatic, as privileges had to be secured which limited feudal authority, and were likely to rouse the jealousy of neighbouring towns. As has been explained, communal government arose from the combined and collective representation of these trade bodies, and these were ever ready to seize powers 
in moments when those hostile to them were in no position to contest the usurpation. The commune had little to show by way of charter for its exercise of authority, but the memory of the old Roman municipalities was still a tradition, and the citizens regarded their assumptions as the reinstating of their cities in their old liberties and rights. The organization of the city may therefore be compared to that of certain low forms of life. Decapitation did not mean death ; there were always nerve-centres capable of directing vital action, of reco-ordinating vital functions, and of repairing mutilations. So long as the guilds remained, so long was there organized authority present, the possibility of reconstruction on social lines of no inferior kind, of development and of immense recuperative and potential power. A commune might be apparently destroyed root and branch, but as long as a few little burghers were left there remained in them an organic principle of recrudescence ever ready to usurp liberty as the tyrants usurped power. We have said that small traders and the great mass of the citizens were unenfranchised. Even in the time of the greatest extension of political power to the masses in Florence (1494) there were only 3,200 who could call themselves citizens, and the city contained nearly 100, ooo inhabitants (Villari, Savonarola). If we may judge by the analogy of the Tuscan towns, which, though they developed their institutions much later than those of Lombardy, were acted on by the same natural causes and manifested in all essentials the same evolution, only those of the more important occupations had citizen rights. Probably mention of " the people " never means more than superior burghers, who, it is possible, were, as in Florence, subject to a special tax, and therefore had a more or less direct voice in the management of their guild, and who were summoned to the popular assembly. This was not so in some, if not in all, communes at first, but when all heads of houses had civic rights their privileges did not long endure ; the mass of the people were specdily ousted and ignored.

For many centuries there could not have been found a square yard of ground that was not claimed in some way by the warrior-caste that had conquered and made themselves lords of the whole land. For the conquered, half-freedom or serfdom was the condition of existence. The third law of Rothari, King of the Lombards, condemns to death anyone attempting to escape from his province (Leges Langobard), and wardens of gates and captains of vessels were subject to the heaviest penalties, extending even to capital punishment, if they aided the fugitive. The first effort of the towns was to recover their freedom and rights in the products of labour. We have seen that by the thirteenth century the landed gentry of Italy, where the possession of real estate carried nobility with it, demanded that government should be exclusively vested in them on the ground of birth, and for the dignity of the communes with which they were incorporated. The food-supply of the city was still to a large extent in their hands; they had struck their roots in the land, and had a stake in the country, wherein there was a coincidence of their personal with communal interests. While commercial wealth was of a fluctuating character and at the mercy of revolt, it was largely put out to interest with foreign powers and dependent on their good-will, and was not subject to the jurisdiction of the commune. The trader gave no security. to society of his loyalty and obedience, and we must repeat that the aristocracy 
were, by their military character and by the fact that they were the cavalry of the army, the natural leaders and the most effective arm of the service, and, owing to their connections, they were specially qualified to deal with foreign affairs- both by knowledge, training, and influence. The merchants, many of whom possessed real property in the country, but whose wealth derived from that source was inconsiderable compared with the income that accrued to them from commerce, bore by far the greater share of the charges of the State. The general increase of wealth had been due to, and was maintained by, their efforts, and if the food-supplies came from the soil it was their wealth which had furnished the means of working it and enhanced its value; and while they were freemen, the noble, holding in fief, was not really free; he was the man of his lord, and was often called upon to sacrifice his personal interests and those of the community to the service which he owed. Moreover, the factions of the nobles were disturbing elements in the State, which tended to paralyze public affairs, and initiated cleavage in the burgher-class. The end of the fierce struggle between the landed gentry and the new men was the entire defeat of the former. Otho of Frisingen tells us that in his time, at the close of the twelfth century, there was hardly a noble in Italy who was not in subjection to the towns, and at the close of the thirteenth century the nobles as a class were absolutely excluded from government. The communes were ruled by traders or by nobles who had become traders. Thus, later, the priors of Florence were members of tradeassociations actively engaged in their calling (Ordin. Justitia. Rub. 32 ct 90); the "nine" of Siena were merchants of the middle class (Malavolti Storia di Siena); the "ancients" of Pistoja were citizens, and no one of noble lineage, or classed among the nobility by way of punishment, could be clected (Jacopo Maria Fioravanti). In Modena a register of the aristocracy was kept, and burghers guilty of the kind of disorders which characterized that class were also placed on this black-list, and all those whose names were inscribed were excluded from public office (Antiq. Ital. medii avi L. IV., Dissert. LII.). Bologna, Padua, Brescia, Pisa, Genoa, and all the free communes followed suit. This expulsion of the aristocracy from power was followed by disorders of the gravest character. Class-rule of the more important sections of traders was much more favourable to the agriculturalist than was the government of the aristocracy which had preceded, or than that of the monarchies which succeeded it. For owing to their trade-relations with foreign countries, where all they desired was freedom for their dealings, the merchants had some rudimentary notions of economics, often fallacious notions, it is true. They were rendered capable of excellent foreign policy, and valued and maintained at home, at least for themselves, the liberty which they so often desiderated abroad. But the opulent classes kept the government strictly in their own hands. They alone were the men who had training in affairs on a large scale, who had experience in foreign concerns, and capacity for foreign policy. That the conduct of the State should be in the hands of "popolani grassi," traders like themselves, excited the jealousy of the small traders and artisans, and their efforts to obtain a proportional share in the government caused frequent convulsions in the State. Ofttimes certain of the nobles sided with the new claimants to the franchise, and, worn out by disorder, we shall find that nearly all the Italian republics ultimately fell into the hands of despotic rulers. 


\section{Guelph and Ghibelline Feuds}

We have mentioned the famous feud between the two houses of Uberti and Buondelmonte at Florence. We have now arrived at a period when certain families got preponderating power in their party, and were recognised as its leaders ; round them their party was wont to gather for the street fights that were of almost daily occurrence-fights in which (except when it arose in its wrath) the populace took no share, but only the nobles and their dependents. These leading families represented the opposite sides of the big burghers and the big nobles; later they represented the big burghers and the new claimants of political power, the little burghers. And often we find a family descended from Teuton conquerors champion. ing the popular cause in both these contests.

In 1215 , Buondelmonte, a Guelph squire of the upper valley of the Arno, demanded in marriage a young lady of the Ghibelline House of Amidei, and was accepted. Villani tells us that while everything was being got ready for the nuptials, a lady of the house of Donati stopped Buondelmonte as he passed her door, and, bringing him into the chamber where the women of her household were at work, raised her own daughter's veil. The maiden was of surpassing beauty. "Here," said the mother, " is the wife I had reserved for thee. Like thyself, she is of Guelph family; yet thou takest to thyself a bride from the enemies of thy Church and race." Buondelmonte was won over ; entranced by the beauty of the girl, he wedded her. The Amidei called the Ghibelline families, with whom they were connected by blood or had close relationship, together. There were twenty-four of these family clans, of whom the Uberti appear to have been the chief, and it was determined that Buondelmonte should pay with his life for the affront he had put on their order. He was attacked, just as he rode past the Ponte Vecchio at the base of the old classic statue of Mars, which still stood there, and was slain. Forty-two Guelph families assembled and leagued themselves to avenge him ; and it was indeed attempted to atone for blood by blood. For thirty-three years the sun hardly ever set except on some scene of blood in the streets of Florence. That political reasons were really at the bottom of the protracted vendetta is evidenced by the fact that the same men who feasted together one day would draw their daggers against one another the next.

This devolution of contest to leading families and their allies took place in every city. Thus we find the great and noble family of Este, allied in blood to the Welfs, at bitter feud with the Salinguerra at Ferrara; and the San Bonifazio warring with the Montecchi (Montagues) at Verona. There can be no doubt that though the chroniclers record the exciting causes of the feuds, questions of class-rule were at the bottom of them. Often a whole quarter of a town was burned down. In II72 Verona was practically destroyed by fire; in I 206 the Montecchi burned the burghers' shops. With party spirit and faction running so high, and class claims unduly enforced on the one hand and refused on the other; with the cities competing with each other for trade and territory, and at perpetual war, the consolidation of Northern Italy was utterly impossible ; and, indeed, the feudal notions of privilege and possession were too deeply rooted for the appearance of such an idea to have been possible. The 
little people, ground down by poverty and hard service, sought protection of the aristocratic side, that gladly took up their cause, encouraged them to riot, and sustained them during the disturbance. In Alessandria and other places we find the "popolo minuto" going over to the Ghibellines, to oppose the rich burghers. Thus aided, the down-trodden class improved its material condition by a genuine democratic movement, and in Florence the movement even succeeded in seizing and holding the reins of government, for a time, in the fourteenth century. But the movement appears to have been one of the inferior traders and artisans only; less skilled workmen were ignored, for they had not much intelligence or knowledge, or the means of properly organizing themselves, so that even this democratic movement was not one of the whole people, but only of the class next below that which possessed political freedom. There was not a trace of stability of any kind in Italy except the stability of trade; the practical business-like Italian, as keen as a Yorkshireman as to the "main chance," somehow contrived to keep production very active. But, politically, topsyturvydom reigned. One day the successful burghers would succeed in freeing their commerce from taxation by the "leisured class"; the next day the other side would " come up" and reverse their legislation. The great number of consuls under varying names is an evidence of some attempt at compromise. We can thus account for the twelve and then fourteen priors at Florence, and for the rule of one "monte" with nine representatives, and then of another with fifteen at Siena.

\section{The Podestà}

It is obvious that consuls with opposite interests to serve, or a consulate that had gone into commission, was hardly likely to prove highly efficient. Authority divided against itself could not well be expected to keep the peace. In I 53 the jurisconsults of Faenza had induced the citizens to call in a Faentin to preside over their tribunals and preserve order among the nobles; and Barbarossa took up the idea and exercised his Imperial authority by establishing an Imperial representative, called the Podestà, in each city that he subdued. The institution was discovered to be of such value in the preservation of peace within the city and in rendering the city effective against foreign foes, that it became rapidly adopted. The cities chose their own Podestà, even when they rejected the Imperial representative, and an office of so much dignity was eagerly accepted by the great lords. We find a non-Imperial Podestà at Verona in II63, at Vicenza in II70, at Treviso in II73, at Padua in II74, at Parma in I I 75, at Lodi and Bologna in I I83, at Florence in I I84, at Milan in I I86, at Pisa in II9O, at Genoa in IIII (Atto tannici I primi tempi della liberta florentina. Lanzani). The Podestà was elected by the Parlamento. The qualifications for office were that he should be a foreigner as far as the city was concerned, of noble birth, not less than thirty-five years of age, famed for valour, of high reputation, and trained in law. $\mathrm{He}$ did not present himself for election. The best men were usually secured, because they were sought for. If the invitation was accepted, the new Podestà took office for a year, and received a sum varying from 70 silver liri at Faenza to 2,000 liri at Milan. At the expiration of office he had 
to give an account of his stewardship, and was conducted home with all due honour. His functions were to sentence, see that punishment was carried out, preside at communal meetings, personify the commune, declare and conclude war, and lead the militia. He was helped by a chancellor, notaries, bailiffs, and other officers, who constituted a bodyguard; these also were foreigners and gentlemen. He was not allowed to bring his wife, children, or relations with him, nor to become familiar with anyone, nor to give or attend banquets. Moreover, he was called upon for reparation if he did any unlawful damage during his term of office, and was often ejected before its termination. In II94 the good people of Bologna seized their Podestà, cast him into gaol, and drew his teeth, a proceeding which gave rise to the practice of the Podestà invariably requiring hostages from the city over which he went to preside.

The office of the Podestà was anything but a sinecure. In II96 we find the Podestà of Genoa reducing the fortified towers of the houses of warring factions to fifty feet from the ground; in I 225 the Podestà of Modena was powerful enough to raze all the towers; fifteen years earlier the two parties in Cremona took up their abode in two separate regions of the city, and each half-city had its own Podestà; in I I I 2 there were two Podesti required at Bologna; in 1223 two at Lodi ; and often they disappear; but the office is invariably reinstituted. The effect of this personal predominance and representation of the commune was naturally to still further exalt certain great noble families who became remarkable for the distinction of their services, and so led the way to the election of a trusted person for a term of years, or for life, as lord of the city. Once become lord, it was only a question of time until the office became hereditary and the powers of lordship more and more absolute. As early as I 208, Este so far abandoned the interests of his Order as to accept the perpetual lordship of Ferrara, and become the first citizen of that republic.

\section{The Continued Contest of Rival Families for Dominance}

Under Guelph and Ghibelline banners there were arrayed the forces of privilege and aristocracy, usually supported by the masses on the one hand, and by the bigger traders, who wanted to preserve their hardwon privileges for themselves, on the other. Compromise had been tried many a time by the readmission of the ejected nobility. It had failed. Proscription of the defeated was now regarded as the only remedy for the ills that vexed the State. The triumphant party turned out its opponents scot and lot; the exiles sought shelter in cities where their own party dominated ; they sought aid as well as house-room, and were wont to return and besiege their native city. Such friends as remained inside were always ready to yield the city by treachery, or even to start civic war in the streets. If reinstated, it was not long before the returned exiles were again expelled. Everywhere faithfulness to a party was placed before civic patriotism. In I2 I I we find Cremona aiding the Marquis of Este to recover Ferrara ; eleven years earlier, nobles, exiled from Brescia, get help from Cremona. Incidents such as these could be multiplied a hundredfold. But all is done in the Guelph or Ghibelline name, and each movement is a responsive throb to the swayings of political parties over the Alps. Speaking broadly, it is always the old aristocracy that is 
Ghibelline, they assume the badge of the house that ever asserted its political independence and opposed the interference of the Church; while the Pope, as bishop of the turbulent republic of Rome, was a convenient rallying cry for the new aristocracy of trade. But purely civic, family, and personal reasons speedily became disturbing and complicating factors in the strife. Yet, on the whole, a city was Guelph or Ghibelline according as the bourgeoisie or nobility happened to dominate it at the time; and a city changed its colours by reason of its having undergone spontaneous revolution, ending in the expulsion of one party and the return of another, or of a revolution induced by the revolution of some neighbour. Since, however, the contest is, in the main, restricted to the war of clans, the city, with all the associated industry that it contains, becomes of increasing value; and where Frederick would have razed to the ground, at a diet of the Ghibelline cities assembled at Empoli in 1260 , when the envoys of the neighbouring republics of Pisa and Siena urged that, for the security of the party, Florence should be demolished and its people scattered, since its population was devoted to the Guelph cause and irreconcilable to the nobles and the Hohenstauffen, and that democratic habits had become second nature with its inhabitants, and when the diet received the proposition with favour, Farinata degli Uberti rose, indignant at this suggested abuse of the victory to which he had just led the party. He is said to have protested that his city was even dearer to him than his Ghibellinism, and that he would join the Guelphs and lead them to a similar victory rather than consent to the ruin of what, in all the world, was next his heart. He carried the day, and is immortalized by Dante as the saviour of Florence (Inf. x., 88-93). In Italy the feudal spirit took the direction of faction, of anarchy; the general opposition of all the cities to each other, now that they had become the chief political factors, combined with the absence of the monarch and the presence of the Papacy to prevent that concentration of power in the Monarchy that took place in other countries; and it was only commercial industry, freed from military service, first, by the localization of disputes within gentes, and then, by the employment of mercenary troops, that not merely saved the country from decay, but made her foremost among European lands in trade, science, and literature.

In the time of Frederick II. we find that, wherever the burghers have chief power, the cities are inimical to him; while the privileged aristocracy, accustomed to rule, aid him in his attempt to repress disorder. The towns knew well enough that whatever his promises might be, he would, by the force of circumstance, have to rule them by means of the aristocracy, acting as his lieutenants, and they resisted a cast-iron system of order which would have prevented their free development. They thus found themselves in opposition to a noble attempt to cast off clerical interference, to establish lay culture, and to reduce the Empire to order. Once again the antinomies of ordered rule and free development were in battle-array.

No sooner was Frederick gathered to his fathers, than we find a struggle cnmmencing between the big burghers and the excluded classes. The not present hims-associations have acquired some little wealth, and because they were $\mathrm{s}$. exclusion from government, though often they Podestà took office fos do the old nobility of the city as distinguished liri at Faenza to 2,oond country magnates who have come to reside 
there. Civil war is common-nay, often continuous, and the city loses its unity, though sometimes, as in Florence, where the old city nobility and the burghers are strong and able to resist the grandi, there is comparative peace. The nobles had no difficulty in finding leaders; such were the Uberti of Florence, the Lambertazzi of Verona, the Visconti of Milan. Yet, in spite of the strife, the men of the trade-associations wcre unwilling to follow one of themselves, unskilled in command, and were unwilling to obey an equal. Hence there arose a splendid opportunity for the ambitious noble among the grandi who sought supremacy. Many grandi took up the burgher's cause, and we find rival houses contesting for predominance; one taking the noble, the other the popular side; of such were the Torriani and Visconti of Milan, the Geremei and Lambertazzi of Bologna; while other examples would be furnished by each one of the scores of Italian republics. These families, as we have shown, repeat the old quarrel, each on their own small stage, while the working city keeps the ring fairly well. Their ups and downs are as a barometer, the reading of which indicates the sort of weather that Empire or Pope and Angevin are experiencing. The cities rejoicing in the rule of the Podestà allowed these contests to go on, for they became little more than the struggles of ambitious gentes, and the fight concentrated itself within the clans ; outside members of the clan, even, were only too glad of peace for themselves. Occasionally there are, indeed, risings of the populace to help one side or the other, and proscription proceeds merrily, so thát all Italy is the scene of an ever-shifting warfare. The head of the predominant faction, called in as Podestà, was soon yielded power for five years, for ten years, for life. Sometimes he is called " elder," sometimes " captain of the people," sometimes even "lord"; but whatever his name, the fact of his sway remains.

An interesting instance of how "tyranny" was even now establishcd over some communes is furnished by the early career of Eccelino da Romano. Verona and the surrounding cities were aristocratic republics, Verona being governed by a senate of eighty members, re-elected annually. The senate of 1225 , being favourable to the House of Romano, ejected the Montecchi from the city and made Eccelino III. of that house, a favourite of Frederick, their Podestà. Eccelino contrived to get the consent of the senate to the introduction of an Imperial garrison, and was thus enabled to consolidate his power ; he became the chosen leader of the antiLombard league of the loyal cities of Cremona, Parma, Modena, and Reggio. The adjacent republics of Padua and Vicenza endeavoured to surprise Verona during the temporary absence of Eccelino ; but Frederick was in the neighbourhood and on the alert: he took Vicenza. Gerard Maurisius, a native of that city, tells us how the German soldicrs seized and dragged him, half-naked, about the streets for three days, and pillaged his house. The town was confided by Frederick to the care of Eccelino. The Paduan government was at this time entrusted to sixteen nobles, and Ghislieri of Bologna, who was acting-Podestà, detected that a Ghibelline conspiracy was afoot among them, and ordered them all to withdraw to Venice. All but one revolted directly they left the city walls, and the citizens, deprived of their leading men, were weak and irresolute. It was openly said in the market-place that they were as a rudderless ship before the wind; and, indeed, since the Guelph Marquis of Este had 
made his peace with Frederick and Eccelino, they had little support to count upon. The exiled nobles were ultimately recalled, and they sent to Eccelino offering to place the city in his power. He put back his helmet and kissed the gates of the town as he passed through them. After some stage-play and affectation of modesty, he nominated one of his creatures as Podestà. Then he ordered the three towns under his control-Padua, Vicenza, and Verona-to support a hundred German and three hundred Saracen soldiers to protect the Imperial cause. The Guelphs retired to their castles, and Eccelino took advantage of this to demand hostages of those who remained, and he asked the more considerable of the citizens to give a proof of their love of peace and their fidelity to the Emperor, by retiring from the city for a few days, assuring them that he had heard reports concerning them to which he gave no credence, but which they could thus easily disprove. Twenty of the leading families took his advice, whereupon he had them all secretly seized and shut up. Noble citizens now began to flee from Padua, but Eccelino invariably razed their towers and houses, so that half Padua was in ruins before he had done with it (Rolandini). He forced all his subjects to enter the army, thus using the very means that might have overthrown his tyranny to sustain it (I237). Eccelino then attacked and took the fortresses of the Marquis of Este, his hereditary enemy, though many of them were esteemed to be impregnable, and the work took him ten years. He subdued Feltro and Belluno, cities on the Alpine slopes, and ruled all the cities of the Venetian plain by his creatures, the Podesti whom he appointed. In every human being, as observers of children will have noticed, the love of power has a tendency to exhibit itself as cruelty; this unamiable tendency, meeting with no restraint, and encouraged by the severities customary in the warfare of the period, got the upper hand of a nature otherwise marked by great ability, crafty statesmanship, and indomitable personal courage. Eccelino developed a thirst for blood and a lust of cruelty which seized every excuse for its gratification, and did not spare young or old, or even his own blood-relations; and he made his name an execration and an astonishment to the nations. And no hand seems to have been raised against this, the first, and perhaps the worst, of Italian tyrants, although a chained prisoner contrived to slay one of his infamous creatures, the Podestà of Verona, on the bench itself; and it was whispered that " he who is willing to die is master of the life of the King" (Rolandini.Monachus Patavinus). Such a monster was, nevertheless, regretted by the commonalty, in whom he found his real support. He destroyed the power of the privileged classes, which they abused, as ruthlessly as the French Revolution, and by the same methods, and his death was regretted by the herd, who preferred one master to many. After the Pope had preached a crusade against Eccelino and he was overthrown, the cities under his sway recovered their freedom; but the continuity of their development was broken, and they soon fell under the dominion of despots again.

\section{RURAL Districts, ETC.}

Ruval Districts. - The nobles, to strengthen their position against the towns, instituted village councils. This was the case in Ambra, I 208. Sometimes the count administered justice in circuit, and sometimes he 
could not pronounce even a legal sentence without the assent of an elected board. Attendance at the popular assemblies was compulsory on all adult males, and there could be no modification in the statutes without popular consent.

Reprisals, or the right of any aggrieved citizen, after proper representation and formalities, to revenge himself on all or sundry of the city to which the aggressor belonged, persisted through the palmy days of the communes, and only quite ceased at a very advanced period of the fifteenth century.

Serfdom, abolished in the communes of Lombardy, still lingered in those of Tuscany; the Florentines only abolished the institution in 1289, and then they only did so to cripple the arrogant Guelph nobility. Fideles, there, could hold land in fee or by paying rent, and could emancipate themselves from bondage to the soil by payment. Bologna, in order to weaken the power of the country squires, had abolished serfdom twenty-three years earlier. The advantage of having direct contributors to the State was gradually recognised in the thirteenth century; but it was two centuries later that the last vestiges of villeinage disappeared.

Early mentions of the Constitution of some of the Smaller Communes of Tuscany. - We learn that in Lucca the guilds formed a council representing the different wards of the city, and each ward was commanded by a military prior. This popular council had its eye upon the Senate, and acted as a check upon it. A Podestà, under the name of Pretor, was at the head of affairs (Mem. e doc. per servir alla storia di Lucca, l., iii., par. 3, pref. p. IO).

Pistoja had a similar constitution to that of Florence, and the exercise of power was divided between a Podestà and consuls. The Podestà was sometimes a native (Status civ. pist. Mur. Antiq. It., V., 547).

Volterra had an elected Podestà and consuls, but no council (Carina Notozie, storiche della citta di Volterra, Pisa, I758, p. 24).

S. Gimignano had first (II 8 I) three or four consuls, annually renewed by the bishop; and from II 99 a podestà, supported by a council of fifty and a popular assembly for grave occasion, summoned by the ringing of the great bell (L. Pecori, Storia della terra di S. Gim. Fl., 1853, pp. 37-64). The same casting off of ecclesiastical dominance which took place in the Lombard communes occurred here several generations later. But all the Tuscan communes were late in developing.

\section{ROME}

\section{From the Ascent of Barbarossa (i i52) to the Concordia with Clement (i i 88)}

WHEN Barbarossa ascended the German throne, he treated the addresses which he received from the Roman people with contempt. They were couched in the usual pretentious terms; they who alone had the power and right to confirm it offered him the crown of Empire. He was bent on subjugating the rebellious cities, and on teaching them their proper 
place in the Empire, and he agreed with the Pope to receive the crown from him, and to subjugate the Romans to his temporal power. The Romans took to arms, and Arnold ceased to treat with Eugenius. The nobles, relying on Frederick, now began to support the Pope. Nicholas Breakspeare (Adrian IV.), the only Englishman who ever became Pope, a man of strong character, and of great fixity of purpose, succeeded Eugenius; and Arnold launched his thunders against him with greater vehemence than ever. Frederick was in Italy, and the Pope felt strong enough to issue his curse against the city. It is difficult to-day to realize the effect of this interdict-the first that a Pope had ever dared to issue against his own metropolis. Baptism and the communion to the dying were still administered, but in the most appalling forms. Marriages were blessed in the churchyard. All other religious observances were suspended. Alarmed at the savage and uncontrollable excitement of the populace, the trembling senators fell at the feet of Adrian IV. and begged him to raise the interdict. Arnold of Brescia himself was a good Catholic, and no one in those days questioned the spiritual authority of the successor of St. Peter.

"Two massy keys he bore of metals twain

(The golden opes, the iron shuts amain)."

Adrian " shook his mitred locks, and stern he spake." He demanded that Arnold should be expelled from Rome. This was done, and the reformer took refuge in a neighbouring castle. The Roman republic had bid for the support of Frederick Barbarossa by offering him the Imperial Crown. The claims of the Papacy were little to Barbarossa's taste, but this offer, coming from a revolted city at a time when his own towns of the North were in rebellion, was an affront. He might have liberated the Empire from the Roman See by acceptance, but he would have broken the theory of its constitution, and his temper was not of an order to accept delegated authority from a decayed and capricious mob that called itself Roman. The abolition of the republic and the delivery of Arnold was the price Adrian asked fos the Crown. Frederick had Arnold seized and delivered to the Pope, and before the Romans had time to recover from their surprise, he was hanged and his body burned in that city to secure the freedom of which he had devoted so long a period of his career. Rome fell into the hands of a potentate clad in an authority all the more fearful because it was supported by spiritual pretensions that were universally yielded to a Prince who was also allowed to be the chief depository of that majesty of the Roman name of which the city was so proud. Rome was dependent on its pilgrims for its daily bread; there was no sound burgher class growing up, and it was torn as no other city, even in mediæval Italy, had ever been torn by the discords of a nobility which the Papacy had created and maintained, and which the citizens were potwerless to chain. The condition of Rome was entirely different from that of the towns of the North; they had repudiated the sway of both Emperor and Bishop; the one was an alien sovereign, who could only manifest his authority fitfully; the other was only a priest who had assumed the temporal character of count. But the Bishop of Rome had temporal and spiritual claims which appealed to the sentiment and reason of the times. The passion for liberty, for the right of free develop- 
ment in Rome, may well have appeared to Arnold's followers to have been dissipated with the smoke of his funereal pyre. But on the day when that noble and exalted spirit suffered for the freedom of the people and the purification of the Church, the flames by which the citizens were first informed of his death were a fire of such nature as could not readily be put out. His dream of freedom never really perished. Seven centuries later his name was still remembered, and served to animate, not merely the restorers of Italian liberty, but the common people of Rome.

Too late, indeed, the blaze of the burning stake aroused Rome; the citizens armed themselves and rushed to the spot; the papal forces repelled them, and they were unable to achieve more than the sad consolation of gathering the ashes of their leader with reverent hands. Arnold being thus done to death, Adrian proceeded to Viterbo to receive Frederick. The Emperor was in the full flush of manhood, and convinced of the justice of his claim to be the fountain-head of the Roman Empire. He was the same man who in his old age had his self-confidence so little shaken by experience that he informed the Mohammedan of his "coming to avenge the defeat of Crassus, and to restore the Empire to its full limits under Trajan." "Bellorum amator, sed ut per ea pax acquiratur" (Rad. Fris.), the man of his age, and reaching its highest standard, he was the last man to abase the monarchy at the feet of the Pope, and this at a time when the Papacy appeared to be, in fact, as it was in his theory of the fitness of things, dependent on him. He neglected to hold the Papal stirrup and aid the Pope to descend. Adrian held his power by virtuc of the Imperial protection; but had he acknowledged this, he would have been no Pope at all. He, also, was a strong and resolute man. He would allow no breach of reverence, and he refused to acknowledge Frederick, and to give him the kiss of peace. It was pointed out to Frederick that he was violating precedent, and that the required homage was done, not to the Pope as a person, but to the Pope as representing St. Peter. Frederick had the rare quality of being resolute without obstinacy; he was ever amenable to reason, and gave way (Murat. Antiq. ex. Cencio Camerario). Presently the deputies of the Senate came out from the city, and informing Frederick, in their wonted " high falutin " manner, of the ancient universal domination of the city, of its escape from the thraldom of the Papacy, and of its present power, demanded a large sum of silver for the honour they proposed to confer on him. Frederick, who had just been engaged in chastising what he considered to be Lombard insolence, was in no humour to tolerate this kind of pretentiousness; he cut them short, and replied that they were dealing with the wrong kind of person to have conditions imposed on him; that it was the prerogative of the Prince, and not of the people, to command; and that his predecessors had procured their authority over a degenerate people, not by payment, but at the spear's point. Whereupon the deputation, snubbed, not for the first time, in high dudgeon, but possibly with some loss of conceit, retraced their footsteps to Rome (Otho Frising). Frederick now marched on Rome, but found it wiser to take up his position in the Leonine city (which had been fortified by Leo IV. in 848 as a refuge against the Saracens, and only communicated with Rome by means of a single bridge). In spite of its fantastic pretensions and its reliance on feudal nobles, the Republic was virile, and when the Pope crowned Frederick without its 
consent, it made a furious onslaught on his troops. The fight took place on the bridge of S. Angelo, and, though a thousand Romans perished, the attitude of the city was so determined that Frederick was compelled to retreat to Tivoli. A year after (I I56) the Pope allied himself with William of Sicily, and sent the Emperor the overweening missives of which mention has already been made. In Italy, while it cannot be said that there was a truly national party, there was a sufficient feeling of community of blood, language, and interests to constitute a formidable coalition of Italians, who were persistently opposed to the German ruler. The feeling originated in native resentment to the barbarian invaders, and had been growing in range and intensity. When Adrian died (II59), this national party, by a majority of votes, elected Alexander III.; but a smaller number of cardinals, supported by the senate and nobles of Rome, set up an antipope, Victor III. The republic still continued in the hands of the nobles, and excluded the Pope from temporal power. But the populace sided with Alexander. Frederick now made the blunder of allying himself with the antipope, who, because he desired to strengthen his not too strong position, affected a submissive policy. Frederick's policy of supporting the series of antipopes that followed this election exposed him to the undying opposition and perpetual intrigues of Alexander, and forced the Pope into a close alliance with the Lombard cities. Frederick had the unwisdom, not merely to support the schism, but also to oppose the Romans themselves ; though he did this probably from a sense of his duty as the protector of public order. For Rome was fighting with bitter hatred her old battles of the earliest ages over again with the neighbouring cities. She advanced against Tusculum ( I I67) which she found defended by Frederick's German soldiery, and the Italian militia were almost annihilated. Then the Emperor marched on Rome with his antipope in his train, and commenced to besiege it. But while prosecuting the attack, he, nevertheless, tried to detach the Romans from the party of Alexander. For Alexander, acknowledged as the real Pope by everybody except Frederick, had contrived by gold and diplomacy to get himself reinstalled by the Romans on the apostolic throne.

The Roman republic was suffering, like Frederick, from the claim to independence of its subject towns. It was in the hands of a feudal class, which therefore had some sympathy with Frederick's feudal notions. A good deal of water had run beneath the bridges since Frederick had snubbed the Roman nobles ; and Frederick, on his side, perceived at last that the republic, ever threatened by Papal pretensions, was his natural ally. He therefore proposed that the two competitors to the succession of St. Peter should abdicate, and that the church should elect a new Pope, whereupon he would grant the city its ancient rights. The offer was too advantageous to the besieged city not to be accepted, and an appeal was made to Alexander, but the haughty Pontiff replied that God's Vicar was subject to no judgment on earth, neither to that of kings, nor of peoples, nor of the Church. But in order to avoid a forced abdication, he fled to Benevento ; and Frederick accepted investiture at the hands of the senate, which he recognised, but over which he appointed an Imperial prefect. He took good care not to leave the Leonine city, however, until, malaria destroying his army, he straightway departed (II67). Ten years later, by the treaty of Venice, the Pope was again restored to temporal power, 
and the prefect became a Papal nominee. Alexander was invited to take up his residence in Rome; but the fact that the Popes are nearly always found in exile proves that they had by no means the authority over the republic which they claimed. Rome successfully assumed towards the Pope the attitude that had been taken by the cities towards the Emperor. In II 88 a treaty was signed whereby the Pope was to invest the senators and to mint two-thirds of the coinage; he might call upon the militia to assert his territorial rights on condition that he supplied the necessary expenses; and the city reserved its right of private war, and expressed its determination to raze the defences of Tusculum. We are carried back to the earliest days of the city of Romulus, but Rome could not achieve even what the Lombard towns had won, far less repeat her own great career. Badly placed for trade, unhealthy by reason of the neglect of the Campagna, where what was once fertile field had become, in great part, a pestilential waste; her citizens for the most part a mendicant rabble, dependent for their subsistence on the disbursements of pilgrim visitors and the ecclesiastical court; unable even to follow the ordinary development of an ordinary Italian city, because she sat beneath the great shadow of the Papacy, Rome yet remained republican at heart, and so persistent was her aspiration, that even in 1866, seven centuries after his death, Arnold of Brescia's memory was still a power, and her streets were placarded with an appeal in his name. But she was not merely republican; she dreamed dreams and wished vain wishes; she aspired once again to rule the world. Nowhere is that megalomania, which is so great a weakness in the Italian character, and which still manifests itself in the attempting of vast enterprises and undertakings beyond the national power or purse to complete, exhibited in a form so grotesquely comic, and at the same time so pathetic, as in the powerless pretensions of mediæval Rome, torn by the factions of her barbarous barons, swayed by the vain fantasies of a noisy, tumultuous crowd, and dreaming of Empire, while prevented, by the combination of many unhappy influences, from consolidating and developing her own urban freedom even.

What Rome dreamed of, the bishops of Rome were silently effecting. Undismayed by disaster, the Papacy relied on the power of spiritual authority and sacerdotal assumption.

\section{From the Concordia with Clement III. (i i 88) to the Death OF FREDERICK II. (I250)}

When, in I I88, Clement III. made a treaty with the city of Rome, he resumed the right of investiture to the senate, but that body was freely elected by the city itself, and any thought of Papal claim to effective overlordship seems to have disappeared. The city governed itself, and made wars on its neighbours ; it razed Tusculum to the ground; and the powerful nobles of the neighbourhood, dreading the increasing power of the Pope, were very glad to cling to the republic and seek admission to its senate. Petty nobles and burghers now began to be outnumbered by great nobles, and an insurrection was the result, which vested the chief authority in the hands of one Benedetto, a plebeian, known as Carus Homo, or the Beloved (II9I). By the aid of parliaments of the people 
Benedetto cut off the papal receipts, administered and legislated for the city, and even made his authority felt in the surrounding country. In two years he was overthrown by a counter-revolution; the nobles came into power, and one Giovanni Capoccio headed them for another two years. After him came one of the Pierleoni, and then, in I I97, yet another of these periodical Roman earthquakes restored a senate of Henry VI.'s imperialistic nobles. The people were far from satisfied with the new administration, and when Innocent III. ascended the Papal Throne he took occasion of their demand for a donative in return for the oath of obedience to grant it only on condition that the prefect, the representative of the Emperor, should do him homage, that he should nominate the senator, who was by far the most powerful man in the republic, and that he should also appoint to the provincial magistracy. It seemed as if the Roman people had now surrendered every privilege they had ever possessed; the election of emperor, pope, prefect, senator, was no longer theirs. But they were the last community in the world to take the rod lying down. Revolution after revolution followed, and it took all the crafty policy of the Vatican to steer the ship through the troubled waters. The object of the Pope was to nominate a single senator; the object of the people to elect their own representative. At last Innocent and the citizens agreed to a senate of fifty-six members, to be nominated by the Pope, but perceiving that the infirm populace was too sick of contention to resist, the Pope reduced the number to a single senator, who was at the head of the judiciary, the police, and the militia, and who only.differed from a despot in that the duration of his rule was fixed, and that he owed certain duties to the Pope who appointed him (I 205). When the contest began between Gregory IX. and Frederick II. the Ghibelline party drove the Pope from the city, and, though peace was repeatedly patched up, it was as repeatedly broken. The "republic" made war on its own account, brought the neighbouring cities under its sway, minted its own money, appointed its own magistrates, and tried peccant ecclesiastics in its own police-courts. It subdued the Campania and Tuscia, and erected pillars with the high-sounding inscription, S.P.Q.R., to set forth its control. Frederick II. had abetted the rebellion against the Pope, but in 1235, when there was a temporary reconciliation between the two potentates, he lent his troops to Gregory, who was thus enabled to re-establish the constitution of Innocent III. The single senator, thus reappointed, appears, as was the case with his predecessors in the office, to have summoned "consilium vel consilia urbis," and there is little doubt that the usual practice in Italy of appointing a smaller council for the consideration of serious business (consiglia di credenza), and a larger council for the passing of the resolutions of the smaller, was adopted in Rome, the senator being, in fact, a Podestà. Traces of this arrangement are found half a century before, for the senate was then divisible into two committees. During the contest of Frederick with Gregory, Rome was divided into factions : the Guelphs were led by the Orsini, and the Ghibellines by the Colonna, and, in order to preserve something like public order, at first two senators were appointed-a Guelph and Ghibelline, and subsequently the two houses received the office in turn. But although Rome took advantage of Frederick's support to snap her fingers at the Pope, she was too well aware of his aim to suppress feudal independence and municipal self-government and establish 
good government and peace under his own absolute domination, to allow him to enter the city. She repelled him in $124 \mathrm{I}$, although the neighbouring cities had declared for him, and assembled such an army to oppose him that he gave up all hope of occupying Rome.

\section{MILAN AND THE CITIES OF THE GREAT PI.AIN}

Milan took the lead in the first Lombard league; she also led the second league. Far, indeed, from being destroyed by the razing of her walls and houses by Barbarossa, she rose from her ruins with enhanced prestige, and remained the first city in Lombardy. Within ten years of her total demolition her energetic population had brought the waters of the Ticino into the city, and were busy canalizing the Milanese territory that extended to Varese, to Lecco, and to Locarno. Throughout Europe the renown of the excellence of the arms she manufactured was spread, and even the far distant Tartar and Saracen sought them eagerly. During the fight for freedom against Barbarossa many Milanese vowed themselves, their families, and their goods to the Mother of God, whom they invoked to aid them. These "Umiliati " established themselves in the Brera after Legnano, and became manufacturers of wool, and afterwards of silk. The workers in wool soon numbered 60,000. In I 84 the silk industry was brought from Palermo, and in a short time gave work to 40,000 operatives. Money-changing and money-lending were profitable occupations. In those days each trade worked in a separate quarter, and after the Peace of Constance the city walls had to be enlarged, so rapidly was the town growing.

The constitution of the Milanese commonwealth was of a parlamento, or general assembly, of 800 members ; it had been larger, and had included all citizens who had their own bread and wine, but the gathering of a multitude was not found to facilitate business. This general assembly elected a credenza of twelve for secret or pressing business. The consuls, who were the executive body, held their office for one year, and had to report themselves to the credenza, when they resigned, as to how they had fulfilled their charge. The manufacture of armour became an increasingly important industry in this and other Lombard cities, and the great irrigation works of the plain were commenced. In spite of troublous times, the industry of the great plain was amazing, and wealth accumulated rapidly, while everywhere was to be heard the hum and clatter of the workshop.

Directly the glorious struggle of the Communes of Lombardy against Barbarossa had ceased, diversity of interests within the towns began to manifest themselves; there was antagonism between the nobles and the citizens, and between the lower order of artisans and the richer burghers. In I 85 Barbarossa had permitted Milan to elect her own Podestà. The fact that the city required one indicated the presence of internal dissension, and many towns found it convenient to adopt the institution in order to quell the rise of faction through the growing number of nobles that had been admitted to citizenship. The Milanese deprived their consuls of 
judiciary power, and entrusted it to the Podestà. He was, in some ways, a kind of dictator. To him alone belonged the right of capital punishment, and this "power of blood" was emblemized by the naked sword which was borne before him. Thenceforward we find him supreme judge, assisted by jurisconsults and assistants in council, and possessed, when occasion required, of the might of martial law. He was always chosen from another town in order to secure impartiality, and from the nobility on account of their social importance and habits of command. $\mathrm{He}$ was usually changed once a year, and his family did not accompany him into the city, in order that he might not strike root and menace its liberties. The Archbishop, who had formerly been count of the town, was still the figure-head of the little state; he controlled the mint, received tolls, and it was in his name that justice was executed. The consuls still remained as magistrates of different functions. The consuls of the commune nominated officials, administered finance, and dealt with foreign affairs ; they were obliged to consult with the consiglio di credenza. The nobles insisted that these consuls should elect their successors, but very soon the people succeeded in getting them nominated by one hundred artisan electors, nominated by the general council, subject to their being selected from the aristocratic body. This law, however, was often ignored by the consuls in possession. There were also consuls of justice, who acted as justices of the pcace, and consuls of the merchants, elected by the various guilds, and these various dignitaries appear to have collectively formed the consiglio di credenza.

Reading between the lines, and putting evidence together, it is impossible to reject the statement we have made that, directly the contest with Barbarossa was over, conflict was renewed between the different orders of society, and that this was the occasion of these constitutional changes. Two years after the institution of the Podestà we find the capitani, or greater nobles, banding together to put down the pretensions of "artisans, butchers, bakers, and such like."

The constitution of all the free towns underwent modifications at this period, and troubles were brewing between the classes of all the communities, which smouldered for awhile and then burst ablaze. Then the struggle recommenced between the Empire and the Papacy, and Guelph and Ghibelline sought the support of the factions that they severally found it advantageous to sustain. Thus, in I I98, there were disturbances between the nobles and popolani of Milan. The latter contrived to have their separate "council of confidence," or Credenza di San Ambrogio. This appears to have consisted of the lesser burghers, and these seem to have found some supporters among the nobles, who inscribed themselves on the various trade registers. The better-to-do citizens, such as merchants and members of the liberal professions, formed another distinct council called Della Motta, and the higher nobles, or capitani, yet another, called the credenza dei gagliardi, with the Archbishop at its head. Each council had its own consuls, and legislated and administered for those under its own jurisdiction. There may have been another council of the smaller nobles, but Verri says that this was identical with the one called Della Motta. In matters affecting the general community deputies from each council were summoned by the Podestà in numbers varying from 200 to I,00o. But, in spite of the clash of interests between the big and little 
burghers, the main division lay between the nobles and the burghers. Their family connections, as well as their subfeudatories and dependents, made the nobles strong. They formed the military caste, and had been the only cavalry that could withstand the onsets of Frederick I. Moreover, they had address and knowledge of courts, and were useful to the city in its foreign relations, and they ordinarily had the support of the Archbishop and Podestà. But, of course, they were not without the usual military and aristocratic arrogance of behaviour, quarrelsomeness, and undue assumption of superiority; and the burghers, as they became wealthy, would not brook this, though, like Mr. Fag in the play, they meted out to their own inferiors precisely the same measure that their superiors had given them. Similar factions formed themselves in other towns. Thus Reggio was divided (II99) between the Mazzaperlini and the Scopazati, and Brescia (I200) between the league of St. Faustin and that of the "Brighella," later known to the stage as the typically plebeian character. Naturally, divisions among the citizens would play into the hands of the aristocratic class, who would manipulate them to their own ends.

But 'not merely were there internal dissensions. Released from a common danger, the towns fell to quarrelling among themselves. In II9I Brescia took several of the rural counts near Bergamo under her protection, with certain castles, which Bergamo thought to be an invasion of its own rights. Since there was an old dispute between Brescia and Cremona concerning the course and navigation of a river, the Oglio, common to both their territories, Bergamo turned to Cremona for assistance. Forthwith the two cities contrived, by exciting the passions or filling the magisterial purses of other towns, to bind Pavia, Lodi, Como, Parma, Ferrara, Reggio, Bologna, Mantua, Verona, Piacenza, and Modena into a common league. The Milanese were the sole allies of the Brescians, and had not yet reached Brescian territory when the allies of Bergamo received a crushing defeat at the hands of the small Brescian army, which charged the enemy with so much élan that they turned and fled, and lost the greater number of their troops either by the sword or by drowning in the river. The field was long known as that of the " dead men." However, Henry VI. on his return march insisted on pacifying the foes.

In I 198 and II 99 there were also furious contests between Parma and Piacenza. Besides these wars of the communes, little wars were carried on by their dangerous neighbours, the nobles of the hillsides, among themselves. All along the base of the Alps and the Apennines a number of robber-nobles were established; and where the hills advance into the plain, as in the march of Treviso, or encircle it, as in Tuscany, eminences which are natural fortresses were strengthened by art, and their possessors were able to hurl defiance at the trading communities below. But the nobles of the plain had, for the most part, been obliged to seek the protection of the cities, and dwelt in fortified houses, with their second line of defence in a strong, high keep; and here they could secure themselves from subjection to the burghers among whom they dwelt. But should their arrogance pass into unbearable outrage, forthwith the Podestà of the city hung out his banner of justice, and his trumpeters assembled the burghers to arms. The fortress was besieged and razed to the ground, and ofttimes the culprit was executed. Thus lawlessness was put down by a general uprising of the citizens, headed by an alien dictator. No 
one appears to have dreaded a further usurpation of power on the part of the dictator; all that was feared was lest he should lean to a party. In Vicenza there were two factions-the lords of Vicenza and of Vivario. Each side nominated a deputy, and these deputies appointed a Podestà. Similarly at Verona the rival houses of Montecchio and San Bonifazio, and at Ferrara, those of Salinguerra and Adelard came to an arrangement concerning the selection of this magistrate. But this arrangement could not last. Factions, impregnable in their castles, nearly matched in their resources, and equally violent and contemptuous of public order, were bound to come to blows; and in doing so, they worked on the mutual antagonisms of neighbouring towns, they contrived to exile the opposite faction therefrom, and they gradually gained an ascendancy therein. The story of the houses referred to is one of base treachery and devilish passion, issuing in bitter hate and involving the towns, not merely in intestinal feuds, but in interurban conflict, and in dependence on the predominant houses. But while this was taking place in the neighbourhood of the spurs of the Venetian Alps and the Euganean hills, the transpadane republics-Bologna, Reggio, Modena, Parma, and Piacenzawere becoming dominant over the neighbouring nobles. In the exceptionally full annals of Reggio we read yearly of some fresh noble submitting to live two months in the town as an ordinary law-abiding citizen, and of the transference of his lands to Reggian government, while he becomes bound to defend the city against enemies. The annals of Bologna, also, are full of similar entries, and, in I I93, the nobles succeeded in exiling the bishop, who was also Podestà, on the ground that he so favoured the commonalty that the authority of the nobles was in danger of destruction. Bologna appears to have had three councils. All citizens of the higher burgher class, from the age of eighteen, constituted the general council ; 6oo citizens constituted the special council ; "the council of confidence" was smaller, though all the jurisconsults of Bologna sat there in their own right. The right to elect members of these councils rested with forty citizens, selected from the four wards of the city by lot, and of whom each set of ten selected its men from its own ward. No initiative could be taken in the councils without at least the sanction of the Podestà or of the consuls; but, on the other hand, nothing could be done without general approval. Usually any motion came from the consuls, and was discussed before the councils by four appointed speakers, whereafter voting on the question took place by ballot. The Podestà and consuls thus had the initiative solely in their hands; and for this reason, in spite of its democratic constitution, Bologna was long dominated by its aristocratic body. The consuls usually indicated the town from which they desired the Podestà to be chosen; he must not be akin to any of the electors within the third degree, nor have real estate within the republic, he must be noble, over thirty-six, and of good repute. The electors, forty in number, were chosen annually by lot from the general and special councils, and, if there was not a majority of twenty-seven votes within twenty-four hours, they lost their right of election.

It is interesting to note that citizens of democratic tendency knew how to turn public disaster to public advantage in a manner not unknown to-day. In I 228, when Bologna had had an unfortunate war with Modena, supported by the Ghibelline cities of Parma and Cremona, her citizens 
took advantage of defeat to rise and force the nobles to surrender their excess of power; and in 1245 they again took advantage of external troubles to still further democratize their institution. The city had a considerable trade with Florence, the intervening Apennines preventing a dissolution of friendship.

In Brescia the nobles had been all-powerful, but when, at the solicitation of Milan, they wished to drag the populace into a war with Bergamo, there was a rising, and the nobles were expelled. The nobles or military society of Saint Faustus allied themselves with the Ghibelline towns of Cremona, Bergamo, and Mantua, while the Brigella, or party of the commonalty, allied itself to the Veronese, and a bloody war ensued. "In the year I200," says a Paduan chronicler, " the populace took away the administration of the town from the magnates and invested themselves with it" (Add. ad Rolandin Reginin Paduce). Thus, as was observed by Bishop Otho, there were few nobles left in Italy who had not come, in some sort, into subjection to the municipalities. The subjection was, however, more apparent than real; they turned defeat into a victory. They were entrusted with the defence of the city; and instead of being scattered all over the country, the members of the caste were now in close association, and they enjoyed the accession of strength that followed some sort of union. Moreover, the Podesti' had a very fine field for training in the arts of government, and contrived in one way or another to apply the instruction when they retired from their year of office. The caste believed itself born to command, and reserved to itsalf the military name. But the citizens were accustomed to political deliberation, they were armed, they had become wealthy, their sires had fought with heroism in a great war for a noble cause, and they would not brook either political domination or social scorn. At Milan, where the Archbishop, whose power had been progressively limited, supported the nobles, the antagonism became so acute that in $\mathrm{I} 22 \mathrm{I}$, the aristocratic body was expelled from that city. It betook itself to its fastnesses, but many of these were besieged and razed by the infuriated populace, and finally the humiliated nobles had to make the best of their failure in order to effect their return to the city. The nobles were also exiled from Piacenza, but there they recovered in the open country, where they were among their vassals, the full force which they had not possessed within the city walls; and by the mediation of the Pope (1221), they were accorded half the rule and two-thirds of the diplomatic offices of the commune. Similarly, Honorius III. had to mediate between the two classes at Mantua (1224, Ann. vet. Mutinens). At Modena, and, in fact, everywhere, the same struggle was going on. In Venezia several astute families were able to take advantage of the contest between Frederick II. and the Popes, and of the never-ending strife of Guelph and Ghibelline factions within the cities, to establish themselves in arbitrary power. At Treviso, Alberic da Romano reigned ; Eccelino, his brother, controlled Padua, Vicenza, and Verona. Ferrara obeyed the Marquis of Este; Mantua, the Count San Bonifazio ; and Ravenna had long been under the sway of Paolo Traversari. The fluctuating accidents of faction excited the most malignant exasperation or acrid ecstasy in the people, and extinguished the pure passion for freedom that erewhile had dwelt in Venezia. In the towns just named there had been dominant families, 
but where the members of the noble order were all more on a level with each other the effect of the despotisms thus established was none the less felt, and they endeavoured to establish unmitigated oligarchies. In Milan matters came to a head in I240. The nobles tried to revive an ancient Langobardic law, which fixed the price of homicide. The plebeians saw that this struck a blow at themselves, and that they were rated at a vile price withal. Moreover, when imposts were heavy, the nobles retired to their country abodes, and, in spite of recent laws which gave an equal share of the government to the two orders, they got hold of all the offices both of Church and State. The populace therefore took the fatal step of calling in (1242) Pagano della Torre as "Protector of the people "- a man who had saved a part of their army after Cortenuova, and whose descendants became tyrants of the city. The other side put itself under the leadership of a fanatical monk-Leone de Parego-distinguished no less by his subserviency to the Pope than for his persecution of heretics, and of whom nearly all the annalists tell the story that when asked by the Milanese, because of his exemplary piety and humility, to choose them a bishop, he replied that he knew no one worthier than himself to fulfil the office, which he, indeed, did occupy, not with humility, but in supporting all the arrogance of the nobles with all the force of his character and will (Ann. Med. anon.-Galv. Flamma Man. Flor.).

Not only was each city in Lombardy divided by factions, not merely was the great league against Frederick in constant conflict with the great league for him, but there were little wars breaking out between neighbouring cities without cessation. Bossi's Hisiory of Italy, in the index to the thirteenth century in the fifteenth volume, is half taken up with such hcads as "Wars of the Lombard Cities," "Private Wars of various Italian Cities," "Other Wars of the Italian Cities," "Fresh Contest between the Italian Cities," "Wars and Tumults in the Cities," "Tumults of Brescia and Milan," etc. In fact, the Italian burgher of those days found his exercise and relaxation in the excitement of a faction fight, or in catapulting a dead donkey over the walls of a neighbouring town; he would seem to have turned out every summer for a few days' campaign as for a holiday.

Since the wars only lasted a short time in each year, and the Lombard land is one of the most fertile on earth, the cities became increasingly wealthy. Some flourished and grew at the expense of others; we find places of great importance in the eleventh century very inconsiderable in the thirteenth. The rich, fat plain gave abundance, and so much to spare that agriculture could maintain the pursuit of commerce in many large cities. ${ }^{1}$ Lombardy became unrivalled in its manufactures, and the practice of lending money at high interest became such a thriving business, that both in France and England the terms Lombard and Banker were equivalent. The annals of Asti inform us that its inhabitants took up the trade in $\mathrm{I} 226$, and made great profits, but also great losses. Thus, in I256, Louis the saint, King of France, seized all the bankers of Asti that were within his domain, and confiscated their possessions to the amount of more than 800,000 livres. Bologna had been famous for

1 Sismondi does not think that so much life was lost by warfare in the thirteenth as in the eighteenth century, and the population of Lombardy certainly greatly increased. 
a school of logic and grammar since the eleventh century; and at the commencement of the twelfth century, lectures were given there on the laws of Justinian by one Irnerius and other famous jurisconsults. In the thirteenth century Bologna became the European centre for the study of civil and canon law ; it was a very close borough, exacting an oath from the professors not to teach elsewhere. The first of modern universities, both in order of time and reputation, Bologna received charters and privileges from Pope Alexander III. and Emperor Frederick I.; and Vicenza, Padua, Modena, Arrezo, and Naples imitated Bologna and contended with it to bear the bell in letters and learning.

The whole reason why the towns were so persistently opposed to Frederick II. is not altogether easy to determine. The tales their citizens had heard from their grandfathers of the terrible struggle against Barbarossa may have rendered them unduly sensitive and suspicious; for certainly their liberties were not directly menaced. But they evidently regarded Frederick's proposal to convoke a diet at Cremona in 1226 and terminate the unhappy anarchy of Italy as a subterfuge. He had erected strong castles to dominate Naples and other towns in Southern Italy and Sicily, and there may have been other subtle indications of Frederick's imperialism, even at this carly period; and, later, their fear was fully justified by the progress made by Eccelino and the family of Romano towards becoming the "tyrants" of Venezia. Nevertheless, at first the towns were not in danger, and they were much divided in their adhesion to the Pope; the contest between Papacy and Empire was not their quarrel, but they made it an excuse for fighting out their own quarrels with each other; and to do this was probably not, indeed, the cause of the renewal of the league, but a great factor in the warfare which followed it.

The war between the different classes of society in the communes became less acute when they perceived themselves likely to be assailed by a common danger in the pretensions of Frederick II. In Milan a compromise was effected in I225, whereby the archiepiscopate was reserved to one of the greater nobility, but other careers, whether military, civil, or ecclesiastic, were thrown open to all. The factions of the city, which at one time had had each its Podestà, agreed to obey a single Podestà, and the nobility, in exchange for predominance in the council of the state, accepted the burden of the greater part of the public debt. A reserve of grain was established, but at the end of each year all storage beyond the reserve limit was sold to the poorer classes, and no organizations were permitted to elect officers without the sanction of constituted authority. During the war with Frederick the nobility succeeded in reaffirming their power throughout the cities of the league; but, directly the cities felt themselves secure against Frederick, we find the Credenza di Ambrogio breaking its engagements, with the captain of the people at its head; the nobles gather round the Archbishop; and the people refuse to march against the invading Pavians. The burghers gained the day, and peace ensued-for a time. By 1247 the Credenza di Ambrogio had come to rule the city, with Pagano della Torre at its head as its ancient. But so impoverished was the city through more than twenty years of warfare, that it had to pledge a famous gold chalice.

Internal and external warfare forced all parties to recognise the ad- 
vantages of a more stable form of government. In I20I the Milanese factions had not been able to get on without three Podesti, one for each party. In $\mathrm{I} 205$, and on to I $2 \mathrm{I} 2$, the city was ruled as of old by consuls, but defeat at the hands of Crema and Parma led to the nomination of twelve captains, and the dissensions of the captains ended in the election, in I 2 I 4 , of a foreign Podestà. The class-struggles led to an arrangement whereby the government was equally apportioned among the contending parties; this happened directly Pavia and Cremona were hostile; but jmmediately on the conclusion of peace, there is discord again, and the citizens take advantage of the refusal of the Archbishop to raise an interdict, to drive out the grandi who supported him as one of their order. All these wretched, petty squabbles rendered dictatorship inevitable, and even desirable, and explain the appearance of one-man power in the cities; for what took place in Milan is but typical of what was also taking place at the same time in every one of the great northern communes.

A word remains to be added as to the constitution of Bologna at the death of Frederick II. The barrier of the Apennines divided the territories of Florence and Bologna, and enabled them to dwell at peace, and even cffect a good understanding with one another. There was much trading between the two communes, and they influenced one another strongly. They fought on the same side against Frederick II., and when the Ghibellines predominated in Florence, Bologna opened her gates to the exiled Guclphs of that city. Bologna stands almost alone in cities north of the Alps for her sturdy preservation of ancient communal forms and the absence of any marked tendency to the establishment of one-man rule. On the death of Frederick, all citizens who had resided in the city for ten years and served in the militia were placed on the electorate; there was a general council of 2,400 members, and a private council of 600 , including the professors at the university. The power of the Podestà was restricted by twelve elders, three being chosen from each of the four wards of the city, and these were nominated by the heads of the tradeassociations. They remained in office for three months, and were not re-cligible until after the expiration of three years. Their function was to guard against abuses, prevent illegal associations from being formed, see that the incidence of taxation was equalized, help to maintain public order, and attend all the meetings of all the councils. No elder could hold any other office; he could, if two-thirds of his colleagues agreed, introduce any proposition of reform, and was flanked by assistants and advisers in the deliberations on any important matters. Lanzani says this body was practically another state within the state. As in Florence, the ancients could not leave the communal palace while holding office, nor might any public functionary approach them individually and in private. In 1253 a captain of the people, who, like the Fodestà, must be a foreigner, was appointed to hold office for a year; the captain gradually invaded the province of the Podestà, to whom he was often in opposition. The councils were convoked by him, and he was practically Minister of Foreign Affairs. The nobility opposed these measures, and sought support from the lower orders. Conflict was frequent, and the success of the Order was hindered by divisions among its members, some taking the Papal, some the Imperial side. The Lambertazzi and Gieremei gradually became the representatives of these factious families, the former being Ghibelline, 
the latter Guelph in their sympathies. As the communes of Romagna, which were dangerously near neighbours, were Ghibelline, the people supported the Guelph Gieremei, while the richer burghers took the side of the Lambertazzi. Riot was the unending consequence. In 1256 there was a reorganization of government. The elders were to be seventeen in number, nine of these to represent the " arts," or trade-associations, and eight a society of arms. They were elected for two months, reeligible in two years, and each ancient was supported by two councillors and eight coadjutors, also elected for the same term of office, and-under the same condition, while the captain of the people was dismissed. No noble was eligible for office unless he was enrolled in a trade-association ; no elder could be present at a deliberation in which his personal interests were involved; and the power of the Podestà was rigidty restricted. The resistance of the Ghibellines, or privileged orders, to these measures only made Bologna more pronouncedly Guelphic. In $\mathrm{I} 27 \mathrm{I}$ the rebellious Ghibellines joined themselves to those of Romagna, while the city leagued itself with the Guelphs of Reggio, Modena, Parma, and Cremona. In this crisis balia (full authority) was given to two jurisconsults and two representatives of each trade-association to arm and purge the city, and thousands were expatriated. As Lanzani observes (Communi Ital., I88I), the nobility excluded from government in 1256 were now excluded from citizenship. Fierce was the result, but henceforward this particular class contest was carried on outside the city. A struggle now arose between the big and little burghers represented by the Maltraversi and Pepoli families.

\section{VENICE}

\section{Venice and Barbarossa: The Fourth Crusade-Taking of Constantinople by the Latins}

THE foundation of the wealth of Venice lay in her salt trade. Not merely was this commodity procurable at home, but Venice later on contrived to rent other sources of supply along the Adriatic coast, and secured the workings of the mines of Austria and Hungary. In every war, whether she achieved victory or met with misadventure, she invariably secured the monopoly of the salt trade to herself, and central Europe was dependent on her for its supply. Her commercial genius, her seamanship, and her skill in shipbuilding, added to her political sagacity, had now made her the rival of Pisa and Genoa in the Eastern trade.

During the wars of Barbarossa with the Lombard leagues, the sympathy of Venice would naturally be with the cities, for the success of Barbarossa would mean the consolidation of the mainland in German hands, and menace her independence. But Frederick was opposed to both the Byzantine Empire and the Normans; and the Venetians had no love for either. Moreover, his ultimate object was to re-establish a universal monarchy, and to recover the Holy Places; and for commercial, if not for religious reasons, Venice desired to see the Holy Land in Christian hands. Consequently, being divided between fear of the growing power 
of Barbarossa and resentment against the animus shown against her by Manuel Comnenus, she gave but lukewarm support to the Lombard league; but, when she discovered that Comnenus, taking advantage of the discords in Italy, was subsidizing the revolting city of Ancona, she joined Frederick in the siege of that town. A serious breach had long been brewing between Venice and the Eastern Empire. Notwithstanding greater wealth, far greater culture, and a unique position, the effeminate Greeks had come to abandon commercial enterprise to the maritime republics of Italy. Their manufactures were unprogressive; they had become indolent and sensual, devoid of honour, and insensible to shame (Nicetas Chon. Const. Stat.). All the Italian coast towns had settlements, by concession, in Constantinople and the Orient; they were self-governing; colonists owned lands and intermarried with the natives of the Greek capital; they were exempt from the vexatious taxes that hindered the commerce of those times. But the Venetian could not conceal his contempt for the timid Greek, and the Greek was incensed at finding his wealth and commerce passing into the hands of the Venetian, who appears to have been the most important of the Italian settlers. The Venetians were specially favoured for the services they rendered when the Normans, under the pretext of seating an impostor, who pretended to be a deposed Emperor, on the throne, attempted what would have been the most brilliant of their exploits, the conquest of the Byzantine Empire and its restoration to the Latin fold. But ill-will had manifested itself between Venetian and Greek, and even in I I52, when the Venetians assisted the Greeks against the Normans, who still held Corfu, violent quarrels took place between the allies, and the Venetians were ill-advised enough to deck a negro slave in the Imperial robes and parade him in a Byzantine ship that was decked out to represent the royal galley. At the earliest opportunity Venice came to terms with the Normans to secure their own Adriatic possessions from the piratical attacks of those adventurers. Such a treaty might be taken by the Empire as indicating an unfriendly policy. Manuel Comnenus had occupied the Imperial throne since I I43. He was bold, licentious, cultured far above the Western standard, and ambitious. His army was full of Germans, Franks, Italians, and Northmen ; and he dallied with the Pope, holding out hopes of his joining the Latin Communion, with a view to getting Papal support for the clearing of Italy from its German suzerains, and the re-establishment of himself, at least in the territory that Belisarius and Narses had conquered and that Justinian and his successors had held. But it misliked him to see the Venetians occupy so prominent a position, and he reduced their importance by extending privileges, not so extensive, indeed, but considerable, to Pisa, Genoa, and Amalfi. He invaded Hungary, and by I I 7 most of the towns of the Dalmatian coast had passed from Hungarian to Greek rule. The Venetians resented the presence of any foreign power in Adriatic waters, and still more the diminished importance of their powerful and wealthy colony at Constantinople. Moreover, Manuel was in possession of the port of Ancona, and the Venetians refused to join him in his attempt to oust Frederick and restore his rule in the exarchate and Pentapolis. Manuel's reply was to fill Constantinople with troops and strengthen its defences, and, when all was prepared, to seize and confiscate all the Venetian ships and property. Venice, to raise funds, issued Government 
stock at 4 per cent.; she was thus the initiator of public funds. The loan was compulsory, but the bonds were transferable. Equipped with the sinews of war, she manned 150 galleys with volunteers, and devastated Eubœa, Chio, and other isles ; but a pestilence broke out, and the plague-stricken ships had to sail home. The public anger at the failure of the expedition and at the introduction of the pest into the city was so great, that the doge tried to take sanctuary, but was slain by the mob ere he could reach it. The Venetians then allied themselves with the King of Sicily and even aided Frederick's vicar in the siege of Ancona ; and Manuel, alarmed at the turn that affairs were taking, once again came to terms with them. In II 82, when Henry, heir to Barbarossa, was betrothed to Constance, heiress of Sicily, Venice found herself menaced by the power of the Empire, reinforced from an Italian territorial base, and gladly entered into a treaty with Constantinople by which she was to receive great commercial advantages in return for supplying an Imperial fleet when called upon to do so. But in I 87 the Venetian settlers were again assaulted, and the turbulent enmity between Greek and Venetian did not decrease. Nor was this all. From the accession of Manuel in I I43, the increasing power of Venice in the Orient was thwarted by the favours granted to her rivals, Pisa and Genoa. Thus, all things ripened for a policy whereby Venice might wipe off her score against Constantinople, secure her power in the Orient, and oust her commercial rivals.

Constantinople, which might have been such a valuable ally, was regarded throughout Europe as an obstacle to the success of the Crusades, and although Venice, as commercial and non-feudal, had not caught the crusading fevers of II46 and II88, as we shall presently see, a wave of the prevalent emotion was about to sweep over her. Now, Constantinople had suffered from the hordes of Northern barbarians in the first crusade ; she regarded Roman Catholicism as heretical and its pretensions and success with "odium theologicum." She dreaded that increase of its power which would necessarily follow from its possession of the Holy Places, as well as the establishment in provinces so near and of which she conceived herself to be rightfully the mistress, of the feudal principle, so contrary to that of despotism. Boniface, one of the crusaders, was also a claimant to part of the Greek dominion. We can thus understand the rationale of the events which we have to recount.

When the fourth crusade was preached, the aged Dandolo, no less courageous than astute, who, though his eyes still shone brightly, was blind, or partially so, offered, in the name of the republic over which he presided, to give transport and adequate defence to 4,500 knights and horses, twice that number of squires, and 20,000 infantry, with provisions for nine months. In payment, he demanded 45,000 silver marks and half of the conquests that might be made. But in those days it was necessary to obtain the consent, first of the six ducal councillors and of the pregadi (ducal councillors), and then of the popular assembly, before these conditions could be ratified. The doge prepared the people by means of preliminary sectional meetings, and I0,000 citizens were then assembled in St. Mark's and the adjoining piazza. Six of the highest nobility of France humbled themselves before these traders and implored their assistance. One of them-Geoffrey of Villehardouin, Marshal of Champagne-has left us a record of his embassy and of the whole expedi- 
tion. Mass was first said, and Villehardouin then made his appeal, during which all six ambassadors cast themselves, with many tears, at the feet of the Doge ; and all the people cried out as with one voice : "We grant it, we grant it!" The republic (1202) fulfilled its engagements with scrupulous exactitude; but, although the crusaders had, not without difficulty, secured the approval of Pope Innocent III. to their convention, many of them evaded their oaths in a most shameful manner. The subjects of the Count of Flanders set off in their own ships ; the Bishop of Autun, Guiche, Count of Forest, and others started for Marseilles to procure their passage thence; a great number found themselves unable to pay their share, and, in spite of generous sacrifices made by the Count of Flanders and others, there was still a deficit of 34,000 marks. The Doge then suggested to the Venetians that they should forgive the debt in consideration of the crusaders aiding them en rou'e to recover the revolted city of Zara, now under the rule of the King of Hungary. Zara, a strong city on the east coast of the Adriatic, when in foreign hands was a menace to the Eastern trade of Venice. The proposal was strongly opposed by those who desired to see the army disbanded, but was, nevertheless, carried. One Sunday the people and the crusading leaders reassembled. Before the commencement of Mass, Dandolo, the Doge, offered to lead and take the cross, leaving the conduct of the State to his son. The high courage, advanced age, and misfortune of the Doge moved the assembly to tears. The Doge cast himself weeping before the altar, and the cross was affixed to the cotton head-dress that designated his high office. And Venetians in numbers assumed the cross then and there.

Up to this point the Venetians had simply supported their rights in a straightforward commercial bargain ; and were not in any sense crusaders. In October the Latins left their quarters on the Lido of San Nicolo, and to the sound of martial music and the strains of "Veni Creator," in pomp and splendour, with display of heraldry, and rich ensigns fluttering in the breeze, the magnificent fleet set sail.

Zara yielded (November I5, I202) after a five days' attack, and the pillage thereof was divided among the confederates. But it was too late in the season to advance, so they wintered there. During their stay menacing letters were received from the Pope, who was incensed at this side-attack on a Christian town. But the Venetians adopted at once that firm, yet respectful, policy, by means of which they always contrived to preserve an independence of the Papacy not known to the other Catholic Powers.

Now, in II95, Alexius had deposed and blinded Isaac Comnenus, Emperor of the East, and imprisoned him with his son, who was also named Alexius. In I $20 \mathrm{r}$ Alexius the younger escaped on a Pisan ship, and appealed to his brother-in-law, Philip of Swabia, who claimed the Western Imperial crown, to aid him in recovering the throne for his father and himself. Philip despatched Alexius to Rome to get the Pope's consent, under a pretence of uniting the Eastern and Western churches. But the Pope refused, and the young Alexius sent to Zara, offering, if the crusaders would restore him to his throne, to bring the Eastern Church to the obedience of Rome, to provide 400,000 marks, and send Io,ooo men to the Holy Land, which he would guard by establishing a permanent garrison of 500 knights at Jerusalem. The hire of the flect 
was to hold good, and Venice to receive roo,ooo marks. Boniface, who led the crusade, was a claimant to the kingdom of Salonica, and the proposal was therefore agreeable to him, and Baldwin and many of the French sided with him, while the Venetians, ever self-seeking and practical, were naturally not unfavourably disposed. But the Papal legates, Simon de Montfort and a number of barons, withdrew. The army demolished the walls of Zara, and reached Corfu, where it was joined by young Alexius.

Beyond all European countries Greece, by reason of its physical character, invites her children to the sea and maritime enterprise, and at this epoch Constantinople shared with Venice the empire of the waves; hence it seemed probable that the approach of the crusaders would be strongly disputed. But corruption and misappropriation of funds found the Emperor unprovided with an adequate fleet. In 1903 the crusaders reached Constantinople. They had before them the task of reducing a city considered to be impregnable. Although the Venetians took the tower of Galata and slipped the chain that guarded the Golden Horn, a general assault failed ; and, in spite of partial success on the part of the Venetians, the enterprise seemed foredoomed to failure. But the cowardice of Alexius the elder led to the loss of the city. He fled by night, and the blinded ex-emperor, Isaac, and his son, the younger Alexius, were led to the throne. Alexius did his best to fulfil the terms of his bargain. He paid roo,000 marks, of which the Venetians received half, besides the 34,000 marks still owed to them by the Latins. But his treasury was exhausted, and he could raise no more without endangering his throne. The crusaders demanded " justice and their bond." Perpetual skirmish went on between Greeks and Latins, and terrible fires in the streets ensued. The crusaders sent a defiance to the two emperors. The angry Greeks replied by attempting to burn the Venetian flect; and their indignation with the young monarch, who indulged in drinking bouts with the Franks, waxed greater and greater. Dreading a revolution, he invited Boniface to garrison the palace. Alexius Ducas, surnamed Marzonfle, from his dark and shaggy eyebrows, seized and imprisoned the younger Alexius and his father. Alexius died, probably from poison, and Isaac from grief; and Marzonfle ascended the throne. The feud between Greeks and Latins continued, and the latter agreed again to besiege the city. The second assault proved successful; a handful of crusaders entered the virgin city and became the masters of the Eastern Empire. They vaunted that, never since the beginning of time, had there been booty so rich. The capital of the East was reduced to a state of degradation and misery, from which it never recovered. The churches, even, were despoiled, and a prostitute was enthroned on the chair of the Patriarch. No compassion was shown : women were preyed upon, chattels seized, and the despoiled nobles of the city escaped from it in rags, amid the insults of a populace which had felt the weight of their wealth and power (Nicetas). Six French barons and six Venetians, representing an army that was vowed to the defence of the Tomb of Christ, assembled to elect an Emperor over the outraged Christian State. They offered the throne to Dandolo, but Pantaleo Barbi, a Venetian, pointed out at once that it was impossible for the first magistrate of a free republic to exercise sovereign power. Dandolo, withdrawn from a candidature 
which he knew his city too well ever to have seriously entertained, thus became the chief voice in the council. Now, Boniface was an Italian lord and a fast friend of the Emperor Philip; Baldwin was less practised as a statesman, less vigorous, and his possessions were less near to Venice. Baldwin was therefore elected.

The conquests of the Republic were entirely disproportionate to the forces at its disposal. Its population could not have exceeded 200,000. Venice, which had so far bcen unable to impose its authority on Padua, twenty miles off, was called upon to rule and defend a vast territory and a vast population. This task was impossible to the State. But an edict was published in 1207 , according permission to all Venetians to alm warships at their own expense, to occupy the isles and maritime cities of the Empire, and to hold them as perpetual fiefs. The Venetian merchants were not slow in profiting by this concession, and maritime empire quickly followed. The Genoese also attempted to acquire a share of the territory, which would seem to have been sufficient for the wants of all the Italian coast-towns ; but the Venetians would brook no rivals. The Empire of the East, thus weakened, became a prey to the invasion of Northern and Eastern barbarians. The fall of Constantinople was the chief cause of the Turkish conquest two centuries later, with its attendant ruin of civilization, letters, and philosophy in a country where they still found an asylum. On the Venetians also it had its effect. Military force and capital were largely transplanted to the East ; in a measure chivalric enterprise took the place of sea-trading and commercial exchange ; it can hardly be that the national character was not changed thereby. Despotic government, necessary in conquered provinces, probably told back on liberty at home. Venice lost the Greek allies that were as barriers against the Moslem, and this ultimately cost her much treasure and seas of blood. It is needless to say that the successful disregard of Papal authority, too, manifested here and throughout her history, was never forgiven by a power which never forgets. And while, by the possession of a chain of islands, she secured to herself the commercial monopoly of the Levant, and rendered herself mistress of the Mediterranean; while she increased her wealth and power, her material greatness, and her political weight and renown; while she obtained a dominion which she held for four centuries, it was at the price of constant warfare with the Turk, whose advent in Europe she had rendered possible.

\section{From the taking of Constantinople (I 204) to the Death of} PREDERICK II. (I250)

Venice had taken the lead in the overthrow of a rule not weak, and of enormous prestige, and replaced it by a government that was one of the weakest recorded in history, vacillating in policy, and unrooted in the affections or interests of its alien people.

The settlement of the possessions she had acquired in the East was no easy matter, and a separatist tendency is shown by the fact that in 1208 her colonists chose a governor without the prior sanction of the home government, and gave him the title and costume of Doge. Eastern affairs continued to distract the attention of Venice from mainland politics ; the Latin Empire was quickly crumbling to pieces; and there is a tradition recorded by Sandi (Stor. civili), that for a moment, in I225, the home 
authorities thought of transferring the seat of government, with all the inhabitants of Venice and the lagoons, to Constantinople, as otherwise that magnificent situation would be lost alike to the Latins and themselves. A "vote of Providence" is said to have rejected the motion by the narrow majority of two. The possession of Candia gave a great deal of trouble, not merely by reason of its frequent insurrections, but because the Venctian citizens were strangely unwilling to settle there. Only five hundred and forty families emigrated, in parties representing equally the six wards of the city ; and this though rich fiefs were to be had for the asking. The constitution of Venice was copied, and four hundred years later, when Candia was conquered by the Turks (I669) the members of the grand council of Candia, which was closed and declared hereditary at the same time as that of Venice, were admitted to the full Venetian franchise, and their names inscribed in the Golden Book. The colony was frequently invaded by the Greeks and Genoese during the thirteenth century; for the Greeks attempted to reconquer the island, and the Genoese to effect a settlement there, thus fermenting the jealous ill-will, due to opposed interests, that already existed between the maritime states. Nevertheless, when Venice thought herself endangered by Eccelino da Romano, Frederick II.'s representative on the neighbouring mainland, who was fast bringing all Venetia under his sway, she allied herself with Pisa and Genoa at the instigation of Gregory IX., and meditated a conjoint attack on Sicily, in return for which she was to receive certain advantages. She did, in fact, acquire Ferrara for the Pope, and established interests there, the defence of which led her on to aggressions, and ultimately to the establishment of an empire on the mainland. At home she was busily employing her wealth in making the city a House Beautiful ; for what Rome was to the ancient Romans, that Venice was to the Venetians-a sacred city whose foundations were in their hearts ; their fervour for her and fidelity to her were stronger than any other passion that glowed, or fealty that ruled, in their breast. Here there was little or nothing of the intramural anarchy that tore to pieces the cities of the mainland. The nobles of Venice were nonfeudal ; they were commercial magnates, having no territorial base ; and secured by her position from attack from without her gates, and, by this peculiar character of her optimates, from the fierce clash of opposing ambitions within, the city had neither walls to girdle, nor fortress-towers to dominate her streets. Her strength and defence was the sea, and she could always command eager volunteers for her fleets, and add to her force by the Dalmatian and other subsidiaries. Although she deemed her position impregnable, she depended on commerce for her existence, and on her navy for food-supplies. Hence her sole safety lay in perfect efficiency; hence, too, all classes regarded the interests of the State as their own and of transcending importance, and they placed general welfare before private ain.

\section{Constitutional Development}

Among the refugees who sought the shelter of the lagoons, there were many of good family; these naturally became a leading caste, separate from the settlers who came subsequently. As the commercial prosperity of the city increased, and she extended her sway over the opposite coast of the Adriatic, the more astute and enterprising citizens acquired wealth, 
and these formed a class whose foreign relations necessitated vigorous efforts to secure order at home, and to conduct, themselves, the relations of the State with the powers and possessions that lay across the lagoons. This seed of a plutocracy was confronted with three dangers : the danger of internal dissension ; the danger of the Doge becoming autocratic ; and the danger of the people, ignorant of foreign affairs and of the mechanism of commercial operations, acquiring power. Not being possessed of a territorial base, and trade in those days being conducted on social principles by means of trade-associations, the spirit of one for all and all for one possessed them. They became a strong oligarchy, and since their own position was secure only so long as the city was contented and flourishing, and their intercourse with other peoples gave them a large scope for observation and the training of political and diplomatic faculty, they developed a wisdom and self-restraint which commanded a ready assent and response from the entire community; and of Venice throughout her career it may on the whole be truly said that-

"None were for a party, All were for the State."

The oligarchy gradually constituted themselves the trustees of the State, and they discharged themselves of the responsibilities they undertook faithfully and well.

The constitutional history of Venice is the history of how this oligarchy contrived to limit the power of the Doge, and to exclude the people from political interference without inducing discontent and danger. In II72, after the disastrous attack on the Emperor Manuel, it was evident that the Doge could act without taking sufficient advice ; a sufficiently strong body of councillors alone would restrain him ; it was also evident that the people in General Assembly were far too numerous, far too subject to the rash manifestations peculiar to the "psychology of crowds" to have the great charge of the safety of the State committed to them. It was therefore established that each ward of the city should elect two representatives, and that these representatives should each nominate forty of the most conspicuously desirable men of their ward to prepare business for presentation to the General Assembly of citizens and to elect officers. At the end of each year the house of 480 members thus constituted was to appoint twelve new clectors, two for each ward, who were to elect the next council.

The plutocracy that had grown up thus obtained possibility for rational debate by a limitation of numbers, a limitation of the electorate for office, and a principle which, springing from the consent of the populace who delegated their authority to the new Council, was the germ of oligarchic government, since each fresh annual council was indirectly nominated by the council preceding it, and not by the people. A check was thus given to democratic control ; a further check was giver to the opposite danger of absolutism by increasing the number of Ducal Councillors to six. The Doge had thus not only a portion of his power transferred to this germ of the future Maggior Consiglio, this new council, which had the appointment of officers in its hands, but he became, although princeps inter pares, one of a council of seven, or senate; and to this senate was entrusted the conduct of foreign affairs and the great matters of State. It could always add to its wisdom by summoning pregadi (special councillors) as before, on 
special occasions, who would naturally be men specially qualified to deal with the grave matters that demanded their services.

On the death of Ziani ( I I 78), the eleven electors who had formerly chosen the Doge gave place to forty, every member to belong to a different family, and each to receive three votes from the four members of the grand council nominated to elect them. Collusion was now barely possible. In I 229 a. further step was taken to restrict the powers of the Doge. Inquisitors were appointed to examine into the manner in which the preceding Doge had exercised his functions, and the result of their examination was the appointment of five commissioners with powers to revise the coronationoath. Tiepolo, who ascended the ducal throne in that year, had to consent to rest satisfied with his salary, to be taxed like any ordinary citizen, and to hold no communication with any foreign power without the full knowledge of the senate. While the Doge was thus rapidly becoming merely a monarch of very limited powers, he was surrounded with increased pomp and ceremony, in order to make the office desirable, and to furnish concrete evidence of the consequence and magnificence of the State. The result of these changes was a stability of government for which Venice is more remarkable than any other power that the world has ever known; and, owing to the excellence of her reputation for wise statesmanship, the communes of the mainland frequently begged her citizens to become their Podesti. It is, however, quite a mistaken notion to regard the Doge as a mere figure-head. Circumscribed as were his powers, he was always a man of large and varied experience in public affairs before he donned the linen bonnet; and the degree of his wisdom and skill in the conduct of public affairs could not fail to make itself felt in the counsels of the Statc.

\section{PISA}

THE Pisans were not merely a commercial people ; they were also warlikeindeed, the most warlike population in Tuscany. The strongholds of the neighbouring Apennines reared a race of hardy barons and country squires, who were ever ready for the fray; and the rich plain gave wealth and influence to the landed proprietors of the State. Twelve miles off, however, was Lucca, an agricultural centre and manufacturing city; such a near neighbour was, of course, an implacable foe; there were always questions of pasturage, boundaries, right of way, and baronial pillage to foster enmity, and feeling ran so fierce that Dante sarcastically says that God planted the high hill that intervenes between the two cities so that they might not have to look one another in the face. Trade rivalry with Genoa gave Pisa yet another foe. Florence, who required a sea-board free to her morchandise, was on extremely good terms with Pisa throughout the early history of both states ; and so, in I 69 , Genoa, at war with Pisa, got the support of Lucca, while later on Guido Guerra, the most powerful of the Tuscan nobles, joined his forces to those of aristocratic Pisa; and still later, not only Florence, but also Siena and Prato gave her their alliance, for the port of Pisa was as necessary to them as to the future Queen of the Arno. At the time when Frederick's vicar, Christian, drew near, Pisa, aware that Frederick was inclined at the time to favour ${ }^{\circ}$ Genoa, sought the alliance of Constanti- 
nople. She had much commercial dealings with that city, and Genoa was her rival there. Christian tried to constitute himself arbiter of her disputes, but Pisa refused, and, wroth at her alliance with the Greeks, he put her to the ban of the Empire (II72); but shortly afterwards he removed the ban, visited Pisa, and suggested certain preliminaries to a treaty of peace to be ratified at a diet in the neighbourhood. His conditions were exorbitant, and the Pisans refused to acquiesce, whereupon he traitorously seized their envoys and cast them into prison. Pisa and $\mathrm{F}$ lorence at once declared against the Emperor, while Siena, Pistoja, Lucca, and the lords of Umbria and Romagna supported him. Pisa beat Lucca, but got rather the worst of it in a sea-fight with Genoa. In I I90 Genoa and Pisa placed their transport service at the disposal of Henry VI., who made them extravagant promises of grants in Sicily ; $\bullet$ but his expedition came to naught. In I 192 Pisa obtained all the regalian rights over a large tract of territory, as well as Corsica, Elba, Capraia, and Pianosa in fief, exemption from billeting soldiery, and the emphatic confirmation of her free institutions. Consequently, she alone of all the Tuscan towns refused to join the league of I I97, in spite of the entreaties of the cardinal-envoys of the Pope ; and henceforward she led the Ghibelline party in Tuscany. Since Florence was the great banker of the Pope, that city became the leader of the Guelphs, and war broke out between her and Pisa in 1222 . In 1228 Pisa defeated the combined troops of Florence and Lucca, and in the same year she sent a large fleet to the Holy Land to support Frederick II. Genoa and Pisa knew quite as well as Venice how to turn the crusades to commercial advantage. But Genoa was rapidly gaining on Pisa ; that city had the finest harbour in Italy, as well as many good and safe anchorages along her coast. Pisa was not so fortunate ; behind her lay a plain, and on the plain was the city of Lucca, her implacable enemy; while Genoa was defended at the back by the lofty chain of the Apeninnes; the harbour of Pisa, also, was at some distance from the city, and constantly silting up. Nevertheless, in spite of her natural disadvantages, Pisa took a slight commercial lead, and her people, while at least equally warlike,were perhaps a little less disunited and quarrelsome than the Genoese.

One of the causes why Pisa took the Ghibelline side was the encroachment of the Papacy on her rights in Sardinia. The "judges" of this island were ever at war with each other and appealing now to Genoa, now to Pisa, for aid ; the result was that the flames of jealousy and commercial rivalry were ever fanned, and the Mediterranean was again and again stained red with sanguinary conflicts between the two powers. Now, it was the policy of the Popes always to support the weaker of the Sardinian nobles, so as to keep the government of that island from consolidation; and in I 206 Innocent III. tried to increase the Papal power and to terminate these conflicts by marrying an important heiress to his cousin; he demanded, in vain, that Pisa should resign her rights to the island. Gregory IX., who was a nephew of Innocent III., acquired by this marriage some lands and rights in the island; he also tried to pacify the insular feuds by a marriage arrangement ; and the bridegroom, the most important feudatory in Sardinia, acknowledged the pretensions of the Church, and abjured the sovereignty of Pisa. On his death, Frederick married his son Enzio to the widow of this feudatory, and gave him the empty title of King; while he confirmed Pisan rights over the island. 
If Pisa was for the Emperor, it behoved Genoa to be for the Pope. Genoa conducted a war along her mountain frontier against the Ghibelline feudatories of Pisa, and suppressed her Ghibelline faction at home ; she sent her galleys to Nice to conduct the prelates to the council which was to proscribe Frederick, and refused to listen to the arguments and warnings of the Pisan envoys, though she was plagued at the time by a Ghibelline rising within her own city walls (I I4I). Both cities sent out their navies; the Pisan, reinforced by Sicilian galleys, was a little the stronger, and after a prolonged, dubious, and bloody battle, the Pisans were triumphant. They sank three of the twenty-seven Genoese galleys, captured nineteen, took 4,000 prisoners and much treasure, and bore off the ecclesiastics on board, who were bound for the congress, to Pisa, where they were imprisoned in the chapter-house of the Cathedral, and loaded with silver chains. This was the first Battle of Meloria, to be avenged forty-three years after by a crushing defeat on the same spot, from which Pisa never recovered.

During all these years Genoa and Pisa had been governed by aristocratic oligarchies, whose furious factions in the former city render it one of the wonders of history that she could have established and consolidated her wide dominion. Though Pisa contrived to assert her supremacy in Sardinia, the death of Frederick II. in 1250 was, practically, the death-blow to the Ghibelline cause, and the event menaced eclipse to Pisa. But at this time she was at the full height of her prosperity, and Christendom looked askance at her intercourse with the infidel. Donizo, the biographer of the Countess Matilda, is horrified at the crowds of "Pagans, Turks, Libyans, Parthians, and foul Chaldeans," who haunted her streets, though she supplied incense from these miscreant sources for the Church, not to speak of jewels and pearls for the adornment of its shrines. The policy of Pisa and Genoa was no less self-seeking than that of Venice. They could unite to fight against Venice in Constantinople, and Pisa helped.Zara in her resistance to Venetian pretensions. None of these maritime tradingtowns were really in favour with the Christian Church, until Genoa bccame staunchly Guelph; they were too familiar with the uncanny Paynim for its taste.

We have scanty records of the internal politics and administration of the city at this period; the constitutional history of Pisa is almost unnoticed by contemporary historians ; we know little more than that the city was under the rule of a mercantile aristocracy, whose main business was to face Tuscan invasion by land and Genoese attacks by sea.

\section{GENOA}

GeNOA shared in the general dread with which North Italy was inspired by the pretensions of Barbarossa, who demanded that his commissioners should be conveyed to the isles of Sardinia and Corsica. The Genoese worked hard at strengthening their fortifications in II 58, when they expected to be besieged ; but, four years later, their historian Caffaro, in recounting Frederick's victories, speaks of him as "the ever august, ever 
triumphant, who has raised the Empire to the pinnacle of glory." In fact, they had come to terms with Frederick; they paid a small tribute and placed their fleet at his disposal to enable him to attack Sicily; while the Emperor, on his side, legalized their dominion along the Riviera from Monaco to Porto Venere, confirmed their civic rights, and granted them Syracuse and other fiefs in Sicily which he hoped to conquer (Muratori Antiq. It. dissert. XLVIII., L. iv., p. 253). At the same time he insisted on their coming to terms with the Pisans, whose traders, I, Ooo in number, had violently ejected the 300 Genoese settled in the royal capital of the Eastern Empire, while the Greek Government looked helplessly on.

But peace did not continue long. When Pisa possessed herself of Sardinia, she had enfeodated it to certain of her citizens, and these had become almost independent and contracted matrimonial alliances with the Genoese, who possessed a few fortified places in the island. One of these feudatories, named Barison, visited Frederick in II64, and offered to add Sardinia to the Empire if he were given the kingship in fief. Frederick, ever desirous of extending the Empire, consented, but kept Barison in his own custody until tribute should be paid. This the Genoese did for him, but had the same mistrust of the man as had Frederick (Obert CancellB. Marangoni, Chron. di Pisa). The other great feudatories of the island renewed their allegiance to Pisa ; they seized Barison's lands, and the result was a bloody war between Genoa and Pisa, marked by the burning of ships and the flaring of fortresses along their respective shores.

Meanwhile, Genoa was torn by factions at home. So furious and ferocious waxed civic strife that the Genoese annalist was forbidden to disgrace his country by recording the details. In I 69 the consuls felt that they must make a last despairing effort to put an end to the wild suicidal warfare ; they felt their way with the principal citizens, and then rang the tocsin bell just before dawn, but while all the town was still asleep; the awakened and alarmed citizens assembled to behold their venerable Archbishop, attended by his clergy, standing before the uncovered relics of St. John the Baptist. The aged prelate then addressed the assembled multitude. To the art of the orator was added the impetus of full and sincere emotion; he appealed to every patriotic feeling, to every noble chord, and still the crowd were swayed, now by his oratory, now by their own fierce passions. One party leader, in a loud voice, invoked the souls of those kindred whom he had sworn to avenge, but ultimately a great wave of responsive emotion lifted the whole crowd in one great enthusiastic impulsion. The gray hairs of the beloved old priest, the entreaties of fellow-citizens, the presence of the sacred relics had prevailed ; foes fell on each other's necks and exchanged the kiss of peace ; oaths were taken by every member of the opposite factions ; they called Heaven to witness the sincerity of their reconciliation. Then the bells burst forth in joyous peal, and the whole people sang Te Deum together before they left the Public Square : a remarkable instance of the swift and changeful pulsations of emotion in that impressionable and responsive period.

No such reconciliation with Pisa was attempted, however, and the contest between the two rival ports not merely continued, but involved neighbouring states. Genoa, in I 69 , got the support of Lucca, too near a neighbour of Pisa to be on anything but bitter terms with her. Genoa had a great advantage over her rival in her natural position. Not merely 
was her harbour the finest in Italy, but she had a multitude of excellent anchorages along her coast. A desultory war went on, but, in I I90, both Genoa and Pisa were so far reconciled that they co-operated to place their fleets at the disposal of Henry VI. The neighbourhood of the great island of Sardinia so near to their shores-an island whereon Pisa was the stronger power but Genoa was not without certain rights-led to perpetual friction ; for the possession of the island was of strategic importance; the coast was exposed to attack from its possessor; it was also of commercial value. Perpetual intrigue and warfare arose from the settlements in Sardinia and Corsica. This factor, as well as commercial rivalry, increased the tension always existing between the two States, and whenever, for reasons explained in our account of the history of Pisa, that city was moved to become strongly Ghibelline, Genoa naturally inclined with equal vehemence to the Guelph cause. During the quarrel between Frederick II. and the Papacy, Genoa was strongly Papal in her sympathies, conducted a war all along her mountain frontier against the Ghibelline feudatories, and suppressed the Ghibelline faction at home ; she sent her galleys to Nice to conduct the prelates to the council which was to condemn Frederick; she refused to listen to the argument and warning of the Pisan envoys, and this though she was plagued at the very time by a Ghibelline rising (I24I). Then came a great naval war and a crushing defeat for Genoa at the first Battle of Meloria (1242). The Imperial party attacked the defeated city by both land and sea; but the Genoese were a stout-hearted race, and wrote to the Pope in these terms : "From the greatest to the meanest among us, we are vowed to devote ourselves and our belongings to avenge this cruel affront and to defend the faith and God's Holy Church. We will not rest, night or day, until we have set your brethren free. The citizens of Genoa work without ceasing by night as well as by day, to build and equip a nəw fleet" (Raynaldus ann. 1 248, §3 60-63).

There was marked constitutional development in Genoa during this period. The consuls came to be citizens of the town, and country nobles were excluded from the office. In IIgo the consuls gave place to an annual Podestà, but an elected board acted as a chəck on him; it was composed of aristocratic merchants, who thus governed the State. Nevertheless this board, or senate, found it politic to get the consent of the General Assembly to decisions of high national importance and even to declare that it belonged to the nation as a whole to determine its own policy ; and, since war could not be made without soldiers, the Podestà was in the habit of convoking the Parliament, or General Assembly, to get the sanction and assistance of those on whom he relied for support. The Podestà, as was usual, was a foreign noble, made at once supreme judge and commander-in-chief. He was supported by two jurisconsults and two knights. Subordinate Podesti governed the Riviera, and four tribunals of lawyers administered the law. The senate seems to have been elected-from eight associations of noble merchants. These associations had gradually obtained, not, indeed, constitutional recognition, but political power, vexed by some show of the antagonism of the people ; and in I227 there was an attempt, which failed, to overthrow them. In fact, under the form of popular government, the real control had come to be entirely in the hands of the oligarchy; the Podestà was a noble; so were the judges and consuls, and the sole board that had any power; the senate 
of eight members was exclusively aristocratic, consisting mainly, if not entirely, of landowners who were also merchants. During the wars of Frederick II. the city was, of course, divided into Guelph and Ghibelline factions ; the Guelphs got the upper hand, and excluded the Ghibellines from all share in government ; but after Frederick's death the plain issues of oligarchy versus democracy are no longer obscured by the intrusion of foreign questions of Empire versus Pope.

The Genoese planted their establishments in Spain, along the North African coast and on the shores of the Black Sea. They soon got as far as the Euphrates, and Moltke, the great Prussian general, who visited Mesopotamia in his youth, expressed his admiration of the military and architectural genius to which the ruins of Genoese fortresses in that region still bore witness.

\section{FLORENCE}

The use of the Pisan port was absolutely necessary to what commerce Florence had; so the weaker of the two states always contrived to remain on good terms with the stronger, and braved in her company the wrath of Christian, Barbarossa's lieutenant. Pisa stood Florence in good stead, for when the former city forced the Lucchese to defend their own firesides, the attention of Ghibelline forces was turned away from Florence ; and when Frederick ordered the cities to send their delegates to him at Pavia and settle their cifferences, they were able quietly to defy him. And, although the Peace of Constance (I I 83) put Frederick into possession of Tuscany as part of Matilda's heritage, his representatives sold their rights. In I 85 , when Frederick revisited Tuscany, he received complaints from the nobles of how Florence had despoiled them of their possessions. Frederick ordered the city to disgorge ; but the wary Florentines adopted a policy of passive resistance, and the monarch was constrained to give way, being obliged to ask their help against the Sienese, who, fearing that they would receive the same command, had rebelled (Malevolti). Siena managed to hold her own, for the Emperor had to march southwards ; and, shortly after, out of heart, and his hopes thwarted, the grand old warrior quitted Italy for ever. And when he left for the land where he was to meet his doom, the pious Florentines showed so much crusading fervour that they obtained from him all the territory within a radius of ten miles of their walls for their own to hold and to keep. During the minority of the young Frederick, Innocent III. asked the support of Tuscany against the Emperor Philip IV. The Tuscan towns perceived that the Pope wanted Matilda's heritage for himself, and they diplomatically replied that they would regain such territory as was not already in the occupation of the Tuscan league which they had formed, and drew up a treaty concerning which the Pontiff wrote that he found therein "certain things incompatible with the honour of the Church. As we wish our rights to be respected, so must we respect those of others. The Almighty Creator has put in the heavens two stars; so has He appointed in the firmament of His Church two luminaries: the greater whereof presides over the day of the soul, the lesser over the night of the body; 
and these are Pontifical authority and Royal Sway; and of these twain the latter draweth its splendour and dignity from the former as doth the moon from the sun" (Inn. III., Epist. I6 Ap., I198). But the towns stood firm, and the Pope determined to conciliate them and rely on diplomacy to manage them to his own ends. The main object of the Tuscan league was to give each town secure possession of its own little conquests. Meanwhile Siena and Florence were both absorbing little places in their neighbourhood. The small castles around had to seek their protection, and the inmates were compelled to take up citizenship. From these descended many of the most prominent families of the city, such as the Pitti. The little walled and castellated towns in the neighbourhood were also conquered by, or sold themselves to, their powerful neighbour. It was now evident that Siena and Florence were the two chief bidders for the hegemony of Tuscany. Florence tried to get behind the confines of Siena, and, by taking the fortified hill-town of Montepulciano, to cut off her commerce with Rome and the South. War succeeded war, and truces were made only to be violated ; and fortune swayed, now to this side, now to that; but on the whole the advantage was with Florence. And in addition to these bigger struggles, there was perpetual warfare with the robber-nobles who commanded the trade-routes from their mountain fastnesses, and demanded toll or life from itinerant merchants when they did not rob and murder them. Moreover, exiles found refuge in some neighbouring city, and the country nobles of one territory leagued themselves with the city of another. So there was plenty of rough work required of struggling little trading communities in those days. The subjugation of the neighbouring aristocracy appears to have been displeasing to Otho IV., who ordered the Florentines to restore their acquisitions. Whereto Innocent wrote to the Emperor reminding him that the "bow should not be kept ever on the stretch: Florence has always been faithful" (1208). The trade of Florence and Siena now began to increase rapidly. It had received a great impetus from the crusades, and their merchants dealt in the drugs and pigments of the East. The Florentines applied Oriental colours in the remaking of woollen goods, which were important to the preservation of the trade, for wool was but a scarce and poor product in Tuscany, and was nearly all imported. They lent money, and as the risk was enormous in the Middle Ages, the interest was far more excessive than that of a modern lender of the worst type even; it brought down on the Florentines the condemnation of the Holy See. But indignation did not prevent Rome from using their financial astuteness as collectors of Papal dues throughout Christendom. Siena and Florence became not merely collectors of dues, but also money-changers to the Papal See; there was scarcely any gold left in Europe, and the number of silver mints and the variety of their issues was almost infinite; so that the money-changers' business required prolonged training and considerable skill. The moneychangers of the two towns, owing to their skill in finance, became, in fact, the Papal bankers, and the adoption of letters of exchange by Florence secured her against pillage ; it was an invention that enormously increased commercial security, and, therefore, wealth. The great "arts," which took the lead, were always those that had foreign dealings. These were the woollen merchants, the carders, the bankers, and the trade-associa- 
tion of the newly-imported silk industry. Next in order came the doctors of medicine (who dealt in the drugs of the East, and became wealthy merchants, while the surgeons and accoucheurs were inferior to them), the jurisconsults, and the skinners. These formed the seven greater arts. At this time bakers, butchers, tailors, shoemakers, etc., were of no political or social importance. The consuls who were at the head of the guilds, from their experience and personal importance, naturally became the consuls or priors of the State. The electorate was very small, and even at the end of the fifteenth century there were only 3,000 citizens who could claim a right to hold political office. The parliament or general assembly of the people met in some church or square not big enough to hold it ; and was therefore merely a body which gave formal assent to propositions brought before it. The nobles were allowed the greatest share in the government, in order to promote an effective " forward " foreign policy; and the increasing wealth of the city furnished the sinews of war or the means of purchasing coveted territory. Owing to the small hold that the feudal principle had taken in Italy, family and personal thirst for power evolved quickly, and its exercise was manifested in a very marked degree. The "individualism" that is so pronounced in the period of the Renaissance, and that has taken a commercial direction in modern times, was born of the communes of the Middle Ages. The Podestà was a foreigner, but he had not much power in Florence and other of the bigger cities, owing to their confederation of guilds and their consuls acting as chicf magistrates. The overlords of Tuscany, after Matilda, had been poor creatures, who never understood the causes of the incessant little wars within their domain, and were obliged to let matters alone, to the aggrandisement and enfranchisement of the cities. No share in the government was given by Florence or any other Tuscan town to its conquered territory. This retained self-government in a measure, but was garrisoned by its conqueror, and had to render tribute and a measure of military assistance. The Florentine consuls with military power (for those who rendered justice were also called consuls), were chosen and controlled by a hundred elected citizens called buoni uomini, and in summer the consuls and nobles, like the fox who had lost his tail, turned out to take the field against the remaining country squires, who, indeed, were found to be noxious, from their predatory habits, to an aristocracy depending on and beginning to take a hand in the useful profession of money-getting. The Podestà, often called the captain of the people, or, as in Lucca, the pre o/ of his town, was a noble, welcome to the nobility, and, being usually a jurisconsult, skilled in civil law. He was clected for a year, so that he might not take root in the city and remain impartial, was usually a foreigner, and had to give hostages. Sometimes in Florence the Podestà was kept in office another year; sometimes he was replaced by consuls, or there were both Podestà and consuls. When there was a Podestà he was at once commander-in-chief, supreme judge, superintendent of police, and chief administrator. Great varieties of the electorate and the forms and designations of government are to be found in the different cities of Central Italy at this period, but the essentials of popular self-government under a foreign Podestà, acceptable to nobles and merchants alike as impartial preserver of public order, are present in all, and are, in substance, identical. 
It would be tedious to trace in detail the manner in which Florence allied herself with her neighbours to conquer her little neighbours that barred her commercial routes or sheltered the citizens whom she had exiled, or the secret practices that she employed to increase her power. But allies, little less astute than herself, soon discovered that Florence was using them as cat's-paw for her own advantage, and the number of her unfriends was increased by this policy. This meant the dissolution of the Tuscan league. Figline, Certaldo, Semifonte, Caprano, fell. All the cities were increasing their territory at the expense of Papal hopes of the fair heritage of Matilda. The city had now cleared its commercial routes ; henceforth its wars were to be on a bigger scale-a scries of life and death struggles with the rivals that were its equals.

The affair of the Buondelmonte and Amidei was an outbreak of factions that had existed for a very long period. The old territorial nobility, headed by the Uberti, refused to submit to the new consulate, and the city was torn by the street-fights of factions which, though supported on both sides by nobles, and chiefly fought out by them, were based on an aristocratic as opposed to a more democratic principle. In I 2 I9, when the cities of Lombardy, Tuscany and the coast, abandoned their rivalries and strife to engage with common enthusiasm in the crusade, Florence alone remained absorbed in her internal quarrels ; but these seem to have interfered but little with her growing trade, or her policy of expansion. Hitherto Pisa had welcomed the transit of Florentine merchandise through her port, and Florence harl been glad of a route to the open sea, but Florence was now big and powerful enough to arouse Pisan suspicion, and was, moreover, anxious to have a seaboard under her own control. In I 220 a Florentine, present at the coronation of Frederick at Rome, chanced to admire a dog belonging to a cardinal ; the owner promised it to him, but, next day, to a Pisan; then, to the one of the two that might come first to fetch it. It was the spark to a powder magazine. Street riots followed in Pisa between Florentines and Pisans, and the Pisan authorities confiscated Florentine merchandise. 'Behind these and similar causes of offence, narrated by the chroniclers, lay grave issues. Here it was a conflict of communal interests. Florence appears to have made an honest attempt to smooth matters over, but Pisa was unwilling to yield a jot. A war followed, in which Lucca was the chief sufferer; indeed, she was only saved from the combined attack of Pisa and Pistoja in 1224 by the adroit diplomacy of Florence. Henceforward the old allies, Pisa and Florence, became bitter foes ; nor will Florence rest content till she has won her seaboard. Her skill in diplomacy was displayed in advantageous exchange of territory with the Sienese; and Orvieto and Arezzo, sniffing danger, allied themselves against the growing Power. Florence next erected forts which commanded the castles of the Count Guidi that lay between it and Arezzo, and then compelled him to sell, and so guarded its territory against the Arezzan danger. This action and the absence of Florentine delegates from the diet of Cremona ( 1226 ) gave dire offence to Frederick II., whereon Florence joined the second league of I.ombardy, and made profit of it by subduing the nobles that were still independent. Pistoja, a city filled with fiery and uncontrollable nobles-that "den of wild beasts," as Dante calls herwas bent on giving some expression of her hatred of her aggressive neighbour. She set up two marble arms on a new fortress; they indicated 
by a gesture of contempt her foul scorn of the city towards which they turned. Florence rang her bells for a month; all her citizens assembled in an overwhelming body. Pistojese territory was devastated, the contemptuous arms destroyed, and a solemn peace enforced, which both parties were ready to violate at the first opportunity. Siena, Pisa, Arezzo, Pistoja and Poggibonsi warred against Florence, Lucca, Perugia, and Orvieto. The Emperor took the side of Florence to win her over, sent an armed force, and put a stop to this quarrel (1228). Forthwith Perugia declared for Siena, and Florence resumed the struggle, marched up to Siena, and nailed the Florentine lily on a gate, but withdrew before the advancing forces of Frederick, who was on his way to the South. Siena's great aim was to get Montepulciano, which, from her mountain summit, commanded the route between Siena and Rome; and the Montepulcians were helped by Florentine troops. With all these little towns, each having an antagonist in all the others, alliances are for a day; the communes fight, change sides, and still they fight, as this or that neighbour becomes most menacing; and the friend of to-day is the foe of to-morrow. Frederick was too strong a power for Florence to brave. At the diet of Ravenna he made her pay a heavy compensation both to himself and to Siena. The might of Frederick threw Florence into the party of the Church ; Siena and Pisa adhered, partly in consequence of this, to the Empire ; Lucca was, of course, Guelph, since Pisa was Ghibelline ; and Pistoja, as the neighbour of both Florence and Lucca, was Ghibelline. Florence took a census of her people to ascertain her power; then she took Porto Ercole, in order to be independent of Pisa ; but the seaport was of little use to her, as it was commanded by Sienese territory. She marched again against Siena, and, unable to carry the city, catapulted a dead donkey over its walls - a favourite insult in the Middle Ages, and one which appears to have always aroused the most undying resentment, as did that of coining money within sight of the defenders of the city walls. Siena had to cede Poggibonsi (1235), but Florence was in fear of the return of the Emperor, and agreed to a perpetual peace, sworn on the Holy Gospels and accompanied by an interchange of fraternal embraces. In I 233 this new passion for peace inspired the Florentines to enforce it between the warring communes of Volterra and San Gimignano ; and four years later they reconciled, rod in hand, the Guelph and Ghibelline parties in Pistoja, where the streets literally ran with blood. But the Florentine nobles were ever burning for a fray, and this unwonted mood did not last long. Frederick was again in Italy, and Gregory IX. was mad for a crusade which was not to the commercial taste or interests of the city. So she sent aid to Frederick, who was besieging Brescia, and when Gregory's crusading friars appealed to the Florentines, they found they had empty benches to address. Straightway the irascible old Pope put the city under interdict. Meanwhile the nobles, who had gained great power in the city on account of the incessant wars which needed their services, were divided more than ever among themselves; and they quarrelled the more that all Tuscany quailed before the vicar-general of Frederick, and that they were obliged, perforce, to cease interurban warfare. The parties were indicated by well understood signs and symbols, such as the turn of a thumb or the feather of a hat. In many cities Guelph and Ghibelline factions had already come to blood. Florence, Lucca, Montepulciano, and other 
cities were quiet; but it was the quiet that heralded a storm. Frederick interfered in the affairs of Florence; he protected Florentine heretics because the Pope persecuted them; he urged the Uberti to contrive the expulsion of the Guelphs from their city. The Ghibellines had the advantage of a garrison of Frederick's German soldiery in the city, but the Guelph party was gaining in numbers and in organization ; it relied on popular support; it had the solid burghers on its side. Skirmishes took place in 1247 ; barricades were erected, and behind them lurked the armed warriors of the parties; while the daily work of the city went on as before. For years a difference of opinion, an unintended slight, had been enough to rouse the companies of the towers; the clash of arms would be heard in several quarters of the city at one time, and the contest would last all day; in the gloaming they gathered their dead. Owing to intermarriage, those who fought one another were often bood-relations, and after the obsequies friend and foe met together to discuss the Homeric virtues and relative courage of the slain.

Frederick had appointed his natural son, Frederick of Antioch, to be Vicar of Tuscany, with a command of sixteen hundred German horse. $\mathrm{He}$ wrote to the Uberti, and together they plotted the expulsion of the Guelph party from the city. The secret was well kept. Around the towers of the Uberti dwelt great masses of the Guelphs. The Ghibellines stole like mice to the barricades of their foes, and carried them, and got quite close to the gate at which Frederick of Antioch was to enter. Three days did the Guelphs fight with the high courage of despair. One youth, a standard-bearer, though in unutterable agony, refused to give up his ensign to other hands, and died still bearing the device. He was borne to San Lorenzo, and buried there, while his comrades held lances instead of candles, and the deep monotone of the funeral prayer mingled with the shrill scream of the battle still going on in the streets. The younger Guelph warriors determined to die rather than yield, but their more prudent elders resolved on living on to fight another day; they forced their youth to retire. Frederick of Antioch entered the gate, and he and his German soldiery remained in the city. The towers of the Guelph nobles were razed to the ground, but their lords took refuge in all the strong places around Florence. The Uberti and their friends had destroyed a hornet's nest, and were attacked by its expelled inmates in whatever direction they dared to venture out from Florence. The Guelphs nursed their wrath, and waited for revenge ; for Frederick was losing ground in Tuscany; and everywhere, alike in the increase of cruelty, severity of punishment, and in the defection of Ghibelline towns, there was evidence of his approaching eclipse. Siena refused him help; the Florentine exiles that had been received at Bologna excited that town to revolt, and all Ghibellines were expelled. Perhaps proscription was the only remedy that could be applied in days when party passion came so readily to blood, but the fierce exiles only became embittered, and their hatred established in their compulsory wanderings; they were ever a menace to their successful opponents ; they entangled their native cities in needless wars with their neighbours; and each city was impoverished by this perpetual life-drain on its best blood, and was kept in a constant state of insecurity, tension, and alarm. An evidence of the savage temper of the time is yielded by the story of the siege of Capraja, after 
the Florentine expulsion of the Guelphs. The city was on the point of starvation, and the Imperialists were in negotiation with the defenders for an honourable surrender, when a shoemaker, whose ambition to become consul had been thwarted, shouted to the besiegers that Capraja was on its last legs. Hostilities were recommenced, and Frederick, soured and envenomed by disappointment and the crumbling decay of his cause, imitated the cruel but successful policy of Eccelino, his vicar in the North, and had the nobles of Capraja blinded and then cast into the sea.

Villani tells us of the simplicity of Florentine life at this period. "The citizens," he says, "lived within bounds; their food was simple, their expenses small; many of their habits appear to us rude and unpolished; they and their wives were content with the coarsest material; many even wore unlined hides, caps, and wooden shoes. The greatest ladies were happy to set themselves off with a simple scarlet gown and a fur mantle with the hood turned over the head; whilst women of inferior degree wore green cambric of the same style. The usual dowry was but IOO livres, and one of 300 livres was considered immense. Most girls did not marry until after they had reached twenty. But though their manners were plain, the Florentines were true of soul ; they were loyal to one another, and aimed at being faithful citizens." 1 But, alas! the only method that they could conceive of showing good citizenship was by an unvarying faithfulness to their party; the city was little to them unless their faction was absolute within it.

The Ghibelline government, established in 1248 , was strong by reason of its being purely aristocratic. The number of Ghibelline families in Florence was fairly large, and each family boasted many members; some as many as three hundred. The Uberti were the most powerful clan, and probably the most disdainful; but the masses were touched to the quick by the aristocratic arrogance of the class, and their trade was impoverished by the contests of party and the expulsion of the Guelphs. In vain did the Ghibellines try to eject the Guelphs from their strongholds in the valley towards Arezzo ; they were themselves surprised in the darkness of the night, and fled back to Florence for safety (1250). Thereupon there was a stir in the city, and cries arose of "Long live the people !" There was talk about the reorganization of the State; and the religious respect accorded to the convent of the Minor Friars at St. Croce was exploited for the propagation of revolutionary idea. The Ghibellines threatened the leaders with death; it was clear, then, that safety only lay in bold action. The populace rushed to the towers of the Anchioni ; and then, with Florentine craft, their leaders inflamed the people against the Uberti. It was the Uberti-only the Uberti-that were to blame (a family is more easily attacked than an armed aristocracy). The people became so reinforced and determined, that the Ghibellines did not dare to face them. Even without their Guelph leaders the people had proved themselves to be stronger than the nobles; they were far more numerous, and had displayed both initiative and audacity. The traders had thus succeeded in curbing patrician insolence, and had overthrown a government that was prejudicial to commerce; they were henceforward discreet enough to convert enemies into friends by welcoming them to the ranks of the

1 Giovanni Villani was Prior in 1317 . 
people. Money was to be made, and before long we find nobles dropping their titles and entering the guilds; while though there was not quite so imperative a need for strong cavalry in hilly Tuscany as on the great plain, the traders got the invaluable support of armed horse. They set up a politico-military constitution, which separated the people into two commands-the governing electorate and the populace-a system not unknown in Italy, as we have seen in the case of the northern towns. For example, at one time there co-existed at Bologna two distinct communes-that of the nobles and that of the commonalty-each carrying on its own government, and issuing its own enactments. In framing the new constitution of Florence, two main aims were kept in view-to organize and strengthen the people as against the aristocracy, and to have an efficient army which should be under popular control. The wards of the city were increased to six, and each was provided with its own militia ; the men were subdivided into companies under the command of corporals, who were elected each year, and the chief command was given to a highly-paid noble. The commander was restrained by the watchfulness of the elders or ancients, flanked by their councillors ; while, as a further check on his power, the Podestà was retained. The "captain of the people," as the commander was called, had the civil function of determining the exact value of taxation; while the Podestà was chief judge, with summary justice in his hands, if that became necessary; and he always commanded the cavalry, and sometimes the army, on foreign expeditions. Both civil and military power were thus exercised by and divided between two chiefs, and each was a check on any attempt of the other at despotic rule. The Germanic conquerors had, it is true, becomc Italian, but their descendants formed a warlike, territorial, and overbearing class, indispensable in warfare, but a turbulent nuisance to the State in times of peace. This class was now held in restraint, for the real power of the State was vested in the elders, ancients, or signoria. Nothing could be done without their presence or authority. They initiated all measures, with a consultative body of roo members. The ancients were elected for two months only, and were isolated during their term of office, and on grave occasions they summoned a general meeting, or parliament, of all who had civic rights. Thus, these priors, as they were ultimately called, were the delegates of the people, and they were both secluded from external influences and prevented from becoming an oligarchy by the shortness of their term of office. The inclinations of ambition were thus checkmated at every turn.

\section{SIENA}

Ghibeli.rne exiles from Milan sought refuge in Siena during the war of the Lombard league with Barbarossa, and the city learned the art of dressing wool from them, and began to develop a considerable wooltrade, as well as other forms of commerce. Though Siena waș Imperialistic in temper, there was a strong civic feeling and self-respect; and in 
I 86 the citizens slammed their gates in the face of Barbarossa's son Henry, who, they feared, might shear them of their little conquests. When Siena received a Podestà, her constitution was suppressed; but Barbarossa granted it to the city that no one should build a castle within twelve miles thereof. A great development of trade and of trade-associations took place in the early part of the thirteenth century, and rivalry with Florence became very strong. Each State tried to get possession of frontier towns, and to threaten or blockade the other's trade-routes, and the still existing Memoriale delle Offece (Archiv. Stor. Ital.) bears witness to the fierce passions and bitter resentments of the time. Want of success in these wars probably led to a decline in the power of the nobles ; and in 1233 the people gained half the seats in the signoria of twenty-four, a body which was elected annually (eight members from each ward), and was headed by consuls, of whom one-third represented merchants and artisans. On the establishment of this constitution, Siena straightway leaped into an ever-increasing power and fame; but the nobles resented the possession of political power by the commonalty, and in I 240 the Podestà headed them in an attack on the liberties of the city. The people, led by one Aldobrandino, fought their way step by step through the steep, narrow streets, and fired palace after palace; the worst of the nobles were ejected, and Aldrobrandino was made Podestà. After this finance was administered by four Provveditori di Biccherna with a council. There was a general council of 300 "good Catholics, not excommunicated nor suspected of heresy." Above this, and the very heart of the State, was the council of twenty-four, which met in such secrecy that the captain of the people and the Podestà were excluded from its gatherings. The Podestà and captain constituted the executive arm of the State, and had the power of calling a general assembly of the people, but only after they had explained their purpose to the general council and obtained its sanction by a majority of two-thirds of the votes.

\section{LIFE, LITERATURE, AND ART}

\section{LIFE}

IN the thirteenth century, nobles and burghers, the descendants of conquerors and conquered, were brought to live together in the same commune; the nobles took up trade, and there commenced that equalization of classes which in some cities passed on to the separation of a merchant nobility, in others, and more generally in the most cultivated and unstable States, to the recognition of personal merit alone. During the tumults and insurrections that disturbed so many cities, the trade-associations carried on police-work among their craftsmen ; the street brawl or the revolution was little more than a wave-driven surface; the deeper waters of civic life were but little disturbed, or soon readjusted themselves to the task of sustaining full flow of life in the troubled conflicts of opposed currents.

Although we speak of the Italian self-governing communes, we must nat 
forget that it was only the highest stratum of society that was represented in the government. Whenever disputes arose, the disputing parties tried to expatriate, or even to wipe out each other. The commune aimed at unanimity, but unanimity was secured by banishment of the weaker side. Italy never reached the conceptions of so much expediency in modern politics, of the polling-booth or the ballot-box as a bloodless field for the fray, and of the acceptance by the minority of defeat. Hence we shall find the commune unable to maintain itself, revolution following revolution with the regularity and almost with the rapidity of the tides, and the tyrant invariably coming, first to head, and then to replace, the republic. Hence, also, the possibility of the emergence and triumph of the individual temper, character, and intellect, from the clan or faction. Up to this period there was practically no personal liberty except the liberty of private war. The individual was included in the structure of the family, the gens, the trade-association, the class-order, the city to which he belonged, and regarded himself less as an individual than as a unit in a composite structure. The Mediæval Church, too, always regarded its members as members of a body far more than as individual souls standing face to face with God, and endowed by Him with individual responsibility.

Men's lives were very simple. Marriage was, except among the humblest, arranged by the families of the couple. Husband and wife ate out of separate pieces of bread scooped out to serve as plate, or out of the same piece, while at supper a servant held a torch. The burghers' clothes were of unlined leather, and ornaments were few or scanty. On the other hand, the great nobility dressed in the silks and furs of the East, and the wandering poet gazed with adoring reverence on the chatelaine who tricked off her beauty in Oriental luxury, and who seemed so different from the plain, hard-worked women of his own class. The poorer sort were usually able to have flesh three times a week, and kept the cold meat for supper ; and in summer many abstained from wine. But among the upper classes intoxication was by no means the rare event it has become in Italy. The general standard of wealth was low ; to many, a small capital of corn seemed riches, and the marriage dowry was small. The signs of wealth among the nobility were the superbness of their arms and horses, and the exhibition of lofty manners to their inferiors.

The silk trade was brought by Robert Guiscard to Palermo in I I48, and, about the same time, the Genoese learnt its secrets by the plunder of two Spanish cities. Silk and wool rapidly became the staple industries of Italy, and Milan was renowned for the manufacture of arms. The wool and silk manufacturers became esteemed as citizens of high position and worthy of all honour. They were wealthy, and their minds were enlarged by dealings with, and residence in, foreign countries. Owing to the crusades, the maritime cities throve greatly by undertaking the transport of the crusaders and getting grants and privileges in the partly conquered lands; and when these were wrested again from Christian hands by the Saracen, Venice contrived by astute commercial treaties to export brass, tin, lead, and the precious metals, wool and oil, and to import, though not without submitting to heavy exactions, Oriental products, and distribute them. The conquest of Constantinople by the Latins also gave a great impetus to Venetian trade, and that of Italy generally.

While the trend of the Northern republics was towards freedom, that of 
the kingdom of the Two Sicilies was towards the subjugation of personal liberty in the interest of order and uniformity. Policed by Saracens, with central courts of justice established, the subjects of Frederick II. were not allowed to marry aliens ; nor, although that enlightened monarch favoured the cultivation of anatomical study by the establishment of a chair of anatomy at his new University of Naples, would he allow students who were his subjects to study abroad, either because he feared the corrupting influences and the bad political examples of aliens, or because he wished to improve and thoroughly establish native institutions. While Frederick persecuted heretics in Sicily, he favoured them elsewhere, and many of his friends were what Dante calls Epicureans, or, as we should say, agnostics, and, in the main, indifferent to religious matters.

\section{RELIGION AND HERESY}

A careful examination of religious strife usually reveals that it is coincident with national, social, or economic antagonisms. Undoubtedly, certain forms of religious worship and belief are found to be in special conformity with the peculiar distinctive qualities of certain racial types of character, but this is not the whole truth. The odium theologicum is a screen behind which march forces of a wholly secular aim. All the heresies of the early days of Christianity will be found to mask profound national differences of character, or tendencies to social and political cleavage, or economic or other sources of discontent ; and unorthodox forms of Christianity flourished most where the centrifugal forces of the Empire were most manifest. Thus, Arianism established itself among the Northern tribes, and Arianism and other forms of religious rebellion made most show along the African and Asiatic shores. In all the contests thus induced, one must not be deluded by the mere religious principle involved. One is perpctually reminded of the old adage, Ckerchez la femme: here some secular cause waits to be detected. The streams of Buddhistic and Zarathustrian thought, mingling with the neo-Platonism of Philo and the Pantheism of the Kabbala, incorporated the Christian notion of redemption, and the eclectic result was known as the " Gnosticism " of the first centuries after Christ. Mani, a Persian who lived in the third century, combined Christian ideas with those of Babylon and Persia, and Manichæism also profoundly stirred the waters of the early Church. From these sources a sect called Paulicians arose in Armenia in the seventh century, and spread along the abode of Arianism to the north of the Greek Empire into Italy, Germany, and France. Gnosticism and Manichæism also penetrated, through the intercourse and warfare of Saracen and Christian, to Provence and the South of France. These various forms of religion were more or less marked by philosophical reflection as well as by spiritual fervour, and they were characterized by repudiation of the Old Testament, which was held to be a doctrine of the Evil or Material Spirit or Demiurge, a belief in the radical depravement of matter, and of the spirituality of God, bearing with it this consequence-that Christ's body was apparent, not real (Harnack, Zur Quellenkr tik der Geschichte des Gnosticismus.--HerzogPlitt. R.E., IX. 223-259). When Europe woke up from the soulless nightmare of its long lethargy, and before its natural impulses were bridled by the Church, it began to rejoice, as a young man in his strength, in the 
freedom and sovereign power of the mind. That the only test of truth is its reasonableness was the assertion of Abelard. Provence was by far the most intellectually active and enlightened district of Europe, and the new religion spread there like wildfire. St. Bernard, writing in the twelfth century, speaks of "churches without people, people without priests, priests without respect, Christians without Christianity, holy places denied to be holy, the sacraments no longer sacred, the holy days without their solemnities." All Provence was in a glow with religious speculation and enthusiasm. Italians and Greeks have always been distinguished by a certain sobriety in their religion and ideal of life. It belonged to the classic races and the classic civilization to value $\sigma \omega \phi \rho o \sigma v ́ v \eta$, or a wise restraint of all passions and a keeping of them in due balance and relationship, as the greatest of all the virtues, because it is their ruler. But the Teuton has always had a romantic and perfervid temperament, and Umbria had always been the seat of a sombre and melancholy religion-the Etruscan. North Italy contained an enormous amount of Northern blood, and the See of Milan was for a long period a self-governing community with a ritual of its own. Hence, from the eleventh century, the Cathari, a branch of Paulicians, existed in Lombardy, and with them was confused the sect of Patarines, revivalists who began to meet in the Pataria, or ragman's quarter of the city, in the eleventh century, and who, equally with the Cathari, were opposed to the marriage of priests, and often to marriage altogether. In that century heresy dominated many cities, such as Florence, Orvieto, and Viterbo. The excitement of the human mind which marks the Middle Ages reached its acme in the thirteenth century. The liberation of cities, the stimulating effects of citizenship and of commerce, acted as a ferment, which not only gave birth to new religious views and intense aspirations, but also found expression in the revival of letters and the fine arts, and carried architecture to its zenith in those glorious fanes which are still the cynosure of all who have perception of the beautiful. But the ferment stirred religious feeling to its depths. Joachim, Abbot of Floris, pronounced that the " reign of the Father is over ; that of the Son is passing ; that of the Spirit is at hand." In Etrurian Umbria mystics abounded. Francis of Assisi (I I 82-I 226) was directed by a voice like Socrates' dæmon, and it called him to renounce his patrimonial rights, to embrace poverty, and to devote himself to the loving care of his fellows. He formed a little order, and Rome had the wisdom to annex the young enthusiast and his disciples. The beautiful heart, that lost itself in love, and the practical intellect of Francis, that converted idea into performance, were used by the Papacy to regenerate the Church from within. Jacopo dei Beneditti of Todi is another example of sacred fervour ; overwhelmed and uprooted by the sudden death of his wife, he gave all he had to the poor, clad himself in rags, lifted himself to God, and wrote hymns marked alike by mystical intoxication and savage censure of the Popes. Fasani of Perugia announced himself as sent of God to disclose His mysteries and pronounce His judgments. His followers were in the habit of scourging themselves to the drawing of blood, and of singing laudi, which, later, developed into mystery-plays. Giovanni di Vicenza so rnoved the people by his powerful appeals that soldiers, citizens, peasants, and knights-atarms of Bologna vowed an end to their hates; and all their weapons lay piled up at his feet; while the government gave him the city statutes to 
revise. The citizens of Padua brought him in triumph into their city enthroned on the sacred caroccio. Vicenza, Verona, Mantua, Brescia, and many other communes vied with each other to honour him and to be first to get him to remodel their laws ; and even the great fierce nobles heard him gladly. On a certain day in I 233 the entire population of Verona and all the neighbouring cities, burghers of the communes of Emilia, accompanied by their city ensigns, the Patriarch of Aquileia, and bishops from far and near, and all the great nobles, gathered in the plain to listen to his clarion voice and moving periods. He exhorted them on the text, "My peace I give unto you ; my peace I leave with you." Amid the most ebullient enthusiasm, he insisted on marrying the children of the contentious houses of Este and Romano, which were at bitter feud with one another. But Giovanni di Vicenza had not the gentle sweetness of Francis d'Assisi. According to Francis's own saying, "the doer is known by his works," and his deeds were wholly born of love. Giovanni used the supreme power that the cities gave him to praise Heaven by lighting the fires of persecution. Soon afterwards the ardours of enthusiasm cooled in the communes that were under Brother Giovanni's sway. In vain did he appeal to the sword he had arraigned; he was made prisoner in a street fight, and only released, discredited and disdained of all, at the solicitation of the Pope.

All this religious effervescence was due to weariness of the factions, quarrels, unrelenting reprisals, and merciless cruelty of those unsettled times. Men were agitated by incessant war within the city gates and in every direction without them. Papal thunderbolts were answered by Imperial bans; unoffending cities were struck by interdict and war ; the fair, fertile land of Italy was soaked in blood and wasted by fire; and plague and famine destroyed those whom battle might spare. Revivalism was no cure for evils such as these. Doubtless it is true that oft times " the tigers of wrath are wiser than the horses of instruction," but that is when enthusiasm is aroused by some great new principle, quick to assimilate and vivify subjective needs into some fresh living form, and to render them organically vital, while it is potent to detect some weakness or inconsistency of objective environment. The new life cannot flourish in the old surroundings ; there must be objective as well as subjective change possible, or neither the " tigers of wrath " nor the "horses of instruction " will avail.

Hence thirteenth century revivalism was foredoomed to failure. But there was a patient, astute statecraft at Rome that knew how to employ and divert, as well as how to destroy, popular movements. The Inquisition already existed in germ. In I I 44 the synod of Verona ordered relapsed heretics to be handed over to the secular arm. There is this to be said for this severity-that all new movements are apt to shake off wholesome restraints, as well as those that are nocuous ; nor had the new religious movements been unmarked by moral license. Innocent III. (I I98-I 2I6), Gregory IX. (I 227-I 24 I), and Innocent IV. (I 243-I254) were men of appalling will-power, and they determined to make Rome, as the rock on which society was built, secure at any price. Innocent III. ordered the Cistercians to visit the dioceses, and "catch and slay the little foxes "; this mission interfered with the episcopal administration, and stirred it into new activity. In I 229 every bishop appointed a priest and a layman to 
inquire secretly into heresy. Dominic, a Spaniard ( I I 70-I 203), had founded an order of begging friars to preach against those who did not venerate the cross or believe in transubstantiation or prayers for the dead; and the Papacy used the followers of the gentle Francis and the impassioned Dominic as tools to winnow the Church from chaff wherewith to feed the fires of the Inquisition. The Franciscans appealed to the heart, and the Dominicans to the conscience ; they penetrated into the secret recesses of every soul ; they became familiar faces in every home ; they filled every pulpit ; they replaced the secular Church in every function; and soon barefooted mendicants rose to the curia itself. Albertus Magnus and Thomas Aquinas, and many of those who occupied the highest seats in the hierarchy of the Church's intellect, were of that Dominican order to which the charge of the Inquisition was entrusted. The inquisitors were further waited on by laymen "familiars." Visitors to Florence will remember a contemporary evidence of the zeal of the two mendicant orders in the service of the "Holy Office" : in the Spanish chapel of S. Maria Novella there is a fresco by Simone Memmi (I283-I 344) which represents black and white hounds (Dominicans and Franciscans) chasing wolves from the holy fold. The effect of the Inquisition and of the victorious wars of the Church was to extirpate the "Albigensian " heresy in Southern France on the infamous principle of the Abbot Arnold of Beziers, who, when asked how God's enemies were to be distinguished from His faithful, replied: "Slay all; God will know His own !" In Italy the method was successful also; there were few who were not obedient sons of the Church in the land where once for merely political reasons, after a struggle between Parma and its bishop, the citizens of that commune passed a law which condemned the body of any person to be burned after death who had repented of his opposition to the Church on his deathbed. For the revolving wheel of Fortune had brought the Papacy to its summit; the theocracy was established with power to bind and loose.

Nevertheless, the snake of heresy was scotched, not killed, by the Orthodox Church. Unorthodoxy is usually associated with social discontent; and revivalism took strange forms of communistic doctrine. Religious emotionalism is apt to disguise sexual aberrations; and while some of the heretical sects professed to observe absolute continence, others appear to have indulged in the theory and practice of free love. The phenomena of revivalism were multiplex; associated with sincere desire for spiritual enlightenment and reform, there were also products of social discontent and sexual instability. As late as 1305 one Fra Dolcino was accused of the most cataclysmal doctrines, social, moral, and religious, and undoubtedly these were to be found among his followers and the Cathari generally; but he was probably guiltless of aught but an honest desire to purge the Papal hierarchy of its spiritual torpor, its material drag-weight, and its callous corruption. Villani, however, assures us that his followers held their goods and wives in common. His was one of many mediæval movements coloured by the communistic theory not unknown to the earliest Christian Church, which, never quite disappearing, took extreme unsophisticated form in the extravagances of Jan of Leyden and the anabaptists in the early sixteenth century, and assumed more determinately reasoned shape in certain American communities of the nineteenth century. Clement V. ordered the total extirpation of Fra Dolcino's followers, who, 
in thousands, withdrew to the hills near Novara, where they were reduced to a life of brigandage, and finally starved out by a prolonged snowstorm. Several thousand perished of cold, and the rest were burned. Fra Dolcino and his beautiful wife, or mistress, were horribly mutilated and exhibited to the insults of the mob, after which they were burned. All these heresies, the brutal form of their suppression, and the heroism of the martyrs, coupled with the intellectual emancipation they implied, were fostered by the growth of literature and learning and had the result that there came into being a widespread suspicion of the doctrines of the Christian faith itself, disguised by a formal submission to the Church. And Farinata dei Uberti, the elder Cavalcanti, and others, even dared to express themselves in the spirit of a modern poet:

"Your chilly stars I can forego,

This warm kind earth is all I know."

Outwardly they conformed, and the Church let them alone. Of this, almost equally unreasoned, scepticism, instances in the Inferno will readily recur to the readers of Dante. Though in the thirteenth century Peter of Verona, the emissary of the Pope, could only subdue heresy in Florence by making use of the factions of that city, and met his death by assassination in Lombardy, where heresy was perpetually revivified by refugees from the South of France, the Holy Office was so thorough in its work that it not merely hunted down and burned the heretics, but confiscated their material possessions and persecuted their children to the fourth generation ; and its heroic remedies met with ultimate success. The children of this world knew how to manipulate it. It was impurely exercised; it was exploited by those that had, in the suppression of those that had not. Then the barefooted friars turned their principles of Christian love into what, from the modern point of view, are more worthy channels; they devoted themselves to the foundation of, and cure of the sick in, public hospitals when, as was too commonly the case, they did not wholly occupy themselves with the prosecution of their own private advantage.

Of the founders of the two greater orders that were chiefly employed in the extirpation of heresy, St. Francis is by far the more attractive character. It is one of the ironies of history that he should have founded an order that became subservient to the Holy Office. He is perhaps the most fascinating figure in the delightful gallery of Catholic saints. Banding himself with the seven friends who formed with him the first brethren of the order, he infused his disciples with the spirit of the sermon on the mount-a spirit which was congenial to the century, perhaps because the actual world was so contrasted with it ; the ideal of Francis was the direct opposite to the practice of the period. The Umbrian nature has always been capable of passionate tenderness as well as of passionate vendette; beasts would run, birds fly to Francesco for protection; he appears to have had that magnetic fascination for animals so strangely possessed by some gentle, sympathetic natures. The birds singing in the groves of Monte Subasio, the common sights of earth, gave him intense happiness, and raised his soul to God. Unlike the ascetics of the Thebaid, he loved the world and its beauty. Like his Master, he turned from the pomp of rulers and rich men, and the brutalizing influence of fierce passions that he witnessed in the strife around him, and deliberately stifled the less gentle 
and more egoistic impulses of humanity in order to cultivate humility, gentleness, and love. "I have but one Father in Heaven," said this " most blameless and gentle of saints " when his father in the flesh repudiated him. Innocence of spirit in him, as in so many saints, was combined with practicality of aim and acuteness, if not depth, of reasoning power. His constant teaching was that " religious teachers only preach well when they do well, for by their fruits ye shall know them." He held it better to bless God for the sun than reason why he shines, and good to listen " to our sisters the birds praising the Lord." The republics produced many saints, and a few suggestions as to certain features in the psychology of saints may not be deemed inapposite in this work.

No Church has been so prolific in the production of saints as the Church of Rome; and no country has produced saints more pure and exalted than Italy. The visions that visited these sublime and guileless minds are apt to be misunderstood in an age destitute of lofty ideality, and to which spiritual ecstasy has become a sign of mental derangement. But madness is marked by disintegration and decay; it is a degenerative process ; and in the saints there is no mark of impairment of co-ordination, no havoc of faculty.

" Bring them to the test,

And they the matter would reword, which madness Would gambol from."

St. Catherine and all the more luminous of the galaxy of these pure spirits are marked by an eminent practicality of life and mind. Given the body of belief to which their time gave ready credence, and it is no mark of mental aberration, but rather of spiritual health and vigour, that their lives should conform to it. They might have replied to an accusation of mental disorder that the true madman was he whose life remained inco-ordinate with the Real; he it was who was "possessed," but by an evil spirit. They assert, like Paul, that they "were caught up into Paradise and heard unspeakable words." There is nothing in this inconsistent with the Catholic synthesis of life ; and if they were rapt by high imagination, that does not constitute a mark of madness. Nor is an explanation of a sort very difficult ; for it must be remembered that, in essence, thought is not dependent on speech, but transcends speech ; it is fore-felt and prefigured before it is framed and articulated ; it represents, defines, and formulates itself either in language, which is but the mustered memories of sound; or in imagery, which is but the garnered aftermath of vision. And the winnowed voices of the past, the sifted discernments of the inward eye, may take such vital force and intensity as to abstract the soul from its material surroundings. We are all familiar with the obliviousness of brooding thought to the passing shows of the moment : like a star, "it sits apart," and is deaf to the disturbances of their appeals. The saint, meditating on the sweet sacred secrets of religion, also became dead to outward things. He not merely thought deeply and imagined sublimely ; his thoughts and his visualization became acutely vital and real ; and he naturally believed them to be an actual effluence from the Unseen. When Immanuel Swedenborg visualized instead of wording, he never failed to express defensible ethical concepts, but to him they came in symbols of sight instead of as linguistic signs. His visions were ideas embodied; he saw with clear intensity what other men might faintly hear in the formulations of linguistic 
token, and for him symbol became fact ; but it did not lose logical coherence. And so, but in a higher degree, was it with the saints : their spiritual genius converted conviction into actual presence ; and that was no unhealthiness or real unsoundness which co-ordinated their quickened spiritual experience with the synthesis of life that their faith furnished; it was rather a white heat of spiritual passion. Recent researches into the phenomena of the subliminal, auto-suggestion and multiplex personality, and the results of hetero-suggestion, both in the normal state and under hypnotic conditions, have enlarged our psychological knowledge, and are not without some bearing on phenomena, which, however, still remain difficult to investigate now that, in these sophisticated days, they have become so rare and rudimentary. The saints were wont to welcome the inspirations that well up from that deep substrate that lies beneath the conscious self, the intimation buried amid the hidden wonders of our being, whence spring occasional voices-voices illusory and voices truethat have to be brought to the stern test of exact inquiry, and which only the psychology of the last few years has ventured to subject to rigorous examination.

\section{Education : The Foundation of Universities}

In the eleventh century Salerno had become famed throughout Europe for the teaching of medicine. South Italy, on account of its intercourse with the Saracen, became acquainted with Arabic medicine; for the cultivated Mohammedan world was in possession of translations of Galen and Hippocrates, as well as of fragments of Aristotle and other thinkers of the ancient world. In the twelfth, Irnerius or Wernerius began to lecture on civil law at Bologna, and thus supplied a real need of the rising commercial centres ; the growing complexities of political relations, too, required the application of a well-defined system of law. Students crowded to Bologna from all parts of Italy ; the town was governed by no highly centralized authority; it was little more than a bundle of selfgoverning guilds, like other cities of the age, and the students that flocked to this alien and not too kindly soil banded themselves together on guild principles for self-protection. Denifle (Die Universitäten, I885) thinks that the guild principles adopted were those of the Teutonic guilds of the twelfth century and not the Bolognese. These " universities," of which there may have been four at Bologna, and which soon had Tuscan and Lombard Universities added to them, under their rectors, forced the city to grant them special immunities and privileges, and even brought their teachers into dependence on them and submission to their laws; they thus became intensely democratic, but subject to dissensions that led to secession. Universities of Italians, Germans, Provençals, and English were founded at Vercelli; Italians, English with Normans, Spaniards with Catalans, formed "universitates" at Padua. About A.D. I200 Io,00o men, mostly of mature age, were students at Bologna alone, and near the same time, in addition to the study of law, there were roganized "faculties" of medicine and of philosophy (which included the ancient trivium (grammar, logic, and rhetoric), and the quadrivium (arithmetic, astronomy, geometry, and music). The privileges which Barbarossa gave to the students were in answer to a petition of his German 
students who suffered grievances, especially at the hands of their landlords. Frederick was shrewd enough to seize such a happy opportunity of enlisting the support of the legal intellect for his Imperial pretensions ; his patronage cemented the natural inclination of the jurisconsult for authority. A few colleges existed at these mediæval schools, but they were solely of a charitable nature for necessitous students. The age was one of rapid growth : new wants were constantly appearing in every department of human activity, and reproductions of Bologna grew up spontaneously at Modena, Reggio, Vercelli, and Vicenza, as well as at Padua. Frederick II. founded a university at Naples, and similar institutions appeared soon afterwards in most considerable Italian cities.

Not merely was the period with which we are dealing marked by intense intellectual, educational, religious, and social fermentation; it also witnessed the dawn of a new literature and the development of a new, abiding, and imaginative passion.

The Development of Literature in Provence: Its Translation into Italy-Origin of Romantic Love-Sicilian Literature

About the year III3, Raymond Beranger, Count of Barcclona in Catalonian Spain, became, in right of his wife, Count of Provencc also. Barcclona was practically a self-governing city, and its trade was, for that age, immense. The result was that its citizens exhibited the vital energy that is produced by liberty, and their count and his retinue acquired a polish and exhibited a magnificence to which the other Christian counts of Europe were strangers. The Moors of Spain were far more instructed in the arts and refinements of life than the Christians of that time ; and, both by war and by trade, they imparted no small measure of their culture to Barcelona and the Catalans. Hence, when Raymond Beranger came to Provence, he brought with him a spirit of liberty, of chivalry, and of elegance, together with somewhat of the discriminating artistic feeling and scientific attainments of the Moors. But the Catalans did not find themselves among a people of greatly inferior culture or of quite alien tongue.

The South of France had been one of the centres where Classic civilization took deepest root and most flourished. This culture, although disturbed by the conquests of the barbarians, remained more than a mere tradition, and the earliest remains of Provençal poetry, dating from the first half of the eleventh century, show a degree of development and diversity which indicate that, in the century in which it was written, the art of giving clear and rhythmic expression to ideal forms was no new thing. Provence, also, owing to its Mediterranean seaboard, held commercial intercourse with Constantinople and the Orient; it had suffered comparatively little from foreign invasion; and its trade was fostered by the judicious administration of its rulers. Its growing wealth and the activity of its cities, not only promoted refinements and the arts, but germinated a spirit of liberty which resulted in the establishment of municipal republics. Now, the Catalans spoke a language so closely allied to Provençal, that they could understand it without difficulty, and free interchange and stimulus of thought became possible between the two races. "From this combination of noble sentiments," says Sismondi in his Li'erature of the South of Europe, "sprang the poetry 
which, in Provence and in the whole of the South of Europe, burst out all at once, as if an electric spark had, in the midst of the thickest darkness, kindled in every part at the same time the brightest flames."

Throughout France feudal castles were enlivened by the visits of " joglars," who were the successors of the " mimi " of the ancient world. This gentry formed a not very reputable class, and amused their audience with jugglery, buffoonery, and song. But, as manners became more refined, certain of them took a higher flight ; in the ruder North they composed and chaunted deeds of derring do; in the South, where greater wealth and security had developed more physical sensibility, the troubadour sang the luxurious throes and sensuous felicities of sexual love. The troubadour was the son of the people ; but his mental endowments, recognised by the cultivated occupants of the castle, raised him, while in their presence, to a kind of brevet-equality with them. Some, perhaps most, were the children of serfs; some were descended from the citizen class. The man who could excite or subdue subtle emotions at will, who could move the proud noble or his lady by his genius, began to be more and more highly esteemed. Certain men of all callings found themsalves to be possessed by the divine fire. Burghers forsook the market; clerics the altar; even those of the poorer knights, who shared in the god-like gift sought the relief of their yearnings and the filling of their purse in the renown and solid satisfaction yielded by the exercise of the new art. Even exalted and puissant nobles, like William of Poitiers and Rambaut of Orange, gave dignity and encouragement to the art by becoming poets themselves.

The sensitive soul, now become the freeman of noble society, is dazzled by the grace and condescension of the chatelaine who welcomes him; he scarce dares to raise his eyes to her sovereign beauty. And as Quinet says (Révolutions d'Italie), " the love of the troubadour is born of sweet shiverings that would have been repugnant to antiquity, since it is woman who becomes powerful, and man feeble ; it is the woman who protects, the man who needs support. She has authority, command, full power. He has for her but timidity and the submission of a serf. The troubadour devotes himself to a person, who from the high social position she occupies, dominates, overwhelms him with her superiority, and remains for him an inaccessible ideal." The peculiar and besetting weakness of woman is, almost invariably, her excessive love of admiration ; ladies encourage this welcome witness to their fascination and evidence of an only half-suspected power. The ladies of the later Roman world were emancipated to a very great extent from social and legal disabilities, and often used their freedom with no inconsiderable license; the German woman, as we know from Tacitus, was treated with a respect which evidently commanded his astonishment. Thus from two sources the ladies of the South derived some traditions both of unrestraint and honourable esteem. And, though they were married at a very early age, and, oftener than not, very unsuitably from every other point of view than that of pelf and power, they were, as is the case in France to-day, allowed an unusual amount of liberty directly they became wives. So it came about that in many cases the affection of the humble bard was returned by his beloved object, and if it were not so returned, a being so exalted, transcendent, and inaccessible, did not cease to be adored; while, in all cases, 
such devotion flattered the vanity of the fair, and was encouraged even under the forms of discountenance. A new form of passion-that of romantic love-was born into the world - a form of which only the faintest rudiments are discoverable in the literature of the ancients or the sagas of the North. Undoubtedly the veneration of the Mother of God prepared the way for the adoration of woman, and we shall see how this worship was enhanced by it, and what strange issues, continuing into our own time, and perhaps to continue for all time, resulted from the conjunction of factors that produced Modern Love.

But such daring consecration of himself to female beauty and refinement on the part of an inferior, and in the presence of a husband or female rivals of the fair, required circumspection in its expression; it had to be made transparent to the lady, undecipherable to the world. It therefore took the form of the highest spirituality, or was disguised by artifice of form or speech. The doctrine of the liberation and unfolding of the powers of the spirit by love, and of the essential equality of souls, thus arose in the expression by the bard of these espousals of the spirit. The amour did not always remain spiritual ; but there was a general agreement to hide and ignore the fact. Wherever marriage is a matter of arrangement, we find that dishonour consists not in the presence of stain, but in its becoming known. But if the cause of reproach becomes too evident, "the poet is killed in the neighbouring forest, and the legend repeats the adventure of the heart of William of Cabestaing " (Quinet), which her husband compelled Margaret de Rousillon to eat (Boccaccio). Nevertheless, there must have been a fairly easy tolerance, as is shown by the fact that Bernart, the son of a lackey, obliged to take his departure on account of the discovery of an intrigue which he was carrying on with his lady, was warmly welcomed by Eleanor, the consort of our Henry II. The new, elevated, and immaterial trend in troubadour verse, arising in the deepest and most secret recesses of the poet's heart, passed into Italy, and became still further spiritualized by Dante, Cavalcanti, and the poets of the later thirteenth century. To have had one's soul penetrated by a glance was to have all heaven opened, to be endued with the principles of a nobler life, and endowed with the restraining force of spiritual affection. This sublime attachment co-existed with ordinary matrimonial ties entered into on strictly family and business principles. But his lady was the means whereby the fair visions of the ideal, the heavenly, the sources of moral obligation, were bequeathed to the sensitive soul. The new doctrine intensified the worship of the Virgin, and in the thirteenth century lady-chapels were added to well-nigh every considerable Christian church. It remains in literature and in fact, though it has lost its pristine transcendence, a possession of to-day.

The troubadours of Provence were welcomed at the courts of the marquises of Este and Montferrat, and by the noble houses of Romano and Camino. A great number of Italians distinguished themselves as composers of Provençal verse, and Nicoletto of Turin, Bonifacio Calvi of Genoa, and Bartolomeo Giorgi of Venice, names forgotten to-day, were the delight of their period. Two men of lofty and disdainful soul stood apart from the crowd of obsequious satellites, and were highly esteemed in the Lombard republics. One, Ugo Catola, devoted his powers to the denunciations of the putrescence and cruelty of tyrants. The pale shade 
of the other, Sordello of Mantua, is to be found in the purlieu of Dante's Purga!orio :

"O anima Lombarda

Come ti stavi altera e disdegnosa,

E nel mover degli occhi onesta e tarda!"

(O Lombard spirit, how thou standest haughty and disdainful, and in the movement of thy eyes how dignified and unhasting !)

Of these two, little remains but their renown.

Frederick II., his son Enzio of Sardinia, his chancellor, Pier delle Vigne, and a host of lambent rhymers imitated the then decaying literature of Provence in Sicilian dialect. Side by side with this artificial copy of chivalrous verse, there sprang up a popular poetry in Sicily, full of the sensuous fervour of the South. The "Contrasto" of Ciullo remains to us of this quite native growth. Provence and Sicily had demonstrated that the mother-tongue was dainty as well as virile, and the way was opened to a literature in the vernacular. The reverence given to women helped on the movement, for scholars like Dante, in spite of their reverence and affection for the Latin tongue, were eager to be understood of ladies (Dante, Vita Nuova, c. xxv.). The poet had carried the strong, frank, free emotion of the people to the Court, and he had brought back something of its discriminating refinement to the people. There was a cultivated audience awaiting the advent of genius, and a noble and pliant instrument of speech ready to become its messenger.

\section{ARChitecture}

From Sicily and the South of Italy, by far the most cultivated States of Christian Europe, now came the inspiration which led to the beautiful Tuscan palace, which will be at once recognised by the instructed in Saracenic work as Saracenic-Sicilian in character. In I 53 the baptistery at Pisa was begun; in I 249 the cathedral of Siena; the apse and west front of S. Miniato, Florence, received their mosaic decorations at the beginning of the century, as did the vault of the Florentine baptistery. As early as the twelfth century architect and sculptor had produced magnificent work at Salerno, Ravello, Amalfi, and Bari; and Niccolo Pisani either came from Apulia, or, if a Tuscan, had seen and was influenced by Apulian art. He is said to have studied the ancient sarcophagi with which the Pisans had surrounded the holy earth they brought from Calvary, thus anticipating that humanistic spirit of the Renaissance, which reverenced both the Classic and Hebrew origins of its civilization, and would fain have combined them. To the beauty of modelling and dignity of attitude of the Classic forms Pisano added a grace, a spirituality, and a delicate insight into hidden things, that opened up a world of art hitherto unrevealed. He is said to have done work at Naples for FrederickII., but he finished his first great work that remains to us-the pulpit of the Pisan baptistery - ten years after that monarch's death. He was not merely a great sculptor, but one of the earliest of the many encyclopædic sons of Italy, for he was also a great architect and a great engineer.

The new art revealed qualities unknown to the art of the antique world; it expressed a new tenderness, the simplicity of human sympathy, the dignity of self-renunciation, the pathos of suffering, the secrets of the spirit, the sense of mystic unity wherein God and man are one. 


\title{
BOOK III
}

\author{
THE CENTRAL MEDIAEVAL PERIOD: 'THE INSTITU'TION \\ IN MOST COMMUNES OF DICTA'TORSHIP-FROM THE \\ DEATH OF FREDERICK II. TO THAT OF HENIRY VII., \\ I250-I3I3
}

\section{GENERAL SURVEY OF ITALIAN HISTORY}

Hitherto we have found the cities advancing by taking advantage of the counterpoise of the feudal system and the pretensions of the Church. We have followed the great struggle between Church and Empire, a drama of absorbing interest, played on a big stage. We have now arrived at a period less dramatic, more complicated, of interests manifold, but these of a less imposing character. The republics, profiting by the exhaustion of the two protagonists of the struggle, take the chief rôle; there is no potentate that is their superior; but their action is largely directed by faction and jealousy, and their quarrels are not due to the righteous contest of opposed principles, but to the shifting antagonisms of sheer self-interest untouched by any lofty motive or irradiating idea. Henceforward Italian history still advances under the Papal and Imperial standards ; attempts are made from time to time to revive old enthusiasms and inspire new hopes; but the great commonwealths pursue their own course without any very serious aid or interference from the two great powers of Christendom. Rome remains, now as ever, the pivot of European politics; but we shall see the Papacy deteriorate and become less powerful in proportion as it grows more profane.

\section{The Angevin Predominance}

Before the death of Frederick, an insurrection in Florence restored the Guelph party in that city and instituted a popular constitution and government. Florence made war on Pistoja, Pisa, Siena, and Volterra, became the leading city in Tuscany, and forced the surrounding cities to rally in support of the party of Church and liberty. But the arrival and rapid success of the "son of Herod" still gave the Guelph party cause for grave anxiety, relieved by his death in 1250 .

Frederick left two legitimate sons-Conrad, who had been crowned King of Germany in his lifetime, and Henry. His testament declared that, should both die without issue, his natural son, Manfred, should succeed. Conrad found that he could not make his way through Italy without encountering resistance from the Guelphs, the result of which might be doubted, so he and his army were transported by the united fleets of Pisa and Sicily from the seaboard of the Trevisan marches to the South. Here matters would have gone very ill for Conrad but for the energy and ability of Manfred, who inherited the charm and talent of his father, and who, though only a youth of eighteen, showed much military dash and skill. The effect of the Council of Lyons, aided by the 
machinations of the friars, resulted in the rebellion of the great cities of South Italy ; but Conrad found on his arrival that Manfred had effectually subdued them. Innocent IV. now perceived that he was powerless to become the master of the South, and he conceived the unhappy project of calling in some foreign prince who should conquer and hold it as his dependent. He died, however, before he could fulfil his project, but it was effected by a successor in the holy chair (Nicolaus de Curbio vita Inn. IV.Raynaldus). Conrad died (I254) at the age of twenty-six, and left his little son, Conradin, to the care of Manfred. His death was the occasion of charges of poisoning made by the Papal party, not merely against Manfred, but against the entire House of Hohenstauffen. An appeal to the Pope made on behalf of the young Conradin received the reply that if the kingdom of the Two Sicilies were placed unreservedly in his hands, he would see what it was fittest to do when Conrad grew up.

The premature death of the young Emperor led the German diet to offer the crown first to Richard of Cornwall, then to Alfonzo of Castile, strangers to the German land ; and the fact that Conrad fought in Italy instead of remaining in Germany to consolidate his power in that disordered country, left it to the mercy of faction. For twenty-three years there was no " King of the Romans " elected in Germany, and sixty years elapsed before Henry of Luxembourg descended into. Italy and received Italian homage. Europe was delivered from the dread of universal monarchy, but Italy had still to suffer from the policy and ambition of the Curia, and the evils that arise in a house divided against itself.

The Papacy had triumphed over the Empire, but at the cost of some damage to its material power and enfeeblement of its moral influence. It had been too involved in the subtleties of political contrivance and the conflict of local animosities and family feuds to control the inheritance of hate which the names of Guelph and Ghibelline still covered, though the principles that they had represented were no longer in conflict. The Lombard league did not survive the struggle, and the cities resumed their old hostile relations to each other, and expended their exuberant energies in the intestinal quarrels of their classes and factions. Burghers that were only foot-soldiers, dependent on men skilled in policy and war and expert in the management of cavalry, were glad to nominate captains of the people to repress disorder and repel the foe, and to invite men of character and renown to fulfil the function of Podestà, introduced by Barbarossa, and found useful enough to be retained, now that this officer was elected by the commune and not imposed by the Imperial will. In I24I, the grateful republic of Milan gave full powers to Pagano della Torre, who had saved them from ruin after their defeat at Cortenuova, and nominated him captain of the people.

Faction ruled in every city, and the triumph of the faction was necessary to give unity and force to municipal administration and foreign policy. The allies that had been the earliest to achieve their freedom were the first to surrender it, and the centres of commerce in Lombardy underwent a process of political evolution which preceded a similar change in the tardier development of Tuscany. Mantua entrusted its defence to the Count of San Bonifazio; Ferrara, to the Marquis of Este. Before long Cremona chose a Ghibelline lord. Nobles dominated Pavia and Piacenza, Brescia, Tortona, and Alessandria; and the Malatesta and 
Manfredi already guided the destinies of Rimini and Faenza. The Ghibelline tyrant Eccelino, hereditary lord of Bassano, ruled Verona, Vicenza, Padua, Feltro, and Belluno by blood and iron. To be suspected by him meant prison, excruciating torture, and execution. The names which escaped prisoners in the anguish of the wheel were carefully noted, and supplied fresh victims to the tyrant. In Padua alone, eight prisons, two of which contained 300 prisoners, were always full, notwithstanding the lively efforts of the executioner to empty them. Alberic da Romano a brother of Eccelino, governed Treviso with power no less absolute, if less ferocious than that exercised by the better known tyrant.

Alexander ordered a crusade to be preached against the tyrant of the Veronese marches : he promised all the indulgences usually given to the deliverers of the Holy Land. The Marquis of Este, the Count of San Bonifazio, the militia of Ferrara, Bologna and Mantua, assembled under the banner of the Church, as did a horde of indisciplined rabble, anxious to obtain indulgences. Their numbers frightened Eccelino's lieutenant at Padua, and the town was easily captured and then pillaged by those whom it had welcomed as deliverers. Eccelino, when he heard of the loss of Padua, disarmed the II,OoO Paduans in his army and cast them into prisons, where all except 200 died by violence, cold, famine, and thirst. For two years the incompetency of the Archbishop of Ravenna, the Papal commander, and the want of courage and discipline in his troops, compromised the Guelph cause and brought disaster to their arms. The Ghibellines of Brescia even put themselves under Eccelino's protection. Eccelino, a diminutive old man, but preserving all the courage, the military skill, the austere habits, and awe-inspiring glance of his maturity, advanced into Lombardy with the finest army he had ever commanded, hoping that the nobles of Milan, with whom he was intriguing, would surrender that great city. He was met by the forces of his ancient associates, Ghibelline nobles, that, disgusted with his "thorough" policy and complete indifference to human suffering, had allied themselves with the Guelphs. When he was sufficiently removed from his base he was attacked on all sides, and Milanese, Cremonese, Ferrarese, and Mantuans cut off his retreat. The Brescians abandoned him. He was wounded and taken captive; he refused to speak, rejected all aid, tore off his bandages, and so ended a life marked by crafty ambition, loyalty to the Emperor his overlord, resolute government, and unbounded cruelty. He died on the eleventh day after his capture. The Papacy profited little by the fall of Eccelino; the kingdom occupied its energies; a Della Scala became Podestà of Verona; and the Guelph lords of the cities worked only for themselves.

The Papacy had its hands full. For Manfred, who had been appointed regent of the Two Sicilies during the absence of Conrad, had resumed rule at the solicitation of the barons, because Conrad's son, Conradin, was but three years old. The kingdom was by far the wealthiest and most important of Italian States; it was claimed as a fief by the Papacy, and the Papacy had deposed the second Frederick and his line, and would not tolerate the rule of an unbeliever, an enemy to the Church, a man closely resembling his father in character and enlightenment, Eastern habits, and reliance on the Saracen. Directly Frederick was dead, the Papal party in Sicily worked harder than ever on the religious prepossessions of 
the Sicilians, and excited revolt in the cities, which were overtaxed, wherein there always existed a drift towards independence, and which were governed for the most part by Arabs much wiser and more civilized than themselves. Manfred was entreated to take command; he did so with reluctance, but he was the only man capable of saving the monarchy. He made an honest and respectful attempt to come to terms with the Pope, but Innocent received him arrogantly, and demanded the oath of fealty, to take which would have been traitorous to his word, and have involved unconditional surrender. Manfred fled, and fell back on his Saracen soldiers at Lucera, who loved him, and welcomed him with transports of joy (1254), and he found himself at the head of a small but efficient army of Saracens and some German troops. $\mathrm{He}$ commenced a victorious march, and closely beset Innocent, who died at Naples I 255. The friends of Manfred took heart, for Alexander IV., the new Pope, though a man of piety, was, as Matthew Paris tells us, " easily led aside by flatterers and self-seekers of the Papal Court," and was altogether a weaker man than his predecessor. Manfred now mastered the revolted South, and, on the report of the death of Conradin, assumed the crown. But the report was not true, and Manfred replied to the embassy sent by the lad's mother that he had reconquered the kingdom, and held it in virtue of the personal affection of his subjects for him ; that to resign it was not his duty, nor would it be to the child's advantage; that no one could hold the kingdom but himself, but he was willing to make Conradin his heir, and would, if it were wished, receive and train him to the kingly office, and cherish him as a son (1260). The Pope now promised to give Manfred investiture if he would clear the South of its Saracens (as if they were not Manfred's mainstay, or could be easily ejected). Manfred now found himself strong enough to send forces to the Ghibellines of Tuscany, who conquered the Guelphs at Monteaperto, and this victory, the alienation of Milan from the Papacy, and the rule of Martino della Scala and other Ghibelline nobles in the North of Italy, provided him with a number of friendly States to the north of his domain. Manfred was now at the height of his power ; in spite of the antagonism of the Pope, he married his daughter to the son of the King of Aragon, and was nominated Senator of the Republic of Rome itself.

Alexander IV. died (I26I), and was succeeded by a Frenchman, Urban IV., of low extraction, but of great parts. He represented the high doctrine of the Papacy with a determined violence greater even than that of Innocent IV. Manfred had refused to take the oath of fealty for his possessions in the South, and Urban offered Manfred's crown to Charles of Anjou, on the condition of his remitting Naples and a large territory to the Papacy, but he was astute enough to demand that Charles should resign his northern possessions on his accession. Charles refused, but at last, after the Pope had abated his terms, and with the reluctant consent of his brother, St. Louis of France, he consented to wage war and become the liegeman of the Pope. Charles was forty-six years of age. "He was wise and prudent in council," says Villani ; "valiant, severe, and dreaded of kings; of the high caste of thought required for great undertakings ; unshaken in adversity; keeping his word; speaking little, doing much; hardly ever smiling ; grave as a priest ; a zealous Catholic ; harsh in executing justice ; forbidding in his looks." He had the temper of a sour 
Calvinist, and, unlike his saintly brother, though skiiful in " high politics," he was a bad administrator. The key to his character was his insensibility; he was cold and unfeeling, and could become unspeakably hard and cruel. His wife was all agog to become a queen; she pawned her jewels to furnish the necessary resources.

A French Pope had called upon a French Prince to rule the most important of southern States, and the nearest to the Papacy. But the curia had not forgotten the pretensions of the house of Hohenstauffen and the long and disastrous contest between Church and Empire. Charles was compelled to swear never, under penalty of deposition, to reunite the kingdom with the Imperial crown, never to assume power in Lombardy or Tuscany, to preserve the immunities of clergy, to pay tribute to the Papacy, and to support it by force of arms. Ambition and the stress of circumstances led, none the less, to the predominance of the House of Anjou in Tuscany and in Rome itself.

Urban was succeeded by another Frenchman, a soldier and a lawyer, who had been secretary to the King of France. Devoted to the House of Anjou, he excommunicated Manfred and his family, gave the venture of Charles the colour of a crusade, levied taxes on his clergy to pay for the expedition, and even mortgaged the churches of Rome to the bankers of Florence and Genoa.

Charles managed to get through Lombardy by a circuitous route through Guelph territory, but, once arrived at Ferrara, the road was open to him to the south. The degenerate descendants of the Normans, the small bands of Saracens, and the levies of a country too accustomed to foreign domination and change of masters to be patriotic, were unable to withstand the vigorous onslaught of the French. Charles's troops were ordered to aim their blows at the horses, which was considered disgraceful in chivalrous conflict. At the critical hour the Apulians deserted Manfred, who preferred death with honour to a life of disgrace. As he adjusted his helmet on the field of Grandella, its feather fell. "It is a sign from God," quoth he. "I affixed it myself ; it is no chance." He died in the contest, his identity unknown, nor was his body recognised for three days after the battle. Then, thrown across a donkey's back, it was ordered by Charles to be flung into a trench, but every soldier cast his stone and raised a cairn to the fallen hero. But, by the order of the Pope, Clement IV., it was disinterred and taken to the confines of the kingdom ; "for," said he, "a heretic must not rest on ground that belongs to the Church." The poor remains were cast into a river.

" Or le bagna la pioggi e move il vento
Di fuor del regno, quasi lungo il Verde
Dov'ei le transmutò a lume spento."

(Purgat., iii. I 30-I 32.)

(Now the rains soak and the winds drive them where, outside the kingdom by the banks of the Verde, they were borne with candles put out [the sign of excommunication].)

Charles distributed the great fiefs of the conquered kingdom among his followers; he expunged the Saracen colonies at Lucera and Nocera, and ruled with so firm and ruthless a hand that in a few years there was not a Mohammedan or German to be found in the Two Sicilies. 
The Florentines rose and drove out the German garrison, commanded by Guido Novello, Manfred's lieutenant; they afterwards received 800 French cavalry from Charles, and entrusted him with the lordship of the city, with all the rights accorded by the peace of Constance to the Emperor; for the merchants who were Guelphs foresaw great profit in the establishment of trade relations with the opulent kingdom, as well as the protection so powerful a monarch would afford to their party and municipal institutions. The success of Charles brought waverers over to the Guelph side in Lombardy also, and Milan, the Count of Bonifazio, the Marquis of Este, and the Bolognese, gave passage to the army of Charles's wife.

The Ghibellines, exiled from the cities, and the Ghibelline lords that still remained faithful to the Empire, now approached the last legitimate descendant of the House of Hohenstauffen, a generous, knightly lad of sixteen years, with tales of the faithlessness, licentiousness, and rapacity of the French, and their entire disregard of ancient privilege and right. Pisa, Siena, and Martino della Scala promised him support; the chivalry of Germany arrayed itself under his flag; he descended the Alps with I0,000 troops subsidized by the Ghibellines; Rome declared for him; the Saracen colony of Lucera revolted; Sicily was in insurrection, and the Pope and Charles found themselves between two fires. Whatever fears Charles may have experienced, Clement IV. remained calmly confident. Thrice did he summon Conradin to disband his soldiery and appear without arms at the feet of the Prince of the Apostles. Conradin gave no heed, and treated even the excommunication which followed with silent contempt. He deployed his army before Viterbo, where the Pope was residing. The affrighted cardinals rushed into the Papal presence : they found the Holy Father on his knees. "Fear not," said he, "there shall nothing issue from these brave shows but smoke." Then he proceeded to the battlements, and quietly watched the manœuvres of the foe. "These are victims," said he, "being led to sacrifice." But Rome received Conradin with all pomp, and with far more enthusiasm than it accorded to its emperors. All seemed to favour him; he entered the kingdom of his fathers by the Abruzzi, and met the forces of Charles of Anjou on the plain of Tagliacozzo (1268). The army of Conradin vastly outnumbered that of Charles; and though the troops of the French King fought desperately, the Ghibellines and Germans were like to prove victorious. Then, by a perilous stratagem, conceived by the wily Alard St. Valery, the troops of Charles were ordered to retire, and when the ranks of the Ghibellines were broken in their eager pursuit, a fresh reserve was cast on them. The trick was successful. Conradin was forced to flee, and was captured when about to embark for Sicily. Charles ordered him to be tried ; in vain was it urged that, as a prisoner of war, he could not be condemned; that he had at least a plausible claim to the throne ; and that his tender years should be considered, even if he had no other claim to mercy. The judges were silent and afraid ; but one shameless jurisconsult voted the death-sentence. This was enough for Charles of Anjou. Conradin was conducted to the marlet-place of Naples, and the victor sat with his servile and compliant court, waiting to see the sentence executed. The judge who had voted his death was there, and read the sentence; and he read no more. For Robert of Flanders, to the honour 
of his name, Charles's own son-in-law, thrust him through with his sword, exclaiming as he did so: "It was not for you wretch, to condemn so noble and gentle a lord." The judge fell dead before the very feet of the King, and neither he nor the moral cowards around him dared utter a single word of anger or rebuke. Conradin quietly undid his mantle and exclaimed, as he rose from prayer: " How the news of this will grieve my mother !" Turning towards the sobbing crowd, he cast his glove among them, as a gage of vengeance, and named Frederick of Aragon, his cousin, as heir to the kingdom. Then the lad asked God's pardon for all his sins, and died, undismayed, as became an unblenching knight. He was buried by Charles's orders in a ditch in the market-place. Old Peter of Aragon, to whom the glove was brought, swore to avenge his blood.

Charles had now come near to the goal of his ambition. The scions of the House of Hohenstauffen were all dead ; the only possible claimant to the throne was the wife of a poor and distant prince, drawing her pretensions through a bastard descent from that house. Charles had no fear; he little dreamed of the expulsion of his French from Sicily and the acceptance of this bastard line that were to come.

After the death of Clement IV. there was no Pope elected for thirty-three months; there was no interference from Germany, and Charles seemed to sit so firmly on the throne that he meditated fresh conquests, and had visions of ruling over all Italy. Pelavicino and Burdo de Doara, both pupils of Frederick II., and the first no inconsiderable man of war, had fallen. Faction had weakened the cities of Lombardy and Tuscany; and when a Guelph diet was held at Cremona and Charles's agents proposed that the league should have a lord, Piacenza, Cremona, Parma, Modena, Ferrara, and Reggio consented; and, before long, Milan, which at first had replied that she valued Charles as a friend but refused him as a master, followed suit, with several other cities in her wake. He had become, by I277, absolute ruler of the Two Sicilies ; Vicar-Imperial of the whole of Tuscany ; governor of Bologna, and by that fact lord of the Guelph towns of Romagna, protector of the Marquis of Este, and therefore paramount in the Trevisan marches ; and lord of many strong places in Piedmont.

In 1280 a new Pope had to be elected. The Papacy had already begun to flirt with the Empire ; Charles was getting too strong. All the Italian cardinals were opposed to the Angevin party, and especially to the relations of the late Pope. Charles clapped the latter under lock and key, and so frightened the others that they elected his creature, Simon, formerly canon of Tours. The new Pontiff (Martin IV.) gave the Senatorship of Rome to Charles, in spite of the constitution, which excluded kings and powerful princes. He admitted French troops to all the places under his immediate or indirect control. Charles now dreamed of a crusade against Constantinople, and of achieving the conquest of the Eastern Empire. But disaffection was rampant at home. As far back as I 266 Clement had reprimanded him for his bad government. " If your kingdom," wrote he, "is stripped naked by your agents, you are blameworthy, and justly so; for you have filled the offices with robbers who commit actions from which the Almighty averts His face. Abduction and adultery mark these men no less than theft and exaction. How can I sympathize with your pretended poverty when you cannot or will not live on revenues which enabled the truly noble Frederick the Emperor, to satisfy the avidity of Lombardy, Tuscany, the 
marches, and Germany withal, and yet to accumulate for himself immense wealth?" Nemesis was at hand, and in the drama of the Sicilian vespers the card-castle of the ambitious Angevin was to be blown from its base, sky-high.

Charles was bent on becoming the most powerful of Mediterranean monarchs. He diverted St. Louis, who led the eighth crusade, to the attack of Tunis, which he rendered tributary to himself, as it had been to Norman and Hohenstauffen; he acquired concessions for the establishment of his merchants there, and secured routes through Africa for their commercial travel. The crusaders reproached him for cupidity, and he certainly sacrificed the object of Christendom to the material interests of himself and his kingdom. Lord of the Mohammedan islands of Pantellaria, Gozo, and Malta, he controlled the straits that unite the two great basins of the Mediterranean; and in $127 \mathrm{r}$ he got possession of Corfu, while he obtained the principality of Achaia from the failing Latin Empire at Constantinople, and established Angevin predominance over the Morea. His operations extended to Tartary; and Brindisi and Bari carried on extensive trade with the opposite coast. As Imperial Vicar of Tuscany, he dominated Central Italy, where the rising traders secured the governmental control of their cities, and, save in Pisa and Siena, sought the protection and trade advantages he offered. As champion of the Guelph cause, he achieved a preponderance which the curia was powerless to hinder, and the Pope, in order that he might remain at peace in his own city, had to yield Charles the command of Rome. Hc imitated the commercial policy of Frederick II., and Apulia and Campania flourished; but, though Brindisi was one of the stages on the route to the Orient, neither she nor Amalfi could compete with the rising and enterprising cities of Venice, Genoa, and Pisa. Amalfi, indeed, still had an establishment at Constantinople which served as a model to her competitors, and her ships trafficked with Barbary, Egypt, and the Levant. By scheming and cunning, Charles got the lordship of Albania, and secured the commercial prosperity of even Barletta, Trani, and the smaller Adriatic ports. The presence of the Court at Naples led to the development of that city as a centre of trade and international commerce, and drew thither the merchants of Tuscan republics to reside; it employed Tuscan workers in marble, and artists. The industries these immigrants brought with them developed, and the ports of the kingdom became a means whereby the merchants of Florence could open up an important Eastern trade. Indeed, the banker-merchants of Tuscany,.who were extending their operations throughout Europe, and by a less rate of usury had displaced and rendered possible the banishment of the Jews from England, entered into close relations with the Angevin monarchy, and, led by the Florentines, inaugurated the commercial control of Southern Italy (vide Yver, Le Commerce de l'Italie au $\mathrm{I} z e$ et I 4 e S. Paris, I903).

The ascendancy of the House of Anjou had not been wholly incontested. In Milan, Otho Visconti, Archbishop of Milan, aided by Ghibellines, had vanquished the Torriani, the chiefs of that republic, and had confined them in iron cages ; and Nicholas III., of the noble Roman family of the Orsini, the reigning pontiff, had everywhere favoured the Ghibellines (1277). He had compelled Bologna, Florence, and Siena to restore their Ghibelline exiles, and seemed to be on the point of rivalling the Neapolitan power 
when he died (1280). It was then that Charles, hastening to Viterbo, removed the Orsini cardinals from the conclave, and, striking the rest with terror, succeeded in having his creature, a canon of Tours, elected as Martin IV. All the provinces of the Church in Sicily were placed under French control; all the ports of the Two Sicilies were busy preparing a great armament for the invasion of the Byzantine Empire, and taxes were levied with increased severity, and collected with redoubled insolence. A noble of Salerno, John da Procida, the friend, confidant, and physician of the second Frederick, visited Sicily in disguise, and took advantage of the general oppression to rouse the hatred of the Sicilians against Charles and his French. He acted with the connivance of Michael Paleologus, the Emperor at Constantinople, and obtained from Spain, where Constance, daughter of Manfred and wife of Don Pedro of Aragon, resided, assurances that he would be helped to restore her. Before the promised assistance could arrive, a sudden explosion at Palermo forestalled the long premeditated and skilfully prepared liberation. A French officer offered an insult to a young married woman in the highroad in the broad light of day. The indignant husband, who accompanied her, passionately shouted, "Now at last let these Frenchmen die !'" As his words rang out, the vesper bells of the churches were calling to prayers, and many people were abroad. The officer lay dead in the roadway, for the people going to the churches to sce ; they at once joined the dead man's relatives in attacking the French, though only provided with the small knives they carried according to their wont. The tumult spread, and the men of Palermo fell furiously on every Frenchman they met. No one suspected of belonging to the obnoxious nation was allowed to live; the word "Ciceri " was used as a shibboleth ; the menacing cry of " To arms ! to arms ! death to the French !" was heard on every side, and by morning over 4,000 corpses strewed the streets. The insurrection did not remain local. Every town in Sicily followed the example of Palermo immediately the news reached it, and the news travelled quickly. As in the twinkling of an cye, Sicily was cleared of its oppressors. The tidings reached Charles when he was busy instructing his creature, the Pope, in the art of governing the world; it meant the end of his ambition, and he is said to have prayed Heaven to suffer him to fall by slow degrees. The Sicilian Vespers not merely put an end to a great Angevin project, it separated the kingdom of Sicily from that of Naples, and, in spite of Papal anathema, ended in the transference of the crown of Palermo to the son-inlaw of a bastard branch of the House of Hohenstauffen. But for Guelph aid, Charles would have been expelled from Italy.

It may not be out of place, at the turning-point we have reached, to review in brief the history of the beautiful island of which we shall henceforward hear far less ; for although the Angevin Kings of Naples preserved a great and predominating importance in Italian affairs, the design of an Angevin King to pursue the great aim of the Hohenstauffen at the establishment of world-power crumbled into dust with the insurrection in Palermo.

Owing to the presence of the Saracen and the Greek in Sicily, very great cohesion had been necessary among its Norman conquerors ; and the power of the King was far greater there than in Northern Europe. The feudal system did not develop itself to the same extent; for the conquerors were few in number, in the presence of heterogeneous peoples, and were confronted by a common danger. However, the Norman Kings were in the 
main sagacious rulers, and the conquerors were so small in number that it was not long before they became absorbed into the Christian population by intermarriage. Moreover, they were to a certain extent cut off from the feudal influences of the North, and they were a singularly adaptable people, who had come to dwell among folk of quite different traditions to themselves, Christians possessing Imperial memories, and Saracens accustomed to despotic control. The presence of a tri-lingual people, professing three or four opposed faiths, necessitated religious tolerance; and the Norman Kings ruled their heterogeneous subjects with a respect for religious conviction which had been unknown to the Christian world since the days of Theodoric the Goth, and which was not shown again until our own period. The result was commercial success and a culture which expressed itself in architecture, sculpture, and the mosaic art. A rich style arose compounded of Arabic, Byzantine, and Romanesque elements, and literature flourished. In the thirteenth century, when Frederick II. ascended the throne, that remarkable man, brought up in a cosmopolitan society, and intimately informed by his early experience of the peculiar character of his various subjects, determined to uproot all vestiges of the feudal system, and centralize and organize the powers of government; he resolved to make the profession of a ruler profitable, to have a full exchequer, and to render his subjects a well-disciplined, obedient, and flourishing people, with no will of their own and no power of resistance. Admixture of race and differences of language and religion favoured his project. He retained the feudal courts, it is true, but he granted and favoured a right of appeal to the crown, represented by trained judges. $\mathrm{He}$ abolished all elective offices under a penalty of personal slavery and confiscation. He prohibited his subjects from marrying or studying abroad without special permission, and he policed the country with Saracens, and employed them as troops.

Brilliant as the immediate results were, a spiritless and subjugated people passively resigned themselves to the contests for the crown which followed Frederick's death; and when the Two Sicilies-the island and Southern Italy-fell into different hands, foreign and unsympathetic rule produced its usual effect in a sullen, intractable people, ever inclined to turbulence, but incapable of throwing off the yoke, far more incapable of self-rule. Such conditions implied misgovernment, just as did the Austrian occupation of Italy in a period so much nearer to our own times; and except as regards ultimate relations to the Papacy, Southern Italy and Sicily have to be considered as forces no less foreign to the Communes of the Middle Ages than were the French and Spanish powers. Naples was practically a foreign power occupying the same peninsula. Its people neither fought nobly for liberty, nor enriched the world by literature or art. Southern Italy and Sicily languished under a cruel political fatr ; their peoples became emasculate and degraded, and we must look elsewhere for any seminal principle or informing germ.

The mere massacre of 4,000 soldiers, the revolt of an entire people, did not dismay the man whose fixed resolve it had been to subdue the Empire of the East. But Sicily was an island ; and Charles's fleet was outnumbered, outmanœuvred, and outclassed by that of Peter of Aragon, the petty prince whom he had despised. Calabria revolted; the Spaniards were thus enabled to establish themselves in the island; and the Two Sicilies 
became separate kingdoms, one Angevin, the other under the rule of Don Pedro of Aragon. South Italy and Sicily, the scene of the great slave risings of ancient days, afforded in their woods and mountain recesses a secure retreat to the disaffected : rigorous government was without effect and, as is ever the case under such circumstances, became more and more atrocious ; the people, composed of so many diverse strands, were never welded into one organized and vital whole ; and the result of the sad history of changing dynasties and unvarying misgovernment is that to-day the Sicilian rejects the law and order of the Italy to which he is affiliated; and the effective control of the country is in the hands, not of the Italian State, of which it is officially a portion, but of the Mafia, an association of robbers who have constituted an unofficial but fairly adequate home rule, and, on the reception of due tribute, very faithfully and effectually protect, against themselves, the life and property of the doubly-assessed citizens.

The Hohenstauffen had been wiped out; henceforward the Empire, while its tradition remains, and Dante, Petrarch, Rienzi, successively dream vain dreams, becomes more and more a mere theory. Germany is absorbed in her own internal troubles, and the days of vigorous action for her in the South are almost over. But the Papacy, by its unceasing efforts to preserve territorial independence, and by calling foreign princes to its aid-a policy initiated by its invitation to Charles of Anjou-prevented Italy from being consolidated into a nation, as the northern peoples were, by means of the sagacious selfishness of their despot kings ; it ultimately ended in her complete subjugation, and kept her, until our own times, bruised and degenerate, under the crushing heel of the foreigner. The unity and spiritual independence of the Church was probably maintained, through rough and heedless times, by the determination of the curia at all costs to administer its own affairs in its own way, in its own house. The Pope was preserved from becoming an Archbishop of Canterbury or a Patriarch of Constantinople, a mere servant and departmental officer of the State; the Christian Church remained Catholic, and was saved from splitting sup into rival dissenting and dissentient bodies; but the fair land of Italy bore the heavy and vicarious penalty. Ultimately the helpless Alma Mater of the modern world sat and watched its liberties crumble and its glorious intellect degenerate under the effects of that foreign interference which the Papacy continued to cite with no less desperation than that with which it first invoked Charles of Anjou and his French.

\section{The Deterioration of the Papacy}

For sixty-four years the German monarchs were of the opinion of Rudolf of Habsburg, who had declined to enter on his rights on the ground that "Italy is a lion's cave whereinto men enter and return not." Nevertheless, the Popes still had a wholesome dread of the Imperial power, which threw them on to Angevin support. They had little authority in Rome, a city only rendered important by its traditions and the Papal presence. They, therefore, hungered for territory as an effective base, and they sought for foreign support until they could acquire it. The series of great Popes ended with Gregory X., a man who really aimed at the general good of Christendom. The first step in the downfall of Papal power as exercised by Innocent II., Adrian IV., and Alexander III., was 
taken when Nicholas III. (I 277-I280), a member of the noble House of Orsini, endeavoured to strengthen his local sway by elevating his family. His example was followed by his successors, Honorius IV. (I 285-I 287), who aggrandized the Savelli, to whom he belonged, and Nicholas IV. (1288-I292), who was not less zealous on behalf of the Colonna. These are nearly the first examples of Papal nepotism, a policy which soon issued in the three great houses making traffic of their valour by hiring themselves and their vassals as soldier-adventurers. Their military experience was employed by them in perpetually-recurring deeds of mutual hostility. The provinces near Rome speedily became the worst cultivated and least populous in Italy, although the wealth of the faithful was poured into Rome. The second downward step was taken when Charles of Anjou carried the three hostile cardinals off to Viterbo, and the compliant college elected a Frenchman to the Holy See. Even for Charles this was a fatal step; he had secured the support of the Church; but by this action he lost the support of the Italian people. ' Martin IV. was succeeded by Honorius IV., a gouty old man, who required a mechanical appliance at service to enable him to turn himself to altar or people, or even to elevate the Host. Nicholas IV., his successor, devoted himself to securing his authority at home by practically giving the rule of Rome over to the great house of Colonna ; and his death was followed by an interregnum of nearly three years. The experiment was then tried of electing Celestine, an anchorite of great simplicity, entire ignorance of the world, devoid of any capacity for affairs. The poor old man was surprised in his mountaincell, and dragged, in spite of his protestations, to the Imperial city (I 294). He was entirely in the hands of the intriguers of the Papal Court, and as pliant as wax in the hands of Charles of Anjou's son, Charles II. of Naples, who got him to nominate twelve new cardinals, seven of whom were Frenchmen, and three of these Charles's own subjects. French influence was now predominant in the curia, and the second link was thus forged in the chain of causes which dragged the Papacy to Avignon. Celestine abandoned all business. He was, indeed, incapable of fulfilling the simplest worldly duty; he manifested only that sublimest form of egoism peculiar to certain saints, an undue preoccupation concerning the salvation of his own soul.

There was a man in the curia unequalled in address. The cardinals regarded him as their right hand, and he had rendered himself indispensable to the pitiful man who occupied the Holy Chair. He got the ear of Charles, Villani assures us, by promising the subservience of the Papacy to his royal will, and occupied his leisure in persuading Celestine that he ought to abdicate. He is even charged with having employed a speaking-trumpet to convey the commands of heaven and work on Celestine's simple piety (Ferreti Vincent. Hist.). Celestine published the consent of the curia that he should abdicate, and the chief actor in the intrigue ascended the chair of St. Peter as Boniface VIII. He is placed by Dante, who had little sympathy with infirmity of purpose, or any weakness of character, in hell,

" Guardai, e vidi l'ombra di colui

Che fece, per viltate, il gran rifuto."

(Inf., C. III.)

(Look! and behold the shade of him who, coward-like, made the great defeasance.) 
Some Churchmen denied the validity of the abdication, so Boniface brought Celestine, now again become simple Piero di Morone, under his own safeguard to Rome. But Morone, who yearned for the quiet hours of prayer in his mountain-retreat, contrived to escape thither. When he was again discovered, he implored to be let alone, and vowed that he would exchange no word with mortal man, save with his co-anchorites. He was aided in making his escape from the Papal emissaries, and, aged as he was, and enfeebled by constant fasting, conducted by a monk, he journeyed through dense forests and the tortuous and difficult goatpaths of the mountains, closely pursued by Boniface's trackers. At last his friends secured a boat, and he put forth on the Adriatic, but was driven back by contrary winds and immediately seized. Crowds followed the simple, pious anchorite to get his blessing, and his captors had to hurry him away from them by night. Boniface clapped the poor old hermit into a fortress, where his cell was so narrow that he had to rest his head on the steps of an altar which Boniface allowed him. Here he died (I 296), twenty-two months after the unhappy inspiration of the Cardinal Latino, who had proposed him for the Papal office. The unusual attack of piety that visited the cardinalate when they elevated this simple soul to the theocratic throne that demanded such extraordinary powers of statecraft and diplomacy, was another step in the downward path now traversed by the Papacy.

Boniface was passionate and obstinate; but he was a born intriguer, perfidious and contemptuous of right. He was too cunning for success. He attempted to secure peace in the South of Italy by diplomatic intrigue with the contending kings; he prostituted the Church to advance the Angevin; and he failed. He called in Charles of Valois, promising to secure his election as Emperor; he counted on his subduing the Bianchi, the Imperialist section of the now divided Guelphs, on making Charles a vassal to the Holy See, and securing temporal power by his aid. Florence and Tuscany experienced and resented his treachery, and became stronger and more independent of the Papacy than ever before. He tried to ride the high horse in appointing a bishop in France without the royal consent, and King and nation responded by asserting the liberties of the French Church. His action thus threw the Church in France into the hands of the King ; and he was himself accused of simony, heresy, witchcraft, and crime, and a general council was demanded to try him. The senile violence of Boniface's temper got the upper hand of his ancient diplomatic skill. He replied by convoking an assembly of the French clergy in Rome, and so tried to strike back at the French King. But a party of 300 French knights set sail for Italy, and by the aid of his Italian foes, surprised and captured him at Anagni. They had intended to slay him, but some lingering respect for his holy office, aided by his venerable appearance and advanced age (he was eighty-six), saved him. While the knights remained irresolute as to their future course of action, the people of Anagni gathered, routed them, and released the Pope. But Boniface seems never to have recovered from the excitement of the three days during which the French held him in captivity. He fled to Rome and threw himself on the tender mercies of the Orsini, but they could do nothing with him. He was probably suffering from senile dementia. He had accessions of rage at the smallest trifle, and he battered his head 
and suffocated himself while left alone in one of these tempests of dotage (1 303$){ }^{1}$

Scarcely was Boniface dead, than the judgment of the Christian world was recorded in an epitaph which history has found no occasion to deny. It was said of the crafty, arrogant, simoniacal, and cruel egoist that he had " come in like a fox, ruled like a lion, and died like a dog."

The eighteen princes of the Church in Rome met and elected, as Benedict XI., a man who had risen to the cardinalate from poverty by sheer ability and worth. But he was surrounded by cardinals of lofty pretensions and territorial power, and the Pope had now come to be the mere puppet of a factious oligarchy of priests. He escaped from Rome to Perugia in order to be free of the directorate, and made an endeavour ts restore some kind of order in Florence; his intentions were excellent; his power of no account. His life was not safe. He meditated escaping to Lombardy; he opened the gate for a reconciliation with Philip of France. But the "pest of France " was not the man to help the Papacy to independence; he meant to hold it in the hollow of his hand. Benedict died after eight days of agony, and it was the universal conviction of his contemporaries that he had been made away with by poison, and even Raynaldus discreetly omits all reference to what was openly stated by Villani, Pipino, and Compagni, although had it not been true, he might be expected to refute it. Villani openly accuses two cardinals-an Orsini and a Frenchman-of the crime.

Twenty-five cardinals assembled at Perugia to choose a new Pope, but they were divided into two factions. One of the Orsini led the Guelph party; another member of the same house led a party which comprised the rival house of Colonna, France, and the Ghibellines. Ten months passed without any possibility of agreement, and then the Perugians determined to starve the college into some sort of compromise. The Cardinal of Prato then proposed that one of the two parties should nominate three non-Italian prelates, and that, after due time and consideration, the other party should select the future Pope from among these. The antiFrench party nominated three men notorious for their opposition to Philip of France and his brother Charles of Valois. Among the men thus chosen was Bertrand de Gotte, Archbishop of Bordeaux. The Cardinal of Prato secretly instructed Philip as to what was going on, and advised him to support Bertrand. Philip at once sought an interview with the Archbishop, and came to a secret understanding with him; he then gave Prato the order for election, and the cheerful chaunting of the $T e D e: \iota m$ by both parties, each of which thought it had a Pope after its own mind, followed the announcement. But astonishment, which soon gave way to -dismay, seized the cardinals when they were summoned by the new Pope (Clement V.), not to Rome, but to Lyons; and soon after he gave back their hats to two Colonna who had been degraded by Boniface, and gave others to ten of Philip's creatures, all Frenchmen. He then shamelessly

1 It was said that he was murdered. The paroxysms of ungovernable rage which convulsed him appear rather to have been symptoms of senile disease of the brain or its arteries; such patients are liable to injure themselves, or to be found suffocated under the bedclothes if left alone, as Boniface was. Perhaps it was due to a dim perception of his pitiable condition on the part of the French that they did not kill him outright at Anagni. 
showed, even in his very first acts, that the Papacy, which had once directed the conscience of the Western world, and commanded the obedience of its kings, had become a State office of the French monarchy. Clement. was no willing tool; he was not insensible to the galling of the yoke. $\mathrm{He}$ was weak and pliant, but dodgy, as weak men are apt to be; and when Philip ordered him to procure the Imperial crown for his brother Charles of Valois, he promised to do so, but warned the German electorate that they must hurry matters on if they did not wish to witness the predominance of French influence. He also recommended the election of Henry of Luxemburg, a poor princelet, but of ancient lineage, recognised by all the world as a knightly soul. To the astonishment of all, Henry was elected, and Clement confirmed the election without delay (1 308). The Pope in Provence was a valuable neighbour to the French King. Philip, therefore was obliged to submit to the action of a man that Italy would have treated with contempt had he been able to return thither. But the Pope, even in thraldom, was still able to balance a German Emperor against the French King, his keeper.

\section{The Expedition of Henry VII. (I3io-I3r3)}

For two centuries the opposition of Church and Empire had secured freedom to all the cities north of the great kingdom. It is now necessary to run a cursory glance over the little republics, and observe what use they were making of their opportunities, and in what directions they were evolving. The first thing that strikes us is that in wealth, foreign commercial enterprise, the development of industry, letters, science, and the arts Italy had far outstripped every other European people, not excepting the Moors of Spain.

While Naples was occupied in fighting Aragon for the possession of Southern Italy, while the Papacy was paralyzed by the absence of order in its territorial base, and while the condition of Germany prevented Teutonic interference, innumerable small States had achieved an almost complete independence, and were subject to frequent revolutions fomented by faction. These turmoils, which indicated the excessive vigour of communities yet undisciplined in the routine of orderly and centralized administration do not appear to have affected their mercantile prosperity, and the contado, or country surrounding each town and subject to it, was highly cultivated by an active and industrious peasantry. The burgher-proprietors of these lands advanced capital, shared the produce, and paid the land-tax ; they undertook the great work of irrigation, which has rendered Italy so fertile. The naviglio grande, which spreads the clear waters of the Ticino over the finest part of Lombardy, was begun in II79, and finished towards the close of the thirteenth century ; the scientific farming of Italy became a model to the world, and the cultivation of the rich districts that belonged to the towns are still in contrast to the wastes of the feudal plains of the Campagna and the South.

The paved cities afforded a strong contrast to the mud-lanes of Paris and London; stone bridges of bold and elegant design crossed the rivers, and aqueducts carried pure water to the fountains. Public buildings arose, uniting strength with grace; scuplture began to reproduce the skill of the antique with a trend tenderer and more individual, if less perfect and calm : 
the formalism of Byzantine painting gave place to the naturalism of a new school; poetry soared like the lark skywards in the Divina Commetia of Dante ; historians recorded past events with some care in research, and contemporaneous events with graceful, honest simplicity; and States vied with each other to secure the brush of Giotto or the chisel of the Pisani ; shops displayed rich stuffs and embellished weapons; yet manners were still simple, and luxury was hindered by public sentiment and legislation. The great wealth of the traders was expended in public works, many of which remain the cynosure of lovers of the beautiful.

The first commune to exhibit what a small free state can do by commercial enterprise and public spirit had been Amalfi ; next followed Pisa, doomed to the same fate she had meted out to Amalfi ; for she was even now yielding her maritime supremacy to her victorious rival Genoa. Pisa was becoming accustomed to the rule of a single person, and was bent on redressing the decline that she had suffered as a sea-power, by extending her sway on land. The government of Venice was rapidly changing into that of a closed oligarchy, and that State was preparing to contest the trade of the Orient with Genoa. All three cities still remained the emporia of the world-commerce of the time. Their galleys transported the furs of Tartary and the expensive products of the Orient to the Western world.

In the North the huge industrial centre of Milan was presided over by the great Ghibelline family of the Visconti, which had ousted the Torriani, and aspired to completer control of the destinies of the State. The aristocratic principle had also established itself in Verona, ruled by the powerful house of Scaliger. There was a general tendency in Lombardy to submit both the control of a turbulent nobility and the factiousness of clashing interests of caste to the dictatorship of strong men.

In Tuscany quite another direction was given to the art of government than in Venice; like the Lombard cities, the Tuscan communes tended to the development of popular liberty ; they had come to the front at a later period, and had not yet evolved a dictator. Their industrious looms manufactured dainty and luxurious products for the transalpine countries. No less than the cities of Lombardy, Lucca, Siena, Florence and other Tuscan towns were the financiers of Europe-a position which they attained from their monetary relations with the Papal court. These petty States were able to dictate to the needy sovereigns of Europe whether they should undertake a conquest or proceed to a crusade. Their merchant bankers had relations with every European Court, and established their countinghouses in the capital towns of every European people.

The Universities of Bologna and Padua were famous throughout Europe. The former was the nursery of great lawyers, and in spite, or perhaps in consequence, of their presence, the townsmen of that rich and thriving city were pronouncedly republican. But the absence of organization caused the city to pass in rapid succession from one powerful family to another, with a constant trend towards Papal supremacy, though interludes of selfgovernment followed insurrection. Padua was free and flourishing, though threatened by the growing power of the Scaligers; she was soon to surrender her liberty to the Carraresi, and she was busily employing her short time of freedom in subduing the neighbouring city of Vicenza. 
The last of German monarchs that shared the grand ambitions and lofty ideas of Charlemagne, the Othos, and the Fredericks, now ascended the Northern throne ( 1308 ). He obtained the crown of Bohemia for his son, but the memory of the Holy Empire of his predecessors was his own chief incentive; it fascinated his imagination and stirred his soul. As ever, his princes, intolerant of a master, taught him how " uneasy lies the head that wears a crown "; and the policy of diverting their energies by letting them try their fortune with him in entering the "lion's den " seconded his ardent desire to restore the glories of the Empire. And, indeed, it was a general feeling of the time that the Emperor was invested with legitimate authority over the peninsula only when he was crowned, or, at least, had crossed the Alps with the intention of receiving the crown. Although three generations had passed away since the last Emperor visited Italy, the tradition of Imperial authority had waxed, not waned, in power. The increased study of Latin literature, and the investigations of jurisconsults into the legislation of Justinian, had helped this growth of veneration for the past. For the spirit of the old Roman world was misunderstood, or, rather, the scholars of the day knew little about it; the ancient Greek world was but a name to them, and Boethius, Symmachus, and Cassiodorus were held in as high esteem as Cicero and Livy; the courtly poets and respectful historians of Imperial Rome were not without testimony as to what was due unto Cæsar, and the jurisconsults breathed the atmosphere of the servile Court of Justinian. Italy was ready to bow down and worship Henry of Luxemburg, the Emperor, master of the world de jure, before whose august feet a path should straightway be made. If anyone could have re-established the Empire, it was he. Never was the time so propitious. Dante and the thinkers of Italy hailed him as the deliverer and saviour of their country, the sovereign sent of God to restore the ancient order ; the learned, full of Pandect and Code, presaged the return of the reign of law; the little States, bleeding from a thousand wounds, looked to him to heal them, and to give the world the Roman peace again. Henry was young, ardent, high-minded, convinced of his Divine right and sacred mission, a devout son of the Church, and ready to yield her her due. Could there have been a better dawn of promise? Four factors were present which doomed these fair hopes. The first was a weak, vacillating, and mendacious Pope. Clement was already busy in setting up Robert of Naples, the grandson of Charles, in the kingdom of Naples, in the interests of France and as a counterpoise to the Emperor. The second factor was the rapacity of the nobles who accompanied Henry, and who regarded and treated Italy as a goodly milch-cow to supply their needs. The third was the insufficiency of the Imperial troops to their mission, and the shortness of their term of service. The fourth was the bitter antagonism of factions in Italy, which fomented endless intrigue, and forced Henry, nolens volens, to take the Ghibelline side.

Nothing could have been more auspicious than the fair seeming of Henry's first appearance on the southern side of the Alps. He had few followers, and he was greeted by legates from the Pope ; the rising House of Savoy gave him greeting, Dante hailed him as the restorer of peace to anarchic Italy and a suffering world (De monarchia); the Lombard nobles promised to bear him to Rome as on a pleasure-jaunt, " with falcon settled on his wrist"; the exiles of both parties hastened to his "court with 
rejoicing, and the mobs of the cities threw up their caps. His coming promised

\author{
"Upon this land a thousand, thousand blessings \\ Which time should bring to ripeness."
}

Henry distrusted neither the Pope, Robert, King of Naples (who had restored Angevin power in the Peninsula), nor the Guelph cities. The family for whom the Ghibellines had fought was long ago extinct, and Henry promised and endeavoured to hold the balance fairly and reconcile the contending factions. But the very name of Emperor excited the suspicions of the Guelphs and the fierce hopes of their Ghibelline adversaries.

Henry rewarded Amadeo of Savoy, his strong adherent, by creating him a peer of the Empire, thus granting another step to the ascent of that able and ambitious house. He nominated Imperial Vicars, and appointed a Podestà to Genoa that, weary of turmoil, had given herself to him for twenty years. But the legates, sent as an evidence of Papal joy at his coming, were watchful and subtle to stir up the fierce forces that underlay what seemed so fair. No sooner had Henry confirmed the rule of the Visconti in Milan than the family they had displaced, the Torriani, leagued themselves with the Guelphs of Cremona and Brescia, and flew to arms. Henry was obliged to besiege Brescia, and to support the war by levying contributions on Genoa and Milan. Pisa, whose commerce was threatened by the growing marine of Naples, and whose importance was further injured by the Florentine merchants having found an outlet for their trade in Neapolitan ports, welcomed him with enthusiasm ; but Florence, that had become by its wealth, ability, prudence, and courage, the real directress of the Guelph party, refused to receive his ambassadors, roused the Guelphs of Italy, and obliged him to place her under the ban of the Empire. Pisa had already furnished Henry with 60,000 florins to pay his descent into Italy ; she expunged his debts, and provided him with arms and ships to convey him to Rome. Rome, garrisoned by the soldiers of Robert of Naples, slammed her gates in his face, and he had to content himself with receiving the Imperial crown at St. John's Lateran (I 3 I 2).

The coronation of the Emperor relieved the Germans from their term of service, and most of them returned home. Henry passed the summer at Tivoli, the place whither Mecænas and Horace and the wealthy Romans of the antique world had loved to retire from the heat of the plain. Had Robert been bolder, Henry's peril would have been increased by remaining on lower ground during the hot season. When the summer heats passed, the Ghibellines of Central Italy rallied round him, and he marched to besiege Florence. The Florentine defenders, vastly superior in numbers to Henry, wore him out ( $13 \mathrm{I}_{3}$ ), and he retired to Pisa, whence he made war on I.ucca, the perennial foe of this loyal city; and, on the arrival of reinforcements from Germany, he began his march to meet the forces of Robert. The King of Naples had but a small support of French cavalry ; his own subjects had but a poor military reputation, and the Guelph burghers, pertinacious and invincible behind fortified walls, were imperfect in strategy"and tactics, and had neither the training nor the dash required for the open field. After fighting his way through Italy step by step, as his predecessors had done before him; after tasting, like them, humiliation at the hands of a Roman mob; after having received the crown in a suburban church from the legates of an absent Pope, it seemed as though 
Henry's star were once again going to break through the gathering cloud. But he was seized by illness on the march, and died shortly afterwards, men said at the time, of poison administered by the monks (I 3 I 3 ). That belief has never been justified by evidence. It was the fate of Henry also, like myriads of intrepid Teutons that have marched in hope to the fair beckoning land beyond the snow summit, to leave his bones to whiten in the "lion's cave" : they repose to this day in a quiet chapel of the noble duomo of Pisa, most faithful and steadfast of his cities.

There were still three great Ghibelline warriors in Italy to uphold the standard of privilege. In the north were Can Grande della Scala of Verona, and Matteo Visconti of Milan; Uguccione della Faggiuola was paramount in Tuscany; Pisa had Arezzo for ally. But some of the Tuscan towns that had not accepted "lords " were united by a Guelphic league.

\section{THE COMMUNE}

\section{The Republics Nominate "Lords"}

IT is evident that we have now arrived at a new epoch in the evolution of the commune. The result of faction is that the head of the victorious faction is given the full powers of the Podesta for a term which allows him to become indispensable to the State. As often as there is equilibrium between the factions, as often as there is an interregnum between the exit of one faction and the establishment of dominance by its foe, the old commune reappears in its integrity, and of this the history of Bologna affords, perhaps, the most conspicuous instance. But at each reappearance of the old form the commune has lost some of its vitality, some of its organization and tradition; its trade-associations have had their own battles to fight with each other; they are wearied, bruised, and corrupted by the growth of individual wealth and its employment as capital, and the wealthy-that is to say, the powerful-are willing to surrender to a prince who will protect wealth. The lower orders, too, require a protector ; the whole commune sighs for the rule of someone so exalted in position that all are equal before him, and who will administer justice and fear none: the way is paved for the enslavement of the republic. Lords come and go, it is true ; at Milan the Torriani, leaders of the popular party, are driven out of the city by the Ghibelline Visconti ; the Torriani prevail again, and once again the Visconti are triumphant. But the lord remains, and ultimately a principality is established.

Often the new lord has to maintain his power and that of his party by violence. The weaker he is, the more violent he becomes. The worst tyrants are the little lords of Romagna. We have seen Eccelino of Verona, in order to maintain his faction, become a monster of cruelty; he had to establish himself by force, and once in power, he had to deal with jealous enemies of his own party, and to extirpate the opposite party, but he could not do without the help of the citizens, and his rule was most popular with the people. Often a city torn by dissension called in a neighbouring 
great lord to restore peace; such a man brought in his own faction with him ; but he was careful so to distribute power as to secure it to himself, and to maintain his rule by just and righteous administration. The blessings of peace were so obvious, that both parties soon combined to sustain him.

Walls could protect from the enemy without; what was wanted was peace within the gates. The strong man who could subdue his own people and make them observe some measure of righteousness, some regard to public decency, and public order, was regarded by the populace as the vindicator and defender of popular right. Once become lord, it was, indeed, to the ruler's interest to favour the people, as his own class was by far the smaller; and if he was cruel, he was only judiciously so. $\mathrm{He}$ was surrounded by enemies, at war without end, and with each foe slain or terrorized there was a foe the less. The citizens, who gave him a position exalted above his fellows, had to be conciliated, for they were his real support.

The despot was the head of the citizen army. We shall see presently how he had often been elected captain of the people, and rose to power in that way. In order to maintain power, he gradually replaced the militia by mercenary troops, and, with the citizens disarmed, he became secure against everything but conspiracy and the assassin's dagger. Soldiers had been hired by the commune of Genoa in II 58 , by Milan in II55, by Verona towards the end of the twelfth century. In I 264 the commune of Milan, at the suggestion of Napoleone delle Torre, instituted a census, and raised a force of 1,500 paid men, each family furnishing the means for the support of a man and a half.

When a Podestà became really possessed of exceptional power, he ended by achieving the "tyranny," in the old Greek sense. But there were other ways in which despots came into being. Often the Captain of the People, leading its forces, heading the trade-associations in warfare, and giving them military training, led his citizen-army in its contests with the grandi. Often the Podestà and the Captain were the heads of two separate States within the State, and the latter thus became the representative of the ancient commune, now disjoined in effect, if not in name, from the commune of the Podestà. Mercenary forces began to be employed everywhere in the second half of the thirteenth and the beginning of the fourteenth centuries; and the vassals and military followers of the Captain, as well as the mercenary troops, looked to him for command, though the latter were paid by the republic. War was the sole occupation of the mercenary, who did not trouble his head with politics, and once at the head of men who recognised his sole command, the Captain was independent even of his own faction. He could put down the robbery of the country squires and all kinds of injustice, judiciously destroy his foes, and cautiously put his friends into subjection without any undue fear or favour.

Later on in Italian history we shall find mercenary generals possessing themselves of States. Such were the Sforza and Braccio. We shall also find merchants or bankers of ability, associated with the interwoven business of great houses, becoming tyrants, despots, dictators, whatever term be most appropriate to the director of the policy of the commune. Such were the Pepoli and Bentivoglii of Bologna, the Petrucci of Siena, 
and the Medici of Florence. Once " signor," the dictator tried to increase his prestige and power in various ways. We find Can Grande of Verona and Polenta of Ravenna giving asylum to Dante; the court became the abode of men of letters, jurisconsults, artists, the men of distinction of the "tyrant's" own party; and an asylum for the numerous exiles of his own colour from other cities. Governing at first by the use of the constitution, the Dictator gradually assumed more and more absolute power. A struggle took place between the tyrants, and some, at least, of the survivors not merely formed dynasties, but princely houses.

Dissension at home and danger abroad, then, necessitated a concentration of power in a single hand. The Italian republic was never more than a loose bundle of guilds; often a single guild or an association of them was more powerful than the State; and in earlier history, especially, the family or gens, equally with the guild, was the real bond of union-a little State in itself, ever in conflict with other families. Hence the affection to a party was greater than the affection borne to the State, and we find, even as late as the fifteenth century, the exiled Albizzi joining the very foes of Florence against whom they had defended her for many years at the cost of immense public treasure and personal self-sacrifice. When the consolidation of a republic remained so imperfect, it does not surprise us to find Petrarch, in spite of his wide and exalted vision of a renovated Roman Empire, advising the commune of Rome to exclude all the inhabitants of the surrounding country and all of foreign birth from participation in her government.

It is often asked why the Italian republics did not unite. Anything like a confederation of republics was as impossible in the Middle Ages as a federation of the world is to-day, and while every little State was urged on to the conquest of its neighbours by the need for securing trade-routes, by the idea, not yet wholly extinct, that the only way to deal with a commercial rival is to crush him, and by the various other causes that we see operant to-day, the notion of the admission of subjugated peoples to a share of the government never so much as entered into the mediæval mind. As Professor Villari says, "the spectacle of a Pisan or a Pistojan in the councils of the Florentine republic would have been as extraordinary as nowadays that of a citizen of Paris or Berlin seated on the benches of an Italian parliament" (Villari, Macchiavelli). A ruler, to gain the general support, would, on the whole, find it to his interest to deal even justice to all; he came, therefore, to be acceptable to the inhabitants of the republics and their subject populations. Again, the ruling class was unaware of the principle of representation, for representation would have been impossible before the days when world-commerce and cheap literature have rendered, or are supposed to have rendered, every man competent to decide on the most complicated problems of policy and administration. They tried, therefore, to keep power in their own hands, and in order to establish liberty and equality among themselves, they instituted a constant change of the officers of State. The result was that the excluded classes, to whom the spirit of liberty had penetrated, invaded these offices, as at Siena and Florence ; and the presence of diverse interests, as well as of amateur statesmen chosen by lot, and constantly on and off the political stage, prevented all continuity of foreign policy, all proper military control, all secrecy in affairs of State ; legislation was either pre- 
cipitate or slow; there was no proper economy of the public funds ; and an able statesman disappeared almost as soon as he had acquired his ephemeral power. These factors, or even the presence of some of them, pointed to the need of a concentration of political power; they led to the oligarchical government of Venice, and to that of the Albizzi in Florence at the end of the fourteenth century, and although oligarchies arose out of the exhaustion consequent on dissension, they had probably some influence in the facility with which military despotisms established themselves in the North, and later on they were the reasons which facilitated the assumption of absolute power by the commercial house of the Medici in Florence.

The income of the Dictator was, in North Italy, largely derived from his own lands ; he disturbed taxation as little as he could, taxes on articles of consumption, on exports and on imports, together with a land-tax based on valuation, gradually coming into his control. The republics, when in want of money, raised loans ; the despot despoiled his Minister of Finance like an Eastern ruler, thus saving his own credit and gaining popular applause for dealing severely with the spoiler of his people (Sacchetti, Nov. 61, 62). The forms of the republic were preserved by the despots, even for a long time after rule had been exercised by a dynasty, in order to conceal the absolutism which they had illegitimately usurped.

\section{Treatment of Subject Populations}

The commune took away all military command and real political control from conquered or subject populations. And since in the fourteenth and fifteenth centuries no one but certain citizens of the chief city had any political rights, not merely were the dependent cities deprived of political importance, but they were subject to the rule of a small minority. For the members of the leading guilds alone took any share in the government, and they were a very small proportion of the population of their own city even. Sometimes, indeed, they were obliged to extend their own governmental privileges to a few of the next orders in the social grade, but never did they do so to the populations of other towns; and, even when the basis of government expanded, there was no really large governing class ; for, later on, even the Ciompi of Florence did not obtain or even claim political privilege for all the inhabitants of that city ; nay, their demands were based solely on the guild system and confined to those of a certain rank in Florence. The dependencies of the commune sometimes possessed a measure of local self-government, but every conquered city became a centre of disaffection, and hence republican states never grew so large as those under a despotic ruler; for, while the tyrant suppressed institutions that fostered the initiative and developed the powers of the citizen, he treated the whole of his domains with just and equal administration.

\section{The Structure of the Trade-Associations and the Rise of Capitalism}

The guilds were the great nerve ganglia of the mediæval city. We have stated that the exact affiliation of the guilds to the Roman collegia is 
unascertained, but that probably the guild was an evolution of the collegium; but we must not forget how similar conditions produce similar results; and if the guilds had a life continuous with that of the collegia, they soon developed structural and functional features peculiar to themselves.

Of course, in the early Middle Ages nearly all trade was done by barter. The means of communication between district and district were so difficult and so unsafe, and the country so subdivided into small jurisdictions, that it was difficult for the workman to go abroad in search of a living. The effort of the guild was therefore directed, first to guarantee good quality of goods to the consumer; secondly to limit the number of apprentices or journeymen, so that there might be work for all, and that the particular craft of which the guild was constituted, and which it was its function to govern, might not be overcrowded by workmen with nothing to do. In the interests both of the guild and the municipality the guilds aimed at good work, the certainty of employment for each workman, and a fair share of business for each member. The master was a masterworkman, and he bought raw stuff for himself or in conjunction with other master-workmen.

For a long period work was carried on without the employment of capital, as we now understand it. There was no opportunity of turning stock over rapidly, or of altering the form of one's wealth frequently; that could only become possible on the development of exchange. The craft-guilds and their members had, at first, nothing in mind but the advantages which their members could share among themselves and the requirements of the municipality to which they belonged. The laws of the guild were framed by a number of equals, and the silk-trade in Venice retained this primitive character. But in Florence and other cities one finds traces of capitalism as early as the very beginning of the fourteenth century. When trade began to extend itself to neighbouring States and across the Alps, goods had to be retained a long while in order to be properly manufactured in large quantities and to await transit. This would imply a great strain, and the man who had the best knowledge of foreign markets, and who knew exactly where to place his goods, would be able to take advantage of a varying market, and would find his operations hampered by the restrictions of an association the laws of which were adapted to a known and practically unvarying market. Hence we find capitalistic organizations taking possession of some of the guilds at a very early date, and it is evident that their regulations were drawn up by big employers of labour with a view to their own advantage.

Now, though Florence as a commercial power appears on the great stage of Italian history at a comparatively late period, a study of her internal organization is a study of that which was in many respects of best and highest, and most characteristic. She was in politics and social science, no less than in the realms of imagination and investigation, the Alma Mater of the modern world; she was the full flower and perfection of her time, not merely in public spirit, letters, science, and the fine arts, but in commercial energy and in finance. Fortunately the records of her great wool-dressing industry are preserved, and from this and other of her records we are able to reconstruct a fairly satisfactory picture of her trade-organization; and there can be no doubt that in examining the 
statutes and records of Florentine guilds, we are practically studying the guild system of Italy.

At first the guilds were not associated with the cares of State ; they, or rather some among them, became the State in Florence and other cities. And in tracing the political evolution of the guild, we are shown that the political life of an Italian commune was not wholly self-evolved; it was seriously affected, now hampered, now helped on, by extraneous influences such as the great struggle between the Empire and the Papacy, by the aggrandisement, decline or fall of the rulers of the South, and by foreign powers who menaced or supported its parties.

Thus, when Manfred fell, it was natural that the Papal party should, more than ever, receive the support of the mercantile cities, which resented the rule of feudal nobles that had their own territorial sources of income and mountain-castles for aggression and refuge. The Guelph faction, to strengthen itself, favoured the representation of the greater traders. The Guelphs had scotched the Ghibelline foe merely; it was still formidable, and the Teuton mercenaries were very formidable; the Papal party, therefore, gave the guilds a completer organization for military purposes, and associated them with the government. Just as on the death of Frederick II. the primo popolo arose, and the Podestà, the leader of the nobles, was confronted by the Captain of the People and the "ancients" of the people, who in some measure corresponded to the consuls that had preceded them, so the death of Manfred, bringing the Guelph party once again into power, helped the triumph of the popular cause. The seven greater arts of Florence were already organized ; the notaries, calimala-i.e., dressers of cloth-changers, wool-merchants, physicians, silk-merchants, and skin-merchants. Thirty-six "good men and true " of these guilds met with the nobles to settle public business ; each art received a consul, rectors, and a gonfalon, or standard, of its own, and was prepared, if required, to assemble in arms. The drapers, shoemakers, butchers, masons and carpenters, smiths, and dealers in second-hand things, had their organizations ; but they counted as nothing in the State; political questions were left to those who, by their learning or by their experience as foreign traders, might be taken as qualified to assume the responsibility of aiding in the direction of the politics and administration of the commune. Soon members of the popolo grasso-i.e., of the greater arts-were called more and more into consultation, and took a separate and recognised place in the councils of the State.

In times of insurrection, each guild maintained public order among its own members, and in course of time these miniature republics became the republic itself. In $\mathrm{I} 282$ the supreme rulers of the State-the Priors-were chosen from the greater guilds; and this government exercised control over all the industrial organization of the city. Aristocratic rank became a disability, and Florence became a republic of the merchant-guilds and the notaries. The greater guilds bore the weight of taxation, as was but just; but the minor trade-associations increased in number, and became more powerful and better organized. They took advantage of intervals of external peace to threaten and advance, and, later on, we shall see them, for a time, become the ruling power in the State. But each art, as it acquired power, became a conservative force ; if the superior arts were 
always ready to humble the new-comer, the guild admitted to political power was always prepared to resist pressure from below.

The State always selected as its ambassadors the ablest, richest, and most prominent merchants; sometimes even Priors were sent. The selection was made by the Priors ; "richiesti," or prominent citizens specially summoned, often aided them in the careful selection of suitable men; but never by any chance were the ambassadors drawn from other than the seven greater guilds.

The most powerful guild in all the manufacturing cities was that of the wool-dressers, or calimala. Together with the money-changers, the members of this guild elected the officers of the mint. They were all men doing business on a large scale, not merely in Florence, but wherever Florentine enterprise went, and Florentine enterprise extended until in the fifteenth century it seems even to have reached as far as China. They had a large voice in the finances of the State, which was regulated by three merchants - the camerlinghi della Camera - two Florentine jurisconsults, and a notary.

We possess the statutes of the Calimala in full from the period of which we are now treating: our regulations bear the date 1302 . They were altered from time to time, but the chief and more permanent of the provisions of the body appear to have been as follows :

Certain religious duties and observances were to be rigidly enforced.

Every two years, or every year if the general council required it, the consuls called together six of the oldest and most experienced merchants, each belonging to a different firm, and these were entrusted with power to change the statutes, they being shut up, without access of anybody, for five successive days to fulfil that purpose; they were allowed a daily meal of two courses. If they carried an amendment by a majority of two-thirds, it was written down, carried sealed to the council, and allowed or rejected by secret voting, or changed, if five-sixths of the eighteen members that formed a quorum so desired.

Every six months the heads of the various warehouses and shops were called to a general meeting. The master of every warehouse possessed two votes, the master of a shop but one. Absentees, unless they were abroad on business, were fined. Three electors from each company of the guild-each company being an association of a separate branch of the trade-were chosen, and the body thus formed elected, in secret conclave, four consuls and a chamberlain. The main conditions under which they selected their officers were that their nominees should neither be their own friends nor those of the outgoing consuls ; no company, or subdivision of the trade, might furnish a consul twice in succession, and no relative of the chamberlain or member of the company to which he belonged was re-eligible for election for two years. The consuls might not leave the city while holding office, save for religious or business purposes, and a notary, who must be a subject of some other State, was to be present at their meetings. The consuls elected a prior from among themselves; they fixed the quality, the make, and the price of commodities. At one time these standards appear to have been settled by the vote of the heads of the guild after debate, but this was put down by the government in 1292. It need hardly be said that the position of the consuls, who thus regulated the entire profits of their trade, gave the merchants who were 
elected very special advantages in their own businesses, of which they were likely, discreetly but very assuredly, to avail themselves. Consuls entrusted with such powers required some very efficient check on their behaviour. Consequently their conduct while in office was reviewed every month by a council of seven members who sat in camera, and if the result of their inquiry were unsatisfactory the case was sent on to a general council, of which an account will be given presently. The notary was heavily fined for the least dereliction of duty, and at the end of his tenure of office, which lasted through two consulates (one year), he was examined as to the discharge of his trust by three syndics.

The general meeting of the calimala elected two councils as well as the consuls, one general, the other special, eighteen members of the former and twelve of the latter formed a quorum. No section of the trade could furnish more than two members to these councils, nor could consuls entertain propositions that these had rejected. The function of the general council was pretty much that of a private detective office; it had its agents abroad, and kept a very active watch on all that was going on, denouncing to the consuls those whom its members suspected of or detected in wrong-doing.

Traders and non-traders were admitted to the guild ; non-traders were of course introduced by sponsors actually in the business, and the heirs of a member had a right to become members themselves; on the other hand, they were responsible for any shortcomings of the deceased member.

The feeling of the Middle Ages was strongly against usury, and this particular guild, as well as others, had stringent regulations against it, which were, in practice, restricted to cases of private loans at exorbitant rates. Thus, if a member was believed to be twice as rich as he ought to be through the legitimate exercise of his craft, he could be hauled up for explanation, and on condemnation, if he had not in the meantime voluntarily surrendered his ill-gotten gains, he was called upon to give up the surplus of what was estimated to have been lawfully acquired. (Stat. I., $\S 7$ ). Yet most of the very wealthy merchants of all the guilds made their money to a very large extent by the practice that was so universally condemned. It was condemned partly on religious grounds, partly because it was a process whereby wealth and power were obtained without adequate labour, though not indeed without considerable risk, and partly because, being so extremely risky a business, especially with monarchs for clients, the rate of interest was enormous. Italians fought the Jews everywhere for the possession of the money-market; they lent Philippe Auguste, King of France, and Edward I., King of England, vast sums which were absolutely lost. And even when banking business was properly established and recognised there are certain records which arouse very natural, though perhaps unjustified, suspicion. For example, towards the end of the fifteenth century there died at Prato a man who had devoted a long life to the useful occupation of money-getting; he had shops in Florence, Pisa, Genoa, Barcelona, Valencia, Avignon, and Majorca. He left the poor of his native town 70,000 florins, whereof about a third was invested in the Florentine Monte (State Bank). He is stated to have been a cat-merchant; but it is difficult to believe that a trade in either furs or fancy varieties of the "harmless necessary cat" can have been the sole object of so large and organized a business, or the 
sole source of so remarkable a fortune (Lettere di uno notaro). Be that as it may, usury flourished in spite of religion, prejudice, or reason, and the wool-dressers throve very well at their trade.

Each guild had its own tribunal, which could inflict fines or expel members. There were accountants employed to register its finance, and vice-consuls were appointed to foreign stations by the consuls at home. Wool-merchants were forbidden to sell cloth made from wool that was not imported from north of the Alps (Italian wool being of inferior quality), or to export fine wool or anything that would help competition outside. The hours of labour were restricted, beginning with the morning and ending with the evening bell, and all sales had to be effected in the shop. Buyers were not allowed to carry goods that they were inspecting farther than the casement, but the seller might take his wares as far as the middle of the street to show them off. Every apprentice was allowed a mattress to sleep on, and women, dice, and all games, except chess and tavola, were prohibited to him. Candles and lanterns were allowed to the apprentice, but not a fire, and idling in the streets, blasphemous language, and bad behaviour were sternly put down. In order to preserve the secrets of the trade, neither masters nor men could take any woman who was not a Florentine to wife without express permission, under penalty of banishment and confiscation of goods.

Labour was very subdivided, and each department was constituted into a company of the guild. A maximum price was fixed for everything, and certain people had special privileges, such as of selling certain kinds of coloured cloth. The organization had its secret police service of sensali, and if the secret denunciation of these men were found to be false, the denouncer was liable to ejection from the company to which he belonged. Journeymen were not allowed to hang about the shops seeking work, and, if they were allowed to work outside the city they had to give a strict rendering of their earnings to their masters. If a workman or apprentice joined a religious Order, that Order had to settle the master's claim for loss or restitution, or it got no further subscriptions from the trade; if the bound servant took to flight, belongings that he left behind him were sold. Masters everywhere supported masters, and the alien refugee could find no employment. He was not taken on unless he presented a written discharge from his last employer.

Such are some of the characteristics of trade-associations at the end of the thirteenth and beginning of the fourteenth century. They pass beyond "grandmotherly legislation," but they were a self-imposed tyranny. Perhaps the man of to-day is not really freer, especially the proletariat, but he is less ostensibly under control. The proletariat of the Middle Ages had no political liberty, no personal liberty whatever, and a perusal of the statutes of the calimala would have saved more than one excellent writer, of generous impulse and imperfect information, from undiscriminating laudation of the condition of the workman in the Middle Ages. Whatever may have been his privileges in the North, they were few in Italy. Probably, however, the mediæval Church took a tenderer care of the defeated in the stern, barbaric battle of life, and exercised a wiser benevolence than does its modern representatives or the modern State. And, after all, captivity to the masters of a trade-association to whom the worker was personally known, and with whom he was in daily direct inter- 
course, may have been preferable to the great impersonal stipulations of capital and the operation of unseen, rigid, economic laws that distress cannot appease nor benevolence alter.

Further proof may be adduced of what excellent care the masters took of themselves. Apprentices were not allowed to set up for themselves unless they went beyond a certain distance from their masters, nor could an artisan become a master or enter into partnership unless he set up in a different neighbourhood. And since each trade was gathered into a separate locality for the convenience of guild-supervision and corporate action in case of need, the artisan was powerless without his master's consent. In Venice only did the oligarchic, independent government preserve the democratic constitution of the guild. The minutest details of each craft were prescribed; even how much metal might or might not be used for a helmet (Perrens). Only one kind of ware might be sold in one shop, but a rich master might have many shops. A tradesman could only sell what his workmen manufactured. Such are some of the rules, but they varied from time to time, and the regulations of a trade were very often peculiar to it, since each craft managed its own affairs. The employers took good care to regulate the maximum wage. If a workman wished to leave his employer the master could retain the man by consent of the guild ; in fact, the guild was a trades-union of masters, and the men were prohibited and prevented from combining. Practically, the workman was the master's serf.

The six great guilds of Florence (for at first the notaries were not admitted) formed a union in which they were represented by their capitudini, and, finally, there was a proconsul at the head of affairs. These merchants were travelled men, men of capacity, with a knowledge of foreign courts, languages, and manners, and possessed of shrewdness and ability to hold their own in the great world beyond; their energies were quickened and sharpened, and their intellectual powers amplified and augmented to a prodigious extent, while the political training which their guild gave them rendered everyone of them at least as capable as any foreign monarch of taking the helm of State, and of keeping some measure of law and order in the city in times of revolutionary change (Perrens).

Certain members of these guilds, merchants and money-lenders, certain Florentine families, got a firm hold of the money-market, and much of the trade of foreign cities. The same thing happened in other cities. Siena, Lucca, and, at first, the cities of Lombardy, vied with each other, and practically ousted the Jews as money-lenders. The families of the Ricciardi, the Bardi, the Peruzzi, the Spini, lent money to English and French merchants, and the debts of crowned heads often caused considerable embarrassment both to the monarchs and the merchants. Edward I. and Edward III. were notorious borrowers, and Italians were as unpopular in foreign countries as the Jews. They were treated with small regard for commercial good faith, and Matthew Paris says the Italian bankers in England would have given up business in London had it not been for the losses which they would have incurred by leaving their handsome palaces. Such men, knowing men and cities, possessed of the means of culture and the fine Italian intellect, and whose domestic life still remained simple and comparatively inexpensive, found their relaxation and enjoyment in the patronage of letters, the construction of great public 
works, the adornment of their city, and the encouragement of the artist.

When the trades were incorporated, monopoly replaced competition and prices were fixed ; but this, so far from producing equality, came in time, as we shall presently see, to be of no small advantage to the masters, and especially to the wealthy masters. When the nobles were compelled to disfranchisement or to enter the guilds, membership became of two kinds, formal and real ; but no citizen could be inscribed without the sanction of the art which he aspired to enter, and he was charged an extra fee if an honorary member, and a still larger fee if a foreigner. It is obvious that inefficient lawyers, doctors, and money-changers are a grave social danger, and care was taken that the exercise of these professions was entrusted to capable persons only.

The quality and quantity of goods were guaranteed by the guild, and the great exporting guilds imposed conditions on the lesser guilds, though these were independent in theory, as did the lesser guilds on those of still inferior rank. It was possible for a poor Florentine to buy his way, if his wealth increased, from guild to guild, until he arrived at one of the great guilds, and had a political future before him. In this limited way a career was always open to talent. Great restrictions were imposed on the alien, and since reprisals were the rule until nearly the end of the Middle Ages, and life and property were specially insecure in northern lands, we find that money could not be borrowed in the thirteenth century at less than 30 per cent. interest. The rule as to usury was applied in a discretionary way and on casuistic lines.

In course of time the notaries of Florence, the last in order of the greater arts, came to occupy the first position. With the growth of trade, the complexities of commercial intercourse, and the accretion of the wealth of the individual, disputes became more frequent and less easy to determine. Hence the notaries became all important to a commercial State, and especially as the drafting of laws and regulations would naturally fall into their hands. But while the framing of laws passed through the notaries' hands, their substance, even those of the edicts of State, emanatcd for the most part from the chiefs of the greater guilds, and the maintenance of public order was practically in their hands.

The communal government was little more than a big guild, and did banking business on a big scale. Letters of credit were used in Florence in 1260 , and are said to have been employed in Venice a century earlier. The Florentine State was perpetually borrowing of the Calimala, and giving its octroi as security; many individuals also made large fortunes by the farming of the taxes.

We have said that the capitalist. appeared very early in the history of the guilds. New and safer lines of trade increased wealth, and tempted the employment of hoarded wealth. When trade advanced from Italy over. Europe in ever-widening circles, the old system, adapted to agricultural centres, was found to hamper commencing international commerce. There came into being a class of men who owned enough wealth to enable them to alter its form from time to time by means of exchange. These men found out, as we have seen, that they could constantly add to their store, not merely by this means, but also by the lending of money at interest; and they were shrewd enough to seize every opportunity of thus 
applying their ever-increasing capital; they learned that they could augment it very quickly and securely by employing it to the direction of the energies of others. Consequently, the guilds tended to become companies of men of wealth, each employing many workmen. This led to associations of journeymen, the precursors of our trades-unions. The small masters were crushed out, and the old affectionate reverence of its members for the guilds waned and gradually disappeared. The beginnings of this process are discernible in the period now under consideration.

The spirit of private gain led the guilds to enforce regulations that were ever more and more antagonistic to public interests, and split them up into a number of minor trades which did not co-operate.

It is, perhaps, desirable while dealing in some detail with the trade. associations, to forestall events and indicate their ultimate fate.

Gradually the guilds became societies for the investment of wealth, and satisfactory dividends depended on the still further suppression of competition. The wealthiest man became the master of his association and controlled its destinies. Needless to say, he did so with a view to his own profit. The formation of nations and the discovery of new worlds led to a shifting of centres of production. New products and new discoveries caused the foundation of towns innocent of trade-associations, and the great centres of trade were no longer to be found in the Mediterranean basin, but in the countries north of the Alps. Finally, in modern times fresh inventions, culminating in the machine-industry, have swept away the guilds of Europe.

The great difficulties that the cities had to contend with were restrictive legislation of rival States, and precarious food-supply. Thus, Venice excluded all other cities from commercial dealings with those places whence she got her food-stuffs ; the entire possession of these places was of vital importance to her. She also compelled her subject towns to purchase from Venctian sources only, and neighbouring towns were obliged to get any food-stuffs they required from the metropolis. Owing to the fluctuations incidental to unscientific farming, lean years were frequent, and famine, followed by pest, was common in Italian cities. It will be desirable to examine a little more closely into the conditions of the agriculturalist, the man who almost alone among traders had no protecting guild.

\section{State of the Agriculturist}

In the early Middle Ages the main business of the man who lived on the land was to provide himself with his own household needs; whatever was left over, was sometimes, but irregularly, given in exchange for what he did not himself produce. Right down to modern times, even, we read of notaries receiving their fees from peasants in kind.

The result of irregular production (for even in Italy produce is dependent on season) was that occasionally prices ran very high, and famine followed even among the peasantry themselves. The abolition of serfdom paved the way to the appearance of the capitalist in agriculture, for the usurer lent money to the land-owner, and rich burghers bought country estates of impecunious or bankrupt owners, and exploited farming to their own advantage. But the towns were then better provided with food-stuffs than before. The peasantry of Italy were released from the tyranny of 
the noble only to labour under the heavier yoke of the burgher. A maximum of salary was fixed, and, borrowing a lesson from the barbarian invaders, the system was preserved whereby half the crop fell to the owner of the land. Repressive legislation kept the peasantry down, and the condition of farmer and labourer alike was appalling. They might hire themselves for a term of years, but if they did not, they were at least bound for a whole year, and if they left their employer without being able to show a sufficiently satisfactory cause, all other employer swere forbidden to take them on. Nor was this all. The labourer, or artisan even, could get no fresh work at the termination of a contract without a formal release.

Half the value of produce went to the proprietor, then half to the tenant. But the proprietor was wealthy, the tenant poor. Food-stuffs began to come in freely from abroad, and ruined the agriculturist, who had no means of contending with loss arising from this source or from the bad seasons which are always the farmer's bane. And if the farmer was badly off, the peasant was in piteous plight. M. Perrens, whose great work on Florence is very full of information on this and kindred subjects, quotes authority to show that not merely were farm-labourers little better off as freemen than they had been as serfs, but that there were restrictions as to the kind of crops the farmer might grow, and that the amount of wheat a baker might buy was also fixed by the State. Export was forbidden, and the price of corn regulated.

\section{ROME}

From the Arrival of Brancaleone (1252) to the Reinstitution of Democratic Government by the Papacy (I3IO)

THE Roman State was now a commune bearing a great resemblance to the other communes of Italy, with an aristocracy torn by faction, and an armed people, organized, and at once dependent on the aristocracy for military leadership and cavalry, and opposed to that class in political aspiration. Each party was determined on absolute sway, and the Pope was always waiting for his chance to come in and rule. But the popolani were winning. Owing to the Crusades, their wealth and importance were increasing; the guilds were developing in organization and in power; they were trained to public life in the disposal of their own business and the framing of their statutes; and from 1267 their consuls entered the councils of the State. In 1252 the Romans made Brancaleone, a Ghibelline noble, their Podestà. He was a resolute and able ruler; he put down the turbulent nobles of the campagna with a strong hand, and established himself firmly in the city and his sway in the country around. He hanged recalcitrant nobles from the windows of their own palaces without scruple or fear. He won the favour of the multitude by calling himself their captain, and by the frequent convocation of the general assembly; but he ignored the two councils, which existed in.Rome, as elsewhere, as much as he dared. But, on the other hand, he favoured the 
thirteen guilds, and aided them in their organization, the effects of which were manifested fifteen years later when their officers sat in the councils of the State. In fact, he favoured the rising commercial class as represented by its wealthy men. The result was that when the clergy, whom he made amenable to the civil law, aided by the nobility, imprisoned him after his term of office had expired, the guilds led a counter-revolution and restored him. The Pope tried to have him assassinated on his journey back; he had interdicted Bologna because she would not restore the Roman hostages she held for Brancaleone's safety. The man who had emancipated Rome from the tyranny exercised over her by her nobleseven those of them that were under Papal direction-and rendered her independent of the Pope, was naturally an object of Papal hatred. Brancaleone was excommunicated, but he was so firmly seated that he treated the sentence with derision and the Pope with contempt, and razed so many castles that the Roman nobility was for the most part wandering in exile. After his death (1258) the unhappy city was more than ever rent by faction, for the opposition of the Papacy to the House of Hohenstauffen produced a whirling tempest, of which the very vortex was Rome. The Pope bribed the Roman people to expel Brancaleone's uncle, who had succeeded him in office; and he only escaped death (as, indeed, did Brancaleone at his expulsion) by reason of the hostages which the Romans had sent to Bologna, their native city. In I267, when matters had quieted down, a committee of twelve citizens, representing the guilds, was constituted to revise the statutes, and in I268 they chose Charles of Anjou to become their senator, with a view to the defence of their State at his powerful hands against the encroachments of the Pope and nobles. In fact, they counted on maintaining the security of their city through the mutual jealousy that was bound to arise between the Papacy and the new power. But when Charles became firmly established in Italy, the Papacy compelled him to retire, and two Romans replaced him with a committee of twenty-six. Soon, however, news came that Conradin was coming to claim his own. Don Henry of Castile was elected senator, the troops of Charles were defeated, the Guelph nobles were overborne, the revolting Campagna was reduced, and the clergy were put under bit and bridle. Then came the disaster of Tagliacozzo, so fatal to the Ghibellines; and Rome had again to submit to the senatorship of Charles for ten years and the domination of his representatives. And at the end of that time Nicholas III. obtained the power of nominating a senator during his lifetime. He had shaken off the yoke of Charles, and, being free to attempt to increase his sway in Rome, nominated a senator every year, alternately from the rival houses of Orsini and Colonna. However, Martin IV., the creature of Charles, reappointed him senator ; and a French garrison was quartered in the city. But when the news of the Sicilian vespers reached Rome, the people rose against the French and slew them, and the Pope was brought to terms advantageous to local self-government. Honorius IV., who reigned for two years (I285-1287), employed his time in enriching his relatives the Savelli. He was succeeded by Nicholas IV., who, perhaps to restrain the Savelli, enriched the great and ancient House of Colonna, to which he was in no way related. His contemporaries caricatured him as emerging from a column and prevented from seeing aught by stout pillars in front of him. An interregnum and a weak 
Pope followed, and the Colonna took advantage of the disorders of the city and its territory to acquire a power that was almost sovereign. The next Pope, Celestine V., a holy but weak man, was succeeded by Boniface VIII., in spite of the opposition of two cardinals of the House of Colonna. That family was in league with Sicily, and Boniface determined to break their power. He preached a crusade against them, and before long Palestrina alone held out in their favour. Boniface took council of the old warrior, Guido di Montefeltro, famous for a victory over the French at Forli and for his defence of Pisa. Guido had become a Franciscan, but he left the cloister to reconnoitre, and reported that Palestrina was impregnable; but he would give advice if Boniface would absolve him from the crime that it would entail. Boniface was by no means a scrupulous priest, and did so, though the doctrine of the Church was, and is, that penitence must precede absolution. "Promise much, perform little," was the counsel of this old warrior-fox of the cowl. And so Palestrina surrendered, but the Colonna, forewarned of treachery, contrived to escape. Though Rome was now no longer ruled by the Colonna, it did not fall into the hands of the Pope, who found the influence of France too strong for him, and shortly after the Papacy went into semi-captivity at Avignon. The people once again raised their heads and reasserted their rights, and in I3 Io the Holy Pontiff made the best of the situation, and sent over his full permission to the city to govern itself in its own way.

\section{MILAN AND THE COMMUNES OF THE GREAT PLAIN}

\section{Milan from the Death of Frederick II. (I250) to the Establishment} OF THE Visconti (1277)

Though in I25 I Milan gave Gregory a sumptuous reception, and devised the silk-covered baldacchino, still used by the Popes, to bear him in triumph through her gates, her finances were, as a result of the long war she had waged for him, in a parlous condition. The payment of municipal debts had to be postponed for full eight years, and the regulation was extended to private obligations. The imposts were enormously increased and so rigorously collected that the people rose in revolt and put their Podestà to death. Hitherto Milan had been ardently Guelph, and even democratic, and it continued so for a time, though the action of the Pope did no small harm to the party. Pagano della-Torre, whose action in succouring the Milanese after their defeat at Cortenuova gained him the popular voice, had been called in to arrange an equitable property-tax; but when the Pope exercised his high-handed methods on the impoverished town, a Ghibelline element began to show its head. Nevertheless Milan called for Pagano's nephew, Martino, as Podestà in I 256. The popular party was in the ascendant, and the Torriani posed as the protectors of the people. Martino was a supple party-leader, with all the stock-in-trade of his calling, but he seems to have been an honourable, well-intentioned man. Opposed to him were the nobles with the Archbishop, one Fra, 
Leone di Parego, a fanatical persecutor of heresy and subservient to the Pope, at their head. The nobles had gradually increased the strength and weight of their armour in order to resist the onset of the foot-soldiery, which had been the main arm of the service in the war with Barbarossa. The weight of this became so great as to necessitate a special breed of strong horses. Visitors to Venice will remember the unusual form of Colleoni's horse in the noblest of all equestrian statues. Nothing could resist the charge of this heavy horse-soldiery; hence a few nobles could decide the fortunes of a field, and the burghers were more than ever dependent on the aristocracy for their defence. This state of affairs increased the disdain of one section of society and the class-hatred of the other. Only those educated to the saddle and feats of arms could be of any service in the new cavalry, and out of this fact, and also from the expulsion of the nobles from cities, grew the professional soldiery, the free-companies or condottieri of the following age. Frederick I. had already employed Flemish mercenaries in his wars, and they were the mainstay of his forces and the terror of his opponents. The new system took root and flourished. The Ghibelline exiles of Florence formed a mercenary army under Guido Novello, and the Guelphs another, under Guido Guerra, that served in the wars of Parma and Sicily. The Marquises Lancia and Pelavicino put their services at the disposal of Milan. They naturally required power and title as well as pay, and menaced the liberties of the State. But, masters of the open field, the heavy cavalry of the aristocracy was of no avail in street-fighting, where a simple barricade put a stop at once to their evolutions and their irresistible charge; and only footsoldiery could undertake the siege of a tower. In the perpetual classwars that took place, whatever advantages the nobles gained in the country were undone in the city, and solemn pacts of peace were made only to be broken. The citizens, getting weary of perpetual interference with their comfort and trade, determined to elect a protecting "lord of the people." But the "people" were divided among themselves. The association called "Credenza," the artisans and lower classes, were for Martino della Torre; but the richer citizens, and those holding a higher social position, the "Motta," wished to clip the wings of Martino, and elected a chief of their own. This leader was killed in a street-riot, and the upper classes of citizens then went over in a body to the aristocratic party. The heads of both parties were banished by the Papal legate; but Martino, secure of the support of the masses, came back in a few days more firmly established than ever, and able to keep his opponent in exile. The nobles now sought the aid of the tyrant Eccelino, but his defeat by Martino vastly increased the power and popularity of the latter. Lodi offered him her lordship, as head of the Guelph party in Lombardy, and his power was naturally more complete and effective in the smaller than the larger city. But his bourgeois foot required cavalry support. In Tuscany the hilly country was in a measure inimical to cavalry, but in the plains of Lombardy they had it all their own way. Martino found it necessary to ally himself with the Marquis Pelavicino, in the name of Milan. Pelavicino was a Ghibelline, and a Paulician. Like Eccelino and Bonifazio of Monferrato, he aimed at power through the people. $\mathrm{He}$ hated the Papacy, excluded the inquisition from his territories, and protected heretical preachers. At this time there were fifteen different 
Nonconformist sects in Lombardy, protesting against the alliance of the landed proprietor with the Church, and their aggressions. The Holy See never forgot or forgave what it considered to be the defection of Martino, but bided its time. The main line of the policy of the Torriani was to keep contending parties from coming to any agreement, and to render themselves indispensable to the people in its contest with the grandi. This end they never lost sight of. Martino and Pelavicino divided between them the military control of Lombardy. They forced the nobles from town to town, and finally brought the Milanese exiles to an unconditional surrender at Tabiago. Their horses had insufficient water, and died of thirst during the siege of that place. Martino saved the dismounted gentry from death, but they were hung out from the walls in wooden cages for the edification and delight of the people (I26I). The Archbishopric was now vacant, and a relative of Martino's was opposed in the Chapter by the aristocratic party. The curia was not slow to perceive that its chance had come, and gave the See to Otto Visconti, a Milanese noble, at that time resident in Rome. This was the beginning of much. When Martino died the grateful citizens asked Filippo della Torre to succeed him. Obliged to depend on some skilled soldierly noble to defend them, the citizens valued the protection he afforded. They none the less valued the settled order which he maintained in their town. If they had been left to themselves, the Lombard cities might have evolved a stable and effective government, as Venice did; but each was surrounded by a militant nobility, with strongholds both in the country and in the city, and dependent on nobles with noble connections for their defence. Hence, they never could suppress the anarchy of classfriction and intrigue. There was no sea to isolate, but a plain favourable to cavalry manœuvres. So the cities of the plain followed the example of Milan, and gave their suffrages to the Torriani to defend them. And in a few years the people learned, to the sorrow of some of them, that one who is at once a protector, a general, and the chief judge of several cities, has already become a sovereign prince. A number of adjacent cities acknowledging a common defender foreboded the future duchy of Milan. The citizens got the repose from faction which they desired, however, for the warrior-judges of the times were men to be feared, quick to act, and swift, brutal, and pithy in the preservation of the public peace. The citizens do not appear to have had any immediate perception that their liberties were endangered. Everything seemed to go on as before. Podesti were often consuls, and other officers were always elected as before; but behind them was the grim figure of the captain of war, supported by his powerful connections and I,500 horse.

Philip della Torre died in I265, and was succeeded by Napoleone della Torre, his nephew. Lodi, Novara, Como, Bergamo, Vercelli, and Brescia (rebellious to Pelavicino), acknowledged him, recognising the advantage, especially in war, of a common rule to a common end and interest. The exiled Archbishop Otto Visconti kept up an irregular war with Milan, which gradually became more serious as the nobles gathered around him, and at last he surprised and captured the unwary Napoleone (1277). Members of the Torriani family rode hard to Milan for aid, but they found the people, weary of contest and of their rule, in revolt, the streets barricaded, their own houses pillaged; and they rode out of the narrow 
streets through an avalanche of stones from the roofs and upper windows. Probably the Milanese populace suspected Napoleone of desiring to subjugate them. Milan sent an embassy to the Archbishop announcing a desire for a permanent lord, and begging him to return. The powers of the lord were at this time limited by the authority of other officers ; but none the less Milan had evolved quite a sort of democratic monarchy, and the Visconti took their place as if there had been a change of dynasty. But the Visconti brought with them an aristocratic element, which had become ruined by proscription and warfare, ready to become mercenary troops and subservient to a master. The form of government was still that of a lordship sanctioned by the people and its councils ; but before long the lord proclaimed his own laws, imposed taxes at will, farmed the revenue, and made war at his own pleasure. The Torriani, excluded by the people of Lodi and Cremona, found a refuge in Parma. Napoleone ended his days near Como in a wooden cage.

The cities which had come under the rule of the Marquis Pelavicino and Buoso of Doara had already emancipated themselves from the yoke of these masters ; but, in the strife of Guelph and Ghibelline, the spirit of faction acquired such an overwhelming ascendancy that no form of republican government remained practicable. Everywhere the strong man who would at least maintain some approach towards decent and effective government was required.

In the war between the Torriani and the Visconti all kinds of old animosities and separate designs were jumbled together. Throughout, the Torriani, though defeated, were the recognised leaders of the Lombard Guelphs, and they remained ever ready to attempt the overthrow of the Ghibelline nobles that the Visconti brought with them. The Credenza di Ambrogio got no advantage from the change; the nobility had learned to work together under a single commander. The wealthier clergy stood by their relatives of that class, and the lower orders regarded the Visconti as their protectors, while the Motta turned against the Torriani to escape popular wrath. It was felt that in the continuance of dictatorship lay the salvation of the city, and Otto Visconti used his victory with moderation. He appointed a Vicar to preside over a new and additional "Tribunale di Provvisione," of which the members were twelve of the wealthiest and most renowned citizens. He proceeded with circumspection, taking care to protect the interests of the lower orders. A master of will and arms, no one was better qualified to play the game than the Archbishop, and henceforth in Lombardy the distinction between Guelph and Ghibelline became a distinction of external politics. In domestic affairs it is no longer to be found.

We have said that the authority of the lord of Milan was hedged in. At this time the Podestà of Milan remained supreme magistrate, and was responsible for the execution of justice and for the preservation of public order. In order to prevent oppression, it was found that the balance of party could be best preserved by a general council of 800 , whereof half were "nobles." Half this body was nominated by the Podestà, half elected by lot. It held office for a year, but every two months there was a fresh council of eighty, composed of members of the classes of privilege - the wealthy burghers and nobles-and of the classes below them, in equal proportions. This was the consultative body of the lord, who 
had, as Captain of the People, the entire military command. For safety in time of war and wisdom in policy, the upper orders really controlled affairs, and the advantage of stability was secured by placing the headship of the city in a single family.

\section{From the Coming of the Visconti to their Restoration (izio)}

When one first sits down to study the history of Italy north of the Apeninnes, one experiences the same kind of vertiginous confusion as in surveying a crowd from a height. There is rapid and unceasing movement. It is animated by passions difficult to interpret. The members that compose it rush, jostle, obstruct each other, change places, fight, and the eye is neither able to follow persons nor distinguish events. Yet the same process of development, the same triumph of liberty, shortly to be followed by its fall, characterizes each little State. The same broad principles operate in each, and there is to be seen in little the ever-recurring laws of political evolution.

The cities were now coming into the hands of despots, who had by no means as yet established an hereditary right to rule, and who received their mandate from the people. The advantages of settled government were so obvious that the Empire recognised these dictators, and gave the chief among them the title of Vicars of the Empire. Dictatorship was given to powerful, masterful nobles for a limited period only, at a fixed salary, by the "elders" of the city or by its assembled parliament. But the history of the Torriani had shown that this power tended to fall into the hands of successive members of the same family, and Otto Visconti, the Milanese Archbishop, prepared the way for his nephew, Matteo, to succeed him. Matteo was strong of body, quick to seize opportunity, an able dissimulator, a clement victor, and as aware of the power of the purse as of that of the sword. In I287 the Archbishop contrived that the people should elect Matteo as Captain of the People for a year. By I 289 he had so ingratiated himself that his term of office was extended to five years, and power was given him to nominate a Podestà, if the one selected did not please him, and to amend statutes. He was flanked by a private council of two collaterali, three jurisconsults, and twelve knights. He knew how to affect deference and modesty, so that before long he was allowed to make war or peace at will. By I290 Novara and Vercelli had made him their lord. In $\mathrm{I} 292$ the Alessandrians, in a war against the Marquis of Montferrat, gave him their captaincy for five years ; and by I 298 Albert of Austria, the Emperor, found it convenient to make $\mathrm{h} \cdot \mathrm{m}$ Imperial Vicar, and all the Lombard cities took an oath of fidelity to him. On the death of the Archbishop, which occurred in 1295, Matteo found himself possessed of full power, and experienced no difficulty in succeeding as head of the family. It was still necessary, however, to exercise the utmost discretion in manipulating the populace so as to get their consent. Thus, in I290, we find Alberto Scotto gaining the signory of Piacenza by sanction of the popular assembly to his assuming the office of captain and lord (Chron. Placent.). And Ghiberto of Corregio, coming into Parma with a Cremonese following in I 303 , in order to "pacify" the city, first got his partisans to shout, "Long live the Lord Ghiberto !" in the public streets, and then got himself confirmed the very same day 
by the special council as lord, defender, and protector of the city, and was invested by the resignation into his hands of the standard of the Virgin and the flag of the Caroccio. Nor was this considered sufficient. His election was confirmed the next day by the general council (Chron. Parmense). Power thus obtained had to be maintained and consolidated by consummate address and dexterity, by the formation of judicious alliances, by imperceptible diminution of the authority of the various councils of State which still continued to sit. A single exhibition of weakness, or error of judgment, or unfortunate combination of adverse circumstances, and the despot was hurled from his seat, to give place, not to liberty, but to another dictator, strong to enforce order and hold his authority against all comers. In I 298 Matteo strengthened his position by marrying his daughter to Alberto, the lord of Verona, who was the most powerful of the Ghibelline chiefs. Two years later he arranged a marriage between his son, Galeazzo, and a daughter of the Marquis of Este, lord at this period of Ferrara, Modena, and Reggio, and so allied himself with the chief of the Lombard Guelphs. Visconti was thus connected with two great houses, and his power, representing that of Milan as well as his own territorial resources, aroused the jealousy of the surrounding great lords. The nobility found him the greatest obstacle to the restoration of their privileges; the fickle people were turning against him, hoping for some advantage from a change; the moderates, his own party, were divided, for his son, Galeazzo, had forced on a fruitless war with Pavia, which had spilt much blood and cost much money; and many of the Visconti themselves had become envious of the primacy of Matteo. Alberto Scotto, lord of Piacenza, to whom the lady of Este had been affianced, and whose betrothal had fallen through owing to the machinations of Visconti, approached the Count of Langusco, who had ejected and replaced the despot of Pavia, those of Lodi, Como, and Crema, all of which towns had lost their liberties, as well as the leading families of Cremona, Novara, Vercelli, and the great Marquis of Montferrat. The della Torre, exiled from Milan a quarter of a century before, hastened to join the league, and a great number of leading Milanese also sought their camp. Matteo threw all those remaining in his power, whom he had any cause to suspect, into irons, not even sparing his own uncle. He left his son Galeazzo in the city with 2,000 men, and departed for the field pursued by cries of " Liberty !" His enemies were so numerous that he was glad to accept the intervention of Venice, and, laying down the supreme power he had usurped, he retired to one of his castles and re-entered private life. The Milanese expelled his son Galeazzo, recalled the Della Torre and the exiles, and passed a sentence of banishment on all the Visconti. It will be observed that there was no contest between nobles and plebs; but on external grounds the old party cries of Guelph and Ghibelline were once again revived, and a Guelph alliance was arranged by a congress at Piacenza (I 302), which included that town, Milan, Pavia, Bergamo, Lodi, Asti, Novara, Vercelli, Crema, Como, Cremona, Alessandria, and Bologna-a curious union of ancient friends and foes. Alberto Scotto was put at the head of this league with power to force the towns to recall their exiles; but either the power of Alberto was growing too rapidly, or the Guelphs took umbrage at his impartiality. Within a year they forced him to quit the league, and expelled the towns of Alessandria and 
Tortona from it also. He revenged himself by offering his scrvices to his foes of the year before, the Visconti. He promised to restore them to Milan, and he allied himself with the despots of Mantua, Verona, and Parma. In $\mathrm{I}_{304}$ the league attacked Alberto at Piacenza, which had been under his government for four years. Piacenza immediately seized the opportunity to revolt. The men of Lodi and Cremona appear to have sympathized with the revolutionary burghers, and withdrew from the army, which then broke up. The lord of Parma hastened up with a small force to rescue Alberto, and advised him to flec if he valued his life. Alberto departed, and then this wily personage endeavoured to secure the dictatorship of the city to himself. But the good citizens of Piacenza again flew to arms to defend their liberties with the rallying cry of "The people! the people!" and this traitor to the town and his friend had to make very speedy and unceremonious departure. About this time there appears to have been a fairly general attempt on the part of the towns to get rid of their despots, who, like so many old men of the sea, were engaged in throttling them. Modena had become a property of the great House of Este ; but in I 306 its people rose and overthrew their Podestà, the Marquis's nominee, though he had the support of 700 horse and $\mathrm{I}, 000$ archers. They recalled all exiles, and set up democratic government again, and for days there were continual rejoicings in the town, the burghers appearing adorned with waistbands of gold and crowned with garlands. Next day Reggio revolted with the aid of some Ghibelline nobles, and in two years' time the House of Este was shorn of its last town, Ferrara. All these revolutions were effected under the rallying cries of Guelph and Ghibelline; but so far were they from representing any opposition of Pope and Emperor that the indifference of Albert of Germany called forth the imprecation of Dante, while the Pope was earnestly endeavouring to effect reconciliation. Meanwhile, the Torriani were gradually recovering all their lost power in Milan. Personal rule had come to be desired.

Henry VII. came into Italy as the honest broker, and hoped to put an end to these contentions. He was accompanicd by but 2,000 horse, and even these crossed the Alps in his wake in straggling companies. All Lombardy was prepared to welcome his coming. Guido della Torre, who was in power at Milan, sent him a message: "Trust to me, and you shall ride through all Italy as with your falcon on the wrist" (Nich. Bo'runtinen; episc.); and Henry was soon surrounded by a court of Lombard nobility. He received both parties graciously; he favoured neither; he was courteous and kindly to all ; but he gave the despots to understand that they had usurped their powers. He insisted that the towns should come under the immediate control of the Empire, and that their exiles should be recalled. He carried the cities with him in this demand, and the despots had to surrender their keys. Their submission was rewarded with titles and fiefs. Della Torre was disposed to resist, but finally he followed the example of the despots of Piedmont. He disbanded his army. Henry was crowned at Milan, and the submission of all Lombardy followed. Genoa and Venice held aloof, offering a thousand excuses, "which," says the Bishop of Botronte, who accompanied Henry, " had but one meaning - that they intended to give themselves neither to Emperor nor Pope." Imperial Vicars were appointed, and golden days 
seemed about to begin. But Henry could not do without money, and his knights had crossed the Alps with the express intention of acquiring it.

In the Milanese senate there now sat both the Visconti and the Torriani. The Emperor asked for 50,000 florins. Visconti proposed an additional sum to be presented to the Empress: Della Torre doubled the sum. In vain did the burghers protest. Henry refused to take less. The aspect of affairs became menacing. The Bishop of Botronte says that he dared not put his nose out of doors for fear of insult. Henry determined to take hostages to Rome with him for the good behaviour of the city, and he included the Visconti and Torriani among those whom he selected. The rivals drew closer together in the face of a common danger. The city was growing very restive. There was much talk of Northern barbarians and of the enslavement of Italy: It was openly said that without other Italian aid the smallest town in Lombardy was competent to deal with Henry and his army. The younger Torriani and Visconti discussed matters together outside the gates. It was announced in Milan that the two families had coalesced. Immediately the city rose in uproar. The militia gathered in the various wards, but especially in the quarter inhabited by the Torriani. Henry was at his wits' end to know what to do, for his small contingent could effect nothing against a town in arms, especially if the rival houses became really reconciled. He ordered his men to advance on the houses of the Torriani before they had time to barricade. There is reason to believe that Matteo Visconti was a double-dealer, for Galeazzo, his son, after waiting awhile, probably to see what was going to happen, joined the Germans with a host of Ghibellines under his command. The nobles and those Ghibellines who were associated with the Torriani in vain besought their chiefs to lead them. The Torriani were engaged in defending their houses, and the party broke up. The barricades were carried, and in a short while the strongholds of the Torriani in the city were sacked and set afire, and the Torriani betook themselves to flight. This disturbance in Milan set the other towns ablaze. All the Guelph cities turned their Vicars and Ghibellines out. Crema, Cremona, Brescia, Lodi, and Como revolted and took up the cause of the Torriani and other Guelph refugecs from Milan. But they were unprepared. They were without any great stock of provisions, without a war-chest. Lodi and Crema had to open their gates to the Emperor, and were pardoned. Cremona shilly-shallied, and although the Ghibellines in the town contrived to give it up, they gained nothing thereby but a cruel imprisonment, the defortification of their town, a heavy impost, and the abandonment of the city to licentious soldiery. Brescia stood out. The old story of the two Fredericks was retold, for Henry had to fight his way step by step. All possibility of reconciling the factions was at an end, and he had to take sides and rely on Ghibelline support to save himself and his little army from destruction. From I 302 to $\mathrm{I}_{3}$ ro the Visconti had been in exile. Once again they assumed the lordship of Milan, a position which they thenceforward maintained for one hundred and thirty-seven years.

The material prosperity of Italy at this period is remarkable. In I 288 Milan had 200,000 inhabitants. There were I 50 hostelries, and the city was provided with water from 6,000 fountains. Her chief products were fine cloth, saddles, harness, and armour. She also engaged in silk 
manufacture, and the monks of the Brera received a large sum for the establishment of a colony of their clothworkers in Sicily. Verona, in I 300 , turned out 20,000 pieces of cloth a year, and the cities vied with each other in commercial enterprise and production. The Universities of Bolonga and Padua were renowned for their scholarship, and especially distinguished for legal erudition. During this period the whole of Lombardy was canalized. These great works remain to-day; they have made the great plain one of the most fertile places on earth.

The despots were, for the most part, men of large territorial property, and while they diverted to their administration the municipal income derived from already existing taxes, they do not appear to have increascd civic burdens, even to meet emergencies. Part of their revenue was derived from their own lands, a register being kept by surveys thereof. Another, and that the most important part of their income, was raised by taxation of commodities. There was also a tax on exports and imports. Protection, in the modern sense, was not, however, even so much as thought of, and even in war time commerce was remarkably little interfered with. Venice seems to have been the great port of the Lombard cities. This was a great building age, and Lombardy began to be adorned with public buildings, though they were of less importance than those of the smaller trading communities of Tuscany. In one respect Milan took the lead. She was the first city to pave her streets. If anyone has the curiosity to learn how, in spite of its fair architecture, a mediæval town appealed to nose and foot, an Eastern city of to-day will probably furnish him with the requisite knowledge.

\section{The Failure of Self-government in the Northern Communes}

By the beginning of the fourteenth century, then, nearly all the cities of the great plain had undergone the political transformation that befell the cities of Middle Italy at a later period. Speaking broadly, they achieved their liberty and their commercial greatness two centuries earlier than did the Tuscan; they fell into servitude two centuries earlier than Florence, the greatest and almost the last free town of Tuscany. What prevented the permanent establishment of liberty was the strife of nobles and burghers, and the exclusion of the small traders from power in the State, an exclusion rendered necessary, perhaps, by their ignorance of foreign affairs. The popolo minuto lived by supplying the great traders and the nobles with ordinary commodities. They were unconcerned with banking and export. They had no opportunity to acquire a knowledge of great affairs. Their vision was limited by the walls of their petty burgh; but they were ever a menace, and ofttimes more than a menace, to the governing classes. They were discontented with the rule of traders like themselves, only in a bigger way of business, and they welcomed the advent of the strong noble, too far above them to excite their envy, who would master their masters. The burghers, too, were divided among themselves. New men were in opposition to old families; the feuds of ancient houses persisted within the city walls, and were fermented by their championship of opposite causes. What Dante said of Florence was true of every Italian city. He compared the commune to a man on a bed of sickness, who restlessly tosses from one side to the other in 
the vain hope that change of position will give rest to his weary and exhausted frame. The citizens were weary. They wanted peace for their business and for themselves. They called in some man of strong and independent character and position, and entrusted him with power for a limited period to secure order. They extended the period, and the path to absolutism was open. They had tried reformers, but the reformers were made by a party for its own advantage, and not for the whole State. Indeed, it was not possible for reform to be made save in a party spirit, so high did passion rise on both sides. Students of our own Elizabethan drama will recognise that in a certain degree human nature has changed even in the three centuries since that time. The warriors and statesmen of Shakespeare are the warriors and statesmen of the Middle Ages. It is true that human nature remains unchanging in its essential characters, but it varies in the manifestation of its main energies and passions, in their mutual subordination and relations to each other in different individuals and races of the same period, and markedly so in the characteristics of different periods. The men of the Middle Ages were men of intense and unrestrained passion, or passion restrained rather by calculation and craft than by any dominant moral principle. They saw but narrowly; they had the intensity and persistence of emotion that comes from limited boundaries of life. Readers of Dante will recognise the difference between his " sæva indignatio," and the comprehensive fellowfeeling of the best Elizabethans, who had arrived at the large tolerance that is assoicated with sympathetic comprehension. We have said that their note of passion, even, falls somewhat unnaturally on a modern ear, so much less fiercely do we feel, and so much more are we accustomed to pull ourselves up, to sit in judgment on ourselves than our forefathers were. The Italians of the Middle Ages, then, were incapable of any broadminded and tolerant political view. Proscription was their method with those who differed in opinion from themselves, and as a result there was no stability in the State. The dictator, called in for a term by common consent of the weary people, maintained peace with so firm and usually so just a hand that he was re-elected or even nominated for life. Had he not been firm, and of fine intelligence to boot, his life had not been worth a day's purchase. He found the Captain of the People opposed to the Podestà, and their powers varying inversely. $\mathrm{He}$ found wobbling councils, narrow views possessing the political bodies of the State. The Podestà and Captain had been prevented from seizing the helm only by fear of the mob and the leading spirits of their party. The dictator had the mob with him. He was a great lord, above local petty jealousies, and he was backed by his own armed force and a territorial base outside the city walls. The more willing the population of a city as a whole were to receive him, the more independent he became of each section of them. Territory conquered by him naturally came under his military rule. He contrived that confiscated property should fall into his hands, and by these means he was able to strengthen his power and fill his private purse. When the art of war was so advanced as to require special skill, mercenaries had to be employed, and he could afford to employ mercenaries to support and extend his authority. But the republican spirit was by no means extinct. It was ever ready to burst forth, and often did so. The military despotisms only gradually became dynastic, and 
even then, such was the temper of the nobles and the people, such the greed and ambition of neighbouring despots, that they rarely lasted long. There never was a time, there never was in that time, an office that required such wary alertness of mind and body, such clear judgment, personal bravery, high intelligence and cunning, as that of despot in a little Italian community. But, given a man of power, with training and skill in diplomacy, brave and able in battle, and with important connections, the councils fell speedily into line with him. He got the financial as well as the administrative and military control of the city, and was soon able to flatter himself with the French monarch of a later period : "L'état c'est moi." It was by sheer ability and force of character that the despots possessed themselves of the cities; it was by ability and force of character alone that they could keep them in subjection.

Of all the towns which were signatories to the Lombard league of 150 years before, Padua and Bologna alone had been able to preserve those privileges for which they had so bravely withstood Frederick Barbarossa. Bologna, by the protection of the Holy See and the support of the Tuscan communes, evaded for a considerable period longer this common fate. Padua, surrounded on all sides by despotisms, faithfully Guelphic in the midst of powerful Ghibellines, was earlier exposed to attacks to which it was inevitable that she should ultimately succumb.

PADUA.-The long interregnum of the Empire had been fortunate for Padua. From the fall of the House of Romano up to the expedition of Henry VII., this town, protected by the Guelphs and the Church, had enjoyed free self-government: she recovered from the disasters brought about by the wars and tyranny of Eccelino in the middle of the thirteenth century, disasters which were in the main confined to the extirpation or ruin of certain of the privileged orders. Padua led the Guelphs of the Trevisan marches. Vicenza was subject to her, and she was famous as a seat of learning, whither foreigners flocked from all sides (Gugl. Cortusio de Novitat. Paduce). In the fourteenth century she produced some of the most distinguished of Italian historians. But her prosperity was menaced by two dangers-the smouldering resentment of Vicenza, ever waiting to throw off her yoke, even at the cost of submitting to a despot, and the customary antagonism of the two social orders within her gates. More than once the helm of State was seized by the handicraftsmen, with tribunes of the people (gas'aldioni) at their head. The Senate was composed of a thousand meinbers, changed annually. So great a council, composed of people who had no skill in statecraft or large experience of affairs, neither procured continuity of policy nor wise and adroit administration. Every little triumph of policy or warfare gave birth in the public mind to insensate pretensions and ridiculous vaingloriousness, while the smallest reverse was followed by craven abasement, of which the nobles profited to re-establish themselves, thereby indeed saving the State from disaster. The political history of Padua, as of so many Italian communes, is that of a passionate people indulging in a cycle of domestic revolutions and a wobbling foreign policy. When Henry of Luxemburg descended into Italy, the Paduans first opposed the Emperor, and then sent Albertino Mussato, the historian, to negotiate for peace. This was secured, but Henry encouraged Vicenza to revolt (I 3 II), and took that town under Imperial protection. A war followed, in which Cane della 
Scala, the tyrant of Verona, took up the Vicenzan cause, and the Paduans, with their usual want of consistency and firmness, again sent Mussato to Henry to secure forgiveness, which they only secured on harder terms than before. Henry had named Cane della Scala Imperial Vicar, and had handed the government of Vicenza over to him. Vicenza opened her gates, and Cane garrisoned the city with a medley of foreign soldiery, who taught the town certain aspects of military occupation (Ferret. Vicent. Albert. Mussat.). The Paduans dreaded lest.Cane della Scala, the Imperial Vicar of the Trevisan marches, should assert his authority over them, so, to the great delight of the younger men, who exhibited the dangerous military enthusiasm of youth, they armed their militia, hired mercenary troops, and declared war. "The country-folk were the first to suffer," says Ferreto of Vicenza. " Their flocks and goods were carried off. All those peasants who were not made prisoners carried all they could of their own into the city for safety. We saw a long line of carts laden with furniture and wine-casks led by the labourers, whilst the womenfolk, with their infants at the breast or borne on the shoulder, came in to take up their sleeping-ground under our porticoes. This way of making war, by slaying or capturing peasants and looting and burning their houses, was taught us by the mercenaries, who knew nothing but camplife. How often have I seen a chain of Paduan peasants, hands tied behind them, dragged along by the accursed mercenaries of Cane della Scala! These kept guard over our captive countrymen, and maltreated them in order to force them to ransom themselves. Nor did the Paduan mercenaries treat the Vicenzan peasantry less cruelly. What had the poor wretches done to merit such wrongs ?" The first effect of the war was that Cane tightened his grasp on Vicenza. He placed four nobles in power, who, with a view to the quicker extortion of money, suppressed all popular government. Conspiracy followed, and was punished by confiscation and exile. The proscribed nobles came to Padua for refuge and took arms against their own city. The Paduans were rich enough, and they had the aid of Cremona, Treviso, and the Marquis of Este, not to speak of the exiles of Verona and Vicenza and the mercenaries (among whom two Englishmen named Williams distinguished themselves). But the strategy was bad, and an epidemic broke out. Moreover, in Padua the leading Ghibelline noble was assassinated, and his party exiled. The chief men of the town were two money-lenders-Pietro d'Alticlinio and Ronco Agolanti-of base birth, who appear to have appropriated the Ghibelline spoils, and were equally hated by the Ghibellines, the people, and that great house of Carrara, ever beloved by the Paduans. The Carraresi excited sedition to depose these two leaders. They introduced a great number of peasants into the town, who attacked Alticlinio and put him to flight, raising the cry of " Long live the people! the people only !" " Death to traitors!" shouted the Carraresi and their followers. In vain did. the Podestà order the militia, who had by this time assembled in the great square, to betake themselves to their several wards. The standard of the people was handed over to one of the Carraresi, who led the mob to sack the house of Alticlinio, which gave them a whole day's employment. Next day Ronco Agolanti's house met with the same treatment, and he and his brother were slaughtered. Someone in the crowd suggested that Mussato, the historian, who had proposed a new 
tax on an equable basis, should be the next victim ; but he escaped, and his house was saved from pillage by the accident that the mob, exhibiting the usual psychological phenomena of crowds, were perpetually being diverted hither and thither to batten on new victims. At last it was discovered that Alticlinio lay hidden in the Bishop's palace. The Bishop was forced to give him up, and when he was done to death popular wrath began to calm (1314). Next day the old form of government by eighteen elders and councils was reaffirmed in a public assembly, and Mussato was recalled. Meanwhile, the army distinguished itself by its licence. The mercenary troops had corrupted every member of the native militia by the example of their cruelty, but neither could nor would transmit their discipline to citizen-bands, which they probably regarded with contempt and derision. Vicenza is only fifteen miles from Padua, and the troops now marched on it; but so degenerate had the militia of those days become that their impedimenta had to be transported in carts (Albert Mussatus). The Paduan army, under their Podestà, Ponzino of Cremona, easily made themselves masters of a suburb of Vicenza, and Ponzino issued a proclamation that robbery should be punished by death. whereupon the inhabitants of the suburb prematurely set up a cry of "Long live Padua!" But the mercenaries objected to being deprived of booty, and Ponzino had to shut his eyes to their conduct. The carts were emptied of military stores and weapons and filled with booty, and not even the sacred vessels of the Church or nuns were spared by the troops. Meanwhile, Cane arrived post-haste at Vicenza with but one attendant. The account of his promptitude of action, of his unexpected coming, of his hurried change of horse by the way, of his call to his old companions at arms, of the single beaker of red wine that he drank, helmet unlaced, at the hands of a poor woman, and of how he charged the surprised Paduans at the head of less than a hundred veterans, reminds one of old ballads of derring-do. Cane was a skilled leader to whom his troops were devoted, and he could keep them well in hand. The Paduan army was occupied in pillage and debauchery. Only a little band of nobles, among whom was our historian Mussato, made any resistance to Cane's little band, and these were obliged to surrender. Cane followed up his victory at the head of forty horse, while behind and following him were five hundred Paduan horse in full flight. The fact that only six noble and thirty plebeian corpses were to be discovered on the field shows the protective character of the armour of the period, and indicates that the era of bloodless campaigns is already opening. After this defeat, Padua called the neighbouring cities of Treviso, Ferrara, and Bologna to her aid, while Cane also sought allies. Heavy rains followed, and Cane admitted Jacopo di Carrara, Scornazano, and Mussato, our historian, the most distinguished of his prisoners, to his Court. The last-named was a man of lowly birth, but of great parts. "He was," says Ferreto of Vicenza, "a man of large mind, prudent, and eloquent. He owed to his talent alone the title and crown of poet; . . . but although sprung from the lowest class, he was raised by the tribunes of the people and popular magistrates to the rank of consular father and the highest honours of the Paduan republic. Happy in his country, he was also fortunate in the munificence of his fellow-citizens, for he obtained in recompense of his labours a great name and great wealth granted him from the public 
treasury." It is evident that we are already breathing the air of the Renaissance, where scholarship and talent of every kind are reverenced, and for the man of genius everything is open if he have but energy and courage. Cane and Jacopo di Carrara appear to have become friends, and Carrara was released to arrange matters. An equitable understanding was come to. But in Padua there was a patriotic party, led by one Macaruffo. It professed jealousy of its country's honour and dread of the power of the Carraresi. Macaruffo and his party plotted in vain to get hold of Vicenza, but they were betrayed to Cane, and their attempt on the city failed. Padua had forfeited a large sum by this treachery under the terms of peace which Venice had promised to enforce. Meanwhile, Cane was ravaging Paduan territory, and had possessed himself of several strongholds; but he spared the lands of the Carraresi. The patriotic party had to seek safety in flight, and the party of the Carraresi were thus practically possessed of the city. The Senate assembled, and an eloquent jurisconsult, immersed in the despotic constitution of the later Empire, is said by Ferreto to have risen after several senators had exposed the critical condition in which the State found itself. "What need of much discourse when we all know the remedy," quoth he, in an address which exhibits the analogical method of reasoning so characteristic of the age. "The abuse of plebiscites is a certain way to ruin. Let us try for once if the mandates of a single ruler will not procure us a better destiny. Everything on earth is subordinated to a single will; the limbs obey the head, flocks their leader. If the whole universe were under the command of a just King, one would see carnage, war, rapine, all shameful actions, cease. Let the voice of Nature persuade you. Let us choose a prince from among us ; let him alone undertake the responsibilities of government, modify the republic, establish laws, issue and repeal edicts, and let him be the lord and protector of our wealth." No opposition was made. Jacopo di Carrara was appointed lord of Padua by general acclamation, and when he was presented to the people, the neighbouring streets, packed with partisans of his house, resounded with ratifying shouts of acceptance. Padua had at length contrived to commit political suicide ( 13 I 8 ).

Bologna seems to have reached the summit of her power in the middle of the thirteenth century. Venice had imposed a tax on all vessels entering the Po. Bologna sent forth an army much more powerful than those with which Charles and Conradin had contested the kingdom of the Two Sicilies. The whole male population joined the expedition, which is said to have numbered 40,000 men. They built a strong fortress and defeated Venice in a great battle; but after three years of warfare the Pope mediated. The Bolognese consented to raze their fortress, and Venice conceded free navigation of the river (I 273). Bologna, like every city in Italy, was torn by faction in the thirteenth century. Class antagonisms, championed by two great noble families, the Gieremei and Lambertazzi, kept the town in perpetual broil. The exile of the Lambertazzi in 1274 left it almost a desert, and all kinds of associations appear to have been organized for party purposes, and perpetuated civic strife. In I 278 Nicholas III. gave Cardinal Latino a special commission to soothe the passions and quell the disorders of central Italy, and nominated Bertoldo Orsino, his brother, as Count of Romagna, over which, as part 
of the heritage of Matilda, the Papacy claimed overlordship. When Latino arrived, he found the exiled Lambertazzi perpetually engaged in making inroads on the possessions of the Gieremei, who were not sufficiently powerful to defend their own effectively. Their feuds extended over all Romagna. On his arrival at Bologna he called a meeting of fifty representatives of each side, and proposed an accommodation by which certain incurably bellicose spirits were to be exiled for a period to places named by the Pope. The associations of the people, which were hot-beds of faction, were to be suppressed, and it was understood that the Pope was to visit any infringement of peace with condign spiritual penalties. No one seems to have been in a particular hurry to avail himself of these terms, but at last the proposals were accepted. Each party gave heavy bail for their behaviour, and all the communes of Romagna signed the treaty. At last, in August, 1279, the two factions assembled in the great square of Bologna. It was hung with rich tapestry and festooned with flowers. The legate, surrounded by dignitaries of the Church in their pontifical robes, ascended a magnificent throne erected outside the communal palace. He exhorted the multitude to peace, and read the appeals and commands of the Pope. Fifty of the more important members of each party swore on the Holy Gospels to dwell in perpetual Christian love with each other, fell on each other's necks in fraternal embrace, and ended the day in feasting and rejoicing, amid universal thanksgivings. Of course, the pacification lasted just as long as such arrangements were wont to do in Italy in those anarchic days.

\section{VENICE}

Eastern Troubles and Rivalry with Genoa to the Peace of i 299

HALF a century after the Latin conquest of Constantinople the Greeks had advanced up to its very walls, and the Saracens had wrested most of the conquests of the Crusaders in the Holy Land from them ; only two or three coast-towns remained in their hands. Of these, the most important was Acre. When there is rivalry between nations, occasion for open rupture can easily be found. The possession of a certain church had not been positively determined, and both Genoa and Venice laid claim to it. The Venetians proposed to refer the question to the arbitration of the Pope, but the Genoese preferred to appeal to arms. They succeeded in ejecting their commercial competitors from both Acre and Tyre (1258), and an irregular naval war followed. Venice now supported Pisa, the ancient rival of Genoa, and consequently found herself in line with Manfred, who was prepared to call Genoa to account for the help she had rendered to her former citizen, Innocent IV. Genoa, regardless of Catholic interests, retorted by allying herself with the Greek Emperor, Manuel Paleologus, who was preparing to turn the Latins out of Constantinople. Paleologus made the Genoese free of his ports, and in return received the support of a Genoese fleet. In I26I Constantinople fell to Paleologus, and the Latins were scattered to the four winds. Most of 
the Venetian settlers were rescued by the fortunate proximity of a Venetian fleet, but a few unhappy Venetians remained in the city: Paleologus despoiled the Venetians of Eubœa, Lemnos, Chios, Rhodes, and other fair islands of the Ægean Sea, and rewarded the Genoese with the possession of Chios.

From 1262 to 1264 the " mid-sea, moaning with memories," resounded with yet another series of naval conflicts between the rivals of her Adriatic and Ligurian coasts. The policy of Paleologus was not to be unfriendly to the power which had befriended him, but to maintain a strictly benevolent neutrality until the issue should be determined. Venice triumphed at Trapani (1264), and the problem had then to be considered by her Senate whether she should endeavour to recover her lost advantages from Paleologus by force of arms, or agree to some kind of advantageous settlement with him. Prudence is usually the virtue of commercial communities. She got Paleologus to agree to reinstate her citizens in their old position at Constantinople, and rested content with that concession.

Venice was pushing her fur traffic in the Black Sea, and Genoa determined to exclude her from that profitable trade. Venice relied on the patriotic spirit of her merchants, and they armed a formidable fleet. Her arsenal was already beginning to be the wonder of the world; the technical ability of her workmen was above all praise. Every merchantman was built of the same pattern, and a sufficiency of similar parts was stored in every port, so that, not merely was the merchant service convertible into a marine fit for war, but it could be refitted in almost any sea. Merchants were not allowed to risk their vessels unduly, for a lading-line was fixed, and when the merchantman became a war-galley its sailors were paid and fed by the State. Galley-slaves were not then used, for the custom of war was to attempt boarding the foe ; but later, when ramming was introduced, and success was not so directly dependent on the courage and initiative of every man, prisoners were compelled to labour at the oars. In spite of the patriotic response of the merchants of Venice and the mobility of her fleet, the Genoese scored the first victory by the device of lashing their ships side by side, thus making an almost impregnable line of battle, which the Venetians, who had no fire-ships, could neither shatter nor disperse (I294). Paleologus took advantage of the defeat to disfavour the Venetian settlers, whereupon the undaunted Venetians anchored in front of the Imperial palace and compelled redress. In 1298 the Venetians seemed on the point of success in an action with the Genoese, when a reserve fleet of the latter bore down and converted victory into disaster. The Genoese bore off with many distinguished prisoners in their holds, among them Marco Polo, who whiled away the dull hours of prison life in Genoa by recounting his travels in Africa and the Far East and his reception at the Court of the Great Cham of Tartary. His work is remarkable evidence of the commercial enterprise and intrepidity of the Venice of his time. Both sides were now getting weary of contest, and the Venetians were so far from being crushed that in I 299 Matteo Visconti, the despot of Milan, mediated, and each party agreed not to molest the trade of the other. In the same year Venice came to an arrangement with the Moslem, whereby she was enabled to traffic in Syria in wood for shipbuilding, arms, and slaves. The two latter kinds of trade were denounced by the Holy Seat as "unlawful for 
Christians," but permission to Venetians to visit the Holy Sepulchre appears to have quieted any qualms that their conscience may have experienced. During this period Venice found increased difficulty in feeding her citizens, which was always a matter of serious concern to her rulers, and which was the chief force that propelled her on her subsequent career of conquest on the mainland. In I 268 the city suffered from famine, and supplies from Italy were refused. She retorted by laying heavy imposts on consigned goods, and insisted that her ships should unload all food-stuffs at the capital.

Constitutional Development to the Closing of the Grand Council and Institution of the Council of Ten

The merchants of Venice were growing in wealth and power. Some rivalry was bound to ensue between her great families, and the aristocratic pretensions and jealous feuds of the mainland found a pale reflex in the city of the sea, although there was, in the scanty islands of the lagoons, no territorial base for the effective support of antagonistic houses. Venice had experienced the ills attendant on faction of yore, and was determined that they should not recur. She put down all heraldic display with a firm hand, and, to prevent dissension among the families qualified to compete for the headship of the State, she evolved a curiously complicated system of election to that office. The Great Council selected thirty of its members by drawing lots ; the thirty so chosen were reduced by the same method to nine. The nine on whom the lot fell now voted a committee of forty, no member of which was eligible unless he received seven votes. The forty were reduced by lot to twelve, and the twelve elected another committee of twenty-five, each of whom was qualified by the reception of at least nine votes. The twenty-five were reduced to nine by lot, and the nine elected forty-five, each of whom must have received not less than seven votes. The forty-five were reduced by lot to eleven, and the eleven elected a committee of forty-one, of which each member must poll at least nine votes. This last committee now proceeded to elect the doge, who could not ascend the ducal chair unless he had received a minimum of twenty-five votes. The way in which the election was conducted is worthy of being recorded. The youngest member of the Great Council was sent to the ducal chapel of St. Mark's, where he prayed for the Divine blessing on the election. He was engaged to take the first lad he met on issuing from the church portal for the drawing of the lots. When the last committee of forty-one had been elected, Mass was celebrated, and every member had to take an oath that he would do his duty with perfect integrity of purpose. A chairman was chosen; each voter passed up to the urn and deposited therein a slip containing the name of his candidate, and two secretaries recorded the names thus chosen. Slips bearing these names were then placed in another urn, and one was drawn. The person whose name it bore then retired, and his merits were discussed. He was readmitted, and allowed to become his own advocate. Then he was balloted for, and if twenty-five votes were found to be in his favour he became doge; if not, the process was repeated until someone achieved the required majority. The new doge was then taken in solemn procession, first to the palace and then to 
St. Mark's, where, after Mass, the oath of accession was administered to him. He was invested with the insignia of his office, and the standard of St. Mark was given into his keeping. Then he was " chaired " round the Piazza and reconducted to the palace, where the ducal cap was placed on his head; and in the evening, after a not infrequent practice of civic communities, everybody sat down to a banquet.

On the mainland, the cities, torn by the opposition of the aristocracy to the bourgeoisie, and by the factions of the bourgeoisie itself, had adopted the rule of a Podestà for effective government, and the Podestà had become a despot, or had been replaced by one. Dictatorship maintained public order and consistency in foreign policy. In Venice the doge had been so carefully hedged in by restriction that a precisely similar change was rendered impossible; but the increase in wealth and power by a few families, who were entirely dependent on the welfare of their city, like all their co-traders, had resulted in an informal but exceptionally stable oligarchic government. In I286 a proposal, which was for a time abandoned, to make the Grand Council hereditary, lay before it. There was much popular discontent, however, and in I289, while the election of a new doge was proceeding, a mass meeting in the Piazza proclaimed one Giacomo Tiepolo, the son of a former doge, as Sovereign. Tiepolo vainly endeavoured to dissuade the citizens, and finally fled from the dangerous honour that was proffered by secretly departing to the mainland. The electors had to remain in the sacred precincts of the church for a fortnight before the popular tumult subsided sufficiently to allow them to sally forth and proclaim the new doge. Disorder again manifested itself when the populace heard the name of the doge that had been chosen, for he was one Pietro Gradenigo, a man inclined to favour big people and of revengeful temper. Tiepolo had to be sought, and the wrath of the mob could only be softened by his return. Gradenigo, who was absent from Venice at the time, was escorted back by an armed fleet. Following this abortive revolution, there was again much consideration as to the exclusion of undesirable people from the Grand Council, and finally it was announced that the council of forty-i.e., the council of judgeswas annually to put up to ballot the names of those who had sat in the Grand Council during the past four years, and that those receiving a dozen votes were to be considered as constituting it. Citizens resident abroad were to be balloted for afresh on their return. This annual election was merely a blind, for during the next three years the forty simply reelected those whom they had seated before. Room was, however, made for new men by allowing the Grand Council to nominate three of its members, who might submit a list of new names. No revocation was possible without the consent of two-thirds of the council, five-eights of the forty, and five-sixths of the ducal councillors, and, finally, after much deliberation, it was established that no one was eligible unless a paternal ancestor had sat in the council subsequent to its creation. The work was now finished. The election of the Grand Council had been transferred from the people to the forty, and was by the forty confined to the aristocracy. This proceeding is spoken of as the "serrata del maggior consiglio" (the closing of the Grand Council), and in I 3 I 5 the names of all eligible candidates-i.e., those who had attained the age of twentyfive-were enrolled in the famous "Golden Book." There was no longer 
an election, but the young aristocrat took his seat in the Great Council according to the formula, "per suos et per viginti-quinque annos." In 1299 a conspiracy of wealthy plebeians menaced this new departure, but this plot was discovered, its leaders executed, and the rest exiled. But in I 310 a far more dangerous conspiracy, which went near to success, was headed by a member of the house evidently so popular with the mob, Bajamonte Tiepolo. There was so much discontent that the citizens were forbidden to carry weapons. A governor of Dalmatia had been made a ducal councillor, which was illegal, and the closing of the Grand Council was bitterly resented. Tiepolo commanded an armed mob, and fought his way with great loss through the narrow, tortuous lanes. They could not penetrate through the troops that the doge had collected in the great square, and were obliged to retire to the Rialto, where they fortified themselves. Street-fighting in Venice, where there are innumerable cul-de-sacs and narrow winding ways, where a barricade could stop a host and there are innumerable intersecting canals, had proved to be such a bloody business that the government feared to attack Tiepolo, who accepted an amnesty, and went into exile.

The oligarchy was now thoroughly alive to its dangers. There was a party bent on the restitution of popular right, and that party conspired. Conspiracy could perhaps be more readily scented and nipped in the bud than controlled by force of arms in a city where arms were at a disadvantage. The palace could easily be rendered secure ; but fortified insurgents could not be easily driven from their quarters. A committee of public safety, the famous Council of Ten, was appointed. The ten were elected for a year, and were not re-eligible for election next year. They elected three capi each month, who were confined to their houses during their term of office. The doge and his six councillors sat with the ten; and of the seventeen, twelve formed a quorum; and, while the doge was perpetual president, three of the six councillors were changed every four months. By the frequent renewal of the council, and by the segregation of the three capi, whose function was to prepare its business and carry its decisions into effect, the possibility of corruption and the misuse of power was eliminated. The proceedings were secret and inquisitorial, but the citizen was safeguarded from injustice in a manner which we shall find exhibited when we come to treat of the fully-developed Venetian constitution. A penetrative, swift, and prompt means of dealing with treason had been discovered, and so effective and stable a body had been constituted that it soon became aware, not merely of its adequacy to the purpose intended, but of its suitability to other ends. Quietly and gradually, and without opposition, it arrogated the powers of the Senate and the direction of foreign policy. Renewed from time to time, it became a permanent institution in 1335 .

\section{THE FINAL STRUGGLE BETWEEN GENOA AND PISA}

Genoa, Pisa, and Venice were in the thirteenth century rival competitors for the Eastern trade. Any two of them were ever ready to profit by the weakness of the third, but anything like continuous friend- 
ship was impossible between the allies. But Genoa and Pisa differed from Venice in that both held possessions in the Western Mediterranean, and the undisputed possession of Corsica and Sardinia by either power meant an arrow pointed straight at the very heart of the other. Hence, the first really great struggle was bound to take place between the two rivals of the west coast, while Venice looked on and awaited the issue. In spite of their wealth, luxury was almost unknown to the citizens, whose commercial dealings embraced Africa, the Orient, and the Black Sea. Pisa had a fruitful mainland, and ruled nearly all Sardinia and Corsica and the Isle of Elba. Genoa also had a profitable contado. Both cities could therefore recuperate quickly from foreign war or the destructive contests of domestic faction, and readily raise what funds were requisite to put what were then counted as powerful and enormous fleets to sea.

In I 282 Genoa, as protectress of the Corsican town of Bonifaccio, put down the lord of Ginerca, whose extortions had become insufferable. $\mathrm{He}$ appealed to the Pisans, who called on the Genoese to desist, and sent some troops to the island to support him. Other provocation occurred. Pisa confiscated a Genoese galley returning from the war in Sicily, and her citizens resident at Acre incited the mob to burn down the quarter assigned to their Genoese neighbours.

Genoa applied for satisfaction, which was denied. Nothing remained to be done but to appeal to arms. A series of sea-skirmishes followed, only of use in disciplining the forces, and in the time gained for the recall of mariners from distant seas. A Genoese fleet (August, 1282) next sailed up to the mouth of the Arno, but had to retire before the sortie of a superior Pisan armament. Eight days after, a Pisan squadron, while endeavouring to repeat the Genoese manœuvre, was scattered and partly destroyed by a sudden storm. The Genoese now put the utmost strain on their preparations. They entrusted the admiralty to a council of fifteen ; they impressed ships and men; they built I 50 new ships of war ; they strained every nerve to a decisive and final struggle. Hitherto, each rival, fearful of surprise, and perhaps animated by the prevailing spirit of chivalry which penetrated even into Italy, had agreed to admit. a notary and four war attachés of the other to report on its policy and armament. There was in this arrangement some slight tincture of the same spirit of disdain for undue advantage which had induced Charles to invite Pedro of Aragon to decide their Sicilian contest by a personal combat between them and a hundred knights a side. The forewarning thus arranged carried with it forearming and the avoidance of peril, or the possibility of due equipment to meet it. The present war was a combat to the death, and the attachés were dismissed. By I 284 both sides were ready for more determined struggles on a larger scale.

A sea-fight off Sardinia issued in the capture of eight galleys and 1,500 men by the Genoese, and, of the squadron of twenty-four, only twelve sail, and these in a crippled condition, succeeded in making the harbour of Pisa. But so far from being disheartened, the Pisans redoubled their efforts. They chose Alberto Moresini, an expert Venetian seaman, for their Podestà, and associated Count Ugolino della Gherardesca and Andreotto Saracini with him as co-admirals. The treasury was almost emptied by previous outlay, but the Pisan nobles threw their private 
fortunes into the public stock. One family alone provided eleven menof-war; three families furnished six ; others from one to five, according to their means and numbers. Over a hundred sail set their prows towards Genoa in midsummer, and shot silver arrows into the port to show that the efforts of their city yet left them precious metal to spare. The Genoese sent a reply to the Pisan navy to the effect that they had not quite done preparing, but that shortly they would return the call; and, indeed, but a few days after, Io7 sail was descried off the mouth of the Arno. The Pisans rushed to their ships with a lust for battle that seemed to promise victory; the Archbishop, at the head of the entire clergy, unrolled the Pisan flag to the breeze, and pronounced the Benediction; the anchors were weighed, and the fleet put out to sea amid the vivas of the assembled city. During the night the Genoese received a reinforcement of thirty sail, and their wily commander sent these into ambush behind the island of Meloria. The fleets thus appeared to be equal, and the Pisans did not doubt that they would repeat the famous victory that their fathers had achieved on the very same spot. They confidently entrusted the safety of the republic and the Empire of the sea to the issue of this single contest. The fleets, divided into several squadrons, rushed towards one another like angry sea-fowl. They met with a clash, and attempts were made to board. Ubertus, the Genoese historian, tells us that the battle raged for a long time without either side gaining an advantage, and the scene seems to have been one of the bloodiest and most horrible in history.

At the very moment when the admiral's ships were grappled for boarding, the Genoese reserve slipped round the point of Meloria and bore down on the Pisan flag-ships. In vain did the captains yell to their men and urge on them that the very existence of their country was at stake. The Pisans gave way before the new foe. Each side had thrown all its resources and all its courage into the prior struggle, and the newly-arrived contingent gained a victory as complete as the contest had been severe. Twenty-eight men-of-war were the prizes of the Genoese, with I I, 000 prisoners, and it was estimated that no less than 5,000 Pisans had fallen in the fight. There was not a single family in Pisa that had not suffered the loss of father, brother, son; and we are told that for six months naught was to be heard there but the sounds of weeping and lamentation. The Genoese returned home in triumph, and their fanes resounded with the usual psalms of thanksgiving. Owing to the machinations of Ugolino, the new despot of Pisa, proposals for the ransom of the prisoners of war fell through. It was finally decided to accept no ransom, but to hold them in gaol, in order that the population of Pisa might not be replenished; and with a littleness of soul baser still, every town in Tuscany, where the ungenerous Guelphs were at this time predominant, surrounded their moribund prey like carrion-crows, and agreed with Genoa to utterly destroy the defeated city. Pisa had lost her command of the sea. Henceforth, she had to be contented with a second place. And she was about to be attacked at her most vulnerable point-her land territory - at a time when war had drained her alike of wealth and men, and it was said that he who would see Pisa must go to Genoa. She had made the mistake of trying conclusions with Genoa while on bad terms with her own land-neighbours. Quos Deus vult perdere prius demeniat. It was a mad enterprise. Genoa and Tuscany formed a league, which 
endured for a quarter of a century, and Genoa even offered Pisan prisoners their freedom if they would become Genoese. No Italian power could successfully make a stand against such a combination, attacking both by land and sea. In the attempt to do so Pisa fell into the hands of a despot.

\section{PISA}

After the conquest of Sardinia by Pisa the noble families in that island were perpetually at feud, and the Papacy, by supporting the weaker, gradually encroached more and more in the government of that island, until there was really some sort of effective overlordship of the Church. In 1206 Innocent III. called on the Pisans to renounce their rights there. One of the Pisan Visconti managed to arrange a marriage with one of the great heiresses of the island who was a relative of Gregory IX., and he recognised the Papal suzerainty and repudiated that of Pisa. He carried with him the Visconti family in that city, who thus became Guelphs. This threw the other great families, especially the counts of Gherardesca, on to the Ghibelline side, towards which party Pisa was naturally inclined of old, an inclination increased by the antagonism of its claims in Sardinia with those of the Holy Chair. Guelphs, under the local appellation of the "Counts," and Ghibellines under that of the "Viscounts," fought fiercely until their feuds were put a stop to by Frederick II. in person.

When Frederick was excommunicated, the Pisans shared the curse with him, and his death left them undismayed. They fought against Florence and Lucca, aided by Siena, Pistoja, and the Ghibelline exiles from Florence, but were overborne by the City of the Lily in her famous year of victories (1254). Shortly afterwards we find the old aristocratic government reformed. Twelve elders (anziani) replace the Consuls; there is a Senate of forty, a General Council, a Podestà, and a Captain of the People. The effect of the triumph of the Guelphs was a reconstruction of the constitution on more democratic lines. But Pisa had many powerful families exercising almost regal authority in distant places, and the effect of this was felt at home in her determined Ghibellinism. The crushing defeat of the Guelphs on the fatal field of Monteaperto once again bore Pisan fortunes asail before the wind, but the Imperial cause foundered with the triumph of Charles of Anjou over Manfred and Conradin. Nevertheless, Pisa remained unshaken in her Imperialism, for the Pope continued to discharge his thunders at her in order to possess himself of Sardinia. Then Charles seconded his efforts by expelling her merchants from his ports. This strategy of the Angevins had the effect of loosening the firm hold of Ghibellinism on the city. Now, Ugolino della Gherardesca, the head of a great Ghibelline family, had married his sister to one of the Guelph Visconti, who was the ruler of Gallura in Sardinia, and who took up his residence in Pisa when the city and the Holy See had come to terms. The Pisans misliked the alliance. They exiled the Sardinian first, and then Ugolino (1275), who betook himself to the rival 
city of Lucca, ten miles off, and, aided by Guelphs, overcame the Pisan arms, and forced the city to receive her Guelph exiles again (1276). Ugolino, in fact, saw that his own party was losing ground in Pisa, and resolved to take the government of his native State into his own hands at whatever cost to her honour or weal. She was compelled to allow Florentine merchandise to pass free through her port, to restore strongholds to Lucca of which she had possessed herself, and to reinstate Ugolino, who affected Guelph sympathies. Yet was Pisa of such undaunted courage that she rode the high horse with Genoa about their international disputes, and brought on herself the Genoese attack at a moment when she was debilitated by internal discords; and of her weakness Genoa must have been well aware, and determined to take advantage. Meloria followed, and Pisa, who refused mercantile concessions to Florence, which would have appeased the other mercantile cities, found herself confronted by the Guelphic league. Ugolino, who had been one of the Pisan admirals at the fatal sea-fight, has been accused of giving the signal for flight. That his main object in life was personal power is indisputable, but that this allegation was unfounded is shown by the fact that the-Pisans appointed him Captain-General, or Dictator, for ten years, and that the proposition came from the prisoners of war at Genoa. A strong, centralized, continuous command was indeed necessary. Pisa was not merely isolated ; she dared not put out a single sail on her own waters for fear of the Genoese. All the States of Tuscany were leagued against her for land attack, and she was in danger of being, not merely blockaded, but actively attacked by the Genoese from the sea. Henceforward Pisa is more closely involved in the affairs of Tuscany. She will become a formidable menace to the Guelph cities of the Arno; but the struggle for maritime ascendancy lies between Venice and Genoa. Ugolino was a man of consummate ability. A Ghibelline, he was related to the great Guelphs-indeed, he passed in Florence for a Guelph-and although the aristocracy generally hated him, his apparent detachment from, and superiority to, the mere factions of party secured his ascendancy over the populace. He was a man with a genius for statesmanship, but wrathful, and consumed by an ignoble appetite for personal power. Into these capable but dangerous hands the Pisans had entrusted the helm of State. The problem before him was to break up the Guelph league, which was determined to make a clean sweep of Pisa, root and branch. He succeeded in detaching the leader, Florence, some said by bribery, certainly at the cost of the cession of strongholds and the expulsion of the Ghibelline party from Pisa. The Guelphs desired that there might be no longer an asylum for them in all Tuscany. Then he approached Genoa, and offered Castro, in Sardinia, as ransom for the prisoners, who received permission to send messengers to their native city to express their views. These greathearted patriots sent word to the Council that they would never consent to such a humiliation of their country; rather would they die in chains than surrender fortifications built by the blood and sweat of their forebears. Should such cowardly councils prevail, the first use they would make of their liberty would be to punish the recreants who proposed it. Ugolino, then, might have the bonds of his power snapped by such undaunted, stubborn, and unmanageable spirits. It became his. policy to let them rot where they were. Lucca he bought over by the sacrifice 
of very considerable territory, an arrangement which was veiled by a series of apparent captures by surprise. His own nephew, Nino of Gallura, the leader of the Guelphs, now approached the Ghibellines, and new factions were formed for and against Ugolino. An attempt to excite the people to revolt met with no response; but a charge, made before the consul and elders, of an illegal usurpation of power was more successful. Ugolino had to vacate the palace of the signoria, of which he had taken possession; but though a new Podestà was appointed, his services were retained as Captain of the People. And he seems to have conducted public business with such adroitness, and made himself so indispensable, that not merely was he able to contrive that negotiations with Genoa, who was ready to release the prisoners for a money ransom, should drag on for thirteen months, but he was able to clear the public palace of the new Podestà and instal himself therein as lord of Pisa. He chose his natal day to re-enter it. When leaving the banquet that signalized his inauguration, in the full-blown pride of triumph, he asked a Lombard guest what more was wanting. "Nothing," was the reply- " nothing, save the counter-project of God." And, indeed, it did not fail, nor had he long to await it.

Ugolino, perceiving that the Pisans were willing to accept the Genoese terms anent the prisoners, broke the truce by commissioning the Sardinian corsairs to prey on the Genoese ; and in order to secure the accession of the Ghibellines, he arranged with the Ghibelline Archbishop, Ruggieri dei Ubaldini, who led them, to eject his nephew, Nino of Gallura, and his Guelph followers from the city. But he had to be wary of Florence, so he withdrew to the country while the scheme was put into practice. The plot succeeded, but the plotters demanded that the Archbishop should share the supreme power with Ugolino. Ugolino refused, saying that he would recognise no equal and suffer no partition of power. The exercise of absolute sway had converted the statesman into a tyrant. Naturally boastful of power, and of ungoverned temper, he had become unapproachable, and those who bore any complaint to him had to brave his wrath, and perchance to brook his dagger. He slew the nephew of the Archbishop, Ruggieri, in one of his ungovernable fits of rage. The Archbishop became acquainted with a plot on the part of Ugolino's nephew, Nino, to reintroduce the Guelphs. He called the Ghibellines to arms, and, after a fierce contest in the streets, Ugolino and his party were overcome. Ugolino and his family were shut up in a prison and starved to death by the chief Shepherd of Souls in Pisa, who combined in his own person the extremest brutality that is possible to a soldier with the colder-blooded vindictiveness that occasionally stains an ecclesisatic. The incident furnished the great Italian poet with one of the most pathetic of his many moving pictures (Inf., Cant. xxxiii.).

Pisa stood one against a host. Not merely had she foreign foes to deal with, but her own people to subdue-the sovereign of Gallura, the partisans of Ugolino, the exiled Guelphs-whilst I I,O0O of her bravest and best pined in the prisons of Genoa. The Ghibellines replaced Ugolino by Guido di Montefeltro, a noted warrior, who reorganized the army and enrolled in it every citizen. Florence was now allied with Genoa and Lucca. Genoese men-of-war sailed into the entrance of the Pisan harbour and "corked" it in the manner familiar to modern times, and 
occupied several of the towers of defence. But Montefeltro soon recovered nearly all the territory Pisa had lost by the swiftness of his marches or the vigour of his attack. Florence was torn by internal dissensions, and the Guelph league was obliged to grant Pisa peace; but she had to make all the Guelph cities free of the Pisan harbour and restore the Guelph exiles (1293). Genoa held Corsica and part of Sardinia, was exempted from imposts in Elba, and restored the few prisoners who survived at a heavy ransom. In I3I2 another Emperor descended into ItalyHenry VII. of Luxemburg - and was hailed with joy by the Imperialist city. She hoped by his aid to dominate Tuscany. She supplied him with funds and arms; she recommenced her fight with the Guelphic league; she even suspended the signoria, and made him absolute lord of the city, wherein he abode two months. But his death in the following year once again frustrated the hopes of the Ghibelline party, and dealt to the Pisans, above all, the deadliest blow. They had expended 2,000,000 florins on his enterprise, and the issue was that they were left alone to fight against enormous odds. Frederick of Sicily, who had been Henry's ally, came in person to discuss the situation with them, but he was too wary to attempt the task which Henry could not accomplish. He refused the lordship of the city and gave no aid. Henry of Flanders and the Count of Savoy equally rejected the proffered honour and danger, and finally Pisa placed herself under Uguccione della Faggiuola, the Imperial Vicar of Genoa, and was granted I,ooo German horse, employed at a considerable cost. Pisa mournfully received the remains of the dead Emperor, and reverently buried him in her great church: then the bulk of his army departed and recrossed the Alps.

Pisa had received a great blow at Meloria. She had lost the command of the Mediterranean, but she retained for a long while the chief trade of the West with Spain, North Africa, and Palestine. That her energies and wealth were by no means exhausted is shown by the fact that she continued to adorn her beautiful buildings, and added to them the gloriously frescoed cemetery, which she stored with the sculptured relics of the ancient world. In its court, deep in soil which she brought from the East, in many shiploads of the sacred earth of Calvary, she was wont to deposit the mortal remains of her great dead. This Campo Santo formed a fourth and last member of the great architectural group that still stands unspoiled by Time, peerless among the constructive efforts of human genius.

\section{GENOA}

The State of Genoa from the Death of Frederick II. to the SigNORY OF HENRY OF LUXEMBURG, I 312

When Michael Paleologus ejected the Latins from their rule in the East, he had availed himself of the services of the Genoese. In return, he sold them the island of Chios in fief. Nine families furnished the money. The island ultimately came under their oligarchic rule, and remained a dependency of Genoa for three centuries, until the Turks took it with the 
goodwill of its discontented subjects. The special favour thus shown by Paleologus to the Genoese, and their intrepid spirit of adventure and colonization, increased the jealousy of Pisa, and still more of Venice. All three peoples were bent on exploiting the East, and the Venetians especially resented the part the Genoese had played. A struggle between the two nations followed, which was continued on and off for five generations, and was only terminated by the victory of Venice in the fight for existence at Chioggia.

Meanwhile, Genoa was convulsed by revolutions at home. In I257, at the expiration of his year of office, Philip della Torre, the Milanese Podestà of Genoa, was accused of jobbery, and the council of eight was suspected of complicity. The mob shouted that it would have no more to do with peculating Podesti and the rule of corrupted wealth ; it would have a chief who was a fellow-countryman, and whose past life gave unmistakable evidence of his patriotism and integrity. Disaffection of the people, which had been growing for a long time, seized on this excuse and opportunity for revolt, and one of the aristocratic demagogues who had fermented, perhaps for his own ends, this popular movement, Guglielmo Boccanegra, was carried in triumph to the altar of San Siro and proclaimed Captain of the People. Next day, thirty-two ancients, four from each company, were chosen to form the council of the new Captain, and this board fixed Boccanegra's term of office at ten years. One of his brothers was to succeed him in the event of his decease while in office. He was to be provided with a knight, a judge, two scribes, a dozen lictors, and fifty archers to guard his person night and day. He was also to have the annual nomination of the Podestà in his hands, subject to popular endorsement of his choice. The Genoese thus contrived to leap straight from the frying-pan into the fire. The oligarchy was overthrown, but the burghers had provided themselves with a full-blown despotism. Two years later the new rule, perhaps, was getting somewhat discredited. The nobles conspired to overturn Boccanegra, but their plot failed. They were exiled and their houses demolished. Boccanegra took advantage of the intrigue to obtain from the council an augmentation of his salary for the purpose of more completely protecting himself with armed men, and by 1262 he was in full command of the State. He raised and deposed from office at will, ignored the council, reversed judgments, concluded treaties in his own name, and finished up by excluding the nobility from any direction of affairs. The territorial classes now made another effort. They seized the city gates in order to prevent succour from reaching the captain from without, and advanced from every quarter towards the Piazza, where Boccanegra awaited them with 800 men. Their passage thither was opposed by an armed troop commanded by Boccanegra's brother. These they overcame; the citizens, also, seem to have stolen over to their side, an evidence that Boccanegra was losing popularity. To prevent further loss of life the Archbishop intervened. Boccanegra resigned his Captaincy, and the old constitution of the city was renewed. But the democracy did not readily acquiesce in the restoration of aristocratic rule. Two years after the resignation of Boccanegra (1264) there was an unsuccessful rising, and shortly after that there was yet another attempt on the part of a demagogue of noble birth-one of the Spinolato make himself Captain of the People. Four families in Genoa had 
become paramount by this time-namely, the Grimaldi, Fieschi, Doria, and Spinola -and their rivalries were already beginning to menace the stability of the State. But her maritime power and commercial activities were unimpaired. Genoa's fleet was as great as those of all the States of Spain and France put together. Her ships were constantly sailing to Pera, the coasts of the Levant, the Black Sea, and Scandinavia. They brought back the furs of Russia, the silks of China, the perfumes of Arabia, the spices of Ceylon, the precious stones and woods of India, the sugar of Lebanon, and the gold and ostrich-plumes of Africa.

The rivalries of the great families in Genoa possessed of contiguous estates and antagonistic interests, privileges, and claims, were due to personal jealousy, but they led the opposite forces of democracy and of an oligarchy which was indeed well qualified to conduct the great business and foreign affairs of a State, but which was unwilling, and perhaps would have been unwise, to extend political power to the ill-informed masses. There was present, too, in an unconscious sort of way, the protest of the economically disinherited, which always expresses itself at first in a claim for political power, and which has only become definite and articulate in its claims in our own day. These great dumb forces spoke through the contentions of the various factions of nobles. The four great.families continued to convulse the State, and in vain did the Papacy, anxious to get Genoese support for the war in the Holy Land, try to re-establish concord.

The Genoese relations with Charles of Anjou were the reverse of cordial. The Genoese had transported Crusaders in Charles's expedition to Tunis, and on their return they were taken by a tempest off Trapani. Eighteen of the largest vessels sank, of which most were Genoese craft, and 4,000 people were drowned. The brother of the pious St. Louis ordered all the wreckage to be confiscated, on the excuse that an old law of King William granted all flotsam and jetsam to the Crown. But Genoa was, by ancient treaty, specially exempted from the application of this barbarous law, as were all Crusaders, as servants of Holy Church. Moreover, they were the comrades-at-arms of the King. Charles listened to no voice but that of his own greed, which was as insatiable as the sea that had devoured so much life and treasure. He had lost the ransom paid him by the Sultan of Tunis in the same tempest, and his unholy gains through this subterfuge were sufficient to replace it (1270). Of the four great families of Genoa, two-the Spinola and Doria-espoused the popular cause. They had brought about several changes in the government of a democratic character, and were recompensed by two members of their family being named Captains of the People and entrusted for an undefined term with the functions of the Podestà (1270). As Charles's unjust seizure of the wreckage occurred at the same time, the Captains and the Government naturally regarded Charles with resentment, and, in spite of their democratic trend, they inclined towards the Ghibelline cause. The Fieschi and Grimaldi and the other great nobles thereupon organized a revolt which failed. They were exiled, and betook themselves to the Court of Charles. They even urged him to make war against their mother-city, that they might be reinstated there. Charles signed an agreement with these refugees, wherein he secured to himself the lordship of Genoa for a term of years, and, on the strength of this precious docu- 
ment, seized the persons and confiscated the property of all Genoese merchants in his dominions (1272). At the same time all the Piedmontese and other allies of the King declared war. The Genoese exhibited admirable self-restraint. They retorted by giving all Charles's subjects within their dominion forty days' notice to quit. Forthwith Charles's Vicar, at the head of the troops of Lucca, Pistoja, Florence, and Arezzo, advanced along one valley, the Seneschal of Provence by another, and the Guelphs of the North came pouring over the mountains ; but everywhere they were successfully met and driven back. Shortly after this the rivalry with Pisa became acute, and after the great sea-fight off Meloria (1284), Genoa became undisputed mistress of the Tyrrhenian Sea.

Genoa was now free to employ all her forces on her other great commercial competitor-the rival sea-power on the Adriatic shore. In I293, hostilities, for which their respective Governments were not responsible, broke out off Cyprus between four Venetian galeases, worked with sail and oar, and seven Genoese merchantmen. Both States were too proud and jealous to come to terms. They stood by their countrymen, and for five years preparations were made for war. In I295 a Genoese fleet of I6o galleys, manned by over 3,500 men, put forth, but could not come up with the enemy. Next year the two fleets again sought for, but did not encounter, one another ; but the crews of sixty-five Venetian galleys attacked the Genoese settled at Galata, opposite Constantinople, forced the inhabitants to take refuge in the city, and fired their quarter. The Emperor Andronicus renewed his alliance with the Genoese, and Venice declared war against him. But the Battle of Corcyra put an end to the war. It was a fierce struggle. The fleets were nearly matched, though the Venetians had an advantage, and the issue for a long time appeared doubtful, when fifteen Genoese sail, which had drawn off to catch the breeze, bore down on the Venetian wing that was already hotly engaged. Only twelve Venetian galleys managed to escape. The Genoese burned seventy-six, and brought eighteen prizes to port, with 7,000 prisoners on board, including the Venetian Admiral. But both States were so exhausted that they were glad to accept the mediation of Matteo Visconti, and in the same year (1299) Genoa came to terms with Pisa, and restored the remnant of her Pisan captives, after a detention of sixteen years. The trade-jealousy of Genoa and Venice was by no means at an end, however, and in I 306 the Venetians engaged to supply Charles of Valois with a fleet for the restitution of Constantinople to the Latins. Genoa naturally entered into yet closer relations with Andronicus, and kept him well acquainted with the state of Western politics. The death of Charles's wife, through whom he laid claim to the Greek Empire, and perhaps want of funds also, put an end to his project, but did not terminate the struggle between the two republics. The fire smouldered; it was far from extinguished.

Meanwhile, Genoa was experiencing a series of domestic convulsions. Proscription went on ; now one side, now another, rose on the wheel of Fortune. A family would unite with old enemies to crush a friend turned foe, and each family fought until exhaustion and ruin necessitated truce. Henry of Luxemburg now appeared before the gates of Genoa, and effected an important change in the constitution of the city. Her historian 
writes that "for the first time we acknowledged foreign domination, an example frequently imitated by posterity. This nation, which spared neither men nor money, which was ever of a sturdy and warlike spirit, ever ready to extend its sway over distant peoples, ever ready for sacrifice, and regardless of peril in upholding its honour against princes, however great and formidable they might be-this same people, wonderful to be told, made no struggle to maintain its independence, and believed that by a ready submission to the rule of a stranger it would put a term to all internal strife. It is, however, true that of all peoples it has least patiently borne the yoke, and has always known, and that before long, how to drive out the foreigner whom it has called in" (Ubertus Folieta Genueno). Henry was determined to make a clean sweep of all the conditions that made for faction and freedom. He replaced the Podestà by an Imperial Vicar. There was a sort of tribune or protector of the plebeians called the Abbot of the People. He deprived him of his armed guard, and he imposed a contribution of 60,000 florins on the republic. The Emperor had to remain some months in Genoa, for his wife fell ill and died there. The contribution was soon expended. Henry ran into debt, and his creditors began to grumble and excite the populace against him. As if the unhappy monarch had not enough to vex him, it was at this time that, at the suggestion of Florence, all Lombardy broke a second time into revolt.

\section{FLORENCE}

\section{From the Death of Frederick to the Restoration of THE GUELPHS (1267)}

ONE winter day a Ghibelline horseman rode into Florence with bowed head, and announced that Frederick II., " the enemy of God and the saints, is in hell, carrying with him nothing but his sins." Speedily a stream of Guelph exiles re-entered the city, and the Ancients put themselves to the vain labour of making these and the Ghibellines swear peace with each other. The new power that the people had achieved was copied by some neighbouring cities. The Guelph or Ghibelline character of these communities was to a very large extent determined by their commercial rivalries. Guelph Florence had now a large and increasing trade with France, England, and the Low Countries. Ghibelline Siena consequently tried to get possession of the places that encircled Florence, so as to close her trade-routes; or the Sienese attempted to add to all commercial treaties the proviso that no trade was to be done with her neighbour. But when, after the death of Frederick, the Guelphs raised their heads again in Florence, Montepulciano, Montalcino, and Orvieto, Siena in her turn was almost enclosed. Florence always adopted the policy of conciliating surrounding States, and, as the redresser of wrongs, was often welcomed. In this way she got ascendancy over them. But she was always ready to attack a self-governing State if it stood in her way, or if she had a serious grievance against it. She was now (I25I) negotiating for the acquisition of two small seaports on the Tuscan Maremma, so 
Pisa united with Siena and Pistoja to oppose her, and there were underhand dealings between the Ghibellines of Florence and Siena. Pistoja was compelled to receive a Florentine garrison. It was a city unstable as water, and as fond of disturbance as the traditional Irishman. Siena found Florence stronger than she had expected, and sued for peace, and Brunetto Latino, the author of the Tesorio, drew up and signed the treaty. Even the precipices and stout Etruscan walls of Volterra did not avail against Florentine attack. Not a drop of blood was shed by the victorious Florentines, not a single house was sacked; but the Ghibelline chieftains were expelled and the Government reformed, and Pisa, affrighted, gave Florence all the advantages she required. So the Florentine army returned in triumph after its "year of victories" (1254), and expelled the intriguing Ghibellines. The city strengthened itself by an alliance with Genoa, Orvieto, and San Miniato, a city commanding the route to Pisa. In the following year Florence sent a body of horse under Count Guido Guerra to aid the Orvietans against Viterbo. Arezzo lay on the road. The Guelphs and Ghibellines were pretty evenly balanced in that city, and the former persuaded Guido to help them to eject their foes. But Florence honourably repudiated the deed, and paid a large sum to Guido to give up the fortresses he had taken and restore the Ghibellines, enemies though they were. For Florence never governed so well, nor behaved so chivalrously and with such a punctilious sense of honour, as she did under her citizen government, simple in life, honest in intention, and as yet uncorrupted by great unequalities of wealth. She estabiished (1252) her gold florin, for money was everywhere debased, and this coin became the standard of value throughout Europe. ${ }^{1}$ When, in 1256, Pisa again levied war on Florence, an attempt was made to corrupt one of the Florentine Ancients, a necessitous man, Aldobrandino Ottobuoni by name, by offering him a fortune if he would induce the signory to raze a certain fort on the seashore, which the Florentines were by treaty free either to raze or keep. Aldobrandino rejected the proposal with scorn, and although the signory had already determined to destroy the fort, he got it to revoke its decision. Nor did Florence learn of his integrity from his own lips, but from the Pisans themselves. Such was the tone of Florentine feeling and her standard of honour. But she could not spare herself the satisfaction of coining her new money in Pisan territory, to do which was considered, together with the heaving of a dead donkey over the enemy's walls, about the bitterest insult that one city could

1 The golden florin weighed about 54 grains Troy, and was of better gold than the modern English sovereign; it corresponds to the French ten-franc piece. 'The first gold coinage of Edward III. of England ( I 343) consisted of three pieces, equal respectively to two florins, a florin, and half a florin, so that the English florin, or noble, was double the value of the Florentine coin. The lira would be represented roughly by our silver florin, not very different from Edward III.'s shilling. The Venetian ducat and the golden scudo were of the same value as the gold coin of Florence. I have attempted to arrive at some notion of the value of commodities in Italy in the Middle Ages as compared with their prices to-day, but owing to the varying and different prices of so many States, and the fluctuations of their purchasing power at different times, it is wholly impossible to arrive at any just estimate of the real value of commodities in relation to their modern cost. The whole subject is full of pitfalls, and I am comforted in noting that wise historians of to-day also evade the obligation. 
inflict on another. The old friendship with Pisa was now at an end. The city of the lily was getting too powerful for Pisa's liking, and was, moreover, ever on the look-out to secure an adequate seaport for her own.

The Ghibellines in Florence, meanwhile, nursed their wrath at their exclusion from public office and the humiliating suspicions with which they were regarded. The antagonism of Guelph and Ghibelline had, in fact, become a sort of vendetta, and so high did public feeling run that when Alexander IV., to his honour, sent a Guelph legate to Florence to appease the factions, the unfortunate priest was charged with having conspired with the Ghibellines, imprisoned, tortured, and finally executed. In I 258 a plot was discovered, and the Ghibellines were obliged to flee the city and take refuge in Siena. Harbouring them was a distinct violation of the treaty of 1254 , and Siena therefore sought Manfred's support; but, as he would not give it without receiving an oath of submission to his authority, she tried diplomacy. She told Florence that she regretted that she had admitted the exiles. Why had they been expelled ? If Florence would give a sufficient reason, she would be most happy to fulfil her desires, but she really could not undertake to go into questions of the civil government of a foreign city. Her treaty was with the Florentines as such, and therefore with Guelphs and Ghibellines alike. Could she break faith with a portion of the people with whom she was in alliance merely because they were under a cloud ? Florence declared war, but confined herself at first to attacks on the smaller allies of Siena, and the result was that Manfred seized the opportunity of extending his power, and reinforced the Sienese, sending his cousin for leader and some men. Florence now advanced up to the walls of Siena, and captured the royal banner in a sortie, but had to retire before the advance of fresh squadrons sent by Manfred. One of the leading Florentine exiles, Farinata degli Uberti, now sent the Signoria a secret message to the effect that Siena was discontented with her government, that the city was honeycombed with sedition, and that the nobles would willingly sell it to Florence. Counsels were divided, but finally the Signoria decided to march as if to the relief of a minor city, Montalcino, which was in straits, but the real object of their expedition was the very destruction of Siena. Lucca, Bologna, Perugia, Orvieto, all the Guelph allies, were summoned to aid, and the Sienese were commanded to pull down their walls. Their reply was a crushing defeat which they and the Ghibellines inflicted on Florence at Monte Aperto (1260). The whole power of the Guelph party in Tuscany was assembled at that fatal field. They numbered 3,000 cavalry and 30,000 foot. The leaders thought only of how to draw the enemy from the sheltering walls of Siena. Farinata kept promising through emissaries that came in secret, and whose real object was to seduce stray Ghibellines in the Florentine camp, that the gate called San Veto should be opened to them. The Anziani (Elders) watched hour after hour, anxiously expecting the signal, and their deferred hope was kept alive, their expectation aroused, by the arrival one after another of these secret agents. Suddenly the gate opened, and a body of German cavalry charged the astonished Guelphs. The attack was immediately followed up by that of all the Florentine proscripts and I,800 Sienese horse. After these, as fast as they could pour. 
came the infantry, composed of 5,000 men of Siena, 3,000 vassals of the countryside, 3,00o soldiery sent by Pisa, and 2,000 Germans. This army was not half as numerous as the Guelphic troops, but it was of single mind, and bent on victory, while the Guelphs contained Ghibelline traitors that turned on their comrades at this critical moment. Imagination and uncertainty exaggerated what was happening, and while the army wavered and was aghast at these defections, it was assailed in the rear by a body of German horse that had crept round a hill. Panic seized the troops ; the cavalry gave and fled ; the infantry tried to hold together, but its ranks were broken; a desperate but vain attempt was made to save the caroccio ; I0,000 men are said to have fallen, and more to have been taken prisoners. There was not a single Florentine family but had to mourn its dead.

The Florentine Guelphs found themselves too much weakened by this defeat at Monte Aperto, or of the Arbia, as the battle is sometimes called, to hold Florence. The discouraged remnant were insufficient to man the extensive walls. All who had held office, all of sufficient distinction for their sympathies to be known to the foe, mounted their horses and sought shelter in Lucca. The Guelphs of Prato, Pistoja, Volterra, and San Gimignano could not hope to maintain their ground. They one and all abandoned their homes and joined the Florentines in Lucca, where tents were pitched by such fugitives as could not find shelter in the church of San Frediano in the spaces of the quarter around it.

The Ghibellines marched into Florence three weeks after the battle, abolished popular government, and instituted a new magistracy of nobles that took an oath of fidelity to the King of the Two Sicilies.

A congress of Ghibellines was held at Empoli. The Ambassadors of Pisa and Siena urged that so long as one stone was left on another in Florence there would be no certainty of the predominance of the party of privilege in Tuscany. The Florentine populace was devoted to their Guelph leaders; there was no hope of mitigating their hatred of the Hohenstauffen; they were possessed of democratic feeling, and had become habituated to democratic habits, therefore wise policy demanded that the walls of Florence should be razed to the ground, and its people dispersed through the neighbouring communes. All present received the proposition with satisfaction. Then Farinata degli Uberti arose and indignantly repelled such an abuse of victory. He protested that he, for one, loved his city even more than his party, and that he would lead his friends and troops to another victory against those around him rather than consent. No one dared push the proposal in the face of such opposition, and the diet separated after decreeing that the Ghibelline league should take I,OOO of Manfred's soldiers into its pay to maintain preponderance in Tuscany.

For six years Florence groaned under the rule of Ghibelline despotism, and her energetic citizens had to content themselves with concentrating their attention on the organization of their guilds and the development of their commerce. The Guelph nobles remained in Lucca. Alexander IV. did what he could on behalf of the defeated Guelphs, and excommunicated Manfred and his Ghibelline following. Florence, no longer very powerful, was now obliged to give up to Siena all the territory that that State required, and had to make the humiliating, confession that she had obtained 
Sienese territory unjustly, a fact discreetly omitted by her patriotic historians.

When Manfred fell (1266) nearly all Italy declared for Charles of Anjou. Guido Novello, who, supported by German troops, governed Florence, hoped to save the situation by readmitting the Guelphs and getting the Pope to remove the excommunication. Pistoja followed suit. Guido exacted a monetary pledge of good conduct from the merchants, and called in two brothers of the Order of the Gaudenti, one a Guelph, the other a Ghibelline, from Bologna. The Gaudenti were not under monastic rule, and their special duty was the defence of the widow and the fatherless. These new Podesti were to be supported by thirty-six citizens, chosen from both parties. To the seven great arts of the lawyers and foreign traders-i.e., the wool-dressers, money-changers, woollen manufacturers, silk-mercers, physicians, and furriers-there were added the trade-associations of linen-drapers, butchers, shoemakers, masons, and carpenters and smiths. The reason of this extension of the franchise seems to have been that these bodies had an important defensive military organization, which would tell very seriously in a tumult. The "arts," or trade-associations, steadily improved themselves in military discipline. That a fray was coming was evident. Guido retained the German mercenaries in the city, but he found increased difficulty in raising the funds for the payment of this small standing army, and the money collected was insufficient. His forces had to be strengthened from the surrounding Ghibelline cities. Suddenly, and without warning, the people rose in full insurrection, led by a Ghibelline noble, who appears to have deserted his party. Barricades arose like magic across the narrow streets, and a rain of stones and arrows from every window, roof, and coign of vantage prevented Guido's cavalry from forcing these hastily-improvised defences. Once again the Guelph party triumphed. Guido and his followers were driven back and forced out of the city gates. They made a faint-hearted attempt to cut their way back the following day, but it was unavailing. The Gaudenti Friars were dismissed, and the citizens sent to Orvieto for a Podestà and roo knights. The Ghibellines were allowed to return, however, for the burghers, immersed in trade, were unwilling to subject themselves to the interferences of warfare; but they sent asking Charles of Anjou for armed assistance. They hoped to reinstate their trade in Naples by means of Charles, who was anxious on his part to have Tuscany and Lombardy under his control, both in order to be free from harass from the North, and to consolidate his power in the South, without fear of Ghibelline neighbours. He sent Guy de Montfort as his Vicar, with 800 knights, and the Ghibellines departed from the city. It will be observed that the trained soldier had become a necessity for Florentine defence. Cruel despot as Charles was, he was an able statesman none the less, and he left Florence to the government of its popolo grasso. $\mathrm{He}$ was content to receive large subsidies, which the Florentines gladly furnished for the sake of his support. He evidently regarded Florence as a sort of hornet's nest, best left to govern itself, so long as it continued to be on his side. For ten years he remained overlord of that city, as well as of other places, and was lord-paramount of Central as well as absolute monarch of Southern Italy. 
From the Restoration of the Guelphs (i267) to the Full EstabLISHMENT OF THE SIGNORIA (I282)

Charles expelled the turbulent Uberti, and executed a few stubborn country squires. He nominated a Podestà, with judiciary functions, and the Captain of the People became a mere commander of the train-bands of the city, a sort of lieutenant of the King's Vicar, but nevertheless a more important personage than the Podestà. The city was, in fact, with its full consent, held by the trained foreign troops of the King. It seemed as though Florence was on the road, like the northern cities, to despotic government. Plutocratic organization was effected by the leading citizens ; the council of thirty-six was too many for initiative, and it was reduced to twelve Anziani (Ancients) or Priors of Arts, two for each ward. These "elders," in consultation with the Podestà, or Vicar, submitted their proposals to a secret council of roo of the richer traders and nobles who had become traders. If a measure passed this council, it was then submitted to another council of 300 burghers and nobles, and then to the two councils of the Captain of the People, consisting of popolani. The first was a special council of eighty; the second and last council to receive the measure was a more general body of 300 . On rare occasions the general assembly of the people (parlamento) was summoned; and nobles had the right to be present, as well as at the larger council of the Podestà. The chiefs of the major arts (capitudini) were called upon to assist in the consiglio di credenza, or council of eighty ; and on special occasions judges, notaries, and noteworthy merchants and artificers were invited to form another council for very special occasions; all who had voted in the consiglio di credenza had a right to appear in the general council. The councils were elected for six months by lot. Citizens who were eligible to office were relatively few in number; even in 1494 they only amounted to about 3,000; they were chosen from the greater guilds, which by the nature of their trade had either intercourse with foreign States, and could deal with the larger interests of the city, or were skilled in law. Thus nearly all qualified citizens were sure of obtaining office, if not now, then at some not remote period; and there could be little abuse of power where its duration was so short. It was an expedient of the plutocracy, when what to-day we choose to call " representative" government remained undiscovered, to secure some degree of popular control. The eccentricities of the private member were rendered impossible by the initiative being confined to the Priors, who put forward their propositions through a notary, and native eloquence in the councils was cut short by a time-limit, and ultimately even this right of debate was lost. Besides these various councils, there were a number of trade-organizations, which had no direct political power, save that their capitudini sat in the council of eighty, and often in that of the Podestà.

But this did not finish the political constitution of the city. Clement (the Pope) and Charles set afoot a republic within the republic, which M. Perrens calls the soul of the State, which answered a real need, though it became corrupt and a menace, which was copied by Siena, survived the republic, and only ceased to exist in the sixteenth century. To understand this institution it is necessary to examine its origin. An investiga- 
tion was made into the amount of property confiscated by the Ghibellines. It was found to amount to 130,000 lire. In 1268 and I 269 the property of the Ghibelline exiles was confiscated, a third went to compensate Guelph sufferers, a third to the commune, and a third to this organization known as the Parte Guelfa. Before long the accumulating funds were retained by this organization.

At its head were from three to nine captains, usually six (three nobles and three popolani), assisted by a private council of fourteen members and a public one of sixty, the latter with the election of their capitudini in their own keeping, since the care of fortresses, defences of the city, and its public buildings was entrusted to the care of the Parte Guelfa. Only six years pass before we discover this republic within the republic intervening in the councils of the State, and allowed a deliberative voice therein. Soon what was determined in the secret councils of the Parte was usually acceded to by the official Government. Ultimately, we shall find the Parte Guelfa become so powerful and tyrannical as to give rise to much opposition and even revolt.

Florence made use of the foreign trained soldiery at her disposal to conquer San Illario, which sheltered nearly a thousand Ghibellines. She won over Lucca, Pistoja, and the Tuscan towns, save Siena and Pisa, to her league, and after the defeat of Conradin by Charles, the Guelphs were in the heyday of their power (1268). The town of Corneto jubilantly festooned its walls with Ghibelline corpses. But the Papacy had no mind to see the Empire replaced by a power which had its seat so much nearer home. The Pope sent to Florence expressing his deep sorrow that the city was divided into Guelph and Ghibelline factions. The Florentines had made use of the forces of Charles, but they had no mind to make him their master. They divined the inner meaning of the missive at once, for Charles had unduly favoured the old Guelph nobility, and had conferred nobility on the predominant Guelph popolani. So, in 1273 , the two parties were reconciled before an illustrious company-the Pope, Charles himself, and the Emperor of Constantinople were present. But the Ghibellines were privately informed that they had better quit the city, or Charles's Vicar would accede to the request of the Guelph nobles and put an end to them. They departed with all haste ; the Pope left the city in a rage, and placed it under an interdict, and Bologna, who had expelled her Ghibellines, and to whom Florence proffered aid, gave armed resistance to her interference (I 274). Florence, none the less, brought Pisa to her knees and took Asciano on the road from Siena to Rome. She was determined to make herself independent of Emperor and Pope alike. She had got rid of the Imperialistic party, but she was torn by quarrels that were marked by murder and violence of every kind; these broke out among the Guelphs within her walls, and she was powerless to repress them, having the Ghibellines still hanging round the city. The contest cloaked the growing jealousy that the political ascendancy of the greater arts aroused among the smaller burghers; the factions of the families of the Adimari and the Donati divided the entire town. A truce of two months was only used by the parties to renew their energies for mutual attack. Nicholas III. was appealed to, and sent Cardinal Latino. Latino demanded full powers, the people were willing to concede them to him, and although balia was ultimately refused, he succeeded in patching up 
peace, even to the point of the reconciliation of Ghibelline and Guelph. The Signoria now consisted of fourteen members, of whom eight were Guelphs, six Ghibelline, assisted by "sages." It was renewed every two months. The militia was composed of two groups, each representing three wards, or half the city; one was commanded by the Podestà, the other by the Captain of the People. It was only to be summoned on extraordinary occasions. The city was properly policed; private understandings between the nobles and the people were prohibited; the laws were revised ; and both parties were bound over to keep the peace under an enormous bail (1280). Having done this good work, Latino departed for Siena to meditate there. A year before Volterra had re-established its Ghibellines; their palaces had been destroyed, but the Guelph palaces were rebuilt at the public cost. Here also the Church was called upon to intervene. Pistoja also readmitted the Ghibellines, and her elders were to serve for a month only. Everywhere, in fact, there was an attempt, aided by the Church, to break through the league between the rich burghers and the Guelph aristocracy by opposing Ghibelline to Guelph once more, and to increase the power of the people themselves. The rich merchants were all for Charles, because of their profitable establishments in his kingdom, and the reason the Church aided the people was to prevent him from dominating the cities through the rich burghers.

The paralysis of power that fell on Charles through the Sicilian vespers gave the Ghibellines heart again. So the Florentines excluded them altogether from public office, and forced the Guelph aristocracy to matriculate in the trade-associations. They tried various experiments with their constitution in order to concentrate its powers, and finally (1282), to enhance the sway of the big merchants, appointed six Priors, one representing each ward and each of the greater arts, save that of the notaries, who already were represented as councillors of the Captain of the People. This Signoria was elected by those going out of office, aided by the advice of the capitani of the seven greater arts, and remained in office for two months only, and its members were not re-eligible during the next two years. Thus continuity of policy was secured with a real representation of the men who directed Florentine trade and finance only, and this was secured devoid of danger of arrogated power or of corruption. The Priors ate at the same table, at the public cost; they were not permitted to leave the public palace (the Palazzo Vecchio was not yet built); they could not give audience save in the presence of two-thirds of their number, and on public business only; and jurisconsults were present at all their deliberations. "Thus was the communal palace made for them a prison; for the State, a fortress" (G. Villani). The Priors consulted from time to time with the chief military and commercial specialists in the State, and the minatest details of administration came under their notice. Their notary had to be a Lombard hailing from some other town than the Podestà or Captain of the People. The Captain of the People was a much more important officer than the Podestà, and after 1283 he was also chief Consul of the guilds, taken from them, and ranking after the Priors. His judicial functions were restricted to offences occurring in his own palace, and then only if the Podestà took no action. But he decided questions of evaluation and taxation, appeal being allowed to a yearly elected foreign jurisconsult. If he found his police to be 
insufficient, he could levy special constables. But in war-time a special Captain of War was elected, and he was paid to levy troops-a foreshadowing of the coming condottieri. The Captain of War was accompanied by two of the twenty-four captains of the city militia as both check and counsel on his action; he could be replaced by the Podestà, Captain of the People, or a captain of the militia; a Prior tried criminals of the camp. The qualifications for the office of Podestà were that he should be a foreign noble or jurisconsult, a Guelph, over thirty-six years of age, subject to no prince, and residing not less than fifty miles from Florence. The Captain of the People and he were elected by their respective councils, over which they presided. Civil actions were tried by a native jurisconsult, elected every six months, but criminal cases came before the Podestà on the complaint of the injured person or a relative if the offence was of slight moment, or of anyone if a grave offence had been committed. In the councils only four members could be heard on the same question, and interruption of the speaker was punishable by a heavy fine. The minutest matters had to pass all four councils, and the voting in the Priors' council of roo was secret; a simple majority sufficed, but four-fifths of the votes were required for the alteration of a statute. The Treasury was in the hands of three Camerlinghi della Camera, assisted by a notary and two Florentine jurisconsults, all elected every two months. The envoys of the State were nominated by the Priors. The general assembly consisted of all matriculated Guelph members of a guild, being not less than thirty years of age, and paying taxes; it was convoked six times a year and on special occasions. Resolutions were sent on by the capitudini of the arts to the Priors, on whose initiation they were placed before the councils. Usually business passed through the whole of this complicated machinery of State in about two days; it could be reconsidered over and over again, and every interest of the big trader, and even of the middle class of burghers, was attended to ; but the little people remained politically ignored. Disagreement among the councils was followed by a general assembly. The five intermediary guilds were consulted from time to time, and great political sagacity was shown by the major and intermediary arts in neither granting nor denying too much political power ; the greater arts were, with the exception of the lawyers, those engaged in foreign trade, and therefore experienced in great matters and foreign affairs; like our own oligarchy, they had the sagacity to extend the franchise when they perceived danger. The nobles changed their names and matriculated in the guilds to retain political power, and being, for the most part, far from wealthy, they married daughters of the burghers, exactly as German officers are wont to do to-day, with the same result of forming an offensive class. Like the Briton, the Florentine loved a lord.

The republic was now governed by a constitution which was stable and did not merely represent, but actually was, the entire trading class that had made it great. It was remodelled from time to time, but persisted, in its essence, unchanged. Florence had become the leading power in Tuscany, and the various States besought her to send them Podesti. She had emancipated herself from the political control of the Church. When the Papacy tried excommunication during the war with Pisa, of which it disapproved, because it dreaded lest Florence should become so 
strong as to snap the chain which bound her to Rome, Florence had gone on her way unconcerned. She saw Pisa humiliated by Genoa, and by slackening her energies against Pisa, she prevented Genoa from following up the full advantages of her victory at Meloria; she obtained advantageous terms from Ugolino, the Pisan despot. She bought bits of the Empire to act as a wedge thrust into Pisan territory. She was Guelph because the Guelphs did not disdain commerce ; she was ever ready to help Charles against her Ghibelline rivals, or to act with the Pope when Charles appeared to be getting too formidable. She had become the chief banker of the Holy See, and most of the Papal wealth passed through her hands. All her rivals were of necessity adherents of the Ghibelline party, for Florence was always on the alert to seize the command of a rival trade-route. Bologna and Lucca were Guelph, and her friends-Bologna because the Apennines separated her from Florence, and the surrounding cities were non-mercantile, and therefore Ghibelline; Lucca because she was nearest to Pisa. Genoa was still friendly, for Florence had not yet achieved the control of Pisa. Arezzo wobbled between Florence and Siena, for she was at an equal distance from both; she cast her lot in with Siena when she found that Florence could not close Sienese trade-routes to Rome and make them her own. Pisa now finds that Florence, become powerful, wants her as a port; Siena is a trade rival, and, like Florence, a Papal money-changer ; both become her bitter foes. Florence can trade freely through the routes of Bologna and Lucca; she tries hard to make her way to the Pisan coast-line; she tries to secure her traffic with Rome by overpowering Siena and Arezzo. But the cities are usually in friendly relation, and confer civic rights on one another; for there is a Ghibelline and a Guelph faction in every one of them, and any morning might discover a revolution, changing a foe into a friend-for a time. This was a state of things to evolke alertness in every faculty, to arouse the full energies of the mind, to call forth from every man whatever of invention, initiative, or power of any kind he had in him.

From the Establishment of the Constitution (1282) to the Death of the Emperor Henry of LuXemburg (I3I3)

The feudal system was dominated by no resident monarch in Upper Italy; hence it was possible for republics to arise which inaugurated the modern world. The Italian communes took the lead in political development, trade, learning, literature, and the arts. The surrounding cities caught the spirit of Florence ; Siena exiled her leading Ghibellines in I 285 , and concentrated her power in the hands of a signoria of nine of the middle class. Arezzo turned the tables on her arrogant but powerful country nobles, and dealt with them with no gentle hands; the result was a counterrevolution, which placed political power entirely in the hands of the nobles, and Arezzo became a refuge for all the Ghibelline exiles of Florence and Siena. These waged war against the two cities. Siena was defeated, but Florence gained a signal victory at Campaldino, in the Casentino ; she found Arezzo too strongly defended to do much against it ( 1289 ), and she was glad to come to terms with Pisa in 1293 , for she was once again suffering from dissensions at home.

The Guelph nobles were elated with their success in the war ; it increased 
their popularity. They directed the Parte Guelfa, capitalized its funds to furnish the sinews of war, and overshadowed the legitimate government. The younger nobles sought to increase their fortunes by wedding the daughters of wealthy burghers that had a vulgar ambition to become connected with men of ancient lineage, whose haughty manners and military distinction bedazzled them. The wealth brought by their brides enabled the aristocrats to make a brave show in the way of splendid feasts and personal display; and they bore themselves with a superciliousness and arrogance which they copied from the knights of King Charles, fostered by distinctions that he bestowed on them. Unsupported by a feudal organization of rank, they had to form themselves into close clans for the purposes of offence and defence, and these were perpetually engaged in private war. In 1287 there was a riot caused by a turbulent young nobleman, one Corso Donati, attempting to rescue a nobleman condemned for murder. The alarm-bell was rung; the people assembled at the summons for justice, and did not disperse until justice was done. This noxious class of aristocrats, enriched by plebeian wealth, had induced the peasants to enslave themselves by contract in order to get a territorial fulcrum ; and in I 289 serfdom was abolished by the republic in self-defence. The nobles preferred to execute their own sort of justice in their own way-a way that ignored the laws of the commune-and they were wont to assassinate those who bore witness against them. Various expedients were tried to curb the lawless and intolerable insolence of the caste ; the wards were frequently rearranged, in order to keep any clan from getting too much power in its quarter, for no one could change his dwelling without leave. But the curse continued to grow. One Giano della Bella, a member of an ancient family that dated from the times of Otho III., was one of the Priors of the city in I292. At an assembly of the people he denounced the disorders of the State, and demanded that the government of the Priors, supported by the reorganized militia of the city, should once and for all assert the supremacy of public law. He carried with him the people and the wealthy burghers, who had been heavily hit by the financial dishonesty of Philip of France, and whom bitter experience had rendered unfavourable to aristocratic pretensions. A commission was constituted with full powers to reform the State. The work of the commission was the famous Ioo Ordinances of Justice. Thirty-seven noble families, called grandi (noblemen), were for ever excluded from political power, and the signoria was empowered to add to the list from time to time such families as might be deemed pernicious to the commonwealth. For the first time in history social position was deemed a disgrace. The evidence of a near relation of an injured person and two witnesses was sufficient for condemnation, and these need not actually have witnessed the crime; accessories were subject to the same penalities as principals. The nobility had to find guarantors for possible fines. In cases of homicide the abode of the criminal was to be razed, and a murderer incurred the death-penalty. Accessories, being nobles, were to be fined 2,ooo lire, or their property was confiscated ; in cases of mutilation the same penalty was enforced on the doers or instigators of the crime, and their hands were to be chopped off if the fine was not forthcoming. If a criminal escaped, confiscation of all his property followed. Witnesses of a crime and those bearing false testimony were severely punished. Appeal was disallowed. 
Every Prior was to be actively engaged in some trade. The Podestà was to be changed half-yearly.

To enforce these enactments, the militia of the city was divided into twenty companies, each of fifty men ; each company was to have its flag and armoury, where it was to assemble, and the entire force was placed under a chief of police, changed every two months, called the Gonfalonieve, or standard-bearer of justice. The Gonfaloniere, re-eligible after a year, and elected by the Priors by a strangely complex method, was to live with them, and the signal for the assembling of the militia was to be the unfurling of his banner from the public palace where they lived; I 50 stonemasons and 50 sappers armed with picks were added to the I, ooo to do the business thoroughly. Giano della Bella aimed at the destruction of aristocratic prestige and power, and when the famous enactments were promulgated by the officers of the commonwealth, the heads of all the guilds, great and small, and the chief men of the city, he proceeded to attack the Parte Guelfa, which iniquitously held confiscated property that they ought to have handed over to the commune. The nobles began to protest against the fulness of the powers that had been entrusted to the people, and complained that, if children fought or a man got pushed down by a noble in a crowd, they might be put in the wrong and suffer confiscation. Giano could not be openly attacked or privately murdered without ruin to their cause, so they intrigued with the Pope, Boniface VIII., to put him and themselves in possession of the city. The most reckless and ungovernable of the Florentine folk were the butchers, and Giano had got into hot water with them in endeavouring to reform the statutes of their corporation. Dino Compagni, the historian, who was the first Gonfaloniere, discovered that Giano was being egged on to these measures by his secret foes, and unmasked them to him. "Let the republic perish and me with it," was the reply, "rather than subordinate right to private advantage or destroy true freedom by cowardly weakness." Soon there was a street row, which was nothing less than a put-up job of Corso Donati's. A trumped-up case was brought before the Podestà, and Giano supported him in his decision; whereupon the mob attacked the Podestà's palace, and Corso had to run for his life over the house-tops. Giano had lost much popular support by rightly siding with the Podestà, and his enemies seized the opportunity to accuse him of having fomented disorder at a time when there were new magistrates hastily and prematurely elected during these disturbances. The city was divided, and it very nearly came to blood, for Giano's brother led the mob close up to the palace of the signoria, and it looked as if civil war could not be avoided. Then Giano, with a self-abnegation which is rare in history, manifested his high and unselfish character in a crisis which penetrated into and revealed that inmost core of self of which we are all so ignorant, and which ever gives misgivings to every man who knows something of himself. He refused to be an occasion for strife, and departed from the city. He was condemned in his absence, and died in exile. "A great misfortune for the city and the people," writes Villani (L. viii., c. 8), "for he was the loyalest man in Florence, and the most devoted to the principles of the commonwealth-one who, above all, desired the public good, and held his own interests as of less importance than the general weal. Proud he was, it is true, and revengeful. The fault, perhaps, brought its punishment when unjust judges wrongly condemned him by 
the very laws which he had been the means of passing. . . . His exile completely changed the administration of Florence ; henceforth the artisans and lower classes lost weight, and the government remained in the hands of the richer burghers" (that is, they lost weight up to the time at which Villani writes).

The nobles had hoodwinked the people ; they now took up trade, assumed democratic names, and got admission into the guilds, and through them to government. The clans still continued, for it would never have done to let landed property go to the great families of other communes ; marriages were arranged by the clans, and the government found it desirable to propitiate them. The State was entirely in the hands of the greater guilds, which were composed of traders and nobles who had become traders; it had to deal with the ancient families who were disfranchised, the country squirearchy, dangerous people proclaimed as grandi from time to time in order to disable them, and the smaller traders, who were beginning to agitate for a share in the government. The latter had begun to taste the sweets of power; for the butchers, shoemakers, smiths, carpenters and masons, and second-hand dealers had been called into council to counterbalance the nobles at the time when balia was given for the framing of the ordinances. The Government had at the same time to classify the minor arts, who appear in the following strange order of precedence: vintners, taverners, cheesemongers, tanners, armourers, locksmiths, carmen, bridle-makers, carpenters, bakers. The rich burghers were extremely reluctant to extend political power to those below them, not merely on account of their aristocratic relatives, but because, as we have indicated, they alone had great dealings with foreign nations, and considered themselves to be exclusively qualified to deal with foreign affairs. They lent money to the potentates of Europe, and the Lombard cities were their rivals in this profession. They were always ready for a spirited foreign policy, and they passed sumptuary laws and readily diminished their personal expenditure when they made big losses, or in order to provide the sinews of war for capturing trade-routes and extending their commerce. On the other hand, the retail traders flourished most when the State was at peace, and money was spent freely ; they liked to see country villas a-building, and, as Perrens slyly observes, the ladies were on their side. The lower orders were therefore opposed to a policy of aggrandizement, and the nobles were naturally ready to use them against the Priors; they had the grievance in common of ineligibility to office; the nobles had the further mortification of being called upon to defend the city which they had once governed. In I 294 the Government was obliged to admit one member of the minor arts. The split of the Guelphs into Black and White factions really veils the division of the dominant party into those who were liberal and those who were conservative in their tendencies. There is this to be said for the rule of the plutocracy : it was enlightened ; it favoured the arts, and spent its wealth on great public buildings ; the taxes were light; there was no public debt; the administration was good; the diplomacy of the State was conducted with a dexterity above all praise ; the governing class produced men like Dante and Cavalcanti the poets, and Dino Compagni the historian; it made a brave show of high genius, profound learning, and consummate capacity for affairs. But it was unable to reconcile the irreconcilable, the conflicting elements and 
interests of the commonwealth; it had to preserve peace and secure unity by a series of elaboratc checks, and it was surrounded by discontented classes, which it could not, even if it would, freely admit to its administrations without nullifying its purposes and endangering the very existence of the city.

Among the grandi themselves there were two parties-the nobles, who were fettered by the " ordinances," and the rich traders, who supported them. The latter class consisted for the most part of new men,who were weak in arms, and who, therefore, were willing to give a modified extension of politicial power to the minor arts ; the minor arts, who were discontented and were pushing forward to political power; and men of high character and speculative and theoretical disposition-the thinkers of the time, such as Dante and Cavalcanti. The nobility, by their lavish expenditure, seem, however, to have captivated the multitude. The ordinances had to be modified. There were thus two questions agitating the community - that of the ordinances and that of the extension of political power. But this was not all. There was personal antagonism between the, perhaps, vulgar new men, who found their chief support in the Cerchi, a recently ennobled family, and the old, narrow-minded and haughty men of blue blood, who rallied themselves behind the Donati. The hotchpotch was still further perturbed by the introduction of a wild foreign ferment, and, later, we shall see the Papacy taking a stir to its own ends. Twenty miles from Florence lay Pistoja, "that den of wild beasts," as Dante called it. Its people were perhaps the most violent, passionate, and factious recorded in history. Pistoja preceded Florence in her attack on the disorderly nobility; she made a "black list" of them in I286. When Florence framed her constitution and passed her ordinances, several States copied her and effected similar revolutions, and in I 294, the Liberals being in power in both cities, the Pistojan Government gave Florence five years' free hand to put their house in order. These moderates, or liberals, of Pistoja were called Bianchi, or Whites, after the descent of the great family of the Cancellieri from an ancestress named Bianca; and the descendants of the second wife of Bianca's husband were by opposition called Neri, or Blacks. Vendetta raged between these Cancellieri, who were Guelphs, and had chased their encmies the Panciatichi and the Ghibellines from Pistoja; it divided the Guelph party on similar political lines to those that obtained in Florence. These bitter strifes continued long after Pistoja became subject to Florence in I4OI, and were not extinguished more than a century later, when the town was incorporated in the duchy of Tuscany. The Florentine government exiled the chiefs of the opposing factions, but, relying on its power to enforce order, gave them harbourage in its own city. The Whites were received with open arms by one party, the Blacks by the other. They were as a spark to the powder-magazine; their nicknames attached to the parties which respectively sheltered them, and the streets of Florence again ran blood. Indeed, as we learn from Villani, so high did party passion rise at all times that two years of tranquillity was considered a long period. The Whites dreaded France and the Pope ; they had little fear of Germany ; they sided with the popolani, and drew near to the Ghibellines because they saw that the Papal pretensions to temporal power menaced Italian liberty. The Black Guelphs intrigued with the Pope, Boniface VIII., who was at enmity with his own burghers at Rome, whither the Florentine passion for 
civic liberty had penetrated; he saw an opportunity of repressing the new spirit and of regaining dominance in Florence.

Three Florentine citizens domiciled in Rome had been sentenced by the Florentine government, and Boniface threatened to excommunicate the city. He had, indeed, the excuse that the accusation was probably a trumped-up one. Florence answered that he had no authority over her domestic affairs. Neri di Cierchi, who had been summoned to Rome, was weak enough to ask Boniface to intervene. Boniface sent the Cardinal D'Acquasparte to mediate. The Whites refused. Nobles rushed to arms and attacked the heads of the guilds, saying, "We are the men who defended you at Campaldino, and you reward us by depriving us of office and power in our own city." The White signory, including Dante, exiled the leaders on both sides. The Black faction went to Perugian territory, where they were near to the Pope, and continued to plot with him; the Whites to Sarzana, between Pisa and Genoa. The Cardinal had departed meanwhile, and put the city under interdict. The Whites complained that that air of Sarzana was malarious ; and the signoria, recognising that they, of the two parties, were least to blame, and, moreover, really expressed a strong popular movement, recalled them (I 300 ). Boniface, who was eager to strengthen the Papacy, of which the spiritual prestige was declining, by increasing temporal power and authority, called in Charles of Valois, a brother of the King of France, to support him against Sicily and the other enemies of the Church. Florence tried to negotiate with the Pope. She was the Papal banker, and could not afford to quarrel with him. She had large commercial dealings with France, and must proceed warily. Enemies surrounded her-Pisa, Siena, Pistoja, Arezzo. She had to express her willingness to receive a vicar if her freedom were guaranteed. But freedom was the last thing that Boniface was willing to grant. This forced the Whites to become practically Ghibellines, though they dared not avow the cause; they expelled the Blacks and razed their houses. Meanwhile Charles was on the march. A neutral signoria was elected at Florence and Dino Compagni, the historian, who was one of the Priors, assures us that they were in unison, temperate, and willing to be fair to both parties; they negotiated with Charles, who was bent on getting money above all things, and who found that he would have to fight his way if he did not agree to the Florentine terms. So he signed a solemn promise to observe the laws and usages of the Republic, and not to claim any right or jurisdiction over it, either as vicar or in any other way. Florence relied on his princely word, threw open her gates, and gave him a royal welcome, though he had received the disaffected Blacks of the district with marked favour before he entered the city. He applied to the authorities for the keys of the gates, and swore yet once again that he would respect the sentences of exile which the Republic had issued. He readmitted Corso Donati and the Blacks the very same night. The Priors protested against this infamous and treacherous perjury. Charles replied that it was no doing of his. He asked the Whites to put themselves into his hands also, in order that, with both parties in his power, he might re-establish the peace and prosperity of the Republic. The Priors were obliged to consent; the chiefs of the Whites did not demur. Charles immediately imprisoned the Blacks and released the Whites. The Priors, too late, rang the tocsin, but the people could do nothing against the troops of Charles and the fierce nobles of the Black 
faction. For six days the Blacks rioted amid the flames of their adversaries' towers, which were first put to pillage, their owners' daughters being forcibly abducted and compelled to marry Black Guelphs. Meanwhile the base and dishonourable Valois feigned ignorance ; said he had not intervened because he mistook the conflagrations for illuminations in his honour (I 3OI). The Blacks seized the signoria for themselves, and Charles betook himself to Rome, where he was reminded by the Pope that Florence was a fountain of gold. Returning, he accused the Whites of plotting against him; he sucked the city dry, and then scuttled with the loot. He came to Tuscany, says Villani, on pretexts of pacification, and he left nothing but war behind him: he departed for Sicily under a show of war, and ended by accepting a humiliating peace.

Tuscany was now torn by contending factions. In 1303 the new Pope sent Cardinal Prato thither, and he was granted full powers for pacification, and even the nomination of the government was placed in his hands. But at Prato, his native city, and at Pistoja, he failed ; and those cities, with Florence, were excommunicated (I 304). After the Cardinal's departure from Florence, the city again fell into the hands of violent factions. Arson was their means of warfare, whereby the nobility was hard hit ; for they had not the ready means of renewing their wealth that the genuine merchants had, and some of them were completely ruined. The Blacks were divided among themselves, and the section led by Corso Donati received the support of the mob. In I 304 the Whites and Ghibellines, in alliance, tried to surprise the city, but failed. An attempt of the Blacks and the Church to turn the Whites out of Pistoja failed. Pistoja defended herself with the utmost gallantry, but was reduced to famine-point, and sent to Bologna for aid. Florence sent ambassadors to Bologna under the pretext of complaining of the aid given by Bologna to her enemies, really to excite the Guelphs of the city against its Ghibelline government. In this they were successful. There was the usual riot marked by conflagrations, and all the White exiles that had come from Florence were expelled; and about the same time Pistoja yielded, not to the united arms of Florence and Lucca, but to famine, after an heroic defence of ten and a half months (I 306). The Church, with a wêak Papacy, weak in Rome and dependent on France, was at sixes and sevens ; and Cardinal Orsini, who favoured the Ghibellines and Whites, attempted to gather an army together at Arezzo, whence he intended advancing to reinstate the Whites in Florence, but he failed to hold his forces together ( 1307 ).

The triumph of the Blacks seemed complete. Pisa and Siena were under Ghibelline control; but the former power was fully occupied in maintaining her rights in Sardinia against the King of Aragon, to whom the Pope had granted that island, and both cities had to sue for peace. The Blacks of Florence were now divided into factions. Corso Donati had married a daughter of Uguccione della Faggiuola, the leader of the Ghibellines of Tuscany and Romagna; a riot was afoot, for the people justly suspected Corso of aiming at autocratic rule, and he and his party had to barricade themselves in their own quarter. The people assembled at the tocsin's call ; the troops of Faggiuola arrived too late to aid Corso, and he was arrested. He leaped on his horse to escape, but injured his head against a projecting stone ; he was followed and slain (1308). In the following year Pistoja revolted, and, although without soldiers, friends, or 
resources, refused to receive a man of mean condition, and supposed to be avid of gain, that Lucca had sent her as Captain of the People. An anonymous contemporary historian of Pistoja tells us that " a great murmur was heard in the city as if it had been a voice from on high: 'Fortify the city.' Straightway, and without any special order being given, men, women, children, nobles, and burghers seized boards, beams, ironware, and, bearing them to the ruined walls, erected barricades. The work was begun three hours before noon, and by the last nightly prayertime (compline) the town was protected by palisades. Then they commenced to dig trenches on the side towards Lucca. ... The Pistojans sent their children away, determined to defend themselves to the last man, and to die together rather than to suffer indignity any longer" (Istor Pistolesi anon). The former Captain of the People, a Florentine, met the men of Lucca, who were en route, and told them that Florence would never permit the ruin of Pistoja. And soon ambassadors came from Siena to intervenc. They allowed, as a sop to the angry Lucchese, that the palisades of Pistoja should be thrown down and that the town should remain open under their protection for eight days. A chief magistrate, freely elected, was to be alternately chosen from among the citizens of Lucca and Florence, the former city being named to conciliate the Lucchese ; and so the independence of Pistoja was practically secured.

These events have some dramatic interest, but they are hardly important ; they were the disorders of so many ganglia of life that had not yet been gathered and co-ordinated into a central brain, as it were. Even the history of a really important State like Florence is largely the history of personal ambitions. Restricted in so many ways by the corporate life of the guild and various associations, society was organized by a series of rival fraternities, which acted as checks on each other ; and the individual, conscious of power, and on whom new ideas were dawning, endeavoured to assert his personal will and character. He aspired to dominate ; the day of individualism, unhampered by any force of public opinion or large conception of patriotism, had come. The renaissance was already dawning, and the dawn brought with it the liberation of all the volcanic energies of human character, bridled only by guild or party. The strong man still bore the fetters of the mediæval association system, which severely repressed individuality; but as a set-off he seized personal power and every opportunity of an emancipation of self from the fetters of all wholesome restraint whenever and wherever he could. If he was faithful, it was to a clan or party : fidelity to a clan or party was a higher fidelity than any that he owed to the State. But the attempt of Donati and his followers to seize the reins of government and overthrow the Republic had brought the Florentines to their senses, and the strident clamour of faction abated for awhile. Political power was usurped by the wealthy traders in Florence. Siena and Pistoja, Bologna and Padua, Modena, Brescia, Pisa, Genoa-all the free cities were alike in this regard, and passed enactments similar to those of that city. There, too, the popolani grassi, the new order, found itself confronted with the unenfranchised commonalty, supported by the disfranchised aristocracy. Disorders were inevitable, but the new rulers were men who, by reason of their dealings with the outer world, were capable of holding their own in the world and maintaining the outer interests of their commune. They were full of party ambition and party 
passion ; but, after all, political passion is of more heroic quality than mere private desire. Public spirit has subtle workings and unobserved undercurrents productive of unexpected results in letters and arts-of strange new blossomings of the human spirit. Even amid the horrors and violence of civil war the new spirit liberated man ; freedom gave him " vita nuova " -a new birth. Every soul had his energies strained, his intelligence awakened, his most strenuous activities demanded of him ; and Florence in particular, vitalized by freedom, communicated to other free towns an impulse of such supreme power that it aroused wherever it penetrated; it awoke the human spirit from deep sleep, and stimulated it to achieve the very summit of artistic and literary power. The vital germ engendered in Tuscan genius blossomed alike in the vision of her poet Dante and the fair, strong tower of her architect Giotto. It has never ceased to kindle and direct in a thousand ways the very soul of the civilized world. Its impregnating force, so far from being exhausted, is as effective as ever to-day ; and we men of the new and greater renaissance are more conscious than our forefathers of the debt we owe our Alma Mater.

The theory of the Two Swords had broken down. But once again an Emperor was approaching Tuscany, this time under the shelter, for whatever it was worth, of the Papal mantle. The cities of the north, which hailed his coming, were soon disillusioned, and all Guelph Tuscany prepared to resist him. The development of the art of war and the subjection of the nobles had left them still capable of resistance behind fortified walls, but ineffective in the open field, even against the feeble force of skilled soldiery that Henry VII. brought with him. Henry delegated a Papal notary and the Bishop of Botronte to precede him, and secure an oath of loyalty from the Tuscan towns. Bologna clapped the forerunner into gaol, and the Imperial legates had to take a mountain-path, which they found beset by Tuscan outposts. Arrived, not without scares by the way, within two miles of Florence, they sent their Papal and Imperial credentials to the authorities of the city, and begged for admission and accommodation. We possess a lively account of the manner in which they were received. "Having received our letters," wrote the Bishop to his Holiness, "the magistrates convoked the Great Council, according to Florentine custom, and this sat until nightfall. Our messenger, wearied by the long delay, and unprovided with a resting-place, withdrew after asking someone to fetch him when his presence was required. When he had secured a lodging, the Council broke up, and events showed us the kind of reply we might expect. Town-criers at this late hour announced in the public places that we were but two miles off, we, the nuncios and ambassadors of that tyrant, the ruler of Germany, who had done his level best to destroy the Guelphs of Lombardy, the man now coming to Tuscany by sea to slaughter Florentines and bring in the foes; that he had sent us, priests, overland to overshadow their country by the Church ; in fact, they publicly renounced our lord the King, and we who were his envoys, and gave permission to whomsoever would to do us injury as to our persons or belongings, being certain that we bore much silver wherewith to corrupt the Tuscans and take the Ghibellines into our pay. Our messenger, hearing this proclamation, dared not stir from his lodging. He dared not warn us personally. But an old man of the house of Spini, who once was banker to Pope Honorius, uncle of Pandolfo, my comrade, wrote him a full account of all 
this. We were in bed and asleep, but we rose when the letter came to us at Lastri, undecided what to do. To return towards Bologna was most dangerous, as we had experienced. We knew no other road, and the lateness of the hour increased our danger. We wrote to the Podestà and Captain of Florence, both of whom were natives of Papal soil, to learn what we might do in the face of this proclamation. In the morning we saddled and packed, and whilst we were at table awaiting the reply we heard the tocsin. Immediately the street was alive with armed men, horse and foot, who surrounded our house, and a burly fellow of the house of Magalotti, a plebeian, tried to come at us by the staircase, crying, 'Death, death to them !' but our host, sword in hand, kept him at bay. During the tumult the soldiers stole our beasts of burden and nearly all our horses; they came by different passages up the staircase, and entered our room knife in hand. Some of our servants made for their lives, leaping into the garden from the windows . . . others hid under the beds in mortal panic, so that we were almost alone. But God, who delivered us from their hands, kept us of good courage, so that I feared not, though I was most in danger. Whilst this was going on, there was high excitement in Florence, some saying that it was not right to exclude us thus, especially Pandolfo, who was a great lord in Rome. Therefore, the Podestà sent us one of his knights, and the Captain, a citizen ; they also requested the aforesaid merchant of the housc of Spini, named Avvocato, if I mistake not, to accompany them. On the way they met some of our cattle being led to the city; these they took away from the soldiers and returned to us, saying that, as we loved life, we ought to be on our way immediately. We desired to unfold our instructions; they refused to hear them. We tried to show them our letters; they refused to look at them. We begged them to allow us to pass through Florence by night, and we would hold communication with none; they refused, saying that they had orders to see that we returned whence we came. Old Avvocato dei Spini warned us against going through Bolognese territory, because there they were already made acquainted with our expulsion, and we should be treated as public foes to frighten others from approaching the land of the League. We, who were only too well aware of the cowardice, wickedness, and folly of the Bolognese, replied that we had no wish to be slain, and should avoid Bologna. After a great confabulation, they finally set us on a path which conducted us to the territory of Count Guido, between Bologna, Romagna, and Arezzo. They could only restore eleven horses and three beasts of burden. My lord Pandolfo was a greater loser than I, for he had more to lose. But I lost my plate and all that I had in the world of gold or silver, except a gold pen and the ring on my finger" (Epist. Botront. ep. ad Clem. V., p. 3I4). The Florentines were determined to resist the Empire, but they would have done better had they conducted the embassy to neutral Modena; as it was, they led them straight into the Imperial fiefs of the Apennines, where the fugitives were received as honoured guests, and whence they secured the adhesion of many important places.

Florence now for the first time found herself taking a leading place in Italian politics. She was not merely the Guelph leader among neightouring cities. She took the initiative in a larger policy. She had sustained, through disaster, the cause of Della Torre in Milan; she had.supplied Brescia with money for defence ; she had excited Padua to revolt; she had 
bribed Ghiberto of Correggio to lead Parma against the Imperialists; she had sent troops to Rome to oppose the Imperial coronation ; she intrigued with the Pope at Avignon and with the French Crown. This little city of traders was the first to conceive of a world-policy, to perceive how powers might be balanced, and to understand how a series of mutual checks might sustain a common independence. The art of the balance of power, developed in the next century so far as the States of Italy were concerned, was now undertaken by the citizens of the little city on the Arno. Florence led the way in politics even now. Two centuries later, just before her fall, Machiavelli, one of her sons, made the first scientific analysis of politics, and the first attempt to construct a science of government.

In I3 2 Henry was before the gates of Florence. The city militia, the Guelph cavalry, could do nothing in the open field before his new levies of trained soldiers. The Florentine army was outmanœuvred and in want of provisions. It stole back to the city by night. But the Florentines could defend hearth and home with no less heroism than ever from behind walled towers. Siena, Bologna, Lucca, Pistoja, and smaller cities, sent their contingents to help; and the city, serene and undismayed, kept every gate open save that which faced the Emperor, kept the routes, conducted her commercial operations, and transacted her daily business as before. So Henry, with sickness in his camp, lost all hope of taking the city which he could not completely invest. He ordered his army to pack up its tents, and departed (I 3 I 3 ).

Nevertheless, the little State suffered from the wasting and exhaustion of its territory and the re-establishment of its exiles in the mountainstrongholds of the neighbourhood: reinforcements were joining the Emperor, who remained in the neighbourhood. It sought support of Robert of Naples, and had to offer him its overlordship for five years, subject to the liberties of the city being absolutely respected, to undertake its defence. At this very moment Henry fell ill and died.

The Florence of this period was full of architectural, artistic, and literary energy. Arnolfo commenced the building of the new cathedral, which Dante watched as it grew, sitting on the steps of his beloved baptistry in I 294. Siena had commenced the building of her great, glorious church half a century, and Orvieto four years, before. Tuscan palaces arose influenced by the style of Arab castles; improvements on the domestic architecture of the Arabs in Sicily. The population was less than half that of Milan. It numbered 90,000 , of whom one-third $(30,000)$ were employed in the great wool trade at 200 looms ; 90,000 pieces of cloth were exported annually, and 25,000 citizens bore arms. The population of the contado was about equal to that of the town.

\section{SIENA}

Siena and Florence were constantly at war with one another concerning Poggibonsi (which lay between them), Montepulciano (which commanded Siena from the south), and other territories ; and in 1254, the year of Florentine victory, Siena had to renounce her hegemony of Poggibonsi, Monte- 
pulciano, and Montalcino. When Siena opened her gates to the "man who held all hell in scorn," Farinata degli Uberti, and his companion exiles from Florence, another war became inevitable. Siena, after some show of reluctance, had to bow her neck to Manfred before he would grant her the aid of his German soldiery. At first he only sent a few men. These, either by accident or the design of Farinata, were all slain in a small battle, and Manfred's banner was borne in triumph to Florence. Manfred, enraged at this insult, sent a large body of German cavalry, and there is some reason to believe that Farinata played for this. The Florentines, confident in the strength of the army they gathered together from the Guelph cities, sent this insolent command to the Sienese : "Cast down your walls immediately, that we may enter where we list." 'The Council of the Twenty-four were taken aback. They knew not what to do, and some were for submission ; but Provenzano Salviani, who appears to have been the signal spirit of the Council, demanded the presence there of the cousin of the King, who commanded the German cavalry. This Count and his followers said they thought it foul shame that Siena should show such craven fear with them at hand to help, and the Council, somewhat reassured, gave proud reply to the Florentines: Siena would "return her answer by word of mouth on the foughten field." The streets of Siena filled with a wild crowd, arming themselves and lusting for battle ; the clergy marched barefooted to the Duomo to implore the help of heaven ; the Twenty-four elected a dictator, one Buonaguida Lucari, who addressed the crowd. "Men of Siena," cried he, "let us surrender ourselves with all our rights to the Queen of Eternal Life, our Lady and Mother, the Virgin Mary! Follow me now, all ye freemen, pure in faith, to make her this offering." Then, in beggar's garb, with a halter round his neck, Buonaguida carried the keys of the city to the Great Church, followed by the people in long procession, barefooted, and crying, "Misericordia!" The Bishop kissed the dictator, and the vendette of generations were consigned to oblivion in fraternal embraces. A quick, passionate, and sincere people fell prostrate in silent prayer. Then Buonaguida announced to our Lady that the city had given itself to her and to her keeping, and placed the city keys on the altar. The Bishop besought the multitude to forget for ever all private enmity, and exhorted them to take the sacrament before marching forth into the presence of death. Throughout two nights hereditary foes continued to seek each other in reconciliation, and to take the pledge of grace ; and on the third day, Friday, September 3, I26o, the Sienese army, of less than 20,000 men, rushed out of the Porta Pispini for " the havoc and the butchery that dyed the Arbia red." On the field of Monte Aperto they "seemed like unchained lions rushing upon their foes. Little did it avail these to call on San Zanobi or Santa Leperata, for they made a bigger butchery of them than do the fleshers on Good Friday " (Niccolo di Giovanni Ventura). In vain did the Florentine youth make their final stand round the caroccio. Cne by one they were mown down, kissing the blood-stained ensign as they fell. The caroccio of the rival city was taken, with many thousand prisoners, and there was hardly a house in a Guelph city that did not mourn a father or a son. Next day the victorious army marched back the five miles from the battle-field to Siena; there the women, weeping with joy, crowned them with garlands of olives as they slowly and solemnly made their way to the cathedral. There they ren- 
dered full-hearted gratitude to the Virgin for her help and deliverance. A series of solemn religious services occupied the next three days. And for so fierce a contest and so signal a victory the price paid by the conquerors was not great. There were singularly few widows and mothers to bewail their dead, so that there was little to mar the joy of so great a deliverance from so imminent a peril. But in 1266 the predominance of the victorious Ghibellines was rudely shaken by the fall of Manfred at Benevento ; and the Guelphs in the city were getting more and more support in the rising democratic sentiment of the people. A year before Benevento there had been street-riots, and a year after the battle the mob fired the communal palace. For Siena was under the leadership of Provenzano, who after his succession (I 260) " in his arrogance thought to bring all Siena into his grasp" (Dante). War broke out again with Florence, and the Guelph exiles of Siena, aided by Florentines and French, defeated him and his German and Spanish auxiliaries, and more than a thousand Sienese were slain at a battle in the Val d'Elsa. So bitter was party spirit that Provenzano was murdered in cold blood by his captor, one of the Tolomei, after he had yielded to him; and a Sienese lady, a Guelph exile, who was watching the battle, and who had vowed to commit suicide if her town triumphed, exclaimed when she saw the defeat of her countrymen, " O God, henceforth I fear Thee no more!' (Purg. XIII., II5-I23). This is but one of the many evidences we possess of how far stronger a passion that of party usually was than that of civic devotion. The high respect rendered by Dante to Farinata shows that he regards him as having triumphed over himself and the warped partisanship of his age.

The defeat at Colle and the death of Provenzano Salvi were an irreparable blow to the Ghibelline party in Siena. Next year Guy de Montfort, the vicar of Charles of Anjou, forced the city to join the Guelph league and open her gates to her Guelph exiles. Siena was Ghibelline as a rule, out of sheer opposition to Florence; for the present she was Guelph. Her traders got more and more power into their hands, and dislike and antagonism to the old aristocracy increased. In I277 the nobles were excluded from public office, and a more democratic council of twenty-four members rulcd the city. In I 280 this was reduced to fifteen members, and in I 285 to nine, all of whom were rich merchants. Guelph predominance meant that of the big burghers. The Ghibelline nobles tried to repossess themselves of the city by force of arms, but the only result of their attempt was to stiffen the existing government. For three generations the upper middle class ruled Siena with firmness and temperate wisdom. The lower classes had not yet become conscious of the yoke; and, like Florence, Siena was never so happy and powerful as when under the rule of an enlightened class of citizens, engaged in commerce of a noble kind (which was of itself a liberal education), and unperturbed by those human claims of the great mass of the producers of wealth which later vexed the administration of the State. A great class had liberated itself, and had acquired the power of directing and achieving its own destinies ; and the egotism of industrial individualism and commercial greed had not yet fully possessed it, though capitalism was beginning to put forth its first feeble leaves in the growing wealth of certain great commercial houses.

The " lords nine, the defenders of the commune and people of the city, and condato of Siena and its jurisdiction," held office for two months only, 
and during that period were immured in the public palace, like the Priors of Florence. Nobles were absolutely excluded from this council, though they were still admissible to the Treasury, or Provveditori di Biccherna. Life during this period appears to have been splendid and sumptuous, while the religious earnestness, ever characteristic of the city, found its expression in the fasting and vision and subjective aspiration of saints : the inevitable carnal Sancho Panza that accompanies fantastic Don Quixote in the inner life of every human soul found expression in the praises of "woman, wine, and dice," sung by Cecco degli Angiolieri.

\section{LIFE, LITERATURE, AND ART}

\section{Life AND RELIGION}

THE Court of Naples, under Charles of Anjou, was brilliant and gay. The knights made brave show of plumed helmets, and the chariot of the Queen was covered with blue velvet sprinkled with golden lilies. The plain costumes of the burghers of Italy gave place to rich silks and furs, and forcign wines were drunk at their banquets. Foreign influence had much to do with these changes of manners. The elevation of dictators in the communes, too, was accompanied by the formation of small courts, and the luxury of aristocratic life soon spread to the burgher class of the tyrannies, and extended to the cities that still remained true republics. Dante bemoans the change from the simplicity of the olden time to the luxury and personal adornment of his own period, and this in spite of sumptuary laws. Much was thought of feasting, and excessive drinking was particularly common. A tax put on the retail wine-trade produced great disorder in Florence ; but at the end of the thirteenth century the Florentine Government had to sacrifice a great source of revenue by putting an end to "drinking on the premises."

There still remained two different kinds of law in Italy. In I 3 I 3 a Pisan wished to marry and live according to Langobard law (Perrens, L. vii., c. ii.). Family life and its regulations were certainly derived from Langobardic law, which mitigated the severity of Roman parental despotism. The members of the family supported and protected each other, and exhibited remarkable solidarity; the family was one of the numerous associations that, bound together by the public powers, constituted the State; each family and association functioning with almost complete independence, and preserving the traditions, and often the practice, of private war. In small matters the father remained supreme ; in great, a family council sat: it arranged marriages, and property could not be sold nor bequeathed without its consent. Purely personal fortune consisted only of the gains of traffic, and, in order to prevent property from going out of the family, every male was put legally before the women of the family. "Woman, good or bad, needs the stick," was a popular proverb.

Slavery was still common. The chronicles of San Gimignano show that in 1253 a request from the Senate of Pisa, on behalf of a Pisan citizen, 
came before the Senate of that little State for the return of a female slave (Davidsohn.-Forschungen, II., I896-I90I). Judicial combats were common, and barbarous punishments were administered, such as blinding, branding, public whipping, and mutilation. The gaolers of criminals were severely punished if they allowed their captives to escape. A warder at Florence permitted a wealthy prisoner that was sick, and only awaiting trial, to go home and be nursed on leaving 500 lire with him as bail. The gaoler was condemned to pay r,ooo lire, and, although his prisoner proved to be innocent, he had to flee to escape payment of the fine (Provvisioni v:., 5 th June, I296).

Astrology was firmly believed in, and even Dante, who has no place in hell for witches, admits that some measure of influence over human character and destiny resides in the stars. In I259, at a meeting of the General Council of San Gimignano, the Podestà, possibly with a view to the ascertainment of favourable moments for his own designs, requested that one Master Jacob, an astrologer, should be permitted to dwell in the castle, and should be provided for at the public expense in such a way as might be beneficial and useful to the commune ("et quod eidem detur aliquid de bonis comunis pro castellanantia"). The scene that follows is singularly like what we may witness in our town and rural councils to-day. One Rainerius Guidi, councillor, rose and objected that the Podestà would not have so very many occasions on which it would be necessary to seek the opinion of the astrologer. Let that gentleman be consulted on the same terms as the gentlemen of the law, and dweil, like them, in his private house.--Carried (Davidsohn.-Forschungen z. Geschict, v., Flovenz. II., I896-I90I). The same records show cutpurses to have been smart and successful. Amusing accounts of these gentry are recorded in the year I 258 (Davidsohn, II., p. 320).

Throughout the thirteenth century business had been growing. All the cities were renowned for their merchants, and Asti, in Lombardy, together with Cahors, in France, were cities that had an unenviable repution for usury. Owing to the insecurity of the times and of the roads, 30 per cent. interest was quite a usual thing. But general letters of credit were employed, as well as orders to pay particular persons, and bills of exchange. These inventions were much used by the Pope and the higher Italian clergy to draw their incomes from beyond the Alps. Owing to every little town having the power of coining money according to different standards, and the varying values of its issues, the money-changers' business was a difficult trade to learn, and required a long experience for its successful employment. Italian merchants and usurers were to be found in every country. They were known in England by the general name of Lombards. Citizens of Lucca, Siena, and Florence gained a firm footing in England, and the English Crown, finding it could raise money from Italian financiers on cheaper terms than from the Jews, banished the latter from the realm (A.D. I290). Usury was of course forbidden by the Church, which was driven to casuistry to determine what was moderate interest, and what immoderate and wholly condemnable usury. The Jew in Italy appears to have had a much more comfortable time than in the North, partly owing to enlargement of the Italian mind by commerce, partly by reason of the respect it bore to Hebrew as the parent of all tongues; and we find one, Marivello, a Jew, friend of Dante, and Jews 
studying the schoolmen even, and holding scholarly intercourse with the learned.

A curious illustration of the coarseness of the age in many respects is given by the treatment meted out in Florence to fraudulent bankrupts. The defaulter was, in accordance with ancient custom, taken to the Mercato Nuovo, indecently exposed to public view, and then compelled to strike the flags of the pavement thrice with his naked buttocks. After this he was considered to be whitewashed, and there was an end of the matter (Guido Pepe.-Perrens, L. viii., c. i.).

Heresy flourished chiefly among the socially lower, and therefore discontented, orders. All dissenters are called Patarines. Benvenuto Rambali of Imola, a contemporary of Dante, says they were to be counted by thousands of thousands. Classical scholars will remember the flagellation practised at the Lupercalia, and that Herodotus mentions the selfwhippings that marked the festival of Isis. These flagellations were either utitized or reintroduced by the Catholic Church as penance. In the eleventh century Peter Damian recommended and practised scourging, and by the thirteenth century there were fraternities that rejoiced in this form of self-mortification. In I 260 the disturbance of peace due to perpetual war led Rainer, a revivalist monk of Perugia, to preach flagellation by example, and by stirring addresses. The new enthusiasm spread. Apostles of the doctrine travelled throughout Europe, whipping themselves and others, and reawakening the sense of sin - a sense which was already beginning to decline in Italy. They were wont to draw blood from their bodies, weeping and groaning, and demanding compassion and forgiveness from God. Certainly some political discontent was mixed up with the movement, or it was manipulated to political ends ; for the Ghibelline rulers forbade the admission of flagellants into their cities. For a time the old Adam was whipped out, and there is said to have been a general improvement in morals; but the movement was spasmodic and emotional, and the results of the "revival" were ordinarily very evanescent. It is noteworthy that the agitation commenced in Umbria, ever, with Siena, the centre of quickened emotion of all kinds.

In the twelfth century Irnerius had opened a school of civil law at Bologna. In I 58 Frederick I. had taken the Chairs under his protection, and allowed the students to have their civil suits tried by their own judges. Universities were soon founded in all the cities of Italy. Frederick II. protected those of Naples and Padua, and soon students flocked from all Europe to the Italian schools; their jurisconsults were in demand by the cities to determine cases, and their doctors of medicine to determine lives. (One unhappy man, we learn from Peruzzi $(4 I I)$ was killed straight away by the administration of a pill containing ten substances.) It was probably safer to apply relics than medicaments, as was done in Florence, where madness was curable by wearing the mitre of San Zenobia (Cento Novelle., Giorn 3, Nov. 7). The poor were treated gratuitously by Franciscan and Dominican monks, but Taddeo d'Alderotto, born at Florence in I 223, was paid fifty gold ducats a day by his patients, and received Ioo ducats from Honorius IV. We have evidence that physicians and apothecaries followed the ancient and Arab medical teaching with exact stupidity, and that they had little powers of original obseryation (vide It. Novellino, Nov. 34). M. Perrens thinks that the fact that Dante elected 
to matriculate as an apothecary shows that that profession was one possessing no very profound standard of professional training. The recently published transactions of the Senate of San Gimignano show that doctors both of medicine and of law were paid retaining fees by the commune.

\section{Thomas Aquinas}

Towards the end of the third quarter of the thirteenth century the great Tommaso of Aquino, better known as St. Thomas Aquinas, the son of the Neapolitan Count of Aquino in the kingdom of Naples, gave the world that great body of scholastic philosophy which is the basis of the teaching of Dante, and, in the following century this achieved for him the rank of the canonized thinker of the Church and expounder of the philosophical thinking it is willing to accept. St. Thomas held that there are two sources of knowledge-the mysteries of the Christian faith and the acquisitions of human reason. From the Holy Spirit, by Scripture and tradition, and through the Church, proceed mystic doctrines, which would be unintelligible or contradictory for human reason, but which are to be accepted by the Christian in acts of faith. By human reason the conceptions and results of Plato, Aristotle, and the thinkers were won ; but the results of human reason are appearance, not reality ; and the harmony and ultimate reconciliation of the apparently contradictory results afforded by the two faculties of faith and reason are resolved in the Absolute Reality, God, who is the source of both streams of experience. Dante expressed St. Thomas's conception in his vision: "Within the depths [of the Absolute] I saw ingathered, bound by love in a single volume, all that through the universe is scattered; substance, accidents, and their relations as though fused together in such wise that what I tell of is pure flame" (Dante, Parad. xxxii:., 85-90). Of course, the assertion of the independence of faith was the assertion of a modified agnosticism; it placed thought in fetters, and virtually confessed the failure of scholastic philosophy.

Aquinas lectured at the Universities of Paris, Bologna, Rome, and Naples, and it is singular to find this born subject of an absolute monarch holding that the State is rooted in the nature of man; a people has therefore a natural right of rebellion against an iniquitous Sovereign, for a state exists only as a means to the welfare of its citizens. The best form of government is monarchical, however. St. Thomas proposed an upper house of legislators nominated by the monarch, and a lower house elected by the people ( $S^{*} . T$. Aq., Summa theologia, I., 9, I05, art. $i_{\text {. }}$ ). It need hardly be said that such a proposal for radical reform had a purely theoretical and academic value in the Neapolitan State. But the " angel of the schools" became the key-stone of Catholic theology, and the tutor of Dante through the mysterious worlds of his vision.

\section{Literature: From the Troubadours to Dante}

'The cultivation of letters in Provence was killed outright by the furious wars of religion in that district.; but in Italy the new literature still flourished. It aimed at sonority of language and fulness of description ; it was monotonous in form, but it contained new elements which would have astonished an ancient ear; it was by turns devout and sensuous; 
passionate and cunningly devised; physical beauty takes the poet by storm ; but he sees it, even in his most sensuous moments, as the materialization of spiritual truth and heavenly beauty, and we perceive the foreshadowings of Dante's Vita Nuova and his transforming love for Beatrice. Two streams of literary influence reached Tuscany and Umbria-one from Sicily, the other from Provence. The stimulation of the intellect by civic freedom prepared the way, and such increase of wealth as might emancipate a portion of civic society from constant and numbing drudgery was a favourable environment; it gave the oxygen, so to speak, and Siculo-Provençal poetry was the spark that fired; but the material on which these forces operated was the latent genius of the Tuscan racegenius not to be in any wise accounted for, that subtle, incalculable, incommensurable collocation of forces that gathers its augmenting energies in the tender cells of life, and that, like the wind of heaven, seems to blow whither it listeth, and scatters in unexpected places seeds that blossom into grace and power.

The ancient literature was marked by temperance, restraint, and severe purity of mood : the new wept and laughed and shot forth deep feeling and ridicule and censure in a breath. Cecco Angiolieri of Siena is the father of the long line that stretches through Rabelais and Montaigne, and Shakespeare and Richter, to Thomas Carlyle. Folgere of San Gimignano holds his sides, and Cene della Chitarra derides the derider, in pure gaiety of spirit. Rustico di Filippo smiles sardonically. Greece, Rome, Brittany, Provence, the East, and peasant-tales are drawn upon in the hints for the tale-teller known as the "Cento novelle antiche." Brunetto Latino writes his vision, which is allegorical, and has moral purposeallegorical, because the mediæval mind was possessed of the doctrine of Swedenborg, that "there is nothing existing in human thought relating to the most mysterious tenets of faith, but has combined with it a natural and sensuous image." The age thought that there was no demonstration like a good symbol; that Nature was a vast imperfect revelation of the Divine mind, which was thus presented in it, as it also revealed itself in broken forms in the pagan faith; so that man might learn the thoughts and purposes of God in the obscure resemblances of classic fable and the objects of life and Nature. Men's notion of productive thinking was that it was analogizing. This view of life and thought ultimately found its deepest and sun-clear expression in Dante. Other writers than Brunetto were leading up to him. Guinicelli is contemplative and philosophical in his Canzone. Guido Cavalcanti and Cino da Pistoja reach the heart; they have sounded the depths of love and sorrow, and the manner conforms to the matter, and the metre to the style; they have learned the art of concealing art; but they speak sincerely, out of the fulness of life that is in them. Mystic Umbria produced her hymnology and poems of devotion. The cities, Pistoja, Lucca, Pisa, San Gimignano, Arezzo, Bologna, Florence, burst into song as their fountains ran water. Every citizen of any education could write poetry that has both feeling and merit. Such poetry is in the Tuscan race, that even to-day the shepherd and milkmaidjof the hillsides are wont to pour forth their souls in the composition of love-songs of a peculiar purity and force. The new poesy is marked by the clearness and precision of its representations, for every Italian is by nature a painter; objective colour and form 
clothe his most soaring imaginations and deepest convictions and emotions.

Dante ( $1265-\mathrm{I} 32 \mathrm{I})$, the pupil of poets of the new style, concentrates in himself the allegorical trend of thought, the mystic love of ladies, the fully-assimilated learning, and all the painting power of poetry in his time. He is best known to the world, with its barbarous and uncritical liking for the merely horrible, by his journey through hell ; that auditory is more obtuse to the charm of the gracious ladies and delicate visions of the purgatory, or the light and music and profound intuitions of the paradise. It has been observed by the critics that Dante is not vague, vast, rhetorical like Milton; he sees everything with minute distinctness ; he measures the very inches of hell, and is sublime, not because he sees dimly, but because he sees all. His phrases are often luminous, severe, concise as a cut diamond ; "jewels that on the fixed forefinger of Old Time glisten for ever." Boccaccio tells us that in Dante's lifetime some called him a poet; others, a philosopher ; others, a theologian. Not merely was he one of the world's greatest poets, but for his time he was a universal scholar. "If we look at the matter of his poem," says Burckhardt, "we find that in the whole spiritual or physical world there is hardly an important subject which the poet has not fathomed, and on which his utterances-often only a few words-are not the most weighty of his time." L. Aretino says that he drew remarkably well, and was a great lover of music. He was the last of the mediæval men, and the precursor of the modern; he, like all the many-sided men who followed him in the next two centuries, knew Goethe's lesson of self-culture, and he added to that ambition a social and political earnestness and religious fervour which was denied to the great modern thinker.

The great constructive power of Dante comes out very clearly in his De Monarchia; yet his political works evince the political dreamer, living in the great vision of what might be and what ought to be, rather than the practical man of affairs. His is not that useful, if shallow, gift of withdrawal from problems that are not pressing; of not pushing inquiry to first principles. He had not the real statesman's gift of clearly perceiving, picking out, and giving an accurate value to all the factors of an existing situation, and then making some small, but not wholly unsuccessful, attempt at disentangling and rearranging the ravelled disorder. For a short period Dante was one of the Priors of Florence, and, as a "White," was banished (A.D. I 302) with 600 others, under penalty of being burned alive if he ever returned. The man to whom the powers that formed him-

" A mighty gift of Hatred gave,-

A gift above

All other gifts benefic, save

The gift of Love":-

the poet, whose passionate hatred was but the other side of his great altruism, passed, with defeated hopes and tortured soul, to eat bitter bread and climb hard stairs in the palaces of Cane della Scala and Polenta and the great chiefs of his party, and wandered over those rough mountainous ascents that he liked so little. Certainly he travelled as far as Paris, perhaps to Oxford. 


\section{ART}

Contemporary with Dante was his friend Giotto, the architect of the fair campanile that Ruskin refers to as exhibiting the perfection of Art, the combination of grace with power. His predecessor, Cimabue, had partially escaped from the conventionalities of Byzantine Art by trying to combine some representation of action with those stereotyped forms associated with religious contemplation. Giotto burst the bonds that fettered Art, and aimed at Nature, while he retained and vastly increased spiritual import and meditative suggestiveness. His frescoes and those of other artists began to replace mosaic wall-decorations. Siena was, perhaps, a little in advance of Florence in painting. Even before A.D. I300, Guido and Duccio, contemporaries of Cimabue, revealed new powers in Art. In both cities pictures of the new style were carried to their shrines amid general holiday; the trumpets were sounded, the bells rang, shops were shut, alms given to the poor, and the magistrates, the clergy, and the populace accompanied the new masterpiece in joyful procession. All labour was deemed honourable, and the painter was not ashamed of keeping a shop (bottega), and being considered a skilled artisan. The city often paid for the materials of a picture, and a few soldi a day was the pittance paid to the artist by the State-just enough to enable him to "scorn delights and live laborious days." The fifteen or sixteen sous paid to the great artist contrast with the fifty to a hundred gold ducats paid to the great physician of the period.

\section{Travel}

In the great naval battle between Venice and Genoa, which took place at Cuzzola (1298), the Venetian Marco Polo was taken prisoner, and one Rusticiano, a Pisan, also a prisoner, wrote down the experiences which Polo narrated to him. A mediæval traveller appears to have thought little of his adventures. There was no profitable book-market to tempt him to recount them, and most accounts of mediæval travel have been given us at second hand. Probably no man had wandered so far as Marco Polo ; but it gives us some idea of the enterprise and energy of the age to find him leaving Constantinople in 1260, and arriving at Camboluc (Pekin). A second journey, begun from Acre (I27I), brought him to Pamir (never again visited by a European until 1838), and to Lake Lob (only reached for the second time in $187 \mathrm{I}$ ) ; thence he passed into Burmah and Cochin-China, holding positions of authority, a statement confirmed by contemporary Chinese records. In the next century (fourteenth) Christian missions were established in the chief cities of Eastern China, and there was a regular overland trade-route between China and the Italian cities. The Canary Islands were discovered in the thirteenth century by the Genoese, and that maritime people also made attempts to reach the East Indies by sea.

\section{SCIENCE}

Awakened interest in life manifested itself in the investigation of Nature. The disorderly misgovernment of Bologna by its City Fathers 
gave rise to the foundation of similar schools elsewhere. The sciences on which the arts of medicine and surgery are based were assiduously cultivated ; and, at the close of the period, some original force of intellect was brought to bear on the investigation of natural phenomena. Two years after the death of Henry VII. we find Mondino, the father of the science of anatomy, demonstrating the dissection of female subjects at Bologna; and he taught, although vaguely, the circulation of the blood. $\mathrm{He}$ speaks of the transmission of the blood from the heart to the lungs. 


\section{BOOK IV}

\section{DAWN OF THE RENAISSANCE. THE COMMUNES UNDER DICTATORS. FROM THE DEATH OF HENRY VII. TO THE COMMENCEMENT OF THE GREAT SCHISM, I 3 I $3-$ I 378}

\section{GENERAL SURVEY OF ITALIAN HISTORY}

\section{The Failure of Louis of Bavaria}

THE temporary success of Henry of Luxemburg renewed the Papal dread of a resuscitated Empire. Shorn of its ancient glory as the Papacy was; unable to reign in peace in its metropolitan diocese; dwelling in Provence under the protection of Robert of Naples, who was the ruler of that country, and in semi-dependence on him and his relative, the neighbouring monarch of France, the Papacy was astute enough to know that the theory of the Two Swords was unworkable, and that a triumphant Emperor would mean a led Pope. For, of all the Sovereigns of Europe, the Emperor was still the most powerful, and he had an almost talismanic support, that command over the imagination and obedience of men that was contained in the magic name of Rome. It is true that the subdivision of authority in the feudal system, with its perpetual rebellion of vassals, meant a weak Empire; but the same principle was firmly established in every Western country except Italy ; and the other potentates of Europe were by no means so strong as they afterwards became. Provence belonged to the King of Naples ; Lorraine, Brittany, Burgundy, and the Low Countries to almost independent princes; Guienne, part of Poitou and Ponthieu, to England, between which power and the King of France there was almost incessant and disastrous war. Even the provincial vassals of the French Crown were far from recognising the monarch's absolute sway; the King had neither wealth nor men at his command; and so feeble was he that not even the bondage of the Pope in Provence caused dread in any Italian breast. Spain was fully engaged in her Moorish wars, and Greece had long since ceased to be feared. It was, therefore, to the Papal interest to support Robert of Naples as the southern neighbour to Rome, an indispensable aid in troublous times; as well as the great free Guelph cities of Tuscany that were Northern barrier-states. The great plain of Lombardy was now almost entirely in the hands of a few despots, of whom the Visconti of Milan and the Scaligeri of Verona were the most powerful. These despots found it to their advantage to take the Ghibelline side; partly because the cities that still remained self-governing were Guelph, and the spirit of liberty was identified with the Guelph standard, save in aristocratic Pisa ; partly because they would be the first to bear the brunt of the descent into Italy of an Emperor hostile to their pretensions. In order, therefore, to maintain their sway, by no means too secure, the new despots of the North declared for the Ghibelline party, to which, indeed, as landed proprietors and as men of 
war by descent and by training from their youth up, they naturally belonged. Robert of Naples dreaded the advent of a powerful Emperor no less than did the Pope. The free cities were naturally anxious to preserve their freedom, and were on the same side. Hence it is that we find at the beginning of the fourteenth century that, in the main, Italy south of the Apennines is Guelph ; and, with the exception of the great free city of Bologna, Italy north of the Apennines declares Ghibelline principles.

When the news of the death of Henry VII. reached Clement V., this wanderer in bondage, feeble in character no less than in power, nevertheless issued another of those strange authoritative claims which have never been more haughtily and confidently set forth than when the Papacy has been bowed by some fresh humiliation or menaced by some unwonted danger. He did what even Hildebrand or Innocent III. had never dared to attempt. He annulled the sentence which the late Emperor had pronounced against Robert of Naples. "That which we do," said the Bull, "we do as much by virtue of the indisputable authority which we possess over the Roman Empire, as according to our right to be regent during an interregnum." Clement, in virtue of this novel assumption, appointed Robert Vicar-General of all Italy. And with this final assertion of the absolute supremacy of the Holy Chair there ends the reign of the man who had basely sold the interests of Christianity to Philippele-bel, who had unjustly suppressed the great Order of the Templars, and who had accumulated immense private wealth by the iniquitous sale of benefices (13I4). However weak and vicious the individual Pope might be on occasions, the Papal councillors, withdrawn from the ordinary ambitions and interests of dynasty and family and nation, have never ceased to exercise some controlling influence, never failed to exhibit the single, haughty, undeviating and consummate policy of the Church.

Of the twenty-three cardinals who assembled at Carpentras to elect a new Pope but six were Italians. But the absence of the Pastor from his Roman sheep had become a scandal throughout Christendom, and parties were pretty equally divided, when two relations of the late Pope entered Caipentras with an armed force, and endeavoured to compel the cardinals to elect a Gascon. There was a general attack by the mob on Italians resident in that city; their houses were destroyed; the Italian cardinals escaped with difficulty; the college broke up; and for two years no attempt was made to elect a Pope. At last, under a solemn promise that no force should be employed, Philip the Tall, Count of Poitou, and afterwards King of France, contrived to assemble the sacred college at Lyons. No sooner were the cardinals collected than he violated his oath, clapped the doors to, and only released them when, at the end of forty days of party strife, they agreed on a Frenchman of low birth, a man who is said to have risen to the cardinalate by sheer effrontery and intrigue quite as much as by ability of a more deserving kind-Pope John XXII. (I 3I6).

Meanwhile the title, King of the Romans and Imperator of the Holy Roman Empire, was claimed by two rivals, Frederick of Austria-grandson of Rudolf, the founder of the fortunes of the Hapsburg family-and Louis, Duke of Bavaria. Various interests complicated the dispute, and the Papacy was quite willing to profit by the weakening of the Empire in the long civil war which followed-a war which served as an excuse for a contest in Italy between Guelph and Ghibelline. 
The growing power of Ghibelline nobles in North Italy, and the renewed pretensions of the Empire, threw the Tuscan towns into the grasp of the Angevin dynasty of Naples. The struggles between the Imperialistic -White and the Papal Black Guelphs paralyzed Florence, and made her an easy prey. In I3I3 she made Robert of Naples her lord-protector, and Lucca, Pistoja, and Prato followed suit. The desire of merchants for the considerable gains that accrued from the Angevin connection preponderated in cities unable to govern or defend themselves. In 1318 Genoa, menaced by the Ghibellines, gave her signory to Robert, and in I 324 she was compelled to do so again. For a moment Pisa, Florence, Lucca, and Siena were compelled to unite under his protection; he played the rôle of pacifier. In I32r Florence gave the Duke of Calabria, Robert's son, her lordship for a period of ten years, with the result that taxes were raised, extraordinary imposts levied, and magistrates appointed at his will, nor dared these deliberate without the presence of one of his councillors (Villani IX., 329). We shall find Raymond de Cardona at the head of Angevin troops occupying Alessandria, Tortona, and Brescia, cities where the Guelphs predominated, and that were leagued with the Guelph confederation in Tuscany. Even in Piedmont Robert was overlord of several towns. This of itself was a menace to the despots of the Northern cities. Moreover, as Sovereign of Provence, he held the Pope in his power, and he was favoured by the French Crown. Opposed to him were Matteo Visconti, lord of Milan, and a good part of Lombardy; Cane della Scala, lord of Verona and part of Venetia; Castruccio Castracani, lord of Lucca and leader of Ghibelline Tuscany; Frederick of Montefeltro, lord of Urbino, leader of the Ghibellines of the Marches of Ancona and the Duchy of Spoleto, and many other smaller potentates. The war proceeded with varying fortunes, but, on the whole, the despots gained in power and extended their rule; the Este family joined the Ghibellines and re-established themselves in Ferrara, and the Ghibelline standard was triumphant almost throughout Lombardy; while Robert and Florence suffered a severe defeat at Montecatini. John XXII., the new French Pope, took advantage of the pretensions of Clement V. to issue another Bull, deposing the despots, who claimed to hold in virtue of the title of Imperial Vicars which Henry of Luxemburg had bestowed on them. "God Himself," asserted the Pope, "has confided the empire of earth no less than that of heaven to the Sovereign Pontiff; during an interregnum all Imperial rights revert to the Church; and he who, without either asking or obtaining the sanction of the Apostolic Chair, continues to exercise the functions which the Emperor entrusted to him during his lifetime, offends religion, commits crime, and outrages even the Divine Majesty" (Bull of April II, I3I7). Visconti's reply was to divest himself at once of his vicarate, and get himself reinstated in his office by popular consent under the title of Captain and Defender of Milanese liberty. Of course excommunication and interdict followed, but these methods had been too freely inflicted to produce any marked effect.

In I 319 , John, finding that his allies were getting worsted in the contest, sent the Cardinal Bertrand du Poïet, who was generally supposed to be his son, as legate to Italy, with full powers to treat the Ghibellines as heretic, summon Visconti as a heretic to appear before the Pope, recall the Milanese 
exiles, repudiate his government, and enforce recognition of the authority of King Robert. The legate was animated by no spiritual zeal, but by a very fervent desire to carve out of distracted and anarchic Italy some domain for himself. The Visconti were unharmed by spiritual thunder, so the Pope strove to aid the Cardinal by calling in Philip of Valois, the son of that Charles of Valois, whom another Pope had summoned to put down the White Guelphs in Florence. This future King of France rode down the mountains with a brilliant suite of seven counts, I20 knightsbanneret, and 600 men-at-arms ; I,500 horse awaited him at Asti ; 1,000 horse were on their way from Florence and Bologna; other help was coming from France. But the Visconti were advancing with twice his following. They did not attack; the art of defence was beginning to outstrip that of assault; mercenary troops who had no interest in the contest were unwilling to push too closely the comrades of yesterday, who might be again boon companions to-morrow; war was in consequence becoming more humane ; brains struggled in strategy oftener than swords clashed in battle. The Visconti asked for a conference ; they pointed out that the little army was caught in a trap in a hostile country, between two rivers; they followed up their counsels with rich bribes; it was to their interest to secure a friend rather than worst a foe ; and they had the satisfaction of seeing the discomfited but relieved Philip ride back over the mountains, leaving some Guelph castles, which he had the charge of defending, in their hands (1320).

The Guelph cause was now entrusted to Raymond of Cardona, a noble of Aragon, but this champion lost ground before the victorious arms of the Visconti and Ghibellines. Hitherto the Papacy had taken good care not to declare for either of the rival claimants to the Imperial Crown. The object of the Papal policy had been to take advantage of the contest, and, by the aid of France, to establish a new kind of sway in Italy, in which the Pope should more directly participate when the bonds of Italy to the Empire, by lapse of time and German weakness, should have become enfeebled and outworn. But the victories of the Visconti forced a change of policy. The House of Austria was connected with King Robert of Naples by marriage, and, moreover, had always had Guelphic sympathies. And of the rival claimants, Louis of Bavaria and Frederick of Austria, the latter had always been more disposed to respect John's authority. John XXII., therefore, offered to take Frederick's side if he would repay the service by creating a military diversion in North Italy, where things were going very ill with the Guelphs. Frederick at once sent his brother, Henry, across the Alps with I,500 men-at-arms. Henry entered Brescia, and was joined by the Della Torre, who had sought shelter in Venice, and other exiles. Visconti had no desire to encounter a fresh adversary; he offered Henry a very considerable sum if he would hold off until such time as Frederick could be communicated with. For Visconti had despatched ambassadors to Frederick, pointing out that it was not his (Visconti's) place to presume to judge between the competitors for the throne, but that he defended the Imperial rights in Italy none the less; and that if Frederick came to Monza for the Iron Crown, he would throw the gates of Milan wide open to his Emperor, and would guard and accompany him through the length and breadth of Italy. But they were also instructed to warn Frederick that, if John and King Robert got the upper 
hand of Visconti, the Empire would never recover its losses; that the new pretensions of the Papacy in acting as regent during the dispute was a menace to the full authority of Frederick no less than that of Louis, the other and less favoured competitor; and that if such a right were established in Italy, it would be extended to Germany, and before long Frederick and Louis would find that neither had the prize, but that the Pope would have secured his secret ends when Robert mounted the Imperial throne. Frederick was struck by the considerations thus unfolded. He sent to his brother telling him to come back if he could do so with honour; which Henry did, for he had found out that he was only fighting for the advantage of King Robert. He had been refused full possession of Brescia on the ground that King Robert was sole vicar and lieutenant of the Empire during the interregnum. Cane della Scala welcomed him gladly during his retreat, and that despot and Visconti congratulated themselves that they had managed to keep on good terms with both aspirants to the throne (1322).

But in the same year Louis was victorious on the savage field of Mühldorf, chiefly by the valour of King John of Bohemia. Frederick was taken prisoner there, and Louis began his reign as legitimate and undisputed Sovereign. He ordered the Papal legate, who was also supposed to be the Papal son, and the Guelphs, who were now gaining ground, to desist from attacking the Visconti. This upset Papal equanimity. John made the unheard-of claim that " the Holy Seat is administrator of the Empire during an interregnum; that to the Pope alone belongs the decision between rivals to the throne; that the examination of approval and admission of the candidate, or, on the other hand, his rejection, belongs to the Holy See alone, and that, until the Pope has made his choice, there is no King of the Romans, nor may that title be taken." John ordered Louis to divest himself from all authority, and having thus spoken, the successor of Hildebrand fixed his sentence, not in Germany nor Lombardy, but solely on the church doors of Avignon. When all this came to the ears of Louis, he sent a conciliatory message to the Pope, but publicly announced that he was only standing on undisputed Imperial rights; that the Holy Chair, after he had addressed it in the title of King of the Romans for ten years, only now discovered that he had used it illegitimately; that he had a perfect right to defend Milan, as it was held directly of the Empire ; and as to the heresy of Galeazzo Visconti in the matter, he, for his part, demanded a council to inquire into the heresy of the Pope himself, and before this council he, Louis, would appear in person to reply to any charges made against him. Meanwhile, the ambassadors whom Louis had sent to Avignon actually obtained a delay of two months for him to appear personally before John and refute the charges made against him. But it was a far cry from Avignon to the recesses of Bavaria, and the time given was designedly insufficient, as Louis pointed out in a manifesto, wherein he expressed himself as desirous of protecting the Church, but no less specially charged to defend the rights and honour of the Empire. By this time the Pope had learned of Louis' intended appeal to a council. He launched anathema against him, and declared him incapable of ruling. But John at Avignon was by no means Hildebrand at Rome, nor had the condemnation precisely as serious an effect on Louis in the Germany of $\mathrm{I}_{324}$ as it had on Henry IV. in the eleventh 
century, when the whole world trembled. The very frequent use of the spiritual lash had perhaps hardened temporal sensibilities. Perchance the world had become a little indifferent to ecclesiastical punishments that, were not always inflicted from strictly and severely immaterial motives. Certainly the anathema pronounced by John produced very little effect.

In 1327 Louis arrived at Trient, and presided over a council of the great Ghibelline chiefs. He was determined to take the Crown in Rome, whether there were Pope or no there to crown him. The Ghibellines offered 150,000 florins to cover his expenses. Louis was a man who was not impenetrable to the sentiments of chivalry; he could even be magnanimous; he had visited his defeated rival, Frederick of Austria, in prison, had released him, had trusted him, and now shared the same board and bed, and even divided the Sovereign power with him. Frederick on his side was prepared to defend Louis everywhere and against everybody, even, as he said, "against the man who calls himself Pope." In vain did John XXII. annul the alliance and Frederick's brother renew the war. Frederick himself remained staunch.

Louis could be warmed by enthusiasms; probably he came to Italy with an exalted idea of his mission ; but Germany was exhausted by prolonged warfare ; and he entered the peninsula with the usual disabilities of an Emperor-want of men and want of money. He was coming to a country which was to a poor German a land "flowing with milk and honey "-whither were wafted the luxuries of the East, and whence came the dainty and expensive delights of life ; a land rich beyond the dreams of avarice-the very Eldorado of romance. Instructed in the theory of his jurisconsults, he claimed to rule this fair territory in a spirit derived from the absolutism of Justinian, and interpreted by the customs of the feudal North. He deemed that, as the overlord of a dependent and distracted country, he had a right to demand all that he needed to pacify and settle it in his own way. He could only retain the obedience of his soldiery by letting them exploit the rich Italian territory very much in their own way; severe restraint was impossible. Italy was far wealthier than in the days of Barbarossa, but it was far more defenceless. The despots who called themselves Ghibelline and the remaining free cities that called themselves Guelph were in reality neither for Pope nor Emperor, but only for themselves : they merely used the Pope and the Emperor; they were far from ready to obey the master whose standard they reared. Louis found himself in a hot-bed of intrigue, where astute and cunning intellect had come to take the place of sword and lance, and one's security depended not so much on the thickness of one's skull as on the plastic alertness of one's brains. Louis was no match for Italians in diplomatic intrigue. His character was neither sufficiently adaptable nor sufficiently intellectual to deal with the wily South. He was unready, undecided, when quick decision was called for, a second-hand intriguer. He had to rely on the aid of those cleverer than himself-men who used him for their own ends. The Empire was already discredited, and in spite of the fine legal theorists of Bologna and Padua, the Empire was not the Power, nor was Louis the man, to still the awakening agitations or regulate the fecundating ferments that were awork in Italy.

Louis opened his batteries on the Pope at Trient by declaring him to 
be a usurper and heretic, and he carried with him a considerable party in the Church itself-in fact, the Pontiff, though both ambitious and avaricious, was too extreme a zealot. He dabbled in Scholasticism, and regarded himself as the metaphysical oracle of the Church, an opinion which contemporary schoolmen did not share; he had, moreover, incurred the enmity of the Franciscans concerning a point of doctrine. Encouraged by these dissensions and the promised support of the Ghibelline party, Louis came to Italy with high hopes, but only a very small army and slender purse, which exposed him to the charge of venality. There was incompatibility between the strange idealistic feudal-absolutism of Louis and the commercial development of Italy, the self-reliant spirit of her free cities and the independence of her despots, who only extended their power, or, indeed, maintained their position, by personal astuteness and capacity for outwitting or conciliating their foes. The Italians speedily came to have a contempt for the blundering chivalry of the North, while they were quite ready to use it to their own advantage. It was inevitable that Louis with his notions of his Divine right to rule, and his want of money and men, should regard Italy, when she tied her purse-strings, not only as perfidious and venal, but as traitorous to her legitimate Sovereign. Louis was in a false position; he was compelled to imitate, though he only succeeded in caricaturing, the perfidious methods of the South. Galeazzo Visconti may have been the oldest and most intrepid champion of the Imperial cause, but it was because it served his purpose to play that part; he fought for his own hand. Louis discovered that he had intrigued with the Pope; Visconti did not furnish the Emperor with the funds he had promised, and even at Trient rival despots-people humiliated by the rise of a family formerly their equals, and the representatives of a people not yet accustomed to servitude-had got the royal ear. So Louis seduced their German troops, and sent the Visconti themselves to languish in the frightful prisons which Galeazzo had constructed for others at Monza.

Louis convoked an assembly of the Ghibelline leaders, and produced papers which proved the secret negotiations which Galeazzo had been carrying on with the Pope ; he obtained from them both money and men $\mathrm{He}$ placed an Imperial governor over Milan, and instituted a council of twenty-four members, each elected by a " tribe " of the city, to manage its affairs. One of the earliest despots to solicit the coming of Louis had been Castruccio Castracani, the lord of Lucca. Castruccio was in great straits at this moment from Guelph attacks without and conspiracy within the city, and Louis arrived at an opportune moment. Castruccio sincerely welcomed the advent of Louis, sent him magnificent presents, and advised him to march on Pisa, which he desired to acquire for himself. Louis found himself in the presence of a strong man, an adept in the wiles of Italian policy, and one to all appearance absolutely devoted to his cause. He relied on his judgment and guidance. The Pisans were enfeebled by the loss of Sardinia; they knew with whom they had to deal in Castruccio ; they feared a Papal excommunication, and at Trient they had offered Louis 60,000 florins if he would leave them to themselves. Alarmed at the fate of Galeazzo and the transference of his German horse to the standard of Louis, they disarmed their own German mercenaries. They sent three ambassadors to plead with Louis : these were imprisoned 
at the instigation of Castruccio. This breach of the laws of nations evoked an honest protest from the Ghibelline Bishop of Arezzo, who had pledged his word for their safety; but Castruccio accused the Bishop of having failed to attack the Florentines when he had been pressing them hard, and of a secret understanding with them, which had prevented the Guelphs of Tuscany from being utterly crushed. Louis decided in favour of Castruccio : Pisa was surrounded and obliged to accept the honourable terms of capitulation which Louis gave, and which he strictly kept, though he exacted a fine of half a million florins. Castruccio was rewarded for his services by being allowed to place the Bavarian arms on his shield, and by receiving the title of Duke of Lucca, Pistoja, Volterra, and Lunigiana. Louis, well received by Rome, was crowned at St. Peter's by Cardinal Colonna, in great state; Castruccio, created Count of the Lateran, carried the sword of the Empire: this adventurer had been brought up in England, and could adapt himself to feudal manners and ideas - that way advancement lay. But the loss of Pistoja demanded the presence of Castruccio in Tuscany, and Louis, who was uncomfortable without the support of a Pope, and, maybe, giving too attentive an ear to his jurisconsults, frittered away his time in creating an Antipope in the person of a monk of the Franciscan Order which was opposed to John. His wiser course had been to march against the King of Naples. The death of Castruccio deprived him of his astutest councillor and bravest warrior: Marsilio of Padua, the great jurist and legal instructor of the Emperor, died at the same time.

Louis now became irresolute in dealing with enemies and dubious friends that he did not understand-men so different from the rude, thick-witted and honester chivalry of the North. His soldiers became discontented at their want of pay; they made this the excuse for seizing and holding castles for themselves, whence they could maraud the neighbourhood. Louis found that he had embarked on a hopeless task. His baser nature had gradually been getting the upper hand; he became more determined than ever to make all he could out of the expedition, and get back home again as soon as might be. Yet there is this excuse to be made for the exhibition of what developed into sheer avarice. The control of Italy required the expenditure of money on men and bribes, and Louis had sufficiency of neither. On reaching Trient he was not altogether disheartened by failure of a first attempt, for he desired to tempt Fortune again. He lacked judgment, and this was shown at Lucca during his return march. He ordered his marshal to gallop the cavalry through the streets as evidence of possession. The mob at once set up barricades, and a street-fight followed, in which the richest quarter of the city was destroyed. It was evident that this was a city that the young sons of its late lord, Castracani, could not hold. It was necessary to place a strong man in power. Louis was the natural guardian of these young people, but he sold the lordship of Lucca to a member of their family who was notoriously inimical to them, and who speedily turned them adrift in the world. Louis proved himself no less faithless to the fulfilment of his obligations to Castracani than Castracani would have been to his obligations to Louis.

Italy was ever the grave of German honour. reputation there when he did not leave his bones,

The Teuton buried his 
Louis led his attenuated forces homewards across the Apennines (I 329). He found the gates of Milan shut against him; he was, however, not too proud a knight to accept funds which Visconti sent him, and after a short campaign in Southern Lombardy, where he gained some advantages, he arrived at Trient, to find Frederick dead and the war in Germany recommenced by his brothers. All hope of redeeming his fortunes in Italy had vanished; henceforth it was needful for him to defend his rights in Germany. He had succeeded in bringing discredit on the Ghibelline party. The essential weakness of his character was revealed-it lacked foundation. Put to a severe test, the fine feelings and nice shades of chivalry, the superstructures of education, had peeled off ; the generous impulses of youth had vanished like a vapour, and the bed-rock of character was bared. He had been faithful to no high principle; he had shown himself feeble, undecided, untrustworthy, injudicious, faithless to all higher conceptions of duty; he had manifested avarice as his leading characteristic ; he had destroyed the Imperial theory, and he had brought ruin on those who trusted him.

\section{The Failure of John of Bohemia}

The Papacy was no less abased and discredited than the Empire. John XXII. had preferred the peaceful dependence of Avignon to the turbulent sovereignty of Rome. He was regarded less as the head of Christianity than as the creature of France. Luxurious, greedy, and vindictive in personal character, he chose to disturb the Church with discussions as empty and dispensable as ever exercised the logic-chopping wits of the most futile of the schoolmen. His Court was scandalous; his administration venal. He was represented in Lombardy by his nephew, or son, Bertrand du Poïet, a bad soldier and worse priest, who aimed at sovereignty. Bertrand employed the authority, forces, and wealth of the Church to further his own base political intrigues; and the chief towns of the North were in revolt. Brescia offered King John. of Bohemia its lordship, and a new and brilliant figure appears to court the inevitable disaster and disgrace that ever befell the foreigner on Italian soil.

"A very gentile parfite knight,"

John was the very type of chivalry. He was a brave and gallant gentleman, winning in manner and fluent in speech, educated in all the easy grace and knightly polish of the French Court. His was the highminded, inconsequent spirit of a knight-errant. His ambition was to redress wrongs and become the arbiter and pacifier of Europe. He was a philanthropic idealist, but while he scoured Europe for wrongs to right, his own kingdom, as might be expected, was left in a deplorable state of misrule. At this moment his reputation stood at its highest. It was through his personal courage that Louis had won the Eattle of Mühldorf ; he had distinguished himself as peace-maker in Germany after that battle ; and Italy, weary of strife and disillusioned as to Papacy and Empire alike, renewed its hope, and hailed with gladdened heart the advent of the brilliant Prince. The troops of Mastino della Scala retired before him; he harangued the Brescians, reconciled opposed parties, recalled 
exiles, and appeared as by magic to have brought back peace and prosperity to an afflicted city. Guelph Bergamo followed suit. Straightway all the towns of Lombardy threw open their gates, even those cispadanean towns that were abandoned to the mercy of the licentious bands left behind by Louis. The Florentines, aided by reinforcements sent by King Robert, Siena, and Perugia, were busily engaged in besieging Lucca, and were on the point of success. Amazement seized them when heralds came from John, commanding them to leave the town alone, and respect the territory of their master the Emperor, on whose behalf the King had accepted the lordship of the city, and intended to re-establish order and peace (I33I).

John was the son of that old enemy of Florence, the Emperor Henry VII. $\mathrm{He}$ was the friend and mainstay of the present Emperor; he was on intimate terms with the Papal and French Courts; he had won the hearts of both Guelphs and Ghibellines, and both parties were weary of strife, but each was too proud to make the first advances. In the North they were now co-operating as brothers. The Florentines, accustomed to political intrigue, knew how chivalrous bearing might disguise insatiable ambition ; they knew how often self-interest will shatter the fairest aspirations into bits; they regarded John with suspicion. It is true that Italy was, and had been for many years, in a condition that $M$. Zeller rightly calls anarchic; but the Italian republics preferred anarchism to tyranny. Florence resolved to resist. The suspicions of its burghers were increased on learning that John had had a secret meeting with the legate Bertrand, especially as the Pope had written to say that John's mission was unauthorized by him. The attitude of Florence cast suspicion of John over all Europe ; it was as though a train of gunpowder had been fired. Robert of Naples took advantage of the changing breeze to bring the Guelph ship to the wind again. Louis of Bavaria declared against John and rallied the Ghibellines, whereupon John left his son Charles in Italy and hurried back to Germany. He succeeded in making his peace with Louis and averting the storm.

Directly John had departed, Mastino della Scala and Azzo Visconti agreed to attack and subdue the neighbouring towns that had opened their gates to John, and make the Oglio the boundary between their respective territories. Brescia fell to the lord of Verona, and he abandoned his old allies, the Ghibellines there, to the vengeance of the Guelphs, who were now assisting him. Bergamo was taken by Azzo Visconti; Vercelli was handed over to him by a ruse. His uncle was Bishop of that city; this unspiritual pastor pretended to be dying, and when visited by its ruler, one Tornielli, he had him seized, threw him into prison, got possession of the gates of the town, and admitted his nephew's forces. In I 332 the Ghibelline despots of the North concluded a treaty with their old Guelph foes, Robert of Naples and Florence, with the object of resisting John, and dividing the Italian States of which he had become possessed.

Meanwhile John had been visiting the French Court, and had even received the blessing of the Pope, who was anxious to push the fortunes of his legate-nephew Bertrand, although the Pontiff was receiving hospitable shelter at Avignon in King Robert's own realm. In I333 John crossed the Alps once more, attended by the flower of French chivalry. But the tone of the country had changed. The old animosities, the old 
ambitions, had resumed their sway. Italy had recovered from her fit of repentance; she had dropped again into her customary temper of suspicion and intrigue. John found that he could no longer exercise his personal magnetism ; there was no identity of interest among his followers that bound them in a common loyalty; every day brought fresh defection or despair. John was not of the temper that gains vigour and energy in misfortune. He had not the inflexible will that shapes disaster itself to its ends. He was the facile idealist who readily releases himself from unmalleable and uncongenial surroundings. A thankless world must be treated according to its deserts : he sold his sovereignty over Parma and Lucca to the Rossi for 35,000 florins ; and Reggio, Modena, and Cremona to the heads of other Ghibelline houses. Thus releasing himself from his engagements, he could hie him to "fresh woods and pastures new"; and the wealth that he acquired enabled him to make a brave show in the tourneys and fêtes of gay Lutetia.

The Papacy continued to remain in Provence. John XXII. was little more than the splendid vassal of France, and was told in so many words by the electors of Germany that the election of an Emperor did not require the approval of the Holy See.

John died at Avignon in December, 1334, after a long reign, during which he had succeeded in scandalizing all Christendom and degrading the Apostolic Chair. By claiming the right of nomination to benefices, and putting them up to auction, he had amassed an enormous fortune, which Villani, whose brother was Papal banker, puts at eighteen millions of florins and seven millions' worth of jewels and plate. The ambitions of Bertrand du Poïet and other Papal emissaries in Italy covered the Papacy with obloquy; and John's conduct to Louis had alienated Germany, while his passion for theological hair-splitting, so strange in such a character, involved him in a charge of heresy, and he had to abjure his opinions the very day before his death. At Papal elections the voting is secret, and it is customary, so long as there is disagreement, for the cardinals to vote for those who have no chance of election. It so happened that every member of the college secretly fixed on Jacques Fournier, the son of a baker of Saverdun, as the least likely to be chosen, and therefore the safest man on whom to throw away a vote. But to the surprise of everybody, including himself, Fournier found himself unanimously named; and there ascended the Papal throne a man who was a stranger to political intrigue, and with more Christian virtues than had adorned a Pontiff for half a century. But a single pious man could do very little in such an office at any time, and especially at Avignon, under pressure from the creatures of the Kings of France and Naples. An attempt on the part of Benedict XII., as Fournier called himself, to reconcile Louis with the Church therefore fell through. Benedict died in 1342, and was succeeded by Clement VI., who took up the ancient policy of the Holy See to abase the power of the Empire, and its newer strategy of wheedling, cajoling, and truckling to the French powers. He absolutely refused to absolve Louis on any terms. The German Emperors looked on Italy as the traditional toad; they had regard to the precious jewel in its head; it was venomous to them; they could do nothing with it; but they would not resign themselves to leaving it alone. In I 338 Louis, undismayed by the discredit of his former campaign, tried to enter Italy, to the relief of 
Mastino della Scala, who was hard beset by the Florentines and had entreated his aid; but he found that his passage through the Trentino had been blocked by a son of the chivalrous John of Bohemia, with whom he was now at variance. In I 346 Louis and his close friend, the King of Hungary, determined to enter Italy; the former, as we have said, to revenge his previous disgrace on the Guelphs and the House of Anjou, which had pursued him with so much rancour for thirty years; the latter intent on the Neapolitan Crown, which he claimed, and for which the crimes of Queen Giovanna (Joan) gave him a specious excuse. Clement had already intervened in the affairs of "the kingdom" as its overlord and as keeper of the Christian conscience ; but he was unwilling to see his rights invaded by the King of Hungary, and still more unwilling to see Louis in Italy again. He determined to assert the Papal prerogative, and, since John of Bohemia had become blind, he offered the Empire to John's son Charles. Charles proceeded to Avignon and engaged to annul all the doings of Louis in Italy, to renounce all sway over Papal territory, never to enter Italy except by the express sanction of the Pope, and to stay but one day in Rome for his coronation. Thus the undeviating, inflexible pretensions and policy of the Holy Chair once more asserted themselves at the earliest opportunity that it was expedient to allow them to reappear. The influence of the Church in Germany and the influence of the family of Henry VII. who was the father of John of Bohemia, and consequently grandfather of Charles, carried the election, but not without some disapprobation in the cardinalate. Charles was generally known as the Emperor of priests; and there would have been a tempest in Europe, shaking the Papacy to its base, but that one of those apparent accidents that alter the whole course of history occurred. Louis was killed by a fall from his horse in I347. Edward III. of England, and others to whom the Crown was offered, refused it, or withdrew their pretensions, and Charles was recognised as legitimate King of Rome, alike by the Empire and the Church. But the fearful plague which swept over Italy and then through Europe prevented Charles from advancing. Pious indignation did not deter Clement from receiving the criminal Queen of Naples and her new spouse. They rewarded Clement with the ownership of Avignon.

\section{The early Struggle between Tyrants and Republics, the Decay of the Kingdom, and the Recovery of Romagna by the Pope}

The alliances of the despots that had gained control over most Lombard cities and the free communes of the centre did not last. The military organization which had been promoted by the fear of an Imperial restoration furnished the despots with increased power, which they employed in the subjugation of one another, and in attacks on little States that still preserved their freedom. Italy was in a state of perpetual struggle, wherein the fittest under existing conditions survived. The conditions required pertinacity, courage, initiative, astuteness, and duplicity, and as these qualities were best furnished by the continuous assiduity of a single strong mind, the "tyrants" acquired more and more power; those most adapted to the exigencies of the times prevailed; the stronger ate up the weaker, and States grew bigger at the expense of their neighbours; 
a process which was hastened by the rancour of party and the reciprocal jealousies of rival communities. Mastino della Scala, lord of Nerona, was the first to break away from the league. He bought and kept Lucca instead of restoring her her freedom, secured a government in Pisa favourable to himself, and menaced Florence ; and that city was obliged to entrust a " conservator" with powers which he exercised in a way little to her liking. Venice gained a foothold on the mainland; Bologna fell into the hands of Taddeo dei Pepoli, the richest of Italian merchants; Genoa gave herself a doge ; and Florence in despair entrusted herself to an odious master, the Duke of Athens, a connection of the Angevin House, whom she soon had to plot against, and successfully removed (I343). In the absence of the Pope, Rienzi, the son of a water-carrier, established an ephemeral dictatorship over the capital of the Cæsars, now the prey of the factions of the Colonna and Orsini, families that converted the monuments of its ancient splendour into mediæval fortresses. In the South, Robert, with a desire to extinguish a claim of the elder branch of his House and consolidate the power of his kingdom, had married his heiress, Joan, to Andrew, the son of his elder brother, the King of Hungary. Andrew conceived that he had a better claim to the Crown of Naples than Robert himself, and the young couple regarded one another with jealousy and hatred. After Robert's death, which occurred in I343, the kingdom was divided between Hungarian and Neapolitan factions, which respectively took the sides of the King and Queen, both of whom claimed to rule in their own right. Andrew was brutal, Joan, refined but lascivious, and the Court was corrupt. Joan assented to the assassination of her husband, and two years after the murder married Louis of Tarento, the man who had instigated the deed (I347). The crown of Hungary was now worn by Ladislaus, the elder brother of Andrew, who determined to avenge his brother and assert his own claim to the Crown of Naples. Undeterred by Papal prohibition, he announced that he appealed from the Church to God, and marching his army through Italy, he took Naples, while Joan fled to her possessions in Southern France, and covered herself under the Papal mantle by selling Avignon to Clement VI., who resided there. But precisely in this year (I348) the most devastating epidemic that has ever visited the Western world was conveyed to Italy from the Orient. In a few months the "Black Death" had carried off a third of the population, and though it mowed down its millions throughout Europe, the advanced civilization of Italy rendered the visitation more hopelessly deplorable there than in other countries even. Everywhere the scarcity of labour it effected led to radical economic and social change. The King of Hungary beheld his retinue stricken, the conquered Neapolitans becoming restive, and his Hungarian Court impatient to quit a country where death, swift and sure, awaited them. He stole quietly out of the kingdom, leaving garrisons behind him of Hungarian soldiery; and Joan and her husband returned to Naples, where they received the felicitations of the Neapolitan barons. In order to eject the Hungarians, mercenary troops were employed, and the country was delivered up to their rapacity. The precious pair gave themselves up to a career of voluptuous vice; the administration was neglected, the people plundered. Naples had already suffered from the bankruptcy of great Florentine houses in I343, for the commerce of the country was chiefly in Florentine hands, and the invasions 
and incompetent rule which followed added social dissolution to economic decay, and reduced the kingdom to a secondary rank in Europe.

The spiritual authority of the Papacy was sinking lower and lower; the rumblings of its thunder, however assiduously worked, no longer induced awe and consternation. To be effective it was necessary that the Papal fiat should be accompanied by at least the menace of the sharp sword. It was adroit policy, therefore, to consolidate the temporal base which the Pope claimed, in order that, as a temporal prince, he might command alliances and give some sort of effect to his ecclesiastical indignation. The success of the jubilee of I 350 brought great wealth to Clement; he had a share in the treasures offered up in the churches as well as in the imposts of Rome, the value of which was greatly enhanced by the presence of so vast a multitude of visitors. Romagna, to which the Papacy laid claim, had never been reduced to obedience; but the time seemed now to be at hand when that might be effected. The Pope was well supplied with money, and the cities of Romagna were in the hands of a number of petty despots ; the citizens were thinned out by plague and emasculated by servitude, and were hardly likely to offer any very obstinate resistance. So the Pope conferred the title of Count of Romagna on his relation, Hector of Durfort, set apart a big sum for expenses, and equipped him with a small Provençal force. It was given out that the expedition was of a punitive nature, and that the lord of Faenza would be proceeded against for leaving the Guelph party ; but the other despots for the most part saw through the subterfuge and made ready to oppose Durfort. The Count manifested the most absolute confidence in his allies, the Pepoli, who were lords of Bologna, while he was secretly instigating the Bolognese to rise against them, thus hoping to secure that city for the Pope. He bribed his soldiers to seize Giovanni dei Pepoli, who had become his guest. Straightway Mastino della Scala, who had signed a secret treaty with the Pepoli, marched against Bologna ; and the Count was now obliged to give up fighting his foes in order to turn his arms against his whilom friends (1350). He promised double pay to his troops if they would do this thing and that; but their ordinary pay remained in arrears. They revolted, and he was obliged to ransom Giovanni dei Pepoli in order to save himself from being imprisoned, as a hostage, by his own men. But while Giovanni was a prisoner, Florence had been appealed to, and replied that she was disinclined to take up arms against the Church for the sake of a usurper, but she wished Bologna to understand that if it had been a question of her defence neither the Florentine war-chest nor Florentine blood would have been spared. This reply, which was given publicly, was soon repeated in the streets of Bologna; the moment was favourable for revolt, but, says Matteo Villani, " degraded by subserviency, the citizens were no longer worthy of liberty; they lost it for their sins, and they were too mean-spirited to recover it." The Bentivoglio, possibly because they already entertained designs of their own, kept the city quiet; Werner and 500 of his licentious soldiery were in the town, and when Florence at last offered to mediate, the Pepoli played at negotiations which removed the more dangerous citizens on an embassy. They sold the city to the Visconti in secret, and put it into their power. Durfort once again attacked Bologna, but the Papacy was parsimonious, and he was obliged to retire to Imola. In vain did Clement renew the charge of heresy and 
schism brought by John XXII. against the Visconti ; in vain did he cite Giovanni Visconti, Archbishop and despot of Milan, and his three nephews to appear before him; in vain did he send his legate to Milan to order Visconti to restore Bologna to the Church, and to choose whether he would remain a priest or continue to aspire to princedom. " Repeat that," replied the Archbishop, "on Sunday at my cathedral after Mass." The legate had the courage to do so, and unfolded his mission to the listening congregation. The Archbishop's reply was to seize a cross with one hand and to draw his sword with the other. "Here," said he, "are both spiritual and temporal weapons ; I shall know how to defend the one with the other."1 Visconti sought to extend his own power, and to establish despotisms in every town : a system of mutual support would keep him secure at Milan; little lords would have to be dependent on bigger; if they did not behave they would be swallowed; and, as the biggest lord of all, the Lord-Archbishop of Milan would exercise the widest and most effective control of any, and profit most by the swallowing process that time would render inevitable. Visconti urged the Guelph Brandagli of Arezzo to seize the tyranny of that city ; they had, indeed, already seized a gateway, and were signalling to the troops of the Archbishop that lay in wait, when the inhabitants ran to arms and drove them from the city. The Guelph republics of Tuscany, alarmed by this new danger at their doors, replied by forming a league which sent a deputation to the Pope. But meanwhile Visconti had purchased the good offices of the mistress of Clement, and some of his cardinals got all excommunications and interdicts withdrawn, and obtained the lordship of Bologna for him. Two hundred thousand florins were spent in bribes on this occasion (1352) (Matteo Villani, III., 4).

Shortly after this transaction Clement died, and was succeeded by Innocent VI. Visconti, dreading lest Innocent should repudiate a treaty obtained by such shameful means, contrived to come to terms with the Guelph powers of Tuscany. Avignon was at this time by no means too secure a residence for the Head of the Church. France and Provence were overrun by marauding and disbanded armies that were the legacy of the great struggle between England and France; the sacred college, therefore, determined to continue the policy of Clement, and secure the Papal control over the States to which he laid claim. Cardinal Albornoz, a distinguished Spanish warrior, was sent to Italy to this end. He was but sparely furnished with either money or troops. Visconti received him civilly, Florence warmly. Indeed, he obtained aid from Florence, for he proclaimed that his mission was to deliver the cities of Romagna from the yoke of their tyrants, and to restore them to the republican liberty which they had once enjoyed under the protection of the Church. Clement VI. had launched a Bull of excommunication against these usurpers, and more particularly against Giovanni di Vico, tyrant of Viterbo and Orvieto, who held ten free cities in thrall; Francesco dei Ordelaff, tyrant of Forli, and the Manfredi of Faenza. Romagna was almost the only part of Italy that now possessed a warlike population ; its little princes did not entrust their defence to mercenaries; they led

1 Giovanni Visconti had his portrait painted in fresco on the wall of the archiepiscopal chapel which he built; he holds a cross and a sword. The picture is reproduced in Gravius, III., p. 306. 
the peasants of their own mountains, and gave the command of companies to dependent country squires. They kept themselves in good fighting condition by perpetually attacking one another; and when, unfortunately, there was peace, they took mercenary service under some other prince or State, carrying their men with them. Albornoz was skilful in supplying his deficiencies of men and money by attracting a good many of these lordlings to his side by proffers of advantage, and by acquainting himself with their various feuds and jealousies, and playing on them. He knew that if he could overthrow the stronger men by the aid of the weaker, it would not be long before the latter would become the dependents of the Church, and rely on it for support.

Malatesta of Rimini formed a league to oppose Albornoz. At last the quarrelsome lords of Romagna perceived that they were threatened by a common danger which required that they should make common cause together. But it was too late ; Malatesta lost courage ; he was defeated, and his brother, one of the best soldiers in Italy, was a prisoner. He abandoned the league of his own formation, and sought for peace ; and as he was a Guelph, at the recommendation of the Guelph towns he was given the possession of Rimini and certain other cities, while yet others were restored to liberty under the protection of the Church. Fermo threw off the yoke of its despot, who had aided Albornoz, and opened her gates to the Cardinal. Francesco dei Ordelaffi of Forli alone stood out; he took no heed of excommunication or of the crusade preached against him. He had a wife of courage, undaunted as his own; he entrusted her with the defence of Cesena, and without allies the intrepid pair took each a city to defend them against the entire force of the Holy See (I 355). In vain did the citizens of Forli, while they professed their entire devotion to the person and family of Ordelaffi, point out the hopelessness of resistance, and urge him to yield. Advancing into their midst, he replied : " Learn exactly what I have determined to do. I shall refuse to treat with the Church so long as I can hold Forli and Cesena and all the strong places that are mine. I believe I can hold them, and I shall do so to my last breath. When I have lost other places I will put my back against the defending walls of Forli, and then against the walls of its squares, its streets, my palace, and the last tower thereof ; but consent will I never that that should be taken from me which is mine." Marzia, Ordelaffi's wife, after sustaining six months of siege, was driven to the upper town of Cesena by the desertion of the burghers. They had opened the gates to the foe. She discovered that her only adviser, the man who enjoyed her husband's confidence, was in secret correspondence with the enemy. She had him decapitated on the castle ramparts in full view of the townsmen below; and thenceforward she was ever to be seen by her foes, by night as well as by day, actively heading her little band of troops, and never once did she lay aside her armour. At last she was forced to retire to the citadel with 400 citizens and soldiers, who had determined to remain with her even to the death. In vain did her father, allowed to pass by the legate, appeal to her to yield; he fruitlessly urged that all further resistance was hopeless, and that, all having been done that was possible, the moment had arrived for honourable capitulation. " Father," replied Marzia, "when you gave me to my lord you chiefly commanded me to obey him in all things. I have done so up to to-day; I will do so 
till the end. He has given this fortress into my care, and has forbidden me to yield it on any pretext whatever without further orders from himself. There is my duty; what care I for death or danger ? My duty is to obey, and not to ponder." But the citadel was mined; it became evident that in a few days it would crash down and bury the brave garrison in its ruins. The defenders forced Marzia to yield; she obtained all that she asked for her brave soldiers; for herself, this woman of undaunted mettle asked not a thing. She was kept in honourable captivity on board a galley in the harbour of Ancona.

The passage of the Grand Company of mercenaries through Romagna made a diversion favourable to Ordelaffi ; and Alkornoz, who had been recalled to Avignon, was replaced by an incompetent monk, who was twice forced to raise the siege by the Grand Company (1358). Then Albornoz was again sent to Italy, and, while he drew money from the Florentines to conduct a crusade against the Grand Company, he used the soldiery they had furnished the means to pay to that end in bluffing Lando and his crew; he deployed his men so skilfully without engaging them that Lando, as head of the Company, agreed to leave the Church and Florence in peace for four years; but was paid a heavy sum for the terms, very much to the disgust of Florence. Indeed, the government of that city refused to ratify the treaty, and, under the command of Pandolfo Malatesta, drove the ruffians out of their territory. Ordelaffi held Forli against Albornoz for two months after the Company had departed, and then, having ascertained that he would get good terms, he yielded unconditionally. He presented himself in the garb of a penitent before the parlamento of Faenza; he confessed his misdeeds against the Holy Church, and vowed to perform certain penitential pilgrimages ; and then the anathema of the Church was removed; he was restored to the lordship of two towns, and his wife Marzia, with her children, were restored to him. The entire province of Romagna re-entered into obedience to the Papacy (1359).

\section{The Expeditions of Charles IV. (I354-I369)}

By this time only six despotisms survived in Lombardy, with minor tyrants under their thumb. The most powerful of these petty States was Milan, in the firm grasp of the Visconti. Western Lombardy was held by the Visconti, Eastern Lombardy by the Scaligers, lords of Verona; the Carraresi ruled at Padua, the noble House of Este at Ferrara, and that of Gonzaga at Mantua. In order to support their power, they employed disbanded German troops and companies of adventurers that entered into the services of princes, and, when out of employment, roamed, ravaged, and plundered the country for themselves. These became the scourge of Italy ; splendidly organized, these robber communities formed, as it were, moving States, levying contributions or war, or both, on the communities through whose territories they passed. The weaker princes, feeling themselves in imminent jeopardy from the power and ambition of the Visconti, took the Grand Company of adventurers into their pay, and suffered from it greater evil than they inflicted on the foe by its aid. The number of free cities was constantly diminishing. Pisa was still independent, but, from her Ghibelline predilections, had associated hersclf with the 
Visconti. The republics of Perugia and Siena were weakened by internal dissensions; and the free communes watched each other with no less jealousy and justified suspicion than did the tyrants. Venice and Genoa were rivals for the Oriental trade, and, after a series of naval combats in both basins of the Mediterranean, the Genoese, at the sacrifice of their liberty, got Giovanni Visconti to protect them and so enable them to re-establish their shattered fleet and attack and destroy that of Venice (I354). Venice was exhausted, and was compelled to conclude a temporary peace (1355).

Charles, who was elected to the German Crown in I347, had not his father's dash, though he inherited something of his chivalry. His character was ill-compounded, and though an excellent Sovereign in Bohemia, he was ill-qualified for the larger statesmanship demanded of an Emperor.

In 1352 the Tuscan republics became alarmed at the growing power of the Visconti and their designs on mid-Italy. The Visconti had bought over many cardinals and secured the adherence of Clement by lavish gifts to his mistress, the Viscountess of Turenne. Bologna was made over to the Pope, who restored it to the Visconti for twelve years. It was represented to Charles that, if he wished to save and increase what little power still remained to the Empire, there was no time to be lost, and forces and means were freely promised. At this juncture Clement VI., who had kept a magnificent and dissolute Court, died, and was succeeded by the Bishop of Clermont, who took the title of Innocent VI.

Venice was no less alarmed than Florence at the menacing power of the ambitious Visconti ; conjointly with Verona, Padua, Ferrara, and Mantua, she entreated the Emperor to come. Deserted by the Church, their natural ally, the Guelphs sought the protection of the Empire, their natural foe. Charles negotiated with the Ghibellines and the free cities alike; he secured the consent of the new Pope, and flattered himself that he had been so skilfully cunning that he could make a holiday progress through Italy and receive the Imperial Crown without encountering any of the difficulties and dangers that had beset his predecessors. Amazed, Italy saw him ride across the great plain at the head of 300 unarmed knights. Arrived at Mantua, Charles tried to mediate between the Venetian league and the Visconti; he could only effect a truce, and the Visconti thought it just as well to let him know how great and real their power was. When he reached Milan they filled the streets with 6,000 horse and 10,000 foot; they adopted the dodges of a theatrical manager, and made the same troops pass and repass his windows perpetually, and the palace resounded with the martial din of a camp. The Iron Crown was brought from Monza to the church of San Ambrogio, and Charles was crowned under conditions which began to take the appearance of gilded captivity. He manifested no alarm, but contrived to make for Tuscany directly he had received the Crown. The guards were doubled in all the towns he traversed; the Visconti followed him up with a large force; and Villani says that he passed through Italy more after the fashion of a merchant skurrying to the fair than of an Emperor on his royal progress. $\mathrm{He}$ arrived at Pisa long before he was expected. Florence sent ambassadors, but prepared for defence, and her subjects drove their herds into the country fortresses. In fact, the presence of the Emperor rendered the situation very critical for the republics. For jurisconsults and men of letters had manufactured a public opinion favourable to Imperial 
pretensions. Petrarch and Cola di Rienzi had taught that the sovereignty of the world belonged to Rome and the Roman Empire. Both had called on Charles to assert his rights on the same grounds as Dante had urged on Henry. The republicans of Central Italy, it is true, tried to show, by citing the first edicts of Augustus and Tiberius, that the Imperial power was derived from the Roman people, and they claimed for their towns their ancient rights as Roman cities. But the partisans of Imperial authority affirmed that the commune was only a legitimate device to secure good government during the absence of the Emperor ; and that when he appeared unconditional obedience was due to him, that all other jurisdiction ceased, and that he became overlord with absolute power. Thus, in the fourteenth century, in a manner not yet fallen into desuetude, did thinkers painfully seek for bad reasons to support obstinate prepossessions. Charles halted at Pisa; and, as the great feudatories were obliged to follow him, he found himself in the spring of 1355 at the head of 4,000 knights, the flower of German chivalry.

Charles now discovered that his real difficulties had begun. He had ruled Lucca for awhile when he accompanied his father, John of Bohemia, to Italy; and he had gained the devotion of the Lucchese. They expected that he would free them from the yoke of Pisa; but Charles had become bound to Pisa. At Lucca he had manifested a genial disposition, and had ruled justly; but the politics of Italy were complex and too confused to be clearly apppehended and righteously dealt with. There was much high doctrine and abstract theory professed, and, indeed, sincerely held, but each petty commune, each petty tyrant, was none the less solely self-seeking. Italy was a nest of hornets-a hot-bed of intrigue; high doctrine covered underhand practice; and Charles succumbed to the temptation to shirk insoluble problems of sovereign government and fish in troubled waters for what private gains he could secure. At least he could exact money from his troublesome subjects; he hastened to make hay while the sun shone.

Troubles broke out in Pisa while the Emperor was residing there. The aristocratic party, relying on Imperial protection, returned from exile, and it chose the very moment when Charles was receiving the homage of the city at the cathedral to attack the " Conservator of the State" and his burgher supporters. Cries of "Liberty and the Emperor! Death to the Conservator!" came from outside, and though Charles succeeded in quelling the disturbance, Gambacorta, the Conservator, thought it well to keep the monarch's goodwill by getting the lordship of the town, the safe keeping of its gates, and the administration of its finances placed in the King's hands. Soon the citizens repented of their rash consent, the opposed parties patched up their quarrel, and Charles, who probably wished to create a good impression in Italy, who had not yet received any support from Germany, and who was not unscrupulous by nature, resigned at once the powers that had been entrusted to him. The three free cities of Perugia, Siena, and Florence had been associated by a common danger, but at this moment Perugia discovered that she held of the Church and not of the Empire, and withdrew from the confederacy. Siena, governed by a narrow oligarchy, also tried to trick Florence to her own ends. The ambassadors of both States appeared before Charles together, and, while the Florentine ambassadors took care not to commit themselves, the 
Sienese delegates offered Charles the unconditional lordship of their city. Charles probably saw through the attempt of Siena to prejudice the rival city in his eyes; he gave the Sienese to understand that he appreciated their loyal offer, but he assured the Florentines that he would give them every consideration consistent with the honour of the Crown. On the return of the embassy, the Sienese confirmed its action, but not without hesitation. Volterra and San Miniato, feeble and fearful of Florence, followed suit. Arezzo was only restrained by dread of the Ghibellines, who were obviously in favour at Court; Pistoja, which was under the protection of Florence, tried to follow the dangerous example set by Pisa ; and the great Ghibelline families tried to excite Charles against Florence. The Emperor imposed a heavy fine (I00,00o florins) to fill his own purse, and teach the Florentines caution in their behaviour to the Empire, but he gave them the rights and fullest liberties of a free Imperial city. Florence, however, was by no means grateful, and the assent of the general council was secured with considerable difficulty. When Charles reached Siena, the explosive forces of that city burst aflame. Each party hoped to suppress the others, and get its position legalized by royal protection.

At last Charles reached Rome, which he entered disguised as a pilgrim, in order to keep his promise to the Pope not to remain there more than one day as Emperor, and to retire immediately after coronation. He prayed in the churches two days, and withdrew without anyone being the wiser, to make a more pompous entry for the great ceremony. He was blessed by the Cardinal-Bishop of Ostia and crowned by the Prefect of Rome at St. Peter's. Charles then placed the crown of the Empress on the head of his consort. He could now regard himself as really and legitimately an Emperor; he knew that he was now so regarded by the world; but he faithfully kept his promise to the Pope, and after riding through the city in Imperial garments, and accompanied by a gay and glittering retinue of 5,000 German and 10,000 Italian horse, he feasted at the palace of St. John Lateran, and departed from the city, and the greater part of his army began to disperse. On his homeward route he found Siena still in a state of revolution; thence he made his way to Pisa, where he indulged the citizens with a pompous bit of stage - effect. He caused a parlamento of the people to assemble in the great open space where stand the four marvels of architecture that distinguish the city above all others. He graciously took one Zanobi di Strata by the hand, gave him the title of poet, and crowned him with laurel. Zanobi then pranced on horseback through the streets of Pisa, attended by the great lords of the Empire, and receiving the plaudits of the mob. Unhappily, Zanobi's works have not come down to us, so that we are unaware whether the poet was of the order of Tennyson or Pye ; but poor Petrarch appears to have suffered some pangs of jealousy at the honours bestowed on a new man by royalty and men of long descent, and that popular applause which is supposed to honour genius. The Lucchese, his old subjects of I332, now crowded to Charles, begging him to release them from the Pisan yoke. The Lucchese settled in France even offered him 20,000 florins to purchase the enfranchisement of their city from the domination of its hated neighbour. These negotiations got to be known; the communal palace where the Emperor was lodging was burned down by accident or design, and, during the fire, the citizens flew to arms; ancient feuds were forgotten, and opposed 
factions vowed to aid each other in maintaining the sovereign rights of their city over Lucca. When Charles withdrew a portion of the garrison from Lucca and replaced it by his own troops, open rebellion took place, and a murderous attack was made on the Germans. Charles put down the insurrection with difficulty, and imprisoned his old supporters, the Gambacorti, who ruled the city. The news reached Lucca in two or three hours; the city hoped that the hour of its deliverance was at hand; peasants from the countryside assembled by night, and the citizens armed themselves; but certain Ghibellines, whose castles had been ceded to Florence by Martino della Scala, fearing that Guelph predominance in the city would lead to a Florentine alliance, signalled their danger to Pisa. Forthwith the Pisan factions were at one again. They marched on Lucca, and routed the peasants, who made an obstinate stand outside the walls; the Pisan garrison threw open the gates of Lucca ; the Germans, who pretended to be neutral, were then attacked, and fire was set to a quarter of the city by the Pisan garrison. The unhappy Lucchese found themselves between the devil and the deep sea; they were attacked by fire behind and by their foes in front; they had to pile arms and surrender. The Pisans expelled the chief citizens, and governed the city with more severity than ever. Happily there was always some near neighbouring city ready to increase its wealth by receiving exiles; so that the proscribed found shelter without much difficulty in those days. But one has not to seek further than the single fact of frequent proscription to find an explanation of the fierce hatred and bitter woes, the wringing of hands and gnashing of teeth, that mark the records of Italy. Charles now lost his temper. He had been flouted throughout ltaly, and he took a mean revenge on the Gambacorti who had been at the head of the Pisan government; someone must be executed as an example; he must give proof of his sovereign authority. He ordered the conduct of the Gambacorti, who were still in prison, to be inquired into; he forgot that they had been the first Tuscans to welcome him; but princes have never been remarkable for gratitude. Of course they were found guilty in accordance with the Imperial desire. They were publicly executed, while the streets were held by German soldiery. Charles was now anxious to get away from a country with which he was by this time on the same terms of misunderstanding and cross purposes as all his predecessors in the Imperial office. He only waited for payment of the sum promised by Florence and of a fine he had imposed on Pisa, and then set off for Germany. So far from receiving any deference or respect, he found the gates of every town closed against him, though it is true that the Visconti graciously allowed him to pass one night in Cremona. He had received the Imperial Crown, but success ended with its assumption. All that he had done had still further abased the Imperial authority; and Italy remained in the same state of furious faction and perpetual petty warfare as before his coming.

Once again did Charles attempt to assert the Imperial authority in Italy. There was an alliance of the Pope, the King of Hungary, and the lords of Padua, Ferrara, and Mantua against the Visconti, which the great Albornoz had organized just before his death (I 359). Charles came across the Alps at the head of a large army; but he had to do with the genius of Hawkwood, the great English mercenary, who was in the pay of the Visconti. Hawkwood cut the dykes of the Adige; and the Imperial 
troops found themselves useless against the strategy and veteran forces of the lords of Milan. Cliarles accommodated; he took money from the Visconti, and disbanded his army; he sold Lucca her liberty at a big price. He was scouted and scared out of his senses at Siena, and he was glad to escape over the Alps with a purse filled by squeezing the ungrateful people that only yielded florins and flouts to the Monarch they professed to revere ( 1369 ).

The Condition of Italy from the Attempted Restoration of the Empire to the Great Schism (I3I2--I378)

The great political genius of the period which witnessed the attempt to revive Imperial authority was Robert of Naples, the protagonist of the Guelph cause. He commanded the astonishment of Villani, the Florentine historian, in contriving to unite Guelph and Ghibelline. Florence and Milan, free cities, and those that were falling under despotic rule, the merchants of Tuscany, and the powerful "tyrants" of North Italy united, at his instigation, to keep Louis of Bavaria and John of Bohemia at bay. The result was that Tuscan merchants commanded the commerce of the great kingdom, and Naples became by far the most powerful and wealthy State in Italy. Even Siena gave Robert her signory for five years (Villani, IX. 352). Only wisdom, firmness, and forbearance could have enabled the chief of the Guelphs and the Church party to enlist Ghibelline lords under his banners. As Vicar-General of the Pope he controlled a whole menagerie of conflicting interests. His foreign relations were extensive; he was in correspondence with the Sultan $\Omega$ f Babylon (Cairo), the Khan of Cathay, and the Rings of Armenia (Yver) ; and if the indolent inhabitants ot ${ }^{\wedge}$ his kingdom failed to answer to the activities implanted,irtheir midst by the merchant-associations of Tuscany, it was less une to Robert's vain and protracted attempt to reconquer Sicily than to their own passive ineptitude. Favoured by a mellowing climate and a fecund soil, even the centuries of atrociously bad government that followed the death of Robert insufficiently account for the heedless lethargy of a people that, with the single exception of the Amalfitans and the citizens of a few other ports, has always owed what prosperity it has enjoyed to the dangerous and ultimately calamitous intervention of the foreigner.

In the ferment of activity that characterized the fourteenth centurya ferment engendered by the intrigues of rival despots, who depended largely on intellectual dexterity to achieve and maintain their position; by the struggles and clever combinations of a number of small States to preserve their independence; by class-struggles within the republics; by the increasing wealth of independent or semi-independent communities-there arose a glorification of intellect which discovered its proper nutriment in the study of classical literature, and expressed itself in literary forms of beauty and persuasion. The Italians of the fourteenth century found an affinity to their thoughts, hopes, and tastes in the best Latin writers; they regarded those writers with religious veneration; they sought eagerly for lost manuscripts ; they hastened to disinter the buried ancient world. A fervour of emulation, a passion for erudition, spread throughout Italy; it was imagined that a chief end of man consisted in 
studying the antique wisdom, and that the highest and fullest life could only be realized by inspiration drawn from its classic fountains. The scholars of Italy collected, collated, and explained the scattered fragments of antiquity, until erudition began to choke native genius, and even to impair the fresh vigour of the Italian tongue. But, to the antiquarian zeal of the learned Italian, Europe owes the preservation of the wisdom of the ancients and the models of taste which the classic genius for propriety and proportion evolved-models, which, for the most part, remained only in fragments, scattered throughout Europe, and on the point of being lost. The strange spectacle is now to be witnessed of tyrants, in positions of power that were fraught with peril, always insecurely held, and that were achieved and maintained by cunning, cozenage, and crime, delighting in the society of poets and scholars; the spectacle of bloody, callous condottieri reading the classics in their tents, and cherishing Scipio and Cæsar as their models; of a debased mob who chanced to dwell among the ruins of Rome, listening with glowing imaginations to the explanation of its ancient monuments, firing themselves into revolt, and eagerly and hopefully trying to emulate the imperious, masculine dignity of the great Roman Republic. The scholars of the period went forth to awaken the dead. The mighty spirits of the Past answered and reappeared, clothed in wonder, and commanding the passionate worship of every class.

Of the many petty despots of Italy the Visconti had become by far the most powerful. Contemptuous of Pope and Emperor alike, they pursued their own course, which led them into a long conflict with the Papacy, that again turned its eyes from Avignon towards the almost forgotten heritage of Matilda.

The Attempt of the Avignón Popes to Recover Temporal Power. Papal and Imperial Decadence

Clement V. had transported the Papacy to France in I 305 . John XXII., Benedict XII., Clement VI., and Innocent VI. had dwelt there, and in I 362 another Frenchman, who was not even a cardinal, was raised to the Pontificate. A lordly palace was raised in Avignon as the permanent home of the Popes; and the sovereignty of the town had been bought of Joan of Naples. The city acquired the name of the Western Babylon ; Petrarch and all the writers of the age speak of its corruption; license and depravity marked its priesthood no less than its laity; the cardinals, raised to the purple through favour or intrigue, were young, and lived scandalous lives, openly and unashamed; sharpers of every kind rushed thither to make their fortunes by chicanery or intrigue; the scum of Italy and France congregated there, and what was esteemed vice elsewhere was regarded as the usual order of the day at Avignon. The Papacy itself was subservient to France, perfidious in its policy, venal in its administration, dissolute in life. The thunders of the Church were beginning to fail. The Sicilians were at open enmity with the Pope for nearly a century after the Sicilian Vespers; the House of Aragon had been unmoved by excommunication; from the Alps to the toe of Italy ecclesiastical censures and punishments were disregarded. In I369 Urban V. sent two legates to Milan, bearing a Bull of excommunication against the Visconti, who were becoming more powerful than the Pope 
himself, even within his own States. Bernabo received the legates courteously and with assumed calmness. He conducted them personally to the bridge over the Naviglio, with a guard of honour surrounding them. Then he addressed them. "I cannot let you depart without either food or drink," said he. " I wish," he continued, with a volley of oaths, "that you may not forget me. Pray choose whether it shall be meat or drink." They understood. One of them plucked up courage enough to express his repugnance to swimming. " Here, then," replied Bernabo, " here are your Bulls of excommunication; you will at once eat, to the last fragment, the written parchment, the leaden seals, and the silk attachments." In vain did the priests plead their sacred office and the sanctity of an embassy. They had to eat, nor were they allowed to depart until they had finished their repast (Andrea Gataro, Ist Padovana). Greek philosophy was fast replacing Aristotle as interpreted by the Church; a debauched clergy no longer commanded implicit obedience; the antagonism between Faith and Knowledge had commenced ; free thought began to take the place of unthinking faith; formalism, astrology, and gross superstition flourished. The Pontiff of yore had upheld spiritual authority; he had not quailed before power; he embodied the Christian conscience and brought the proudest monarchs of Europe to their knees to seek reconciliation and pardon; the Popes at Avignon were the creatures of France ; they had been compelled to wink at the vileness of Philip the Fair; they had been ready tools to suppress the Templars; they had made shameful bargains anent crusades that were never intended to take place; the Christians of the East had been deluded by false hopes, and then abandoned, without shadow of help, to the sword of the Moslem. The subserviency of the Papacy to the French Crown was execrated throughout Europe. Every Bishop was compelled to dwell among his flock, but God's Vicar, the head Bishop of the Church, seemed to hold himself exempt from this and every law, social, moral, or divine.

But Avignon was becoming as insecure a residence as Rome for the Papal Court. France was in a state of anarchy following the English wars ; the Jacquerie, the revolt of the peasantry, made the country insecure; the Free Companies had more than once forced the citizens of Avignon to man the walls, and the Papal exchequer was seriously taxed to buy them off. Kings and priests, saints and scholars, sent unceasing petitions to the Holy Seat to return to the centre of the ancient and the Christian world. Catherine of Siena wrote "to the most sweet Christ on Earth, on behalf of the Christ in Heaven," to come and rescue poor bleeding Italy and the suffering Church ; the bold and eloquent appeals of Petrarch circulated throughout Europe. Catherine in Italy and Petrarch throughout civilization were among the most tremendous forces of their time. Urban V. swore at his election that he meant to re-establish the Papacy in Rome; could he but do that he would be straightway content to render up his soul in peace. Urban returned to Rome (1367), but the times were not ripe for the Popes to take up their residence in Italy. He was flouted; he reigned, but he did not rule; he sighed after the flesh-pots of Egypt, the comparative safety and tranquillity of Avignon. The whole Papal Court, chiefly French, urged his return to the plaisant pays. His moral scruples were set at rest by the thought that he might perhaps reconcile France and England, two countries that were again at 
war. He returned, but only to die (1370), and was succeeded by the nephew of Clement VI., who ascended the Papal throne as Gregory XI.

The absence of the Popes had led to the independence of the Papal States. The genius of Albornoz, exercised in the pontificate of Innocent VI., had subdued but a portion of the Papal dominion into feudal dependency on the Papacy; the Curia was losing its hold of Italy; the Visconti were becoming a dangerous power; Naples was no longer a strong support; it was necessary to have some secure possessions in the peninsula for occasions of need. The tyrants of Romagna were, indeed, only so far subdued that they became vicars of the Church. Bologna and a number of smaller cities retained their republican forms of government, though they owned the overlordship of Rome, and submitted to the authority of her legates. But the Papacy was far away at Avignon; its spirtual prestige was again at low-water; the government of the legates was atrocious. These representatives of Holy Church even projected the subjugation of 'Tuscan States, which they were engaged to defend, at the very time when the Florentine troops had been placed at their disposal to carry on their war with the Visconti. The cardinal-legate who commanded the combined army had his head-quarters at Bologna, a city which he had taken from Visconti da Oleggio (1360). He came to a secret understanding with his foe, Bernabo Visconti, and suddenly launched Hawkwood, the greatest strategist of the Middle Ages, with a formidable mercenary army, to surprise Florence. Florence, indignant at the shameless treachery of the Church, whose faithful ally and servant she had always been, sounded an appeal to arms. She was joined by Siena, Lucca, and Pisa, and even treated with the lord of Milan, who was ever ready to see his foes weaken each other and bide his own opportunity. In ten days eighty towns cast off the Papal yoke, reconstituted the commune, or recalled the former lord. The cardinal-legate was ejected from Bologna (1 376), and the Republic was reconstituted under twelve anziani (elders) and a gonfaloniere of justice. Even Rome joined the league. Florence had no sooner sounded the war-trumpet than the whole cardcastle of Papal dominion was swept away in a whirlwind of popular wrath (1375-1376).

The Papacy sent the bloodthirsty Robert of Geneva, afterwards known as Clement VII., to restore the Papal power. He let loose on Romagna his company of Breton mercenaries, the most ferocious of the brutal banditti that the French wars had engendered. Bologna made a separate peace with the Pope, retaining her republican organization. Faenza, conquered by John Hawkwood, was treated with the utmost barbarity; it was pillaged, its women violated, 4,000 of its men put to death.

Gregory XI. at last felt the necessity of coming to Rome in person (1377). He was welcomed, but he was by no means allowed to become master in the city, and the war with Florence still went on. Bernabo Visconti entered into secret negotiations with Gregory to seize and deliver up the Republic. Florence was induced to assent to a congress to be held at Sarzano for determining how to restore peace to Italy (1378). Bernabo Visconti presided, and the Florentines were ordered to pay him and the Pope the whole expenses of the war. But at this moment news arrived of the death of Gregory, and the congress broke up, for the whole aspect of affairs was changed. 
There had now been a progressive degeneracy in both the temporal power and spiritual authority of the Papacy for a whole century. Boniface VIII. had been powerful as Sovereign, feared and obeyed as Pope. The outrages to which he was subjected in his declining years were the first symptoms of decay. His successors at Avignon used the contributions of Christendom to support their own private wars, or lavished it on their mistresses, their unavowed sons, or their creatures. John XXII. servilely complied with the desires of Robert of Naples to make war against the Visconti; he declared war against the Empire, and refused reconciliation; he sent Bertrand du Poïet to curtail the privileges of the States that held of the Church, and only succeeded in desolating them. And now the work of Albornoz was undone; the sword had failed; the Pope's temporal power could hardly be said to exist ; his spiritual authority depended far more on habit and superstition than on genuine and general religious conviction. But worse was to follow; the great schism was at hand.

Nor had the Empire suffered less degradation than the Papacy. Imperial authority had revived in Germany through the talents and energy of Rudolph of Hapsburg, but, like the wise prince that he was, he had avoided Italy. Henry of Luxemburg had carried his victorious arms to Rome ; it almost appeared as if he were on the point of restoring the Imperial sway in Italy, when death claimed him. The civil war which followed between Louis the Bavarian and Frederick of Austria did much to destroy Imperial authority in Italy. The nation was seeking for some centre of unity; the Empire did not supply it. Louis had regarded Italy as a milch-cow; John of Bohemia was nothing but a feudatory knight-errant; Charles had neither the chivalry of John his father nor the statesmanship and martial qualities of Henry, his grandfather. His feudal army was no match for the trained mercenaries and full purse of Visconti and the Italian States. Reverence for the Empire was decaying; it had become a theory incapable of inspiring any serious action, any effective change. Wenceslaus was inert and dissolute; the Germans themselves revolted and overthrew him, and his fall and shame were the measure of the discredit into which the Empire was rapidly falling. None of its conquests had endured; and the failure of the wise and courageous Robert of Naples in the war between his allies, the Guelphs of Florence and Padua, against the Ghibellines of Lombardy was not the only sign that revealed the dissolution of old ideas, the real power of the small State, or the extreme feebleness of the German Emperor in Italy.

\section{ROME 1}

From the Coronation of Henry ViI. (I3I2) to the Death of Cola Di RiEnzI (1354)

We have taken the view, justified by contemporary records, that Henry of Luxemburg came to Italy with an earnest and noble desire to restore peace and renew the glories of the Empire. Dante and all the choicest and most generous spirits of his time acclaimed his coming. The Popes 
had oppressed the people, and done their best to destroy the libertics of Rome ; they had attempted to institute order at the expense of freedom ; they had been unequal to the task of establishing despotism, partly owing to the resistance of the people, chiefly owing to the opposition of a strong and fierce nobility. These had defied the Pope ; they were little disposed to surrender their factious freedom to an Emperor who, however omnipotent in theory, had already exhibited his real weakness in his march through Italy. Led by the Orsini, many nobles allied themselves with Robert of Naples. The Colonna, the hereditary foes of the Orsini, declared for the Emperor; with their aid and that of the Senator, Henry took the Capitol by assault, and possessed himself of St. John Lateran, where he was crowned; of the Colosseum, now turned into a fortress; and of certain fortified houses constructed of the ruins of ancient Rome. The cardinals refused to crown him until they were compelled to do so by the populace. St. Peter's and the castle of St. Angelo, once Hadrian's tomb, were held by the Orsini ; many of Henry's adherents, out of heart, returned homewards, and he had to depart, master of but one-half the city (1312). He left two Captains of the People to preserve order ; these were driven out by the nobles and replaced by two senators. Forthwith the people rose, captured and imprisoned the nobles, and elected one Jacopo Ascotti Captain of the People, with twenty-six buoni uomini. Unhappily the Romans had not the courage or the power to put the nobles to death and bring the conflict to an end; but a parla nento declared them to be excluded from power, and that henceforth the Roman people, through its tribunal power, should bestow the Imperial authority on the Emperor it should choose to invite to the Imperial city. The Orsini made a very practical commentary on this assumption of Roman majesty; they and the Guelph nobles regained possession of the city, and put an end to popular government. Rome, deprived of the Papal presence, though its traditions prevented it from degenerating into a paltry place, dwindled into a city of very small real importance. Consequently, when Louis of Bavaria and the Pope were at variance, Rome took the opportunity of turning against its absentee Bishop and the vicars of King Robert of Naples who, under the Guelph régime, ruled the city. Louis was surrounded by all enemies to the luxury of the Church and opponents to its temporal power; minorite friars and philosophic teachers were his enthusiastic advocates; the Roman people were weary of the shameless bluster, the supercilious insolence, and the fierce impetuosity of turbulent nobles, and, aided by the Ghibellines, they drove out the vicar of Robert, seized the castle of St. Angelo, and once again re-established democratic rule. Sciarra Colonna, a Ghibelline, became Captain of the People, and ruled with fifty-two burghers, four representing each of the thirteen regions of the city. Sciarra chased the Guelphs from the city, and ascended the Capitol in triumph, and Rome, liberated once more, invited Louis to receive the Crown (I 328 ).

But while the Pope was busily occupied in heaping up treasures which moth and rust do corrupt at Avignon, his spiritual charge was left to the care of indifferent pastors, and his city to the decay attendant on obscurity.

“ The hungry sheep look up, and are not fed,

But, swollen with wind and the rank mist they draw,

Rot inwardly and foul contagion spread." 
The great Houses of Colonna and Orsini tore the city with the convulsions of their fierce hate. The sides were equal in strength; truces were for a day; the contest was renewed on the morrow ; when the faction fight had passed through the deserted streets ruffians, beggars, and bandits haunted them, and the vicars of King Robert were powerless to stay for a single day this savage strife and clash of arms. At last the burghers took the matter into their own hands; the King might send his vicars as he chose; they ruled themselves with a directing council of two senators and thirteen heads of regions. Two authorities claiming the obedience of the city, however, caused friction, and the burghers made their peace with Benedict XII. by granting him supremacy over the senate. Matters were not improved, however; the city suffered no less than before from the hurlyburly of its nobles; so, in I339, the burghers seized the Capitol and sent to Florence for aid to break the power of the barons. The Florentines, mobile-minded and apt at constitution-mongering, forgot the very different conditions which obtained in Rome, where the guild-system was but little developed, and the citizens were not under the multiplied control of the trade-associations at home. They set up a government of thirteen priors, a Gonfaloniere of Justice, and a Captain of the People. This government fell through, and the Pope once again nominated his senators. Yet over this scene of decay and death, this mere " rubbish-heap of history," as Gregorovius calls Rome, the past shed a strange and ironical lustre. Petrarch was crowned laureate by the Papal Senator on the Capitol, amid the plaudits of cut-throat nobles, tatterdemalion burghers, and foul assassins - amid the garbage of Italy, who still, with shameless and unconscious mockery, claimed for themselves the rights as well as the name of the Roman Senate and People (I34I).

Two great forces were operant in Italy-one unconscious, the other ill-informed-a desire for unity, and the recollection of her past. The peninsula sought, unwittingly, for some principle of unity. Such a principle in the form of monarchy, monarchy often disobeyed, but which, because it was a veritable and incorporate principle of unity and order, exercised an authority greater than that of the sword, had already begun to establish itself north of the Alps, and was gathering the scattered forces of the peoples into the nations of the modern world. But monarchy was impossible in a land where the traditions of universal empire and independent municipal self-government obtained; where petty despots were struggling with each other and with the republics, and none was strong enough to swallow up the rest; and where the fierce spirit of faction had become an unreasoning ensign of endless rivalries and envious contests and intrigues. Italy, then, was lacerated by the social and political disorders of the present, but she had not forgotten the glories of the Empire and the greatness and magnificence of the Roman world. That glory, attested by a thousand proud but shattered remains, scattered through the length and breadth of the land, assumed a monumental calm when viewed through the veil of the ages. The revival of learning and the increasing formalization of religion threw men's minds back more and more on the past, and they pondered over its dim and distant lustre, and wondered whether, even yet, the dead bones and disintegrated corruption might not be made to live and breathe once again. The theory of the world and of the Church was that the Empire was by origin Divine. This was the 
imperishable belief of Dante and Petrarch, of Aquinas and Marsilio. There now sprang to the front a man of ideas, an enthusiast, one possessed of large and lofty conceptions, a megalomaniac if you will, and certainly a man who exhibited the too frequent combination of superb ideality with superb egotism; but who knew that what he vividly conceived all men vaguely but deeply felt, and who was strong because he was able to give clear utterance to what was dumbly present in the hearts and desires of his fellows. He dreamed a dream and imagined a vain imagination, but human and self-centred as he was, he was stung by the same Divine gadfly that urged Arnold and Dante and Petrarch and Mazzini, and that through centuries of blood and tears drove the great Italian people to seek, and at last to find, their unity.

The dreamer was Cola di Rienzi. He was of lowly origin : his father was an innkeeper, his mother a washerwoman ; but he had shown exceptional talent, had been highly educated, and followed the profession of a notary. He was devoted to letters, and as he pondered over Cicero and Livy, dead Rome took again for him warm and breathing beauty of life ; his imaginative soul was infused and impregnated by the lofty and heroic spirit of the ancient world; he quickened, as it were, into new life by a perception at once exalted and poignant-a perception of the continuity of history and of a real identity of Rome in her dominance with Rome in her decay. Civis Romanus sum sang in his brain, and he did not merely dream, as Dante dreamed, of the eternal city, the world's metropolis, restored to her ancient magnificence and splendour, a light and a balm to the nations and the seat of a universal monarchy, the restorer of peace. Rienzi, with the temerity engendered of patriotic devotion, of soaring imagination, and of the self-confidence of sublime egotism, said to himself : "And I am the man to bring the new earth into being."

When we contrast this brilliant conceit of classic restoration with the impoverished and sordid state of the mediæval city, we are astounded at the temper of mind which could repose such reliance on its own powers ; and we perceive at once that such an effort in the hands of such a man at such a time, and put forth in such a way, shows that he had neither selfknowledge nor clear perception of the real world around him. And yet, if the ideal and the immaterial is, after all, the nearest hit to reality that blundering, erring man can make, Cola di Rienzi sped his arrow for a real and noble mark, while if actuality and success are to be the test, modern Rome, the capital of Italy, bears witness to a certain sagacity that, after all, dwelt in the minds of Cola and his predecessors. What Rienzi saw with his mental and perishable eye was a city almost deserted and in ruins, dominated by the great monuments of a dead world turned into barons' keeps, or pulled to pieces to strengthen robbers' strongholds ; a poor and barbarous nobility truckling to an absent Pope for the bestowal of privileges, too poor to pay soldiery, and relying on cut-throat and bandit henchmen; a senate that was a senate only in name; an impotent semblance of popular government; murder and arson, so common as to pass almost unremarked. And the condition of Rome, rent and shattered by the rage of barbarian factions, was essentially the condition of every city in Italy. Every city, every social unit in the peninsula, was an Ishmael, whose curse impelled his hand against every man and every man's hand against him. What Cola saw with his spiritual eye was 
a regenerated Rome, purged by affliction and ennobled by Christian revelation, once again imposing the Roman peace on others, and respecting it herself.

Cola was of such eloquence and learning that he was sent with Petrarch to Avignon, in $\mathrm{I} 342$, to implore the Pope to return to Rome. He gained the friendship of Petrarch, and Clement VI. heard him with attention, and bestowed very substantial marks of Court favour on him; he was appointed Papal notary. Rienzi returned to Rome with the Papal promise of observing a jubilee every half-century. Naturally he now became a most popular man in Rome, for jubilees brought money to the city ; he had greatly increased his reputation. He seized the opportunity to strike at the hearts and imaginations of the Roman people. $\mathrm{He}$ appealed to the eyes as well as the ears of his audience by pointing to the monuments of the great past; he expounded their meaning; and by means of allegorical pictures-for allegory was the familiar and acceptable ratiocination of those days-he communicated something of his own vision and his own temper to the responsive crowd. An unknown contemporary historian gives us vivid descriptions of these scenes. Cola was ever wandering about the city, examining her classic remains and expounding their meaning to whosoever cared to ask. He came across a bronze tablet which recorded the investing of Vespasian by the people with Imperial power. He dressed in the pure white toga of an ancient Roman, exhibited the tablet at St. John Lateran, and explained its meaning. Already we begin to find something theatrical in Rienzi, something of the vanity that is rarely inseparable from the actor's character, however completely he may identify himself with his.part. " Behold," the orator declaimed, " behold the impressive grandeur of the Roman citizens in the great days that are past; they conferred power on Emperors, and Emperors derived from them, as their mandatories, the exercise of their authority. These were naught, except by the grace and delegated authority of your ancestors ; and you, blind men, have suffered that the eyes of Rome, her Emperor and her Pope, should be torn away from you ; and that they should derive from and depend on you no more. Hence has peace departed from this holy city; hence is the blood of your nobles and your citizens poured forth, not in public defence, but in private quarrel; hence do you squander your strength in petty discord; the city which once was Empress is now become the by-word of the nations. The jubilee draws near; the gaze of the entire world will be upon you ; Christians from the uttermost parts of the earth will journey hither-are they to find here nothing but feebleness and ruin, oppression and wrong ?" (Frammenti di storia Romana). The nobles heard their order attacked with contemptuous indifference; the commonplace burghers asked whether pictures and big words were going to change the world; but the few who believe that words may stand for ideas, that ideas may precipitate into facts and cut the throats of men and change the destinies of empires, came in growing numbers and listened with growing enthusiasm. Private injury reinforced Cola's deep sense of public wrong. A younger brother had been slain by the nobles in the public street, and when pressed for redress, that scum of society had shown its usual contempt for the dregs ; nothing could be less worthy of regard than a mere son of the people. They subjected Rienzi, moreover, to personal affront. John Colonna got him to 
meet a company of nobles at dinner; and the party made him the butt of its rude witticisms. Cola was to them merely an amusing madman, especially when he promised to hang this man and decapitate that man in the days when he should become ruler. For he had found that men's minds were a-ripening; he judged his time was drawing near. On the first day of Lent, I347, he put a superscription over the door of San Giorgio : "Yet a few days, and the Roman people will renew its ancient pride." He called a secret meeting of notaries, learned men, and even the less unsympathetic among the poorer nobility, and harangued them more eloquently than ever before on the stately memories and glorious destiny of Rome ; and he began to deal with the renewal of that ancient fạme as a quite practical matter; he pointed out the sources of revenue, and declared that he spoke and strove with the full sanction and promised support of the Pope. This was probably true. The Papal policy was to become independent of French influence, to have a second home in Rome, to restore the temporal power, and Cola was likely to serve as a convenient cat's-paw; if he failed, if the seed fell on stony ground, the Papacy would be no worse off ; if he sowed ripening corn, the Holy Chair would know how to reap the harvest. The meeting separated after taking a vow on the Gospels to re-establish Roman freedom.

A favourable opportunity soon presented itself. The Colonna and their leading men of war went into the Campagna to safeguard a transport of corn. This little incident throws revealing light on the insecurity of Roman territory. Cola spent the entire night at Mass and in prayer, and then, armed but bareheaded, preceded by flags emblematic of Peace, Justice, and Liberty, and escorted by the Bishop of Orvieto, vicar of the Pope, a body of chosen youths, and an armed guard, and followed by a rapidly-increasing multitude, he proceeded to the Capitol. There he harangued the people and incited them to arrange for the establishment and maintenance of public order, and, since he took the Gracchi as his model for the distribution of regular alms to the poor, the propositions were accepted with enthusiastic shouts, and the Roman people invested Cola with full authority to act. Stefano Colonna, who was the most powerful of the Roman barons, and reputed to enjoy Papal favour, hurried back to the city. Cola ordered him to depart, and when the old warrior treated the command with contempt, Cola sounded the call to arms on the Capitol. The citizens assembled, and Colonna had to take hasty flight to Palestrina, attended by a single henchman. ${ }^{1}$ The other barons received the same order and made a virtue of necessity : they acceded. The city was guarded by an organized militia, and notorious evil-doers were executed. The titles of Tribunes of the City and Protectors of Rome were conferred on Cola and the Papal vicar. Rome was once again rendered habitable for decent folk, and Cola determined to compel the barons. to maintain order and justice in the Campagna. He had the entire force of Rome at his back, and he was supported by the moral sense of Christian Europe. He called on the nobles of Campagna to pre-

1 The genius of Petrarch throws a flood of light on the characteristics of the barons of Rome and the Campagna. Old Stefano Colonna was the very embodiment of their fierce spirit, and Petrarch brings him out in high relief. He says that " although age has somewhat cooled his fires, yet seeking peace he always contrives to secure war; he would rather go down to the dust fighting than bend his never-vanquished brow" (Petrarca, Lettere Familiari, v. 3). 
sent themselves at Rome and take an oath to supply the city with provisions, to safeguard the public highways, to protect widows and orphans, to assemble, when summoned, at the capitol-with or without arms, as required of them-to respect the Government, and to give no shelter or succour to its foes. They complied. Cola then sent to apprise the Pope of his doings, and we learn from Petrarch how the arrival of accurate intelligence calmed the wild alarm of the Papal Court that the first incoherent reports had aroused. Cola's messengers bore the Papal insignia as well as those of Rome. " We have brought these," said they, " through the midst of multitudes on their knees; they have kissed them with rapture as a sign that roads are safe and brigandage stopped." The Pope hoped to make a good deal of money out of the approaching jubilee, and he was delighted to know that the usual risks of the " Romeo "1 were at an end. It meant that the jubilee would "draw "; moreover, the ardent enthusiasm of Petrarch for the restoration of the rights of "the Holy Seat of God's Vicars, the Pope and Emperor," was contagious. It was a feeling shared by all scholars and emphasized by the tradition of ages; and as Petrarch himself says, the mere name of Rome counted for much. Perhaps what had most disturbed the Papacy was the fear that Cola had effected only too much for its own purposes. Cola sent his envoys to nearly all the powers of Europe, announcing, under the title of " Nicholas, stern yet clement; tribune of liberty, peace, and justice; illustrious liberator of the Holy Roman Republic," that the roads were free, and inviting them to send deputies to Rome, form a European council, and discuss with him on the means of good government in the Christian world. Everywhere the envoys were well received; a wave of contrition and desire for better things seemed to spread over Europe; and Florence, Perugia, and Siena sent cavalry to the new tribune, with the promise of further aid if required. But now the egoistic weakness of the artistic nature and its love of effect began to manifest themselves in. Rienzi. He delighted in seeing the barons stand before him with crossed hands and bowed neck, while he remained seated. He became intoxicated with success. There is some truth in the adage about setting beggars on horseback. His wife was wont to attend Divine service accompanied by a youthful guard, and followed by a train of noble dames ; and Cola sought to give himself increased dignity by marrying his sister to one of the haughty Roman nobles. His vanity grew with the rapidity of a gourd ; it was fed by the appeal of the Emperor Louis to him to effect his desired reconciliation with the Pope; by the request of the King of Hungary that he should execute vengeance on the murderers of his brother; and by the appeals of the royal murderers themselves, who addressed him as their dearest friend. The tribune summoned a public meeting of burghers and the Hungarian Embassy. When he had donned the tribunal crown, he informed the Embassy and the meeting that he "would judge the world with justice and its peoples with equity." He got himself knighted, and, in the middle of Sacred Mass, cited the Emperor to appear before him, declaring Rome and all the cities of Italy to be free and their citizens possessed of Roman citizenship, and that the Emperor was merely the delegate of the people. Then, drawing his sword, he flourished it in every direction, declaring, "That belongs to me, and that to me, and that, and

1 So the pilgrim to Rome was called. 
that." The Papal vicar, who hitherto had been heart and soul with Cola, protested in vain. Cola drowned his voice with a fanfaronade of trumpets. Now began a period of wasteful and ostentatious extravagance at the public expense, which gradually lost him the favour he had won of the populace. He went through a turgid ceremony, and declared himself to be a knight of the Holy Ghost: The man became more and more inflated. At a feast which he gave to his old enemies the nobles, Stefano Colonna started a discussion on public expenditure, and then, lifting the gold fringe of Cola's garment, inquired, "And do not you, tribune, think it would be better if you wore the modest garments of your equals rather than this parade of expensive foppery ?" Cola left the hall without a word, and ordered the arrest of all the nobles present, on the plea that he had discovered a conspiracy. He then called a parlamento on the Capitol, and announced that he was going to have the traitors beheaded, and relieve the people for ever from the yoke of barons. Whether it was a case of letting "I dare not wait upon I would," or whether Rienzi's conscience upbraided him for an accusation that probably covered pique, he converted the occasion into a tremendously successful bit of stage-effect. The nobles were condemned; all were shriven, all but Colonna, who refused. Then, amid all the accessories of a carefully-arranged theatrical display, at the last moment before the rigour of the law was to take effect, Cola mounted the tribune, took for his text "Forgive us our sins," and pleaded with the people for the forgiveness of these truly repentant misdoers; his word for it they would misbehave no more. His eloquence produced its usual effect ; the prisoners were led one by one before the multitude, with bowed heads, to receive their pardon; and then the successful actor and stage-manager passed on to another act. $\mathrm{He}$ exhibited his magnanimity; he preferred these would-be assassins, who had sought his life, to offices of State in the Campagna. The nobles were no sooner set free than they retired to their country fastnesses, and resolved to reply to sham heroics with real warfare.

Cola now showed himself to be a physical coward, another frequent mark of an artistic and imaginative nature. He kept within the shelter of the Roman walls, and tried to bear up the courage of the burghers, which there was no reason to doubt, by a daily recital of miraculous visions and heavenly promises of support. But the men of Rome were of stouter heart than the idealist who had animated them ; if they needed a leader, it was some lusty soldier, not a coward and dreamer of dreams. They fell upon the nobles, who by this time had come up to their gates in force, and routed them. This gave another opportunity for theatrical effect to Cola. He went in processional triumph to the Capitol and deposited his insignia of office at the altar of Our Lady in the Aracœli. He then turned round to the people and boasted of having abased those whom Emperors and Popes had proved themselves unable to curb. $\mathrm{He}$ showed so little real magnanimity that he refused funeral rites to Colonna and his son, who had fallen in the fight; and instead of following up the victory by pursuing the defeated barons to their lairs, he contented himself with knighting his own son on the spot where old Colonna had fallen, and wasting precious time in commemorative feasting. His conduct alienated his friends ; and his foes, under the Orsini, again stole up to the gates of Rome. 
Hitherto fortune had favoured the tribune. Not merely did the world hail the resuscitation of Rome, but the astonished Pope, in spite of very natural political perplexity, had given countenance to Rienzi. In fact, he could do little else ; the humbling of the barons would favour his own designs, the kingdom of Naples was in an anarchical condition, and could furnish no aid to further his schemes. The Pope was an absentee; the F.mperor was impotent; all hitherto had favoured, all had gone well with Cola. A newly-arrived Papal legate was, however, personally prejudiced against him; he placed himself, indeed, in secret communication with the barons; the interests of the sacred college-a college that had been so largely recruited from among the Roman barons-inclined that body to sympathize with them. They had been taught a deserved lesson, and their triumph might now mean the triumph of the Papacy. The legate awaited a favourable moment to excommunicate the tribune : it came, and Rienzi was visited with anathema. The barons still held the Campagna; an exile from Naples with his companions in arms had contrived to establish himself in the city itself; Rienzi had endeavoured to control him, but, egged on by the legate and the Colonna, he now ventured to defy Rienzi to turn him out of his fortifications.

The tocsin rang all day and night to call the people to arms. But they were weary of increased taxation and theatrical displays; they showed no interest in the expulsion of the Neapolitan. In vain did Rienzi harangue the assembled multitude; they had come without arms ; and his moving periods, while they still melted the citizens to tears, failed to arouse them to action. Then Rienzi renounced his authority; and not a single voice begged him to retain it. He ordered his silver trumpets to sound, and he and his followers marched, not without dignity, to take refuge in S. Angelo, whither his wife followed him in disguise. His rule had lasted less than seven months. Three days after his resignation of office the barons re-entered Rome, with resentment in their hearts, and the unhappy city fell a prey to anarchy even worse than that which it had experienced before the advent of its brilliant tribune (I 347).

The great Jubilee of I 350 brought $2,000,000$ visitors to the city, which added very greatly to her prosperity, as well as to much filling of Papal coffers. And Rome was fortunate in that the Black Death passed but lightly over her. The fate of the two Papal legates sent over for the special purpose of granting indulgences gives an idea of the horror of life in Rome in this period. One had his palace stormed by a mob, and was obliged to flee from the city for his life ; the other, after receiving a warning in the shape of an arrow shot through his Cardinal's bat, never again ventured abroad without being armed with protective armour from head to heel. The Papacy vainly tried to establish some kind of order. The people of Rome vainly sought for a man who might replace Rienzi. A new leader, one Giovanni Cerroni, was made rector of the city, and was successful in clearing it yet again of its ruffianly barons. But while every republic in Italy was at the mercy of a rude, overbearing, and explosive nobility, directly this order was expelled, the community found itself without military leadership and practically without defence against its foreign foes and its own banished barons. It was this turmoil and weakness of the cities which gave the despot his opportunity ; it was this which enabled him to consolidate his power. Scarcely a free State now remained 
in Italy : Orvieto and Viterbo had fallen to Vico, and Vico was advancing against Rome. So the barons had to be recalled again, and, untaught by adversity, they resumed their ancient arrogance and renewed their ancient feuds. The Orsini and Savelli set all constituted authority at defiance. In the public streets, wild, fuming, headstrong bands fought each other the livelong day; and Cerroni, whose popularity soon waned with the fickle people, like Rienzi's, vainly called them to arms, and then abandoned a hopeless task. He resigned the rectorship of a city where government had become impossible, and departed thence.

When Innocent VI. succeeded Clement VI. he appointed two senators, one an Orsini, the other a Colonna ; but a few weeks after their installation, food being dear, the populace rushed the Capitol. Orsini was stoned, and Colonna only escaped by the skin of his teeth and in a mean disguise (Matteo Villani). Baronial contests were as unceasing as ever. Behind them, in all probability, were arrayed class antagonisms and class demands. Rome was torn by party strife until, in $\mathrm{r} 353$, the exhausted city again tried the experiment of having a plebeian ruler. It is evident from this that, in spite of his egotism and theatricality, Rienzi had had his hand on the pulse of the people, and knew the secret throbbings of its heart. Not merely had he interpreted its aspirations; his genius had not wholly failed when he had turned his attention to the practical problems of rule. Rome appointed one Baroncelli tribune, who had sufficient force of character as well as sufficient popular support to execute some of the barons and enforce order on the others. While Baroncelli was in power, Innocent sent his legate, the Cardinal Albornoz, to Rome, and Albornoz was accompanied by Cola di Rienzi. The Church, its treasury filled by the faithful at the Jubilee, was now able and determined to recover its temporal power in Italy. Its spiritual power being decadent, it became more than ever necessary that it should become materially strong. Skilled in the reading of human character by the very exercise of the ecclesiastical profession, and thrown wholly on astuteness and penetrative diplomacy to supply the deficiencies of its weak material power, the Papacy was quite competent to take a very exact measure of Rienzi's character, of his influence, and of the degree of his serviceability to itself. The Pope had designs on Rome which he intended that Albornoz should work, partly by the charm of Rienzi's name and presence. Rienzi's weaknesses and extravagances had been forgotten; the Roman people remembered only the promise of fresh hope, the execution of severe justice, the revival of ancient dignity, that he had bestowed. The citizens crowded to Montefiascone, where Cola and Albornoz were halting. " Come back to Rome," prayed they; "come back to thy city. Thou alone canst deliver us. Be our lord, and we will serve thee with all our strength ; doubt us not; never did we desire and love thee as now" (Frammenti di storia Romana). Alas! Rienzi had undergone degenerative change. Baneful elements in a luxuriant but never well-compounded nature now manifested their corrupt and corroding dominance. He had become a guzzler, fat and inert of body, and, worst of all, he was the mere tool of Albornoz. The champion of the liberties of Italy gave a rare colour to the liberal sentiments of this ecclesiastical protagonist of the Guelph cause. His powers of eloquent persuasion had not deserted the great orator. He had always found favour at the Papal Court; and Albornoz was resolved.to use him, 
but to keep him in leash. Even for the purification of the Church it was necessary for the Pope to become a temporal Sovereign, master in his own house. The days of the abstract despotism of the Spirit had departed.

The haughty Cardinal refused to let Rienzi go with them until the Romans showed some spirit by arming themselves against Vico, the tyrant of Viterbo. When Vico fell, Albornoz lost this excuse. He was obliged to confer the dignity of Senator on Cola, in accordance with an order from Avignon; he resolved to leave Rome to Cola and her own resources and devices until she should be glad to come to heel at his command. He gave Cola no help either of money or men. Now, Cola had far too many foes among the revengeful barons of the Campagna to venture thither without an escort. It says much for the charm of his plausible oratory that at Perugia he rendered the two bandit brothers of Montreal, the great free captain, enthusiastic on the subject of a renewed Italy, and got them to lend him a considerable sum. He was thus enabled to hire an escort and make his way to Rome in safety. He was welcomed with genuine enthusiasm by the people, and received letters from the Pope, which flattered the snob in him by recognising the title of nobility he had given himself ( 1354 ). But Cola soon found himself in a very difficult position. He had to make demands of the people coincide with views of Albornoz and the Pope. When Montreal, the unconvinced and suspicious uncle of his-benefactors, came to Rome to keep an eye on him, he had him seized and slain ; and, though the execution of a heartless adventurer was signal warning to the hordes of depraved rascals who were ravaging Italy, men had become so accustomed to view the companies as merely pursuing a trade-il faut vivre-that they animadverted on the ingratitude of the judge instead of applauding the justice of the sentence. Rienzi was also injudicious enough to hang a popular citizen ; and, since he had to besiege the Colonna at Palestrina without the wherewithal to pay his soldiery, he was compelled to levy unpopular taxes for their support. Doubtless Albornoz had foreseen what would happen. Rienzi's old ostentatious and extravagant ways, his new caprice, and the exigencies of government, thus brought him, in the course of a very short time, into general disesteem and disapproval. Censure speedily became hate; and in days when a change of government was always effected by a sanguinary revolution, it only took two short months for risings to burst out simultaneously in two different quarters of the city ; moreover, it was high time in Rome for some fresh excitement. A mad mob rushed to the Capitol with shouts of " Long live the people! Death to the traitor Cola di Rienzi !" Of all his friends, his guards, his servants, but three persons were found to stand beside the Senator. The palace doors were set on fire, and while the people waited for them to fall that they might rush in and slay and plunder, Rienzi, dressed in knight's armour, tried the magic of his winged words once more. But he could not make himself heard in the din, though he tried again and again. He was driven back by showers of missiles, and finally an arrow wounded him in the head. In every man there is present both the hero and the poltroon: The commonplace, natural, animal man conquered the hero in Rienzi. He cut off his beard quickly, and covered himself with a porter's mantle. $\mathrm{He}$ piled some bed-clothes on his head, as if he had been plundering; 
and as he passed through the crowd, which, now that the doors were burned down, trooped into the palace, he pointed to the place whence he had come as if it were full of booty. He passed unrecognised as far as the last door ; but his gold bracelet betrayed him to the ruffianly crowd. Cola at once threw off his disguise and acknowledged his identity. $\mathrm{He}$ was taken to the stairs of the Capitol, to the place before the old trophy from Egypt, the lion of porphyry, whence he himself had been wont to pronounce sentence. But a profound silence fell on the mob whilst Rienzi awaited his fate with crossed arms and lowered and meditative eyes. Then, as the silence continued, he raised his eyes, and, surveying the crowd, raised his magic voice for the last time. An artisan of strong political views, dreading the effect of Cola's eloquence, immediately thrust his sword through him. The spell was broken; the contagion of passion, so characteristic of the psychology of mobs, spread; everyone strove to secure his own hack at the ill-fated Senator. Rienzi's dead body, covered with wounds, was dragged through the city, and finally hung up at a butcher's stall. So perished one who will ever serve as a remarkable study in "curiously compounded clay," a man whose nature was not all dross, nay, one who, take him all in all, was a noble Roman - a patriot less lofty of soul, it must be granted, than Arnold, or Dante, or Bussolari, or Savonarola, or Mazzini, but full of fantastic poetry and of a personal fascination which captivated peasant and Pope alike. Cola di Rienzi held the key to the secret mind and aspiration of his own age. He unfolded in direct and penetrative speech what had been dumbly, dimly felt in every heart. Were he alive to-day, his quick-eyed genius would, perhaps, reveal the perplexed riddle of our hearts' desire in magnificent unfoldings of human rights and dignity, and the return of golden years. He would certainly move every breast in Italy what time he might interweave the memory of her Imperial past with the prospect of her brilliant rejuvenation, and throw around the vision the spell of an idealism greater than his personality.

\section{From the Death of Rienzi to the Return of Gregory XI.}

The absence of the Pope from Rome was even more injurious to the prosperity of the city than to the authority of its Bishop. Cardinal Albornoz had been sent by the Pope to pave the way for his return by reconquering the Papal States, and he carried out his work ruthlessly. But his success merely consisted in transforming despots into feudatories under the title of Vicars of the Church, and in forcing the free communes to take an oath of obedience. Directly any real pressure was put onthough it must be admitted that the Papal authority was often applied with strange unwisdom by hare-brained, flint-hearted, and stiff-necked legates from France-the bond was snapped. It became evident that now that the spiritual bond of union between the nations was broken, now that great, compact States were beginning to appear, now that France was in such disorder that continued residence in Avignon had become dangerous, the Pope must return to Italy, repossess himself of material power, and that, in order to do so, he must first of all be master of his own city. The task would be the easier that Albornoz had often been hailed as a liberator from the tyrannies of the petty lords. 
Rome, too, was fast falling into ruins. The wolves of the Campagna ran about the deserted streets, and a large proportion of the population consisted of thieves and beggars who snatched a poor and precarious livelihood. The nobles had, to a large extent, been wiped out by Rienzi, and the younger among those that were left were away engaged in the congenial occupation of pillaging other parts of Italy as condottieri. The traders were ruined by the absence of the Pope, and therefore Albornoz was welcomed by Rome, and the Pope was acknowledged to be the head of the Republic. He at once named a foreign senator so as to keep the nobles, exhausted and few, in check. By I 360 we find seven "reformers" of the State elected by ballot every three months. The Pope still remained away, however, and Rome practically governed herself. She took good care that the nobles should be admitted neither to the Government nor to the militia, which appears to have consisted chiefly of cross-bowmen, commanded by four antiposti. After the Florentine model, where the gonfaloniere of the companies was associated with the signoria, the antiposti sat with the two banderesi, elected to preserve order in the city and guard its liberties. Before long the reformers became the real heads of the Government. Within two years from the constitution of this signoria dei banderesi, as it came to be called, it had very tough work to do. Velletri had been defended by the nobles, but fell to the Romans, and the nobles revenged themselves by a truculent outburst in Rome itself. The banderesi succeeded in driving these turbulent barons forth from the city, together with certain of the reformers who took their part; but the fight was long and bloody, and condottieri had to be employed. No sooner was the Government quit of the nobles than it had to employ its full force against some of the many bands of mercenaries that infested Italy, and went on hanging unruly nobles. It also attempted reform by a revision of the laws.

Urban V. received the lordship of Rome and the keys of the castle of S. Angelo in I 367 , but in I 370 he again departed for Avignon. In 1377 the despicable Robert of Geneva, determined to put down the revolt of the States of the Church, massacred the inhabitants of Cesena without distinction of sex, age, or person, and Florence sent the "standard of liberty," which was the ensign of revolution, to Rome. We find that at this time thirteen banderesi, or standard-bearers, constituted the Government, each representing one of the rioni, or wards of the city. But Rome was in decay ; the signoria saw houses replaced by huts, churches in ruins, quarters once populous become dreary wastes, trade ruined, the remaining population impoverished, and they were more anxious for the return of the Pope than for the establishment of liberty that would bring them no bread. They were, moreover, aware that Gregory XI. was meditating leaving Avignon for Rome, for he perceived that unless he took up his abode in Italy he could never hope to regain the revolted States. And so eager were the banderesi for his return that they offered him full sovereignty directly he should plant foot on Italian soil, and to resign their office ; they also promised that the Roman people should refer the magistrates chosen by them to the confirmation of their Sovereign.

The Florentine eight-of-war sent the Roman signoria one of these appeals, the elegant latinity of which was often more effective in the fourteenth century than an army with banners. It ran as follows : 
"To the illustrious banderesi of Rome, our honoured brothers ! Although we have so far entreated you in vain to defend, with courage not to be cast down, your own liberty and that of Italy, and although the only reply that we have received from you has been distinguished by style and not by matter, yet, now that we perceive your freedom to be menaced by ruin, we do not hesitate to repeat our sincere and wholesome warning. We perceive only too clearly-and unless you desire to be blind you must also see-that the Sovereign Pontiff, whom you await with such loyal sincerity, cares nothing for your city; he detests the idea of residing therein ; he comes back from no sense of the duty of a Bishop to his see, but to suppress your freedom and change it into servitude. Why does he demand the abolition of your Government, if it is not to remove the support of Roman freedom ? What curb will remain to insolence, what refuge for the weak, if your holy council, on the existence of which peace and valour alike depend, is effaced on the arrival of the Court? Even should the Pope restore the city to its ancient beauty, even should he raise the Romans to their old Imperial height, even should he plate your walls with gold as of yore, of what would it avail if liberty were the price ? Rather should the offer be refused. We only beg you to bear yourselves as the heirs of Rome, where freedom and courage descend from sire to son through the ages. You yet have the power; there is still time; the would-be destroyer of liberty is still without your walls ; look, then, to your safety and that of the Roman people ; from the moment that you desire it, at the smallest sign, we will strain every nerve, as if it were our own freedom that was menaced for we know that once you have gone under the yoke, however easy at first it may seem to you to bear it, there will no longer be any possibility of casting it off" (Rigacci P. I., ep. 17, p. 58, zvitten by Coluccio Salutati, Chancellor to the Florentine Republic and once Secretary to Urban V. and Gregory XI.). But the Romans were unmoved; they refused to accept the troops the Florentines were ready to send; they wanted a revival of trade, and they knew that revolution meant the independence of their own subject towns. Gregory made a triumphal progress into the city ; he rode a magnificent horse with rich trappings ; the noblest men in Rome held the baldachino over him, and merry-andrews and jack-puddings tumbled before him, while the people spread his path with the winter flowers of Italy (January I 7, I 377).

\section{NORTH ITALY : THE DESPOTS OF NORTHERN ITALY AND THE FORMATION OF SMALL STATES}

\section{The General Character of the Tyrannies established in NORTHERN ITALY}

DWELLING on a great plain, where city train-bands could make no effective stand against bodies of disciplined cavalry, and in unceasing peril from rival communities and ambitious despots, it seemed a less evil to the towns north of the Apennines to surrender their liberties to a single strong ruler than to remain in a condition of anarchy at home and insecurity from 
external foes. It was some satisfaction to have order preserved and justice speedily executed within the city walls, however arbitrary or illegal the power that put an end to anarchy. The quarrels between nobles and burghers within the city ceased when a strong ruler arose, mighty enough to secure his position by exiling his foes, actual or potential, and sufficiently elevated in position to convert his arrogant equals into courtiers anxious to please him. He affirmed his sway and popularity by the exhibition of an impartial mind, and by taking just cognizance of the claims of all. The nobles, unable to preserve their order, save by submission to a chief, became gradually converted into Court dependants; the burghers were unable to combine, and had neither the soldierly qualities nor the habits of command needful to secure the respect and obedience of mercenary troops ; the common people were content to be ruled by a master so elevated in station that he was, in measure, above the prejudices of rank, and who democratized society by the very fact of his despotism, for all had the equality of servitude. By the beginning of the fourteenth century nearly every town north of the Apennines and those of Romagna had submitted to a master. The burghers bad thought that constitutions could be safely changed at will; the forms of communal government had been in the hands of a few. The communes, in their constant fluctuations and incessant change of officers, had exhibited as unceasing oscillation as the waves of the sea. The cities subsisted on commerce, and the only notion of increasing trade, in days when guilds fixed the quality of goods and underselling was reprehensible, was by the means, not wholly forgotten to-day by trading communities, of ruining each other in warfare. These incessant wars of themselves necessitated a centralized Government, and despotic rule was inevitable. There was also a great temptation to a public man to become a despot. If a man possessed wealth, he necessarily wished to guard his interests by taking an active part in the guidance of the State; and, once prominent in public life, he was ever in danger, perhaps from private foes, certainly from the machinations of the opposite party. Exile always hung over him as a Damocles' sword. Hence the repeated attempts of men of mark to seize the helm of State ; hence, also, the insecurity of the tyrant when he had obtained it. And so high did party passion run that it blindly helped the aspirant to power. A furious faction was regardless of all but its own triumph, even when triumph meant bondage; and triumph was the sweeter that it carried with it the proscription of foes. The want of compactly organized government, the co-existence of many councils and guilds and foci of power, also facilitated the establishment of tyranny (in the old Greek sense of the word). This want of organization, which in the time of Barbarossa had implied indestructible vitality and recuperative energy, and which had so often proved the salvation of the State when cities were razed and territory devastated, now, under changed conditions, prevented all common effective action against the new master. The councils could do little or nothing with their crude militia against mercenaries in the hire of the despot, and skilled in all the recent expansions of martial science; the unequal distribution of wealth. inevitable because of its great unforeseen increase, developed individualism, even in civic councils. Men had lost much of the temper of the earlier Middle Ages, whercin the individual always felt himself to be a member of a party or a family-only knew himself, indeed, as a member of some class or order to 
which he belonged. There was a certain unconscious reaction going on against the old, also unconscious, but very present, temper of mind; everybody was now much more disposed to fight for his own hand, and felt the needs and resources of his own nature. Arbitrary Acts also had been so common, misrule so constant, that men cared not whether the Acts of Podesti or judges were legally justifiable or not, so long as they were prompt and effective. In a word, the social conscience was becoming relaxed and disintegrated. The Guelph and Ghibelline parties, the forces of Iiberalism and Conservatism in politics, were so nearly balanced that the usurpers were constantly engaged in war, civil or communal. To be always under arms was impossible for the citizen; he came to depend more and more on mercenary aid, and this necessarily strengthened the tyrant and consolidated his power. Often enough the streets resounded with the cry of "Popolo ! popolo !" Often enough, by treason or by the successful conspiracy of exiles, the tyrant was attacked and overthrown. During the earlier years of the rule of the despots there is not a single example of a ruler who retained his power for ten consecutive years but, either he succeeded in reinstating himself, or another despot filled his place. Liberty was not re-established; every revolution was accompanied by scenes of blood and horror ; it was followed by wholesale forfeiture and compulsory exile. And the man who contrived to secure the judiciary powers of the Podestà and the military authority of the Captain of the People, and united them in his own person, found himself surrounded by men who up to that moment had been his associates and equals, who were not ready to submit tamely to unquestioned authority; his foes in exile were in arms ; they usually had the support of rival cities, and were ever plotting to overset him and his party ; the fate of his predecessors and neighbours served as a warning of how short a time his tenure of power might endure, and that, so far from transmitting sway to his posterity, he might deem himself exceptionally favoured if he could preserve it to himself. He usually owed his position to military talents and clever double-dealing; he had to maintain it by relentless and perfidious policy. Intricate and subtle craft, artifice and device, wile and circumvention, chicanery and cunning, marked the diplomacy of the Visconti at Milan, the Scaligeri at Verona, the Marquis Cavalcabo at Cremona, Alberto Scotto at Piacenza, Venturino Benzone at Crema, Correggio at Parma, Beccaria and Langusco at Pavia. Acts of bad faith, duplicity, fraud, treachery, and unscrupulous dealing, constantly repeated, debased the public conscience, and made rulers dead to honour and lost to shame. To cheat was to be sagacious; to be cruel was to be secure. The man who knew all the expedients which he could employ, who was determined to let no scruple interfere with his doing the best he could for himself, who could deliberately employ all means to his own advancement and his own ends, was the one most likely to attain a precarious and usually brief tenure of power. Once possessed of power, it had to be preserved by the continued exercise of the same qualities. The despot employed his mastership in pursuing the allurements of his fancy or the gratification of his lusts. Every power of the human soul, except the ethical sentiment, was thus called forth and developed by unceasing discipline and exercise. Ability, not birth, gave position to the tyrant; it was also the key that unlocked the favour and rewards of the Court. The despot had no legitimate title to sovereignty, unless he happened to be an 
Imperial Vicar, or could procure that title. The bar-sinister was disregarded in Italy. Bastardy was no hindrance to merit; a family in peril rallied round the ablest of its sons, whether lawfully begotten or not. There were no feudal prejudices, but there were often resentful kinsmen, and domestic bloodshed became an everyday occurrence in Italy. Sometimes his family would sacrifice a ruler to the public wrath ; sometimes the whole family participated in the rule of the State, because the ruler required advisers, and he might deem those of his own household the least unsafe for his confidences. The greater tyrants, with no legitimate title, and often with no marked distinction of birth, had nevertheless to take a position in the Imperial scheme ; they encouraged the artist, the preacher, the man of letters-all who might add to the dignity and lustre of their little Courts. In the clash of wit and the conflict of argument they disciplined and sharpened their own mental powers ; they exercised themselves in sampling and gauging the intellects and characters of men at the same time that, by the renown of some and the servility of most of their distinguished suppliants, they enhanced the brilliancy of their own meteor-reputations. They welcomed distinguished exiles of their own political colour. Polenta of Ravenna and Can Grande della Scala welcomed the banished Dante, who tells us in one of his restrained and pithy passages how hard it is to eat the salt of such hospitality and force one's knees up the princely stairs. A refugee-historian of Reggio, one Sagacius Mucius Gazata, has left us an account of the munificence of Can Grande: "Different apartments were assigned to each guest with servants, and each took his meals, daintily served, in his own room. The different rooms were indicated by diverse symbols and devices; frescoes of Triumphs for warriors; of Hope for exiles; of the Muses for poets; of Mercury for players; of Paradise for preachers. During the repast musicians, buffoons, and jugglers perambulated the chambers; the halls were adorned with paintings which suggested the vicissitudes of Fortune ; and Cane sometimes invited certain of his guests to his own table, notably Guido di Castello of Reggio, who, on account of his sincerity, was called the simple Lombard, and the poet Dante Alighieri."

The encouragement bestowed on letters gave rise to much fulsome flattery, for the poet praises in proportion as he is paid ; it tended at first to the encouragement, but ultimately to the degradation, of belles-lettres and the arts, and to the decay of the human spirit. For if the Republics were turbulent, at least every citizen could play the part of a man ; and out of the seething ferment of city life there soared heavenward into free air the unfettered genius of Italian intellect and sensibility; but a subtle corruption invaded the talent that was attracted to the petty Courts of Italy. These seemed to nourish genius, but they really pampered it ; they were subtle means of restraint, whereby the highest soarings of the spirit were rendered impossible, and degeneration and death became inevitable. The luxury of these little Courts and the decay of civic spirit told back, even on commercial energy. Venice and Florence and the Tuscan towns were still free, and their merchants were to be met with in the streets of London and Paris, and in the bazaars of the Orient. Northern bankers, who had given a new word for their occupation- "les Lombards "- to the French language, gave place to others ; and the men of Florence and Lucca, and not those of Asti and Milan, were to be met with in the exchanges of the foreigner. The industry of Lombardy could hardly perish-it was too rich 
a land-but it became restricted to agriculture and manufactures. The emulation of the little communes was lost. The wealth and power of the tyrant depended on the growth of his city ; for this reason, and because it was necessary to swallow lest they should be swallowed, the rulers and cities most fitted to the struggle continued that policy of warfare and absorption of their neighbours which Milan and the free communes had begun. The councils were retained, and the burghers enjoyed a good meausre of selfgovernment in purely civic affairs. Taxes were left pretty much as they were; a land-tax was raised on valuation; the despot got his income from excise and from the confiscation of the property of his foes. Occasionally cities suffered spoliation at the hands of their master, when he could contrive it aptly; and for many years the cities of Central Lombardy were in a deplorable condition, even under the best of these rulers. They were rigidly governed; their territories were ever being overrun and devastated by foreign foes and their own exiles ; castles were often in revolt against the city and its despot ; and ravage which could not be suppressed was punished by reprisal, which only aggravated the evil. But in this respect the Lombard cities were hardly, if at all, worse off than the Tuscan republics, where wholesale proscription was a commonplace. For example, the Annales Arretini tell us that in I 340 the Ghibellines of Arezzo, between the ages of thirteen and seventy, were banished en masse ("Quod omnes Ghibellini a XIII. annis usque LXX. exirent de civitate"). And no one arose to question this procedure as being anything but eminently wise and just.

b. The conquest and absorption of smaller towns by the great cities, and the more or less successful formation of dynasties in Milan and other cities, prepared the way to the transformation of Italy into a continent of small States. For a long while, however, the formal consent of the communal councils to his dictatorship was sought by each successive tyrant, and legitimatized his sway. The history of the larger and therefore securer powers, thus become one-man powers, is evil reading; but that of the smaller States is far worse. There the ruling families were equally numerous and equally greedy with those of the major tyrannies, but their means were less, and consequently they were less able to secure themselves. They poisoned and cut each other's throats with the greatest complacency in their struggles for inheritance, and the fittest villain survived and flourished. The only small tyrannies that furnished examples of judicious government or intellectual ardour were those that were connected with or dependent on larger States. In the larger States the tyrant soon lost his soldierly qualities, but he preserved and improved his mental qualifications for rule. In course of time, as we shall see now or in our subsequent narrative, all sorts of people rose to the headship of States : feudal lords, like the Este of Ferrara ; Vicars of the Empire, like Eccelino of the Trevisan marches; burghers, like the Medici of Florence, the Bentivoglio of Bologna, the Baglione of Perugia; Captains of the People or Podesti, like the Torriani of Milan and the Carraresi of Padua ; mercenary captains, like Castruccio Castracani of Lucca and the Sforza of Milan ; and sons or relatives of the Pope, like Bertrand du Poïet, and later the Riario, Della Rovere, Borgia, and Farnese.

Occasionally the policy of cruelty became a monomania; the bloodthirstiness of Eccelino da Romano was never surpassed. Materially there can be no doubt that the citizens were better off when they became subjects. 
Painting, music, sculpture, architecture, science were fostered; freedom of speculation and of speech was gradually stifled. Even in the kingdom of despotic Frederick II. men had been wont to discuss abstract questions of government, and St. Thomas Aquinas, his subject, wrote about an ideal constitutional monarchy, with an Upper House nominated by the Sovereign and a Lower House appointed by the people. He also allows the people the right to revolt, but this kind of speculation, which in the eleventh century extended in the monasteries to theological scepticism, was purely academic. And while the academic theory of the Two Swords still held sway, the practically-minded despots of the North simply used the advent of the Emperor to their own ends, and shut their gates on him when he had served their turn.

\section{The Visconti, Scaligeri, and their Neighbours}

Napoleone della Torre had got the Emperor Rudolph to name him Imperial Vicar, and it seemed as if the Torriani were permanently fixed in their rule over Milan. Several years before his legalization of position the head of the family had been created perpetual anziano, and exercised almost absolute rule over the city and neighbouring towns. The family could command I, 500 horse, besides the troops of the city it held together, and the chief offices of the State were divided among its members. During a succession of short-lived Popes, the Archbishop, Otto Visconti, took advantage of the unlikelihood of Papal interference, collected forces, and surprised and captured Napoleone, who ended his life in a wooden cage. The dynasty of the Visconti succeeded that of the Torriani (1277). The Torriani had established themselves by espousing the popular cause; they had risen to sovereign power by abasing and proscribing the nobility. The Visconti returned at the head of the exiles, but they were now little more than a rabble of mercenaries ruined by prolonged banishment. The people had become familiar with subjection; and, while they had their councils and associations as before, they were no longer animated by any vital principle of independence; they no longer possessed any quickening enthusiasm for frecdom. The Visconti ultimately transmitted their rule to foolish and degenerate offspring, but the Milanese, even when they rose in revolt, never again made a whole-hearted bid for liberty. The Torriani replaced the Visconti in I 302 only to give place to them again in $131 \mathrm{I}$. Cremona revolted against Henry VII. in I3II; he razed its walls and ruined its citizens by the imposition of a tremendous fine, while the city was given over to the license of the German soldiery. In I3I5 Cane della Scala, the lord of Verona, allied himself with Passerino, lord of Mantua and Modena, with the design of subjugating the defenceless town as well as Parma and Reggio. The allies ravaged Cremonese territory; they occupied villages that had no means of resistance; they took fortified places by assault, and massacred their defenders; they advanced as far as a suburb of the city. The Cremonese were at famine-point; the populace accused the big burghers of being the source of their woes, and demanded that the example of neighbouring cities should be followed, and that one of their own citizens should be entrusted with supreme command. But the oligarchical party resisted for a while, and one of the Ghibelline leaders, 
a certain Ponzino Ponzoni, vowed that he had rather see the place of his birth in flames than under the yoke of a tyrant (Albert. Mussat. de gest. Ital.). A riot followed, however, and the Marquis of Cavalcabo was given the lordship of the city. The oligarchs of the Republic withdrew to the villages, and incited them to resistance. Ponzino was urged by Cavalcabo to return, but he replied that " he had always fought against servitude, and no motive remained to fight foreigners if the sword of tyranny was hung over one's head ; that he had no country unless Cremona were free." In six months Cavalcabo gave place to another despot, and in I322 the town fell to Galeazzo Visconti, the lord of Milan. Meanwhile another great despotism was arising hard by. In I260 Mastino della Scala had profited by the ruins of the House of Romano. He became lord of Verona, and although he was conspired against and assassinated in I277, the tyranny passed, as an inheritance, to his brother and his brother's children. This was one of the exceptions in Italian history wherein a tyranny became dynastic. Other despotisms were the Houses of Este, at Ferrara, Polenta at Ravenna, and Camino at Treviso, Feltre, and Belluno.

Cane della Scala, who had attacked Cremona, was strong, ambitious, bold, restless, a capable warrior and statesman. $\mathrm{He}$ had aided Henry VII. to the utmost of his power, and he sought and obtained the title of Imperial Vicar and the lordship of Vicenza as a reward; and Vicenza deemed it policy to open her gates. Cane garrisoned the town with mercenary soldiers of many lands, who were consequently incapable of combination against him, and whose interest lay only in obeying his commands. The restless turbulence of Padua led to more than one war between Cane and that city, which ended in the loss of its liberties to the Carraresi. From the point of view of the Ghibelline despot there was far greater chance of peace with a city governed by a Ghibelline chief, whom he could enter into alliance with or replace either by himself or by some dependant, whether by force or fraud, than with a republican town, distracted by conflicting counsels, with no steady calculable policy, and setting an example of freedom, by far too hard by his own subjects to be suffered by a prudent ruler. And then there was always the incentive of ambition and love of power.

During the wars of succession in Germany the Papacy, aided by King Robert, claimed control of the Empire during the interregnum, and in the fierce wars which ensued, while the free cities were on the Guelph side, fighting for their independence, the Ghibelline chieftains, under the mask of duty to the Empire, fought to maintain and enlarge their despotisms. The two most distinguished of the Ghibelline chiefs of North Italy were Matteo Visconti and Can Grande della Scala ; and whatever antagonisms of policy might have disturbed their good relations in quieter times, they were so hard put to that they and all the Ghibelline leaders kept shoulder to shoulder. In I 3 I 5 Matteo Visconti found himself so beset by the exiles of Bergamo on the east and the Guelph party of Pavia, Vercelli, and Alessandria on the west, that he was on the point of losing Bergamo. But he was no less skilled in diplomacy than in war. He granted the Bergamesque exiles an advantageous peace, and then threw his full force on the Pavisans, whom he first defeated, and then took their town by surprise. He managed by this success to secure the persons of several 
members of his ancient enemies the Della Torre, and Pavia was so severely treated that Tortona and Alessandria sent him their submission. He was now master of Milan, Como, Bergamo, Pavia, Tortona, and Alessandria. Of all the stout and wily captains of the Ghibelline party Matteo was considered as the most perfect model, and he received from his contemporaries the title of "Great." More than once, when his party was hard pressed by a faction of fellow-countrymen, not inferior to themselves in number or energy, struggling against the superior resources of the King of Naples and the wealth and prestige of the Papacy, threatened by France and Germany alike, Matteo had been its mainstay and salvation. He was but ordinarily brave, no very exceptional general, but his political ability, his knowledge of the workings of the human heart, his imperturbable calm, his promptitude and undeviating purpose in action, his skill in dissimulation, his mastery over the strongest and most unconquerable natures, raised him above all the princelets of his time. At first he had been arrogant, and alienated alike his equals and his subjects ; and his fall in $\mathrm{I} 3 \mathrm{O} 2$ had been the consequent of his errors. But he had employed the nine years of his exile in self-discipline, and qualified himself for the leadership of his party; and, from the time that the coming of Henry VII. enabled him to seize the reins of government once again, though he carried on a ruinous war and ruled a people not remarkable for meekness, not a single town revolted against him, not a single one of his undertakings fell through. The thunders of Papal excommunication affected him not at all. He was never treacherous to his friends or cruel to his foes ; and his four sons were obedient to his lightest wish. But he was getting old-Villani gives him ninety years-and suddenly he seems to have awakened to the weight of the excommunication which had been pronounced against him. He sent an embassy of devout sons of the Church to the legate Du Poïet, to learn on what terms he could be absolved from his sins and the interdict removed from his dominion. Bertrand du Poïet had often been ignominiously defeated by Matteo, but the Churchman had forfeited none of his arrogance; he demanded that the Visconti should recall and reinstate all the exiles and enemies whom they had striven against for half a century, and then abdicate. This meant the ruin of the family ; but Matteo's "conversion " was so genuine, that he put the legate's answer before the council. Immediately the charm of his sway over them was broken. Everyone perceived that all had suffered to feed the vanity and ambition of a family. Galeazzo Visconti, the eldest son, hurried back from Piacenza and saved the situation. Matteo abdicated in his favour, and was henceforward to be seen ever haunting the churches of the State, repeating the Creed, and calling on the faithful to bear witness to his orthodoxy. He died the same year, I 322, but his death was kept secret, partly for policy, partly because the Pope had ordered his ashes to be scattered to the four winds (Tristani Calchi Hist.Bonincontrii Morigice Chron. Mod(ctiense). Galeazzo had been busily engaged in winning over the city and the army; and, when it was no longer possible to conceal his father's death, he considered himself strong enough to take the title of Captain-General; and a victory gained by his brother over Raymond of Cardona and the troops of the Church seemed likely to fix him in that position. However, a Ghibelline noble who had been exiled and his wife seduced by Galeazzo, contrived, by the aid of 
$\mathrm{Du}$ Poïet, to get up a revolt in Piacenza; and the pious people whom Matteo had entrusted to negotiate with the legate, aided by one Lodrisio Visconti, a relative of Galeazzo, so worked on the Milanese, that soon cries of "Peace, peace! Long live the Church!" were to be heard in Milan. The German mercenaries, whom Galeazzo had been unable to pay, joined the mob. Galeazzo, at the head of the troops that remained faithful, made three separate attempts to quell the insurrection. Thrice he failed, and then he turned his horse and left the city. The new Government consisted of the nobles who had engineered the rebellion and the traitorcaptains of the hired soldiers. There was no cohesion among the new rulers, no resolution in their councils. Lodrisio Visconti appears to have repented of the part he had played; he bought over the mercenaries. Galeazzo gathered all his forces at Lodi. The doubly traitorous " soldiers of fortune " reopened the gates of Milan for him, and he marched in at their head, and had himself proclaimed anew "Lord and Captain-General." The plotters in their turn had to flee away to the legate. But things were going badly with the Ghibellines. Marco, the most warlike of Matteo's sons, was twice defeated with great loss ; Tortona and Alessandria opened their gates to the legate ; the Guelphs of Genoa surprised and drove away the besieging Ghibellines; the people of Romagna revolted and slew the Count of Montefeltro, who ruled over them; Milan was besieged by Raymond of Cardona; and everywhere complete ruin threatened the Ghibelline cause. But an embassy arrived from the Emperor, and the Imperial name acted like a talisman. The lords of Verona, Mantua, and Ferrara rallied to the rescue, and the siege of Milan was raised (1323). But Galeazzo had enemies of his own house-Lodrisio Visconti, who had been a traitor before, and his own brother Marco, who shared his authority. When Matteo intrigued with the Pope it gave a handle to these conspirators, who were supported by those citizens who still sighed for lost liberty and the disaffected among the nobles. Cane, Passerino, and Franchino Rusca, at this time despot of Como, were also opposed to Galeazzo's policy. They made representations to Louis, who got his German mercenaries to seize Galeazzo, and locked him up with his family in his own horrible cells at Monza. But at the earnest solicitation of Castruccio Castracani, the Duke of Lucca, the prisoners were released, and Galeazzo became a mercenary leader under Castruccio. He died of fever the following year. In I 328 Louis offered to sell Milan to the Visconti. Giovanni, the third son of Matteo, accepted the red hat from Louis's Antipope ; and Azzo, Matteo's nephew, promised to pay the purchase money. Once seated in Milan, Azzo shut its gates on the returning Emperor, preferring open war to the dangerous honour of his presence, accompanied, as he was, by a crowd of hungry, reckless foreign troops. In quarrelling with the Emperor, Azzo had become the good friend of the Pope. He substituted the title of Vicar of the Church for that of Vicar of the Emperor, and procured a bishopric for his uncle, who renounced the red hat of the Antipope. But there soon returned to Milan another uncle, Marco, the brave, restless, and skilful soldier, who had covered himself with what is commonly termed glory in the service of Castruccio Castracani, who was regarded as the hope of the Ghibelline cause, and who was enthusiastically received by the Milanese. Such a man, with such a reputation, was dangerous. Azzo invited him to a family gather- 
ing, and, as Marco was leaving the sumptuous feast that had been prepared, requested a private interview with him. Marco was waylaid by assassins and strangled as he was making his way to keep the appointment, and his body thrown out of the window on to the public square. This is no isolated deed of blood and treachery. Azzo was a mild and humane ruler, but he had acquired Milan by the expenditure of personal effort and private means, and he was resolved to keep at all costs what he had so laboriously obtained. He acted according to what was fast becoming an established code in despotic families, where to be weak was to be undone, and to rule and remain secure in one's rule implied the absence of all moral scruple and similar feeble superstitions.

The elder generation of tyrants had been men of a manlier type. An atmosphere of license and self-indulgence, when self-indulgence might be safely exercised, now pervaded these petty Courts. A man of austere character became, like Cassio, suspect-" He hath a lean and hungry look: mistrust such men." The air of the Court was lax; the nobles, for whom no other career remained open, gave themselves up to pleasure. Now, the son of Passerino of Mantua spent much of his time in debauch with his three cousins, the Gonzaga, and one of these was supposed to have an intrigue with Passerino's mistress. The young lord swore to be revenged on the wife of the seducer, and the Gonzaga obtained secret aid from Cane della Scala, for tyrants, unless they were leagued in opposition to a common danger, usually had some sufficient motive to help abase a neighbour. Though Passerino had lost Modena, which, aided by the Church, had revolted, he was, nevertheless, regarded as the most firmly-established lord in Lombardy. He made much of the Mantuan nobles, and secured their constancy by admitting them to his councils, and his city, seated in the midst of a lake, was considered impregnable. Cane may have regarded him as a dangerous man. Filippino Gonzaga retired to his country seat on the pretext of its being harvest-time, and he gathered labourers round him on whose loyalty and courage he could rely. One night he armed them, and the band joined the men-at-arms sent by Della Scala. Filippino's brother got one of the city gates opened to him on pretence of some love-tryst, and forthwith the troops entered, and shouted to the men of Mantua to throw off the yoke of Passerino and his taxation. Passerino and his son were slain, and Ludovico Gonzaga, brother-in-law of Passerino, and father of the conspirators, was proclaimed lord of Mantua ( 1328 ), and confirmed as Vicar by Louis of Bavaria the following year. There his descendants ruled until the commencement of the eighteenth century.

One of the strong men of the old school of "tyrants" was Cane della Scala, surnamed the Great. A man of unflinching character, he was frank of speech, faithful to his principles, and scrupulously observant of his word. He secured not only the love of his soldiery, but of his people, and even of his foes. The first among the potentates of Lombardy, at least after the death of Matteo Visconti, he became the special patron of learning and the arts; his Court was an asylum for all the Ghibelline exiles. There might be met Dante and other poets; and Verona remains adorned even to this day by monuments of Can Grande's love of the beautiful in architecture. But while encouraging the arts of peace, he found his chief occupation and glory in warfare. The family of the 
Scaligeri had for some time been lords of Verona, and, in I3I2, Cane obtained from Henry VII. the title of Vicar. In I3I5 he was the acknowledged chief of the Ghibelline league in Lombardy, and Vicenza, Feltre, and Cividale were under his rule. In I 328 Marsilio di Carrara, who ruled in Padua in the Guelph interest, finding himself unsupported by either the Pope and King Robert, the Duke of Austria and the Duke of Carinthia, or the Republics of Venice, Florence, and Bologna, powers to which he had appealed in vain, came to terms with Cane. A matrimonial alliance clenched the bargain; Cane rode into Padua, and left Marsilio to rule as his lieutenant. In the following year Cane attacked Treviso, which capitulated, and he became absolute ruler of the Trevisan marches, but he was assailed by a mortal malady at the very moment of his triumph. He was carried to the Cathedral, and died on the fourth day of illness, at the age of forty-one. He left no legitimate offspring, and two nephews succeeded him. One, Alberto, was a devotee of pleasure, and left the cares of sovereignty to his brother Mastino, who reproduced the talent but not the virtues of Can Grande. By this time the terms Guelph and Ghibelline covered legacies of hate. Sons fought on the side that their fathers had adopted; old scores had to be settled, and blood to be avenged by blood. Neither party had a monopoly of despots or of free communes. The D'Este at Ferrara, the Carraresi at Padua, the Rossi at Parma, the Malatesta at Rimini, were Guelph. Florence, at the head of the party, was, however, the champion of liberty, and the glory that she achieved in her fight for freedom reflected itself on the whole party; and by the end of the fourteenth century Guelph and republicanism, Ghibelline and despotism, had once again become convertible terms. But at the period of which we write Italy was torn by insensate faction and insatiate ambition, private and public ; and Empire and Papacy were alike in a decadent state. Florence entered into a league with the Ghibelline rulers of Lombardy and Robert of Naples to check the pretensions of John of Bohemia, and to prevent the transference to the Empire of lordships which John had been unable to preserve. The nobles to whom estates had been sold negotiated, one after another, to give up their towns on conditions profitable to both parties. Through the mediation of Florence it was arranged that Piacenza, Cremona, and Lodi should fall to Visconti, Parma to Mastino della Scala, Reggio to Gonzaga, and Modena to the Marquis of Este. All of the confederates had gained their ends except Florence. She had spared the territory of the Lucchese because she hoped to become its mistress by purchase. The Rossi, who had been nominated lords of Lucca, sold Parma to Mastino, and, blindly relying on his friendship, allowed him to negotiate for them and enter Lucca with 500 men-at-arms. But Mastino was fully aware what a vantage-ground he had acquired in a strongly-fortified place in the heart of Tuscany. His dominion stretched from the Alps to its borders, and he felt, like Rollo, in Normandy, "J'y suis ; j'y reste." He began to make his influence felt in the Ghibelline cities of Pisa and Arezzo, which respectively close the valley of the Arno to the west and south-east of Florence. Mastino, established in Tuscany, might aim at the sovereignty of all Northern and Central Italy, if not of the whole peninsula. The dominion of the tyrants had, in some measure, cemented the common bond of language between their oppressed subjects and dependent cities. 
There were even the first faint movings of the spirit of national life. But self - interest was a vastly more powerful lever. Siena, Bologna, Perugia, and Venice united with Florence to oppose Mastino; the Ghibelline despots of Northern Italy entered the league. Charles, the son of John of Bohemia, and the Duke of Carinthia, attacked Mastino and captured Cividale and Feltre ; but the army of the Visconti merely marched into his territory and back again (Cortusior Historia.-G. Villani). Piero dei Rossi, the Florentine general, hung about Padua awaiting his opportunity. Now Padua was under the rule of Alberto della Scala, the pleasureseeker, who abandoned all business to the Carraresi. We are told that he had even dared to force the wife of Ubertino of Carrara, and saw in Ubertino either the forgetful or complaisant husband. Ubertino held his peace ; but he affixed two inconspicuous horns of gold to the crest of his helmet, and bided his time (Ist. Padovana di Galeazzo Gataro). Mastino was suspicious of the Carraresi. He wrote to his brother repeatedly, begging him to be on the watch, to arrest, even to murder, the suspects. He discovered that the Carraresi were intriguing with the State of Venice, which, of course, was most anxious to break the power of so menacing a neighbour as Mastino, and wrote off to his brother to seize the traitors at once. Alberto was playing chess when the letter arrived, and he gave it to Marsilio di Carrara to read. Marsilio perused it without moving a muscle. "Your brother," said he, when the game was over, "writes to say that he wants you to send him a peregrine falcon at once for his hawking." He took care not to let Alberto out of sight the whole of that day, and warned Ubertino to get ready for a night's work. In the dead of night the followers of the Carraresi stealthily surrounded the palace; the Guelphs opened the city gates to Piero dei Rossi and his cavalry; Alberto was surprised, seized, and carried to the prisons of Venice, accompanied by his buffoon, who insisted on sharing his lot. Piero dei Rossi kept good discipline in his troops ; Padua suffered no damage, and Marsilio di Carrara was made lord of Padua by the citizens, and joined the Florentine-Venetian alliance. Piero dei Rossi was killed in battle shortly after, and one of his brothers succeeded him in command, but did not exhibit his talents. Nevertheless, Brescia revolted and went over to Azzo Visconti (1337). Mastino now became very hard pressed. The son of John of Bohemia held the mountains against the Emperor Louis, who could do nothing for his ally, so Mastino adopted the time-honoured policy of detaching one of the confederates. $\mathrm{He}$ arranged matters with the Venetians, whose policy was ever consistently self-seeking. He ceded to them the fortresses that they required to secure a food-supply from the mainland. The Florentines got next to nothing; the Rossi were restored to Parma ; and Alberto della Scala was set free (1 $33^{8}$ ).

But while Italy was secured by this treaty from one menace, she was threatened by the growing preponderance of another and still more powerful despot. The dismembering of the possessions of the Scaligeri had augmented the might of Azzo Visconti. He alone of all the rulers of the period concerned himself with the interests of his people and sought to strengthen his ascendancy by making himself beloved. The mildness of his rule secured him well-wishers throughout Italy; and we have seen how the Brescians became his willing subjects. Mastino meditated revenge at the very moment when he signed the treaty of peace with 
Azzo. Vicenza was surrounded by encampments of mercenaries, who refused to budge until they were well paid, and caused equal concern to Mastino and their late employers. These troops were for the most part veterans who had followed the Emperors, and forsaken them, or remained behind, for the sake of better pay. It mattered not to them for whom they fought so long as they could secure the best terms for themselves ; they had become a pest to the country, because citizen forces, however numerous, were of little avail against their discipline and experience. The Italian rulers and free cities competed for their services in time of war; for, being of different nationalities, and speaking a different tongue, they were strangers to the passions that convulsed Italy, and were not so open to the wiles of diplomacy. Their employment saved the blood of citizens ; it allowed of more prolonged and effective warfare ; it admitted of a State continuing the arts of peace, and therefore of strengthening the sinews of war while engaged in hostilities. Since the mercenaries were often of the same race and spoke the same tongue; since they were strangers in a foreign land, and the causes of conflict were matters of perfect indifference to them, battles became merely a matter of tactics; the soldiers were unwilling to shed each other's blood; and, after the fight was over, the vanquished were merely despoiled of their horses and armour and dismissed without ransom. At present the Italians were chiefly aware of the great advantages of this mode of contest. They had yet to learn the irreparable evils that followed the employment of condottieri. The dealings of Mastino with the troops around Verona gave them a first lesson. Mastino employed Lodrisio Visconti as an intermediary - the man who had twice conspired against Galeazzo. Banished from Milan, he had found refuge in Verona. Lodrisio proposed to the troops that they should march against Milan and take out their pay in the pillage of that State. He pointed out that there were no troops assembled likely to oppose them; he reminded them of how the Catalan company had carved out a realm for itself in Greece, and he urged them to copy the example and make war on their own account and for their own benefit. The Germans were not slow to jump to the scheme of the wily, quick-witted Italian. They chose him and one of their number to lead; they called themselves the Company of St. George, and they advanced on Milan, 2,500 horse, and a great number of infantry. Their numbers waxed greater daily, for recruits were constantly falling in (Cortus. Hist. de Nov. Pad.). This time the contest was not bloodless. Instead of playing with war, the mercenaries had to meet an infuriated people. Each side achieved successes and experienced defeats; there were five bloody battles in one day, and these fierce fights of Parabiago put an end both to the war and the Company of St. George. Lodrisio Visconti and his two sons were taken; but the German troops were only disarmed and dishorsed, in order to avoid the expense of keeping them in perpetual captivity. Azzo had experienced great loss in these battles, but his success enhanced his prestige. He was at this time (1339) lord of ten towns in Lombardy-i.e., Milan, Como, Vercelli, Lodi, Piacenza, Cremona, Crema, Borgo, San Donnino, Bergamo, and Brescia-all close together, and forming a compact State. He had a legal claim to the heritage of one of the richest Sardinian families ; he thus became a citizen of Pisa; and that city was congratulating herself on the strength she had 
thus acquired, when he was suddenly carried off in his thirty-eighth year (1339). He was succeeded by his uncles, one of whom, Giovanni, bought the vacant archbishopric of the Court of Avignon for 50,000 florins, cash down, and a yearly payment of I0,000 florins ; while the other, Luchino, became lord of Milan. Luchino ruled there from I 339 to I349. He executed justice fearlessly and severely. He was a skilful man of war, and patronized letters. He sought renown by extending patronage, and Petrarch wrote pompously in his praise. But his policy was perfidious, his dissimulation inscrutable, and those of his own house, even, fell victims to his suspicious nature. It is said that he was poisoned by his wife to avert her own intended death. The Archbishop, Giovanni, who succeeded him, kept the aggrandizement of his house steadily in view. He was a man of indomitable will, of a self-reliance singular even in an age when everybody, to survive, had to possess that quality. $\mathrm{He}$ found himself lord of Milan, Lodi, Piacenza, Borgo San Donnino, Parma, Brescia, Crema, Bergamo, Novara, Como, Vercelli, Alba, Alessandria, Tortona, Pontremoli, and Asti. He had already arranged to buy Bologna of the Pepoli, and he now completed the purchase. Although a son of the Church, he successfully and intrepidly defied the Papacy. The Court at Avignon positively feared to interfere with him, and he placed himself at the head of all the despots of North Italy. By his aid Benedetto Monaldeschi became tyrant of Orvieto (135I). He secured Gubbio to Gabrielli ; and the death of Mastino della Scala, who was succeeded by his three weak and vicious sons, left him without a rival.

The House of the Scaligeri became degenerate, and its closing annals are marked by increasing crime. The two younger sons of Mastino murdered their elder brother. Each then plotted against the other, until one succeeded in imprisoning and finally murdered his brother to secure the succession to his own bastards. In the next generation we find the same crimes repeating themselves. A brother has his brother assassinated in order to reign alone, and we see him poisoned when a wretched fugitive from the advancing power of the Visconti.

Florence was now the only rival Power to Milan. Bologna could not be regarded as safely secured until Florence was overcome. Florence was unsupported by the other Powers, who thought the danger to themselves far off as yet. Visconti had enclosed Florence as in a net, and he sent Giovanni Visconti d'Oleggio to attack her. But Oleggio failed to take Scarperia, a fortified townlet which he attacked. He could not support himself in Florentine territory, where every herdsman had driven his cattle under the protection of walled townlets ; and, when he left Tuscany, the Guelph towns, awake now to their danger, had leagued themselves with Florence.

But the Archbishop knew how to employ the power of the purse as well as the force of the sword. He bought the mistress of the Pope and cardinals enough to acquire the Papal cession of Bologna; he kept Tuscany in a turmoil with his intrigues, and sent aid to the tyrants, so as to gain time, consolidate his power at home, and support little centres of despotic authority throughout Central Italy. When Albornoz came to Italy to reconquer the States of the Church, Visconti had no fear of interruption from the Papacy ; it had its hands full. He was free to attack the lords of Mantua, Verona, Ferrara, and Padua, relatively feeble, and divided 
among themselves. But the acquisition of Genoa roused alarm in Venice. Her ambassadors, assiduous and skilful, succeeded in reconciling these weak and quarrelsome princes, and a treaty was signed whereby each was to furnish 4,00o horse to attack the Archbishop, and Charles the Emperor was called to their aid (1353). Next year the Archbishop died of a carbuncle, from which neither he nor anyone had expected any great harm to arise, and the rule of his State passed to his three nephews. To the eldest, Matteo, voluptuous and inert, was given Piacenza, Parma, Bologna, Lodi, and Bobbio, with nominal precedence of the others ; Bernabo, the second brother, had Cremona, Crema, Brescia, and Bergamo, and he took the military command ; while Galeazzo, the youngest, took Como, Novara, Vercelli, Asti, Tortona, and Alessandria, and became Administrator-inChief of the entire State. The unity of the State was thus preserved by a concentration of the military and administrative powers in two distinct hands, while it was divided into three manageable sections, each presided over by one of the heads of the House. But, soon after, the eldest of the brothers died. He had had no scruple in violating the sanctity of the home in pursuing his pleasures; and the Visconti gave out that he had died from debauch. But it was current, and was believed in Italy, that his brothers, perceiving that his vices and insane disregard for the rights of husbands and fathers constituted a menace to the State, had had him slain by a dish of poisoned quails (Chron. Petri Azar.-M. Villani.-B. Corio Storia di Milano.-Ripamontius Hist. Med.-Pauli Jovii Matt. Grav.). Probably only a tenth part, or less, of the tales of Italian poisonings are true ; but there is overwhelming evidence that, in days when political differences were not settled by degenerate parties in manly conflict, and there was no polling-booth, but when, none the less, unanimity was essential to any Government at all; and could only be secured by slaughtering or exiling the weaker side, foci of disaffection had to be ruthlessly suppressed, even at the cost of violating all natural feeling. Self-preservation and the welfare of the State demanded the secure imprisonment of any dangerous member of a ruling family no less than of a foe, or even meting out the swift, more certain, and irreversible doom of death. To pity was to be weak.

The war with the Venetian league proceeded with no great manifestation of vigour on either side. The Visconti had two other wars on hand. Oleggio Visconti had so broken the spirit of the Bolognese by the merciless slaughter of conspirators, and by gaining the affections of his hired soldiery by successful arts, that he was firmly established in that town, and had become practically independent. So complete was his control of the city, that, incredible as it may seem, during the war with the Venetian leaguc, he led the Bolognese militia forth to the campaign armed with sticlss only. On the field he gave them their arms. After the victory he demanded and received their weapons, and marched them home again, armed only with their sticks (Matt. Villani.-Math. de Griffonibus Memoriale Historic.-Chron. Mutineuse.-Johan de Bazano.-Petri Azarii Chron.). The Visconti called on Oleggio to resign his lieutenancy of Bologna. He refused, joined the Venetian league, and played a distinguished part in the war. When peace was concluded (1358), Oleggio was recognised as an independent ruler. He aided the family to which he belonged in a war which they were carrying on against the Marquis 
of Montferrat. He aided Albornoz, and mediated peace in Romagna ; and he effected the escape of Lando and the Grand Company after their defeat by the Florentines at Scalella. But neither any members of the I ombard league nor any of those whom he had aided had any place in their natures for gratitude or any kind of unproductive sentiment. The Visconti not merely detached Lando and afterwards Baumgarten with all their mercenaries, and took them into their own service, but they also secured the services of the very men that Oleggio had lent them, and declared war on him. The legate sent him just enough men to safeguard his own designs. Florence refused aid, in spite of her own obvious interests, as she wished to maintain good faith and observe the treaty she had made with the lords of Milan; and, since defence was hopeless, the legate urged that Oleggio should cede Bologna to the Church. The situation was complicated. Bernabo Visconti tried to buy the legate; he also tried to buy Oleggio ; Oleggio was in treaty with both sides (I360). But the legate seems to have been the highest bidder. Oleggio escaped by a ruse from the city which he had tyrannized over for five years, and that was preparing to pay old debts with interest; and the legate, while he gave the rule of the city into capable hands, restored its municipal government. Bernabo Visconti was informed that the Pope had claimed his own again, and was ordered to remove his troops from Papal territory. Visconti retorted that the Pope had infeodated Bologna to the late Archbishop for a term of years. The cardinals, many of whom had been bought by Visconti, pronounced against him, however, and war commenced. Albornoz called in Hungarian soldiery, the dregs of a people still halfbarbarous, and since he got little pecuniary help from Avignon, let them ravage the country, which they very effectually and brutally did. But they taught the Italians a military lesson-the use of light cavalry. The Milanese were finally repulsed with great slaughter, and it is said that Bernabo, on learning of his defeat, put on black, and for many days no one dared approach him (I36r). Finally, three years later (I 364), Visconti renounced his claim on Bologna on condition that Albornoz, who was sometimes wont to act independently of Papal sanction and support, should be replaced. At the same time he made peace with Montferrat and the smaller Lombard States, with whom a prolonged war had been carried on. It was, indeed, felt by everyone that the sufferings endured at the hands of the companies which harried Italy when at peace no less than Italy when at war, required united efforts for their subordination or ejectment.

The war with the Visconti and the Marquis of Montferrat which we have just mentioned had lasted for some years. The Marquis was Imperial Vicar of Piedmont and lord of Turin, Alessandria, and other important towns ; he joined the small States of Lombardy, Padua, Verona, Mantua, and Ferrara, which were leagued in opposition to the growing power of Milan. He had a private cause of quarrel with the House of Visconti, and he succeeded in detaching the Beccaria of Pavia, who were lieutenants of the Visconti, and who owed the long continuance of their authority, and the consequent increase of their wealth and power, solely to the perils of displacing them while so dangerous an enemy as Montferrat remained at their gates. One after another all the cities in Piedmont under the rule of Milan declared for Montferrat, who was a universal favourite in Piedmont. The 
Visconti concentrated their full forces on Pavia, in order to punish the Beccaria ; the city was closely besieged; and appeared certain to fall, for the Beccaria were not merely divided among themselves, but were notoriously lascivious, degenerate, and in every way debauched (Petri Azarii Chron.).

Italy has never been wanting in patriots--pure, unselfish spirits, many of whom have gone their way to martyrdom with unshrinking and faithful step, have fearlessly entered the dark and forbidding portal, and so, through dusty and oblivious death, have kept alive the vital germ that today vivifies and reanimates united Italy.

"Unto each man his handiwork, unto each his crown The just Fate gives ;

Whoso takes the world's life on him and his own lays down, He, dying so, lives."

There appeared in the fourteenth century a man who was perhaps the strongest of all this glorious band, and whose name is none the less almost forgotten. His work ended in failure-failure that had no dramatic finish ; he lived out its memory, indeed, half-dead, in the enforced and ignoble silence of a convent-cell. To those who know the story of Fra Jacopo dei Bussolari, he is one of the immortal dead who lived-

"In deeds of daring rectitude, in scorn

For miserable aims that end with self."

Fra Jacopo had devoted himself to the religious life at an early age ; he had joined the Augustines, and his superiors took him from the seclusion of a hermitage, and sent him to preach at Pavia. His earnest eloquence produced a strong impression and even some reform in the life of the city; and the heads of the Beccaria, aware of the dangers with which their House was menaced by the dissoluteness of its younger members, supported him. One of them who was ill, used constantly to be carried in a litter to hear his discourses. For nearly half a century the Beccaria had ruled in Pavia ; the city had prospered commercially under their sway, but the effect of material well-being on a restrained and dependent people was manifest in the degeneration of both rulers and ruled.

Fra Jacopo did not belong to that unctuous race of popular preachers who content themselves with the platitudes of subjective ethics. $\mathrm{He}$ thundered against public abuses, the outward agencies that cripple and deform the spirit of man; against the egotism and cowardice that counsel resignation to slavery; against the corruption, the injustice, the cruel indifference, the positive oppression of those set in high places. $\mathrm{He}$ aroused the people against the Visconti, who had held them in the hollow of their hand ; he got aid from the Marquis of Montferrat; he led his followers from the altar-steps to the attack of the three redoubts which were occupied by besieging German troops, and such was the vigour of the onslaught and the care with which he had made his preparations that the trained mercenaries fled from before him, and the siege of Pavia was raised at the very moment when all Italy was expecting her fall (1356). Bussolari continued to denounce tyranny; discourses that had been useful to the Beccaria when directed against the Visconti became dangerous when applicable to themselves. The friar had served their turn when he beat the 
besiegers off, but the new spirit that he had infused into the people had bəcome a dangerous force in his hands. They attempted his assassination, but the citizens formed themselves into a guard that constantly accompanied him. Bussolari took the precaution to assure himself of the support of the Marquis, and then he ascended the pulpit to lay bare the degraded servitude into which the city had fallen at the hands of corrupt masters ; he exhorted the people to cast off their shameful yoke. Then and there he nominated twenty of those present as leaders and tribunes of the people ; he instructed each of them to form a company of 100 men in his own district; he appointed four commanders, and his selection was confirmed by the unanimous voice of the congregation.

Without force or violence of any kind, by mere passive resistance, the Beccaria beheld themselves divested of all authority. In vain did they endeavour to murder the friar; his vigilant guards frustrated every attempt. They appealed to the Visconti, and tried to throw open the gates of Pavia to their forces. But the watchful monk was aware of the intrigue; he disclosed it to the people; and a captain took word from the democracy to one of the Beccaria to leave the city. Tremblingly and hastily the proud noble obeyed; his brother followed him, and, established in their own strongholds, they sought, night and day, to contrive with the aid of their creatures inside the walls to retake the city. These intrigues were also discovered ; twelve conspirators were executed, and all the Beccaria were driven forth (1357). Bussolari was a friend of Petrarch's. Petrarch, who was in the service, and enjoyed the hospitality of the Visconti, to his eternal disgrace, was subservient to their desires, and wrote to Bussolari begging him to exert his influence towards peace rather than war, towards submission rather than revolt. The poet, sincere only in his devotion to nice shades of feeling and delicate cadences of phrase, moved the honest, earnest preacher not one jot. Nor did the friar pay greater attention to the commands of his religious superiors. He not merely directed the fortunes of the new Republic from the pulpit, but he worked as well as talked, followed his flock with their sickles, helped to reap from the territory of the Visconti a harvest to replace that which had been rapt from their own lands. In I 358 the Visconti, discouraged by the perfidy of their mercenaries and the loss of their possessions in Piedmont, as well as those of Novara, Como, Pavia, and Genoa, came to terms with Montferrat; he was to give back Asti ; Pavia was to remain a republic. But though both sides were exhausted, these articles of the treaty were never carried into effect ; the Marquis did not surrender Asti ; the Visconti still tried to get hold of Pavia. Bussolari dreaded lest the palace of the Beccaria should serve as a fortress to some of their adherents; he urged the people to demolish it, and forthwith not one stone was left standing upon another ; the chips were carried away to serve as heirlooms and memorials to future generations of the fall of a tyranny. Money was needed to subsidize the troops of Montferrat, for the town was again closely invested, and these alone could raise the siege. Bussolari contrasted personal vanity with civic duty in his discourses, and women sent in their jewels and silks and brocades, and naught of gay attire was to be seen in Pavia-only black mantles and coarse gowns. Next year ( 1359 ) the Marquis succeeded in getting some provisions through the investing lines, but the enemy was closing tighter on the city. The exiled Guelphs had been readmitted, but 
the Beccaria, dwelling in their castles, had recovered their ancient influence over the Ghibellines of the countryside ; the country people had not come under the spell of Bussolari's personality and stirring appeals to large issues; and Ghibellinism, the patronage and protection of the landlords, was the predominant creed of the land. The old rallying cries were renewed; the whole of Pavian territory was in league with the Ghibelline enemy, and Montferrat could render no service, for the Grand Company had betrayed him and passed over to the lords of Milan. Pestilence, moreover, appeared in the beleaguered city. Bussolari saw that further resistance was futile. He arranged terms of capitulation; he secured permission to the Guelphs to continue to reside in the city to which they had returned; he got the municipal government, which he had re-established, confirmed by the victors; for himself he asked nothing. Galeazzo Visconti promised everything; he broke every oath; he cited Roman laws, and suborned jurisconsults to demonstrate that, as Imperial Vicar, such oaths did not bind him. He sent the Guelphs packing, abrogated the municipal constitution, and substituted his own autocratic authority. In this depth of their humiliation the Pavians lost not one jot of their reverence and love for Fra Jacopo ; they followed him wherever he went with earnest and affectionate solicitude. Galeazzo carried him away to Milan, and not daring, perhaps, to adopt stronger measures against a Churchman, and one who held the devoted affections of a subject-city, he handed him over to the tender mercies of his own superiors. The subservient Order, on the pretext of ecclesiastical disobedience, condemned him to that cruellest of martyrdoms- " to live a life half dead, a living death, and buried," in the dungeon of the monastery at Vercelli. There this true soldier of the Cross endured, like his Master, that worst of all human sufferings, that experience of failure and sense of desertion which is the last bitterness possible to the heroic soul (Matt. Villani.-Benvenuti de S. Georgio Hist. Montisferv.-Franc. Petrarchee Familiares Epistola, I7.-Petri Azarii Chronic.).

Meanwhile the league of Montferrat, Mantua, Verona, Ferrara, and Bologna had engaged the services of the Grand Company, which was subsisting, in its accustomed predatory way when unemployed, on the little State of Ravenna. These States also addressed themselves to the Emperor Charles for aid. Charles was glad of an opportunity to resent the indignities to which the Visconti had exposed him ; but, with his usual weakness, he preferred to do so covertly, and therefore, since he had no great genius for profound and well-calculated dissimulation, he did it ineptly. He had left a vicar behind him at Pisa, one Bishop Marcovald, who found himself quite without authority, and decidedly uncomfortable in that turbulent town. Marcovald was permitted to proceed to the army of the league, but with the understanding that it was not to leak out that Charles had sent him until victory was certain, when he might use the Imperial authority. But the militant Bishop was burning for an opportunity of personal distinction. When he arrived at the camp, he found it already joined by the Grand Company, and he lost no time in unfurling the Imperial colours, and summoning the two Visconti brothers to appear before him as guilty of tyranny and treason (Matt. Villani) (I 356).

The Visconti replied that they were permanent Vicars of the Empire, and as such would visit Marcovald with capital punishment for putting himself at the head of a band of brigands. But Visconti's inercenaries, 
men from Germany and Brabant, under the pretext that they could not advance against the Imperial flag, remained in the cities ; they did not wish to fight against the Grand Company, which was always a harbour of refuge ready to receive them when business was dull and purses thin; and the Visconti dared not compel them, knowing that they would at once pass over to the ranks of the enemy. Consequently, at first, the allies had it all their own way.

But the Grand Company was no more eager for conflict than the Visconti's soldiery. Instead of advancing to the siege of Milan, they contented themselves with ruining the country by pillage and dishonouring its women, and positively refused to march. The Marquis of Montferrat came to the conclusion, in which he was quite warranted, that the two armies had a complete understanding with one another, and that they were only enemies to the country that they pillaged. He suspected that his men would deliver him over to the Visconti, who had put a price on his head, so he quitted the army with 500 horse, and contrived to surprise and take Novara. The lord of Parma left a few days afterwards with 700 horse, and attempted to take Vercelli, but without success.

The Milanese put old Lodrisio Visconti at the head of their troops, the same man who in I 322 had re-established the Milanese Republic, who in 1327 had delivered Galeazzo over to Louis of Bavaria, and in I 339 had conducted the Company of St. George at Parabigio against the lord of Milan. The mercenaries did not dare to disobey him; he led them against the Grand Company, and after an obstinate resistance, Marcovald and 600 of his men-at-arms were taken prisoners, as well as Count Lando and nearly all the other leaders of the Grand Company ; but these were quietly let go by their friends the mercenaries. By I 358 both sides were heartily sick of the war; they could neither do with nor without the mercenaries, and these had such a good understanding with one another that all their battles were shams; every real attempt of the combatants at strategy or tactic was balked. Over and over again a body of troops would ravage the country right up to the gates of Milan and retire, laden with spoil, while the vastly greater army of Milan rested on their arms and looked on. On the whole, the Visconti got rather the worst of it. Pavia was still in revolt; Novara and Como were lost to them ; Genoa renounced their overlordship. The allies were no less exhausted, and peace was made in 1358 .

After the fall of Pavia only Genoa and Venice remained free cities in North Italy. Lombardy and Venetia were divided by six despotismsnamely, Milan, Verona, Mantua, Ferrara, Pavia, and Piedmont. Of these the chief and most powerful was Milan. It is true that the forms of a republic were still preserved, but the poor remains of liberty were being rapidly subverted by the Visconti and other despots. Theoretically, the "tyrants" were leaders of a party, freely accepted by the people, and granted the lordship of the city for life by the commune. There was no regular succession; sometimes the State was divided by different members of the same family among themselves; sometimes brothers reigned together; sometimes the most capable person of the family, whether legitimate or not, was placed in the succession, to the exclusion of the dead man's issue; sometimes a new reign was inaugurated by a revolution. Desirc of peace and weariness of faction had induced the communes to submit to strong rulers who could make themselves feared and obeyed; 
even injustice was better than anarchy. At first, under the Torriani, the Podestà of Milan was retained; the councils still met. But the rulers, followed by their armed and warlike retainers, and supported by their family and friends, trained to warfare in the petty contests between neighbouring strongholds, became masters that could not be shaken off. There was no constitution, but the strongest of governments are not those that are made by constitution. The masters were wealthy; they could employ mercenaries ; the citizens became unaccustomed to war, and were defenceless without them. If one master were overthrown, freedom could not be maintained; the city fell into the hands of another. At first the form of obtaining sanction from the people and councils was adhered to; but bit by bit, and especially from the advent of Bernabo Visconti, the master took it upon himself to exercise sovereign rights; he farmed out the revenue, issued his own edicts, imposed his own taxes, and made war as he pleased. Might or craft replaced right. The title and rights of perpetual lord of Milan howsoever obtained, were the only legitimate title and rights that the despots of that city possessed. Though renewed as member after member of the Visconti assumed power, their effective title lay in the strong right arm, the crafty brain, the helplessness of the people, and in continued want. By subtle cunning, artifice and finesse, duplicity and guile, sometimes by manly daring and skill in the foughten field, the cleverer scoundrel contrived to dispossess his neighbours; he could only hold his own by dispossessing other people who had an ample revenue; and possessed of revenue, he knew how to employ it. Provinces might be ruined by rapine, commerce choked by war, manufactures abandoned, agriculture neglected, fertile farms go out of cultivation, little it mattered to the established despot, so long as discontent stopped short of real danger; he was sagacious enough to administer his own finance in an orderly and fruitful way. The Visconti in particular always contrived to feather their own nest. They had an ample revenue, and they rewarded faithful service with a liberal hand ; they knew exactly what to do to hold conquered territory by the exhibition of favour or the excitation of hope of advantage, or fear of consequences. They had their secret service, and paid their partisans or suborned traitors in every neighbouring State; they were prodigal in their expenditure for political purposes, but rigidly economical in every other respect. Consequently the power of the purse was always theirs, and they were therefore pretty confident of victory whenever they could gain time; for when the enemy had exhausted his resources they still had enough remaining in their treasury to buy mercenaries who would fight or men who would betray. The employment of mercenary troops was the opportunity of the despot; he could now amass wealth for himself by their means, and the greater the number of cities which he came to control, the more independent he became of any one of them. Disloyalty to the despot only increased his power, and served to augment his fortune; he confiscated the property of the traitor, and it became his own; his private purse made him independent of the public treasury; he could hire mercenaries, and keep his cities in subjection without raising extraordinary taxes. But some semblance of free institutions still lingered; the spirit of freedom was not wholly extinct; it smouldered, and every now and again some favouring political whirlwind fanned it into a passing blaze.

- The principal citizens soon became fairly content. There were no 
changes of Government, and therefore no wholesale banishments of defeated parties from the State. A conquered town, moreover, saw its patriots driven out ; the countryside, too, was content ; there was increased security of life and person. In the days of the Republic, citizenship had been confined to a very small minority, and necessarily so ; for in the days when there was no printing, no education of public opinion, and when family bonds or the honour and claims of the trade-association held the first place in the citizen's moral consciousness, and when representative government was therefore impossible, a large electorate would have meant complete anarchy. Under the new régime, if all were subordinate to a single will, that single will was directed, through self-interest, to continuity of policy, and to attempt some justice in administration; the tyrant held his position by virtue of his ability, and the inhabitants of subject towns and of the countryside ofttimes enjoyed equality of privilege under an enlightened and impartial rule. However he might mismanage affairs, one aim of the despot was necessarily to keep his people fairly contented; and so long as he was able to favour himself, there was no reason for, but every reason against, favouritism. A republic granted freedom to a limited number of its own citizens only, and never to subject cities; a despotism, if there was less freedom for a class, was more impartial to all its subjects. As Guicciardini remarked to Machiavelli, the conquests of a commune aggrandized the commune at the expense of the political annihilation of the conquered. And this was one reason why, at a later period, the Republics favoured despotic Milan rather than republican Venice, and Venice became, in spite of her enlightened rule, the most hated of Italian States. It was also one reason why Milan not merely fell under a despot at an early period, but why she remained under a despotism. As a republic, she had subdued the surrounding small States; Milan consequently became a metropolitan city, swollen beyond its natural growth as one of many trade-centres by the advent of the citizens of subjugated towns. The immigrants would thus form a very large class, excluded from all political power, and the tyrant was hailed on all sides, partly as liberator of the city from the interminable disputes of clans and parties and districts, but by the majority, both of citizens and their subjects, chiefly as the administrator of justice, and even as the avenger of wrongs. The conquests of the Republic increased its external power, and diminished its inherent vitality. It paved the way to tyranny, and when the tyrant had accumulated a purse sufficient to command an overwhelming mercenary force, he ceased to be equitable, for he had become secure.

\section{The Declension and Fall of Bologna}

At the beginning of the fourteenth century, when Bologna had given a home to the exiled "Whites" of Florence, the latter city sent an embassy to Bologna under the pretext of complaining of the aid rendered to Pistoja, which was undergoing a siege at the hands of Florence, but the real mission of which was to stir up its Guelph populace against their Ghibelline government, and turn out the "White" immigrants. It was given out that there was a secret understanding between the Lambertazzi and the Ghibellines of Lombardy. There was a revolution, and the Lambertazzi were exiled, whereupon the cardinal-legate of the Pope arrived. $\mathrm{He}$ 
was received with insult, and forced to flee to Imola. He sped the city a parting shot, excommunicating it, and ordering the professors and students of the University to betake themselves to Padua. This seems to have had little if any effect, however. The thunders of the Church accompanied sheet-lightning only; they reverberated among the clouds; the flashes of episcopal anger did not usually strike the earth as of yore. Before the invention of printing, books were rare and costly. They were collected in University libraries, but oral teaching necessarily took a much more important place in education than to-day. At the beginning of the fourteenth century the love of learning drew i 5, 000 students to Bologna from all parts of Italy and Germany for the study of civil and canon law and of medicine. The usual spirit of gown versus town arose, and by reason of their esprit de corps it was difficult to make these turbulent young people respect or submit to the law which they were occupied in studying. A student named Jacques de Valence, popular among his fellows as possessing more than his share of the frank grace and charm of youth, chanced to fall in love with the niece of the most famous of the professors of canon law. He succeeded in running away with her, and defended himself with rash courage against the townsmen whom her irate father had assembled to the rescue. Jacques was finally seized and decapitated by the Podestà. All the students protested against what they considered to be an infringement of their rights. They claimed to be independent of ordinary tribunals -in other words, they claimed practical immunity from punishment. They were backed by their professors, and the whole body of teachers and taught, after vowing never again to enter the gates of Bologna, betook themselves to the rival University of Siena. This was a very serious matter for a city much of the wealth of which depended on its being a great educational centre. There was at that time a citizen, named Romeo dei Pepoli, who was considered to have the longest private purse in Italy. His fortune had been gotten by usury, and he designed by its judicious employment to get the supreme political power over the city into his hands. His family were the traditional protagonists of the claims of the small bourgeoisie. He bid for popularity by his generosity and zeal for those oppressed by the laws, and he even tried to rescue a convicted notary by force. When the University was transferred to Siena, it was Pepoli who induced the Senate to force the Podestà to eat humble pie. He had to renounce all jurisdiction over the members of the University, and the scholars and professors were implored to return, the latter with augmented salaries. Pepoli became suspect. The Guelph nobles and the more important burghers formed a coalition against him, called the Maltraversa, a common name for the Conservative party in Italian cities (che s'attraversa al male). The adherents of Pepoli were nicknamed the Scacchese (chess-board), from his coat of arms. The Scacchese contrived to elect in I 32 I a Podestà who was Pepoli's partisan. The Maltraversi now openly accused Pepoli of aiming at despotic power. They reminded the city of the loss of liberty in all the towns of Romagna; they pointed out the familiar arts by which Pepoli was striving to subdue the city; and, finally, they succeeded in bringing about a revolution. Pepoli had to run for his life, leaving his money-bags behind him to keep the people too busily engaged for pursuit. His houses were razed, his wealth confiscated, and all his family and adherents were sent into exile. Nevertheless, Pepoli 
carried on a secret correspondence with his adherents in Bologna, and an unsuccessful rising took place in his favour the following year. It cost his chief partisans their lives. But he remained on excellent terms with the despots of the North, who were ever ready to help shackle their natural enemies, the free towns. And when Pepoli died, the Ghibelline despots did not desert his son. Their united forces of nearly 3,000 men invaded Bolognese territory, to which the Bolognese opposed an inferior effective, though numerically superior, force. In vain did the Florentines, who sent them a contingent, beg them to avoid a fixed battle. Florence had just lost the field at Altopascio, and Bologna deemed it a point of honour to redeem that defeat of the Guelphs. The armies met at Monteveglio, and the Guelphs again lost the day. Their Podestà, their leaders, and their best men were taken prisoners, and Bologna was besieged; but the Ghibelline army was not powerful enough to take the city, and retired with considerable booty ( 1325 ). Bologna now found that her ally, Florence, was hard beset, and that it would be necessary to follow the example of that city, which had put itself under the protection of the Duke of Calabria. She called in the Papal legate, the Cardinal Bertrand du Poïet, nephew or son of the Pope. Tortona, Piacenza, Parma, Reggio, and Modena had given themselves to the Church for so long a period as there should be an interregnum in the Empire. Bologna opened her gates to the legate, and conferred on him her lordship and that of all her territory (1327). The legate was intent on carving out a principality for himself, but in I 333 all Romagna, instigated by the Malatesta, the Polenta, the Ordelaffi, and the great families of each city, broke the bonds of his authority, and the bubble that $\mathrm{Du}$ Poïet had blown burst into thin air. Bologna was not yet free, and Du Poïet erected a fortress to command the city, juggling the citizens into the belief that the Pope was weary of Avignon, and was coming to dwell there. Directly the walls were capable of defence, he lodged a garrison of Provençal soldiers inside them, and began to let the citizens understand that they had a master. Two factions, as usual, divided the city - the party of authority led by Taddeo dei Pepoli, the richest and most ambitious citizen of the commune; and a party less in favour with the lower classes, but which stood for communal liberty. This latter party was in I 334 in communication with the Marquis of Este, who led the army of the Guelph league. The Marquis, by admirable strategy, forced the garrison to leave the new castle to meet him in the open field. The leaders of the party of civic freedom then appeared in the public places sword in hand, and called on the citizens to seize the opportunity and recover their freedom. "We," said they, "risk exile, the burning of our houses, and the confiscation of our goods for liberty Will you be craven, you who venture less than we ?" A shout of "Long live the people! Death to the legate! Death to the wicked, cruel tyrant!" arose from the multitude that had gathered. They rushed through the streets, slaying here and there a stray French soldier, and tried to take the fortress by assault. But in this they failed, and they sat down before it to besiege it in the orthodox way. The Florentine Government was no sooner informed of the situation in which the legate found himself than it sent an embassy and a guard to take Du Poïet under its protection. As lord of Bologna he had been the enemy of Florence and all free cities; as defeated in his designs and in danger, they 
saw in him a representative of the Church. Nothing but this saved him from the vengeance of the people. But this stroke of policy would not have availed Florence against the machinations of Du Poïet had not the Pope died.

Bologna had had her full share of the disasters that attend civil war, but she still continued to flourish. She was quite as wealthy as Florence, and disputed the hegemony of the Guelph party with that city; and she exercised an influence over Romagna similar to that which Florence exercised over Tuscany. But the mother of universities had lost much of her civic vigour under the administration of the legate. The Pepoli had also gained the affections of the lower classes and the support of the poor nobles by the lavish use of their great riches. They had affected an inordinate zeal for the Guelph cause, and supported the legate longer than did their adversaries, the Maltraversa. They accused the latter of favouring the Ghibellines, and the charge was not without influence on the people. Several distinguished families became attached to their fortunes, among them the Bentivoglio, afterwards to become despots of the city-a family for whom their flatterers claimed a descent from Enzio of Sardinia, the bastard son of Frederick II., though certain cynics said the stock was derived from a butcher. In I334, after the expulsion of the legate, there were disturbances at Bologna, and the Maltraversa, the party representing the big burghers, were defeated, and their leaders exiled, together with the Ghibellines. The latter were allowed to return shortly afterwards by an unusually indulgent Government; but the Pepoli faction contrived to get them exiled once more. Three hundred and fifty were expelled from the State, and their relatives were forced to settle in the countryside, and prohibited, if business required their presence in the city, from approaching within a certain distance of the great square. The Pepoli began to bear themselves as if the place already belonged to them. Giacomo, the son of Taddeo, had promised to procure a benefice for a friend, and when the Bishop refused to appoint him, boxed his ears. The Bishop seized a knife and wounded Pepoli. $A$ riot followed. The mob sacked and burned the episcopal palace, and the Bishop barely saved his life by incontinently taking to his heels (Cronica di Bologna). Now, a certain Brandaligi dei Gozzadini had also achieved a considerable personal influence. He was at the head of the Maltraversa ; but the services of that family, in expelling the legate, had excepted them from proscription. Pepoli is said to have curried favour with the "Whites," their sworn foes ; and when he had worked them up so that a fray between the two parties was imminent, he came forth boldly and offered mediation. He took Brandaligi by the hand, calling him his brother and the helm of the State. He brought him to his own house, and made his own sons, who were in league with the "Whites," lay down their weapons before him ; and when he had persuaded the entire faction of the Maltraversa to disarm and disperse, his partisans, who had been gathering in another quarter of the city, fell on Brandaligi and forced him to flee. They pillaged and burned the houses of their opponents according to wont, succeeded in purging the magistracy of all who had oligarchic leanings, and proscribed all opponents (1 337). At this time Bologna was leagued with Florence and Venice to oppose the ambitions of the Scaligeri, who were aiming at dominion over North and Central Italy; and since 
the art of war had advanced beyond the amateur faculty of city trainbands, the city employed a large number of professional soldiers, who were mostly Germans. These gentry, being human, preferred to treat with a single despot rather than with a corporate body; and the despots had always fostered this natural inclination by indulging the mercenaries, as being the power by which their dominance was preserved. Taddeo dei Pepoli had won over the mercenary troops, and the political discontent of the disinherited workers did the rest. There was a prearranged demonstration. The soldiers cunningly interspersed shouts of "Long live Taddeo !" with those of " Long live the people !" The many-headed had no leaders-they were all in exile. Taddeo led on the soldiers; the public palace was forced, and Taddeo was proclaimed lord of Bologna. Some days after the militia, and later on a general council of the people, sanctioned this coup d'état. The friends of freedom were either in exile, or had not the courage of their convictions. Ten votes only were recorded against Taddeo ; and a blind democratic wave succeeded in destroying the liberty of all in attacking the exclusive privileges of a few. The last of the Republics north of the Apennines had ceased to exist (I 337).

The new lord of Bologna soon discovered, or feigned to discover, plots against the new despotism, and all who might become dangerous to the arbitrary exercise of his authority were proscribed. He made his peace with the Church by recognising the overlordship of the Pope, promising to pay an annual tribute, and putting his forces at the Papal disposal whenever they were required. Benedict XII. had his price. His indignation faded away, and he removed the interdict with which he had visited Bologna. ${ }^{1}$

1 The subsequent history of Bologna is intimately associated with that of the Papacy, Milan, and Florence, and is treated of in detail in our consideration of those Powers. It will be sufficient to give a broad outline of the subsequent fortunes of the Republic, which fell under many masters, native and foreign, but was long in forgetting its pristine freedom, and made repeated and often successful attempts to reacquire it. But internal dissensions invariably brought about its submission to Milan, to the Pope, or to a powerful family among the burghers. Taddeo was succeeded by his sons, Giovanni and Giacomo. Unable to maintain their power, the Pepoli sold the city in 1350 to Giovanni Visconti, lord and Bishop of Milan, for 200,000 florins. The Visconti got a legal title from Clement VI. by payment of 12,000 florins a year ; and, as we have seen, Giovanni Oleggio, a bastard of the House, ruled the city. He freed himself from the authority of Milan, but was obliged to cede the city in 1360 to Cardinal Albornoz, the legate of the Church. In I379, the people of Bologna, together with the other States of the Church, threw off the Papal yoke at the instigation of two citizens, Taddeo Aggoguidi and Nanne Gozzadini. In I40I, a rich citizen, Giovanni Bentivoglio, was made lord, but he was overthrown in the battle of Casalecchio by the Visconti. The city, which had had enough of despotism, renewed popular rule, but only maintained freedom for a brief moment, falling into the net, first of Gran' Galeazzo Visconti, and then of the Church at the hands of its representative, Cardinal Cossa. Once again liberty was regained; but the city fell into the hands of the condottiere Piccinino ( 1438 ), after which the rich Bentivoglio family seized the reins of power, and ruled the wealthy city in much the same way as did the burgher Medici family at Florence. By the intrigues of the Duke of Milan and the Pope, Annibale Bentivoglio was assassinated in 1445 ; but a youthful bastard of the House was called upon to lead the interests it represented; and in 1447 Pope Nicholas V. made a treaty whereby his overlordship was acknow- 


\section{VENICE}

\section{The First Attempts to Found a Continental Empire}

THE rivalry between Genoa and Venice in Eastern waters smouldered, ever ready to burst aflame. When Charles of Valois meditated the recovery of Constantinople, Venice promised to supply him with a fleet and to keep a dozen galleys patrolling Eastern waters. Genoa, anxious to curb Venetian power, and to prevent Sicily from taking the lead in the Western Mediterranean, informed Andronicus Paleologus of all that was going on, and prepared to oppose the Catalan mercenaries, led by Frederick of Sicily. Even the death of Charles did not prevent the Venetians from aiding the Catalans, as rivals of the Genoese, when these killed Gauthier de Brienne, the Duke of Athens, and possessed themselves of his duchy. ${ }^{1}$ Genoa continued to take the side of the Greeks (I 306-I 3II).

The smaller despots of the mainland were now being swallowed up by bigger rulers. It became inevitable that Venice-largely dependent for food on the mainland; whose position might be seriously changed by any such diversion of river courses as might easily be effected, now that great irrigation works were undertaken in North Italy; or who might have the mouths or courses of important rivers closed to her by fortresses ; and who possessed monopoly of the salt-trade, which might be broken by the competition of lagoons not under her control-should extend her sway over the mainland, especially as, owing to her oligarchic form of government, she evinced a continuity and persistence of policy to which all other States were strangers, and which, while some of them grew up and perished like ephemera, gave her a full thousand years of preponderance on both shores of the Adriatic and beyond.

While Venice sent a deputation to Henry VII. to exhibit her respect for the Empire, she had at the same time declared her independence. Her ancient history and her trade connected her closely with the East, and her lagoons kept her isolated from the currents of the Maelstrom of the mainland. But the time was approaching when this severe isolation could no longer be maintained.

Azzo of Ferrara died leaving no legitimate children. The Pope, under Matilda's bequest, conceived himself to be overlord of Ferrara, and supported Azzo's brother; but Venice opposed this arrangement, on the ground that Fresco, Azzo's natural son, had the better claim, and had made that claim over to her. Gradenigo, the Doge, and his party, took a view that, whether it be openly acknowledged or no, is still dominant in politics, and was defended by Fichte the philosopher. "It is the duty of every good ruler and of every worthy citizen to increase the

ledged, but real power remained in the hands of the Bentivoglio, until, in $\mathbf{1}_{512}$, Pope Julius II. incorporated Bologna with the States which the Papacy was consolidating. The period of the greatest prosperity and celebrity of the State was that of its turbulent independence.

1 His descendant, Gauthier de Brienne, titular Duke of Athens, became despot of Florence for a brief period. 
Republic and seek its welfare by every possible means. Opportunities are rare, and those are wise who know how to improve them," quoth the Doge. The Pope excommunicated Venice and placed it under an interdict. Its trade was at a standstill; its merchants were half ruined throughout the civilized world; but the Republic remained unmoved until the Ferrarese citadel which it had occupied fell, and then it made peace with the Pope (I 3 II) on securing certain commercial rights.

The growth of the Scaligeri was felt to be a serious menace to Venice. That great House held the passes of the Alps, the navigation of the Po, and the neighbouring cities of Padua and Treviso. Mastino built a fortress opposite Venice to warn off the Venetians from the salt-pans, and imposed dues on Venetian merchandise. Venice had much trade with the mainland and many dealings with Germany over the passes; so this new obstacle to lucrative traffic hit her hard. She retaliated by imposing dues of her own, but Mastino della Scala had the whip-hand, and he knew it. Venice could not exist without food-stuffs, and a tariff-war could only be disastrous to her. Many State documents with imposing leaden seals passed between the Powers. "Tell the Doge to save up his leaden seals," laughed Mastino ; " he will need them all to roof the Campanile." It was probably real scarcity of food-stuffs that forced Venice to join the Florentines in 1336, and that made her accept a separate peace so eagerly nearly three years later. In 1338 , when Mastino, abandoned by his allies, was hard pressed, the Republic made a separate peace, whereby she secured free navigation of the Po, and the possession of Padua, Treviso, and other towns. The Carraresi, the former lords of Padua, were replaced by the Republic, in the vain hope that they would remain grateful dependants; at worst, for the present, the Republic could be sure of daily bread. Venice, in her dealings with her mainlandconquests, thus began, from the very first, what became her persistent policy. She gave each subjugated city all powers of self-government consistent with the maintenance of Venetian supremacy and the security of the city against attack from without. The Scaligeri, after Mastino, were degenerate, and relatively powerless; but the more distant Visconti of Milan were growing more ambitious and more influential, and evidently would have to be dealt with. In the East, too, the barbarous and maleficent Turk was taking the place of the mild and chivalric Arab, and directing the forces of the Moslem world. The weakening of Constantinople had opened the way to a new and terrible foe : Christianity became justly alarmed, and the great Republic was besought to defend all Christians travelling by sea. She acceded, but with a commercial astuteness that leaves even England and Holland in the rear. She asked for and secured her price, to be paid out of ecclesiastical tithes (I347). Meanwhile, in spite of the claims of the King of Hungary, and of his attempts on Zara when he marched South to Sicily, Venice had been able to keep her hold on Dalmatia.

\section{Venice and World-Commerce in the Fourteenth Century}

In the fourteenth century the Mediterranean was the great high-road of commerce : America was unknown; the passage round the Cape was undiscovered; the nations of Asia had but a limited coast traffic ; and the 
great caravans unloaded on the shores of the Euxine or on the banks of the great Russian rivers, or on the quays of Greece, Syria, and Egypt. That ancient, immemorial sea, that had been ploughed of old by forgotten Cretans and traversed by the galleys of Sidon and Tyre, that had been brightened by the intercourse of Hellas with the greater Hellas of the West, and the waves whereof had been reddened by the life-blood of contending Rome and Carthage, was now ceaselessly traversed by Italian merchantmen, and had more than ever before become the theatre of the commerce of the whole known earth. Pisa no longer took a prominent place among maritime Powers. The commerce of Sicily and Naples, the reputation of whose marines dated from the days of Amalfi, had declined under autocratic rule. Greece had long been in decay. France had been compelled to hire Genoese galleys in the recent war with England, though the marine of England was then very small. In the North the ports of the great Hanse League were already flourishing; but their vessels rarely passed the Pillars of Hercules. Barcelona, however, enjoyed the protection of the King of Aragon and the liberty of a self-governing republic; and the maritime enterprise of the Catalans gave them the third place among the sea-powers of the world; but the first place was disputed for by Genoa and Venice.

The barbarous North supplied the world with wood, hemp for sails and cordage, pitch, beeswax, tallow, felt, furs, and skins. The great rivers of Russia brought these commodities down to the Black Sea, and along its banks were to be found the stations of Genoa and Venice, established under treaty with the successors of Ochtai Khan and Zengis, who for a hundred years had been the invaders, and often the rulers, not only of Russia, but of Poland, Hungary, and Moldavia. The most important of these stations were Caffa and Tana. Caffa, in the Crimea, was an outpost of Genoa, who had bought her rights from a Tartar chieftain at the commencement of the fourteenth century. It was a stronglyfortified place, with large shops and sumptuous palaces, that reproduced the characteristics of the parent city. Another mart, where the luxuries of the South were exchanged for the products of Tartary, was Tana, a city on the Tanais, near Azof, and under Tartar rule, but where Genoese and Venetians had rich and important colonies, and Florence and other cities had opened their counting-houses. So important a place was it, that, when a row with the Tartars, or fires, or earthquakes ruined the merchants of Tana, waves of commercial depression spread over the entire West.

Whilst the north coast of the Euxine gave our forefathers the products that we now owe to America, the opposite shore furnished them with nard and cassia and the unguents of royal state, the barbaric pearls, the uncut gems, and the bespangled art and luxurious fabrics of the Orient. The stately magnificence of Persia, and the patient industry of Asia Minor, discovered itself to the Western world through the gateways of Synope and Trebizond. The former city was a meeting-place for direct intercourse with the new Turkish rulers of Western Asia ; the latter, and still more important city, was a fragment of the Byzantine Empire, even yet governed by a Comnenus. The streets of both cities were crowded with Italian merchants, and their harbours witnessed the daily arrival and departure of Italian galleys. Trebizond was the great port for the 
Armenian trade. The Armenians had recovered their independence in the twelfth century; they were a mountain-race, the most sober, active, and industrious people in Asia, attracted to the Latins by identity of faith ; for twice in the twelfth century and once in the thirteenth had the Armenian Church been formally reunited with the communion of Rome. Venice had secured from them the monopoly of the important camlettrade, or the exportation of the fine hair of the Angora goat. Venetians in Trebizond were exempt from taxation, allowed to mint their own coin, observe their own laws, and transport the merchandise of Tauris and Persia without let or hindrance. Trebizond was also one of the great markets for the spices and aromatic oils of the Indies. Trade in these luxuries was the most profitable in the world, and the merchants who engaged in it became richer than princes.

The Eastern merchants of those days took their hazard along several insecure and unguarded lines of communication; and it may be interesting to indicate the more important of these precarious and perilous paths. Caravans laden with the spices and textiles of India and China crossed Bactriana or Bucharia; thence the merchandise was carried down the Oxus by boats, and across the Caspian Sea ; the Cyrus was then ascended, the Phasis followed, and the Black Sea reached.' Other merchants sailed along the Persian Gulf and up the Euphrates. The valley, not then ruined by the Turk, was defended by massive forts built by the Genoese, which commanded the admiration as well as the astonishment of the great Moltke when he visited them in his youth. Thence caravans took the goods across Assyria and disembarked them at the different ports of Palestine and Asia Minor. Another route was by way of the Red Sea and across the desert to Alexandria. All along the extensive coast-line from the Crimea to Alexandria were ports possessed by Turk and Tartar, Greek and Arab, which owed their wealth to Italian traders, and contained Italian colonies. By far the most important of these cities was Constantinople, and though the effete Greek had abandoned commerce on a large scale, the industrious Italian had kept the city what it had been from the days of its foundation, the great market of the Orient (vide Nicephor. Greg. Hist. Byz.). Here Venice possessed a walled quarter, with a separate anchorage, and a Government of its own. Still more important was the Genoese quarter, granted by Michael Paleologus in recompense of the aid which Genoa had given him to recover the capital. The Genoese held Pera or Galata, opposite Constantinople, and on the other side of the harbour. Pera was defended by a triple wall, and its palaces, built in terraces rising one above another, had begun to rival those of Constantinople both in number and magnificence. Genoa, therefore, was the leading Power, not merely in the Euxine, where she had almost a monopoly of the fur-trade, but at the very heart of the world-commerce of the fourteenth century.

\section{The Great Naval War with Genoa (1350-1355)}

The mediæval world was evidently to witness one of those great struggles for the carrying trade of the world and the possession of foreign markets which are by no means yet among the unhappy far-off memories of history, and which, in more modern times, have provoked frequent duels between 
England and Spain, Holland and France. At the time of which wc are now dealing the most trivial dispute might at any moment renew, in fiercer form, the contests of former years. The two great commercial rivals that remained, their greatness and their arrogance swollen by the annililation of the might of Pisa at Meloria, and the decay of Naples and Sicily, were ready to embark on a struggle which would strain every nerve, demand the employment of every resource, and finally become, in all probability, a fight for commercial, or even national, existence.

Genoa quarrelled with the Tartars of Tana, where both she and Venice had factories. She forbade intercourse with them until permission to fortify Tana was accorded to the colonies, and offered Venetian merchants the use of Caffa, which was entirely her own port. But the Venetians, while willing to take shelter at Caffa, continued to trade with the Tartars at Tana. The Genoese at Caffa seized the blockade-runners. In the existing temper of the rivals war was inevitable. Genoa had behaved generously to Venice. She had offered the use of her own port; if she had, indeed, exceeded her rights in blockading a port in which she had not an exclusive, though she had a major, interest, the Venetians would profit by the security of fortifications at Tana hardly less than herself, and the merchants had taken a mean advantage of the hospitality they accepted. On the other hand, Genoese success would mean the mere tolerance of Venetian interests in the Black Sea, where the Genoese were already predominant. Venice might be excluded therefrom at any future moment if she consented to take a subordinate position; and the traffic was highly profitable. Venice sent a fleet to the East. She attacked a far smaller Genoese fleet, and after prolonged battle, took all the vessels but two and carried them off to Candia. But Filippino Doria, the Genoese Admiral, who had escaped to Pera, organized another small fleet, made a successful onslaught on the harbour of Candia, retook the captured galleys, and triumphantly sailed back to Genoa. Meanwhile another Venetian fleet had made an unsuccessful attempt to surprise and take Pera, and an attempt to secure the alliance of the Greeks failed. Cantacuzenus, the Greek Emperor, was perfectly satisfied to see his two foes engaged in weakening one another (1350). Genoa happened at this moment to possess an advantage which was exceptional with her, though with Venice it was the rule : her parties were for once in accord, and a strong Doge, Giovanni da Valenta, was at the head of affairs. She sent a fleet of sixty-four galleys, manned by half the sailors of Liguria. Pisani, the Venetian Admiral, apprised of the approach of this formidable force, sought shelter at Negropont, the ancient Chalcis in Euboea. Here plague appeared, and carried off many of his men. Venice, finding herself unable to equip a fleet equal to that of Genoa, secured the help of Peter IV. of Aragon, who asserted rights in Sardinia which the Genoese had contested, and of Cantacuzenus, who, thinking that the Venetians would now be likely to win, determined to aid them in crushing the Genoese, who were now under the command of Paganino Doria.

The Genoese were the most powerful colony within his domains, and confident in their strength, had wantonly insulted him. The Doria tried to get aid from Anne of Savoy, whose son, John Paleologus, laid claim to the Eastern throne, but failed. A great fleet, half Venetian, half Catalan, was approaching, so he raised the blockade of Negropont, and 
surprised Tenedos, where he took up winter quarters (1351). Pisani, with a new fleet, made up of Venetian sail scattered through the Egean, the Syrian, and the Black Seas, and reinforced by the galleys that had been blockaded at Negropont, left the Greeks to besiege Pera, and put into Morean harbours, where, although the stormy season had caused the loss of nine vessels, he found himself still in command of seventy galleys. The inaction of winter quarters fretted the angry armadas. Both sides were

\section{"Even now \\ As mad as the vex'd sea."}

At the end of January, I352, fierce hostilities were recommenced, and in February the two fleets met at the Thracian end of the Bosphorus, Doria's object being to defeat the united fleets of Venice and Catalonia and attack Constantinople. But wind and tide were with the Venetians. Doria would have had little chance against Venetian rams under these circumstances. He drew aside, and let the Venetians sail triumphantly into the Golden Horn. There they were reinforced by eight Greek galleys and a host of smaller craft, and the Greek Admiral persuaded Pisani to take advantage of his superiority in force and return to the attack, especially as the Genoese had suffered in carrying out their manœuvres. Doria, who had a pilot's intimate acquaintance with the coast, crept with seven galleys into the smooth waters of a shallow channel, protected by rocks and shoals, and ordered his fleet to make towards him while engaged with the advancing foe. Pisani made vigorous efforts to ram the Genoese ships, but the wind, already fierce, grew stronger and stronger; black clouds swept down over the summits of the angry waves, signals could not be perceived, even when ships were close to one another; the galleys were driven near rocks, the presence of which was only marked by lofty spouts of foam as the great black billows broke over them; and ever and anon spars whisked swiftly past to announce some cryptic disaster. The Genoese pilots skilfully rescued many of their vessels by manœuvring them behind the rocks and casting anchor, while the Catalans, in endeavouring to pursue them, only succeeded in wrecking many of their own ships. Three Venetian galleys succeeded in coming up with the Genoese Admiral and attacked him, two at the prow, the other at the poop; but the superior handling of their ships enabled the Genoese to capture all three. Meanwhile the fleets, divided into small squadrons by the fury of the elements, fought separate engagements. Ten Genoese galleys were stranded and burned by the Venetians. Elsewhere, three other galleys shared the same fate, and six, pursued through the Bosphorus, sought safety in the Black Sea. But neither side gained a decided advantage. When night came, cries of the wounded and shouts of command mingled with the howlings of the wind and the roar of the waves. Occasionally the lights of a vessel, mounting some cresting wave, would flash out into the murky wintry night and disappear. In spite of the blackness and the storm, the Genoese of Pera rowed their shallops through the stiller backwaters, and brought succour to the wounded, or surprised scattered vessels of the foe. Deceived by the torches these bore, some vessels ran aground; others found themselves in the harbour of Pera itself ; others sought to escape certain death by the tempest in yielding to an enemy less implacable. But the two Admirals, with the bulk of 
their fleets, still fought on in the Bay of St. Phocas. They divined one another's presence by sound, not by sight; and, when a gust of wind favoured, they let themselves go before it and rammed. Towards dawn, Pisani, who was the most weakened, sought refuge in the harbour of Therapea, which was defended by the Greeks. At daybreak, the sea, which began to go down, washed up its wreckage and its dead. The Genoese had lost thirteen galleys, besides those that had fled to the Black Sea, but they had taken fourteen Venetian, ten Catalan, and two Greek galleys. The Venetian loss was 2,000 dead and $\mathrm{r}, 800$ prisoners ; but the Genoese loss left them little to rejoice over (Cantacuzenus.-Matt. Villani.Niceph. Greg.-Mariana Hist. de las Españas). Pisani set sail for Candia before Doria could blockade him, and the latter, turning all his force against the Greeks, besieged Constantinople with the aid of Orchan the Turk, and forced Cantacuzenus to sign a peace, the terms of which excluded Venice and Aragon from all ports of the Empire, and gave free trade therewith to Genoa (1352). He then set sail for Candia, hoping to come up with Pisani ; but the latter had departed, leaving his wounded on the island. An epidemic had developed among them. It spread over the island, and soon infected the Genoese fleet; and before making Genoa, Doria had to throw 1,500 of his dead overboard. Both republics had come out of the first campaign exhausted both of money and men.

In vain did Clement endeavour to mediate between the republics; disaster seemed only to infuriate them. He summoned them and the King of Aragon to send ambassadors to Avignon, but neither his authority as head of Christendom, nor his recognised diplomatic skill, availed. Petrarch, too, who was on terms with Andrea Dandolo, the Doge of Venice, somewhat similar to those of Voltaire with Frederick in their happier days, wrote flowery appeals to his friend for peace--appeals marked less by earnestness than by choiceness of phrase. Dandolo replied in periods less precious, but more pithy. All that Petrarch effected was to win-what perhaps he most wanted---the admiration of the learned for his erudition and the delicacy and richness of his style. They were passed on from hand to hand, and read and commended by the erudite, often long before they reached the magnate to whom they were addressed. Innocent VI., too, who succeeded Clement in $\mathrm{r} 352$, again tried to convoke a congress, but the Genoese, instead of sending a delegate to Avignon, approached the King of Hungary, who had not forgotten that the Venetians had taken that bone of contention, Zara, before his very eyes in 1346 . The Sclavs of Dalmatia wished to rejoin the kingdom. They had been hardly treated by Venice, lost no opportunity of revolting, and a free outlet to the sea appeared to Hungary-as to Austro-Hungary to-dayto be indispensable. Louis of Hungary was more powerful than his predecessors had been. He sent to Venice to enforce his claim to all the ports of Dalmatia, and on refusal declared war. Venice, however, by means of that able diplomacy which was her just pride, succeeded for the present in averting war in Dalmatia, and fitted out, in concert with the Catalans, a fleet of seventy galleys, while Grimaldi, the Genoese Admiral, set sail with a squadron hardly less strong. The Venetians met the Genoese off Loiera in Sardinia; hid their smaller vessels behind their larger, three of the latter being huge Catalan "cocks" -tall, strong, short vessels, each manned by 400 Catalan fighting-men. The Venetian 
vessels had also their complement of soldiers bound for Sardinia. The Genoese went gaily to battle; the sea was calm, and they despised the " cocks " that had no oars. To prevent the line from being broken, they linked their boats together, and only left four ships frec at each wing. The Venetians and Catalans did the same, but left eight ships free on each side to attack the Genoese four.

Whilst the wings engaged, the centres advanced slowly towards one another, forming two enormous masses that were intended to break through the opposed rank by sheer momentum. The "cocks " were at anchor, but at this critical moment a wind sprang up from the south and filled their sails. The cables were cut; they drove against three end galleys of the Genoese line-of-battle, and sent them to the bottom. Then they attacked the neighbouring galleys with showers of darts and stones. Notwithstanding the brave fight that the Genoese were making, their Admiral perceived that the day was lost. He contrived to detach eleven ships to join the eight which were unlinked, and manœuvred them out to the open sea. The Venetian Admiral was puzzled as to what these tactics might imply, and awaited the event. But Grimaldi had lost heart. He made off under the cover of night for Crenoa, and in the morning the thirty galleys that remained surrendered to the Venetians. The Genoese lost 2,000 men and 3,500 prisoners, including the flower of Genoa. The dismayed Genoese gave themselves to Milan for protection, and Venice, in alarm, induced Ferrara, Mantua, the Carraresi, and the disjecta membra of the domain of the Scaligeri, to form a league with her. Next year (1354), while Pisani was seconding the unsuccessful attack of the Catalans on Sardinia, a Genoese fleet, under Paganino Doria, the hero of the Battle of the Bosphorus, sailed up the Adriatic and threatened Venice. The city was in panic. All citizens were compelled to arm ; the arsenal was at work night and day. A great chain guarded the narrow channel which gives admission to the port, and Doria, finding the city well defended and that Charles IV., who was in Italy, insisted on a truce, sailed away for the Archipelago. Thither Pisani followed him, and occupied the port of Sapienza, or Porto Longo, for repairs. He guarded the entrance with six great vessels and twenty galleys, which he chained together, while his Vice-Admiral, Morosini, beached fifteen galleys and twenty armed barques. Towards winter, Doria learned the whereabouts of the enemy, and sailed up, offering battle. Pisani ignored his taunts, and thought to bide his time ; but Giovanni Doria, the Admiral's nephew, with the reckless daring of youth, dashed into the harbour between Pisani's linked ships and the shore, and was shortly followed by twelve galleys. Pisani allowed them to pass without resistance, believing that they had caught themselves in a trap. The younger Doria, however, delivered an impetuous attack on the half-beached squadron of Morosini, which it was not easy to defend under such circumstances. The Venetians, who little expected the attack, made, indeed, but feeble opposition. Doria soon captured the whole squadron, and turned his prows to take Pisani's ships in the rear, while his uncle was delivering a frontal assault. He set two of the captured galleys ablaze, and drifted them against the linked squadron, causing so much terror to the Venetians that they surrendered without further struggle. Doria returned to Genoa with the entire Venetian fleet and nearly 6 ,ooo prisoners. 
Never had such a blow fallen on Venice ; and, to add to her discomfiture, her ally Cantacuzcnus was deposed and replaced by an emperor devoted to Genoese interests ; the King of Hungary menaced Sclavonia ; the King of Aragon was entirely occupied in attcmpting to subdue revolted Sardinia, and the felicity and almost the existence of the Republic was threatened by one of those conspiracies, so common in other States, so rare in Venice.

The Doge at this time was Marino Falicri, a man getting on for seventy, and married to a young and beautiful woman, of whom he was insanely jealous. He was, in particular, suspicious of one Michele Steno, one of the three chief judges of the Forty, or criminal tribunal. This man was really courting the favours, not of the Dogessa, but of one of her ladies At a public fête the pair behaved with some unrestraint, and Falieri ordered Steno to leave the room. Steno took the mean and despicable revenge of going into another room and scribbling a couplet on the Doge, which reflected on his honour and the virtue of his spouse. ${ }^{1}$ Falieri complained to the proper authorities, expecting the matter to be brought before the Council of Ten, and the offender severely punished. But the Venetians were not ripe for doctrines of lèse majesté. The case was brought before the Council of Forty, over which Steno was wont to preside, and a month's imprisonment was deemed adequate to the offence. It is pretty clear that the old antagonism between nobility and Doge was still marked. The Doge, with the vindictive temper of "infirm and choleric years," extended his resentment to the Forty and the entire aristocratic class because it had not taken the matter to heart as he had done; perhaps, too, because the indifference with which the matter had been treated indicated an indifference to his ducal dignity and authority Now, the insolence of office and social position had been keenly felt by the common people, who, by the constitution of Venice, were deprived of both. The aristocracy bore itself towards the people with a measure of haughty indifference; the young "bloods" of Venice had conducted themselves with contemptuous disregard for the sanctities of the domestic hearths of their inferiors. There was discontent among the artisans of the arsenal, and sullen, silent, but ever-smouldering hate of the privileged by the dispossessed Orders. Rebellion was in the air ; though, for nobles and populace alike, it was not easy to manipulate revolution in a city that is a chaos of canals, and its quarters divided and intersected by them in every direction. Probably this difficulty of revolt was one of the factors that insured the stability of Venetian government. An attempt, however, was now to be tried.

The Venetian Government, while reserving the direction of the State to a privileged Order, allowed the great salaried official positions to be filled by plebeians. Plebeians might thus-though they had no direct voice in affairs--become permanent secretaries or heads of department, and probably some bore the same important relation to, and exercised similar influence on, those in authority, as do our permanent secretaries on the members of the Cabinet.

Israelo Bertuccio, a plebeian, was head of the arsenal. He had had his

1 "Marin Falieri dalla bella moglie

Altri la gode ed egli la mantiene."

Sanuto vite di Duchi, p. $63 \dot{\mathrm{i}}$. 
honour injured by a noble, and placed his case before the Doge himself. "Expect no redress," replied Falieri. "I also have been insulted in a similar manner, and the so-called punishment of the offender has been nothing but a new offence to me, as a man, and to the office I hold." The Doge laid bare the resentment that rankled in his heart, and Bertuccio unfolded the names of those who were malcontents in the arsenal. The result was that fifteen plebeians met from time to time at the ducal palace, and held secret conference with the Doge. Each engaged to bring forty true and tried men. All were to assemble on a certain night, and then, at the signal of the alarm-bell of the palace, which could not be rung without the Doge's order, the report was to be spread that the Genoese were upon them. The conspirators would make their way towards the square of St. Mark's meanwhile, keep the narrow entrances, and massacre the nobles as they came up in answer to the tocsin's call.

Everything was prepared. The secret had been most carefully kept; but, the evening before the execution of the plot, a Bergamesque, who had been asked by one of the conspirators to lead his band of forty, heard certain details which did not seem to him to correspond with what the signory, in whose secret service he had supposed himself to be employed, were likely to intend. His suspicions were aroused, and he went at once to one of the Council of Ten, and they proceeded together to visit the Doge, whom, of course, they were far from suspecting of complicity. Falieri got confused. At one time he said he knew all about the plot; then he tried to pooh-pooh the whole business. Doubts arose in the mind of the Senator. He left the Doge, and carried a list which had been furnished him by the Bergamesque to the Ten. The council ordered the arrest of everyone named on the list. Guards were stationed throughout the town. The suspects were tortured, and it was discovered that Falieri himself was at the head of the conspiracy. The attempt, so near to success, to establish a despotism by means of the populace, was thus throttled; but, as the Ten were not empowered by the Constitution to bring the Doge to judgment, they called twenty of the chief citizens (Giunta or Zonta) to aid them in constituting a special court. The Doge was confronted with the witnesses, and avowed his guilt. Ten of the conspirators were hung in a row from the window of the ducal palace, and Falieri was decapitated on the great staircase of the ducal palace on the selfsame spot where he had sworn an oath to be faithful to the trust imposed on him. The gates of the palace were kept closed during the execution ; but directly it was over one of the Ten appeared on the balcony, holding aloft the bloody sword of the executioner. "Justice has been done on a great villain," he announced. The doors were thrown open, and the people, admitted into the courtyard, beheld the decapitated body. In the long series of the portraits of the Doges in the great council-chamber of the Venetian palace one place is vacant : it is that which should have been occupied by the effigies of Marino Falieri. It is vacant because Venice ordained that it should remain so to remind generations yet unborn of the unpardonable wickedness and utter futility of any treason to the State.

A few months after this event the Senate paid a heavy war indemnity to Genoa, gave up the point about Tana, and accepted the Genoese offer to establish a warehouse at Caffa (1 355 ). The sense of insecurity at home had no small effect in bringing about such unwonted concessions. 
From the Loss of Dalmatia (I358) to the Beginning of the Last Great Struggle with Genoa (1378)

Twice had Louis of Hungary led armies into the kingdom of Naples to avenge the death of his brother. "Often," says Matteo Villani, "he undertook great things with his ground insufficiently prepared. $\mathrm{He}$ trusted to good fortune, relying on the courage of his soldiers as they relied on his; and his urbanity and good-nature secured him the affection of his subjects. More than once he exhibitied promptitude and decision in great affairs, but he was cleverer at withdrawal from an awkward position than in meeting disaster with fortitude and courage." The Venetians had thwarted his designs in I 345, and the Genoese had been at the pains of keeping his resentment alive. He declared war against Venice in 1353 , and every year he menaced her with a formidable invasion.

The city of Zara and all the towns subject to Venice along the eastern shore of the Adriatic were allied to the Sclavs and other subject races of Louis by ties of blood, language, customs, name, and ideas. It seemed to them that they had been torn by Venice from their kindred. Theik commerce had been diverted, and their natural destiny to be the ports of the kingdom was thwarted. Seven times did Zara revolt, and, though Louis' predecessors had never held effective possession of Dalmatia or Croatia, he regarded those parts as belonging to the Crown (Bonfinius Rerum Hungaricarum.-Petri de Reva de Monarchia et S. Corona Regni Hungar.). Lonis demanded the restitution of these ports. He refused all compromise. He would not accept purchase-money or tribute from Venice. He haughtily dismissed the Venetian ambassadors, and prepared to make simultaneous attacks on Zara, Spalato, Trau, and Nona on the Adriatic, and also on Treviso, the only possession of Venice on the mainland, a place which they had acquired at the end of the war with Mastino della Scala eighteen years before (1356).

The power of the Crown in Hungary was at its height. The people had come out of barbarism. The nobles had not yet so far consolidated their power in their fiefs as to be able to defy the monarch. They held for life only, and never transmitted to their sons. Louis advanced at the head of 40,000 or 50,000 horse, to the dismay of the Italians, who seldom employed more than 3,00o. This host of warriors, accustomed to fight Tartars, were armed only with bow, arrows, and a long sword, and instead of cuirass, they wore several doublets stitched together. Their saddles were so constructed as to serve as pillows by night, and each man carried a bag of meat pounded into powder, of which he made a thick soup when he could get nothing better. But in Italy, where fodder was stored up in fortified places, and pasturage was poor, the horses suffered ; and therefore the larger the army, the greater the difficulties of the commissariat.

A detachment of 4,000 horse was sent on in advance, and occupied the Trevisan marches. A Morosini was Podestà of Treviso, and Venice sent three proveditors to that city to serve at once as a body to advise and keep an eye on him. The suburbs and all villages capable of harbouring the enemy were burned; but when the King arrived with 4,000 more cavalry, Francesco di Carrara, the lord of Padua, although he was the 
ally of Venice, accepted Louis' offer to regard him as a neutral on condition that he should provision the army. Louis took Conigliano, which was the key to the marches, and which the advance guard had passed by. Asolo and Ceneda soon fell, but Treviso could only be taken by famine, for its walls were strong, and the plain around so plentifully supplied with springs, that undermining the walls was impossible. Moreover, his undisciplined cavalry plundered the Paduans who brought food to the camp, so that they soon ceased to furnish it, and therefore the besiegers soon found themselves in want of food.

Venice now made proposals of peace. Zara was to become independent ; some other Dalmatian towns were to be restored to the Crown; others to be retained, but as fiefs, and by the payment of tribute. Louis refused any terms less than the surrender of the whole Illyrian seaboard. But hardly had his answer reached the Republic, when other despatches arrived, announcing that there had been sedition in the camp as well as famine, and that Louis had marched his 50,000 men back into Hungary, leaving 2,00o horse behind to guard Conigliano. It was evident that the old trouble that always hampered a royal unpaid feudal army had recurred. But Louis had by no means abandoned his enterprise. He had only changed his method of attack. He had learned that his army was too large to be fed, and that the term of feudal service was too short to be effective. He arranged, therefore, for a succession of small armies, each to consist of 5,000 men, to spend two of the three months which they were compelled to scrve within the area of contest, while a month was allowed them for going and returning. The first of these armies arrived in the autumn, without the Venetians daring an attempt to contest their passage. Again did Venice sue for peace. She offered the surrender of all Dalmatia save Zara; again were her offers rejected. At the news the inhabitants of Trau and Spalato rose against the Venetian garrisons, disarmed them, and declared themselves to be Hungarian subjects. During the following year ( 1357 ), while the blockade of Treviso was resolutely maintained and the country desolated, the Ban of Bosnia advanced against Zara, the strong fortifications of which aforetime had several times resisted Hungarian arms. But this time treachery effected what assault could not achieve. The German prior of a contiguous monastery entered into secret negotiations with two German officers of the investing army. He let the assailants into his church, whence they took the neighbouring gate by surprise, and drove the Venetian garrison to the castle.

Louis was known to be chivalrous, and the Venetians, reduced to seek peace at any price, determined to throw themselves on his magnanimity. They carefully selected their ambassadors, and these represented to the King that they left it to him to impose terms; they were prepared to accept them. Louis replied that he had made war only to recover his own. He wanted his own back again. He had no desire to make unjust conquests; he would restore the fortified places he had captured in the Trevisan marches; he did not need money; he would impose no indemnity; but the Doge must divest himself of all title to Dalmatia, and, in any future maritime enterprise that he (Louis) might undertake, must furnish him with a fleet of eighty galleys, the expenses of which he would defray. Peace was proclaimed early in 1358, and henceforward the 
Doge, who, since the conquest of Constantinople, had borne the title of Duke of Dalmatia and Croatia, and lord of a quarter and a half of the Roman Empire, had to content himself with a more modest title.

That Venice was able to maintain war against a coalition, after the prolonged contest with Genoa, was a marvellous evidence of her recuperative power. The Turk was becoming a formidable sea-power. The strength of Genoa was scarcely reduced. The lords of Padua, dreading absorption, and disliking their situation as the rulers of a bufferState, had renounced their alliance. Venice had been defeated by Louis of Hungary; but her woes were not yet at an end. In 1364 Candia demanded that twenty savii, or wise men, should represent that colony in the councils of the Republic. "We were not aware that you could boast of twenty sages," was her scornful reply. The modern idea of federation had not yet dawned on the mediæval mind. If not always the State, yet always the dependency was governed on the patriarchal principle of the family. An autocratic head, personal or corporate, issued fiats that it was impious to disobey. Revolt followed, but it was sternly and effectively repressed. The Carraresi began to fortify the Continental shore of the lagoons, with the design of starting salt-works of their own. This infringed Venetian monopoly, and led to a war in which the Venetians were but partially successful. And when the contest for the Eastern trade was renewed between Genoa and Venice, the King of Hungary, the Patriarch of Aquileia, who ruled over the mountain passes of Friuli, the Scaligeri of Verona, the republic of Ancona, the Duke of Austria, and the Queen of Naples, made common cause with the Carraresi against the too-powerful Republic ; while Bernabo Visconti, on the other side, sent mercenaries to devastate the lands of the Genoese. The campaign on land was conducted by condottieri, and was indecisive. It was marked chiefly by rapine ; and Genoa contrived to buy off the lord of Milan (1378). The real struggle took place by sea between the rival maritime Powers, neither of which had any other idea of securing and extending its own commerce than by annihilating all competitors. Both Powers had been engaged in a process of getting all they could from the decaying Eastern Empire by putting on pressure and availing themselves of its internal dissensions. Where rivalry and hate run high, mutual offences are easily provoked, and the irritation due to differences of interest and policy is easily inflamed into deeds that can only be wiped out by war. A renewal of the old contest was inevitable, and could only be terminated by the practical effacement of one or the other of the claimants to the mastery of the seas.

John Paleologus, the degenerate Emperor of Constantinople, was now little more than a vassal of the Turk. Amurath, the Turkish Sovereign, declared that his own son and Andronicus, the eldest son of Paleologus, were conspiring together to dethrone their fathers. Paleologus was by no means convinced of his son's guilt, but he was practically a dependent of Amurath, and he ordered his son and little grandson to be blinded. The work was badly done. The victims sought shelter with the Genoese, and physicians partially succeeded in saving their sight. The Genoese then offered to restore them to their rights if they would cede the Isle of Tenedos, which commanded the mouth of the Dardanelles. A treaty to this effect was signed. Constantinople was attacked and taken; the half- 
blind Prince placed on the throne, and Paleologus and his two other sons incarcerated in the same prison to which he had consigned Andronicus (Phranza Protovestiarius.-Ducas Mich. Nepos.). The Greek Governor of Tenedos refused to surrender the isle to the Genoese. He called in Venetian help, and the Senate ordered its occupation. In I 378 a Genoese fleet, which was cruising in Eastern waters, attacked Lemnos, which belonged to Venice, and took it, but failed to capture Tenedos. A war of a very different character to the mock heroics of mercenary armies had begun - a war which would call up every sailor from every distant sea, which would be embittered by hand-to-hand combats of the citizens of two republics that were engaged in a life and death struggle; a war which would bring into bold relief that self-effacement, that whole-hearted devotion to his mother-city which was, at bottom, the religion of the Venetian.

Genoa protected the navigation of the Tyrrhenian Sea by a fleet of ten galleys. Venice sent thither fourteen galleys, under the command of Vittore Pisani, the most illustrious of her many gifted sailors. The two fleets met in a storm, but the violence of the tempest only served as a stimulus to the furious passions of the rival crews, and after a sharp and bloody contest, the Venetians were triumphant. They sank one ship and took five others. But this success was counterbalanced by failure to take Famagosta in Cyprus, where the Venetians sustained great loss, though they were supported by the troops of Bernabo Visconti and his son-in-law, the King of the island, who had revolted against his feudal superiors the Genoese.

\section{GENOA}

From the Death of Henry ViI. (I3I3) to the Election of a DOGE (I 339)

THE territorial holdings on the lower heights of the Apennines enriched and gave power to the Genoese nobles. Four families were especially influential by reason of their wealth, numbers; and bellicose character. The Doria and Spinola were Ghibelline, and dominated Genoa after Henry VII. had resided there ; the other two families, the Grimaldi and Fieschi, Guelphs, were now in exile. But fierce rivalry existed between the Doria and Spinola; each wished for sole ascendancy, and in I3I4 it came to blood. For twenty-four days every palace was in a state of siege, and the issuc remained undetermined. The Doria then called the Guelph Grimaldi and Fieschi to their aid, and the Spinola, driven out of the city, withdrew to their mountain-fastnesses. The Guelphs were readmitted to the Government, and, either to balance the Doria, or because of a nobler desire for reconciliation, they urged the Doria to make peace with the Spinola. The Doria refused, and the Guelphs took the law into their own hands, and admitted the banished Spinola, but without their arms. A curious result followed-the Doria, affronted and afraid of the united power of three families, exiled themselves ; the Spinola, finding themselves unable to hold their own against the Guelphs, also left the city, and Genoa 
was ruled by that party without opposition. Behind all these permutations, commercial and social interests were probably working, causes not recorded, and which it is difficult to divine with certainty. A common fate drew the exiles together; they took Savona and D'Albenga, divided power between them, called the Ghibellines of the mountains to their aid, and were promised support by Cane della Scala ( 1317 ). It was evident that Genoa was to become the cockpit whither the battle of the two great parties which divided Italy would now be transferred, and that the struggle would be concentrated there. Next year (I 3 I 8) Marco Visconti, son of the lord of Milan, crossed the mountains and besieged the city by land, while a Ghibelline fleet, furnished from Sardinia by the exiles, blocked the sea-way, and took the fortification near the lighthouse. The town was hard beset, and appealed to Robert of Naples, as head of the Guelph party. It would never have done for the Mistress of the Mediterranean, who swept the seas between his two realms of Provence and Naples, to fall into the hands of his foes, so Robert manned a fleet and came himself to the aid of the city with a small army. Gratitude was paramount in the Genoese breast, and the lordship of the city was given to him for ten years. Every citizen took an oath of loyalty, but suspicion became general that the whole thing had been engineered by a monarch eager for power. The Ghibellines were undismayed, and even gained some advantage ; but a series of bloody conflicts, lasting through the autumn and winter of 1318 , were without decisive result. A growing sense of the importance of the issue led to a reinforcement of both sides. The Marquis of Montferrat, Castruccio Castracani, the lord of Lucca, and troops sent by Pisa, by the King of Sicily, and even by the Emperor of Constantinople, arrived in the Ghibelline camp. Florentines, Bolognese, and Guelphs from Romagna hurried up to strengthen King Robert. The besieging army could make little use of its heavy cavalry on the mountainous shores round Genoa, and Robert ordered a sortie and cut their communications, compelling Visconti and the army to retire (I 3 I9). Robert now ravaged and pillaged Ghibelline possessions in the country round, and compelled the Genoese to burn and utterly raze to the ground the great Ghibelline palaces within the city; then, accompanied by the clergy and the head of St. John the Baptist, he went to the Cathedral to offer the usual thanksgivings. Robert next departed for Provence to visit the Pope, and the Ghibellines immediately recrossed their mountains and renewed the siege. For four years did it last, and still Genoa held out. The great captains were fighting elsewhere, and did not appear, but the warfare was none the less fierce. The possession of each redoubt, every church, every house capable of being held was almost daily contested; war wasted the two Rivieras, and the maritime colonies of Greece and the Levant took up the quarrel.

Exhausted by four years of strife Genoa was hardly in a condition to be an effective force in Italy. Yet civic strife speedily reappeared, and the "submerged" began, as in other cities of Italy, to make themselves felt as a power in the State. In 1338 Philip of Valois took into his service, to fight the English, twenty galleys manned by Ghibellines of Genoa, and twenty others manned by Guelphs of Monaco, Antonio Doria being Admiral of the united fleets. After a year's service there was mutiny because Doria had not paid the sailors in full; the commanders were 
deposed, and the crews chose others. Philip pronounced in favour of Doria, and threw the ringleaders into prison, whereupon a considerable number of sailors deserted, and returned to Genoa full of grievances and complaints. Genoa was seething with rancour against the four great families who for seventy years had been occupied in perpetually ousting each other, disturbing the State, and controlling it with oligarchic arrogancc. The family in power invariably usurped all government functions, and its members were supreme in the city, in the dependencies of the city, in the army, in the fleet. Nobles, no less than the common people, chafed beneath the infliction, and when the sailors arrived, the inhabitants of Voltaggio took arms to punish the Doria. The insurrection spread to the valleys and to Savona, and in that city one of their leaders delivered a revolutionary harangue from the pulpit of San Dominico. Inflamed by the discourse the mob attacked and overcame Eduardo Doria, the governor of the town, the magistrates and nobles, shut them up in a fortress, elected two plebeians Captains of the People, and instituted a council of twenty sailors. The men of Savona then marched on Genoa, which was ripe for revolt. Genoa was then under the control of the Doria and Spinola; these had taken the right of election of the Abbot of the People to themselves. The Abbot was a functionary specially charged, like the tribunes of Rome, with the protection of the privileges of the people. When the disaffected of the city were reinforced by the Savonese they demanded their right to a magistrate of their own choice, and this was acceded. Twenty plebeians were chosen to elect the new Abbot. They assembled on September 23, I339, and the Government, the nobles, and the whole population gathered to hear the result. Suddenly some man of the people shouted that one Simone Boccanigra was the man for them-there they had an energetic man, a man experienced in affairs, a man as wise as he was courageous, and who, though of long and distinguished lineage, had ever proved himself a friend to the people. The idea was taken up; there was universal shouting for Boccanigra; the electors chose him; the Government, in the present temper of the people, could do no other than accede, and in spite of his sincere unwillingness Boccanigra was enthroned between the two Captains of the People, and the sword of office put into his hands. When he could obtain silence Boccanigra spoke. "I am deeply sensible," said he, " of your sincerity and goodwill toward me, but the office you give me has never been held by one of my family, and I do not wish to be the first to bear it. Grant me, therefore, I beg you, that it may be conferred on someone whom it better befits than me" (Georgii Stelle Ann. Genuens). The mob recognised that the title of Abbot of the People was hardly sufficiently dignified for Boccanigra; it might grace a plebeian, but not a man who counted a Captain of the People among his sires. "Bc our lord, then," shouted the mob, "be our Doge ; we want you and you alone for protector." The Captains of the People themselves, fearing the spirit of revolt that animated the crowd and pervaded the city, pressed Boccanigra to accept the position. The new Constitution, though established in the midst of popular hubbub and enthusiasm, remained free and republican, councils represented the people, and Boccanigra was invested with strictly limited power. 
The Struggle with Venice (I 348 ) to the Protectorate and EXPULSION (1 356 ) OF The Visconti

Boccanigra made an honourable and temperate use of his power as Doge. He was stern to put down the excesses in which the successful revolutionaries indulged; he saved the life of a Grimaldi who was his own personal enemy; repressed the feudatories, who were too often the spoilers of the countryside, and brought all the fortified places of both Rivieras under the control of the Government, save Monaco, which the Grimaldi succeeded in defending, and Ventimiglia, which the united forces of the banished members of the four great families still enabled them to hold. During his five years of office the fleets of the Republic chastised the Turks in the Black Sea, the Tartars near Caffa, and the Moors off the coasts of Spain (Ubert. Folieta Genuens. Histor.-Georgii Stella Annales Gen.). But the nobles gathered at Ventimiglia, kept up constant warfare against the city, and at last Boccanigra, weary of the eternal struggle, resigned his Dogeship, and retired into private life. Moreover, new men were arising, who by reason of their wealth had arrived at power. The ascension of this commercial oligarchy, composed of men that had risen from the ranks, aroused the animosity of the populace that they exploited and among whom their fathers had been numbered. And not merely did the mob hate them, but there was much rivalry and bitter feeling among the new men themselves.

Meanwhile the clouds were gathering in the Orient. Civil war, due to the pretensions of royal rivals, desolated the Eastern Empire in the first half of the fourteenth century. While the Greeks were becoming weaker ; while their dissensions had brought the terrible Turk, already master of Asia, into Europe ; while two Emperors and three Empresses were crowned in one day with jewels of paste, and the Emperor only derived 30,000 bezants from imposts, the Genoese had become strong, their commerce was growing daily, and they drew nearly seven times the amount of the Imperial dues from the same source (Niceph. Gregoras). Genoese nobles, expatriated by the rancorous quarrels between the democracy and the aristocracy at home, had conquered Chios; Phocea had also become Genoese, and the whole land groaned under that vexatious and arrogant rule. The Empire was disturbed by violences due to religious hate, by the incursions of Turk and Servian, and by the decrepit caprices of a weak monarch ruling over a politically and commercially degenerate, but, even yet, highly civilized people. The Genoese saw with alarm that the unhappy monarch was increasing his marine, though it was to hold Thrace and the Bosphorus against the Turks. He offended them by not allowing them to enclose the hilltop which commanded their colony at Pera-a not unwise precaution on his part. They seized the opportunity which an illness of the Emperor afforded them, and captured it for themselves. The Senate and merchants of Pera would have been content had Cantacuzenus, the Emperor, been willing to cede the ground; but the sailors and parlamento insisted on a disarmament of the Byzantine fleet, and negotiations, of course, fell through (1 348). The Genoese began the war with vigour, and flattered themselves that in fifteen days they would have the Greeks on their knees. Pera, their colony opposite to 
Constantinople, was fortified by a triple wall, rivalled the metropolis in size, and probably exceeded it in wealth; and in four days the colonists put a formidable little fleet to sea, and burned nearly all the men-of-war, merchant vessels, and warehouses of the Greeks, while those who remained at home, both men and women, worked night and day to strengthen the fortifications. But the Byzantines were chafing under the insult that had been done them by a colony of tolerated foreigners, whose religion they detested, and whose customs they derided ; they roused themselves to quite unwonted activity. The autumn had already arrived when the Genoese, reinforced from their other colonies, advanced to the attack of Constantinople; they were repulsed with considerable loss, not by soldiers only, but by the citizens themselves, whose manhood had at last been roused (Niceph. Gregoras). The Emperor Cantacuzenus, as he himself tells us, now gathered his forces to the siege of Pera (Cantacuzeni Imp. Hist.). In vain did the knights of Rhodes attempt to mediate. All they could do was to remove the women and children and treasures of the Genoese to the safety of their own isle.

Next spring ( 1349 ) the Greeks launched a great fleet, which they had been busy in constructing, against their foes ; but the sailors were largely impressed labourers and workmen. The Genoese knew at once, by the style in which the banks of oars rose and fell, the kind of seamen with whom they had to do. They puzzled the Greeks by their evolutions, and when at last they attacked, terror seized on the Greek fleet. Disorder reigned; many leaped overboard and were drowned; and the entire fleet was brought in triumph to Pera. Constantinople was in panic. Those who manned the walls had witnessed the fight and its issue. Four days after the fight an Embassy arrived from Genoa. It was conscious that trouble was brewing with Venice, and Genoa knew that she would need all her strength to protect her commerce. She offered, on behalf of Pera, to give up the land that had been taken, and to pay a large sum by way of indemnity. Cantacuzenus, not to be outdone in generosity, or equally anxious for peace, replied that he had enough territory to be able to spare the little that the Genoese wanted, and put them in possession of the coveted ground. It is curious that, while Cantacuzenus and Nicephoras Gregoras give us an account of this war, the Genoese chronicles maintain utter silence. It would appear as if they had some sense of shame at the rapacity of their colonists.

Meanwhile, stirring events were happening on the shores of the Euxine. Some man of Western nationality had killed a Scythian at Tana, and Gianis Bey, the Tartar Khan, had chased all Italians out of Tana, and pursued them as far as Caffa, where they had found shelter with the Genoese. Caffa was besieged for two years without success, while the Genoese burned Tana, ravaged the country, and reduced the besieging force to starvation-point. The Genoese then attempted to "boycott" Tana, hoping that all the Western peoples would help them to teach the Tartars a lesson. They opened Caffa to everyone, and offered the same advantages to foreign settlers as they would have got from the Khan. But the Venetian refugees at Caffa broke through this restriction by trading with Tana, and, of course, as they had no competition to deal with, made immense profits. The Genoese were determined to maintain the blockade, and they attacked and confiscated Venetian vessels which they caught 
engaged in this traffic. The Venetians, in consequence, despatched a large fleet, defeated the Genoese forces, and re-established themselves at Tani (1350). The Greeks and the King of Aragon thereupon declared against Genoa, the latter because Genoa had successfully defended the rights of the Doria to certain Sardinian fiefs to which the King laid claim. A battle in the Bosphorus was so fiercely contested that neither the blackness of night nor the ragings of tempest served to interrupt it. It ended in a victory for the Genoese, but a victory that was hardly less costly than a defeat. Nevertheless, the Venetian Admiral, Nicolo Pisani, set sail for home, and the Genoese Admiral, Paganino Doria, turning his forces against the Greeks, compelled them to accept peace (vide p. 374). Next year Antonio Grimaldi met a superior fleet of united Venetians and Catalans at Loiera, off the coast of Sardinia. The Genoese lost the battle. Thirty sail and 3,500 prisoners, the flower of the Genoese nobility and traders, fell into the hands of the enemy, and 2,000 were killed during the fight or were drowned in sunken vessels. In the previous campaign, too, they had suffered cruel losses from the outbreak of pestilence in the fleet. Genoa was weary of eternal civic strife. She felt, too, that she must humble Venice at any cost. In spite of the remonstrances of Florence, she appealed to the Archbishop Giovanni Visconti to become her protector, and take up her quarrel. Visconti was already master of Lombardy, Emilia, and a part of Piedmont, and it seemed that before long Tuscany must submit to him-him, if anyone, it behoved the Venetians to fear. The Doge, Giovanni da Valenta, was deposed, and the Count Palavicino, whom Visconti appointed as Governor of the city, made his entry, accompanied by 700 horse and $\mathrm{r}, 500$ foot. Visconti at once set to work to build roads from the city across the Apennines into Lombardy, which, of course, could prove of military service to him ; relieved the poor ; and sent money to the Senate to rebuild the fleet. He at once insisted on the public peace being kept by the contending factions, and he did his best to secure an understanding with Venice. He sent Petrarch as Ambassador, and charged him to assure Dandolo the Doge that he was far from sharing the national antagonism of his new protectorate to the Venetians, and that if his mediation failed, at least he was unwilling to embroil himself and his States. But Venice knew that if Visconti could but succeed in consolidating his power, her own days were numbered. Her statesmen were no less astute than the great Archbishop. She declared war against Visconti, and both cities redoubled their efforts to prepare for the ensuing campaign (1353). Next year Paganino Doria sailed up the Adriatic, ravaged its coasts, and threatened Venice, and then made for the Archipelago, where he and his nephew came up with Pisani and inflicted a crushing defeat on that Admiral. Doria returned in triumph to Genoa, carrying the Venetian Admiral with him and nearly 6,00o prisoners. The Battle of Porto Longo had, indeed, avenged Loiera (1354). At the beginning of the following year a revolution in Constantinople, organized by a Genoese, put a Paleologus on the throne of Cantacuzenus, who was forced to take the tonsure. . In the civil wars of the Greeks the Genoese had always been attached to the party of the new Emperor, and the result of this fresh blow to the :Venetians was that they sued for peace. They promised to pay 200,000 florins indemnity, to establish a counting-house at Caffa for three years, and to suspend all Venetian commerce at Tana for the same 
period. Filippo Doria now set sail with a fleet for Sardinia, in order to force the King of Aragon to join in the treaty of peace, but, having received a check, he made for Tripoli. The debasing rule of the Turk had not yet ruined the North African shore. The Moorish population had preserved or regained its independence ; the cities were busy ; manufactures flourished; and agriculture was pursued with scientific method. The love of letters still survived; and if the Moslem never achieved political liberty, the descendants of the Arabs had brought with them something of the free air of the desert, and their descendants had not wholly lost their ancient spirit of manly independence. Piracy was the last thing dreamed of by a people that were then far more civilized in many respects than the races of Europe ; piracy was the last thing they dreaded. But Tripoli had revolted against Tunis, and Filippo Doria saw a favourable chance for an unwarrantable and wicked raid. While Tripoli was dreaming of anything but assault, Doria suddenly attacked it, and carried off nearly 2,000,000 gold florins and 7,000 slaves, men, women, and children. But the Genoese, either rising above the religious prejudices of the times against those of alien creed, or because they feared reprisals on their merchants, that were spread through so many of the lands of the infidel, or, after the nature of mankind, from a combination of loftier with baser motive, took the merely human and unimpeachable view of the crime. They sent into perpetual exile the freebooting Admiral and all who had shared in his dishonour.

After the death of the Archbishop Visconti in I354, his successors were inclined to tighten their grip of Genoa. But the Genoese had been accustomed to freedom for too long a period to submit tamely to the yoke. At a time when the Visconti were embarrassed by their enemies, and found themselves fronted by the Grand Company, cries of "Liberty! Death to tyrants!" resounded through the streets. The citizens took arms. They attacked the public palace, and ejected the Vicar of the Visconti, who, with his soldiery, was obliged to flee the city. Then the burghers sent to Pisa for their old ruler, Boccanigra, whom they reinstated as Doge. Pisa, glad to abase the Visconti, sent a body of cavalry with Boccanigra, now grown old, to help their ancient foes in the re-establishment of their Republic, and the two Rivieras immediately declared for Genoa, save Savona, Ventimiglia, and Monaco, which were, however, successively subdued (1356) (Matt. Villani.-Georgii Stella Ann. Gen.-Chron. Placent. Ubert. Fol. Gen. Hist.).

\section{The Commercial Element Rules in Genoa.--Feuds of Rival Houses}

The commercial element in Genoa, strengthened by new men of great means, aspired to political dominance. Simone Boccanigra, Doge of Genoa, gave a banquet to the King of Cyprus, and died shortly afterwards $\left(136_{3}\right)$. It is said that the food he took at the feast was poisoned. Whilst he lay betwixt life and death, the citizens ran to arms. His relations were imprisoned, and Gabriello Adorno, a man of strong character and a Ghibelline, albeit of plebeian origin, was made Doge. $\mathrm{He}$ represented the smaller burghers. A rival Doge was set up-one Leonardo da Montalto. He represented the larger trading interests. Two years 
afterwards he was sent about his business, with all his party, and the usual civil war resulted, which raged all along the Riviera. At last he took refuge at Pisa with the leading Ghibelline exiles of Genoa, and the scattered remnant of the Ghibelline flock were led by Fregoso, another merchant. Adorno was Doge from I 363 to I 370 , and was deposed in a revolution. His rival, Fregoso, replaced him, and henceforward the bloody feuds of the Adorni and Fregosi, families that had come up from below, occupy no small place in Genoese annals. Henceforward the nouneaux viches take the place of the old nobility in the great offices of State. They rise on the ruin of the aristocracy only to perpetuate their political vices. They were often men of a firmness and power of character befitting their ambition. But ambition, and that spirit of party which is but disguised egotism, lay at the root of Genoese, as of Italian, political life generally. They were the kind of men who compelled Guicciardini to pronounce the memorable indictment of human nature-a not wholly unjustified judgment-applicable to most of the Italian history of the Republics; a judgment that accounts both for their unceasing disquiet, and explains the inevitableness of their enslavement. Guicciardini says : "It seems clear to me that the desire of dominating one's fellows and asserting superiority is natural to man, so that there are few so in love with liberty that they would not seize a favourable opportunity of ruling and lording it. Look closely at the behaviour of the indwellers of the selfsame city; mark and examine their dissensions, and you shall find that the object is preponderance rather than freedom. Those, then, who are the foremost citizens do not strive after liberty, though that be in their mouths, but the increase of their own sway and pre-eminence is really in their hearts. Liberty is a cant term of cajolery with them, and disguises their lust of superiority in power and honour" (Gnicciardini Opere Inedite, vol. ii., p. 5I). The new men were not wanting in talent and courage, and they were superior in power of purse, so that each successive ruler controlled the State pretty effectively for a time. But the popularity of a party or a statesman in office always wanes ; and in a very short time there was sure to be revolution and a new Government, for the new men had no consideration for the toiling masses to which they or their fathers had once belonged.

The Genoese were not idle in squeezing the decaying E.mpire at Constantinople, a process in which they proved themselves to be quite as expert as the Venetians ; and their Levantine trade remained enormously great. In Cyprus the two peoples were rivals, as everywhere in the East. They conducted themselves there with anything but moderation. In I 373 the Cypriots rose and massacred every Genoese in the island. One man only, left for dead on the ground, and whose disfigured face bore witness to his tale, contrived to escape, and told his countrymen the horrid story. A fleet was manned and despatched to the East. By swift and unexpected attack Nicosia and Paphos were taken. At the latter town, consecrated of old time to Aphrodite, a number of beautiful Greek women were taken, and were sent back to their homes by Damiano Catani, the Admiral, in spite of the murmurs of his men. "The mission entrusted to us by our country is not to ravish women," he said. He subdued the island, and conducted the war in no spirit of vindictiveness, but of high-minded and just vengeance, a spirit which also actuated the 
authorities at home. Pierre de Lusignan, the King of the island, was reduced to submission, but the Republic reinstated him on condition of the payment of a yearly tribute of 40,000 florins. But he married the daughter of Bernabo Visconti, and remitted his wife's dowry in order that Bernabo might make war on Genoa. The acquisition of Cyprus by Genoa, and of the Isle of Tenedos, commanding the Bosphorus, by the Venetians, were the proximate causes of the great fourth war between the Republics ; but the first attempt of Venice to eject the Genoese from Famagosta, of which they had taken possession, ended in total failure.

The Genoese Government was now a government of new men, with every power educed and disciplined, except the powers of self-abnegation and sympathetic imagination. Everybody who was anything at all conceived himself to be of too much importance to sink his individuality and become a mere unit in the Senate, wherein personal power was apt to be negated by the exigencies of continuous and impersonal policy. There were less constraining class-obligations among the new men than among the old aristocracy. Everyone now aimed at personal power.

\section{PISA}

\section{From the Death of Henry VII. (I3I3) to the Conquest OF LUCCA (I 342 )}

Pis a was in despair. She believed herself to be on the verge of ruin. She had expended an incredible sum on the Emperor Henry, and now he was dead. She was exposed to renewed attack, and she must meet it with diminished resources and bereft of the prestige attaching to the Imperial name. The Pope issued a Bull (I3I4) appointing Robert of Naples Imperial Vicar of all Italy during the interregnum; and the interregnum threatened to be long. With the fulminations of the Church a.t his disposal, the Sovereign of South Italy and Provence might prove to be a formidable foe. Florence, Lucca, Pavia, and other cities recognised his authority. The men-at-arms that had remained with the Pisans were few in number, and those few were costly (Ranievi Sardo Chronaca Pisana); so the " consuls of the sea" and the elders (anziani) of the city took counsel together. Robert was at this time preparing to invade Sicily, so an Embassy was sent which arranged the following terms : The Pisans were to supply the King of Naples with ships and money; the Florentines were to be free of Pisan tolls; the Lucchese were to have their fortified places restored to them; they themselves would recall their exiles and give them civic rights. Pisa had no further need for Uguccione della Faggiuola, who was in command of the German troops. Uguccione was a man of great physical vigour; no other man could support the weight of his armour. His manners were rough, but he was sagacious in counsel, valiant in battle, swift in resolve. The peace did not please him. He summoned the people to arms; he paraded living eagles, the Ghibelline symbol, through the streets; he succeeded in overthrowing the opposite party, and, calling the council together, issued a 
decree in its name that none but Ghibellines by descent should become magistrates. Uguccione, backed by his own party, was practically despot of Pisa.

Lucca had been Guelph during the last half of the preceding century, but an oligarchy had gradually contrived to dominate, and when, in I $30 \mathrm{I}$, the "Whites" were expelled, the oligarchical Government of the city became still more pronounced. But a split occurred. A section of the nobles took up the popular cause, and obliged a recall of all exiles. Party strife again broke out, and Uguccione marched on the city, made a breach in the walls, and delivered the town over to pillage before the rival factions, who were too busily engaged in fighting one another to take heed to the city defences, were aware of his arrival. Lucca was sacked with gusto by the Pisans. They glutted their traditional hate; and the booty was not small. Lucca had a large banking trade, and readers of Dante will remember how one of the elders is brought to the hell of barattors in the "Inferno " :

“Ecco un degli anzian di santa Zita."-Inferno, c. xxi. 38.

(Lo! one of Santa Zita's elders. ${ }^{1}$ )

A vast sum of money belonging to the Pope and awaiting transit to France was among the spoil. Florence and her allies declared war. The restless spirit of Uguccione was in its element; he was here, there, and everywhere, ravaging the territories of Pistoja, San Miniato, and Volterra. He captured the most important fortified places in the Val di Nievole, and besieged Montecatini.

Philip of Taranto, the eldest Prince of the House of Naples, advancing at the head of a superior army, embracing the available forces of the Guelph league, raised the siege; but Uguccione suddenly doubled, and utterly routed him at Montecatini. The brother of the King and the son of Philip, with many people of distinction, and 2,000 rank and file, were killed, and $\mathrm{I}, 500$ prisoners were taken. Uguccione returned in triumph to Pisa (1315). His eldest son had been slain in the Battle of Montecatini, but Uguccione left another son in command of that city. But next year the Pisans seized the opportunity of the absence of Uguccione to revolt. Lucca followed suit, and Uguccione was obliged to take refuge at the Court of Can Grande of Verona, where he found himself in the society of a still more illustrious exile, the poet Dante.

The Pisans replaced Uguccione by Count Galdo della Gherardesca, under the title of Captain of the People, and the Lucchese entrusted the defence of their city to Castruccio Castracani, their most distinguished and most ambitious citizen. Robert of Naples, who had learned a lesson at Montecatini, proposed a truce, which was accepted by the Guelphs and Ghibellines of Tuscany. The terms were the same as before, but the Pisans engaged to erect a church for the repose of the souls of all who had died at Montecatini, which became to them rather a memorial of a glorious victory than a temple of conciliation.

1 Santa $\mathrm{Zita}$ is the patron saint of Lucca and also of maidservants. She died in the year 1272 , or perhaps in 1278 . She was the domestic servant of one Pagano Fatinelli, and was remarkable for holiness of life. Toynbee's Dante Dictionary (1898) says that until recently, according to Ampère, a ballad-story of her life was sold by Lucchese hawkers. 
The crushing defeat at Meloria had lost Corsica to Pisa, but she still monopolized the trade with Palestine, Africa, and Spain. The Pisans had, however, a land frontier to defend ; they were afraid of their Guelph neighbours; they entrusted their defences to the neighbouring warlike nobles of the Apennines; by tradition they were the stout supporters of the Emperor, and they had expended on a lost cause more than they were called upon to give or than they ought to have afforded. So little did they now feel able to cope with Genoa that they did not attempt to take advantage of the weakness of that city, though it was torn by civic discord. Little by little they had to give up their position in the Levant ; they could no longer defend their colonies in Syria against the Moslem, nor their ships against corsairs ; they ceased to be important at Constantinople; their flag was but little seen among the isles of Greece ; they had lost their trade with the Guelph kingdom of Naples, and the commercial competition of the Catalans and the Sicilians themselves, especially since these opponents were naturally favoured by their King, drove them out of Sicilian markets. But they were still powerful on land, and, in order to remain so, they were obliged to rely on their nobles. None the less they were unwilling to surrender their freedom; there was always a middle and lower class that stood for liberty, and the old contest between civic freedom and feudal institutions, of which no inconsiderable and unimportant vestiges are to be found to-day, were acute in the Pisa of the early fourteenth century. The democratic party had chosen the Count Nieri della Gherardesca to be their captain of war after the death of his nephew. $\mathrm{He}$ adopted the time-honoured method of kicking away the ladder by which he had risen. His natural affinities were with his own caste, and he was hand in glove with those with whom he and his forebears had been at feud. The ancient antagonism between patricians and plebeians was accentuated; the plebeians chose one Coscetto di Colle as their chief, and for two days the streets ran blood. Coscetto was taken prisoner and decapitated by Gherardesca, while, on the other hand, fifteen of the leading exiles were chased out of the city by the populace, and their houses razed to the ground. Castruccio Castracani saw his opportunity, and marched towards the city. Instantly the gates were shut, the family quarrel ended, and all Pisans were as brothers, to resist the invader. The astute Castracani observed how easy it was for a city to defy a lord unpossessed of a fortress, and he built himself one when he returned to Lucca (I322).

Next year a new trouble fell upon the Pisans. Nearly thirty years before, Boniface VIII., of evil memory, had given Sardinia to the King of Aragon in order to detach that monarch from his brother, Frederick of Sicily. This unholy compact remained on paper only, and the unsparing aid given by Pisa to the Aragonese Kings of Sicily had caused it to be forgotten. Certain feudatories of Sardinia besought Alfonso of Aragon to undertake the conquest of that island. The interest of Pisa in Sardinia was mainly commercial. Certain places had been fortified and garrisoned, notably Citta di Chiesa and Castro di Cagliari, but the rest of the island was held by feudatories who were not distinguished either by devotion or even by obedience to their motherland. The chief of these feudatories was Hugo Bassi, a bastard of the Pisan House of Visconti, who, as Judge of Arborea, ruled one-third of the island. The Republic, before investing him, had 
charged him I0,000 florins as a penalty of illegitimate succession, and Hugo was of the temper of Edgar :

\section{"Wherefore should I}

Stand in the plague of custom and permit

The curiosity of nations to deprive me.

Why bastard ? wherefore base ? ...

Now, gods, stand up for bastards !"

He intrigued with Alfonso for the surrender of Sardinia, and then communicated the design of the King to Pisa, demanding aid to hold the island for them. He divided the troops that were sent into small companies, distributed them over his part of the island, and, directly he was sure that Alfonso was on the way, caused every Pisan within his jurisdiction to be slain, whether peaceful trader or man of war, and opened his ports to the Aragonese fleet (1323). Alfonso had appealed to the Papacy for support, but although Pisa was Ghibelline, the Pope had the decency to refer him to the ecclesiastical courts to prove his right. Alfonso contrived, however, to get support among the feudatories, and when he landed he found himself in possession of about a third of the island. Pisa was at this time threatened by the Guelph league of Tuscany, as well as by Castruccio Castracani. No peace had been concluded with the kingdom of Naples, and now she was attacked by the rival House of Aragon; enemies thus beset her on all sides, but she did not abandon hope of retaining Sardinia. She equipped a fleet, but it was met by a superior force, and she deemed herself happy in being able to land a small body of troops. Citta di Chiesa and Cagliari were besieged, and the former fell, but the garrison was allowed to march out with the honours of war and reinforce Cagliari (1324). A new fleet was equipped by Pisa, and landed a small army without opposition, but the stronger Aragonese forces won a pitched battle, feudatory after feudatory was overcome, the Pisan fleet fell into the hands of the enemy, and finally Cagliari fell, after an heroic resistance. Both sides were severely crippled; the King had lost I5,000 men by battle or disease. Consequently when the garrison of Cagliari sought terms of capitulation, they were offered honourable conditions : Pisa was to retain Cagliari as a fief of Aragon, the private property of Pisans resident in the land was to be respected, but Sardinia was to pass to the King. These terms were ratified by Pisa, and peace ensued. Eut the King kept the word of promise to the ear alone; he erected a fortress which completely commanded Cagliari (I324.). Next year Pisan vessels were seized, and the war recommenced. But so exhausted was the Republic that she was obliged to seek the aid of ancient foes, Genoese who had been exiled by the Guelphs, and were established at Savona. The fleet, indeed, was put under the command of a Doria, but it was defeated with great loss. Soon after Cagliari, the last possession of the Republic in Sardinia, fell; and next year, at the intercession of the Pope, peace was re-established, and prisoners exchanged without ransom ( 1326$)$.

Pisa was now by no means so strongly Chibelline as she had been. She had quarrelled with her nobility; the Ghibellines had given her no aid during her Sardinian War; she was anxious to recuperate her powers ; it was desirable to keep at peace with Florence--a strong Florence meant keeping Castruccio Castracani, the dangerous lord of neighbouring Lucca, 
at bay. So when Castruccio and the Ghibellines invited Louis of Bavaria to descend into Italy she was at her wits' end, for Castruccio and Louis were too friendly to her taste. She dreaded lest a mistake in policy should bring about a rupture with the Emperor on the one hand, or with the Pope, and so involve excommunication, on the other. She sent an Embassy to Trient, where the Emperor was, and offered 60,000 florins as the price of neutrality and independence. When Louis deposed Galeazzo her anxiety redoubled. She disarmed her German mercenaries, and, acting on the advice of her ally, the Ghibelline Bishop of Arezzo, sent a fresh Embassy to Louis. Castruccio thought he saw his opportunity. $\mathrm{He}$ persuaded Iouis to refuse to receive the Pisan ambassadors, and reject all their propositions. He had them seized, and threatened them with death if Pisa refused to open her gates to the Emperor-elect. This was too much for the Bishop of Arezzo and the Ghibellines; a violent altercation followed, and the Bishop of Arezzo left the camp. There still remained, therefore, some sense of honour and good faith in Italy. Louis appeared before Pisa, the gates were closed against him, and he and Castruccio commenced a siege. Castle after castle in the contado declared for Louis; there was a strong Imperialist party in the city itself; the city fathers found themselves unable to raise the necessary means in the face of strong opposition; the treasury was exhausted; and, worst of all, the common people rose in insurrection, urged on by the chiefs of the democratic party, who had been excluded from the administration for seven years-ever since the time when Castruccio had taken advantage of a rising to attempt the liberties of the city, and had, very unintentionally, only succeeded in bringing the citizens back to their senses and reestablishing responsible government. It was very important for Louis not to lose the good favour of the Imperialistic mainstay among the free cities. When Pisa made overtures he promised that neither Castruccio nor the exiles should enter the city, that he would not attempt to effect any change in the Government, and that the contribution of Pisa to the Imperial expenses should be the sum she had herself offered him at Trient. The Pisan Embassy was released, the city received Louis, and he saw to it that his troops behaved themselves. But the nobles who had urged the mob to revolution were dissatisfied ; the Government must be overthrown at all hazards. They called a parlamento, which denounced the terms of capitulation, recalled the cxiles, and gave Castruccio leave to come in. Louis now knew how far steadfast was this star of his Empire ; he determined to teach such loyal subjects a lesson, and he fined them 500,000 florins (1327). Louis gave the town to the Empress, but Castruccio insisted on becoming her representative, took possession, enrolled her militia in his army, and bled the town afresh to refill his warchest. When Castruccio died (I 328 ), his eldest son succeeded in " rushing"1 the town, and speedily overcame all Pisan resistance. Then there was a revolt, and he and his brothers had to flee. Tarlatino of Pietra Mala was the next Imperial Vicar placed over a State once so opulent, but now practically ruined by the expenses of unsuccessful warfare, the loss of her colonies, the decay of her commerce, internal discord, and oppressive

I It was the custom of the "lords" of towns to " rush" their cavalry through the streets in order to indicate that the govern ment was overthrown, and that they had entered into full possession. 
taxation. In I 329 Count Bonifazio della Gherardesca, the leader of the plebeian party in the city, intrigued with Marco Visconti, whom the revolted troops of Louis had chosen to lead them as being a man credited with intimate knowledge of all the wiles and complications of Italian politics. It was plotted to turn out the Imperial Vicar and his guard. Visconti sent some of his troops, the revolt was successful, and once again an independent Republic was established.

But there was no rest for any republic in Italy in those days. Almost immediately a war broke out with Siena for the possession of Massa in the Maremma, and instead of throwing all their energies into this war, nobles and plebeians were at loggerheads. The democracy under Bonifazio kept the upper hand. To them trade was everything, and sentiment and tradition of small importance ; they were opportunists, and inclined to the Guelph side. But the nobles of Pisa, having territorial possessions, held other views ; they had fought for their own hand against the Guelphs over and over again; they were proud of their victories; it was a matter of small importance to them whether the commerce of Pisa flourished or no, and class feeling was their strongest prejudice, territorial independence their strongest interest. They conspired with Mastino della Scala, whose secret ambition was to dominate in Tuscany, and received promise of immediate support whenever need should arise. One Benedetto Maccaroni engineered the designs of the aristocratic party. A dispute ran high at a council meeting concerning the election of an officer; Maccaroni called his party to arms. But Count Bonifazio was more alert than his foes expected. In a twinkling he arrived at the public palace, his troops occupied the square in front of it and chained up the exits whilst the nobles were opening the prisons and burning the ledgers of the State in the hope of currying favour with the mob. At last the two parties met, and the nobles had to give way, but they retired slowly towards the gate of the city, which they hoped to defend until the arrival of Mastino's troops. The news took wind that reinforcements were coming, citizens that had hitherto remained neutral ran to arms, and attacked the nobles with so much vigour that they fled from the city, which was thus relieved from the presence of all its high families ( 1335 ).

Pisa, under the rule of the middle class, showed considerable vigour ; her interests were now mainly concerned in the defence and administration of the State, for her maritime predominance was fast disappearing, and her harbour, gradually silting up, was incomparable with that of Genoa. The neighbouring city and State of Lucca had always been a thorn in the flesh, and in 1335 Mastino della Scala obtained it by purchase. This despot, like an octopus, had been pushing out tentacles in all directions, and seizing little State after State ; but in $\mathrm{I} 34 \mathrm{I}$ the dispossessed sons of Ghiberto da Corregio succeeded in reinstating themselves in Parma, and Mastino, at war with Milan and Mantua, was too busily occupied to hope to regain the city, the loss of which cut his communications with Lucca. He therefore determined to put that city up to auction. Two rival and envious States, Pisa and Florence, were eager to bid, but Florence was able to afford the higher price. Perhaps there was a little vain-glorious boasting among the Florentines on their success. When a general council was held in the cathedral of Pisa the Prior of the Elders opened the meeting by a speech which is preserved in the chronicles of the city." "We have 
called you together," said he, "to announce that Florence has bought Lucca. The Florentines say that this purchase will be a lever wherewith to force the gates of Pisa ; already they threaten to invest us right up to our very gates, to reduce us to slavery by hunger, and, when we have succumbed, to beat down our defences, demolish the three chief wards, and give the name of Little Florence to the fourth. You see for yourselves the path of duty and honour." The assembly shook with wrath and indignation. In vain did some speakers suggest a pacific policy. "To Lucca! to Lucca!" was the shout that answered them. "We declare for war ; our lives and our possessions be the pledge; our very women will arm in such a cause, and God defend the right against pride and spite !"

Many Ghibellines banished from Florence had taken refuge in Pisa; they acted as intermediaries, and soon Pisa had as allies all the Ghibelline nobles of Tuscany and Romagna, and all the enemies of Mastino north of the Apennines, including Luchino Visconti, lord of Milan, who gave the most valuable help of all by sending 2,00o horse under the command of his nephew, Giovanni Visconti of Oleggio (134I). Florence was totally unprepared to meet such a vigorous foe. The Florentine General shillyshallied, and was unable to relieve Lucca, which was closely invested by Pisa, and in 1342 the Lucchese opened their gates, and the Pisans took possession of the city. It was an unlucky purchase for the Florentines ; thereby they lost not merely victory but liberty itself, for they had to throw themselves into the arms of Gauthier de Brienne.

\section{From the Conguest of Lucca (i 342 ) to the Peace of Pescia ( 1364$)$}

The acquisition of Lucca seemed to place Pisa at the head of the Tuscan powers ; Pistoja and Volterra at once put themselves under her protection. But her alliance with the Visconti might be as dangerous to her, as it rendered her formidable to other Powers, and the war had drained her of I,500,000 florins. And, to add to her danger, the old struggle between nobility and people was resumed directly the war was over. The Republic had weakened itself by lending troops to Milan, and during their absence Visconti d'Oleggio conspired with certain of the old nobility to drive out the Captain-General, Count della Gherardesca, and recall the sons of Castruccio. The plot was discovered; one of the conspirators was beheaded, the rest banished, their houses razed, and Giovanni d'Oleggio ignominiously expelled from the city. When news of this was brought to Luchino Visconti at Milan he imprisoned all the Pisans who were serving in his army, and sent Oleggio at the head of 2,000 men-at-arms to ravage the Pisan land; but, passing into the Tuscan Maremma, they found a foe more terrible than the sword. Malaria reduced the force, so that, without their having engaged in a single battle, Visconti was obliged to recall the poor remnant of his troops and make peace (1345). The war would never have been undertaken had not Pisa discharged her brilliant body of hired cavalry after the acquisition of Lucca. They, under the command of Werner, the German mercenary, organized themselves into a moving military State, and carried havoc and desolation through the length and breadth of Italy. 
Pisa suffered no less than the rest of Italy from the great famine of I 347 ; and probably economic distress had much to do with the envenomed struggle of new factions which appeared in Pisa-or perhaps they were but old factions revived under new names. At this very moment the Black Death made its appearance. The young Count Renieri, head of the House of Gherardesca, had been made Captain-General of Pisa in his boyhood, as if it had been his hereditary right. His relative, Dino della Rocca, and the heads of the popular party, acted in his name. He was now eighteen, and showed that he possessed some individuality of character and ideas, and a will of his own. Consequently his hereditary enemies combined to get hold of him and use him to their own ends. The most distinguished of these Bergolini, as they were called, after a surname given to the young Count, was Andrea Gambacorta, the head of a family destined to become all-powerful when the pest should have swept away or enfeebled the other great families. Dino had tried to hold the old party of the counts and the leaders of the popular party together, and many of the most illustrious of Pisan Houses were of his following. They held the Government in their hands, but rightly or wrongly Gambacorta accused them of malversation, and gained the populace to his side. The party in power was popularly known as Raspanti (the "grabbers"), and it boded ill for them that the party out of office had obtained the favourable ear of young Gherardesca, and was supported by the masses. At this juncture Gherardesca died, and the Raspanti were accused of having poisoned him. The atmosphere grew more electric every day. Lampoons and ribald verse were circulated in spite of prosecution; in vain were the opposed leaders forced to unite their respective families by marriage-ties, to swear at the altar to preserve peace; men remained at home fully armed, and night after night the city was lit up by incendiary fires. At last restraint came to an end, there was a revolution, the Raspanti were driven from the city, and Andrea Gambacorta was placed at the head of affairs ( 1348 ). The party which had once been that of the nobles now led the people, and the Gambacorta remained at the head of affairs. It was led by one Francesco Gambacorta, a wealthy merchant, when Charles IV. came to the city on his way to coronation (I355). One of the exiled Raspanti-Paffeta, Count of Montescudaio, of the Gherardesca-had acquired favour with Charles, and availing themselves of this the Raspanti called the citizens to arms, choosing the moment when Charles was at the cathedral receiving homage from the city, which had promised to furnish him with 16,000 florins towards the expenses of his coronation. Cries of "Long live the Emperor and liberty! To death with the conservator!" resounded through the streets, but the attempt was abortive. Charles contrived to put it down, and the insurgents laid down their arms. Gambacorta, however, to strengthen his authority and counterbalance the favour with which Charles regarded his foe, gave the Emperor the signory of the town, with the custody of its gates, and the management of the treasury. A sudden fit of repentance seized the citizens when they saw that they had sacrificed freedom to passion. The magistrates insisted on a reconciliation between the two parties, and both agreed to ask Charles to restore the city its freedom. The forces at his disposal were small, for his German reinforcements had not yet arrived. Pisa_had_always been faithful to the Empire, and he resigned. the signory 
with good grace. On his return, the Lucchese, whom Charles had governed during the time of his father, John of Bohemia, thirty-three years before, beset him, as they had done on his first visit, imploring him to restore its freedom to their city, and the citizens resident in France are said to have offered the Emperor a bribe of 20,000 florins. The Pisans got to know of this, and during a fire which broke out in the communal palace where the Emperor was staying, the burghers armed themselves, the rival parties promised to bury the hatchet, and to unite to one end-the maintenance of Pisan supremacy. Charles sent his troops to occupy the chief fortress at Lucca, and its garrison was withdrawn to Pisa. Then the Raspanti rose ; they led the infuriated burghers, who killed I 50 of Charles's German soldiers, and besieged the cathedral where Charles had lodged since the fire. Pafetta, however, skilfully withdrew his own party from the fray, and led them to the Emperor, offering him support, and laying the entire blame on the Bergolini. The houses of the Gambacorti were carried by assault and razed; all the Gambacorti were arrested; the insurgents were attacked by Pafetta and the Germans, and dispersed. In a couple of hours Lucca knew what had happened at Pisa; an insurrection was rapidly organized. Certain Crhibellines, however, who were not let into the secret, but who perceived that something was afloat, and who dreaded lest Lucca should ally herself to Guelphic Florence, signalled to Pisa from their towers for help. Instantly the two parties of Pisa were again at one, and though opposed by 6,000 peasants of the countryside they were admitted to Lucca by the remnant of its Pisan garrison that had been prompt to secure the gates and walls. The city was fired round the insurgent Lucchese, who were marshalled near San Michele, and these, surrounded by encroaching flames and a girdle of foes, were compelled to surrender. All burghers distinguished by birth, wealth, or personal ability were exiled, the others were disarmed, and Pisan supremacy, already marked by severity, became henceforward an odious and oppressive tyranny. Whether Charles was enraged at the checks and insults he had everywhere received, whether the weak monarch was influenced by Pafetta, or whether there were causes that we cannot discover, he wreaked his vengeance on the Gambacorti. He appointed a judge to try them, and, so Villani tells us, gave him orders to bring them in guilty. As the Pisan revolt could not be brought home to them they were accused of plotting to murder the Emperor. Seven of them were decapitated on the Piazza dei Anziani, all the ways thither being blocked by German soldiery. Charles exacted a large fine from the Pisans for their recent behaviour, and departed for Germany. The Italian Republics had become too powerful for a German monarch to rule, and it was a mistake on both sides to continue to entertain the old sentiment and tradition of the Holy Roman Empire. Directly Charles left, his favourite, Pafetta, was seized and sent to Lucca to prison, and sentence of banishment was passed both on his more dangerous associates and on the remaining members of the Gambacorti who were domiciled in Florence. The aristocratic Ghibelline element was again wholly dominant in Pisa, and no occasion was omitted on the part of the Raspanti of showing ill-will to the great rival city of the red lily. All the petty lords of keeps along the Florentine frontier who had ever manifested Ghibelline proclivities were petted and encouraged to betray their country, the commercial treaty of ${ }^{1} 342$ was violated, and every attempt was made to compel 
Florence to declare war. But Florence refused the direct arbitrament of battle. She dealt a deadlier blow by transferring her trade to the Sienese port of Telamone. Commerce abandoned the city for the new harbour; the port was empty, the markets abandoned, the counting-houses deserted, the workpeople out of employ. All the blame was thrown on the Government; the Raspanti were justly accused of having forced on a war while the Bergolini had always adopted a policy of conciliation. All the business men of Pisa were discontented with the pass to which the Government had brought the city, and a money-changer set to work to sound his clients. $\mathrm{He}$ found them disposed to rise against the Raspanti and recall the Gambacorti, who, being engaged in commerce themselves, were by no means very hostile to the Tuscan Guelphs, for, on account of the large territorial holdings of the Pisan aristocracy, the struggle in Pisa was still one chiefly influenced by the dominance of a noble class, instead of having evolved, as in Florence, into a demand of the lower orders for more political power met by the resistance of big burghers. The plotters arranged to seize the square on Good Friday ( 1360 ), recall the Bergolini, and restore their commercial rights to the Florentines. But there were traitors in the camp. The plot was revealed on the evening before it was to be put into execution. Eighteen of the leaders were arrested, of whom eight were executed and ten banished, and much more severity would have been exercised but that so many burghers were implicated that the Raspanti dared not pursue the matter.

A year later Florence acquired Volterra at the moment when Pisa was on the point of purchasing it from its despot. Pietro Gambacorti and his adherents left their refuge in Florence, and invaded Pisan territory without any effort on the part of the Florentines to restrain them; and Giovanni di Sasso, who had been in the Florentine military service, had possessed himself of a fortified place in Lucchesan territory with the connivance of Florence. A series of such affronts as had been exhibited on both sides could end in nothing but warfare. The troops lining the frontier could not refrain from mutual insult; and when Sasso offered the castle of Pietrabona, which be had taken, to the Florentines, they accepted in order that they might exchange for it two other fortified places of which so-called exiles of Pisa had possessed themselves. War was declared, and Florence ravaged Pisan territory without the Pisans, who were visited by plague at the time, being able to make any effective resistance.

But the Florentine army lacked discipline, and soon ceased to be any grave danger to the Republic, though Florence organized a fleet that did much damage to what remained of Pisan commerce and maritime enterprise (1362). At last the plague was stayed, and Pisa was able to act with more vigour. She succeeded in some small military enterprises. Extraneous help was needed, however, and Bernabo Visconti sent the " White Company" of Englisnmen, to whom the Pisans engaged to pay 40,000 florins for four months' service. Before they could arrive the Pisans suffered severe defeat at the hands of Pietro Farnese, the Florentine General, losing their own commander. who was led captive to Florence with I5O of his best soldiers. Then the plague which had passed over Pisa broke out in the Florentine camp and also in Florence, and the White Company arrived just at this time. The Florentine commander was a poor soldier, and the prevalence of the pest rendered defence 
difficult. It was now the Pisans' turn to ravage territory and return affronts. The Florentines had minted money outside the gates of Pisa ; the Pisans did the same before those of Florence, and, having heaped insult on insult, returned home (1363). After resting awhile the White Company renewed their engagement at a cost of 50,000 florins, and were supported by a fresh company of 3,000 cuirassiers under the command of Anichino Baumgarten. These were sent by Galeazzo Visconti, who was extremely glad to be quit of them, as he had made his peace with the Church, and the concurrent war in Lombardy was at an end (1364). The Pisans now commanded the services of 6,000 men-at-arms, and deeming that the possession of what was in those days a very imposing force would ensure peace, they begged the Pope to intervene. The Florentines refused to submit to any terms while their arms remained inglorious, and hired the Company of the Star, but the wily lord of Milan bribed their leaders, and delayed their arrival. The Pisans, under John Hawkwood, passed before Florence, and devastated the territory beyond. On their return they took some entrenchments outside the gates of the city, with much slaughter, and Baumgarten got himself knighted, and conferred the order on several of his companions-at-arms on the scene of victory. The companies held a night-fête on lofty Fiesole, and the Florentine warders had the mortification of seeing them dance around their fires, and hearing them mock the city by derisively shouting the sacred formulæ used in the councils of the Priors. Hawkwood continued his devastating march through the Upper Arno, and returned to Pisa by way of Cortona and Siena, having very completely wasted nearly all the Florentine territory. And though the Florentines managed to burn Leghorn and the Pisan port, the Company of the Star had not yet arrived. But Pisa had the misfortune to lose Baumgarten, who, seduced by Florentine gold, would not renew his engagement, and Hawkwood, owing to the alertness of the captains, failed to surprise the Florentine army, though it had been betrayed by its General, Galeotto Malatesta. The Pisans lost 3,000 infantry, of whom one-third were slain ; for Hawkwood retired at once with his men-at-arms when he found that the plot had failed. The Florentine commanders, Pandolfo and Galeotto Malatesta, had more than once courted defeat in order to weaken the State, and so make themselves masters of the city. Florence, therefore, renewed negotiations which the Papacy, as mediator, had set on foot. Everything was arranged, when an unexpected revolution overthrew the Government at Pisa, and very nearly caused a renewal of warfare. The Visconti had covertly done all the damage to Florence that they could ; they kept up communications with a party in Tuscany by whose aid they hoped to become masters of Central Italy; they furnished Pisa with money and men; they delayed the arrival of Florentine support ; they still hoped that a continuance of the war would so try the strength and patience of Pisa that she would place herself in their dependance; it would further their plans could the proud and insubordinate Pisans be brought first of all to feel the bridle of a master. Agnello, the Pisan Ambassador at Milan, was able, ambitious, subtle, insidious, a plebeian, engaged in trade, and hitherto of no great consideration in the State. He belonged to the dominant Raspanti party, and Bernabo Visconti offered to aid him in every way to secure the lordship of Pisa if he would afterwards hold the town, really as his lieutenant, though nominally as his ally. 
Agnello, on his return to Pisa, had the audacity to propose at one of the council meetings engaged in discussing the terms of peace with Florence, that, in order to inspire more confidence in Bernabo and their military leaders, and to secure more secrecy in matters of State, it would be well to elect a lord of the city, and so, afresh, every year. To give a colour of straightforwardness and honesty to his proposal, he further suggested that Piero d'Albizzo di Vico, one of the most honourable of Pisan citizens, who had just been appointed Ambassador to treat with Florence, was the man for the office. Piero repudiated the proposal with loathing; he retorted that peace, not the surrender of freedom, was required to save the country. But after Piero's departure for a congress to be held at Pescia, Agnello returned to the attack. The Raspanti were the party to which the middle class adhered, and it shows the growing importance of the middle class in Pisa, and probably the influence of Florentine ideas in the days when so many of her merchants settled in Pisa, that one Vanni Botticella, the grandson of a butcher, had the effrontery to solicit the office for himself. Agnello replied with singular skill: he lauded Vanni for his ready response; but did his fortune provide him with the wherewithal to pay the mercenaries, as the lord of a town was required to do ? Vanni had to confess that that was beyond his powers. Whereupon Agnello reiterated his demand that someone of both wealth and ability should be selected. The mistrust of the shrewder among the citizens was aroused ; it also was bruited abroad that gatherings of soldiery and suspicious characters took place at Agnello's house. One night several citizens armed themselves, and, proceeding to the signory, demanded that a domiciliary visit should be paid to Agnello. It was accorded forthwith. But Agnello had received warning. When the armed guard arrived at his house they were immediately admitted. It shows how simple burgher life still was in I 364 , that this man, who was prepared to pay down at least the 30,000 florins which it appears would be required for the hire of troops only, kept but one young girl as servant. Agnello's wife appeared with some sort of garment thrown over her. "My husband is asleep," said she ; " he is very weary, but if the State has need of him I will awake him." Even the citizens who had insisted on the visitation had their suspicions disarmed; they were ashamed of having disturbed a respectable woman and brought her out of bed in a half-naked condition. They returned to the elders (anziani), declaring that they had unfortunately made a mistake-their suspicions were without foundation; and they went home again. But directly they had gone, Agnello leaped out of bed fully armed, and put himself at the head of his banditti. He marched them to the palace of the signovia, and surprised the guard. John Hawkwood, who had been bribed by the Visconti, was at hand to aid him with his cavalry. Agnello took the presidential chair in the council-chamber, and had the anziani summoned. "Our Lady," quoth he, "has revealed to me this very night that, for the good and peace of this city, I should assume, at least for a year, the title and functions of Doge. In order to obey this command from Heaven I have just paid 30,000 florins of my own money to the troops for arrears. I have summoned you that you should acknowledge by your suffrages this Divine appointment." The startled anziani, surrounded by the creatures of Agnello, could do nothing. They swore obedience; then one by one 
the more important of the men of Pisa were brought to the palace, and partly by the presence of peril, partly by the promise of lucrative office, they were induced to take the oath. This business went on all night, and next day, with ducal pomp and circumstance, Agnello paraded the town, accompanied by the Government, and the people, forced by, the soldiery, acclaimed him Doge.

Agnello had the skill to consolidate his power by a plan copied in part two centuries later by a Genoese patriot: he united sixteen families into one, of which he became the head. He gave them all the title of Count, and the same heraldry, and promised at the end of a year to put his office into commission among them. No one ever better followed the advice which the Count of Montefeltro had given to Pope Boniface : "Promise much, perform little." He shortly dropped the title of Doge for that of Lord. He never appeared before the people save sceptre in hand and decked in cloth of gold, and he must needs be approached by petitioners on their knees, like any Pope or Emperor of them all.

\section{The Overthrow of the Doge Agnello and the Recovery of her INDEPENDENCE BY PISA (I 368-i 370)}

Agnello retained the dogeship of Pisa for four years. In I 368 Charles IV. crossed the Alps for the second time. In lcague with the Pope, the King of Hungary, and the lords of Padua, Ferrara, and Mantua, he came to liberate Lombardy from the rule of the Visconti, and Italy from the Free Companies. But the Visconti were strong, the mercenaries were skilled, and Charles was weak. His troops could do but little, the enterprise was expensive, and the Visconti bought him off. The astute Italians had taken his measure, and they seized advantage of his presence to change their governments, and secure the Imperial imprimatur to their new constitutions. The Lucchese, with whom Charles had dwelt when a Prince, seized the opportunity. They entreated him to visit them, and their Guelph exiles, grown wealthy in France and elsewhere, offered to buy the freedom of their native city at the monarch's own terms. Agnello, by no means secure at Pisa, looked forward to the advent of Charles and his I,200 horsemen with alarm. He sent to compound with him; he offered to surrender Lucca if he were confirmed in his rule of Pisa as Imperial Vicar. The monarch was complaisant. He received Agnello outside the walls of Lucca and knighted him, a distinction which in turn Agnello immediately conferred on his nephews and firm supporters. But at the very moment when Charles publicly declared Agnello to be Imperial Vicar at Pisa, the hastily built hustings collapsed, and Agnello's leg was broken. On the receipt of the news, the Pisans, who in spite of family quarrels were agreed on the question of their land empire, and who felt humiliated and chagrined to the last degree at the surrender of Lucca, rose in revolt to a man. A government of twelve elders (anziani) was appointed to rule Pisa under its ancient laws, and the cxiles were recalled, except Pietro Gambacorti. Agnello, lying on a bed of sickness, submitted to the inevitable, and surrendered all claim to the city.

But Pisa did not delay to abuse her newly-won freedom. The old spirit of feud and faction was only put down by the association of certain coolerheaded burghers and nobles, who were soon 4,0oo strong, and who formed 
a Society of St. Michael. To the Bergolini and Raspanti they cried, " A plague on both your Houses!" and they succeeded in restoring order in Pisa for a time. There was still an undercurrent of bitter feeling against the Raspanti. A series of disasters were traced to their administration. Commerce had decayed ; a disastrous war with Florence, increase of taxes, the tyranny of Agnello, the loss of Lucca-all the evils that afflicted the city were attributed to them. If the Republic pardoned so many crimes, why should Pietro Gambacorti still be under the ban ? His parents had perished by an unjust sentence ; he was the favourite of Charles ${ }^{1}$ (Bernardo Marangoni Cron. di Pisa.-Paolo Tronci Annali Pisani).

Two leaders of the Society of St. Michael interceded on Gambacorti's behalf, and he was recalled. He got a popular ovation on his arrival, and, proceeding to the cathedral whilst the bells rang out, he swore to remain a simple citizen, to serve the Republic, and to forgive his foes.

But the Bergolini were still nursing their wrath against the Raspanti. In Easter Week they armed and attacked the palaces of their enemies, and half the town would have been in flames if Gambacorti had not intervened. "I have pardoned them," he is reported to have said-" I, whose parents they slew. By what right do you refuse to do as I have done ?" Gambacorti's appeal was so far successful that he stayed the riot, but the Raspanti were ejected from any share in the government. The Bergolini took office, and the Society of St. Michael, conceiving that there was now no further need for its services, dissolved. The Raspanti were, however, still possessed of a fortified gateway, which the followers of Agnello had never evacuated, and they sent an Embassy to Charles, who was at Lucca, to intervene. There happened to be a deputation of the first citizens of Pisa in Lucca, sent by the Republic to represent it at the Imperial Court. Charles clapped the whole Embassy into gaol, and sent his German troops into the city through the gateway held by the Raspanti. The Pisans were prepared. They rang the tocsin, they bore off the seats of the neighbouring cathedral to make barricades, they manned the baptistery with crossbowmen. The men were ready to contest each barricade ; the women, even, were out with them, and tore up and passed on the stones of the streets for missiles. The troops were repulsed, and the Chancellor of the Emperor was forced to seck a private interview with the Government. It is surmised that he was not inaccessible to bribery, for he withdrew his troops; and, though soldiers were left to guard the gateway, they were soon forced to surrender, and the gateway itself was gutted by the people, so that it might no longer be of any similar service (Bern. Marangon. Cron.). The Emperor retaliated by doing some harm to the countryside, but he was very glad to make terms and squeeze some gold out of the city for the expenses of the expedition. He could not rule Italy, but since, whenever she appealed to her Emperor, she flouted his authority, it was but just and proper to mulct her for disobedience !

Lucca was free from the domination of Pisa, but she had to pay Charles 200,000 florins for her emancipation. Charles found himself impotent in his Imperial office. The Italians were turbulent subjects. They professed to respect constituted authority ; they were perpetually in insurrec-

1 Charles, who was quite open to the reception of a thankoffering for the pronouncement of justice, had received an honorarium of 10,000 . florins from Gambacorti. 
tion directly it was applied, and all Germanic conceptions of the rights of a monarch were systematically set at defiance by them. At least, they were rich, and could be squeezed, and the gold of Italy would go to the adornment of Prague and the superb bridge which was to cross the Möldau. But the freedom of Lucca was as yet more apparent than real. ' Its citizens were still in the power of the Imperial Vicar, and Bernabo Visconti was ever ready to buy Lucca of the Vicar, or to take it by surprise. At last, after fifty-five years of bondage, Florence, the Pope, and the lords of Padua and Ferrara, afraid of the machinations of the Visconti, lent the Lucchese money to buy out the Vicar, and they re-established their Republic in I 369 .

The Lucchese were Tuscans to the core. They possessed all the energy, all the business aptitude, all the passion for freedom of their race. Their exiles had vied with Florentine and Sienese in the commercial enterprises and financial operations of Paris and London. The Lucchese now directed their energies to the construction of a constitution. They copied the Florentine model. The city was divided into three wards; the signoria was to consist of a gonfalonieve and ten anziani; it was to sit for two months only; but the bursa, or bag, containing the names of those eligible, was to be filled with names to last for twenty or thirty successive changes, to be determined by drawing the names by lot. The signoria was to be flanked by thirty-six buoni uomini, who should sit for six months; these were intended to give steadiness and continuity to its policy; and a general council, renewed yearly, was to consist of 180 members. Nobles were rigidly excluded from all share in the government.

The citadel of Castruccio was demolished, and a new communal palace was erected. A yearly fête-day, marked by all the dignified pageantry of State, henceforward marked the day of liberation, and the coins of the Republic of Lucca bore the effigies of Charles IV.

\section{FLORENCE}

From the Death of Henry ViI. (i3i3) to the Expulsion of the Duke of Athens (1343)

THE North of Italy was in the possession of despots hostile to the Papacy, and desirous of having their hands free from its control, so that they might consolidate and extend their power. The South was occupied by a King who owed his possessions to the Papacy, and could only maintain them by remaining consistently Guelph. That monarch had possession of the Pope at Avignon, and both the great members of the House of Anjou, he of Naples and he of France, meant to maintain their hold of the chief pastor of Christendom, and utilize the Papacy to their own advantage. Tuscany lay between the two rival interests; its cities were divided in their political proclivities, rather from mutual jealousy and self-interest than from conviction, and Tuscany therefore became the arena of contest. The Guelph party appeared to be the party of liberty, because the despots who had established themselves in the North were Ghibellines. Florence, 
Siena, and Bologna leagued themselves together. Bologna, though not in Tuscany, and separated from Tuscany by a range of mountains, was a self-governing city, and had commercial interests which bound it to Florence, for it was situate on one of her most important trade-routes. Pistoja, Prato, Volterra, San Miniato, and other smaller towns also joined the league. Pisa, although free, remained Ghibelline, and Arezzo was ruled by a Ghibelline Bishop. The neighbouring towns of Romagna were all under the sway of despots. Thus the parties appeared to be evenly balanced, though there presently arose a man in Lucca who turned the scale.

Surrounded by her exiles, enemies to their own town, and with her trade-routes commanded by Ghibelline States, or by Guelph States which might at any moment become the prey of the banished party, and whose captains of war were rapidly making themselves the masters of the free towns, and threatening Florentine independence by their ambition, there was no alternative for Florence but war. Moreover, the Guelphs of Lucca, banished from Lucca by the new despot of that city, Uguccione della Faggiuola, appealed to Florence for aid, and Lucca and Pisa, both Ghibelline, blocked the direct route to the Mediterranean. Florence was at war with Arezzo, but she gave the Arentines advantageous terms, concluded peace, and braced herself for a struggle with the redoubtable captain (1314). She twice appealed to Robert of Naples for aid, and got two small contingents, each commanded by one of his brothers (13 I4-13 I 5). Robert had not found his powers quite adequate to the situation. The Guelph organization had been lax and inefficient, and the brothers of the King were not men to cope with the rough, sagacious old warrior of Lucca. In numbers the Guelphs had the superiority. Bologna, Siena, Perugia, Citta di Castello, Agobbio, Pistoja, Volterra, Prato, and certain towns of Romagna sent contingents, but they were no match for the impetuous military geuius of Uguccione, and their army was half destroyed on the fatal field of Montecatini (13 I5). Florence was probably saved from falling to Uguccione by revolts in Lucca and Pisa, which, made at an opportune moment, when Uguccione was present in neither city, were crowned with success. Every Italian city was like a slumbering volcano : there was little evidence of subterranean fire ; the olive flourished and the vine grew, and then suddenly and without warning there was a quivering, and a terrific outburst spread panic and dismay. There resided in Lucca a man who is credited with having engineered the revolt, one Castruccio Castracani, still young, but who, during the banishment of his family, had wandered in many countries, including England, and had picked up no small experience of soldiery and the ways of men. He had become a military leader, no less brilliant than brave. He was a past master in all the insidious devices and ingenious jockeyship necessitated by the developing diplomacy of the age. He had the trick of gaining devotion and inspiring fear; he could ignore hate when it was powerless, and perceive, with unerring acumen, which way advantage lay. He knew when and where to bestow confidence, and he could read the thoughts and form a just estimate of the powers of men. Moreover, he was just entering on his prime, being about thirty years of age. Four years after the revolt, he had so won the hearts and captivated the imaginations of the Lucchese that he induced them to banish the Guelphs, and when he asked for 
sovereign power it was accorded him by 2 ro votes, and there was but one dissentient voice. Castruccio had obtained and fostered the favour of all the great Ghibeiline chiefs, and he had now secured, in the possession of Lucca, a fulcrum for his ambitious purposes. It was a wealthy town, his perquisites were considerable, and he managed them with economy; the Lucchese, since their share in the glories of Montecatini, had acquired a taste for war, and Castruccio animated and guided their military ardour; the mountains, tilled by hardy peasants, furnished excellent material for troops, and their lords, who dwelt in the fortified eyries of the Apennines, had varied the tedium of youthful idleness by brigandage on land or piracy on the neighbouring sea. Castruccio organized the material with which he was so happily furnished, and attracted exiles and adventurers to his little Court; these he disciplined and attached. In the year when he received the lordship of Lucca, the Pope called on Philip of Valois, the cousin of the King of France, to come to Italy, and rout the Ghibellines. Philip was the son of Charles of Valois, whom a previous Pope had summoned to put down the "Whites" of Florence. This was Castruccio's opportunity. He attacked the Florentines, and ravaged the valley of the Arno, and when Philip, caught in a trap between the Po and the Ticino, had to accept a humiliating treaty from the Visconti, the war continued. The Florentine Priors showed military incapacity, and twelve buoni uomini were added to strengthen them, which Villani says was a success. In I 323 Castruccio managed to seduce the mercenary troops employed by Florence, the first instance of that treason to the employer which later became so common among those soldiers of fortune. Castruccio then advanced to the siege of Prato, a place within a few miles of Florence. The Florentine signoria, deprived of mercenary troops, called on the citizens to arm. The shops were shut, the walls manned, and I,500 horse and 20,000 foot advanced to the relief of Prato. The ban was removed from all exiles who should join the army, and 4,000 "Whites" and Ghibellines, better men of war than the burghers, fell into line. The citizens had high hopes of victory; their nobles were far less sanguine; they know that arms and enthusiasm do not make soldiers, and, moreover, they were malcontent. When the authority over the city accorded to Robert had expired two years before, the Florentines, always uneasy under the protection of that powerful Prince, proscribed its nobles right and left, and compelled bail for good behaviour with no light hand, and there was general complaint among the body that they, the sole efficient defence of the city, were alone deprived of the protection of its laws. A council of war was held, and there was such division of opinion as to the desirability of attacking Castruccio with a citizen army that a message was sent to Florence for further orders. Indecision paralyzed the signoria and the councils; the war-spirit of the mob prevailed. The streets were choked with crowds shouting for war, and orders were sent to Count Guido Novello, the General, to proceed. But Guido was in no hurry to attack Castruccio, who had withdrawn from Prato to Lucca, and the exiles were advised by the nobles to look to their own interests, and make quite sure of the amnesty. They rode off in a body, and presented themselves before the gates of Florence, demanding admission. The signoria in alarm clapped the gates to, to prevent sympathizers in the city from rendering them aid. The Guelph nobles 
pretended to require the services of so many valiant warriors; the excuse was a valid one, but the signoria had penetration enough to perceive their real object : it was obviously a ruse of the caste to recover its lost preponderance. The temptation to yield was great; to refuse was to imperil the very existence of the State. The signoria pulled themselves together. Never before had they exhibited such resolution (Ammirato, vi.295). The nobles within were plotting to open the gates, to set fire to the houses of the city fathers, and, in the confusion attendant on a conflagration, to slay their adversaries, and then set up their own laws and suppress the ordinances. This would have won the favour of Castruccio, and stopped the war. Amerigo Donati, son of the wild and impetuous Corso Donati, il bavone as he had been called, was at the head of the movement. But the warders of the ramparts discovered a midnight mecting of the conspirators. Florence could not afford to lose more of its men of war, or aggravate the situation, and the signoria, for once, exercised clemency; the leaders of the conspiracy were only banished. Though countless dangers menaced the Republic, it remained undaunted. The enemy, led by a formidable and wily General, was busy devastating the countryside, fortresses were surprised, indispensable allies were threatened with destruction, treason was in the air, and the most dangerous foes to the city were those within her gates. She set to work to reorganize her militia and reform her constitution. The summoned militia had been. wont to assemble at the doors of their standard-bearers, and their gathering could be easily prevented by a few resolute horsemen blocking the narrow streets. The troops were divided into too many companies for these tactics to prove successful; there were to be fifty-six of them. The Government had been changed every six months, the priors going out of office as well as the buoni uomini and gonfalonievi of the companies, and a certain number of burghers of the richer class from each quarter. The inconveniences of such frequent change of administration were manifest. There resulted a want of continuity in policy, and each election gave an opportunity for sedition to rear its head. The existing Government had secured public confidence by its discovery of the plot; it was allowed to name, in conjunction with the electorate, magistrates enough to last for forty months. All the usual forms of election were retained; the names of those elected were written on closed slips and put into " purses," whence they were drawn by lot. This example of imborsazione was followed by all the Italian cities, and was in use in Sismondi's time at Lucca and other places. The Podestà and Captain of the People were to be deposable by the Priors, and became their obedient tools. The statutes against dangerous nobles were made more stringent, and popolani, aiding or abetting offenders, were made amenable to the law. The new method of election appeared to establish a greater equality, for a larger number of citizens were necessarily called to office when so large a number had to be elected at one time. But it admitted men of a lower standard of ability. Faction was crippled, but emulation was crippled too, and every considerable citizen could count on entering the Government in due turn.

One afternoon in May, I325, the Priors and the chief burghers were seated at a banquet in the church of San Piero Schieraggio. They were celebrating the bestowal of arms on the "Executor of Justice" and a 
German High-Constable whom they had taken into their pay. Suddenly a message came that Pistoja had been surprised by Castruccio. The news

" displaced the mirth, broke the good meeting

With most admired disorder."

The guests rushed to arms, and overturned the tables in their anxious haste. They could not believe that the news was wholly true; there might still be time to arrive and save the neighbouring city from some great peril. The tocsin summoned the troops, and Prato was reached the same evening; but there the news was confirmed, and the blank and dejected army retraced its steps to Florence. Pistoja was a strong place, of great importance to Florence. It commanded a high route to Bologna, and the mountains to the west, which furnished another route, bristled with robber-castles and were already in the possession of Castruccio.

Three years before, the Abbot of Pacciana, a man of great importance in Pistoja, had taken advantage of the enfeeblement of the city, which was financially impoverished, ill-provided with soldiery, and which had lost the flower of its chivalry, to obtain its signory. He had preached the doctrine of peace, and the unhappy peasants of the countryside, who, as usual, had suffered most in warfare, and the lower orders of the city, who were much more interested in a flourishing retail trade than in the high politics and Chauvinism of the big traders and aristocracy, heard him gladly. The Abbot entered into secret negotiations with Castruccio, who read the man with his usual unerring judgment. He knew the Abbot to have neither strength of character nor ability to retain the signory when he got it. Castruccio disbelieved the monk when he promised to transfer the city to him. He was ready to wait. When he fell, Castruccio's own chance would arrive. By the aid of Castruccio, the monk seized the city, and was joyfully proclaimed lord of Pistoja by the mob. He governed most vilely (Ist. Pistolesi Anonime), and was overthrown and replaced by his nephew, who, after the manner of ruling families of the time, plotted against him, and whom he tried to murder. The new lord, Filippo dei Tedici, tried to maintain his independence by playing off Castruccio and the Florentines against each other. He subsidized Castruccio to leave him alone, and got the money from Florence under the pretext of being her ally. But, aware that the game could not last long, he offered to sell the signory of the city to Castruccio for 10,000 florins and give one of his daughters in marriage. Tedici secretly let in Castruccio at the head of some of his troops, and the troops waiting outside then rushed through the town, cutting down those Guelphs and Florentine soldiers who attempted resistance.

Florence sent out against Pistoja the most formidable army she had ever raised. A thousand Florentine horsemen equipped themselves at their own charges; I,500 men-at-arms, mostly French, and I 5,000 foot accompanied them, and daily 3,00o gold florins were taken out of the war-chest. Raymond of Cardona commanded-the General who had opposed the Visconti, and been taken prisoner by Galeazzo, and released on oath not to serve again against the Ghibelline cause, an oath from which the Pope, who was above all the considerations which weigh with the plain man, had released him. Reinforcements came to the aid of 
both armies, and the Florentines gained some small advantage over their foes. Cardona besieged the castle of Altopascio in August, 1325, a place renowned for its strength, and succeeded in taking it; but, owing to the summer heats, sickness broke out in the camp, and Cardona, who was greedy of gold, found it a paying game to release certain impatient nobles and weary burghers from their military duties, and hang about the castle after it fell to see what more he could get from fat citizens anxious to be released from the perils and discomforts of a campaign. Though such carpet-knights were probably of little use, precious time had been lost, which Castruccio employed in securing the succour of the lord of Milan by the payment of I0,000 florins.

Cardona was no match for Castruccio; he was outwitted and outgeneralled at every turn. Galeazzo Visconti sent his son Azzo with 800 horse, and when the two armies met near Altopascio in fixed battle, though their numbers were about equal, a mercenary leader lost heart, and fled with the troops under his immediate command. The Florentines, discouraged by the defection of their leader and the flower of their troops, made no very sturdy resistance, and Cardona and many important Florentines were taken prisoners. The possession of Pistoja enabled Castruccio to advance with perfect safety into the very heart of the Florentine State. He sat down before the gates of the city, and kept fête on the very spot where from time immemorial the Florentines had been accustomed to race their horses. Even the common women of the camp raced for prizes, and the humiliated Florentines, insulted by a class of depraved sluts, had not sufficient manhood left in them to make a sortie or even to disturb the fête. Florence, which, however beautiful, was as unsavoury and unsanitary as the other cities of the Middle Ages, suffered from overcrowding. All the peasantry of the countryside had sought refuge within its walls, and an epidemic raged. The dead were buried quietly, so that the number of those who perished should not strike terror into the hearts of the affrighted and almost despairing people. Castruccio ravaged the whole plain of the Middle Arno, and after fortifying Signa, a place between Florence and Lucca, retired to Lucca. He entered the city in a triumphal procession, headed by the caroccio, which Florence had lost in the great fight at Altopascio. It was adorned with olive-branches, and bore the arms of Florence reversed. Cardona and the Florentine prisoners followed it. Their ransom added close on 100,000 florins to the coffers of Castruccio (I 325$)$.

In the same year the Ghibellines of Lombardy attacked Bologna, and gained a crowning victory at Monteveglio. In vain had Florence urged the Bolognese not to be rash. They were determined to a venge Altopascio, and troops lent by Florence were among the crushed army.

Robert of Naples, the head of the Guelphs, had been for some years in Provence manipulating and strengthening his hold on the Papal Court at Avignon. He had now returned to Naples. Florence sent Ambassadors, who urged the power and ambition of Castruccio, how he had consolidated the forces of his party and secured the aid of Northern Italy. They recalled the services of their own city, and begged Robert to aid them in their extremity. But the monarch knew the art of profiting by the disasters of his friends. He told them that they should have re-elected him as lord of their city. He was ever ready to help his friends, but 
he owed it to himself, as a monarch, to rule and not to serve. If they were willing to accept himself or his son, the Duke of Calabria, and invest him with autocratic powers, they might have his assistance. He knew the turbulent spirit of the city, and preferred to enforce law and order untrammelled and unperturbed by notions of liberty and self-government. The Florentines had perforce to pass under the yoke, but they strove hard, and not without success, to preserve their freedom and self-respect. The Duke of Calabria was appointed to the signory for ten years, at a cost of 200,000 florins, and he was to supply 1,000 foreign cavalry during the war and 400 in times of peace. Siena managed to submit to terms less exacting, though she also had to give the Duke her lordship. Prato, San Miniato, San Gimignano, and Colle, towns subject to Florence, also had to yield themselves to the Duke, who proved to be a worse foe to his allies than to his enemies. He began to rule as a despot in Florence ; he squeezed out of the city more than double the sum that had been promised; he reduced the priorate to a name, tried to get the suffrages of the Florentine women by abolishing all sumptuary laws, and, worst of all, perhaps, he did nothing against Castruccio. Shortly afterwards Bologna was obliged to give herself to the legate $\mathrm{Du}$ Poïet.

In I 327 a new danger menaced the unhappy Florentines. Castruccio, the Visconti, Cane della Scala, and the other Ghibelline chiefs, invited Louis of Bavaria to descend into Italy, and take the Imperial crown (I327). Castruccio was embarrassed by the presence of the Duke of Calabria. He had discovered intrigues in Lucca against his power, and, although he made an example by burying twenty conspirators alive, head downwards, and banishing Ioo others, he dared not follow up all the ramifications of the plot, so numerous were the plotters. He breathed more freely when Louis consented to enter Tuscany and reached it without the Cardinal-legate, now lord of Bologna, daring to oppose him. Louis found Castruccio an able adviser and a consummate strategist. $\mathrm{He}$ began to look on him as his right hand, and he invested him with the dukedom of Lucca and the neighbouring cities. Florence and Castruccio regarded one another with mutual dread. Each side feared to fight, and Castruccio and the Emperor marched on to Rome (1328). Then the Florentine forces moved. A French General in the Florentine service surprised and took Pistoja, where the Burgundian soldiery behaved with such brutal rapacity and in such a spirit of wanton destruction, that they spared neither friend nor foe, and reduced the city to an almost defenceless condition. The news of the capture soon reached Castruccio, who had accompanied the Emperor to Rome. - He at once returned to Tuscany at the head of $\mathrm{I}, \mathrm{OOO}$ men-at-arms and as many archers. He forced fresh contributions from Lucca, and took advantage of the gift of Pisa to "rush" that city after the fashion of the times. For, when a captain wished to possess himself of a town, he was wont to take it by surprise, gallop his cavalry up and down the chief thoroughfares, helmet on and lance couched. He overthrew all barricades before the burghers could man them, and seized all the points of vantage. Then he made the Pisan militia advance with his troops to the siege of Pistoja. Three hundred horse and I,ooo foot, all mercenaries, and the Guelphs of the city were its sole defence. But the Florentines ordered an army of 600 veterans and many thousand militia to march to its aid, and sent a gage of battle 
to Castruccio, which that wily General accepted, fixing the day and hour of the fight. He employed the interval in fortifying his camp, and, when the hour came, refused to budge, and the Florentines were unable to carry it by assault. Castruccio had learned that the Pistojese were short of provisions, and he knew that he had only to wait for them to surrender. No wonder that hearts sank in Florence, and that the burghers' courage almost forsook them as they witnessed what appeared to be the approaching triumph of the Ghibelline arms. Castruccio was the ablest captain of his age, of whom Florentine Villani speaks as "a man of prudence, perseverance, and courage." Behind Castruccio were the Emperor and the great despots of the North. Florence, 'too, was surrounded and almost isolated by foes in arms. It did not appear that Castruccio had arrived at the zenith of his power even. He was now Imperial Duke of a fair part of Tuscany, and lord of the Genoese coastline and of more than 300 fortified places. "He was," says Villani, "more formidable than any lord or Italian tyrant who had reigned for ages." Doubtless he, too, thought " his greatness was a-ripening." But, writes Villani, " he never left off his armour, and was ever busy on horse or afoot watching the watchers of the camp, driving folk on, raising redoubts, digging trenches, and beginning everything with bis own hands, so that this being done in the dog-days, he fell ill of a fever, which also afflicted the busy troops." Galeazzo Visconti, the former despot of Milan, who was serving with the army, was among those who died. Castruccio himself, when he felt that death gat hold u pon him, left his duchy to his eldest son, and strictly charged him to " rush " Pisa and Lucca and assure himself of sovereignty, and not to assume mourning until he had made himself secure. Moreover, he ordered his death to be concealed for ten days after the event. Having given his instructions, he died. All these things were done, and ten days afterwards the news set Florence at her ease (I328). Castruccio is a striking example of the lowered moral tone which the "tyrannies" of Italy necessitated. The unbridled gratification of personal ambition and the dangers surrounding the ursuper were commingled with exigencies of State and necessities of public duty; all sense of right and wrong became confused and debased. Success was fast becoming the standard of right, to swallow or be swallowed the necessity of the case, and successful guile the admiration of the time. Sovereign sway and masterdom were to be gained by those who

\section{" bore welcome in their eye,}

Their hand, their tongue, looked like the innocent flower

But were the serpent under it."

Among the tyrants Castruccio was held as a model for magnanimity. ${ }^{1}$ Yet he sent the family to whom he owed his first rise towards power to a frightful death, and ordered two members of another family, who had delivered him from the power of Neri di Faggiuola, to the scaffold.

The death of the Duke of Calabria about the same time gave the Florentines an opportunity of altering their constitution. Florence, renowned for its love of letters and arts, was still more remarkable for its republican spirit; it may almost be said of the city of the red lily as

1 " Et quidem is erat Castruccius, ut quoniam ita ferebant tempora, nullius manu libertas honestius periret" (Beverini Annales Lucens). 
Stevenson said of France, that politics were its religion. Twenty times over did it alter the form of Government to limit its authority, to preserve its plasticity, or to strengthen its power. There had been examples enough of the dangerous and inconsiderate enthusiasm that attends on crowds ; the problem was to keep the Government in the hands of far-sighted men of affairs, and at the same time not to rouse discontent among the excluded. A committee was formed consisting of the Priors, as representing the Government; the gonfalonievi, as representing the train-bands ; the Captains of the "Party," as acting for the Guelphs; the commercial judges, standing for trade interests ; and the consuls of the arts, as denoting the opinion of trade. Each body in turn chose citizens whom they might deem worthy of a public position ; they must belong to certain arts, be Guelphs, and at least thirty years of age. Assessors, drawn from among the people, were to sit with this committee and see fair play. The list they framed was then to undergo revision at the hands of a balia-i.e., a body clothed with full authority, composed of the six Priors, twelve buoni uomini, nineteen gonfalonievi (standard-bearers) of the companies of militia, twenty-four consuls of the arts (or guilds), and six deputies from each of the six wards. Of these a majority of votes was required for the election of Priors, consuls of arts, buoni uomini, and gonfalonieri. The council of roo-the credenza was abolished-and the special and general councils of the Podestà were united. There were now two councils - that of the people, consisting of 300 plebeian members, and another of fifty, half being nobles and half plebeians; both councils were to be renewed every four months. But the consequence was intrigue in the preparation of the imborsazione. These frequent and sudden changes were ever characteristic of democracies, and it was one of the merits of the oligarchies that, in spite of vices, they used existing institutions to effect their purposes, and were not perpetually remodelling the State on theoretical principles.

Florence was no sooner relieved from immediate danger by Castruccio's death than she commenced an aggressive policy against the Ghibelline tyrants. She was resolved henceforward to oppose any foreign power that might cross the Alps to intervene in Italian home affairs. The various States that Castruccio had gathered under his rule fell apart at his death. His sons were driven from Pistoja by the Panciatichi, an old Ghibelline family. But Pistoja was exhausted, and the Panciatichi were glad to offer Florence possession of certain important frontier fortresses, the acceptance of a Florentine garrison, and eternal friendship. Henceforward the city at the gates of the Apennines becomes Florentine, and Pistoja, though considered as an allied and not a subject city, disappears from the political map. The smiling valley of the Nievole and its many fortified places, which had been under the rule of Castruccio, also gave themselves to Florence. In I 334 one witnesses the strange alliance of Florence with its ancient foes, the Ghibelline despots of North Italy, to turn out the lords that John of Bohemia had established in certain cities. Mastino della Scala acted as broker for Florence, and purchased Lucca, which had passed from hand to hand after the death of Castruccio. $\mathrm{He}$ cheated them of their bargain directly he obtained possession of the city (1335). Florence declared war against her treacherous ally, but she had to cope with a power vastly superior to her own. Mastino was lord of 
nine towns, which aforetime had been the capitals of separate States, and his yearly revenue was 70o,ooo florins, greater than that of any monarch of the time, save the King of France. All the lords of Lombardy were Ghibellines, and therefore his allies, and he had much prestige and influence. He gave asylum to all illustrious exiles, and Cortusio, the historian, tells us that he found twenty-three dethroned rulers enjoying his hospitality. He meditated nothing less than to become lord of Italy, and Florence alone barred the way. Florence was wealthy; her rich citizens were at the head of affairs, and were always ready to supply the needs of the State, and keep the markets of the world open to themselves. A council of finance was formed, and all the coffers of private enterprise were placed at its disposal. A military council of six, representing the six wards of the city, was entrusted with the conduct of the war for a year.

Florence had enemies to right and left of her. On the one side was Lucca, on the other Arezzo, which had fallen into the power of one Pietro Saccone dei Tarlati, a Ghibelline chieftain, who added the subtle falsity of Italian diplomacy to the rough valour of a mountaineer. He commanded the eyries of the Apennines, and was ever ready to swoop down from his fastnesses on the plains below. Siena, Perugia, and Bologna, the ancient allies of Florence, were weakened by civil discord, and King Robert of Naples had become inert from age. In Genoa the Ghibelline party had triumphed for two years, and the city was divided against itself. The Papacy had practically lost all its influence in Italy, and the little despots of Romagna were wont to cling to the stronger party-they had all to lose and nothing to gain. There was always danger, too, that Louis would recross the Alps. Such was the position of affairs when the Florentines approached Venice for help. Venice, up to this time, had been almost entirely occupied with her colonies and her commerce. She held no soil on the mainland, and was by no means anxious to have dealings with Continental Powers. The quarrels of Guelph and Ghibelline did not affect her. She did not hold of the Emperor, and she was practically independent of the Pope, for she kept her clergy subordinate to the State. She sat serene by the Adriatic, her eyes cast seaward, indifferent to the petty intrigues and turmoils of the mainland, and, so far as she had any sympathies, she was supposed to incline to the Imperial cause. But she could not but regard the growth of della Scala's power with grave apprehension. Florence sent quiet word to her merchants to sound the Venetian Government. They found it favourably disposed, and an alliance resulted. The Rossi of Parma had been jockeyed by Mastino; they had led the Guelphs until the crafty legate Du Poïet had forced them on to the Ghibelline side, and they had been dispossessed of their signory by the duplicity of Mastino. Piero dei Rossi, the youngest of six brothers, had secured the devotion of his German troops. He was considered to be the beau idéal of Italian chivalry ; he was virtuous and high-minded, of charming manners and generous to a fault; he gave all to his followers, and contented himself with the horse on which he rode. He escaped from Verona, where he was held as a hostage, and offered his services to the Florentines, who, having proved his valour and skill, put him in command of the army of the league. He scored a series of brilliant successes in the Trevisan marches (1336-1337). Florence had urged the Ghibellines to seize the con- 
quests of John of Bohemia for themselves; she now incited them to attack the arrogant Mastino, and gratify ambition and hate. Padua opened her gates to the Florentine General, who allowed no license to his triumphant soldiery. Though he was slain in battle shortly afterwards, the arms of the league continued to triumph. But when Venice made her own terms with the crestfallen Mastino, Florence found that she had contracted a debt of 450,000 florins, had been obliged to hand over certain taxes to her creditors for six years, and had been hard hit by the war then going on between England and France, which brought ruin to her merchants. For Philip of France had several times debased the currency, and in I 337 had put all the Italians in France under lock and key on the pretext that they were usurers, and only released them when they paid heavy ransom, while Edward of England had filled his war-chest with a loan of 200,000 florins, the greater part of which he was quite urable to pay, and this causing the ruin of the great Houses of Bardi and Peruzzi, dragged down many other Houses in their train. Whilst the city was fighting Della Scala in the North she was also engaged with Pisa and Arezzo in Tuscany, and was, moreover, exposed to instant danger from the Ghibelline party in towns subject to her sway, and lurking within her own walls, even. She mistrusted the experience and abilities of her own citizens for supreme power, and she was unwilling to incur the risk of uniting the military and civil powers in a dictatorship, so a foreigner, Jacopo Gabrielli of Agobbio, was chosen as "Conservator of Justice," granted a guard, and given full powers to deal with suspected persons (1336). Gabrielli proved to be so especially bloodthirsty that at the termination of his period of office a law was passed that no one henceforward should be chosen from Agobbio. The next occupant of the office, Accorimbene di Tolentino, proved to be as venal as Gabrielli had been cruel, and the Florentines abolished the office. The Florentine arms were hardly less successful in Tuscany than in the North. Such successes were gained over Piero Saccone that he sold Arezzo, for which 60,000 florins were paid. The parte Guelfa was re-established in Arezzo after an absence of sixty years, two fortresses were built in the city to keep it in subjection, and a new Government was established. But Perugia complained of injustice, in that Florence reserved the fruits of victory to itself, and for the first time in her history the city was accused of bad faith (1337) (G. Villani.Ist. Pistolesi.-Andrea Dei Cronica Sanesi).

When Florence signed the Treaty of Venice ( I339) she had experienced nineteen years of continuous fighting, and the countryside of the valleys of the Nievole and the Arno had been devastated every year, and were, to a large extent, gone out of cultivation. Happily the land was largely possessed by rich burghers, and the teeming soil soon responded to the productive power of wealth. Much as Florence had suffercd, her business was but little affected, and her merchants were to be found in the warehouses of Antwerp and Venice, the markets of London and Paris, the ships that sailed to the Orient and the North, and among the armed companies of traders that traversed the great trade-routes of Europe. She equalled Venice in wealth, and her revenues were surpassed only by those of the King of France. The income of the State was 300,000 florins a year; the ordinary expenditure in time of peace was but 40,000 florins. Not a single member of the Government received any salary; the distinction 
of serving his country was the burgher's highest a mbition, and his exceeding great reward. All citizens between the ages of fifteen and sixty had to serve in the militia, which numbered 25,000 men, and there were, in addition, 80,000 men available from Florentine territory. The State contained about half a million inhabitants, and such was the public spirit of the times that private wealth was employed, not on the vain expenses of ostentation and luxury, but on great public buildings"glorious works of fine intelligence." The city was surrounded by delightful gardens, the joy of the richer burghers, and it was rapidly assuming an appearance of captivating beauty and new magnificence. Education was not neglected. From 8,000 to ro,ooo children attended school ; 1,200 of these learned arithmetic, 500 or 600 studied grammar or logic. There were I IO churches, of which 57 were parish churches, 5 abbeys, 2 priories, 80 convents, and 30 hospitals with I, ooo beds for the sick. There were' never less than 1,500 foreigners staying in the town. The nobility were under a cloud; 1,500 noble families werc subject to the Ordinances of Justice, and only 65 nobles were allowed to serve as armed horse.

Two hundred wool factories turned out yearly 70,000 to 80,000 picces of cloth worth $\mathrm{I}, 200,000$ florins, a third of which sum sufficed to pay the workmen's wages. The Guild of Calimala, consisting of 20 members, rolled 10,000 pieces of foreign cloth yearly, and earned 300,000 florins. There were 80 bankers, about roo judges, 300 advocates, 60 medical men, Ioo druggists, 146 master-masons and carpenters, 300 master shoemakers, and the mint struck from 350,000 to 400,000 florins every three years. The number of mercers cannot be ascertained; they appear to have used barrows and not shops. Thirty years before, Florence had possessed a greater number of wool-factories, but the trade was not then so lucrative nor the goods turned out of so fine a quality, as English wool was not used at that time. Now English cloth was imported and remade. In I333 a great disaster fell on the city-the Arno overflowed its banks, and inundated its valley right down to Pisa and the sea. The public charges due to this disaster swallowed up an entire year's revenue, but in spite of the malice of Nature and man the State maintained a most flourishing condition.

The inhabitants of this Athens of the Middle Ages were renowned for their gay wit and vivacity. They had a mocking humour from which one little expected the shrewdness exhibited in their commercial and political policy, or their firmness and self-control. They, in fact, were deliberate and reflective at core. The depth of character, the impressionability, the raillery of the Florentine, were, moreover, combined with an ardent energy, a purity of taste, and a delicacy of imagination that have given him, for all time, a first place in letters, science, and the arts.

Florence was now the leader of those cities which stood for liberty and self-government. She was too strong for Papal aggression, and she had held by the Pope even when the Ghibelline party became in turn, and for the nonce, the party of liberty what time they fought under the heroic Princes of the House of Swabia against an aggressive Papacy. But she allowed herself to fall as little under Papal as Imperial control. And now that Italy was the theatre of social disorder, now that every year a fresh revolt hurled a fresh despot from his throne, when organized com- 
panies of soldiers, turned brigands, began to roam and devastate the land ; when States were made and disintegrated with the rapidity of the turns of a kaleidoscope or dissolving-view; when the rulers pass in quick and bloody succession; though republic after republic had to resign its liberty to hands from which the prize was perpetually wrested; though untold convulsions wrecked the land "even till destruction sickened," Florence still kept her independence ; as yet she still held aloft the torch of freedom. The result of a life so agitated was an energizing of the spirit, a will to live. The individual had learned to regard himself as an independent being, as a power. If he were proscribed, half a day's march would carry him across the frontier; he found an asylum with some rich and powerful despot, and there was always hope that, by wile or wisdom, he might return. The energies of man were stimulated ; his powers aroused ; hope never failed. But Florence was about to fall on evil days, and share, happily for a time only, the fate that had befallen her peers. She soon repaired the ravages of war, but then came lean years and famine, and after famine pestilence. Fifteen thousand souls perished in the summer of I 340 ; there was scarcely a single family that did not mourn its dead; and the Government curtailed the ceremonials of funeral to disguise as much as possible the evidences of the desolating force and extent of the epidemic. And without pause a fresh and worse evil befell the city. A dozen leading citizens had so manipulated the imborsazione that the magistracy had become their creature, and they were enabled to pull the wires of government. To preserve their power from the attacks of the nobility, on the one hand, and of the unprivileged Orders on the other, and to prevent an awakened and misgiving people from examining too closely into the conduct of a future election, the little oligarchy created the office of rector or magistrate of justice, and flouted the law by placing in it the same Jacopo Gabrielli of Agobbio, of whom we have spoken, as Captain of Defence, with a strong personal guard and arbitrary powers. The severity or the injustice of Gabrielli fell heavily on the noble families of Bardi and Frescobaldi. They plotted with those of the neighbouring nobles who had contrived to preserve some show of independence; it was arranged that these were to assemble under the cover of night behind the walls, and an attack was to be made during early service on the morning of All Saints' Day. But the plot was discovered; the gates were shut, the tocsin sounded, the militia assembled, and, after an ineffective attempt on the part of the country nobles to possess themselves of the bridges, the conspirators in the town were exiled. Debarred from Guelph refuges, they took their departure to Pisa, where they joined the enemies of their country, not that they did not love it, but that they loved it only under the control of congenial government, which they still hoped to re-establish. Now, Parma had fallen into the hands of Mastino della Scala, and was a connecting-link between his domain in the Trevisan marches and Lucca, which he had purchased. He replaced the Rossi by his maternal relatives of the House of Corregio. But Azzo, a scion of the House, was not content with his position of feudatory. He obtained help from Robert of Naples, one of the Visconti, and the Gonzaghi of Mantua, and, by the connivance of his brother, "rushed" the town. The dominion of the Scaligeri was thus cleft in twain, and Mastino, engaged in a precarious war with Milan and Mantua, gave up hope of recovering possession of Parma, or of holding 
Lucca much longer. He put Lucca up to be bid for by Florence and Pisa. The Florentine Government had known of Azzo's plot, but refused assistance; they had also refused the loan of $\mathrm{I}, \mathrm{OoO}$ horse which Luchino Visconti offered them wherewith to attack Lucca; but when the German garrison put Lucca up to public auction, public condemnation of their previous policy was so severe that they appointed a commission with full powers to purchase the city of Mastino. Through the medium of the Marquis of Este. the price was arranged, and hostages were given on both sides to secure good faith. Florence had outbid Pisa, and Pisa would now have her most formidable enemy at her own gates (I34I). All the States of Italy became alarmed at Florentine ambition ; Luchino Visconti, even, joined the league which was forming, and Genoa and pretty well all the Powers of Northern Italy arrayed themselves on the side of Pisa, as well as the Florentine exiles and the Ghibellines throughout Tuscany and Romagna. The Florentines had provoked a war for which they were little prepared, and the gigantic coalition was able to surround Lucca with a double ditch and palisade, and with a circle of twenty miles of redoubts. Two months elapsed before the Florentines could gather and equip a sufficient army. At last they sent forth 2,000 mercenary horse, I,600 auxiliaries, largely furnished by Mastino, and ro,ooo foot-soldiers, under an incapable General. Lucca was now less marketable; Mastino lowered his price, and would have reduced it still further had the Florentines beaten him down. However, the Florentines paid the price, managed to get their garrison in, and Mastino's garrison marched out. The Florentine Government, interfering in matters military with which they were little competent to deal, ordered a fixed battle to take place. The Pisan army, nothing loath, accepted the gage, removing their palisades to show that they relied only on their valour. Each army levelled the space that separated it from its foe, and battle was given. The noble youth of Siena led the van, and broke the first two of the Pisan lines, but the second line of the Florentine army did not recognise the advantage that had been gained; nay, misled by false report, thought that the day was lost, turned, and fled. Whereupon the third line of the Pisans fell on the men of Siena and the first Florentine line, and their victory was complete. The Florentine General and I,O00 soldiers were taken prisoners. Florence, undeterred by this mishap, sought aid of Robert of Naples, and even offered to recognise the rights which he claimed over Lucca, but in vain ; she then turned to Louis of Bavaria, who sent his ambassadors to treat of terms. The negotiations presented no considerable difficulties. Although Louis remembered the resistance of Florence to John of Bohemia, he wiped the sponge over her disobedience to himself. But while negotiations were on, fresh troubles arose in Germany; the Guelphs of Italy thought that Florence was going to desert her colours and turn Ghibelline; the Neapolitan nobles demanded their capital which they had entrusted to Florentine merchants, and a great number of the best houses went into liquidation. Nothing came of the approach to the Emperor. However, Malatesta, of the Malatesta of Rimini was put at the head of the Florentine forces, while a relative of his conducted the Pisans. Both men were past masters in the game of circumvention and deceit, which they had learned in the high school of wiletheir native Romagna. Malatesta tried to seduce the Pisan mercenaries; 
the Pisan General was as alert and cunning, and it was a case of no fighting and stalemate in intrigue (1342). At this time Gauthier de Brienne, the titular Duke of Athens, was passing through Florence. He had once been, for some little time, the deputy of the Duke of Calabria in that city, and seems to have acquired favour there. He was supposed to enjoy the partiality of the Kings of France and Naples. Robert, in his negotiations, had spoken of sending him at the head of a force to help the city. Florence still hoped to win Robert's aid, and in an evil hour, when Malatesta withdrew from Lucca and that city fell to the Pisans, De Brienne was appointed both as Commander-in-Chief and Captain of Justice. This dangerous appointment would never have been made but for the existence of serious divisions among the burghers. The aristocracy, excluded from political power, not merely felt their hearts boil with the sense of this indignity ; they were treated in the most arbitrary, and often in the most unjust manner ; they thirsted for consideration and for power. The governing class, the popolani grassi, the fat traders, were often imprudent and incompetent, and Villani accuses them of venality and peculation. They hoped to divert public attention and dismiss public wrath. They intended to manage De Brienne as they had managed Gabrielli, and if the State were malcontent, he would serve as a whippingboy. They had to learn that this man, who professed himself to be a ready instrument in their hands, was not less desirous of masterdom than they, and far more skilful in intrigue, less sensitive than they of private injury, less fearful of public doom. De Brienne was connected with the King of Naples, but he was nothing but a debased soldier of fortune, who combined French frippery with the coarse and bloody-minded brutality of a German trooper, and the insidious wiles of a tricky Greek. He increased the popular favour with which he was greeted by the execution or ruin of unpopular magnates. Thereat the dethroned nobility felt that at last there was tit for tat given, and, as to the lower orders, social arrangements and legally constituted superiorities are rarely really loved by those who are under the wheels. They thought an avenger of the oppressed orders had come, a Prince above cringing and intrigue, a man bearing the naked blade of justice, and ancient abuses would fall before its rigorous sweep. Doubtless the inundation of the Arno, the war, the epidemic, and commercial failure had produced much distress and social discontent in Florence. The public mind was unsettled. De Brienne let the nobles understand that, if he were clad with sufficient authority, he would revoke the ordinances of justice. Many commercial houses were on the point of failure ; he was the man to advance public monies, and tide them over their difficulties. He fanned the flame of discontent in the lower orders, and treated them with affable and calculated condescension. The twenty commissioners of war went out of office, and the Duke's party began to speak openly: the war had been ill-conducted, the Government was corrupt, the State needed a master-hand to set things right, and the Duke would be the right man in the right place. This kind of talk went on in the tavern, the guild-court, and the guardhouse. At last a deputation ventured to wait on the Priors, and suggested that the signory of the town should be conferred on De Brienne. The gonfalonieve held his peace until he had conferred with the Government and the heads of the militia, and then he replied. He said that it was 
grievous to remember that of yore Florentines knew no other danger than this which was proposed, of running its neck into a noose. "Go," he continued, "tell the Duke that in far direr straits our ancestors and yours have appealed to foreign powers : the Ghibellines besought Frederick and Manfred for aid ; the Guelphs betook them to Charles and Robert; but, however great the monarch, in whatever peril the State, public liberty was preserved, and our ancestors avoided giving Florence a Sovereign; such a want of manhood our wives and children would never pardon, nor could we forgive ourselves for incurring the shame of servitude" (G. Villani). This reply evoked some answering enthusiasm, which the Duke hurried to allay by protesting that he had no designs on Florentine liberty, that he only wanted a free hand for a limited period to do what he alone could effect, and that he merely desired the same sort of dictatorship which, more than once in her history, Florence had been glad to bestow. While he was thus expounding himself to the Government, his heralds exercised his right as Captain of the People, and convoked a general assembly, to be held in the Piazza of S. Croce. More than once in the world's history the liberty of a nation has been surrendered in a plebiscite, where the principle of one man, one vote, represents an equality which is non-existent, and where the true units of a people, its various interests, are not represented at all. In the peculiar psychology of crowds, clamour is contagious and emotionalism spreads like wildfire. The Duke arrived at the meeting surrounded by his guards, and followed by all the nobles of Florence, save the Della Tosa. The Priors proposed that the existing powers of the Duke should be renewed for a year. A mad chaos of voices shouted for full lordship to be conferred on De Brienne for life. The mob rushed forward, lifted him on their shoulders, and bore him into the public palace, while the Priors had some difficulty in effecting their escape; they tossed the great book of the ordinances of justice to the nobles, trailed the emblem of the State in the mire, and burned it in the public place. Then they tore down the arms of the city, and replaced them everywhere with the device of Brienne. A few days after, a compliant signory confirmed the Duke in his lordship, and Arezzo, Pistoja, Colle, San Gimignano, and Volterra, followed suit. The Duke invited all the French and Burgundians in Italy to come to his support; he reinforced himself with 800 men-at-arms, and he sent to France for his relations and friends, and gave them military command. Walter de Brienne had become a very great personage, but, as Philip of Valois observed, he had taken up lodgings at but an exceedingly uncomfortable inn.

Florence had hoped that her new despot would renew the war. But he was poor ; it was necessary for him to amass money if he wished to keep what he had got, and it was undesirable for him to leave the city. He proposed peace on terms which Pisa was ready to accept. Lucca was abandoned to Pisa, but Pisa was to pay an annual sum, and the Florentines were made free of her ports for five years; in fifteen years' time both Pisa and Florence were to recall their exiles. Hope was thus artfully given to the vast multitude of banished folk, and their favour won by De Brienne. This treaty (1 342) caused great discontent even to the party most closely attached to the Duke. And the lower orders were not satisfied with the sops thrown to them. Filling the public service 
with men drawn from among them did not fill every hungry belly ; turning the Priors into nonentities, depriving them of their palace and customary pomp, dismissing the captains of the militia, did not establish the people in that political enfranchisement which is the first blind attempt towards emancipation. De Brienne cancelled all laws that regulated the guilds, and the guilds became his foes. He had to play down to the butchers, wine-merchants, and wool-carders; and these gentry alone were on his side. He was, however, astride the steed, and he began to fix his knees and ply the rowels. He levelled houses to build him a fortress; he turned private dwellings into guard-houses, and gave no compensation to their owners; he laid hands on taxes that had been assigned to creditors of the State; he nearly doubled the land-tax, forced loans, and established new taxes, so that Florence was skinned to the tune of 400,000 florins in ten and a half months, and half of it sent away to Apulia and France. When his fancy was taken, he had no respect for the domestic honour of the wealthiest burgher, and the daughters of the poor were at the disposal of his licentious soldiery.

The Duke was not unaware of the growing discontent. Suspicion fell on this man and on that man, and whomsoever he suspected he put to a cruel death. He allied himself with the lords of Verona, Ferrara, and Bologna, and such a league menaced whatever of freedom remained in Italy. "Firenze non si muove se tutta non si duole" (When all are suffering, Florence is aroused), says a Tuscan adage. All classes were affected now. The nobles had obtained nothing but ingratitude; they were further than ever from holding political power. The rich burghers, too, had been tricked; they were ousted from rule, and once they had monopolized rule. The middle class suffered from increased taxation and diminished trade; the lower class had been deceived by impracticable promises. The bloody executions of a reign of terror filled Florence with bitter loathing, and unfruitful years brought gaunt famine on the poor. Three separate conspiracies for the assassination of the Duke - one headed by the Bishop-were afoot, but they were baffled by his wary watchfulness. He then seized two obscure citizens and put them to the torture, and they confessed that one of the Adimari was at their head. Adimari was seized, and when the news spread, almost everyone was afraid that all was up, and that his own complicity was known. It was a case of qui s'excuse accuse. The Duke perceived that the whole city was in conspiracy against him. He sent to Taddeo dei Pepoli, despot of Bologna, for reinforcements, and summoned 300 of the leading citizens to meet next day at the palace and determine the fate of the two prisoners. $\mathrm{He}$ intended the meeting to take place in a hall with barred windows, and ordered his guards to close the gates when all should be assembled; then they were to be massacred, and the soldiers rewarded by being let loose on the city, which they might pillage at will. Much was surmised; it was felt that something dire was about to happen. Terror fell on the city; the noise of preparations within the palace increased the general alarm. Those who had been summoned to the meeting visited one another at night. Fear had imposed silence; fear now broke it. The various knots of conspirators became aware of each other's purposes ; they also became aware of their own strength. They agreed not to obey the Duke's summons; they remained at home under arms, and 
gathered their faithful friends and servants around them. The groups formed quietly and unobtrusively, for 600 of the Duke's horse were patrolling the town. No time was to be lost ; the Bolognese were already coming down the mountain-side. Suddenly some of the lower orders gave the signal of revolt. Forthwith every palace in Florence vomited its men. There was a rush for arms; the streets were barricaded. The Duke's patrols, taken by surprise, sought shelter in the palace, and 300 were slain or captured in the streets, fighting their way thither. The Duke gathered his cavalry before the palace, but every issue from the square soon had its barricade. Every house bristled with foes and discharged a rain of missiles at the troops, who were again compelled to beat a retreat to the shelter of the palace.

Meanwhile other bands of insurgents had forced and taken the palace of the Podestà and the prisons, and the captives were set free. On the left bank of the Arno the inhabitants seized the gates, the doors, and the bridges. If one half of Florence succumbed, there was still another half to be conquered. In the evening these transpontine citizens grew confident, and crossed the bridges shouting: "Death to the Duke! Long live the commune and liberty!" A thousand horse and ro,ooo wellarmed foot were waiting to confront the Duke and his soldiery, and the streets were alive with desperate men less well equipped. In vain did the Duke release Adimari, and send him to expostulate with the people. Already they had begun to seek and slay the agents of the tyranny. Help was coming in on all sides, and a provisional Government of seven nobles and seven popolani was appointed. There were 400 Burgundians shut up with the Duke in the palace, and they had no food. Then the Bishop of Florence, who had organized one of the conspiracies, took upon himself the more specifically priestly task of mediator. But the Duke could only save his own life by abandoning the Judge, the chief minister of his cruelty, to the mob. He was literally torn to pieces by the people, as well as his son, a lad of tender years, but who was wont to belie his gentle face by getting the executioner to prolong the preliminary torture of the condemned at the judicial murders of his father. Through the Bishop the Duke solemnly renounced all right and authority over Florence : he was to ratify this disownment directly he was safe and sound out of its territory. The Bishop and certain leading people promised to protect his retreat. ${ }^{1}$ These saw the last of Gaultier de Brienne when they reached neutral terri-

1 Among those who came to the aid of the Florentines, and who signed the compact with the Duke, were Sienese Ambassadors. The Duke had endeavoured to foment the chronic agitation of their State and stir up the mob against an unpopular Government, in order to make himself master of that city also. Bindino da Travale, in a Chronicle recently edited by Vittorio Lusini, says that the revolution was due to Sienese organization, and that the Sienese standard therefore surmounted the Florentine turrets for three days after the expulsion of the Duke. One has always to be on guard against suppressions and exaggerations due to the national vanity of the chroniclers, and the rivalry of the cities was very strong ; but Bindino's merit is that of an entertaining writer rather than of a serious historian. (La Cronica di Bindino da Travale [1315-1415], Siena, 1900.) The Sienese Ambassadors remained to help reconstitute the Government, and it is conceivable that the Sienese flag may have been raised for awhile in grateful recognition of their services. Certainly the Sienese Government was privy to one of the three conspiracies against the Duke. 
tory, and forced him to approve and sanction his deposition. He reached Venice, and stole off for Apulia, bilking his soldiers of their pay, and the Day of St. Anne, which had seen Florence released from his tyranny, became a feast-day in Florence, with a solemn Office and great gifts to St. Anne, who became thenceforward the patron-saint of the city (I 34.3) (G. Villani.-Istorie Pistolesi._Andrea Dei Cronica Sanese).

From the Expulsion of the Duke of Athens (1343) to the Peace WITH PISA (1364)

Florence had thrown off the yoke of a tyrant, but her subject States immediately threw off the yoke of Florence. Cowed by the troops and military prowess of De Brienne, they had little dread of the citizen-militia (1) an impoverished city. At the time of the war with Mastino the signory garrisoned Arezzo, Pistoja, Volterra, and Colle d'Elsa ; it possessed nineteen fortified places within the confines of Lucca, and forty-six within its own territory, not to speak of the castles which belonged to nobles, the subjects of the State. Now Florence was reduced to a low position among the States of Tuscany. Arezzo made a stroke for freedom, and drove the Florentine commander from the town, while the Tarlati, aided by the Ghibellines of the city, took Castiglione Aretino. Pistoja expelled its Florentine garrison, and razed their fortress to the ground; she captured Serravalle, the military key to the State, and re-established popular government. Santa Maria a Monte and Montopoli, two fortified places that had belonged to Lucca, revolted, and set themselves up as independent States. Colle and San Gimignano also turned out the Florentines, and became independent. Volterra also rebelled, at the instigation of her former lord, renewing her allegiance to him.

But Florence had enough to do just now in the work of reorganizing her Government to be much concerned with questions of overlordship and dominion. The Bishop and the fourteen citizens elected during the revolt were glad to get the aid of the Sienese Ambassadors to settle conflicting pretensions, and establish some kind of suitable and steady government that would command the acquiescence and recognition of the citizens-at least, for a term. The first thing to be done was to redistribute the city into fresh wards. Two sestieri, Oltr' Arno and San Pier' Scheraggio, comprised half the city. The redivision consisted of wards equal in population and wealth, and to be equally represented in the Government. They were those of San Spirito (Oltr' Arno), Santa Croce, Santa Maria Novella, and San Giovanni. A formidable problem had next to be dealt with. The nobles had been almost displaced socially by rich merchants who had acquired territorial power in the country, who had their vassals and hangers-on and family clanship and fortified houses exactly like the old aristocracy, and who were reproducing their haughty bearing. Moreover, the possession of landed property carried nobility with it in Italy. This class had monopolized the powers of government, and possessed both organization and strength. But the classes above and the classes below agreed in regarding the " new men" with envy and dislike, and attributed to them all the misfortunes that had befallen the State. Twenty-five deputies from each quarter, of whom eight were nobles, were chosen by the Bishop and his associates to settle 
the problem of the reconstitution of the Government. This balia decided that, since a whole people had risen to set itself free, citizenship must belong to all. Each quarter was, therefore, to return one noble and two burgher Priors. It was necessary to conciliate the nobility in order to restore the prestige of the State and to give it military effectiveness, as well as to keep the hated fat burghers in check. Hence, the ordinances of justice were suspended, and wrong-doers, whether of noble blood or no, were subject to the same penalties.

The Florentines, more than the citizens of any other Italian city, had exercised the remarkable ingenuity and mental alertness that characterized them, in perpetual constitution-mongering. The State, unfortunately, contained irreconcilable elements, which no constitution could coalesce into a national party. If other conditions are favourable, the worst of constitutions becomes malleable and workable ; if the conditions intrinsically clash and interfere with each other, a heaven-made constitution will fail. The only constitution worth having is one that is expressive of the real meaning and direction of vital principles of being and of growth. Florence had incompatible and opposed principles within her. Hence, the sad, scornful lines of her poet:

\section{"Atene e Lacedemone, che fenno \\ l'antiche leggi, e furon si civili, fecero al viver bene un picciol cenno \\ Verso di te, che fai tanto sottili provvedimenti, che a mezzo Novembre non giunge quel che tu d'Ottobre fili. \\ Quante volte del tempo che rimembre legge, moneta, offizio, e costume hai tu mutato, e rinnovato membre !" 1}

$$
\text { Purg., vi. }
$$

Florence was not in the position of Venice, where all the great nobles were merchants and all the great merchants were nobles; where there was no territory around the city to foster the feudal notions and arrogance of lords of the soil, or nurse their wrath when they retired thither in sulky mood, or feed their haughtiness by the subservience of hereditary serfs. In Venice, too, the rulers, dwelling in the came city as their subjects, and with no whither'to seek for aid or to flee to for refuge in times of danger, were compelled to be ever mindful of good government. Venice was their all, and there grew up in Venice in consequence an unparalleled sentiment of devotion to the State. But in Florence each party felt that it alone was constituted to be the saviour of the State from other parties that were ever trying to dispossess it and usurp its rights; and this feeling had been aggravated by repeated acts of wholesale banishment, until every Florentine came to love his city much because he loved his party more. The nobles, once more enfranchised, again abused their power. - They paid off old scores and renewed their ancient turbulence. In defiance of the claims of civic allegiance, they indulged in lawless deeds

1 "Athens and Lacedemonia, which made the laws of old and were so refined, held aloft but a puny standard of orderly living compared with thee, who beforehand constructest such finespun measures that that never holds till November which thou spinnest in October. How oft within the reach of thy recollection hast thou altered laws, moneys, office, and usage, and reconstituted thyself !" 
of rancour and revenge; the old scenes of implacable enmity and bloodshed were re-enacted in the streets of Florence and throughout the State. The displeasure of the citizens grew to wrath; righteous indignation brought many of the noble class to the popular side. Less than two months after the drawing up of the new constitution there was a popular rising, and the four Priors of noble birth were compelled to resign. The nobles did not tamely submit. Andrea Strossi, one of their number, succeeded in getting up a riot directed against the fat burghers ; but it was put down, and he had to flee to save his neck. Then the nobles tried arming their dependants and the peasantry, and sought Ghibelline help ; but the burghers were beforehand with them. Led by the Medici, they stormed palace after palace. Step by step they cleared the entire part of the city on the right bank of the Arno ; but the nobles held the left bank, and were being rapidly reinforced from the countryside. In vain did the citizens attempt to carry the Ponte Vecchio and the Ponte S. Trinità. The third bridge, the Ponte alla Carraia, they succeeded in forcing. They were now joined by the citizens who dwelt on the left bank. The great family of the Bardi were the last to give way. Other clans had yielded to the immense array of citizens who swarmed along every lane and alley to the attack; but the Bardi still kept the Via di Bardi and the bridges, until they were pressed, front and rear, by two irresistible forces. Then they were compelled to give way. Tower after tower was toppled down ; palace after palace was fired by a justly-incensed but organized and steady crowd, led by their gonfalonieri and the captains of the companies. This time they were determined to see the matter through, and have done with it.

A new balia was formed; the signory was reduced to eight Priors-two from each quarter-and a gonfalonieve. The fat burghers had been thoroughly frightened; they recognised the leverage that the aristocracy possessed in the discontent of the artisan-classes. For self-preservation they were obliged to extend political power. For some time the people had been forcing their claim to political consideration. In I 294 the minor arts were recognised, and one member was admitted to the priorate. Now, two places only were given to the fat burghers, three to the middle arts, and three to the little arts or artisans. The signoria was flanked by twelve buoni uomini and the sixteen captains of the train-bands, as advisers.

This time the nobles had not acted together. Many families sided with the people; others were too unimportant to inspire any great apprehension. Five hundred and thirty families were admitted to the bourgeoisie on condition of resigning all aristocratic pretension. Among these are enumerated many who became the most illustrious families of the city, such as the Spini, the Scali, Brunelleschi, Compiombesi, Giandonati, Guidi, Tonsinghi, and the Counts of Certaldo and Pontormo. The ordinances of justice were again enforced, but with more moderation, only close relations being held responsible for the misdoer, and not his entire kindred. These internal troubles rendered Florence powerless abroad; she was therefore glad to confirm the Duke's treaty of peace with Pisa (1343).

Florence, devastated by war, was now to experience the horrors of famine and pestilence. Incessant rain fell in the autumn of 1345 and spring of I 346 throughout Italy and France ; as a result of this, the harvests 
of every kind failed. Provisions became extremely dear. A pair of capons was cheap at a florin; pullets and pigeons cost ten to twelve soldi a pair. The cost of bread was relatively much higher than that of meat; it advanced day by day, and reached an unheard-of price. The Florentine Government exhibited an active sense of responsibility beyond praise. The markets of Sardinia, Sicily, and North Africa were put into requisition, and deposits paid; but half the purchases never reached Florence ; they were stopped by the hungry Pisans or Genoese. The signory saw to the baking and distribution of bread at a fixed price, and the indigent, vastly increased in numbers from the countryside, were provided for. During the famine not a single soul in want went wholly unrelieved, and the city kept open house for the stranger. The law of debt was suspended so far as it related to small sums, and all debtors to the State and persons convicted of petty offences were released from prison on Easter Sunday. All those against whom the State was proceeding for default were allowed to redeem their debt by a cash payment of i 5 per cent. ; but so widespread was the want of money there were but few who could avail themselves of the offer. In spite of all that was done by governmental and private enterprise, the sufferings of Florence were very great. The poor, especially women and children, showed least resisting-power ; but nearly the whole community had its vitality lowered. And after famine came pestilencefirst, an epidemic which carried off about 4,ooo Florentines, and then the passage of that most dire and awful of visitations, the terrible Black Death. The Plague seems to have ravaged the Orient with peculiar malignity in I347, and the galleys of Italian merchants who fled, as they thought, before it, were none the less presided over by the dread presence, mocking, lethal, invisible. By the time Sicily was reached, so many of the sailors had died that the galleys were abandoned. The sick spread the infection rapidly over the island, whence it spread to the Western Mediterranean, while those fugitives who were not yet stricken continued their hopeless flight from the unseen terror that accompanied them. They reached safety, as they believed, in Genoa and Pisa. There, and in all the unswept, unsanitary seaports and cities, the carrion Death found congenial habitation. In I 348 it passed from Genoa and Pisa over all Italy, and in the two following years it swept the whole of Europe, and so depopulated the Republic of Iceland that the population was no longer sufficient to constitute an organized nation. Never has the human race experienced so dire a scourge. Not the cities merely, but nearly all agricultural districts were swept by it. Men died in the street, by the country wayside, on the field, and where they died they lay. The streets of the cities were lined every morning with bodies placed outside the houses for removal, and there was, naturally, a general loosening of all human restraints, accompanied by the liberation at once of the noblest impulses of self-abnegation and the basest derelictions of duty. Milan and the northern slopes of the Alps escaped lightly, but Boccaccio thinks that Florence lost IOO, o0o inhabitants, or about three out of every five. At Pisa, six out of every seven died ; at Trapani, in Sicily, everybody perished, not one single soul remained. Genoa lost 40,000 inhabitants, Siena 80,000. The Sienese historian, Agnolo da Tura, tells us that he buried five of his sons with his own hands in the same grave, and this was by no means an extraordinary event. The underfed-that is to say, the poorer 
and most numerous portion of the population-yielded the greatest number of victims; but a vast number of people of distinction were destroyed, and the sudden cessation of so many chronicles at this period is a silent but illuminating witness to the ruthless universality of the Plague. It probably sent three-fifths of the population of Europe to their graves, though it only passed over, and did not remain many months in any one place.

With the economical result of the great visitation in England we are familiar. It is more difficult to trace the result in Italy, where the conditions of life were much more complex. There was, of course, an enormous displacement of riches. All of those connected with ministrations to the sick or the disposal of the dead who survived, found themselves greatly enriched. Such were doctors, druggists, attendants, undertakers; such people as poulterers, who supplied sick dietary, and drapers, who furnished weeds. Certain astute people, by buying cheap and selling dear, became very wealthy. Workmen raised their wages two or three fold, and exorbitant remuneration was generally claimed and paid. In agricultural districts only the very best lands were worked, as the demand for produce was reduced, and so scanty was the supply of labour that profits were absorbed by the labourer, and the employer usually got little or no return. Many people became rich by stripping the dead or pillaging the sick of their jewellery and money, and servants strutted about in the fine clothes of their masters ; for, since the advent of the Duke of Athens, French manners and fine clothes had established themselves in the city. The spendthrift dissipated the accumulations of provident generations, and, for a while, society was in a topsy-turvy condition. No Government seems to have recognised the nature of the new economic factors with which it had to deal. The Florentine signoria witnessed the prodigality of the wastethrift; they observed that the needy became opulent, and they thought the State was suffering from a plethora of wealth. They searched the old statutes to revive sumptuary laws ; they fixed salaries and prices, raised taxes, and, of course, effected much harm and no good. The effect of the Plague was like that of an earthquake. Old landmarks and distinctions were confused or destroyed ; the ancient arrangements of society and of the State were overthrown or failed to adapt themselves easily to the new conditions; the stability of the commune suffered, and the insistent strident voice of the "little people " was heard above all the clamours of the State.

The vengeance of Heaven did not put a period to the ambitions and passions of man. The Papacy was busily occupied in endeavouring to subdue Romagna; the Visconti of Milan had possessed themselves of Bologna ; Genoa and Venice, the natural allies of Florence, were engaged in a mortal duel; Mastino was dead, and the House of the Scaligeri at Verona was enfeebled, degenerated, and had allied itself with the Visconti ; the kingdom of Naples was torn by the contentions of rival pretenders and the devastations of marauding mercenaries; it could render no help; Siena and Perugia thought themselves sufficiently far off to be secure from the machinations of Milan, and would render no help. Florence was isolated, but she was undaunted; she alone had the courage to oppose her power to that of the other great States of Italy at this period, though that power was backed by all the Ghibellines of Tuscany, all the tyrants 
of Romagna. Bologna was in the hands of the Visconti; one of her trade-routes, therefore, was dominated by the foe. It became above all things necessary to see to it that the mountain-passes of the Apennines should be secured, and that the fidelity of Prato and Pistoja should be assured. Unhappily, Pistoja was always an uncertain quantity in politics, and Prato had fallen into the hands of a family which, owing their first advance to Florentine favour, had pushed themselves into a position of almost despotic predominance in that little city. Florence bought her rights to Prato from the Queen of Naples, who inherited them from the Duke of Calabria, while she made sure of the bargain by marching her militia thither (135I). The Government also tried to surprise Pistoja, but the assault was furiously repelled, and caused just indignation both in that city and in Florence itself. Nevertheless, possession of Pistoja was indispensable to security, and Florence had to invest the town, but it was a mere investment. Attack was carefully avoided, and skilful negotiations resulted in Florence being allowed to garrison the citadel and two important fortified places, full freedom being otherwise conceded to the Pistojese. Florence was now mistress of the passes to the north, but new enemies appeared to the south. At Orvieto, Benedetto Monaldeschi had seized the tyranny with the aid of the Archbishop of Milan. He had given the signal to his hired ruffians by stabbing his own relatives as they were coming away in a party from the public council. Giovanni Cantuccio dei Gabrielli, taking advantage of the fact that nearly all the leading citizens of Agobbio, a city famous for its jurisconsults, were absent, had established a tyranny in that city, and, when besieged, called in Ghibelline aid. Thus, on all sides the Florentines were exposed to the attack of the great despot of Milan and his numerous satellites in Italy. The Visconti had summoned a Ghibelline congress, and the presence of Florentine exiles and Pisan and Lucchesan deputies, of the Ghibelline nobles of the fiefs of Siena, and of the lords of Forli, Rimini, and Urbino, indicated that no trifling tempest was about to disturb and try the State. Suddenly the news reached Florence that a Pistojan exile had surprised an Apennine fortress, that a pass was lost, and that Giovanni d'Oleggio, the Milanese General, was encamped within four miles of Pistoja. Happily, Oleggio could not advance into the plain until the main body of his troops came up with him, and Florence had just time to throw a body of men into Pistoja. Along all the routes that converge to Florentine territory came the mercenaries and armed vassals of the Ghibellines, spoiling and burning on their march. Pisa, alone of the Ghibelline confederation, failed to attack Florence, though her representative had sat at the Ghibelline conference. That republic was not too anxious to strengthen the growing and overshadowing power of Milan, nor to turn the scales against a city which was a rival, it is true, but which, like herself, was one of the last strongholds of liberty.

Florence sent an Embassy to Giovanni Visconti d'Oleggio to ask him the reason of his hostile march into their territory without any declaration of war having been made on his part, or, so far as they knew, any just cause of offence having been given on theirs. Oleggio received the deputation in the presence of his council of war, and expounded despotic views with a plainness and directness of speech almost worthy of Bismarck, while his tone of smug satisfaction in his mission sounds strangely familiar 
to the modern ear. He replied : "My lord, the Archbishop of Milan, is a powerful, benevolent, and gracious lord, nor would he willingly inflict suffering on any. Wherever his power extends, peace and concord are to be found, nor is there any lord who more loves and exercises justice. We have been sent here with no evil intent, but to re-establish unity and peace, to put an end to the dissensions and dissembled hates that divide the Tuscan folk. He knows full well the spirit of discord, spite, and faction which vex Florence and ruin all the other communities of this country, and he has given us the mission to put a stop to this state of things, and to bring you again under better government by his counsels and protection. He is fixedly determined to effect a reform in every Tuscan town; if gentleness and persuasion are unavailing, he will employ force. He has ordered us to march up to the gates of your city, to attack you with steel and fire, to put your possessions to pillage, until, for your own good, you choose to submit yourselves to his will" (M. Villani). Florence was quite unprepared for war ; she entrusted the defence of Pistoja and Prato to the few mercenaries at her command ; all other places were left to their own resources, and it seemed as if Visconti d'Oleggio would have it all his own way: he devastated the valley of the Arno right up to the very walls of Florence. But the peasantry, exposed as they had been in times past, or but passing, to the depredations of robber barons and robber squires, were obliged to dwell in communities walled in and defensible, whence they were wont to set forth to their daily labour. They had secured all their cattle and possessions behind the walls of these fortified hamlets, so that no booty was procurable without a formidable siege. The Ghibelline army soon began to lack provisions ; it had to forsake the plain, and betake itself to the Mugello, and there it occupied itself with the siege of Scarperia. Scarperia was not walled all round; on one side its defences consisted solely of a ditch and palisade, and it had but a small garrison, while the attacking force rallied all the Ghibellines of the mountains, and seemed to spread over the whole landscape. Yet the gallant little force determined to resist to the bitter end, and give Florence time to make an arrangement with some disengaged mercenary bands. Unluckily no free-captain was willing to incur the enmity of the powerful lord of Milan, and Florence had to rely on the patriotism of her militia. She armed her peasantry; she received some help from Siena (Pisa remained resolutely neutral), and she was able to make many captures of provision-trains destined for the Milanese; she remained quiet and steadfast; business was kept alive by a certain proportion of citizens who were not under arms, and the State Bank continued to do business as usual. All attempts on the part of Oleggio to take Scarperia failed ; the garrison was reinforced by night by a bold and skilfully arranged movement; two assaults were repelled; an attempt at mining failed; the besieged succeeded in burning the siege-machines in a sortie. Oleggio then attempted to surprise Scarperia in a night attack; the storming party strove until morning, and then Oleggio, baffled, sounded the retreat, and led his army back to Bologna by routes commanded by Ghibelline country-squires of the mountain-side. He had insufficient food and forage, the weather was bad, and his camp was filled with sick and wounded ( I 35 I).

Directly they had seen the backs of the Milanese army the Florentines 
took measures to secure themselves against the repetition of so unpleasant a surprise. They fortified the Apennines, engaged a large body of mercenaries, increased taxation, and formed a league of defence with Perugia, Siena, and Arezzo. These four republics bound themselves to maintain a standing force of 3,00o men-at-arms, but Florence alone had more than that number in her service. The league sent an Embassy to the Pope, Clement VI., but the persuasions, aided by the purse, of Visconti had influenced Papal policy, and the rebuffed Tuscans, deprived of the support on which they naturally relied, had recourse to the grandson of their old enemy, Henry VII. ; they sent to Charles IV., King of the Romans, pointing out that if the power of the Visconti continued to grow he would cease to be Sovereign in Italy, and declaring their readiness to furnish him with arms, money, and men; matters even went so far that Charles sent one of his chancellors to Florence to arrange details, but at the last moment he found it impossible to leave Bohemia, and the curiously propounded alliance between Guelph States and a Ghibelline monarch fell through (1352). Meanwhile the war went on. Visconti divided his forces so as to give help to all the neighbouring enemies of the Republics. Both sides were, however, afraid to venture on a full putting forth of their powers, and Visconti was especially fearful of a renewal of Florentine negotiations with Charles, and that a less favourable wind might blow from Avignon, for a new Pope had succeeded to Clement (Innocent VI.). The Republic of Pisa mediated, and restitution of captured castles was made on both sides. And the advent of Albornoz, intent on recovering Romagna for the Pope, so far neutralized the power of the Visconti in Central Italy that Florence breathed with some degree of freedom. Consequently, when Charles IV. descended into Italy, Florence was able to make a firm stand, and courteously ask the protection and friendship of the Emperor, and the maintenance of their wonted liberty, without a hint of homage or subordination. The Sienese Ambassadors spoke next, and, contrary to their stipulation with the Florentines, offered Charles the lordship of their commune. Other cities followed the example of Siena, and Ghibellines poured into Pisa to claim of Charles a reward for the services done by their ancestors and themselves to the Empire ; they supplicated that he should avenge on Florence the contumely with which she had treated his sire and his grandsire (M. Villani.-L. Aretino). Charles was too astute to be led into any rash engagement; as a shrewd practical man, in want of money, he made the anxiety of Florence, as to what was likely to happen, serve his need. He insisted that she should pay a fine for restoration to Imperial favour, and made her magistrates Vicars of the Empire. Florence thus took rank as an Imperial town without forfeiting a single privilege of a self-governing republic. Nevertheless, it was only with great difficulty, and after repeated explanations, that the Florentines were made to comprehend and accept the proposition. The very notary who read it broke down, and the meeting was so affected that it dissolved. Next day the Act was seven times rejected, and then, finally, passed. The bells alone went merrily in Florence, so jealous were its citizens of the complete liberty of the State ; they had tasted servitude, and they would prefer death even to its semblance. Shortly after the return of the Emperor to Germany, Florence was relieved to hear of the death of an old enemy, Pietro Saccone of Pietra Mala. Pietra Mala.was the lair 
of a crafty old fox who was skilled in the art of surprising small places, a past master in the adroit management of his party. Trade was now brisk in Florence, and like Siena and Pisa, but to a greater extent, she bought out the great and little lords of the neighbourhood who still remained independent of her jurisdiction. But the good.understanding which had now subsisted for some years between Pisa and Florence began to fail. Pisan exiles were domiciled in Florence, and this kept old hatreds smouldering; moreover, the struggle for the possession of Lucca was forgotten by neither side; the broken power of Florence had recovered itself, and she again became formidable ; the Government of Pisa tried to divert to foreign affairs the attention which the citizens were inconveniently directing to home concerns. Some of Pisa's discharged mercenaries were, by the apparent connivance of the Government, enabled to seize on Florentine strongholds in the Val di Nievole. As the men had been discharged, and the Pisan Government disclaimed all responsibility, this could not be made a casus belli by Florence ; but, on the pretext of requiring money to arm her ships against corsairs, Pisa taxed all merchandise entering her port, thus breaking a treaty with the Florentines signed in I 342. It was evident that Pisa wanted Florence to declare war, but this Florence resolutely declined to do; she employed another and more effective method. She ordered her citizens to close all business transactions that they might have with Pisa; she entered into alliance with Siena, whereby she bought harbour rights to Talamone in the Sienese Maremma; she got Siena to engage to fortify that port, to improve the roads, and to terminate all commercial relations with Pisa; she refused to notice the repeated attempts which the Pisans, who found their commerce shrivelling up, made to provoke her to a declaration of war, and, as her merchandise was seized at sea by a combined Pisan and Genoese fleet and taken perforce to Pisa, she went to the pains and expense of sending it by land to its destination, even if that destination were far-off Flanders, whilst she was engaged in organizing a fleet in Provence to protect her sea-borne goods (1356). Soon this State without harbour or marine had armed fourteen Provençal or Neapolitan galleys, and made all respect the liberty of the high seas. In I36I the bad feeling existing between the two cities was further aggravated by the acquisition of Volterra by Florence. This ancient stronghold of the Etrurians, which is still surrounded by prehistoric walls, looks down from its volcanic hilltop with aged eyes over the plain of Pisa and the blue Tyrrhenian Sea, and across the hills of Tuscany to the vine-clad eminences and slopes covered with sweet-chestnut that enfold Siena and Florence, the cities of a younger time. Surrounded by powerful republics, she had been unable to preserve her freedom; she had fallen under the rule of a despot who had enemies of his own family, and who, finding it impossible to preserve power, was on the point of selling the signory to Pisa. The Volterrans got wind of this, and rushed to arms; they seized and imprisoned their ruler, and sent to Florence and Siena for aid. - Florence was first on the field ; she occupied various fortified places, and finally the city; she took over its military control for ten years, and engaged herself to respect the liberty and independence of the citizens. The first use the Volterrans made of this restitution of civic right was to decapitate their former despot, who had brought this humiliation upon them. But 
Pisa was highly incensed at having so important a prize snatched away when it was within her very grasp, and other sources of annoyance fanned the growing ill-will of the Republics to one another. Pietro Gambacorti, whom the Pisans had exiled to Venice, came back to Florence and invaded Pisan territory ( 1362 ), and although the Florentine Government prohibited its subjects under severe penalties from joining the expedition, that it had been allowed to start at all was regarded as an unfriendly act, as also that a discharged mercenary was allowed to possess himself of a mountaincitadel commanding an important part of Lucchesan territory. Pisa marched against Pietrabona, the fortress in question, and the besieged offered to give the castle over to Florence. A parlamento was called by the Florentine Priors to vote on the question of peace or war ; the people cried out with one voice for war. But the Florentine General arrived too late to save Pietrabona; it was captured by the Pisans, who bore themselves towards the Florentines so insultingly and indecorously that the war was bound to go on, though the Florentine General retired for the time being. On a certain day at a certain hour that had been fixed by astrologers (for the revival of science and learning had carried the revival of astrology with it), the Florentine army received its colours, and marched into Pisan territory, which, the Plague being at Pisa, it was able to ravage at its will. But the army was greedy for high pay, and became mutinous. A hat was then hoisted on a lance, and all the discontented were told to separate themselves, as goats from the sheep, and gather round the hat. A thousand horse immediately gathered round their new standard, and, under the title of Capaletti, they formed themselves into a free company, and departed for Arezzo in search of plunder. Meanwhile Florence had not been idle at sea. She employed Genoese and Neapolitan craft, took the Isle of Giglio, possessed herself of the two towers which defended the harbour of Pisa, and carried away the great chain which closed its entrance to decorate the doors of San Giovanni, the Florentine Baptistery (1362). Pisa now turned for help to Bernabo Visconti, the head of the Ghibellines in Italy at that timc. Bernabo was pressed by Albornoz and his league to the south and east, and by the "White Company" of Englishmen that was in the service of the Marquis of Montferrat on the west. He easily contrived to get the White Company into the service of Pisa, for it was exhausting the treasury of the Marquis. Thus Visconti, by an adroit piece of diplomacy, relieved himself from vexatious and harassing attacks on one border, succoured an ally, avoided a rupture with Florence at an inconvenient season, and appeared to behave generously to a foe who at any time might become a useful friend-the Marquis of Montferrat. While the English company was on the march the Florentine troops gained an important victory, and after the time-honoured mode of deriding the enemy, the Florentine mint was set up before the gates of Pisa. The siege of Montecalvoli was then undertaken, and the place would have fallen but for an Homeric ruse of the besieged. Every night they let soldiers stealthily creep out of the gates, and these, covered with dust, were readmitted by broad daylight, and welcomed as if they belonged to the White Company ( $M$. Villani). So, dreading surprise, the army withdrew, and shortly after the English arrived at Pisa-2,500 horse and 2,000 foot. The Florentine Commander-in-Chief had dicd of the Plague, which had now passed from 
Pisa to Florence. The Pisan army marched on Florence, and met with no resistance; it was now its turn to flout. It also set up a mint; races were held. The Pisans erected a gallows, and hung thereto a dead donkey or so, with superscriptions bearing the names of members of the Florentine Government. They scoffed, sneered, jeered, and hooted to their heart's content, and then went away, fully satisfied and re-invigorated to display their energies in the devastation of the surrounding country.

When the Plague had somewhat declined, the Florentines endeavoured to engage mercenaries; but they were debarred from doing so by the astute artfulness of Visconti. At last they got together about 2,000 illdisciplined, ill-armed horse, whom they put under Pandolfo Malatesta, lord of Rimini, and one of the race so ignominious, even among Italians of Romagna, for knavery and want of faith. Malatesta was determined to take advantage of the weakening of the city through plague and recent sedition, of which we shall have presently to speak, and of their obvious fear of the English, to sell his services to the Florentines at the price of his lordship over them. He purposely allowed himself to be surprised and defeated; then he rode hard into Florence, and declared to the Eight of War that there was one way, and one way only, of saving the city-namely, that of joining the judiciary to his military power, so that he might uphold the one by the other, and punish the plots of the disaffected. A consiglio de' richiesti, a meeting of the most considerable and respected citizens, was called. A Peruzzi arose and spoke : "Beware of granting Malatesta any new power," said he. "He aims only at the tyranny. Remember the Duke of Athens, his surreptitious overtures and subsequent behaviour. Think of the sweetness of liberty, and live or die, but preserve it !' (F. Villani). All danger from the White Company was forgotten : the soldiers were compelled to renew their oath of loyalty. Malatesta did not appear to be at all put out, but he plotted to let the Florentine militia be cut to pieces by the White Company. The meditated treason did not take effect, however, for it came to the knowledge of the Priors. Yet, so hard up for a skilled leader were the Florentines, that, even after this, they let Malatesta off with a reprimand, and though they removed the militia from his command, they retained him in their service until the term of his engagement was up.

Florence had the unusual experience of a winter campaign, for the English, coming from a land where to live at all one must be indifferent to the unkindly fluctuations of climate, laughed at the Italian winter. The White Company was composed of I,O0O "lances" and 2,000 foot. The term "lance" comprised three horsemen who fought together. Their horses were only used to bear them and their heavy armour to the field; there they dismounted and fought on foot. The heavy lance was lowered, and required the united efforts of two men to keep it steady, and the advance was made with much shouting, but slowly, in closely-locked rank. Each soldier was encased in heavy armour, and behind him marched a page or two to attend to his wants and keep his armour bright. The White Company brought detachable scaling-ladders into use; but, in spite of successes, the Pisans required still more soldiers to force an advantageous peace. The Visconti had now made peace with the Pope, and Galeazzo Visconti with the Marquis of Montferrat. Baumgarten's German company was therefore idle, and the Visconti sent it on, 3,000 
strong, to Tuscany (1364). Pisa had now 6,00o mercenaries at her command, the largest number yet employed. She got the Pope to mediate, hoping to secure what terms she pleased.

The Florentine signoria was unwilling to accept humiliating terms, and yet it feared to undertake the responsibility of continuing the war. Once again it summoned an extraordinary council of richiesti. The eight citizens designated to control the operations of war announced that the Company of the Star, consisting of 4,000 soldiers, was coming from Provence, 2,000 from Germany, and that 3,000 men were in the actual employment of the city. Then the treasurer set forth the debts and resources of the State. Afterwards the Papal representative was admitted, and the demands of Pisa, which he set forth, appeared so excessive that it was determined to continue the war. But Galeazzo Visconti bribed the Company of the Star, and kept it from coming to the aid of Florence, while John Hawkwood, called by the Italians Acuto, the a.blest military commander of the Middle Ages, ravaged the State, and Baumgarten and several of his companions were knighted outside the gates of Florence to aggravate and deride the helpless citizens.

But the term for which the German and English companies had engaged themselves to serve Pisa was coming to an end. These men were perfectly indifferent to the merits of the side they espoused. War was to them a mere trade, and their chiefs came to a secret understanding with Florence to leave Tuscany. Hawkwood alone remained in the Pisan service. The Florentine army was now led by Galeotto dei Malatesti. The city was obliged to give the command to a leader of noble birth and experience, or foreign mercenaries would not follow him, and there were few Guelphs left with the necessary qualifications, for when Guelphs secured a tyranny for themselves, they became Ghibellines. A Malatesta was again chosen because that House ever remained Guelph.

But Galeotto had also designs on the Republic, and put himself into treasonable correspondence with Hawkwood. Happily Malatesta's plot was seen through, and by the counter-arrangements of the Eight of War, what might have been a disaster was turned into a victory. But the untrustworthiness of her General determined Florence to seek for some way of securing peace. The recent victory restored her wonted pride and prestige. Pisa was no longer strong in arms, and Florence had more to fear from her General than from the rival city; so recourse was had to the mediation of the Pope, and peace was signed at Pescia in the autumn of 1364 . Pisa readmitted Florentine merchants in Pisa to the exercise of their ancient rights and privileges, and gave up the fortified place, the possession of which was the immediate cause of the war. Other castles taken by either side during the war were surrendered, and Pisa engaged to pay 100,000 gold florins war-indemnity within ten years.

Meanwhile internal dissensions vexed the city. A seat in the Government was, it is true, open to all qualified citizens-that is to say, all citizens belonging to certain guilds and paying certain taxes. But nobles were wholly excluded from political office; and the older and more numerous a family, the more difficult was it for its members to get into the signoria. There was a law of divieto of I 307 , whereby office could not be taken twice until a term of years had expired; two men of the same name might not be Priors, buoni uomini, or gonfalonieri at the same 
time; also, if one member of a family was in office, all his relations were disqualified. Now, most old families formed quite large clans, but new men often did not know their origin, and bore no family name, and, consequently, office came to devolve more and more frequently on quite new and almost unknown men. The classes who could boast of their birth conceived, then, that they had a legitimate grievance in that they, the descendants of those who had established Florentine liberty, were ousted by men whom they accused of ignorance and incapacity. And they further complained that many of these men were of Guelph origin; for they maintained that, at first, both parties had been equally favourable to liberty, and when despots arose they were to be found on both sides ; but the preponderating power of the Visconti, who had everywhere stood by despots, had identified Ghibellinism with autocracy. On the other band, when a Ghibelline town threw off the yoke of its despot, it became Guelph in order to enter into the Florentine alliance, and hence many who once had been Ghibellines had come to dwell in Florence and hold offices of State. Now, for nearly a century the Captains of the Guelph Party had administered the confiscated estates of the Ghibellines. These Captains were four in number, two being nobles. They were elected by lot, and held office for two months only. This Parte Guelfa had become the very soul of the State, but it was often directed by overbearing, ambitious men, who, as merchants, had learned the power of the purse. In 1358 they decreed that any Ghibelline accepting office might be condemned to punishment by fine, or even to loss of life at the arbitrary discretion of the Podestà. Six witnesses were sufficient to condemn. The credibility, the examination of the witnesses, was entirely in the hands of the Captains of the Party and Consuls of the Arts, and a citizen, once condemned, was for ever excluded from office.

Shortly after the passing of this law it was bruited abroad that the Captains of the Party had prepared a black list of seventy cit:-ens. Hitherto the Party had acted in a way that commanded general approval, but there was considerable jealousy and suspicion now aroused by the arrogation of unwonted powers. The zealots among the Guelphs asserted that liberty was endangered, and that rigorous measures alone could preserve it. Those more moderate urged a modification of the law. After much heated discussion it was agreed not to change the law, but to modify the organization of the Parte Guelfa. Two more citizens were added to the Captains, and the two places hitherto reserved to knights only were thrown open to the entire order of nobility. It was also agreed that, when twothirds of the Captains were of the opinion that a person was a Ghibelline, the suspected person should be warned not to accept office under penalty of prosecution. This saved the ammoniti (the admonished persons) from penal pursuit, it is true; but the divieto (prohibition), as it was called, practically excluded capable men of ancient family, while the Government, however often it was changed, remained in the same hands, since those who were obnoxious to it were " admonished." Florence was thus ruled by an unconstitutional oligarchy composed of an ambitious clique, that was possessed of vast funds accumulated by the confiscation of property, and that manipulated the laws of the republic to seize and keep power and rule the State. Florence was a republic, but its Government could hardly be said to derive its authority from direct consent. 
None the less, the Parte Guelfa that pulled all the State wires exhibited much ability, and had deserved well of the State. It had humiliated Pisa without declaring war, made the power of Florence felt upon the alien sea, done what many of the Sovereigns of Europe had been unable to effect-it had made itself feared by the great mercenary companies, and kept them at a distance without paying tribute ; and it had kept faith with the Visconti against its own interest and the appeal of the Church.

The Parte Guelfa could not be directly attacked, but the constitution could be remodelled. Bartolomeo dei Medici and two ammoniti plotted, with certain nobles, to seize the Public Palace, believing that the citizens would support them if the seat of Government and the resident Priors were captured. A go-between, who was engaged in beating up forces, communicated the plot to a Bolognese, through whom it came to the ears of the Papal legate. Florence was surrounded by men who only awaited a favourable opportunity to pounce upon her and become her master. Such an one had been Oleggio, the former tyrant of Bologna; but Albornoz, either from a loftiness of soul, uncommon among Statesmen, or because he doubted whether the seizure of Florence might not be as the capture of a Tartar, while the friendship of a strong Government would serve the interests of the Church, refused to countenance the plot, and, indeed, revealed it to the signoria. The Bolognese, finding that he could get nothing out of Albernoz, offered to sell the details of the plot to the signoria. This offer was known to Salvestro dei Medici, who then held important office, and he told his brother Bartolomeo. Bartolomeo saw at once that the Government held a clue to his design, and he made a clean breast of it to Salvestro, who revealed it to the signoria. The Government used a rare clemency. It affected to believe that the list furnished by one of the go-betweens was a calumny on honourable men. Only two were punished, and the rest were, for the most part, converted from foes into loyal supporters of the administration. But it is evident that republican forms of Government had not the firm and equal rule marked by the tyrannies, and that there was general dissatisfaction smouldering under them.

The specious peace that comes of protected trade, and the ease that there is when there is lack of responsibility ; the comfort of more secured possessions ; the comparative absence of the goad of political danger and of the often inconvenient stimulus of civic duty-all these dubious advantages were very attractive to the fat burgher, and as the despot kept up the forms of civic liberty, and only by slow degrees riveted his fetters on the people, despotism had proved a success. Very few independent States were now left, and of these the most important-Siena, Pisa, and Perugia-were constantly in danger of sharing the common fate of Italian republics. And about the time of this Medicean conspiracy (136I), similar conspiracies in those cities gave evidence of certain disadvantages inherent in the forms of government to which they clung.

From the Peace with Pisa to the Peace with the Pope (1364-i378)

In the year 1368 the Emperor, Charles IV., made his second journey to Italy. He complained bitterly to the Embassy which Florence sent to meet him that the Republic had possessed itself of San Miniato, Volterra,

$$
28-2
$$


and Prato, which he claimed as Imperial property, and he took advantage of a revolt of the first named of these towns to occupy it. Florence prepared for war, and Charles, who was sadly in want of money (he had to pawn his crown to the Florentines), backed down. But on his withdrawal from Tuscany the citizens of San Miniato sent to Bernabo Visconti, as Vicar of the Empire, for assistance. Bernabo seized the offered opportunity. The citizens of San Miniato foolishly played into his hands. $\mathrm{He}$ was eager to paralyze and absorb Central Italy, and he sent John Hawkwood to their assistance. The result was a strong coalition of Florence, the Pope, the Marquis of Este, the lords of Padua and Reggio, and the Republic of Bologna. Pisa forgot her old enmity, and Lucca, emancipated by Charles, joined the coalition. Both cities were near neighbours of San Miniato, and the presence of the troops of Milan on their borders was anything but agreeable.

The Florentine mercenaries were on the very point of taking San Miniato when the signoria, anxious to conclude the war, ordered their General to give battle to Hawkwood at Cascina. He was defeated and taken prisoner, but a capable commander still remained before the walls of San Miniato. There was treachery within, and the city was taken (1370). The war was pushed on with some vigour, but it was very expensive. There had been no decisive action, and, on the death of the Pope (I 370), both sides were glad to sign peace on the basis of status quo ante. Next year Bernabo renewed his attack on the Church, but Florence refused to take up her cause. There had been dissensions in the city, which will be recorded later, and the Albizzi, who were excluded from holding office, were suspected of complicity with the legates of Bologna and Perugia. It was feared in the city that the Papacy, bent on the establishment of temporal power, would hardly be likely to respect Florentine liberty. Florence was justified in this course both by preceding and subsequent events, for the legate at Perugia had taken advantage of a sedition in that town to exile the Raspanti, the party most favourable to freedom, and then built a citadel that dominated the town; and his successor had seized the occasion of a bad harvest and hard times to deprive the city of all its privileges, and establish the absolute authority of the Pope. A letter of excuse which Gregory wrote to the Sienese increased the general suspicion of his design on the Tuscan communes. The war between the Pope and Visconti proceeded, but in 1374 a truce was effected for one year, and this gave the Papacy an opportunity to pursue its artful designs.

One Guillaume de Noellet, a French Cardinal, was legate at Bologna. All Italy had suffered from inundations that had washed away the seeds and seedlings, and Florence had her full share in the disaster. Plague appeared in the city and reduced its population by 7,000 in six months; the city was in a state of political ferment. Florence was of pacific mind, and her troops, as well as those of Siena and Pisa, were on a peace footing. "The legate," says Poggio Bracciolini, "judged the Tuscans as if they had been unstable French." He calculated that if he could contrive to increase the general suffering there would be a revolt in the city, and that, worn out by famine, discord, and the expenses of warfare, it would give itself to him.

Florence drew a portion of its supplies from Romagna and Bologna. The legate stopped this supply, in spite of the prohibition of the Pope. 
The signoria, at the expense of 60,000 florins, got corn from afar. Winter passed, and when the harvest drew near, the legate sent Hawkwood, at the head of a numerous troop, to burn down the Florentine crops ; while at the same time the legate of Perugia, also a Frenchman, took advantage of a feud between the citizens of Salimbeni and the nobles of that town to ravage its territory also. De Noellet wrote to the signoria of Florence to explain that Hawkwood had no authorization for his proceedings. He had, it was true, formed a band of adventurers from the troops which the Church and the Visconti had disbanded; but perhaps a good heavy ransom would satisfy the condottiere. But the discovery of a secret intrigue at Prato to deliver that town up to the legate instructed the Florentines as to the value of his protestations. Florence was aghast at the perfidy and ingratitude of the Church to a city that had exhibited such undeviating devotion. She at once appointed a council of eight, afterwards called the "Holy Eight of War," and entrusted it with full powers. This Ministry promptly tried to save the crops by negotiating with Hawkwood, and sent to the legate to request his recall. The legate replied that Hawkwood was no longer in his service, forwarded them a cooked copy of his discharge, and then sent privately to that General, telling him to offer impossible terms. Hawkwood asked r 30,000 florins. They were paid at once, the Florentine clergy being called upon to furnish half the sum. The legate then sent orders to Hawkwood to stop negotiations; but he had seen the copy of discharge. He was naturally unwilling to take the odium on himsclf that attached to his employer, as wcll as to surrender a sum beyond the dreams even of his avarice. He wer $t$ bis way, drew 35,000 florins from Siena, 30,000 from Pisa, and then took pay under the other scoundrelly legate of Perugia. The mine had missed fire ( $(375)$. Gregory XI. wrote to Florence to explain that Hawkwood, during his march from Bologna to Perugia, had not been in Papal employ. Indignation in Florence was at boiling-point. The administration of the districts under Papal control had been infamous. Leonardo Aretino writes that "the French legates ruled in this manner: they were contemptuous, and well-nigh insufferable ; they strained their authority over free towns; their subordinates, their retinue were of a kind fitting to men of war, not of peace; they filled Italy with foreigners; they erected fortresses in each city, regardless of cost, and exhibited how abject and enslaved were the people whose liberty they had stolen from them; they excited the hatred of their subjects and the challenge of surrounding States" (Leonard. Aret. Hist.). The nephew of the legate of Perugia had pursued a married lady of that city with libidinous attentions. In trying to escape from his too-importunate solicitation, she had fallen from a window and been killed. Great indignation was aroused in Perugia, and justice was demanded of the legate. "Why all this fuss ?" was his reply. "Do you mistake a Frenchman for a eunuch ?" A few days after, there was a similar offence : another married woman was carried off by force, and the legate ordered his nephew to restore the woman to her husband or lose his head, but gave him fifty days to do it in (Gazata Chron. Regiense). The cup was full to overflowing. The signoria and Eight of War called richiesti to their counsel. Alvisio Aldobrandi, the gonfalonieve of justice, spoke. He combated the lingering superstitions that might oppose the defence of freedom. He submitted 
that ecclesiastical condemnations had no force when pronounced by fraudulent mouths, and that religion often served ambition as a mask. He proposed no less a task than the setting free of all the people who groaned under the oppression of the legates. He counselled that the aid of Bernabo, even, should be sought. "I know full well," said he, "that he is perpetually seeking his own personal ends, and is not likely to concern himself about our interests ; but he is fiercely opposed to priests and the power of the French in Italy. The hatred which we alike share will give us common interests" (Poggio Bracciolini). The speech of the gonfalonieve was warmly received and acted on. The support of Bernabo was secured, and Siena, Lucca, Arezzo, and Pisa, successively fell into line. The Eight chose as captain Conrad of Swabia, and gave him two banners : one bore the communal arms; on the other the word "Liberty" was embroidered in thread of gold. A declaration was made that Florence was ready to aid all who might choose to cast off the Papal yoke.

City after city burst into insurrection. Citta di Castello was the first. It drove its garrison into the citadel. Before long help arrived from Florence, and the garrison surrendered. Hawkwood was on his way to Citta with a part of his force. Perugia availed itself of his absence to rise ; in a few days two fortresses which the legate had built were captured and razed to the ground. Viterbo renounced allegiance at the instigation of the Prefect of Rome. Monte Fiascone rose, and, with the swiftness of a prairie fire, the flame of revolt burst forth in Foligno, Spoleto, Todi, Ascoli, Orvieto, Toscanella, Orti, Narni, Camerino, Urbino, Radicofani, and Sarteano. Within ten days eighty cities or fortified places had thrown off the yoke of the Church. Some, however, sought to give themselves to Florence, but Florence, with magnanimity beyond praise, replied by sending them her flag inscribed with the magic word "Liberty," and urged them to constitute themselves into independent republics. Others recalled their ancient lords. Forli gave the signorial power to Sinibaldo dei Ordelaffi, the son of Francesco and Marzia, its heroic defenders in times gone by.

In 1375 the Church owned the allegiance of sixty-four towns and I 576 fortified places. In 1376 , she was left in possession of Rimini alone.

In February, I376, the Pope, who found the work of Albornoz absolutely undone, summoned the Florentines to appear before the Holy Consistory and answer for their misdeeds. The Florentines sent three Ambassadors. They spoke with the courage and determination of freemen. " Nothing," said their spokesman, "would have induced Florence to take arms but the defence of its liberty ; but that which we have enjoyed for four hundred years is so incorporated in our nature, has become so dear to our heart, that there is not one of us who would not die to preserve it." The Italian Cardinals are said to have wept at these soulstirring words; the French remained unmoved. Florence was placed under an interdict; the Government was excommunicated and anathematized. All Princes were ordered to seize Florentines resident in their realms, to sell them as slaves, and to confiscate their property. The unpopularity of the Italian bankers in France and England was great; they were regarded there as pernicious foreign usurers. Interest was considered as immoral ; the general feeling of the Middle Ages regarding loans was that of John Ruskin. Perhaps the guilds, the people, and the 
clergy furnished bad reasons for an obstinate prejudice or a self-preservative instinct. At all events, the Pope appealed to the strongest convictions of the populace and the strongest passion of rulers-cupidity-and his commands were executed without delay in the two Northern countries.

When Donato Barbadori, the chief Florentine Ambassador, heard the sentence read, he turned towards a crucifix. "I call upon thee, Almighty Father !" said he. "Thou just and all-seeing God! since man condemns us, be Thou our witness of the unrighteous sentence. At Thy last judgment Thou wilt utter a juster decision !"

Whilst the Ambassadors were at Avignon, the Pope sent a mission to Florence to try to terminate the quarrel. But negotiations were interrupted by the revolt of Bologna, which occurred in this wise : The Eight of War, who, in spite of excommunication, were called the "Eight Saints" by the Florentine people, had sought to rouse the faction of the "chessboard" in Bologna. But the Bolognese seemed rather to side with the faction of the legate, the Maltraversa. The legate was, however, unable to pay Hawkwood, and allowed him to help himself by the sack of two small dependencies of the State. This was done with unheard-of barbarity, and at the same time it was rumoured that the legate was in treaty with the Marquis of Este for the sale of Bologna itself. The factions united; they surprised the castle by night, and next morning the flag of the people fluttered over the great square. The tribes and tradeassociations assembled and nominated a Standard-bearer (gonfalonieve) of Justice, and, shortly after, the general council proclaimed an amnesty for all exiles. Florence sent Bologna her flag of liberty, with 2,000 horse and 500 foot soldiers, and considerable pecuniary help; and the new Republic razed the Papal fortresses and entered the league. The war proceeded with the utmost barbarity. It was a mere incident of the contest that Hawkwood, at a time when Faenza had not declared itself, slew 4,000 of its inhabitants on mere suspicion. A body of Bretons, the last of the Free Companies remaining in France, was allowed to pass through Lombardy by Bernabo Visconti, whose brother had made his peace with the Church. The Cardinal Robert of Geneva, afterwards Antipope Clement VII., was chief in command. The Breton troops were led by Jean de Malestroit. “Are you prepared to enter Florence ?" asked the Pope of him. "If the sun penetrates there, why should not we as well ?" replied Malestroit. Rodolfo di Camerino, the Florentine commander, had not merely to face Papal troops. The conduct of, Bernabo rendered him suspicious of the intentions of Lando, whom the iVisconti had sent, ostensibly to his aid. Robert of Geneva sent to Bologna, which Rodolfo garrisoned with all his troops, asking him why he skulked behind the walls. "To keep you out," was the reply. The legate tried to seduce the Bolognese themselves. They remained steadfast. "We are ready to endure all rather than submit ourselves anew to those who have given us such cruel proofs of flaunt, insolence, and avarice," was their answer. "I shall remain here until I have washed hand and foot in the blood of the Bolognese," vowed the Cardinal ; and his conduct did not belie his words. Under the pretence of an amnesty, he got admission to Cesena, and put every living soul to the sword. But the deed awoke not fear but righteous wrath in the breast of the league. Perugia had the service for the dead performed in all her churches, and all the cities 
of the league followed her example. Gregory XI. came himself to Italy, and Florence again sent a fruitless Embassy to him. Hawkwood had concluded his engagement with the Pope, and this able captain passed over to the service of the Republic-a great gain of strength. Camerino, who had quarrelled with the Eight of War, on the other hand, took the pay of the Pope and the command of the brutal Bretons.

One of the most influential personalities in Italy at this period was Caterina Benincasa, known to posterity as St. Catherine of Siena. A woman of lofty and perfervid temperament, like so many of the best and purest spirits in ages marked by the uproar of violent and conflicting interests and the feverish disquiet of passions unconstrained, Catherine sought refuge in the rapture of religious meditation and the enthusiasms of the holy life. She was a woman of great mental endowment, of sympathetic imagination, and of mystic temperament. She combined the vast conceptions of masculine intellect with the personal pity and tenderness characteristic of womanhood at its best. She commanded the ear of the Papacy, the respect of the condottieri, the devotion of Italy. She dreamed a great dream of a renovated Church. She was not blind to its shortcomings and its sins; but the Pope was to her the sacred representative of the Most High. She repeatedly speaks of him as her "most sweet Christ on earth."

She had written to the Pope urging him to come straightway to Rome, and told him that he could only be victorious if he adopted the spirit of his Master. She wrote to the Florentines, reminding them that the Pope is Christ's Vicar, left for the care of souls, and whoso disobeys Christ on earth, who is the Viceroy of Christ in heaven, even though that Viceroy should be a devil incarnate, such an one refuseth to share in the fruit of the blood of the Son of God (Le Lettere di S. Cat. da Siena). She had visited the Pope at Avignon, and carried messages from the signoria. The Pope sent her back as mediator to Florence. Catherine was of too pure and lofty an imagination to understand the temporal ambitions of the Court of Avignon. There is no trace of any such conception in her noble letters. She was not devoid of practical sagacity, but she was an idealist, and she had the weaknesses and limitations of an idealist.

The signoria of Florence took a juster view. That highest of all qualities, the combination of lofty conception with clear and sober judgment, was ever a mark of the high Florentine intellect. The signoria revered the saint; they misdoubted the politician. Gregory sent Ambassadors to Florence. The populace in Italian cities was oftener against its Government than for it ; the Florentine people might be wavering, or veering towards discontent. The Ambassadors refused to unfold their mission save to a parlamento. "It was granted. "The Holy Father knows full well," these began, "that the Florentine people do not desire war ; it is the work of certain ambitious people who increase their own store at the expense of general misery. Nlready they have illegally extended their term of office ; their aim is to dominate in the name of liberty." Gregory called upon the Florentines to depose the Government, and he would immediately grant them peace. The gonfaloniere replied in the name of the people. He said that nothing but repeated wrongs and the mad ambition of churchmen could have alienated Florence from her ancient devotion to the Church. But patience has its limits, and on this point all Florence 
was at one. Florence was ever desirous of peace, but the conditions of peace must be unfolded, that Florentines might see how they bore on the real authors of the war.

The Pope, on the receipt of this reply, renewed his anathema. This time he sent, not merely to the great Princes, but to all Constituted Authorities of every kind, ordering them to confiscate Florentine property within their jurisdiction. Hitherto Florence had observed the interdict. She now defied the ecclesiastic pretension of one whom she considered to be an impious Pope. She reopened her churches, and forced her priests to continue the holy offices. The Papal armies were unsuccessful, but the fatal spirit of faction did more for Papal interests than her condottieri. In Bologna, as in Florence, the popolo minuto were disaffected. The lower orders were in favour of autocratic promise rather than oligarchic refusal ; they conspired to call back the Pepoli. The plot was discovered, and its authors, including some of the "chess-board" faction, were banished. The remainder of this party, now called the Raspanti, carried on the government, and remained faithful to Florence; but in the spring of I 377 election by lot brought the opposite faction of the Maltraversi into power. They sedulously cultivated the favour of the populace, and by a coup d'état exiled the Raspanti, and made a separate peace with the Pope. Gregory XI. saw and seized his opportunity. He conceded communal self-government to the Bolognese, and only stipulated that a Vicar of the Holy See should be acknowledged. This Vicar was to be one of themselves, a member of the Embassy sent to him, who was a jurisconsult. The Prefect of Vico also negotiated a separate peace, and Florence, deserted by two of her most powerful allies, and vexed by the conflict of factions at home, consented, at the Papal suggestion, to accept the mediation of Bernabo Visconti. All communities were ill at ease when they were on bad terms with their Spiritual Father, and if for no other reason that that of healing the breach, the Florentines would have been glad to pay the indemnity which, as conscience-money, States were always wont to pay the Church at the close of a quarrel with it. But Bernabo Visconti had arranged with the Papacy to divide the mulct between them. $\mathrm{He}$ cast Florence in 800,000 florins war-indemnity, and, as arbitrator. there was no appeal against his award. But at this juncture the Pope died, and the schism of the Church which followed gave Florence an opportunity of compounding with Urban VI. It was arranged that she was to pay 70,000 florins within the year, and 180,000 florins within the subsequent four years (Th. de Acerno. G. Capponi).

\section{SIENA}

'The Rule of the Rich Merchants and Rise of the "Popolo Minuto"

SiENA contrived to enlarge her territories, but a wise foreign policy kept her friendly with Florence. She even tried to play the part of a seapower, and purchased Talamone on the coast. She spent colossal sums on the place, but the harbour was for ever silting up immediately after 
each dredging, and malaria rendered the town uninhabitable. She favoured learning and the arts with a magnificent patronage. In r 32 I she reconstituted her University, and filled its chairs with distinguished scholars of Bologna; and the liberal public spirit of her citizens raised and adorned those graceful towers and noble buildings which still lend a unique charm to the fair hill-town-l'amorosa madre di dolcezza. They were enriched by the genius of her greatest painters-Duccio, Simone Martini, and Ambrogio Lorenzetti. Siena aided Florence in I $3 \mathrm{I}_{2}$ to defend her gates against the Emperor, Henry VII., and helped to supply Brescia with the means of defence; she suffered, in consequence, by Imperial ravage of her territory. She vied with Florence in the wooltrade, and did a large export business to the Levant. Both cities were governed by rich merchants, and both Governments had common interests - to keep the nobles from resuming power, and to maintain a republican Government in the hands of a wealthy and enlightened burgher class. Hence, Siena joined the Guelph league ; she suffered with Florence in the defeat at Montecatini in I315. But when Charles of Calabria rode into the city on his way to assume the lordship of Florence (1326), she barricaded her narrow streets against him, made him accept her conditions, and, later, she aided the Florentines to reorganize their Government when they expelled their tyrant, the Duke of Athens (1343).

During this most glorious period of the history of Siena she was under the rule of the rich burghers; but there were, from time to time, attempts to overthrow the Nine. Although we speak of the Italian self-governing communes, we must never forget that it was only the very highest stratum of burgher society that was represented by the Government, and that, whenever disputes arose, the disputing parties tried to expel or exterminate one another. They aimed at unanimity, but unanimity was secured by the banishment of the weaker side. Italy never reached the conception of our modern expedient; there was no bloodless battle of contested elections. The successful party was possessed by fierce passions of triumph ; the weaker was too fiercely defiant to accept defeat after the manner of our minorities. Some intevests were represented; heads were by no means counted.

Complicated with the interests of political parties were the interests of family clans. The gens was the unit of Italian society in the Middle Ages, and the vestiges of this institution remain to-day. Hence, parties were defended by the same families after changes, more or less complete, in their ambitions and policy had taken place. Tradition counted for much, and the gens could be no other than a conservative institution. Conservative feeling and tradition were especially forceful in a country which boasted so prolonged and ancient a derivation and history, and on which the dead hand of the past weighed so heavily. The antagonism of nobility and rich merchants, first with the middle class, and then with the lower strata of society, and the fluctuations of the seething conflict of all the contending currents of general politics in Italy, together with personal and family ambitions, produced an instability in communal government which led to its ultimate domination by the tyrant. But this unresting turmoil also rendered possible the emergence and triumph of the genius of the individual. The individual, though his claims were stiknurbed by links which bound him to guild, clan, or faction, became 
emancipated. The extension of commerce was already beginning to break down the old guild-system, and individuals already amassed large fortunes and founded families, though the organized selfishness which characterizes the modern industrial system had not yet appeared. All this is true of all the free " republics" in Italy, and was as marked in Siena as anywhere.

We have seen Siena under the power of the gentiluomini; she is now under the power of the Nine, a rule of rich merchants who have displaced the nobles. We shall find the nobles allying themselves with the lower unrepresented classes, who arealready beginning to make their demands heard as the wealth and luxury of the city increases. They also become better off or worse off in changing economic conditions of the city, and temporary prosperity makes adversity harder to be borne. The classes still excluded become turbulent in their demand for political power. We shall in time find the Nine replaced by the Twelve-a government, for the most part, of notaries and petty tradesmen - and the Twelve, in their turn, by the fifteen riformatori, who are again plebeians and new men. Thus arise parties which, being upheld by the family groups of the city, and dominated by family interests, become more and more conservative with time, and are replaced by newer orders or monti-Monti del Popolo, Aggregato, Nobili Reggenti-that either represent new demands or the coalescence of old parties having community of interests.

In Siena, in the period of the Government of the Guelphic Nine, the great aristocratic houses continued their feuds. We read in the chronicles of the city of serious conflicts in the public streets between the rival Houses of the Salimbeni and Tolomei, and of the whole city being under arms. The Tolomei were opposed to the Government, and, to gain their ends, plotted with the notaries, the butchers, and certain other discontented crafts, to overthrow it; but this attempt was repressed (1318). A similar rising took place in 1346 . It was suppressed, and plebcians were hanged ; but the Captain of War dared not touch the nobility. Then, in I348, came the terrible Black Death. Hitherto feasting and riotous living, varied by fits of passionate penitence and devotional enthusiasm, characterized the golden times of the Noveschi. The Sienese had a high-strung, mystic temperament, remarkable even amidst the imaginative enthusiasm that has ever throbbed and thrilled in the Tuscan heart. White-robed hermits that had left the vain and luxurious delights of the city to lead serene and holy lives in that Olivetan order they went out to found, came back to Siena to tend the plague-stricken. They faced man's fate and died. But when the pestilence passed, the remnant of the city that were spared gave themselves up to joyous living with an abandon that reminds one of the Decameron and heralds the Renaissance. The enormous economic disturbance of the removal of 80,000 people, as Agnolo di Tura gives the number of the dead-certainly, three-fourths of the population perished-soon began to be felt, and although we are told that the survivors dwelt together like brethren for a time, the pity and terror of the dire tragedy had not purged the heart from its passion nor pride from its oppression.

Since 1283 Siena had been governed by the Monte dei Nove, a Government composed of the wealthier plebeian class, from which the nobles and Ghibellines were excluded. This signoria was, at first, chosen by a 
meeting of all qualified citizens-that is to say, by a small number only of the male adult population; a body of men was elected to serve for a year, from whom nine-three from each quarter-were drawn by lot every two months. The constitution of Siena thus resembled that of Florence at the same period. The Noveschi took part in every new election, and as very few adverse votes were sufficient to exclude a candidate, while a great majority was necessary to expunge a name once accepted, they contrived to form a close corporation, and by unanimous action they and their friends became a self-elective body; so that the elections were in the hands of not more than ninety citizens ( $M$. Villani). For seventy-two years their Government was marked by considerable ability, but there was a strong liberal movement going on which was probably greatly increased by the moral and economical disturbance and general social upheaval caused by the Black Death. In I355, Charles IV. was to pass through Siena on his way to Rome for coronation. Everywhere in Italy the displaced were allying themselves. The poorer citizens, who had not arrived at political rights, joined with the nobles, who had been excluded from them, and the appearance of the Emperor gave the signal for a demonstration. Charles had sworn at Pisa to respects the rights of Siena, and to nominate the Noveschi as his Imperial Vicars. One spring day he entered Siena, accompanied by the Empress, with banners flying and fanfaronade of trumpet, the people cheering them enthusiastically as they rode through the city, surrounded by their escort of knights in glittering armour, and all the pageantry of an Imperial procession. But, directly the royal pair dismounted at the palace of the Salimbeni, shouts arose of "Long live the Emperor, but death to the Nine !" The Piccolomini led the demonstration, with the connivance of all the other magnates, except certain of the Salimbeni, and they were supported by the entire population of the city. Aristocrats, the smaller traders, the rabble, even many of the rich merchants, joined in the cry. Next day the popolo minuto armed, and at nightfall the chains of the city were broken, and the keys of the gates brought to the Emperor. The panicstricken Government, deprived of all support, spent a restless night in the Palazzo Publico, whence they might see flames arising from their houses, which the mob had put to sack and fire.

Charles, even had he chosen, could have done nothing with his mounted bodyguard in narrow streets, so easy to blockade and hold against him. But Charles did not choose. The populace was friendly to him, the aristocratic caste was in league with the people, and the restoration of aristocratic power, supported by the folly of the people, is never unacceptable to the monarchical mind. Next day Charles rode through a franticallyapplauding mob to the palace. He accepted the resignation of the Nine, and they owed it to him that their lives were spared by the indignant populace, goaded on to fury by the younger nobles. Perhaps Charles found or deemed himself impotent to check the riot; perhaps he desired to curry favour : he certainly permitted the mob to sack the palaces of the Ministers of Finance (Provveditore di Biccheria) and that of the consuls of merchants, as well as those of certain wealthy wool-merchants; and the mob burned State-papers and the criminal records before him. Fixing the chest of the State to the tail of a donkey, the rioters dragged it with shouts and jeers through the streets. The Nine found themselves exiles 
in their own city : their own servants dared not minister to them ; the very priests feared to give them consolation. In the evening Charles sent out his soldiery and tried to restore some sort of order. Presently he appointed the Patriarch of Aquileia as his Vicar, and nominated twelve nobles and eighteen representatives of the smaller people to reform the Government. His object was to bring the city under effective Imperial control by means of re-establishing the nobility and making concessions to the discontented and clamorous populace. Then Charles and the Empress rode on to Rome, having in Siena, even more than in Pisa, witnessed the humours and tasted the quality of an Italian Republican mob.

This council of thirty then appointed a new Government. The order to which the Nine belonged was permanently excluded from office, and their names erased from public records. A new bursa was formed, whence every two months twelve names were to be taken by lot, four from each terza; and one of these was to be Captain of the People. They were to belong to the popolo minuto. But this signoric could engage in no foreign or important policy without the concurrence of another council of six nobles. To act as a still further check, I 50 men of noble birth were added to the general council of 400 members, and over all was the. Imperial Vicar, Charles's natural brother, the Patriarch of Aquileia, for whom he wished to establish a lucrative principality.

His bid for popular support, which was probably, in the intertwining of human motives, also an honest endeavour to settle the just claims of the two dispossessed classes, made Charles more popular than ever. On his return from his coronation, Siena went wild with excitement. The monarch graciously knighted sixty of his delighted subjects, many of whom were of low birth, and these were borne up to him on the shoulders of their shouting comrades to receive the unwonted honour. That plebeians should be knighted, and not for military service, seems to sound the knell of chivalry and forebode the decay of medirval thought and feeling.

The Sienese were a sincere but emotional people, rash and inconsiderate in action. Directly the Emperor had departed, they had occasion to reflect on what they had done. The Patriarch occupied the public palace, and relegated the signoria to a private mansion. He only had a few knights to act as a bodyguard, so in rather less than a fortnight the city was again under arms. Iron chains effectively prevented the passage of cavalry along its tortuous narrow lanes, and the Patriarch was compelled to readmit the signoria to their palace. Yet another four days, and a quarrel between some of the richer burghers and artisans grew into a riot. Charles was left stranded at Pisa in the midst of similar disturbances, for the greater part of his German suite had returned home with their followers. He wrote to the Sienese begging them to restore his brother to him safe and sound, and promised that henceforward he would leave them alone to govern themselves in their own way. The Twelve made the Patriarch appear before the general council ; they made him renounce all office and prerogative, and give up all castles in their territory which he had garrisoned, and then sent him back to his Imperial brother divested and discomfited, but, let us hope, enlightened by experience. The six nobles had to lay down their office, and the Government of twelve, 
most of them small tradespeople, with a notary or two to guide them, alone held the reins of office.

The reign of the Nine had been oppressive; the reign of the Twelve was corrupt. The Noveschi had been men of capacity, trained in greater affairs than trade on a small scale; the Dodicini were less competent, and they had lost the favour and support of the aristocracy. Montepulciano repudiated their authority, and transferred its allegiance to Perugia. The Dodicini retaliated by inciting Cortona to resist the ambitious designs of Perugia.

Perugia, owing to the occasional presence of the Papal Court, had never acquired quite the same degree of liberty as the other cities of the Papal States ; but Cortona had speedily fallen into the hands of petty despots, while Perugia had maintained much freedom, though it was torn by the dissensions of its factions and the feuds of its great landed families. Perugia was not a highly-important State, but, since the time when Bologna had fallen under the sway of a master, Bologna had declined, and Perugia had profited by its decline. The overlordship of the Pope had sheltered it from the pretensions of the Empire; its commerce flourished; it aspired to extend its sway over a number of small towns in the neighbourhood, most of which had fallen under the rule of petty despots, and none of which were able to offer prolonged resistance. Perugia, in fact, had become the dominant power in Umbria.

In I 358 Siena sent 500 horse and some infantry to the support of the lord of Cortona. He had had the freedom of the former city conferred on him, and Siena had guaranteed a treaty which he made with Perugia, and which the Perugians were now violating. Perugia had played the part of the wolf in the fable, and accused Cortona of troubling the waters : she had sent to Florence to complain that the lord of Cortona had a design on certain of her fortified places. Florence charged her by her honour and for the unity of the Guelph party to renounce an unjust war ; but Perugia, relying on the unpopularity of the lord of Cortona, laid siege to the town, hoping for an insurrection.

Siena followed up this first squadron with another and larger one. She took Anichino Baumgarten into her service. Baumgarten was at the head of a company 1,200 strong. To this troop Siena added 600 menat-arms in her own service, and the combined forces succeeded in raising the siege of Cortona. The seat of war was now transferred to Perugian territory. The two armies tried to outmanœuvre one another without coming to the hazard of battle, but it so fell out that a conflict was ultimately unavoidable. The advanced guards crossed swords, battle became general, Baumgarten was taken prisoner, and the Sienese were routed. It was now the turn of Siena to be invaded, but this time the country was not laid waste. Perugia desired peace, and though the victorious troops advanced up to the walls, it was arranged that Montepulciano should remain under the control of Perugia for five years only, and that Cortona should be under the protection of Siena. Seven years later (1 365) Montepulciano once again recognised the preponderating power of her old mistress, and placed herself under Sienese sway.

The Government of the Twelve lasted for thirteen years. During that period the richest merchants and the nobles, the monte of the Nine, were excluded from office. The " new men" of the bourgeoisie, the well-to-do 
middle class, ruled the city in the same spirit of intolerant and selfsatisfied exclusiveness that marked all Italian parties. The Government soon became as odious to the governed as its predecessor; the nobles were banished with a free hand ; the condition of the masses gave rise to discontent. Then the party in office split into two factions, each allied with noble families that were at feud-feuds that were complicated by, and disguised, political quarrels. The very members of the Government were ready to fly at each other's throats, and were only held in restraint by the political sagacity and moderation of one of the Salimbeni. The Emperor was expected; he was on his second expedition into Italy; now was the time for a change of government, and getting the royal imprimatur to clothe it with authority. Salimbeni died in the nick of time. Sismondi is of opinion that the fierceness of feud between the nobles was at this time largely affected to disguise their common design; it served as an excuse to collect their vassals. They secured the adhesion of the Monte Noveschi and some malcontent plebeians; they assembled no fewer than 8,000 armed men in the city, ranged under Guelph and Ghibelline flags. Suddenly the men massed; they took the Public Palace by surprise; the Twelve attempted no resistance, but departed quietly to their houses, and all strongholds were surrendered. The authors of the coup d'état now announced that they were going to govern the city after the manner of their forefathers ; the consulate was re-established. The consuls were to be thirteen in number ; five were to represent the five great familiesi.e., the Tolomei, Salimbeni, Piccolomini, Saracini, and Malavolti; five others were to be chosen from the country-squires; three from the rich burgher class, the Monte Noveschi, who were thus readmitted to the Government (September, I 368). The new Government sent representatives to the Emperor, but so did the excluded Twelve, to whom the Salimbeni went over, in spite of the consular office now in their possession. Charles professed himself perfectly ready to adjudge the political variance, and promised the Imperial protection to all. He sent on Malatesta Unghero, one of the lords of Rimini, as Imperial Vicar, at the head of 800 horse.

The Government was little disposed to receive the Vicar and his cavalry, but the parte of the Twelve had less to lose. The Salimbeni suddenly sallied forth fully armed, and, joined by the party of the Twelve, threw open a gate of the city, and admitted the Imperial forces. They had gained a point in welcoming the Imperial authority; and, indeed, the whole thing was prearranged. If Charles could establish a Vicar as tyrant, that tyrant would sit in a firmer seat if the nobles had not exclusive power. The world was beginning to learn that popular government easily lends itself to autocracy. The Government had been in power now for fully three weeks ; they had employed the time in fortifying their palaces and enrolling soldiery. The contest was fierce, and at first the cavalry could make no headway; but at last, after a dozen battles, the great campo, where the famous horse-races are now held, was gained, and in a last fierce fight the Public Palace was stormed and sacked by the townspeople. The nobles fled to their palaces, hurriedly snatched up what valuables they could carry, and fled to their country-seats ; and Malatesta fortified himself in the city, and ruled it as Vicar for four months. But under his auspices a balia of 124 citizens tried a new experiment in constitution- 
mongering, so fashionable in those days, and even down to that recent time when the world woke up to the great fact that States are organic, and have a continuous organic development which will not readily submit to severe surgical experiments. This consiglio de' riformatori was wise enough, not only to recognise the existence of the monti, but the existence of the lower, though not of the lowest classes. They created a new signoria of twelve, of whom three represented the Noveschi, four the Dodicini, and five the popolo minuto. The Salimbeni were rewarded by being made burghers, and so enfranchised, and were given five castles in Sienese territory. The proportional representation of the signoria was also observed in the concilio of 650 citizens.

The Emperor, who remained at Lucca, heard with satisfaction of the revolutions which were taking place both at Pisa and Siena. The more the cities exhausted themselves, the more dependent they would become. He set off for Siena in October, and was received by the new Government, garlanded and bearing olive-branches ; for the Sienese were ever fond of symbols and nice sentiments. He knighted Niccolo Salimbeni, " and small pleasure did it do anybody" (Cronica Senese), and then set off for Rome with his pockets well filled by a handsome contribution. The nobles were all the time keeping the countryside in a state of ferment, which extended to the villages round the city itself.

It was not always Florence who led Tuscany in political evolution or disintegration. While the nobles were menacing the city from without, and the Twelve were intriguing to regain their supremacy within, and the Imperial Vicar was playing his own game, the lower, though not the lowest, classes, men still excluded from the franchise, seized the Palazzo, and ejected the members belonging to the Nine and the Twelve alike. By mutual concession, bali $a$ was again given to 150 burghers, and this council constructed a signoria of fifteen, eight mémbers belonging to the popolo minuto, four to the Dodicini, and three to the Noveschi. Henceforward the families represented in this Government were known as the Monte dei Riformatori, or of the greater number, while those of the Dodicini and Noveschi are often spoken of as the parties of the middle and lesser numbers.

At the end of the year Charles and the Empress again rode into Siena. He was at once influenced by the monte of the Twelve and the Salimbeni ; but there is this to be urged on behalf of his bias, that the whole of the State was being ravaged by the nobles and country-squires. $\mathrm{He}$ demanded that five of the greater fortresses of the countryside should be put into his possession, that the standard-bearers and militia should take oath of obedience to him, and that the Dodicini should be possessed of a greater voice in affairs. The Government summoned a general council of over 800 citizens, and flat refusal was given. The Salimbeni, who aimed at securing by force what the Medici achieved by intrigue, the rule of the State acquiesced in by the people, now rode through Siena, shouting, "Long live the people! Death to those who seek the return of the nobles !" But the signoria was on the alert ; they ordered the great bell of the Mangia to be tolled, and the populace armed and came surging along every narrow lane. Malatesta, on the other hand, charged into the"square at the head of his cavalry, and the Emperor, armed cap-a-pie, with a garland over his helmet, rode at the head of his horse and that of 
Holy Church to join him. Three thousand cavalry faced the mob, the Emperor heading a detachment. The three senators who represented the Nine left the palace at the summons of Malatesta, and in spite of the remonstrances of their colleagues. But the Twelve, who remained, were men of pluck and resolution; they ordered the Captain of the People to lead the militia to the attack. Every church-bell in the city was clanging; band after band of armed citizens were thronging up the hillsides and along the three long crests that converge and meet near the campo. They bore down on the cavalry of Malatesta with such fury that they were as helpless as if attacked by a nest of hornets; their horses were ripped up, and with great difficulty they retreated to the Palazzo Malavolti, which they began to barricade. Meanwhile, the Emperor and his horse were trying to force their way into the Palazzo, part of which was already in the possession of the party of the Twelve and the Salimbeni, when they were met at the Croce del Travaglio by the victorious hosts that had defeated Malatesta. Charles's standard-bearer was killed, his men were routed, and desperate was the fight they had to make to cover his retreat. Two of his nephews fell, as well as half his men, and the hospitals of the city were crowded with wounded. The fight lasted for seven hours; the palace of the Tolomei was made a halfway refuge, and here, perhaps, the battle waged most furiously. In vain did the Salimbeni send one of the family, olive-branch in hand, to ask for a truce. The Captain of the People sternly bade him go back, and at last the Emperor was driven to the palace of the Salimbeni, where he was left to his reflections by the Captain of the People only because he thought it wise to exercise moderation in victory.

The Sienese were a fervent, passionate people, with deep loves and hatreds; they were a high-strung people, capable of nourishing high ideals of conduct, and even, sometimes, of putting them into practice; they were not wanting in impulses of magnanimity. While this fierce conflict was going on, twelve of the fifteen, who still sat in the councilchamber, sent for their erring brethren who had left them, and a goodly company of citizens, garlanded and bearing olive-branches, reconducted them to the Palace, where, amid the blowing of trumpets, their brother senators met them and led them back to their seats, and kissed them, and begged their pardon if they had offended in aught. It was characteristic of this people, too, that, directly they have nothing to fear from the Emperor, we shall find them treating him with the consideration due to the first King in Christendom. But they ordered the Salimbeni to leave the city, and, to force them to do so, they proceeded to starve them out: no food was to be given to the Emperor or any of his following.

Neri di Donato, the contemporary Sienese chronicler, gives a graphic picture of what followed. He says : "Never was wretch in a more pitiable fright than the Emperor. The soldiers could but stare at him ; he wept, be explained; he fell on the necks of those who drew near him; he swore that he had been misled by Malatesta, by the Podestà, by the Salimbeni, and the Twelve; he set forth at length how and what had been offered him. He let out that Francesco Bastali had been a go-between; the man was arrested and given over to the Captain of the People. and search was made after other traitors. The Emperor tried negotiation with the signoria and the people; he appointed the first Imperial Vicars in per- 
petuity ; the people were to be absolved of all that they had done ; right and left, he bestowed far more than had ever been asked of him. $\mathrm{He}$ was all a-tremble and dying of hunger, and seemed to have lost his wits ; he wanted to get away, above all things, but he could not; he had neither a horse, nor money, nor an escort. With great difficulty, the Captain contrived to get back a part of that of which the people had robbed him." Then, by-and-by, he grew calmer, and even had the assurance to ask for compensation for injuries received and a gift for exercising his royal clemency and bestowing his royal favours; and the Sienese were sufficiently high-minded, or had still enough of Imperial superstition left in them, to accede. They exhibited the same temper throughout the whole incident; they granted him 20,000 florins, and paid a part of it straightway, that Charles might be able to leave the town with some show of decent retinue. As Charles left the city, a number of the Salimbeni were detected, disguised, among his followers. They were arrested, and given over to the Captain of the People, and whispers went abroad that they had again been plotting to recover Siena and wreak dire vengeance (I 369).

I1 spite of the conciliatory temper in which the representatives of the Dodicini had been sought and readmitted to the signovia, wild and vindictive passions swelled again immediately ; and for months anarchy reigned in the city and the country districts. The signoria, now called "Defenders," and the Council of Reformation that had appointed them, formed a society - the Casata Grande del Popolo-to guard the constitution, and, further, charged an esecutore to enforce order. The Florentines were brought in to reconcile the parties; they decided that the great banished families should be recalled and allowed to serve in minor office, but should not have the right of becoming "Defenders," "Gonfalonieri," or "Councillors of Reformation."

As in Florence, the humbler workers in the wool trade-the staple manufacture of Siena-were half-starved and oppressed by their employers. They had some kind of organization among themselves. In I 37 I there was a bread-riot a mong these men; granaries were ransacked; some of the ringleaders in the riot were captured, tortured, and condemned to death. Forthwith the association mustered its forces, and demanded the release of the prisoners. The rioters became so menacing that the Captain of the People, hoping to quell the disturbance by the release of the prisoners, went in full state to support the popular demand, and the authorities were now compelled to comply. But success only inflamed the rioters ; roars of "Down with the Nine !" "Down with the Twelve!" "Long live the people!" resounded through the thoroughfares. The banner of the people was snatched from the hands of the Salimbeni, who flaunted it from the front of their palace ; the ensigns of the gonfalonieri were also captured ; the nobles, who endeavoured to block the way, were overthrown; and the mass of wool-workers and meaner sort in the city burst open the doors of the palace of the signoria by the momentum of their mass merely. The representatives of the Noveschi and the Dodicini - that is to say, the representatives of all " respectable burgherdom "were expelled, and their places filled with men of the "greater number." The popolo minuto, in fact, rose and swept everything before them in Siena seven years before the revolt of the Ciompi took place in Florence. 
A magistracy of uninstructed artisans could not last, and the Council of the Reformers cudgelled their brains to effect some kind of arrangement between opposing interests. While negotiations were going on, however, the Dodicini, or party of the wealthy masters, the Captain of the People, the three standard-bearers of the three wards of the city, and the Salimbeni, conspired together to capture the city. The Captain of the People was to secretly fill the Palazzo Publico with his men, fully armed, while the Salimbeni were to march up to the city gates. Then, at a preconcerted signal, the gates were to be seized, each standard-bearer to block the entrance to his long, narrow ward, and every opponent to be secured and slain outright. But there were too many people in the plot for the secret to be well kept ; so much leaked out that many of the conspirators were under arrest, and the attempt was therefore perforcedly and prematurely made. By this time the Defenders were fully on the alert; they heard suspicious sounds in the Palazzo, and caught the Captain of the People in the act of stowing away his men. When dawn came, it revealed the gonfalonieri and the "fat burghers," with the representatives of "law and order," in possession of the campo or square before the Palace and the crossway of the Croce del Travaglio. Two thousand men, fully armed, rushed down the narrow mouths that led to the wool-carders' quarters (property when assailed has no mercy); these smote the people hip and thigh; they burst into their hovels; they slew and spared not; women and children and aged men were spitted on the lance, or hacked to pieces by the sword. The nobles and the older order of burghers-the Noveschiwere not going to let the "fat burghers" murder the people wholesale and establish a middle-class Government over their heads. Stimulated by self-interest, perhaps, and, let us believe, by some worthier feeling of pity and disgust, they rapidly armed, and moved forward in a compact body to the rescue of the Government. The battle raged fiercely before the Palace and along the three ridges of the town, but at last the nobles and Noveschi gained the day, and very creditably sustained the Government. Fortunately, the Salimbeni came up late, and could not get into the town. The Captain of the People and a gonfalonieve were beheaded; the other two gonfalonieri had escaped. It was now necessary to remodel the Government; the Noveschi were rewarded by the bestowal of three seats, but the nobles were still excluded, so that twelve of the fifteen defenders still represented the "greater number," and, as in Florence later, the "greater number" (of workers) was given a voice in the State by being admitted to the Monte di Riformatori. The new Government was essentially a Government of the "little people" and a few notaries. The nobles retired to their country seats, and carried war up to the very gates of the city. Bands of mercenaries took advantage of the unsettled state of the country to raid it. Florence, by superior powers of intrigue snatched Arezzo from Siena at the very moment when she was about to purchase that city. And, in a war with the Prefect of Vico, Hawkwood gained such advantages that peace had to be purchased. Florence, now once again in the hands of her skilful politicians, the Albizzi and their party, was unwilling to have the example of a truly democratic State fanning the hardly extinguished aspirations of her own disinherited. The Government could not last; it is wonderful that it survived as long as it did; nothing could keep it alive but its honest and devotẹ 
patriotism. The continuer of the Cronica Senese bears unwilling witness to the purity of its intentions and the merit of its measures; he says : "Although I do not belong to that party, yet I must confess that the Riformatori, being more completely working-class than was ever any administration, was none the less composed of men devoted to the Republic, and exhibited a higher degree of courage in public affairs than any other Ministry has shown."

\section{LIFE, LITERATURE, AND ART}

\section{LIFE}

PASSION flared up in an Italian city like lighted straw, and constituted authority was powerless to put down frequent street riots and insurrections in the free republican cities. There was an attempt at police, but the organization was chiefly employed in energetic interference with personal liberty. Houses were subject to rigorous examination (Cibraio, p. 389). Citizens were not allowed to remain out after certain hours, a sharp lookout had to be kept on the surreptitious return of exiles, and the condition of roads and bridges and the behaviour of courtesans were placed under police supervision - at least, in Florence. No one was allowed to possess more than a certain measure of corn. Fires were of great frequency, and there was some attempt at the organization of fire-brigades to cope with them. The interference of the Government extended to very minute matters ; it was paternal, even to the regulation of the number of resident artisans. The growth of wealth and the example of the tyrant's Court led to a great increase of luxury, in spite of sumptuary laws. But ways were not wanting to evade these. Women were peculiarly successful in circumventing the edicts. The novels of the period, especially those of Sacchetti, give the attentive reader a fund of information on this matter, as indeed on many of the manners and customs of the time. The wearer of the forbidden ribbon sought exemption on the ground that it really was not a luxury : it was a necessity ; it bound a simple garland together. Buttons were prohjbited : the ladies cut them in half, and contrived to fix the ornamental part on the dress, and then they ceased to be buttons within the meaning of the law. Many a plain burgher was ruined by the extravagance of his aristocratic helpmeet, and the dainty, well-born lady would appear to have had a great contempt for her plain spouse, the trader, to whom her family had married her for his wealth"(Cento Novelle, Giorn. III., n. 7). The strange desire to copy male attire, which we see to-day, was not unknown to the fair sex of the Middle Ages (Chron. Placentent), nor certain other weaknesses which are even now observable, such as dresses so open as to expose the armpits and even lower; and Sacchetti observes that, had the ladies but taken off their shoes, they would not have been dressed at all. Shoes were fantastic, and the dresses sometimes so inconvenient, that it required delicate adjustments to be able to sit down. At one time dress had been expensive and means small, and different parts of the dress, or of the same garment, were manufactured of whatever stuff was available, independent of colour; now the greatest attention was 
given to artistic harmony and extravagant design. Nor were the men behind the women in the exaggerations of fashion.

The house was hardly equal to the garment. Below, narrow slits that would hardly admit the passage of a weapon, but whence the foe could be observed and a missile hurled at him, served as windows; and there were iron rings affixed to the wall to hold torches and banners. The doorway was small, and the upper windows, of no great size, unglazed, were provided with oiled linen and unpierced heavy shutters. The rooms had little furniture in them, but in good houses the walls were sometimes tapestried ; oftener they were bare. There were but few dishes, of copper, brass, or even of silver, and these were passed on from generation to generation; but silver dishes were becoming more common than of yore. Bread served the place of forks, but in the fourteenth century the fork was occasionally employed in passing round the meat, because the growing sensitiveness of the age was becoming aware of the fact that hands were liable to get very dirty. Nightdresses were not yet invented. On the whole, the burghers lived in a manner which we should consider plain and even meagre. The richest man in Pisa had only one servant-maid. Nevertheless, banquets were frequently given. They were accompanied by music; the meats were coloured with saffron; and the women of the house were ceasing to serve at table. Ordinarily, man and wife ate off the same plate. Musk, balsam, amber, and all kinds of abominations that would have delighted the heart of the learned doctor in Peregrine Pickle, flavoured the banquet. Guests were wont first to bathe in the Arno, eat cucumber to get up an appetite, wait about the filthy street until they were all assembled, and then enter the door in the order of rank. Sometimes simple vegetables, such as those on which their forefathers were wont to feast, were kept on the tablecloth-for tablecloths were usedin remembrance of the good old days. The witty talker, and even the buffoon, became professional diners-out; their reputation spread, and they often found it lucrative to travel (Sacchetti, n. 5 I. - Ant. Pulc. $-L a$ Proprieta di Mercato Vecchio, Delizie). At the banquets far too much was eaten, and of too rich a quality. Foreign wines were drunk, and good living became so common that severe gout was an ordinary penalty. Doors were kept open, both for light and ventilation, and street-urchins and street fowls were wont to come in, and the banquet was interrupted from time to time in chasing them out. In private life it was no uncommon thing for refuse and offal to be thrown under the bed. Saturday was washing-day; the house was cleaned, and a woman of superior rank gave herself and her children a bath : the well at the back of the house was used for this purpose. The houses were crowded together on account of the small space allowed by the fortifications, and the unsanitary condition of the city led to frequent outbreaks of infectious disease. But such it life undoubtedly created love of the country by contrast. Men took the risks of war, and built them country villas. It was when Rome became an overgrown city that Horace and Virgil show a dawning appreciation of the ever-varying delights of country life; it was in the Middle Ages that men first awoke to the manifold subtleties of natural beauty ; it was only near our own time, when the engineer had opened up difficult country by passable roads, that mankind began really to enjoy

" the high places and the peaks

Of earth-o'ergazing mountains." 
The houses of the peasants were very rough, and hardly allowed of the rudiments of decency; and readers of the novels will remember that the secrecy of the private apartment could easily be violated, or was not very strictly preserved.

Holidays were frequent, on account of the great number of saints' clays in the calendar, and pilgrimages were made an excuse for change of sccne. Funerals became very sumptuous. At first there were only professional weepers employed, and bells were rung; but obsequies became so ostentatious and costly that repressive legislation tried to limit the display. Marriages were arranged by an intermediary (mezzano), and the names of the contracting parties were furnished to the Government. All the members of both families assembled at the bride's house on the wedding-day; a banquet was given, and then followed a curious custom that is obviously a relic of marriage by capture. The bride's young male relations barred the way with a ribbon, which the bridegroom brokc through. If a virgin, the bride was covered by a veil, according to the custom of classical times. A certain number of the relations-a number fixed by law-returned from church to a feast, while the crowd of sightseers collected outside the open doors. ${ }^{1}$ In due time the wife probably received a drubbing to keep her in obedience ; but, however badly she was treated, infidelity could not have been really very common, for the husband usually exhibited considerable confidence in his spouse (Sacch., n. 85, 86.Cento Novelle, Giorn. VIII., n. 3). There was a house for the reception of widows in some towns, but, as a rule, these ladies preferred independence and gaiety. Courtesans had been segregated, but they were now allowed -in Florence, at least-to dwell where they pleased, so long as it was not near a tavern or a house of religion. In that city, disobedience to this law entailed a whipping, or, if proved to be an old offender, branding on the face and flank (Provvisioni, January 9, I3I8). The Florentines were, however, very reluctant to punish women, and they escaped the meshes of the law, there, more easily than in most communes, nor was the net set for them so fine (Perrens).

The two social bases of morality-the unifying bonds of society-in the Middle Ages were loyalty to the family and loyalty to the guild. The family comprised all those who had blood relationship. Members of the same noble family lived together in a separate little quarter, the houses often communicating with each other and always protected by the great tower, which served as a castle and refuge when the kindred were attacked by other noble families, an event by no means unfrequent; for, since society was a mere truss of separate interests gathered together, and by no means a welded and organic whole, and there was little or no centralized control or repression, each family was fairly free to take the law into its own hands, and jealousy, insult, and injury led to reprisal. Since, moreover, a wrong, real or supposed, suffered by one member of a clan was resented by all its members, it became necessary above all things to preserve and increase family wealth and power. A relic of this state of things is still to be found in noble palaces, where cousins to the ninth degree may be discovered occupying the various floors or suites of rooms of the same great building. And in Italy generally, and in Southern

1 Opus erat a conjugio abstinere totam noctem causa sacramentum observandi matrimoniale. 
Italy in particular, the young person is far more the child of the whole family, far less under the direct jurisdiction of the father, than is the case with Teutonic nations. Indeed, parental authority is largely replaced by the family council. The result of all these conditions of the family in the Middle Ages was that all marriages among families of any pretension whatever were arranged by a parliament of those akin, with a view to the general good of the gens. Youths and maidens accepted their spouses at the dictation of the family conclave as unquestioningly as they had received their parents at the hands of Nature. Hence, it was held to be extremely improper-a thing unheard of-for married couples to exhibit any undue mutual interest or sexual affection in public, for it is obvious that any demonstration of affection, any such tacit admission that mutual attraction, far less passion, could enter into the matrimonial bond would have been certain to sap and subvert the social edifice, or at least to weaken its coercive power and diminish its stability. Thus, if Dante was really attached to his wife Gemma Donati, it would have been extremely indecorous for him to have mentioned her affectionately in his writings - and, in fact, he never does so-whence certain of his commentators and critics have drawn unjustified conclusions as to their relations to one another. Natural reticence concerning the physical relations of love, combined with the spiritualization of passion for a lady not his wife-indeed, no longer alive-and the impolicy of uxoriousness when marriage had to be wholly subordinated to family duty, suffice to account for Dante's silence ; and we have not the least right to conclude anything from that silence as to what his real feeling for Gemma was. In Dante's case, as has been said of Shakespeare and his commentators, the poet and his interpreters illustrate the opposite poles of intelligence. But human passion and sentiment cannot be dammed up in its natural course without bursting the artificial barrier or pursuing strange and unexpected divagations. This unnatural arrangement led to the worship of the married woman, which, as was previously pointed out, was not only the origin of romantic love in literature, but nurtured and strengthened its roots in life. The love of the gifted, low-born poet, for the cultivated chatelaine, married to some uncongenial and elderly baron, tended, as we have endeavoured to show, to break down the barriers of caste. Devotion to a lady became not so much a conventional duty as a religion, and we find it the effective stimulus to high aspiration and mystic yearnings in Dante, and to a warmer and less exalted but very real and persistent emotion in Petrarch. In both these cases devotion was of the character that we misname platonic. It did not, in spite of its sincerity, prevent the high-souled Dante from becoming the father of a family, nor did the more flesh-and-blood passion of Petrarch, a passion which lasted eighteen years, until the death of the married lady who inspired it. She died in I 348, leaving a large family. He became the father of an illegitimate son born in 1337 , and an illegitimate daughter born in 1343 . These passions were sometimes anything but confined to spiritual yearnings and mystic devotion, but the theory of these attachments was that the worship of woman, as revealing what is heavenly and pure, is capable of cleansing the dross from the soul and couching the spiritual eye of its blindness to the perception of that which is heavenly, delicate, and divinely gracious. The lady, with all the coy address of her sex, and its love of 
admiration, knew how to tighten the chain that bound her lover to her. If she were virtuous, she gave him some solace and comfort by bestowing the encouragement requisite to keep his devotion. She soothed him by accepting service, and requiring him constantly to attend to her behests ; she encouraged the continuance of his devotion by her smiles, while she withheld any more serious favour. Hence, devotion to ladies led to a doctrine of unrequited service, a theory that merely to love is its own exceeding great reward.

The position of women still remained unsatisfactory. The young girl was dumb until she was married, and then silence was regarded as an evidence of virtue. In the higher classes the only women worth talking to were the married ladies who had some experience of life; the young girl was ignored and kept out of society. From the point of view of arranging mariages des convenances, this was a desirable precaution; but it emphasized the worship of the married lady. Most wives amused themselves by watching processions and what was going on in the street, and led secluded lives, their chief excitement being to chatter with their servants and inferiors in rank. The novels are full of gibes at the stupidity of the wife of the plain burgher.

The aristocracy found their chief strength in the coherence of the family. Sometimes the result of crimes, and always the debts, of one member of a burgher family were borne by all. Hence, no one could leave the State or marry without the family consent. Bastards had no legal rights, but were frequently legitimated by the Church, or had money given them by their father, while women could not escape from the world by taking the veil, unless they brought the convent a dowry. A lady of high rank was educated and might ride out falcon on hand, but women of the middle class were cotally ignorant, stayed at home, and, when alone, slept with the female servants. In cultivated society the women were as educated as the men and halted at no indelicacy in conversation, save the use of obscene words. Decency in language, according to Boccaccio, saves the treatment of every subject from indelicacy. And, indeed, women were far from scrupulously careful at their toilet, and the "Spying Toms" of the period might witness a great deal through the half-closed door. Only virtuous girls had a chance to get married, howeve1, though the meretricious arts of painting and clying the hair were not considered indelicate.

The priests of the mendicant Orders, who spied into heresy, came to be generally hated. An honest woman took care to keep out of their way, and the keeping of mistresses was one of the least of their sexual irregularities (Boccaccio.-Sacchetti). Sorcery and incantation were believed in, and their professors were consulted. I $\tau$ is an evidence of the emancipation of Dante's mind that there is nothing of this belief to be found in his Divina Commedia. There was a great deal of what we should call revivalism and mission-work in the cities, with the usual conversions and relapses. There is strong evidence of the prevalence of unnatural vice, in spite of punishment.

The judges and doctors of law were very pompous, very conceited, and very venal. Sacchetti tells a story of a judge who was bribed with an ox ; whereupon his opponer $t$ in the suit offered a cow with calf, and gained his cause, since two beasts are of more value than one (Nov. 77). Fees, as well as presents, were received in kind ; but at Venice the admirable system 
of State-appointed, State-supported judges gave no such opportunity to corruption. Party and personal passion also were wont to outweigh strict legality. Between the judges and the notaries there was constant feud, the former considering themselves vastly superior to the latter. If a prisoner did not confess, time was given him, and then he was sometimes tortured. The penalties of the law were like those of the Chinese in barbarity, and, being so severe, the condemned were often let off on the next feast-day (especially if the prisons were full), or pecuniary punishment was substituted. Captives of war were shockingly treated; Sacchetti speaks of their being put in irons and exposed to the sun (Nov., 135). Beggars were then, as now, a great nuisance, in spite of the admirable hospitals and charities instituted in the various cities. The peasants were illinstructed, but sat at their doors playing chess (Sacch., n. I65) ; we learn from the novelists that they were ill-dressed, disgusting in appearance, and dirty in habits.

Some tradition of feudalism, and examples of chivalry set before the Italians by the expeditions of the Emperors, led to ridiculous parodies of knighthood. Everybody, down to the baker, in republican cities aspired to be a knight, says Sacchetti with contempt. A Sienese knight who had to appear before Gregory X. was so ignorant that a spokesman was necessary. The real aristocrat went abroad to be knighted ; those who received the honour in Italy were created in a variety of unorthodox ways, went through a pompous ceremonial, and, if jurisconsults, physicians, or notaries, were probibited afterwards from claiming payment for advice, or sitting behind a desk to give counsel. The physicians had some little knowledge ; they used the cold bath in fever (Sacch., n. 37), advised their patients to go to mineral-water baths, and were sometimes wise enough to adopt an expectant treatment in the absence of precise knowledge. Everything new in the way of treatment was tried, however, and its day then, as now, was soon over. The doctors of medicine and the apothecaries were perpetually at variance, the physician not liking the man who sold spices to come between the wind and his nobility, nor relishing his professional competition. Surgery was for the most part too mechanical an art for the dignified doctor, and he and the druggist handed that branch of the healing art over to the barber. The apothecary often became wealthy, owing to his traffic in the costly balsams and spices of the East. Trades that are quite respectable among ourselves, such as furniture-making and baking, were, for some undiscovered reason, esteemed vile.

Italian financiers and merchants had extended their operations throughout Europe. The Bardi of Florence farmed the English customs, probably as security for loans; the King of Sicily owed the Peruzzi of the same city roo,ooo gold florins. The expenses incurred by the Florentines, when against Mastino della Scala, led to an assignment of the taxes to private citizens; the lenders collected the taxes, and deducted is per cent. This debt was consolidated into a monte, with large reductions from the capital and less interest. This State was considered to be a bad creditor, and a bigh rate of interest was exacted from it; the shares were transferable. In Genoa the creditors of the State, organized into a Bank of St. George, collected the taxes, and paid the interest over to the State; in fact, the State was mortgaged to the Bank, which came in time to resemble our East India Company ; for it ultimately managed foreign colonies and possessions 
in its own way ; the holdings of the shareholders were inalienable. Interest on money was fixed at Verona at $12 \frac{1}{2}$ per cent. in 1228 , but at Modena in I 370 it was 20 per cent. The secure Bank of St. George paid from 7 to ro per cent. The general jeopardy of the times necessitated a large rate of interest. Usury was, of course, strongly condemned by the Church, but it was possible to secure her connivance by judicious gifts.

\section{ReLigion}

The degradation of the Papacy and its "Babylonian Captivity" exercised a very prejudicial effect on Catholicism. The corruption of the Church and social discontent caused the various heretical sects to increase in number and fervour; all kinds of enthusiasms and excesses in doctrine. and practice were rampant, from vegetarianism to repudiation of sexobligations and free-love. Opposition to the Pope, the clergy, and the Church was widespread, and the two great Orders of St. Dominic and St. Francis were employed to root out heresy. Various obscure sects, called the Fraticelli, with headquarters in Turin and the Marches of Ancona, took up the doctrines of the Cathari ; these bodies originated from the discontent of Franciscan extremists, and were persecuted by organized inquiry in 1335 , I 368 , I 373 , and later. They persisted until the Reformation. So long as religious questions were not involved with social disputes, or so long as there was no active opposition to the Church, heretics were let alone ; indifferentists, known as " Epicureans," were tolerably safe.

The hills of Umbria and Siena produced sweet mystic saints, whose calm and quiet spirits walked in all humility with the Unseen, and found their sustenance in thoughts of Divine compassion and mutual love between man and man what time the vineyards and the city-streets were torn with the contentions of passionate hate and ran with human blood. Of St. Catherine of Siena we read that at her very voice, or even looking on her, hearts were changed. Disfigured by small-pox, all her womanhood was absorbed in her espousals of the Spirit; all her potential motherhood spent itself on the relief of suffering, nursing the plague-stricken, and supporting the condemned criminal and the dying in the dark hour of inexorable fate. Unable to write herself, she dictated letters which are models for the perfect expression of womanly feeling and mystic devotion. But this daughter of a Sienese dyer was no me1e contemplative dreamer. Before she was thirty she had become a political power; she travelled to Avignon, and had no small share in inducing Pope Gregory XI. to return to Rome.

\section{MoRALS}

The course of the fourteenth century was accompanied by progressive lowering of the moral standard, starting with the highest circles of society. The rapid increase of wealth was to some extent a corrupting influence, but a much more important cause of moral decay was the nature of the despotisms established over so many communes. The headship and control of the State was illegitimately acquired and illegitimately held. The tyrant, once master of the city, was by no means safe ; danger surrounded him on every side. He was subject to the ambition and the defection of those who served him; to be ousted from power and confined in a cage, or 
put out of the way, by the return of the exiled leader of the rival side ; to treachery of every kind, even that born of the jealousy or thwarted ambition of those akin to him ; to insurrection ; to assassination ; to the revolt or bad faith of the mercenaries he employed, or of the rulers of cities of which he had become overlord; to the treacherous attack of ambitious rulers of rival States. Hence the tyrant, in order to succeed, had to possess a rare combination of qualities, such as personal fearlessness, military aptitude, a power of reading the minds and characters of those about him, an unerring judgment of men and affairs, the gift of dissimulating his feelings, opinions, and intentions, an utterly unscrupulous use of means to a given end : no scruples of conscience, no shadow of remorse might visit him. Since the lives and fortunes of the family to which the tyrant belonged depended on the audacity, ability, and force of character of their representative, the bastard was often put forward to the exclusion of legitimate issue. Career was open to the kind of merit that was fittest to the existing conditions, and the ablest man came to the front, irrespective of legitimacy, of ancestry, or of class-distinction. The lowly born, the tradesman's son, anyone, might rise to command an army, and, perchance, become master of a State. The confusion which thus arose struck at the heart of that family association, and even at that confederation of the industrial classes which lay at the root of social morality. The end justified the means, and old ethical ideas began to dissolve. The State being illegitimate and the law not always respected, the people began to sympathize with the criminal, and to hide him and his crime.

Environment, while debasing the moral sense of the despot, not merely favoured the success of ability, but developed it. Ability was a sine qua non of success, not merely in the tyrant, but in the members of his Court and in the mercenary Generals whom he employed. Surrounded by a thousand dangers, the intellect was kept in the tensest state. For the sake of some measure of security, the tyrant administered justice equally to all, and the general administration of States governed by despots was, perforce, wisely directed to the public good. The condottieri, at the head of moving States, as suspicious of their employers as their employers were of them, obliged in some way or other to secure the doubtful obedience of their own officers; the little despots, surrounded by even more danger than the greater rulers ; and even the magistrates of the republics, perpetually endangered by revolution-all had to reach and maintain the highest degree of efficiency. The despots and even the condottieri sharpened their wits and sought to increase their prestige by surrounding themselves with scholars, artists, poets, and men of ability; and from these centres the waves of intellectual discipline and moral disintegration extended and expanded over the whole country. The notion of fame, derived from classical studies, pervaded society; we find it prevalent even in Dante's time; but as thoughts of immortality became vague and remote, or even doubted, the kind of immortality derivable from reputation became more eagerly desired. The Roman notion of fame was bound up with that civic devotion which was the real Roman religion, but the mediæval aspirant to that poor immortality had no such sentiment; his vision of it came to him through the gate of horn, not of ivory. 


\section{The New SPIRIT}

The rediscovery of letters, the unfolding of the ancient world, also revealed man to mankind ; the joy of living began to replace the fear of death ; the ambition for full employment of every human faculty, and the desire to live a life replete with passionate enjoyment, occupied minds that had hitherto only meditated on the hollow skull, and battered their bruised souls with a haunting sense of sin. The worship of the poor, often mutilated, remnants of the past competed with the reverence, if not with the superstition, accorded to the relics of the saints; even the most devout souls regarded the magnificent mythology of the ancient world as

"Vast images in glimmering dawn,

Half shown, then broken and withdrawn."

The period was, like our own age, a medley of confused and conflicting currents, wherein the main set of the stream was hardly to be discerned. The seekers of the past discovered the present; they awoke to the joy and passion and beauty of life ; they left the theological for the real world; they cast away the ragged shreds of that sense of vileness which oppressed the mediæval world, its fear, its shivering dependence on a crude and cruel heaven, its burial of the individual in his family, his guild, his caste ; they found themselves human, with the ambition of Faust to know and enjoy, and they boldly set forth on the perilous quest. The existing bonds of society began to be unloosed with the advent of the despot and the scholar.

Learned men were in request; the clash of vulnerable armies on the foughten field was being converted into the opposing weights of invulnerable armour ; intellect in strategy and tactics was being substituted for military courage and enterprise; States were subdued by oratory ; scholars became ambassadors; and a well-written argument or eloquent appeal in Latin acted like a talisman, and was capable of subduing an admiring world into silent submission. A man removed the candles from before the Crucifix at Ravenna, and placed them before Dante's tomb, saying, "Thou art more worthy than the Crucified One." It was a sign of the times. The magistrates of the Florentine Republic wrote to Petrarch with obsequious reverence, telling him that neither past nor future would know his equal.

A passion for glory, for excitement, for new sensation, for encyclopædic knowledge, marks the fourteenth century; the known world is travelled over, and its natural phenomena regarded with a new interest. Petrarch jumps out of his bed to watch the storm; mountains and even volcanoes are climbed; everything receives purely objective treatment; the beauty of the natural world is recognised and delighted in, from the glorious majesty of the setting sun and the compelling grace of youth to the unobtrusive sweetness of the field-flower ; from the sombre majesty of rocks to the playful plashes of the falling stream. But, above all things, the writings of the ancients were lovingly, carefully, painfully sought for and studied; they were the avenues to encyclopædic knowledge : Sic itur ad astra!

\section{Literature}

Translations from the Latin were becoming common: these give evidence the dawning of the Renaissance. And side by side with the reverential study of antiquity, and, indeed, out of that study, human reason began 
once more to repose a sublime confidence in itself. Thought began to wing its flight to regions whither, since the death of the ancient world, it had not dared to soar. The study of ancient government and practical experience of political life in the cities led to dissertations that strike the modern ear as strangely familiar. Marsilio of Padua, born in 1270 , of the burgher class, dedicates his Defensor Pacis to the Emperor Louis of Bavaria. $\mathrm{He}$ will allow that it is possible that kingly rule is the most perfect, but he tells us that the foundation of society is the people, by whom, properly, laws are made, and that it is due to this fact that they command obedience (i. 9). He tells us that when the making of laws is entrusted to a few, we have no security against error and self-interest; the whole people alone can know its own requirements, and give effect to them. The supreme power in the State is therefore the whole of the citizens, or the majority of them in full assembly, or their elected representatives (i. I 2). The Church should not have the power of punishing heresy, but leave it to the condemnation of God. The Church should be wholly under the control of the State, except as to doctrine-a position only taken up by the most advanced modern States. But all these speculations are brilliant insights, not scientific inductions, and Marsilio's genius was restricted by the limitations and analogic arguments natural to his time.

Historians writing in the vernacular appear, and their prose is both elegant and to the point. Giovanni Villani, a Florentine, who had travelled in France and the Low Countries, and who had had military experience and held political office in I 316 and I 320 , was a well-qualified historian, observant, reflective, and almost scientific in his treatment of events. Dino Compagni, who has left us an interesting and vivid history of his times, was also Prior of his city. Riccordano Malaspina, who belongs to a somewbat earlier period, and other historians and scholars, continued to write in Latin, and vainly tried to recover the elegancies which adorn the ancient authors. They are far inferior in vividness and felicity of expression to the men who wrote in their own living language. The general cultivation of poetry told back on prose style, for, however hopelessly the poetic muse may be pursued, her worshipper does not leave her shrine wholly unrewarded; nothing is so conducive to vigour, clearness, and even exactness of expression, as a training in versification ; and hence in Italian, as in all languages, excellence in prose-writing followed from, and did not precede, literarydiscipline in verse.

Two men, renowned in their own day for their scholarship and Latin writings, hold a secure position in the temple of literary fame for what they considered of less worth-Petrarch for his Italian poetry; Boccaccio for his collection of short stories in the vernacular.

Francesco Petrarca (I 304-1 374) was the son of a "White " Ghibelline who was expelled from Florence with Dante in $\mathrm{I} 3 \mathrm{O} 2$. A desire for future glory, even more than for present renown, which at times he found somewhat embarrassing, was the mainspring of his intellectual life. When twentythree years of age, he saw the Laura whom he immortalized, for the first time, in a church at Avignon. His friendship with her was not very intimate, but she inspired an ardent and somewhat sensuous devotion, that expressed itself in a series of passionate and chivalrous sonnets-a form of art which he brought to perfection. He pours forth the melancholy, the joy, that is characteristic of adolescence ; every moment of his experi- 
ence contains a heart-throb and the substance of a poem. He grows, later in life, into a keen critic of the science of his day, and turns away from ploughing the sands of scholasticism to study history, archæology, and natural phenomena. Petrarch has abandoned the worship of woman idealized; she is not for him, as for Dante, the revealer of mystic things ; he addresses melancholy or heart-swelling or sensuous verse to woman ripe and real ; he forsakes the skies for the warm, passionate earth. His is essentially the rich, generous breast of the artist; the soil lightly receives and welcomes every evanescent and luxuriant growth; he thrills with all moods, all passions; now he palpitates with republican ardour for Rienzi ; now he overflows into passionate panegyric of Colonna, Rienzi's foe ; he is transparently clear, penetrative, and analytic, but invests his realism with the fine flame of inspiration that ascends from his heart's core. This exile's son, who had to become a cleric by reason of poverty, is crowned poet by Kings, and earth's mightiest vie to do him reverence. Such was the temper of the time that a blind old man traversed all Italy with tottering steps to embrace the knees of the man who pursued his studies in chambers of purple hangings, and whose friends protested against his visiting so low a person as a literary goldsmith of Bergamo, though goldsmiths were then people of dignity and position.

Boccaccio (I3 3 - I375), the bastard son of a Florentine citizen, after losing six years in the study of canon law, visited the gay Court of Robert of Naples, where he witnessed the public examination and crowning of Petrarch, and fell in love, at first sight, with Maria, a married lady, natural daughter of King Robert, immortalized in his works as Flammetta. After much delay, his passion was returned, and Boccaccio became the faithful friend and defender of the lady's half-sister, the infamous Queen Giovanna, who connived at the murder of her husband, and whose reign marks the beginnings of Neapolitan decadence. Florence gave him the lectureship on Dante which had just been founded, and thereby he became the intimate friend of Petrarch - a friendship which only death terminated. It was due to Boccaccio's efforts that a Chair of Greek was founded in the Florentine University, and he himself was renowned for his Latin writings. but we remember him for his Italian prose works, L'Amorosa Fiammetta, and, above all, for his Decameron, a source from which English authors have drawn from Chaucer to Tennyson, and which inspired Lessing's Nathan der Weise. The Decamevon is a series of stories that range over the whole gamut of human passion and experience, from highest tragedy to mockery and coarse licentiousness; from situations of true pathos to those of brutal unrestraint. He is the first artist for art's sake, and he said cverything he chose to say with hardly a trace of self-consciousness or shame. He expresses the rebound of the human spirit in its escape from the circumscriptions and restraints of an earlier age ; heaven has no attraction, hell no terror, for him; he rejoices with perfect indifference of soul in all manifestations of life ; in its dignity, its strenuousness, its pathos, its mockery, and, above all, in its contrasts. He is the man of nis times, and exhibits the first symptoms of their decadence. There is a want of the more delicate and spiritual sympathies in Boccaccio, of real fineness of soul; he lacks the note of true sensitiveness and high breeding. There is an essential deadness of her.t in the plan of the Decameron : gentlemen and ladies retire from the plague-stricken city to a villa on the hillside, 
and, while Death is mowing his harvest in the valley below them, they pass the time in sensuous enjoyment during the daytime, and in the evening amuse one another with the recounting of tales, many of a very free character, but which the absence of any coarseness of expression is supposed to redeem from all vulgarity. This free intercourse, this comradeship of men and women, indicates how, without any noisy demands, the education of the lady in the fourteenth century was assimilated to that of the man, and how silently the revelation of the classic world and the rediscovery of human nature had equalized the sexes, and liberated woman as well as man from bondage. Ser Giovanni Fiorentino and Francesco Sacchetti, minor novelists, imitated Boccaccio ; their works are full of illustrations of the manners and modes of thought of their times. But after Boccaccio and Petrarch the great stream of Italian literature disappears underground ; the revival of classicism destroys literature in the vernacular for a time, all the more readily that women could now read Latin.

\section{ART}

The work of Niccola Pisano showed the commencing influence of Gothic fabrics on the South; but Italian Gothic, though it possesses a beauty of its own, owes its sumptuous glory far more to glittering mosaic and precious marble than to purity of design. The Italian naturally inclined to the tranquillity of the long line, to shadow that required the small window, and to the cool spaciousness of the open dome; he clung to the ancient traditions of art, and never shared in " the passion that leaves the ground to lose itself in the skies." The rich glories of colour in Italian churches give the worshipper the feeling of heaven attained, presented; there is little of aspiration. The Gothic church at its best is a lantern of light pouring in through high, wide, jewelled windows ; it was totally unsuited to the excess of light in the burning South, where shade and repose are grateful ; and consequently, Gothic principles are only half adopted ; Italian churches do not soar, and the arch is combined with the level line. Often the nonabsorption of the Northern spirit is revealed by the absence of a sense of unity and proportion in the work ; but in arcading and cloister, in porch and monument, and, above all, in campanile, the Italian Gothic yields to none. There is little north of the Alps that may compare in restrained loveliness and stately splendour with the Florentine tower whch Giotto began ; in severe solemnity with the tower of the communal palace of the same city, or in delicate grace with the Mangia of Siena. The altered baptistery and cathedral of Pisa and its Campo Santo are splendid works; while the $\mathrm{Ca}^{\prime}$ d'Oro-the Golden House-of Venice, adorned with the peculiar Venetian arch, delights the dazzled eye with its sheen of gold and Oriental marble and its elaboration of delicate carving.

In sculpture, Florence and the neighbouring republics became the centres of artistic power. The lessons of Niccola Pisano were taken up and improved on by his successors. Sculpture preceded painting in its development, and Giovanni Pisano, Andrea Pisano, Orcagna, Arnolfo del Cambio, and others, left works which remain cynosures of art. Bartolommeo Van adorned the lower story of the palace of the Venetian Doge with incomparable work, while unknown sculptors gave us the magnificent tombs of the Scaligeri at Verona. 
In painting, Simone di Martino, Lippo Memmi, and Ambrogio Lorenzetti, all of Siena, are marked by penetrative insight and deep earnestness of devotion; they gave their city works of noble imagination; while Orcagna of Florence achieved a richer style. The other artists of the period are full of decorative feeling; and, speaking to men who could not read, they set forth the deepest reflection and all the wisdom of the age in ways which would reach both the understanding and the heart; but they were not destitute of sincere striving after technical excellence. The new style of architecture required a new style of decoration, and the goldsmith developed into sculptor, painter, and architect ; it was his amoition to excel in every form of manual art. The centre of this development was Tuscany, the home of those art-loving Etruscans from whom the people had descended, though native art of high excellence and purity was produced throughout the land, from the slopes of the Alps to the southern promontories of the kingdom of King Robert. The vigour of the northern mind combined with the calm, contemplative, spirit of the ancient world, and, under the influence of Christian feeling, a new art began to bud in fresco and on easel ; it was destined to unfold itself in the next two centuries into most perfect and mature manifestations, and to irradiate a "light that never was on sea or land." 


\section{BOOK V}

\section{THE FORMATION OF STATES : FROM THE COMMENCE- MENT OF THE GREAT SCHISM TO THE ESTABLISH- MENT OF SFORZA IN MILAN. THE CONDOTTTIERI, $1378-145^{\circ}$}

\section{GENERAL SURVEY OF ITALIAN HISTORY}

\section{The Great Schism}

For three generations the Roman Pontiff had been a stranger to his own see. French Popes had endeavoured to subdue a portion of Italy : their legates had never been other than unsympathetic and ambitious; sometimes they had been vicious; they overran fair provinces with the ferocious bandits of Brittany; the statesmen of Naples became their creatures; France was ever ready to support them. The death of Gregory XI. at Rome ( 1378 ) brought matters to a crisis ; it gave rise to the Great Schism, one of the heaviest blows which the ever-threatened but resilient and imperishable Church has received in the course of her eventful, chequered career. Sixteen cardinals entered the conclave to elect a new Pope : eleven of these were French, four Italians, one, a Spaniard. The customary intrigues began : Gregory XI. and Clement VI. had appointed a number of Limousins as cardinals ; this compact body intended to elect their own man, and excited the jealousy and opposition of all the other members of the Sacred College. What was going on within the cardinalate became known outside ; the Roman people suspected that a French Pope would return to Avignon, and a crowd gathered round the palace, shouting, " Give us a Roman, or at least an Italian Pope !" When the cardinals entered the Vatican, an armed crowd followed them, and after an hour of riotous behaviour, they were only persuaded to retire by promises that forty of them should be allowed to remain. The forty searched every corner of the palace to make sure that there were no soldiers hidden away and no secret passages of communication. Meanwhile the crowd without kept up its howl of "Give us a Roman!" (Vita Greg. XI. penes Baluzium.Vita Greg. ex Bosqueto). Next came a deputation from the Roman Government, setting forth the ancient grievance of the abandonment of Rome by the Pope and its cardinals; the evils wrought by the agents of foreign Popes who lived away from the lands over which they claimed dominion, and the see of which they were supposed to be pastors; all the woes that the Papacy had wrought to Italy, and the true fatherhood of the earlier Popes. These derelictions of duty were pointed out in modest but clear, forcible, and unanswerable terms. The Sacred College replied that it was astonished at such presumption; that the Holy Spirit would direct its choice, and not man. The deputation withdrew in ill mood, and shouts from outside of "Give us a Roman!" reverberated through the closed doors. The College had spoken firmly, but the tumult outside was not without its effect. The situation was one not wholly devoid of peril; the Roman people remem- 
bered its share in the Papal elections of the past, and the Italian Four gained greater weight; both parties now sought their alliance. The Limousins gave up hope of electing one of themselves; they agreed to put forward one of their creatures, Bartolommeo Prignani, a Neapolitan and Archbishop of Bari. He had lived so long in France that he might pass for a Frenchman ; he was a subject of the Queen of Naples, who favoured the opposite side, and he was an Italian; everyone ought to be satisfied. Ultimately only Cardinal Orsini, who wished to be elected himself, and who was encouraged in his opposition by the tumult which was still going on, stood out. The Archbishop of Bari was chosen, who assumed the tiara as Urban VI. But the cardinals dreaded to announce the result to the people, who were waiting in no very sanctified spirit to pillage the palace of the new Pontiff, according to ancient privilege and wont. Orsini went to the window, and announced that the election had taken place. "Who is he ?" shouted the people. " Go to St. Peter's, and you will learn," was the reply. The mob thought that the Cardinal of St. Peter's, a Tebaldeschi, had been chosen; they sacked his palace, and all Rome was in a delirium of joy. Meanwhile the new Pope and the cardinals sought the safest places they could find : it might be no child's play when the mob came to find out the truth. However, matters passed off better than might have been expected, and the new Pope was installed.

All might have gone well, but the conclave had made a singularly bad choice ; the new Pope was vain, rash, impolitic, and his manners were far from suave. He set about reforming the abuses of the Church. Cardinals were only to have one course at dinner; he set the example. Simony should be put down; he would excommunicate any cardinal that should accept a present; he would nominate enough Italian cardinals to outvote foreigners. He did not mind telling one cardinal to hold his tongue concerning matters that he did not understand; another was informed that he was a fool, and yet another that he was a thief ; the last was a Frenchman, and replied to His Holiness that he lied "like a Calabrian." Matters went from bad to worse ; it even came to the introduction of mercenaries, and a skirmish with the Romans ensued; the very Italian cardinals ceased to obey the Pope. There was some thought of appointing a Papal Coadjutor, but the idea was dismissed, and, finally, all the cardinals present at the election declared that they had been intimidated, and that the election of Urban VI. was null and void. Urban retorted by giving twenty-nine priests the red hat, thus forming a new college, as it were. The answer of the old members of the college to this was to segregate themselves, assemble at Fondi, and elect a man of undoubted talent, but whose character is indelibly written in history by the black massacre of Cesena. Robert of Geneva, the Cardinal-legate who led his bloodthirsty marauders through Romagna in I376, who told the Bolognese that he would wash his hands and feet in their blood, who shouted to the reluctant Hawkwood, "Kill them all ; I will have blood !" became Clement VII. Christianity divided : Spain, France, and Naples declared for Clement ; Italy, Germany, carrying with her Austria and Hungary, as well as England, obeyed Urban because they hated France ; so did Portugal, because of the opposite adherence of Spain (Thomas de Acerno.-Theod. a Niem. de Schismate).

Both Popes had a line of successors ; each claimed universal dominion, which it was patent to the meanest understanding that he never could 
achieve. The fault lay with the Church, and with the Church only. On the death of Clement VII., the Kings of France and Aragon, the electors of Mainz and Köln, and Pope Boniface IX., had implored the French cardinals to end the schism; but they rode too high a horse to descend; they were too proud and stiff-necked to give way; thereby they would tacitly own themselves in the wrong. They elected a Spaniard, who took the title of Benedict XIII., and who, though he had been most zealous in trying to effect a reconciliation as a cardinal, had a most scrupulous conscience, and furnished objection after objection to retirement directly he became Pope. Could the world wish to substitute an excommunicated schismatic for its legitimate Pope ? In vain did a council at Paris call on both Popes to abdicate ; in vain did a second council decide on coercion. Avignon was besieged ( 1399 ), Benedict captured, and still there remained a way out; for the Emperor Wenceslaus had promised to coerce Boniface IX., and the promise remained unfulfilled. Benedict was allowed to escape (1403); while fresh men successfully represented the rival Churches, with every pretence of a desire for union, power proved so sweet that, though "mutual abdication" was always under discussion, it was nothing but a canting phrase. The indignation of Christendom swelled high; the rivals had to agree to meet; but obstacles and excuses were not wanting, and, as Lèonardo Aretino said, "One Pope was like an aquatic creature that was careful not to leave the water, while the other was like a land-animal that had no desire to leave the shore." The world got more and more disgusted and impatient. A Pope drawing his income from France alone was rather an expensive luxury to that country; the market in indulgences stunk in the nostrils of the German clergy. This practice was begun by Boniface IX., the venal, and conducted by his agents in booths, next the high altar, adorned with all the tinsel magnificence of a cheap-jack's stall at a fair. Heresy was rampant; the doctrines of Wiclif had penetrated to the heart of the Continent, and John Huss, Jerome of Prague, and Jacob of Meissen, were eloquently expounding heterodoxy and reform. The situation was becoming dangerous; it seemed as if identity of doctrine would disappear with unity of administration; scepticism, indifference, and unbelief were more rife than ever. The cardinals on both sides consented to meet together at Pisa. No sooner was this agreed upon than both Popes manifested the sincerity of their protestations by taking their departure, the one to Rimini, the other to Perpignan-each accompanied by three or four cardinals faithful to his cause. The general council met, however, at Pisa, declared itself to be œcumenical, deposed both Popes and elected the Archbishop of Milan, who took the title of Alexander V. (1409). The sole result was that there were three Popes in the field instead of two. The three parties, Popes and cardinals alike, made ignoble war on each other by the circulation of base libel and vile charges. The Holy Fathers and their cliques displayed an energy and ingenuity in vituperation and invective worthy of a Renaissance scholar or a modern Billingsgate porter. Evil-speaking and defamation were rife in the divided Church. When Alexander died, he was said to have been poisoned by his successor, John XXIII., in order to get his tiara, and the election was reputed to have been packed. Scandals such as these, however untrue, tended to undermine faith and corrupt morals. Another œecumenical council was convoked at Constance ; John was coerced into a promise to 
abdicate, and then succeeded in eluding the vigilance of his guards, and made off ; he was recaptured, formally deposed, and imprisoned in Gottleben. Gregory XII. was discreet enough to surrender a hopeless situation. Spain abandoned the cause of its countryman, Benedict XIII. ; the Spanish cardinals saved their face by convoking the council (as if it were not already in existence, and actually sitting at the time), and proceeded thither. Violence of vindication is ordinarily inversely as certainty of conviction and security of tenure; the council was bent on reforming the Church ; it cemented its concord by burning John Huss and Jerome of Prague at the stake; but the bonds of fellowship that were tightened in the exercise of strict discipline on others were relaxed when it came to a question of reform at home. There was, especially in Germany, general execration of the prevalence of simony, which raised the whole question of the sources of church-revenue. For three years language that can be euphemistically designated as " unparliamentary," and behaviour that savoured little of the spiritual world, characterized almost every meeting of the council. Disorderly meetings were frequent ; national antipathies manifested themselves, and it was dreaded that these violent scenes, wherein almost everybody bawled and no one listened, would end in disruption and a worse schism than ever. At last a Pope was agreed upon : Otto Colonna took the tiara, with the title of Martin V. No sooner was he elected than he showed statesmanship by dismissing every project of reform; he relegated them all to the representatives of the various nations to shape and secure ; he assured and protected his own rights, and then he dissolved the council (I 4 I 8).

Italy had for the most part come to regard the Papacy as a political asset, and one by no means without value; the Court of Rome was a fountain of honour and a National distinction. The force of habit and convention replaced vivid religious belief; Aristotle and Plato had more weight with the scholar than the Bible. The rank and file of the Church, even Bishops and Abbots, were poor, and paid taxes; their conduct was often exemplary; they excited no cupidity; they were regarded with tolerant indifference. Rome was practically self-governing, and the Pope had no authority in his own city. The Parliament of the Church had been rorced into supremacy ; it had asserted its authority over the successors of Hildebrand; it had made and unmade its rulers. These were the main results of the Great Schism.

\section{Italian Politics during The Great Schism}

Meanwhile a war, marked by singular determination and courage on both sides, had arisen between the two great maritime States that had possessions in the East and sought to secure monopoly by effecting the ruin of one another. Genoa and Venice fought from I 378 to I 380 , to the exhaustion of both republics. But while the strong Government of Venice enabled her to recover very quickly from what had seemed impending ruin, and she conquered Padua and Verona (I404-I406), Genoa, in the hands of factious parties, fomented and led by rival parvenus, never quite recovered from the check which, when victory seemed certain, she had received through sending her fleet into the lagoons at Chioggia. There she entered a trap, and her navy was compelled to surrender at discretion. 
Giovanna of Naples had taken the part of Clement VII., and was closely involved in the Great Schism. She was excommunicated by Urban VI. because she had taken Clement under her protection and given him hospitality at her Court. She awakened the resentment of the aged King of Hungary, and his memory of the murder of his brother, her first husband. She named Louis, Duke of Anjou, brother to the King of France, as her successor, in order to secure the powerful protection of the French Crown, though her legitimate heir, since she had no child, was the last Prince of her race and that of Charles of Anjou, Charles of Durazzo, the cousin to the Hungarian monarch. Louis of Hungary sent Charles with a Hungarian army to Italy. He traversed it without encountering any opposition, entered Naples, where the Queen could not arm a single person in her defence, and compelled Giovanna to surrender. He kept her nine months in confinement, and then ordered her to be smothered under a feather-bed. His secret aspiration was to dominate the peninsula ; and the big burghers of Florence, doubtless hoping that the restoration of strong government in the South would enable them to extend their commercial operations; and convinced that their own superior political abilities, disciplined by dealings with Courts and by residence abroad, were absolutely required to conduct the larger policy of the Republic ; confiding, moreover, in their power to withstand the ambition of Charles, and irritated at the assumption, and what they conceived to be the abuse, of power by inferior classes, gradually succeeded in displacing the small traders and artisans, and reinstituted a Government favourable to the King, though watchful of him (1382). For, as we shall presently recount, four years before one of those revolutions of the unconsidered small traders and artisans that from time to time disturbed the Italian republics had placed political power in the hands of the lower middle class.

Scarcely was Charles seated on the Neapolitan throne than Louis, Duke of Anjou, the Prince nominated by Giovanna as her successor, sailed from Provence with an army on board, and the discontented barons of Naples formed an Angevin party and deserted Charles. The Angevins, however, frittered away their forces in a series of small engagements and unimportant sieges, and the death of the Duke, near Bari, led to the withdrawal of his troops. Meanwhile Urban VI., who had taken up his abode in the kingdom, assumed a wholly intolerable bearing towards the monarch he had favoured, and whose administration, probably very bad, he now attempted to control. Charles invited the Pope to visit him. "It is not the wont of Popes," replied Urban, " to frequent the Courts of Kings; but it is the duty of Kings to kneel at the feet of Popes. Let him annul the taxes he has levied, and I may, perhaps, still find myself able to welcome his appearance before me " (Giornal. Napol.Gazata Chron. Reg.-Ann. Min. Bonin.). The Pontiffs, even of a Church rent in twain by schism, could still maintain their ancient haughty assumption of superiority to monarchs, though they were exiles, and owed those monarchs the hospitality of asylum. The former Bishop of Bari was supported by discontented barons, and Charles was obliged to besiege him in the castle of Nocera, where he had established himself. Three or four times a day the Pope was wont to present himself at the windows, with candle and bell, to curse and excommunicate the besieging army. Artillery was not yet introduced into the kingdom, and the siege was 
protracted until some schismatic barons, though of the opposite party, released the Pope. But now that Charles was relieved of the Papal presence in his kingdom, the death of the King of Hungary left his throne vacant, and although the Salic law applied to that kingdom, the eldest daughter of the late monarch ascended it. Charles now embarked on an enterprise to recover the Hungarian Crown, but he was inveigled into the apartment of the young Queen, whom he had deposed, and her mother, and assassinated in their presence (1386). Ladislaus, a lad of ten, succeeded his father Charles on the Neapolitan throne, and his accession was disputed by Louis, the son of the late Duke of Anjou, also a minor, but whom Giovanna had nominated to the succession. The war between the two children, directed by their mothers, and supported by rival factions in the kingdom, spread ruin over the land, and prevented Naples from having any effective voice in the politics of Italy. It was not until I 399 that Ladislaus finally succeeded in overcoming the Angevins and subduing the kingdom. Constitutionally brave, and a student of the art of war, he had grown up among the horrors attendant on civil strife. He was an expert in craft, a master of dissimulation, a monster of perfidy. $\mathrm{He}$ had been educated in a school that developed the cold heart and calculating brain. He had acquired a thirst for power, and was devoid of moral principle. Failing to secure the Hungarian Crown, he concentrated all his ambition on Italy, and he took advantage of the Great Schism, which he contrived to prolong, to make himself master of Rome, Perugia, and almost all the cities of the Papal States. Florence, thoroughly alarmed, twice called Louis of Anjou to resume the struggle, promising him support. The first time that Louis answered the appeal he had to return hastily to France, for the Genoese ejected the French entrusted by them with the defence of their city, and Iouis dreaded that his communications by sea might be interrupted. The second time, Louis gained a great victory over Ladislaus at Roccassica, but he did not know how to take advantage of it. He again retired, and Ladislaus, who owed his success chiefly to the talents of Sforza, the condottiere, made some fresh conquests in Tuscany every year. The Florentine Republic, attacked on cvery side, was no longer in a fit condition to offer effective resistance; but Ladislaus was seized with illness, and died (I4I4), leaving the throne to his sister, Giovanna II., a woman forty years of age, but still conspicuous for her gallantries. She left the government of the kingdom to her lovers, who fought one another for power, completed the ruin of the realm, and annulled its influence on the politics of the peninsula.

In Lombardy the great House of Visconti not merely preponderated, but Gian Galeazzo, by the employment of infernal subtlety and dissimulation, very nearly succeeded in dominating the whole of the peninsula up to the confines of the Kingdom. Personally a coward, he relied on bands of mercenary troops, the faithfulness of whose commanders this consummately astute ruler knew how to secure. As guardian of the young Marquis of Montferrat, he had West Lombardy under his thumb, and by forgeries, misrepresentations, and prejudicial advice, he allured the Marquises Este and Gonzaga into traps which left them no resource but his protection. He took advantage of the wickedness of Princes less astute and self-controlled than he, and led them into crimes of which he was the prime author. Partly by fraud and partly by force, he destroyed 
the power of the Scaligeri at Verona, ejected the Carraresi from Padua, and flaunted his appropriate ensign, the serpent, beside the lion of St. Mark. Florence was only saved by the genius of John Hawkwood, erst an Essex tailor, the greatest mercenary leader of his time. Pisa, Siena, and Perugia were forced into acceptance of Visonti's overlordship to escape the evils produced by their internal dissensions, and he legitimatized bis position by buying a title from Wenceslaus the Emperor. He forced certain of the little States of the Apennines which, under their martial despots, were ever at war with each other, to come under his protection; took Assisi and Bologna, and commanded all the trade-routes of Florence, which was now completely encircled. But the pestilence, which was now perpetually reappearing in Italy, carried Gian Galeazzo off in 1402, and led to the temporary dissolution of a State, the existence of which largely depended on the consummate statecraft of its " tyrant."

Venice, which had had experience of the dangers that might threaten her from the mainland, destroyed the Carraresi, who had established themselves in Verona, the ancient capital of the Scaligeri, and became mistress of Padua, Vicenza, and Verona ; while Florence possessed herself of Pisa, and reduced the lordlings of the mountains near herself.

The fall of Pisa put an end to Ghibelline power in Tuscany ; and Florence, that had fought for her existence from I 390 to 1402 , found herself not merely one of the most considerable powers in Italy, but the only very considerable representative left of ancient republican principles. In spite of the long and arduous struggle, her silk and woollen manufactures had greatly increased. Intellectually and artistically she occupied an incontestable position as first in the very first rank of Italian cities. She was the chief protectress of what Italian liberties remained, and, consequently, was the chief object of the machinations of Ladislaus. The Republic saw the devices of the two most powerful enemies that she had ever encountered undone, at the very moment that resistance seemed hopeless, by the abrupt intervention of death.

Italian Politics from the Council of Constance to the Dissolution of the Council of BASEL (I4I6-I449)

No sooner was Florence delivered from the peril that menaced her from the South than she again had to meet menace from the North. The death of Gian Galeazzo Visconti was followed by the dismemberment of his States; his condottieri, faithful during his lifetime, possessed themselves of certain Lombard cities; while in others the families that had been overthrown reappeared and resumed their rule. By a similar course of persistent perfidy and crime, political astuteness, and secret practice, Filippo Maria Visconti proved that he inherited his father's evil talent, though he often employed it in ways that remain incomprehensible, unless we suppose that he loved intrigue for its own sake. He succeeded in acquiring, one by one, the disjointed fragments of his father's State, though he was unable to gratify his ambition of extending it and becoming King of Italy. Controlling the wealth created by great manufacturing cities, he was able to hire mercenary armies and command the services of great Generals.

"The kingdom" (Il Regno) was still the wealthiest of Italian States ; it 
even surpassed Milan; but it had never had any principle of vital coherence, and now it was under the rule of a vicious Queen, Giovanna II., the sister of Ladislaus. Giovanna was attacked by Louis III. of Anjou, who claimed the Crown on the ground of the nomination of his House by Giovanna I. ; and Martin V., who had aclnowledged Giovanna, supported the pretender against the dissolute elderly widow, whose Court was characterized by indecency, and her realm by chaos. Giovanna retorted by naming Alfonzo of Aragon as her successor. A ruinous war followed, wherein the famous condottieri Sforza and Braccio, the heads of two rival military schools, were employed, and wherein they died. Mutability, restless energy, characterize the politics of Italy at this period; nothing remains constant but egotism, and that has become mean and mercenary. Visconti did not neglect the opportunities of intrigue to still further weaken the already enfeebled South. He allied himself with Giovanna and the Pope. The great captains being drawn away to the South, he was free to push on his own army to Romagna, after acknowledging the right of Florence as protectress of that country. His armies inflicted six successive defeats on those of the Republic. Florence then sought and secured the help of Venice. A league was formed, which was successively joined by the lords of Ferrara and Mantua, the Republic of Siena, the Duke of Savoy, and the King of Aragon. Carlo Malatesta, Niccolo Piccinino, the younger Sforza, and Carmagnola, were the famous tacticians to whom and their bands this war gave employment. This attempt of Filippo Maria to augment his State not proving as successful as he had wished, he signed a treaty of peace, and then sent Sforza and Fortebraccio into the States of the Church, under the pretext of executing the commands of the Council of Basel against Pope Eugenius IV. Possessed of a garrison at Genoa, he launched a fleet against Alfonzo, the King of Aragon, who was contending for the now vacant Crown against the second House of Anjou, which had been again nominated by Giovanna as her successors. $\mathrm{He}$ secured the person of Alfonzo, and then let him go, to prevent France from becoming too powerful. Genoa, in disgust, ejected Viscor ti's garrison; Florence, ruled under the forms of republican government by Cosimo dei Medici, the foremost of her merchant princes, recommenced the war with Visconti ; while Alfonzo of Aragon returned to Naples to continue a war in which he ultimately proved victorious. He took Naples in I442, re-established peace, and, while he loaded his subjects with taxes, gained-not wholly without some measure of desert-the title of "Magnanimous" from the crowd of scholars whom he welcomed, protected, and rewarded.

Meanwhile Pope Eugenius IV., under the pretext of desiring a reconciliation with the Eastern Church, proposed to transfer the sittings of the Council of Basel to Italy. The Council of Constance, which wished to reduce the Pope to the position of a mere official of the Church, had arranged for the rcgular convocation of Councils to dominate the Papacy and reform the Church. The Council of Basel was the fruit of this ordinance, and it refused to accede : it refused to lose its independence. The result was a new schism at the very moment when the Emperor of Constantinople and his theologians were declaring that the two Christian Churches were reunited (1439). The presence of two rival Popes increased the confusion, laxity, and want of principle of the age. The Italian powers 
took sides in accordance with their own self-interest. Visconti and Alfonzo were for the Pope set up by the Council (Felix. V.) ; Venice, Florence, and Réné of Anjou for Eugenius.

The successes of Francesco Sforza menaced the security of Visconti. He extricated himself by giving Sforza the hand of his heiress, and then involved his new son-in-law more than once in the meshes of his perfidious policy in order to keep him from becoming too powerful; saving him, when his ruin became imminent, for family reasons, or for the value of his support. Sforza, like so many of the condottieri, had already become a powerful lord, with possessions in the centre, the north, and the south of the peninsula. He was firmly supported by Cosimo dei Medici, and held his own in the marches of Ancona. Encouraged by the successes of Sforza, Venice and Florence attacked Visconti, who at once made peace with his son-in-law; and Sforza, with the approval of Cosimo dei Medici, who dreaded Venice, was on his way to help Visconti, when he learned that he was dead (1447).

The Milanese made vain efforts to recover their freedom, and an excellent opportunity presented itself for the union of three rich and powerful republics-Milan, Verice, and Florence-supported to the north by the warlike republics of Switzerland, and elsewhere by the feebler republics of Genoa and Bologna, Siena and Lucca. Perhaps an alliance of patriotic and wealthy free States might have preserved the independence of Central Italy, but no cohesive sentiment or force existed. Milan fell into the grasp of Sforza, who founded a dynasty ; while the inevitable tendency of capital to seek security for its operations under the protection of a despot also led Florence to submit to the carefully-veiled control of Cosimo dei Medici. Cosimo was Sforza's banker, and an excellent understanding was established between Florence and Milan to preserve the balance of power in the peninsula. The acquisition of Pisa by Florence gave the latter State access to the sea, and rendered her independent of Neapolitan ports. It increased the desire of the Kings of the South to subdue her, and, by the withdrawal of her commercial activity in the Kingdom, added in no small measure to the decay of a people always dependent on foreign enterprise for their development.

Italy had now become a system of five principal States-Venice, Milan, Florence, Rome, and the Kingdom-perpetually harassed by the crosspurposes of conflicting interests, forming alliances for the purposes of the moment, and each one only kept from swallowing its neighbour or being swallowed, by the opposition of the rest. The smaller States had become the more or less rebellious thralls of unsatisfactory hangers-on of these great powers, or preserved a precarious independence merely, in consequence of their mutual jealousies. Venice had extended her territory on the mainland as far as Bergamo and Brescia; Milan ruled from Alessandria to beyond Crema, and from the Alps to beyond Parma ; Tuscany was dominated by Florence ; Rome was trying to recover the obedience of her States.

The swift changes of policy during the whole of the fifteenth century are as difficult to follow as the shiftings of a pack of cards or a dance of midges. The clue lies in grasping the traditional policy of the greater States. The Duke of Milan was bent on extending his sway eastwards at the expense of Venice, and surrounding and conquering Florence, with 
the ultimate aim of getting control of the Papal States, and employing the wealth thus acquired in the subjugation of the Kingdom. Venice, ever on the alert, tried to break the power of the Duke, and extend her sway westward at his expense, and southward to thwart his scheme. Florence felt the necessity of increase of size, but remained, on the whole, on the defensive against the Visconti, occasionally against Venice and the Pope. The anarchical condition of the Papal States compelled the Pontiff to endeavour to reduce them to submission, and to institute some kind of order, for they were in the hands of men of war, trained to warfare from the cradle, born condottieri, and early initiated in scenes of blood and cruelty. The very weakness of the petty despots of Romagna made them ruthless and virulent. Perugia, Viterbo, Orvieto, and the cities round about Rome, were given up to faction; and the noble families, among themselves, and the nobles and burghers, came to blood almost every day. The dissolution of Naples, wealthy by reason of its size and climate, was the necessary result of its having become a heritage contended for by the rival Houses of Anjou and Aragon. Its decay was further aided by the fact that many of its fiefs were, through the influence of the Pontiffs, held by Roman barons, and, since the Kingdom itself was also a fief of the Church, there was constant interference of the Papacy in its internal affairs, with disastrous results, not merely to the Kingdom, but to all Italy; for the Pope.favoured now one competitor, now another; now he was hand in glove with Florence, now with Alfonzo and the Duke of Milan. Rulers of the second rank, such as the Duke of Savoy, the Marquis of Montferrat, the lords of Ferrara and Mantua, were, in self-preservation, compelled to adopt the shifty tricks of their great neighbours, and the feeble petty despots became, as is always the result of weakness, the most treacherous and the most cruel. They held their own by terrorizing their subjects, and their States were conspicuous for maladministration ; and, to add to the confusion, the mercenary leaders were constantly carving States for themselves out of the possessions of those whom they served or opposed, and as constantly losing them. Braccio seized the signory of Perugia, his native State, and subdued many of the smaller neighbouring States, but the son lost what the father had acquired. Attendolo Sforza got great possessions in Naples, and became Grand Constable of the Kingdom. His son Francesco achieved a principality in the marches, which he lost, but we shall find him, later, founding a dynasty in Milan.

\section{The Pope becomes an Italian Prince}

Pope Martin V. came back from Avignon to Italy, but not to Rome. His own capital and all the Papal States had cast off their allegiance to their Sovereign during the long exile, and Martin was glad to accept the hospitality which Florence proffered him. He came, a landless lord, exhibited little graciousness or gratitude, and when, in 1420 , Braccio, the great condottiere, visited the city, the contrast between the brilliant soldier and the discourteous and discontented Pope; between the man who gave brilliant tourneys to the State that had employed him and the man that thought converting a Bishop into an Archbishop was sufficient 
recognition of Florentine hospitality, was felt, even by the street-urchins. They were wont to follow His Holiness with ribald shout and song:

“Papa Martino

Non vale un quattrino,"1

was the popular catch-song. The scorn of Rome for her resident Popes had extended to Florence, now that the Pontiff had removed thither, and Martin V., unused to contumely, wiped out from his mind all remembrance of Florentine goodwill, and cast about for fresh allies who would be more willing to help the successor of the fisherman to become a lord with lands again (Leonardi Aretini, Comment, R.I.S., p. 931.-Scip. Ammirato, Stor. Fior., xviii., p. 987).

Martin laid himself out to secure Braccio, and induced that soldier to surrender Narni, Terni, Orvieto, and Orta, of which he had possessed himself. $\mathrm{He}$ allowed him to retain Perugia, Assisi, and several other towns, as a Church feudatory. He seized the opportunity offered by a revolt in Bologna, followed by the seizure of supreme power in that city by one of the Bentivoglio. He declared that a promise he had made as to its freedom was revoked, and he induced Braccio to acquire it for him by force of arms (1420). The fact was that the Papacy had had the need of a territorial base driven home more than ever during the long exile. There was religious revolt in Bohemia; the Pope had become subordinate to œcumenical councils; his spiritual influence was but a shadow of what it had once been; religion had degenerated among the masses into formalism, habit, or convention ; the good things of life were sought by the traders-" getting and spending, they put forth their powers "; the new learning had brought back the joy of life to humanity ; men were absorbed in the living of this life, not in subordinating it to the next; the hierarchy had become corrupt, and nowhere more corrupt than in its chief Bishop and the cardinalate; the worldly desires of the Papacy and its political interests required that it should become master of its own house, should aspire to hold the balance of power in Italy, in order to preserve itself from being swayed this way and that way, mere flotsam and jetsam in the constantly fluctuating political currents of the peninsula ; and the Popes were therefore bound to become more and more worldly, to aspire to the station of Italian Princes, and to secure that station by the accepted methods of Italian despots. The balance of power in the Western world was beginning to replace the regulative influence of the Papacy, and it was necessary, if the Papacy was to retain any influence at all, that it should become a temporal power. Henceforth, until the Reformation in the North compelled Catholic reaction at home ; until the renewed spiritual activity of Germany forced the spiritual energy of the Catholic Church to awake from its long lethargy, the Papacy became more and more worldly. It subsisted less on real reverence than on wort, custom, and tradition; and, to preserve even this hollow ghost of the piety of the past in Italy, it had to make a material show, to patronize the new learning, to promote the arts, to clothe itself in pageantry, to impress the vulgar with trappings of State, and, above all, to rivet its disjointed and rebellious States, at the cost of perfidy, cruelty, and force, into a compact, homogeneous, and powerful kingdom. 
While he was still at Constance, Martin had received an Embassy from Queen Giovanna II. of Naples, sent to do him homage as her overlord. Her General, Sforza, held Rome, and it was arranged that that city should be handed over to the Pope. The States of the Church were in a condition of anarchy; the nobles of the Campagna were incessantly at feud with each other. The Campagna, in consequence, had become a pestiferous waste. Rome itself was half a desert, half in ruins ; its people were beggars ; its streets full of thieves (Villari, Macch., Lond., I 898, p. 46). Martin put an end to the remains of Roman freedom, and by means of his relatives, the Colonna, began to restore some kind of order in and about the city. But to get their support he was obliged to lean heavily upon them, and reward them with all kinds of concessions. We have seen how of old time Popes were obliged to enlarge the power and possessions of their relatives ; but as they were old men, who had not long to reign, a great number of conflicting interests were created, which, more than anything else, led to the aristocratic brigandage that ruined the Papal States. Martin readopted the old policy. He gave a new impulse to Nepotism by bestowing lands on his relatives in his own States, or acquiring fiefs for them in Naples ; he meddled with the affairs of the South, inclining now to this, now to that foreign competitor for the Crown, initiating that policy of which we shall see the sad fruits in the foreign occupation and ruin of all Italy.

Although Martin V. succeeded in re-establishing order and some measure of prosperity in his dominions, his own greed and that of the Colonna produced general discontent. Taxes were increased, and little States took provincial position with regretful remembrance of their prior importance. Bologna revolted; but Florence, in spite of ancient friendship, had only just concluded peace with Milan; she did not desire to have a fresh war on her hands; she refused to aid ; and the little despots round, accustomed to act as condottieri, offered their services to the Pope. Hostilities continued until the next reign, when a compromise was arrived at (I43I). But, with the single exception of this town, Martin succeeded in possessing himself of all the territory that held of the Church before the Great Schism.

The policy of Martin may be summarized thus: Allied with Naples, to give Braccio a sop, and keep in peace with him ; then, allied with Sforza, to end the Neapolitan imbroglio in favour of the French. On the death of Braccio, he set himself to win the States of the Church, leaving them their existing rights and independent privileges, but compelling order and peace.

The new Pope, Eugenius IV., was determined to crush the Colonna, endowed by Martin with dangerous power, and enriched by the wealth accumulated by the late Pope's avidity. He secured the aid of the rival House of Orsini. Eugenius was a thorough monk-austere, dogmatic, opinionative, obstinate. He abstained from pleasure as a religious duty; but, as we gather from his career, self-command was a stoical virtue, humanity an epicurean : neither found lodgment in his anchorite conscience. His biographer and contemporary, Vespasiani, depicts him as a saint; but Eneas Sylvius, afterwards Pope, who was Ambassador of the Emperor at his Court, and who had the advantage of being a man of the world, and a student of men and cities, says that, though he had 
loftiness of soul, he was immoderate, and for ever substituting his own blind will for discretion (Orat. AEn. Sylv. de Morte Eugenii.-Vespasiani, Vita Eugenii $I V$.). He began by calling on the Colonna to restore the gold amassed by the late Pope. He needed the money sadly, for the States of the Church had taken advantage of Martin's death to revolt. The aged treasurer of the late Pope was tortured, 200 Roman citizens were put to death, Martin's palace was razed to the ground, the public monuments erected during his reign were destroyed, and though, by the aid of Venice and Florence, order was re-established, Filippo Maria sent condottieri into the Papal States. Of these, Sforza established himself in the marches of Ancona, Fortebraccio at Tivoli. Two years after his accession Eugenius had to beat a hasty retreat from the city of which he was Metropolitan, and seek refuge in Florence. The Romans declared their Republic re-established; the Pope had to find safety in a church, and only contrived to get away in disguise. He had to skulk beneath the gunwales of a boat on the Tiber, and was rowed off towards Ostia, pursued by a volley of brickbats. It was the crowning insult of a series, which a man like Eugenius knew how to avenge when his turn came. At present his dominion was in the hands of condottieri.

The new Pope was also engaged in a contest with the Church. The Council of Constance had compelled the Pope to convoke a new Council every seven years, but it is usually easy to find a loophole in laws and regulations devised by the unwisdom of collective bickering and debate. In that perlustration so distinctive of a legislature, the Council of Constance had omitted to fix a minimum term for future sittings, and the Papacy had seized the opportunity afforded by this oversight to dissolve the next Council nearly as soon as formed. The retort of the next Council of Basel to this was an entire withdrawal of the synod from the jurisdiction of the Pope, and a declaration of the superior authority of Councils to Popes. The power of creating cardinals was taken away from the Pope, and Eugenius was summoned to appear personally at Basel before the Council within three months, or take the consequences of contumacy (1432). Thus, at the same time that the Council was pursuing Northern heresy with fire and sword and seizing every opportunity of sending Reformers through temporal to eternal fires, it was unconsciously breaking with ecclesiastical tradition, and unconsciously encouraging the very Reformation it condemned; for there was logically no halting-place between an alteration of Church-government which subverted the foundation on which the Church stood and a plunge into the logomachy and dissolution attendant on doctrinal dispute. The Church had reared itself on the rock of the Papacy; was it to change the secure foundation of that absolutism for the shifting sands and varying fortunes of œcumenical controversy? Italy stood firm by the Pope; classical and ecclesiastical tradition had weight with her; she was proud of the presence of the Head of Christianity on her sacred soil; her quarrels with the Pontiffs were, after all, but family disputes; perhaps, too, in the dissolution of all moral ties that was disintegrating her society she felt the need of retaining every bond she could, however formal, that might still hold together the loose truss of purely personal lusts and inclinations in some sort of social and political union.

The historical view was the one taken by John Paleologus VI., the 
Emperor of Constantinople, who, hemmed in by the Turks, sought readmission to the Roman Communion and that support of Romanist Europe to his failing arms which he hoped his submission would bring. The Council declared the Pope contumacious. Eugenius replied by convoking a new œeumenical council at Ferrara. Paleologus attended with the Patriarch of Constantinople and a body of the Greek clergy (1438). The Council discussed questions of unleavened bread, of purgatory, of the procession of the Holy Spirit, and one of much more practical importance-the authority of the Pope. It declared for that authority, condemned the rival council, and excommunicated all those who should adhere to it. It moved on to Florence, and declared the Greek united with the Roman Church. By inducing some of the representatives to proceed to Rome after its dissolution, by falsely devising sham deputations from the East and treaties of which the Churches in those quarters had not the least knowledge, the Papacy increased its prestige and enhanced its claims to Catholicity (Annal. Eccles. I442, § I, p. 264.-Labbe Concil, L. XIII.-Acta Concilii Florentini, pars. iii., p. II97 et seq.-Sismondi H. des Rep. It., chap. lxx.). The Council of Basel retorted by formally deposing Eugenius and electing Amadeo VIII. of Savoy as Felix V. Felix was acknowledged by Germany, France, Spain, and a part of Northern Italy; and a wordy war of calumnious imputation, strong. language, and excommunication, was set afoot. It seemed as if the Papacy had received a mortal blow, but the weakness of federal government was soon made evident, and in 1447, when Eugenius died, the election of Nicholas V., whose learning commanded respect, and who had the support of the Emperor and the King of France, gave an opportunity for reconciliation. Felix V. resigned the Pontificate, and he and his effect of the are admitted into the Sacred College of Rome. The real to increase it, and anoththe Council of Basel to curtail Papal authority was of infallibility formally promuis was laid to the foundation of the doctrine councils in I 870 .

red by the most representative of all

There issued from the Council of Flor

in the revival of letters and the intellectuce a result of much importance world. Eugenius was by no means a schosdevelopment of the Western by scholars when at Florence, and during his negr, but he was surrounded Church he was obliged to lean on them. They tiations with the Eastern Sacred College, and speedily came to dominate it."re advanced to the patronage of learning and the fostering of the fine flower Henceforward the ment became a passion with the Papacy.

But while at Florence the Pope and his Court were $\operatorname{losin}_{\varepsilon}$ in the wandering mazes of theological subtleties, and varyi themselves

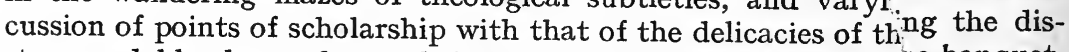
stern and bloody work was being done elsewhere by those wie banquet, out the Papal orders. It was above all things necessary to rec tho carried consolidate the temporal power.

The intemperate rule of the Papal Vicar had caused Bologna, ? second city of the Papal State, to revolt in 1438 . The same cause $\mathrm{L}_{4}$ the been the occasion of Sforza's occupation of the marches of Ancona in 1433. Eugenius availed himself of the constantly conflicting currents of various Italian interests and the complexity of warfare which resulted 
therefrom to endeavour to eject Sforza, the condottiere, who had possessed himself of the marches of Ancona. The legate of the Pope followed the army of Piccinino, Sforza's rival, who was in the employment of a coalition of Milan, Naples, and the Papacy. He exhorted the soldiers to valour ; he promised them eternal life if they died in defence of the Church; he condemned the enemy to eternal fires. But success lay with Sforza. $\mathrm{He}$ surprised and defeated Piccinino at Monte Lauro (1443), and was only prevented from pursuing his advantage to the full by shortness of cash. Yet he succeeded in again attacking and defeating Piccinino at Mont' Olino (I444); and Simoneta, who was present at the battle, speaking of the religious exhortations, promises, and anathemas of the legate, slyly observes that " they were not heard, or were not attended to, as is always the case when that kind of appeal is made to men of war-cattle not over-remarkable for piety, or solicitous of spiritual welfare" (Joannis Simonete Hist. Franc. Sforza, L. VII., p. 353). The Pope had to come to terms with Sforza. In the course of the war Sforza had recovered part of the marches, and he became feudatory for what he retained, with the title of Marquis. But the Pope never relinquished his attempt to deprive Sforza of possession of the State with which he had thus invested him. Prayer and fulmination were not the only weapons employed by Eugenius. Vitelleschi, Bishop of Recanati, and afterwards a Cardinal, was employed to levy troops, and smite and spare not at Rome and in the Campagna. Vitelleschi wiped out the family of the Prefetti di Vico; he nearly succeeded in exterminating the Colonna and Savelli; he broke the power of the great nobles of Rome; he demolished their castles; he utterly destroyed rebellious towns; he " made the country a desert, and called it peace." And, indeed, the sway of the Pope was effectually restored, for Rome and the Campagna were waste and half-abandoned, and there was no power of resistance left. The famished peasants offered to sell themselves as slaves for bread, and Vitelleschi entered Rome in triumph. Accused of treachery, Vitelleschi was imprisoned in S. Angelo, and the Pope returned to Rome.

Not merely was cruelty exercised in warfare, but the same perfidious methods that characterized the other rulers of Italy were employed by Eugenius. The successor of the fisherman, the inheritor of the charge of Christ, the Holy Father, whom, half a century before, the idealistic Catherine of Siena had been wont to address as her " most sweet Christ on earth," neither forgot nor was allowed to forget that he was the Official Head of a great organization, which must remain wholly independent, and required temporal possessions as security for its undisturbed peace and the exercise of its universal functions. His claim to temporal kingship brought him into conflict with the designs and wills of the menacing rulers and adventurers that surrounded or occupied the State of which he conceived himself to be monarch de jure, though far, indeed, from being ruler de facto. To gain his ends, the sword was useful as an occasional weapon. The swords of others were more useful still. Most useful-nay, indispensable-were those crooked methods that were now so universally employed as to cease to seem base. Political dealings have always been exempted from the injunctions of the Sermon on the Mount; they are considered to have a special ethic or license of their own ; the Prince is the trustee of futurity, and private morals must bow 
to national or ecclesiastical welfare. Set among men who held assassination as regrettable necessity and guile as intellectual distinction, the Papacy descended to stratagem, circumvention, the setting of nets and toils, and even the secret removal from this life of the obnoxious and obstructive.

The effort to secure or maintain temporal power, so necessary to the unity of the Catholic Church, frequently brought in the foreigner, and at last we shall see the foreigner come to stay, destroy Italian freedom, and blight and distort the Italian intellect for more than three centuries. The seizure of temporal power was now interfering with the internal development of the kingdom of Naples, and hastening degeneracy and corruption there.

\section{The Last Coronations at Rome}

In I4IO, as the Catholic Church had three Popes, so Germany had three Emperors. Wenceslaus was regarded as deposed, but he continued to reign in Bohemia; Sigismund, his brother, King of Hungary, and the Margrave of Moravia were competitors for the Imperial Crown. But the Margrave died, and Wenceslaus gave up his claim to his brother. Leonardo Aretino, who had a personal knowledge of the new Emperor, says that " he was a man of real distinction. His features were pleasing, his presence noble, and yet vigorous; his magnanimity unfailing, both in peace and war; his extreme liberality was his only fault, for his generous presents deprived him of the means of pursuing diplomacy or warfare" (Leonard. Aretino, R.I.S., L. XIX., p. 936). A kindly, full-blooded man, his very excellencies made him an unfit ruler in that astute, unscrupulous, furtive time. He had already visited Italy in 1413 , and, although a man of pleasure, he had exhibited indifference to danger or fatigue. $\mathrm{He}$ had gone to Poland, to France, to Spain, to try to put a stop to the schism. He was capable of vengeance when once he was aroused; but he was amenable to reason, and a devoted son of the Church; and when he found that his light cavalry could do little against the Venetians, whom he had fought for two years concerning the occupation of Dalmatia, he had wisdom enough to accept the intercession of Pope John XXIII. (I4I3). He was the author of the Council of Constance, and he presided over that of Basel. He desired to be crowned at Rome, and, flattered by the loyal messages of Filippo Maria Visconti, so different from the rough treatment that he was accustomed to receive at home, he determined to accept the Duke's offer of his wealth and arms to restore peace to Italy (I43I). But it was a very different Italy from that of the great days of the Empire. Small but wealthy States had arisen, defended by mercenaris troops, and the authority of the Emperor, though still formally acknowledged, was valueless, unless it could have been supported by a professional army capable of crushing all opposition. The Emperors', from Barbarossa downwards, had achieved small success in their expeditions to put Italy in order, yet, even in the decay of Imperial authority, the two expeditions of Charles IV. in the fourteenth century had been the occasion of revolutions ; absurd expeditions of Rupert, in I4OI, and of Sigismund, in I4I3, were marked by trifling wars. This time the Emperor came, on the solicitation of Visconti, with high hopes of restoring peace by his aid, and 
re-establishing the Imperial authority. He just succeeded in being crowned, and that was all.

He arrived in Milan towards the close of I43 I, accompanied by a cortìge of nobles to the number of 2,000, and received the Iron Crown of the kingdom at the ancient church of San Ambrogio, but Visconti did not appear: that suspicious politician had shut himself up in his castle, and never once cast eyes on the monarch he had invited. He passed on to Parma, where he remained five months, trying to settle the disputes between the Council of Basel and the Popes; and meanwhile the war between Milan and Venice went on as before, and Carmagnola was put to death by the Republic.

Sigismund next proceeded to Lucca, which had thrown off the yoke of Guinigi, its despot and now saw its territory attacked by Florence and defended by the troops of Visconti. The arrival of the Emperor caused the Florentines some little anxiety, so they made a demonstration of their forces to overawe him, and gave him a further lesson by defeating some of the cavaliers of his feeble cortège, who were rash enough to engage on the Lucchesan side. The Florentines could have captured the Emperor without difficulty, but they preferred to let him escape and carry the disquietude which his presence caused into the Papal States (Scip. Ammir., Ist Fiorent., B. II., L. XX., p. I082). He therefore was given an opportunity of making off, of which he gladly availed himself, and so came to Siena. Sigismund still retained hopes of imposing peace on Italy by his Imperial authority, but he had neither troops nor money. He was treated as an impecunious foreigner, and found himself, to all intents and purposes, a prisoner. He laid the position in which he found himself at the door of the Duke, and Bonincontri of San Miniato heard him exclaim more than once that " that perfidious tyrant had caged him in Siena like a wild beast" (Bonincontrii Miniat. Ann., L. XXI., R.I.S., p. I40). At last peace was proclaimed, and after being shut up for eight months in Siena he proceeded to Rome ( 1433 ), where he found the Imperial Crown by no means an easy one to wear, for the Catholic Church was at war with the Hussites of Bohemia ; the new Pope, Eugenius IV., was at war witl all the Colonna, the relatives of his predecessor ; and the Pontifical Govern. ment was at war with all its subjects. Having no army, the Emperor was powerless to interfere in the affairs of Italy, and the impracticable temper of the Pope prevented any compromise concerning those Church matters which, as good Catholic and German Sovereign, so closely. affected Sigismund. He therefore seized the opportunity of a lull in the wars going on around to return to Basil, where he again presided over a general council of the Church that proved to be almost as pernickety and unmanageable as was Eugenius himself, and destitute of that strong undercurrent of unconquerable resolve which supported the determination of the Pope and his curia to uphold Pontifical prerogative.

In the vain hope of winning back some of the ancient rights which had been wrested from the Imperial authority, another Emperor, Frederick IV., arranged with the Papacy to receive the Imperial Crown. He was the last of the Cæsars who arrived at Rome to that end (1452). He had to wait for a lull in the chaos of selfishness, strategy, cunning, and crosspurposes which vexed Italy, and then he crossed the Alps to meet his destined bride. It is curious to read how his Ambassadors, proceeding 
from Germany to the Court of his bride's father in Portugal, travelled through Geneva, Dauphiny, Languedoc, Catalonia, Aragon, Castille, and Galicia, disguised as pilgrims. They were robbed by brigands, rescued by the governors of towns, and set up again by the ubiquitous Florentine usurer (Hist. De Spons. et Coronat. Frid. III. apud Pezium Scrip. Austr., L. II., pp. 569-602). Frederick passed through Lombardy and Tuscany as a private gentleman rather than as a monarch. The days of Roncaglia and its glittering diet of Princes and barons, and the humbler suppliants from cities, were for ever at an end. But there were still lists and feasting, pageantry, circuses, and the dance. Court-honours were flung about right and left to whosoever would pay for them ; dukedoms, marquisates, countships, had their price; patents of nobility found a big market; bastards were legitimatized; forgeries were condoned for cash down; and the venality and greed of the Imperial Court destroyed the remnants of whatever respect was still preserved for the Empire. The great designs of Charlemagne and Otho the Great, the heroic chivalry of Barbarossa, the large and enlightened conceptions of the second Frederick, had issued in the fripperies of Court-function and the toutings of Court-officials. The sway of the Empire in Italy was virtually at an end.

\section{THE CONDOTTIERI}

THE development of industry in Italy, and the advance of civilization in that peninsula far beyond the degree attained by the remainder of Europe, led to the employment of mercenary troops that replaced the citizen-militia. The movement was favoured by the astute, wealthy dictators of the cities. They perceived the advantages of securing their precarious position by the employment of hired troops dependent on them, and the citizens, thus released from the necessities of foregoing business in times of war, gladly abandoned the discipline of military life. An extraordinary development took place in these mercenary bands. They proved no unmixed blessing to the mercantile communities; they not merely devastated the country, formed new States for their commanders, and paved the way for the subjugation of Italy by the foreigner, but even gave new rulers to constituted States. Though these bands were to be met with during several centuries, it was in the period of which we are now treating that the system of employing condottieri was most used, and the military organization of these bands became most highly organized.

In the fourteenth century Italy was ravaged by roving bands of mercenary soldiers out of employment. The harbingers of these condottieri were undoubtedly the Normans, who, in the eleventh century, were wont to hire themselves out in the quarrels of Southern Italy, without troubling themselves as to whether they had any personal interest in the disputes of their masters, or about anything save the pay they received. They were, like Dugald Dalgetty, ever ready to change sides, but were less scrupulous than that warrior in finishing their term of service before changing masters ; and they omitted no opportunity of fighting for their own hands, or of 
establishing themselves in the country. Later on, Frederick Barbarossa brought mercenaries from Flanders with him when he fought with the Lombard cities; and still later the Venetians employed hired soldiery, but on a very limited scale.

Henry of Luxemburg, Frederick of Austria, Louis of Bavaria, the Duke of Carinthia, and John of Bohemia were responsible for the introduction of successive bodies of foreign soldiery into Italy. The besttrained men were anxious to enter a service so much more remunerative than anything they could obtain at home. The Italian States found how immense was the increase of strength they secured to themselves by the employment of trained heavy cavalry ; and these men, who had devoted a lifetime to the practice of war, received vastly higher pay than the most skilful artisan could obtain. Large numbers of the soldiery who accompanied the Emperor into Italy remained behind when he left for home. Men of war from their youth up, they regarded fighting as a trade, superior to all other trades because it was better paid and had few slack times. They were not the kind of men to be overburdened by scruple; they were men of action, who took life pretty much as they found it; there was a demand for warriors, which their accomplishments enabled them to supply on advantageous terms to both parties. The despots were quick to perceive the advantage of employing this new heavy cavalry, which was specially trained, and proved itself to be so wholly irresistible. It was, moreover, composed of foreigners, who were not likely, owing to difference of language, race, and interest, to conspire with subjects, who were not too eager to return to the ploughing of their native fields, but were willing to serve for as long a time as they were paid ; whose employment allowed the industry of the city to proceed without grave interruption, and releasing the citizen from military duty, relaxed his militant spirit, and made him less likely to rebel, and less formidable in rebellion ; and who were men that would carry out plans of aggression without question or scruple. But bodies of troops, for the most part of the same nationality, fighting for a cause concerning the merits of which they knew little and cared less, soon learned to outmanœuvre each other when opposed, so as to avoid serious damage. At first the despots were not financially prepared to keep a large body of armed men in times of peace. The soldiers were discharged at the end of a war, and, though employment was pretty constant, there were times when they found themselves without it. They were bound by no sentiments of affection to their employer : to obtain money was their aim. They were accustomed to fight against the man to-day whom they had served, perhaps, but a little while ago ; and the transition was easy from this to breaking a contract and passing from side to side during a contest. Desertion and treachery for gain became common; and when they were disbanded they were quite ready to go on raiding lands as they had been accustomed to devastate them in war-time. They co-operated in bodies in times of war ; the transition was easy to organizations of their own. They formed themselves into free companies, trade - union associations, or guilds, as it were. The company was ready to hire itself en bloc to the highest bidder when war threatened, or to do the best for itself in its corporate capacity when pay was in arrears, or bigger pay was proffered. Organization enabled the band to keep up its lucrative standard of life on the cessation of 
hostilities, and reimburse itself for the shortcomings of peace. During the thirteenth century the mercenary men-at-arms were of noble birth, holding warfare to be the noblest of human employments, and always serving under some General of high rank; but the aristocratic sentiment of feudalism was never strong in Italy, and, at a time when Italians only were engaged as condottieri, we find (in the early part of the fifteenth century) Sforza Attendolo, a Romagnan peasant, commanding troops, and, in the latter half of the century, his descendants occupying the throne of Milan. Men went through a thorough apprenticeship in the service, were paid according to their length of service and experience, and rose by sheer impetus of personal character and brain-power.

In the early years of the thirteenth century a number of Catalan mercenaries had been employed by the Latins in Greece. Deprived of their leaders by death or capture, they had nominated their own Generals, and formed a sort of Government of their own. They allied themselves with the Turk, ravaged the provinces of the Greek Empire, which, not being Catholic, were lawful prey, and then quarrelling with the Duke of Athens, a Frenchman, killed him, and established themselves in his State. In I 339 Lodrisio Visconti put himself at the head of a body of German troops : he reminded them of what the Catalans had done in Greece. They called themselves the Company of St. George, made war on their own account, and advanced towards Milan, but were defeated at Parabigio. After the war of Pisa with the Visconti, the Pisans disbanded their troops (I 345); a German adventurer, who called himself Duke Werner, proposed to these men that, since their trade was slack, they should start business on their own account; he promised to be responsible for payment; he did not propose to conquer the little States through which they might pass, but merely to lay contributions on them; men-at-arms were a necessity; the price paid to them showed the value of their services; they must keep themselves in practice; they must live meanwhile; and the land that could not do without them in its turmoil must support them in its amity. This body of 2,000 horse, which called itself the Grand Company, was equally prepared to fish in troubled or in still waters. It was the first of the great marauding bands that traversed Italy; its soldiery left death and desolation in their wake; their skill in arms made them indispensable allies in time of war ; they had no object but the gratification of lust and greed.

The companies that followed the Grand Company got better and better in organization and discipline. They gradually became moving States, admirably organized, with a chief council of the leaders and captains of both cavalry and infantry. Important affairs were discussed in a parlamento of all the corporals; there was a completely graduated rule of constables, marshals, and corporals ; there were judges, notaries, and treasurers of the camp, a finance office, a commissariat department, and an office for the distribution of booty. They sent Ambassadors to States and Kings. The camp was followed by parasites of parasitestraders, money-changers, mountebanks, and harlots, many of whom were kidnapped nuns.

The companies had the whip-hand. They were more powerful than most of the little States from which they exacted contributions at will; militia could not stand against them; if they were opposed by hirelings, 
the latter were always more than half inclined to join the Company; if company was opposed to company, unending campaigns and mockbattles were the result. License reigned among them when off duty; the leaders, while maintaining military discipline strictly, allowed their men the completest freedom out of the ranks, or when ravaging a country-side. The service became most popular, and was never in want of recruits. The mercenaries stopped short of no crime and no cruelty; they were brutalized by a life of unremitting and unrelenting warfarc; they saw nothing but war. Werner added to his title of leader of the Grand Company that of "Enemy of God, pity, and pardon," and this was graven on his silver breastplate (Istorie Pistolesi).

Werner ravaged the territory of Siena, and the city had to buy him off. Montepulciano, Citta di Castello, and Perugia were also put under contribution. The warlike lords of Romagna, too feeble to resist individually, too jealous and distrustful of each other to combine, had their lands devastated. Each was eager to pay Werner to attack his neighbour, and, the business done, found that he had to ransom himself. Werner was discreet enough never to remain so long in one district as to allow of a combination against him. He passed from Romagna to the little State of Bologna. The exiles from that city offered him wealth if he would drive the Pepoli from the despotism; but the Pepoli had a formidable force. Werner preferred a bird in the hand, took klackmail of Pepoli, and passed on. He ravaged Modena, Reggio, and Mantua; but the Lombard rulers were more powerful than the petty Princes of Romagna. The Marquis of Este, the Gonzaga, and Mastino della Scala were advancing to oppose him; the Pepoli, and even Luchino Visconti, had joined them. Werner had not as yet learned all the advantages that belong to a small but compact body of trained horsemen, accustomed to fight together. He accepted a large sum of money to depart to Germany, and his followers were dismissed in companies sufficiently small to cause no great trouble on the march. They carried off rich results of Italian industry, which they soon dissipated in animalism and the orgics of debauch (1343).

When Louis of Hungary took temporary possession of the kingdom of Naples in 1348 , he discharged his mercenary followers, and among them Werner. Werner gathered a troop around him, which he organized much more thoroughly than his first company, and marched into Papal territory by way of Terracina. War broke out again in the Kingdom; Werner flew back thither like a carrion crow, but he was taken prisoner by surprise, and entered the Hungarian service again. During this war the mercenaries had it all their own way, and they accumulated spoils to the value of 500,000 florins (Dominici de Gravina Chron.-Matt. Villani). After the division of the booty, Conrad Wolfart and Fra Montréal, two captains of condottieri, remained in Apulia in the service of the King of Hungary, while Werner, with Count Lando, set out for Northern Italy.

Montréal, called by the Italians Fra Moriale, was a Provençal and a Knight of St. John of Jerusalem. The troops under his command were so disciplined, and, at the same time, so rapacious and regardless of every commandment of God or institution of man, that Queen Giovanna called in Malatesta, the lord of Rimini, to eject them. Moriale was besieged at Aversa, and was compelled to capitulate and disgorge ; but, though 
discredited and in disrepute, he none the less continued to frame yet vaster projects of plunder. He wrote to the mercenary captains in Italy, promising service and good pay; he gathered 1,500 men-at-arms and 2, ooo foot under his colours, and marched on Rimini, laying the country waste with fire and sword (1353).

Moriale was the first to organize the company as a State. He appointed a council with its treasurer and secretaries to constitute a governing body. Judges were appointed, who administered rigorous justice in the camp. Booty was sold to the traders who followed it ; and while every license was allowed to the soldiery outside the camp, strict discipline was enforced within it, and the camp-followers were protected from all injury. By means of this discipline the camp was always well supplied with all that it needed, and could always dispose of its plunder in an excellent market. The Company grew very wealthy, and mercenary troops all over Italy sought every opportunity of quitting their engagements and joining it. In vain did Malatesta seek for allies. Perugia and Siena refused to provoke Moriale; Florence sent Malatesta but feeble support, and he had to promise to pay 40,000 florins to get rid of Moriale : he delivered up his son as hostage until the money was forthcoming. He had to disband all his troops to pay the required sum, and these at once joincd the brigands, who were further reinforced by the enlistment of several of the first barons of Germany. This needy gentry flocked like vultures over the mountains. The Tuscan republics recognised their common danger, and formed a league against the Company; but Moriale succeeded in detaching Perugia, by promising to traverse that State without stopping and always pay his way. Perugia, with eager selfishness, availed herself of this opportunity to avoid warfare and expense. Moriale then led his band to Sienese territory, and the Sienese were only too glad to pay him to pass on. The Florentines in vain sought Pisan help. Moriale advanced into Florentine territory with 5,000 horse, 2,000 men who had lost their horses, armed cap-it-pie, 1,500 chosen infantry, and 20,000 camp-followers, who were very useful in pillaging the country-side and bringing provisions into camp. Florence paid blackmail to the tune of 25,000 florins, Pisa 16,000 florins, besides handsome presents to the leaders; and Moriale then set out for Lombardy, and hired his troop to the league against the Visconti that was headed by Venice, for 500,000 florins for four months' scrvice (1354).

Moriale had thus secured subsistence for the Company during the winter. He put it under the command of one Von Landau, or Lando, as the Italians called him, and, accompanied by a squadron, procecded to l'erugia to see how the land lay in the south, whither he contemplated leading his company in the spring. The terrified Perugians received him with all deference. They conferred the freedom of the city on him ; and, as his two brothers had lent money to Cola di Rienzi, he had the temerity to procecd to Rome, where Rienzi, in spite of protestations that he was a General and entitled to rights of war, cut off his head as a warning and terror to other evildoers of the same kidney (I354).

The Grand Company commanded by Lando was disengaged after the truce effected by Charles IV. Its members, mostly men of good birth, seem to have been not wholly dead to the higher feelings and dictates of chivalry, especially when indulgence of sentiment could be combined with 
the pursuit of business. Two poor German knights, dependant on their swords alone, came to Italy expressly to avenge the death of their sister, a young and beautiful Countess, who, while on a pilgrimage to Rome, had the courage to repel the advances of Bernardino Polenta, lord of Ravenna. The Countess was lodging at a hostelry, and Polenta, unaccustomed to have his desires thwarted, attempted violence. The young lady stabbed herself rather than yield. The brothers won the ear of the entire Company, and the State of Ravenna was put to fire and sword. The unhappy peasants paid for the crime of their lord ; the evildoer, secure in his citadel, escaped (Matt. Villani.-Ann. Casenates) (1355).

Lando then proceeded to the Abruzzi and $\Lambda$ pulia, which he visited with sack and sword. The Company settled down for awhilc quite comfortably in the environs of Naples, divided themselves into small parties, occupied the country-seats, and enjoyed themselves in feasting and revelry. Help was sent for, but the King had no money to pay for help when it came, and the soldicry he had summoned joined the Company. At last he succecded in raising ready-moncy enough to buy the brigands off, with the promise of more to follow. Lando led his troops through the marches of Ancona, and kept his word to Cardinal Albornoz that he would do no harm there. He again ravaged the lands belonging to Polenta, and then took pay of the league against the Visconti ( 1356 ). His men played at hostilities with the soldiery in the pay of the Visconti, but were defeated by old Lodrisio Visconti, who took a more serious view of war (1356). Two years later we find that the Grand Company was 3,500 strong in cavalry, with a numerous infantry. Siena had suffered a defeat, and, burning to wipe out the disgrace, she hired the Company to waste Perugia. Florence, though the harvest was not reaped, and the Republic had no forces to oppose to so formidable a band, refused to let Lando pass. She fortified her mountain-passes, and sought to arrange with the commander that Tuscany should be free from his visitations for at least two years. Lando accepted a mountain-route which the Florentine Ambassadors weakly conceded, but retained the Ambassadors as hostages to secure that no attack should be made on him on the march. Though these hostages werc among the most illustrious and honoured of Florentine citizens, dread of what retaliatory vengeance might be wreaked on them did not restrain the peasantry from resenting rapine. Two villages had been sacked on the march, and the hardy mountaincers revolved vengeance in their minds. The Grand Company had to pass through a gorge two miles long, surmounted by lofty summits. From this an ascending footpath led up a stecp slope. This footpath was called the Scalclla. The Grand Company was divided into threc bodies. The Florentine Ambassadors were in the van, and traversed the Scalella, mceting with no opposition. The main body, commanded by Lando himself, found the top of the pass held by fourscore peasants. This handful of men gave the signal by hurling down rocks. Immediatcly, on every height, appeared a multitude of armed men. Great rocks came crashing down on the army below. In vain did Lando order his Hungarians to scale the mountain-side; they were driven down into the valley. The leader of the rear-guard, which was just"comiug up, was swept by a boulder into the mountain torrent, where both horse and rider perished. There was the utmost confusion and 
disarray; horses jostled and reared in terror in the narrow way; panic seized horse and rider. The peasants descended from the heights, and, without losing the advantage of position, used their rude weapons with effect. They thrust at the soldiers, and pushed them over the edges of precipices. These threw down arms and baggage and fled. A dozen mountaineers took Lando, who was wounded, prisoner, but were foolish cnough to let him go for a big ransom. He fled to Bologna, leaving behind him 300 dead, a number of his men taken prisoners, I,000 warsteeds, 300 palfreys, and all his rich booty ( 1358$)$.

The advance-guard, commanded by Amerigo di Cavalleto, had passed on unscathed. Those soldiers of the other divisions who had escaped capture or the sword were dispersed in every direction. Amerigo conducted his little band to Dicomano, which he hastily fortified. He threatened the hostages whom he had with him with dire vengeance. The treaty they had concluded with the Grand Company had been unauthorized by Florence. Even had it been authorized, it was annulled by the unwarrantable outrage on mountain-villages in Florentine territory. Now was the opportunity to rid the city and all Italy of a cancer which was preying on her life-blood. Florence could depend on I 2,000 armed mountaineers. She directed that the blow should be struck. But the hostages were craven enough to prefer personal security to the duty they owed their country. They induced the peasantry to lay down their arms; they conducted Amerigo and his forces across the mountains. He reached the State of Imola in a single day, after a forced march of over forty miles. There he rested, and the scattered forces of the Grand Company gathered around him, vowing vengeance against Florence. And the weak Florentine signory, that lot had summoned to office, did not even call the Ambassadors to account, though they had first exceeded the powers with which they were entrusted, had then dared to usurp the authority of the Government of which they were the servants, and out of a base love of life had countermanded its wise and just determination.

Anichino von Baumgarten shortly reinforced the Company with 2,000 German horse, which quitted the service of Siena and Perugia to join their countrymen and avenge their defeated arms. But the mountainpasses were strongly defended, and the Company remained in Romagna the rest of the year, unable to do more than bite their nails and gnash their teeth.

The Company was rejoined by Lando. It raised the siege of Forli, and swept from State to State in Romagna, despoiling the vassals of the Church. The Church excommunicated and preached a crusade against the marauders. But Albornoz was not in Italy. The new legate was a man of no particular force of character, and the Company had it pretty much its own way. However, the winter of 1358-1359 was long and severe, and the Company lost half its horses from want of fodder. About Christmas-time Albornoz returned, and was liberally supplied with means for prosecuting the war by the Florentines. The very poor gave their goods to aid this sacred cause of putting down brigands, and the Government lent 700 horse. But Albornoz misdoubted what the result of battle might be. He negotiated a treaty with Lando, whereby the Company engaged to abstain from attacking either Florence or the 
Church for four years. on payment by himself of 45,000 florins, and by Florence of 80,000 .

For the second time Florence found herself committed to a treaty which she had not authorized. She refused to ratify, and put Pandolfo Malatesta, lord of Rimini, at the head of 2,000 horse, 500 Hungarian light cavalry, and 2,500 archers in mail. Italy was at last aroused, and determined to teach the free companies a lesson. Bernabo Visconti sent I, O0o men-at-arms and I,O0o foot to the aid of Florence ; the Marquis of Este sent 300 horse ; the lord of Padua 200. The injury that Italy had suffered from these bullying bands effected the alliance of absolutism with republican freedom. But there was no real principle of unity in Italy as yet. Each little State was, after all, but a loosely-knit collection of parties, associations, and clans; its neighbours were its rivals; and coalitions were made to-day to be dissolved to-morrow. Perugia, Siena, and Pisa each pursued what it conceived to be its own immediate interests; they compounded with the bullying band. Lando led his company through Perugian territory, and offered to treat with Florence. Several nobles who professed to be her friends, and some of the leaders of the Company who had formerly been in her service, offered to mediate. Florence refused. Then the Marquis of Montferrat, who wished to engage the Company in his service, offered the city 12,000 florins as recompense for any damage that might be done if the Company were allowed to pass through its territory. The country-squires, who were in terror for the safety of their property, urged the Government to accede. The Government stood firm ; it gave an absolute refusal. All Italy applauded ; but the help that arrived was small. Even so, it was very acceptable, for there arrived a few well-trained men. Citizen-militia, untrained to fight in heavy armour, could not stand against skilled heavy cavalry, trained from youth up to the exercise of arms. A hundred years before, a squadron of German cavalry had routed at Monte Aperto the strongest army of infantry that Central Italy had ever equipped. At Campaldino the infantry had to throw themselves under the horses' hoofs and eviscerate the creatures before the battle could be won. The armour worn by the mercenaries was so heavy that it was carried by henchmen, and only donned on the field of battle; the foot-soldiers were assailed by an iron-clad monster, and transfixed by his long strong lance before they had a chance of opposing him as man to man; if the lance missed, they were borne down by the momentum of the stout, heavy horse and his rider.

For a long time Lando hovered round. He moved through the States of Perugia, Siena, Pisa, and Lucca, without daring to attack the Florentine army. At last he ventured into Florentine territory. On July I2, I 359 , heralds rode into the Florentine camp bearing a torn and bloody glove stuck on a bunch of thorn. One of them presented a letter, daring anyone who had the hardihood to remove the glove. Pandolfo, in the presence of the entire army, laughingly snatched it away, and vowed his readiness to defend the name, the justice, and the honour of the Republic on the battle-field. He ordered wine for the heralds, and gave them largesse. Then they were conducted from the camp amidst a fanfaronade of trumpets. Whilst awaiting battle, up rode Biordo and Farinata dei Ubertini, Florentine exiles, who put their country and the common safety before party and revenge. They asked the honour of 
being allowed to add their small troop to the defence of the Republic. They were welcomed with enthusiasm, and a few months later the remains of Biordo were accorded the honours of a public funeral by his mothercity.

A fortnight elapsed before Lando made an advance as if he were about to attack the Florentines. Pandolfo moved his troops up to meet him. But when Lando had come up to a table-land called the Campo alle Nosche, which is surrounded by torrents and crags, he halted his men and threw up defences. In vain did the Florentines send out parties of light troops to skirmish and endeavour to draw him from his strong position while they sent their infantry into the mountains to cut off his retreat. The Grand Company was in great straits for want of prorisions, but they declined battle, and suddenly set their camp ablaze and beat a hasty retreat to Lucchesan territory. The Company was discouraged and disgraced. It had lost a good part of its spoils, and soon broke up, except some detachments, which, under Lando and Baumgarten, passed into the service of the Marquis of Montferrat. Florence gave Malatesta an ovation when he repaired thither to resign his insignia of command. She sent Bernabo Visconti I, ooo horse to help purge Italy of its pest; but they did not serve him long, for Bernabo seduced the Grand Company to enter his own service.

The courageous firmness of Florence was the death-blow to these organized moving States, whose citizens were freebooting bullies. The cessation of the wars between England and France set free numbers of them to serve in Italy; but, at Campo alle Mosche, both the mercenaries and Italians learned a lesson. There was the White Company, mostly English, with German leaders; the Compagnia di San Giorgio, the great English General, Sir John Hawkwood, being one of its leaders ; and other bodies of soldiers for hire, who passed over into Italy, and it is true that they bullied and plundered in their turn. But public opinion had exhibited itsclf in public resistance, and was likely to do so again. In fact, it did so again more than once, notably'when, in I 363; the Sienese, aided by German and Hungarian horse, thoroughly defeated the Compagruia del Cappello; and in 1367 , when Siena made a fine though ineffectual cffort to oppose Johu Hawkwood. The soldiery came for gain ; warfare risked the plunder they carricd with them: there was a slower but safer way of acquiring riches-to fight mock-battles with one another in the scrvice of the various States. The Italians had achicved a success; it augmented their self-respect. Florence set the example. She taught other States that security lay in resistance, not in submission.

He is little acquainted with human nature who docs not know how important an element in the history of the world is the fierce joy of battle. ltalians, fascinated by the free, roving life, the spirit of adventure, the license of the camp, the prestige of arms, "the mortal combat or carcer with lance," not to speak of the equally effective attraction of high pay, had already begun to join these companies. Italians now began to form companies of their own. Dethroned tyrants, defeated party-leaders, vigorous youths in search of a career, took to arms and joined a company, as in the eighteenth century broken-down gentlemen and the more necessitous or adventurous took to the roads. The little despots joined the company of some distinguished leader or formed a band of their own, 
in order to be trained in arms, to gain experience in the art of war, or to form a squadron of defence. The citizens of a conquered State or the exiles of a defeated party took up the life for a livelihood, and for the discharge of their disappointed energies. It was a career which, in the chronic state of war of the mediæval world, supplied continuous as well as lucrative employment.

Romagna and Umbria, given up to internecine contest between their petty barons, became the great nursery of Italian warfare. Alberic di Barbiano, lord of some castles in the neighbourhood of Bologna, formed a troop in 1377. His Company of St. George became the great military school of Italy. The Italian States were not slow to discover that Italians were possessed of every military quality, and the day of the foreign adventurer was doomed. Here was a career open to the gentry, that had the traditions of arms in their blood, an outlet for the martial encrgy that had proved so troublesome in communal history.

The manner in which a soldier took rank was by the number of lances he had broken. The profession opened a career to military merit independent of the mere aceidents of birtl. A country-squire of warlike spirit trained and led his vassals ; a man of enterprise and ability gathered kindred spirits around him. These little companies grew; their leaders, dependent on success for a following, developed and exhibited what of military genius they had in them; and Italy became the great school of war, and laid the foundations of military science. Within the Company, as well as in other fields of Italian enterprise, the distinctions of hereditary rank broke down. The peculiar dignity that was ascribed to possession of fiefs and exercise of arms in the North was relatively undeveloped in Italy; there was more feudalism there than feudal sentiment. That peninsula preceded the North in the development of industry and the discipline of culture; feudalism was an exotic ; and what of feudalism still remained was mainly to be found on the ficld of battle. But thereoll personal prowess and intellectual ability and the power of command told ; the personal qualities of the individual were evoked; a career was opened to the genius of the individual, irrespective of station, and, as we have stated on an earlier page, we find Muzio $\Lambda$ ttendolo Sforzil, the son of a peasant, who began life as a stable-boy, rising to lead a company and direct the forces of the kingdom of Naples. So rapid were the gyrations of the wheel of fortune, that men rapidly rose, not merely to the command of troops, but to the direction of States. Sometimes by circumspection, craft, cruelty, and the exercise of constant prevision, they were able to hold what they had obtained ; oftener they were hurled from the summit of their ambition by insurrection, the intrigues of neighbouring tyrants, or assassination. Pandolfo Malatesta ruled in Brescia for a brief space; Otto Bono Terzo achieved Brescia; Facino Cano became governor of Parma. Most morcenary leaders, if Italian, had risen from the lower classes, or were lordlings in turbulent Romagna; nearly all were bastards. In the fifteenth century Borso d'Este, who ruled at Ferrara, was a bastard; so was Sigismondo Malatesta, the condottiere lord of Rimini ; Sforza, who became Duke of Milan, was the illegitimate son of a horse-boy; Niccolo Piccinino, the first of the three great Generals of that name, began life as a butcher at Perugia; and the great Carmagnola had been a herdsman. The Italian novelist Sacchetti has his 
gibe at the adventurers when he makes a shoemaker aspire to the lands of Camerino (Sacchetti, Novella XC.).

Trained in a camp which had all the organization of a State, and backed by men accustomed to obedience, it is no wonder that the remarkable men who had risen by sheer ability to the command of the Company should aspire to seize and hold those among the smaller States that had least power of resistance ; the more so that the anarchy of the times could not be controlled by the feeble and divided Governments that, derived from the rule of guilds and separate communes, were no longer suited to the requirements of the age and the expansion of municipalities into States.

Thus it was, to take an example, that Sforza Attendolo, the stable-boy, surrounded by his warlike kith and kin of Romagna, and men brought up in penury and inured to hardship, by Generals rendered loyal in the rough ethics evolved in the camp, and by an army which he had created, and which depended on him, dreamed of a better plan than pillage to support himself and his company, and determined to carve out a State. This able peasant of Cotignola was raised to the rank of Great Constable of the kingdom of Naples by the King, Ladislaus. He had been given seven towns in the patrimony of St. Peter by his master, and he held several small fiefs of Siena. From this basis he designed to extend his power. He had passed from the service of one master to another, and always contrived to get lands as a reward for his transient devotion, and he had the skill to keep as well as to acquire. While still holding the great office of High Constable, he was suddenly cast into a noisome dungeon by Giovanna II. of Naples, but was released by his heroic sister, who, in full armour, forced his gaolers to set him free; and his abilities were such that he was soon again in request: he was ordered to march against his great rival, Braccio. He and Braccio headed the rival schools of arms in Italy; and when he was drowned in fording the river Pescara (I424), his illegitimate son Francesco, a youth of twentytwo, the youngest of his father's Generals, by mere force of personality, took his place, and at once secured the oath of loyalty from his soldiery. This guaranteed him the possession of his father's fiefs. He visited his father's lands, passing from one to the other with great rapidity; and then, presenting himself before the Queen, was given the formal command of his troops (for she had no alternative), and received the name of Sforza. Braccio, the rival leader, had also carved out a State for himself in the distracted States of the Church, and had received Capua and certain other fiefs in Naples, which, however, revolted, and returned to the rule of their former Sovereigns at his death in the battle of Aquila (1424). Francesco Sforza was a man of immense self-mastery, and he became the first of a line of Sovereigns. His father had been the rough, impetuous soldier, liable to be carried away by gusts of passion (he had stabbed Ottobuono, lord of Parma, while that ruler was negotiating with Este, the lord of Ferrara) ; but Francesco Sforza, while no less brave than Attendolo, was a match for anyone in self-command and circumvention. When Fortebraccio, another condottiere, established himself at Tivoli, in 1433, Pope Eugenius was obliged to cede the marches of Ancona to Sforza, with the title of Marquis, in order to get his support against the aggressions of that General. Driven from this fief by the machinations of Filippo Maria, the lord of Milan, and the Pope, who 
had no scruple in withdrawing a grant made under the stress of circumstance, he nevertheless succeeded in becoming lord of Milan and one of the four great powers in Italy.

As States grew bigger and stronger a balance of power became established in Italy, and it was no longer possible for condottieri out of employment to live by brigandage, and levy contributions with such ease as aforetime. Romagna, where the very kitchens of the houses looked like armouries, divided up into small tyrannies, was difficult of achievement, and hardly worth the pains ; and many small States were drawn into the various systems of power which were in equipoise, so that it was more dangerous for a moving State to exist by terrorism and plunder. Several severe lessons had been taught to the condottieri. and, although they did not wholly desist from attempts on the weaker States, they had grown somewhat cautious. Moreover, the development of political balance, and the unceasing warfare of the times of Filippo Maria, kept them in continuous employment. But as late as I455 Jacopo Piccinino made a very serious raid on the old lines. He had succeeded to the reputation and the Company of his father, Niccolo, and of Braccio, the founder of one of the two great military schools of Italy. Venice had resolved, during a time of peace, to pay the great Bartolommeo Coleoni IOo,ooo ducats yearly to maintain his company in readiness for her service, and had dismissed the remainder of her troops (in fact, the standing army of the modern world already looms in the distance). Piccinino was among the disbanded condottieri, and he led his band of 3,000 horse and $\mathrm{r}, 000$ foot to prey on whatever States he might find to be defenceless. His troops were without money, and, accustomed to nothing but camp life: they would have been unable to earn their living in an honest way, even had they possessed the faintest desire to do so. Piccinino led his company through Modena, and the Duke was only too glad to furnish it with provisions and give it God-speed. Even Malatesta Novello was obliged to give him greeting in the town of Cesena. He then passed through Bologna, where his father had exploited the factions to his own advantage ; but Sforza had taken the precaution to send a strong force thither to uphold the existing Government, so nothing was to be done there. Unable to do otherwise with Florence or any powerful State, Piccinino contrived to pay his way very scrupulously while he passed through Florentine territory to that of Siena. No one was particularly interested in the defence of Siena-certainly not Florence, her rival; but Pope Calixtus and Francesco Sforza, the Duke of Milan, sent bodies of troops to follow up Piccinino and prevent his return. These two forces united, but while they were debating whether to attack the marauder or not, he fell unexpectedly upon them, and nearly succeeded in routing them ; but they rallied, and he drew off. Piccinino was in correspondence with the traitorous commander of the Sienese forces, but the intrigue was discovered, and although he had captured and pillaged several places, he was obliged to retire to Castiglione della Pescaia, a fortress which the King of Naples had captured in a former campaign; there he rested his troops, hoping for reinforcements from that King; but the surrounding country yielded little food and much fever. Contrary winds detained the Neapolitan fleet, and troops sent by the Duke of Milan, Venice, and Florence, held him shut up in his fortifications, unable to make any 
attempt at attack. In vain did Alfonzo try to negotiate on his behalf ; the blockading Generals remained honest and firm. Alfonzo was very desirous of putting Piccinino at the head of an army which should be at the service of a league of States that he was anxious to form against the advancing Turk. Francesco Sforza stoutly opposed the proposition. He would not have Italy tributary to this "brigand-in-chief." While the debate was proceeding, fever was decimating both the blockaded and the investing armies. When winter came, Piccinino, nothing daunted, gathered his gaunt and sickly crew together, and surprised and captured the Sienese port of Ortobello, the pillage whereof put his troops in funds. $\mathrm{He}$ surrendered this and all his conquests in the spring to Siena, their legitimate owner, for 20,000 florins, and marched off to take service under Alfonzo, who had engineered this mulcting of Siena to replenish his purse.

At the beginning of the fourteenth century all the professional soldiers in Italy were strangers, speaking a different language, and out of all sympathy with the people among whom they camped, and wholly indifferent to the causes for which they fought. At the end of the fifteenth century they were nearly all Italians. Gradually the conduct of the soldiery towards the peasantry and townsmen of the country and places they occupied became more humane. Condottieri, sprung from a labouring class of the same breed and speech, were naturally disposed to have some fellow-feeling with them. They began to respect the fruits of labour. The smaller nobles and country-squires and the smaller despots, who were often leaders, were little disposed to indulge in a kind of warfare by which their own villages and fields might suffer in turn; the bigger despots were unwilling to have a country spoiled which they hoped to render profitable to themselves, and were reluctant to issue orders for rapine and ravage-orders, moreover, which would certainly have been disobeyed in a considerable number of cases. Another consideration that helped to put a stop to marauding forays was that every village, almost every farm, was situated on the top of a hill or hillock, carefully fortified, and, before the introduction of efficient artillery, easily defended ; directly war was declared all available crops were gathered and garnered within the defences, and as armour grew heavier and heavier, cavalry could do nothing against them; their number was enormous. The little territory of San Miniato in the Val d'Elsa contained eighty fortified places, and the State of Florence about 40o. Hence, since the troops found little left on the ground, they had to depend on the interception of convoys. The great game of war thus became an intellectual exercise between commanders of great strategic and tactical ability, and, before long, it was recognised that the destruction of private property was no essential part of war. Defence had so far outstripped attack, that a handful of old women and children in every fortified village almost sufficed to defend the little community from serious rapine. There never was a time when war did less harm to peaceful country-folk than that of the Italian condottieri towards the close of the fifteenth century. These mounted men in armour, these " moving castles," as Professor Villari calls them, could not engage in combat when the ground was at all broken, for their horses had to be of a special thick-set breed to bear so heavy a mass and their own armour to boot. An engagement could hardly take place unless 
the commanders on both sides were agreed to give battle. The gage of war, in the fourteenth century, was sent, and if accepted, the ground was levelled by each side before the conflict began. But battles became rarer and rarer, because each General usually laboured under some disadvantage. Diplomacy was largely used, and the artifices of rhetoric and scholarship were enlisted in the clientship of active service no less than in the negotiations of state-craft. And men who fought for lucre and not for a cause, who fought to-day against the companions of yesterday, and who speculated in war as a shrewd operator of to-day might speculate on the stock-exchange, were not eager to shed blood. They invested in what was almost a dead certainty of gain; they were not prepared to put their lives at hazard, with the chance of losing life and pay. The General was careful to economize his force, and did nothing rashly that might diminish it; the soldier was careful to safegnard life, horse, and equipment. The battles of the fifteenth century were almost bloodless battles. To be taken prisoner meant paying a ransom. The foughten field became well-nigh as harmless as a chess-board-a school of skilful manœuvre merely. Ofttimes there was not a single battle fought throughout a whole campaign.

Walled towns could not be taken by cavalry. Hence, in the days anterior to the introduction of artillery, towns and even walled villages were secure so long as provisions held out, and the inhabitants were bold enough to man the walls and defend them. Danger began only when resistance slacked. Old men, women and children could hurl down stones on the heads of besiegers, or baptize them with boiling pitch. Artillery had been used by the English at the Battle of Crecy, I 346, but it was developed and employed very slowly, and at first, according to Villani, with an effect due rather to its noise than to anv serious harm it did. Even Machiavelli, writing at the beginning of the sixteenth century, indicates how easy it was to deal with the clumsy cannon of that period, which could not be fired twice in the same battle. Hallam remarks that there never was a time when the development of the arts of defence so entirely checkmated the science of attack as in the later Middle Ages. Soldiers could do little against one another ; they could do nothing against towns.

But the development of military warfare into a game of diplomacy and strategic and tactical skill, and the entrustment of defence to a professional class, enfeebled the military ardour and sapped the defensive strength of the Italian people, and aided, when the time came, in rendering them the helpless prey of the foreign invader.

So dependent was Italy on her condottieri, that they not only received enormous pay, but were rewarded by the signory of towns and the possession of fiefs. We are constantly meeting with ephemeral States which the mercenary leaders carved out for themselves, making each successive little hill-town they acquired the basis for farther attack. Thus, Braccio, who occupied Bologna in the name of the Pope, gave that city her liberty in order to attack his native city, Perugia (1416), and made it the capital of a small principality. Attendolo Sforza, master of Rome, held many strong places in the States of the Church and the kingdom of Naples at the same period. Pope Eugenius gave the marches of Ancona to Attendolo's son, Francesco Sforza, with the title of Marquis ; 
while Fortebraccio seized Tivoli and other possessions of the Church. Francesco, obtaining the hand of the illegitimate daughter of the Duke of Milan, became the founder of a dynasty that brought the foreigner over the Alps to the subjugation of Italy. Thus the condottieri made enormous fortunes or became rulers. But they were of immense service to their employers, and gave peace to the people-a peace that ended in enslavement; for families that had usurped the lordship of the cities were glad to free the people they governed from military service. The employment of condottieri had a triple merit in their eyes : it gave that repose to the trader which was the main reason why he submitted to despotic rule; it made him unused to arms, and therefore a less dangerous subject ; it increased the power of the purse, and, as the despots had contrived to get control of taxation, the longest purse was likely to win in days when cunning had succeeded to violence, if the purse was employed with judicious foresight. Both the self-made Princes of Italy and its republics seem to have been really grateful to their mercenary defenders, though these defenders were constantly changing sides at the solicitations of the longest purse. The fresco of an Essex tailor turned soldier still adorns the Duomo of Florence (Sir John Hawkwood) ; the great equestrian statue of Colleoni, perhaps the noblest of its kind, is one of the sights of Venice ; while that of Gattamelata is the pride of Padua. Colleoni became very wealthy, and he lavished his means on the famous chapel that remains the gem of Bergamo.

And their strong characters secured the affectionate devotion of women no less than the attachment of their employers. When Brunoro languished in a Neapolitan prison, a paramour whom he had borne off from her home, and who was always to be found fighting at his side in armour, ran half over Europe to secure a good word for him from his former employers, and finally succeeded in touching the heart of Alfonzo, the " magnanimous" King of Naples. Porcelli saw them ten years later : Brunoro had had the gratitude and decency to marry his mistress. $\mathrm{He}$ was advanced in years, squint-eyed, half paralyzed, but still able to serve ; and his wife, now yellow with age, withered, and shrunk, still bore his heavy armour for him, and tended him with affectionate fidelity (De Gest. Scip. Piccinini, R.I.S., XXV., p. 43). The human interest and the light thrown on the substantial identity of human characteristics beneath the great superficial differences induced by era and environment must be our apology for recounting this incident.

\section{ROME}

\section{The Extinction of the Republic by the Popes}

THE city was by no means willing to surrender to Gregory XI. such full powers as it had entrusted to Urban V. Rome retained her republican Government, having a Senator and thirteen banderesi; and the disillusioned and disappointed Frenchman was about to return to Avignon, when he was seized with Roman fever and died. The next Pope, Urban VI., though an Italian, found the task of governing the city hardly less difficult 
than that of governing the world. He had the Great Schism to deal with abroad, the excommunicated, the schismatics, everywhere ; and he tried what placing the ban of the Church on the banderesi at home might effect. For forty years, during the whole time of the Great Schism, Rome was the perpetual scene of popular revolution, Papal expulsion, and Papal return. Now, the Senate was in power, and the Pope flecing in terror across the Campagna ; to-morrow it would be the Pope's turn to drive out the masters of a day and terrorize his unruly subjects by a few judicious hangings. Nevertheless, on the whole, though fortune swayed, now this way, now that, the Popes gained ground steadily. Urban VI. made Charles of Durazzo Gonfalonieve of the Church and Senator of Rome. Charles was bent on taking Naples, and Rome was near enough to Naples to furnish a bad example, so the Pope relied on him to bring the city and its banderesi into submission. When Urban died, he was succeeded by Boniface IX., an astute and clever man, who was as bent as Urban on being master in his own house. The Romans took advantage of the accession of a new Sovereign to resume self-government. Boniface was shrewd enough to perceive that the tottering edifice of Roman liberty would soon fall. He was content to secure the immunity of clerical evildoers from civil tribunals, and from taxation; while the Romans promised to lend their aid to oust the rival Pontiff from the neighbouring town of Viterbo. He even surrendered nearly all the subject cities round about that had been reconquered to the Republic. But he was too poor even to pay his own troops, and soon there was a revolt, and he had to ride hard for dear life over the hills to Perugia, and bide the time that he knew was coming; for the Jubilee of A.D. I 400 was drawing near. The poverty-stricken Romans had to choose between replenishing their empty purse or losing a good season through the absence of the Holy Father, and with no one to welcome or attract the pilgrims. Already the defection of half Europe, owing to the Great Schism, would make a serious difference to Rome; but half a loaf was better than no bread; surely it was better to submit under what good terms might be secured and be comfortable than be proud and starve amid the writhings and bickerings of a liberty that was anything but peace. The very name of freedom is apt to nauseate under such circumstances. The Pope was implored to return. He made his conditions, and he took good care that they should be enforced. He relied on Ladislaus of Naples, whom he had supported, and the presence of his soldiery. He would have the nomination of a Senator in his hand and the suppression of the Signoria dei Banderesi, which he regarded as the mainstay of all the insurrectionary spirit now left in Rome. The Romans granted everything; then they plotted, and the plot was discovered. Forthwith, exeunt conspirators, and follows, the fortification of S. Angelo, the Capitol, and the Vatican. The Colonna then tried to get up a revolution, and forced their way through the city, heading a gathering mob. But the Capitol was so ablydefended that the rebels were defeated, and thirty-one of them captured and hanged. In the absence of the executioner the life of the youngest was spared on condition of his taking the vacant post: he hanged his own father and brother. Then Boniface preached a crusade against the Colonna, and they were compelled to submit. The tremulous, tottering Republic had fallen at last; the Pope was master in his own home 
again ; and the jactitations of the barons and the populace were obviously but the death-throes of an expiring era.

The Pope relied on Ladislaus to support his rule in Rome. But Ladislaus aspired to a far greater dominion in Italy than $i l$ regno, as Dante calls the Papal fief of Naples. If the Pope became King de jure, it would be hard if Ladislaus did not become King de facto. Yet neither could do without the other; and Kings are ephemeral and Popes permanent, so poor Rome had little chance. Yet the Romans were not wholly subdued. When Boniface died they again flew to arms, refusing to acknowledge the new Pope unless he resigned his sovereignty of the city. Innocent hid the steel gauntlet of force under the velvet of concession. Ladislaus' troops were at hand, and the Romans could hardly refuse such a magnanimous offer as permission to choose seven magistrates, while the Pope only chose three and a Senator. But his temporal as well as spiritual headship must be acknowledged; the seven must swear an oath of obedience to him ; clerics must be handed over to ecclesiastical courts ; moreover, seeing how much Rome had suffered in the past, no more than five lances must be lent by any single baron to the people; and it would be better if the Captain of the People had merely judicial powers, and, to secure fairness, were nominated by His Holiness. And if this were conceded, the people might make what laws and regulations they pleased. Of course, the concession had to be made: Innocent was so bland, and the lances of Ladislaus were so near and so ready, and, moreover, when Rome tried for better terms the Pope threatened to side off to Viterbo. The capitulation was signed in 1405 .

Even yet the Romans had not quite lost their ancient characteristics. Even now they ventured to threaten the Pope with expulsion if he did not bestow a little more attention on heavenly matters and a little less on material interests. What followed is recounted by an eye-witness, the great Florentine writer, Leonardo Aretino, in his memoirs: "About this time," he says, " I was called to Rome and kindly received by the Pope, and I obtained favour and employment, which gave me a position among his intimates. It seemed to me that the Roman populace took advantage of the liberty they had recovered. Of nobles, the Colonna and Savelli were to the front; the Orsini were out of favour, as they were supposed to be for the Pope. The courtiers were numerous and wealthy, and among them were many cardinals, mostly men of high distinction. The Pope then resided at the Vatican. He only desired rest, and he would have been content if he had only been allowed to enjoy it ; but the perversity of certain people of weight with the populace prevented the calm from continuance. Uneasiness increased daily; the King made his cavalry pass viâ Rome; the Pope had to assemble his own soldiers, and this was the beginning of the trouble.

" Outside Rome, on the road from Tuscany to Latium, is a bridge over the Tiber called the Ponte Molle. It is fortified, and the Pope had garrisoned it; but the Romans claimed its custody, in order that this way into Latium might be secured. One night they attempted to surprise it; the guard defended, and there ensued a stout contest. Up came the Pope's cavalry in the early morning and put the assailants to flight, and some of them were wounded, others slain outright. The fugitives ran back to Rome, drew up at the Capitol, and the populace gathered 
round them. It happened to be a feast-day : the mob had nothing to do, and were heated with wine; they ran to arms, unfolded their banners, and marched on the Pontiff's palace. Our soldiers also made ready for battle; they put their weapons in order, mutually encouraged one another, fell into line, and put the castle of S. Angelo into a better state of defence. Nightfall postponed the attack of the mob, but both sides remained the night through under arms. (The Tiber separated them, so they were both pretty secure.) During the next few days there was talk about coming to an understanding, and a body of Roman citizens approached the Pope with this end in view. As they were returning home they were attacked before the tomb of Hadrian" (castle of S. Angelo). "Eleven of them were taken; the others succeeded in escaping. The prisoners were led to Lodovico dei Migliorotti, the Pope's nephew, who had given the order to seize the deputation, and he put them to a cruel death. Among them were two gentlemen that the Roman people had chosen to govern the Republic; the rest were citizens of position, of whom some had given evidence of being well affected to the Church." We learn elsewhere that the Pope's nephew had left the consistory to organize this butchery, because he was offended at the tone taken by the deputation, and he went out at the very moment when the meeting had taken a more moderate tone (Pievo Minerbetti, I 405, c. II.-Jacopi de Delayto Annal. Estenses, R.I.S., xviii., p. 1034.-Annal. Bonincontrii Miniatensis, R.I.S., xxi., p. 93). Leonardo Aretino continues: "When the news of this spread through Rome, the people ran to arms ; the streets filled, and everywhere shouts and imprecations were to be heard. I myself was in considerable danger that day; for, believing hostilities to be suspended while the Roman deputation was interviewing the Pope, I crossed the river and was in the city. Directly I heard the tumult I tried to get home, but the Hadrian Bridge was barred by armed men. They were the friends and relations of those who had been slain, and who had gathered together for revenge. Directly I recognised them I wheeled my horse round and fled. When I got to a side-alley I got down, covered myself up with my servant's cloak, and mingled again with the crowd. I succeeded in passing through the middle of the armed men without being recognised, and arrived among friends. The first thing that struck me was the corpses of the murdered men lying in a heap in the middle of the street, all bloody, and pierced by big wounds. I stopped, horror-struck, and I ran my eyes over the faces. I recognised, through my tears, the faces of several of my friends. I then went to the dwelling of the Pontiff, and found him plunged in grief. He had had nothing to do with the butchery. He was a sweet-natured and peaceful man, and nothing was more repugnant to his character and kindliness than effusion of blood. He deplored his fate, and raised his eyes to heaven as if to call God to witness his innocence" (Leon. Aretini Comment., R.I.S., xix., p. 922).

The commander of S. Angelo began to waver. The Pope's nephew had not enough troops, and Innocent fled the same night to Viterbo. Scarcely had he left when Ladislaus, King of Naples, called in by the Colonna and Savelli, entered Rome with a small army and demanded the lordship of the town of the citizens. But the Romans had not driven out an ecclesiastic to take a soldier for their lord. They accused the 
nobles of treachery. One citizen refused to have a soldier billeted on him, and all his neighbours aided him in resisting. The scrimmage developed into a bloody fight, lasting up to nightfall, and Ladislaus had to evacuate Rome. But he fired four different wards to keep his memory green.

This attempt of Ladislaus was advantageous to the Pope. The Romans begged him to return, and he came back, bringing his nephew with him in spite of all that had happened; and his notorious violence (I 405).

The Great Schism continued, and Ladislaus, the truculent King of Naples, strove every nerve to get what advantage he could out of it for himself. He aspired to be King of Italy, and to convert the Pope, his suzerain, into his subject. Twice, under pretence of restoring order, he possessed himself of Rome-in 1408 and 1412 , and he held the city from the latter date until his death in I4I4, when Rome and the Papal States at once threw off their allegiance to Naples, and drove out the Neapolitan garrisons. But Rome, like so many cities of the time, became the prey of the contests of those rival schools of Braccio da Montone and Attendolo Sforza that were employed by the rival lovers of Giovanna II. of Naples or the rival Princes that aspired to the succession. The kingdom of Naples was ruined by the contests; every State in Italy was impoverished and weakened by these chaotic wars; and Rome became half a desert and half a collection of huts, with little but broken monuments and ruined churches to witness to her former greatness.

At last, after nearly half a century of disorder, the Great Schism was healed, and Martin V. came to Rome (I 420). He found the Campagna almost entirely gone out of cultivation, and become a pestiferous waste, the little cities of the States at perpetual feud with each other, and the barons shut up in their castles, hurling defiance at one another, and living largely by pillage. Martin adopted the policy of the other despots of Italy. He allowed the commune to retain the names and forms of self-government; but he converted the institutions into those of purely municipal character. All political control he reserved for himself, and gradually he succeeded in restoring order and security, but at the expense of freedom.

The fiery indiscretion of his successor, Eugenius, again led to a revolt, but the stern Cardinal Vitelleschi and his ruthless soldiery subdued the city, and Eugenius, who only saved his life by a disgraceful flight in disguise, returned thither and reigned in the most perfect tranquillity. The next Pope, Nicholas V., was a great scholar and patron of letters and art; and, aware of the impressionability of mankind to the outward show of dignity and magnificence, he determined to make Rome once again the capital of the world and its most beautiful city. He employed the grcatest artists he could find to this end, and Renaissance Rome is but the partial fulfilment of his vast design.

But the literary atmosphere of a city becoming remarkable for its classical learning and refinement, revived traditions of past glory, and nourished hopes of future freedom. A great measure of intellectual liberty was enjoyed under the rule of the new Pope, who gathered scholars together and gave them employment on the ground of their scholarship, and not of their religious opinion or absence of opinion. Any form of intellectual freedom tends to extend itself to the whole brain of the indi- 
vidual, and to permeate the whole of society with its atmosphere. But on one point the Pope was firm: he demanded immediate obedience, and refused to be worried with political questions and debates which drew him from the charms of learned repose. At the death of the late Pope, one Stefano Porcari had a seat in the municipal council. He, like Cola di Rienzi, was a man wrapped in vague imaginations that gathered round an earnest desire for the restoration of the freedom and glory of the great days of ancient Rome. Porcari harangued the council until the Archbishop of Benevento, who presided, ordered him to desist. He pointed out that every little town in the Papal States had its own laws and a charter, and governed itself, only paying a yearly tribute. No place was so weak and wretched as not to make a bid for freedom on the death of its despot. Imperial Rome was the only exception-the only city that had neither the energy nor the self-respect to set itself free. He was spoken of as a dangerous man at the Court of the new Pope, and when he took advantage of a street-row to utter similar views, he was sent off to Bologna, and ordered to appear personally before the governor once every day. Porcari's blood boiled when he remembered the story of the gradual assumption of authority by the Popes; how Rome had been a republic during so long a time; and how, even since the return of the Papacy and its assumption of Imperial power, Eugenius had been ejected from the city. Since the return of the Popes there had been continual abuse of power, frequent executions, rebellions in the Campagna, and general discontent, both among the nobles and the people; morcover, the priests surrounding the Pope were exhibiting all the degenerate vices and setting the bad example of any luxurious worldly Court of them all, while their retinues were insupportable. And to these arguments that appealed to Porcari's mind Machiavelli adds another. Whether some of Machiavelli's statements are literally true is not even open to question, but they are invariably true in essence, and are always introduced either as a means whereby he may unburden his own opinion or illustrate some general characteristic of the times. He says that Porcari was possessed by Petrarch's canzone, Spirto gentil che quella membra reggi, and believed that the prophetic soul of the poet, looking forward to a new freedom for Rome, had also foreseen that Porcari was to be the object of the hopes and desires of the seven-hilled city, the man ever more mindful of others than himself (Mach., Ist L.vi., p. 246). Porcari resolved, then, to risk his own life for the liberty of Rome. He found an enthusiastic disciple in a nephew, and before long was able to count on nearly 400 people of like mind, 300 of whom were soldiers. A banquet was arranged for the eve of Epiphany, at which Porcari appeared. $\mathrm{Hc}$ had feigned illness in order to escape the vigilance of the cardinal-governor of Bologna, and had come with all haste to Rome. He made his appearance dressed in a garment of purple and gold, which he had donned less from ostentation than with the design of passing the doorkeepers at St. Peter's the next day ; for they were wont to judge of rank by appearance, and were not likely to refuse admission to one who wore gold lace. Some of the conspirators were to be clad in the uniform of the nightwatch, and to drag along others to the Capitol, under pretence of their being seditious persons ; and directly the doors were opened, all were to rush in and take that important place. Porcari and his men were mean- 
while to seize the Pope and cardinals in front of the door of St. Peter's. With such hostages in their hands they counted on being able to force the cession of S. Angelo and the Roman gates, and then the tocsin would be sounded, and the Republic reconstituted. This programme was set forth by Porcari with great eloquence, and hailed with enthusiasm. But the Senator got wind of the meeting, and while Porcari was still orating, he surrounded the house with his guard. The dependants of the conspirators were thus cut off from orders. Then the Senator gave the word of command, and the house was vigorously attacked. Porcari's nephew fought his way to a place of safety, but Porcari himself was dragged forth from a trunk, and all the principal plotters were secured. There was no public examination, and it is but fair to say that what we know of the aim of the conspiracy has a suspicion of taint in coming from prejudiced sources. Porcari was hanged straightway, and that unshriven, with nine of his associates-a most unjustifiable act, for if they were traitors to the Crown these men were loyal as Catholics, and had a right to be confessed and receive the Sacrament. Nicholas was very much alarmed, and his rule became very severe. He believed that his life had been conspired against, and he had fugitive plotters followed up in the various States to which they had escaped, extradited, and hanged (1453) (Leo Baptista Alberti, de Conj. Porcaria.-Diario Romano di Stefano Infessura.-Platina, Vita di Nicolo V.-Cronica di Bologna.-Annal. Bonincontrii Miniat.).

\section{THE PREDOMINANCE OF THE HOUSE OF MILAN}

\section{The VISCONTI}

THE supremacy of the Torriani in Milan had rendered possible the tighter grip of the Visconti, a House marked by consummate ability, and, in the earlier days of its rule, by personal prowess. The Archbishop Otto was followed at the close of the thirteenth century by his nephew Matteo. The misfortunes which befell this great Ghibelline leader and his son Galeazzo hardened the fibre of the race. Trained in the school of adversity, Azzo Visconti learned how to secure the love of the people, and greatly extended the rule of Milan by absorbing a number of small principalities. His uncles, Luchino and Giovanni, who succeeded him, were no less marked than he by personal courage and military talent.

The employment of mercenaries permitted of a new kind of man ruling with success. Dependent no longer on any sort of popular goodwill, there was little to check his greed and exactions, so long as he was possessed of intellectual energy and ability, of a sound knowledge of men and affairs, and of an unscrupulous and apt policy. When Matteo, Bernabo, and Galeazzo Visconti succeeded Giovanni the Archbishop, it was not long before expediency and calculation necessitated cold-blooded and remorseless crime. Matteo was murdered by his brothers, who continued to absorb the countless small lordships around them; defied the Pope, who was uaturally alarmed at the menace to his temporal power in Ilaly of so formidable a neighbour; and laid their snares for the Tuscan 
republics. Although in theory the Visconti held their authority direct from the Councils of Milan, and there was nothing like hereditary succession established, still, the ablest members of the family were always nominated. Theirs was the power of the purse, and they had all the advantage that accrues to de facto rulers. Their position was sufficiently secure and their rank established for Galeazzo to purchase Isabella of Valois, the daughter of the penurious King of France, as a bride for his son Gian Galeazzo, at a price of 600,000 florins, the bridegroom being eleven years of age ( 1360 ). Eight years later he sold his daughter to the dissolute Duke of Clarence, the son of the English King, under the cover of a dowry of 200,000 florins and five towns in Piedmont. ${ }^{1}$

When Galeazzo died he was succeeded by his son, Gian Galeazzo. Neither nephew nor uncle were men of war. Gian Galeazzo, indeed, was timid, even to pusillanimity ; but he had the great advantage of absolute self-command, while Bernabo was passionate. The uncle was quite ready to snatch power from his nephew to aggrandize his own numerous family. Duty and remorse, and even affection, had little weight with men who lived in daily danger of murder and treason, insurrection and conspiracy ; who had to guard against the secret dagger and the poisoned bowl. Bernabo tried several times to dispose of his nephew; but Gian Galeazzo, surrounded by spies at Pavia, was easily able to counteract his uncle's machinations without giving the least evidence that he was aware of them. Suddenly he affected piety. He was constantly at church, spending his time over his beads, and filling his Court with monks and priests. Bernabo thought his nephew had taken this pious turn because he was suffering from an accession of the cowardice that was native to him, and he was confirmed in this opinion by the increased precautions with which Gian surrounded himself, and by his reported extreme nervousness at every sound and movement. Gian now announced that he was going on a pilgrimage to a chapel not far from Milan, and he set out with a large escort (1385). Bernabo met him, and after an affectionate embrace, Gian suddenly gave an order in German to his guard to seize Bernabo and his two sons. Gian Galeazzo had evidently chosen his time well, for he was able to carry his prisoners to their city of Milan, where the populace received him gladly. Bernabo and other relatives ended their days in a dungeon.

Gian Galeazzo was a man who had the cold, calm intellect of Machiavelli's Prince: He possessed a consummate knowledge of all the springs of human action; he knew no scruple; he was restrained by no noble or unselfish instinct; he was misled by no passion or weakness; for him, as politician, nothing was wrong but a mistaken judgment, nothing right but expediency; he had the cold blood and the wisdom of the snake; he was the very type of Italian policy.

Gian set all the little States round about him by the ears, and then, when any two were engaged, he would join one to overcome another, and usually contrived to swallow both. He was aided by a consiglio, or sort of cabinet council, and conducted difficult and distant wars from the privacy

1 The wedding was celebrated with unprecedented magnificence. The guests were seated at many tables according to their rank; but it is characteristic of the times and the honours bestowed on learning that Petrarch was almitted to the table of ruling Princes (Bernard. Corio, stor. Milan.). 
and seclusion of a well-guarded fortress. His power depended on his wealth, and all his finance had increase of his privy purse for its object; but taxes, however heavy, were gathered in with economy. His rule was just and equitable, and the material prosperity of his State continued to increase. He utilized the existing councils of subject States as offices of administration and public order; they became civic councils, in fact, and the cities were governed by Podesti who owed their office to him, and were his obedient underlings. He knew the efficacy of the pen to control human destinies, and at his hands it became as powerful as the sword. He was surrounded by States that employed the same weapon with equal facility and effect, and it was necessary, in days when almost every Italian merchant was a diplomatist and dealt with Kings, to employ men whose wits were sharpened by scholarship to a keen edge of address. His penetrative insight into character enabled him to read ability and integrity wherever it was to be found. It was one of the paradoxes of his character that, when once he had selected his agent, he reposed full confidence in him; he always fulfilled his promises, and advanced him to station and wealth. He thus surrounded himself with the ablest diplomatists and Generals of his time. Since his wealth was enormous, he could reward his servants well; his personal magnetism kept them devoted to him ; and, since he depended on the services of many, he could always dispense with, and had the power to ruin, any unfaithful servant. Fear, the domination of his able, subtle mind, and the efficiency of his system of espionage, kept them faithful. The good faith that he observed with his Generals and Ministers not merely kept him better served than any other ruler, but gave him a useful reputation with those whom he intended to deceive. He cared nothing for the claims of descent ; the most capable man was preferred to the highest office, and he nominated in his last testament Francesco Barbavara, his chief confidant, who had been head servant in his establishment, to be President of the Council of Regency.

Gian Galeazzo, like all the despots of his time, took a real pleasure in intellectual recreation. He sought the society of all men of letters, patronized the fine arts, and subsidized the University of Milan. We owe to him the foundations of the Certosa di Pavia, and that strange structure that is so suggestive of a gigantic wedding-cake-that mixture of debased Gothic and misplaced statuary-the Cathedral of Milan. Intellectual recreation was not merely a source of glory and pillar of strength to Gian Galeazzo, but had, at this period and later, as genuine an attraction for the average Italian despot as pigeon-shooting and horse-racing have assumed for the modern man of rank and leisure. In vain did Wenceslaus, the Emperor-elect, seek to destroy Gian Galeazzo's power. Failing to effect a strong combination against him, he made the best of a situation which he was powerless to alter. Gian Galeazzo had the whip-hand; the Emperor was open to a money offer ; and, in I395, he gave sanction for the union of those States into a duchy, which two centuries before had fought their gallant war of freedom against Barbarossa. Henceforward the Visconti had a regular title, and the principle of primogeniture obtained in the House. But the establishment of the dukedom gave rise later, on the extinction of the main line, to the pretensions of the Emperor as overlord, and of the Kings of France as inheritors through a daughter of Gịan Galeazzo. 
The way now seemed clear to become King of Italy. The Papacy was weak, Naples in a state of anarchy, the remaining republics throttled, Venice enfeebled, Florence exhausted. Free Italy despaired, but the best-laid plans are subject to the interruption of unexpected, irrelevant, and illogical interference. In spite of every safeguard and precaution, and just as he thought " his greatness was a-ripening," plague seized the Duke and carried him off in the autumn of 1402 .

The will of the late Duke directed the division of his territory among his sons, of whom Gian Maria, the eldest, was only thirteen years of age. Gian Maria was to have the duchy from the Ticino to the Mincio ; Filippo Maria was to be Count of Pavia, with the surrounding country; and a bastard, Gabriello Maria, was to have the lordships of Crema and Pisa. But during the minority of his sons the Duchess and a council of seventeen, including his ablest Generals, were to govern. The man whom nobody could trust was thus obliged to confide in the honour and good faith of others. But now that the control of the master-mind was removed, mutual antagonisms began to manifest themselves in the Council of State. Francesco Barbavara, whom Gian Galeazzo had appointed its president, had been a domestic in the late Duke's service. The Duchess relied on him for advice, and this gave displeasure to councillors, certain Visconti, and others of noble birth. Scandal had it that Barbavara was the lover of the Duchess; there was a rising in Milan; and, while the Duchess remained in the fortress-palace with Barbavara, the insurgents took it on themselves to appoint a new council. The Duchess feigned submission. She summoned the new council to deliberate with her in the castle, and, once in her trap, she cut off a head or two, and clapped the rest of the captives into dungeons. There had already been revolts which were cruelly suppressed. Everywhere there were families to be found that once had ruled, but had been dispossessed by the late Duke ; these aspired to rule again; and in each little town there was a party that resented the reduction of what had once been a small State to provincial rank. Cremona revolted; Bologna threw herself on the protection of the Church ; the mercenary captains tried to save what they could from the fire. Anarchy spread throughout the duchy. The Duchess miscalculated her power; she hanged malcontents to strike terror into the heart of the Milanese; she only succeeded in exciting wrath and indignation. There was a second rising; the person of the young Duke, Gian Maria, was secured; and in his name a new Ghibelline Council made war on the Duchess. There was anarchy throughout Lombardy. The two parties waged savage war until, in I404, the Duchess was captured, and, it was currently reported, poisoned (Piero Minerbetti, I 404, c. I 3, p. 509.-Poggio Bracciolini Hist. Flor., L. iv., p. 294.-Sozomeni Pistoriensis, p. I 83 ). The great State, put together piece by piece by the crafty statesmanship of the late Duke, was thus rent asunder, almost into the ultimate elements that constituted it. Filippo Maria was supposed to rule at Pavia, but the Beccaria had resumed their old authority in that city. Facino Cane was master of Alessandria; Georgio Benzoni of Crema ; the Coleoni of Trezzo ; Cavalcabo of Cremona ; Rusca of Como ; and the son of a butcher-so now could ability mount from the gutter almost to the "golden round "-ruled at Lodi.

History has no more dismal page than that which records the events 
that followed the death of Gian Galeazzo. There was a universal struggle among the Generals for what prizes they could secure, and the capture of a city was invariably followed by its sack. Dominated by pure greed, the soldiery scemed incapable of human pity. The looting of a town was their pay. The honest citizen was put to merciless torture to reveal his hidden store; wife and maiden were the victims of blackguards, brutalized by the life of the camp, whose trade of warfare was unredeemed by any generous object or ennobling aspiration. People of wealth and culture were reduced to beggary, when they were not torn from the villa to perish on the scaffold. Lombardy was crushed and ruined, and its condition helps to explain the ease with which Filippo Visconti was able to reimpose the old yoke on a suffering and exhausted population. The populace were unable to deal with trained soldiery, their spirit was broken, and the peace and greater equity of absolutism was a refuge and hope to them. (For an account of these sad days see Andree Billii, Hist. Med., L. ii.-Leonardi Aretini, Commentor, T. xix.-Platina, Hist. Mant., T. $v$. -Joseph Ripamont, Hist. Med., L. iv., apud Grevium, L. ii.)

Gian Maria, the elder son of Visconti, was entrusted with the congenial occupation of punishing State criminals: it was all the part he took in the government. Accustomed to scenes of violence and punishment from his tenderest years, he developed into a bloodthirsty young ruffian. His favourite amusement was to set a pack of hounds on the condemned, whether they were gentle or simple, old people or mere children. These dogs were fed on human flesh, and specially trained to the chase (Josephi Ripamontii, Hist. urbis Med., L. iv., p. 591.-Pauli Jovii, Vicecomitum Hist., P. xi., p. 327.-Andr. Billii, Hist. Med., L. ir., p. 32.-Lud. Cavitellius Crem. Annal., p. 1402). The sway of this young blackguard was restricted by the armed usurpation of Facino Cane, despot of Alessandria, who also ruled at Pavia on bchalf of Filippo Maria, the second son of Gian Galeazzo. Facino became regent of Milan. Undoubtedly both boys would have disappeared had Facino had any children of his own. In I4I 2 Facino was stricken by a mortal malady, and Gian Maria could give himself up to unrestricted hilarious holiday, like a youth released from tutelage; only his special form of amusement lay in the suffering of others. He was put an end to, happily, by a band of Milanese nobles while on his way to church, and Facino died a few hours afterwards.

It was generally believed that the conspirators meant to do away with Filippo Maria, and to hand over the heritage of the Visconti to a bastard scion of the House. But, if the plot was in being, Filippo Maria soon checkmated the plotters : for he exhibited the rapid energy and genius of his father: he had the same power both of controlling and masking his passions; he was no less crafty, dissembling, and traitorous; he had, in large measure, the same gift of penetrating character and divining who would be useful and trustworthy; he soon showed that he knew how to instil mutual suspicion into the minds of his Generals, and keep them dependent on him; how to protect himself by means of spies; how to recover his lost estates; but, though closely cast in his father's mould, though he resembled him in pusillanimity, and, like him, lived in the seclusion of a strong place, whence he devised and issued his commands, he had a rashness of decision, a want of persistence, and an instability which marked him as a smaller man. 
On learning of the death of Facino and his brother, he at once assured himself of the fidelity of those who guarded him at the castle of Pavia, where he was a sort of honourable captive. He scared the Beccaria, who had hitherto been wont to give him the law, into tame submission; he won over the partisans and soldiers of Facino; and, most wonderful stroke of policy of all, he persuaded the lady so recently widowed, Beatrice Tenda, into inmediate marriage with himself. The bridegroom was scarcely twenty; the lady was quite double his age (Andr. Billii, Hist. Med., L. iii., p. 37). The garrison of Milan held firm for the legitimate successor of the late Duke against the bastard pretender, who was obliged to flee; and the marriage so established Filippo Maria that he was soon able to secure himself at Milan and execute the assassins of his brother (1412). Four years later we find him so firmly seated in his dukedom as to conceive himself strong enough to get quit of his elderly bride. $\mathrm{He}$ trumped up a charge of infidelity, and the accusation was supported by the public avowal of the reputed lover, who perhaps hoped to escape torture or even to save his life by false confession. Both of the accused lost their heads on the scaffold (Andr. Billii, L. iii., p. $5 \mathrm{I}$ ).

$\mathrm{He}$ detected the genius of a simple soldier of fortune and put him in chief command. No choice could have been more fortunate. Carmagnola soon subdued Lombardy as far as the Adda. Unable to defend Piacenza against Malatesta, he sent all its inhabitants out of that city, together with their belongings, and so thoroughly and conscientiously was this done, that, when the hostile troops entered the deserted streets, they found nothing to loot except old iron, and the ghastly appearance of the dead city drove them from it in a sort of panic. This great town remained uninhabited for a whole year, except by three poor wretches, who squatted in as many remote quarters. When the citizens began to return, they waded along the streets through grass knee-deep, and their doors were almost impenetrable from a thick growth of hemlock (Annal. Placent., R.S.I., L. Xx., p. 874). The persistence, strategy, valour, and duplicity of Carmagnola were successful. Bit by bit Northern Italy was falling under the sway of the Duke; in I42I Genoa submitted; next year San Donnino, Parma, Bergamo, Cremona, Crema, and Brescia, were acquired. But while in Lombardy the spirit of resistance was almost dead, and North Italy was an easy prey, the spirit of freedom which abode with the Swiss, the Venetian, and the Florentine peoples offered fierce resistance to the projects of the Duke. When he attacked the Levantino valley, which leads up to the pass of the St. Gothard, 3,00o Swiss peasants held the ground against 80,000 trained Italian troops led by the greatest General of the age, and compelled them to retreat after a fierce conflict wherein every Swiss slew at least three of his foes. Bellinzona was already in the hands of Carmagnola when the battle was fought, and he ultimately occupied the valley, for he had purposely given the Swiss an opportunity of returning across the St. Gothard to their herds; but, in spite of want of cohesion, the Swiss taught the despots of the South what it was to deal with a free people sworn never to give way on the field of battle, never to yield themselves prisoners, and to respect the women of their foes. Master of Northern Italy from the summit of St. Gothard to the Ligurian Sea, and from Picdmont to the States of the Church, Filippo Maria was now more powerful than any Prince that had reigned since the days of 
the Lombards, and only Venice and Florence remained to dispute his conquering progress. Venice defeated him over and over again, but he was always ready to make peace in order to refill his treasury and return to the attack. Florence fought him for the rest of his life. She was defeated again and again, but she never gave in. He even interfered with the struggle of French and Spaniard for the throne of Naples. He captured Alfonzo of Aragon, only to release him when he found that the Angevins were getting too strong, and that he might have the French to deal with both southwards and westwards. For forty years the devilish machinations of Visconti kept Italy in a perpetual broil. As he had no legitimate children, everyone who thought he had the least chance of the succession met him with his own arts, and increased the peril of his position and the general sense of insecurity. Yet, through all, he managed to extricate himself from the results of many rash acts with remarkable dexterity, and to consolidate and organize his duchy. His ablest General was Francesca Sforza, the bastard son of Muzio Attendolo Sforza, who had been a peasant of Romagna. This man belonged to a family of fierce warrior-souls, men and women alike. He was a ruffian by nature ; but, by his enormous energy, indomitable valour, and keen eye for unscrupulous self-advancement, he became a great captain, High Constable of Naples, and despot of many cities. Attendolo had lost Court favour, and was about to suffer death, when his sister, armed cap-ì-pie, forced his guards to release him, and so great was the force of his personality and his renown that he was once again given a royal command. To the son, Francesco, Filippo Maria held out the bait of the hand of his one child, a bastard, named Bianca. There was a pretty play at circumvention between these two types of their time, each ready to destroy the other, and each pretending devotion: it was a case of diamond cut diamond. But Visconti was over-subtle ; throughout his diplomacy issued in crisscross results. In his wars with Venice, Florence, and the Pope, his moves were so complicated that he was for ever giving himself check. At last he was obliged to give Bianca to Sforza (I44I), in order to balk the demands of his Generals, each of whom aspired to the succession. He hoped now to bind Sforza more closely to his service. But Sforza was so able a commander that he was always in request. He had fought for and against almost every Power in Italy ; and, like his father, he had acquired territory for himself, and was a ruling power as well as a condottiere. Plot and counterplot still went merrily on. Visconti wanted to keep Sforza to heel ; he had no intention of getting rid of him-he was too valuable to be disposed of, too helpful in times of peril. On the other hand, Sforza was not the man to become the creature of the Duke. He had quite as excellent a control of his passions; he never gave way to temptations of anger or revenge; he kept his eye steadily fixed on the succession; he was as often to be found opposing the Duke as leading his armies ; he knew his man, and that he had more to gain by exciting fear than by currying favour. In I 447 Filippo Maria died, somewhat unexpectedly, of dysentery, to the great relief of the States that his diabolical cunning had kept in a chronic condition of trepidation and a perpetual warfare as of Valhalla - peace concluded to-night to be broken to-morrow. But, singular to relate, the Duke had had intimate friends, and they mourned him. For this strange, dingy creature with the protruding eyeballs and 
furtive glance; this ugly shifty being that men had known as a skeleton in his youth, and that now presented the unctuous obesity of a priest; this anomalous prodigy, fearful of the mention of death while he sent men to their doom without a moment's misgiving or remorse, frightened half out of his wits at a thunder-clap while he issued orders that threw all Italy into convulsions; this master of dissimulation, perfidy, and intrigue; this portentous Prince, ever mistrustful of himself, ever suspecting the designs of others, so mean in his manners, so dismal in his life, who lived almost hermetically sealed up in a strong fortress, surrounded by a dull Court; whose only recreation was now and again to look after his horses or follow the chase ; this last morbid product of the courageous and vigorous stock of the Visconti, was human after all. He had been a constant and generous friend to a few well-selected intimates; he had known whom he might trust, and these he trusted implicitly. Though in matters of policy he was the quintessence of treachery, neither commander in the field nor Minister of State had once betrayed him. (EEneas Sylvius. Benvenuto da San Giorgio, R.I.S., L. xxiii., p. 7I I.-Sismondi, c. lxxi.Villari, Macchiavelli, Lond., I 898, p. 23).

The throne was now vacant, and there was no legitimate heir to it. Each successive Visconti had always reigned in Milan under the formal pretence of popular acclamation. The thousand and one little States of Italy were now for the most part absorbed into five great Powers-Milan, Venice, Florence, Naples, and the Papacy. The last-named Power claimed much, and was once again beginning to rear its head as a great territorial force. The question was whether the lingering tradition of freedom in Milan would reassert itself, whether the duchy would once again break up into its component parts, perhaps to fall piecemeal into the voracious maw of Venice, and so disturb the balance of power.

The Re-establishment of the Milanese Republic, its Overthrow by Francesco Sforza, and the War with Venice, to the Peace OF Lodi (I447-I454)

The Duke had lived in retirement; his people never saw him ; Ambassadors were accorded audiences but rarely; so it was easy for his Ministers to keep his death a secret until they should determine what course to adopt. But most of his councillors had served in the wars in one of the two great rival schools of condottieri, and the rivalries of the field seem to have been carried into the council-chamber. The pupils of the military school of Braccio were all for offering the sovereignty to the King of Naples, as an old ally of the late Duke, as being the richest and most powerful of Italian rulers, and as the most likely to bestow personal reward. The old companions in arms of Sforza, on the other hand, urged his claim through his wife and the engagement made by the deceased ruler. This division in the Cabinet led to the disclosure of their practices ; for the partisans of Alfonzo, under pretence that they were executing the last injunctions of Filippo Maria, quietly introduced the lieutenant of the King into the castle, with a small following of his men, and the fluttering of the Aragonese flag above its battlements let the cat out of the bag a little too soon. The title and rights of lord of Milan had always been awarded to each successive Visconti by the acclamation of the city councils, 
and some had not ceased to deplore the unhappy day when a foolish vote and the intrigues of Archbishop Otto brought about the loss of liberty.

In a trice the shops were shut, the passage of the streets barred by chains, and every way up to the castle stopped by the excavation of deep trenches. Patriots roused the quarters, the citizens assembled at the six gateways of the city, and each of the six wards nominated four delegates. They thus constituted a supreme council, which, after the manner of the Florentine signoria, was to be renewed every two months. And when the condottieri in the town, who had been summoned to the castle, and who had just sworn fealty to Alfonzo, were dismissed, they, too, were carried away by the popular enthusiasm, joined the people, and took service under the new Republic (Joann. Simonete, L. ix.). No objection was made to the burial of the Duke with the pomp due to his rank, but everybody was in a state of anxiety, what with the Spanish troops in the city, the army of Sforza outside, and the trepidations and hopes centring round the new Government. One by one, the citizens who followed the bier slipped quietly away, even the priests disappeared, and hardly anyone was to be found to deposit the body of the Duke in its last resting-place behind the high altar of his new cathedral (Jos. Ripamontii, L. v., p. 610).

The first anxiety that beset the new Government was the recovery of the castle, for there was reason to fear that its garrison might hand it over to Venice. But the temper of the town was so menacing that the small garrisons occupying the two great fortresses of the city reflected on how many weary leagues separated them from the armies of Naples or Venice, even, accepted terms and marched out. Then the whole population set to work to demolish those strongholds of despotism, and worked might and main until they were level with the ground.

The next step taken by the council was to express their desire to live in peace with everybody, and to follow up the arrangement for a treaty which, at the instigation of the Pope, the late Duke had been on the point of settling. But this proposal did not suit the book of the Venetians, who retired from congress, and set themselves ready to get what they could out of that disintegration of the State which they foresaw must come. The yoke of the Republic was likely to be even less liked by the provinces than that of Visconti, and they were bound to make a bid for the recovery of their ancient freedom. Florence, moreover, was not wholly well disposed to the new Republic. The Venetian forecast was correct. Pavia, the ancient rival of Milan, declared itself free ; Lodi, where the Guelph faction predominated, and that had considerable commercial relations with Venice, asked for a Venetian garrison. Piacenza followed the example of Lodi ; Parma and Tortona split off into separate republics; Asti gave itself up to a French General, who claimed it on behalf of the Duke of Orleans, both in virtue of a promise made by Filippo Maria and as a dowry of one of the daughters of the House. Back came all the exiles to these cities, driving the Milanese before them. Como, Novara, and Alessandria alone remained loyal to the metropolis. That evil, but perhaps inevitable, constitution of the mediæval republics that gave subject-communes no State rights, and that fierce passion of party that knew no compromise, nor aught but exile, short of death, for a political opponent, now, as ever, was bearing bitter fruit.

The commune was in no small perplexity. The time had passed for 
republics on mediæval lines to flourish: the day of larger States under centralized command was dawning, though men did not know it. Here were they, abandoned by half the duchy, badly obeyed by the other part, especially when it came to matters of taxation, with demands coming in on every side for the restoration of public order, and there was no money or supply of men at their command to enforce it. The Milanese found themselves menaced on every side by the Savoyards, by Alfonzo, by the Frenchman (who laid claim to the heritage of the Visconti as issue of an intermarriage), by the Venetians. Florence was at the very best lukewarm. What was to be done ? The great captain lay at their doors with his forces. Would he help ? They sent to bribe him; they offered him the old conditions and the old pay if he would only fight the same enemies of the country whom he had fought of yore; he should have Brescia or Verona to boot. Sforza accepted; the commune played straight into his hands.

Sforza was a man of resolution and resource. He wasted no time; he intimidated Pavia into resistance ; he gathered up the scattered condottieri of the State; he knew men and how to secure them; he gained over the Piccinini at a critical moment, when the anarchy around was driving them fast into the arms of Venice, by going right into their camp with but a small escort and showing them his confidence in their honour as soldiers ; he offered Cremona to the one and Crema to the other Piccinino to clench the bargain, and so paid off old scores. And now that he and these followers of Braccio had buried the hatchet, he secured the services of Bartolommeo Coleoni of Bergamo, and forced the Venetians to retreat.

Pavia was torn by faction; unable to stand alone, some were for seeking the protection of Charles VII., King of France; others were for the Dauphin, who, according to the traditional habit of Courts, was at variance with his father; others declared for the Duke of Savoy, the Marquis of Montferrat, the Marquis of Este. Sforza sent his agents into the city, and soon a deputation arrived from the Senate of the commune offering him its lordship. The citadel was given up to him, and he was conducted with all due pomp and circumstance to the cathedral, where he rendered public thanks to God for so great a grace (Joann. Simonetce, L. $i x$.) (1447).

Naturally, the news from Pavia did not best please the Milanese Government; they had, indeed, tried to put a stop to what had nevertheless happened. Sforza exhibited complete diplomatic skill : he pointed out that he could not reduce the town, and that if he did not accept, it would imply the introduction of some powerful and by no means friendly Sovereign; surely it was better for Milan to have so great a friend as himself for a neighbour rather than an enemy; he made a present of a small stronghold he had just taken as a sop; it witnessed to the purity of his.intentions. Milan could not do without him; she growled, but she had to submit. Sforza ordered the soldiers that guarded the Pavian frontier to give the Milanese no cause of offence, and above all to behave well to the Savoyards, who were getting what they could of the possessions of the late Duke. Then he despatched a small fleet at his own expense to attack Piacenza, and thus demonstrated his entire devotion to the State that employed him.

The Government was at its wit's end to know what to do. The Marquis 
of Este, the Corregio, the Genoese had seized neighbouring places; the Duke of Savoy, the Marquis of Montferrat, were trying by soft enticements and large promises to seduce the towns into opening their gates to them ; and, worst of all, the French governor of Asti was advancing at the head of a French army to conquer the duchy for his master, the Duke of Orleans, the nephew of the late Duke. They sent, in their straits, to sue peace of Venice : Venice stood firm and refused.

Sforza was clever in preventing the French General from attacking him. He showed himself prepared for war if he invaded Pavian territory, but he reminded him that for thirty years he had defended the claim of Anjou to the Neapolitan State, and had lost his own country thereby. So the French passed him by and wasted their strength, as he knew they would, in the first of the many sieges that lay before them, after which Bartolommeo Coleoni gave them a crushing defeat and took most of them, including their General, prisoners.

In those days, the taking of a great fortified city by assault was an event almost unheard of. The means of defence had outstripped the means of attack. But the development of artillery began to renew the fiercer horrors of war. The wall of Piacenza was breached, and the troops rushed in. Nothing could exceed the horrors that followed. Citizens were tortured to make them disclose the wealth they were supposed to have hidden; their wives and daughters were violated, and Io,ooo of the inhabitants were floated down the Po and sold as slaves to the highest bidders of neighbouring cities. Of course, a stern example was necessary; rebellion must be put down with the strong hand : that has always been the view of most statesmen and all soldiers, and in the fifteenth century there was, as always, more lip service rendered to God than regard for His image. Antonio da Ripalta, the author of the Annals of Piacenza, tells us that he lost everything, but was released on account of his reputation for learning, and his son.was fortunate enough to effect an escape.

Contrary to his understanding with Milan, Sforza accepted the lordship of Tortona, and the Milanese sent Coleoni to eject his lieutenant from that city. It was evident that the Republic and the General would not long row in the same boat; but Sforza was above all things anxious to use Milanese money to keep Venice out of the territory he meant to have for himself, so he pocketed the affront and bided his time. The Milanese Senate, moreover, was indisposed to open rupture; the services of Sforza were too valuable to be lightly dispensed with; if peace could be established, the difficulty would be shelved. Two Generals, the Piccinini, were jealous of Sforza, and they were employed as go-betweens. A treaty was drawn up, but it had to be approved by the council of 800 at Milan. There is no field so favourable to the artful adventurer as the "collective wisdom" of a council, and no one knew better than Sforza how to sow dissensions among these trustees of the nation, so as to protract the war and profit by the distraction that must inevitabiy arise. Of course, the courcil had divided into parties of which one derived its views from the ancient Guelph, the other from the Ghibelline tradition. The Guelphs were all for peace, a compact Republic, and no Sforza in command; the Ghibellines mistrusted an alliance with Venice, deplored the loss of territory that was demanded, believed that its cession would open 
up roads to Milan, and were by no means pleased that the Guelphs were likely to get the prestige of extricating the Republic from its troubles. The agents of Sforza were active everywhere with whispering, warning voice ; they missed no opportunity of fomenting jealousy, irritation, and party spite. When the council met, a ward broke into open rebellion, and the timorous council, in order to restore order by diverting attention, gave the fatal pronouncement for war (1448) (Joann. Simonete, L. $x i$.-Jos. Ripamontii, L. v.).

The treasury was almost empty, and several military leaders withdrew from the service of the Republic. Sforza did not ask for money; he did not wish to give a handle to those who were still working for peace. His soldiers were flush of money from the sack of Piacenza, and he desired to be the "only General " of the State. He exerted himself to get the complete confidence of the Government. Before long he had recovered possession of nearly all the strong places on the right bank of the Adda. He was now ordered to besiege Lodi, and he made various excuses, for Lodi in the hands of foes would keep the Milanese uneasy, and prevent the Government from consolidating its power. But the brothers Piccinini were alive to the military importance of the place, and Sforza was obliged to give way; in fact, he perceived that the Government had become exceedingly suspicious of him, and it was necessary for him to cloak his designs by promising to await and implicitly obey all their instructions. He could safely do so, for he knew what invariably ensues when the operations of war are conducted or controlled by a set of civil dunderheads, who are always quite ready to assume the direction of affairs of which they are entirely ignorant. Soon the very safety of the army was imperilled, and Sforza demanded and obtained unlimited powers from the discredited Senate. Immediately he began a brilliant campaign against the Venetians. He burned their fleet on the Po before Attendolo, their General, could come up to save it, and employed his genius for tactics with such skill on the field of Caravaggio that he captured the entire Venetian army almost to a man; but, of course, scarcely anybody was killed; condottieri respected one another; it was only when a town was captured that there was any slaughter to speak of, and then, as at Piacenza, the mercenaries made up for lost time.

Both republics were now anxious only for peace, but Sforza had resolved otherwise. His term of service was nearly up; the Piccinini were jealous of his success; he had beaten the Venetians too thoroughly for peace, for peace would mean the triumph of the Republic and the extinction of his hopes. He therefore despatched the Piccinini to besiege Lodi, while he advanced on Brescia, and so hampered negotiations by the active prosecution of war. Venice had dismissed the unfortunate Attendolo, and was casting about for a General; its Senate made secret overtures to Sforza; they promised to help him to get possession of Milan for himself if he would only change sides.

It was an age when the power of intellect had replaced the chaotic circumgyrations of mere force ; say, rather, world-policy was directed by that astute cunning which takes the place of intellect, when the energies that excite to action "are those that cluster round the selfishness of the individual, and the imperious fiat of duty has ceased to be obeyed. The Visconti, the smaller lords of Italy, and the acknowledged heads of the 
Christian faith, the very Popes themselves, had given the example of perfidy, not once or twice, but innumerable times, and for more than a generation. That men can abandon principles and calculate consequences, was the doctrine of the times, and the doctrine was not without its benefits. It was a relief to the masses to submit to the equal rule of Princes. Often the sway of the Prince, secured by subtlety, meant peace to the State. At all events, Princes were in power, and there were so many of them, with such conflicting interests, that security even could not be obtained without subtlety, and control implied crookedness and craft. Successful duplicity had become a virtue, and Machiavelli expressed the opinion of the later Middle Ages when he said that shame lay with the man who failed; it did not attach to the successful trickster (Nicolo Mach., delle Istor, L. vi., p. 212). Sforza was esteemed a faithful friend, and he was not only the confidant of Cosimo dei Medici, but his companionship was sought by the most illustrious and educated Princes and scholars of his time. Career was open to talent, but the times were such that one must either sink or swim, and statecraft was no academic arena for fastidious moralizations. When one is surrounded by sharp knaves, bent on spoliation, the principles of the Sermon on the Mount are hardly of immediate application. Sforza had been brought up among condottieri, and a band of condottieri in those days was a moving State. He had commanded such a band from his youth up, and he had had to hold his own in the marches of Ancona. He had devoted his life to the acquisition of Milan, and he regarded himself, by virtue of his marriage with the late Duke's only child, as its legitimate Sovereign. He had the training and the power that make a statesman, and, when the offer of Venice came, it chanced to come at the right time, so he accepted it. But, degenerate and lax as the tone of public morals had become in Italy, Sforza's friend and secretary, Simoneta, who was one of Italy's ablest historians, is at pains to attempt to justify his master's conduct as provoked by the conduct of Milan; and Sforza himself, addressing his soldiery, alleged that the Milanese were not merely treating the army unjustly by negotiating a premature peace, but that they were bent on snatching Pavia and Cremona from him and effecting his ruin, and that he was changing sides merely in self-defence and out of regard to the interests of his army, his wife, and his children (Joann. Simonete, L. xiv., p. 486). Sforza's compact with Venice was that he should evacuate all his conquests in Brescia and Bergamo, and renounce all claim on the Ghiara d'Adda. In return, the Venetians would help him to conquer the other possessions of Visconti for himself. But he knew full well that he could no more rely on Venice than on Milan. He must depend on his own cunning and his own right hand ; he must enfeeble both by playing off one against the other, enrich himself as condottiere to the best of his ability, and then, backed by a faithful soldiery, throw off the mask at the right moment and enter into his heritage.

Piacenza, broken by suffering, opened her gates. The Generals of Milan began to desert their colours and join Sforza. Montferrat made terms with him in order to get possession of Alessandria. In vain did the Milanese Senate send two Embassies of entreaty. Sforza was no longer the obedient subject. He assumed the mien of an outraged Prince; he demanded the sovereignty of Milan as of right, and offered pardon to 
those who immediately returned to their obedience; he even sent an Ambassador to exhort the Milanese people in Parliament assembled. But no sooner had his emissary spoken, than a Milanese citizen, Giorgio Lampugnani, leaped up on the rostrum. He exhorted the Milanese to dare all, to suffer all, rather than surrender precious liberty, rather than submit to the yoke of a traitor and the caprices of his wife, the bastard issue of a tyrannical House. Not merely would they admit Francesco, but the entire House of Sforza, a race of bastards and the issue of adultery, who would all be masters in Milan and exploit it for the gratification of their lusts and greed. If the Milanese desired to preserve their women from dishonour, their goods from confiscation, and their purses from the inroads of the extortionate tax-gatherer ; if they did not wish to see the strong castle that once dominated and cowed the city rebuilt; if they did not wish to sweat in enforced labour to rear that stronghold, at once badge and instrument of servitude, again ; if they desired to retain the freedom they had won back, they must resist Sforza to the last man. Surely they were men to live in freedom or to die for it (Joann. Simoneta, L. $x v$.).

This harangue excited the already inflamed auditory to the utmost enthusiasm. Traitor and turncoat were the mildest terms applied to Sforza. Nor did the anger of the Milanese confine itself to mere invective. Piccinino was appointed Commander-in-Chief, neighbouring fortresses were garrisoned, the town-militia were provided with muskets, then quite a novel weapon, and private citizens poured forth their wealth to secure the threatened liberties of their town.

But artillery had changed the conditions of warfare, and the means of deience were no longer equal to those of attack. In three days the cannon of Sforza effected a practicable breach, but Sforza was unwilling to put the city wherein he intended to rule to the last horrors of capture by assault; he turned the waters which bore provisions to the city. Nevertheless, the Milanese continued to hold out against hope. They were well provisioned, and now that their water-mills no longer worked, they erected windmills to grind their corn. Presently, Sforza was reinforced from Venice, and he led an army northwards and received the submission of the lake district. Thence he passed to the plain, and Romagnano, Tortona, and Alessandria threw open their gates (1449).

Milan held within her walls knaves to the full as dangerous as the betrayer who hovered without them. Gonzaga, brother of the Marquis of Mantua, and one of the accomplished pupils of that generous and noble schoolmaster, Vittorino da Feltro, was in command of the city troops. He aspired to the tyranny of the city, not with the hope of holding it, but of disposing of it for a round sum either to Sforza or Venice. The opposition of impracticable parties was, indeed, in some sort an excuse for his conduct. He affected the protection of the weaker Guelph faction, and excrted himself to introduce Milanese Guelphs into the Government. The immediate effect was that the Ghibelline aristocracy began to negotiate with Sforza, but always with some regard to the conservation of such shreds of Milanese, or rather of Ghibelline, liberty as they might contrive to preserve, and a document in cipher fell into the hands of Gonzaga, who, too shrewd to denounce them, pretended to do them honour by sending them on an Embassy to Frederick III. An escort accompanied them, 
and, directly they were well away from the city, hurried them off to Monza, where they were executed, tortured, or thrown into dungeons. The remnant of the aristocratic party in the city took to their heels when they heard of this, and Gonzaga had a free field. He favoured the lower classes ; humble citizens were elevated to the magistracy, and the confiscation of the property of aristocrats refilled the public purse. Gonzaga affected all the hatred that his party felt for the great commander ; his proclamations announced that he would yield the city to the great Turk or to the great devil in hell rather than to Sforza.

Parma surrendered to Sforza. He invested Milan more closely than before, and then his luck seemed to desert him. His troops in the North were defeated; the widowed Duchess, who still resided in Milan, and who was very popular, got her brother, the Duke of Savoy, to take up the Milanese cause ; and the two Piccinini, who had got comfortable winter quarters free of expense by turning over to Sforza, deserted him when spring came (1449). The younger of the brothers proposed to Francesco Piccinino that they should not merely desert, but surprise and attack, their allies. He argued that everybody got on by perfidy; that Sforza had employed it, and a man was a fool for his pains if he did not apply the instrument which was in the use of everybody. But Francesco refused to listen. "The honour of a soldier is above the subtleties of dialectic," he told his brother. "Rulers employ perfidy against one another universally, and one has to do as others. But perfidy on the battlefield would destroy all military comradeship and confidence, and the name of Piccinino would descend to posterity with an indelible stain " (Joann. Simoneta, L. xviii., p. 552.-Jos. Ripamontii, L. v., p. 625). It is evident that Francesco Piccinino was not so entirely superior to dialectic subtlety is he conceived himself to be.

Encouraged by an apparent turn in the tide, Milan enrolled her militia to an extent not known for several generations. She put 20,000 citizens, armed with muskets, on the field. The troops of Sforza, unaccustomed to sanguinary conflict, were panic-stricken at the prospect of a real battle, and the General tried in vain to show them that a single cavalry charge would disperse these undisciplined levies. All that he could effect was to keep them sitting still on their horses, and this was enough. The Milanese were on the way to raise the siege of a town, but a body of heavy cavalry sufficed to alarm them and block their way. The half-savage Savoyards were defeated by Bartolommeo Coleoni, the Venetian General, after a fierce and bloody battle. Accustomed to combat the French, they fought with the ferocity of wild cats. The field was covered with the slain, and when they drew off, the Italian condottieri, accustomed to quite another style of warfare, sat on their horses, trembling at the unwonted spectacle, and what they had gone through. This battle made a profound impression on the Italian mind, and the ferocity of the French became a tradition which prepared the way for the future victories of the dwellers beyond the Alps and the conquests of Charles VIII. (Joann. Simonete, L. xviii.-Ann. Placententini Antonii di Ripelta.-M. Ant. Sabellico.

The little town of Vivegano defended itself with marked resolution and valour against the attacks of Sforza. Ammunition soon ran short, but the defenders, nothing daunted, took up their ancient weapons. A 
breach was made in their walls, only to unmask a new rampart of eartl behind it. An assault was attempted at break of day; the priests and young girls rang the church bells and went about the streets in religious procession, while the women stood behind the men, donned each man's armour as he fell, and continued the defence of hearth and home. The besiegers, beholding dead men rise to life, as it were, and processions of sacred images flitting about amid the confusion of battle, while the clangour of conflict mingled with the tolling of bells, deemed that Vivegano was helped by Heaven, and were half paralyzed by superstitious terror. The battle lasted all day, and at night the wall was so far cleared of its defenders that some soldiers attempted to scale it. But they slipped, and rolled bruised and bleeding among the troops who followed. Panic spread; the invaders fled and leaped pell-mell into the moat, doing themselves and each other no small damage. The whole army believed it had to deal with enchantment, and Sforza, for the honour of his troops, was obliged to order a retreat. But Vivegano was no longer able to defend itself, and during the night a deputation succeeded in obtaining favourable terms of capitulation. The gallant defence, by drawing off Sforza's troops, had been of considerable service to the Milanese ; it allowed them to reap their corn (1449).

Meanwhile, dissensions at Milan between the small traders in power and the aristocracy. were exhausting the energies and sapping the patriotism of the Republic. In July, the heads of the Government, which was renewed every two months, and therefore possessed neither strength nor continuity of purpose, were thrown into gaol directly they gave up their office, and men of superior rank and education were chosen to replace them. The new Ministry tried the last resource that remained to the Republic ; they sent to negotiate with Venice. The strictest secrecy was preserved, but Venice procrastinated because she had another secret intrigue on hand, of which Sforza held the threads. It was concerning the cities of Crema and Lodi. Both cities were obtained by treachery. When the standard of St. Mark floated over the turrets of the former city and that of Sforza over those of Lodi, Venice was ready to accept peace. The Ten sent to Sforza at the very moment that he had again sat down before the walls of Milan to inform him that the issue of the war hung in the balance, and that he would undoubtedly be delighted to hear that peace was arranged, especially as he had already secured so much. Of course, Sforza knew perfectly well that his rapid success had aroused the jealousy of the Lion of St. Mark, and that peace would never have been acceded to but for fear of his becoming lord of Milan. Events in Milan were favourable to his hopes, for a new signoria, composed of less well-born and more obstinate defenders of liberty, had exiled Gonzaga and a crowd of " respectabilities," and it did not require a Sforza to perceive how this weakened the city and embittered faction at a time when the State needed unity above all things. But Sforza still held his hand; his time was not yet come. He had lost several able Generals, and there were signs that Alfonzo, King of Naples, might, even at this eleventh hour, espouse the cause of Milan.

Peace was signed at Brescia (September, I449). The Republic of Milan was to be bounded by the Adda, the Ticino, and the Po ; Sforza was to give up Lodi, and renounce his claim to Milan ; but he was to be recog- 
nised as lord of Novara, Tortona, Alessandria, Pavia, Piacenza, Parma, and Cremona. If the Republic of St. Mark had withdrawn from its pledged word that it would help Sforza to become lord of Milan, it had not behaved ungenerously; the treaty would make him one of the most powerful rulers in Italy. But Sforza had played for a high stake, and he was not the man to be put off with a compromise. Venice had to deal with one of the astutest diplomatists of the time, a man versed in every dodge of statecraft, and quite capable of dealing even with Venetian Embassies. He feigned to accede, and sent his brother to Venice, ostensibly to bear his acceptance, really to postpone negotiations, while he withdrew his troops from the immediate neighbourhood of Milan and stationed them where they could easily leap back on the city. Meanwhile, one of his great opponents, Francesco Piccinino, died, leaving, however, his less scrupulous and more daring brother in command of the Milanese.

When the time came for Sforza to sign the truce, and the Milanese had finished sowing their seeds in the fields, Sforza refused point blank to ratify the treaty; and, to put himself right with the world, or perhaps to appease his own conscience, he found no difficulty in discovering theologians who held that one was by no means under moral obligation to observe a treaty which one has agreed to through stress of circumstances. Complaisant ecclesiastics in plenty wrote numerous and voluminous tracts in his defence. Of these he bore the expense, and for these precious apologies he secured a large circulation. The cold season had come on, but he disposed of his forces so skilfully that they blockaded Milan, and could cut off its communications with Venice without leaving their comfortable winter quarters.

In spite of the advent of winter, then, the campaign was continued, and Sforza by his rapid movements defeated both the Milanese and Venetian troops before they could effect a juncture. By skilful negotiation and rectifying the frontier he warded off all danger of attack from the Duke of Savoy. Two perils now confronted Sforza-famine and a simultaneous double attack from the city and from Piccinino, who had left Milan, and who was expected to return with provisions that Bartolommeo Coleoni had convoyed as far as Como. But Sforza had taken up so strong a position in the suburbs that he cut off Piccinino, and the chief anxicty that now remained ( 1450 ) was the scarcity of provisions in the camp, and this anxiety was daily increased by the mutability of his own Generals and Piccinino; for it had become the habit for condottieri to bargain with the enemy for change of service at enhanced pay, even while they were actively engaged against them (Joann. Simoneta, L. $x x$.).

But if the army of Sforza was getting into a critical condition, the state of Milan was becoming deplorable. Sigismond Malatesta, the Venetian commander, hesitated to attempt the relief of the city, for he had married a daughter of Sforza, and then dismissed her to a better world in order to marry his mistress ; and he naturally dreaded that, if he lost a battle, he would incur the just vengeance of his whilom fatherin-law. And time was fighting on the side of the investing army. The very dogs of Milan had disappeared in the stewing-pot, and the poor were reduced to eat the roots and herbs that grew by the ramparts. Thousands of exhausted wretches had fallen down in the streets and 
died there ; thousands had attempted to get through the investing lines and escape into the country, but the soldiery were resolute in driving them all back into the city again, save the younger women whom they kept for themselves (Joann. Simoneta, L. xx.-Crist. da Soldo Ist. Bresciana, p. 863). It was evident that before long Milan must succumb to famine. Sforza was waiting for this. He might have taken the city by assault long ago had he been more impetuous and less politic; he had not done so because he knew how to wait, and desired to spoil his heritage as little as might be. But there was another crafty and calculating foe also awaiting events. Venice had an agent in the beleagured city watching the interests of St. Mark, and waiting until the Government, exhausted and hopeless, should seek protection from the great Adriatic power. The signoria were ready to do almost anything rather than capitulate to the man that had betrayed the city, and at whose hands they had suffered so much. While negotiations for surrender to Venice were proceeding, the gnawings of hunger excited gaunt and empty starvelings to gather together and demonstrate. Hunger had emaciated their bodies; it had only stimulated their hearts to rancour, and their facile passions to revenge on somebody, anybody. All had endured; all had by no means suffered alike. These lean and desperate wretches broke into the Public Palace. The signoria fled before them, but the Venetian Ambassador had the hardihood to face the reckless crowd, and even to try and persuade them. In a trice they cast themselves on him with fierce execrations; a moment more, and they relieved Milan once and for ever from the dangerous presence of this stranger within her gates. The insurrection spread from quarter to quarter, and the soldiery even were powerless to stem the current of popular wrath. The insurrection started on the evening of February 26, I450; it lasted all night, and in the morning a general meeting was held to determine what should be done. The Government had been destroyed, and the meeting exhibited the normal peculiarities of a mob. Sforza was an object of hate ; still more Venice, always regarded with jealousy by the Milanese, and now denounced as the true contriver and abettor of all the woes of the State. It was evident that Milan must get help somewhence or give in. Some were for surrendering the lordship to the King of Naples; others were all for the Pope; others for the Duke of Savoy. Then, when the opportune moment came, an agent of Sforza got up and spoke. He pointed out that Naples, France, the Pope, were too far off, and Savoy too feeble to save them; but if they wanted to appease their hunger, put an end to their sufferings, and stop the war, there was a simple expedient-let them trust to the well-known kindness and clemency of Sforza, the legitimate successor of Visconti. This prospect of immediate relief from the mordant cark and care of the last months was hailed with joy. Sforza was suddenly transformed from an evil foe, for whom no curse could be too bitter, into the saviour of Milan; and the meeting, wheedled and cajoled by a few honied words and the vision of a full platter and no coil about getting it, sent the agent to carry to the General the submission of a whole people.

Sforza at once set forth for Milan, distributing bread to the clamorous crowd that came rushing out of the gates and surrounded his troops as they marched along. In vain did the leading citizens try to impose conditions before admitting him to the city; the soldiery pushed by; the 
populace thought of nothing but bread. Surrounded by a close-packed crowd of enthusiastic citizens, Sforza rode to the Church of Our Lady to thank God for this grant of his fair hopes and reward of prayer, ruse, and diplomacy. Then he set to work with energy to scour the country and hurry up convoys of provisions for his famished people; he defrayed .the charges and suspended the octroi. In two days all the strong places round about that had held out surrendered, and the Venetians retired across the Adda (Joann. Simoneta, L. xxi.-Anton. di Ripelta, Annal Placentini, R.I.S., T. xx., p. 901). Then he pointed out that the Milanese were still far from entirely free from danger of Venice, and affected to consult the people as to whether they would prefer to receive a billeted army for their defence or to re-erect a fortress. Of course, the fortress was chosen as the least irksome of two necessary evils, and the new tyranny was secure (Villari, Mach., Lond., I898, p. 25).

Two ycars passed before Venice made any determined attempt to oust Sforza, and she began badly. The Ten mistrusted their own General, Bartolommeo Coleoni, and were bent on disarming his soldiery. The attempt led to a tumult in the camp, and Coleoni, making his escape, took command under Sforza.

On the side of Venice were ranged the Duke of Savoy, the Marquis of Montferrat, and Alfonzo of Naples, with the benevolent neutrality of the Pope. Alfonzo, powerful as he was, naturally counted for little in the North. He was more formidable to Florence, and that State entered into close alliance with Sforza and subsidized him, in order to preserve the balance of power in Italy.

The war was conducted by various small companies with varying fortunes, but when the two great armies approached one another, the one commanded by Sforza in person, the other by Lionessa and Jacopo Piccinino, each side was afraid of losing all by a single cast. At last Francesco Sforza summoned up resolution to defy his opponents to stand the rigour of the game. The gage was taken up, and the armies met on the designated plain. It was a cold, dismal November day (1452); the fog was so dense that the enemies could not see one another. They sent their trumpeters forward to sound defiance, and as the men could not fight in the mirk with the weapons of their trade, they fired off their tongues like fishwives until the fog turned to drizzling sleet, and drove them, cooled, into winter quarters. Thus ended a campaign which had been undertaken at enormous cost, and after huge preparations, and wherein the best commanders of the day took part (Joann. Simoneta, L. xxii.Crist. da Soldo Ist. Bresciana). It was a reductio ad absurdum of the whole system of condottieri. Nevertheless, one Porcelli, a Neapolitan courtier, sang of this ridiculous campaign in elegant flowing Latin verse, wherein Sforza becomes Hannibal, and Piccinino, Scipio. It was dedicated to the latter, and is to be found in Muratori, L. xx and $x x v$. Porcelli gives the reader a distinct impression that he had his cheek in his mouth the whole time, and, as he hoped to be rewarded for his work, he must have calculated on a considerable lack of perception or of sense of humour on the part of the warriors whom he belauds.

The winter of 1452 was occupied in the usual successful attempts to seduce the Generals of the foe from their service, and, according to Neri Capponi, who was several times Florentine Ambassador, both at Venice 
and Milan, there was an attempt on the part of the Ten to remove the Duke by assassination. The details of the story arouse one's incredulity, for we are told that a poison, brought from the Levant, if thrown into the fire would suffocate anybody in the room. The agent of the Ten who was to use this poison was to receive I0,000 florins, but he revealed the whole plot to Sforza, who kept the poison for his own employment (Comment. di Neri di Gino Capponi R.S.I., xviii., p. 122). Such a poison is certainly not known to modern science, and Simoneta, Sforza's secretary, is silent concerning it. We can only admire the vein of child-like credulity in the shrewd character of the Ambassador, or his love of the marvellous. The war lagged on until the spring of 1454 , amid the treacheries and defections of mercenary leaders. At last both sides were heartily wearied. of this expensive and fruitless contest. Private negotiations took place, and the peace of Lodi was signed, whereby Venetia got her claim to Bergamo and Brescia acknowledged, and Sforza retained the Ghiara d'Adda.

\section{VENICE}

\section{The Life and Death Struggle with Genoa}

THE chief scene of the protracted war between Venice and Genoa now shifted to the Adriatic. While Vittore Pisani took several ports now belonging to Hungary on the Dalmatian coast, Lucian Doria, the Genoese Admiral, captured Rovigno in Istria, burned and pillaged several small towns, and threatened Venice itself ( 1378 ). But Pisani had successfully protected Venetian commerce, and there was no deficient supply of food-stuffs, which came from Apulia.

During the winter Pisani sought permission to lay up his fleet, but the Senate, fearing that Venice might be blockaded, refused. Pisani therefore cruised about off Pola, and an epidemic breaking out, thousands of his sailors died on shipboard, tantalized by the sight of the harbour close by. And when Pisani entered the port to see to repairs Doria hove in sight with twenty-two sail. The Venetians begged and prayed their commander to give battle, and he put out to sea with twenty-four sail, partly manned by men of Pola. The Genoese were attacked with vigour ; Doria was killed, but Ambrogio Doria, his brother, took command, and the heroism of worn and sick sailors and raw recruits did not avail against the skill and discipline of the Genocse. Fifteen galleys were taken, with $\mathrm{I}, 900$ prisoners, including four members of the Great Council ; and Vittore Pisani escaped to Venice with seven sail only. He was at once cast into prison, and threatened with capital punishment, pour encourager les autres.

The Genoese lost no time ; they followed up the victory by sending a fresh contingent, which brought their fleet up to forty-seven galleys, and appointed another Doria, one Pietro Doria, to the chief command. $\mathrm{He}$, having made his arrangements with the lord of Padua, took up his station off the port of Chioggia, a few miles from Venice, early in August (1 379).

Between Chioggia and the islands on which Venice is built lies a shallow lagoon, bounded on one side by the low, melancholy sandbanks of the 
mainland, on the other by the equally sad and deserted Aggere. The Aggere is, at its broadest, but I, ooo paces across. Beyond lies the Adriatic, and one can see across it to the far-off blue mountains of Istria. The waters of the Brenta and Adige drain through the lagoons into the sea along several narrow openings, each of which the Venetians hastily closed by a triple chain and great floating fortresses (sandoni). Here and there, at the most pregnable points, the chains were further strengthened by huge interlacing beams, so that any attempt to effect an entrance appeared to be impossible (Ubert Folieta, Hist. Gen.). But Pietro Doria reconnoitred the entire Aggere, and arranged with Francesco di Carrara that the opening of Chioggia should be attempted by a simultaneous attack. While Doria assailed the defences from the sea, Carrara, who had built roo barges at Padua and sailed them down the canals of the Brenta, attacked the defences from the lagoon side, and the entrance was won (August I 2, I 379). Twenty-four thousand men now beset Chioggia, which was defended by the inhabitants and 3,000 soldiers furnished by Venice. Little Chioggia, a suburb of the town, soon surrendered. It was connected with Chioggia by a long bridge which was held by Venetian soldiery. The Genoese made an attempt to burn it down by means of a fire-ship, and its defenders, thinking it was really set ablaze, rushed back to the town with so much precipitation that they left the drawbridges behind them unraised. The Genoese and Paduan troops perceived their advantage, rushed on at the double, entered the town pell-mell with the retreating troops, and soon rendered themselves its masters. Eight hundred and sixty Venetians perished, and 3,800 prisoners fell into the hands of the allies. The town was proclaimed a possession of Carrara. It was a capture of the utmost importance. Henceforward there was direct land communication between the fleet and their allies on the mainland; the lagoons-nay, Venice itself-was open to them. It was no wonder that the citizens showed the white feather. The people crowded round the ducal palace, they implored the Government to buy peace at any price, and save the city from absolute destruction. In vain did Andrea Contarini the Doge assume a fearless demeanour ; in their hearts all men believed things to have come to a hopeless pass, and Ambassadors were sent to Chioggia to sue for peace. Carrara was inclined to accede, on heavy terms, but nothing would satisfy Doria short of the complete and permanent disablement of the rival State. The insolent terms in which the refusal was couched served as a tonic to the disheartened city. But day by day news arrived of the fall of Venetian fortresses that guarded the mouths of the Adige.

On August 24 twenty-two galleys and forty other vessels filled with soldiers sailed up by the Lido to within two miles of the city, but they were received so warmly that they had to sheer off; and the Venetians, instructed by the event, devoted all their energies to the fortification of the narrow sea-ways by which alone the shallow lagoon can be traversed. But the populace were disposed to rely less on triple walls than on the keen eye, clear judgment, and undaunted mettle of the hero who came from an illustrious race of sea-dogs, the man who had so often led them to battle and victory, and who was now languishing in the prison-vaults of the ducal palace. Crowds surged to the ducal palace demanding his release. "Give us back our Pisani! We will only fight under Pisani ! 
Long live Pisani !' was the cry. The national favourite is said to have dragged his chains so that he could get to the bars of his cell, and to have shouted back:." Venetians should never shout anything but 'Live St. Mark !' "'

The Government was compelled to accede; Pisani was released and put in command. All the population worked night and day to equip a fresh fleet. Rich citizens poured forth their private resources for national defence. Pisani superintended the outworks on the waterways and the Aggere of Malamocco. He blocked the Grand Canal and the Guidecca with piles and other obstructions, stationed guard-ships all around the city, and anchored "cocks," or rounded vessels built like a fort, and furnished, for the first time, with cannon, at the openings of the principal canals. One gleam of comfort came to the menaced people. The King of Hungary had sent Charles of Durazzo at the head of ro,ooo troops to attack Treviso. But Durazzo, at the invitation of Pope Urban VI., was bent on the conquest of Naples, and was anxious to push on. He entered into negotiations with the Doge, and allowed Treviso to be revictualled, with the result that the armies of the mainland were held at bay, and their military evolutions on the mainland ceased to give serious concern to Venice.

And then good news came from the Levant. Towards the close of the preceding year, Carlo Zeno, who had distinguished himself in a land command, was, according to the fashion of times when the military and naval professions were not fully differentiated, made Admiral of a small squadron. He sailed boldly through the midst of the Genoese fleet in the Adriatic, made several prizes in Sicilian waters, terrorized the Tyrrhenian Sea, devastated the shores of the Riviera Levante, and, receiving reinforcements, made for Constantinople, aided John Paleologus to reascend the Imperial throne, and was now in full sail to the rescue of his country.

It was time. Blockaded both by land and sea, the people were threatened with famine, and provisions were already scarce and dear. The people clamoured to be led to battle, since it was better to die fighting than to starve. There were hulks in the arsenal, and several vessels in construction, but the treasury was exhausted. The Government promised to inscribe in the Golden Book the thirty plebcians who should give most practical evidence of their devotion to the State. The aged Doge made a public appeal. He vowed that he would lead the fleet in person. Enthusiasm was at its height; a spirit of heroic resolve and self-sacrifice animated rich and poor alike. In spite of commercial depression and ruinously high prices, the citizens vied with each other in throwing their wealth into the public purse, and by the end of October thirty-four galleys were completely armed and fit for sea. But Vittore Pisani was too prudent a commander to lead raw recruits against the veteran crews of Genoa. He spent some of the time, now become so precious, in training them on the lagoon near home. The appearance of a new fleet on the horizon produced some disquiet at Chioggia. The Genoese concentrated their forces, and worked hard to render Chioggia impregnable. They put twenty of their galleys into winter quarters, where they could not be surprised, and sent twenty-four galleys to Friuli for supplies, for Chioggia, situated like Venice on the lagoon itself, was also liable to have 
her supplies cut off from the mainland. The Venetians were ever on the alert, and privation visited Chioggia equally with Venice.

The recruits had two months' training in manœuvre, and on the night of December 23 the Doge in person led thirty-four galleys, two cocks, sixty big craft, and more than 400 boats, towards Chioggia. The Genoese fleet had returned from Friuli, and was in harbour, with Doria's fleet of forty-seven galleys. Four thousand Venetians landed, but were repulsed ; and a cock destined to close the entrance to the harbour was taken after fierce resistance. But the Genoese in the heat of battle had set it afire. It sank and blocked up the channel, and the Venetians followed up the advantage by sending thither barges laden with heavy stones and sinking them, so that this entrance to the harbour was effectively corked. They also contrived to seize the adjacent promontory, called Lova, and fortified it to prevent the entrance being unstopped. But there were several other issues from the port. Pisani contrived to seal one of these, and with an inferior fleet and raw sailors, disheartened by the defeat of their comrades under the Doge, he undertook to blockade the port. The Genoese could not now manœuvre in the canal or form line of battle, but they had to remain so close to the entrance that they lay right under the guns of Brondolo, and a stiff breeze or any other accident might take away at any moment all the advantages of their position. The Doge had inspired his division with enthusiasm by swearing that he would never return to Venice until he had taken Chioggia, and Pisani pushed two of his galleys right into the canal, and endeavoured at great loss to fortify the bank at the promontory of Fossone opposite to the convent of Brondolo, which was occupied by the Genoese. But provisions ran short, and the ships in the canal were under heavy fire. The long-expected fleet of Zeno had not arrived. Deferred hope, hunger, and immediate danger disheartened his crews, and they urged their leaders to abandon the enterprise. The Doge tried to defer the evil day. He promised that if Zeno did not arrive before New Year's Day he would raise the siege. In that event Venice would be besieged. The worst might happen. The great interests of the Republic lay in the East, and it might be wise to transfer the Republic to Crete (Marin Sanuto). But on the fateful morning (January i, I 380 ) Zeno, in command of forty galleys, laden with munitions of war, rich booty, and, most precious of all, an abundance of foodstuffs, sailed majestically into the Venetian harbour. Four other galleys followed, and the fleet was brought up to fifty-two sail. The whole situation was changed. If the Genoese should succeed in breaking the blockade they would hardly be likely to escape defeat at the hands of so vastly superior a fleet. But Pisani was determined "to make assurance doubly sure." He would leave nothing to chance. He was more determined than ever on sealing the harbour. On January 6 he gained a land fight at the Lova promontory, and, a few day's afterwards, he finished his redoubt at Fossone. There he planted two great cannon, one capable of casting stones weighing I 80 pounds, the other stones weighing I 50 pounds. These "bombards" were charged at night and fired off in the morning. They could only be fired once a day, and more often missed than hit; but wher they struck the mark their effect was serious, for fortresses were not yet constructed with bastions and earthworks. Pietro Doria, the Genoese Admiral, and his nephew were killed by one of these primitive cannon at Brondolo on 
January 22. He had come to inspect the defences, when he was struck by masonry broken off from the monastery wall, and next day the fragments of another wall shattered by another shot killed twenty-two men. Napoleone Grimaldi now succeeded to the Genoese command, and his first order was to dig a new canal through the Aggere, for the Venetians had sunk two galleys in the important channel of Brondolo and completely "corked" that exit. In order to prevent the execution of Grimaldi's project, Zeno was put in command of 5,000 mercenaries, who were to land on the Aggere, while Pisani was to attack the fortified monastery of Brondolo from the sea-front.

On February 19 Zeno landed his men and tried to force the bridge leading from Little Chioggia to the town itself. He was resisted by a body of 8,000 Genoese, while I,500 men, released from the monastery, tried to take him in the rear. But by skilful tactics he got behind them instead, and drove then towards the bridge. The front ranks that held it took fright; they turned and fled, and, meeting their comrades that were advancing, the two masses of men got entangled and massed together at one point of the bridge ; their weight broke it down, and numbers were precipitated into the waters below. Most of those Genoese who remained on the Venetian end were either killed or taken prisoners. Meanwhile, the monastery of Brondolo, left almost defenceless, was taken by Pisani, as well as ten galleys, captured shortly afterwards.

The Genoese now found themselves shut up in Chioggia and closely besieged, with no provisions to spare. The women and children were sent out of the town, and were treated by the Venetians with great humanity. The Genoese Government at once sent Gaspardo Spinola overland to take command of the besieged army. Francesco di Carrara seized the opportunity of a sudden rise of the waters to get forty ships bearing foodstuffs through shallow channels that had never been used before. But communications became more hazardous day by day. Valour was of little avail when there was no opportunity to exercise it. Starvation told on the men, and Spinola offered to surrender Chioggia if he might retire with his fleet. It was now the turn of Venice to refuse. The Venetians had once scanned the horizon day by day with eager eyes and beating hearts for the sails of Zeno ; the Genoese were now no less anxious for the arrival of help from Genoa. Matteo Maruffo had been despatched in January. He had taken seven Venetian galleys laden with provisions at Manfredonia; he had gathered together all the Genoese ships that were scattered over Mediterranean waters, and on June 6 he appeared off Chioggia. But the Venetian commanders had the advantage now, and they were unwilling to expose themselves to the risks of battle. They maintained a fleet of twenty-five galleys only, which they manœuvred in the shelter of the lagoons. They strongly fortified every opening, and employed the bulk of their sailors in patrol-duty along the coast of the mainland. Chioggia was absolutely isolated and shut in. In vain did Maruffo seek by fierce taunt, invective, and insult to goad them to battle. They listened as if they did not hear; their impassive silence bore with it the irrevocable irony of doom.

However, all was not yet lost. Maruffo sailed to Fossone and contrived to occupy the passage through which produce came to Venice from Ferrara. The tables were again turned, for this time it. was Pisani 
who was anxious for battle and Maruffo who kept in the shelter of the lagoon.

Day by day smaller vessels of the Genoese had been captured, but they constructed new boats from what planks and even furniture Chioggia could supply. They tried on June I 5 to clear the Venetian palisades and gain the vessels of Maruffo, with whom they had contrived to communicate and had arranged a plan. But they were closely watched. They found themselves exposed to sudden attack at the most critical moment. Their last hope vanished, and the boats, built with.such infinite invention and pains, fell into the hands of the foe and were burned. By the middle of June the Genoese were at starvation-point. Of fortyeight galleys shut up in the harbour, only nineteen were in decent condition. The garrison was reduced by death and disease, and in a fearful condition, and the commander was compelled to surrender at discretion. The Venetians behaved with generous prudence. They released the mercenaries without ransom, let their own hired troops share all the booty, and only took 4,000 of the prisoners back with them to Venice. Venice was saved, but Maruffo still rode the Adriatic with thirty-nine galleys at his disposal. The treasury was exhausted, the revenues of the State could not come in, the garrisons of subject cities had been weakened to defend the capital, and Treviso was on the point of surrender to Carrara. Maruffo took Trieste, Capo d'Istria, and Arbo in succession ; and in August Venice lost by death Vittore Pisani while seeking provisions in Manfredonia. Pisani was the darling of the fleet, the idol of the citizens, the one of all her trusty sons on whom Venice could most rely. ' He was truly great, not less fearless in fight than sure in strategy, as humane as he was courageous, modest in the hour of victory, and, rarest gift of all, rising to the fullest height of human dignity in the dark hour of injustice and ingratitude, suffering and shame.

Attempts at compromise came to naught, and the war continued. Venice saved Treviso from falling into the hands of Carrara by ceding it to Leopold, Duke of Austria. By this cession of the last of her possessions on the mainland Venice could give her undivided energies to her navy, and while the Genoese contrived to keep to the Adriatic, and hold the Dalmatian ports for Hungary, the Venetians despatched a small fleet to the Ligurian coast to give the Genoese a lesson on certain disadvantages of war when it is brought to one's own doors. But both combatants had, as is usual with brave peoples, learned to respect one another. Both were so exhausted that all they could now do was to harass one another by privateering, and when Amadeo, Count of Savoy, proposed to mediate, both belligerents were heartily glad to end their quarrel. Venice gave up Tenedos to the Greeks and all Dalmatia to the King of Hungary. Carrara obtained his ancient boundaries, and was released from all obligations to Venice, and prisoners were exchanged without ransom (August, I 38 I).

Venice had only just succeeded in saving herself. Genoa had lost her fleet and the flower of her men. Venice, however, had the advantage of having no feudal aristocracy, of being insular, and of possessing a stable constitution and just and equal laws. Genoa was a territorial power. Her hillsides were in the grasp of passionate and contentious nobles, faction dominated in and without the city, and her exhaustion from this 
war led to her surrendering herself to her powerful land neighbours and to France. The continuance of these intestinal discords rendered her impotent to renew the contest for the maritime supremacy of the world. On the other hand, Venice had a settled Government-one which, in days when States were controlled by despots or by a caste, was of the best. Pride in his city lit the eye, thrilled the breast, of every lagoon dweller, great or small. Love of Venice bound all citizens together in bonds of a common devotion :

$$
\begin{gathered}
\text { " the worth } \\
\text { "Of Venice did not fall below her birth." }
\end{gathered}
$$

Commercial energy and astute statesmanship soon repaired her vast losses. She was still destined to

" hold the gorgeous East in fee, And be the safeguard of the West."

\section{From the Peace of Turin (I38I) to the Establishment of the} Republic on the Mainland (I432)

Directly peace was concluded trade began to revive. Petrarch, who was a great traveller, and ranged Europe from Paris to Sicily, urged by multa videndi amor ac studium (Familiares), visited Venice, and leaves us an interesting account of his impressions. He says: "I see, sailing out from the port, ships that are as big as my mansion, their masts taller than its tower. They are as mountains floating on the waters. They go to face incalculable dangers in all parts of the world. They bear cargoes of wine to England; honey to Scythia ; saffron, oil, and linen to Assyria, Armenia, Persia, and Araby ; wood to Egypt and Greece. They return heavily laden with products of every kind, which are sent to every part of Europe. Where the sea hath bounds, the sailors quit their vessels and become bearers by land. They bargain in Hindustan and China, and the Caucasus and the Ganges are no barriers, nor do they stop till they reach the Indian Sea." Great care was taken to foster Venetian commerce and manufacture. Foreign workmen were attracted to the city by the concession of special privileges. The State kept close watch to prevent the export of certain raw materials, so as to preserve monopoly of manufacture, and the Government gradually but very completely subjugated the guilds, at once encouraging and controlling them, and safeguarding the interests of small men and artisans. The merchant, enabled to pursue his calling without the intrusion of irrelevant issues, developed commerce to the dignity of a science and the precision of an art. The plebeian had learned by now to be content to let well alone, and not to interfere in politics; and the only disorder from which the city suffered was from the bands of young bloods who roamed the lanes by night, as the Mohawks of the eighteenth century were wont to prowl about London.

The death of the King of Hungary in 1382 was followed by anarchy in that country. The Venetians, with their customary diplomatic skill, contrived to influence affairs in Hungary to their advantage ; and, shortly after the King's death, Dalmatia became an independent kingdom, so that the Republic was delivered from the dread of the might of Hungary extending itself by sea-power and disputing her supremacy in the Adriatic. 
The ban of Bosnia was the new monarch. He began his conquest of the seaboard in 1387 , and by 1390 all the Dalmatian coast that had been Venetian was under his rule.

Anarchy in the Neapolitan kingdom also brought advantage to the Republic. The beautiful and fertile island of Corfu, the ancient Corcyra, guarding the entrance to the Adriatic, threw off the yoke of Naples. It had belonged to the kingdom after the expulsion of the Latin Emperors from Constantinople. Corfu adopted a republican form of government, but the proximity of the Ban of Bosnia induced it to offer itself to Venice on condition that all its privileges should be preserved (1386). The duchy of Durazzo, an important city which Charles of Anjou had taken from the Greeks, and which had remained in his family until the recent dynastic disputes in Naples, was captured by Venice (I 386 ), and next year the feudatories who governed Argos and Napoli in Roumania chose Venice as their overlord. Probably Venice would have profited to a much greater extent by the troubles of Hungary, Naples, and Greece, but that her energies were chiefly directed to keeping watch on the mainland.

Francesco di Carrara had bought Treviso, which the Venetians sold to the Archduke of Austria during the war. The Carraresi objected to Venetian monopoly, and were now possessed of all the mainland contiguous to the lagoons. Venice had not yet wholly recovered from the effects of the great war, and she saw her trade-routes in the possession of a family by no means friendly to her, and that had leagued themselves to her foes. She allowed herself to be hoodwinked as to the real character and intentions of Gian Galeazzo Visconti, the lord of Milan ; and, to subdue a present foe, she laid herself open to a greater though more remote danger. Now a bastard of the Scaligeri had secured the rule of Verona by the murder of his brother and his brother's family. Francesco di Carrara expressed horror, affected or real, of such criminal methods, and was inimical to the new despot.

Venice seems to have worked on the bastard despot to take his revenge on Carrara by declaring war. She promised to subsidize him, but in the event of his complete success, Treviso and the possessions of the Carraresi were to be handed over to the Republic (Andrea Gataro, Storia Padovana). Della Scala suffered a defeat, but prisoners were nowadays mercenaries, and it had become the custom of mercenaries, whom fellow-feeling made wondrous kind to each other, to release their unfortunate brethren without exacting other ransom than their arms and horses. Venice paid the expenses of the battle, and urged della Scala to a second attempt. But disaster again befell his troops. Gian Galeazzo was not the man to miss such a golden opportunity. He could swallow one or the other of his neighbours if they weakened themselves; it little mattered which was taken first, in due time the turn of the remaining ruler would come. $\mathrm{He}^{\circ}$ offered his services to both in turn, and, after some shilly-shallying, both were ready to fall into the trap. Carrara forestalled Della Scala, ${ }^{1}$ Verona speedily fell to the arms of Gian Galeazzo, and Della Scala fled to Venice. Vicenza was also taken, and although by treaty it should have been at once handed over to Carrara, that was not the method of Visconti, and

1 Andrea Gattaro says that all Carrara's councillors were the creatures of Gian Galeazzo or of Venice. 
Carrara knew him too well to dispute the matter. He contented himself with trying to preserve his own territory by coming to terms with Venice. They were refused. Meanwhile, Gian Galeazzo sent an Embassy to Venice offering an alliance against Carrara, whereby Treviso, Ceneda, and certain fortresses should be given over to the Republic, while Padua should be retained by himself. Now Padua had been engaged in perpetual warfare for twenty-four years; she was bowed down with taxation, and was ready to rebel. This is probably the reason why Venice lent an ear to the arch-deceiver. ${ }^{1}$ If she refused, the expected revolt in Padua would very likely be successful, and then she would lose all. Of the probabilities of such an event she was well aware through the communications she received from her secret agents, for she had an excellent secret service established everywhere. Padua could not stand against the might of Milan, however, and if Venice agrecd, she might still get something, for Carrara had written to the Emperor, the Pope, and all the Kings in Christendom complaining of the bad faith of Gian Galeazzo ; and, while Gian had some show of right to Vicenza through his second wife, immediate bad faith to Venice in the matter of Padua would emphasize Carrara's charge. She must be opportunist in her policy, therefore, and await events. The treaty of partition was signed. Venice sowed the wind; she was now dreading lest she should reap the whirlwind.

She took the precaution of insisting on the admission of the Marquis of Este and the commune of Udine to the alliance. In vain did Francesco Carrara attempt to avert the evil day by abdicating in favour of his son, Francesco Novello. Padua refused to defend its lord, and on promise of safeguard, the Carraresi put themselves into Gian Galeazzo's hands. $\mathrm{He}$ violated his word, and cast them into prison ; and Gataro tells us that, when the Paduan Embassy came to do him homage, he raised the mask for a moment, and promised them that, if God but granted him five years more of life, he would equalize matters and give them satisfaction on Venice, their ancient foe, by putting an end to the pretensions of that half-drowned city. If such a promise were made, we may be sure that Gian Galeazzo had some reason to placate Padua. He gave nothing for nothing, especially his secret counsels.

Francesco Carrara succeeded in escaping the vigilance of Gian Galeazzo. He regained Padua by passing with his troops through the bed of the Brenta. Verona also revolted against Gian, but was again subdued, for dissensions broke out between its inhabitants. It helps us to understand the growth of tyranny in Italy when we learn that while the traders wanted to start republican government, the lower orders preferred the equal rule and comparative tranquillity of despotism. They did not want Gian Galeazzo, however; they were for restoring the House of Della Scala (Piero Minerbetti, I390) (I390). And now the elder Carrara died in captivity: it is characteristic of the man who had violated his faith that he sent the body to Padua with all honour and respect.

1 Sismondi says that blind wrath with Carrara caused Venice to ally herself with the lord of Milan. This is an absurd explanation. Venice was far too astute to sacrifice her interests to revenge. She had made an initial mistake, perhaps ; she now found herself on the horns of a dilemma: she chose the couree of action that deferred danger. 
Venice witnessed the continued aggressions and growing power of Gian Galeazzo with no small concern. He was now the wealthiest and perhaps the most powerful Prince in Christendom. The Venetian Government temporized by receiving the newly-restored lord of Padua with all honour, but they held aloof during the war which Florence and the allies made on Visconti. They did not wish to plunge into a contest which might terminate disastrously, which would certainly ruin their trade, and which, even if successful, would establish the Carraresi more firmly in their State. Their policy at this period was a hand-to-mouth one : they manœuvred; they accepted the offer to mediate between Gian Galeazzo and his foes, but as mediators they procrastinated. And the death of the despot ( I 402) relieved them and all Italy of their well-founded fears.

Venice beheld the advance of Gian Galeazzo with impotent dismay; his unexpected death relieved her from an urgent danger. The great number of contiguous States that he had enmeshed in the net of his dark and subtle design now began to break away. The control of his widow was weak; the cities began to revolt; his trusted servants seized lordships for themselves wherever they could. Guglielmo della Scala entered into a compact with Francesco di Carrara whereby, if Scala got possession of Verona, Carrara was to have Vicenza. Verona was taken, but Scala died a month afterwards (1404). Of course, it was at once said that Carrara had poisoned him. Shameful accusations are easily made and easily believed. An ignoble world loves to besmirch the reputation of the great. The report was credited. In days of bad treatment and no pathology almost every death of a notable person was attributed to slow poison if anyone could profit by his decease, and there is no reason to disbelieve Gataro and Corio, who say that Della Scala died from fatigue, fever, and dysentery. And Carrara certainly took no immediate advantage of the death of his ally, but at once invested the two young Scaligeri with their heritage, though on a charge, true or false, of intrigue with Venice he arrested them a month later, and had himself proclaimed lord of Verona. The Republic and Carrara were both competitors for Vicenza, Verona, and Bassano, and both had negotiated with the Duchess. Vicenza declared for Venice, which was already possessed of Treviso. The Duchess offered to yield Bassano, Vicenza, and Verona if Venice would keep the Carraresi at bay. Venice sent a herald calling on Carrara to abandon the siege of that town. "Let us make a lion of St. Mark of him," said one of the Carraresi, and slit his nose and cropped his ears. This infraction of the inviolability of the herald observed by all civilized peoples, gave the Senate great disgust. Carrara was intriguing in the city itself. He was as able in the field of diplomacy as in that of battle. The Venetians engaged mercenary troops and occupied Cividale, Feltre, and Belluno. The dykes were cut, so as to flood the Paduan district before war was formally declared. Venice was quite ready. She had wealth, she could pay her condottieri well. No Venetian was ever allowed to take command of land forces lest he should attempt to carve out a realm for himself, but she always sent provveditovi to look after the warchest and to watch the conduct of the war, especially that of the Captains, and to warn the State if they meditated treachery. Even if her Captains proved unfaithful she was safe from all attack. She hired 9,ooo horse. The army of Carrara was outnumbered, but he made up for his deficiencies 
by his activity, good generalship, and clever fortification of the numerous canals that intersect the country. Venice engaged the services of two other armies. She spared no expense ; she was prepared to make any pecuniary sacrifice ; in fact, the war is said to have cost her 2,000,000 ducats. Verona was soon taken. Padua, Carrara's capital, which inclined towards Venice, was besieged. The fortified towns and villages around surrendered, and plague appeared in the city itself (I405). Nevertheless, Carrara made a desperate and successful sortie, and captured the Venetian flag. In November an attempt was made to take Padua by assault; it utterly failed. The Venetians are said by Gataro to have attached written messages to the bolts which they shot into the city warning the inhabitants that if they did not yield within ten days Padua would be given over to fire and slaughter. Carrara's son, who had maltreated the herald, even begged his father to yield, but Carrara, though the city was disaffected and he had lost hope of help from Florence or any other power, was de i zd to face his fate. One night his guards opened one of the gates to the Venetians, who are said by Sanuto to have begun by slaughtering the traitors who let them in. Carrara rushed to the defence. The tocsin sounded, but the citizens were more intent on hiding their valuables than on taking up their arms. He then asked for an armistice, and declared to the Venetian General and the three Venetian. provveditori, or "overseers," who accompanied him, that he would surrender the city on honourable terms, but on any other conditions he would still defend to the last gasp the two wards of the town, which had separate walls, and could still hold out. The provveditori replied that they were not empowered to treat, but they invitod Carrara first to surrender, and then he would be able to negotiate with the Senate in person. Carrara obtained the promise of the Venetian General that, if he could not make terms with the Venetian Government, the city should be given back to him in its present half-captured condition ; and he nominated two deputies, who, together with eight elected by the Paduan council, were to arrange the conditions of surrender. The Doge and Senate refused to give an audience to the nominees of Carrara, but they promised the delegates of the city itself to preserve all privileges if they surrendered at once and of their own accord. With the Carraresi Venice was not inclined to treat. Two of the deputies returned to consult with the Paduans, and there was some demonstration among the populace against the Carraresi ; but the great bulk of the people appear to have taken no active part in the discussion. Under these circumstances, the eager faction had it all its own way. A Podestà was appointed by them, the gates of the city were thrown open, and the Republic of Venice was proclaimed as lord of the city (1405). Meanwhile, Carrara and his son vainly implored the Venetian General to restore him, but the factors of the situation had shifted. Padua had decided for itself, and Carrara played his last card by embarking for Venice. His landing was not encouraging. A howling mob surrounded him shouting: "Death to the Carraresi !"

Venice had run great danger from the vast power acquired on the mainland by Gian Galeazzo Visconti. Francesco Carrara was also a man of consummate ability. He had energy and friends; he had manifested an implacable hatred to the Republic. His son had ignored the usage of civilized people in his brutal treatment of the herald; had put an 
unpardonable indignity on the State; had even defiled and filthily travestied the sacred insignia of the Republic in the person of its representative. The secret, subtle threads of Carrara's policy had been traced out; there were dark designs abroad. The Ten sat, and the Carraresi were condemned. Father and sons were informed by a priest who came to confess them that they had to die. They were given the Communion and afterwards strangled; then the bodies were honourably buried (vide Romanin, Storia Documentata). The people of Venice were content. The popular comment was truly Italian: "Omo morto, vera fina!" (It's a real finish when a man's dead!).

Destiny, that sometimes seems to deal generously and sincerely, is apt to keep Punic faith. If ever a power had seemed to sit secure on the waters, it was Venice. But the lagoons were shallow, and could be silted up. The attempt had already been made to turn the waters of the Brenta. Venice was once impregnable, but the question of adequate food-supply had begun to vex her increasing population, and she had experienced positive want in time of war. She was surrounded by foes; not merely had she acquired the hate of the Carraresi ; she and the Visconti, the Scaligeri, the family of Este, had opposite interests. She could not trade with the East unless she had also a market in the West, and it was absolutely necessary to her commerce to control the passes through the dolomites, and she held her monopoly in the salt-pans of the littoral in an insecure tenure. Powerful States were beginning to form around her, and the entrances to the lagoons might be easily closed both seaward and landward. Not merely would the existence of the State conceivably be imperilled in time of war, but a considerable Power in possession of the mainland might impose such taxes on transports in time of nominal peace as would be the undoing of the Republic : a tariff-war would ruin her more stealthily but far more surely than blockade. Venice cannot be eulogized as never having departed from the scrupulous observation of honour and good faith. She was quite ready to meet guile with deception and stratagem with snare, but her wiles and circumventions were instigated by no personal motive; they were the result of counsel and deliberation; they were well weighed and considered, and were undertaken in a spirit of pure patriotism for the safety of the motherland or the preservation of her stately splendour and serene repose. Venice turned her steps to the mainland with anxious consideration, hesitatingly, and with no light heart. Her rule there implied perpetual unrest and menace; it implied the expenses of a mercenary army that she could not but employ with hesitation and mistrust. But the threads of human wisdom and will are woven by the shifting shuttle of seemingly cold and indifferent Destiny. It was inevitable in the determinations of Fate that Venice should become a land power. Action that is inevitable can scarcely be called a mistake, and once in possession of Padua, she was forced on and on. She had to become increasingly stronger and greater by land, and to reap the results that befall any nation that aspires to rule on land as well as by sea.

Her policy to her subjects on the mainland was just and generous. It was vastly in advance of the policy of the time. The Senate publicly professed that it aimed at the love and devotion of its subjects. A Captain of War and a garrison were sent for security; a Podestà to preside 
over the high courts of justice. Rectors in constant communication with the Senate controlled taxation and the police, and they were compelled to observe the laws and regulations of the city. In very grave cases the Ten were consulted. Local self-government was encouraged, and a system of State education was set on foot. The subject provinces became devoted to the Republic. The administration was just and strong, and they grew wealthy very rapidly owing to the connection; but those families who had been used to the exercise of authority, or who had aspired to it, chafed; many of them exiled themselves, and fanned germs of jealousy and dislike to the Republic which existed throughout Italy.

In I4II, Sigismund, the Emperor, a restless and precipitant Prince, was bent on getting hold of Dalmatia, which Venice had purchased of his predecessor. He sent a body of Hungarian horse into Friuli to eject the Patriarch of Aquileia. The Patriarch took refuge in Venice ; Sigismund occupied the district, and it was with difficulty that the Venetians kept the Hungarians out of Treviso. ended in a truce of five years (I4I3).

A war with no marked result Venice found Sigismund engaged in a double war: he was defending his frontier against the Turk, and he was engaged in a religious war against the Hussites. The Patarirch of Aquileia, the Duke of Tetschen, was allied with the Emperor, and could be attacked with impunity, since the hands of his overlord were full. Friuli was of great importance to Venice, on account of the great trade routes over the Alps that opened out from that district, and the possibility of acquiring other land lying between Venice and her Dalmatian possessions. Feltre and Belluno, and finally Udine, fell. The whole countryside submitted, and that part of Istria which had been feudatory to the Patriarch and the Duke of Gorizia did homage to the Republic (I 420).

The Turk, who was menacing the civilization of the West by land, and was steadily taking advantage of the divisions of Christendom to extend his sway into Central Europe, began about this time to show that he was likely to be formidable at sea also. He had the audacity to pursue Venetian merchantmen into the harbour of Negropont, and threaten the city. There was always a Venetian fleet patrolling those waters, and it came up with the Turkish fleet at Gallipoli. Some attempt at a parley was made, but the blood of both crews was up ; some ships were already engaged. In his despatch Pietro Loredano wrote: "As commander, I confidently rammed against the first line of the hostile galleys; they were crammed with Turks, who combated like dragons. I was surrounded, an arrow pierced me below the eye, my hand was disabled; I received many wounds, but they did not prevent me from fighting, nor would aught but death. I succeeded in capturing the first galley and hoisted my flag on it. The Turkish crew was hacked to pieces, and we routed the other ships of the fleet " (Sanuto). The victory was complete ; I, Ioo prisoners were taken, and the pilots and Christian renegades were slain (I4I6).

The danger from the Turk was as yet but a little cloud. The old danger on the mainland was renewed by the restless ambition of Filippo Maria, the son of Gian Galeazzo, who exhibited something of the organized sincerity, dissimulation, mendacity, and double-dealing of his father, and whose wealth made him formidable, as he had funds enough to subsidize 
army after army. In order to preserve himself on his throne from the menace of surrounding States, in order to preserve his prestige and recover the sway of his father, it was necessary for him both to consolidate and extend his possessions. All round him were men ready to snatch at power. If he did not extend his dukedom, he stood a good chance of losing it. His father had very nearly been King of Italy, and he was marching rapidly in his father's footsteps.

Venice saw the danger, but the State was divided. There was a jingo party ; there was a peace-at-any-price party. The one desired to crush Filippo Maria, and dominate the mainland ; the other to temporize, and await the issue of events. This party was opportunist, and it dreaded the dangers of embarking further on the extension of empire by land. The Doge, Tommaso Mocenigo, was a "little Venetian." His last words -he died in 1423 -were a solemn injunction, an earnest prayer to the Senate to undertake no more wars for conquest ; to adopt a pacific policy, and, above all things, not to elect the impetuous Francesco Foscari, the leader of the Chauvinist party, as his successor. ${ }^{1}$ Mocenigo's party considered that now that Padua and the littoral of the mainland were under the control of Venice, now that she had command of the passes of the Alps, now that there was no fear of attack from the Patriarch of Aquileia and the Count of Gorizia, it was better to let sleeping dogs lie. The Turk was formidable, and the Republic might require all her resources to meet him, for he was already nearly a match for her by sea, and he had overthrown Servia, the other competitor for the decayed land empire of Constantinople; Constantinople was cut off from Europe by a well-consolidated Ottoman Empire; the nature and institutions of the Ottoman demanded war; they would find plenty of military occupation by land : meantime, would it not be better to trade with them rather than fight them, which they surely would prefer, seeing that their energies were occupied in Continental campaigns ? sufficient unto the day was the evil thereof. On the other hand, the war party thought that Venice would never be secure from the danger of famine until she had rounded off her possessions by a natural frontier, or was so powerful on the mainland as to be too dangerous to be lightly attacked. The only way to remain strong was to become stronger. The peace party agreed with the war party that Venice had nothing to fear in the Levant just now. Now, therefore, was the opportunity to extend and consolidate her power. Great States were forming around, and predominance in Italy was indispensable to the very safety of the Republic.

Mocenigo's warning was vain. The choice fell on Francesco Foscari. But party spirit still ran high under his rule, and the peace party were

1 Moncenigo's recorded speech gives interesting information concerning the wealth and power of Venice. Her merchants had at this time capital invested in every part of the world to the amount of $10,000,000$ ducats, bringing in an annual profit of 4,000,000 ducats. They received, therefore, 40 per cent. on their operations. The houses of Venice were valued at 7,000,000 ducats, and their rental was 500,000 ducats. Three thousand merchantmen sailed the seas, and the navy consisted of 43 galleys and 300 smaller vessels; these were manned by 19,000 sailors. The mint issued 100,000 ducats yearly. From her possessions on the mainland Venice drew I I,000,000 ducats and 900,000 ducats' worth of cloth, on which she made a profit of 600,000 ducats. She had already expended 900,000 ducats on the war by which she acquired Verona and Padua. 
not without relations with those subjects of the mainland who were malcontent. A number of the ruling caste had become poor and needy, and were open to bribery and manipulation. The State decked itself more than ever with the trappings and embroideries of external magnificence, but there was a canker at its heart.

Florence had been defeated over and over again by Visconti; she had vainly appealed for help; she appealed again. The Doge, it was said, was a King to the people, a mere senator in the council, a prisoner in his palace. Hallam says that no hereditary Sovereign would have submitted to the subservience to the signory and the galling restrictions which were imposed on him; but a Doge of large experience, strong character, and inflexible will was of no small weight in the councils of the State : such a Doge was Foscari. Florence made a second appeal, and to her supplication there was attached a threat: "If you refuse to help us, we will see to it that the whole edifice comes crashing down over our head. We refused succour to Genoa when she strove with you ; then she made Visconti lord : if you refuse to help us in our need, we will make Filippo a King" (Romanin). Genoa was once again in the power of Milan, and there was no knowing how formidable the Duke might become at sea, for he had the harbour, the maritime and commercial energies, and the old hate of the Genoese against Venice at his disposal. These motives to action were strong; nor were these all. A great soldier had placed his services at the disposal of the State. Carmagnola made his voice and influence heard and felt. He had been a simple soldier of fortune, but the keen eye of Filippo Maria had marked his courage. The Duke was more than half a coward, like his father, but, like him, he admired and rewarded bravery, and was a keen judge of intellectual capacity. Carmagnola more than any man had contributed to the restoration of the Duke's fortunes. He had married his daughter, and had amassed an enormous fortune, a great part of which he invested in Venice. The Duke mistrusted him, and he escaped to Venice, where he gained the ear and confidence of the Senate. He exposed the tricks and perfidies, and what he knew of the plans of the Duke, and urged the Senate to declare war and employ him against his late master. His grievance against Visconti was acutely personal, for the large fortune which he had invested in the duchy had been sequestrated.

Foscari addressed the Senate; he made a stirring appeal to its loftier and more disinterested emotions. "Were I at the uttermost ends of the earth," he said, " a nation in peril of losing its freedom would make me haste eagerly to its aid." He appealed to self-interest and the instinct of self-preservation. "Shall we sit quietly by and see Filippo suppress the Florentine free State? Then will he carry devastation and ruin throughout all Italy. He will exhaust and conquer it without serious impediment." It was true. Florence alone stood between Filippo Maria and the realization of his ambition, and Florence had been repeatedly defeated and exhausted. The party of war gained the day (Romanin).

A treaty of alliance was signed by the two republics. They engaged to share the burden of 16,000 horse and 8,000 foot. Florence engaged to put a fleet on Genoese waters, Venice to send one up the Po. All conquests made in Lombardy were to fall to Venice. The Marquis of Ferrara, the lord of Mantua, the republic of Siena, the Duke of Savoy, and the 
King of Aragon, successively joined the league, and war was declared in January, 1426.

Carmagnola opened the campaign by seizing a ward of the city of Brescia that was separately fortified. He had delivered the city from Pandolfo Malatesta, and was held in high honour by many of the citizens. The Guelphs were very disaffected under the rule of Visconti, and let him into the lower part of the city where they dwelt; but there were three other quarters, which were separately fortified and surmounted by a great citadel. The fortifications were strong, and the situation of Carmagnola was not devoid of danger. His genius, aided by the recent improvements in artillery, triumphed, however. There were five successive capitulations, at long intervals, of five fortresses, and, finally, Carmagnola was master of the entire town. Pope Martin V. now tried to mediate. The Duke was agreeable to resign his pretensions to Brescia and Bergamo, and peace was proclaimed at the end of the year (1426).

Filippo Maria Visconti was truculent in provoking war, but the least misadventure to his arms was sufficient to make him draw his claws in. But his wealth was enormous, and no sooner was peace proclaimed than he sought to renew the war. By this method he was enabled to withdraw from an enterprise with no very serious loss, and immediately recommence his policy of worry and exhaustion. The war recommenced in 1427. The Venetian Admiral sailed up the Po, and succeeded in burning the Milanese fleet; but want of soldiers prevented him from following up his success. Carmagnola, too, was, or professed to be, ill. He had fallen from his horse, and, when he returned to the command, he allowed himself to be surprised, and lost 1,500 men, who were taken prisoners. Henceforward, no one ever had cause to complain of his rashness in the field; he increased his precautions against surprise; he encamped within a laager of waggons. Seventy thousand men were now in the field-a prodigious army for those times-and an immense expense to both combatants. So large an army involved development in strategy and tactics. The Duke, pusillanimous as he was by nature, came into the field to encourage his troops. A battle was fought, but it was indecisive. The Duke, learning that the Duke of Savoy and the Marquis of Montferrat were invading his western frontier, retired to Milan, and shortly afterwards one of his Generals defeated the Piedmontese (I427).

Filippo Visconti had not the magnetic personality nor the art of managing his Generals that his father had possessed. Niccolo Piccinino, Francesco Sforza, Guido Torello, and Della Pergola commanded rival bands, and their dissensions allowed Carmagnola to win a series of successes. Filippo Maria had encouraged the rivalry of his Generals in order to get the best out of them, and to prevent anyone of them from becoming too powerful. He avoided giving offence to all by preferring none; but the mutual jealousies of the Captains and their troops produced so much incompetence and military loss that he had to entrust the chief command to Carlo Malatesta. Malatesta was a man whose rank would probably command respect; but he was a poor General, and in spite of the advice of his Captains he attacked the strong position taken up by the wary Venetian commander, and lost the day (1427). He was taken prisoner with 8,000 men-at-arms, an immense booty fell to the victors, and so bloodless had battle become that not a single man died on the field. 
Now it was the custom of condottieri to release prisoners of war without ransom, but to retain their horses and armour. We have explained the reason. Condottieri were well paid; they often only sought victory when the confidence of their employers was shaken; they had no interest in the quarrels in which they engaged, and the foes of to-day had been boon companions, and hoped to be so again. Nearly all the soldiers taken had served under Carmagnola, and more than once during the campaign they had shown that their affection for their old General was not abated. During the night following the victory nearly all prisoners were set free. In the morning the provveditori sought the tent of Carmagnola to complain. Carmagnola was an abler man than any of the Generals employed by the Duke ; he hoped to be recalled some day to the Duke's service when the war was ended; he had money invested in Milan, and he was not going to court unpopularity with his army, or break through those conventions of warfare that were so advantageous and agreeable to the free companies; the Republic of Venice ought to be only too thankful for the service he had rendered it ; he certainly would not become its submissive servant in a military matter with which it was unusual and impertinent for civilians to meddle. He ordered all the prisoners that were still to be found in the camp to be gathered together. Then he addressed them : "Since my soldiers have liberated your brethren in arms I am not going to behave less handsomely; take your departure, gentlemen," said he (And. Billii Hist.-Naugerio Storia Venez.). The provveditori had to put up with what they could not prevent. Carmagnola could be as high-handed as the Senate; he was indispensable to the Senate, but the Senate was not indispensable to him. The Senate continued to show him every mark of favour, but they did not forget.

Visconti bought new armour and harness of two Milanese armourers (for the city was great in the manufacture of harness of all kinds) and re-equipped his men; yet he began to be relatively inactive. The secretary of the Duke, who had been at the bottom of Carmagnola's dismissal, died about this time; it is possible that this event may have excited the thought of a possible return to Milan into vivid hope. Carmagnola refused to push on to Milan, though he gained some slight successes. Visconti repeated his usual policy ; he made terms with Savoy, resigning Vercelli. Florence was exhausted, the Lords of Ferrara and Mantua ruined; Visconti could get nothing but vain promises from the Emperor; Carmagnola was anxious for a peace which might restore him to his property and his family; the war party in Venice alone desired war, though the Turk was ever hovering around and menacing Venetian possessions in the Levant. The Pope mediated, and Venice was obliged to give way; she got the Adda for her frontier. Carmagnola got back his fortune, and his family was restored to him (1428). But Visconti, while keeping within the exact letter of treaties, and the public obligations usually respected in that day, exhibited a cunning that was truly devilish. His spies were everywhere; his policy was to prepare in times of peace for provocation of war. He kept Italy in a turmoil, and had his finger in every pie. There were dark intrigues abroad: an attempt was made in I 430 on the life of the Doge. Florence had again been defeated by a Piccinino, one of the Duke's Generals. Venice was genuinely alarmedthat arch-enemy, the Duke, must be overthrown at any cost, and when 
Florence appealed to her for help against their common enemy, and promised to furnish both money and men for a campaign in Lombardy, as well as to sustain the war in Tuscany, the war party again prevailed. They engaged Carmagnola as their General; he had money invested in Venice, so they felt sure of him. They gave him a huge salary, and promised him the lordship of Milan in the event of success. The long purse and persistent intrigue of Visconti, however, was beginning to tell on the treasury and patience of the State. There was a secret offer made by Venice of 25,000 ducats for his assassination. But Carmagnola had money locked up in the dukedom as well as in Venice; he was opposed by two great Generals, Niccola Piccinino and Francesco Sforza, commanding the best troops in Italy, and Sforza had been promised a natural daughter of the Duke's in marriage (she was at present only seven years of age). Carmagnola tried to play a double game. He would not be too energetic; he would enjoy his pay while the war lasted, and on its termination he might yet re-enter the service of Visconti, and take the position to which he aspired. He lost a battle and I,600 prisoners; he only saved himself by precipitate flight. About the same time the Duke got other successes near Cremona and in Montferrat, while one of his Generals succeeded in penetrating into and ravaging Florentine territory (I43I). Then a Venetian fleet that had been sent up the Po was attacked and almost destroyed, twenty-eight galleys and forty-two transports were taken, 2,500 men were killed, and an immense booty fell to the Duke. This armament had cost the Venetians 600,000 florins. Meanwhile, Carmagnola was on the wrong bank of the river to render aid. The defeat was to some extent avenged by a victory in western waters over the Genoese, now become subjects of the Duke, but Carmagnola remained strangely inactive, and made no attempt to repair the disaster on the Po, which was attributed to his faulty strategy or want of zeal. He did not even advance to the siege of Cremona, a gate of which had been surprised by some of his own men. Carmagnola furnished the Senate with specious excuses-his inaction had been enforced; the prevalent epidemic among horses had dismounted half his men; he had feared an ambuscade on the road to Cremona. The Senate affected to believe him, and spoke of the possibility of arranging terms of peace. Would Carmagnola come to Venice to discuss the matter ? He arrived, accompanied by the lord of Mantua, and both were received with every honour due to men of such distinction. They were met by the most prominent citizens, and conducted to the ducal palace. The Senate was sitting, and Carmagnola was received with apparent respect. The deliberations continued far into the night, and Carmagnola's guard went to bed; then he was arrested. He was secretly tried by the Ten, put to the question, after the universal barbarous practice of the age, found guilty, and given over for execution. Twenty days after the trial he was gagged, and his hands tied behind his back. He was led to the Piazzetta, and publicly decapitated between the pillars of the two patron saints of the Republic, the columns of St. Theodore and St. Mark (1432).

It was a bold step for the Republic to take, but she was convinced of the General's perfidy, and she was content with no divided service. She, at least, was not going to be at the mercy of her condottieri ; the inferior talents of a General who could be depended on were preferable to the genius of a man on whom she could not rely. 


\section{The Wars with Milan to the Peace of Lodi (1455)}

Each summer saw a new campaign opened by Visconti against Venice. Every truce, every peace (and truces and peaces were plentiful), was merely a dodge of Visconti to get breathing-time. In the main the question of success resolved itself into whether Visconti or the Senate had the longer purse, and could best hold out in the gamc. The policy of Venice was menaced by the opposition of more than one external foe. Her merchant nobility were called upon to make enormous sacrifices, but their patriotism responded to the call. For the real religion of the Venetian was the worship of his city. Stress of circumstance and native idealism had given supreme value to the maintenance of Venice. The worship of his city could even emancipate the individual citizen from considerations of personal profit, the political party from the prejudices of passion. The merchant nobles held themselves to be trustees of a great State, of which the permanent interests were their own. Those wealthy men whose nameswere not inscribed in the Golden Book saw their sons occupying high positions in the civil service, or present in official, though not in deliberative or determining, capacity in the councils of the State. The people were content because they enjoyed the peace of a settled Government and the advantages of trade that undeviating policy and expanding territory procured for them. But the recent expenses of imperialistic policy, and the concentration of political power in a class, some of the members of which were poor or vicious, now began to cause some measure of dissent. Discontent began to penetrate even this compact, consolidated, and forcible State, in spite of commercial prosperity. Men had not forgotten that, but a few years before, the Doge had been deprived of his right to summon the general assembly, and that the form of consent to his authority had been taken away from the people. There still remained a section of the oligarchy antagonistic to the prosecution of the war, and the discontent of the dispossessed families on the mainland and Visconti's machinations strengthened this party of peace, and while the usurped power of the Ten was disliked by many, the wealthy nobles were suspicious of the Doge. He was believed to curry favour with the poorer nobles, and he had certainly given lavishly of his wealth to dower their daughters when he was procurator. There can be no doubt that the presence of an idle and impoverished noble class was becoming a menace to the State. Out of these undercurrents of unrest came conspiracy. In I433 measures swift and stern had to be taken, and two years later the intrigues of Visconti were successful in getting the last of the Carraresi to try to rccover the States lost to his family, and in urging Polenta, the lord of Ravenna, to renounce his allegiance to Venice. Both attempts were unavailing. Carrara was taken and executed between the columns of Theodore and Mark, Polenta was banished to a distant possession, and Ravenna was definitely annexed (I44I).

Meanwhile Venice and Florence remained in more or less loose alliance against the efforts of Visconti to become master of Italy. Florence was not too pleased to see Venice creeping eastward and southward, but it was to the common interests of the two States to oppose the wealthiest, craftiest, and most ambitious potentate in Italy. Perpetual ivarfare was 
carried on by mercenary troops, and tactics were developed into a fine art by such commanders as Francesco Sforza, Gattamalata, Piccinino, and a host of other condottieri. Sforza was usually to be found fighting on the side of Venice and Florence, but all the Generals had no other interest in the war than the pursuit of their own advantage. The battles were not sanguinary, for comrades-in-arms were extremely unwilling to do each other much harm unless there was a chance of carving out a State for themselves. The greatest injury done by these campaigns was to the treasury; and marches, countermarches, and almost bloodless battles fought by men in armour so heavy as to be impenetrable to the weapons of those days, are chiefly of interest to the student of the evolution of the art of war. Various permutations and combinations complicate the history. These arose from the conflict of almost innumerable interests; from the simultaneous ambitions of competitors to the throne of Naples; from the Papal policy; from that of Florence and Venice; from the anxiety of feudatories to be free, of small States to aggrandize themselves or defend their interests, of faction to seize an advantage and get the upper hand in the cities. Entanglements arose from aggressions of rapacious condottieri, who established themselves as despots wherever they could, and the mutable intentions of Filippo Maria Visconti, whose designs and apprehensions were so subtle and occult that they were ever an unknown quantity in the game. Divested, not without difficulty, of these interfering factors, the story of the later stages of this war, which lasted on and off for twentyone years, from the year I 426 to 1427 , when Visconti died, may be summarized thus :

In I 437 a formal assent to the conquests made by the republic was obtained from Sigismund the Emperor. In I438 Filippo Maria endeavoured to isolate Venice. He succeeded in detaching the Pope by offering to recover for him all the States that he had infeodated to Sforza ; he also forced Polenta, the lord of Ravenna, to eject the Venetian garrison, and to place himself under the protection of Milan. His General, Piccinino, compelled Gattamelata, the Venetian commander, to retreat, and besieged and cut off Verona and Brescia. Venice was now so hard pressed that she had to seek help from Florence, for in spite of an heroic defence of Brescia the fall of both Verona and Brescia was expected daily, the support of Ferrara was lost, and the Marquis of Mantua had joined the Duke. The campaign of I 439 was opened by a march across the mountains of the army of the allies under the command of Sforza; he thus outgeneralled Piccinino, the Duke's commander, and relieved Verona. But Brescia, suffering both from plague and famine, was still closely invested, and a Venetian fleet sent down the Lago di Garda was surprised and burned. Piccinino contrived to block the way to Brescia, and defeated Sforza at Bardolino, but the latter General resumed his old tactics : he again made for the mountains, and marched round the eastern bank of Lago di Garda. Piccinino then embarked his army on the lake, and met his rival at Tenna, a castle commanding a valley along which the troops of Sforza were marching. Several skirmishes took place without much result, but at last Piccinino, who was naturally of impetuous temper, was indiscreet enough to give battle, although he held his foe as secure as a rat in a trap. The withdrawal of Piccinino's troops from before Brescia had allowed the lean and hungry citizens to creep over the mountains, and weird and gaunt 
forms appeared on the hillsides, and began to hurl rocks down on the Milanese troops at a critical moment. Not much harm could have been done by them, but the Milanese cavalry was unaccustomed to encounter any very serious danger ; they took fright and fled precipitately, throwing themselves in their blind rush into the arms of the enemy, by whom most of them were captured, while Piccinino was obliged to retire and shut himself up in a neighbouring castle. Prolonged resistance would have been impossible, but Piccinino was not the man to be taken if mother-wit and hazardous stratagem might serve him. He had a sturdy German body-servant devoted to him, and who put him into a sack. The German, taking advantage of night, carried his burthen on his back to the field of battle, and affected to be busy rifling the dead. He contrived not merely to evade the attention of the victorious soldiery, too intent on despoiling the fallen to take very much notice, but also to pass the men on sentry-go, and carried his heavy load into safety (Cristoforo da Soldo, Ist. Bresciana, L. xxi., R.I.S., p. 815.-Joann. Simonete Histor. Franc. Sforz, L. v., p. 28I ). Eight days after Piccinino is said to have captured Verona, which, however, Sforza soon forced him to abandon. Piccinino now retired to Tuscany to pursue the war there, and his absence enabled Sforza to clear the districts of Brescia and Bergamo of the troops of Visconti. Sforza now went into winter quarters, whence Piccinino routed him out, and matters were going very badly with the Venetian General when Filippo Maria Visconti, not too safe at home and surrounded by self-seeking warriors, each of whom had an eye to the succession, offered to fulfil his ancient promise of giving the hand of his only child and heiress, the bastard Bianca, to his old General. Of course both Venice and the Duke were in the hands of their mercenary leaders, and both in truth were weary of the costly game in which they had indulged for so many years. Sforza married Bianca, and peace was patched up. The antagonists were content to accept their old boundaries (I44I).

Only two years elapsed, and the tortuous policy of the Duke led to an understanding between the Pope, Alfonzo of Naples, and himself, whereby Sforza was to be expelled from the lordship of the marches. This of course led to a counter-alliance between Venice and Florence, and a renewal of hostilities. Soon after, a reconciliation was effected by Florence between the Duke and his son-in-law ; but Sforza's Generals deserted to the King of Naples, taking almost all his forces with them. Nevertheless, in November, I443, when Piccinino had gone into winter quarters, Sforza returned the surprise visit he had once received from that General, but was unable to follow up his advantage for want of funds. All this time there had been no declaration of war between the republics and the Duke, and the allies took advantage of it to put pressure on Visconti. Piccinino was recalled, and died shortly after. But in 1446 Visconti used the absence of Sforza, who was marching towards Rome, to seize his bride's dowry, the towns of Cremona and Pontremoli. The republics considered this to be an infraction of the treaty, and declared war on the Duke. They pressed his Generals back, right to the very gates of Milan. The Duke was in straits ; he sent to Alfonzo for help. He offered the restitution of Asti to Charles VII. of France if he would but send to his support. $\mathrm{He}$ pointed out that a State such as Venice has a longer life, a more uniform aim, and is more persistent than a monarch; that it had striven to subju- 
gate all Lombardy for a century past, and that, once secure in the great rich plain, Venice would command the passes both of the Alps and Apennines, and, undisturbed by individual interests, but impelled by the public good and the increase of the power and wealth of the city, the undying Senate would subjugate all Italy, and become a menace to the West. Alfonzo was convinced, the view of Cosimo dei Medici was not dissimilar, France alone thought the danger too distant. Sforza himself, approached by the Duke, was found to be of the same mind. Visconti tools care to point out that he was getting enfeebled by age, that Sforza was his sonin-law, and, through his wife, would become his inheritor. Without his support he was lost, and with his fall would disappear Sforza's own hopes. Sforza had old scores to pay back to the Duke, but self-interest weighed with him more than resentment; he became ambiguous ; he really wanted to gain time. Cosimo diminished the subsidies sent from Florence, for the Duke was in such a position that there was little to be feared from him now. The Venetians became more than suspicious of Sforza; they attempted to seize Cremona by stealth, but Sforza was on the alert, and defeated the project. This event turned the balance. Sforza accepted Visconti's proposal ; he entered once again into the service of his fatherin-law. But no sooner had he done so than Visconti stopped all pay, ordered Sforza to march on Padua or Verona, and forbade both him and Bianca and their son to approach Milan. It was not a part of his crooked and perverse policy to give any of his servants too much power, not even a son-in-law and the father of the grandchild in whom he seemed to take great interest. Venice retorted by sending Attendolo, their General, into Milanese territory, and the country was laid waste right up to the walls of Milan. The signoria called on the Milanese to rise and recover their freedom from an aged and feeble tyrant, and extinguish the House of Visconti. Should they obey the summons they would have Venice for a shield, and all their ancient liberties should be protected, or Venice would even re-establish them as a republic if they desired it.

Once again was Visconti compelled to seek the strong right arm of his son-in-law. Sforza had no choice but to accede : not merely was it to his advantage to do so, but he was destitute of funds, and almost despoiled of the Marches. He surrendered his claim to the Marches to the Pope, got money from Alfonzo, and set out to the relief of Milan. But while still on the march he heard of the death of Visconti and the revolt of Milan (August, I 447).

The Republic was reconstituted at Milan, and the new Government endeavoured to negotiate peace with Venice. But Venice had no burning desire to see a focus of liberty established on the mainland so near to her own subject cities. She had got a lust for territory; she believed that she would never be quite secure until she ruled the great plain from the Alps to the Apennines. She was unwilling that a war, which had lasted for a generation, and had almost exhausted her resources, should be so barren of result. The old Doge Foscari and the signoria refused to negotiate unless the new republic was prepared to refund all the expenses of the war, and give reparation for damages sustained: until this was done Venice would prefer to keep her conquests in Milanese territory.

Venice undoubtedly committed a political blunder if Milan really retained sufficient of the spirit of liberty to uphold a permanent and strong 
republican form of Government, but that may well be doubted. Had it been possible for Venice to peer " within the womb of time and see what seeds would grow and what would not," she would certainly not have adopted a policy which led France and Germany to claim the heirship of Visconti, and was one of the main factors in the enslavement of the peninsula to the foreigner. But probably the Venetian Government saw that the partition of North and Central Italy between the three republics of Florence, Milan, and Venice was an impracticable dream. She could not foresee the future, and there were passions and ambitions that lent themselves to the moulding hands of incalculable destiny. The subject cities of Milan revolted, and declared their autonomy ; Sforza assumed the command on behalf of Milan; Michele Attendolo was entrusted with the direction of the Venetian army. In vain did Attendolo try to draw Sforza away from the siege of rebellious Piacenza. Piacenza fell, and negotiations for peace were entered into. These proved futile owing to the intrigues of Sforza, whose secret aim was nothing less than the dukedom. Sforza soon recovered all the Milanese territory that lay on the right bank of the Adda. He succeeded in burning the Venetian fleet at Casale Maggiore on the Po, and finally took almost the entire Venetian army prisoners at Caravaggio. Maria Sanuto says that only one man was killed (Vite de' Duchi, p. I I29). This is certainly an exaggeration, but tactics and timidity appear to have become the ruling factors among mercenary soldiers in the field, while truculent voracity still marked their conduct when off it. Fifteen hundred horse managed to escape, but not a single foot-soldier; the two provveditori of St. Mark were taken with immense booty, and Sforza, unwilling to make the Republic of Milan too formidable for his purposes, and unable to deal with prisoners almost as numerous as his own troops, had them stripped and released (I448) (Joann. Simonete, L. xiii.).

Discouragement fell on Venice. The strongest of her fortified cities had been taken, the finest fleet that had ever navigated the Po had been burned, the most numerous army ever despatched to the mainland had been defeated and despoiled of its treasury, its horses, its armour. The Government removed Attendolo from his command, inquired closely into his conduct, and ordered him to retire to his fief of Cornegliano. Milan was ready to give up Brescia in order to secure peace, but Venice entered into secret negotiations with Sforza, and offered to help him to the sovereignty of Milan if he would come over to their side. But a little more than a month elapsed after the battle of Caravaggio when it was agreed between Sforza and Venice that the territories of Bergamo, Brescia, Crema, and the Ghiara d'Adda should be ceded to Venice on the accession of Sforza to the States of Filippo Maria, and there was to be mutual support to that end. Within a year Milan was compelled to negotiate with Venice, but the transaction was kept profoundly'secret. The object of both the new Republic and of the Doge and Senate was now to prevent the able and warlike commander from getting command of the city. Venice held her hand until a conspiracy should pull off of which Sforza held the threads : this plot was successful; in September, I449, Crema and Lodi both surrendered, and the banner of St. Mark floated over the former town. Venice had got all she had bargained for. She informed the General that she had signed an armistice with the Republic, and with- 
drew Bartolommeo Colleoni and her army. A fortnight later a treaty was signed at Brescia whereby Milan and Venice both acknowledged Sforza as lord of Novara, Tortona, Alessandria, Pavia, Piacenza, Parma, and Cremona, so that, although Venice withdrew from her promise to make Sforza lord of Milan, she was ready to accede to his becoming an extremely powerful ruler, and cannot be accused of having behaved ungenerously towards him. But such an arrangement was far from satisfying the ambitions of Sforza. He claimed the heritage of his father-in-law, and nothing less would serve him. He had worked and suffered to this end for years, and he was determined to be lord of Milan or nothing. $\mathrm{He}$ refused to sign the treaty. Within a year he was proclaimed Duke in the streets of Milan (1450). Sforza had served Florence in her wars; he was secretly financed by Florentine bankers, and he had the friendship and confidence of Cosimo dei Medici, who manipulated the Government of that city. Fear of Venetian ambition caused Florence to ally herself with the successful condottiere, and the defection of her ancient ally obliged Venice to arrange a new balance of power in Italy. Alfonzo reigned at Naples, and though Neapolitan piracy had led to the burning of forty-seven vessels in the port of Syracuse and the raiding of the coasts of Sicily and Naples by the Venetian fleet as late as the preceding year, the Neapolitan King entertained designs, and had even made attempts, on Tuscany. $\mathrm{He}$ pocketed the Venetian affront, and allied himself with Venice. Florence and Sforza, therefore, were opposed by Naples and Venice. With Sforza went the Marquis of Mantua, a pupil of Victorin of Feltro, the celebrated schoolmaster of the " joyous house." The Marquis was a scholar and a patron of letters; he was no unworthy pupil of the great teacher, a "very gentle parfite knight" of those days, but that did not prevent him from despoiling his brother of his share of the family estate. Policy did not admit of a brother near the throne, and Charles really seems to have been of a character that rendered him somewhat inconvenient as a near relation. The Marquis of Ferrara, a much more powerful Prince, educated by the great Greek scholar, Guarino of Verona, was also a cultivated man of letters, and, though he had studied warfare under Braccio, his temperament was pacific, and it was by his intervention that his father-in-law, Alfonzo, and Florence had been brought together. He died in 1450, and his brother Borgo, a bastard like himself, succeeded him. The new Marquis adhered to the Venetians while abstaining from active warfare, and exerted himself to bring about peace. The Marquis of Montferrat and the Duke of Savoy also took the Venetian side. The alliance of Naples and Venice was followed up by the ejection of all Florentines from both territories, and although the approaching coronation of Frederick III. postponed hostilities, war was declared almost immediately after that function was over (1452). Venice threw down the gauntlet to Sforza, Alfonzo to Florence. Florence took René, Count of Anjou, the titular King of Naples and aspirant to the throne, into her pay, and he descended into Lombardy. René succeeded in detaching the Marquis of IMontferrat, who had a personal grievance against Sforza, from the coalition against him. The Count was of a singularly a miable and conciliatory disposition, but he was not able to impregnate his army with his own gracious spirit. Fifteen thousand men, trained in the brutalities of Anglo-French warfare, were of different mettle from the tacticians of Italy. They did not play 
at warfare as if it were a game of chess ; they carried Pontevico by assault, and spared neither man, woman, child, nor even those who surrendered. The massacre of their comrades roused at last the Italian valour that had become so sluggish. The very troopers of Sforza turned against the Frenchmen with fury; they charged them through the streets, fired the houses where they were billeted, and were only called off, and that with difficulty, by Sforza himself. But the brutality of the French had this salutary result : it helped to put an end to the war. Town after town, fortress after fortress, fearing a like fate, sent in their keys to Sforza. The universal panic reached even the seasoned veterans of Venice, and they took to their heels. René returned to France, hopeless of ever getting the Neapolitan Crown, sensible of the inferiority of the French to the Italians in the art, if not in the ferocity, of war, and chagrined at the bad feeling which the atrocious behaviour of his men had bred between the two races. His withdrawal, by weakening Sforza, disposed him towards peace. The contemporaneous fall of Constantinople was a heavy blow to Venetian commerce. She had been too exhausted by the war to send support to the tottering city, even could such aid have availed. Everyone cursed the intestine wars that had cut off the bulwark of Christianity in the East from succour. A congress assembled at Rome was unanimous for peace that the united forces of Italy might be turned against the Turk; and the Cardinal of S. Angelo, the Papal nuncio, made his voice heard above all for the unity of Christendom and the defence of its faith (Epist. Card.S. Angeli apud Porcelli de Gestis Scipionis Piccinini Deca II., L. v., p. 35.Joann. Simonetce, L. xxiii., p. 645).

But this unanimity could not last. Immediate interests near at home are always more potent than possible and distant dangers, and contrition is a fugitive passion. While no great amount of help might, it is said, have saved Constantinople, it would require a gigantic effort to reconquer the city. When the congress assembled everybody professed a sincere and earnest desire for peace, but everybody asked too much for himself. Alfonzo required Florence to reimburse what the war had cost him; Venice demanded the restitution of all that Sforza had conquered in Brescian and Bergamesque territory, with the cession of Cremona, and the Po and Adda for a frontier. Sforza, on the other hand, demanded Crema, Brescia, and Bergamo, which the Venetians were unable to defend, and which he charged them with having unjustly acquired. And the Pope, if one may believe Simoneta and even Manetti, his panegyrist, was not sincere in his call for a crusade. "He was prudent enough to perceive that the wars of Italy secured the peace of the Church, that the concord of its rulers, on the contrary, menaced its tranquillity" (Vita Nicolai V. a Janetto Manetto, R.I.S., L. iii., P.rii., p. 943.Joann. Simonete, L. xxiv., p. 666). Consequently he was urbane in manner, but saw to it that negotiations did not come to a point. The Venetian Ambassadors had the penetration to perceive what was going on ; they did not believe that Alfonzo really desired peace, and the Senate entrusted a monk with the mission of coming to a secret understanding with Sforza. Venice was ready to withdraw her pretensions to Cremona, but she wanted Bergamo and Brescia. Sforza insisted on the cession of Crema, which would be a thorn in his side in the event of future hostilities. The Council of Ten desired peace above all things, but they did not like to appear to give way. They sent to Bartolommeo Coleoni to arrange to hand over 
the city to him if he would affect to surprise it, but their emissary discovered that Coleoni was meditating a transfer of his services to the Republic, and advised the Ten not to put too low a price on themselves. Meanwhile Sforza had learned that not merely Coleoni, but also Sigismondo Malatesta was about to abandon him for Venice, and the Florentines sent to say that financially they were nearly played out, and could not give endless aid to Sforza. Sforza at once reopened negotiations, and a member of the Venetian Senate was despatched to Lodi, disguised as a minorite, in order to evade all suspicion of what was going on. At the end of eight days an agreement was come to, and shortly after the terms of peace between Venice and Sforza were proclaimed to an astonished Italy. Venice acquired Bergamo and Brescia, but lost Ghiara d'Adda. Various rectifications of frontier affecting the smaller rulers were proposed, and all the participants of this universal war were invited to sign the treaty of Lodi (1453).

\section{The Reign of Francesco Foscari (1423-1457)}

During the long reign of the Doge Foscari (1423-I457) Venice may be said to have reached and passed the zenith of her glory. Even the conquests of the Turk seemed at first to increase her power, for islands and little States, finding their impotence to protect themselves from the advancing enemy, had sought the protection of St. Mark, and become the tributaries or subjects of the Great Republic. Her conquests on the mainland inspired her citizens with the belief that they were destined to rule all Italy, or at least the greater part of it. Even when Constantinople was captured by Mohammed II. the wonderful skill of the Venetian diplomatic service turned what was at first rightly regarded as a disaster of the first magnitude into a matter of apparent unimportance. The Venetians captured by the Turk were redeemed, and a treaty was concluded with the Sultan whereby Venetians continued to enjoy the same self-government in the city that they had done under the Christian Emperors. They retained their own courts of law, and free trade and a thoroughly good understanding were cstablished. Doubtless the great war with the Visconti, which prevented them from sending an armament to defend the Eastern Empire, enabled them to effect this treaty. The Turk knew the great maritime power of Venice, and Venice had stood neutral in the contest.

She now had a land empire close to her shores, she was sure of a plentiful supply of food-stuffs, and she commanded the passes of the Alps for the transit of her merchandise. The balance of power in Italy was established and was likely to give her present security. America was not yet discovered, nor had the great highway to India round the Cape been traversed, so that there was no dread of any possible disturbance to her commercial supremacy. Palaces were rising along her waterways as if at the waving of a magician's wand; her dames were decked in silks and satins and brocades ; her men, still sober in their attire, were animated by confidence in the destiny of their city, and were remarkable even among Italians for their commercial shrewdness and enterprise, so that, as a Milanese said, "those who traded with them had needs to strain both eyes and ears " (Pietro da Casola, Viaggio, Milan, I 855). Her citizens were so busy that they had neither time nor inclination for politics ; they had gradually 
been excluded from participation in government, and could not have attained to it without the doubtful experiment of a revolution, for which as shrewd citizens they had no stomach. They had enough to do with the management of their own trade associations, which were organized with a view to the common good, and had not been exploited by the capitalist to his own advantage as elsewhere in Italy. The class of merchant nobles were their brethren in the guild, and there, at least, there was no sharp separation of classes, and so much was this outlet for political energy encouraged that even the sausage-makers had a guild (Cam. Mod. Hist., Vol. I., p. 284). The poor were well looked after; there were many benevolent associations and hospitals for the sick; so that the people were marked not merely by content, but by rcal enthusiasm for the city for which, indeed, they were rcady to dic at need.

There was, however, a canker in the State. The noble class contained many unworthy, idle, or incompetent scions, and these had bred that worst of all causes of corruption that can infect a State-a proud, poor, and discontented aristocracy. The Doge had always been suspected of endeavouring to increase his power by subsidizing this class. He had given a fortune to endow its daughters ; he was a man tenacious of purpose, and of undoubtable will-power. When he was elected he was over fifty, but he was young for a Doge, and he preserved the full vigour of manhood throughout the greater period of his long reign. Though he had the misfortune to lose three of his sons he was suspected of aiming at the aggrandizement of his family, and he was usually at cross purposes with the Ten, who were determined to preserve and augment the power which they had usurped. Foscari was a man of strong family affection, which he lavished on his surviving son Jacopo, an empty man and given to trifle. The Ten struck at Foscari through his son. As early as 1445 a Florentine exile made a secret accusation against Jacopo to the effect that he had received presents from Filippo Maria, the Duke of Milan, and enemy of the State. He was strappadoed, and made a confession, which was probably true, and the Ten exiled him to Roumania, but, on his earnest appeal, softened the sentence to residence in any place he might choose in the Trevisan. Jacopo had broken the Venetian law, and one cannot accuse the Senate of meting out undue severity. In 1450 one of the three Inquisitors of State was assassinated, and as a servant of Jacopo's had been seen in Venicc on the day of the murder and had been one of the first to give the news, information was given, the man was seized, and, after the cruel manner of the times, tortured to discover the truth. He was submitted no less than eighty times to the strappado, but continued to affirm his innocence and that of his master in the most unshaken way. But Jacopo was still suspected, and the Council and the Doge were at such variance that this did not content the Ten. Jacopo was seized and tortured in turn, but with no result, and he was then transported to Canea, and the informer rewarded. But Jacopo's reason became affected, and the Senate were humane enough to allow him to return to Venice and see his father, after which he was taken back to Canea without delay. And soon after the real author of the murder, a man who had been guilty of previous crime, confessed. Nevertheless the Ten kept Jacopo in banishment, and refused the old Doge his earnest request to resign the ducal dignity. There was evident fear of what might happen should the Doge be released from the 
trammels of office, or Jacopo be allowed to return. Jacopo had regained his reason, and seems to have suffered from home-sickness in his far-away place of banishment. He was brought back on the charge of having been in secret correspondence with the Duke of Milan (1456). Jacopo did not deny the allegation; he said that life had become intolerable to him, and he had written the letter and purposely placed it where it was certain to be discovered, since he would rather see his father and Venice and die there than lead a life in death at Canea. In spite of this avowal Jacopo was put to the torture with a view to the denial of its truth. Then his father, wife, and relations were allowed to visit him. The aged Doge, leaning on his staff, was scarcely able to drag himself to the place where his son lay lacerated, with his wounds covered with bandages. Jacopo still harped on being allowed to remain in Venice. "Return to exile, my son," replied the Doge. "Since your country orders you, you must obey." But while returning to the palace the old man broke down, and fell forward in a faint. Jacopo was sent back to Canea, where, after a year of close imprisonment, he was to have had a certain measure of freedom, but he died shortly after his arrival there.

The unhappy Doge, now in his eighty-sixth year, was broken by this last blow, and became incapable of fulfilling the duties of his office. His mind remained clear, but he succumbed to the terrible and hopeless loneliness of age and personal loss. The man who had held the helm of State, and calmly steered the good ship through such troublous waters, had warm family affections. He had maintained the authority of Venice against a beloved, if foolish, son, and the conflict of duty and prudence with passion undermined a constitution which had withstood the attacks of age. $\mathrm{He}$ had been that being most odious to the Ten-a strong Doge with a will of his own, and the enemies he had created had little pity for his domestic calamities, and no reverence for his past services or his advanced age, for the force of personality can repel as well as attract, can induce hatred as well as devotion. There was no precedent nor provision for enforced abdication, but the Doge was now clearly incompetent, and his chief foe among the Ten proposed that the difficulty of deposition could be evaded if Foscari were induced to resign. Twice before he had wished to abdicate, and his request had been refused. Now Foscari firmly declined to go back on that oath which he took at his coronation-namely, to fulfil his duty to the end. The Council met again : Foscari was formally released from his oath, awarded a life pension of 2,00o ducats, and ordered to quit the palace within three days. Among the councillors who bore this order the Doge remarked one whom he could not recognise. He asked him for his name : it was given. "Ah !" said the Doge with a sigh, " your father was my friend." At the appointed time his ducal cap was removed and his ring broken, and the aged man slowly and painfully descended the stairs up which thirty-four years before he had wended with firm and resolute step to take on the leadership of the Republic. The heroic old man refused the proffered arm, but bore himself with gentle dignity, and so passed from the palace to lonely privacy. So general was the indignation that all reference to the event was officially prohibited. The aged heart of the ex-Doge was broken. He lived but a few days longer. As he heard the bells announcing the accession of the new Doge a bloodvessel burst in his chest, and Francesco Foscari found peace. 


\section{GENOA}

The Doge Fregoso was replaced by Niccola di Guarco in I378. Under his presidency Genoa conducted that struggle for existence with Venice which is recounted in the previous section. It was found necessary in that struggle to entrust the command of the forces of the State to the nobility, and it is to the credit of the Doria, Spinola, Fieschi, and Grimaldi that they responded nobly to the call. Genoa brought Venice down on her knees, and when the disaster of Chioggia occurred, and Genoa lost the finest fleet and the stoutest army she had ever sent against her foes, she was still able to sweep the Adriatic, and to dictate a peace advantageous both to herself and to her allies, the King of Hungary, the patriarch of Aquileia, and the lord of Padua. But Venice recovered rapidly from her exhaustion, because her constitutional oligarchy was nothing but the embodiment, instrument, trustee of a great impersonal but throbbing idea-that of the living mother-city whose honour required the self-effacement of every great noble, the willing service of the meanest citizen, and the devotion of all. In Genoa, on the other hand, there was no cohesion among her citizens ; she was torn by faction and lust of rule. She exhausted her strength in internal quarrels, and her sun soon set in a long night of servitude to foreign masters.

Probably the nobles aspired to taking the helm of State into their own hands again. Certainly the war had been very costly, and taxation was vastly increased, and in Holy Week, I 383 , during which the use of bells was prohibited, the tocsin was employed to summon the discontented to arms. They were headed by the butchers, who appear to have been as truculent a. body in Genoa as they were in Florence. The Doge was obliged to consent to the exclusion of the nobles from the councils of the nation, the suppression of a tribunal alleged to be partial, the recall of exiles, the remission of obnoxious taxes, and the disbanding of his personal guard. The return of the Fregosi and Adorni who were in exile by no means contributed to the peace of the city. The Doge was obliged to renew his guard; this united the various factions. An assault was made on the palace, and he had to flee in disguise.

No city in Italy was so divided by so many irreconciliable parties, so torn by the feuds of rival families, as Genoa the shameless, as Dante had called her. Men still ranged themselves under Guelph and Ghibelline banners, though the reason of the distinction was buried in the graves of the great Emperors and the great Popes. Nobles and citizens still formed two opposed camps, old vendette were handed down from father to son, and the quarrels of the new men, the Adorni, the Fregosi, the Montalti, and the Guarci replaced those of the Doria, the Spinola, the Grimaldi, and the Fieschi in the city, while those old families dwelling in country castles made war on one another, or united to harass the capital. Secure in their impregnable castles the old nobility still dominated and desolated the Riviera, and were a constant bale and menace to the State. They commanded the services of the sons of the soil, whose rights ranked with those of the bullocks they yoked, while the new men had their following among the sailors and workpeople in their employment. The sons of the 
merchants commanded their ships; the men, often very devoted, were trained to blind obedience. The conditions were favourable to the development of courage and resource ; the leaders were often men of very marked ability. During four years (I390-I394) Genoa was the scene of ten revolutions, and ten Doges successively supplanted one another. Gian Galeazzo, the crafty despot of Milan, whose design it was to subdue all Italy, was not slow to have his finger in the pie, and to save their city from falling into his power negotiations were entered into with the Ministers of Charles VI., the demented King of France (1396). It was arranged that Genoa should be governed by a French Vicar, with the same authority and subject to the same restrictions as the Doge. The Council was to be composed of an equal representation of Guelphs and Ghibellines, nobles and plebeians. The Vicar was to have two votes, and ten castles under his command in order to insure his safety, but he might not impose taxes or have aught to do with finance. The President of the Council was to be a Ghibelline, and Genoa was to retain freedom in foreign policy. But the attempt was a failure. Faction was not to be subdued, and two years later the Vicar fled to Savoy to save his life. Five great battles were fought within the walls of the city, twenty magnificent palaces were burned, many public buildings demolished, and property destroyed to the value of more than a million of florins. Nothing but the absolute exhaustion of every person and party terminated the strife, and the French Vicar was again installed in office, this time with almost plenary powers (I396) (Ubert. Folieta, Hist. Gen.-Georgio Stella, Annal. Genuens). Genoa did not throw off the French yoke until I4II, and after a brief period of servitude to the Marquis of Montferrat she re-established what she conceived to be a republic in I4I3. She had, it is true, a.Doge elected after the Venetian pattern, but political life in Genoa was one unceasing coil. It was no longer a strife between parties, between Guelph and Ghibelline, or the aristocracy and the people, but a free faction-fight, where old injuries were treasured up for retaliation, and unending efforts of the clergy and those in authority to bring about at least temporary reconciliation were thwarted by some haughty look or biting word or misinterpreted gesture. Then the sword was drawn, widows and orphans went into mourning, and shortly the vendetta recommenced. Enterprise decreased, commerce languished, the countryside was laid waste, castles blazed away, and rich and sumptuous palaces were razed to the ground. Genoa was not without wise and patriotic Doges. One, in particular, Tommaso di Campo Fregoso even owed his election to a previous Doge, who was an Adorno, and therefore an hereditary enemy, but whom dignity and magnanimity of character converted into a friend. Fregoso was a man of moderation, public spirit, and generosity ; he paid off the debts of the Republic, a sum of 60,000 florins, out of his private purse, and he was supported by five devoted brothers of great capacity for public business (Ubertus Folieta, Genuens Hist., L. x., p. 545.-Johannis Stella Ann. Genuens R.S.I., L. xvii., p. I 264). But jealousy or some other cause led to the emigration of the faction opposite to the Fregosi, and these sought the Court of Milan (I4I8). Filippo Maria sent Carmagnola against the city, and the Florentines refused to help unless they were allowed to purchase Leghorn. Florence bclieved that the Genoese were perfectly able to take care of themselves, and were in no serious danger, but in 
I420 Alfonzo of Aragon, to divert the public mind in Spain, adopted the time-honoured dodge of the monarch-foreign conquest. He set sail with a big Catalan fleet, circumnavigated Corsica, and attacked it without any provocation whatever. The whole island fell to his arms or intrigues save Bonifazio only. This strong place would have been starved into submission, but it was revictualled by the daring and skill of Giovanni Fregoso, the brother of the Doge, who sailed right across the great Catalan fleet into the harbour. Alfonzo gave up hope, and sailed to the south to make a bid for the throne of Naples. The expenses of the war determined the Genoese to sell Leghorn to Florence for I00,000 florins (I42I), and wearied and worn out by the war with the Duke of Milan, they gave him the sovereignty of the city on the same terms as the King of France had held it. The presence of a lieutenant of the Duke in the city was agreed to, but the continuance of their liberties was guaranteed (I42I). The Doge Fregoso resigned, and was given in compensation the lordship of Sarzana, whereby the Duke characteristically violated one of the stipulations as to boundary-observances of the treaty he had just signed with Florence.

The strong hand of the Duke kept the raging passions of the city within some sort of measure, but in 1435 their turbulent energies found a fresh outlet. René of Anjou and Alfonzo of Aragon were competing for the Neapolitan Crown, and Alfonzo was besieging Gaeta, by which he hoped to secure the communication of Capua with Sicily, and close the route to Naples to the French. René was supported by the Pope and the Duke of Milan. The Genoese had large trading establishments at Gaeta, and the Genoese in the city were on excellent terms with its inhabitants. Not merely, then, was Gaeta occupied by a foe to the Duke, but Genoese commerce was in danger of being captured by their trade rivals, the Catalans, who were a formidable and adventurous sea-power. The city was beginning to suffer from famine, and all the "useless mouths "were sent out. Troops of women, children, and old men arrived at the camp of the besieger. Alfonzo was a soldier-adventurer with all the vices and virtues of the character; he was generous, capable of sincere affection, though self-seeking and self-indulgent, but he shared with his time a genuine love of letters, and letters had disciplined his mind. Literature had been as a golden key that had unlocked the human heart to a man far from insensitive of nature. The man who always carried a classic author in his saddle-bag, who later made peace with Cosimo dei Medici on the strength of a Latin codex, had learned to value magnanimity, and to reach something of largeness and openness of soul. He refused to send the poor wretches back, and told his protesting Generals that he would rather be wanting of a city than of humanity. Probably his action lost him Gaeta, and led to his own captivity, but it gained him the hearts of the Neapolitans, and opened the way to the throne. It was one of the acts which have gained him the title of "the magnanimous" (Uberti Folietce Genuens Hist., L. x.-Barth. Facii, L. iv.).

A Genoese fleet was despatched to the relief of Gaeta, and was met by that of Alfonzo. The Catalans were defeated, and the King captured. $\mathrm{He}$ inquired into the rank of the various Captains, and when he learned that one of them was of a family whereof a member held the sovereignty of Chios, it was to this man alone that the proud Spaniard would surrender 
his sword. Not merely the King, but his brothers and the entire fleet were taken, and the Genoese, when they heard of the victory, renewed the memories of their ancient prowess, and thought that the golden days of their glory were going to return. Three days were set apart for thanksgiving, and the day of victory was ordered to be observed as a holiday for ever (1435).

But Visconti would not allow the royal prisoner to be taken to Genoa ; he must be conveyed to Milan. Filippo Maria already scented the danger of the French in Italy; he perceived that, once securely settled in the South, they could advance both over the Alps and from the "kingdom," and that Italy would be squeezed, exhausted, as in the coils of a serpent, and eventually swallowed. A close understanding was arranged between the whilom foes, and the Genoese were ordered to reconduct Alfonzo, with all the honours due to royalty, to the scene of their victory.

Genoa no sooner heard the news than smouldering discontent changed to open demonstration, and it was evident that there would be a revolt. The Duke summoned the most illustrious citizens to his Court. He said that Alfonzo was going to cede them Sardinia as the price of liberty, and sent them away rejoicing at the notion of recovering so great a prize. $\mathrm{He}$ also sent 2,000 troops to Genoa under the pretext that they were to be despatched to Sardinia. But soon the Genoese discovered that they had been gulled. And then there came an Embassy from Gaeta asking them to take the city and defend it ; but the Duke got hold of the envoys, tried to seduce them into receiving Alfonzo as their King, and sent them back without giving the Genoese a chance of accepting the offer.

The Genoese took advantage of a change of commander to revolt. The outgoing governor passed beyond the walls to receive the new official. When both were about to enter, the gate was closed by certain conspirators, the soldiers shut out, and the governors themselves were justled apart, and had to flee for their lives. One reached the fortress, the other was overtaken and slain, and his body exposed to public view outside one of the churches, while the whole town resounded with shouts of liberty and the clang of men arming. One after another all the strong places in the territory followed the example of the chief city, and the Republic was re-established. The laws were revised, and Embassies sent to Florence and Venice to seek admission to the confraternity of free peoples against the tyrant Duke (I435).

All Genoese territory was now under the control of the reconstituted Republic, but the conditions were unfavourable to its stability. It was still torn by the strife and coil of factions, and counted henceforward for very little in the political system of the peninsula. No Doge was able to quell the fierce passions of opposing interests, no accommodation that could reconcile them was possible. First there were the noble families holding many a stronghold up in the mountains and along the shore, possessing the confidence and devotion of many a sea-worn mariner and veteran archer who had fought under them in the battles of the State. The Doria, Spinola, Fieschi, and Grimaldi were indispensable to the fleets and land forces of the Republic. They were entrusted with a command which no one else could take. They had led the Genoese arms to victory in Sardinia, Sicily, South Italy, and the East, but while entrusted with military and naval leadership they were excluded from political power. 
Plebeian families had risen to wealth and sway, and were allied by common commercial interests and matrimonial alliances (that were determined by considerations of wealth, position, and power) with the various nobles, and all were divided into factions by opposed ambitions and conflicting purposes. Two such plebeian families, the Adorni and Fregosi, had come to the front in politics, and disputed the dogeship between them. The inevitable result of the complications and strife of faction was that the favourite of chance and the hour came to the front, and ruled for a brief space. No ruler represented any permanent principle. Hence was it that Genoa became the scene of unceasing revolution, and was for ever voluntarily surrendering herself to the rule of the stranger; hence was it also that she was for ever freeing herself once again from the chains she had sought.

Genoa chose for her first Doge, after throwing off the yoke of Visconti, one Guarco, the son of the man who had directed the Government of the Republic during the great struggle with Venice that had issued so disastrously. But the haughty Fregosi and Adorni, strong in their wealth, their landed possessions, their little armies of dependants, and their alliances with the nobles, were ill content to see anyone but themselves holding the rudder of the State, and each was always prepared to snatch it from the other by violence. Tommaso Fregoso, who had been elected to the dignity of Doge in I4I5, and who had hitherto deserved so well of the Republic, considered that, as a man who had never been formally deposed, as one who had merely submitted to the inevitable treaty with the Duke, as the citizen who had ten years before aided the enslaved city, though unavailingly, to cast off her yoke, he was unjustly deprived of rights that he not only had never forfeited, but to which he had established a still further claim, and that the dogeship should have been restored to him, and not given to that far less important person, Guarco. His appeal was supported by the presence of Battisto Fregoso, the hero of the great victory over the Catalans at Bonifazio, and, what was still more to the point, by a determined following fully supplied with arms. The Council was persuaded to acknowledge the legitimacy of Fregoso's pretensions (Uberti Foliata Genuens. Hist.-Jacopo Bracelli, de bello Hispano.Agostino Giustiniani, Annali di Genova).

From the dark substrate of animate nature there well up directive impulses that are often the coalescence of principles which eventually separate from each other and are discovered to be really opposed. The identification of right with might is a motive force of this nature. At first it is unquestioned, and it abides, a deep-seated fallacy, not always to be laid open in the quiet of the study, and always operant in the confusion of active life. The false acceptance of might, as bearing right in its bosom, may not have exercised much greater sway over human action in the Middle Ages than it does with such artless unconsciousness in our own times; but its action was more pronounced in Genoa than elsewhere in Italy even, because in Genoa, more than in any other State, there was a profounder political chaos, and this doomed to still-birth or destruction any nascent sense of any distinction existing between what is unwarranted of justice and what is to be achieved by force. The violent clash of interests, the unceasing flux of events, and the loss of all authority that was unsupported by efficient force, phenomena which marked the daily political life 
of that disturbed State, liberated private passion, and strangled the sense of public duty. The Genoese lost all sense of shame if there were a chance of snatching political power. They had no compunction in taking arms against the State, or relying on the assistance of neighbouring powers that were its enemies, and the States around were not slow to meddle with the vexed internal politics of Genoa, and engineer them to their own advantage. The Duke of Milan instilled the notion into Battisto Fregoso's head that the Genoese had only placed his brother in power on account of the services he himself had rendered to the Republic, and that he was allowing the Doge to reap the fruits of his own deserts. Visconti offered him every assistance, and, in fact, he seized the Public Palace while his brother was attending Divine service. But the better class of citizens rallied, rushed the palace, and took Battisto prisoner. Tommaso not merely refused to condemn his brother to death, but gave him a free pardon, and appointed him, in the following year, Admiral of the galleys which the Republic lent to King René (I 438) to aid his attempt to seat himself on the Neapolitan throne. Three years later another brother was given the command of another fleet, and this aroused the anger of the nobles, who claimed that it had been agreed in the Senate that commands should be given alternately to nobles and plebeians. Gian Antonio dei Fieschi, who had strong claims to the post, retired in dudgeon to his castle, and sent to Alfonzo of Naples, the great antagonist of the Republic, for help. The Duke of Milan also seized the opportunity, and offered aid to the nobles. The Republic was soon assailed on three sides at once. Fieschi came down from the mountains with his own men and the Milanese. The Marquis of Final, always ready to aid the enemies of the Republic, opened the ports and forts of his little fief to them, and the Catalan fleet ravaged the shore. But the Genoese were undaunted; their hate of the Catalans, due to former conflicts and eommercial rivalry, kept them hostile to Alfonzo, the Spanish King of Naples, and they poured forth their wealth and strength like water in the service of René, the rival pretender to the Neapolitan throne. But they were only bolstering up a lost cause, and when Alfonzo became completely victorious, and was more firmly established than ever on the throne, their anger turned against the Fregosi who had directed the disastrous war, and who were assuming a great deal too much of the outward insignia of authority to please either their rivals or the general public. The death of one of the Fregosi was attended with such funeral pomp that the citizens were in a state of high disgust and anger, and Gian Antonio, one of the Fieschi, sailed into the harbour one night, surprised the town, and captured the Doge (1442).

The dogeship was now put into commission. Eight "Captains of Liberty" were nominated to constitute a council heading the State, but it was a hotchpotch of Dorias, Spinolas, Fieschi, and Adornos, nobles and plebeians. It only lasted a month, and constant bickerings and antagonisms then led to the nomination of a new Doge, one Raffaello Adorno. Gian Antonio dei Fieschi, annoyed that all his efforts should have ended in giving power to yet another plebeian, retired to his fief and recommenced civil war, while one of the Fregosi fled to Visconti, and opened up hostilities from the Duke's territory.

The family of the new Doge had been a long time in exile at Naples, and advantage was taken of this to come to terms with Alfonzo. It was 
agreed that Genoa should furnish that monarch with the tribute of a golden bowl every year. But in 1445 Alfonzo received it with such humiliating ostentation that he caused much annoyance in Genoa, and the Adorni, who did not think that Raffaello had given them sufficient power and position in the Republic, induced him to abdicate on the ground that the people were discontented with him for having signed the treaty with Alfonzo. They put another member of the family, Bernabo Adorno, in his place. Bernabo got a bodyguard of 600 Catalan soldiers from the King, which was not at all to the taste of the high-stomached Genoese, and scarcely a month had elapsed when Janus Fregoso sailed into the port at dead of night, accompanied by eighty-five picked youths, and fought his way through the narrow streets, wherein paucity of numbers did not tell so much, until he reached the palace, overcame the guard, and took the ducal chair for himself (1447).

During all these troubles a change had been gradually taking place in the mercantile world which provided nuclei of stability in the midst of political unrest. In Florence and elsewhere State banks and private banks had been instituted, and these flourished exceedingly, and among the most flourishing houses was the Genoese Bank of St. George. The bank managed the public revenues during these times of disorder, and whatever internecine or foreign war was carried on, whatever revolutions convulsed the State, the bank was held sacred, and discharged its liabilities; but now Janus, who was carrying on war with the Marquis of Final, a man who ever allied himself to the enemies of the Republic, impounded the interest which was due to him. Final was taken and its fortress razed, but its inhabitants were left unmolested, and a third of the Marquisate was given back to a relative of the late lord (1449). This victory happened in the reign of Janus Fregoso's brother, who succeeded him, but who was deposed after ruling but a little more than a year ( $\left.145^{\circ}\right)$. The vacant dogeship was now offered to Tommaso Fregoso, who had retired to his town of Sarzana, but he pleaded the infirmities of age, and the vacant presidency of the Republic was given to another Fregoso.

\section{PISA}

From the Recall of Pietro Gambacorti (i368) to the Conguest of Pisa by Florence (1406)

Pietro Gambacorti was now Captain of the People and the directing spirit of the Pisan Republic. Gian Galeazzo Visconti was its great and dangerous foe, as of every republic. His subtle policy, his powers of dissimulation, his dark and dangerous designs, carried uneasiness and anxiety through the length and breadth of Tuscany. Pisa and Florence drew near to one another in the common danger. One of the free companies, probably instigated by Galeazzo, raided Pisan territory ; and before Florence could be appealed to for help, 4,00o horse appeared at Sarzana, sent, they said, by Visconti to defend Pisa from the brigands. Gambacorti and the Government saw through the trick; they closed the gates of Pisa in the face of these would-be helpers, while they welcomed the Florentine reinforcements. And so that attempt fell through (1388). Gambacorti, 
with considerable tact, managed to keep up friendly relations both with Florence and Milan ; he was a man of straightforward purpose, whose conspicuous integrity and genial manners gained the confidence and even the affection of the Pisans, though his relations contrived to secure all the most important positions in the State for themselves, and were cordially disliked. Year after year Gambacorti was re-elected Captain-General of the Republic, and by the respect that he inspired in Florence, and the tactfulness that he exhibited towards Galeazzo, he gave his-country several years of peace and commercial prosperity.

But faction was by no means at an end in Pisa, and Gambacorti's friendly policy towards Florence was far from being to the liking of the aristocratic and anti-Florentine parties. Pietro Gambacorti had a friend, Jacopo d'Appiano, a man of mean extraction, but whose father had suffered with the Gambacorti in I 348. When Pietro came into power, he remembered the devotion of the father, took the son to his heart, got him made permanent Chancellor of the Republic, made him his confidential adviser, got him to stand godfather to his son, and now, at threescore years and ten, the lifelong friendship of the pair seemed unabated. Appiano was a declared partisan of Gian Galeazzo, and had secured so many firm friends that the Florentines gave more than one warning to Gambacorti that he ought to be a little less trustful. But Gambacorti was incapable of treachery himself, and he judged others by his own standard. There was feud between the Houses of Appiano and Lanfranchi, and under cover of this, Appiano kept a guard about him. Gambacorti was very anxious to effect a reconciliation, and to this end he summoned Lanfranchi to his palace ; the myrmidons of Appiano murdered him on his road home, and took shelter in their master's house. Gambacorti ordered them to be delivered up to justice. Appiano refused. The Bergolini party offered their arms to the Captain, but he replied that he desired nothing but the ordinary course of justice, which would be administered. Meanwhile Appiano got foot-soldiers from Lucca, and headed the Raspanti and a host of hotbrained Ghibellines. When he felt himself sufficiently strong, he led the attack ; the contest was fierce and long, but at last Appiano and his following fought their way to the palace of Gambacorti. Gambacorti ordered his men not to shoot at his old friend, and acceded at once to Appiano's request that he should confer with him. He went out, and his false friend betrayed him even as he pledged his unaltered regard. Appiano gave his hand ; it was the prearranged signal, and Gambacorti fell covered with wounds. His friends fled, his house was pillaged, his sons made prisoners, and then poisoned in their cells. Soldiers, peasants, brigands, poured into the town, and ransacked the houses of the Bergolini and the leading Florentine merchants. Pisa was terrorized, and Appiano easily got himself made Captain and defender of the city. He contrived to be knighted. Gian Galeazzo filled the town with his own men under the pretence of supporting his friend ; and Appiano, while he was master of Pisa, was none the less under the thumb of Visconti (1392) (Piero Minerbetti, 1392.-Chron. Estense.-Sozmeni Pist. Hist.-Mem. storiche di Ser Naddo.-Scip. Ammirato.-P. Tronci Annal Pisani).

But Visconti wanted to tighten his hold of Pisa. Appiano was getting old, and his sons were shallow-pated and inept. Pisa was getting restive under the yoke, and, under the pretence of supporting authority, Galeazzo 
sent 300 lances into the city. He sent with them three of his creatures, who surprised Appiano by night, and tried to bluff him, so as to get the keys of Pisa and certain fortresses. Appiano got rid of them on the assurance that he would get the official sanction of the anziani the following day ; but no sooner had they gone than he assembled his soldiers, attacked and overcame the troops of Visconti, and forced a prisoner to reveal the whole plot, to which certain Pisans were found to be privy (Piero Minerbetti.-Sozomeni.-Bonincont. Miniatensis Annal.-Marangoni, Cron. di Pisa.-Scip. Ammirato). Florence sent her congratulations on the escape, and offers of aid against Visconti ; and Visconti, who never showed more self-control and hypocrisy than when his plans failed and he was at a whiteheat within, highly approved of the conduct of Appiano, and hoped that whenever his people abused their powers they would meet with a like fate. He abandoned his creatures to the just wrath of the Pisans, and though his whole life was one long lie, he succeeded in raising doubts as to the truth of his complicity (Piero Minerbetti.-Leon. Aretino.-Corio, Ist. Milanesi.Scip. Ammirato). Appiano even put difficulties in the way of a treaty with Florence, probably because he was only secure so long as he had Visconti to depend on (1398). Soon after he died, and his son found that he was incapable of holding Pisa without external support. Florence had no mind to bolster up a tyranny, so he sold the city to Visconti for 200,000 florins, and the Isle of Elba, and certain castles. The young Appiano retired to Piombino, and founded a family which ruled there for two centuries, when the principality was united to the Neapolitan Crown. He managed, in spite of the tears and entreaties of the people, to deliver up Pisa to the troops of Gian Galeazzo.

Pisa had lost her foreign trade and her colonies, but she was still powerful on land; she could neither absolutely conquer her feudatories nor hold them in any sort of order ; and though she was the most militant of Italian republics, and renowned for bravery and military capacity at a time when the other Italian peoples had almost abandoned the career of arms, she was obliged to concentrate her forces in a single hand. She thus had the advantage of controlling her factions and maintaining her power; but she was ever on the alert against an invasion of public right by her dictators. In Pisa, as in all the republics, freedom died hard.

When Gian Galeazzo Visconti died (I404), he left the lordship of Pisa to his natural son, Gabriello Maria Visconti. Florence, learning that the defences were in bad condition, at once despatched an army to set the city free, but found that new strong fortifications had been hastily thrown up, and that every precaution had been taken to defend the city. There had been a faction in Pisa strongly hostile to the rule of Visconti, for taxes were raised, confiscation of property freely utilized, and the citizens were beginning to perceive that they were called upon to provide, not merely for defence, but to defray the expenses of a luxurious little court (Piero Minerbetti.-Scip. Ammirato.-Sozmeni Pist. Hist.). This essay of Florence, dictated far more by self-interest than by anxiety to liberate Pisa from Visconti and restore her freedom to her, had the effect of fixing the Milanese ruler more firmly on his seat ; for he was immediately supported by Boucicault, a marshal of France, who held Genoa. The last thing in the world that Boucicault or Genoa desired was for Leghorn and Pisa to fall into the hands of Florence ; and the Pisans were no less anxious 
to keep that enterprising State from subduing themselves or obtaining a sea-board. Boucicault got possession of Leghorn, merely required a nominal tribute from Pisa, threatened Florence with the Imperial wrath, and, when he found that dread of that great potentate had worn too thin to be effective, he clapped all the Florentine merchants in Genoa into gaol; nor did he release them until Florence had submitted to a four years' truce with Pisa.

But before long Boucicault found his hold of Genoa weakening, and he made overtures to Visconti to get rid of the lordship of Pisa, which he could not preserve for him, and make money out of the Florentines, who would be glad to buy it. The Pisans got wind of the intrigue, revolted, and besieged Visconti in the citadel. Boucicault then sold the signory to Florence for half the sum he had originally demanded, jockeycd Visconti out of his share, and ultimately put him to death on a charge of treason which was said to have been trumped up.

The citadel of Pisa was given up to Florence in August, 1405 , but the new commander seems to have been a vainglorious blockhead. He sent the soldiers of Visconti about their business, and relied on Florentine militia. The citizens, of course, besieged the citadel with vigour, and bombarded away at the weak spot; it was where a tower dedicated to St. Agnes joined on to the city walls. Now, it took some hours to charge the cannon of those days, and the Pisans noticed that when they were going to fire the defendants always ran to shelter; they made a feint, and then scaled the walls at the moment when the Florentines had abandoned them; the citadel was taken, and at once razed to the ground by a people once again all agog for freedom.

Pisa sent an embassy to Florence without delay, offering the fairest terms. Heaven, not man, had decided ; Pisa had no desire to abuse the favour that God had granted her; she would even pay Florence the purchase-money of the city ; but she required the restitution of Librafratta and Santa Maria.

There was an opposition party in Florence that was anxious to come to terms ; but the Government was too strong, and orders were at once sent out to advance on Pisa. Now, at this time the Raspanti faction was in power at Pisa ; it had been set on its legs by Appiano, and supported by Gabriello Maria; the Bergolini were excluded from power, the Gambacorti were exiled. A common danger united hostile factions ; Bergolini and Raspanti hastened to swear eternal brotherhood; they shed their blood in the goblet before they pledged one another, and they arranged marriages between their young people. Adversity made strange bedfellows, and the hates of generations were to be hushed for ever. But Giovanni Gambacorti, recalled from exile, had a single eye to his own profit ; he remembered what his uncle had been, and, by dexterous manipulation, he got himself nominated Captain of the People. No sooner did he achieve power than he abused it by the oppression of his old opponents ; he confiscated their goods ; he shed their blood even (Piero Minerbetti.-Poggio Bracciolini).

Probably the chief reason why the Pisans entrusted Gambacorti with authority was that that House had been allied for so long a period with Florence ; they hoped that he would be able to bring about a peace between the two States. But Florence was bent on acquiring a city that had been a thorn in her flesh for generations ; big States were forming in Italy,. 
and in self-preservation it behoved her also to become a big State; above all, she desired a good sea-board. She refused to negotiate, and told the Pisans that they were lawfully purchased, and must return to the obedience of subjects; at present they were rebels (Poggio Bracciolini).

Pisa was too well fortified to be taken in anyother way than by famine; the bulk of the Florentine army sat down before her walls, while certain smaller bodies attacked the fortified places in her territory. Pisa made desperate efforts to get food-stuffs ; she despatched several galleys to Sicily for grain, one of which, overtaken by galleys which the Florentines had equipped at Genoa, took refuge beneath the tower of Vado. A certain Florentine, named Pietro Marenghi, who was wandering in exile and under forfeiture of life, happened to be on the bank ; he seized a torch, and, holding it aloft, swam to the galley. Thrice was he wounded by the bolts of the foc, but he succeeded in reaching the prow, and, secure beneath its shelving shelter, had sufficient strength left, not merely to set it on fire, but to regain the shore. One is glad to learn that his grateful country acknowledged the gallant deed : Florence recalled him to citizenship, and received him with distinction (Matt. Palmerii de capt. Pisarum).

Pisa also engaged two free companies, but both were intercepted and routed by the Florentine forces. The city, at its wits' ends, then sent to Ladislaus, the ambitious King of Naples, offering him the signory; but Ladislaus was not yet firm in the saddle, and, on getting an assurance from Florence that his designs on Rome would not be interfered with, he plumply refused it. The lord of Parma and Reggio, bribed by Florence, also refused his aid. By the beginning of the New Year (I406) the Florentines had gained possession of the Val d'Era, the Maremma, and nearly all the fortified places and castles that held out for Pisa. More troops than were wanted to tighten the blockade were now at the disposal of the invaders, and they used the surplus for the siege of Vico Pisano, a strong place in the neighbourhood of the beleaguered city; two redoubts, communicating by a bridge, were built on opposite sides of the Arno, to shut off the city from the sea, and Florentine galleys, equipped at Genoa, patrolled the mouth of the river. No grain whatever could reach the devoted city, either from Sicily or elsewhere. Fortune tantalized the despairing citizens with hopes that were never to be realized ; she bestowed visions of release, accidents of favour, and then turned them to their disadvantage. One day the Arno, swollen with flood, carried away the bridge which connected the redoubts; the Pisan defenders, ever on the alert, rushed to attack the feebler of the two forts ; but Sforza and Tartaglia, not without the gravest risk, swam their squadrons across the fierce flood, and drove the Pisans back, disordered and discouraged. Then the rivalry of these two great Captains broke out into open enmity, but Gino Capponi, one of the Ten of War, hastened from Florence, and patched up the quarrel by his consummate address. The antagonism of the Generals, which was known to the Pisans and raised their fainting hope, positively turned to their disadvantage ; for Capponi was judicious enough to give the one complete control of the Arno above, the other below the city, and the Pisans found themselves more closely invested than before even. Then fever appeared in the camp of the foe, and once more inspired hope, for the besieged saw the ranks of its enemies thinned day by day; but the Ten of War were men of conspicuous ability and resource ; they lost no time in changing the cantonments, and sending the sick into 
fortresses where they could rest and recover; while the fever appeared also in the city, and, aided by famine, played havoc in a place whence there was no possibility of moving into a more salubrious air, or slackening effort, or securing repose. The infirm, the aged, the women, the children, were put out of the city; they were driven back again by the inflexible foe. The Pisans then hoisted the flag of the Duke of Burgundy, and sent heralds to the camp to announce that they had given their city into the keeping of that powerful Prince ; the Florentines heard, and sat, as before, unmoved. The beleaguered citizens sent an embassy to the Duke, and day after day they watched for some distant dust-cloud to indicate the approach of his relieving army; and no army came (Jacopo Salviati-he was one of the Ambassadors). The Pisans were reduced to their last crust, and still they preferred to die, one by one, rather than surrender. But Gambacorti had absolute command ; Pisa was accustomed to invest one man with authority, as all States permeated by dissension or militarism, and especially States possessed by both evils, must necessarily do. Gambacorti entered into secret negotiations with the besiegers, and asked all he could for himself-nothing at all for the brave people that had confided themselves to his defence. He bargained for Florentine citizenship, certain freeholds, the rule of Bagno, several fortified places near it, and 50,000 florins. The Florentine Government acceded, and he threw open the gateway of San Marco by night. The Florentine army entered, and took possession of the Borgo ward. Next morning they marched quietly through the town, preceded by waggon-loads of provisions, which they distributed to the famished population. The city was found to have absolutely exhausted provisions of every kind ; some stores of sugar and cassia and three emaciated cows were all that could be found. The population had subsisted for some time on the grass and herbs that grew by the roadways or on the walls ; they were lean and famine-stricken; they could only have supported life a few days longer; but they were still capable of manifesting impotent wrath at the treachery of Gambacorti, and bitter shame at the surrender of their independence to their ancient and inflexible foe (1406). The chronicles of Pisa end with this event. Capponi, the new Governor, sent all the Gambacorti and 200 of the leading citizens to Florence to serve as bail for the continued submission and good behaviour of the State; high-spirited men, unable to break the yoke, evaded it by joining the free companies ; those whom circumstances compelled to remain still exhibited the ancient energy for a longer period than any other people. Florence was a hard taskmaster; her orders to her officers were to "crush every germ of revolt" in the conquered city; and this policy of minutely and oppressively restricting the freedom of her Pisan subjects lasted until the Medici adopted a humaner course. Such an administration was economically fatal, and the great sea-power that had dominated Tyrrhenian waters for five centuries, and whose military powers had gained her sway and prestige on land when she had lost the control of the sea, became a mere Florentine port, and saw the greater part of Florentine goods, in spite of the conquest, pass through Genoa, her ancient rival, or the rising port of Leghorn. For her ancient harbour was silted up, and those places gave better anchorage and embarkment.

It was the established policy of every Italian State, except Venice, at this period to crush its conquered territory, so that rebellion might become 
impossible, and to drive into exile all bold free spirits by harshness and cruelty. The Florentine Ten of War had given orders to this effect; for years there was a continuous stream of emigration from Pisa, and the city found itself drained of its best blood and economically ruined. On the reconquest of Pisa by the Medici nearly a hundred years later, they pursued a wiser and nobler policy. Lorenzo endeavoured to restore the ancient glory of the University, and compelled Florentines to pursue their studies there, and in many ways a sounder method of dealing with the economic condition of the defeated State was adopted.

\section{FLORENCE}

The Revolt of the Ciompi (i378) and the Rule of the Lesser ARTs (I $378-\mathrm{I} 382)$

THE little State of Florence had led the party of freedom in Italy. Sincerely religious still, she had broken with tradition, and had appealed to the tribunal of God against a Papacy degenerate and mundane. She had learned the power of wealth, and the means of employing it. She had become so rich that she lent money to nations far more powerful than herself, and subsidized her party everywhere, as England did during the Napoleonic wars. She knew how to foment disaffection in order to preserve the balance of power; she had "backed Brescia against Henry of Luxemburg; she made Padua ungovernable by Cane Della Scala" (Trollope). And if the ruling classes could not endure to submit to arbitrary power, they loved to exercise it. In those days of intolerance and absence of any political education of the masses, any large extension of the franchise was impossible. So far as citizenship was extended, so far was the Government also the governed : authority was by consent, and the Florentines made the nearest hit to constitutional self-government attained in the Middle Ages and the age immediately succeeding them. The self-consciousness of a great people set itself before the eyes of all men in a great way; the outward show of the city was a manifestation of its soul.

The war with the Pope did not interfere with the progress of the magnificent buildings with which Florence was adorning herself. Her commercial activity continued to bring her great wealth. Her bankers and her wool-merchants were rich beyond the dreams of avarice ; but although the Duke of Athens had introduced French fashions and French display, the life of the favoured classes was still very simple. Men devoted their fortunes to the adornment of the churches of their faith, and to the erection of noble buildings which should perpetuate their name, add dignity to their city, and be things of beauty and refreshment to the souls of all men. Most of the great churches were already built, or were nearly completed. The Duomo, the Baptistry, the glorious Campanile, the rugged strength of the Palazzo Vecchio, the Loggia dei Lanzi, the Bigallo, and the churches of Santa Maria Novella, Or San Michele, Santa Croce, and most of the public buildings were to be seen then pretty much as we see them to-day. 
While triumphs of architectural genius were in process of completion, and the intellectual life of Florence was quickening and putting forth fresh shoots in every direction, the mediæval passion for unity of political opinion, which instituted an intolerance as fierce as ever disgraced the odium theologicum, manifested itself in Florence no less violently than elsewhere. The disappearance of feudalism in Italy delayed organization. It brought out the highest qualities of the human spirit, but it admitted of irreconcilable antagonisms.

Certain of the fat burghers, allied with the old Guelph nobility, had already become a sort of new nobility in the State. They were led by the Albizzi and Strozzi, and were supported by the Parte Guelfa. Opposed to them were the Ricci, Alberti, and Medici-quite new merchant families, of great wealth, but who sought the support of the people. The quarrels of the Ricci and Albizzi had become acuter and acuter during the past twenty years. The Parte Guelfa represented the new aristocratic tendencies in the State: the opposed party stood by the signoria, which, as the recognised Cabinet, ought to have been supreme; to a certain extent they also played to the gallery. They were supported by the Eight of War, whose undaunted bearing in the contest with the Pope had roused the enthusiastic praise of the common people, and whose powers, renewed from year to year, menaced the predominance of the conservative Parte Guelfa. The oppressive and continued interference of the Guelph Party had earned them no small degree of hatred; and that hatred was justified, for Machiavelli tells us that they had become more powerful and more feared than the Government itself. Less reverence was paid to the signoria than to the chiefs of the Party, and every Ambassador coming to Florence bore his credentials and message to the Captains of the Party as well as to the signoria. It looked as though the old dispute between Guelphs and Ghibellines would be renewed in Florence, and the party of the Ricci were already designated Ghibellines.

The Parte Guelfa had attacked the "Eight Saints" by inscribing certain of their supporters on the list of Ammoniti; they disfranchised men on the plea that their forefathers had fought against the Church, while the whole city at that very moment was in arms against the Church ; they even dared to exclude one of the Eight Saints, together with some of the most important men in the State (Marchione de' Stefani.-Scip. Ammirato). At the death of Gregory XI., the parte determined to take advantage of the negotiations for concluding the peace that was practically secured to expel the Eight and their followers, to seize the Palazzo of the Priors, and to secure their own supreme power. The situation had become too acute for conciliation; family feuds which had been going on for years were coming to a head; action had become necessary and should be prompt.

For beneath the rivalries of family and faction there seethed discontent. The State was volcanic and ready to explode, and in the explosion the nouveaux riches, welded now with the remnants of the old nobility, would be the first to suffer. Changing commercial conditions, the appearance of capital, the rapid renewal of wealth by operations which perpetually multiplied it, were already undermining the power of the old trade associations, and shifting it from the Government and the guild to 
those opulent classes who grew ever more opulent. The Black Death had shuffled the fortunes of the individual and shifted the equipoise of economic conditions. All over Europe there were popular risings; the great dumb masses, who produced more than they could consume, were asserting their necessity in a blind and blundering way, and claiming the right of a man to live as a man. The enemies of the people were precisely the wealthy merchants of the Parte Guelfa. In feudal countries the nobility were attacked : in Florence the old nobility and the mercantile classes were welded by now into one oppressive class. The Republic had spent 3,000, ooo florins on the war; many of its merchants were ruined by the orders the Pope had issued to foreign powers; these and the wealthy class of new men, who smarted under the snubs of the more ancient families, took the liberal side. The social discontent, which had been fermenting for a century, was coming to a head. Every class wanted power for itself, but the combination of the people with wealthy men was most menacing; their accession to power would increase that of the Eight; it would lead not merely to reform, but to reprisals. The new signoria, drawn by lot, chanced to be Ghibelline, and the wealthy Salvestro dei Medici, one of the new men, was to be gonfaloniere of justice ; he would have the public forces at his disposal. The mob always require an idol to symbolize their aspirations and be, as it were, a magnetic focus of union; they think in the concrete, and require an embodiment to an idea; Salvestro might prove to be another Giano della Bella; it was indeed time, from their point of view, for the oligarchic party to act.

It was agreed among the chiefs of the party, on the proposition of Piero dei Albizzi, that, during the march of the processions on the approaching eve of St. John, their dependants among the peasantry and partisans should assemble ; that they should rise in revolt, exile the Ammoniti, and deliver the city up to the government of sixty of the party. It was impossible for the Parte Guelfa to include Salvestro among the Ammoniti ; he was too decided a Guelph, too popular, and had too many friends. Intrigue was tried in order to exclude him from the post of gonfalonieve; it was met by counter-intrigue. If Medici became gonfaloniere the plot might fail. Salvestro, like every Florentine, was a man whose vanity and pecuniary interest compelled him to raise himself with unceasing effort, to achieve every point of vantage, and, if he could, to strengthen himself in his position by advancing his friends. As Perrens remarks (Hist. de Florence, $X$. ii.), caste interest only dominated personal interest because it was its surest guarantee.

The new Government took office. There was an inundation of petitions. Society had become unstable; there had been heavy losses in banking, and as the Budget did not provide for war expenses, additional taxes on real property had been capriciously levied. The Party was implored to suppress denunciations, not to strike two at a time in the same house ; to restrict the exercise of their powers, and to punish only those who were really Ghibellines. The signoria admitted petitions, but recoiled from the prospect of civil war: this gave heart to the Parte Guelfa; they continued to abuse their powers and exclude citizens from office for no offence but being their enemies. The burghers grew furious, the parte more determined. The Captains of the parte held a secret meeting, and called on the Priors to execute the ordinances. Salvestro counselled 
patience until he should be proposto. For the gonfaloniere and the eight Priors had each the right to propose resolutions in turn, each for a day. These resolutions were then submitted to the signoria, the collegio, and the councils. Stability was thus maintained at the expense of initiative, for all initiative had to issue through some member of the signoria: no amendment was admissible, and a two-thirds majority of all the different bodies to which a resolution was submitted was necessary before it could take effect. On June I8, r 378, Salvestro was to take his turn as proposto, or proposer of reforms and new laws. The Council of the People was summoned - a not unneeded precaution, seeing that the Captains of the Guelph party were already gathering their forces.

The day came. Salvestro rose and proposed to the collegio of the twelve buonuomini and the sixteen gonfalonieri of the companies that the ordinances of justice should be reinstituted against the magnates; that the authority of the Captains of the party should be limited ; and that Ammoniti unjustly disfranchised should be enabled to recover their civic rights. There was strong opposition in the meeting. Salvestro left the chair without a word, and proceeded to the Council of the People (or Council of the Commune, as it came to be called).

"Gentlemen," said he, "I thought my duty as gonfaloniere compelled me to repress the insolence of the magnates, and to reform laws that are abused; but the enemies of the people make so much opposition that, so far from rectifying the evil, I am prohibited from divulging the remedies I proposed. I can do no good. I can no longer remain in an office the highest functions of which $I$ am prevented from exercising. Therefore, I resign, and shall retire into private life."

A scene of great disorder followed. The signoria and the collegio came rushing in, and kept Salvestro from departing by main force. A slippermaker seized Carlo Strozzi by the collar, and gave him to understand that he and his party were by no means going to have it all their own way. The crowd surged outside. Benedetto Alberti sprang to the ledge of a window, shouting: "Long live the people and liberty!" The artisans ran home to arm, the shops were closed, and the square filled with armed men. The Guelph Party could do nothing; they found that they had but a handful of followers. The frightened Priors passed the resolution which Salvestro had proposed ; the collegio confirmed it ; the Council of the People was obliged to ratify it the next day. Intimidation had succeeded, but there was still danger that the parte would have recourse to arms. The whole city was on the alert throughout the night; the least spark would have set the heather on fire.

And, indeed, though there ensued a period of external calm, it was evident that it was on the surface only. Men knew that the fight would soon be fought to a finish. Houses were fortified, valuables removed to secure places, shops remained closed, knots of armed men gathered in the streets.

In the multiplex and loosely-knit polity of an Italian commune, the wards, the various companies of the militia, and the trade associations had their own organizations, and were the units of which the central Government was composed. Of these several units, the trade asociations were, as befitted commercial cities, by far the most important. The minor fourteen arts of Florence. engaged in retail trade, were jealous of the 
political power, privilege, and wealth of the major arts, which comprised the money-changers, the great wholesale dealers, the notaries, and the physicians. The bigger people of the greater arts had reproduced all the faults of the nobles; they were supported by the Parte Guelfa, which was devoted to the interests of the rich; they regarded the poorer and uncultured citizens with disdain. There were, however, a few of the popolani grassi who, from private pique or honest intention, held out a helping hand to their less favoured brethren, tried to secure them a political hearing, and hoped by their means to repress the excesses of the Parte Guelfa. These were ready to give them the rights which they demanded.

But besides the lesser arts that had some political representation, there was a considerable number of organized crafts that remained disfranchised. There were no less than twenty-five little trades associated with the wool industry that might become very dangerous by reason of their numbers. All of them were organized on the model of the great guilds. As far back as the year I 300 seventy-two of these little trades were presided over by consuls, and the Duke of Athens, to secure popular support, had granted every trade a consul and organization of its own (1343). These powers were afterwards abrogated, and much discontent followed. The effort of every organization that was excluded from government was to secure its political rights, but when once it got them, so far was it from helping the other organizations, that it invariably fell into line with the official view, and endeavoured to keep them out in the cold. For it was the constant effort of the arrogant magnates, who took what we should nowadays call an imperialistic view of policy, to exclude men who came betwixt the wind and their nobility, and who, being chiefly interested in retail trade, might be inclined to "pettifogging" politics. The expenditure on war, too, necessitated economy in domestic disbursements, and this naturally interfered with the prosperity of the small trader, and embittered the relations of the classes.

But below the artisan was the poorly-paid day-labourer, engaged in manifold employments. Such were the Ciompi, whose disgusting employment was to beat the crude wool with sticks, and a variety of abject, halfnaked creatures, who were engaged in the most degraded kinds of work: serfs also were still to be met with coming in from places at a distance. These men could not but feel the difference between their condition and that of the rough-tongued master whose heap of wealth they were occupied in increasing. Hitherto they had had no hopeless aspirations to political power; they had seen art after art admitted to the Government, but they got nothing from them. Hitherto they had seen party succeed party, each promising to do marvels ; they had seen one set of middle-aged gentlemen succeed another, and nothing was done. Each guild, as it secured power for itself, had been too afraid of losing it to do anything but swim with the aristocratic stream, and the would-be protectors of the poor were pretty sure to be admonished by the Parte Guelfa. There must have been much brooding in sullen discontent. The "oppressors' wrong, the proud man's contumely," the pinch of hunger, and the shame of impotence are apt to wear away the finer sensibilities. The popolo minuto was a dangerous class in Florence ; it was shortly to gather itself together and manifest its power.

Thus everything pointed to a revolution. The great growth of wealth 
had for the most part fallen into a few hands ; a more ostentatious mode of life was becoming the habit of the rich ; frippery and foppery, says Villani, had been introduced by Charles of Anjou, and the charge is supported by the evidence of the frescoes of the time; plague and famine had passed over the city, and these and the bankruptcy of some had shifted the boundaries of class, while a temporary dearth of labour had given the labourer a sense of his own importance ; the franchise had been extended, but the aspirations of rising guilds had been suppressed; the wealthy had abused their power, and some among them led the opposition ; neighbouring Siena had given the example of a successful rising of the mob; there were all the ingredients of a hell-broth present.

But as is usual in revolutions the upheaval commenced slowly and gathered momentum as it went. A revolt of the lower orders was hardly contemplated. At first the revolution was directed against the Parte Guelfa, and had for its object the diminution of its powers and the restoration of the Ammoniti, the friends of the people, to their political rights. One day in the middle of June the various companies assembled at their trysting-places, and marched, gonfalonieri at their head, before the signorial palace, shouting, "Long live the people! long live liberty! throw the traitors out !" The companies of the major arts were content with a demonstration ; the minor arts, pushed on by the lower orders, marched through the streets, and attacked the house of Lapo di Castiglionchio, the chief of the Parte Guelfa, who had the good-fortune to escape in the disguise of a monk. His house was sacked and burned to the ground. The mob attacked, one after another, the palaces of the chief offenders in the matter of the Ammoniti, and treated them all in the same way; the prisons were forced, and the prisoncrs released. Next day the monasteries were attacked, and the lower orders marched against the luxurious monastery of San Spirito. An attack on religion was not to be endured. Certain members of the Government, accompanied by archers, dispersed the mob, and hanged five robbers of sacred relics. But the crowd gathered again, and made for the treasury of the Parte Guelfa. The arts, now dissociated from the rabble, guarded the treasury; they were at one with the Priors when sacred property was attacked. All folk from the countryside were ordered to leave the city; authority was given to seize anyone carrying stolen property, and rope him up to a column of the nearest loggia, and all citizens were ordered to lay down their arms. The night was quiet, but the signoria had learnt that the rabble could use fire and force as well as the nobles of eld-could con a lesson and repeat it with unexpected emphasis.

Salvestro and the signovia gave absolute balia to themselves, the Captains of the party, the Eight of War, the collegio, the syndics of the twenty-one guilds, a council of eighty-four in all, to reform the State. The balia ordered the Ammoniti to be restored, though they were to be excluded from public office for three years; the authority of the chiefs of the party was curtailed, Castiglionchio was declared a rebel, and Carlo Strozzi and Piero dei Albizzi were proclaimed as magnates; the city was put under a kind of military law, and since the revolution seemed to be at an end, nothing was done for the poor. The way in which the Parte Guelfa was to be restricted is characteristic. A new body, another aristocracy, another State within a State, fully armed-the consorteria-was formed (Gino Capponi.-Perrens). 
The time came round for the change of ministry. The new Ministers were received in silence. The Ammoniti, half reinstated, were still burning for revenge, the artisan classes talked about governing themselves with arms and an organization of their own. Urged on by the Ammoniti, the arts presented a very moderate petition for their immediate reinstatement - the replacement of the chiefs of the party by new men, and the refilling of the "purses" with new names for the magistracies of State. In spite of the recent order the arts were armed, and fear of them effected an immediate consent from the collegio and the councils. A commission was appointed to carry out the reform, and the guilds professed to be satisfied.

But the masses had learned their power. Robbery and violence went on unchecked, hole-and-corner meetings were held. The signoria was weak and undecided; it had lost the support of the aristocracy; it could not rely on the middle classes; it suspected Salvestro dei Medici of being in league with the lower classes, but he was too powerful to be attacked, so it contented itself with a reprimand; it knew that sedition was afoot; it was powerless to put it down. On July 2I the mob found the great Piazza occupied by armed soldiers; they at once fled, but rang the church bells and re-formed. Then they rushed to the Piazza and occupied it. Shouts arose of "Long live the people! Long live the arts! Release your prisoners, or we will burn the palace over your heads!" Then the cry changed to "To the gonfaloniere of justice!" The new gonfaloniere was a Guicciardini ; they captured and burned his house, the Hall of the Wool-Merchants, and the houses of many of their enemies. They seized the flag of the gonfalonieve, and marched ahead. But no personal harm was done ; there was no pillage (Letter of Gio. Medici, Del. xvii. I65. -Perrens). But so little were they conscious of the meaning of their own movement, so unable to transcend habit and mediæval modes of thought, that in the evening they travestied the installation of knighthood by making knights of Salvestro dei Medici and sixty-one others, in perfect simplicity and good faith. It is significant that while at last they had learned their power, while they had a dim perception of the sovereignty of the people, the people was incapable of exercising its sovereignty aright. Tradition still held sway. Of the sixty-one only two were plebeians ! Cruel masters were punished without pity by the mob. The riots went on day after day. The Bargello was defended, but the doors were fired and forced, and the Podestà had to desist from resistance to save his life. The houses of the Captain of the People and the Executor of Justice were burned down. Florence itself seemed to be given over to the flames.

The revolutionists now sent a deputation to the signoria, who remained in the Palazzo defended by an armed guard; they presented a petition from the trade associations, and two petitions from the little people. They demanded that the scandalous abuses of the Parte Guelfa should be put an end to once and for all, and that a club-house should be bought by the State for the trades of baser kind. This shows us that the main object of the little people was to improve their social condition, and they hoped to effect this by obtaining a recognised position. That they were associated with murderous ruffians was hardly their fault; that is the fate of all movements of reform when they can only pass into being by force of arms. They also asked for more equitable taxation. The 
bells were rung, the streets rang with shouts. What could the Priors do but concede? But the councils had to assemble to confirm the assent of the signoria. The revolutionists sent a trumpeter through the city warning the citizens that anyone who went about hiding his face in a cloak would be instantly killed ; it was necessary for them to prevent secret conspiracy. A rumour spread that the signoria had summoned cavalry to their aid. The Ciompi and other rioters kept guard in the Bargello, which was crammed with armed insurgents, and all Florence was armed and kept watch that night.

The next day, July 22, one of the Priors broke the law which kept the signoria in the Palazzo during their term of office. He came out into the public square, announced that the Council confirmed the assent of the signoria, and indulged the mob with the glibness of an oily tongue. But the crowd was not to be hoodwinked. The Prior was treated with all respect, but he was not allowed to re-enter the palace; he was conducted with all distinction to his own house. The mob mistrusted the suave promises of the Government, the unctuous phrases of their orator had failed of quenching the fire; nay, they had served as oil to fire. The blood of the populace was up; they determined to strike home. They surged into the palace headed by Michele Lando, their favourite of an hour, bearing the standard of justice. They insisted on his becoming gonfaloniere of justice, but they were moderate enough in other demands; they called upon constituted authority to reform the State. Salvestro dei Medici and other people of standing acceptable to the populace were requested to advise. These rich people had had the political sagacity to foresee something of what was coming ; they had fomented discontent, and had secretly helped the movement. They had now the riot upon them, and Salvestro in particular had to tread with infinite wariness and sow with infinite discretion the seeds of future power. The Ambassadors of other republics also endeavoured to assist in the scheduling of a new scheme of government. Lando, in spite of the distinction which he has received at the hands of the imaginative Machiavelli, was little more than the temporary idol of the mob. He was really the unconscious puppet of Salvestro. Salvestro and a few cool heads still had weight with the people, but every now and again the people got out of hand. A ruffian told the mob that the Executor of Justice was hiding at an inn. They rushed thither, dragged him from his bed, tore him to pieces, and bore the fragments in triumph on their spears' points.

Concessions were granted. Three new arts were constituted. The first, that of the Ciompi, comprised 9,000 men. The second and third were curiously composed. We find that trades that to-day are by no means considered as degrading were then esteemed vile. The makers of church furniture, of doublets, of hose are to be found among these outcasts of society - why, we know not; with these were associated in the second guild the shearers, menders, and scourers of wool. In another guild were associated together silk and cloth weavers, tinters, fullers, and wool-combers: Between them these two arts numbered 4,000 men only. The officers of the new guilds were voted for singly, and not drawn by lot. It was settled by the balia that the three new guilds of the masses were to be represented by three Priors, while the same number of representatives was severally accorded to the major and minor arts. Hitherto certain interests had 
been represented in the State. Interests were still represented, but the principle of representation by population was also combined with the old idea, for the numbers of those engaged in big business, together with the scioperati, or people of independent means, of the minor arts, and of the proletariate, were about equal, and were now equally recognised in the State. Yet even the Ciompi did not claim citizenship for all.

Those who believed in the incapacity of the lower orders to conduct foreign policy and administer the State were disappointed. Responsibility revealed unsuspected qualities of wisdom and restraint. The foreign policy of the new signoria was excellent; internal policy was drastic; everyone was commanded to work. But the new signoria was powerless to execute these edicts. The wool-merchants purposely diminished their output. In vain were the employers of labour and others who had left Florence threatened with the ordinances if they did not return. Trade naturally languished, and the Ciompi found themselves worse off than before. There is nothing so powerful as hunger and death from famine in perverting the just judgment of a people. Popular anger augmented day by day, and was directed against the new Priors, who were drawn so largely from the people, and who were doing their honest best for them. Two new demagogues appeared-one L.ucca da Panzano, who had been excluded from political power because he had seduced his daughter-in-law; the other Ciardo, a man of the people. The lower orders assembled on August 28 3,000 strong, and put themselves under the leadership of these men. They marched on the Palazzo, and demanded that the syndics of the arts should be excluded from office for ten years, that knights should be held incapable of holding office, that salaries should be reduced, that for the next two years no poor man owing a debt of less than fifty florins should be imprisoned, that past offences should be absolved, and that Salvestro dei Medici should be given the charge of certain revenues. All these demands were put in a confused higgledy-piggledy way. The mob were told that everything would be sent on to the Council for their acceptance. The disturbances remained unabated. Lucca da Panzano submitted to having his spurs of knighthood hacked off; his friends of the people desired it. He managed to keep the populace inflamed by haranguing them about the prisoners; the gaols were opened and the prisoners released. Then he led them to the Palazzo of the parte, and urged them to take and use their standard. Now his followers woke up to something of Panzano's design; he wished to degrade the parte, but they were not going to replace their standard by that of their enemies. Panzano saw that his life was in danger, and incontinently fled. Night was now drawing on, and it behoved the mob to keep together: they marched to the monastery of S. Maria Novella for advice. They sent to the signoria demanding that all the deliberations of the signoria should be submitted to them before being sent on to the councils for approval. Soon a deputation from the signoria arrived at the monastery and was kept a couple of hours cooling its heels before it was received. A fresh demand was made that a new council should be formed. Nothing short of absolute dictation to all authorities would now satisfy them. They turned against the men they had elected to lead them: of Michelc Lando, in particular, nothing too bad could be said.

On August 3I there was an attempt at another riot. The lower orders congregated in three districts, and concentrated in front of the Palazzo of 
the signoria. But the arts had determined to act together and defend the Priors; they were already assembled and under arms. The mob shouted for the Priors to take an oath to do their bidding. Lando refused. The populace made ready for a rush, but the palace doors were immediately shut to, and the arts began to drive the mob before them. Courage failed them when they found the lesser arts had turned on them. The great bell tolled; Michele Lando rode through the streets bearing the standard of justice, and followed by an armed force. The mob, no longer supported by the truculent butchers, fled before him. By evening all heart was lost, and the rebellion was at an end. Then all concessions were revoked, except that the three little arts were allowed to retain their constitution and were represented by one Prior only, the major and minor arts having three Priors each. This majority of four gave Florence a Government wherein the tradespeople and those below them predominated for many years. As in the French Revolution the middle classes triumphed, because it was not recognised even by the rebels themselves that the revolt was at core a social revolt. None the less, the insurrection of the Ciompi was nothing but a blind struggle of workpeople against their employers-one of the first of the long series of contests between labour and capital (vide MS. Strozzi.-Diario d'anon.-Ammirato Provizione.-Gino Capponi.Marchionne di Coppo Stefani).

\section{The Recovery of Power By the Oligarchy of Big Traders.}

Conservative reaction set in against the popolo minuto, but at first it was moderate. The mob was excluded from political power; the small tradespeople triumphed. They remaincd solid among themselves, but in foreign policy they had to depend on men of large experience; and the men on whom they were compelled to rely were men such as Giorgio Scali and Salvestro dei Medici-men of subterfuge and knowledge of the world, who professed to be the friends of liberty, who really aimed at its destruction and at ruling the State themselves : liberty was their stalkinghorse. But soon the grandi and the mob that had lost all hope of political enfranchiscment werc conspiring together. Exiles carried on intrigues with Charles of Durazzo, whose star was in the ascendant, and urged him to march his army through Tuscany on its way to claim the throne of Naples (1379). Several of the Ciompi were visited with condign punishment, but in a month's time another plot was discovered, and several of the chiefs of the Albizzi party were denounced. For years the Albizzi and their friends of the Parte Guelfa had rendered great service to the State. The rise of the towns was the death-blow of feudalism, and the decline of the Italian aristocracy had carried with it the decline of Italian arms. Forced to mix with the burghers, there had been intermarriage between the richer citizens and the nobility, and the latter, of Germanic origin, lost their military valour, but gave an accession of vigour and vitality to the burghers, as the burghers had given it to them. The new rich middle class thus formed, having lost their ancient military efficacy, turned their energies and initiative into the fields of commerce, and the preservation and extension of those fields necessitated war. Unable to fight themselves, especially under the changed conditions of warfare, they had to entrust the defence of their vast trade to the bands of skilled soldiers that were for 
hire. This necessitated a vast expense ; they heaped taxes on themselves no less than on others, and maintained their power by a merciless proscription of their foes. It was due to the Albizzi party that Florence had conducted her successful campaign against Gregory XI., for they had profited by the confusion of the Republic at and after the expulsion of the Duke to take and hold the lead in the State. Whenever Florence is menaced by external foes, this party of the " fat burghers " is to be found in power. Whenever there are fat years of plenty, the voice of the disfranchised is to be heard, and the opposite party-the party of the popolo minuto-comes into power. We have seen how, directly the war with the Pope slackened, the people began to rear its head ; we shall see presently how, directly Forence is menaced by rival States, the Tory party takes the lead. But change of party was effected by fightings, beheadals, injustices, cruelty, and banishment.- The Albizzi were now trying to reinstate themselves ; certain of them were ready to do so at any cost; their machinations were more than suspected, and, as we have said, certain leaders of the party were denounced. They were tried before the Podestà, the Captain of the People, and the Executor of Justice, who declared them to be innocent. But the consuls of the arts and the public were not satisfied : there were shouts of vengeance; this time not the poor should suffer, but the rich, who more deserved it. Marchionne dei Stefani, whose insipid writings become of great interest just now-for he was Prior of the city precisely at this time, and always on the side of the small traders-says that Benedetto Alberti declared that, if authority failed to do justice, the people would execute it themselves. These words were as fuel to the flames. Four citizens were added to the bench, and the judgment-hall was closely guarded. The examination of the accused was resumed, and enough was squeezed out of them to give colour to their condemnation. Two of them were executed the next morning, and Filppo Strozzi and Giovanni Anselmi were condemned. But just as the executioner had raised his sword to behead them, appalling screams were heard. Everybody thought nothing less than that Charles of Durazzo and his troops were entering the city. All fled, even the guard round the scaffold, and nothing would have been easier than for the condemned men to have escaped. But Strozzi was a man of proud and heroic fortitude; he scorned to save his life by ignominious flight. As he was reconducted up the staircase of the Bargello, his step was unshaken, his mien dignified and resigned. Twice he turned to the Captain of Justice, and reminded him that God required him to do his duty. Such, in spite of their arrogance, their ambition, and their indifference to social suffering, was the stuff of which that great party was composed which upheld Conservative and what to-day we should call "imperialistic" principles in the Republic. Directly the tumult subsided, the prisoners were led back to the place of execution and decapitated. The public thirst for blood was sharpened, not assuaged. Furious cries for "The others ! the others !" rent the air. The Captain of the People, who, like the Podestà and the Executor of Justice, was a foreigner, refused to give the order. " Kill them if you like," said he ; "I believe them to be innocent, and never will I consent." The people were all armed, owing to the scare about Durazzo ; they roared and yelled out their intention of tearing the prisoners to pieces. " Execute them," they shrieked, " or we will make shreds of them, and not merely of them, 
but of all their kin." Piero dei Albizzi and his companions could not but hear the threatening howls of the mad mob. With a calm courage and dignity that reminds one of the ancienne noblesse, Piero pointed out to his companions in misfortune that there was no hope for them; all that remained was to accept the inevitable, and so save those that were dear to them. They agreed to accuse themselves of treason, and, in spite of the protestations of the Captain, they did so. The signoria was weak, and the assessors of the Captain, who had been appointed by the people, were only too glad to press home. All were executed, to the delight of the populace, including Donato Barbadori, the citizen who had so boldly appealed from the Vicar on earth to the King in heaven before the consistory of Gregory XI. They died one and all reasserting their innocence. The execution of these distinguished men was followed by a holocaust; every suspected person perished, and therein, in all probability, those who had really engaged in treasonable practices were justly punished; they avowed their guilt, and died expressing a triumphant joy that their death would not avert the event; they were fortunate in shedding their blood for the time-honoured parte; so far from repenting of what they had done, they would do it again.

The Pope took the side of Charles of Durazzo; Charles sent his mercenaries through Tuscany, and Florence had to engage John Hawkwood to guard her territory. Charles seized Arezzo, and Florence had to compound with him by furnishing a sum which she deducted, however, from that which she still owed the Pope (I380). The military energy of Florence was much abated by the death and banishment of so many of the class which was most characterized by martial ardour. Many of the exiles flocked to the Court of Charles, who had established himself on the throne of Naples without a struggle. He was the heir of Hungary, and the Adriatic afforded the best of all means of communication between the two kingdoms. The balance of power in Italy was destroyed, and Florence was menaced by a new strong power in the south. Meanwhile, there was social discontent at home. Wealth migrated from Florence; the pretext was economy-the real aim was to hamper the Government by reducing the revenue, and so to necessitate new burdens on the poorer classes, and discredit the middleclass Government. The rate of interest payable by the State bank had been fixed by law at 5 per cent., and any proposal to increase that dividend involved capital punishment. The law had been evaded by inscribing as much as three times the actual amount received; once before the interest had been reduced, but now the bank reverted to its 5 per cent. dividend, except in the case of foreigners, with whom the old system was continued to preserve the high reputation of the bank. This caused considerable indignation, and the wealthy classes deemed it intolerable that mere petty tradesmen should dare to interfere with high finance. The employers of labour were also alienated by the revocation of the law which fixed a maximum for wages in certain trades. Altogether there was a considerable arrest and dislocation of business, and the lower orders, and many others besides, of both sexes suffered (Diario d'anon.-March. di Coppo.-Ammirato). Only external danger saved the city from internal tumult. But at last tumult arrived.

Giorgio Scali and Tommaso Strozzi, wealthy merchants who backed the new Government, adopted the usual methods of proscription to maintain 
their power. They appear to have encouraged informers, and one of these men was convicted of bearing false witness, and imprisoned. Scali and Strozzi organized a mob which attacked the palace of the Captain of the People, sacked it, and delivered the prisoner. (See concerning these events : Sozmeni Pistor. Hist.-March. dei Stefani.-Mem. Stor. di Ser Naddo da Montecatini.) Such an outrage could not be tolerated. Strozzi, forewarned, saved himself by flight; Scali was arrested and executed (1382). External troubles produced their usual effect, and this time they were reinforced by the political extinction of one and the death of another popular leader, and by the financial mesh which had been so carefully prepared to entangle the popular Government, and from which they could not extricate themselves. The reaction had come, and it was time for the party of privilege and foreign policy to be recalled and resume the reins of government. Even the artisans and some of the Ciompi were ready to reform the State and recall the exiles. There was another coup d'état; the nobles, the rich merchants, the entire party of the Albizzi, reinforced by the populace, advanced on the palace ; there was little opposition, for the truculent butchers remained neutral. Balia was given to a hundred citizens to reform the State.

On March I the new constitution was promulgated. It was ordained that the gonfaloniere of justice should always be elected from the major arts; that four of the eight Priors and seven of the twelve buonuomini should belong to the major arts, as well as the gonfaloniere of justice; and a similar preponderance was given to the major arts in every office of the State. The Council of the People was made chiefly representative of the major guilds; but the Council of the Commune was left unaltered, since wealthy burgherdom predominated therein. Exiles were to be recalled; the debtors of the commune were to be given time to pay their debts; the tax on oxen of labour imposed by the late Government was remitted, and even repaid. Two of the recently organized guilds were suppressed (Ammir. jun.). There were petty rows and riots, off and on, throughout the year, and the rioters played into the hands of the Parte Guelfa. The disturbances issued in the restriction of the minor arts to a third share only in the Government.

There can be little doubt that the minor arts were incapable of taking the larger views which the wider training of the wealthy merchants enabled them to pursue. The attempt of the masses was premature and abortive, because the conditions of mediæval life were incapable of giving them requisite political education. Capital had appeared in the world; the masses were led by men such as Salvestro dei Medici, who were capitalists, and who used them as tools to secure their own interest and the power of the purse. Reaction had set in ; a spirited foreign policy ensued; but the oligarchy was none the less doomed to fall before the astute capitalist who, posing as the benefactor of the people, contrived in time to fetter and control them.

The revolt of the Ciompi was really the outcome of unsatisfactory economic conditions; but these were not merely imperfectly understood: they only vaguely entered into the consciousness of the time. The masses refused to be the pariahs of society any longer. They had seen the classes above them successively rise to political power, and they made a bid for political power too. Political ambition always precurses economical 
revolt when that is imminent. The franchise had already been so extended that serious resistance on the part of the wealthy was not possible ; but when the masses achieved political power, they were in the hands of demagogues who ruined them by their excesses, and of the wealthy, who rendered their government impossible. Hence reaction arose ; the political aim had been realized, but the fruit withered as it was grasped. The intrigues of rivals turned the popular passions to the immediate profit but ultimate ruin of the popular movement; and we shall see the idol of the populace presently become the master of the State. The Florentines were a practical, acquisitive, shrewd, and able people, but the internal evolution of the State was ruined by the hatred and rancour of parties, the love of tyrannical power, and the absence of any statesmanlike sense of compromise. There was no conception of republican government possible which did not include proscription and exile. The old antagonism of two separate races-the Germanic conquerors and the vanquished Latinswas the true origin of the fight between the feudal nobility and the burgher class ; it also lay at the root of the conflicts between the nobles themselves. When the nobles were finally vanquished, the wealthy ruling class, formed by an admixture of the two opposed orders, ruled entirely from a class point of view; they could hardly do otherwise, when the masses were ignorant and untrained, when the city was menaced by foreign foes, and successful commerce depended on successful foreign policy. But the martial power and ardour of the nation was destroyed, and the payment of mercenary forces implied a ruinous taxation that was injurious to trade and productive of external discontent. Yet the quarrels of the city were, after all, only family quarrels; Florence, on the whole, presented an undivided front to the world. The aristocracy of the burghers always obtained political power in troublous times, and however tyrannical and unwise their domestic policy may have been, their foreign policy was consummately able. They sent their ablest men forth as Ambassadors, and the exquisite diplomacy of Florence saved her existence, and, to a large extent, relieved her of the heavy expenses of hired armies. Such a system was bound to be rudely shaken from within, and the growing power of the purse enabled a family that posed as friends of the people to effect and maintain by astute and imperceptible strategy what the tyrants of Milan effected by ruder methods. The appearance of Salvestro dei Medici as demagogue already announces the appearance of the modern capitalist; he was the harbinger of the overthrow of the Republic, which his family never ceased to undermine with subtle and calculated craft. Reaction due to the failure of the government of the lesser guilds led to a spirited foreign policy, followed by another reaction; and then came the establishment of the wily, secret, and unperceived government of a family that had been nobodies, who in the changing economic conditions of the age had become a new power, possessed of great wealth which they knew only too well how to employ.

Salvestro dei Medici, and not Michele Lando, was the real leader of the Ciompi. He used them and the lesser guilds to attack the greater guilds of which he was a member. His object was to lay the foundations of power for himself and his family, and to abase his rivals. His popularity secured him from the attack of his foes; it also enabled him to some extent to guide the movement; it was at once sword and buckler to him. Although 
the fruits of victory soon withered, they were not wholly lost to the lower orders ; the lesser guilds gained some ground, and, on the whole, Salvestro's popularity was vastly increased by his share in the movement.

The Rule of the Albizzi from the Fall of the lesser Arts from Power (1382) to the Death of Gian Galeazzo Visconti (I402).

The Parte Guelfa was again in power (1383), and at once began a policy of resistance to the great and growing power of Gian Galeazzo, the ambitious lord of Milan, and a policy of expansion, which was necessary if he were to be held in check. Arezzo, forty miles up the Arno, was enfeebled by her perpetual intestinal dissensions. A French army marching against Naples had taken the city, but a lieutenant of Charles of Durazzo held the citadel. The Tarlati and a number of exiles gave themselves to Siena, and that territory was consequently enriched by sixty-nine fortresses and a large extent of territory. It was the adherents of this party still remaining in the city that admitted the French troops, and it seemed as if Arezzo would fall into Sienese hands. But the Duke of Anjou, who was contesting the Crown of Naples with Charles, died, and his General, finding that he could not take the citadel, and that its commander had already sold it to Florence, negotiated with the Republic. Florence thus entered into the possession of Arezzo, much to the chagrin of Siena, for that city was also in treaty with the French commander at the time, and had given him valuable aid in the campaign. The bitterest rancour against Florence reigned in every true Sienese breast (I384) (Orlando Malavolti Storia di Siena). And this offence was followed, four years later, by Florentine support of the people of Montepulciano, who had exiled the Sienese party in the city, and practically become a dependancy of Florence. Florence thus cut the road from Siena to Rome, and a hostile garrison faced her back door, as it were. However, Florence refused to accept the overlordship of Montepulciano, and tried to maintain peace with Siena. It was not her policy to have Siena as an enemy, with Gian Galeazzo, her ambitious enemy, becoming so powerful. Siena, in a white heat of passion, offered herself to the lord of Milan, but he was at war with the lord of Padua, and did not want a coalition between the Carraresi and Florence. He not only refused, but took care to acquaint the Florentines with the fact, and with his wonted hypocrisy he assured them that under no circumstances whatever would he disturb Tuscan peace. Shortly afterwards, however (1389); he intrigued to get hold of Pisa, Bologna, San Miniato, Cortona, and Perugia. He was now the master of North Italy, and the young lord of Padua came to Tuscany for shelter and aid. There was scarcity of foodstuffs in Florence, and it therefore behoved the Government to be wary. Gian Galeazzo was more emphatic than ever in his protestations of amity, so Carrara was received with but cold welcome. A little later, however, on a second visit, he found the signoria better informed of the real character and intentions of Galeazzo. They began to understand how profound was the dissimulation, how specious the hypocrisy of the man whom the older Carrara even had only just come to judge with exactness. " Now," wrote he to his son, "I know Gian Galeazzo. Neither honour", nor pity, nor sworn faith ever yet inclined him to a disinterested deed. If he ever seeks what is good it is because his interest requires it, for he is without moral 
sense, and goodness, like hate and anger, is with him a matter of calculation." The signoria privately subsidized the young Carrara to employ mercenary troops, but Pietro Gambacorti, the leading citizen of Pisa, was less wise, and became one of Galeazzo's dupes. The age of unscrupulous diplomacy and bad faith was in its infancy as yet, and Florence once again lent an ear to Visconti's representations. She sent word to Carrara that he had better drop his enterprise, as she had entered into an offensive and defensive league with the lord of Milan ( 1389 ). Immediately afterwards, however, fresh evidence of Visconti's treachery caused her to renew the negotiations with Carrara, and war was declared ( 1390 ). Florence did not feel herself strong enough to stand against Visconti and his allies single-handed. She implored the protection of France. France was willing to give it, but at the cost of a nominal tribute, and the recognition of the French Antipope at Avignon. The chief citizens of the city (richiesti) were summoned by the signoria; they indignantly rejected the proffered terms. The citizens emptied their private purses into the coffers of the State, and John Hawkwood, the whilom protagonist of the foes of Florence, but who bore an intense hatred to Gian Galeazzo, was taken into their service. Bologna joined Florence, and the two allied cities now controlled an army of 3,00o lances (implying 9,00o horse), of which Florence contributed two-thirds.

Siena, Perugia, where the nobles were in the ascendant, and the lords of Urbino, Faenza, Rimini, Forli, and Imola all stood for Visconti, and his troops were vastly more numerous than those of the triple alliance of Carrara, Florence, and Bologna, but the invading troops were spread along too long a line. The war reduced itself in Tuscany to a series of small raids, and the besieging of small fortresses. The real seat of war was the Trevisan marches, where Carrara was hailed by Padua as a deliverer. Everywhere the villagers, groaning under the unwonted exactions of their new master, flocked to his standard. By midsummer, I390, he could call on the General who held Padua for Visconti to surrender. The reply was that only a fool, after being compelled to leave by the door, could hope to climb back again over the walls (Andrea Gataro). But Carrara knew the city well. Like Cyrus, he entered by the dry bed of the river, and soon the whole of Paduan territory was reft from the hands of Galeazzo. The result of this was that Visconti had to withdraw his troops from Siena and Bologna. John Hawkwood was thereby released from frontier warfare, and able to concentrate his energies on the great seat of war in Lombardy, and Este lost so much territory to Carrara that he was obliged to make peace with the allies. The Count of Armagnac, who was related by marriage to that Bernabo Visconti who had been murdered by Gian Galeazzo, was subsidized by Florence to attack Gian, and all the wiles of the Milanese despot could not seduce him from his compact. But he was defeated, and John Hawkwood found himself stationed in danger in the Ghiara d'Adda, with his retreat cut off. With a generalship which commanded the enthusiastic admiration of another great General-Arthur, Duke of Wellington-he contrived to get free. He crossed the Oglio and Mincio, but was again cut off. Floods aided the tactics of the enemy, and Hawkwood was isolated between the Adige and the Po. But no accident of nature or obstacle of invention sufficed to impede the genius of the great mercenary. He was a man of great originality of mind; the bulldog tenacity of his race told in adverse and seemingly hopeless hours, and he 
possessed the enthusiastic confidence of his soldiery. He conducted a marvellous retreat, and when Visconti sent his troops to overrun Tuscany, Hawkwood was already there awaiting them (I39r). The result was that peace was arranged in 1392 ; but, as one of the Florentine Ambassadors observed, there was only one good guarantee of its observance-both sides had felt the weight and sharpness of the sword. The treaty of peace did not, however, ensure tranquillity to Florence. Balked in arms, Gian Galeazzo threw all his energies into intrigue, and in that art he was a past master. Although he had disbanded his mercenaries, he had a secret understanding with them, and they were constantly making inroads into Tuscany, and giving Florence much trouble and anxiety. And in 1394 Florence had the misfortune to lose her great General. John Hawkwood died on a little estate which he had purchased near Florence. The grateful Republic opened its cathedral to receive his remains, and there on the wall Englishmen can see to this day an equestrian portrait of their great countryman "Acuto," as the Italians called him.

The mercenaries whom Galeazzo was enabled by his wealth to retain on half-pay continued to threaten Florentine territory, and harass that of their allies. In this way Visconti first endeavoured to weaken the prey that he had marked out for his. The Florentines tried to retaliate on the same lines, but with poor success. They sought the help of the King of France again; but the untoward destruction of the flower of French chivalry by the advancing Turk at Nicopolis put an end to this hope (r396). An attempt of Visconti to get possession of San Miniato by treacherous means was thwarted by the loyalty of its citizens to Florence. Of the two dominations they preferred that of the Republic (1396). The danger had been great. Had Visconti got possession of this town in the heart of Tuscany he could have exhausted Florence by the constant harass of slow warfare; he could have bled her to death by the pin-pricks of rapine without risking a single great battle.

As it was, his troops ravaged the valley of the Arno. But Galeazzo over-reached himself; he attacked the lord of Mantua without any declaration of war. Mantua has the natural defence of its lake, and offered a long resistance. At last the troops of Visconti managed to burn down the fortified bridge that commanded the lake, and it seemed as if Mantua must fall. Then Florence came to the rescue. She sent 3,00o horse to the relief of the city, and at the battle of Governolot the allies gained a signal victory. Six thousand men and 2,00o horses were killed or captured, and Visconti tried to secure peace. Months were occupied in weary negotiation, for it was difficult to accept an agreement wherein fraud and bad faith were sure to enter. At last Venice, uncertain what course to adopt with regard to Galeazzo, decided to gain time ; she mediated and offered to ensure peace, and a truce was signed for ten years ( 1398 ).

Defeat and the truce only served as a stimulus to the restless, crafty weavings of Visconti's policy. The very same year he bought Pisa, and took possession of it early in $\mathrm{r} 399$. His myrmidons on half-pay ravaged Perugia and Siena. The former city was exhausted by the unending conspiracies and warfares of her passionate nobles, who kept her in a whirlpool of disorder, and Siena was reduced by class conflicts, the Plague, and the interminable war with Florence. She had been an ally of the lord of Milan for ten years. Gian Galeazzo pretended that he was not likely to 
renew the compact; this redoubled the anxiety of the exhausted State, and finally Visconti graciously assumed the protectorate with increased powers (I 399). Perugia followed the example of Siena, and 800 of Visconti's horse entered the city, January 3I, I 400. The ensign of the Duke was spread out to the breeze an hour before sunset, the date and the hour having been fixed by the calculations of his astrologers. Visconti was at pains to explain to the two cities that Florence had been disturbing the waters, not he ; it was she that had secretly subsidized the free companies, so seeds of mistrust were carefully implanted on a soil only too ready to receive them.

Florence now found herself surrounded by the allies of Visconti. The Counts of Poppi and Bagno, and the Ubertini feudatories, had become his men ; and Venice, weak as a land power, had not dared to stir. Lucca and Bologna were the hotbeds of revolution and discontent, and must, it seemed, fall into Gian's power before long; Rome and Naples were impotent to aid. The Plague was abroad again; the fourteenth century was closing in gloom and despair.

But worse was to follow. A ray of hope came only to disappear. Wenceslaus, the incapable German Emperor, had been deposed. Germany was poor, and relied on Italy as a source of revenue to her ruler. The dukedom which Wenceslaus had bestowed on Visconti might be held to deprive the Empire of revenue, and Visconti was wealthier than any other Italian power. Robert, the new Emperor-elect, was expressly charged to annul the investiture and make war on Visconti. He sent Ambassadors to Florence, who deputed citizens to accompany them to Rome and get the support of the Pope. But solicitation was in vain. Boniface IX. was too timid to incur any risk, and the negotiation fell through (1401).

Day by day fresh plots fomented by Gian Galeazzo were discovered. There was a conspiracy afoot of certain Pistojese to deliver the city to the Duke. The conspirators were exiled, but they surprised the castle of Sambuca, and carried on predatory warfare tor three years, reducing the country to such a condition that Florence was ultimately compelled to annul all the privileges of Pistoja, and unite the city to the Florentine State. Robert now assembled his troops at Trient; he was furnished with 200,000 florins by the Florentines, who promised that more should follow, but only half his feudatories put in an appearance. And Visconti's General, Jacopo del Verme, at the head of Italian troops, routed the Imperial army. The Germans had made no great advance in armour or tactics in the course of the last century, and the astonished world woke up to the fact of the overwhelming superiority of Italian cavalry. Fresh negotiations followed between the Emperor-elect and the Florentines, but the latter had little confidence in the persistence or power of Robert. They submitted their differences to the arbitration of Venice. Astute Venice was deceived by the subtle craft of Visconti. He had carefully avoided manifesting any illwill towards or suspicion of the Republic. Padua still stood as a barrierState between Venice and the dukedom. The Senate were willing to do the allies a good turn, but not to incur the resentment of their powerful neighbour. The Venetian Government therefore decided to return a refusal to help the Florentines, and while these were still urging the Venetians to take their part, the army of Robert was breaking up and recrossing the Alps in detachments. At last the Emperor himself departed, 
and though he came back to take 65,000 more florins from Florence, the danger to Gian Galeazzo had by then ceased to be formidable, and he turned his attention to Bologna. This city had been torn by faction for three years, and in I4OI Giovanni Bentivoglio, who had a secret understanding with the Duke, and who was supported by the nobles and the Maltraversi party, after a fierce fight got possession of the city. He had promised, if he was successful in seizing the city, to sell it to Visconti ; but once master of it, and accepted as its lord, he conveniently neglected to fulfil his share of the agreement. Visconti now attacked him. Florence sent aid, but the Bolognese, who detested the yoke of Bentivoglio, refused to fight, and the allies were defeated at Casalecchio (I4O2). The night following the battle the Bolognese rose in insurrection. Some of the insurgents were in correspondence with the Duke, who had promised to restore the Republic, and these opened the gates of the city to his troops. Bentivoglio was taken prisoner, and put to death by a personal enemy two days afterwards; one of the Florentine Ambassadors died of his wounds, and the other, one of the Ten of War and principal men of the State, was made prisoner. The Duke had promised to restore Bologneso liberty. He kept the word of promise to the ear. Anziani were elected, and edicts issued in the name of the Republic, but the very next day his cavalry "rushed" the city. One of his creatures proposed that the lordship should be given to the Duke, and the phantom republic ceased to exist.

It was now possible to Galeazzo to ruin Florentine commerce ; the ports of Siena and Pisa were closed to it. One little harbour, that of Motrone, near Pietra Santa, in Lunigiani, alone remained open to its bales, and the Duke sent 800 horse to cut off this last trade-route to the sea. Pistoja was worried by constant raids; the Ubaldini held many a mountain track, and menaced Firenzuola. For ten years the Republic had maintained unequal war; she had been subjected to a series of reverses; her routes were blocked in every direction, and her only ally, the lord of Padua, could bestow no help; on the contrary, he sadly needed it. Genoa, Perugia, Siena, Pisa, Lucca, Bologna, had lost their freedom. A physical coward, the Northern despot sat solitary and well guarded in his castle at Pavia, and there like a malignant fate he seemed to spin the web of destiny. Central and Northern Italy were for him a chequer-board for the workings of his dark and deep-laid designs, or a chace for the exhibition of his vulpine craft and crooked wisdom. What remained of free Italy was worn out by war, and it seemed that the ambition of Galeazzo to be King of Italy was about to be accomplished. But an irrelevant accident, or what might seem to be such, often determines the destiny of peoples, and diverts the course of history. The Plague reached Lombardy, and Gian Galeazzo was attacked. Like Louis XI., he was a devout believer in the stars. A comet had just appeared in the heavens, and Galeazzo, with that curious passion for fame which he shared with his contemporaries, thanked God that $\mathrm{He}$ had manifested the sign of his recall to all men (Ann. Bonincontrii Miniatensis). He died September 3, 1402, and the comet might indeed be taken to " portend divisions," for his possessions fell to pieces, and the balance of the States in Italy was restored.

During these external dangers that menaced the Florentine State the Government remained in the hands of the haute bourgeoisie-the wealthy 
merchants, who were skilled in foreign affairs, and who appear to have developed a fine Tory prejudice, which was not, however, without some cause and some justification. They, as foreign traders, were alone directly and immediately interested in foreign politics and in the prosecution of foreign warfare. The petty trader or the artisan knew little and cared less about the external relations of the State ; he hated war, for war meant retrenchment on the part of the wealthy, and what suited him was free expenditure and small taxation. Consequently the Albizzi were determined at any cost to secure the continuance of their power ; they tried to remodel the State by means of the new councils and the balia, so as to approximate towards the stability of Venetian oligarchy; they ruled with a high, determined hand; they had the effrontery, through four of their creatures, to malke a list of the names of all those citizens who were most to be counted on as supporters of themselves, and from the list a borsellino was formed, whence two members of every signoria must henceforward be taken. Three years later Gian Galeazzo Visconti remarked that a certain section of Florentine citizens, under cover of excessive zeal for the Guelphic cause, had contrived to tread on their fellows and fetter the Republic, and the supercilious assumption and high-handed audacity of the rulers of the hour in Italian republics enable us to understand how the despotism of one was accepted in so many cases as a refuge from the tyranny of many.

The continuance of war favoured the maintenance of power by the Albizzi ; but in I393, when the campaign which Hawkwood had so brilliantly conducted was at an end, the lower classes rose en masse, and crowded round the palace of Vieri and Micheli dei Medici, the heads of the family now, for Salvestro was dead. They entreated these "Liberal leaders " to take up their cause, and protect the lesser people against an oppressive Government. Either the Medici were too timid or too feeble, or they had the good sense not to weaken the Republic at a time when danger had by no means passed by ; they refused, and put out all their powers to pacify the multitude. The Government took advantage of this demonstration to exile the heads of the Alberti family, who were the leaders of the opposition, as the Albizzi family were of the party in power. The reaction had therefore no other effect than to strengthen the Government. In fact, in this year a very clever move, not unknown in modern politics, was made by the Tories. Young people of rank flattered the minor arts by matriculating into them. Their wealth, their prestige, their audacity and habit of rule, soon enabled them to lead the uneducated masses by the nose. The classes most dangerous to the Government thus had their teeth drawn, and the signoria got power to impose taxes and raise loans without the authority of councils. Fresh lists of those admissible to office were made out, and all obnoxious names were excluded. Three of the Priors must be of the list contained in the borsellino. If a gonfaloniere of justice did not come to heel he was changed. The Priors must be at least forty-five years of age ; by that time men have usually lost the impolitic, if generous, impulses of youth, and though the power of ammonizione was taken away from the Parte Guelfa it was only because it was no longer of service to a party that had come to an understanding with what remained of the magnates. The whole object of the party of rich merchants was to secure the future control of the State entirely to themselves, so that 
there might be benevolent oligarchical rule unirritated and undisturbed by intrusive irrelevancies.

Long before they had fully carried out their programme they suffered from internal dissension. In 1396 a split took place in the Albizzi party. Maso dei Albizzi was at that time quite the chief man in Florence, the opposite party being led by the Medici and Alberti. Donato Acciaiuoli was, next to Maso, the most considerable man of his faction, but we suddenly discover him conspiring for the recall of exiles and the re-establishment of some kind of balance between the two parties of the State. The plot was discovered, and Acciaiuoli banished. Probably the pressing danger of Visconti's ambitious intrigues concentrated the authority of the Albizzi, and centralized it in Maso, and this aroused the alarm and jealousy of his fellow-citizens, for in I 398 , directly after the victory at Governolo removed a pressing danger, we find a third plot afoot. The younger members of the illustrious Houses of the Medici, Ricci, Spini, and Cavicciuoli suddenly traversed the streets in full armour, and called on the people to put a stop to the tyranny of the Albizzi. A crowd gathered, and followed them in silent, surprised astonishment. The attempt was a dead failure; the young men were taken and executed. They confessed that they had hoped to kill Maso and overthrow the Government.

This Government of rich merchants of established family at this epoch was the saving of the State. It was selfish and oppressive to the people, but it was composed of men of great natural ability, and special training and experience in great affairs, accustomed to deal with the Princes of Europe, taking in the traditions of policy almost with their mothers' milk. They alone penetrated the hypocrisy of Gian Galeazzo at a time when he bamboozled the Pope and even the Venetian Senate, and all Italy seemed blind to his machinations. They were men of such tenacity of character that no calamity could turn them ; of such public honour that, so far, no change of circumstance had ever induced them to withdraw from their pledged word; of such fidelity to their party, and so convinced of the justice of their principles that the Government remained as single of purpose as any dictator of them all. They were, moreover, inspired by a true love of liberty, as they understood liberty, and though it was really only the freedom of a privileged class, they fought for and maintained it as a sacred possession. They were arrogant, inconsiderate, oppressive; their faults were many and grievous, it is true. Strong Governments are not usually remarkable for any very high development of the sympathetic imagination, but with all their faults the Albizzi were possessed by a strong sense of duty, and followed it whithersoever it led.

"The spirit of self-sacrifice

The confidence of reason gave."

\section{The-Subjugation of Pisa (i406) and the Danger from Naples (I 408-I4I4)}

The Albizzi Government, representing a reduced and Conservative electorate, still had grave problems of foreign policy perpetually presenting themselves for solution. They had been left alone of Italy to fight the battle of liberty against Gian Galeazzo. No sooner was he dead than the 
vultures flocked to prey on the carcase. Pope Boniface IX., anxious to recover Bologna, Perugia, and Assisi, allied himself with the Florentines to despoil the inheritors of the Duke (I 402 ), but directly he recovered what had once belonged to the States of the Church he abandoned the Republic and made a separate peace. In vain did Florence remonstrate. The object of the alliance had been not merely the recovery of Papal possessions, but the freedom of the Tuscan cities, and only the first half of the enterprise was attained. Boniface protracted negotiations until public feeling had somewhat calmed down, and then signed his separate treaty for peace. Isolated once again, Florence did not desert the Guelphs of Lombardy, but sent them money and men ; she tried to help the Pisans and Sienese to throw off their yoke, and subdued all her rebellious Ghibelline feudatories in the Apennines (1404). The Government was long-sighted enough to allow a natural frontier to bound Florentine territory; they neither attempted to extend their conquests beyond the Apennines nor to form permanent alliances, though they continued to help the revolting cities of the North. Gabriello Visconti, the natural son of Gian Galeazzo, ruled at Pisa, but he had been obliged to cast himself on Boucicault, the Governor of Genoa, for support. Boucicault found that every day he maintained his own position with increasing difficulty; he wished to secure the friendship and support of Florence ; he was no longer in a position to aid Visconti, and he advised him to sell Pisa to the Republic. It was arranged that Visconti and Boucicault should share the purchase-money between them, and in June, I 405 , Boucicault entrusted a Florentine citizen, then resident at Genoa, with a confidential mission to the signoria. The price asked was 400,000 florins, of which a certain portion was to go to the aid of Francesco da Carrara, now at war with Venice. Visconti had some doubt as to the good faith of Boucicault; he suspected that he would see little enongh of Florentine gold himself; he procrastinated, and, meanwhile, the intrigue took wind. The Pisans rushed to arms, and forced Visconti to take refuge in the citadel. Visconti was now quite willing to sell, and the Florentines entered into possession of the citadel and certain fortresses at the price of 206,000 florins, payable in instalments. The Pisans, the most martial people in Tuscany, were not likely to sit down tamely while they were bought and sold like so many of their own oxen; they attacked and took the citadel, and sent Ambassadors to Florence to remonstrate and point out that the occupation of the citadel violated a treaty between the two States signed the preceding year. Whatever Florence had paid they offered to reimburse. The moderate party in Florence were very much against any attempt at the subjugation of Pisa ; they dreaded the expenditure of men and money and the risk involved in incurring a fresh war. But the "imperialistic" party prevailed. Pisa had caused Florence much annoyance, and had interfered very seriously with her trade on more than one occasion, notably in the war of forty years ago concerning Volterra ; and although the harbour of Pisa was silting up, and had become of little value, still Pisa stood between Florence and the sea, and was always a menace, whether she stood by herself or was in alliance. Great States were growing up around, and Florence also must extend her territory. The party in power had no really strong opposition to encounter, however, and they determined on war. A year's war and a year's siege followed. The Pisans fought gallantly, but lost both on land and sea. They offered 
the lordship of the city to Ladislaus, King of Naples, but that monarch did not sit sufficiently tight on his throne as yet to meditate such distant conquests ; moreover, the Florentines bargained with him; they engaged to leave him alone in his designs on Rome if he would leave them alone in their siege of Pisa. At last Pisa, worn down by fever and famine, was compelled to capitulate.

Gian Capponi, one of the Ten of War, was entrusted with the government of Pisa, and on his entry into the city he assembled the citizens, and promised that Florence would treat them with every consideration. But in those days a State had to be either anvil or hammer. A common Christian faith was a matter of traditional and conventional lip-service, or a purely personal relation between the individual soul and the Church, as such, and the Deity. Its morality was subjective, and Christianity then claimed to sway international relations even less than it does to-day. The Pope, once arbiter and guardian of the Christian conscience, was now almost a nonentity and powerless in practical affairs. Va victis was the sentiment of the times ; economical laws were scarcely at all understood, and the goose that laid the golden eggs was frequently maltreated or killed outright. The Ten of War really sent orders to crush every germ of revolt, and to drive out all dangerous citizens with the most unrelenting severity. Streams of citizens flowed forth into exile. Many took up a military career ; for the high spirit of the Pisan did not tamely submit; he was always plotting against his cruel conqueror. Many were compelled to transport themselves to Florence, or to go into banishment. "Never was Jew treated by Gentile as the Pisan by the Florentine" (Johannis Ser Cambii Chron. Scrip. Rer. Ital., xviii.) (1406).

In order to subdue Pisa, Florence was compelled to abandon the policy that she had pursued for a whole century. She had aimed during that period at a balance of the Italian powers ; she was always ready to help the weak against the strong, either by alliance or by actual aid in time of war ; she now allowed Milan to reconsolidate herself, Venice to acquire a firm grasp on the mainland, Ladislaus of Naples to become powerful in the South. Henceforth the balance of power was to be between fewer but larger States.

Hardly had she organized her new Government in Pisa when Florence was threatened by Naples, a State which had become so rotten that it fell an easy prey to a Prince of ambition and capacity.

Ladislaus, the son of Charles III., had succeeded his father while still a minor. But there was another aspirant to the Neapolitan throneLouis II. of Anjou, whose father had been nominated as her successor by Queen Giovanna at the instigation of the Hungarians, whose King she had married. Ladislaus had grown up in the midst of civil war and conspiracy; he had been educated in a school where personal bravery, profound dissimulation, self-command, and great mental endowment were required, not merely for success, but for the preservation of bare life. A man of parts and of power was sure to secure followers; a man possessed of the faintest scruples of conscience or the smallest sense of the righteous claims of others would have fared as hardly as a consistent Buddhist surrounded by prowling, stealthy carnivora, or incautiously intruding into a nest of envenomed snakes. Ladislaus was a man of his times and acceptable to his times; he was debauched, he was cruel, but he had brains, and he 
was wholly unrestrained by any stupid sense of duty or consideration for others. When he wanted to marry a Princess of Cyprus he repudiated his first wife, who, after the inconsequent manner of women, was passionately attached to him; he was one of the first, if not the first, to secure divorce from the weakened Papacy (for hitherto the Church had not ventured to annul its own sacrament), and he kept his wife in ignorance of the fact until the Bishop read out the Bull when both were at service, and descended from the altar to tear the wedding-ring from her finger. Ladislaus shut her up for two years, and then ordered her to marry one of his favourites. As she was dragged to the altar, this spirited woman turned to her new spouse and congratulated him on his rare fortune in securing as mistress the wedded wife of the King (Bonincontr. Miniat. Annal.-Giannone, Ist. Civile). Ladislaus abandoned the hopeless task of enforcing his claim to the Crown of Hungary, and concentrated his energies to secure the kingdom of the South. He drove Louis and his brother Charles of Anjou from Italy; he contrived to aggravate and protract the Great Schism; he fished in troubled waters, and under the pretence of aiding the Italian Pope he got possession of Rome, Ascoli, Perugia, Assisi, and a great part of the States of the Church; he gave Gregory XII, 20,000 florins a year, and took the revenues of those States himself; he hoped to subdue the greater part, if not the whole, of Italy, and to seize the Imperial crown, and he had for his device Aut Casar, aut nullus (Jacopo de Delayto, Annal. Estensis).

Florence barred the way. He called on her to recognise him as legitimate Sovereign of the States of the Church, which would have been tantamount to acknowledging his suzerainty over her. Florence refused. "What troops have you to oppose me ?" he asked the Florentine Ambassador. "Your own," was the reply. Florence was ready, by self-denial and selfsacrifice, and at any cost, by means of forced loans even, to resist. She offered superior pay, and drew many of the condottieri of Ladislaus to herself; for these wary gentry were too shrewd to take service for any lengthened term, and were always ready to change sides for higher wage. Among them was the great commander Braccio, a Perugian exile. Ladislaus had accepted the signory of that city, had promised to protect its banished men no longer, and had, it is saicl, even attempted, at Perugian instigation, to get Braccio, who had served him with unusual fidelity, assassinated.

The Twelve at Siena were suspected of inclining toward Ladislaus, but the Government in power was against him, and both Florence and Siena sent Embassies to the King to try and avert the storm at the same time as the King sent a mission to them to try to detach one from the other by the bribe of specially advantageous terms. The Sienese remained firm, and war begall.

Ladislaus put a superior force in the field; the territory of Siena was ravaged up to the very walls of the city; Arezzo was threatened, but not a single fortified place surrendered. The Neapolitan navy infested the Pisan Sea, and took the Isle of Elba-a possession of the lord of Piombino, a vassal of Florence-and at last Cortona surrendered (I 409). But Braccio, now one of the Florentine commanders, succeeded in cutting off Ladislaus' supplies, and, without exposing his little army to the issues of a great battle, compelled him to withdraw to Rome, though he left garrisons behind him at Cortona and other towns. The Florentines now called Louis of Anjou, 
the rival claimant to the throne, to take advantage of his opportunity. $\mathrm{He}$ arrived a.t Pisa with five galleys and I,500 horse, was acknowledged by the council of Pisa, and received investiture from the Pope, and the standard of the Church. He was warmly received by many cities feudatory to the Pope, but failed to take Rome. Louis was discouraged, and sailed for France, but Florence succeeded, on the withdrawal of Ladislaus from Rome, in taking possession of that city at the opening of the New Year (14IO). The Florentines were received with joy by all friends of freedom in Rome ; their army conducted itself with such exemplary discipline that Rome sent a deputation to Florence to thank the signoria (Piero Minerbetti). Louis of Anjou had by this time collected more troops, and set sail for Italy ; but meanwhile Genoa took advantage of the absence of Boucicault to renounce the French yoke. The fleet of Louis was defeated at Meloria, and the city declared for Ladislaus in order to keep the French at bay. Genoa, Florence, and Siena wanted the same harbours, so the two latter cities now had a little war with Genoa on their hands, as well as the bigger contest. Siena lost Talamone, and this unexpected side issue dragged along for three years until the peace of Lucca (I4I3). Louis contrived to land, but he was without money, and his army without stores. Florence did not feel inclined to pay the whole expenses of the war; Ladislaus was anxious to detach the Tuscan towns from the alliance against him, and offered to come to terms, and in I4II Florence and Siena withdrew from the contest, Ladislaus surrendering Cortona and two fortified places to Florence as an indemnity for certain damages sustained by her merchants at the commencement of the war. Florence now had to exert some political pressure on her neighbour Bologna, which rebelled against John XXIII., who had been lord of that city long before he became Pope. Directly he set out from Bologna for Rome, now open to him, the citizens captured the citadel and defied him. The revolution might give a new opening to aggression; it would certainly weaken the Pope, and, perhaps, menace the continuance of the league, so Florence sent experienced Ambassadors to the Bolognese, who promised to remain in obedience to the Pope for as long as he recognised their liberty (Mem. di Jacopo Salviati, one of the Ambassadors.-Cronica di Bologna.-Mathei de Griffon.). The Pope, deserted by his last ally, Louis, had now to come to terms with Ladislaus, but in I 4 I $_{3}$ the King suddenly advanced on Rome, took it, gave up all Florentine property in the city to pillage, and promised his soldiery that they should soon have the sacking of Florence itself. The Republic at once set its house in order ; Ten of War were nominated to conduct it, condottieri were engaged, and several feudatories of the Church placed their services at the disposal of the Republic for periods varying from five to ten years. Florentine expenses, however, had been very high, and an enormous proportion of the income of the merchants had been cheerfully given up in the form of forced loans in order to meet them. The Government therefore tried to avoid war by every expedient. John XXIII., who had fled to the city for refuge, was not admitted, though he was given shelter in a country house belonging to the Bishop, and before long he departed for Bologna, where another revolution had reestablished the sway of the Church. The negotiations of Florence with Ladislaus dragged on, but meanwhile the Neapolitan King subdued all the patrimony of St. Peter up to the frontiers of Florence and Siena, and 
nearly succeeded in getting the Marquis of Este to attack Bologna, where the Pope was. Such a movement would have obliged the Florentines to divide their forces, and they only escaped it by the most adroit diplomacy and the mediation of the Emperor Sigismund, who was then present in Italy, concerning himself with the Schism and Italian affairs (I4I3). Ladislaus, finding his project balked, kept quiet during the winter, but in the spring, having filled his treasury by exaction and the sale of titles, he led an army of I 5,ooo men-at-arms to Rome, and promised his troops abundant pillage in the rich cities of Tuscany. He was for ever giving vent to his annoyance at the impertinence and extreme boldness of Florence in daring to thwart him, but when Florence sent her Ambassadors he was as conciliatory and deferential as could be. He had a great respect for the signoria; it was so just and impartial. Would they act as arbitrators in his unhappy difference with the Pope ? He was not attacking the overlordship of the Holy See ; he only wanted to get his position legitimatized as Vicar of the Church over the territory that he had brought into order and was administering; he was ready to pay any just and equitable tribute (Scipione Ammirato). John was engaged with negotiations concerning the Council of Constance, and just now these were at a most critical stage. The tiara itself was in danger; he was at too great disadvantage to be of avail in the defence of his own States, far less could he be useful to Florence. In a word, both he and Ladislaus were as full of dissimulation and mealy-mouthed dishonesty as they could be. Florence could hardly hope to stand against Ladislaus alone without ruinous expense and possible disaster, and, conjointly with the cities of Bologna and Siena, and Braccio di Montone, she signed a treaty of peace, which she well knew was only an armistice to gain time (1414).

Three years before forced loans had caused considerable resistance. Florence had to reorganize her councils. One, consisting of I4I members, included of the gonfalonier and the Priors, the assessors, the Captain of the parte, the Ten of Liberty, six councillors of commerce, twenty-one representatives of the guilds, and forty-eight citizens. Another council of 200 was open to all who, since the suppression of the Ciompi, had been eligible to the three greater offices of State. Fifty names were drawn at a time, all of whom were to be not less than thirty years of age, and not more than three belonging to the same clan of related families. On any question of war a majority of two-thirds must be obtained; the question was then to be taken before the I4I, and then on to the Consiglio del Popolo and the Consiglio del Commune. Thus it was hoped that, the real mind of the city being ascertained, no objection could be raised to the enforcement of loans or increased taxation if such became inevitable. When the war with Genoa arose (I4II) the real question was one of harbours. The large merchants who governed were of one mind, the councils were divided, so the gonfalonieve, the Ten, and the Priors settled the business by putting an armed guard at the doors of the Session until the members gave way. But now there was a general feeling that open war would be better than prolonged suspense, and the signoria had again to put pressure on the councils in order to enforce the policy of delay (Istorie Anonime di Firenzi).

Happily the unexpected death of Ladislaus ${ }^{1}$ relieved the tension of

1 Ladislaus and one of his numerous mistresses died within a short time of cone another from some virulent venereal disease. It could hardly have been syphifis, 
the situation. Providence had removed the Neapolitan King, like the Duke of Milan, at a moment when the future of the Republic seemed charged with failure and misfortune (1414). Rome at once threw off the Neapolitan yoke, civil war between the rival Houses was renewed in the South, the immediately succeeding rulers were as incompetent as they were corrupt, and that decay of the Neapolitan kingdom that the energy and talent of Ladislaus had temporarily arrested became more evident than ever.

\section{From the Death of Ladislaus of Naples (1414) to the Recall of Cosimo dei Medici (I434)}

The expenses of almost continuous war had been tremendous. The war of the Eight Saints against the Pope had cost 2,500,000 florins, the three wars against Gian Galeazzo had cost 7,500,000 florins, and the subjugation of Pisa had implied a further expenditure of $1,500,000$ florins (G. Dati). Consequently the Government gladly renewed its ancient alliance with the kingdom of Naples, and with the newly-elected Pope of reunited Catholicism. Rome and the Papal States had thrown off his authority, and Florence gained prestige and hoped for future favour by offering him a home within her walls. She secured a very good understanding with Braccio di Montone, who had carved out a State for himself and was ruling at Perugia, and since Lombardy, torn to pieces by the break-up of Gian Galeazzo's dukedom, was no longer a menace, she now hoped for a peaceful time to recover from her exhaustion and extend her commerce.

For thirty-five years Maso dei Albizzi had been the leading spirit of the party in power, and when he died (I4I7) a body of able men, all of the haute bourgeoisie, presided over the filling in of the lists from which the Priors and the other officers of State were drawn. But there was a great deal of discontent smouldering in the city. Florence had by this time become a city of extremely rich merchants and an extremely poor proletariat. And not only were riches unevenly distributed, but the wealthy trader oppressed the lower classes. He had learned the secret of exploiting labour to his own advantage, and had discovered that the human claims of the worker were incompatible with the swiftest and completest returns on his capital. He had become so important a person that his material interests were above every other public consideration. The State must be governed with a view to the material interests of the upper class of merchants and financiers. Many rich traders, however, had sprung from the ranks since the revolution of the Ciompi, and they found their natural aspirations checked by the rule of the oligarchy. Consequently, both these men and the mass of the people were ill content with the rule of an oligarchy which, although demonstrating such conspicuous ability

as that complaint seems to have been unknown in Europe until nearly a century later. Of course, especially as the lady in question was the daughter of a Perugian physician, she was supposed at the time to have administered poison to the King in some subtle way. Poison, witchcraft, and technical terms are convenient havens of refuge for small knowledge and hasty diagnosis, and throughout the Middle Ages and the Renaissance the unexpected death of an eminent person was usually ascribed to poison. The theory had the considerable advantage of administering at once to a very human inclination to calumny, and a no less natural natural love of melodramatic excitement. 
in foreign policy, remained exclusive, and out of sympathy with the needs and aspirations of the great bulk of their fellow-citizens. The family that by reason of its wealth, its trade connections, and, perhaps, its ability, stood at the head of the opposition was the Medici. In I370 Salvestro dei Medici was the real leader who pulled the strings of the Ciompi insurrection, and although that movement only achieved temporary success some little advantage was gained by the popolo minuto, and Salvestro became a very popular man. Salvestro died in I388, and when the Albizzi came into power, and a strong foreign policy was required above all things, his son Vieri was wise enough to keep quiet without losing touch of his political friends. Giovanni dei Medici, one of the family, devoted himself to banking. The assembling of the Council of Constance (1414I4I 8) enabled him to achieve a colossal fortune, and of course the members of his family and his friends shared in his success. The power of the purse had got the whip-hand in Florence. The Albizzi had not dared to attack Salvestro, and the Medici who followed him were wise enough to abstain from anything more overt than an attitude of benevolent neutrality towards the malcontents until the coming time when they should have become sufficiently indispensable to the commercial life of the city to strike and strike home, and assume the direction of affairs. Giovanni dei Medici found himself sufficiently powerful to oppose the Albizzi in the councils, and the Government discovered that they had caught a Tartar that they could not subdue, and who was not at all likely to leave them alone. Doubtless a conflict between the rival parties would have occurred much earlier than it did but for the reconstruction of the duliedom of Milan by Gian Galeazzo's son Filippo Maria. The rehabilitation of the duchy at the hands of a man who inherited all the craft and much of the ability of his father diverted public attention from home questions to foreign affairs. Yet, though Filippo recovered State after State that had belonged to his father, and his General, Carmagnola, was pushing Genoa very hard, Florence refused aid to that State unless she were allowed to purchase Leghorn. Leghorn had been given over to Boucicault, the French Legate at Genoa, by Gabriello Maria Visconti, the despot of Pisa, and when that General was deposed Genoa had come into the possession of the port of which the Florentines were naturally avid, for it was a place of some commercial and strategic valuc, and quite close to their new acquisition, Pisa. Genoa refused to part with Leghorn, and the Albizzi received yet another check in being obliged, by the peace party and public opinion, to sign an agreement with Filippo Maria by which the signatories agreed to delimit their interests.

But four years later Filippo Maria, now in the plenitude of his power, violated this treaty; he meddled in the affairs of Romagna, and his armies were approaching Tuscany in every direction. War was therefore declared (I423). From the outset the Florentines were unfortunate. Braccio, a General at this moment fighting on behalf of Alfonzo of Naples, but for whose services they paid an annual retaining fee, was killed in battle at the very time when the Florentine envoys came up with 66,000 florins to engage him and his band, and the victors robbed them of every coin of it all. They then engaged Carolo Malatesta to lead the army of the Republic ; and Pandolfo Malatesta, one of his Generals, was beaten at Forli, and Carolo himself was taken prisoner at Tagonara. The Duke received his prisoner with diplomatic courtesy; he loaded him with attentions; he 
fêted him on every available opportunity; he gave him his freedom without ransom or condition; and he gained his object : Malatesta transferred his services from the Republic to the Duke (1424). Florence sent out another army; it was defeated in Romagna, though this was not wholly to the disadvantage of Florence, for Piccinino, her General, induced the lord of Faenza, who was his gaoler, to desert the Duke and take sides with the city. But a fourth defeat awaited another army that had been despatched to Liguria; the Florentines were worsted for the fifth time at Anghiari, and almost immediately afterwards came off badly at Faggiuola; they had suffered six serious disasters in succession, entirely unrelieved by the smallest success on the field, and four of these overthrows had happened in a single year ( 1425 ).

Yet the Albizzi and their party did not quail : they enrolled a seventh army; they sent their most skilful diplomatists to seek aid from every power that was interested in maintaining the balance of power in Italy. Sigismund, the Emperor, was too much occupied with Turks and Hussites to help; the Pope would not, the Venetians seemed uncertain. Florence sent three Ambassadors in succession to Venice; the lords of Mantua, Ferrara, and Ravenna, who were getting alarmed at the growing power of the Duke, seconded their efforts ; Carmagnola, once the favourite General of the Duke, but who was now in disgrace with him, offered his services, and Florence secured Venice as an ally. Peace was sued for by the Duke, who was losing ground, in 1426 ; it was necessary for him, for the present, to stop a losing game and to consolidate his shaken power; but the war soon recommenced. By 1428, though Venice was harassed by the Turk in the Levant, matters were going well for her on the mainland, and she was unwilling to come to terms; but Florence had incurred a debt of 230,000,000 florins; the war was costing her 70,000 florins a month, and the expenses had to be borne by a State having a circumference of only about fifty miles, and the chief burthen fell on a city of only roo,00o inhabitants. The Duke was willing to recognise as allies of Florence, and therefore sacrosanct, Siena, the Fregosi, Adorni, and Fieschi of Genoa, the lords of Romagna, and Paolo Guinigi, the chief man in Lucca, who had hitherto been opposed to the neighbouring city; and Florence signed a second "Peace of Ferrara" (1428). Of course, it was a peace only in name: the Duke recoiled to make the better spring, but it gave all parties the breathing-time which they sadly needed.

The great problem that presented itself to the Florentine Government was how to raise the wind in a way that would not increase the growing dissatisfaction at home. Could this be quelled and funds raised by some astute policy? Could it be put down by the strong hand, perhaps ? For a century and a half there had existed a tax on real property, known as the estimo; it had been instituted in the time of Guido Novello in I 266 and was dependent on a committee of citizens, who made a rough valuation. The taxpayer had been called upon to pay on an extremely low estimate of his effects. In 1346 the realty to be taxed was described in a registry; it bore at that time on all who were called upon to carry arms or were engaged in trade, and it was still fixed by secret committees of their fellow-citizens, and the results of their inquiries were submitted to the judgment of a foreign arbiter. But the estimo proved to be a failure: everyone either tried to make fraudulent representations, or avoided in- 
vesting in what was not personal property. Heaps of citizens contrived to evade the tax in one way or another; rich men had the effrontery to pretend to be poor, and even contended that those liable to the service of the State should be exempt from taxation. In vain did the opposition and others retort that there were plenty of citizens in Florence who were willing to relieve them of that obligation. There was a good deal of corrupt practice ; and there were many other taxes, and these were unfairly distributed. In fact, we learn that the poor were paying five times as much as the rich (Rinald. Commiss., XLVII. ii. 324); nay, the poorer and more defenceless the man, the greater in proportion was the load of taxation he bore. The Albizzi called a secret meeting in 1426 , at which seventy leading men were present; it was held with a view to coming to some arrangement for further limitation of political liberty, and it was decided to try whether Giovanni dei Medici could be squared. The Medici were the heroes of the working classes and the small traders; their great banking transactions, business connections, and personal adroitness, made them persone grate to many of their own order. The negotiation with Giovanni was, needless to say, secret: he refused all overtures. The Albizzi could do nothing against so powerful, popular, and apparently so politically moderate a man : they determined, therefore, to abandon the notion of suppression, and to try reform. It is usually, though not universally, believed that Giovanni dei Medici was the author of the castato; it was carried (1429), and this though the minor arts were so politically enfeebled that they found it to their advantage to side with their masters, and were largely directed by the magnates who had matriculated into them, and the rich were naturally disinclined to pay their proportionate quota. The castato had become necessary to raise the wind, and perhaps to avoid revolution. Every compatriot had to return his name, age, the number of his family, his occupation, his property of all kinds, his cattle, and slaves. (But since serfdom was abolished in Florence, this must refer to his serfs in territory subject to the State.) Sixty citizens, drawn by lot, nominated a council of ten to adjudicate. Capital was to be estimated as yielding an income of 7 per cent. ; and no charge was to be made on encumbered capital, debts, rent, beasts of carriage or of burden, implements of trade, and necessities; and a deduction of 200 florins was allowed for everyone in the household. A ro per cent. income-tax was put on all income after abatement had been made ; there was no appeal, but there was to be a triennial revision. All other direct taxation was repealed, but foreigners were to be liable as well as subject provinces. This was the castato.

Hitherto the yoke of Florence had been in some measure disguised; there had been local autonomy, and subject cities had regulated their own taxation; now the fact of servitude was revealed; taxation and representation did not go together; half-healed wounds were reopened, and revolt followed. The Florentines thought it fair that subjects should pay for defence ; it was never dreamed of that they should be allowed a voice in affairs, when it was so difficult for any party to maintain itself in office and every faction was trying to hustle the other out, and the only way to rule was by banishing all opponents. None the less, cities that had been free resented the destruction of the one great right left to them-to regulate their own finances. Nearly every subject town refused to submit; citizens tried passive resistance; Volterra, in particular, pointed to the 
conditions in the treaty of union, and the promise that her tribute should not be increased. A Volterran who had been dragged to a Florentine prison was released under promise of filling up his form, but no sooner did he return to his native city than he commenced to harangue his fellowcitizens and incite them to resistance. Their city was not garrisoned, and the citadel and fortified gateways were speedily filled with armed men. The alarm of the signoria was great; it was feared that the spirit of revolt would spread to other provinces, and a detachment of militia was sent off at once, and reached Volterra by a forced march. The representative of the signoria enlarged on the clement disposition of the Government, and on the risk to which the Volterrans were exposing themselves. Fear prevailed; the mob killed their ringleader, and Volterra came at once into unqualified submission (1429).

The expedition against Volterra had been conducted by Niccola Fortebraccio, a nephew of the great condottiere Braccio, and for a long time the faithful and trusted servant of the Republic. Fortebraccio had secret orders from the signoria to advance against Lucca, as if on his own account. Lucca stood between Florence and full possession of the Pisan seaboard; out of fear of Florence, Paolo Guinigi, the lord of Lucca, had embraced the side of the Duke of Milan in the late war; and now, at least, a convenient opportunity presented itself of testing the defensive power of the little State and the loyalty of its people to Guinigi. It was hardly possible for a little community in the position of Lucca, surrounded by powerful neighbours, to hold its own without entrusting defence into individual hands ; and Guinigi had ruled at Lucca for thirty years. He appears to have been a man of parts, clever in steering the State clear of warfare, a judicious legislator, a good administrator, but devoid of any of the brilliancy of achievement or grace of manners that captivates the imagination or heart of the crowd. His character was en grisaille; it was destitute of colour ; and when Fortebraccio invaded his territory, the Lucchese gave up all for lost. All the fortified places along the frontier hung out the Florentine colours, and Florence felt so sure of an easy conquest that she declared war against Guinigi (1429). Giovanni dei Medici was dead, but his sons Cosimo, now forty years of age, and Lorenzo, and the opposition generally, went with the Albizzi ; lust for territory, commercial greed, the natural desire to subdue a neighbouring State that had been the ally of an enemy, and to seek a natural frontier, prevailed over party antagonism. But the State was in such financial embarrassment that they sent an insufficient force : it was supposed that Guinigi was too feeble to offer prolonged resistance. Astorre Giani and Rinaldo degli Albizzi were appointed commissaries of war. Neither men had the prudence and self-restraint of the old leaders of the Albizzi party; a long exercise of power rendered them domineering and cruel. The town of Serravezza, already inclined towards Florentine rule, submitted at once, but Giani gave his soldiery full license. The town and countryside were looted, and the ruined inhabitants wandered homeless and starving through Tuscany, and aroused general resentment ( 1430 ). In vain did the signoria recall Giani ; in vain was compensation given to the inhabitants of Serravezza; the mischief was done ; all the subjects of Lucca returned to their obedience; the very soldiers were disrespectful to the commissaries; they refused to invest Lucca closely; and the Lucchese put their house in order for. the siege. 
It was current that Rinaldo Albizzi had put money into his own pocket that had been set apart for victualling the camp; disgusted at the accusation, he retired to Florence, and Cosimo, in spite of his countenance of the war, found himself strengthened by the discredit of his rival.

Filippo Brunelleschi, who built the glorious dome of the Florentine Cathedral, and who, like all architects of his time, was also a brilliant engineer, proposed to utilize the heavy rains of winter by damming up the waters of the Serchio, and then releasing them against Lucca in order to breach the walls. But the Lucchese succeeded in cutting through the Florentine dike, and the country become so marshy that the Florentines were obliged to retire from the neighbourhood. The Lucchese were armed with a novel weapon, none other than the musket, hitherto unknown in Italy. The sons of Guinigi were old soldiers who had fought in Lombardy, and their sorties were invariably successful. Guinigi sent for assistance to the Duke of Milan, Venice, and Siena. Siena regarded the attack on Lucca as another step towards the conquest of Tuscany by Florence ; and Petrucci, one of her citizens, who was smarting under a personal affront, sent a considerable force at his own expense ; he also contrived to get the secret support of the Duke, who ordered Sforza, with whom he was supposed to be on bad terms, to advance, and that able General soon forced the Florentine army to retire. But Guinigi either found that the defence of Iucca cost him more than it was worth, and tried to sell the city to the Florentines, or there was a base plot on the part of Florence to sow distrust of Guinigi in the minds of the Lucchese by engineering a lie. Letters of the Florentine commissaries were discovered which purported to refer to an offer of Guinigi to accept 200,00o florins. Petrucci and Sforza conspired together to seize Guinigi ; he was taken in his bed with four of his children, and they and the eldest son, who was in Sforza's camp, were sent to the Duke, and imprisoned by him at Pavia (And. Bilii.-Poggio Bracciolini.J. Stelle Ann. Genuens.-Petri Russii Hist. Senens.-Or Malavolti Stor. di Siena). The Lucchese gave Guinigi's palace to Petrucci to pillage; they presented his horses and arms to Sforza; moneys found in the palace they added to the public treasury. ${ }^{1}$ A gonfalonieve and ancients were appointed, and the reconstituted Republic once again governed itself according to its ancient usage (I430).

The Republic of Lucca at once sent an Embassy to Florence to seek friendship. The Ambassadors were charged with the message that Guinigi had been unfriendly to the neighbouring republic, but now he was gone for good ; the city was again free, and would remain what it had always been-the faithful ally of Florence, the ardent supporter of the Guelphic cause. But greater States were arising in Italy-Venice, and Milan-and Florence must extend its territory to equal them in power : it would never do, thought the Florentine Government, to leave a State independent that was so near to Pisa and their own gates; they aspired to the possession of Tuscany ; they even refused the offer of the Lucchese to surrender Montecarlo and Pietra Santa; they shilly-shallied over the negotiations in order to induce Sforza to enter their own service ; they failed to seduce him

1 It shows the advancing luxury of the times that the palace should contain goods of sufficient value as to be worthy of Petrucci's acceptance, and this after the removal of all specie. Sixty-six years before, Adorno, a man of enormous wealth, who made himself lord of Pisa, only kept one little serving-maid. 
into such flagrant dishonour, but they succeeded in bribing him to retire to Lombardy, under colour of some debt due to his father that remained owing; they paid him 50,000 florins for his departure, and then they recommenced the war. But they had to count with the Duke; he secretly instigated the Genoese to insist on the letter of an old treaty. Genoa demanded that Florence should raise the siege of Lucca, which she was already prosecuting with vigour, and on her refusal, Piccinino was placed at the disposal of the Genoese by the Duke, who, as far as he was concerned, was careful to avoid an open rupture. The fresh troops of Piccinino fell with great vigour upon the Florentine mercenaries and militia, that were wearied by a long campaign and weakened by disease; they took them prisoners almost to a man. All the artillery and stores and 4,000 horses were captured at this battle, which took place on the banks of the Serchio (I430). Probably the Duke would have pursued his advantage, for Pisa was ready to rebel, and Siena had allied herself with Genoa, but that he dreaded lest Venice should take advantage to renew her attack on his own immediate domain. And, indeed, next year the indomitable Florentine Government, notwithstanding the appalling amount of the public debt and taxation of Venice, induced her to join them against the Duke, by a promise of contributing 20,000 ducats a month for war expenses, and holding out the bait of Cremona. Genoa, Siena, Lucca, and the lord of Piombino were allied against Florence; Pisa was awaiting a favourable moment to rise and recover her liberty; and when the Milanese General, Piccinino, drew near to Pisa, the Florentine Government only prevented revolt by expelling every male capable of bearing arms, and retaining their women and children as hostages for their good behaviour. Nevertheless, the greater part of the warlike people thus banished went over to Piccinino. Volterra, also by no means contented with its yoke, was only kept in check by the strong hand. The district round welcomed Piccinino; he ravaged the Val d'Elsa; Arezzo was menaced. But all three powers were near exhaustion. The war dragged on slowly, and a third peace of Ferrara was signed (1433) on terms of restitution, and a renunciation by the Duke of his Tuscan and Romagnan alliances. Cosimo dei Medici took an important part in promoting this truce, for he needed time to consolidate his growing power.

A great change and a great decay had befallen the republican constitution of Florence. The Albizzi and their party had done their best to copy the institutions of Venice in order to give stability to their Government and to transfer power entirely to themselves, as representing the high commercial interests of the State. The signory was loaded with ostentatious honour and dignity; but as it advanced in outward stateliness, it was, like the Doge of Venice, curtailed of real power. It had become the mouthpiece of the clique that manipulated it. Sumptuous banquets, music, buffoons, and publicity, had succeeded the old austerity, and the chief concern of the Priors was lest they should be docked of their salary. To resist the Albizzi was dangerous (Perrens). The gonfaloniere, once the least of the signoria, had become their acknowledged head; but his power was more apparent than real; he only held office for three days. The Notary was a much more important personage, for he held the threads of policy. The Ten of Balia, created in 1382, when there was balia to. refill the lottery-box of office, had come to occupy the first place in the 
State; war was constant, and they directed war; they intruded on other offices, and one finds them even recommending a Bishop to Pistoja (Commiss. Ren., I425). The Ten of Liberty, created in I 372 to prevent oppression, were really engaged in the suppression of liberty. The councils were always constituted by those in office, and every council was " packed," every office of State was filled, by the ruling oligarchy. Opposition from without was effectively warded off by the secrecy of voting, which prevented all interference with internal corruption and manipulation. There was apparent intimacy between the oligarchy and the Medici and their friends, but it veiled an intense enmity; the Medici were astute politicians and excellent men of business; they knew the value of "lying low and saying nothing." Their conduct contained subtler implications than their words.

Antagonism to the Government was very rife, but it had to be very secret; it made use of the " brotherhoods," associations which, now that the guilds were decaying, gained more and more importance. It is to these fraternities that we owe the gates of Ghiberti, the dome of the cathedral. The Government ruthlessly suppressed these institutions as nests of faction in I4I9, sold off their goods, distributed the results among the poor to secure the quiescence of the masses, and turned their buildings into private houses. The oligarchy professed the noblest sentiments; all Florentines should live together as brothers, and faction and division must therefore be put down. A balia of citizens eligible to the council of 200 was to meet twice a year, and name eighty citizens upwards of thirtyfive years of age, not being divieto, of whom twenty were to be chosen from each ward and five from each standard, and their function was to put down these political abuses (1429). (For full details vide Perrens, Histoive de Fl., vol. vi.) But Rinaldo dei Albizzi was now at the head of the oligarchy. Rash, impetuous, wrong-headed, he was the last man to hold the oligarchy together now that it was undermined by dissatisfaction and assailed by the insidious attacks of persistent ability. For opposed to him was Cosimo dei Medici, a man who had never been young, who possessed all those qualifications for statesmanship which Rinaldo lacked, and whose disposition and method served to evoke all the blundering rashness of Rinaldo's character. Cosimo had great natural advantages: he was a man of vast wealth; his father, Giovanni, had left nearly a quarter of a million of florins, besides oustanding moneys and freeholds. He succeeded to the headship of a family which had become distinguished in the astute merchants, the popular politicians, and the prudent statesmen it had produced. He was ripe in experience; he was just forty years of age at his father's death, and his energies were still undiminished. He was associated by business, birth, or marriage with all the important families. Quite imperceptibly and by most subtle methods he had succeeded in becoming the most considerable man in the State. His manner was grave, slow, and respectable; he was invariably mild, affable, and even kindly, and he gave the impression of possessing all the modesty, prudence, sagacity, and trustworthiness that should characterize a responsible merchant. It is true that his reticence and almost unnatural calm gave rise to some suspicion, but suspicion was usually dissipated by the even tenor of his life and the good report of all his associates, and even of his foes. His imperturbable outward mien was so far an index to his charatcer that he 
never allowed any event to ruffle his inward calm or disturb his calculating intellect. He knew to a hair what would bring him popularity, and how to turn popularity to political advantage. He had the nose of a Jew for successful business, and he had contrived to turn the wretched war against Lucca to the discredit of the Government and to his own political and pecuniary advantage. He was careful to screen his political designs by avoiding the precincts of the Public Palace, as if he had no great interest in politics; but at the banquets he gave at home he gathered round him all the great connections of his family, all those important people with whom he had business relations, the scholars to whom his own learning (he knew Greek) commended him, and the artists whom he patronized; and among the public men with whom all these manifold social relations brought him into touch he was skilful to probe for discontent, and subtle in fostering dissatisfaction. But while he made himself agreeable to the rich, he knew how to fascinate and become indispensable to the poor. It was said of him that he dressed like a peasant and lived like a King. $\mathrm{He}$ never offended men below him in station by ostentation or hauteur; he treated the meanest citizen with consideration and respect. His charity was bounded only by calculation; he would relieve the indigent of their obligations to the State by paying their taxes and restoring them to citizenship; he would subscribe large sums to public works, but save odd pennies, and avoid jealousy or suspicion by only appearing as a generous donor among many. Thus, he subscribed a big sum to the rebuilding of San Lorenzo by the great Brunelleschi, but other dwellers in the parish gave smaller sums. He was ever ready to do anyone a good turn when it would increase his reputation, and he bidded systematically for the gratitude of his fellow-citizens in order to increase his following. Hence he had a great number of grateful or expectant dependents, as well as business and family connections, whom he could use as his creatures. But he disarmed or postponed the suspicion or ire of the Government by being also ready to lend to the State in those times of financial difficulty which continued warfare so often brought about. Thus he became more powerful every day, and even the henchmen of the Government were veering towards him. $\mathrm{He}$ had become too important a person either to be banished or ignored, and he was made gonfalonieve of justice more than once. The era had arrived when ruse replaced force, and the cunning brain counted for more than the valorous arm.

Experience of the Florentine mob in Parliament assembled had taught that it was always ready to shout with the stronger side; the Government always knew how to hoist liberty with its own petard. But precaution was taken to secure unanimity. Armed troops guarded all the exits, and not a single follower of Cosimo dared to put in an appearance. When a mob had assembled the Public Notary shouted out, "Are you gathered together in two-thirds of your number, O men of Florence ?" "More, more!" was the answer. "Are you willing that there shall be balia to reform the State and save it from conspirators who would wreck it ?" "Aye, aye !" The gathering then dispersed. The balia, now invested with full powers, did away with election by lot; ten accoppiatori were to elect the signoria in future; and it made other changes which secured absolute power to Rinaldo and the oligarchy. Cosimo saved his life by bribery. The venal gonfalonieve, who had been bought by Rinaldo, 
received I,000 florins from Cosimo. The Government could afford to let him go; he could not be visited in prison by his friends without the sanction of two-thirds of the signoria and of the gonfaloniere, and it was, perhaps, politic after all not to drive opponents into too tight a corner. Cosimo was exiled for ten years. He was sent out of the city by night, and directly his departure was known he was received everywhere as a patriot and a martyr. Pistoja gave him a royal reception; the scholars in exile whom he had befriended exerted themselves to extol his virtues and prepare for his reception (1433). Modena and Venice turned out their masses to receive him as if he had been the saviour of the land. He was only an astute and cultured merchant, big brained enough to see that letters, art, and the purse had become powers in the world, and could be controlled by a plutocrat to his own advantage. Rinaldo perceived now, but too late, that he had made a false move. The balia either had feared or thought it impolitic to exclude every person who might be suspected from the list of eligibles for office. Rinaldo tried in vain to get the magnates and the old nobility readmitted to offices of State. Cosimo was missed by the populace, his friends fostered reaction, and popular dissatisfaction with the oligarchy was growing; they had played too open a hand. Conspiracy was abroad; the election of the signoria by lot had to be resumed. This of course meant that, sooner or later, there would be a Government favourable to the Medici in power. Rinaldo meditated a coup d'état, but his henchman, Palla Strozzi, bluntly refused to aid him. Within a year of Cosimo's exile there was a signoria composed entirely of Mediceans. The leaders of the Albizzi were summoned to appear; some of them flew to arms, but others, more timorous, drew back. The true weakness of the oligarchy was manifested ; one of Rinaldo's brothers, even, was for Medici. Rinaldo dei Albizzi and all the hot-blooded youth of the party were burning to attack this plutocrat Cosimo, this new moneyed power that, like some strange sea-beast with its tentacles, was stealthily grasping and bid fair to strangle the Republic. Huge fortunes had been made before now by the farming of taxes, by usury, by commerce, by finance, but they had been employed by oligarchs for the oligarchy. Here was a man winning "golden opinions from all sorts of people," and prepared, perhaps, to strike at the oligarchy itself. So long as the older men were alive-such men as Niccola d'Uzzano, who remembered the revolution of the Ciompi-temperate measures prevailed. The "old hands" saw their party splitting up; they saw section after section incline towards Cosimo; they feared the result of collision, and they temporized. But directly Niccola d'Uzzano died, Rinaldo dei Albizzi, no longer restrained by his prudent councils, with more temerity than discretion, made it manifest that there would soon be a trial of strength between him and his foe. He was only waiting to strike until the election by lot should give a signoria favourable to his purpose. Cavalcanti tells us that "no signoria could be elected without the whole city being in a state of disturbance" (Cavalc., vol. i., p. 494). "Nor could any case, whatever the justice or injustice of it, be decided at any court without the two parties struggling over it, one to get the better of the other; and after this manner was our poor little city governed " (Cavalc., vol. i., p. 495). Now, one of Albizzi's friends was about to become gonfaloniere, but the election was likely to be annulled, since he owed moneys to the State; he was ambitious of the 
post, and Albizzi bought him over by paying his debts. Directly the new gonfaloniere appeared on the scene he was ready to settle off old scores with the enemy of his party, and exhibit his gratitude to Rinaldo. Rinaldo was passionately desirous of crushing Cosimo. Cosimo had been twice in office; he had been Ambassador to Ferrara; he had seduced many of Rinaldo's party; personal hatred as well as partisanship entered into the contest. Rinaldo's tool waited to preserve some show of the decencies of political life awhile ; everything should be done with a show of justice. At the end of a week he summoned Cosimo to appear before the signory. Cosimo was charged with usury, with falsifying the accounts of the army of Lucca, with peculation; richiesti were summoned to give emphasis and an appearance of impartial rectitude to the proceedings. A parlamento was then called: so important a citizen must be condemned, if at all, by the whole electorate. Pope Eugenius IV., who was in Florence, tried to mediate, and this completed the disablement of Rinaldo. He did not dare appeal to arms now; he ordered his troops to retire, and the signovia at once concentrated its own armed forces in the communal palace and points of vantage. A parlamento was summoned, a balia appointed, Cosimo was recalled, and every citizen who had been at the head of the oligarchy was banished. The party of the Albizzi, so glorious in selfdenial and in foreign policy during its early years, had exhibited the deterioration that follows on continued power; they had suppressed the just claims of the poor ; they had ground the workers under heel in order that they might garner up for themselves the produce of their toil ; they had disfranchised and demoralized them beyond hope of redemption, and their reward was that another trader, perhaps not more compassionate, but assuredly more astute, was to gather the fruits of their labour.

\section{The Manipulation of Public Affairs by Cosimo det Medici}

Cosimo returned to Florence in triumph. He had played the part of Mæcenas in his exile, and men of letters and artists had caused his praises to resound throughout Italy. His political acumen fitted him to play the rôle of Augustus quite as well as that of Mæcenas; he was regarded by the democracy as their champion, and he relied on the people who, defeated as they had been, and no longer aspiring to political power, had nevertheless to be counted with and humoured by the Government. He knew how to take advantage of their enthusiasm, and how, by affecting humility and simplicity of life, by patronizing men of intellect, and by exhibiting a calculated generosity, to keep the embers of enthusiasm from growing cold. Under the guise of simple citizenship he covertly converted influence into authority. Had he not received popular support he would have been dead or banished within a week: with popular support the great trader ruled Florence throughout his life, and founded a dynasty. It came to pass that the blood of the Florentine banker flowed in the veins of many a proud European Sovereign. The need of concentration of Government was felt. To establish anything like absolutism was contrary to the Florentine spirit and to its worship of the very name of liberty. So to operate as to bring about the substance without introducing the form, to become the ruler of the State while preserving the forms of republicanism, to adapt the existing machinery to his own wants and to the wants 
of his time, was the work that required a subtle genius like that of Cosimo. The operation was rendered the easier that his was one of those eras wherein wealth accumulates and men decay. The guild system was largely in the hands of capitalists, the masses were dependent on moneyed men, and the dodges of needle-wit were more efficacious than the brutalities of main force.

Balia with full powers enabled him to establish himself and his friends ; it was appointed every five years, and by getting it renewed Cosimo solved the problem of life-long rule. He employed the balia to reward his supporters, for the first thing to be done was to fix his creatures to him with hooks of steel. The castato was disliked: before long the castato was abolished. His friends could now fill their purses and ruin their foes; there was no longer an income-tax with a fixed scale; no one knew now how much he might be called upon to pay, and as, owing to the heavy pay required by condottieri and the interminable war with Visconti, taxes had to be raised ten or fifteen times a year (Guasti Prcemio alle Lettere di uno Notaro), foes were fearful of what might happen. The abolition of the tax took security, as it were, for their good behaviour. As all the leaders of the opposite party were in exile, Medici and his followers had the game entirely in their own hands, and he was determined to tolerate no external serious opposition without his party and no other aspirant to leadership within his party.

The dissensions between the Pope and the Council of Basel were also favourable to Cosimo's prestige and that of the city. It was partly by stress of circumstance, partly by his able management, that Pope Eugenius IV. transferred the Council from Ferrara to Florence ; the revolt of the nations against the absolute power of the Papacy was answered in that city by the declaration of the supremacy of the Pope in all matters, even over the assembled Church; it was a doctrine consonant with Guelphic feeling, and it gave Florence augmented fame, which the presence of the Emperor of Constantinople and the union of the Greek and Roman Churches enhanced still further. The Emperor was induced to exempt Florentine merchants from taxation at Constantinople, a privilege which, unhappily, was to come for ever to an end in fourteen years' time, when New Rome should fall to the Turk.

The exasperation of the people at Florentine defeats had had much to do with the expulsion of the old Government. Cosimo saw to it that not even their women remained in the city. The proscribed party had urged Filippo Maria to renew the war against their own mother-city, the city they had defended with so much zeal and self-sacrifice. It was unpardonable treason, though Florentines never had loved their city so well, loved they not their party more. Party often stood in their affections before family claims; ever were they partisans before they were citizens; and this feeling was increased by the bitterness of banishment and the companionship in exile of their personal friends, sharing with them the same sentiments and the same misfortune. One Francesco Gianfigliazzi had been proscribed; his daughter-in-law lay ill and unable to move in Siena; his son was also laid up at Bologna. The distressed mother, able to leave one anxiety behind her, and anxious to relieve her mind from another, left a recovering invalid to tend the other sufferer. Her way lay through Florence; she adopted disguise, and passed through the city in safety. 
But on her return journey she was arrested and put to the question, and Cavalcanti tells us that he saw her supported by two berrovieri, her limbs dislocated, on her way to the stinche or prison where prostitutes were confined (Cavalcanti, xiv., c. 4). In the Tuscan way of publishing proscription, Cosimo caused portraits of his enemies to be painted on the walls of the Bargello, where they were represented as strung up by the feet, each foe being designated by his name in big letters. But while capable of resentment and unrelenting severity, Cosimo secured general support by the introduction of a sliding scale in taxation. This yielded an even greater revenue than before, because its popularity allowed of the taxes being raised at very short intervals. The sick and people unable to work were exempt.

Cosimo was by far the greatest citizen in the Republic, but there was another leading man of his party who did not always share his views, and who was possessed of very great wealth ; this rival was Neri Capponi, the son of the man who had brought Pisa to heel. Now Capponi had a friend, one Baldaccio d'Anghiari, a condottiere, and Cosimo was fearful that if Capponi once became gonfaloniere he would contrive a coup d'état by the aid of Baldaccio and overthrow him. The blame of what follows is ascribed by Cavalcanti and Machiavelli to the supporters of Cosimo, but Guicciardini accuses Cosimo himself of the whole design by which he rid himself of one dangerous foe and cowed a powerful rival (vide Mach., Op., ii., p. 81, 84.-Cavalcant., Sec.Sta., vol. ii., c. I6.-Guicc., Op. Med., iii., p. 8). Advantage was taken of the absence of Capponi, who was on an Embassy to Venice, and of the gonfalonieve at the time being a creature of Cosimo's; and also a personal enemy of Baldaccio. Baldaccio was induced to visit the palazzo of the signovia, and while walking with the gonfaloniere the latter gave the signal, and Baldaccio was thrown out of the window (1440). There was considerable indignation expressed at this murder, for the dead man was allied to big families. But he had given himself airs, and was far from passionately devoted to the best interests of the Republic. Cosimo and his party remained quiet and self. possessed; the excitement soon subsided ; it was generally recognised that States are not governed by paternosters. Capponi was thoroughly intimidated; he understood that Cosimo was only an enemy to those that aspired, and he gave no further cause for suspicion.

Florence was growing in size and wealth. "The Sabbathless pursuit of fortune," as Bacon calls it, possessed the city. It was possible to squeeze out 500,000 florins yearly in taxation, nominally graduated, really imposed at will. By r443 an Ambassador could write to Sforza that the Government forced levies and raised taxes in the most arbitrary way. Those of the wealthy who were obnoxious were so heavily mulcted that many left the city. Those to whom the State owed money were often obliged to sell their claim at a fraction of their value, for the State exacted debts due to it, but delayed payments of its own obligations. Many of the Medicean party were thus enabled to make considerable fortunes. Many citizens took to country life or joined the exiles to avoid imprisonment, for debtors to the State were thrown into gaol without scruple or mercy. Even in the country, Calvalcanti says, there was no safety for them.; they were harried twice a year, their houses cleared of furniture, their crops carried off, and this simply as punishment, no deduction being 
allowed on the sum due, whatever might have been pillaged or destroyed. No citizen could preserve independence. Gino Capponi, a contemporary Florentine, says that it seemed as if the Mediccan party were trying to impoverish the Republic and enrich themselves.

Discontent grew, especially among the higher classes. But the balia was now about to be renewed, and it was seen to that it should be packed (I444). The renewal of balia and of terror every five years was the keystone of Cosimo's system. The scrutiny of the names of those eligible to office was made by the Priors and colleges. Obnoxious people were imprisoned or deprived of citizenship with a pretty free hand, and ten accoppiatori were selected to determine what names were to be put into the lottery purses. Selection by lot was thus reduced to a sham, and it would be hard to say whether the effrontery or hypocrisy of the Mediceans bore the bell. The following year Cosimo became gonfalonieve of justice for the third time, and he was already preparing for the next balia. He charged eight of his creatures to examine and prepare whatever new " reforms" might be required.

The power of the purse had triumphed all along the line, and Cosimo knew how to employ it; he had discovered the secret of Augustus, and while he remaincd a more private citizen he might have said to himself with the Grand Monarque, "I,'état, c'est moi." He strengthened himself by associating other wealthy people with his own business transactions, for in becoming a politician he never ceased to be the shrewd trader, though his liberalities prevented him from increasing his fortune. He was no idealist, but ever the practical, shrewd, hard-headed, somewhat unscrupulous man of affairs. To Luca Pitti he said, "You run after the infinite; I am content with the finite. You lean your ladder against the sky; I prefer to set mine on terra-firma, and then I don't fall through over-ambition." Machiavelli quotes a few of his terse, pithy sayings that paint the man : "Better a city ruined than lost." "States are not governed by paternosters." "You may make an excellent citizen with two ells of crimson cloth" (Mach., Opere, vol. ii., pp. 148-155). His friend Vespasiano Bisticci says that he did not for a moment believe that he would found a permanent dynasty. "I know the humours of my city ; before fifty years pass we shall be expelled, but my buildings will remain." These religious buildings and charitable gifts were, according to Bisticci, of the nature of restitution to God for money not over-well gotten, and he was wont to say that God was never to be found on his books as a debtor: but, although he was no great scholar, this man of business had a real love of learning. If befriending his poor scholar-friends made him popular, his connections with the rich made him powerful. He knew that rich people are averse to revolution, that when wealth gets concentrated into a few hands the employment and fate of the masses are in their grasp, and he worked on those lines with vulpine astuteness. He married a daughter to one of the Tornabuoni, and did all he could to combine and associate together those whose interests would be imperilled by revolution.

As to the reality of Cosimo's rule under the mask of republican simplicity of life, that he was the manipulator of the machinery of State, that the freedom of Florence had disappeared, and that the Republic was really dead, there is overwhelming evidence. Enea Silvio, afterwards Pope Pius II., wrote of him that "he is the arbiter of peace, war, and laws 
at his house is it that the affairs of the Republic are decided and public officers chosen; he lacks only the name and pomp of royalty" (Pii II. Pont. Comment. rerum memorabilium). Nicodemo Tranchedini wrote to Sforza: "When you desire this thing rather than that, write privately to Cosimo, and you may be sure of getting it. Popular governments are not like others, and Cosimo cannot always be at the palace, as formerly" (he had the gout) (quoted by Perrens. Hist. Flor. depuis la domination Med. I., p. I69). "Nothing is done without him" (Nicodemo a Sforza, ibid.).

Under the Albizzi taxation had been heavy; under the rule of Cosimo it was almost ruinous. In the first twenty years after Cosimo's return no less a sum than 4,875,000 florins was raised by means of special taxes, levied in the most arbitrary and irregular fashion. The balia of 1452 raised sums of 580,000 florins and 360,000 florins in two levies that followed one another in quick succession, and 50,000 florins were wrung from people hitherto exempt. In war-time such sacrifice was necessary; the Medicean Government put the finances of the State on a war footing even in peacetime, and as the castato was abolished, the wealthy in power dodged their obligations. "One does nothing but pay," wrote Alessandra Macinghi Strassa, "although we have peace and tranquillity. The amount of money drawn from us is amazing. Truly we do not know how to raise the wind any more" (vide Perrens, vol. $i$.). Of course, the great brunt of this fell on Cosimo's opponents. To be with him was to become wealthy; to be against him spelled utter ruin. Nevertheless, the Medicean party, now practically all Florence, began to experience the cleavage that takes place in every faction that has held power for any length of time. But the split was not serious : a new aristocracy was forming within the party, but business obligations and financial complexities prevented any serious mischief from arising. In 1454 there was a new balia, and the popular section of the party got election to office by lot re-established. But the new signoria would not come into office until 1455, and Florence had become so entirely Medicean that the alteration in the constitution gave Cosimo no uneasiness; the attempt at popular government was sure to issue in unsettlement and disorder, and that would only give him his opportunity to come forward as a deus ex machina, and set things right ; meanwhile, modest neutrality was a desirable veil for real power; keenwitted men had no desire to see him become a Prince, and they were in his toils so long as he continued to affect the modest demeanour of a trader and did not openly show his hand. The new Government was hailed with transports of joy by the people (1455), and Rucellai, the new gonfaloniere, and the ministry, took a natural and particular delight in humbling the more arrogant and notorious spoliators. Cosimo witnessed all this with satisfaction; his clients would have more need of him than ever, and it was a useful lesson to them (Mach., L. vii.-Commentari di Filipo de' Neoli, de fatti civile di Firenze, L. iii.).

Before long the very men who had been opposed to the renewal of balia were imploring Cosimo to join them in insisting on one. Cosimo refused ; he wished the fruit to ripen before he plucked it, and events proved his sagacity. Matteo Bartoli, during the time that he was gonfalonieve, tried all his powers to get balia; the sole result was the passing of a law by the councils that Parliament could only be convoked when there was a perfectly unanimous desire for one on the part of the signoria and college, 
and approval by both councils (Scip. Ammirato, L. xxiii., p. 85). This defeat entirely humiliated all who had tried to free themselves of Cosimo, and they naturally looked to him as the only man who could come to the rescue. Cosimo, with infinite astuteness, became a secret accomplice in what followed, but he still maintained apparent neutrality. Luca Pitti, a wealthy merchant, a man fond of self-assertion and display, bold and headlong, was left to engineer the plot. Everything was prearranged ( 458 ). Nicodemo wrote to Sforza before the coup d'état. Sforza was now lord of Milan, and the trusted friend and confidant of Cosimo, for their political views coincided, and they were absolutely necessary to one another if the balance of power in Italy was to be maintained. He said : "To-morrow there will be here the lord of Faenza, with 300 horse and 50 foot, and more of Simmonetto's people. On Tuesday others will come in from the countryside. The foot-soldiers will be lodged in the houses belonging to the arts surrounding the square; the horse of the lord of Faenza will be on the plain of S. Savil, outside the gate of Alla Croce; Simmonetto's horse between the Lastra and the gate of Pisa. The morning of the day fixed for parlamento they will arrange themselves as ready for conflict on the square. The populace will be unarmed. The signoria will produce a list of a number of people to whom they will say they have given balia, and will ask the people if they are content. Well-wishers will shout 'Yes,' and, as usual, all the others will follow. The signoria, exulting and applauding, will rise and re-enter the palace, and the holiday will be over. Then bit by bit the number of the balia will be reduced; there will only remain a few, who will reconstitute the State after their own mind, and so that it shall last for a good time, and so good-bye to this commune that has existed on agitation. Piero di Cosimo [Cosimo's son] arrives to-day. He wishes to look on at the rare business, and can do so without danger. He leaves his wife and children, well taken care of, at Cafaggiolo " (Nicod. a Sforza, Perrens, I. I 88).

And so it was done. A Machiavelli, who had spoken strongly on the danger of summoning parliaments, and of the subversions of liberty by balie, was seized and put to the torture. In his agony he named others of the same mind as himself. Exile and even execution followed, and what was done was supposed to be justified by the death of Pope Calixtus III., the brigandage of Count Averso, and the anarchy of Rome! Three hundred and fifty-two citizens became an electorate responsible for the election of the Government taxation and extrajudicial proceedings.

This balia was to be renewed every five years ; the castato was thrown as a sop to the populace, and its administration entrusted to a commission of ten. The signoria was now really in the hands of Cosimo's creatures; but as its power was curtailed, its apparent dignity was increased, to throw dust into the eyes of a people already half blind. The Priors were no longer called Priors of the Arts, but of the "liberty" which had ceased to exist. To the superficial observer the most important man in the State was not Cosimo, but Lucca Pitti. While Cosimo dwelt in the small palace now known as the Riccardi, Pitti was building himself a magnificent palace on the other side of the Arno; he welcomed presents on all sides for the expenses of this great edifice, and gave harbourage to any malefactor or exile who was willing to work on it.

It was an age of magnificence-an age of famous architects, painters, 
sculptors, and men of letters, adorned by such great Florentines as Battista Alberti, Luca della Robbia, Masolino, Paolo Ucello, Angelico, Benozzo Gozzoli, Brunelleschi, Ghiberti, Donatello, Michelozzo Michelozzi, Massacio, Filippo Lippi, and Marsilio Ficini. The strenuous years had issued in a flower of art. Those great buildings, great pictures, great sculptures, were being rapidly produced which have made Florence the world's treasure-house.

The last days of Cosimo were clouded by sickness and the visitations of death. He was himself a martyr to gout, and his eldest son Piero inherited the malady in so aggravated a form that he was ill able to attend to business. His second son, Giovanni, on whom his hopes rested, died, as well as Giovanni's little boy. Cosimo, carried into his palace in a litter, is said to have remarked with a sigh, "It is a big house for so small a family."

Cosimo died in 1464 , leaving a more populous city and imperishable records behind him. Such memorials are San Lorenzo, San Marco, and the Badia of Fiesole, and the libraries of the two latter buildings. The disappearance of so great a figure caused universal lamentation. Sforza wrote to the surviving son in such terms that Piero begged Nicodemo, Sforza's envoy, to entreat his master to write no more similar sad, tearful letters, but to resign himself, as they all must do, to the will of God.

The dead man, who could be calculatingly cruel and prudently kind, merciful or audacious, as occasion befitted, must have been of consummate ability even in that age of extraordinary men, and had cunningly piloted the ship of State through dangerous waters. He was at least genuinely sincere in his love of the finer flowe of intelligence, and in his dislike of pomp. He ordered that his body should be interred in San Lorenzo, with a plain stone placed above it. And it was not because he had converted a tumultuous oligarchy into a body of subservient courtiers that after his death they inscribed "Pater Patriæ" on his tombstone. For a year had elapsed since the uncrowned King of Florence had been gathered to his fathers, and there was now no one to bestow rewards. The Florentines gave expression to the genuine conviction of their time ; and assuredly, whatever his faults, however subversive of liberty his policy, Cosimo was not devoid of public spirit and a sense of the dignity and grandeur of that State the fortunes of which he had for so many years directed.

For thirty years Cosimo had held the threads of the foreign policy of the Republic, no less than its internal administration, in his hands. His schemes were based throughout on the preservation of the balance of power in Italy. The very year that he was recalled to the city Imola had risen against her Papal garrison, and admitted the troops of Visconti. The Duke had had time to recuperate his forces since the peace of Ferrara, and deliberately broke his pledge to leave Romagna alone. Gattamelata was sent by Venice at the head of her forces, Tolentino commanded the Florentine mercenaries, and Piccinino led the troops of Milan. Victory fell to the Duke, and of the army of the republics, consisting of 6,000 horse and 3,000 foot, we are told that scarcely a thousand men escaped capture ; but only four men were found dead on the field, and but thirty wounded, and those slightly, so bloodless had battles become, partly because the heavy armour of the soldier was proof against the musketry and other weapons of the day, partly because successful tactics, not mutual slanghter, 
were the object of the condottieri (vide Scipione Ammirato, L. xx., p. I099.Cronica di Bologna, p. 651.-Joannis Simonete Hist., L. iii., p. 233.Poggio Bracciolini, L. vii., p. 384.-Ann. Bonincontrensis, p. 142). Notwithstanding this victory, the war lagged, and the exhaustion of both sides led to a restoration of peace on the old basis of the treaty of Ferrara. But the proscription of the Albizzi and their adherents by the new Government led to a renewal of war. Burning with hate and shame, the fiery and impetuous Rinaldo urged Visconti to resent the reception of Genoa into the Veneto-Florentine alliance. For Genoa had cast off the Duke's authority, and by the treaty of peace his lordship of that city had been acknowledged by the republics. The lofty patriotism which had inspired the Albizzi in their glorious administration of sixty years counted as nothing now ; it was as a light thing borne off by a hurricane of passion; let them but get back to Florence, and they would know how to deal with its foes, whether external or internal. They promised Visconti every aid in their power, and induced him to recommence the war. But the wily "Biscione" set about it in his own stealthy way: he did not declare war, but despatched Niccolo Piccinino to thread his way through Liguria and menace Genoa, but with instructions to lose no opportunity of taking the Florentines unawares.

Cosimo had perceived that it would be essential for him to rely on some condottiere with whom he could come to an understanding as to mutual support. He found such a man in Francesco Sforza, the count of the marches of Ancona. Sforza and Cosimo appear to have been thoroughly to one another's mind ; the count, as has been told, was the bastard son of a Romagnan peasant who had risen to be a great General, and his ability was so marked that at the age of twenty-three he took over the command of his father's company. The association of the sagacious, longheaded merchant and the capable and ambitious soldier remained staunch, and in the main their interests were identical, and the intimacy was broken only by death.

Sforza proved more than a match for Piccinino (1436). He put out his full strength in the struggle; for he had been promised the hand of the Duke's daughter, and aspired to the rule of Milan; he knew that this promise would be kept, if at all, by fear alone, and he must preserve his country, his reputation of being the best General of his times, and his army. The Duke tried to seduce him from the service of the Florentines, but in vain. Did he give ear to the blandishments of Visconti, Sforza knew that he would be the victim of his artifices-that his army, somehow, would be dissipated. The republics would pay his expenses, and keep it on a full footing, which his own purse would not enable him to do; it would be an easier task for him to aim at the lordship of Milan if he undermined the Duke ; and if he was to retain his county, it must be through the balance of power in Italy ; and here, above all, his policy jumped with that of Cosimo. At this juncture the united power of the two republics and the Popes about balanced that of the Duke and Alfonzo, the King of Naples; and so long as it lasted, the smaller States were safe. Such considerations as these were emphasized by emulation: Sforza and Piccinino respectively inherited the fierce rivalry of Sforza's father, Attendolo, and Braccio ; and under the guidance of these two great Captains, two great military schools or associations had grown up in Italy from the closing years of the fourteenth 
century. If Piccinino and his troop were on one side, it was de rigueur that Sforza and his following should be on the other

Lucca was a thorn in the side of Florence ; in self-defence she invariably took the side of the enemy; and Florence was bent on getting possession of the neighbouring city. Sforza laid her territories waste, but the Lucchese shut themselves up in their city, and awaited the turn of the tide (I437). Meanwhile, the Venetian General, Gattamelata, had been beaten, and, at the urgent solicitations of the Venetian Government, Sforza was despatched to Lombardy to oppose the victorious Piccinino. But he refused to invade the territory of his prospective father-in-law, and this forbearance enabled him to reopen negotiations for the hand of Blanche. Cosimo dei Medici went to Venice, ostensibly to put pressure on Sforza; but that far-seeing statesman was not likely to over-exert himself too vigorously on behalf of a State that had become so powerful and approached so near: Cosimo had not lived an exile in Venetian territory without forming his own conclusions as to the political designs of that republic. The matter ended in a truce for ten years, signed by Florence, Lucca, and the Duke, wherein the conquests of Florence on Lucchesan territory were confirmed, and Lucca reduced to a little power, with a radius of six miles from the city walls (1438). But shortly afterwards the greater part of the ceded territory was restored, whereby Florence retained some solid advantage, and mollified a foe that might become troublesome at an inconvenient moment.

Only two years passed, and this truce was broken. Venice had continued the war, was getting very hard pressed by Piccinino, and Florence despatched Sforza to Lombardy. Visconti was determined to punish both Florence and Sforza. He intrigued with the agent of the Pope to oust Sforza from his country, and he despatched Piccinino to Tuscany (1440), where he was joined by the Malatesta of Rimini, who turned their backs on the republic they had served so long, and on whom Florence depended in large measure for troops. To add to the troubles of the Florentines, it was discovered that Vitelleschi, patriarch of Alexandria, the favourite of Pope Eugenius IV., and who had been subsidized to lead an army against the forces of the Duke, was in traitorous correspondence with Piccinino. Vitelleschi was the ruffianly priest who had re-established the temporal sway of Eugenius ; he had devastated the Campagna, and given his soldiers a hundred days' indulgence in purgatory for every fruit-tree they cut down; he had become too powerful for his master's liking, and shortly after Eugenius had him entrapped into S. Angelo and executed. The Count of Poppi then revolted, and drew Piccinino into the Casentino. Tuscany was ravaged by the advancing army; and at last, learning that the Florentine troops were encamped at Anghiari in a plain suitable to the evolutions of heavy cavalry, Piccinino, who had been resting at the foot of the mountains at Borgo San Sepolcro, advanced, accompanied by 2,000 of the inhabitants of that place, who smelled pillage ahead. So laxly were military precautions undertaken in those days that the Florentines appear to have had neither outposts nor vedettes, and the men were spread about under what shelters they could find from the burning midsummer sun. But, happily, Micheletto Attendolo, a relative of Sforza and one of the best of the Florentine condottieri, observed a cloud of dust on the horizon, gave the alarm, and by the time Piccinino came up the soldiers had been able to don their heavy harness, although this was by no 
means done in a second. In fact, there was time to fill up the ditches, uproot all stumps, and level the ground for manœuvres. The Milanese cavalry had to approach by a bridge over the infant Tiber; they forced their passage across this, and drove a portion of the Florentine cavalry before them, but were assailed and outnumbered by the troops that lay to right and left of them, and obliged to retreat. Possession of the bridge was disputed for two hours. The battle swayed to and fro; now the Milanese crossed the river, now they had to give back; but at last the Florentines got possession; they crossed and drove the Milanese pell-mell before them. Ditches opposed the co-operation of the two wings, and these the Florentine troops defended, and so kept the wings separated. Soon the Milanese army was in confusion on the rough ground, which impeded its evolutions, and gave way. Retreat became a rout; 22 out of 26 Captains and 400 officers were taken prisoners, with 1,540 men able to pay ransom, and 3,000 horse. But of the 22 Captains, Neri Capponi, the Florentine commissioner, who accompanied the army, could only find 6 when they were counted; and next morning, when he wished to pursue the advantage, his condotticri refused to follow; half the day was lost in dispute, and nearly all his troops scooted to Arezzo to dispose of their booty, and only came back at night. The fact was that the condottieri had too much fellowfeeling for one another to press too hard on the opponent to-day who might be a comrade-in-arms or repay a good turn to-morrow. Machiavelli is at pains to assure us that in this great battle, which lasted four mortal hours, actually nobody was killed, and only one man injured, and that by a fall from his horse (Mach., L. v.). But Machiavelli is always saying that kind of thing; he wanted Florence to organize a citizen army, and he "invests with literary merit" in order to emphasize his contempt for hired troops. In truth, according to Biondino, the Apostolic Secretary, 60 men were killed and 400 wounded ; according to Poggio, 40 were killed and on the Florentine side 200 wounded, of whom Io ultimately died (Scip. Ammir., L. xxi.-Poggio Bracciolini, L. viii.). The last thing in the world the condottieri wanted to do was to hurt one another, and had they wished to do so, they were so heavily armed that every man had the protecting carapace of an armadillo. Owing to the unremitting efforts of Neri Capponi, the Casentino was recaptured, however. In I44I Visconti gave his daughter to Sforza, and peace was again established.

Before long the Duke and the King of Naples were joined by the Pope. The three made an alliance, the object of the Holy Father being to dispossess Sforza of those marches of Ancona with which he had invested him. Florence now found herself against the Pope. Eugenius seized the opportunity to try to repossess himself of Bologna. He had formerly resided in that second city of his States for a considerable period, and in order to assure himself of its complete dependence, his legate, Vitelleschi, pretended that His Holiness was desirous of reconciling all parties. Amnesty to all exiles was offered, and when Antonio Bentivoglio returned, after fifteen years of exile, to the city which he had once governed, he was treacherously seized as he left the church where the legate had been engaged in administering the Sacrament, immediately gagged, and carried away to execution without any interrogation or form of trial. Another citizen was hung before the altar of the palace by the Podestà, who had invited him thither, and both bodies were buried without Church rights. The 
legate wished to inspire terror; he but excited wrath and indignation. The moment that Eugenius left the city it revolted, called in Nicolo Piccinino, Visconti's General, and reconstituted the Republic under the protection of Milan (1438). But Francesco, the son of Nicolo Piccinino, who commanded the garrison, mistrusted the leading Bolognese, and kept them with him as hostages for the good behaviour of the town. The Bolognese petitioned Filippo Maria and Piccinino in vain for the release of these men, but at last his friends contrived the escape of one of them, Annibale Bentivoglio, and he was let into the city by means of a rope-ladder which was lowered by night from the town wall. Everything had been quietly arranged, and suddenly there was a call to arms at midnight; the tocsin sounded, the citizens rushed to arms ; shouts of liberty rent the air, and Francesco Piccinino was surprised in the castle and captured (1443). There were always fierce factions in Bologna. Bentivoglio was the head of one, and he was called upon to assume the reigns of Government. Bologna, once again a free republic, took her natural place in the FlorentineVenetian system. But now that, as we have seen, the Church was allied with Visconti, they were agreed on one point. Bologna, that had cast off the authority of both in turn, must be taught a lesson, and its wings of freedom clipped. Whether it should ultimately fall to Pope or Duke could be decided later on. It was arranged that Bentivoglio should bo assassinated at a time when the Papal and Ducal troops were at hand to follow up the murder. Bentivoglio, a man of integrity and honour, and whose constant effort was to bring the factions of the city together, was asked by a conspirator, one Ghislieri, to stand sponsor for his little infant. As this man belonged to the ranks of his hereditary foes, Bentivoglio was only too delighted to accept the olive-branch, and seal the pact of friendship by entering into a sort of sacred relationship to the Ghislieri. After the babe was baptized Bentivoglio and Ghislieri walked back to a banquet prepared at the house of the latter. When they arrived at the house several of the conspirators who were following surrounded Bentivoglio and drew their weapons. Bentivoglio's hand sought his sword, but Ghislieri pinned him by the elbows, exclaiming, "Godfather, godfather, you must learn patience !" and while he was thus held the others stabbed him. The conspirators then rushed through the city shouting for "Liberty and the People," and murdering every male Bentivoglio they came across. The Bolognese were paralyzed, but they were very far from willing to place themselves again under the heel of either Duke or Pope. The soldiers of the allies had not yet come up; the Ambassadors of Venice and Florence bestirred themselves, and offered the use of the troops of their Governments. Bentivoglio had been universally beloved, and his loss was keenly felt by most citizens. When the first shock of horror and alarm had passed away the Bolognese rose in their wrath; they tore the leader of the faction to pieces, burnt down the houses of its chief men, and shut out the troops of the Pope and his ally, who revenged themselves by wasting the country round about (Cronica di Bologna, L. xviii.). But not a single adult Bentivoglio survived to take the slain man's place. Yet it was reported that a bastard of a certain scion of that House was dwelling at Florence. An Embassy was sent thither to make inquiries. It appeared that a young Bentivoglio had had relations with a married woman, and she was reputed 
to have borne a son, who was really a Bentivoglio, but who went by the husband's name. The putative father was dead, and Santi, the supposed Bentivoglio, now a youth of twenty-two, dwelt with his uncle, Antonio Cascese, a rich merchant and a friend of Neri Capponi, who tells the story (Capponi Comment., R.I.S., L. xviii., p. I 207-I 2I I). No one had the least suspicion that the boy was not a Cascese, and when Capponi and Cosimo, accompanied by the Ambassadors of Bologna, told him what they believed his parentage really was he fired up at the suggestion of his mother's dishonour and his own bastardy, and refused to consider for a moment the position that was offered him. At last he was unwillingly obliged to take time at least to think the matter over. It would obviously be to the advantage of Florence to have a man who had been brought up as a Florentine in command of the neighbouring republic, and when Cosimo saw that the young man was really beginning to have doubts about his birth, and to weigh the pros and cons of the situation, that "old parliamentary hand" clenched the matter by a remark which reveals his close knowledge of human nature. "No one is in a position to advise you," said he ; "you must settle the matter for yourself. If you are the son of Ercole Bentivoglio you will feel impelled to enterprises worthy of your father and your House ; if you are the son of Cascese you will stop in Florence and spend an easy life in manufacturing wool." The speech of the old man went home to its mark: Santi declared for Bologna, assumed the name of Bentivoglio, undertook the guardianship of the infant son of Annibale, and was knighted on the very day of his triumphal entry into that city (I445).

The death of their arch-enemy Filippo Maria Visconti in 1447 by no means relieved the Florentines from the anxieties and burdens of war. Alfonzo of Aragon was assembling an army in Central Italy, and had induced a little fortress in the upper valley of the Arno to revolt ; it was garrisoned by his troops, but soon retaken by the Florentines, and the attempt to enter Tuscany by this route was thus closed to him; his next attempt was made through the Maremma and Volterra (1447). Several fortified places fell to him, but one little fortress, Campiglia, made an obstinate defence, and Alfonzo was obliged to raise the siege. He now attempted to take Piombino, a little principality which had remained in the family of Appiano, the notorious burglar of Pisan freedom. In vain did Florence attempt to get provisions into the famished city by sea, yet the inhabitants continued to resist in a most heroic way, the very women fighting against the foreign troops of Alfonzo, and at last the King was obliged to draw his army off, for it had been decimated by malaria (1448).

Meanwhile a republic had been established at Milan, and its liberties were assailed by Sforza. Two opposite policies were offered to the Florentines; the Republic or Sforza must be supported. Neri Capponi and his party took the view that the Milanese would be able to re-establish their freedom, and that the rival ambitions and mutual jealousies of the regenerated republic and Venice would drive each to seek the support of Florence. Cosimo with clear vision foresaw the triumph of Sforza; he knew his man, and to a certain extent trusted him; he believed that he would conquer, and that he was not likely to turn against his old ally; indeed, self-interest would forbid him to do so. Venice would henceforth be Sforza's bitterest foe ; he would be kept so much in check by Venice 
that he could not turn against Florence even if he would, and he would be strong enough to check Venice in her designs in the direction of Tuscany; she of all Powers was most to be dreaded; he had lived there and knew. Throughout Cosimo had had a secret understanding with Sforza, and had advised him to pursue his own advantage.

\section{SIENA}

THE Riformatori had positively ruled for seventeen years, when the rescue of a prisoner was the occasion of belated revolution. The Dodicini compelled his release, and the party of the Riformatori were obliged to have recourse to arms to support the authority of the Government. The Dodicini, the Noveschi, and certain nobles remaining in the city, joined their forces in opposition, and fierce and bloody battle was waged up and down the streets. The lowest orders, on the whole, were inclined to support the Riformatori, but while they were intensely agitated, they were divided among themselves. The issue was determined by the cunning of a Jew, who probably had some pecuniary interest at stake. The Chronicle says that he approached one of the Saracini, and advised him to set up the shout of "Long live peace!" and he would assuredly carry the rabble with him. The advice was followed ; the mob immediately received a fresh accession of forces, charged the Riformatori, and the battle was won. The nobles were readmitted into the city, but remained excluded from the magistracy. A new Government was instituted; it consisted of ten Priors, who were to be changed every two months; four represented the Noveschi, four the Dodicini, and the remaining two places were given to a new Monte del Popolo, consisting of those of the greater number who had not taken part in the Government of the Riformatori. From the fact that burghers not of the Nine or Twelve had hitherto been excluded, the inference is clear that the Riformatori had been no less jealous of any expansion of privilege, no less tenaciously exclusive and avid of complete power, than all the republican Governments of their time. Men beginning to feel the impetus of personality, but not yet released from the thraldom of that family and guild association wherein the individual was nothing and the organization all, had yet to learn policy of conciliation and practice of compromise. The Riformatori were absolutely deprived of any voice in the affairs of State, and the greatest contributors to its wealth were expelled from the city and its contado. They set up in Pisa, in the Papal States, and in the kingdom of Naples. "And I," says the chronicler, " who am not of the Riformatori, say that it was unwisely done ; thereby was the city impoverished and became decayed; for, batch by batch, more than 4,000 citizens, excellent workmen, were banished, and not one in six returned " (I 385). Wholesale proscription did not heal the wounds of the city. Disaffection and conspiracy remained behind; foreign affairs went ill for the Republic. Troubles broke out at Montepulciano, a dependancy of Siena; its people, owing to a bad observance of obligations by Siena, sought to put themselves under the protection of Florence as they had been of old time. War followed, and Florence was victorious. In I 389 the city was so weakened by internal troubles that she sought the alliance of Gian Galeazzo, who appeared to 
discerning eyes to be likely to become King of Central and Northern Italy. A Ghibelline poet of Siena, "il Saviozzo," even wrote a canzone, wherein he hailed the tyrant as the coming saviour of the Italian people. But many of the nobles of less imagination than the poet had greater insight, and went into voluntary exile. In I 395, worn out by plague and famine, the decline of trade, and the inveteracy of dissension, Siena surrendered herself to the wily Milanese, and, not content with an oath of submission, the impoverished and exhausted people, overjoyed at the prospect of the protection and control of a strong hand, inaugurated their era of servitude by riotous revel and foolish festivity. And, in the irony of events, but a century before, the spiritual fervour and imaginative skill of a Sienese painter had adorned the Palazzo Pubblico with a fresco representing a gay and joyous city under the rule of justice and freedom with an invitation to the signoria, written on a scroll, to turn their eyes to the figure of Good Government, whence sweetness and peace proceed. "Everyone may travel and work and sow the seed without fear or hindrance while the commune maintains Justice as its Lady, for she has deprived the wicked of their power." And on the opposite side men might see then as to-day the allegory of Bad Government waited on by Pride and Avarice and Treason and Division and Cruelty, and typified by Tyranny enthroned above-a hideous, horrible shape, holding dagger and poisoned cup as the instruments of his rule-and Fear carrying a scroll over a sacked and desolate city, and on the scroll a warning concerning the end of selfish ambition. But the final subjugation of Siena was yet far off. The death of Galeazzo soon gave Siena her release. The old story of spiritual insight and practical impotence, of high aspiration and of treason and division, recommenced.

Gian Galeazzo Visconti, Duke of Milan, died in 1402, when he seemed at the very point of securing the dominion of Italy. His possessions, not yet consolidated, fell to pieces. Probably by the secret influence of Florence, the Salimbeni, the very family who out of jealous rivalry with other noble families had called in the Duke, aided by the Dodicini, roused the people to recover their liberty. It must not be forgotten that the Monte dei Dodicini was composed of the order of new men who had become wealthy merchants, men corresponding to the class to which the Medici belonged in Florence, and opposed to the Noveschi, or older order of merchants, who on the exclusion of the nobility from Government had come to occupy the position of a hereditary class, a class represented in Florentine politics by the Albizzi. The Noveschi, united with the populace, opposed them, and, after the usual street fighting, prevailed. But shortly after, as already stated, the weakened power of Milan admitted of a peaceful renunciation of its authority. The Government now consisted of a coalition of the order of ancient merchants ; of the Monte dei Riformatori, or the order of those families which had reformed the Government in the time of the Emperor Charles, and which had been largely formed of the popolo minuto; and an order of increasing power, the Monte del Popolo, the order of those who had not been represented by the Riformatori. This Monte ultimately received nobles who became popolani, and immigrant families. Each monte gave three Priors to the city, and the Captain of the People and the gonfaloniere of justice were successively chosen from each ward of the city and each of the three orders now in power. 


\section{BOOK VI}

\section{THE PERIOD OF BALANCED POWER. THE FULL RENAISSANCE, 1450-I494}

\section{GENERAL SURVEY OF ITALIAN HISTORY}

\section{The Italy of Princely Houses}

THE latter half of the fifteenth century presents us with an Italy no longer the arena of petty struggles between little communities that group themselves under the faded tatters of the Guelph or Ghibelline ensign-no longer falling piecemeal under the sway of the stronger despots or republics. Men had forgotten the great struggle of the temporal and spiritual powers ; the Emperors had withdrawn across the mountains to make a pretence at the exercise of Imperial authority in their own. land; the Popes were masters of Rome, but claimed to sway many turbulent peoples that, for the most part, fully occupied their attention and energies to curb and consolidate into a Papal State. Naples was under the sway of a Spanish Prince. The duchy of Milan was ruled by Francesco Sforza, the bastard son of a Romagnol peasant, who arrogated to himself the title of Duke, which not even the enfeebled and degenerate Empire had deigned to confer on him. The D'Este of Ferrara had puchased the duchy of Modena from the Emperor; the Gonzaga were Marquises of Mantua; and a younger branch of the great Byzantine family of the Palæologi held the Marquisate of Montferrat, which in I 305 passed to them, through their ancestress, the Empress Irene, by the extinction of the male line of its powerful crusading Princes. The great House of Savoy held the eastern and western gateways of the Cottian Alps and the rich lands of Piedmont. Florence was under the thumb of the Medici ; it retained the name, but hardly the reality, of a republic; and its rulers, masquerading as private citizens, had by business connections got the support of its bankers, the control of its finances, and the direction of its government. Genoa "only preserved the liberty of changing its masters," and was imploring the protection, now of Naples, now of France. Venice, under an hereditary oligarchy, was the bulwark of Italy against the great tide of Ottoman invasion. She, for the most part alone and unaided, fought the battle of Christian civilization; she was still mistress of the eastern shores of the Adriatic, of the whole of what is now known as Venetia, and nearly half Lombardy, and was still intent on grasping territories in Italy as the reward of services, and on inducing the Turk to trade rather than fight with her.

The alarm caused by the fall of Constantinople to the Ottoman Turks (I453) produced a temporary alliance of the antagonistic forces in Italy, but Alfonzo of Naples continued to attack Genoa, which had recognised his overlordship and then rebelled, and Genoa entrusted her defence to John of Calabria, the son of King René of Anjou. When Alfonzo died, his bastard son, Ferrante, was recognised by the barons, bishops, and cities of the kingdom; but the Papacy favoured the French House. A war followed between the rival pretenders to the Crown, in which Venice took 
the Angevin side on account of maritime squabbles with the kingdom, and Florence was only constrained to remain quiet by pressure which Sforza, lord of Milan, whose boundaries were coterminous with those of the Venetian Republic, brought to bear on his ally, Cosimo dei Medici, the virtual ruler of the Tuscan State. Pius II., who now occupied the Papal throne, was eager for a crusade against the Turk, and wished to preserve the established order in the peninsula. He declared for Ferrante, and sent him troops; Genoa, at the instigation of Sforza, expelled its Angevin garrison ; and finally, after fluctuations of fortune, Ferrante, aided by Scanderbeg, the Albanian, a Moslem renegade, famous for his contest with the Turk, established his rule in the South.

The war between the Venetians and the Turks continued, to the progressive exhaustion of the Republic of St. Mark. She lost Negropont ( 1470 ), and was obliged, in the default of Christian, to seek Persian support. She laid waste Caria and the Greek cities of Asia Minor, which were subject to the Turk; she tried to make up for her losses by manipulating the affairs of Cyprus to her advantage, became the guardian of Caterina Cornaro, the daughter of a rich Venetian citizen and widow of the former King, got her to abdicate, and administered the island (1489). Meanwhile, the Turk had enslaved the Eastern Empire, and turned the Venetians out of Scutari (1479) and the Genoese out of the Crimea ( 1475 ).

On the mainland Galeazzo succeeded his father, Francesco Sforza, and, though avid of pleasure, reduced the Milanese to severe subordination by the discipline of his troops, the excellence of his judges, and the severity of his police. Cosimo dei Medici was succeeded by Piero, and then by Lorenzo, and the power of the family was more and more firmly established. The Pope, Sixtus IV., finding his projects for the enrichment of his nephews in Romagna balked by the policy of Lorenzo, united his forces with those of Naples against Florence ; and, to distract Milan, Genoa was instigated to revolt against its protector, Sforza, while the Pope called down the Swiss from the mountains. The Plague ravaged Florence and Venice, and the Turks ravaged Venetia and compelled the cession of more territory in the Levant. Galeazzo Sforza having died, Ludovico Sforza declared Gian Galeazzo Maria Sforza to have attained his majority, ended the regency of his mother, and took the reins of government, with the sanction of the Pope. Milan, Naples, and the Papacy were thus united to ruin Florence, but Lorenzo dei Medici, by abandoning the Republic of Siena, and by consummate diplomacy, detached Ferrante from the confederation. At this juncture the capture and temporary possession of Otranto by the Turk frightened the States into an evanescent peace.

The Pope now plotted with Venice, when that State was disputing questions of salt monopoly with the Duke of Ferrara. He offered the Venetians Modena and Reggio if they would seize the Duke's State ; the Pope's nephew was to replace the D'Este at Ferrara. Naples, Milan, and Florence undertook the defence of the Duke of Ferrara. The Marquis of Montferrat and Genoa took the side of the Pope and Venice, the party lines being settled by questions of local policy and jealousy. The war seemed likely to be favourable to the Pope and Venice; but Sixtus mistrusted the Republic, knowing that it would not ultimately acquiesce in having his nephew Riario master of Ferrara and the salt-pans, and he went over to 
the opposite confederation. He employed spiritual thunder with little effect, and Venice gained Rovigo and several stations on the Neapolitan Adriatic by a peace which sacrificed the interests, and even the territory, of all the smaller to the larger States (I484).

In the midst of the political debasement of the time, classic models fired young men of Milan to sacrifice their lives in an attempt to end the tyranny there ; while baser plots were laid against the Medici at the instigation of the Church; and the general relaxation of morals became pronounced. Divine sanction was no longer sought as a basis for right-doing, but each man did what was good in his own eyes. To live a full, free, passionate life was the desire of the individual, now that he was emancipated from the antique restraints of the gens and the rigorous supervision of his craft-guild. Old restrictions were relaxed by the changes in political and social life, and religion had become a mere formal habit, or even a half-credited superstition, without effect on aspiration or conduct. Literary pedantry and scholarship still flourished, but were accompanied by the free flow of verse in the vernacular, born of the joy of life ; and the fine arts acquired ease of form and expression, and a new and reverent grace. Religious revival, under Savonarola, attempted in vain to stem the overwhelming current that had set in towards worldliness ; but the vital religion of the men of this age was the worship of

\section{"Beauty enthroned; and though her gaze struck awe They drew it in as simply as their breath."}

Influenced by the classic revival, but yielding themselves unrestrainedly to their own free, spontaneous impulse, literature and art developed on vital lines ; they were protected and fostered by Princes who could only maintain their position by the possession and exercise of keen intelligence ; men of parts themselves, they delighted in the society of the scholar, the artist, and the poet, and considered them to bestow the highest distinction on their elegant, fascinating, but dissolute and unprincipled Courts.

\section{The Temporalization of the Holy See}

While the princely Houses waxed in greatness, the Papacy emulated their sway and state. Eugenius IV. was succeeded by Thomas of Sarzana, who took the title of Nicholas V. (1447). Nicholas was a man of great force of character and remarkable erudition. He was persona grata both to the Emperor and the King of France, and his election brought about the abdication of the Antipope Felix V., who represented the republican tendency in the Church in the schism which arose from the opposed claims of the Papacy and the Council of Basel. Nicholas filled Rome with classical copyists, and sent all over Europe to collect precious manuscripts. Jannozzo Manetti tells us that more Greek authors were translated during his reign than during the five preceding centuries. He practically rebuilt Rome, and strove to make it the cynosure of the Christian world. The Roman Catholic Church has always had a clear perception of the psychological law that sense-impressions are the matrix of belief, and Nicholas V. was determined, on an appeal to the convictions through sense, "to create solid and stable convictions in the minds of the uncultured masses." $\mathrm{He}$ said; "there must be something that appeals to the eye: a popular 
faith, sustained only by doctrines, will never be anything but feeble and vacillating. But if the authority of the Holy See were visibly displayed in majestic buildings, imperishable materials, and witnesses seemingly implanted by the hand of God Himself, belief would grow and strengthen like a tradition from one generation to another, and all the world would accept and revere it. Noble edifices, combining taste and beauty with imposing proportions, would immensely conduce to the exaltation of the Chair of St. Peter" (quoted by N. Young, Story of Rome, Lond., I90I, p. 264). The money for these works was raised by a Jubilee, which in a few days filled the coffers of the Medici, the Papal bankers, with the sum of several hundred thousand florins.

Nicholas was succeeded by a Borgia, a Spanish jurist who came to Italy to push his fortunes. The new Pope strained every nerve to advance his nephews, and filled the administrative offices of the State with men who, like himself, were Spanish adventurers. Although he had come over in the service of Alfonzo of Aragon, he joined the Neapolitan barons in resisting the claims of the bastard son of that monarch, Ferrante, on the ground that the legitimate line was extinct : his real object was to reaffirm the Papal suzerainty over that kingdom. Crime and disorder increased during the reign of Calixtus III., and when he died, all Spaniards, including the Pope's nephews, had to flee for thcir lives.

Enea Silvio Piccolomini was now elected to the vacant See (I458). Once again a learned man sat in St. Peter's Chair, and one of the most essentially " human" characters in history. What Terence's rascal says, Piccolomini might in the fullest sense have applied to himself : "Homo sum : nihil humani a me alienum puto." In youth he had been a man of pleasure ; he had travelled much, " seeing men and cities," and had become only too well acquainted with the vie intime of the various lands he had visited. He had even been as far as barren Scotland, where he "lightly loved and rode away." He wrote novels and works which are by no means edifying, but which reveal the moral tone of his time; for, like Iord Beaconsfield, he gave an outlet to his pungent wit and satire by describing the true adventures and characteristics of himself and his friends under a thin disguise. His verses, comedies, and tales exhibit the ningled coarseness and literary finish of his age, and one detects a cynicism and sarcasm which show that, though indulging in frivolity and sharing in the wickedness of his companions, he was not wholly possessed by animalism, but had an undercurrent of contempt for the life he led. Like every young Italian, the world was his oyster, to be opened by the keen edge of intellect, and he supported the authority of the Council of Basel, and became secretary to its Pope, Felix V. Afterwards he was appointed secretary to the Imperial Chancery. A happy interaction of conviction on interest and of interest on conviction brought him round to the support of Papal as opposed to Conciliar authority, and the way to advancement was open to the ambitious scholar. As he grew older, the elements of goodness and even greatness in the character of the future Pope became more pronounced. $\mathrm{He}$ had had a large experience of life, roughing it among Scottish peasants, enduring the subordinates of the German chancery, dwelling among beerswilling German students and Teutons, who would even awaken their children at night to give them wine for their health's sake; staying at vile inns, and drinking vile beverages; writing in the midst of indescribable 
din and confusion; managing stubborn Bishops and imperious Princes and intriguing courtiers; all the rich phantasmagoria of life had passed before him, but he retained a rare appreciation of the various manifestations of human character; he even developed lofty enthusiasms, and he still bore the music of Nature in his breast, and sought refreshment in her varying aspects with the love and simplicity of a little child. As Piccolomini aged, the gold in his nature separated itself from its dross, and stood forth thrice refined. As is sometimes the case, moral and intellectual development invested him with almost a new character, until he could regard the old discarded self as a stranger, and tell his friend to forget "Piccolomini and remember Pius." He was eminently a man of his time, a representative of the great period of the Renaissance, but he had more moral stamina than most men of his age, and was capable in his old age of more selfdevotion. Before a great issue, the Eastern danger, Pius II. becomes

" happy as a lover, and attired

With sudden brightness like a man inspired;

But yet a Soul whose master-bias leans

To homefelt pleasures and to gentle scenes."

Many and versatile were the endowments of the man who tells us that " the more one knows of a subject the more one is in doubt concerning it ;" whose keen eyes had regarded life amid the intrigues and cabals of the council, the pomp and splendid magnificence of Papal retinues, and the curious crowded life of Vienna; who was equally interested in the Court and the camp, the Curia and the cloister; but who still found himself most at home on some Tuscan hillside or in the seclusion of his own study. With all the weaknesses of the literary character, Pius was one of the men who never cease to grow in intellectual and moral stature ; his natural perceptions remained undimmed by scholarship, and his sense of the greatness of his trust undisturbed by the temptations of its power. He stood almost alone as the statesman who perceived the pressing need of a union of the divided forces of blind, quarrelsome Christendom against the might and menace of the Moslem, and there are few things in history more touching than the spectacle of the dying Pope, racked with suffering, equipped neither with the inclination nor the temper of the hero, ordering his jolting litter to bear him to Ancona, and, arriving, to find neither fleet nor army, nor hope of them, but only death awaiting him there.

On the death of Pius (1464), a conclave assembled in the Vatican, and each Cardinal took oath to observe certain laws which were passed with a view to the reformation of the Church and the restriction of Papal power, or, rather, of Papal license. The cardinals, among whom was the as yet unascertained future Pope, vowed each one of them, if elected, to war against the Turk, and apply a portion of his income to that end, not to leave Rome without the consent of the cardinalate; not to increase the number of cardinals, nor to nominate more than one relation as Cardinal, nor any man not over thirty and possessed of a University degree ; and not to declare war without the consent of the Sacred College; voting was to be done openly, and an œcumenical council was to be held every three years. No sooner was the Pope elected than he repudiated his oath, and annulled the laws which he had assisted in making ; and he got the College, partly by entreaty, partly by menace, to make the same volteface. He then ex- 
pelled all the scholars from his Court to make room for his own sycophants ; and this gained him the undying hatred of the learned, so that we are presented with contemporary portraits of him in which he is represented as a far worse Pontiff than he really was. He was, indeed, given up to a life of pleasure; but he set about making life and property a little more secure in Rome; he compelled the barons of the Campagna to obey him, and he fought vigorously against the Malatesta of Rimini, who were villainously bad samples of the petty tyrant. Intent on bringing the States of the Church into subjection, he was wholly indifferent to the Turkish danger.

Paul II. was succeeded by Francesco della Rovere, a man descended from the lowest class, though he claimed to belong to a noble Piedmontese House. It is said that Sixtus IV. obtained his position by bribing the corrupt College ; but he began well. Soon, however, the real character of the man declared itself. "He was the first," says Machiavelli, "to show what a Sovereign Pontiff can do, and how much that which was formerly called by a plain name can be varnished by pontifical authority" (Mach., Ist., L. vii.). He put up every post for auction; he not merely adopted the fatal traditional policy of the Papacy to secure authority by thrusting nephews into power, but he was possessed by a real mania for advancing them. His brother's sons, the Della Rovere, and his sister's, the Riarii, were pushed forward in season and out of season. When the Medici opposed this policy, a conspiracy against their lives was hatched in the Vatican, and if the Pope was not privy to the plot, he condoned the offence. He was ever on the look-out to snatch some fresh province for a nephew; he joined the Venetians in their attack on Ferrara with this sole object, and thus lighted a general Italian war in which Rome was attacked by Naples, and the old disorder among the Roman nobles renewed itself. He was obliged to call in Roberto Malatesta of Rimini to quell the disorder, and tilen, when Malatesta succumbed to Roman fever, tried to filch that principality from his defender's son-a project which Lorenzo dei Medici and the Florentines defeated. The Pope now changed sides and joined Naples, because the Venetians prosecuted the war for their own profit rather than for that of the Pope. But his conduct was not wholly dictated by family policy. He often acted from caprice or resentment, offended the entire cardinalate by giving the red hat to a handsome lad of eighteen, who appears to have been of good character, but with nothing to recommend him but a pleasing face ; and he pursued the Colonna with a vindictiveness that nothing could appease. His nephew, Girolamo Riario, a bloodthirsty ruffian, first got possession of the castle of one of the Colonna by promising to spare his life, and then had his head cut off. The funeral services were held at the Church of the Holy Apostles, and the dead man's mother suddenly seized the severed head by the hair and held it aloft for the people to gaze on, exclaiming, "Look how a Pope keeps faith !" The Pope died five days after the declaration of peace ( 1488 ) ; and men repeated a Latin epigram to the effect that no power of dread or darkness could destroy Sixtus, but that the mere whisper of peace was enough to prove fatal.

Sixtus was absolutely unscrupulous, but he had not the far-seeing cunning of the Princes by whom he was surrounded. Yet he made the political force of the Papacy felt; he established the See of St. Peter as 
one of the great powers of Italy, and his very rashness and unwisdom made him the more dreaded that he was a quite incalculable factor in the machinations of his time. His nepotism did the State this service, that it kept the barons of the Campagna in wholesome fear, and prevented Naples from taking advantage of their usual turbulence. The general aim of his policy was the union of the Papacy and Naples against the Northern powers of the Peninsula.

The Papacy was now put up to auction, and was bought by Cardinal Cibo, who took the name of Innocent VIII. Like Paul II., he took an oath in order to break it, according to the principle established by Innocent VI. in I353, whereby no prior oath can bind pontifical authority, since the only authority with which the Sacred College-there being no Pope-is invested is to elect a new one. He had had to swear to observe conditions which elevated the cardinalate and reduced the Pope to the condition of a constitutional monarch. This Papal repudiation of a solemn oath is not without some shadow of justification. It is obvious that, as was the case in the elective monarchy of Poland, where the nobles usurped power on the death of each King, a series of encroachments might easily be made on the sovereign power of elected Popes by the princes of the Church, and this with the greater rapidity that the elected Pope, being usually a man advanced in years, the Holy Chair became vacant very frequently. And the coalescence of the temporal with the spiritual power had been going on for centuries, and now, in the decay of religion, the temporal power was all-important. Italy had ceased to be an agglomeration of small republics, and had become divided into important States, and the Papacy, on account of its prestige and its increased temporality, was the most important power in that balance which was so necessary to the preservation of peace. If the Pope was not to become a sort of Archbishop of Canterbury to the King of Naples or some other power, his own temporal possession must be assured. Innocent told the Florentine Ambassadors flatly that if they did not aid him against the violence of the King of Naples, he would transfer his Court out of Italy. Renunciation of the temporal power would have meant diminution, if not loss, of influence over the Christian States.

Lorenzo dei Medici married his illegitimate daughter to the Pope's son, whereby the Pope was precluded from seeking aid from Venice, and Innocent tried to break the power of Naples by fostering rebellion among the Neapolitan barons. The barons of the Campagna took advantage of the war to besiege Rome, which was soon in a state of fearful anarchy: dead bodies were to be found every morning lying stripped in the streets ; malefactors had the choice of hanging or taking service as Papal troops to defend the city ; crime of every sort could be compounded for by payment to raise funds ; the houses of the cardinals were defended by bravoes, for the cardinals were by no means all loyal supporters of their Sovereign. The Pope was so hard pressed by Naples that he was obliged to invite King René to enter Italy; then Ferrante of Naples compounded for peace by paying the Pope an annual tribute, and halcyon days ensued. The Papal States, however, were in a worse condition than Rome even, and violence was the rule throughout the land that owed allegiance to $\mathrm{His}$ Holiness. The corruption of the Pope made matters worse: he was entirely led by his favourites; he unblushingly acknowledged his seven 
natural children, and spent his days in riotous living. Justice and benefices were openly sold, and his chamberlain was wont to say that, "The Lord desireth not the death of a sinner, but his purse."

Innocent even contrived to extract money from the infidel. He got possession of Djem, brother of Bajazet, the Sultan of Constantinople. Djem had contested the throne with his brother, failed in the attempt, and escaped to Rhodes. The Knights of St. John, who ruled at Rhodes, had received 35,000 ducats a year from the Sultan for his safe custody, but the Pope raised the sum by 5,000 ducats. The writers of the period speak in the strongest terms of the wickedness of the Pope and his Court. Lorenzo dei Medici warned his young son, who had been made a Cardinal, and was about to visit Rome, against that "sink of all iniquity," and Infessura called Innocent a " monster of wickedness." He died in ז492, to be succeeded by a still more portentous product of the age so prolific in prodigies of every kind. In Innocent's reign heresy gained such ground that more than 1,500 households in Rome had to pay fines for heretical opinions, and one member of the Curia was discovered using words of derision at Mass (Creighton, Hist. Papacy).

\section{MILAN}

ONCE secure in the possession of the duchy, Sforza started great public works. The public hospital and enormous canals for navigation and irrigation which exist to-day attest the benevolence and excellence of his administration. His Court became one of the most brilliant in Italy; it was sought both by Italian scholars and Greek exiles, and his daughter Ippolita became renowned for the elegance of her latinity. Sforza had devoted all his energies to the attainment of a great prize ; neither humiliation nor defeat had ever daunted him or moved him one hair's-breadth from his chosen course ; and, so far as power and position can satisfy the human spirit, he "had attained." There was something of the force of true greatness in the man, the calm of whose short, light sleep neither peril nor fatigue nor any anxiety could affect; who was equally indifferent to the fierceness of the summer sun and the snows of winter, and ever led his armies to battle unhelmeted; who secured the genuine admiration of Francesco Filelfo, the Court poet, of Giovanni Simonetta, the historian, and of Cecco Simonetta, his own secretary, and retained the affection and respect of the wife to whom he was by no means undeviatingly faithful (for, as is often the case, Sforza, while indifferent to ordinary forms of self-indulgence, was remarkable for sexual passion). He died in $\mathrm{I} 466$, leaving a dynasty which was destined to disappear speedily, for all the elements of political stability had been destroyed by him and the Visconti ; and unless the roots of Government spring and obtain their sustenance from the bases of society, they are doomed to be uprooted. Sforza tried the impossible when he aimed at moulding and pruning the State so as to establish himself and his family. The tyrants of Milan had only succeeded in destroying the bed-rock of social organization, in the absence of which the noblest projects of Government are founded in shifting sand. The despot or the thinker, with his scheme for reconstructing the State, is but 
a single force among the great forces of society; he sows the wind, and apparently sweeps everything before him; thereby he liberates great, slumbering, unseen, unsuspected powers, and the whirlwind is his reward.

History ordinarily exhibits the youthful despot as the weakest and cruellest of men. Undisciplined and undeveloped character usually breaks down under the dire strain of early power. The story of the Roman Empire is replete with illustrations of how full of bale to himself and the State is the accession of too young a ruler; and Milan is not without its witness to this general rule. Galeazzo Maria Sforza was not wholly destitute of the qualities which had made his father great: he was skilled in the art of military discipline, and if his council knew how to maintain public safety, to administer justice, and to rivet the fetters of tyranny on the reluctant Milanese, he was discreet enough to give them his support ; he was polished in manner; he knew how to assume and combine dignity with the outward show of kindliness ; but inside he was full of avarice and malice, a false friend, and wholly unscrupulous in the gratification of his lusts. Taking advantage of the general corruption around him and the growing feeling that all license was allowed to the Prince, the guardian of the State, no woman was safe from his advances, and he took a particular pleasure in boasting of his successes to injured husbands and the members of dishonoured Houses ; once won or forced, his newest mistress was given over to his lackeys, and many a rich subject was made to gratify his greed for gold, or buried alive, or tortured to death. And all this took place in an age remarkable for its intellectual development and its fine feeling, not merely for the beautiful, but for the tender and the true.

It was almost the full tide of the Renaissance. Man, in discovering an ancient world, had found himself, and the strangest contradictions of human character and aspiration were exhibited at the same time and in the same person in a period unrestrained by the coercive influences of religious or social synthesis. Carlo Visconti, Girolamo Olgiati, and Giannandrea Lampugnani had been educated by Niccola Montano, a Bolognese scholar who was occupied in giving the higher education to the youth of Milan. Montano, steeped in classic literature, inspired his pupils with an enthusiasm for liberty, and he took care that they should also acquire a knowledge of arms under the condottieri. He was regarded as a dangerous man, had been exiled, recalled, imprisoned, released (Tiraboschi, Storia della Lett., L. iii., c. v., § 28). Nursed by Montano in admiration of the great conspirators of ancient Greece and Rome, these three pupils were of the opinion of Seneca and Milton :

"There can be slain

No sacrifice to God more acceptable

Than an unjust and wicked King."

(Seneca Her. Fur., 922, tr. Milton.)

Two of them had suffered at the hands of the despot; Olgiati had seen a sister sacrificed to his brutal lust; it is said that Lampugnani had been despoiled by him. The three met in the Court of San Ambrogio, and Olgiati has left us an account of what followed in his last dying confession, written by his own hand : "After our talk together," says he, "I entered the church, threw myself at the feet of the holy Bishop's statue, and prayed to him, 'Holy and powerful Saint Ambrose, hope and warder and support 
of Milan, if the project of thy fellow-citizens and children, to put an end to tyranny, impurity, and monstrous wickedness, is worthy of thy approval, help us in the perils and hazards of our adventure to deliver our country.' Having prayed thus, I rejoined my companions, and exhorted them to be stout of heart, telling them that I felt full of hope and strength, for I had called on the holy protector of our land for aid." Olgiati goes on to say that during the next few days the conspirators read the classics, rehearsed the perils before them, and practised with dangers. The curious mingling of revenge, civic patriotism, devotion to the classics, and worship of saints, is wholly characteristic of the period. "The sixth hour of the night before St. Stephen's Day, destined for our deed," he goes on, "we gathered together again for the last time. We arranged the hour of entering the church, the part each one of us was to take, and all details, as far as one could, where unexpected tricks of chance might happen. Next morning we repaired to the Church of St. Stephen, and prayed the saint to bless the great deed that we were going to accomplish in his holy place, and not to be wroth with us if we soiled his altar with blood, since this very blood would effect the liberation of the city and the State. After repeating the customary prayers of the Church to the proto-martyr, we repeated another, composed by Carlo Visconti." The deed was done before the altar. Lampugnani knelt before Galeazzo, and made as if he had a petition to present. As he poignarded him, the other two conspirators also struck home. Sforza screamed out " O God !" and was dead before the Ambassadors at his side comprehended what was happening. The church was all confusion, and Lampugnani nearly effected his escape ; but his foot caught in the dresses of some women who were on their knees, and he was seized and killed on the spot. Carlo Visconti got out, but was pursued and also killed. Olgiati reached home, but his father shut the door in his face, and he sought refuge with a friend. He tells us that he was on the point of issuing forth to call the Milanese to assert their freedom, when he heard a crowd coming, and found that they were dragging the dead body of his friend Lampugnani through the mire; paralyzed with horror, his strength and mother-wit seemed to desert him, and he was recognised and conveyed to prison. He was submitted to the most fearful torture, and his bones were dislocated, but he put the memory of Roman stoics before him to strengthen a strange sort of Christian fortitude and confidence. He had no doubt whatever that he had done a righteous and meritorious act; his body was broken, but his soul remained undismayed, and by order of his judges, and before the eyes of those who were to execute him, he wrote his statement, which concludes thus: "And now, O holy Mother of our Lord, and you, Duchess Bona, I entreat you to provide for the safety of my soul. I petition only to be left enough consciousness and strength to confess my sins, and then I am ready to undergo my fate" (Confess. Olgiati. In Grevii Thesauro Rer. It.). In vain did the confessor endeavour to get him to repent of his crime. "I have been a great sinner," he replied, " and deserve far worse torture for other sins ; but the righteous deed that I have done is a solace to my conscience : far from esteeming it a sin, I believe the Judge of all will pardon me my other offences thereby. No ignoble motive actuated the deed, only the desire to remove an insupportable tyrant. So far from repentance am $I$ that could I come back ten times to endure the same tortures, and consecrate 
every energy and every drop of blood to so noble an end, I would not hesitate to do so." The executioner, in tearing away skin from the flesh, a part of the torture to which he was submitted, did indeed make him groan ; but he recovered himself at once, and said in Latin, "Death is sharp, but fame is everlasting." He was only twenty-two.

The eldest son of the Duke was a child of eight years, but the spirit of freedom was dead in the people ; the Government was not even seriously menaced, and went on as before. The real director of the State had been Cecco Simonetta, the brother of the historian, a man of great capacity and no less learning, and the masses were content with the loaves and fishes a stable Government secured them. But the five brothers of the Duke hastened to Milan to get what they could for themselves; they accused Bona, the widow, of undue partiality for Guelphs, and, on the suggestion of the Marquis of Mantua, both parties, which perhaps now represented hates rather than interests, were given an equal allotment of seats. Faction reigned at the Court of Milan. Simonetta, who had seen fifty years of service under three successive rulers, had almost sovereign power, but he was opposed by one Tassini, who had been a favourite of the late Duke, and had risen from the position of a body-servant to become the confidant and favourite of the Duchess. Tassini, in order to strengthen his power, had secret relations with Lodovico Sforza, a brother of the late Duke, and known to his contemporaries as the Moor, on account of his swarthy complexion. Lodovico was a man of great timidity, but of still greater ambition, and he advanced into Milanese territory with an army, and took possession of Tortona and many strong places under the pretext that he was going to deliver the Duchess, his nephew, and the people from unfaithful and rapacious Ministers. Tassini persuaded the Duchess to invite Lodovico to Milan. "The side you have chosen," said Simonetta, "will cost you your State, and me my life." No sooner had Sforza arrived in Milan than Simonetta was cast into prison, and told by Lodovico that he might purchase his release at the sacrifice of his fortune, which lay in the hands of Florentine bankers. "I have been illegally imprisoned," replied Simonetta, "my house has been pillaged, myself insulted ; this is my recompense for faithful service. If I had done wrong I ought to take the consequences, but my fortune is the wage of honourable service and strict economy; it shall go down to my children. God has been gracious in giving me so long life ; I am ready to depart " (Diaro Parm. -Bernard. Corio). Simonetta was tortured and then beheaded, and his wife went mad with despair; his prophecy was fulfilled. Lodovico, in order to rob the Duchess of the regency, discovered that his nephew, now twelve, was a singularly precocious lad, and contrived that he should be declared fit to govern. Tassini, who had called him in, found himself supplanted, and was conveniently exiled, while the indignant Duchess thought it wiser and safer to retire from Milan into the country. The young Duke was now his uncle's prisoner; Lodovico ruled in his name over a country of which the yearly revenue was 700,000 ducats.

Lodovico was one of the master minds in the statecraft of his time, and his ambition as head of one of its greatest States was to extend his sway. He had risen by unscrupulous means; he had to maintain a precarious position by all the versatile devices of faithlessness and temporary expedient. Deficient in personal courage, and even of nerve in 
the presence of danger, he knew how to select his agents, and he was well served by spies in every Court of Europe. He endeavoured to add to his lustre by becoming the munificent patron of letters and the fine arts, and his ability made such an impression on the great Leonardo da Vinci that he remained for years quietly studying his character and adorning his Court. But his expensive administration was carried on by increased exaction from his suffering subjects. His rule had not received official confirmation, and he gave his niece to Maximilian the Emperor in marriage, with a dowry of 400,000 ducats, to secure it. His weakness lay in the fact that the Duke of Orleans and the Emperor both had claims to the kingdom, and that his State was not free from the old antagonisms of faction. $\mathrm{He}$ caused every copy of the will of Gian Galeazzo Visconti, which bequeathed the succession, in default of male issue, to the heirs of Valentina Visconti, the Duchess of Orleans, to be destroyed, and then approached France with a view to divert French pretensions to Naples, and so save Milan. Florence, Rome, and Naples were soon alarmed, and united in their determination to oppose him, and Lodovico's position became increasingly precarious, especially as his army was unequal to the defence of the duchy, and his great resources were diminished by his lavish expenditure. The King of Naples demanded the resignation of the regency to Lodovico's nephew, by this time of full age, and whom he had, by a mistake in policy, married to a Neapolitan Princess. Dreading surprise from his Italian foes, dreading what action Venice might take, Lodovico endeavoured, on the one hand, to delude his neighbours with fair words and specious promises, while, on the other hand, he hurried the advent of Charles VIII. In 1494 the French King crossed the Alps. Soon after the Duke conveniently died, and the Milanese Senate, representing that his son, a child of five years, was incapable of reigning, requested Lodovico to assume rule in his own right. After due profession of hesitation and reluctance he acceded.

\section{VENICE}

\section{The War with Mohammed II. (1463-1479)}

The rival Servian Power had fallen for want of consolidation, and a series of able rulers formed a firm and organized Moslem State. The Turk was steadily advancing; he had conquered the eastern shores of the Lower Adriatic, and all Italy would have been open to invasion had he at that time been possessed of a fleet. The nomad throve as long as he conquered; his impulse was to advance; but he organized as he advanced. Turkish invasions and the consequent enfeeblement of the Eastern Empire had accelerated its internal disintegration, and the violence of the Musselman's onset had caused a general exodus from the provinces that he occupied to those that still remained free from his presence. The population, thus reinforced, ought to have offered vigorous resistance, but long servitude had destroyed the courage and evil legislation had debased the character of peoples that Nature, perhaps, had not cast in a noble or heroic mould. When Constantinople fell, the little State of Trebizond, which 
called herself an Empire, still maintained a precarious independence on the Euxine, as well as another Christian State called Iberia, and the great Genoese colony of Caffa. Between the Black Sea and the Adriatic lay seven States-Croatia, Dalmatia, Bosnia, Servia, Rascia, Bulgaria, and Transylvania - that were nominally feudatory to the Crown of Hungary, as well as Wallachia, the language of which testified to its ancient allegiance to Rome. There also lay the States reconquered from the Turk by Scanderbeg, the heroic defender and avenger of Epirus. Greece was almost wholly in the grasp of the Turk, but the Florentine family of Acciaiuoli still held the duchy of Athens, and the Peloponnesus was still divided between two Christian despots. Rhodes was held by the valiant Knights of St. John, the House of Lusignan ruled at Cyprus under the suzerainty of the Soldan of Egypt ; Candia, the ancient Crete, Negropont, the ancient Eubœa, and several other islands belonged to Venice, and Chio to Genoa ; Venice held many a strong fortress along that famous eastern coast of the Adriatic, a land inhabited by a wild and hardy race of mountaineers that gazed with wonder and disdain on the vast ruins of the sumptuous Palace of Diocletian. In the archipelago, many of

" the sprinkled isles,

" Lily on lily that o'erlace the sea,

And laugh their pride when the light wave lisps Greece,"

still retained a precarious independence. Forth from the conquered lands the wealthy, happy to escape slavery at the price of quitting their possessions, monks bearing duplicates and triplicates of the selfsame relic for the perplexity of the faithful, learned men carrying precious manuscripts, and rich merchants with hastily-packed bales, came crowding into Italy. The country was full of Greeks and the Christians of the East, and they looked to Italy to restore the Christian power in the Orient, as the peoples yet unsubdued relied on the strong forces of Italy to aid them in their defence. Alas! they relied on a broken reed. The spirit of the Crusades had become a hollow ghost, the elegant Latin of appeals by Enea Piccolomini, sincere as they were, had lost the force that dwelt in the rough accents of Peter the Hermit ; every Prince was too eager to extend his dominions, too jealous of his neighbour, and too suspicious of his neighbour's intentions to answer to the Pope's appeal; the land was exhausted by the warfare of the first half of the century; the inland republics were immersed in money-making; and a danger distant in space is never regarded as entirely of pressing and really present moment. It was the destiny of Venice to bear well-nigh the whole force of Turkish attack, and to safeguard the high interests of the West.

In I 458 Rascia and Servia fell, in 1462 Sinope, Cerasus, and Trebizond submitted to the Turkish yoke, in $\mathrm{I}_{4} 6_{3}$ Bosnia was conquered, and the Turk spread over Sclavonia. The Turk was ever approaching nearer and nearer to Italy, and only one, or at most two days' journey might have carried the Venetian citizen out of his own territory to the presence of Turkish outposts.

It cannot be said that Christians bore themselves towards Turks in a way to impress them with the moral superiority of the Christian faith. A slave belonging to the Mussulman ruler of Athens made off with public cash, and shared it with the Venetian commander of Coron as the price 
of asylum. The Turks demanded the extradition of the slave and the return of the money, and the answer was that the man was a Christian and could not be given up to infidels, nor was the money returned. The Turks took Argos, where a Dandolo was in command, by way of reprisal, and the incident led to war (Marin Sanuto, Vite de' Duchi di Venezia, p. I I72). It was represented to the Venetian Senate that the moment was favourable to the acquisition of Morea (Peloponnesus), that 20,000 Greeks were ready to take arms, and that if the peninsula were once in the hands of a maritime power, there would be no danger of future dislodgement. Trade with Constantinople had become of less importance since it had fallen into the hands of the Turk, and a small army and a fleet were despatched (1463). Argos was retaken, and the Hexamiglion, the narrow isthmus, only six miles long, which separates Peloponnesus from the rest of Greece, was efficiently walled in fifteen days by 30,000 Greek workmen, who obeyed the strong directing will of Venice, but had never had the forethought or the energy to build it before for themselves, though the materials had been collected of old by their forefathers to that end. Soon only one or two small fortresses remained in the possession of the Turk, except Corinth, which was besieged. But before long exaggerated reports reached the camp concerning the force that was approaching; it was even estimated at 80,000 horse. The Turk was in the full flush of religious enthusiasm and victory, and his fierce, unchecked career had chilled the soldiery of Western Europe. Craven fear reigned. The truth about the Turkish army was that it was small, and its commander had written to the Sultan to say that it was impossible for his men to carry the great wall that had been built. But when word came to him that the Italians had abandoned the Morea he advanced with caution, and could scarcely believe his eyes when he found the works abandoned and the fleet on the horizon in full sail. Morea was easily reconquered by the Turk, and Venice lost the few stations she possessed there.

Meanwhile, the Pope was trying to pull the Christian States of Europe together to succour the Christians of the East and defend the West, lest that too should go down piecemeal before the advancing Crescent. Louis XI. was too much occupied with intrigues against the House of Burgundy and with building up the Crown of France to take heed to what the Holy Father might urge; the Duke of Burgundy was in mortal terror of what Louis would do in his absence, and had his own little ambitions to pursue ; Germany was in a state of anarchy; each of the Italian States was watching the others, to plunder and encroach when any one of them was off guard; the heroic King of Hungary, Matthias Corvinus, and the Republic of Venice alone took up the proposal with ardour. Venice was at this time engaged in a war with another Christian power, and the scene of conflict was perilously near the Turkish border. For the city of Trieste was under the protection of the Emperor Frederick III., Archduke of Austria, and he resolved that all merchandise entering Germany by way of the Adriatic should be disembarked there. Venice was prepared to resist both the might of Germany and the onset of the Turk; a blow had been directed at her commerce, and must be met without delay. But hostilities were arrested by the intervention of the Pope, and an agreement was come to (1463). The Pope invited the Doge of Venice to join him in personally conducting the crusade. The Doge was aged, 
and tried to excuse himself, but the Pregadi would hear of no evasion. One of them told him flatly, "If your Serenity will not embark with good grace we shall have to employ force, for we consider it to be a matter wherein the honour and well-being of the State is concerned, rather than that of yourself." However, the Doge finally got himself off the leadership of the fleet, on the score of ignorance of naval warfare, and substituted a kinsman. But the dream of Pius was not destined to be realized. The Doge, indeed, appeared at Ancona with a small fleet of only twelve galleys, for mercenary troops were not at all contented to receive spiritual indulgences in lieu of solid pay. Trained mercenaries came and turned back, and the crusaders who remained were mostly a crowd of miserable wretches without leaders, money, provisions, or arms, who trusted to the Holy Father to supply all these necessities. And Pius was dying. His indomitable courage had forced him to fulfil his vow, but he arrived borne in a litter, and suffering exquisite pain. When he looked out on the Venetian galleys, he remarked, "Hitherto the fleet has been wanting to me ; now that it has come I shall be wanting to the fleet." His last words were an exhortation to pursue the holy undertaking, and after asking the cardinals to pardon all his faults, the gentle Pius - great scholar, accomplished historian, keen observer of nature and politics and man, the entirely human Pope-breathed his last in the arms of his great friend the Cardinal of Pavia. With his death the project fell to the ground. In order to keep up appearances the cardinals proposed to add five armed galleys to the Venetian fleet, but in a few hours they had reduced their offer to three galleys. The navy set off, and was soon recalled by the Venetian Senate (I464).

While the contest with the Turk was still proceeding, Venice had another war on hand with the Knights of St. John of Jerusalem, who were in the possession of the island of Rhodes. Under the veil of religion the Grand Master of the Order had seized two Venetian vessels, pretending that there were Mohammedan merchants on board. Venice regarded the act as one of piracy, sent the squadron which had been destined for the abortive crusade to Rhodes, and taught the knights a severe lesson (I465).

Meanwhile a fleet of thirty-two galleys was waging war against the Turk in the Levant under Lodovico Loredano, who endeavoured to prove the sincerity of his religious faith by his vindictiveness. No mercy was shown to Mohammedan prisoners: Lesbos was attacked, and 300 Turks were captured; most of them were impaled, others were drowned, and the rest, by special grace, were merely hanged. The only result was that the remaining Turks were possessed with the courage of despair, and the siege of a fortress on the island had to be abandoned after it had cost the Admiral 500 lives. Loredano is said to have felt the disgrace of failure so keenly that he died immediately after re-embarking his men, and it is evidence of how little was thought of the most inhuman and ferocious treatment of the infidel that Sabellico, after recounting his ferocities, speaks of the "elevation of soul and courtesy which rendered Loredano illustrious even among his equals" (1465).

In the Morea the Venetian army suffered such losses that Sigismond Malatesta, whom Pope Pius had sent to command the Venetian forces in recognition of their moderation in consenting to stop the conflict with Trieste, was appalled at the smallness of his command; he openly expressed 
his regret at ever having come. He attacked the citadel of ancient Sparta without result, and then burned the town occupied by the very Christians he had come to succour. And soon afterwards he departed to defend his city of Rimini against the intrigues of Pope Paul II. In 1466 Vittore Capello, the new Venetian General, attacked Athens, which was still adorned by her ancient monuments and inhabited by a large and wealthy population. Galley-slaves were now employed in vessels of war, for ramming had taken the place of boarding in naval warfare. The galley-slaves were the scum of Venetian prisons, and these wretches, as well as the soldiery, looted the people they had come to deliver, and made an inglorious retreat with the booty. But there is this to be said in excuse of the ruthless treatment of Christians under Mohammedan rule-they were quite content with it, and were regarded as aiders and abettors of the Turk and faithless to the claims of their religion ; moreover, they belonged to the Greek form of Christianity. A raid was made on Patras, where many wealthy fugitives from the rest of Greece had gathered ; but while the soldiers were dispersed in plundering the various quarters, they were fallen on unexpectedly by 300 Turkish horse, and barely $\mathrm{I}, 000$ men succeeded in escaping. The Turkish commander was, perhaps, not wholly unjustified in making an example of those who thus raided Turkish subjects under the false pretence of coming to their rescue ; he impaled the corpse of the Venetian provveditore and the living body of the commander of cavalry, who fell into his hands. Nevertheless, Capello did not lose courage ; his troops had shown want of discipline, but the Turk had not shown superior valour. He renewed the attack, but had to retire after the loss of I,000 men; and Veniero, who succeeded him, did nothing but defend fortresses and hold his own during the sixteen months of his command.

The fate of Italy was now hanging in the balance. Once across the Adriatic or round the north of that gulf, and Italian cities would be ablaze, their citizens transported to far countries, and sold into slavery ; mothers would see their children torn from their arms to recruit the ranks of the janissaries and become the foes of their kindred and those who had given them being; even as Greece, Macedonia, and Illyria had been blotted out, so also would Italy cease to be. More warlike States than Italy-Epirus, Macedonia, Servia, Bosnia, and Sclavonia-the populations of which had depended on their own manhood for defence, and not on hirelings, had been wiped out by the conquering Turk, and the Turk was still rapidly advancing. And yet Italy remained supine ; no confederacy was formed, no army organized, no war-chest prepared to meet the common danger. Sforza reigned in Milan, bent solely on maintaining and consolidating his power ; Naples was in a ruinous condition, owing to the perfidy of its King and the conspiracy of its barons ; Florence was at the mercy of factions that had lost their ancient valour, and was led by men in whom the sentiment of duty was replaced by the belief that it is due to every man to make the most of life for himself; the chief anxiety of the Holy Father, Paul II., was to grab some paltry little States to which he had no just title, and add them to his ecclesiastical domain; Genoa was in a chronic state of anarchy, and every State was justly suspicious of every other, and was kept thereby in a condition of constant alarm and preparation. Even in the reign of Nicholas V., that clear-sighted statesman and alert thinker, Enea Piccolomini, afterwards Pope Pius II., wrote 
words of warning that fell unheeded. "Mohammed is among us," said he ; "the Turk waves his scimitar over our head; our ships are shut off from the Black Sea; the foe holds Wallachia, whence he will proceed to Hungary first and then Germany. Meanwhile we dwell together exhibiting mutual strife and hostility. The monarchs of France and England contend together; the Princes of Germany rush to arms to fight one another ; Spain rarely enjoys peace ; Italy is in a perpetual ferment by the ambition of rulers for the acquisition of alien lands: were it not desirable to turn these energies against the enemies of our faith ? It is your office, Holy Father, to bring the Kings and Princes into brotherly union, and inspire them to take counsel together for the safety of Christ's kingdom." Humanism, intolerance of the Greek Church, petty ambitions, and petty jealousies, barred the way. Venice stood alone against the common foe; she alone defended the interests of Christendom. Yet while, during her wars with Milan, she constantly equipped armies consisting of nearly 20,000 heavy cavalry and almost as many foot-soldiers, she now never had more than 2,000 men under arms in the Morea, although her Greek allies were almost valueless in the field. Two thousand men, then, and those only furnished by one State, constituted the barrier that Italy opposed to the momentum of Ottoman conquest. The question naturally arises why Venice conducted so weighty a struggle in a manner so unworthy of her ancient vigour. For she alone saw the danger; she alone was to bear the brunt of a life and death conflict with the common foe.

It must be remembered that Venice was never for others, but ever for herself; no country was ever more "patriotic." The energies of Mohammed II. were almost fully occupied in his great struggle with Scanderbeg; as yet the Turk had not become a sea-power, and Venice was mistress of the seas. Had she thrown her full force into the struggle in the Levant she might indeed have drawn the Turkish energies away from the path of conquest, but she would have concentrated them against herself; she was always much more ready to trade with the infidel than to fight him, and she hoped to come to some arrangement, believing her colonies fairly secure. The Venetian mind, moreover, was very practical, and preferred to take short views ; the Turk was pretty busily engaged in a great Continental war, and, while she could hold on to her own fairly well in the Levant, it would be unwise to attempt the crossing of dangerous rapids when a bridge might still be found to span them, or to precipitate a life-to-death struggle that could be postponed and might possibly be evaded; then, again, she had to keep tight hold of her possessions on the mainland, to keep Milan and her other foes in Italy in check; she was still feeling the effect of the late wars; a spirit of self-indulgence and the accursed dry rot of ease had begun to invade the inmost being of her nobility, and, lastly, her eastern colonies had a looser hold on her imagination and affections than the possessions so close to her on the mainland.

The Venetian looked down upon his Eastern subjects with the self-complacency and self-gratulation that might almost become a Briton. $\mathrm{He}$ regarded and treated the Greek as a false and corrupt creature, the Dalmatian as a barbarian, and his attitude towards these peoples was one of command, condescension, and toleration. He ruled, but he did not settle permanently among the people he ruled; he went among them to make his fortune, and, that aim accomplished, he returned home. Unlike the 
Briton, with this sole end in view, he became unscrupulous. The administration of justice was venal, malversation was common, defence was sacrificed to cupidity, peculation invaded the public service, no care was given to insure good and righteous government; to secure Venetian monopoly of commerce was the Venetian aim in being in the Levant at all. Fortresses were erected with the sole object of keeping the subject-population under; not as defences against external foes: no attention was bestowed on agriculture, and the local soldiery consisted, for the most part, of badlytrained and badly-armed natives. In fact, the East was exploited for the benefit of a few merchants. The possibilities of a rich soil and a fructifying climate were disregarded, and, consequently, the hardy and warlike population of Dalmatia resented oppression, and were perpetually in revolt, while the down-trodden peoples of the Levant cared not a jot whether they were under the heel of Venice or of the Turk. True, the Turk took the children and converted them into janissaries, but tribute-money was light, and collected by local officers, and in this respect they were better off under Turkish rule.

On the death of Pius II., Paul II., the new Pope, called a consistory together, and summoned the Ambassadors of the various States with the view of forming a league against the Mussulman; he asked for varying sums to be subscribed by the States of Italy for the prosecution of war. But the Ambassadors held no authority to treat of such a matter,and they were unsupported by the States they represented. The proposition fell stillborn. The sums required of the various States are of interest as giving us some idea of the relative wealth of the Italian peoples. The Pope was to pay 100,000 florins, Venice 100,000, Naples 80,000, Milan 70,000, Flurence 50,000, the Duke of Modena 20,000, Siena I5,000, the Marquis of Mantua I0,000, Lucca 8,000, the Marquis of Montferrat 5,000.

Scanderbeg was dead; he had entrusted the Republic with the guardianship of his children, but his State, the last buffer between Italy and the Turk, had disappeared. Matthew Corvinus had defended Hungary for ten years against the Crescent, but Paul II., who regarded heresy in Bohemia as more dangerous to Christianity than the advance of Mohammed II., encouraged civil war on the very borders of the new infidel Empire. Though Macedonia and Bosnia had been visited with fire and sword, Matthew Corvinus allowed himself to be seduced by the prospect of adding Bohemia to Hungary, and consumed his energies in a war against Christians. Mohammed was free to pursue his relentless course. A Turkish army invaded Croatia, where they put 8,000 Christians in a single town to the sword, and carried off 3,000 more as slaves. They drew near to the borders of Friuli and Trieste, but without undertaking the conquest of any strong place, and then departed laden with booty, and driving I 5,000 Christians, that they destined for the slave-markets of Constantinople, before them. They spared neither old men nor children, all the crops were burned, every beast that was not worth taking away was slain, and 18,000 dead bodies rotted on the fields. This army was detained eight days by a swollen river, and might easily have been annihilated, but Corvinus was too busy in seizing the Crown of Bohemia to think of the Turk, while the Venetians carefully abstained from advancing by land lest the Turk should discover how easy is the land-route to Italy. They threw their strength into their navy, and their commanders continued to 
behave in the same disgraceful manner as before. Niccola Canale, commanding a fleet of twenty-six galleys, seized Eno, a rich trading centre, inhabited solely by Greeks. The town was sacked, and even the nunneries, which had been held inviolate by the Mussulman, were given over to brutal soldiery; then Eno was burned, and 2,000 captives, including many wellto-do Greek ladies, were carried back to Negropont as slaves. The news of this sack of a city belonging to the Greek communion was brought to Rome at the same time as that of an advantage gained over the other heretics in Bohemia, and thanksgivings were offered up for the double event (Annal. Eccles. Raynaldi, I469). The result of this flouting of Mohammed and treatment of his Christian subjects was that the following vow was read out aloud in every mosque throughout the Empire: "I, Mohammed, son of Amaruth, Sultan and Governor of Baram and Rachmaël, raised by the Supreme God, placed in the circle of the sun, crowned with glory above all Emperors, blessed in every respect, feared of mortals, powerful in arms, by the prayers of the holy ones in heaven, and of Mohammed the great prophet Emperor of Emperors and Prince of all the Princes that are from the rising even to the setting sun-I promise to the only God, Creator of all, by my vow and oath, that I will neither sleep nor eat delicately, nor seek what is pleasant, nor touch what is beautiful; that I will not turn towards the East if I fail to overthrow and tread under my horse's feet the gods of the nations, those idols of wood and bronze and silver and gold and pigment which the followers of Christ have made with their hands. I swear I will cleanse the earth from their wicknedess to the glory of God of Sabaoth and of His great Prophet. And to this end know ye all, ye circumcized, all ye my subjects who are believers in Mohammed, your chiefs and helpers, if ye have the fear of God, the Author of heaven and earth, in your bosoms, and dread of mine own invincible power, gather ye yourselves around me, the seventh day of the moon of Ramadan, this year 874 of the Hegira, obeying the word of God and of Mohammed, of whom the first shall surely be our aid by His providence, the second by his prayers " (Card. Papiensis Epistola 380.-Raynaldi, 1470). And straightway the Mohammedan world betook itself to what was, to it, a new and untried method of fighting. The Turk equipped a huge fleet, and stood out from Constantinople. The Venetian supra-comito wrote that the Turkish fleet was comprised of 400 galleys, and extended six miles. "The sea had become a forest ; if this is incredible to the ear it is stupefaction to the sight" (vide Romanin, vol. iv., pp. 335, 336). Three hundred thousand men were reported to be advancing on Greece. Doubtless these accounts are grossly exaggerated, but it is certain that the schemes were so large that those of Venice were totally incapable of opposing them. The Turkish vessels were small, for the Turks were not yet such skilled navigators as to manage ships of large size, but thirty-five Venetian galleys were quite unequal to sustain a conflict with such numbers. Profiting by the darkness of night these hid behind an island while the Turks sailed by. Canale saw the fleet sail towards Negropont; he despatched three galleys laden with provisions to Chalcis, the capital of the island, which was likely to be besieged, but when, a few days afterwards, he sent two other galleys thither, the Turks had already fortified every strait. Up came the Sultan with an army that Sabellicus, the most moderate of contemporary historians, estimated at 200,000 men. Mohammed encamped on the shore opposite to Negropont, 
and constructed a great bridge which united the island with the mainland (1470). The siege was begun, and each gun of the Turkish artillery fired fifty-five cannon-shot a day, an unprecedented number for the period, and an evidence of how completely up-to-date the Turks then were.

The disheartening news was brought to the Senate. The war had already cost Venice nearly a million and a quarter ducats, and now their most important fortress in the Archipelago was menaced and in a parlous state. All available galleys were manned and armed, and sent out one by one, as soon as each was ready, with orders to Canale to defend Negropont at any cost. The Governor of Candia sent seven great galleys full of provisions to join the fleet. There was no time to lose. Thrice had the attempt been made to take Chalcis by assault, and although each had been repelled, the garrison, no less than the assailants, had suffered fearful loss. Aided by a favourable wind Canale, with a few ships, managed to break through the chains that closed the narrow strait, but fear, or some other cause, detained the greater part of the fleet, and Canale could not summon up courage to break down the bridge, for behind it lay the Turkish fleet in serried ranks, and it would be a hand-to-hand fight; there would be no room to manœuvre. The moment would have been opportune ; Mohammed was afraid of being cut off from the mainland, and was on the eve of sounding a retreat. In vain did Canale send message after message to his fleet to come up and help. Mohammed, seeing that no attempt was made to destroy the bridge, ordered a fourth assault to be made; the breaches were practicable, and though the besieged fought with great courage they were obliged to abandon the walls. Even then they fought on ; the streets were barricaded, and each barricade was defended to the bitter end. Mohammed gave orders that not a single male over twenty years of age was to be spared, and the corpses of the entire adult male population of Chalcis were first collected in the public places and then cast into the sea. The citadel still held out, but the commander surrendered on the understanding that his head should be saved. Mohammed had him sawn through the middle, with the remark that he had promised him his head and had not taken it away. The Venetian seamen who witnessed this terrible scene with impotent fury, turned their prows, and fled with all haste from the scene, and henceforth the Crescent replaced the Lion of St. Mark in Negropont.

The wrath of Venice against Canale was great; it was to wax greater still. Powerful reinforcements came up, and he found himself in the command of 100 Venetian galleys. And Venice built her galleys well, and on the same pattern; they were worked by the hardiest sailors on the Mediterranean; while the Turkish fleet, even if formidable in point of numbers, was a heterogeneous collection of merchantmen and transports, manned by a scratch lot of men wholly untrained in manœuvring and signalling and the arts of naval warfare. Canale was not merely incompetent and timorous himself, he was surrounded by incompetent and timorous officers, who decided at a council of war not to attack the Turk, when the Turk had already given himself up for lost. But at last he tried to effect a landing in Negropont; it was mismanaged, and failed. Then came sailing up Pietro Mocenigo, an Admiral sent by the Republic to replace Canale. Mocenigo offered to serve under Canale if he would attack. Canale refused, but said he was willing to serve under Moccnigo. 
Then Mocenigo produced his authority from the Senate, and sent him back to Venice in irons, whence he was committed to captivity, in spite of literary apologists who defended him in choicest latinity, and of the appeal of His Holiness himself.

Hitherto the narrowest strait had sufficed to present an insoluble problem in navigation to the Turk. He now appeared as a formidable sea-power. Alarm became general, for Venice could no longer plume herself, or be regarded by others, as mistress of the waters. All Italy agreed at last to form a defensive league (1470). A diet was also held at Ratisbon with a view to the union of all Christendom against the Turk. It was agreed to fit out a powerful armament, but only after the expenditure of valuable time in discussion, and then the armament remained a force on paper. Nor did the undertaking of the Italian States possess much more vitality; it had, however, the effect of forcing Mohammed II. to make an attempt to come to an understanding with Venice, but negotiations fell through.

Venice and the Pope left no stone unturned. They negotiated with Hassan Beg, the first monarch of the dynasty of the White Fleece in Persia, and induced him to declare war on Mohammed. His Ambassador bore defiance to Constantinople. Appearing before the Sultan, he emptied a sack of millet-seed, which he then swept aside to indicate that his master would similarly brush away the hosts of Mohammed. The Sultan retorted in like Oriental manner; he ordered some fowls to be brought in that soon made short work of the seed. "Tell your master," said he, "that as my fowls have eaten up his millet, so will my janissaries finish those Tartar shepherds whom he hopes to convert into soldiers" (Marin Sanuto Vite dei Duchi).

While Hassan Beg was attacking Georgia, Mocenigo, the Venetian General, carried on a savage and piratical raid on the coasts of Asia. $\mathrm{He}$ promised a ducat for every Mussulman head that should be brought him. He strengthened his army by employing the Stradiotes of Roumania, whom twenty years of guerilla warfare had converted into trained soldiery, and who formed the body of light cavalry that henceforward became an indispensable arm of the Venetian service. Mocenigo ravaged Caria and the isle of Cos, and then, reinforced by galleys furnished by Naples and the Pope, he devastated Pamphilia and Ionia and burned Smyrna (1472) without the Turkish fleet daring to leave home waters to attack him. The crusaders were by no means particular in distinguishing between Christian Church and Turkish mosque; all was good fish that fell into their net; a Christian head passed easily for a Mussulman's, and sold for a ducat; the women were first violated and then sold as slaves. When the year drew towards an end Mocenigo went into winter quarters, and the commander of the Pope's contingent returned to Rome, where he imitated the ancient triumph. Twenty-five Turks, specially spared for the occasion, preceded him on as many camels (Stefano Infessura, Diario Romano, p. II43.-Sabellico, Deca III., L. ix.-Raynald. Annal. Eccles., I472). While in winter quarters a young Sicilian, who had escaped from Constantinople, offered Mocenigo to set the Turkish fleet on fire if he would lend him a boat. He was granted a barque filled with fruit and manned by picked men of the fleet. When he got to Gallipoli he commenced to sell the fruit to the Turkish soldiers there, and was allowed to anchor near the fleet. He then succeeded in setting fire to several vessels, but his own 
ship was caught by the flames; he was taken, and sawn in twain. The grateful Senate pensioned the brother and dowered the sister of the dead hero.

Meanwhile the Pasha of Bosnia advanced rapidly through Carniola and Istria into Venetian territory, and carried fire and sword to within three miles of Udine, the capital of the Venetian province of Friuli. But although fear made every Venetian heart beat quicker, this was a mere piratical raid, and the troops of the Pasha returned home when they found themselves overburdened with booty and slaves whom they drove before them in herds.

The Venetians were now thoroughly alarmed; they were but feebly supported by Italian, and not at all by the other European Powers. They made desperate efforts to urge Hassan Beg to renew his efforts. Hassan Beg had a Christian wife, to whom he was much attached, and her sister had married a Duke of the Iggean Sea, whose five daughters had all become the wives of Venetian nobles. An Ambassador was sent to the Persian Court. He passed by way of Asia Minor, accompanied by an Ambassador whom Hassan had sent to Venice, and who was now returning. We have an account of the journey of this Embassy from the hand of Barbaro, the Venetian Ambassador, himself. He was already an old man. Finding it impossible to get through Asia Minor with a big caravan, he left the presents which the Republic were sending to Hassan behind him. The little band was attacked by Kurds, and the Persian, a secretary, and two men were killed. Robbed and grievously wounded, the gallant old man still struggled on, and eventually found Hassan at Tauris. $\mathrm{He}$ remained with that monarch five years, and returned to Venice by a caravan route through Aleppo.

Lest one Embassy should fail to reach Hassan Beg the Senate despatched two others by quite different routes. Of one of these we have no account, except that it travelled viâ Trebizond ; of the other, Contarini, the Ambassador, has left a record. He left Venice in February, 1473, arrived at Frankfort on the Oder in March, traversed Poland, and reached Caffa, on the Black Sea littoral, in May. Thence he sailed to Colchis, and after many adventures, and suffering much from the petty rulers and evildisposed peoples of Georgia, he passed through Armenia, and arrived at Ispahan in November, only to find that Hassan had already suffered defeat, and that his power was by no means so great as to be of much service to the Republic. On his return journey, which he began in 1474 , he found the roads watched, and had to make a détour. He passed the winter with poor fishermen on the Caspian, and came to Astrachan, then in possession of the Tartars; thence he proceeded to Moscow, and reached Venice in the spring of 1476. Both of these Ambassadors made journeys as dangerous and adventurous as any that have ever been undertaken.

Hassan Beg advanced into Armenia, but was badly beaten by Mohammed, who possessed the most modern type of artillery, while the Persians were little accustomed to firearms. Mocenigo was too late to co-operate with the Persian army, but he continued to spread terror through Asia Minor. Throughout the campaign of 1473 he had acted alone, but now a papal legate offered to join him with ten galleys " if he wished to do something for Christianity." Mocenigo regarded this message as an insult, and refused the aid so ungraciously offered. Moreover, affairs in Cyprus 
required his attention, and his presence there was most important to the Republic. The Papacy was never on very good terms with Venice; the Republic was too independent in matters ecclesiastical to suit the views of the Curia, and the support given by the Papacy with such warmth in 1472 became a mere show of assistance the following year, and by 1474 no trace of it was to be found. The Duke of Milan continued to pay his quota with punctuality, but, on the whole, on Venice, and on Venicc alone, fell the expense, the sacrifice, the loss, the anxiety of the war. She received no sympathetic encouragement in her endurance, no recognition of her sacrifices and valour, no sign that there was any sense of obligation for the security her protection had afforded. The Pope appeared particularly thankless; he ceased to furnish his subscription, and Venice withdrew her Ambassador from Rome.

We have said that Mocenigo's presence was required at Cyprus. That island, the third largest in the Mediterranean, had once been rich and fertile, producing wine, oil, and corn in abundance, and the copper to which it gave its name. It was the generous gift of Richard Ceur-deLion to the House of Lusignan (I 191), but under their bad government its population and prosperity had decreased. The last of the line left a legitimate daughter and bastard son; the latter disputed his sister's succession to the throne. Both Genoa and Venice had settlements on the island, and the fact that Genoa supported the claims of the daughter sufficed to induce Venice to favour the son. Marco Cornaro, a Venetian resident in the island, poured forth his own wealth and that of his countryman to provide the bastard with sinews of war, established him on the throne, and gave him his own beautiful daughter in marriage. The new King died soon afterwards, and rebellion followed, owing to hatred of Venetian predominance; Mocenigo was called in to restore order, and the posthumous daughter of the late King, Catherine Cornaro, was presented at the font by the Venetian provveditori and Mocenigo as sponsors. All opposition was severely suppressed by Mocenigo, and, in fact, if not in name, Venice became the ruler of the island (I473). She was thus, in no small measure, compensated for the loss of Negropont.

But Ferrante, King of Nalpes, had his eye on the island. He arranged with certain Cypriotes who objected to Venetian rule to marry a natural son of his to a natural daughter of the late King. And since Genoa had held certain places in the island, and was under the protection of the Duke of Milan, Venice dreaded that she would be assailed by Milan on the mainland and by Genoa in Cyprus, while she still had the dire struggle with the Turk on hand. With consummate adroitness she seized an opportunity of effecting an understanding with Milan, and so secured peace on the mainland. Naples was in close alliance with the Papacy; the Papacy had created its feudatory, Frederico of Monte Feltro, Duke of Urbino, and was rapidly becoming master of Central Italy, so menacing Florence directly and Milan indirectly, by destroying the balance of power. The Venetian Ambassadors, with their usual skill, succeeded in forming a close alliance between Florence, Milan, and Venice to oppose the ambition of Naples and Rome. The Duke of Ferrara then joined the alliance, and the Pope and the King of Naples were invited to unite themselves with this league to secure the tranquillity of Italy. They contented themselves with a general assurance that they had no desire to vex the 
waters, but they refused to sign any treaty; they found themselves held in check, however, and the chagrin of the Pope, fanned by the fact that he did not possess that fulness of ecclesiastical authority in Venice which he exercised elsewhere, envenomed him against the Republic, and had much to do with the withdrawal of his support from her enterprise against the Turk.

Meanwhile, the Turks besieged Scutari; but, after both sides had suffered incredible privations and visitations of disease, the Turkish army was compelled to withdraw. The Venetian Senate hung up the banner of the town in St. Mark's as a memorial of the fidelity and courageous resistance of its inhabitants (I474). Venice took advantage of this success to make anotner attempt to come to an understanding with the Sultan, but his terms were impossible of acceptance, and, next year, the Turk appeared before Lepanto, a Venctian fortress which guarded the entrance to the Venetian Gulf. He met with no success, for a Venetian fleet rode those waters; and an attempt on Lemnos was also foiled by the vigilance of Loredano, the Venetian Admiral. By this time both sides were getting exhausted, and a six months' truce was arranged, of which advantage was taken by Venice to tighten her hold on Cyprus. The Ten secured the bastard sons of the late King and their mother, and had them transported to Venice.

The Venetians, warned by the previous invasions of Friuli by the Pasha of Bosnia, entrenched the Isonso from near its mouth to Gorizia, and stationed an army there. But suddenly, in the autumn of 1477 , before any news of any movement of troops in Bosnia reached them, the Venetians found themselves confronted by the Turk. The enemy succeeded in crossing the river, and vanquished the defending force, pursuing it in its headlong flight with their wonted fury. The slaughter was terrible, but many were spared and taken prisoners. The Turk swept on, and set fire to every farm-house, barn, poor cottage, and the country mansions of the Venetian nobility that they came across. Sabellico, the historian, who was then dwelling in a fortified place near Udine, says that he stood on a turret by night watching the terrible progress of these fires, and it seemed to him as if the whole plain were a lake of flame (M. A. Sabellico, D. III., L. x.). There was terrible excitement in Venice and the country round, and the Republic rested not night or day in its strenuous efforts to meet the coming evil; but, when the Turks reached the Piave, they wheeled round and departed home again. Meanwhile, the struggle in the East had gone ill for Venice. The Turks attacked Croia, and were driven back into the mountains; but while the victors were looting the deserted camp, the Mussulman army re-formed, swept down on them, and slew vast numbers, including the Venetian in command (1477). Croia was now running short of provisions; it was closely invested, and it was evident that its fall would be only a matter of time.

The position of Venice was now becoming serious. Matters in the East had taken a very grave aspect; North Italy had been devastated by the invading horde; and, in spite of heavy reinforcements of cavalry and militia, it was doubtful how far the ruined provinces would be capable of resisting future attack. In a few years the Crescent might be established in the very heart of Lombardy : the other States still gave no assistance to the Republic; the intrigues and ambition of the Pope and his nephew 
were a perpetual source of disquiet; and the resources of the State were severely strained. The Ten sent to Constantinople, offering to surrender Croia, the isle of Stalimena, the "Arm of Mano" in the Morea, and all the places acquired during the war, and to pay roo,ooo ducats. Mohammed was willing to accept these terms, on condition that Venice added an annual tribute of 6,000 ducats. 'The Ambassador asked for two months' grace to get a reply from his Government. Meanwhile, the Kings of Hungary and Naples entered into separate negotiations with the Sultan, and recognised all his conquests. Hassan Beg was dead, and Persia in disorder; no help was to be expected from the East; and Croia was reduced to the last extremity. Venice was compelled to bow her haughty neck and accept the terms ; whereupon Mohammed changed his tone ; the conditions had become altered, he said; now, no human power could save Croia ; but he would accept Scutari. Malpieri, the Venetian Ambassador, refused, and left Constantinople.

The starved defenders of Croia were now reduced to ask for terms; they were nearly all veterans who had served in Scanderbeg's army, but they were assured that they would be allowed to withdraw and go their way in peace if they surrendered. They obtained a written promise to this effect in the Sultan's own hand, and departed, carrying their goods with them ; but scarcely had they left the city, when Mohammedan troops seized them, put them in chains, and conveyed them to the Sultan. Mohammed saved those who were likely to be ransomed, and ordered the massacre of the rest. The garrison had been companions in arms of the gallant Scanderbeg: thus perished the last remnant of that courageous little band of warriors that had so long held the Turk at bay in Epirus ( 1478 ).

Mohammed now besieged Scutari, which made heroic defence. The Turkish artillery soon effected a breach in the walls, and made a fierce attempt to enter the town. The gallant janissaries came up body after body, but were met, first with such a shower of stones, shot, and arrows, and then by sưch hand-thrusts of sword and spear, that they were slaughtered to a man. Mohammed, furious at this check, kept on forming company after company to carry the breach : company after company failed : the struggle, begun at daybreak, was carried on right through the day and night, and until noon of the following day. Then the attempt was abandoned as hopeless, for one-third of the intrepid Turkish troops lay dead in and around the breach. Mohammed now gave up hope of carrying the city by assault, and sat down to starve it into surrender, while some of his troops attacked neighbouring fortresses, and sent word to the Pasha of Bosnia to march his troops into Venetia. The Pasha's forces met with Fabian tactics that obliged them to retire towards the frontiers of Germany, which they employed themselves in raiding.

Misfortune after misfortune visited the unhappy Republic: she was conducting war against the Turk in the East, and at the same time the Turk was threatening her close at home : the ex-Queen of Cyprus, who had been dethroned by the last bastard King, aided by Ferrante of Naples, was appealing to the Soldan of Egypt, lord paramount of Cyprus, and he appeared likely to take her part against Catherine Cornaro, the Venetian protegee; the Pope and Ferdinand were intriguing still, and Tus any, the ally of Venice, was suffering invasion at the hands of the Pøpe. Venice 
was more than half ruined by many years of war; she was left to fight the battle against the Crescent alone, by those whom the Crescent menaced no less than herself; and that perpetually recurring curse of Italy-the Plague-was sweeping away her population, so that she was unable to go on with her armaments or even to assemble her councils. "Troubles came not single spies, but whole battalions "; word was brought from Scutari that eight of her best commanders had been killed, and that provisions would last for but four months longer. At first the Senate, which, owing to the Plague having dispersed or slain or seized its members, had been got together with difficulty, resolved to fight on to the bitter end, though the revenues of the Republic were reduced to Ioo, ,oo ducats only; it was even determined to subsidize the Albanians to rise against the Turk; but, at subsequent meetings, the approaching exhaustion of resources became manifest; fears were entertained of losing Cyprus, which was likely to be invaded by its suzerain, the Soldan of Egypt, or captured by the ex-Queen and her allies; it was questionable how far Friuli could be held against another invasion; and the Florentines sent begging Venice to terminate the Eastern war, and pointing out that so far from their Republic and the Duke of Milan being able to assist Venice, they required Venetian help against Ferrante of Naples, who was on good terms with the Turk; the Pope maintained a threatening attitude, and Genoa was overtly hostile to the Lion of St. Mark. The Senate came to the conclusion that peace must be made if the Republic was to be saved, and that, since Mohammed had suffered so serious a check at Scutari, now was the favourable moment to secure it (Andr. Navagiero, Stor. Venez.).

If Venice was near exhaustion, her opponent was not in much better condition, and was equally glad to come to terms. A treaty was signed with the Grand Turk, whereby Scutari, the key to Montenegro, was to be surrendered, but all conquests made during the war by either party were to be restored; further, Venice was to pay I0,000 ducats, which the Turk regarded as tribute money, and the Venetian as payment for the right of free trade with the whole Turkish Empire. The astuteness of Venetian diplomacy appeared in a stipulation whereby any State not engaged in actual warfare with the Sultan would be immune from attack if it hoisted the Lion of St. Mark. Venice intended, then, to make capital out of the very terror inspired by the Turkish arms.

The peace thus concluded relieved Italy from the awful danger of Turkish invasion; but it was received with anything but satisfaction. Venice would now be free to make her force felt in Italian politics. Naples and Genoa had exhibited unfriendliness, and dreaded retaliation. The Pope, who had withdrawn from a war that he had designated " sacred," accused the Republic of being a traitor to Christianity: he published a Bull to the European Powers, in which he declared that, " not content with desertion, the Venetians have rendered themselves still more culpable; they have not been ashamed to aver in our presence and that of our brothers the cardinals, the Ambassadors of the Emperor, the King, and the Duke of Milan, and before a Christian assembly, that they intend to keep to their pact with the miscreants, and are resolved to commit no offence against them " (Bulla Sixti IV., I6 Kal., Sept., 1479). The Pope's aim was to draw Venice into fresh conflicts, and to deprive Florence of her support. And besides Ferrante, Genoa, and the Pope, there were 
other Powers-Milan, Ferrara, Mantua, and the little tyrants of Romagna - that, although they were allies of Venice, were secretly chagrined at the liberation of power which the cessation of war brought to their neighbour. Venice had come to an honourable arrangement with her Eastern foe, only to rouse a hornet's nest about her on the Italian mainland : she was accused of time-serving and narrow-minded self-interest by the most eminent exponents of the qualities they hypocritically condemned.

The main requisite of the Republic was repose. The taking of Constantinople meant a dead loss to her of property valued at 300,000 ducats ; and during the warlike reign of Foscari, many merchants had failed for about one-third of a million ducats each. Perpetual warfare had caused great depression in trade, and her conquests on the mainland added little real wealth to the State. She had bought military glory at its usual price - the impoverishment of the commonwealth.

Mohammed in his old age was as restless as ever. He laid claim to the ancient possessions of the Roman Empire of the East in Italy; and the unsettled state of that country, owing to the ambitions of the Pope and the King of Naples, gave him a favourable opportunity to effect a landing. For the Pope was desirous of drawing Venice into war, in order that she might be still further enfeebled and Florence deprived of her support. For the same reason he took advantage of a petty dispute on the frontier, and incited the Swiss to take arms against the Duke of Milan, the close ally of Florence. The Pope was determined to ruin Florence and extend Papal power and endow his nephews at her expense; and, since she resisted, all Italy was at war. Ferrante, King of Naples, had designs on Tuscany; and Venice and Florence had been united in policy against both Pope and King ; but Lorenzo dei Medici, the real ruler of Florence, had recently come to an arrangement with Ferrante, and Venice found herself isolated. Sismondi speaks of the Venetians having betrayed Italy by sending a secret Embassy to Mohammed, urging him to attack Ferrante, and Pope Sixtus is accused of having also had an understanding with the Turk. It is even hinted that the Venetian fleet accompanied the Turk as a blind to his intentions. The historians of Venice do not hesitate to attribute this diabolical policy to their country. But examination of the secret archives of the Senate shows that the incredible libel is, indeed, entirely without foundation. Romanin, the great Venetian historian of our times, has investigated these documents, and quotes them; he says : "When Mohammed made peace with Venice he found quiet insufferable, his ambition remained insatiate, and he longed for new conquests. His fleet, commanded by Keduk Ahmed, soon ejected Count Leonardo from Santa Maura and Zante, and then sailed to the siege of Rodi, while a division swerved into the Adriatic to take Otranto, and committed the most dire atrocities there. Several historians tax the Venetians with having been the instigators of this movement, to pay Ferrante out; but the following information, gleaned from the secret papers of the Senate, will free them from that charge ; we see, indeed, from beginning to end, how perturbed the Republic was at movements of which she could not foresee the issue. On August 23, I479, came an envoy of Ahmed, offering his support to Venice against her enemies. Her reply was that, while grateful to His Magnificence for his kindly offer, she had only taken part in the Tuscan disturbance to protect her trading settlers, and her merchants 
still carried on their business in Tuscany as freely as before, and that as to the proposal to take the offensive against King Ferdinand (Ferrante), the Republic had already fully informed her Ambassador, Giovanni Dario, at Constantinople on this point; nor had she anything to add except her sincere and fixed resolve to continue to live in an assured peace with the Sultan. But, having gleaned from this same Ambassador that the Turk harboured bad designs against the King of Naples, and had goodwill towards the Republic only, the Captain-General, Vettor Siranzo, was ordered that, if the Turkish fleet should attack the kingdom of Naples, he should withdraw to Corfu and attend wholly to the protection of that island, acting so as to run not the least danger of coming into collision with the Turk. Afterwards the Sultan was written to direct, and also Ahmed, to the effect that it was entirely contrary to the mind. of the Republic to excite the Pasha to any enterprise against Naples, or to desire any one to suffer offence or injury; and, though the Ambassador of Ahmed came to Venice concerning certain disorders in Italy, they were not of such a nature as to directly concern the Republic. To Niccola Cocco, Ambassador at Constantinople, a message was sent to try to turn the Sultan from his project.

"So little truth is there in the statement that there was an understanding between Venetian and Turk that the former were in a growing state of doubt and dread, and on June I 3 the Government wrote, urging Cristofero Duodo, the provveditore, to look well to the defences of Corfu, and on July 2 they sent a despatch to Vettor Siranzo to the effect that advices informed them that one Turkish fleet was sailing for Rodi, and another seemed to be turning towards the gulf; therefore, it behoved him to keep his eyes open, for Ragusa might be menaced, and he should therefore betake himself to Cattaro with all speed. If afterwards the Turk was found to be bound for Apulia the responsibility must be his whether he should remain in the gulf or sail to Corfu. . . .

"The Republic, scarcely emerged from a sixteen years' war against the Turk, was most anxious to preserve peace, and when Jacopo Veniero, provveditore of the fleet, wanted to know what attitude to take, replied that he should bear himself in a friendly manner, but follow the Turkish ships considerably in the wake. Should he be asked for provisions they should be given for due payment, but if pilots were demanded he must find some excuse to refuse. And so far was the King of Naples from suspecting Venice of so black a crime that he approached the Senate in terms expressive of full confidence to seek aid for the liberation of Otranto, whereto reply was made that they must beg to be excused, since they had concluded peace with the Turk, and they found themselves just then in a condition which required its preservation" (Romanin, Storia Documentata di Venezia, iv., p. 394). The watchful company of the Venetian fleet was entirely misjudged by historians of a slightly later period, even those of the Republic, and the calumny has been repeated by still later writers, to the damage of the reputation of the Republic. 


\section{The War of Ferrara}

No sooner was the war in the East brought to an end than Venice found herself involved in questions concerning the monopoly of salt and custom dues on the mouths of the Po (1482). The Duke of Milan, finding that the Venetians were gaining an advantage, tried to secure terms, but these were rejected, and next year the Pope, Sixtus IV., who claimed the overlordship of Ferrara, ordered the Venetians to abstain from attack. On their refusal he launched an interdict against the Republic, the reply to which was an appeal to the next general council, and this appeal was nailed to the door of one of the churches of Rome. But the State had sufficient drain on its resources in administering its territory ; the treasury was exhausted, the public debt was great, the wealthy merchants had even sold their plate for the State, and women carried their gold ornaments to the mint. Public enthusiasm was never greater, and public rejoicing was justified when, in 1484 , peace was proclaimed, Venice gaining Rovigo and Polesina. In this war floating batteries were used for the first time.

\section{GENOA}

A GREAT blow fell on all Christendom, a blow that was felt by Genoa most of all. Constantinople was taken by the Turk, and, before long, Pera, the great Genoese colony that almost rivalled Constantinople in wealth and magnificence (1453). Dreading to lose Caffa or Theodosia, her colonies on the Black Sea, Genoa transferred them to the Bank of St. George, for the directors of the bank were shrewd merchants, who kept a steady eye on the " main chance," and steered straight to their commercial advantage unmoved by the vexing of the waters around ; they alone kept level heads when insensate faction was swirling without and within the Senate-house. Corsica was also transferred to the great bank, for Alfonzo had seized one of its ports, and was threatening the rest of the island. Alfonzo regarded the re-establishment of the Fregosi as an act of rebellion, and, in all probability, the golden bowl, emblem of dependance, had not been sent. In vain did the Pope and the Doge urge the importance of Christian unity, and of opposing a solid front to the advancing Turk; the war went on, and the Doge put forth no fleet, for he dreaded the enemy within the gates more than the enemy without: Fregoso, indeed, had good cause to abstain from foreign enterprise. $\mathrm{He}$ vanquished the disaffected by a ruse. Pretending that he had gone for a country journey he hid with a number of troops in the palace, and soon what he had expected to occur took place. The malcontents siezed advantage of his supposed absence to rise and attack the Public Palace. At the-right moment Fregoso made his unexpected sortie, took the assailants in the rear, and sent them running for life. Many were slain, many captured, and so me executed (1455).

The Catalan vessels did great damage along the coast, and the Bank of St. George was getting exhausted through its unceasing efforts to help the colonies against the Turk. In vain did Genoa appeal to Sforza, the 
ruler of Milan, to Florence, to Venice, for aid against Alfonzo : all these powers had signed a treaty with that monarch. Pope Calixtus III. made fruitless efforts to reconcile warring Christendom, and especially to put an end to this quarrel between the Spanish King of Southern Italy and Genoa. Direct negotiations between the two Powers were a dismal failure. The erudite classicists of Alfonzo's Court replied in State documents which illustrate the scurrilous invective that the overburdened brain of the mediæval scholar found so refreshing and delightful. "You are the real Turks in Europe," says a letter of July 23, 1456 ; "we will deal with you first of all, and we will not cease until by Christ's help we have you crawling to our feet for grace. Then only shall we undertake, and that in spite of you, the expedition against the Turks in Asia to which we are committed." The letter further accuses the Genoese, not wholly unjustly, of having been the first to bring the Osmanli across the Straits (Bonincontri, R.S.I., L. xxi., p. I 59). Fregoso besought the Kings of England and Portugal for help (Raynaldus. Ann. Eccles., $\S 5$ et 9, pp. 454, 455); he was surrounded by personal enemies envenomed by the long war and the great drain on resources that the protection of Genoese colonies had caused the Republic. He made earnest appeal to the King of France and his relative, René of Anjou. He besought the latter to renew his claim and attempt on the Neapolitan Crown. In I458 Fregoso succeeded in getting Charles VII. of France to accept the lordship of Genoa, the Republic retaining all the rights and liberties of a free city; and John of Anjou, Duke of Calabria, the son of René, who had been in command of the Florentine troops, assumed the governorship of Genoa in the place of the Doge. The only result was that Alfonzo redoubled his efforts to subdue the city ; its harbour was invested by the Catalan fleet while the Adorni, the Fieschi, and the Spinola, who were in exile, attacked it on the land side. John of Anjou closed the harbour with strong chains and floating bulwarks, and filled the fortresses with French and Genoese soldiers, and awaited attack. But news came that Alfonzo was dead, and immediately the blockading fleet dispersed, some sail making for Spain, others for the south, while the troops of the exiles retired over the mountains (I458).

The Duke of Milan was by no means happy at seeing the French again making an attempt to rule in the South. He foresaw the danger of having the French on both sides of him, and he stopped Cosimo dei Medici and the Florentines from espousing their cause. He also took advantage of the discontent of the very man who had called them in, and he invited the Doge and the Fieschi to collect an army within his own territory for an advance on Genoa. The Genoese remained within their walls, but stoutly defended their new Governor, with whom they seem to have been well content. Gian Antonio, the head of the Fieschi, advanced too near the walls, and was killed by a culverin, and so little was the discipline, so completely self-seeking were these undisciplined barons, that each retired to his castle to secure it against the attacks of his own relations. The first campaign failed, therefore, and Piero Fregoso had to retire (I459).

The Duke had address to win the affections of the city he governed. He left its institutions untouched, and placed every question before the Senate and the people. The result was that the citizens took up the French claim on Naples with ardour, while Anjou's opponent, Ferrante, the 
bastard son of Alfonzo, sent money to Fregoso to gather another army. Soon the united fleets of Provence and Genoa set sail for the South, and Fregoso resolved to take advantage of the absence of so many men to make an attempt on the city. He contrived to pass through an unguarded gate with a small following, and felt sure of surprising the city, but he was met with a shower of stones as he rode along the narrow streets, and was battered to death. The army outside, demoralized by his disappearance, was overwhelmed, and many were taken prisoners. A Fregoso and a Fieschi were executed as rebels; but the soldiers were set free on taking oath that they would fight no longer against the House of Anjou.

The possession of Genoa was of prime importance to the House of Anjou in their attempt to secure the Neapolitan Crown. The ports of Liguria gave them safe harbourage, and the galleys of the Republic were not merely invaluable in actual combat but of still greater service as transports for their troops. Care was taken not to offend the delicate sensibilities of the Republic, but war and plague combined to impoverish the public revenues, and the absence of exiles and of citizens engaged in warfare diminished the financial resources of the State. Contributions forced from the wealthier citizens caused considerable discontent. The nobles proposed further taxation of the community; the plebeians desired the abolition of certain exemptions enjoyed by the nobility. This contest between privilege and the people revived ancient quarrels, the French Governor inclined to the nobility, and the followers of the Adorni and Fregosi, the men of the people, revived, though the heads of these families were in exile. At this juncture the King of France was illadvised enough to request the Genoese to fit out an expedition against the English. Now Genoa had a considerable trade with London; Genoese merchants were established there, and the Genoese were not at all willing to sacrifice them nor their English trade. Every day some fresh proposition was made in the councils, and every proposition was followed by the usual interminable discussion of such bodies. But one day, amidst heated discussion, a member, whose name remains unrecorded, shouted that it was by arms and not by words that the people should maintain their rights; he rushed out of the council chamber in a rage, and ran through the streets calling on the people to arm.

At first few citizens responded, and the authorities tried to disperse the little crowd by haranguing and cajoling them ; but, bit by bit, the mob increased; by night-time the whole city was under arms, and the French Governor had to retire to the fortress, leaving word with the ministry to continue to expostulate, for gentle measures seemed likely to succeed. But, meanwhile, Paolo Fregoso, Archbishop of Genoa, came into the city with a following of peasants devoted to his family, and at another gateway Prospero Adorno appeared with a similar following. The town was in the hands of the populace, and free street-fights began, while the French were still in occupation of the castle. The Adorni soon began to fraternize with the French ; they were won over to this by the nobles, and it seemed likely that the Archbishop would be ejected from the city. But secret agents of the Duke of Milan and Fregoso were at work exhorting the populace not to be led away by the nobles, but to seize the opportunity to drive the foreigner out, and reconstitute the Republic. The fickle mob turned at once to the siege of the fortress, while the Archbishop 
took advantage of this diversion of popular attention from him and his followers to negotiate with Prospero Adorno. He pointed out that their interests were identical in so far as they were both opposed to the nobility and the foreigner, and that they might very well combine the two families to share the headship of the State between them, turn and turn about. If Prospero agreed he would at once help to place him on the ducal throne and content himself with the archbishopric. This negotiation appears to have taken place outside the city, where eight Captains of the People had been elected to carry on government by a popular assembly. Directly it was agreed to both men were readmitted, and Prospero Adorno was elected Doge with a unanimity rarely seen in Genoa (Cronica di Bologna, R.I.S., L. xviii., p. 736.-Uberti Foliete, L. xi.-P. Bizarro, L. xiii.Ag. Giustiniani, L. v.).

The siege of the fortress went on but slowly, for artillery was wanting, so recourse was had to Milan. This was playing into Sforza's hands in a twofold way; helping Genoa was in the direct line of his policy against France; it also gave him a hold of the city that he coveted; and, as he was on very good terms with the Dauphin, afterwards Louis XI., and Louis was on very bad terms with his father, he did not mind incurring the ire of the French monarch. But he had to manipulate Fregoso, for the old envenomed rancour between Adorni and Fregosi was again manifesting itself. Charles VII. proved to be a more formidable foe than Sforza had thought to reckon with. He and the old King René fitted out a very strong expedition. René landed at Savona, which had remained faithful to France, at the head of 6,000 men, nearly all of good birth and armed with helmet and breastplate, but serving on foot, as was wise in so mountainous a country; they were joined by nearly all the aristocracy of Genoa, and Sforza therefore hastened to reconcile the Archbishop and Adorno. Prospero, with the flower of the Genoese youth, undertook to hold the mountains, Adorno to defend the city; both were in want of money, and they seized thirty of the richest merchants to exact contributions. The thirty replied as one man that they would die rather than pay the smallest coin exacted in such a manner, and so establish a disgraceful precedent and example (Joann. Simonete, L. xxviii.-Uberti Folietce, L. xi.-P. Bizarro, L. xiii.-Ag. Giustiniani, L. v.). The French fleet anchored without meeting with any resistance, and the city, now thoroughly frightened, could casily have been taken by assault. But the Genoese exiles were unwilling to expose their native place to the horrors of such a capture, and beseeched the King to trust to their powers of persuasion ; René, who liked the Genoese, and owed them some gratitude, readily acceded, and so the favourable moment was lost. During the next three days the Genoese had time to take heart: they occupied the heights in force. A battle ensued, which was the bloodiest contest of the century - at least, on Italian soil. Two thousand men were found dead on the field; for, when the French gave way, the weight of their armour prevented them from escaping. The victory of the Genoese was signal, and it would appear that, although many might have been saved by the fleet, which was close to the shore, René, who commanded it, refused to aid the fugitives, saying that gentlemen who fled deserved neither compassion nor help.

Directly the victory was assured, Adorno closed the gates on the Arch- 
bishop; but the latter and his followers seized boats and rowed into the city by way of the harbour. Once inside the town, they firmly refused to go out. There was but little parleying; blood was up on both sides ; the spirit of battle was still upon them ; and the victorious army achieved a second success, this time on their own countrymen within the walls of the city. Adorno and his party were driven out of the gates, and Fregoso, who appears to have had some lingering scruple as to the union of the two functions of Archbishop and Doge, got his cousin elected to the latter dignity. The troops of Rene were no longer able to hold the fortress, and René delivered it up to Lodovico Fregoso, who had been Doge from 1448 to I45O. This was a dodge of the King's to sow dissensions in the archiepiscopal family. But the Archbishop was quite equal to the occasion; he came to terms with Lodovico, deposed the Doge, and nominated Lodovico in his place (146I). The death of the King of France now deprived René of the support on which he most counted; but the Dauphin, Louis XI., who succeeded, let Sforza understand that, as King of France, he would not forget the very hostilities against a French House which he had encouraged as Dauphin : a new potentate of the Italian, crafty, trickster species had ascended the French throne. Italy had taught the lesson in the new diplomacy, and was before long to reap the fruit. The defection of Genoa was a heavy blow to the Angevin party in Naples : it deprived them of annual subsidies, of a formidable fleet, and of the co-operation of the army, which was so badly beaten at Genoa that it was not in a condition to proceed to the South. The French still held Savona; but when, three years later, the Prince of Anjou gave up his pretensions to Naples, Louis XI., in spite of his threats, found work to do elsewhere, and that it was convenient to cede all his rights over both Savona and Genoa to Francesco Sforza, the ruler of Milan.

Meanwhile things had been going ill at Genoa. Lodovico Fregoso, the Doge, was a just and amiable man, quite unfitted to rule over the turbulent city. He was interfered with by his cousin, the Archbishop, who gathered up, as it were, into his own person all the violence of character, the ambition, and the masterful self-reliance of his race. He surrounded himself with all the factious spirits that had been bred and nurtured in the civil wars, all the pardoned brigands that had fought, bravely enough, in the late war, but that were now starving because there was no fighting going on ; they could not rob as they would, and were incapable of honest work. The Archbishop never ceased to remind this precious crew that it was he who had achieved the triple victory of routing the French, the nobles, and the Adorni ; that they had shared his danger and shed their blood at his side for an ungrateful country, which condemned him to milksop ecclesiastical functions and them to oblivion and privation; had they possessed a little more pluck they would have fought, not for others, but themselves, and Fortune would have smiled on those whose bravery had deserved her favours. Having thus fanned the flames of cupidity and resentment in the breasts of this worthy following, he led them stealthily to the Public Palace, surprised it, dethroned his cousin, and installed himself as Doge in his place (May I4, I462). But, to his astonishment, Fregoso found himself confronted with an antagonistic city : every honest man and good Catholic was disgusted at this outrage on the laws by a Bishop of the Church, and though unworldliness has 
never been a marked characteristic of prelates, and was at this particular period their distinction even less than ordinarily, public sentiment drew the line at such an unblushing violation of the theoretically Christian spirit. Fregoso found it convenient to resign a month after his usurpation. Eight Captains of the People assumed the reigns of government, and a few days after Lodovico Fregoso was recalled and received the ducal cap for the third time.

But Paolo Fregoso was not the man to be balked by merely passive resistance. Before long he had secured the support of other interests in the State ; and, accompanied by a band of ruffians, he seized his cousin, the Doge, and hauled him in front of the fortress; there he erected a gallows, and threatened to hang their Prince with the garrison as spectators, if the doors of the citadel were not thrown open. The garrison gave way, and Fregoso was able to secure Bulls from Pope Pius II., wherein, after certain exhortations, he is recognised as Doge, released from his oaths, and permitted to conjoin worldly and spiritual functions (1463) (Raynald. Annal Eccles., I462, § 51.-Uberti Folieta, L. xi., p. 621.-Comment. Pii Pape II.-P. Bizarro, Hist. Genuens., L. xiii.-Ag. Giustin. Ann., L. v.).

Fregoso gave the command of his rascally followers to one of the Fieschi, and abandoned himself to the gratification of his cupidity and of other passions quite unbecoming a Doge, and still less an Archbishop. His myrmidons thought nothing of entering the houses of the richest merchants and carrying off whatever took their fancy, even the women. Every day saw some resisting citizen slain or someone fall the victim of ancient vendetta. It was as if the town had been taken by assault and given over to plunder, and worse; and this condition of things lasted for some months. Everybody escaped from the town who could do so. Every place in Genoese territory along both the Rivieras repudiated the authority of the Archbishop; while Sforza gained over nobles and influential plebeians alike, and even seduced the truculent Fieschi, who commanded the brigands that served Fregoso as an army. Up went the colours of the Duke all over the State, and the Archbishop, unable to withstand the gathering tempest, confided the fortress to two members of his family, with 500 of his best soldiers, and then sailed away from the port to take up the congenial occupation of piracy on the high seas until such time as the wheel of fortune should again revolve and enable him once more to resume the ducal cap and the mitre (1464). And, in fact, we shall still meet with him in both capacities; he even received the red hat of the cardinalate from the Holy Father for contemplated service against the Turk. But at present the tide was against him. The town was opened by his Lieutenant to the forces of the Duke, and one of his relations betrayed the castle for 14,000 gold florins. Then twenty-four deputies rode over the Apennines to Milan, and offered Sforza the signory of the city on the same condition-that of self-government-as had been made with the King of France (1464).

What saved the commerce and colonies of Genoa at this time was, as we have stated, that powerful company known as the Bank of St. George. It was, in fact, the Treasury of the Republic; it collected the public taxes, and administered colonial government. Thus, even in the latter half of thefifteenth century, we have a $n$ instance of how the loose organization of the Italian Republics, which admitted of disorder, was neverthe- 
less a means whereby what would have been to a more highly organized community quite fatal results of civil war were to a large extent escaped from. During the wars of the fourteenth century Genoa had been obliged to borrow money of her citizens, and about the year I407 the borrowers, forming themselves into a distinct corporation, known as the Bank of St. George, were allowed to collect the taxes and pay the surplus, after deduction of interest, over to the State. The State thus became indebted to a single corporate body. We have seen that when, in 1453 , the Aragonese threatened Corsica, and Genoa lost Pera, she agreed to entrust the Bank with the possession and defence of Corsica, the colonies in the Levant, and those in the Black Sea. In fact, the Bank was placed very much in the same position as that which our own East India Company once assumed. At the head of the Bank were eight, and sometimes twelve, protectors, elected annually, and there appears to have been a general council of one hundred members (Vigna, Cod. Gen., I868-1874). In 1460 a special committee of four protectors was appointed for colonial affairs, and this committee appointed three Consuls every year to rule Caffa, each one presiding in turn over the destinies of the colony for a year, while the other two acted as his coadjutors and as checks on his administration; besides these gentlemen the Caffan Governor had also a Grand Council. The maintenance of Genoese authority in Caffa was regarded by the whole West as a matter of the utmost importance, not merely to the city, but to all Christendom. The protectors of the Bank of St. George often called a council of twenty carefully selected members of the Bank to their aid; they rendered their accounts to the audit of one hundred representative members; and annually 480 members of the Bank were summoned to a general council, half being chosen by lot and half by ballot. The original debt of the State had been divided into shares of roo libræ, which could be neither sold nor transferred, and the magistrates of the Republic had to take oath to keep the Bank inviolable. This financial institution, in the bundle of associations that made up the Republic of Genoa, was regarded as the least corrupt establishment in Italy, and the factor that made most for peace. It became, in fact, the salvation of the turbulent little State of which it was custodian, taxgatherer, and treasury, at the same time playing the part of a commercial bank (Hist. of Banking, N.Y., 1896, vol. iii., p. 154).

But even the Bank could not save the Crimean colony. At this time Caffa rivalled the mother-city in size and importance : it was the great market for the purchase of woods, wax, skins, and from it came the products of the mines of the Caucasus and the silks and cottons of Persia. But the capture of Constantinople by the Turk rendered the voyage to Caffa dangerous, and a reinforcement of mercenary troops had to be sent by way of Hungary, Poland, and little Tartary. Difficulties with the Tartars led to the interference of Mohammed II., and in $1475 \mathrm{Caffa}$ was taken, its chief inhabitants murdered, I,500 children conveyed to Constantinople to recruit the janissaries, and the remainder of the population transported to Pera. The Genoese domination of the Black Sea was at an end (1477).

While Francesco Sforza lived, he observed the conditions under which he had become protector of the Genoese State. But the advisers of Galeazzo Sforza, his son and successor, not merely tried to break through 
the stipulations, but Galeazzo insulted the city, when he was received there with mediæval pomp and splendour, by donning shabby attire, refusing the palace provided for him, and shutting himself up in the safe retreat of the fortress. He then meditated cutting the city in twain by continuous fortifications extending from the citadel to the sea. One of the Doria commanded that the works should be stopped; whereupon Galeazzo gathered an army of 30,000 men and threatened the city, but soon thought it wise to disband the troops. Meanwhile, the Genoese were steadily arming themselves, and one Girolamo Gentile, a young lawyer, gathered a host of armed followers, and rode with them through the city, possessing himself of the gates, and calling on the people to throw off the yoke. The city fathers assembled at the Public Palace under the presidency of the Governor, and, owing to defection, Gentile found himself with only thirty determined followers. The Consuls of the trade associations thereupon intervened, and after being reimbursed for the cost of his attempt, Gentile left the city (1476). When Gian Galeazzo Sforza was assassinated, the Fieschi, the Fregosi, and other exiles scaled the walls, and called on the citizens to strike for liberty, and even Pietro Doria buried the hatchet of hereditary feud and joined the insurgents. Thereupon Prospero Adorno was released from prison by Simonetta, the chief adviser of the Milanese Court, and was offered the government of the city and its contado if he would restore the State to Milan, under the old conditions of perfect self-government. Partly by address, partly by force, he contrived to secure the adhesion of the Senate and people. At that time the citadel, as usual, still remained in the possession of its garrison. The Fieschi held out in their country castles, but were finally subdued.

A startling contrast is yielded by the condition of Genoa and that of Venice. Its nobles, like those of Venice, were merchants and seamen, but their territorial possessions, and the fatal inheritance of vendetta and feudal traditions involved them in perpetual discord, and plunged their country into insecurity. Any notion of compromise was but rarely entertained by the contending parties; the smaller ports round, under the dominion of the families, were jealous of each other and of Genoa, and, undoubtedly, the ready surrender of the city fathers on this occasion to the rule of the Duke of Milan was due to the same reason that the city ceded itself not a few times, a reason which was frankly acknowledred to Francesco Sforza-the community desired to live for awhile unmolested, and in some sort of ease (1477) (Cagnola. Archiv. Stor., iii., p. 165).

In the war between Ferrante of Naples and the Pope against Florence, Ferrante negotiated with Prospero Adorno in order to create a diversion at Genoa and prevent Milan from aiding Florence. Adorno received a considerable sum from Naples to help him to secure the independence of the State. Six Captains of the People were nominated, and Adorno changed his style from "Governor" to "Doge" (I478). A fierce battle ensued in the defiles of the Apennines, wherein the Milanese were defeated, stripped of everything by the peasants, and re-entered Milan, garlands of leaves being the only covering they could procure. But the Milanese Gevernment succeeded in coming to some sort of terms with the Fieschi and Fregosi. Adorno was compelled to leave the town, and by 
paying 6,000 florins to one of the Fieschi and the same sum to the Neapolitans, Battisto Fregoso contrived to become Doge of the free city (1478!. That astounding personage, Paolo Fregoso, the uncle of the Doge, who had himself been twice Doge of the city; who had exploited it during his reign, and then turned pirate; who had received the red hat from Sixtus IV., and been given command of the fleet destined to be sent against the Turk, had returned to Genoa in I479. Battisto Fregoso has left us an account of the crimes and odious vices of the truculent Cardinal (De Factis et Dictis Mirabilibus), and of how he was seized by him when merely paying a call, and deposed : Paolo Fregos olost no time after this capture, he tells us; he convoked an assembly of 300 citizens, and had himself proclaimed Doge.

It had been the aim of Florentine diplomacy to keep on good terms with Genoa, for much Florentine trade passed through that convenient port. When it was under the control of Milan, the ally of Florence, it became the chief port of Florentine commerce. But in I480, notwithstanding that Lorenzo dei Medici and the King of Naples had come to terms, one of the Fregosi seized the town of Sarzana, which his father had sold to the Florentine Republic. Florence now meditated recovering the town, and the Genoese ceded it to the Bank of St. George, which already possessed the neighbouring fortress of Pietra Santa. War broke out between the two States, and in 1484 Pietra Santa, and in I487 Sarzana, were lost. Thereupon the Cardinal allied himself with Lodovico the Moor, and many of his followers joined the Fieschi and Adorni. Civil war followed, and there was a proposal made by Milan to split up the Republic into two halves, of which one should be under the rule of the Adorni and Fregosi, with Savona as its capital, and both States be received under the protection of Milan. Neither side would accede to this proposition, and the civil war continued to be waged more fiercely than ever, until the Cardinal was forced to abdicate (I488). He found refuge in Rome, where his plots to assemble a force and restore himself to power by the aid of his partisans and those families that he could secure were only prevented by the swift interference of Cardinal Della Rovere, afterwards Pope Julius II., who was swift, vehement, and resolute, and quite the man to deal with the hatred of opposing factions.

\section{FLORENCE}

\section{The Last Years of Cosimo}

WHEN Sforza ascended the ducal throne there were general rejoicings in Florence, and an Embassy representing both parties was despatched to Milan to offer congratulations. Sforza, on and off, had aided or been in the service of the Republic for twenty years; the Florentines took a certain pride in having been, in part, the instruments of his fortune, and they looked forward to the possession of Milan as a friend instead of an inveterate and subtle foe. Of course the Florentine envoys were welcomed with usual international courtesy and festivity, and, indeed, there was a little more sincerity in the show than is usually the case, 
for there the occasion implied a real redistribution of alliance among the Italian powers to the advantage of Florence. On the one side were ranged Venice, the King of Naples, and the Papacy; on the other, the old enemies, Florence and Milan: Venice and Florence were parted; and Fiorence and Milan, the head of the Guelphs and the head of the Ghibellines, were together.

Before long all Florentines were ejected from Venetian territory, and in 1452 Venice declared war against Sforza, and Naples against Florence. Alfonzo intended his natural son, Ferdinand, or Ferrante, Duke of Calabria, to succeed him, and he had had him educated by Frederick of Montefeltro, the Count of Urbino, one of the most skilful commanders and accomplished rulers of an age remarkable for martial skill and intellectual development. This young man was sent to subdue Tuscany, but the fortifications of quite small places sufficed to hold him in check (I452). Next year Ferdinand made a second attempt, which was as inglorious as the preceding, for fever proved a sure ally to the Republic. The most remarkable event of the campaign was the treachery of Gambacorti, Count of Bagno. Gambacorti, descended from the great Gambacorti of P.sa, was related to the Albizzi. He had aroused the suspicions of the Republic ; it learned that he was about to exchange a poor fief that he held of them on the borders of the Casentino and Papal States for a far richer one in the kingdom of Naples. Gambacorti at once repudiated any hint of treachery, and sent his son of fourteen to Florence. Although the signoria was warned more than once that he still meditated bad faith, they pointed to their hostage, and refused to believe the allegation. But now, when a Knight of St. John of Jerusalem appeared with a squadron at the gates of Gambacorti's chief fortress, he lowered the drawbridge. A Pisan at his side noticed the consternation of his retainers, and divined that the Republic was being betrayed; he took his master by both shoulders, shoved him by main force beyond the portcullis, and let it down; then he raised the flag of Florence, shouting, "Long live the Republic!" The vassals of the Count took up the cry, and the place was saved. Some tincture of improvement in human feeling is shown by the generosity of the signoria. Not merely was the son's life spared, but he was sent back to his father without ransom. And the faithful Pisan and his supporters received a magnificent acknowledgment of their services from the State (Scip. Ammirato, xxii., p. 77.-Ann. Bonincontrii Miniatensis, p. 157.-Ist. di G. Cambi, R.I.S., xx., p. 313).

In I 455 , a year after the exhausted Powers had signed the treaty of Lodi, Alfonzo consented to accept peace with Florence, for there was a fresh alliance between Sforza, Florence, and the Venetians themselves, to insist on peace being preserved throughout Italy.

The strong hand of Cosimo was less felt in the closing years of his life. Sickness disabled him, and faction and proscription began to disturb the State. But foreign relations remained undisturbed. During his administration the State enlarged its boundaries: Borgo San Sepolçro was bought of the Pope ; Montedoglio, the Casentino, and the Val di Bagno acquired. But Cosimo failed over what would have been the most important acquisition of all, on which Cosimo had always had his eyethe possession of Lucca, which Sforza always promised to help him to obtain when he should become Duke. That great adventurer con- 
veniently evaded his promise directly he was securely seated on the throne and the time for the redemption of his word had come. But such an attempt would probably have renewed the fires of war, and what everybody wanted now was tranquillity and peace, remission of taxation, and pursuit of private gain.

\section{Florence under Piero dei Medici (I464-i469)}

Piero, the heir of Cosimo Medici, was practically bedridden ; the people called him " il Gottoso," and he had to be caried from place to place in a litter. His intellectual calibre was by no means equal to that of his father, and his malady prevented him from close application either to public or private affairs. Nevertheless, in spite of a few malcontents, he was recognised as the chief man in the State, and regarded as occupying his father's position. Piero was forty-six years of age, not without experience, and although his own abilities would never have secured him such high position, his father's prestige made it fairly secure among the Medicean party, and the Medicean party was practically the Florentine party. The ramifications of banking and commerce and the growth of States were rapidly altering the world; capital is always sensitive, and any convulsion, such as a revolt against the unobtrusive but no less real power of the Medici, would have been keenly felt ; it would have produced much dislocation of wealth and destruction of profitable undertaking. Then, too, most of the opposing party were in exile, and were more or less ruined by exclusion from Florentine commercial undertakings; there was increasing difficulty in finding a profitable outlet for wealth and energy in the more highly organized commercial world now beginning to develop. The succession of Piero, then, was a recognised thing, not only in Florence, but throughout Europe, and the world accepted him just as they accepted the Kings of France or England.

Cosimo had been very lax in calling in debts; he had greater ability and interest in matters of intellect or affairs of State than in the conduct of his own business; he had not followed the tradition of his House by greatly enlarging the fortune left him by his sire; and Piero, unable to pay any very close attention to affairs, called in certain outstanding debts. The result was that many houses failed, not merely in Florence, but in Venice and Avignon, and he made himself not a few enemies. More than one incident enables us to see that the ancient path of commercial rectitude was by no means followed either by Piero or some of the other merchants of his time. One Lorenzo Larioni, for example, put his affairs, which were in an embarrassed condition, in Piero's hands; his creditors obtained a small percentage of their due, and the debtor found himself with his honour tarnished a little, perhaps, but with his pockets fuller of something more substantial than a poor abstraction; he was set up again richer than he had been for ten years (Lettere d'una Gentil., quoted by Perrens, i., p. 358).

The enemies of Piero began to increase both in numbers and activity. They tried to undermine his position, and to weaken the support of the Duke of Milan and the Holy Father. The balia expired in 1465, and election to the signory, but not to other offices, was again decided by lot. But since the "purse" had been filled by the Medici, this change, while it 
was hailed with satisfaction by the discontented, did not seriously affect the position of Piero. Everything remained pretty much as before; the tribunals, the finances of the State, remained under Medicean control, and corruption was so wide spread and the number of Medicean clients and dependants so great, that there was little to fear. Soderini, the new gonfalonieve, tattled about banishing the Medicean partisans, but he found himself powerless, and it was remarked of him when he went out of office that he " had come in like a lion, but went out like a lamb." Abuses had been exploited not merely by the Medici but by the rival House of Pitti, and the friends of Piero and of Luca Pitti, though opposed to each other, were combined in offering a determined opposition to the reformations which Soderini desired. Too many interests were involved to admit of any attempt of the gonfalonieve or anyone else being crowned with success, and Soderini was not a strong man.

Counting on the mental inferiority and bodily weakness of Piero, and the death of Francesco Sforza, the old ally of his House, the "patriots" sought the support of the Duke of Modena, who, as his States touched those of the new Duke of Milan, was the natural enemy of that potentate. Modena promised to send I, 300 horse, and Soderini engaged 300 German troops. But Ercole Bentivoglio, the reputed bastard scion of the House which occupied in Bologna a position analogous to that of the Medici at Florence, who, largely through the instrumentality of Cosimo, had come to rule there, and who had been brought up among the Mediceans, sent word of warning to Piero. Piero was very ill, and was staying in the country at the time, but he showed more resource, energy, and ability than his enemies had given him the credit of possessing. Machiavelli, who, to illustrate principles, is in the habit of colouring facts very highly, gives an exaggerated account of what followed; but the truth of the matter is that Piero sent off at once for armed help from Milan and Bologna, and proceeded in his litter, accompanied by his friends, to Florence. He packed his house with armed men, succeeded in detaching Pitti, who had just as much to fear from the "patriots" as himself, proposing to him an alliance of the two families by marriage, and sent Benfivoglio's letter to the Senate to excuse himself for having gone under arms. Piero's promptitude enabled him to forestall the conspirators, who were in nowise ready. Soderini summoned all the people of his ward, and accompanied by his German troops went to Luca Pitti to implore him to join them without delay, and before troops could come up from without to Piero's aid. Luca, who had been thoroughly juggled by Piero, refused. Both parties remained under arms; but the signoria, dreading the effects of public disturbance, got them to negotiate with one another. This was all that Piero needed; he gained time, and in a few days the new gonfaloniere and signovia were chosen, and they were all Mediceans. The outgoing and the new signoria combined to present terms of agreement to both parties ; provisions were unhesitatingly signed by both sides, and violated by Piero directly the new Government was securely in office. As Machiavelli says, "It seemed as if God had delivered the city into their hands. It was feigned that Soderini was again preparing a revolution, and the new gonfalonieve, the creature of Piero, called a parlamento, which the Medici had expressly stipulated not to do. The square was filled with armed men ; eight adherents of the Medici were nominated as balia; and 
this new authority, armed with plenary power, suspended election by lot for ten years, and filled the purses with Mediceans. Many citizens at oncc took to flight, and all the enemies of Medicean rule were proscribed, and men were dragged out of the religious processions going to the thanksgiving for the salvation of the State which the signoria had ordered, and led to the scaffold or the prison (I466) (Jacopo Nardi, Hist. Flor., L. i.Comment. del Nerli, L. iii.-Scipione Ammirato, L. xxiii.-Jo. Mich. Bruti. Hist. Flor., L. iii.-Comment. Jac. Cardin. Papiens, L. iii.Guern. Bernio, Storia d'Agobbio, R.I.S., L. xxi.).

Piero dominated in Florence unopposed, but Italy was filled with Florentine exiles. Those driven out by Cosimo in 1434 joined the newcomers, and they agreed to assemble in Venice and seek its aid. On hearing the news the Florentine signoria set a price on their heads, and prepared for war, securing to themselves the support of the Duke of Milan and the King of Naples.

But Venice, however eager to deal a blow to Florence, was handicapped by her war with the Turk; she therefore urged the Florentine exiles to seek her old condottiere, Bartolommeo Coleoni, the same General whose equestrian statue stands on the piazza of San Gianipolo ; nay, the Venetian Government did more-they supplied him with secret funds. Galeazzo Sforza, the degenerate son of Francesco, took command of the allied army by virtue of his rank; but he had the blood of Gian Galeazzo and Filippo Maria Visconti in his veins, and proved himself as unwilling to fight, when it came to the point, as he had been eager in rushing to the camp. The astute Florentines invited him to their city that they might show him their respect and regard by fêting him, and sent secret orders to Federigo da Montefeltro, their General, to engage the enemy during the Duke's absence. The battle was a little more bloody than was usual among condottieri, on account of the employment of field-pieces, and this discouraged both sides, neither of which, indeed, could claim the advantage. Both Venice and Florence were extremely disinclined to continue the war, and by the mediation of the Duke of Modena and the Pope peace was concluded (1468).

The Florentine signoria, so far from recalling the exiles or restoring their property to them, went on with fresh proscriptions; and, either justly or not, many were accused of complicity in plots which may or may not have had real existence. Justice had become absolutely venal, and the magistrates of the State employed their high office to gratify their cupidity or spite. Piero dei Medici cannot be held responsible for these atrocities. He was suffering worse than ever from what would appear to have been rheumatoid arthritis; he was in the country, confined to his bed, and every joint in his body was more or less fixed ; he could move his head only. Meanwhile public attention was diverted by magnificent public fêtes, and the pens of the learned, of so much value in those days, were bought by the patronage of Piero and the bestowal of presents and small pensions. Piero died in December, 1469, desiring for himself the same resting-place and the same simple funeral that had been given to his father.

Though not possessed of ability of a very high order, Piero on more than one occasion showed great discernment and capacity; he could take rapid action, and one cannot but admire the crippled invalid; so heavily 
handicapped by a disease which tends to weaken the mind as well as the body, who nevertheless maintained for himself the headship of the State. Less crafty than his father, he nevertheless knew how to deal very effectively with Luca Pitti. Pitti had headed the conspiracy against him, and his followers were known as the "Mountain," from the highly-situated Palazzo Pitti, and because opposed to the "Plain," for the Palazzo Medici stood low. Piero knew how to detach Pitti by guile, and then he left him unpunished. He had inveigled the vain, stupid old man into conduct which earned him the hatred of the Mountain and the contempt of the Plain. Pitti had attempted to outshine the Medici, and only succeeded in exhausting his resources. The palace he built was destined to become the dwelling-house of the Medicean Grand Dukes; its builder died dishonoured and disdained. And it was a bold thing to support Galeazzo Sforza at the moment when the death of Francesco threatened the collapse of his hard-gotten State. Piero's vigour in dealing with the conspiracy of I 466 seems to show that, had he been possessed of better health, he might have proved himself a strong ruler; and his bust by Mino da Fiesole suggests a certain natural frankness of character which is wanting in the portrait of Cosimo by Benozzo Gozzoli.

\section{Florence under Lorenzo dei Medici (1469-I492)}

Cosimo left two sons-Lorenzo and Giuliano-to bear the burthen of the great House. Lorenzo kept a diary, and he wrote in it as follows : " The second day after his death, although I, Lorenzo, was very youngin fact, only in my twenty-first year-the leading men of the city and the ruling party came to our house to express their sorrow for our misfortune, and to persuade me to take upon myself the charge of the government of the city, as my grandfather and father had already done. This proposal, being contrary to the instincts of my age, and entailing great labour and danger, I accepted against my will, and only for the sake of protecting my friends and our own fortunes, for in Florence one can ill live in the possession of wealth without control of the Government " (vide Armstrong, Lorenzo de' Medici). This passage furnishes the key to Florentine politics and to the policy of the House of Medici ; the preservation of purely personal interests was the great aim of Italian rulers, and behind these purely personal interests there was not, as was the case in the kingdoms of the North, a national interest supporting the monarch in his ambitions. The direction of Italian politics did not favour national consolidation, while the direction of the peoples North of the Alps was towards consolidation. In the North, monarchy coincided with the general national interest, because the ambition of the monarch dominated and fused many conflicting claims and aspirations, and so subordinated and directed them as to consolidate the State and render it compact. In the North commercialism had not interfered with feudalism so as to prevent the subordination and subjugation of feudal units at the hands of the Prince. In Italy, on the other hand, commercial development and feudal relics were jumbled together throughout the land; personal individualism triumphed : local selfishness, ignorance, or patriotism, by whatever name one may choose to designate the civic sentiments and convictions evolved under Italian conditions, reigned supreme in mer- 
cantile cities. Consequently, there was, in Italian States, no such fusion of the various factors of society into a self-conscious and independent whole as there was in the North ; no similar evolution of the maxims and claims of nationality.

Lorenzo was a man of marked ability, considerable literary aptitude, and educated sympathies, devoted to every form of art and every kind of enjoyment, neglectful of business, which bored him; but, in the core of self, bent on personal rule and the dominance of his House. His character is seen in his countenance, preserved to us by the genius of many contemporary artists; we see him in the first flush of manhood, the period when he assumed the responsibilities of his House, in "The Adoration of the Magi " by Botticelli ; and the effigies of Giuliano, his brother, and his passion for the quaint and elusive loveliness of Simonetta, are also eternalized in the canvasses of that most subtly fascinating of quattrocento masters. Lorenzo affected deference to his elders; he flattered his enemies by consulting them one at a time; but he had an unerring eye for those who would be true and efficient supporters of his House, and he sought and followed the advice of men of proved judgment, and of no too exalted position in the Republic. On these men he relied; and, bad at the vulgar details of the counting-house, lived his real life in the society of fair women and witty men of letters, in the enjoyment of the arts and the grosser pleasures of sense. Tommaso Soderini, brother of the Soderini who had plotted and failed against Cosimo, really directed the affairs of the State until time had ripened the genius of Lorenzo ; and Soderini had the wisdom to exalt the prestige of the Medici and to strengthen the party by strangling his own claims to precedence. With the mass of citizens there was no difficulty; all they aspired to now was bread and entertainment.

Among the cities subject to Florence, Volterra had retained no small measure of self-government; she paid tribute of about one-tenth of her income ( $\mathrm{I}, \mathrm{OOO}$ florins), and received her Podestà from the ruling city; but she made her own laws, garrisoned and governed the strong places in her territory, and elected her own signovia every two months. Questions as to the management of an alum-mine led to a series of bloody street battles, pursued with the fury of faction, so constant a characteristic of the Italian commune; and Florence interfered. The counsels of Lorenzo, who had a pecuniary interest in the alum-mine, were rejected, and he determined to enforce his advice by exercising the strong hand (1472). The Volterrans sent to the various Italian States to implore protection, and the Florentine exiles were ready to help, not that they had any passion for liberty, or sympathy with the claim of Volterra to manage her own affairs, but because they cared not how they might injure their own city if they could only overthrow the Government that kept them in banishment, or at least could contrive to give it an unquiet time, "which, if not victory, were yet revenge." Soderini was all for temporizing, but Lorenzo had an eye to his business interest in the alummine ; he knew that the capture of the rebel city would not prove difficult; and he desired to prove his power and enhance his popularity. Volterra soon fell, and the undisciplined soldiery subjected it to the worst outrages; the municipality was abolished, and a fortress erected to keep the city cowed. 
Then Lorenzo dexterously got a balia chosen to fulfil his designs; he converted this institution, which had only been employed in emergencies, into a permanent office. He nominated five accoppiatori to select those alone who would establish Medicean power. Medicean power was now secure, and on a firm basis. By this time the signoria had been eclipsed by the pushing forward of the gonfalonieve; for a body, even when it is composed of creatures, is less easy to manage than a single creature ; and any odium that might be incurred fell on the gonfaloniere, for, though he was the chief officer of the State, he was not always a nominee of the great House.

The executor of justice had by this time degenerated into a mere public headsman ; and the only function of the Podestà was to ratify the decisions of the signoria, to whom the "power of blood" had been entrusted in Cosimo's time. The councils of the people and the commune were not suppressed; but since they acted as possible checks on Medicean ambition, their powers were annulled, a new council of one hundred, elected by the accoppiatori, having the office of deliberating on all petitions.

While still preserving the station of private citizens, the Medici had contrived to secure the powers of absolute monarchy. This new Government depended wholly on them. If it proved rebellious, the Medici would withhold their sustaining hand, and anarchy and financial ruin would follow. Lorenzo dei Medici was secure of the support of men of letters, whom he flattered by his own very considerable literary efforts : he possessed the artists to whom he extended his patronage, and the populace that he amused with fêtes and pageantry. The Medici could remit or diminish the taxation of those who served them; they could alter the rate of interest paid to creditors of the State Bank; they could sentence accused people as they pleased; they could appropriate the public funds, and they did so, for Lorenzo was extravagant and a bad man of business, and constantly in debt ; they could replace the money withdrawn by increasing taxation and putting the screw on the disaffected; and they had the power to humiliate great families, and give a sop to Cerberus by exalting those of low degree.

Among the rich-Florentines who had been suppressed and despoiled by Lorenzo were the Pazzi, a noble family of ancient blood that had been admitted to the city by Cosimo when he exiled the Florentine nobility who were his political opponents in 1434 , and wished to strengthen his position by calling in men of still higher lineage. The Pazzi became very wealthy bankers, and had intermarried with the nobility, but Lorenzo got a law passed, with retrospective action, whereby the Pazzi, claimants to a very large property, were deprived of their rights. Lorenzo, moreover, kept them excluded from public office. Francesco Pazzi thereupon left the city in dudgeon, and repaired to Rome, where he became banker to Pope Sixtus IV. Now, Sixtus was passionately fond of his nephews, the Riarii, and was bent on securing temporal power by putting them in possession of the States to which the Papacy lay claim. Lorenzo had prevented the favourite nephew of Sixtus from acquiring Imola, by blocking up the avenues through which he could have drawn the money necessary for the enterprise; and the Florentine Government, finding the Republic endangered by the increased proximity and restless ambition of the Papal power, had further given help to the despot of Citta di 
Castello when he was attacked by Giulio della Rivere (the warrior-cardinal who afterwards became Pope Julius II.), and had joined the alliance of Venice and Milan to hold the Papacy and the King of Naples in check. Sixtus conceived that he owed Lorenzo a heavy score, which he was quite ready to pay with interest ; he appointed the son of a Florentine exile, a bitter enemy to the Medici, to the See of Pisa. Of course, the Florentines refused possession to the new Archbishop, and this prelate, Francesco Salviati, was also ready for revenge.

Christianity had degenerated into a mere formal profession ; the Church was rotten; it had forgotten what religion really means; and the Italian mind was influenced by antique Roman models, while the antique Roman spirit was entirely misunderstood. Already, men, nursing themselves on what they conceived to be the spirit of Brutus, had made away with the tyrannical Duke of Milan ; and various conspiracies, successful and unsuccessful, had been organized in Italy. Liberty was dying; insurrection had become impossible; Machiavellian principles were practised before Machiavelli studied them and reduced them to scientific form and order; and the Princes of Italy were perpetually plotting against one another and employing all the artifices of treachery and all the tactics of foul play; policy was emancipated from morals; cunning set traps for the unwary ruler; statecraft was the domain of emancipated intelligence, and failure the only disgrace. Perhaps the Pope and the Ambassador of the King of Naples-certainly the disappointed Archbishop and the Pazzi, who confused their own jealousy and resentment with patriotism, and who supposed themselves to be behaving like "the noblest Roman of them all "- arranged for the removal of the brothers Medici.

The plot was hatched at the Vatican. Whether the Pope was cognizant of the plot or not, Papal troops were sent on various pretexts to the Florentine frontiers on the east, west, and south; a body of conspirators assembled in the town, and it was arranged that the fatal blow should be dealt in the Cathedral, at the sacred moment of the Real Presence, when everyone would be on his knees, and ought to be contemplating the mysterious and awful habitation of the sacred cup by the Judge of all the earth.

The conspiracy of the Olgiati had indeed removed the tyrant of Milan, but had failed to re-establish liberty in that city, because no one knew of their intentions or was prepared to take advantage of the event. Vast numbers were consequently engaged in this conspiracy, and it was deemed necessary above all things that both Medici should fall at the same moment, so that one might not survive to avenge the other. It was arranged that some of the conspirators should occupy the Public Palace and intimidate the signoria, while others called the people to reassert their freedom ; and four troops were given orders to the same end. On two occasions all the preparations of the conspirators missed fire, for Giuliano was not present at the fêtes whereat it was first arranged to do the double deed. Machiavelli has left us, in his "Florentine History," a graphic account of what ultimately occurred, an account illustrative of the temper of the times. "More than in any other business," says he, " a great and resolute soul, hardened by experience to deal with life and death, is needed here, wherein even skilled warriors, stained though they be with blood, have been found wanting. ... That so envenomed a hate, so steadfast a resolve 
to do such an enormity could be so dexterously and unshakenly kept hidden by Francesco [Pazzi] and Bernardo [Bandini] is indeed worthy of note. For, in conducting [Giuliano] to the church, they amused him, and even in the church plied him with merry jest and the light talk of youth. And under pretence of embracing him, Francesco took the precaution to press him close to see whether he wore a breastplate or any other kind of protection. . . . He covered him with wounds, and stabbed him with such fixed resolve and blind fury that he seriously injured one of his own legs."

Lorenzo was only slightly wounded in the neck. He made for the sacristy, and was able to lock himself in ; Giuliano fell dead, and nineteen stabs were found in his body. The two priests who had failed to kill Lorenzo were pursued and cut to pieces. Meanwhile, Archbishop Salviati hoped to secure the palace of the signoria, but his followers in trying to conceal themselves near the portal had shut themselves into a chamber, and were unable to open its spring-lock. Salviati passed on to the gonfalonieve, but his countenance was so agitated, and his manner and language so embarrassed, that the gonfalonieve sprang to the door, seized Jacopo Bracciolini, who had concealed himself behind it, by the hair, delivered him to the warders, and soon discovered and was able to overpower the other conspirators. Some were stabbed, some were tossed out of window; but Salviati, Jacopo Bracciolini, and two of Salviati's cousins, were straightway hanged at the open windows. All the conspirators discovered in the palace perished, save one man, who was discovered four days after hiding in a box, and was let off as having been sufficiently punished by hunger and fear.

Jacopo dei Pazzi had rushed through the streets trying to rouse the people to arms with the old cry of " Popolo ! Libertà !" but the people had lost their old passion for independence and their love of political excitemont ; they enjoyed the bread and circuses of the Medici, and they replied with shouts of "Palle, Palle !" meaning the Medicean arms, those gilded pills which still grace the establishment of the London pawnbroker. The enraged populace made for everybody who was denounced, or had shown the least opposition to the Medici, or was in the smallest degree suspected of being in league with the conspirators ; they were hunted down, torn to pieces, and their severed limbs carried about on pikes. Jacopo dei Pazzi escaped to the Apennines, but was caught by mountaineers and was hanged. The fury of the populace left Lorenzo little to do, but that little was done very effectively, and a terrible example was given to would-be conspirators, while the only effect of the plot was to rivet the power of the Medici more securely than ever before (I478).

But Lorenzo, even now, was far from being safe. The troops that had been sent by the Pope crossed the frontier, and Ferrante of Naples also sent a small army. Florence had been approached by a son of Braccio, the great condottiere, who asked her help to reconquer Perugia, which his father had held, and she had refused. He then directed his arms against Siena without any objection on the part of Florence, for there was never real goodwill between the rival cities. The Sienese had borne this in mind, nourished their grudge, and now they combined with the Pope and King Ferrante. Federigo of Montelfeltro, Duke of Urbino, took command, and announced that he was warring, not against the 
Republic but against Lorenzo. The Pope issued a Bull excommunicating the Republic if Lorenzo and the entire Government were not given up for the murder and outrage done on the Church. "Unheard-of crime," read the Bull ; " they have laid violent hands"on an Archbishop, and hanged him publicly from the windows of the palace on the Lord's own day !" The Florentines expressed their regret at having taken the law from ecclesiastical tribunals into their own hands ; but the Pope was implacable. Whether the Pope was an accomplice in the plot or not he committed himself to the avenging of the dead assassins. The city prepared for defence; she sent to Milan, to Venice, to all the European Powers, giving what she deemed to be proof of the complicity of the Pope in the plot, and the Tuscan priesthood was assembled to protest against the excommunication. Louis XI. declared that Lorenzo's only crime was that he had not been killed; he stood up stoutly for Florence, and it seemed as if there would be a European league against the Papacy. The famous Ambassador, Philippe de Comines, the historian, was sent to Florence ; European Kings saw a brother in the uncrowned King, and the longerheaded of the cardinals expostulated with Sixtus, who professed to be desirous of putting the matter in the right light before the world. $\mathrm{He}$ expressed himself as much pained that Louis should lend an ear to Lorenzo and his accomplices rather than to him, who had received his authority direct from God, and was accountable to Him alone. And he delayed and shilly-shallied, trusting to time to blunt the edge of resentment, or to the revolution of circumstance to prevent a league from forming against him, and meanwhile he pushed forward the war. (For the details of the Pazzi plot, and the general belief of the times as to the complicity of Sixtus, see Scip. Ammirat., L. xxiv.-J. Mich. Bruti, Hist. Flor., L. vi.-Machiavelli, Istoria, L. viii.-Jacopo Nardi, Ist. Flor., L. i.Conjurationis Pactiance, Comment. Politian.-Allegr. Allegretti, Diari Senesi.-Anton. Galli, De Rebus Genuens, R.S.I., L. xxiii._Comment. di Ser Filippo Nerli, L. iv.-Diar. Parmense, R.S.I., L. xxii.-Strinatus apud Adimarum, in notes ad. Conjurat. Pactiance Comment.-Annal Bononienses Hieronymide Bursellis, R.S.I., L. xxiii.-Bulla Sixti IV., 1478.-Memoires de Phil. de Comines.-Card. Papiensis, Ep. 693.)

Ten of War were elected by the Florentines to conduct the campaign, but nothing save misfortune attended the Florentine arms. The Duke of Ferrara was appointed to lead the mercenary troops, and he was suspected of treachery. He allowed some strong frontier places to be taken, and then went into winter quarters. Lorenzo had convoked a council of the leading Florentines directly the Papal manifesto was issued, and offered to submit to exile or even to death rather than expose the city to attack, but the Council replied that they would devote their fortunes and their lives, too, if need be, to his defence, and they remained of the same mind ( 1478 ). In the following year dissensions broke out among the mercenary troops, some of whom belonged to the military school of Braccio, others to that of the rival traditions of Sforza; the co-operation of the two factions was impossible, and the army had to be divided into two separate forces. Then the mercenaries were defeated by Neapolitan troops, and Colle and Poggibonsi, on the Sienese border, fell to the son of Ferrante of Naples, the Duke of Calabria, who aspired to get hold of Tuscany from the vantage-ground of Siena. Venice was 
exhausted and Milan was in a disturbed state, for Lodovico Sforza was bent on seating himself on its throne. No help, therefore, could come from Italy. Florence turned to the aged René of Provence, who promised 6,ooo horse to push the clains of his House to the Neapolitan throne. Reliance on the House of Anjou was the last forlorn hope of the Republic ; it was drained by the heavy expenses of the war, its countryside had been ravaged, its commerce was declining, merchants in far-off lands had had their goods seized by rapacious monarchs in response to the confiscation ordered by the Pope ; it was felt that but for the Medici the war had never been, and one of his reputed friends and partisans told him plainly that " our city is done up ; we don't want war, nor to remain under interdict to save your influence" (Jacopo Nardi, Ist. Flor.-J.Mich. Bruti).

When the first peal of Papal thunder was heard in Florence, Lorenzo had made the city what was in appearance a noble offer, though he must have known full well that the identity of his House with the city and the temper of the people were such that that offer would not be accepted. He now showed himself capable of subjecting himself to what was, in reality, a noble risk.

The Pope had a personal spite against Lorenzo, for the failure of the Vatican plot had subjected him to the threats and reproaches of all Christendom; his designs for the extension of the Papal power through the advancement of his family had been checked; he felt personally humiliated, and he had an imperious and vindictive temper. But Ferrante of Naples had no personal antagonism against Lorenzo ; he opposed him on political grounds only; he wished to extend his authority over Upper Italy; the State of Milan already gave him considerable power in Lombardy; Genoa was almost a dependency of the Neapolitan Crown; his son, the Duke of Calabria, was gaining ground in Siena, and while he desired to overbear the opposition of Florence to his schemes, he did not wish to see her overthrown in such a way that the Pope would strengthen himself in Tuscany. Ferrante was a man "accustomed to destroy his enemies by treacherous means. With cynical cruelty he would embrace them, caress them, and entertain them gaily at dinner before sending them to their death "(Villari, Mach., Lond., 1898, p. 58); he was treacherous and tyrannical, but he possessed political penetration, and Lorenzo believed that Ferrante's shrewdness would keep his falsity in check; he was convinced that he could make the King see that their interests jumped together, and he boldly entered the lion's cave. Lorenzo was received at Naples as if he had been a reigning Sovereign, and he unfolded himself to Ferrante in a series of long interviews. He pointed out that a continuance of the war would mean the introduction of the French, who were already eager to renew their fight for Naples ; that the Pope was aged, and the next Pope might be equally inclined to nepotism and find it equally advantageous to take the opposite side; that Italy was by no means secure from Turkish invasion, and would require unity for effective opposition; and that the stable Government of the House of Medici, if they obtained Ferrante's friendship, would be of much more service to Naples than the constant changes of Government and the policy of a turbulent republic (J. Mich. Bruti, L. vii.). Ferrante detained Lorenzo a long time to see what would happen during his absence from Florence. Florence remained firm, and, finally, he signed a treaty with Lorenzo. 
Lorenzo had played a bold game, and he had won. Florence feared Ferrante ; she did not fear the Pope when he stood alonè. Her gratitude, her enthusiasm were unbounded. Lorenzo might have achieved a throne ; but his political penetration saved him from a step for which Florence was not yet ripe, and he continued to rule the State, only, more firmly and thoroughly than before, screened behind that traditional mask of his House, the affectation of simple citizenship (1480).

He took advantage of his popularity to get a new permanent balia of seventy created-all good men and true, in the Medicean sense. All matters of every nature were to be first brought before this new council. The gonfaloniere were to be admitted on their retirement, unless the Council chose to exclude them, and the body was to nominate those eligible for office, a business which they took four years over, in order to thoroughly test aspirants for power, and trim them into habits of future submission by the allurements of expectancy. The council was permanent, but from it two committees were drawn every half-year-one for foreign, the other for domestic affairs. The other councils continued to sit as before. But in 1490 some symptoms of insubordination appeared among the seventy, and Lorenzo reduced its authority, securing the reform of the State to a balia of seventeen, whereof he was himself a member.

The obsequious council of I480 paid Lorenzo's debts. He loved to live in magnificence, to bestow charity with an unsparing hand, to surround himself with a pomp that would feast the eye and subjugate the reason. He was wholly unscrupulous in money matters, entrusting the management of charities to those whom he wished to reward, and throughout his rule public moneys were used to meet his private needs, or sustain his banking house in times of crisis or from the consequences of injudicious speculation. He organized a spy system, which pryed into the minutest details of private life, and he interfered with the private concerns of citizens without the least scruple or hesitation. Yet Guicciardini remarks that " if Florence was to have a tyrant she could never have found a better or more delightful one." And it must be confessed that, if freedom languished, public order came to be much better respected under Medicean rule than it was in the old turbulent times. There was less liberty, but there was also less crime. Trade flourished, the city grew, and public works were erected on a large scale. Scholars were provided with public appointments, the full recognition of art led to its full development; Plato and philosophy and the religion of love and beauty were discussed at the famous symposia at the foot of Fiesole; it seemed as if the Nine Muses had taken up their abode in the beautiful city on the Arno, and Florence shed a light over the world of art and thought and letters-" the light which never was on sea or land," which is destined ever to abide with us and cheer the saddened heart of our disillusioned modern world. The palace in the Via Larga became a school where the conflicts of intelligence trained the minds of future Popes. The quick quip and the merry jest resounded through the hall, interspersed with mystic interpretations of Greek philosophy. For Ficino and Pico della Mirandola

" In thoughts more elevate might reason high

Of Providence, Foreknowledge, Will, and Fate-

Fixed fate, free will, foreknowledge absolute-

And found no end, in wandering mazes lost." 
Pulci might be heard reading to an enraptured audience that strange, sweet, unaccustomed medley of human emotion and romance of incident from the immortal pages of his Morgante, and Lorenzo, himself a poet, sat at the head of his hospitable board and gave impetus to them all.

The conquest of Otranto by the Turks (1480) so thoroughly frightened Sixtus IV. that he hastily concluded peace with Florence; the fortresses which she had lost on the borders of Siena were recovered, and, later ( 1487 ), Sarzana was recaptured.

When Sixtus died Lorenzo altered his policy. He allied himself with the new Pope, Innocent VIII., and so checkmated the fierce antagonism between Milan and Naples ; hence he became the very centre of the balance of power, and was called "the needle of the Italian compass"; the Pope made his infant son a Cardinal; and, uncrowned as he was and without title, he took a higher place than ever among the potentates of Europe. Even after the conspiracy of the Pazzi, the Sultan recognised his importance by extraditing one of his conspirators, ${ }^{1}$ while Louis XI. had treated him as a brother ruler. The liberties of Florence still remained lulled to sleep by the opiates of artistic luxury and sensual enjoyment, which he well knew how to administer, and he was, perhaps, all the more beloved that he had so large a share in that delicate and delightful art of adorning the indecency, which, as Walpole remarked, everybody is able to understand. At the height of his popularity and power, however, and while still in the prime of life (he was forty-five), he was summoned by the silent, unexpected, austere messenger that comes to all. Neither dissolved pearls nor powders of precious stones were of any avail. Lorenzo, the corruptor of Florence, sent for Savonarola, the monk who attempted to become its regenerator, and, according to Poliziano, the most trustworthy of many authorities, the two repeated together the prayers ordained for the dying. Lorenzo passed away quietly in April, I492, and after lying awhile in the peaceful seclusion of San Marco, his bones were gathered to those of his fathers in San Lorenzo.

Lorenzo had adopted the precise methods of corruption which have been employed by so many usurpers, and which were familiar to the French of the last generation during the occupation of their throne by Napoleon III. He found himself in a position in which he must either sink or swim, and under conditions where moral scrupulosity did not obtain. The anarchy of republicanism, where the Republic was nothing but a loose agglomeration of families and trade associations, and the development of the commune into the State, had furnished growing capitalism with its opportunity. In some States, as in Milan, a feudal family or a successful military adventurer founded an acknowledged despotism ; in other States, as in Florence, Bologna, and Siena, wealthy merchants established a real tyranny which was disguised by the retention of republican forms. The Medici did not stand alone in their policy

1 The Sultans frequently give evidence of their sense of international obligation and courtesy; and, in spite of the well-known prohibition of the prophet, the Grand Turk had his portrait painted by Gentili Bellini, who went to Constantinople for the purpose. There can be no doubt that in the thirteenth century the Arabs were much more civilized than the Christians, and the Turk was becoming modified in the fifteenth century, both by Arabic influences and by those of commercial intercourse with Christian nations. 
or success. Other citizens of other cities, such as the Bentivogli of Bologna and the Petrucci of Siena, were equally apt at the trick of exploiting existing institutions to the establishment of their own personal power. All the despots, dependant on diplomacy for safety in the midst of so many ambitious little States and conflicting interests, caught the spirit of intellectual liberation, and surrounded themselves by men of letters and artists, who gave distinction to their Courts. Giovanni Bentivoglio, uncrowned King of Bologna, intermarried his daughters with the established Princes of the land, just as the recognised despots did. And the substitution of consistent foreign policy and some measure of order in the administration of the State seemed a compensation for the loss of a freedom which had been abused, and which, after all, never was the possession of the great mass of the people, though they had been transfused with its spirit. The impetus generated in the clash and conflict of intelligence in the struggles for liberty and rule in the past had not yet exhausted itself ; it still issued in the production of great scholars, brilliant thinkers, romantic poets, and imaginative painters. Trade flourished and wealth increased in Florence, while in Perugia and Genoa and some other States the streets still resounded with the bloody conflicts of enveromed party, and these republics were unable to hold their own against powers that were becoming stronger and bigger every day.

\section{SIENA}

Siena was now a place of far less importance than before; she had been outstripped by Florence in commercial development and extent of territory, and though sumptuous palaces were built during this period, the unceasing strife of faction and the constant attempts of the banished to effect a return by armed attack, together with a series of inglorious wars, prevented the development of the Republic that had been so weakened by the great exodus of 1385 . She fought with Florence against the common enemy, Ladislaus of Naples, who tried to accomplish from the South what Gian Galeazzo had nearly succeeded in effecting from the North-to become King of all Italy. When this danger was over, jealousy of Florence again induced a war with that city, and then Piccinino, the condottiere, tried to take possession of the weakened State (I455). The great defects of the constitution of the Republics were that, in order to prevent any particular person or family or clique from seizing power, the Government was chosen by lot, and was frequently renewed. This arrangement had the advantage of bringing home to every eligible citizen the responsibilities of rule, and of developing the faculties of manhood, but it was wholly unsuited to times when the loose organization of the community into separate subsidiary governments of family, class, and trade association liberated fierce passion. It allowed of men of great mental and moral inferiority coming into office, and it rendered continuity of policy impossible. The Republic, half conscious of these defects, adopted the Florentine expedient of giving balia or extraordinary powers to fifteen citizens, who were to be entrusted with the defence of the State against Piccinino. The council of balia thus constituted to deal with a 
special emergency ultimately became the central and most powerful magistracy of the State. The signoria still retained all the outward dignity of chief officials of the Republic, but real control was gradually usurped by the new council. And just as in Florence the balia was manipulated by the Medici, so in Siena it was the sword and mouthpiece of the various parties that from time to time got the upper hand in that turbulent community. Now it was managed by the Monte dei Popolani, now by the Monte dei Noveschi, then by Pandolfo Petrucci, later by the Spanish Governor of the city, and ultimately, a century later, by the representative of Duke Cosimo of Tuscany.

The new Collegio di Balia proved its strength. The lesson that Venice had given to Italy in the execution of Carmagnola was not forgotten, and when the discovery was made that the Sienese commander, Conte Giberto da Corregio, was holding traitorous correspondence with Piccinino, the fifteen took advantage of his coming to the city in order to receive certain sums that he demanded of the Government, to summon him to their presence. They received him with all due ceremonial observance. Once inside the Sala di Concistero he was cross-examined as to his doings, and confronted with proofs of his treachery. "Do you apprehend that I am your prisoner ?" asked the Count, rising in a rage. "Anything but a prisoner," was the answer. The signal was given, and armed men rushed into the hall to execute him. In a moment all was over, and almost before life was extinct the body was thrown out of window. But though the policy of Venice had been followed, it was not pursued with the calm contemptuous imperturbability of the Eastern Republic. Siena was a small, weak State, and the Pope was informed that the Count had been slain in a street riot. When the truth became known Calixtus III. gave absolution to the fifteen, but refused it to the city, with the sarcasm that it would never do for heaven to be a celestial Siena (L. Banchi, Archiv. Storico Italica, Ser. iv., Flor., I879-1880).

Piccinino was in alliance with the King of Naples, and there were not wanting certain of the Noveschi to conspire with that monarch to secure the predominence of their own party at the expense of national freedom; for, more than ever, party was before patriotism.

And now a Sienese nobleman, Enea Silvio Piccolomini, was chosen to the chair of St. Peter (I458). In recognition of the honour, Siena admitted his family to the franchise, but took care to distribute the members among the monti, and Siena is still gorgeous with the frescoed pageantry of the great scholar-Pope, while the glorious architecture of Pienza, his birthplace, bears evidence alike to his family piety and his artistic perception. But proud as Siena was of her Pope and her Pope of Siena, Pius failed to obtain the restoration of the aristocracy to their pristine political power.

The continued exclusion of the old aristocracy and the Dodicini from office may have been wholly justified by a desire to maintain the sort of equilibrium that obtained in Siena; but it naturally gave rise to much heart-burning, and the ambitious King of Naples was not slow to employ the discontent of these political outcasts to further his own ambitious design of becoming King of all Italy, or at least of carving out a principality of Tuscany for his son, the Duke of Calabria. Siena became a fulcrum to which he applied the lever for the subversion of all Tuscany. The Republic, always jealous of Florence, joined the league of the Pope and 
the King of Naples against Lorenzo dei Medici ; she was obliged to lean on some powerful State to defend her territories, and, after Ferrante had arranged terms with Lorenzo, he thought the time had come to tighten his grasp on the stormy little State. He had demanded the recall of the exiles, but this was stoutly denied him. His son had a strong party in the city. Weary of strife, or deprived of share in the Government, they wished to submit their city to his rule, and the Duke carefully fomented the mutual dislike of the Noveschi and the popolani. He left some of his mercenaries in the city when the war was over, and remained in the neighbourhood himself. One day in June, I480, the Monte dei Noveschi, certain of the Monte del Popolo, and the mercenaries, got up early, and occupied the great open space opposite the Palazzo Pubblico. The Riformatori were successfully expelled, and the Duke, who had stayed away in order to appear quite innocent, now rode into the city to " preserve order," as he said. The simple Sienese welcomed him with enthusiasm. "When he got to the door of the palace all the people rejoiced, trumpets sounded, bells rang a gloria, guns were fired off, and there was uproar of rejoicing " (Diar. Alleg. Allegretti, R.I.S., xxiij.). It was agreed that the ejected monte should be replaced by a new Monte dei Aggregati, to be composed of certain nobles devoted to the Duke, of Dodicini, and, by ducal request, of a few well-disposed Riformatori and of certain other popolani who had been in league with Piccinino and were also for Neapolitan control. Undoubtedly Siena and probably all Tuscany would have become an appanage of the Neapolitan Crown, but the taking of Otranto by the Turks required the Duke's energies in his father's kingdom, and, when the Sienese were called upon by Ferrante to return to Florence those border castles and territories which they had captured from that city, the King and the Duke were no longer popular in spite of the banquets and festivities with which the Duke had indulged the passionate, pleasure-loving people.

Furious party fights, almost incessant scenes of bloodshed and wild disorder, followed the disappearance of the Duke from the scene. Furious partizans exiled one another turn and turn about; streams of blood flowed down the steep streets ; men were cast out of the palace windows or led to the scaffold. The Noveschi, the Dodicini, the Riformatori, the Nobili were by turns attacked, proscribed, excluded "for ever" from political power. In the midst of all this Siena again saw herself given over by her own pious but undisciplined people to the care of Our Lady. Arrogant merchants were replaced by truculent demagogues, and the number of Sienese in exile grew greater day by day. In vain did the Pope send a peacemaker; he retired in disgust. The mess did not lack stirring ; Lorenzo dei Medici in particular was not sorry to see a neighbour weakened. At last the exiles, supported by Naples, Innocent VIII. and Florence, attacked the city, and carried the gate of Fontebranda with very little bloodshed. The Government was reconstituted, prominence being given to the Monte dei Novi. It described itself as "pious, and devoted to the glorious Virgin " ( 1487 ). Of course plot and agitation, street fighting, chopping off of heads, and expulsion went on, and the State experienced changes of government of quite kaleidoscopic character. But the monte of the Nine got more and more power, and the balia was worked by the governing caste to its own preservation. In I494 Siena had one of its passionate fits of contrition. The duomo was once more 
crowded with hereditary foes, who kissed one another and swore on the cross to become brothers "for ever," while the notes of the Te Deum ascended to the cupola. The curse which excited the astonishment of Uncle Toby was nothing to the horrible maledictions that were called down on those who should break the peace. "And now may it please God that this may bring peace," writes the Sienese diarist, "but I misdoubt it" (I494). The "revival " was sincere while it lasted. Even five months later it had not spent itself. Governing power was fairly distributed among the different cliques, amnesty was given to the exiles, and there was another great sacred service with much singing and ringing of bells.

A certain measure of peace was now given to the city. The Noveschi of the time, men of ancient burgher lineage. with great traditions, had got the State into their hands, and ruled it by means of the balia. They were people of considerable education, and great patrons of art and learning, disciplined by adversity, and with some instinct for government. They followed the Venetian pattern of concentrating authority in a cabinet, and a consiglio dei tre segreti, chosen from the balia, brought its powers to an effective focus. Instituted in 1492, it was often suppressed by the enemies of the Noveschi, but always restored; it was the main engine of a Government that had, in fact, become oligarchical. The State was in the hands of wealthy burghers, like Florence before the rise of the Medici ; these formed a highly cultivated class that patronized letters and the arts, and among them is to be found the scholar-patriot Niccolo di Bartolommeo Borghesi, who became Secretary of State and professor at the University, and Pandolfo Petrucci, who was put in charge of the piazza in front of the Public Palace, and thus enabled to lay the foundation of his preponderance. 


\section{BOOK VII}

THE INVASIONS OF ITALY BY THE GREAT POWERS:

THE LATER RENAISSANCE, I494-I530

\section{GENERAL SURVEY OF ITALIAN HISTORY}

\section{The Papacy and the Foreign Invaders}

\section{The Invasion of Chavles VIII.}

WhEN Innocent III. died, vast sums began to pour into the Roman banks. It was evident that the Papacy was for sale to the highest bidder, and that the bidding would run high. One of the competitors, Roderigo Borgia, the nephew of Calixtus III., was a man of great wealth. He expended it lavishly, and by this and by the unsparing but judicious placing of big promises, he got the requisite majority of votes. It is said that only five votes were not for sale. Roderigo was then a hale, sanguine man of sixty-one years, of no very large brain, but of a good deal of driving power. He was half intoxicated with joy at his success. "I am Pope, Pontiff, Vicar of Christ!" he shouted, with the delight of a successful schoolboy at a game. Roderigo was the adoring father of a fair-sized family, chiefly by a lady to whom he gave a variety of husbands and to her husbands place and emolument; but this hardly deserves notice : his predecessor had openly avowed himself as the proud head of a family of sixteen well-favoured youths and maidens, all of his own begetting, and the new Pope does not appear to have laid claim to so many. He was, indeed, rather a welcome successor to the Papal chair, for he had had considerable discipline and experience in affairs, was a trained jurisconsult of Bologna, and esteemed to be a good companion and full of bonhomie. For Alexander was one of those essentially selfish men who gain a good name among their fellows by a bluff manner and the absence of any hypocrisy concerning those little frailties to which most men are inclined, and which they freely excuse in one another. Such petits défauts were almost commendable in a man who had become an Italian Prince and the official head of a Church that was now almost purely official. They did not detract from the qualifications of the Vicar of Christ.

Borgia took the title of Alexander VI., and his consecration was marked by all kinds of mythological festivities, while inscriptions in his honour informed an admiring world that "in Cæsar Rome was great; now she is at her greatest, for Alexander VI. reigns : the first was a hero, the last a God " - "Cæsare magna fuit, nunc Roma est maxima. Sextus Regnet Alexander, ille vir, iste Deus " (Greg., Luc. Borg.). But the new Pope's position was not wholly satisfactory. The son of the late Pope had sold his possessions to the powerful Orsini, and it was not at all certain that Ferrante of Naples had not supplied the purchase-money to get a fulcrum near Rome. Vain, foolish Medici (the younger Piero of that House) piqued at what he considered to be a want of consideration for His 
Magnificence, had induced Ferrante not to send an Embassy to the new Pope. The result was that Lodovico Sforza, surnamed the Moor, alarmed at the general demand made on him to give up the rule of his duchy to the nephew whom he had dispossessed under the pretence of regency, and conceiving that Florence and Naples were allied against him, concluded a counter-alliance with Venice and the Pope, and threw himself on Charles VIII. of France, who was meditating a renewal of the ancient claim of Anjou to the kingdom of Naples. His nephew, the legitimate heir to Milan, was, we are told by Comines, a quite incapable person (Mem. Ph. Com., L. vii., c. ii.); and Lodovico gave his niece in marriage to the newly-elected Emperor of Germany, and obtained for himself the investiture of the duchy. But this grant was secret, and Lodovico was anxious to get Charles into Italy, so that, by increasing his own importance and support, he might declare his investiture and secure his position (I493).

It was a dangerous game to play. The various States of Spain were united by the marriage of Ferdinand the Catholic with Isabella of Castile, and by the conquest of the Moorish kingdom of Granada. The Emperor, Maximilian, united the Low Countries and Burgundy with Austria, and was likely to recover Imperial authority in Germany. The French Crown had subjugated the peers of the realm, and controlled a vast and obedient kingdom, enjoyed a large revenue, and commanded a brilliant army. The Turks menaced the whole shore of the Adriatic, and the Swiss, who had learned how to fight by maintaining their independence against Charles the Bold, were turning their valour and skill to market advantage, and becoming the hardy mercenaries of the highest bidder. Italy was surrounded on all sides by powers that had become gigantic, and not one of which, fifty years before, had given her the least uneasiness. Nor was she uneasy now. Her wealth, her previous superiority, had given her a sense of being perfectly secure from the uncivilized peoples across the Alps. One man, and one only, sounded the note of alarm. Jacopo Sannazaro, a Neapolitan Court poet of Spanish origin, called attention to the danger, a danger which, as their despatches show, even the astute political agents of Venice failed to realize.

Charles, educated on romances, thought himself another Charlemagne. He entered Italy with an excellent, well-equipped army of nearly 4,000 heavy cavalry, nearly 30,000 foot (Gascons, Bretons, Swiss, and French), and a train of the best artillery in Europe (1494). But, as Comines tells us, " everything really needful to a great enterprise was wanting; there were no tents, there was no ready cash." Savoy and Montferrat threw open the gates of the Alps and the fortresses of Piedmont. Lodovico gave them access to the ships of Genoa. Venice, confident in her own strength, observed neutrality, and compelled Ferrara and Mantua to follow suit. Naples was joined by the Tuscan Republics and the Papacy.

At Asti Charles was assailed by the plaints of the young Duke of Milan, (Gian Galeazzo Sforza) and his mother; but the smiles of Milanese ladies had greater power over him than the widow's tears. Charles adhered to the supplanter who had called him in, and a few days after, by the hand of God or of his uncle, Galeazzo conveniently ceased to breathe. The Neapolitan army was held in check in the Apennines, the Neapolitan fleet defeated off Rapallo, and Charles advanced along the shore-line, 
where Florentine fortresses might have delayed his army and exposed the besiegers to the pestilential fevers of the marches. Piero dei Medici was seized with terror, however, advanced to greet Charles, surrendered the fortresses to him, and lost Florence in consequence ; her citizens rose against Medicean rule. Pisa revolted: the sea had receded from her harbour, but the ancient spirit survived in her diminished population, and she furnished the mercenary troops of Italy and Europe with soldiers that commanded admiration, even of the French. Charles left a garrison in Pisa and advanced to Florence; he found it impossible to restore Piero dei Medici. He was threatened by Piero Capponi, and dreading attack in the narrow streets, departed for Rome by way of Siena, the Neapolitan army retiring as he advanced. He entered Rome on the last day of the year, without encountering the least opposition.

Now, for the first time, the Italians learned the changes that had taken place across the Alps. Hitherto she had been held facile princeps among European countries. Her wealth was still as great as that of all the European nations put together, for she had been their manufacturer, carrier, and banker. But while they were becoming colossi she had developed no principle of nationality; she had entrusted her defences to mercenary troops that had developed the art of war by developing the art of avoiding battle. This was not the first time that the Northern nations had been called in to Italy : it was the first time that they had appeared as mighty. Had she possessed any principle of union she might even now have held her own, for her common people were still uncorrupt. But she possessed no such principle, and just as the more intellectual Greek fell before the Roman, so was she destined to fall before races of lower type. The very intellectuality and individuality of her men was in her disfavour. In spite of the shiftings of trade, wealth, and power caused by the discovery of a new world across the Western ocean, and the opening up of a new route to the East by the Cape, she would probably have fallen to the strongest of her own despots, developed a principle of nationality, and in some way regenerated herself, had she been left alone. Other nations have passed through periods of corruption and survived, and although foreigners often spoke of the treachery of her politics, they exhibited no less treachery among themselves or towards her ; they complained of the Italian because he had a finer intelligence, and beat them at their own game. But the bad faith of the monarchs of Europe concealed a vital principle of growth; behind the greed of the throne there was the support and impetus of growing nations, the desire for unity and order. In Italy there was no nation and there was no patriotism : each despotic, each republican State was for itself alone. Individualism had triumphed, and it fell in the moment of its triumph before a loftier principle. The Pope was inclined to resist Charles. But his latest mistress, the beautiful Giulia Farnese, fell into the hands of the French, and His Holiness was in despair until she was ransomed. And when Charles pointed his guns at the castle of St. Angelo the Pope gave way.

Alexander had the faculty of throwing off disagreeable reflections. Even when Charles was advancing, he devoted his days to hunting, his nights to dancing and feasting and the company of light women and of his children, of whom he was passionately fond. He paid for these entertainments by the sale of benefices, and by wringing money out of 
unhappy wretches, Moslems and Jews, driven from Spain, who could find no better refuge than the Holy City. For, truly, a cut-throat and graceless city had Rome ever been, even in the days when Boccaccio feigned that it converted a Jew to Christianity when he beheld that religion survive in such a sink of iniquity. And now it was so full of loose depravity, knavery, rascality, grossness, and atrocity of every kind; it had become so unutterably vicious and so full of villainy, that the poor souls must have been hard put to it indeed before they took refuge in a place that might have passed for some miscreated consequence of hell.

Alexander celebrated Mass before his new friend the King, and knew so little of priestly duty that he had to be prompted. Charles passed on towards Naples. Here he met with some slight resistance, which he punished by the massacre of all the inhabitants of two small towns which he carried by assault. Alfonzo II., the reigning monarch, abdicated on behalf of his son, Ferrante II., and whether they were influenced by terror or discontent, or by both, his subjects began to revolt ; the barons, the cities, sent deputations to Charles, and the whole kingdom of Naples surrendered without fighting a single battle. He was crowned King of Naples and Jerusalem, Emperor of the Orient. It is a French contemporary writer who bears witness to the excessive cruelties of the French. He says that it hardly appeared to the French that the Italians were men (Zeller). They had all the contempt of rude warriors for a people unaccustomed to the use of arms.

Meanwhile the Powers of North Italy regarded the facile conquest with jealousy and alarm. The Duke of Orleans, afterwards Louis XII., who had remained behind at Asti, declared his pretension to the duchy of Milan as heir to his grandmother, Valentina Visconti, for it had been agreed thai ${ }^{+}$in default of main heirs the duchy should pass to Valentina's issue. Lodovico Sforza, alarmed at this, brought about a league of Venice, the Pope, the King orf Spain, and the Emperor Maximilian, and he and Venice assembled a powerful arrmy, chiefly of Venetian troops, near Parma. Thirty thousand men were reaity to oppose Charles' retreat.

Charles determined to return to "France, leaving half his army to hold Naples. He passed through Rome in peace, the Pope shutting himself up in the castle of St. Angelo. He ref used to surrender Pisa to Florentine subjection, and marched on to the Apennines. Gonzaga, Marquis of Mantua, commanded the allied trioops, and awaited him. Charles was attacked while in full march juisi after crossing the Taro; his divisions were at some distance from each (nther, and for some time his army was in great danger, but French impetiosity and Swiss obstinacy ultimately carried the day. The Italian pnen-at-arms were dishorsed in large numbers, and immediately slain bry the camp-followers. Three thousand five hundred Italians lay dead onl the field. At Asti he had to ransom the Duke of Orleans from Sforza, who was besieging him, and then repassed the mountains (I495) : after having produced in Italy violent disturbances as of a passing hurriciane. Pisa had thereby been set free from Florence, Florence from the Modici ; the old equilibrium of States was destroyed; Italy was rendered dejendent on foreign nations, and a vicious tyrant and a vicious Pope were leist undisturbed to earn the hatred of their contemporaries and the obloquy of posterity. 
Naples, which had welcomed the advent of the French, now rose against them. Ferrante II. was recalled by his people, and after many battles the French were expelled from the kingdom (I 496).

\section{The Invasion of Louis XII.}

The accession of the Duke of Orleans to the French Crown (I498) boded fresh ill to Italy. He took the titles of Duke of Milan and King of Naples. Venice was again menaced by the Turk and by Maximilian, who laid claim to Venetian possessions on the mainland as appertaining to the Empire. The Senate signed an alliance with Louis to abandon the duchy to him, reserving Cremona and the Ghiara d'Adda to themselves. Maximilian was irritated by the Swiss, and to attack them the more effectually abandoned his alliance with Lodovico. Alexander seized the opportunity to consolidate and extend his temporal power. He had a son, Cesare Borgia, a man of force and energy, who knew no restraint human or Divine, but only the skilful gratification of his lusts and ambitions-a crafty, prudent, calculating statesman, handsome, and whose personal magnetism made him the most powerful person of Rome and seems to have fascinated his father, even though he was believed, probably. with justice, to have murdered his own brother, the Duke of Gandia, with whom he had quarrelled concerning the loose affections of the wife of a third brother.

The only restraint known in Rome was the restraint of personal consequences, the only duty conceived of was to enjoy life to the fullest, and to devote all one's powers to the protection, perfection, and adornment of one's personal existence and the exercise of its power. Cesare was a man of no scruple but of great intellectual ability, and it became Alexander's aim to enrich his son's life and to gain him great possessions. He determined that Cesare was the man to do the needful work of consolidating and augmenting the Papal States; he combined statecraft with paternal benevolence, and the Vatican looked on with equanimity at the prospect of a powerful Church vassal replacing those disorderly municipalities and rebellious despots of the worst type that still occupied a feudal position towards the Papacy. For the condition of the Papal feudatory States was indeed deplorable, and nothing but complete subjugation could possibly relieve them from the incessant warfare between jealous and ambitious petty rulers, and the rivalries of families that were for ever executing vendetta within the circuit of almost every city. The condition of the country may be gathered from the fact that when one of the Papal legates was nominated to Perugia and Umbria he found, among other quite ordinary incidents, that one baron had smashed the heads of the children of a rival against his walls, cut the throat of the wife, who was big with child, and then, discovering that there still remained one infant, had nailed it like vermin to the door of his palace (Josephi Ripamonti, Hist. Urbis Med., L. vii.). The Campagna had been emptied by the wars of the Orsini and Colonna, and crime, cruelty, and treachery were doing their best to depopulate and brutalize the other States of the Church. Devoid of moral scruple as was Cesare Borgia, cruel as he could be in warfare, it is an evidence of his brilliant intellectual powers that, as we shall see, he not merely succeeded in re-establishing full authority, but in 
instituting good government in the districts that had been disordered for so many years.

The Papacy had its due share in the iniquity of calling in the foreigner. For Alexander secured French aid for the enterprise of his son. Louis VII. desired a divorce from his wife in order that he might marry Charles' widow, and so possess himself of her dowry of Brittany. Alexander granted it, relieved Cesare of his ecclesiastical vows, and sent him to the French Court with an autograph letter recommending him " as our most dear son, our very heart, than whom we hold nothing dearer" (Molini, Documenti di Storia Italiana.-Firenze, I836, I837, vol. i., p. 28). The King made Cesare, who had been a Cardinal, but was released from priestly vows, Duke of Valentinnois, and it was understood that the Pope would support the King's claim to Milan as a descendant of the Visconti on the spindle side. Nevertheless, the Pope had certain designs on Naples which required the aid of Spain, and the Spanish Ambassador and Alexander frightened one another with threats; the one offered to prove that Alexander had become Pope by nefarious means, the other promised to throw the Ambassador into the Tiber. The Venetian Ambassador, a clearsighted man, after the manner of the emissaries of his State, wrote home full details of the Papal Court; he said that Alexander's policy was wobbling, that his sole design was to advance his family, that he wished to get Naples for Cesare, and that meanwhile he was making Rome the noisome dungheap of the world.

Lodovico had no allies. Florence had to guard against the intrigues of the Medici; she was bent on bringing Pisa again into subjection, but fearing to excite jealousy she dared not assemble an adequate army for that purpose, and her rivals, Siena, Lucca, and Genoa, actuated by dislike of Florence rather than love of Pisa, sent the beleaguered city aid. Frederick of Naples was fully occupied in re-establishing order in his exhausted kingdom, and had neither money nor men to spare.

A powerful French army crossed the Alps (August, 1499). They took two petty frontier fortresses by assault, and put the garrisons and almost all the inhabitants of the villages they had served to protect to the sword. This ferocious proceeding had its due effect; it spread terror among the Milanese troops, and the Duke fled to Germany to seek the protection of Maximilian. Louis arrived at Milan, and the trembling people of Lombardy, and even of Genoa, placed themselves under the French yoke. But when Louis returned to France at the end of the year a general ferment spread through Lombardy. The insolence of the victors, their violation of all national institutions, their contempt for Italian manners, their evil administration, their oppressive taxation, rendered the yoke odious and unsupportable. Lodovico the Moor, acquainted with the general unrest, returned to Italy in February, I 500 ; he appeared at the head of a small Swiss army. Como, Milan, Parma, and Pavia threw open their gates to him; Novara capitulated. Louis sent De la Tremouille with an army, in which there were I0,000 Swiss, to suppress the "Moor." The Swiss in both camps came to a base understanding; an order from home, or the gold of Louis, effected the desertion of Lodovico's mountaineers, and the ex-Duke, who attempted to escape in disguise, was betrayed by a soldier of Uri and sent to France, where he ended his days in the obscurity of the State prison of Loches. A strong Governor, the 
Cardinal George d'Amboise, was given to Milan; his moderation and the reconstitution of a kind of national assembly reconciled the Milanese to French direction.

Frederick of Naples, alarmed by the facility with which Louis had conquered the duchy, now sued for peace, and offered to hold his kingdom as tributary to the French Crown. He relied, however, on the support of Ferdinand the Catholic, who had sent sixty vessels and 8,000 chosen infantry to Sicily. But Ferdinand had recently proposed a secret understanding to Louis whereby, while the French entered the kingdom from the North, its ostensible defenders should advance from the South, and instead of giving battle should occupy and divide the kingdom between their respective masters. "This infamous treaty," says Creighton, "was the first open assertion in European politics of the principles of dynastic aggrandizement." The French army arrived at Rome at the same moment that the Spaniards landed in Calabria; they passed on to Capua, and entering the city while the magistrates were signing the document of capitulation, put 7,000 of its inhabitants to the sword. Frederick gave up hope, surrendered to Louis, and was sent to France, where he was kept in captivity, but his imprisonment was rendered as little galling as possiblc. The whole country surrendered without resisting, and Cesare Borgia entered Naples with the French army (I 5OI). The object of his presence was to show the amity between the Pope and France; the Colonna and the malcontents at Rome could no longer oppose a Pope that had the support of France, and with Rome quiet it was possible to proceed with the reduction of Romagna.

But no sooner was the Neapolitan conquest terminated than disputes began concerning boundaries, and soon they broke into open warfare. Louis delayed sending reinforcements to his General while negotiations were pending; the result was that, after a struggle in which the famous chevalier Bayard, " sans peur et sans reproche," fought bravely, the French army was practically destroyed, and by 1504 the whole kingdom of Naples had, like Sicily, become a Spanish possession.

\section{The Conquests of Cesare Borgia.}

When Louis entered Milan, Cesare hied thither to pay court, bearing the French flag. ' Louis gave him money and some French lances, and with the title of Gonfaloniere of the Church he set out to eject the petty tyrants of Romagna and the marches of Ancona, the last nurseries of arms in Italy; for everyone of the feudatories was a condottiere. The Pope had already plied the Orsini against the Colonna and the Colonna against the Orsini in the Campagna, where these two great families were paramount, and he had succeeded in weakening both. He was thus fairly secure at home, and under the pretext that they had not paid their dues, Cesare set out to dethrone the Vicars of the Church. Ancona, Assisi, Spoleto, Terni, and Narni still remained republics, delivered over to faction and constantly at war with their neighbours. Vicars of the Church ruled the rest of the States, the Varani and Fogliani dividing the marches almost entirely between them. Sinigaglia was a fief held by the Rovere ; the ancient House of Montefeltro held sway in the mountains of Urbino ; in Umbria the fierce family of the Baglioni governed Perugia,; Citta di 
Castello was under the excellent military rule of the Vitelli ; in Romagna a Sforza ruled at Pesaro; the Malatesta held Rimini, which they had governed since the thirteenth century, and the present ruler, of evil renown for cruelty and debauchery, like the other condottieri Princes of the province, was subsidized by Venice and practically independent of the Pope. Cesena, indeed, was under the immediate government of the Church, which had snatched it from the Malatesta, but Forli and Imola were subject to the House of Riario, which Sixtus IV. had raised from utter meanness and obscurity; while the Manfredi held Faenza, situate between Forli and Imola, under the supervision of Venice, for whom it laid open an easy passage into Florentine territory. Venice had also possession of Ravenna and Cervia, snatched respectively from the Houses of Polenta and a branch of the Malatesta ; Giovanni Bentivoglio had for forty years been despot of Bologna; and Ferrara, the remotest and most independent of Church feudatories, had for ages been in the possession of the noble House of Este, which united with this the Imperial fiefs of Modena and Reggio. The numerous Courts of so many little despots that had displaced republican Governments gave Romagna an appearance of wealth and elegance; they were the resort of scholars and poets ; architects built and painters adorned shapely palaces, and delicacy and refinement characterized the society within them. But the expenses of these luxurious Courts crushed an overtaxed and miserable people, and the struggle for power among the petty Princes engendered an insecurity which led to treason, assassination, and atrocity of every kind within the family circle itself. Each petty government was founded on force, maintained by force, and only force could overturn it. Cesare Borgia knew full well that if he could become master of the petty States of Romagna, the people would pardon every crime, every cruelty, every treason, if only he secured them peace and granted them justice.

He took Imola and Forli (1499); the successes of the French caused Bologna, Ferrara, and Florence to withhold their aid from the Romagnol princelets. In I 5 Or Faenza had to capitulate; Cesare violated the terms of surrender, and after overwhelming Manfredi with protestations of friendship, had him strangled. Cesare was now (I 5OI) invested with the duchy of Romagna by his father; he exercised cruel severity to repress crime by means of his subordinate, Ramiro d'Orco, and in order that no resentment caused by his lieutenant's inflexible administration might fall on himself, he knew when and how to dispose of him. One morning a scaffold was found standing in the market-place of Cesena, and from it hung the corpse of the man before whom all had trembled; the stained instruments of death lay beside the body, and this bloody exhibition was the only, but suggestive communication on the subject vouchsafed by Cesare to his new subjects.

He now sought to enter Tuscany, divided between four republics and the little principality of Piombino. The republics were enfeebled by their wars with each other, and Siena had come under the control of a citizen, Petrucci, who was fully occupied in maintaining his position. Cesare forced Bentivoglio to pay him tribute for Bologna, and tried to foment a conspiracy in Florence, but found himself unable to procure revolt; he secured a subsidy, and left his lieutenants to take Piombino, while he joined the French forces that were marching on 
Naples. He could do no more at present, as he was forbidden by France (I5OI).

The Pope, who had favoured the entrance of Louis into Italy to further the interests of Cesare and so strengthen his own temporal power, was privy to the secret negotiations between France and Spain for the division of Naples ; indeed, he hoped to get something out of it for Cesare, and had dreams that his son, who had exhibited the craft then needed for greatness, would perchance arrive at the kingship of all Italy. When the Spaniards rounded on the French the Pope bargained with Louis to help him if Naples or Sicily were given to Cesare. He married his daughter Lucrezia to the Duke of Ferrara, who was too strong to be dispossessed at present. Twice had the Pope annulled his daughter's previous marriages for political reasons, and Cesare had made away with her third husband, the Duke of Bisceglie. After the failure of a first attempt on the Duke's life Borgia remarked that "what could not be done at dinner shall be done at supper." Lucrezia and Bisceglie's sister cooked the wounded man's food since no one else was to be trusted; but, unable to use poison, Cesare appeared one evening, sent away the two unresisting ladies, and had Duke strangled in bed. The Pope was in such awe of his son that it is said he did not dare utter a word when Cesare murdered his favourite servant and confidant in his arms ; indeed, he was extremely proud of so hopeful a young Prince, and sold red hats to furnish him with money for his wars ( $P$. Cappello, Venetian Ambassador ; vide Alberi, Relazione.Gregorovius Geschict. v. Rom.).

Returned from Naples, Cesare induced the Duke of Urbino to lend him artillery and forces to reduce Camerino; he turned them against Urbino itself and captured it. The little Republic of San Marino sought his protection; he took Camerino, and had its lord and his two sons strangled. Complaints of his conduct reached the Court of Louis, who had come to Asti. The Borgia seduced Louis' great Minister, the Cardinal Amboise, by dangling the prospect of succession to the Papacy before him; it was proposed to elevate to the Sacred College a sufficient number of priests who could be relied on to vote for him. Louis was influenced by his adviser, and also by the personal charm of Cesare ; he lent him 300 lances to continue his work, even against Bologna, though Bentivoglio had paid him for his protection.

The treachery of Cesare towards Urbino was a mistake; the Duke was popular with his subjects; they revolted and restored him ; and some of Cesare's own condottieri, including the lords of Citta di Castello, Perugia, Fermo, and the representatives of Bologna and Siena, afraid lest their turn might come next, entered into a conspiracy with the Orsini to overthrow him. These men were no less perfidious than Cesare, and one of them, at least, was of a character even more false-hearted. They were incapable of mutual trust or of obtaining the confidence of the other foes of the Borgia. Cesare had remarkable suppleness in diplomacy, a frank, genial address, a persuasive charm, a confiding manner, which deceived even the shrewdest. He was made aware of the plot, and effected an apparent reconciliation; the Duke of Urbino fled ; Sinigaglia was captured, and then Cesare seized and executed the conspirators, while in Rome Cardinal Orsini was arrested and imprisoned. Citta di Castello and Perugia submitted to Cesare, and when France tried to check 
his career Cesare took advantage of the successful treachery of Ferdinand towards Louis in Naples to turn his coat, enter into friendly relations with Spain, protect Pisa, and scheme to subdue the republics of Bologna and Florence. With France and Spain at war, the Papacy felt tolerably secure, and Central Italy seemed to be within Borgia's easy grasp. "If there were not war between Spain and France, where should we be ?" exclaimed the Pope : Aut Casar aut nihil was now the frequently-repeated motto of the young model of Machiavelli's "Prince." Cesare told Machiavelli that he had prepared for every eventuality; for his father's death ; for the manipulation of the conclave ; for the elevation of one of his own creatures to the Papal throne. One thing only did he forgetthe possibility of being himself ill at the time of Alexander's decease.

Yet it may be doubted whether all the political acumen and ingenuity in the world could, even under the most favourable circumstances, have led to solid success and the establishment of an Italian kingdom. There was no national sentiment in Italy; she was a heterogeneous collection of different kinds of government, different institutions, different traditions, different impulses; she was now subject to the interference of two strong European Powers, governed by absolute monarchs who pursued single ends, one of them firmly established in the North, the other still more firmly fixed in the South of her territory; the republics were indeed weak, and Venice was the only State that was capable of real resistance ; but the resistance of Venice would have thrown Cesare on the support either of France or Spain. Alexander leaned towards Spain, for he was a Spaniard; but he intrigued with France, offered North Italy to the Venetians as the price for their aid, pressed Maximilian (who was meditating a descent into Italy to take the Imperial crown) to give Pisa to Cesare, as otherwise he would accept the French offer of Naples in exchange for Romagna (Giustinian. Despatches, May 29, June 7, 8, 31, I 503). Such fickle diplomacy at such a time shows the uneasiness and impotence of the Borgian policy.

Alexander fell sick and died, and Cesare was ill at the time, and unable to make any essay of his designs. Of course, it was said that the Pope was poisoned : the evidence shows that he died of Roman fever, and that many ambassadors, cardinals, and Cesare himself, who had sat with the Pope al fresco after a banquet, were seized at the same time with the same complaint.

The Orsini and Colonna returned to Rome ; Cesare's troops surrounded the Vatican, indeed, but the Sacred College managed to evade them ; a French army approached Rome to support the pretension of Cardinal d'Amboise, and Cesare deserted the Spaniard to ally himself once again with the French. But all his Spanish Captains left him, and the cardinals refused to choose a new Pope until Cesare left the city and D'Amboise had promised to remain at Nepi. The cardinals elected almost unanimously the aged and reputable nephew of Pius II., who took the title of Pius III., and D'Amboise, having nothing further to wait for, marched on to Naples. The Orsini and Colonna now came to an understanding; they defeated Cesare's troops, which had re-entered Rome, their leader at their head still ill and dispiritcd and carried on a litter. Cesare had to seek the security of the castle of St. Angelo, with the permission of the Pope. Pius III. died ten days after his election, and Borgia, who 
had never exhibited any tendency to good faith, was obliged to trust himself to Julius della Rovere, now Pope Julius II., his oldest and most inveterate foe. The cities of Romagna curried favour with their old masters by returning to their obedience, Venice seized Rimini and Faenza, Julius demanded the citadels of Romagna, which still held out for Cesare, and on his refusal to surrender them had him seized and imprisoned, and then given over to the Spaniard. The projects of the Borgias were vast, vaster than the means to achieve them that they found at their disposal. Cesare, in his fallen fortunes, experienced the bitterness of captivity in the fortress of Medina del Campo-a mild fate for unsuccess in the doubles and duplicity of sixteenth-century statecraft. After two years' imprisonment he effected his escape, and met a death worthier of a better man, the death of a soldier, in 1507 .

Bad as the Borgias were, it can hardly be said that they were worse than the high-class society that surrounded them. Men played for great personal stakes in the age of the High Renaissance : to seize and hold the reins of government was securer and far more delightful than to remain in an ignoble and equally if not more perilous privacy; to have chosen the latter course would have been unintelligible to and suspected of one's contemporaries. The observance of strict honour would have been fatal ; at least, it would have been as effective as the correct conduct of a law-abiding citizen in society where the production of a pistol or the adoption of a ruse were of more avail. The astute and ambitious survived, and personal as well as dynastic aims knew of no other end than personal or dynastic success. The Borgias were treacherous murderers, but they were no worse than most of the Princes of their time ; they were licentious, but the "family" had ceased to be the corner-stone of exalted society. Alexander was a carnal man, who enjoyed his own life far too much to seriously interfere with the enjoyment of others. He may have poisoned a cardinal or two to " raise the wind," but this could not have been a fixed practice, for Creighton has shown that the mortality among the cardinalate was not greater in Alexander's time than before or after (Creighton, Papacy, v., 57). Cesare was bold and unscrupulous, but as far as good government may condone, the " Gonfaloniere of the Church " could plead that justification for his career. He could become taciturn, and he affected mystery when he did not affect frankness of manner; both he and his father were Spanish, and the family circle conversed in this foreign tongue : these facts of themselves caused suspicion and dislike. The scandals concerning the Papal family witness not so much to its supreme degradation as to the corruption of the age and of its high society, and the tales of subtle poison, circulated at the time, cast a strange and lurid light on what men thought possible, and even likely, in a period unrestrained either by social circumscription or religious convention, and marked by the liberation of all human passions and aims from the restraints of intellectual synthesis, the bonds of public conviction, and the coercive force of authority.

\section{Julius II. and the League of Cambrai.}

The election of Pius III., a hopeless invalid, was due to a combination of parties to gain time and get rid of the French army and the pretensions of Cardinal d'Amboise. Pius died, as a contemporary says, "before any- 
thing could occur to mar his pontificate, which would most assuredly have happened. For he had not committed simony, nor warred against Christians, nor murdered, nor hanged, nor beheaded, nor wasted the patrimony of St. Peter on war, nor on his bastards, nor on others " (Epist. Sigismondi Senesis, Siena, 1877). The pro-French and pro-Spanish parties in the Sacred College had time to collect their strength. Julius della Rovere, by promise, among other things, to confirm Cesare Borgia as Gonfaloniere of the Church, got all the Spanish votes; the French party saw in him only the man who, out of hatred to Alexander VI., had warmly invited the French to enter Italy; and by various treaties and simoniacal practices Julius was proclaimed Pope before the doors were shut on the conclave. He was skilled in arms, and had been Papal legate in France, where the display of his marked ability led to his paramount ascendency in the College of Cardinals until the accession of his enemy, Alexander. Julius' life had been licentious, restless, and passionate, but no one who has seen Raphael's portrait of him at Florence, or even the inferior replica in our own gallery, will fail to have been struck with the evidence of the latent energy, decision, vehement power and superiority presented in a face that overawes and commands a perhaps unwilling respect.

Julius was resolved on recovering the lost fiefs of the Church, although almost his sole means of effecting his object lay in his iron will, his vehemence which affrighted, and his imperious princeliness of soul which overawed. The cities of Romagna gave in their submission. Julius then demanded of Venice the restitution of the little States she had seized in Romagna. The refusal of Venice meant unedurable submission or appeal to foreign aid. Julius saw and said that the disunion of the Italian States would enslave them to alien Powers, but Venice had been shameless enough to seize Rimini and Faenza when Romagna threw off the authority of Cesare, and was impolitic enough to hold on to them. The Pope's hot indignation at an intolerable aggression decided him to repel one evil by summoning another. Spain and France were effecting a treaty of peace, and the Pope contrived to bring about a separate understanding between the Empire and France, whereby it was agreed to attack Venice and divide her territory on the mainland (I 504). Nothing came of this agreement at the time, except that Venice tried to pacify the Pope by surrendering a few unimportant places; but Venetian greed had irritated more than one European Power, and all were jealous of her wealth and magnificence. The first step had been taken towards a coalition against her, and the fiery old Pope went on nursing his wrath and resentment.

By promising the red hat to the three nephews of Cardinal d'Amboise, Julius withdrew French protection from Bentivoglio, the despot of Bologna, and then the astonished world saw yet once again a Pope heading an army. Perugia opened her gates, and then Bentivoglio fled before the Papal troops, that were preceded by their commander's Bull of excommunication, and a French army advancing against him from Milan. Gradually Perugia began to shake off the evil influence of her former masters, the Baglioni, and reformed her constitution on genuine communal lines; in Bologna Julius instituted an oligarchy of forty, and so restored a shadow of Republican freedom; but his legates were ill-chosen, 
and the citizens, though they submitted to Papal rule, remained ripe for revolt. Although Julius was not free from simony, he promulgated a Bull which put an end for ever to actual money transactions in Papal elections ; but he was rash enough to restore their fortresses to the Colonna and Orsini.

The restless-brained and clever but unstable Emperor, Maximilian, that stormy petrel of the politics of his time, now decided to proceed to Rome to take the Imperial crown, and deprive France of the Milanese which he claimed through his second wife, Bianca, the daughter of Galeazzo Sforza. He offered to divide the conquest with the Venetians. But the Republic had small confidence in the statecraft or abilities of the Emperor, and a short war followed, during which the capricious Emperor advanced and retired, and then went to North Germany, while his small army melted away. But friction occurred between the Venetians and the King of France, each charging the other with having acted with a sole view to self-interest; and Maximilian smarted under the loss of Goriza, Trieste, Pordenone, and Fiume. The time was now ripe to recover the territory which Venice had snatched from the Church. She had made no friends and many foes, for France coveted the portion of Lombardy she had retained as the price of the overthrow of Ludovico the Moor; Spain grudged her the ports on the coast, which she held by a legal title, though maintained by a purely self-regarding diplomacy which connived at the infamous treaty of partition between Louis and Ferdinand; Maximilian and the Pope were smarting under recent injuries. The commercial instinct for aggrandizement and the even, just government, past security, and wealth of a small city, commanding only three millions of subjects, made the lords of desolated plains and miserable peasants green with jealousy, and this base emotion was the true inspirer of their hate. Instigated by Julius, the quondam foes united; for the first time since the Crusades rulers were of one mind ; and the recently-formed Great Powers agreed to inaugurate the restoration of European concord by falling on and dismembering an independent State. A secret league was arranged at Cambrai (December, r 508), whereby Maximilian and France were to divide Venetian possessions on the mainland between them, the Pope would recover Ravenna, Rimini, Faenza, and other places, and Spain would get possession of Monopoli, Trani, Brindisi, and Otranto. Hungary and Savoy were to be invited to join ; the former was to have Dalmatia, the latter Cyprus. Venice had been accused of not having defended Europe against the Turk with sufficient energy : none of the contracting Powers engaged to fulfil that duty.

France declared war on Venice within a month (I 509). Hostilities commenced in April, and three weeks after the Pope issued his Bull of excommunication against the Republic. The Venetian Generals disagreed, and the Venetians lost the battle of Agnadello. Bergamo, Brescia, Crema, and Cremona surrendered, and by the end of May the French had conquered the country assigned them by the treaty of partition. The campaign was marked by a renewal of martial bloodthirstiness to which Italy had long been a stranger. Henceforward bigger armies were employed; the field was again covered with the slain; defeat was followed by ruthless pursuit; national hatred of the foreigner inspired more determined resistance ; and the foreigner endeavoured to intimidate by the exercise of barbarous severity. Louis hanged the Venetian 
governors of Caravaggio and Peschiera ; he ordered the garrisons and even the inhabitants to death; he put the wealthy Venetians who fell in to his hands to ruinous ransom. Henceforward the struggle between Italy and her foreign invaders grew bloodier year by year.

The French suspended their operations after the end of May; but the disasters of the Republic encouraged the other Powers; they fell all at once on the maimed and exhausted foe. The pontifical army vied with the French in ferocity; all the inhabitants of Brisighella were put to the sword, and Romagna yielded ; the Duke of Ferrara, who had joined the league, took Rovigo and the ancient patrimonies of his house without resistance; the Marquis of Mantua seized territory that Filippo Maria Visconti had compelled his great-grandfather to surrender. The conjoined fleets of France and Spain advanced towards the Apulian coast, and Venice recalled her commanders, and sent word to her subjects on the Adriatic that henceforward they must account themselves Spaniards. Maximilian's army was slow in collecting; he had dissipated the subsidies he had obtained from Flanders, but a Vicenzan proscript entered Padua with a gathering, unopposed. Treviso alone resisted. A cobbler waved the Venetian flag before the mob, and drove the Vicenzan exile and his followers from the city. The grateful Senate exempted Treviso from taxes for fifteen years, burned the list of tax-payers in the market-place, and again advanced its troops (I 509).

The Venetian Senate had advised its subjects to submit. It recognised the impossibility of holding its possessions against so many enemics, and took the generous resolve to release all its dependents from their oath of fidelity since it was no longer able to defend them ; it knew that in letting them feel the foreign yoke the regretful memory of their own paternal Government would be cherished, and that they would yearn for and catch at an opportunity of again hoisting the Lion of St. Mark. Venice had perhaps relied on the jealousies of the Powers to keep them apart; she believed that jealousies and hatreds would yet serve to divide them. Her calculations were justified. The evacuation of the mainland obliged the allies to execute the provisions of the treaty of Cambrai, a proceeding that revived their envies and antagonisms. Maximilian, who had done nothing, was all for taking Venice itself; Ferdinand the Catholic, who had got what he wanted, was already regretting the eclipse of Venice, and meditating on the possible resuscitation of her power; Louis, having acquired the portion allotted to him in the bond, had disbanded his army and withdrawn to France. At the bottom of the soul of Julius there was magnanimity and a larger patriotism than was current in the peninsula; he was now possessed of the territory he claimed, though he still continued to demand absolute submission on the ecclesiastical questions in which Venice had always retained an independent obduracy; but he could not but have been remorseful that he had been the soul of the league; he meditated how he could expel the foreigner from Italy, extend his own dominion over Ferrara, which was in Matilda's bequest, and overthrow French preponderance. Meanwhile Venice waited secure in her lagoons, where she had stored hier war-chest, her army, and her fleet. Her selfcontrol began to manifest its just consequences. The dispossessed ruling classes of Padua had declared for the Emperor, and exercised a revived authority in his name; they aspired to Imperial distinctions, and desired 
to rule the people as the nobles of Austria and Hungary ruled their serfs ; they became arrogant, and within two months the populace was all for Venice. Venice took advantage of this to surprise Padua, and the mob sacked the palaces and the Ghetto. The Bishop of Trient, charged with the defence of Verona, felt himself insecure, and sent to Mantua for reinforcements; the Marquis answered the appeal, and was taken prisoner ; Padua was strongly garrisoned, and, while Maximilian was busy collecting a formidable army, Venice got reinforcements over the Adriatic, raised among the sturdy mountaineers of Dalmatia and Albania. Maximilian appeared before Padua at the head of the largest army that Italy had seen for ages; the infantry was composed of 18,000 landsknechte, 6,000 Spaniards, 6,000 adventurers of all nations, and 2,000 Ferrarese ; there were 106 mounted cannon, and 6 huge mortars, besides artillery sent from Milan. France, Julius, and Mantua sent small contingents, and the army numbered altogether not far short of 100,000 men. The mutable Emperor displayed his best qualities; he was put on his mettle, and he exhibited personal bravery, military ability, indefatigable activity, and the qualities that he really possessed but ordinarily dissipated in fickle and ever-shifting activity. The good government of Venice now bore its fruits; the peasants had cleared the country to the best of their ability, and while Padua was well victualled, the hostility of the agriculturalist threatened the success of a prolonged siege. Dissensions arose in the patchwork army, and it is said that the intrepid, romantic Bayard refused to advance to the assault on foot unless accompanied by the German Princes and nobility ; if they were willing to get off their horses the French chivalry would show them the way to the breach. The Germans replied that they fought only as men of birth-that is to say, on horseback (Mémoires du Chev. Bayard, C. xxxvii., xxxviij.). The commander of the French lances and the chief of the German staff were on very bad terms with one another, and Maximilian, with his usual incalculable inconstancy, abandoned the siege (October, I 509), and soon after wended his way homewards up the long valley of the Adige, while the formidable army of the league broke up into its component parts. Maximilian had no money to go on with, and he charged his allies with abandoning him; the King of France quarrelled with Julius about the nomination of a Bishop, and seized the revenues of the Church in the duchy; the brute force of the Teuton and the cold malignity of the Spaniard in robbing, and the brutalities of organized bands of the French, called " flayers," had wrought up the people to a bitter resentment of the coarse, insensitive cruelty of the invading races, for which their own more subtle, civilized methods had little prepared them. Julius withdrew his troops, although on account of ecclesiastical differences he did not yet openly favour Venice; Vicenza hoisted the Venetian standard, and Verona remained the sole important place not in Venetian hands.

Venice now recognised the full rights of the Church, and received absolution ( 5 IO), and the Venetian army was recruited by the condottieri of the Papal States, the best soldiers in Italy. The Pope cast about for help to eject the French; he approached Maximilian, but the only effect was to increase the Emperor's resentment against Venice; Maximilian even tried to get the Turk to attack her. Julius invested Ferdinand the Catholic with Naples, but Ferdinand was too wary to break with the 
league. Then Julius bethought him of the Swiss. The Swiss mercenaries had been the mainstay of French arms-needy, brave, natives of a country where everyone was poor and ignorant and the national and cantonal authority possessed neither the restraining power of dignity nor the coercive force of wealth, these hardy adventurers had come down from the mountains and sold their lives for a song. But made aware of their value they had struck for a higher wage, and the French King had dispensed with their services. Julius sent Schinner, the diplomatic Bishop of Sion, to confer with the Diet. The venal Diet hesitated; the members were open to French bribes; but I0,000 Swiss advanced on their own account : they found they could do nothing against the French and retired (I5IO). The Genoese exiles tried to take Genoa and failed; the Papal troops took Modena, indeed, but the Venetians were repulsed before Verona. The French army now advanced towards Bologna, where Julius lay sick, and he was offered terms by the French General, for Louis was ill at ease in warring with the Holy Father ; but the Pope's energy, even in sickness, and the arrival of Venetian help saved the situation, and Julius called on the Christian Kings to attack France. Recovered from his illness, the rigours of winter did not prevent the Pope from leading his troops in person over the snow, and he took Concordia (I 5 IO) and Mirandola (I 5 I I). Then the death of the French commander led to the appointment of Trivulzio, a General of Italian birth, and nephew of the man whom Louis had first entrusted with the government of the Milanese. Trivulzio recovered Concordia and Mirandola; Bologna had to be abandoned; the Bentivogli re-entered the city, and the colossal bronze statue of the Pope, the work of Michael Angelo, was overturned and cast into cannon. The King of France meditated the deposition of Julius, and in conjunction with Maximilian summoned a general council of the Church to meet at Pisa, to which Julius retorted by convoking a general council of his own to meet the following year in Rome. Julius now fell seriously ill, and was seized by a lethargy so profound that a report of his death spread everywhere. Fortune seemed to have deserted him (August, I 5 II).

Meanwhile Pisa had held out against Florence for fourteen years. From I 507 to I 509 she had been defended by Louis and Ferdinand merely to extort money from the Florentines as the price for her surrender. At last it was agreed that IOO,OOO florins should be paid to the King of France, and 50,000 florins to the King of Aragon, as indemnity for alleged breaches of agreement. The foreign friends of Florence thus called upon her to pay for permission to reoccupy territory which had once belonged to her, and that she considered and they admitted to be her own. The treaties were signed in March, and in June, I 509, Pisa, horribly reduced by famine, opened her gates to her ancient masters. Florence tried in every way to conciliate and attach a proud people, but almost every family that had the means emigrated, and the population, already reduced by war, iontinued to diminish after the Florentine reoccupation.

\section{Julius II. and the Holy League.}

In spite or, it may be, in consequence of rejecting the counsels of his physicians and refusing their remedies Julius recovered, and at once employed all his energies to baffle France. He approached Spain, England, 
and Venice. Louis refused the Ambassadors sent by Ferdinand and Henry VIII. to request the restoration of Bologna to the Pope ; he replied that he would guard it as he would Paris (Guicciardini, L. x.-Fr. Belcarii). In October, I5II, it was publicly announced that a Holy League was formed of the Pope, the Most Catholic King, and the Venetian Senate to preserve the unity of the Church threatened with schism by a conventicle at Pisa, to recover the city of Bologna for the Holy See, and all other fiefs that belonged to it (this meant Ferrara), and to drive out of Italy whoever should oppose (that is to say, the French King). Commercial disabilities instituted by France and the hope of booty also induced the Swiss to make independent war. Gaston de Foix, the Governor of Milan, was now threatened on all sides, but he maintained his ground against the Swiss, and drove them back to their mountains (I 5II). Meanwhile Florence dared not oppose the sitting at her city of Pisa of a council which she supposed would be representative of France and the Empirc: to this depth of abasement had the chief of Tuscan republics fallen. The Council of Pisa opened with the presence of three dignitaries representing the two monarchs and the Church, and all the priests of Pisa immediately left the city to avoid interdict. At length four other discontented cardinals arrived under the safeguard of French troops; they were excluded from the cathedral, and had a difficulty in securing a church where they might hold Divine service. Ultimately they were compelled to an undignified retreat from Pisa to escape the consequences of a quarrel between their pompous servants and the more sprightly youth of that city.

But more serious matters were in movement. The Spanish Viceroy, Ramon de Cardona, advanced from the South at the head of a powerful army in compliance with the designs of the Holy League, and besieged Bologna ; the Venetian army was on the move, and Brescia was ripe for revolt. Gaston de Foix, Duke of Nemours, nephew of the French King, a brilliant young soldier, was placed at the head of the French army ; he inspired his troops with his own enthusiastic spirit; he advanced with ever memorable rapidity, and forced the Spaniards to raise the siege of Bologna, and beat a precipitate retreat through Romagna. Meanwhile Brescia was taken by the Venetian army, and Bergamo and other places revolted against the French. Gaston de Foix hurried up to Brescia, encountering and defeating the Venetian army, commanded by one of the impetuous Baglioni of Perugia, on the way; he then attacked Brescia. Bayard, the "chevalier without fear or stain," was the first to scale the ramparts; he was dangerously hurt; the soldiers believed him to be mortally wounded, and this inflamed them to avenge his loss; the city was taken ; its citizens, that still continued to shower stones and tiles and firebrands from housetop and window, were slaughtered to the number, after the most moderate computation, of 7,000 or 8,000 , and the city was given over for two days to the brutalities of the soldiery; neither social position nor even the veil protected the Brescian women. But a just Nemesis pursued the French, and "of these pleasant vices made them whips to scourge them "; the pillage of Brescia amounted to 3,000,000 crowns, and, say the "Mémoires of the Chevalier Bayard," nothing is more certain than that the taking of Brescia was the ruin of the French cause, for they got so much that most of them turned back and left the war " (Mem. C. L.-Fr. Guicciardini, L. x.-Petro Bembo, L. xii.ar, awr. Ann., I 512). 
Meanwhile all parties, even the French, were competing for the services of the Swiss, but the mountaineers asked exorbitant terms. France, however, possessed in De Foix a military genius of a very high order; only twenty-two years of age, his record was one that few aged warriors have attained. But six weeks elapsed before he could reorganize and discipline his army, and then he marched for Romagna. Ramon de Cardona had taken up strong positions, and De Foix marched against Ravenna. The forces of the league were obliged to advance to raise the siege, and on Easter Sunday, I 5 I 2 , the most murderous battle that Italy had yet seen took place-nearly 20,000 dead covered the plain. In this battle mobile artillery was, for the first time, the decisive factor. The Spaniards were compelled to retreat, but they did so in good order; Gaston, furious at this, charged them at the head of a small body of men, was unhorsed, and slain. Ravenna was taken, but it had been bought at a big price; and the French commander who succeeded De Foix was incompetent. Julius fooled the French King with a pretence at negotiation, while he urged Venice to employ the Swiss at any cost, and he patched up a peace between Maximilian and Venice, and even got the Emperor to join the league. Even before this Maximilian allowed 30,000 Swiss to pass through the Tyrol, and soon after he recalled all Germans who were serving under the banner of France. Ferdinand and Henry VIII. of England made a simultaneous attack on Louis, and he was obliged to recall his troops from Italy to defend himself at home. As these withdrew the Swiss occupied the Milanese in the name of Maximilian Sforza, the son of Lodovico the Moor.

The Pope did not forgive Florence for her support of France. When the victorious Powers met at Mantua it was proposed that Florence should be mulcted in a heavy contribution, but the Medici presented themselves before the congress, asking to be restored, and paying down Io,ooo ducats on the spot. There was a strong Medicean party in Florence, and the Government was weak, but it prepared for defence. Ramon de Cordona advanced on Prato, which shut its gates against him; it was well fortified but defended only by country militia wholly unused to serious warfare ; it was taken, the militia put to the sword, not less than 2,000 people slaughtered in cold blood, and the richer burghers tortured until they disclosed their wealth or were ransomed by their friends. Next day a revolution took place in Florence, the Medici entered, a pretended assembly of the people was held, attended chiefly by soldiers and strangers, and the creatures of the family were entrusted with full powers.

The Pope recovered Bologna, Ravenna, and the rest of Romagna, and his lieutenant, the Duke of Urbino, made himself master of Modena and Reggio, though the Marquis of Este held on to Ferrara. Brescia still held out for France; the Swiss who supported Sforza against Charles, the grandson of the Emperor and the Most Catholic King, were given the head of Lago Maggiore and Lugano; Sforza and his Swiss demanded Cremona and the Ghiara d'Adda to be yielded; Maximilian required Vicenza and Verona, which Venice absolutely refused to give up. Julius, in order to give weight to his council, ignored by France, was obliged to seek acknowledgment by the Emperor, and had to support Maximilian. Venice retorted by approaching France ; the Papal and Imperial claims to Piaccęnergiarma, Reggio, and Modena conflicted; a Spanish 
army advanced to Brescia and took it, and the Swiss remained in the duchy, the real masters of Milan. Such was the tangled skein that had to be unwound when Julius was taken ill and died (February, I513). His last moments were marked by dignity and a mixture of affection and majesty, of dispassion and fixed resolve, of dignified contrition and solicitude as to the due government and purification of the Church. All Rome, from the noble to the mendicant, went to kiss the dead man's feet, and prayed with streaming eyes, even his enemies, for all Italy believed that he had saved her (Grassio, Paris de, quoted Camb. Mod. Hist., 1902, vol. i., p. 252). All he had really saved, perhaps all he sincerely sought to save, was the temporal power, and that he had gone far to consolidate. And if not a munificent patron of artists, Julius II. was a sincere lover of art. To this love we owe many of the best achievements of Raphael's brush, some of the finest productions of Michael Angelo's chisel, and that vastest of Christian churches, St. Peter's, the offspring of the great imagination of Bramante, who designed it to be as imposing as his successors have allowed it to remain spacious.

\section{The Struggle between France and the Empire.}

Italy had felt the power of the great States that had grown up around her, though she had not yet fully realized how very powerful they had grown; the smaller States had become the dependents of the larger, the larger States were coming under the direction of the great Powers. Papal authority had revived, but it had taken a temporal rather than a spiritual direction, and it was necessary that the Pope, now become the most formidable of Italian Princes, should command the worldly respect of the worldly Princes of the West. The Medici had been reinstated in the first city of Tuscany, and the Sacred College elected Cardinal Guliano dei Medici, the son of Lorenzo and head of the House, to succeed Julius. He was a man in the prime of life, " magnificent," like his father, in his love of learning and the arts and lavish expenditure; that he was ignorant of matters of faith and but indifferently pious was of small importance ; as the head of the rulers of Florence he added the control of Tuscany to that of the States of the Church. Leo X. found himself in possession of Emilia, Umbria, the marches, and Latium, and all-powerful at Florence, while the States of Lucca and Siena were tremblingly submissive. The Pope ruled 4,000,000 people, and the Papal name still commanded some deference in Europe.

The King of France had been attacked by England and Spain ; he lost Navarre, but secured peace with both his opponents, and, strengthened by the Venetian alliance, meditated the recovery of the Milanese. The Swiss were masters there, and ruled in the name of Sforza the Duke; they had no notion of the art of government, and made a mess of their attempt at a business for which they were unfit by nature and training. A French army strengthened by German mercenaries was sent into the Milanese under La Trémouille and Trivulzio, and was welcomed by the Guelphs ; by the aid of a French fleet a French party succeeded in a coup d'état at Genoa; the Venetians advanced as far as Cremona, and Novara. and Como alone remained loyal to Sforza. But bodies of Swiss descended the mountains to Novara, crept along under cover, and surprised the 
French. Eight thousand of La Trémouille's troops are said to have perished, and, having lost all his stores and artillery, he was obliged to recross the Alps. The Venetian army also retired, and Cardona, who had hitherto remained inactive, watching them from the Papal States in Emilia, now advanced and reoccupied the territory they had seized. The Spaniards and Leo were at peace with Venice at the time; they professed to act on behalf of their ally Maximilian. Probably Cardona was impelled chiefly by a soldier's love of booty ; France had been his master's foe, and there was ready the excuse of punishing Venice for the encouragement she had given to France. Leo was, it is true, pursuing Julius' policy, but a reason nearer to his heart was that he desired to provide territory for his nephews and, as a side issue, to increase the Papal power. The lieutenant of the Emperor, the Cardinal of Gurck, now took the direction of the war; the troops were never paid, they had to live by pillage, and the heartless greed of the French and Germans induced a hatred of both races which three centuries of subsequent sufferings at their hands did not allay. Nor were the Papal troops free from blame. Padua was ineffectually besieged, and Gurck shot his cannon-balls across the lagoons towards the capital. When the siege of Padua was raised the Spaniards tried to retreat to Trient by way of Bassano, but the Venetian troops, Stradiots from Illyria, and the hardy peasantry, harried them. The Governor of Padua ventured out to take them in the rear, but the Romagnol infantry proved no match for the veteran Spaniards; the Venetian troops were utterly defeated, and the Spaniards took up winter quarters on the Euganean Hills. Once again crushing disaster had fallen on Venice, but the Senate faced the mutations of fortune with an equal mind; no thought of acceding to the demands of Maximilian entered into their consideration; they wrote to their General not to despair, and voted a fresh army ( 15 I 3 ).

The theatre of war now shifted from Italy to the West. Henry VIII. of England, in accordance with a treaty with the Pope, the Emperor, and the King of Aragon (now practically King of Spain), attacked France, and won the "Battle of Spurs." James IV. of Scotland, the ally of France, was killed at Flodden Field, and Trémouille, besieged by the Swiss at Dijon, capitulated, while the French fleet was destroyed by a storm at Honfleur. But the Pope and his allies began to reflect that the time could not be far distant when Charles, the grandson of Maximilian, would unite the Crowns of Austria and Spain, and that Louis had proposed a matrimonial alliance between his daughter and another grandson of Maximilian, with the Milanese for her dowry. The union of so many States would render the Papacy a mere protected monarchy; it would endanger the balance of power in Europe, and, to crown all, a capable monarch sat on the Turkish throne. By a happy coalescence of mutual checks in the political game, not unmarked by bad faith, quiet was restored, except in Venetia.

When La Trémouille surrendered to the Swiss at Dijon, he had promised that the French claim to Milan should be abandoned, and to pay 400,000 crowns. Louis refused to ratify the bargain, and the remainder of his reign saw vast military preparations. On the death of Louis (I5I5), Francis of Angoulême ascended the French throne-a selfish man, licentious, and essentially vulgar in soul, quite shallow, with a fondness for 
art, full of impulsive megalomania, and determined from the outset to win back Milan. He was supported by an intelligent and thrifty people, who accepted a new-found unity, and quietly submitted to the Crown. The King directed and controlled a novel power. At peace with his neighbours, he was able to throw the most formidable army that had yet invaded Italy on to the plains of Lombardy by a mountain pass which had hitherto remained unknown to the soldier. Trivulzio led the French army, and met with little resistance. But Swiss troops were coming down the passes in great force. Francis tried to negotiate in vain ; the towns were for peace, but the men of the forest cantons, led by Schinner, the Bishop of Sion, determined to move on to Milan, where the Guelph party had been overthrown. On September I3, I515, the Swiss troops encountered the French at Marignano, where they lay in a bad position, but protected by irrigation canals. The day was already far advanced when the Swiss began their attack; despising all artifice of war, they tried to break the French centre by sheer intrepidity and personal courage; some rushed up to the very mouths of the cannon that guarded the King; they had succeeded in disordering the ranks of the foe when night fell; the commingled troops fought on for four hours by the light of the moon. Deep darkness alone stopped the strife, and, during the night, the French trumpets were continually sounded, and the horns of Uri and Unterwalden made reply (Mémoires de Fleuranges). The Cardinal of Sion supplied the Swiss with provisions from Milan, while the French concentrated their troops and rearranged their batteries. When day dawned, the battle was renewed with fresh fury ; the Swiss repelled the charges of the heavy cavalry of their foes, and were effecting a flanking movement, when Venetian troops arrived on the scene and turned the fortunes of the day. The Swiss retired in good order, and their victors were too exhausted to pursue. Two days after, since no more money was forthcoming, they recrossed the mountains. Marshal Trivulzio had had an experience of eighteen pitched battles; he avowed that those were child's-play compared to this "battle of giants ": 20,000 dead covered the field, of whom two-thirds were Swiss.

The victory of Marignano was decisive. Eight of the Swiss cantons signed a treaty of peace with Francis, receiving large sums of money as a recompense for the abandonment of their claim to bailiwicks in the Milanese ; and this compact furnished Francis with the opportunity of raising such Swiss infantry as he might need; Cardona withdrew to the South; and the Pope and France came to an understanding whereby the Pope seized Urbino and gave it to his nephew. Maximilian Sforza relinquished his sovereignty and became the pensioner of France. But Maximilian the Emperor was far from relinquishing his claim to Milan : in $5_{5} 6$ he advanced with an army of German horse, Swiss infantry from the cantons that had not signed the treaty with Francis, and Spanish and Italian auxiliaries. The Swiss, however, were unwilling to fight their countrymen, and Maximilian had not money enough to go on singlehanded. He acceded to a treaty whereby Verona was given back to the Venetians, who had already conquered Brescia, and who thus found themselves reinstated in pretty much their old position on the mainland. But their population was reduced to one-half ; their treasury exhausted; the New World had been discovered; the Cape of Good Hope had been 
doubled ; and their old trade-route, interrupted by the Turk, was beginning to be superseded by a cheaper and safer passage for the Eastern trade. Tho whole Orient was open to the hardy sailors of the Atlantic; and the commercial supremacy of Venice began to wane.

In I519 Maximilian died, and his grandson, Charles, succeeded to possessions vaster than any that had been gathered under one rule since the days of Imperial Rome. The son of Ferdinand of Aragon and Isabella of Castile, the rich and fertile Moorish kingdom of Granada was added to what was to be his inheritance, in I 492 ; the Two Sicilies, abundant in corn and wine, in 1504 ; the fat water-meadows and industrious cities of the Low Countries, in I506; Navarre, with its hardy mountaineers, in I 508 ; and now he succeeded to the archduchy of Austria, the first of German States. Columbus had added a new, and as yet only partiallydiscovered, world, inhabited by weak and unwarlike peoples, to his domains, and but four years before he became Archduke of Austria, "Stout Cortez, with eagle eyes, had stared at the Pacific." The possessions of Charles were almost inconceivably vast, the limit to their expansion immeasurable, unknown; the responsibilities of government were enormous, but Charles was the ablest monarch in Europe, and an adept in the art. In vain did Francis attempt to balance such a mighty sway by aspiring to the Imperial Crown: the electors gave it to Charles, who henceforward was known as Charles V.

War was inevitable. All Europe was menaced; Italy was in deadly danger. Leo at first urged France, Venice, and England to a simultaneous attack on Charles; but those Powers fought shy of plunging headlong into a gigantic contest, where advantage of position was of the first importance. Diplomacy centred round the English Court, where Wolsey contrived to make the protagonists on both sides seek his master's favour, and held the balance between them. Then the shallow Pope, bent on Ferrara, the State in Julius' programme not yet acquired, found France hand in glove with Este, and Venice by no means anxious for the Papacy as a neighbour. Leo turned to Charles. " Cardinal dei Medici," says Guicciardini, " who knew the most secret intentions of the Pope,told me that he hoped, first, to expel the French from Genoa and Milan by the aid of Charles, and then to expel Charles from Naples by the aid of the French ; thus realizing that independence of Italy at which his predecessor aimed." Charles promised Leo everything he wanted-Parma, Piacenza, and Ferrara for himself, a duchy in Naples for a bastard scion of the Medici. But he counselled delay. The tension was already too great for delay. France had already attacked the Low Countries and Navarre, and the French arms were successful. The counter-stroke was given : the united Papal and Imperial troops, under Prospero Colonna and the Marquis of Pescara, advanced into Lombardy and took Milan, and Pavia and Lodi, Piacenza and Cremona, threw open their gates. In the midst of the joy that attended this first success, Leo fell ill and died ( I $_{52}$ I). He received the news from Milan with the same child-like, uncontrollable joy with which he had received the tiara- "How happy this crown makes me !" he had said. He was unfit to deal with great issues; he hugged and hungered for refined enjoyment, as a miser hugs and covets gold ; he sought luxurious ease as a saint returns to his cell; and he thought no price too great to pay for a pleasure : the liberal sale of indulgences to build St. Peter 
shocked the German conscience and produced the Protestant revolt, and when Leo died the Papal treasury was empty.

The Sacred Conclave quarrelled over the Papal States, which they intended to divide among themselves; and, as no agrcement was likely to be come to, an absent Cardinal, Adrian Dedel, a former tutor of the Emperor, was elected. He had never been in Italy, and was regarded there as a sort of barbarian. His election was practically a confirmation of Leo's later policy; but an austere, doctrinaire, Dutch Puritan, who objected to Pasquino and his squibs, and called the Laocoon a heathen idol, was not likely to reform a cultured, if corrupt, society, or please the luxurious princes of the Church.

The new Pope was at Utrecht at the time of his election; and Prospero Colonna carried on the war during the interregnum and Adrian's absence from Italy. But, towards the end of his career, Leo $\mathrm{X}$. had found great difficulty in paying his troops, and Colonna was obliged to disband all his German and Swiss mercenaries, excepting r,500 men, while the Florentine auxiliaries, not being sure what policy a new Pope might adopt, went home. The whole expense of the war fell on the Papacy, for Charles V. was fully occupied in dealing with the French in the Netherlands ; Castile was in revolt; Valencia and Majorca were desolated by a fierce war carried on between the nobles and aristocracy, and thus the whole energies of Spain were otherwise engaged; while the pay of the little army of the Emperor in Lombardy was in arrears ; and, meanwhile, Francesco Maria della Rovere marched on Urbino, where the populace welcomed him with enthusiasm ; after a half-hearted resistance the Papal commander yielded Perugia to the Baglioni, and Sigismondo Malatesta recovered Rimini, of which his father had been deprived twenty years before by Cesare Borgia. Francesco Sforza was, indeed, nominal Duke of Milan, but he was wholly unable to protect his subjects from being trampled on by the Spanish and German soldiers who upheld him ; Naples was turned to profitable account by the Spaniards, who professed to govern it ; and the Marquis of Montferrat and the Duke of Savoy had practically allowed the French to become masters of their States, through which the armies of Francis could pass afresh to the ravage of Italy.

Marshal Lautrec, the French Commander, still occupied the greater part of the duchy of Lombardy; he advanced towards Milan. The Milanese, stimulated by the harangues of an Augustinian friar, raised 10,000 German troops to defend the city; while the French army was reinforced by Giovanni dei Medici, whose troops marched under black ensigns in mourning for Leo X., and so got that nickname of the "Black Bands," under which they were to become famous ; for they restored the military reputation of Italian infantry. Lautrec took Novara; but Pavia, which he besieged, was relieved by Colonna; and the Swiss, foiled of their prey, weary of a war of tactics, and accustomed to have their own way, gathered before the tent of their General and demanded payment, or to be led to profitable battle (Fr. Guicciardini.-Pauli Jovii Vita Ferd. Piscarii._Galatius Capella.-Mem. Mart. du Bellay.Paolo Peruta). The Swiss were the sinews of his army, and Lautrec advanced towards Bicocca, about three or four miles from Milan, on the road to Monza, where Prospero Colonna had taken up a strong position. Colonna's tactics had been of the Fabian order, and Lautrec had adopted 
a similar policy; but the Swiss, ever impetuous, and resentful of slow warfare and empty money-bags, paid no heed to the entreaties of their commander; they charged along the road, which led through a deep dell, and here twenty-two leaders and over 3,00o foot perished without being able to make any impression on the enemy. In vain had Lautrec sent another portion of his army to make a flank movement : its partial success counted for nothing. The Swiss had performed prodigies of valour, but the repulse they suffered was complete, and Colonna still held his ground : not merely the Spanish and German troops, but the Milanese militia had fought well. Even yet the Swiss might have won had they renewed the attack; they fled, though in good order, and, in spite of the remonstrances of Lautrec, departed for their mountains. The General then left the army for France, in order to vindicate his skill as a military commander, which was impugned (April, I522). Lautrec had been appointed to the command solely because he was the brother of the King's mistress ; he had failed because the King's mother was his enemy, and had purloined the money destined for the campaign (Mem. de Martin du Bellay.-Fr. Belcarii Comm. rer. Gall.-Arnoldus Ferroni). Lautrec was succeeded in the command by Lescuns, marshal of Foix. Lescuns was even less fortunate ; Lodi was surprised ; Pizzighettone, considered to be one of the strongest of Italian fortresses, capitulated at the first show of attack; at Cremona the "Black Bands" of Giovanni dei Medici demanded arrears, turned their guns against the French, and threatened to open the gates to the foe. Lescuns was now forced to offer terms to Colonna, who consented to the retention of Milan, Novara, and Cremona by the French, if they would evacuate the rest of Lombardy ; for he was anxious to possess himself of Genoa, feebly garrisoned by the French, but without the possession of which the Imperialistic conquest of Lombardy remained uncertain. While terms of capitulation were being arranged, a few Spanish soldiers surprised the city; and although the inhabitants had not been disposed to defend it, it was pillaged with the utmost barbarity, and irrespective of what party the citizens belonged to ; Genoa was one of the most important commercial centres in the world, and the ruin of so opulent a place was felt by well-nigh every merchant throughout Europe.

The Commander-in-Chief of the Imperial forces now found Lombardy too exhausted to support his troops, and withdrew them to the States of the Church, where they were allowed full.license, in spite of the strict alliance between Pope and Emperor. Charles of Lannoy, the new Viceroy of Naples, and the Imperial Ambassador at Rome also contrived to impose taxes on the Italian States to support the Imperial army. Milan had to pay 20,000 ducats a month; Florence, I 5,000; Genoa, 8,000 ; Siena, 5,000; Lucca, 4,000; and even the Marquis of Montferrat was mulcted at the dictation of these Imperial subordinates. This was but a symptom of the approaching enslavement of Italy; she was already called upon to pay for the forging of her fetters.

Adrian was loitering in Spain; but, as his old pupil, Charles V., was about to travel to that country, Adrian, who wished to appear as, and to be, the impartial father of all Christian peoples, and not of one only, hastened on to Rome to avoid meeting him. His chief aim was to reform those abuses in the Church which had given a handle to the Reformation, 
and to unite Christendom against the Turk, who had just taken Rhodes from the Amalfitan Order, the Hospitallers of St. John, after a memorable siege. He invested the Dukes of Ferrara and Urbino in their duchies, but obliged Sigismond Malatesta to evacuate Rimini, where the populace had found his rule to be less to their liking than they had hoped. The Papal dignity has never been found conducive to advancement in spiritual excellence, or a very congenial field for the exercise of spiritual gifts; and the new Pope, puritanical by nature, and a scholastic philosopher by taste and education, soon found out that his position involved him in the tortuous paths of policy. He discovered that his principal Minister and confidant, Cardinal Soderini, was secretly engaged in a Sicilian intrigue, and was urging Francis I. of France to attack Sicily at the very time that he had been charged to bring about a reconciliation between the two greatest monarchs of Christendom. Adrian confiscated the goods of Soderini, and espoused the cause of Charles.

Charles V. was now all-powerful in Italy. The capitulation to Colonna and the capture of Genoa had been followed by that of the French garrisons that were left ; and Francesco Sforza was reinstated in Milan. Venice was protected by the treaty which ended the war of the league against her, and, in spite of the succour which she had given France, Charles, obliged to fight with formidable foes without and rebellious subjects within his empire, had refused to consider her as at war with him : now he declared that he would not long suffer a mere enclave in his dominions to enjoy peace while remaining covertly hostile (Fr. Guicciardini.-Paolo Paruta, Ist.Ven.). The well-meaning Pope urged all the Italian Powers to settle down as beati possidentes - that is to say, under the dictation of Charlesand he was ill-advised enough to call upon them to do so in order to defend their common country against the aggression of Soliman, the Turkish Sultan. But Venice was congratulating herself on having a good understanding with the Turk, and she had had sufficient experience of old of the value of Papal leagues against the Moslem; negotiations hung fire for nine months, and, in the end, Venice refused point-blank to defend the kingdom of Naples, except against a Christian Prince, while she got rid of the pretensions of Austria and the Empire in her territory by a payment of 200,000 ducats. Peace seemed now secured, and Italy groaned only under the exactions of the Imperial troops that she had to support, when news came that Francis was massing troops in Switzerland, the Pyrenees border-land, and the confines of Italy. The "pacificator of Europe " was obliged to abandon the rôle of father to all Christians, and assume that of defender of the peace of Italy. In August, I 523, the Pope signed a treaty at Rome, whereby he, the Emperor, the King of England, the Archduke of Austria, the Duke of Milan, Cardinal Medici, on behalf of Florence, Genoa, Siena, and Lucca, engaged to defend Italy.

Francis was delayed by a treasonable conspiracy, and could not safely leave France. Conspiracy also was active in Lombardy : the pro-French party tried to kill Sforza, the Duke of Milan, and seized and held the little town of Valenza, on the Po, for a day or two, but the plot had no other issue than the torture and subsequent execution of a great number of suspected Milanese of good family. Francis, for his sins, had the misfortune to confer the chief command on William of Gouffier, better known as the Admiral Bonnivet, a pleasant companion, an agreeable flatterer, 
and an incapable soldier. Prospero Colonna was entrusted with the defence of Italy, but he was at this moment weakened in mind and body by illness; he had not believed in an invasion, he had disbanded many of his troops, and he was ill-supplied with money by the Emperor. Moreover, the Venetian Senate had put the command of their troops in the hands of the Duke of Urbino, a man whose manner of avoiding every danger was in perfect accordance with the circumspect policy of his employers. The Ticino had run almost dry, so that the aged Colonna, after having himself transported in a litter to survey the enemy's camp, found the defence of the passage impracticable, and withdrew on Milan (September, I 523 ).

At this juncture an event happened which changed yet once more the balance of parties in Italy, and cast the league into disorder. After a few days' illness Adrian VI. died, on the very day when Bonnivet crossed the Ticino. Although Italy was already confronted with a new and formidable invasion; although a tempestuous conclave, embittered by the hostility of pro-French and pro-Imperial parties, might well give the Romans pause, no calamity seemed worse to them than that of which Adrian's unexpected death relieved them-the presence of a Pope who did not know their tongue; who had no predilection for poetry and the arts. They could have stood a little piety had it been accompanied by a little grace. Adrian had been confronted by an animosity which he had little deserved; while alive he was spoken of as the barbarian Pontiff (il barbaro pontefice); and his death was greeted with indecent joy. Next day the door of his physician was discovered garlanded with flowers, and bearing this inscription, "From the Senate and people of Rome to its deliverer" (September I4, I 523).

The Sacred College was divided into an old and young party. The elder cardinals, nominated by Julius II. or his predecessors, supported Cardinal Colonna, member of a House devoted to Charles V. and the Imperial cause ; the younger cardinals, nominated by Leo X., supported his cousin, Cardinal Giulio dei Medici. A prolonged struggle ensued, and it seemed likely that an Orsini might be elected; whereupon Colonna, dreading to see the pontificate held by the great Roman family that was from of old the rival and enemy of his own House, offered to give his votes to Giulio if his wealth were restored to him, if he himself had the post of Vice-Chancellor, and if an amnesty were accorded to all those who had opposed the Medicean candidature. These terms being agreed to, Giulio dei Medici was raised to the pontificate under the title of Clement VII. Few Pontiffs had ascended the throne with a better reputation. Clement had gained the affections of Florence, which he had governed for several years with almost absolute power; he had been the principal Minister of Leo X. and the director of his policy; he was industrious, not addicted to indulgence, prodigality, or pomp ; and he conjoined the declining, but still considerable, might of Florence to that of the Papal States. The populace and men of letters that had been patronized by his cousin, Leo X., needy, grateful, and expectant, hailed his accession with joy : much might be expected of a Pope who was an Italian, and who belonged to the most distinguished family of one of the most distinguished of Italian cities, renowned for its patronage of all that gives charm and grace to life; a man indued with the double power of Florence and Rome. At the news of 
his election the Duke of Ferrara, who had taken advantage of the death of Adrian to seize Reggio and threaten Modena, gave up his projects; and troubles excited in Romagna under Guelph auspices, with the secret support of France, were immediately quieted. Clement sent a legate, accompanied by the only two representatives of the direct line of Cosimo dei Medici, the bastard grandson and great-grandson of Lorenzo the Magnificent-Ippolito and Alessandro-to govern Florence. The first was but sixteen years of age, son of the Duke of Nemours and a woman of Pesaro; the second was born of a father whose own paternity was not indisputable, and a mulatto slave, whose dark complexion, thick lips, and frizzy hair he inherited.

During the two months which elapsed between the death of Adrian and the accession of Clement, Bonnivet, in command of 4,000 horse and 30,000 foot, did nothing but exhibit incapacity. He wasted time, and allowed Colonna to fortify Milan. Although he took Lodi, Monza, and Caravaggio, Colonna adopted the tactics of Fabius Cunctator, and to some extent revolutionized the art of warfare. By the judicious selection of positions and the stealing of cunningly contrived marches, he taught how inferior forces may avoid battle and wear out an enemy. Unhappily, this great General was suffering from severe illness all the time, and succumbed to it in December, I 523. Just before his death he had forced Bonnivet to rétire to Bigrasso. Early in 1524 the Constable of Bourbon, head of the younger House of Bourbon, the most powerful Prince in France, who, slighted by the King, and at variance with the King's mother, had fled to Italy and taken service under Charles V., arrived in Milan with a reinforcement of 6,00o landsknechte and many French nobles. 'The Constable and the Marquis Pescara were put in command, and Venice gave her commander, the Duke of Urbino, word to join the Imperial forces. But Charles V. sent no money, and the soldiery pillaged the peasantry they were sent to protect, while the Generals extorted enormous sums from the Italian States to support the war. The Imperial army, paid in gold and pillage, and flushed with success, began to attack the French. Three thousand Spanish, wearing shirts over their mail, surprised the troops of Bayard by night at Robecco ; nearly all the horses were captured, nearly all the men taken or slain, and Bayard himself had to fight his way to freedom. Pescara crossed the Ticino, and got behind the French army, and Bonnivet was obliged to take refuge in Novara, while the Imperialists tried to surround him. Reinforcements came from France and Switzerland, but Giovanni dei Medici and his Black Bands blocked the way to men of Graubünden that were advancing to the aid of Bonnivet, and then marched to Biagrasso, accompanied by Sforza, the Duke, and his Milanese militia. The victory was dearly purchased, for the place was plague-stricken ; the militia brought it home with their booty, and 50,000 inhabitants of Milan perished of it during the summer (I 524). Bonnivet now found himself in a position of considerable peril ; he stole away by night with his army from Novara; he was wounded in endeavouring to save some artillery while crossing the Sesia, and obliged to relinquish the command to the Chevalier Bayard. Bayard had scarcely taken it over when he was himself wounded by a Spanish arquebusier, and, "when he felt that he was injured, he cried 'Jesus !' and then, 'Alas! my God, I am slain.' Then he took his sword by the hilt and kissed the hilt, which 
was a cross, and made the sign of the cross, repeating aloud, "Miserere mei Domine.' However, Bayard managed to dismount, aided by his major-domo, who never left him, and was laid at the foot of a tree, face towards the foe, and here the Duke of Bourbon, who was in pursuit of our forces, found him, and told Bayard how it grieved him to find so excellent a knight in that sad plight. The Captain Bayard made response : ' Sir, there is no occasion to commiserate me that die an honest, reputable man. But I have pity for you that serve against your Prince, your country, and your vow.' And a short while afterward the said Bayard yielded up the ghost, and his body was delivered to his major-domo with a safe conduct to bear it to Dauphiny, where he was born " (Mem. Martin $d u$ Bellay). The Imperialist troops followed up the retreating French, and 400 Swiss, in the far rear, goaded by their perpetual harass, turned round and attacked the pursuers with fury: the little band was surrounded by vast numbers and completely wiped out, but their obstinate resistance enabled Bonnivet to effect a retreat, leaving behind him in the Val d'Aosta twenty cannon, which he was unable to take across the Saint Bernard. Though the forms and even something of the spirit of knighthood persisted through the sixteenth century, the death of Bayard is the swan-song of chivalry, that romantic dedication of the soldier-gentleman to "God and the ladies " at the union of which " discordant names " the eighteenth century, in the person of Gibbon, affected to blush. Whatever the vices and defects of knight-errantry, its standard of conduct and of honour vindicated justice, modified policy, animated poetry, and gave a dignity even to warfare throughout the Middle Ages; its almost complete absence in Italy is painfully perceptible ; its spirit alone gave grace to feudalism, and cemented that complicated method of tenure, delegated duty and reciprocal fidelity into what may be called, with some approach to justice, a system ; and its code of propriety and manners, passing into the Italian Courts at this period, found development and expression in Castiglione's Cortigiano, and became the model on which the modern gentleman was formed.

Novara, Alessandria, and Lodi were surrendered, and in a few weeks not a Frenchman was left in Lombardy. But the fruits of Imperial victory were no less bitter to Italy than the presence of the French had been. She had merely changed her master. Clement charged his English Nuncio to approach Henry and implore his good offices with Charles to put bounds to the vexations imposed on Italy by the Imperial representatives; extraordinary contributions were still demanded of Florence ; Milan had not independence; she was governed nominally by one of the Sforza family, really by the troops of Charles ; Venice gained none of the advantages which her treaties should have secured her; no respect was paid to the Holy See (Lettera di Gio. M. Gib. Datario a Mess. March. Lango Nuntio in Inghilt.). And, on the other hand, Bourbon wrote to Charles and Henry, urging the prosecution of war. Charles at once pushed his forces into Provence, where they besieged Marseilles, and, in their turn, achieved disaster : Henry sent subsidies, and promised armed support ( 1524 ).

Francis I., at the head of a powerful army, crossed the Alps : he left the pursuit of the Imperialists, that were retreating from their disastrous Provençal expedition, to a detachment of the army, judging that exhausted 
and humiliated troops, after forced marches over a difficult and inhospitable country, would not be in a fit condition to make effective resistance. $\mathrm{He}$ arrived at Vercelli the same day that Pescara, who, with Bourbon, commanded the Imperialists, arrived at Alba. Every advantage seemed to lie with the French, except Generalship. The Imperialists readopted their old Fabian strategy: certain strongly-fortified places were to be held, such as Alessandria and Pavia, and Milan, if it were possible, though that city was more than decimated by plague. Clement, who, as "father of all the faithful," had been anxious to get Charles V. to grant peace when Provence was threatened, ceased to trim : Venice and he became apprehensive of the French now, as they had been of the Emperor : unable to " look into the womb of time and see what seeds would grow," they contented themselves with securing an acknowledgment of their neutrality from Francis. Bourbon, Lannoy, and Pescara, the Imperialist Generals, retired to Lodi ; their distress, for want of money to pay their soldiers, was great; Milan was evacuated by Sforza; and the French sat down to the siege of Pavia, the defence of which was entrusted to Antonio de Leyva. The Pope began to manifest that lack of insight and of foresight, that timidity and irresolution, which rendered continuance in any consistent policy impossible to him : he inclined strongly now towards what appeared to be the winning side, and first counselled Francis, always in the interests of Christian peace, to send an expedition to Naples, and then tried to dissuade him from that enterprise. Francis sent the Duke of Albany to "the kingdom," where the Angevin party was fermenting, and where Aquila and the Abruzzi were in open revolt. The Duke of Ferrara went over to France, paying 70,000 florins, whereof 20,000 were expended on artillery; Lucca paid Albany I 2,Ooo ducats, and sent him artillery as he marched through Tuscany; Florence received him as a friend ; Siena, like Lucca, bought her ransom ; and Giovanni dei Medici and his Rlack Bands transferred their services from Charles to Francis.

Undoubtedly, what Francis ought to have done was to follow up the dispirited, unpaid Imperialist troops, and try to overwhelm those that had not fled to fortresses, or drive them into Venetian territory, where they would have found themselves among very doubtful friends. Instead of this, he hoped to take Pavia by assault; he failed, and had to attempt to reduce it by famine, with forces somewhat weakened by Albany's expedition, which had been despatched southwards. And Charles paid no attention to Albany, whose forces had been driven back to Rome ; but he sent fresh German reinforcements to Lombardy. The Imperialist Generals took up an excellent position near F'avia, and were even able to supply the city with ammunition and food. lirancis was now between the city and the hostile camp, and all his Generals implored him to raise the siege, except his evil genius, the incompetent Bonnivet, who prated about glory and the honour of the Crown. Vanity and self-sufficiency carried the day, and Francis continued the siege. Things began now to go badly with Charles. The surprise and capture of Chiavenna by a Milanese General called off 6,000 men of Graubünden to defend their own hearths and homes; and reinforcements for the French were cut off as they descended the mountains ; the hero of the Black Bands, too, got badly wounded. Still Pavia was so closely beleaguered that an assault on the French camp became imperative. The armies were, by this time, nearly 
equal in numbers, Francis having 8,000 Swiss, 7,000 French, 6,000 Italians, and 5,000 Germans, and superiority in artillery and cavalry. On February 25 , I 525 , the Imperialists began the attack, and the first advantages fell to the French, but their very success contributed to their undoing, for the impetuous charge of Francis' German troops stopped the fire of the artillery, in which the real superiority of Francis lay. The charge of the French soldiery was terrible ; no bloodier battle had yet been fought, but the discipline, firmness, and experience of the Spanish arquebusiers began to tell; the superiority of the bullet over the pike was manifested, for the Swiss could not exhibit their wonted courage ; and, at an opportune moment, Antonio de Leyva brought his garrison out from Pavia, and took the French in the rear. The Black Bands were almost extirpated; the flower of French chivalry lay dead on the field. Bonnivet, finding the day lost, courted death with visor raised, and was slain; the King, who had lost most of his noble comrades, fought on bravely ; but his horse fell, covered with wounds, as he was endeavouring to escape, and Francis was obliged to surrender. All his most illustrious Generals were dead or prisoners, while the Imperial troops had not lost more than 700 men. France was left to the government of the King's mother, Louise of Savoy, an intriguing but spirited woman, who showed herself capable of guiding the State with much more discretion than had been manifested by that shallow person her son.

\section{VII.-Charles V. and Clement VII.}

Francis wrote to the Queen-mother that all was lost except honour: It was not true : France had lost many Generals, but most of her troops were foreign mercenaries; her resources were not exhausted; her own territory was intact. Venice was, indeed, exhausted by her prolonged warfare with the Turk in the Orient, his pillaging expeditions into Venetia, her long contests with Milan and other Powers on the mainland, her contest with the league of Cambrai, and this last war; and, moreover, her trade was vitally deflected by the discovery of the Cape route to Calcutta and the Far East; she no longer occupied her former commanding position among Western Powers. The thoughtless prodigality of Leo X. had dissipated the resources of the Papacy ; and Clement VII., called upon for subsidy in the war between the Houses of Hapsburg and Valois, had been obliged to starve public works and even learning, oppress the people, and tax the clergy : even so, the pay received by his cavalry did not enable them to feed their horses. So, unable to pursue their advantage after Pavia, the victorious Imperialists remained mischievously inactive. For, under Charles V., idleness was considered honourable, industry a reproach, monopoly was multiplied, commerce hampered, economics ignored; consequently, the soldiery remained unpaid, and the garrison of Pavia turned its cannon against its officers, and refused to obey until arrears were forthcoming. Military discipline had never been worse ; the soldiers were allowed to ravage the countries they were supposed to protect; and many of them made off for home with what booty they had collected.

Albany's army had retired towards Bracciano, for security in the fiefs and fortresses of the Orsini, the faithful friends of France ; whereupon 
the Colonna attacked the Italian troops of the Orsini and gave the world to know how little Papal authority was respected, and how easily the Pope might be made the catspaw of faction within his own House. Albany remained at Bracciano, by no means a quantité négligeable. And to add to Clement's troubles, his secret correspondence with Francis had been found in the King's tent, and the Generals of Charles were increasing their exorbitant demands for money. Venice approached him with a proposal to form a league : the Senate represented that the Imperialist Generals, poor as before the battle, without adequate artillery, or the munitions of war, were no longer capable of resisting united Powers; but if there were delay, the States, beginning with the poorest, would be compelled to furnish them with gold, and it might come about that Italy would have to provide the means for her own subjugation. Venice proposed to unite with Clement and the Duke of Ferrara ; their States would afford unbroken communication, Swiss could be hired, and the co-operation of the Duke of Albany and the lances that had escaped from Pavia under the Duke of Alençon, might, perhaps, be secured by permission of the Queen-regent. While Clement hesitated, the Imperialist Generals, in order to squeeze contributions from the Pope and Florence, quartered their troops in Parma and Piacenza, and an offer came from Charles to guarantee the security of the Medicean House for payment. Clement VII. was a master of wily diplomacy, but his mediocre character unfitted him to deal with a great emergency. In order to get out of a present difficulty, he took the nearest means. He signed an agreement between the Emperor and the Duke of Milan on the one part, and the Church and Florence on the other, whereby the latter were bound to supply the former with funds for their troops (Fr. Guicciardini.-Pauli Jovii._Vita Ferdin. Davali.P. Paruta.-Fr. Belcarii.-Scip. Ammirato.-Giov. Cambi, Ist. Fior.).

No sooner had the Pope bought himself off the immediate difficulty than the apprehensions of Venice were realized. The Imperialist Generals demanded 50,000 ducats of Ferrara, I5,000 of Montferrat, I0,000 of Lucca, I 5,000 of Siena, graciously granting the latter permission to change her Government and overthrow the ruling family of the Petrucci and the oligarchical signoria. About this time 200,000 long-promised ducats arrived from Spain; but the troops were no sooner paid than the Imperialist Generals demanded 25,000 extra florins from Florence, and billeted soldiers in the country round Piacenza ; and, while they emphasized the refusal of the Emperor to ratify certain conditions they had made with the Pope, they stuck to the money he had furnished in view of the terms being observed. However, the Duke of Albany sailed away from Civita Vecchia, bound for France, where the Queen - regent was burning to avenge the French and release her son from captivity.

In fact, Louise of Savoy let the Pope, Venice, and the Duke of Milan understand that she was prepared to leave Lombardy to the Duke, and to renounce the French claim to Naples if the Italians would help her by a general attempt to turn the forces of Charles out of the peninsula. Clement was most eager to aid the project: he wished to go down to posterity as the deliverer of Italy (Guicciardini, Storia d'Italia, L. xiv.). He sent proposals to France requiring subsidies in men and money, the hand of a French Princess for the Duke of Milan, to secure perpetual alliance, and the Two Sicilies for himself. But France sent no help; 
the Queen was concentrating her powers on effecting the release of Francis, and the Italians, who mistrusted each other, hastened to give obscure warnings to Charles, so that if things went wrong they might pose as his most devoted adherents. In this game of deceit Clement was not the most backward. In a " memoriale mandato d'ordine del Papa Clemente VII. a Monsignore Farnese," he gave Charles a hint to look after his Captains. At this moment the Constable Bourbon and the Marquis Pescara were irritated at the Viceroy of Naples having privately transported Francis from Italy to Spain; and a Genoese emissary came to Milan bearing proposals for a league from His Holiness. These were communicated to one Morone, the Secretary of Sforza, a man learned in jurisprudence and the classics, of great insight into diplomatic doublings and treacherous shifts of policy, and reputed to be the best reader of cryptic intrigue in Italy. Morone approached the Marquis Pescara, a Spaniard by descent, but whose family had been domiciled in Naples for a century. Pescara, Charles's Commander-in-Chief, was generally acknowledged to be the best General of his times; but he was now bitterly incensed against the Emperor for the removal of Francis. Pescara was offered the kingdom of Naples, and, of course, the renaissance of learning being yet in full tide, he was assailed with the inspiring example of classical heroes, together with some appeal to the incipient national feeling of the land he had adopted, and the more vulgar delights of wearing the " royal round." Pescara, however, had had too large an experience of life, and especially of the little confidence that was to be reposed on the Italians of his time, to be led away by ambitious or idealistic dreams; he knew the power of Charles, the weakness of Italy, the fickleness of France, and, above all, that he himself was afflicted with a mortal illness. He listened to Morone, and used him to supply immediate practical wants : he set himself to get money from the allies, and bore himself in the negotiations in a way that might have been expected of a shrewd General who, after the manner of his tribe at that time, felt himself under no sacred national constraint, and bound to the person he served by bonds that the lightest pretext or pique would serve to loosen and that the conclusion of a term of engagement naturally severed. Pescara decided that the plot would not succeed; he feigned complicity, and, meanwhile, kept Charles fully informed of what was going on, and sent to Germany for fresh troops of landsknechte. As Professor Villari observes (Machiavelli, Lond., 1898, vol. ii., p. 455), both Pescara and Morone "were playing a double game, and both were aware of it." Each suspected the other. Morone declared to Pescara that if the thing proved hopeless, he would throw himself heart and soul into the Emperor's cause. On October 14, I525, Pescara invited Morone to a conference in the castle of Novara, where he lay ill. All the projects were explained anew. Morone had arrived in the company of De Leyva, who had commanded at Pavia when the French were routed, and who had threatened to murder Morone if he could but get hold of him. Everyone told him he was invoking his own fate; but he had calculated on Pescara's selfishness, the only thing relied on in the faithless diplomacy of the times. He told Pescara that he had been warned of his duplicity, "but," said he, "I trust in your Excellency as I do in God." And, meanwhile, Pescara was writing to the Emperor that he could lead Morone by the nose as it might please him (Miscellanea 
di Storia Italiana, Turin, 1865, vol. iii., pp. 407, 422, 423). Morone was allowed to leave the castle. Then he was arrested and brought back, and compelled to rehearse the plot before De Lcyva and the Abbot of Nazaria ; he protested against the breach of faith, but wrote a full account of the whole conspiracy, including the damning fact against Sforza that he was engaged in the plot against the Emperor at the very time that he was seeking the Imperial investiture of the duchy. This was what Pescara wanted : he straightway rode to Milan and took possession of the city. To the amazement of everybody, though Morone was kept a prisoner, his goods were left by Pescara in the hands of his family, and when the General died, three months after, in the prime of life, he had the grace, in his testament, to implore the Emperor to grant full pardon to Morone, " as otherwise I should hold myself guilty" (Dandolo, Ricordi, p. 202). Bourbon kept him in prison until he had squeezed him dry of his wealth, and then gave him freedom, with the appointment of Commissary-General in the Imperial forces. The whole incident furnishes a curious study in psychology and certain curious associations and still more curious dissociations of idea in the ethical consciousness.

Two months before the arrest of Morone, Francesco Sforza received the investiture of Milan on very hard terms. He had to pay 100,000 ducats, cash down, and engage to furnish 500,000 more ducats at fixed periods ; he had, moreover, to undertake that all salt used in the duchy should be procured from the Austrian salt-mines, thus abandoning to the foreigner the most lucrative source of State revenue ; he was also heavily mulcted by the Imperialist Generals. The Duke was at this time, like Pescara, seriously ill, and when, after the discovery of the conspiracy, that General demanded the possession of fortress after fortress, having no longer Morone to advise him, he ceded several ; but Pescara's demands became so excessive that, driven to bay, he fortified himself in the castle of Milan, where he held out for another year, and only capitulated when completely reduced by famine. Venice, in spite of the danger to which her complicity in the plot exposed her, gallantly refused to treat with the Emperor unless the Imperial garrisons were withdrawn from the duchy.

The death of Pescara gave renewed hope to the Italian States : Bourbon and Lannoy, the Viceroy of Naples, were both out of the peninsula, and Venice urged the Pope to form a league while Sforza still held out in the Milanese citadel. The Queen-regent of France promised both men and money ; Henry of England became France's guarantee ; the Pope, acting also on behalf of Florence, and Venice were capable of furnishing an army of 1,800 men-at-arms, 2,000 light horse, and 20,000 foot, while the combined French and Venetian fleets were available for an attack on Genoa or the Neapolitan ports. But Clement was under the influence of two men who led opposite parties in the inner counsels of the Papacy ; one, Giammatteo Ghiberti, Bishop of Verona, like himself, a bastard, was the Pope's most intimate friend, a man of piety, honesty, and power, who inclined to the French side as most likely to help the freeing of Italy; the other was Nicholas von Schomberg, a Saxon by birth, friar of the Dominican Order, devoted to the German cause, a capable diplomatist, guarded in his conduct, once under the evangelistic influence of Savonarola, then, on the side of his foes, the Medici, in Florence, and evidently of less conspicuous integrity than Ghiberti. Clement was never quite.safe from 
the turbulence of the Roman barons, and swayed now to this side, now to that, according to the exigencies of the moment; he was weak, irresolute, and faithless, and always under the influence of either Ghiberti or Von Schomberg. The possession of Milan was of vital importance to the Eimperor ; two Powers of the first magnitude could not sit down side by side in the peninsula, and if Milan and Lombardy were held by France, she could pour her forces overland on Naples, while Charles could only defend that possession by a difficult sea-transport. The Emperor sent proposals to the Pope, carefully concealing his knowledge of the detection of Morone's conspiracy, and what was practically the deposition of the Duke, so that he might be able to declare the Duke a traitor, and revoke his proposal. He offered Reggio and Rubbiera to the Pope, and the support of Francesco in the duchy. In the event of Sforza dying without issue, the Constable Bourbon was to succeed. But Clement, though this proposal had originally emanated from himself, now saw that it was a trap : Bourbon would be nothing but a Viceroy: he refused to consent to this article, and the Imperial Ambassadors proposed two months for communication with their master, during which period Clement was to enter into no communication with the other side. This was a ruse to gain time; but Clement acceded, judging that the Queen-regent would use his alliance as a lever to get better terms for the liberation of her son, and would probably offer to abandon the Papacy in order to get Francis home; while, if she had to make what terms she could, they would be bitter to France, be violated, and lead to a war of revenge (Fr. Guicciardini).

Charles was prudent ; he was the last man to believe in Francis' friendship or gratitude; but he dreaded an Italian league. He demanded the duchy of Burgundy and certain lordships, the liberotion of French Flanders from French suzerainty, the abandonment of all pretensions on Italy, and the aid of an army to accompany the Emperor to Rome when he should choose to assume the Imperial Crown-that is to say, an army to help him subjugate Venice, Florence, Lombardy, Ferrara, and the Papacy. Francis acceded, and was liberated on March I7, I 526 ; once free, he lost no time in repudiating the treaty.

Italy had never been more eager to expel the foreigner than when she learned of the treaty of Madrid. Luxury and refinement had, indeed, penetrated into the Courts of Princes, but the peoples of Europe beyond the Alps remained semi-barbarous, and the soldiery, who took up arms as a trade, were inconceivably sordid and rapacious, and the life developed all the callous brutality that was in them. From end to end the highlycivilized States of Italy had been subjected to the exactions of heartless foreign Generals and the insolent greed of licentious soldiers. In Sicily wholesale execution failed to stop insurrection; the ancient Constitution of the island had been violated since its monarch had come to reign over half Europe. Sicily was left to the mercies of a delegated rule, which had to maintain itself by force ; and, even so, the fear of execution failed to check conspiracy. The kingdom of Naples, in area nearly half the peninsula, had its trade crushed by the granting of monopolies ; its agriculture ruined by the billeting of savage troops, whose pay, owing to the peculations of officials, rarely reached them ; justice was ill-administered, and the unhappy peasantry too often took to a life of brigandage on the 
mountains. The States of the Church were already the worst governed in Northern Italy ; they had suffered from the wars which subjugated them to the Papacy, and from the presence of the foreign freebooter. The long attempt of Florence to recover Pisa, for many years her subject, and the stout resistance of Pisa in her struggle to recover her still more ancient freedom, had desolated half Tuscany, and the industrious citizens of Prato had learned by the bitter experience of a sack what were Spanish bowels of compassion. Throughout that great eastern plain of the Po, which owed allegiance to the Lion of St. Mark, there was not a little district that had not experienced the brutality of the German and had not been ravaged several times since the league of Cambray. Genoa had been recently put to pillage by Pescara and the Spanish troops. Ferrara, so long coveted by Julius II. and Leo X., had been bathed in blood. The heaviest sufferings of all had fallen on Lombardy. She had been the theatre of war since the first expedition of Charles VIII. ; she had been taken and lost time after time by French, Spaniard, German, and Swiss, and regarded them all with equal terror. Piedmont and Montferrat, while not active participants in the hurly-burly, had, by virtue of their position, become one of the cock-pits of the contending forces, and their inhabitants were punished by one side for having experienced the violence of the other. The circumstances seemed favourable for a really national effort. The Milanese were goaded into fury, and the despoiling of Sforza had been the last straw; insurrection in Milan was a daily occurrence ; while Charles's troops, enfeebled by desertion, wanting the munitions of war, and badly paid, had difficulty in holding their own against the people they had despoiled. Charles, in spite of a wealthy marriage with Isabel of Portugal, was still needy; a peasant revolt in Swabia had set Germany on fire; the embers of civil war still glowed in Spain, and her obedience to the Emperor was but half-hearted; Hungary, the former foe of Italy, was battling for life with the Turk; the Sovereigns of Europe were alarmed at the extent of territory ruled by one ambitious Prince ; and, while Francis renounced his pretensions on Milan and Naples, Henry of England egged on the Pope to form a league which would secure the liberty of the Italian States and of all Europe. In May a treaty was signed between the Pope, Sforza, Florence, Venice, and France. England held aloof, an early instance of that combination of essential selfishness with platonic sympathies, which, repeated in times of less political faithlessness, have contributed in no small measure to achieve for her that by-name of "Perfidious Albion," which ingenuous Englishmen are wont to repudiate.

The capitulation of Sforza, besieged in the citadel of Milan, had not yet taken place, and the allied troops of Venice and the Church marched to his relief. The Imperialists in Milan were in a parlous condition; they had to appease the insurrectionary citizens by a promise that they would withdraw all troops not absolutely necessary to the siege of the citadel. But though Pescara, his greatest General, was dead, Charles still had devoted and capable Generals in Milan in the persons of De Leyva and Del Guasto. Francesco Maria, Duke of Urbino, commanded the allies, and advanced with that cautious slowness that had now become a defect, while the Spanish commanders in Milan broke their compact with the citizens and deliberately irritated them to desperation, in order that they 
might cow them with the rigour of reprisal. A fresh rising, thus excited, was suppressed by a prearranged massacre of the mob, and ended in the disarming of the citizens and the expulsion of the Captains of the militia and the magistrates of the city. But throughout Lombardy the people rose, and at Lodi the Imperialists were surprised, and the town thrown open to the army of the league. The Duke of Urbino advanced, though far too slowly, to the very gates of Milan, and then withdrew, perhaps because Bourbon had come up from Genoa with a small reinforcement. The Papal commanders vigorously opposed this decision of Urbino, who personally commanded the Venetian forces; it confirmed the proverb that the Venetian and Church swords had no edge, and it induced mutual mistrust. The King of France held aloof ; Urbino was suspected of compromising the Pope, while keeping Venice from real hostilities ; a little Spanish garrison at Carpi intercepted the despatches passing through Parma and Piacenza; the Colonna and forces on the Neapolitan frontier menaced Rome; and the Papal purse was already empty. The citadel of Milan was surrendered, and Urbino, who might, perhaps, have relieved Sforza by a little vigorous promptitude, now reinforced by 6,000 Swiss, the only help Francis sent, turned to besiege Cremona, a perfectly useless proceeding, which consumed valuable money and time.

We have said that the Colonna were menacing Rome. Charles had sent Don Ugo de Moncada to Clement to attempt to secure a truce and rouse the Colonna if he failed. De Moncada's mission proving unsuccessful, he departed, and having given the Colonna the word, they deceived the Pope by a treacherous truce, and then rushed into Rome, sacked the Vatican and St. Peter's to the amount of 300,000 ducats, and obliged Clement to flee to S. Angelo. The Pope, in terror, sent for De Moncada, promised a four months' truce with the Emperor, pardon for the Colonna, and the withdrawal of the Papal fleet from Genoa. Clement felt that he was safe in avenging himself on the Colonna ; a full consistory was called, the lands of the Colonna declared to be confiscated, and a force sent to take possession.

The surrender of Cremona set the army of the allies free. The Duke of Urbino had taken umbrage at not having sole command: he had frittered away the precious moments, when assistance to Doria and the fleet that was blockading Genoa would have been invaluable; for Genoa afforded a ready means for the disembarking of Spanish reinforcements to Lombardy. The army consisted of between 30,000 and 40,000 men, whereof one-third were Swiss. But, meanwhile, Cardinal Colonna, with I, OoO men at his heels, had been able to reduce the Pope to some sort of submission to Charles, and the Papal contingent was withdrawn. Nevertheless, Clement contrived to violate his oath by continuing Giovanni dei Medici in his service, with 4,00o troops. The Holy Father sent Giovanni orders to declare himself to be in the pay of France, but that brilliant Captain threatened to go over to Charles unless a State were given him, " and," wrote Guicciardini, " he is quite capable of doing as well as threatening." And, to crown all, Imperialistic Siena had refused to change her Government, and put the Florentine and Papal forces to a disgraceful rout. However, Urbino marched on with diminished forces to Milan, and, instead of trying to take the city by assault, sat down to blockade it, whereby a Spanish fleet was able to disembark an army 
commanded by Lannoy, at Gaeta; Frundsberg had time to come over the Alps with I3,00o landsknechte; Alfonzo, Duke of Ferrara, irritated by Clement, passed over to the Imperial side ; and Giovanni dei Medici, who communicated his own impetuous valour to his Black Bands, fell in a conflict with the landsknechte of Frundsberg. The Duke of Urbino had abandoned the siege of Milan, for he had a well-ground mistrust of the ability of the troops with which he was provided to face the foreigner, and especially the Spaniard; and Venice had a just suspicion of the purposes, and, above all, of the vacillation of Clement, and was anxious not to push matters too far. It was now that Bourbon squeezed 20,000 ducats out of Morone, and got money wherever he could, in order to leave Milan and cross the Po ; and the inaction of Urbino enabled the army of Milan and the one that had come over the mountains to effect a junction.

Mean while a Papal army, sent into the South, had surprised and defeated Lannoy and his troops, half of whom were Neapolitan. Encouraged by this success, Clement sent troops to advance on Naples, while the blockading fleet of Genoa was ordered to ravage the cities of Campania. But the fleet soon got enfeebled by the garrisons that had to be left behind in captured towns, and the army was so ill-supplied with money and provisions that the enterprise had to be abandoned. On the other hand, Bourbon's troops twice mutinied for pay; on the first occasion Bourbon pointed out that salary was not the only way in which a soldier might reap the reward he fought for ; on the second, the Duke of Ferrara sent money to appease the mutineers. Frundsberg was siezed with apoplexy while he was haranguing his troops, endeavouring to repress sedition.

Clement was now in a quandary; he had supported the whole burden of the war for three months ; the French fleet had failed to come in force, or his enterprise against Naples might have succeeded : Henry of England hung fire ; Venice thought only of herself ; and the Duke of Urbino refused to protect Rome and Florence ; Siena was Imperialist ; Florence ready to cast off the Medicean yoke; Lannoy was in command in the South, Bourbon advancing with a horde of half-savages from the North. Clement, therefore, concluded a truce with the Spanish Viceroy, to last for eight months (March, I 527). He promised to restore the property of the Colonna, to relinquish Naples to Charles, Milan to Sforza, and 6o,ooo ducats to the Constable of Bourbon. Directly the treaty was signed, he dismissed troops, leaving Rome almost defenceless ; for he was unable or unwilling to support the continuance of such a tremendous expense. The news was brought to Bourbon. Inaction with a turbulent army would have been impossible. The sum he had received from Clement was not enough to appease his destitute and clamorous troops. Bourbon demanded more money; and, while negotiations were on, he seemed likely to besiege Bologna; but the army had determined to pillage some rich city ; they had made the expected sack a common form of oath; they insisted on going forward; they nearly killed a messenger from the Viceroy, who bore, or affected to bear, an order for the truce to be respected. Bourbon gave word to march; the Count Del Guasto, Pescara's nephew, who nourished patriotic feelings that were not always consonant with his duty to his master, withdrew from the army, and was then declared to be expelled from it by court-martial. Men that had kept their hosts in 
Milan bound to the foot of their beds or imprisoned in cellars; that had taken pride in dishonouring their wives and daughters before their eyes ; that had applied refinements of torture to enforce the due performance of every command, conjoined with others of like kidney-Protestant landsknechte, whose main interest in religion lay in the spoliation and appropriation of everything connected with the Church-were not likely to stay their hands with rich Florence close at hand, and Rome not so far off. The Viceroy, Lannoy, agreed with an emissary of Bourbon to raise $I_{50}, 000$ ducats, and that the army should retire directly 80,000 ducats of that sum was paid. Florence raised the smaller sum, and was melting down her church plate to furnish the remainder, when word came that Bourbon refused to ratify the bargain. But the army of the league was brought, by the efforts of Guicciardini, the Florentine, sufficiently near the city to cause Bourbon to sheer off for Rome, much to the spiritual delight and edification of his Lutheran followers. Bourbon pushed on rapidly, pillaging as he went, and arrived before the walls of Rome, not merely without having met with opposition, but before the Pope could be convinced that he had left Tuscany. The Pope, vacillating, at last proclaimed his adhesion to the league: it was too late. The Duke of Urbino followed Bourbon's army in his usual deliberate way; he turned aside to Perugia to overthrow its Government instead of marching on Rome, and when news came to him that the city was taken and the Holy Father besieged, he proceeded leisurely on to observe, from a distance, exactly what might be happening.

The troops of the Constable arrived before the walls of Rome (May 5, I 527). They had left their artillery on the way, but the city was not in such a state of defence as to offer much resistance. Clement had indeed tried to replace the troops that he had so unwisely disbanded; he asked for voluntary contributions, which Roman avarice, even at this time of peril, denied him; he sold three red hats, but there was no time to receive the money; he armed the lackeys of Church dignitaries and the shopkeepers of Rome, that had neither courage nor discipline. Clement had hitherto passed from fits of confident and unjustified assurance to moods of depression and craven dread ; but now all timidity disappeared, and was replaced by the reckless audacity of the gambler who throws his last stake. The defence of Rome was entrusted to Renzo da Ceri, of the House of Orsini, a man who had not fulfilled the expectations which his defence of Cremona had aroused, and Messer du Bellay, who had brought the news of Bourbon's advance. On the morning of the 6th Bourbon led his men to the assault : he was killed near the Janiculum while scaling the wall-a feat which that exquisite braggart and unwitting exponent of the mind of the Renaissance, Benvenuto Cellini, claims as his own deed (Ben. Cellini, Life Tr. Symonds, I888). The death of their commander, so far from dismaying, seemed to animate his troops to revenge. Philibert, Prince of Orange, took the command, and the Leonine city was captured, while Clement had barely time to seek safety in the castle of S. Angelo; he witnessed the slaughter of hundreds of Romans, even of youths, who vainly threw away their arms and supplicated quarter on their knees. In vain did Da Ceri endeavour to persuade the Romans to break down the bridges and hold the city against the Colonna that were advancing from the South; the assailants occupied Trastevere, and crossed the Sistine 
bridge into the main city. Count Guido Rangone and a small army, whose services Clement had fatuously refused, wisely disobeyed, and arrived the same day, but too late ; and a mist prevented the straight firing of the brave Swiss guard. As it was, the assailants lost a thousand men ; but they were nearly 40,000 strong; I 5,000 of them German troops, largely composed of ruffians whose revolutionary Protestantism, so far from evoking the beauty of holiness, had but unchained their latent malevolence. These reformers

\section{"Called fire and sword and desolation \\ A godly, thorough reformation."}

With them were united 6,00o Iberians, the hardened "devildom of Spain "; blackguards that had deserted from the army of the league ; all the vagabonds that had been picked up on the march ; base Italian infantry from Calabria; and the scoundrels of Sciarra Colonna, and other nobles who lived by rapine and rascality.

Never, perhaps, in the history of the world has a great capital been subject to such a scene as ensued; never have there been let loose on a defenceless population troops more ruthless and less in hand. The former mistress of the world was abandoned to a pillage unparalleled in the most calamitous periods of her eventful history. Barbarians-Alaric the Goth and Genseric the Vandal - had sacked Rome : it was reserved to Christian civilization to exhibit greed, pollution, and atrocity in full measure in the city which had once been the mother of human order and the nursery of faith. Shrieks and groans of unhappy wretches put to torture were to be heard on all sides; the streets were littered with the spoil of sanctuaries enriched by the veneration of twelve centuries, and broken church furniture and altars, from which their gold and silver adornments had been rudely torn ; cardinals' houses were pillaged, and they themselves beaten and put to ransom again and again; women of every rank, even nuns, were ravished and tortured; priests were slain outright, or left to die of their wounds; even children were made to wince and writhe to discover hidden treasure. The Bishops of Spain and Germany were as little spared by their countrymen as those that were Italian; Ambassadors, even, were treated as the rest, and the soldiery fought each other over their spoils. After the first day of fury, slaughter ceased ; the Germans contented themselves with picking upall they could lay hold of, smashing "idols," and getting drunk; the Spaniards were infinitely subtler and crueller in their brutality : they invented new tortures, and extorted fresh ransoms from all that fell into their hands; the Italians, especially those of the Abruzzi, vied in violence and desecration with those whom they could not equal in courage. One-fourteenth of the population perished; the remainder fled, and the city was left to the soldiery ; while the peasants from the fiefs of the Colonna trooped in, and removed household furniture and what the captors had left untouched. Plague broke out, but it did not make the rapacious soldier loose his prey. This scene of crime and agony did not last a few days only: it was protracted for nine months, for it was not until February I 7, I 528, that the Prince of Orange finally withdrew what remnant of the army diseases bred of vice and dirt had spared.

Clement made terms with the Emperor. Both sides had exhibited bad faith, but Clement was beaten in a game of deception in which his part had 
been the more honourably motived. He agreed to pay 400,000 ducats and surrender Piacenza, Modena, and the ports of Rome. Meanwhile Florence rose against his Medicean nephews, expelled them, and reconstituted the Republic, though she did not abandon the league ; the Duke of Ferrara seized Modena and Reggio; Venice, Ravenna, and Cervia : the work of Julius was being undone, and it looked as though the edifice of the Temporal Power would fall to pieces. Never had the Papacy been so humbled in the dust. The cities of Germany resounded with new doctrines ; many of her Princes had cast off their allegiance to the Catholic faith; the Emperor, ruler of a domain that vied in extent with that of ancient Rome, while professing to be a devoted son of the Church, had proved himself the bitterest foe of the Holy Father ; with sixteen cardinals Clement was held a strict prisoner in S. Angelo by the Spaniard Moncada, though the plague had reached that citadel. But already Francis of France and Henry of England had clasped hands: Henry was anxious to liberate Clement, and, as a reward, to be set free from his elderly Queen ; he promised money and men to Francis, who was bent on recovering lost territory and restoring the prestige that had been lost on the field of Pavia. The Vicomte Lautrec was put at the head of a powerful army, and set forth from Lyons (July, I 527). Marching over the Alps, he took possession of Western Lombardy. Andrea Doria, perhaps the most illustrious member of a famous House, had placed his services at the disposal of France; he commanded her fleet, in order to drive out the rival Adorni from his native city, where they espoused the Imperial cause ; and, by the help of the faction of the Fregosi, Genoa once again bore the French flag; Alessandria was taken, Pavia surprised, and its innocent burghers given over for eight days to a rapacious soldiery that rivalled the Spaniard in cruelty; the greater part of the Milanese was handed over to Francesco Sforza; only Milan remained in the hands of De Leyva.

But Lautrec did not proceed to the siege of Milan: he resolved to liberate the Pope. Undoubtedly it was dangerous to leave the strong fortress of Milan in his rear ; but the Dukes of Ferrara and Mantua had come over to the French side, and he secured the friendship of Florence. On his advance he learned that Clement had got free : Moncada had received the 400,000 ducats for his ransom, and allowed him to escape before the time appointed for his release, probably to prevent his own soldiers from detaining him to extort a second ransom. Clement professed to be eager for peace, but he was secretly in communication with Lautrec, who determined to advance on Naples. Lautrec advanced through the Abruzzi, and the Imperial troops, having emptied Rome of everything they thought worth having, evacuated that city. They were now only i i,ooo strong, and their leader, the Prince of Orange, took up a position to protect Naples. The South yielded to Lautrec : Naples was blockaded by the combined Genoese and Venetian fleets; the Venetians took possession of their old ports in the kingdom; supplies from Sicily were cut off by Genoese vessels ; the Imperial fleet was destroyed by Filippino Doria ; and, in the North, German reinforcements were obliged to oreturn home, the country being too ruined to support them; and though Pavia was recovered and Lodi besieged, in Milan itself De Leyva had to impose a heavy tax on bread, in a desperate attempt to meet the ordinary expenses of government. It looked as if the Imperial cause were lost. 
And so it would have been but for a blunder of Lautrec and the stupendous and unteachable stupidity of Francis. The parsimony of the French King prevented his supplying Lautrec with funds. But this was not all. He attempted to make Savona, ever the rival of Genoa, his naval depot. Doria, his Genoese Admiral, was a republican, a sailor, and a patriot ; he remonstrated. Francis' reply was to order the seizure of Doria and his galleys. Doria managed to withdraw his fleets in time, and the astute Emperor at once offered to respect Genoese liberty if Doria would serve him. The bargain was struck, and when the situation appeared most hopeless, Genoese galleys provided Naples with ample provisions. At the same time, Lautrec's troops were disheartened by the prolonged resistance of the city and the appearance of plague in their camp.

Lautrec was in many respects an able General, but he was proud, harsh, obstinate, and fond of having his own way. He lost valuable time in Apulia, and allowed Orange to arrive at Naples before him ; and he was unwilling to expose forces that were never really large enough for so big an enterprise to the loss that would attend an assault on Naples, although Orange had lost the greater part of his army by disease. In spite of the remonstrances of his officers, he had determined to sit down before Naples and reduce the city by blockade. His soldiers, under a burning sun, with putrid water to drink and no great supply of provisions-harassed, moreover, by the light cavalry of the enemy, which was superior to their ownsuffered from pestilential fever. In six weeks his effective force was reduced from 25,000 to 4,000 men, and he himself was down with fever. Nearly all the officers died, and at last Lautrec also succumbed. His courage and invincible obstinacy had supported the spirit of his forces ; now that broke down. His successor, the Marquis de Saluces, gathered the remnants of the army, and, taking advantage of a storm, withdrew to Aversa, where he was soon obliged to capitulate. Capua surrendered, and the prisoners of war were, with cold-blooded indifference, confined by the Spaniards in the royal stables, where no care was taken of them, and only a few survivors ultimately emerged from the horrible heaps of corpses and manure to return to their own plaisant pays. The campaign saw the end of the famous Black Bands, composed almost wholly of Tuscan light infantry, and esteemed to be the best in Europe. The pestilence engendered in the stables also spread through Naples, and continued to decimate its inhabitants for a long period.

The capitulation of the French did not end the war. The Prince of Orange, unable to pay his troops, executed certain barons of Angevin proclivities, and confiscated their estates; he then proposed to the rest that they should buy pardon. Some resisted, and began that long course of violence, anarchy, and brigandage which was the Neapolitan protest throughout the long foreign domination of an oppressive, grasping, unjust, and perfidious Government. Wherever the Spaniard went he introduced wrong systems of economics and finance : he mortgaged taxes to financial houses, and his widely-scattered possessions led to a multiplication of expensive councils, burdened with red tape. A complicated bureaucracy was the source of nearly all the evils of Spanish rule.

In September of this eventful year (1 528 ) Andrea Doria appeared before Genoa. To free his country from the foreigner was his ambition, and the moment was favourable, for the city was disaffected, and the French gar- 
rison ill paid, reduced in numbers, and afflicted with pestilence. At the head of thirteen galleys, he sailed into the harbour, and landed 500 men, who compelled the French Governor to retire to the citadel, and then to capitulate. Doria might easily have made himself the "despot" of the city, but, to his eternal credit, the magnanimous sailor refused the sovereignty offered him by Charles V., and left it to the citizens themselves to settle what form of government they would choose. An oligarchical Republic was formed, which remained in being with little variation for three hundred years.

The war lingered on, but peace was ardently desired on all sides. The Turk was under the walls of Vienna, and all North Germany fermented with Protestantism. There were active negotiations, delayed only by the anxiety of each potentate to deceive his allies in order to get better conditions for himself. Margaret of Austria, aunt of Charles, and Louise of Savoy, mother of Francis, met at Cambrai (I 529), and, in a conference at which no witnesses were present, arranged "Le Traité des Dames " (the Ladies' Peace). Francis abandoned his allies, and gave up Italy, Flanders, and Artois, but received the possessions of Bourbon and Orange. Clement sent a nuncio to Barcelona, and signed a treaty of perpetual peace with Charles (1529): Florence was to be given to the bastard Alessandro dei Medici, who was to marry a bastard of Charles. The Italian princelets had learned that nothing was to be gained by an attempt to cast off the foreigner: a change of masters was all that could be achieved, at the expense of the devastation of their country by plague and rapine; war meant an empty exchequer, exaction, and ransom, and endangered their thrones. The renunciation of Francis meant Spanish supremacy in the peninsula ; Charles was not the man to make many fundamental changes, but he was the man to keep all the little States under effective control.

\section{The Emperor Charles V. supreme in Italy.}

Charles had concluded peace with the Pope ; he was expecting news from Cambrai : he had prepared a warlike expedition to conquer Italy, and with this he set forth from Barcelona. When the news arrived of peace with France, what with the army of Leyva, and fresh forces that had poured over the Alps, Italy was helpless at his feet; her best friends were the Turk, that had ravaged Hungary and was besieging Vienna, and fermenting Germany, where the working of social discontent had appeared above the surface, and where wholesale rejection of Catholic dogmas was spreading fast. Charles was perhaps a little less given to double-dealing than the statesmen of his age ; he was not a great man, but he was the greatest of the three chief monarchs; he was persevering, and possessed a sense of duty; he knew how to choose capable and devoted servants. Pescara, De Leyva, Lannoy, Orange, Bourbon, were faithful to him in adverse seasons ; those immediately surrounding him were devoted; in his way he was conscientious, and he may well have flattered himself that he was bringing unity and peace to Italy such as she had never known. A great task was near its accomplishment; greater awaited him elsewhere. Charles met the Pope at Bologna. Florence was to be restored to the Medici, an operation that led to one of the most famous sieges in history. The Emperor was naturally clement, and he re-established Sforza in his duchy, but gave 
Pavia to De Leyva, while Como and the citadel of Milan remained in Imperial hands as security for the payment of 900,000 ducats, to be wrung from an exhausted land. Sforza died five years after, without issue ; his estates escheated to the Emperor. Venice was called upon to restore Ravenna and Cervia to the Pope, and the ports in the Adriatic that had been seized to the Emperor, and to pay a war indemnity. The question of the ownership of Modena and Reggio, disputed by Clement and the Duke of Ferrara, was left to the future arbitration of the Emperor, assisted by jurisconsults ; ultimately they were adjudicated to the Duke as fiefs of the Empire. The marquisate of Mantua was transformed into a duchy, the Duke of Savoy and the Marquis of Montferrat, hitherto under the protection of France, hastened to the Court of the Arbiter of Italy. The republics of Genoa, Siena, and Lucca sought his Imperial protection : Florence alone remained recalcitrant.

And now, on February 23, I350, Charles received the two Crowns at Bologna ; on February 24, for the first time for eighty years, and for the last time in history, Italy witnessed an Imperial coronation at the hands of her œcumenical Bishop. The lord of a large portion of the Western Empire, of a realm that never submitted to Roman rule, and of a new world beyond the fabled Atlantis, the confines of which were yet undetermined, Charles found himself possessed in Italy of a power of which neither Charlemagne nor Otho had ever dreamed. The power of the holy Roman Empire had been limited by the prerogatives of the Church, the privileges of Princes, and the liberties of cities. The great struggle between France and Germany had recoiled from nations possessing national feeling to foreign soil. France, Spain, the Low Countries, had been invaded, but their populations were warlike ; there was genuine national feeling. Italy was unwarlike ; her republics had for the most part disappeared, and those that remained were in decay; her people had not developed national feeling; the practice of proscription had put local party above local patriotism; hence the wealthiest and most civilized country in Europe was the weakest, and the great war had localized itself there. Now, Charles, the victor; was the immediate Sovereign of the Two Sicilies ; Florence was doomed to fall under Medicean rule, and continue to exist only as a protected State ; all the other republics were, as far as political relations were concerned, subject to the policy of Charles ; Ferrara, Mantua, Milan, Savoy, Montferrat, existed by the Emperor's goodwill ; the Papal States were wedged in by his possessions, and were equally dependent on him. Venice alone had succeeded in escaping the fate that had menaced her, by following that cautious and timid policy by which she preserved her national existence for three centuries longer ; but she had ceased to count as a factor in European politics. When Charles set out for Germany in April, I530, there was no occasion for alarm lest the subject provinces he left behind him should break their chain. He had fettered the Pope for the present : the power of the Inquisition might be used for political purposes ; and to break with the Church would be to arouse the clergy, that had enormous power, at a most opportune moment; but his troops were aiding Clement in the subjugation of Florence for the Medici, and for the present he held the Pope in the hollow of his hand.

The Pope sent the Prince of Orange, who had presided over the sack of Rome, to the siege of Florence. The noble resistance of the republic is 
elsewhere described : after a ten months' siege the city fell, and Alessandro dei Medici took the reins of government (1530). The "persuasion" of Spanish troops supported the little oligarchy of Lucca, and the Republic of Siena was furnished with a Spanish Governor and a Spanish garrison.

\section{VENICE}

\section{The Turkish War and the League of Cambrai}

VENICE had flirted with France to oppose her ancient enemies, the Milanese, but the rapid successes of Charles VIII. filled her with apprehension. She had suffered throughout her existence from the troubled condition of the mainland ; she now saw herself confronted by danger on either hand: she dreaded the Turk, who ever preferred war to peace in the East, and the power revealed by the French in their rapid subjugation of Naples. She joined the Holy See, Lodovico the Moor, the Emperor, and the Kings of Spain and England in a holy league against Charles. Milan and Venice alone fought : the latter hoped to gain fresh Apulian towns by means of her fleet; but the battle of the Taro and the withdrawal from Italy of Charles was hailed by the populace with wild delight. But when Louis XII. renewed his pretensions, the Republic, trusting in its strength to maintain its own, allied itself with France, on the promise of receiving Cremona and its contado. Lodovico was suspected of having urged Maximilian the Emperor to claim Venetian conquests on the mainland, and the State justly believed him guilty of systematic deceit. Soon the signoria learned that Louis had basely arranged with the Pope to restore the Papal States in full. Now they held some of this Papal territory. The Emperor, also, annoyed at the support which Venice had given France, demanded the cession of the feudatories which she had carved out of the duchy of Milan, and the littoral of the mainland.

- Nothing daunted, after the death of Alexander VI., when the conquests of his son, Cesare Borgia, fell away, Venice seized Faenza, Cesena, and Rimini. The success of the Spaniards in Naples proved that the Republic, to use the expression of a late English Prime Minister, had " put her money on the wrong horse" ; she had again been obliged to fight the Turk and reserve her chief resources to resist that most formidable of all her many enemies. Bajazet II. had just declared war. Marauding bands continually descended from the mountains of Turkish Albania, and laid Dalmatia waste. The Turkish Pachas offered rewards to every traitor who attempted to yield or capture any of the Levant stations. Corfu very nearly fell into Turkish hands, Zara was besieged, all the Venetian merchants in Constantinople were put in irons, and the Sangiak of Bosnia crossed the Isonzo with 7,00o cavalry, and ravaged the rich country nearly up to the lagoons. Perhaps the dread of having two formidable foes to deal with at the same time also weighed with Venice in her alliance with Louis of France.

Her Admiral, Antonio Grimani, lost his nerve at Sapienza (I499); her fleet was utterly routed; places in the Morea that she had been unable to garrison properly by dearth of men and means were lost, and she had to accept an ignominious peace. Grimani's failure was probably due to 
broken health; the Republic accorded him three physicians, and dealt with him very leniently.

On the death of the Doge (15Or), it was found that he had indulged in corrupt practices, and a new court was established to investigate the acts of each Doge on his decease. The increasing poverty of certain nobles was already giving the State concern, and the news of the pursuit of the Cape route, discovered in I486, caused so much alarm that a commission was despatched to Portugal. In the lives of States no less than of men "troubles come not single spies, but whole battalions." The appearance of the foreign Powers in Italy gave the Venetian Ambassadors much anxiety and much work to do ; and now the Republic was threatened by a European coalition. Notwithstanding that the French and Emperor both claimed the Milanese, France, the Emperor, Spain, and the Pope combined against the Republic ; Florence, Mantua, and Ferrara were her jealous foes ; it was an opportunity for the Turk to take Venice at a disadvantage and attack her, but, fortunately, the Ottoman was exhausted, and required time to recruit. Julius was to have Ravenna, Faenza, Cesena, Imola, and Rimini ; Maximilian was to take all the country from Verona to Istria, from the Alps to Roveredo ; France was to seize Bergamo, Brescia, Crema, Cremona, and the Ghiara d'Adda; the four Adriatic ports of Brindisi, Gallipoli, Otranto, and Trani were to be reoccupied by the Spaniard; Cyprus was to fall to the Duke of Saxony, and Dalmatia to the King of Hungary, if they should join the clandestine league. Her thirst for dominion had brought all the Powers down on Venice, except EnglandPowers no less marked by cupidity than herself. The secret treaty of Blois ( 1504 ) was followed by the league of Cambrai, signed by Margaret of Austria and the Cardinal d'Amboise (I 508).

France was the first to declare war, and Julius followed up the attack by launching a Bull of excommunication against the Republic. The Venetian army consisted of 42,000 men, under commanders that were ill yoked together-the impetuous Bartolommeo d'Alviano and the cautious Pitigliano. Both were able Generals, each in his separate way, but their disagreement lost them the battle of Agnadello (May 14, I 509), though the French troops did not exceed 30,000. But only half the Venetian mercenaries were engaged, for Pitigliano was determined to act on the defensive. "All is lost by treachery and disloyalty," wrote Sanudo. The portion of the army that fought distinguished itself by heroism ; 4,00o men were slain. Not merely was the State threatened with the loss of its domination : Venetians had invested their money in landed property, and the State depended on the voluntary contributions of these men to keep its treasury full. The Republic was paying the penalty of its proveditorial systen. Condottieri were, indeed, not to be trusted, but there was lamentable interference with military matters when these two good Generals, excellent apart, were ordered to work in concert by an inexpert war office.

Bergamo, Brescia, Crema, Cremona surrendered, and the French planted their banner on the border of the Ghiara d'Adda, the limit of the territory accorded them in the treaty of partition. Louis signalized this rapid conquest by cruelty : the Venetian Governors of Caravaggio and Peschiera were hanged for resisting ; the garrisons and inhabitants put to the sword ; the wealthy Venetians that fell into his hands put to enormous ransoms. 
The French now suspended their operations (May, I 509), but the Emperor, the Pope, the Duke of Ferrara, the Marquis of Mantua, and Ferdinand of Aragon invaded the provinces of the Republic on all sides at once. The Senate, unable to resist so many enemies, released its subjects from their allegiance, let them feel the foreign yoke, looked forward to the time when the robbers should quarrel among themselves and the subject cities be only too glad to return to the just and gentle Venetian rule. Unsupportable brutalities of the invaders soon inspired the Venetian cities with hatred of them: Treviso rose in June, Padua in July; both cities drove out the Imperialists, and the banners of St. Mark began once more to advance.

For the first time Italy fully realized the enormous power that the transAlpine nations could bring against her. Germans, Swiss, French, Spaniards, Savoyards, mercenaries of the Pope, of the Marquis of Mantua, of the Duke of Modena, advanced against Padua-in all Ioo,ooo men, with roo pieces of artillery. Yet the siege had to be abandoned, and Julius, having obtained all he wanted from Venice, seceded from the alliance (i 5 Io). For seven years, however, the war went on, marked by indescribable cruelty. Fugitives from the French were deliberately suffocated in a quarry near Vicenza, and German, French, and Spaniard outvied each other in coldblooded outrage. Venice now contrived to ally herself with France; but

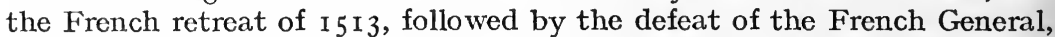
found the Venetians only separated by the lagoon and the fortresses of Padua and Treviso from the United German, Spanish, and Swiss forces. Still, the Venetians did not blench : Loredano, the Doge, set a public example of devotion to the State by sending his own silver plate to the mint to be coined.

The complicated politics of the time gave Venice some advantages in the vicissitudes of the war waged between France and the Austro-Spanish coalition. In I $5 \mathrm{I} 6$, by the treaty of Noyon, Venice ceded Verona, Roveredo, and Friuli to Maximilian ; but soon after, by a series of transfers, she was reinstated in nearly all the territory taken from her by the league of Cambrai. The struggle between the Emperor and the French King continued, and the Republic found herself between the anvil and the hammer. The tension was terrible; the debates in the Senate became increasingly stormy ; the existence of the State appeared to be at stake ; the duplicity of diplomatists was the chief factor to be considered ; Venice had to choose one side or the other, and she found herself committed to a military struggle with an army that was feeble compared with the forces of the foreigner; she was compelled to fight at the disadvantage of an exhausted treasury and diminished territory and resources. In the shifting complicated policy of the time Venice trimmed and veered, but, on the whole, she adhered to France, and engaged to furnish one third of the forces needed to expel the Emperor from Lombardy. These were placed under the Duke of Urbino, a commander who proved to be weak and irresolute. Continual state of war proved an exhausting drain to the Republic as well as to every country dragged into it. Venice was not included in the " Ladies' Peace " of Cambrai ; but, by a separate treaty, that of Bologna ( 1529 ), she re-established herself as far as the Adda, restored Ravenna to the Pope, the Apulian ports to the Emperor, and paid 200,000 ducats. She was, to all appearance, in very nearly the same position that she occu- 
pied before the appearance of the great trans-Alpine States in Italy ; but, in reality, she was exhausted, overshadowed by greater Powers than herself, her prestige injured ; and she never fully recovered her former proud position.

\section{FLORENCE}

\section{The Expulsion of the Medici}

THE larger interests of Florentine commerce required that its foreign policy should be in the hands of its financiers, and that it should be characterized by continuity of purpose and singleness of aim. Lorenzo had so manipulated the State that the Medici would have remained secure in their predominance had his prudence and judgment been inherited in ever so slight a degree. The number of the lesser arts had been reduced from fourteen to five; the balia of accoppiatori made a mere consultative body of the Council of Seventy, and the Council of Seventy had put all the other bodies of the State into the shade, so that those citizens who were doubtful friends were deprived of power. And the consultative body was not necessarily consulted (Guicciardini, vol. iii., c. 8, p. 80). The continuance of balia depended on the Medici, but the continuance of the Medici was not so entirely dependent on the balia. Nevertheless, there was a certain amount of discontent in the city. The extravagance and thriftlessness of Lorenzo, and his borrowing of public moneys, obliged the Government to raise taxes in fresh coinage, whereby the community had to pay onefifth more than the sum nominally demanded. Money had been raised by all sorts of ruses and frauds (G. Cambi, Del. xxi., 54.-Al Rinnuccini, p. I47.-Guicciardini, vol. iii., c. 89, p. 80 et seq.-Machiavelli, viii.Ammirato, xxvi.-Sismondi, c. lxxviii.-Perrens, t. ii.). Piero Cennini wrote on the margin of a schedule of one of the many new taxes : "Whatever you are, seei $g$ that you are rich and multiply your wealth, you are not the friend to the poor that you seem." But, on the whole, the city was prosperous. The wealth of Italy was at that time certainly not less than that of the whole of Europe put together : all the luxuries of the East were carried by her vessels and transhipped in her ports; she was the great manufacturer of the highest class of goods ; the extent of her agriculture is shown by the fact that there were as many villages in the Roman Campagna then as there are houses now ; and, of her great commercial centres, Florence stood first. All would have gone well had Piero dei Medici been a man of ordinary discretion. But Lorenzo's son had a Roman Orsini for his mother, a woman who possessed all the haughty pride and insolence of the class to which she belonged, and Piero both inherited and caught her spirit. His own wife, too, belonged to that contemptuous family. He had the brutal bearing of the Roman bandit-baron; he was highly educated, but cared for nothing but athletic sports; and the circle of families that composed the inner ring of government, and that had acceded with no very good grace to the sovereignty of the father, was by no means willing to concede similar powers to the son. The younger branches of the great House, descended from the brother of Cosimo dei Medici, began to show opposition, as did certain connections by marriage, such as the 
powerful Houses of Rucellai and Soderini. Piero succeeded in getting his relatives arrested, but was not allowed to have them executed; they were exiled and left the city, accompanied as far as the gates and beyond, as if they were celebrating a triumph instead of going into banishment, by a crowd of citizens who vowed devotion. (Jacopo Nard.-Comment. di F. de Nerli).

Lodovico Sforza, who now ruled at Milan, was anxious to unite all the Italian powers against foreign aggression. Although the Italians were by no means fully aware of the strength of the great nations forming around them, yet they could not but perceive the danger to themselves of the military powers by which they were surrounded. Venice, indeed, was too near to Lodovico and too formidable to be admitted into the league, but he arranged that Milan, Naples, Ferrara, and Florence should send Ambassadors to secure the adhesion of the Pope ; and, to exhibit how perfectly agreed these powers were, he proposed that only one Ambassador should speak, and that one should be the one least likely to be entrusted with the mission-namely, the Envoy from Naples. Piero was chosen as Florentine Ambassador ; his vanity was piqued at not being able to display the splendid retinue, on whose fripperies he had expended a small fortune, exactly as he wished; and he came to a secret understanding with the King of Naples, which overthrew the balance of power in Italy, and so led to that coming of Charles VIII. to claim the Neapolitan crown which brought disaster to Italy and Florence alike. This, at least, is the account given by the Florentine historians ; but it is clear that now that the tenacity and wisdom of Lorenzo was withdrawn, and that an incompetent man replaced him, the balance of power in Italy could no longer be preserved. Florence and Naples were now in alliance; and the defection of Florence, the ancient ally of the House of Sforza, ultimately compelled Lodovico Sforza to call in the French. But Venice was isolated, and would have to struggle against Milan and confront all Italy. Venice, therefore, urged Charles VIII. to claim, not merely Naples, but to advance against Milan, to which the House of Orleans had a certain pretension through the marriage of Valentina Visconti to the first Duke of Orleans. The Venetian Ambassador believed that Charles would never really make the venture. Of the two States, Naples and Milan, the richer, and the one to which Charles had a direct claim, was Naples : he could secure Naples if he was allowed to march unopposed through North Italy, while, by contesting the sovereignty of Milan, he might end by losing both. These considerations were reinforced by rich presents from Lodovico Sforza, and Charles determined to leave Milan alone and attack Naples. Now, the Medici had important financial interests in France, as had all Florentines ; but still more important was it to keep the French out of Italy. So Florence, Rome, and Naples found themselves united in a common desire to hold Charles in check. But many Florentines were on the side of France, and not the less so that they were hostile to Piero. Indecision reigned in the city, while the French army was afraid to advance ; for by doing so they would leave Sarzana and Pietro Santa, Florentine fortresses that were the key to Tuscany, garrisoned by the enemy in their rear.

Piero, thoroughly alarmed, both at the gathering storm in the city and at a war which he was unable to conduct with vigour, remembered how his father had entered the lions' den, but forgot that he had neither his 
father's judgment of circumstance, nor his father's strength of character and influence. Already were the French in a quandary, dreading the evil climate of the Tuscan Maremma and what a siege might cost them, when Piero arrived at their camp accompanied by Florentine delegates (I494). Moreover, though Comines wrote that "the French behave smoothly to one another, and mistrust one another none the less," Charles was learning that Italian diplomacy was astuter by far than his own. Lodovico the Moor was apparently his friend, but he knew that Lodovico had only brought him in to secure his own power : the legitimate ruler, Gian Galeazzo, whom Charles had met at Pavia, was dead-poisoned, so men said, by Lodovico ; and, as we have said, Charles was not so blind as to be unaware that Lodovico had only called him in to paralyze the Italian powers while he secured Milan to himself, and that he was already busy in forming a secret league of the Italian States for his expulsion. Examination of the secret political documents of the time shows that Charles must have surmised that he was entangled in a dark web of " diplomacy," in weaving which every power had lent a cunning hand to its own security or advancement. Yet Charles bore a bold front: Italian condottieri were wholesomely afraid of the fierce French, who fought in earnest, and who had left ruin and terror enough in their wake.

Piero deprecated the anger of Charles at his having refused to allow him to march his army through Tuscany: he referred him to the treaty of Florence with Ferrante, to which Louis XI. had consented; he pointed out that withdrawal from this treaty would have exposed Florence to the resentment of Naples; but since that danger was now over, Florence was ready to show her devotion to France. The King demanded that the keys of the citadel of Sarzana should be handed over to him. Piero consented at once, without even consulting the other Florentine envoys. Astonished at this ready response, Charles demanded that all the other fortresses on the route of march, including Pisa and Leghorn, should also be surrendered: it was agreed to. There was no written treaty, only a verbal understanding that the King should restore the fortresses when the war was over; that the Florentines should lend him 200,000 florins; that the King would extend his protection to the city, and sign the written treaty there. It need hardly be said that the other envoys were indignant, and that Florence was not merely alarmed, but angry at the assumption of a despot's rights which Piero's father had, indeed, exercised, but always with the affectation of consulting and securing the consent of the Republic. The party of liberty was rapidly gathering strength and courage, and it was animated by the preaching of Savonarola, the famous Dominican revivalist (Fr. Guicciardini, Ist., Lib. i.-Pauli Jovii, Hist. Sui Temp., Lib. i.-Scip. Ammirato, Lib. xxvi.-Jacopo Nardi, Ist. Flor., Lib. i.Phil. de Comines, Lib. vii., c. ix.-Arnold. Ferronii, Lib. i.). When Medici arrived at Florence, he found the doors of the signoria closed against him. He sent to his brother-in-law Orsini for aid, but the message was intercepted, and the citizens gathered under arms in the Piazza dei Signoria, ready to obey the mandate of the Priors. Cardinal Giovanni dei Medici tried to get up a shout of “ Palle ! palle !" the old Medicean war-cry, taken from the famous three gilded pills which were the arms of their House ; but the citizens listened to the cry with ominous silence. Orsini contrived to bring up soldiers, and Piero and the Medici sallied forth, and tried to 
buy the populace by scattering largesse broadcast among them : the lower classes picked up the money, but the only thanks they rendered were muttered curses. Then the tocsin sounded, and the Medici, exhibiting more discretion than valour, rode out of the gateway towards Bologna. The portcullis fell with significant clang directly the last crested helmet had passed beneath it. It is amazing that Piero did not seek the protection of the French King; he went to Bologna, where Bentivoglio, who occupied a similar position in that city to that which the Medici held in Florence, expressed his contempt for a ruler that fled, little dreaming that he too would end his days in exile.

Some rioting and pillage of Medicean palaces followed, on the excuse that the Medici owed the people money. The palace in the Via Larga was reserved by the signoria for the King of France ; it was saved, indeed, from the Florentine mob, but was not so scrupulously treated by the French officers when they came ; and so the great collections of statuary, paintings, engraved gems, and books, so laboriously collected by Cosimo and Lorenzo, were scattered. The Medici were declared rebels by the signoria; their goods were confiscated ; a price was put on their heads, and all the families exiled during the sixty years of Medicean rule were recalled and re-established in citizenship; all the frescoes that celebrated the victory of I434 and the failure of the Pazzi conspiracy were erased; and the cousins of Piero, whom he had exiled, returned to Florence, abjured their name, and adopted that of Popolani.

Then the reconstituted Government, unequal to cope with the arms of France, and puzzled at the diplomatic imbroglio that perplexed all Italy, sent an embassy to explain matters to Charles VIII., to invite him to Florence, and to prepare the way for some definite understanding. The spokesman of the party was to be the strange friar Savonarola, the man who, like Arnold of Brescia and Jacopo dei Bussolari, was a patriot-priest, and who was supposed by the populace to possess power of miracle, with which he more than half credited himself, and gifts of prophecy, with which he wholly believed himself to be endowed.

\section{SAVONAROLA}

Girolamo Francesco Savonarola was the scion of an aristocratic House that had migrated from Padua to Ferrara. He was from his birth a selfabsorbed and self-assertive child. His high-strung temperament manifested itself in his early years. His childhood was abnormal in a way that marked an idealistic and precociously and unhealthily subjective nature. While other children played, he pored over his books, and he had that overpowering sense of personal sin so strangely absent from the ancient world, so rapidly disappearing to-day, so characteristic of the ancient Jew and the typical Christian, and to which the susceptibilities of childhood are so readily aroused. Convinced not merely of his own wickedness, but of the very evident corruption of the Church and the world, he was equally impressed with the need of saving his own soul and of breaking the wings of that " foul bird," the Papacy, in so far as it had degenerated into a corrupting influence. At twenty-three he escaped from home and took vows at Bologna. His early letters show him to have been of an argumentative disposition ; narrow, and yet not wholly devoid of sympathetic imagina- 
tion; capable of much tenderness and still greater obstinacy. He made himself but a poor classic; he remained an orthodox Catholic, but he had the confidence of a Wiclif or a Luther in doctrines of grace and in the power of personal faith. He knew more of the schoolmen than of Plato; most of the Bible. His voice and manner were against him : the former was weak, and yet harsh; his features hard, his figure attenuated, his gestures ungainly. Like Demosthenes, he determined to overcome natural disadvantages, and he soon succeeded in making himself a great preacher. As early as 1484 he claimed the gift of prophecy at Brescia, and when he came on foot to Florence in 1489 he gained the people by the homeliness of his metaphors and his free use of the simple illustrations of the Bible ; while the dilettanti, ever on the look-out for some new sensation, found their vague neoplatonism tickled by his mystic tropes.

Florence was anything but a wicked Italian city. The burghers were for the most part honest traders, and the bulk of the people led simple, God-fearing lives, such as characterize most communities of shopkeepers. True, there were remnants of the old pagan saturnalia that had been handed down to the generations from Etruscan and Roman forbears, and Lorenzo dei Medici fanned these dying embers by his festival processions that went through the streets singing his libidinous songs. The wealthy merchants, or, rather, their sons, were given to luxury and extravagance, and there was some sexual irregularity; but, in spite of the exigencies of diplomacy and of trade, the leading men were by no means devoid of religious feeling, as is shown by the earnest attention they gave to the platonic teachers, and by their intense dislike of the dissolute Court at the Vatican. Lorenzo himself was fully conscious of his own defects, and sat at Savonarola's fect : indeed, Savonarola's invectives against the outward magnificence and inward hollowness of the Church were acceptable to the Florentine mind. Savonarola had intellect enough to perceive that the States beyond the mountains were growing great, and would turn the dissensions of Italy to their own profit. He boldly prophesied woes unutterable that should come to Italy by invasion. A resuscitated sense of mystery always appears in ages of decadent religion. Men were impressed by the emaciated figure, the earnest eyes, and the sentence of impending doom that the sincere and impassioned friar poured forth with the homeliness of a Franciscan and the religious authority of his own Order; and when Charles approached Tuscany, his prophesyings seemed to be near fulfilment, and his authority and influence were clinched. He had foretold the coming of foreign hosts led by a new Cyrus, and lo ! the new Cyrus had come with a host of fierce warriors of strange races from beyond the Alps. Gigantic Swiss, rude and fierce, light Gascons, as ready with the blade as with the tongue, and stolid Scots-uomini bestiali-were led by French fops, who could nevertheless play the man against the unheroic mercenaries. And these barbarians were skilled in a kind of warfare unknown in the peninsula; they had developed the art of war, and they were accompanied by an improved artillery.

The leading men in Florence were bent on the establishment of an oligarchy, but the King was drawing near; the frontier fortresses were his now, and his intentions must be ascertained; somehow he must be dealt with satisfactorily before anything could be done. Piero Capponi, who knew the King-for he had been Ambassador in France-was elected to 
head an embassy, and Savonarola was chosen as spokesman. Savonarola was a man of high ethical intuition, one who walked daily with God; he had keen perceptions, but they were transmuted and idealized by his exalted religious imagination. Charles, fantastically romantic, irresolute, swayed, now this way, now that, by men stronger than himself, wholly incapable in affairs, with an ugly face and the figure of a freak at a fair, was very unlike the ordinary notion of either a conqueror or a deliverer of Israel (vide Mem. de Philippe de Comines.-Guicciardini) ; but the intense emotional subjectivity, the earnestness of purpose, and the lofty idealism of Savonarola, converted the victorious monarch into a great instrument of Divine Providence, a celestial flail to bring the nations through tribulation to the peace of God, and he addressed him with the confident conviction of the inspired prophet of the Lord. He welcomed Charles in the name of God; he warned him to listen to his words and grave them on his heart; he bade him spare the city, whereof the sins were manifold and grievous, but wherein were also faithful servants of Christ enough to claim his protection. Then and then only would the Lord attend his arms with victory, would extend his kingdom, and admit him as His faithful servant into the eternal abode of the blessed. But the reputation of Savonarola had hardly penetrated to Paris : Charles had heard a good many sermons in his life, and here was one more to endure. He listened with politeness, and replied that everything would be arranged satisfactorily on his arrival at Florence (Perrens.-Jacopo Nardi, Ist, Fior., Lib. i.).

The King meant to restore Piero. Piero was in Venice ; the Venetians, already alarmed at the power and energy manifested by France, dreaded lest Medici should become a puppet in the hands of the King; they advised him not to trust himself to Charles, and they kept a secret watch on his movements. The citizens of Pisa, where Charles was lodging, seized the opportunity to throw off the Florentine yoke ; the King granted his protection; the Florentines were driven out, and a French garrison established in the citadel (November, I494). Then the King marched on to Florence. The streets were garlanded and gay with banners, and the men shouted "Viva Francia!" as Charles and his 12,000 men passed through the city to the Duomo ; but the condottieri in the pay of the Republic were ready ; the citizens had their arms at hand, and every house was crowded with the sturdy peasants of the hills. Charles was lodged in the palace of the Medici, and negotiations commenced. The King tried to ride the high horse ; he informed the Florentines that he had come with his army, and that therefore he regarded the city as his, but he would like to know whether his people would prefer to obey the Medici as his delegates, or a signoria, to be supervised by his own jurisconsults. The Florentines replied calmly but firmly that they had opened their gates freely to an honoured guest, and that they certainly had no notion of surrendering their liberty to him or anyone else. Meanwhile, in spite of feasting and illumination, the French felt far from comfortable; some Swiss who had not behaved themselves had been roughly handled; and a conflict in narrow streets, with fortress-palaces and barricades defended by an armed population to be carried and stones coming down like hail from the roofs, formed anything but an inviting prospect. Charles came down in his requests, but got angry about the resistance to his demands for money. "Then I will bid my trumpets sound," cried he. Capponi, who represented Florence, 
tore the treaty in half, and said : "So be it ; we will sound our bells." Charles tried to laugh it off, but Capponi left the room. At last an agreement was come to. Charles was to have I00,000 florins for his Neapolitan expedition, and to be called the " Restorer and Protector of the Liberty of Florence" - a title about as empty, meaningless, and insincere as those academic honours which royalty is always graciously pleased to receive, and which the obsequious learned do not blush to bestow. Pisa and the Florentine fortresses were to be restored when the King should quit Italy, and the commercial privileges accorded to Florentines in France were ratified. The treaty was signed, but still the King lingered in the city. Perhaps the females of Piero's household, the Orsini, may have been influencing the weak monarch. The Florentines grew more and more disquieted, the tension greater day by day. Then Savonarola left his cell and came into the presence of the King. He threatened him with the dire vengeance of the Almighty if he did not leave the city without delay. Savonarola, speaking the word of the Lord in the midst of 20,000 fighting Florentines who were of his mind, in a city whereof every other house was a citadel full of armed men, was something more than a mere friar preaching one of those tedious sermons one has heard so often. Charles took the hint, and departed with his French, their hands full of the valuables of the very Medici whose interests they had been so anxious to defend.

The credit of the monk was more firmly established than ever. His prophecies had been fulfilled : born of political perception, they enabled him to manifest his real political powers. He alone had so loved the city as to dare confront the monarch : to him the city owed its deliverance. Up to the time of the advent of Charles in Italy Savonarola had taken no part in politics, confining himself to ministration to souls, to religious exhortation, and to the awakening of the moral consciousness of the city : henceforward he becomes the greatest political power in Florence.

It was the notion of the time that peoples could be moulded by constitutions ; that it only required the application of intellect to devise a satisfactory form of government. There was no clear conception before our own day of a people as being a living organism, with a vital structure of its own which develops itself, the evolution of which can, indeed, be modified and guided by patient study, but which is of so delicate and yet tenacious a character that force may in truth crush but can never coerce it. Savonarola had the merit of seeing deeper. He succeeded in retaining the old institutions, though they underwent much modification ; he tried to graft the principle of Venetian continuity on to the democratic requirements of Florence : his great error lay in his puritanism, and his belief that the principles proper to a theocracy will bind and control the fulness of life and the passions of men. He was called upon by all parties to advise.

For, when the Medici were expelled, a parlamento had been summoned, and the signoria proposed that balia should be given to accoppiatori ; in other words, another of those provisional governments, so frequently met with in the history of Florence and Siena, was constituted. Twenty citizens were nominated to select the Priors; the Medicean instrument of the Council of Seventy was abolished (it had already split up into pro- and anti-Medicean factions). It was found that time had brought about such changes that the old councils of the people and commune no longer represented real interests, and they also were done away with. It was agreed 
that there should be a register of those possessing citizen rights, and that these should elect the magistracy at the end of the year. The oligarchy had triumphed, for the Twenty were paramount. But the Twenty were divided into faction by family and personal antagonisms, and some of them began to play the rôle of the demagogue by fermenting popular discontent. Indeed, so menacing was the attitude of the mob that an unfortunate tax collector and several other officials had to be sacrificed to popular clamour ; while, to gratify the growing demand for equal treatment, very inferior men were despatched on important embassies. One of the Soderini, who was fresh from Venice and enthusiastic about its institutions, felt galled at being excluded from office. He had a sincere desire to serve the State, but personal ambition and personal resentment were mingled with loftier feelings. He proposed a Great Council of all qualified citizens, and a lesser body for concentrated powers. But those in power were for keeping it to themselves. Danger was in the air, for, as Guicciardini observes, an oligarchical Government would only have meant reaction, and the people were already getting out of hand. At this pass recourse was made, by common consent, to the " man of God," who was preaching purity of life and simplicity of manners and Church reform, and who had hitherto withheld himself from politics. Savonarola consented to advise, and his advice showed his practical sense. He proposed that the gonfalonieri of the companies, the twelve buonuomini, the Twenty, and the Ten of War (including Soderini) should present their schemes. Then he began a course of political sermons, advocating the Venetian model, which gave continuity of policy, to be specially adapted to the democratic instincts and inheritance of Florence. The idea satisfied Soderini and the majority ; the wisdom of the advice was apparent to the meanest understanding; and henceforward the sermons of Savonarola became the oracles by which the legislation of the Republic was directed. A Grand Council of all above twenty-nine years of age, whose ancestors had served the State for three generations past, was formed, and to this were added a certain number of younger men " to incite them to virtue," and of citizens who could not claim much ancestral distinction. Then, by a happy admixture of the principle of equality, which alone preserved liberty, and that of selection, which alone was likely to secure talent, an electorate was to be chosen from this council by lot, who should select and nominate candidates for the magistracy; and these could not be elected unless they obtained an absolute majority of votes. The General Council was to choose another council of eighty men over forty years of age, to be renewed every six months, but eligible for re-election, to deliberate on grave matters of State, to appoint Ambassadors; and to supervise military matters. The ancient institution of the signoria and Gonfalonier of Justice was to be retained, and its consultations were to be aided by small colleges, including the Ten of War and the "Eight of Pratica," an old standing committee of State. Thus, Savonarola preserved the old, proved constitution of the Republic, while he safeguarded liberty by the retention of the principle of election by lot, gained efficiency by the introduction of the principle of representation, and followed, though afar off, the Venetian example of continuity. The signoria, on proposing a new law or a new war, or other important matter, would consult the small colleges composed of the gonfalonieri of arts, the buonuomini, and selected citizens-all forming what was called a pratica. 
After due discussion, the matter was to be relegated to the Council of Eighty, and then to the General Council, both of which could reject but could not discuss the proposition. Savonarola believed that the people would be content with the superiority of those whom they had themselves elected, and he thus endeavoured to combine the Medicean principle of the select council for efficiency in war and foreign affairs, with democratic demands for a voice in directing the destiny of the State. The machinery of State thus oiled, and with a new improvement here and there, began to work easily, and Savonarola now took up his parable against arbitrary and irregular taxation, and against parlamento, or the popular assembly, which he pointed out to have been the great engine whereby the Medici had acquired their despotism. Immediately, tithes were introduced into fiscal policy, and the parlamento was abolished " for ever," with anathema and death for whosoever should seek to reintroduce it. Savonarola was convinced of the importance, for the truest welfare of a State, of making every citizen its guardian, and of bringing home to him the greatness and importance of his trust; but he had no confidence in popular political emotion, though he had in religious; he knew it to be transient, and he saw how, in Florentine history, the people in parliament assembled had become the mere tools of oligarchy to their own undoing; he also exhibited a wise antipathy to discussion in large assemblies. He did the good work of instituting a State pawnbroking establishment; but his preaching was ineffectual against the popular demand for an appeal from the Eight, who judged State offences, to the General Council. In fact, this measure was pushed on by the personal enemies of the friar.

For, needless to say, he had made personal enemies, and these availed themselves of the hotch-potch of religious enthusiasts, political theorists, self-seekers, and class and family antagonists that made up the political life of Florence. There were many parties in this State that would fain rival the speed, secrecy, and statesmanship of the Venetian system, under the impossible conditions of conflicting authority, inherited partisanship, and absence of centralized control. The old quarrel between effective pilotage of the State through dangerous waters, and the protection of a liberty essentially incompatible with such pilotage; of the directive initiative of experts who tend to become despotic, and the assertion of popular rights which tend to be swayed by every passion of the moment, was never more exhibited than in Florence; and, to make matters worse, there was no clear differentiation of office, but the various departments of State were jumbled together and confused. And, worse still, a wealthy and powerful class had been excluded from office in Florence since the ordinances of justice; and the classes that had not held power hitherto were still practically excluded from all share in government. The State still remained in the control of the upper middle class, and the upper middle class was a house divided against itself. The excluded nobles and the excluded mob were largely under the influence of Savonarola, who preached that religion and politics were inseparable, who denounced the Medici, not so much on account of their despotism as because they had debauched the people, and who looked forward to the restoration of ancient virtue through the return of freedom. This party, then, of those who were all for freedom, and some of whom followed the friar in his puritanism, were designated the piagnoni, or "snivellers." Those who belonged to the 
old oligarchy, the younger members of which had a cavalier-like contempt for Savonarola's puritanical principles and detected the hypocrisy of many of his followers, were called the arrabiati, or enraged. And among them were young men of evil and dissolute life, the compagnacci, or bad companions, who were quite ready to get rid of the obnoxious friar by the readiest means at hand. And, fourthly, there was still a party of Medicean adherents, who would have been expelled but for Savonarola's plea for amnesty, who hated him none the less, and who imitated their patrons by bidding for popular support. These were the bigi, or "grays," so called on account of their obscurity. The pulpit, "drum ecclesiastic," was now converted into drum politic, and rival preachers were set up against Savonarola.

Nevertheless, the friar was still the popular hero, and the Florentine enthusiasm for liberty was unbounded. Donatello's David was set up at the gates of the Priors' palace to indicate that the young republic had overthrown despotism, and his Judith, as a warning to all future usurpers of power, with the legend at the base, " The citizens have erected this as an example for the public well-being."

Savonarola's political programme may be described as consisting, first, of the restoration of the fear of the Lord and severe rectitude of conduct; secondly, the welfare of the community; thirdly, universal peace; and fourthly, political reform. He appealed to the highest instincts of man, but he apppealed in a narrow puritanical spirit; and when it came to practical politics, he was as blindly and immorally one-sided as most other ethical enthusiasts; he was as bitter against the righteous rebellion of Pisa as any of the purblind company of the wicked : Our Lady told him in a vision to ally himself to France, and so subjugate the revolted city : he had become more Florentine than the Florentines, and their maltreatment of Pisa counted for nothing in his eyes. That, however, made for him among the people, who were for "their country, right or wrong "-at least, so long as their country chanced not to be against their party.

The religious fervour, excited by Savonarola's unwearied invectives, entreaties, and denunciations, still waxed. Precious pictures by Botticelli were consigned by that master to the flames. Psalms and mystic hymns were chanted by processions organized in honour of Our Lord and Our Lady ; chants of the mysteries of Divine love replaced the carnal ditties of Lorenzo, and friars and bald-headed citizens, garlanded with flowers and accompanied by children, passed along the streets, singing and dancing with the fervour of a latter-day Salvation Army, but possibly with more of sweetness and grace. The gawds of women and the pornographic literature of men, valuable pictures of pagan themes, jewels, and all the pomps and vanities of this wicked world, were unhesitatingly cast into the bonfire by men and women coming straight, in a state of spiritual intoxication, from the exciting oratory of the friar. The mystic fire that burned in Savonarola's heart set that of Florence ablaze ; an ascetic reaction followed the license of the Laurentian time ; for Savonarola enforced the suppression instead of the wise government of human desire.

The Deity is found, not in the whirlwind and the earthquake, but in the " still, small voice." "It was a holy time, but it was short," writes one who praised God that he saw it (Luca Landucci, Diario). But, while it lasted, the good friar hastened to " keep the young generations in hail 
and leave them no battered house "; with questionable judgment, he organized them, and they went about the city in companies, with childgonfalonieri leading them, seizing emblems of vanity, stopping gambling, collecting alms for the poor, and advising the Priors how to reform the morals of their elders.

Savonarola now began to attack the scandalous life of the Pope: he was no Protestant; he attacked no dogma; but his soul revolted at the horrible corruption of the Church at its centre, Rome, and in its head, the Pope. He preached the need of a council and of thorough reform. Pope Alexander VI. was a burly, energetic, sensual man, not wholly conscious of his own unholiness (Desjardins, Négociations, vol. i., p. 393). He had experienced a great fright when Charles menaced Rome, and he did not want to go through it again ; he dreaded what might result from the alliance of Florence with France; he believed Savonarola to be intriguing with Charles; and his suspicions were augmented by Lodovico the Moor, who had called the French into Italy, and was now anxious to push them out again. He tried all his arts and wiles to detach Florence from the French alliance, but Florence was bent on the reacquisition of Pisa (Charles had promised to restore the subject city, and Florence hoped on, relying on the promise of Charles, and still more on the prophecy of Savonarola). Alexander at first treated the friar with forbearance, and even with gentleness; possibly some feeling of reverence for the saint may have existed in the heart of the sinner; and Alexander only became cruel when his passions were thwarted. He invited Savonarola to Rome in terms that seem to show his appreciation of the man. Savonarola suspected a trap, and refused to come. The Pope now united the Tuscan to the Roman congregation, and the friar was prohibited from preaching; but, by the intervention of the Florentine Government, Alexander had to revoke the prohibition. Then the Pope tried flattery ; a Cardinal's hat was hinted at. The reply of the frair was to thunder against Papal corruption with the energy of Boanerges. The Church was now aroused : it had not forgotten the Hussites of the North, and it girded up its loins for war against this friar that had aroused the Florentine conscience and might awalke the dormant moral sense of Christendom.

Meanwhile, the large party in Florence that was all for freedom, but by no means for a theocratic government (which meant the extinction of what little personal liberty existed in the fifteenth century), grew in numbers and in power. A new signoria, not unfavourable to the Medici, was elected, and Piero dei Medici took advantage of this to come from Rome and try to capture the city by surprise. He failed, and the attempt threw the Government into the hands of the Arrabiati, who were in secret communication with Rome and Milan. The plotters were executed at night, without grant of appeal to the General Council ; and this deprivation of their legal right, concerning which Savonarola was silent, gained him fresh foes. The Compagnacci even tried to assassinate him. The city, wearied of the spiritual joys of religion, began to sigh after the flesh-pots of Egypt, and it became manifest that Savonarola had overstrained the devoutness of Florentines, and that a reaction was setting in against the austerities of his rule. Then Charles VIII. died, and Pisa remained unrestored to Florence-nay, was restored to her own freedom. And Savonarola, burning with righteous indignation at Court tales of Papal incest and at 
true accounts of villainies perpetrated in the Pope's family and household, took it on himself to write to all the Potentates in Christendom, calling on them to summon a council and purge the Church of its offences. The letters were intercepted, and one was shown to Alexander. About this time the Pope excommunicated Savonarola, and Savonarola treated the excommunication with contempt. He denied the authority of a bad man to prevent him from preaching, and, after giving the Sacrament to his followers, he spoke to the populace in the square outside his convent, holding up the Host that he had consecrated, and calling on the Most High to send down fire from heaven, and on hell to swallow him, if he deceived himself or the people, and if he were not God's own messenger. But the Government in office at the time was hostile to Savonarola; even the Piagnoni were disturbed at his excommunication and his defiance of the authority of the Father of the Church. And then an event happened which gave the Pope and his enemies the opportunity for which they now thirsted.

A Franciscan monk, preaching at Santa Croce, said that Savonarola pretended to be possessed of miraculous power. Well, let him prove it, by undergoing the ordeal of fire with the preacher. Both men would perish, but the Franciscan did not mind sacrificing his own life, for he would prove that Savonarola was a false prophet, and deliver the Church from teaching that meant damnation to those who accepted it. The challenge was reported to Savonarola, who rightly regarded it as unmeet and improper. But Fra Domenico Buonvicini, a narrow-pated visionary, a blindly enthusiastic disciple of Savonarola had already taken it up and was inclined to credit himself with miraculous power and special Divine protection. So, when Francesco di Puglia, the challenger, answered Fra Domenico that he had defied Savonarola and not his follower, but that another monk was prepared to go into the fire with Domenico, Savonarola hesitated, and the signoria, now acting in concert with Rome, the Arrabbiati, and the Compagnacci, egged him on by direct persuasion, and stimulated him by the fatal incitement of derision.

All Florence was eager for the ordeal. The religious enthusiasts were mad to prove their friar right by a miracle from heaven. Savonarola's foes chuckled at the self-condemnation of a heretic to the flames; the signoria was heartily glad to be so easily quit of a business wherein they had to balance Savonarola's still real power against the damage to Florentine business that an interdict might bring about ; and the majority looked forward with eager curiosity to a spectacle which now, at the end of the fifteenth century, was a startling anachronism. And the Pope clinched the business by writing to the Franciscans to thank them for the zeal they showed in being ready to sacrifice their lives in the defence of the authority of the Holy See ; he declared that the glorious exploit would bestow eternal fame on them (April, I498). The fated day came. Fra Domenico's enthusiasm convinced Savonarola that he, Domenico, had received a message from on high; and both sides appeared ready to enter the fire. But the only object of the Franciscans was to start popular disturbance and get Savonarola seized; they made various excuses, and delayed the ordeal until a thunderstorm came on and wetted the fuel, and the signoria then declared that it could not take place. Here, in all logic, the matter should have ended. Savonarola's foes, and not Savonarola, had evaded the test. But the crowd was furious at being balked of a spectacle, and 
the fanatics of Savonarola's party were wroth with him that the attempt had not been made, while the politicians and wiser heads among the Piagnoni were angry at his weakness in yielding to such a mediæval proposal. Savonarola's party, therefore, was out of heart and disorganized, and the Arrabbiati, the Bigi, the Compagnacci, and the signoria were free to foment disorder. San Marco, Savonarola's convent, was stormed that same night, and he and his followers led off to prison.

Savonarola was put to the torture. At first he held to the Divine authority of his prophetic gift. Then he declared that the spirit had departed from him. It is too painfully evident that he was never quite sure of how far and in what manner he was inspired : the desire to possess extraordinary powers had bred the credence he gave to them; he had battered himself into belief. And now his soul as well as his body was on the rack, for he found himself at war with himself, and with no very assured conviction where he most required it; he tasted that bitterest of wormwood when he found that what had seemed to be his deepest beliefs and firmest supports had vanished-that God had forsaken him. Yet he stoutly maintained his sincerity in all that he had done, and that his every action had been dictated by pure devotion to God and the public weal. The essential truthfulness of Savonarola's nature is manifested in the patent sincerity of his so-called confession. He never falters as to his motives. Pain and weakness dispel the clouds of pride and self-assertiveness, and leave his soul naked and simple as that of a child; he doubts himself now that he sees himself more clearly; and what he sees he reveals. It was enough for the tormentors. They distorted his truthful statement into a confession of fraud. They had already strained the constitution; it was little to twist evidence in order to convict him. But the time had drawn nigh for the election of a new signoria, and it was necessary, and was contrived, that the election should be favourable to the Arrabiati, the party in power. Savonarola had often desired to improve the constitution, but the Government remained, as always, favourable to the development of individuality indeed, but cruel, because weak and easily manipulated by a party or a person. To unite the consistency, the swiftness, the secrecy of Venetian polity with the freedom and manifold claims of Florentine democracy was impossible. The new signoria was crueller than the last; it welcomed apostolic commissioners sent by the eager Pope. They came furnished with orders that, even were Savonarola another John the Baptist, he must be slain. They put him to the torture once again, but he was firmer than before : they condemned him in the teeth of evidence, and they hanged him on a gallows which Jacopo Nardi says, in spite of alterations to destroy the resemblance, still retained the appearance of a cross. After the hanging, the bodies of Savonarola and two of his followers-Fra Domenico and Fra Silvestro-were burned. A few faithful gathered up the relics that could be found, and they are still to be seen, garnered in the friar's cell where he worked and prayed, surrounded by the gentle imaginations of Fra Angelico, in that place of deep, sweet, and unvarying repose, the convent of San Marco. (The best accounts of Savonarola and interpretations of his character are given by E. Armstrong, M.A., Modern Cambridge History, vol. i., cap. 5, Cam., 1902, and Prof. Villari, Life and Times of Savonarola, tr. L. Villari, I899.) 


\section{The Downfall of the Republic}

From the time of the failure of the minor arts to maintain their ascendancy down to the fall of Piero the high civilization of Florence had prevented scenes of violence. The principle of order triumphed; the principle of liberty decayed. With the expulsion of the Medici the republican system was tried again ; and, in a period of crisis, when old standards of right and wrong had disappeared, when new standards had not yet appeared, when the lofty enthusiasm of Savonarola excited the emotions, but failed to affect the reason of an age of decaying conviction, when the city was torn by faction within and rebellion and the moving of great forces without, the experiment was foredoomed to inevitable failure. Already scenes of violence which had been unknown for a century were repeated ; nay, they assumed the worse forms of irregular condemnations and corrupted public life.

Florence, in endeavouring to recover Pisa, had to strive against France, her ally; Pisa found herself, in the singular policy of the times, at once relying on France and seeking the support of the enemies of France, Lodovico Sforza, the Pope, and Venice. Venice responded warmly at the instigation of Lodovico the Moor, who did not think it likely that that State would endeavour to seize a city so far from her base, who wished to enfeeble Florence, the last ally of France, and was anxious to save himself as much expense as possible. Venice sent her magnificent light horse to Pisa, and they succeeded in ravaging Florentine territory. But when Venice desired to send fresh troops through Milanese territory, Lodovico, who now suspected the Republic of a desire to become overlord of Pisa, barred the way. An attempt was then made, unsuccessfully, to send troops through Romagna (1498). The capricious Maximilian, who had arrived in person at Pisa, disappeared almost as soon as he came (1496). All Florence was of one mind about Pisa : every citizen was bent on reconquering the city ; but there were no men at hand of commanding character or of high ability. The State, as Machiavelli tells us, was venal and corrupt ; intelligence outweighed character. Paolo Vitelli, a man of great military reputation, was at last placed at the head of the army, and when an astrologer declared that the fortunate moment was come, a service was held in the cathedral, and the Captain set forth. But the Ten of War were changed every two months ; secrets leaked out; there was no confidence either in the Ten or in the signoria, which only held office for two months, Generals were jealous of each other; the sterner virtues had given place to place-seeking and self-advancement by intrigue; expenses mounted in geometrical proportion beyond the capacity of the resources of the State to supply ; and, to crown all, just when the walls of Pisa were breached and the Florentine volunteers were rushing to carry the city by assault, Vitelli drove them back with blows. Men now remembered many a clear case of intrigue against Vitelli, and ordered him to break up the camp. He had allowed important prisoners to escape ; he was suspected of collusion with the Medici and the Petrucci of Siena; nothing but the incapacity of a Government changing with such frequence, and the general belief in his military talents, would have allowed him to retain the command up to now. Under the pretence of wishing to confer with him on military 
matters, the Florentine commissioners dined with Vitelli, and then had him arrested. He was conveyed to Florence and tortured, and, though he avowed nothing, we know from the Venetian records that he was really a traitor (Archivio dei Fravi, "Misti," c. x., vol. $n 275$, carte $23_{1}$, vide Villari Mach., p. 244.) He was decapitated (1499).

The advance of the King of France caused fresh alarm. Since Louis was anxious to proceed unimpeded to the conquest of Naples, he received the Ambassadors of Florence at Milan, and, with a view to the subjugation of Pisa, the latter submitted to arrangements as to mutual aid. No sooner was the immediate danger from France met than the advance of Cesare Borgia in Romagna threatened to substitute a single powerful neighbour for many weak ones. By I5OI Cesare was master of the greater part of Romagna, and demanded provisions, a free pass through Florentine territory towards Piombino, and a change of her Government The first two demands were acceded to. By ${ }_{502}$ he succeeded, with the aid of Piero dei Medici, in getting Arezzo to revolt, and rapidly subdued place after place, so as to hem in Florence on all sides. To the south he held the country from Piombino to Perugia, and had won over Petrucci, the de facto lord of Siena, to his side. To the east Arezzo and the Val di Chiana were in revolt, and the passes of the Apennines led from a country under his control ; to the north Pistoja was weakened by faction ; to the west Lucca was Medicean, and Pisa had offered herself to Cesare. Then Urbino was captured; but this revealed the Borgia's hand to Louis, who was not at all willing to see more territory fall into Cesare's hands. The King intervened, though he had found occasion to complain to the Florentines that they failed to give him efficient aid in his Neapolitan war.

The danger was pressing : it was evident that the securing of consistent policy necessitated that the Government should have long tenure of office ; and, after much discussion, a compromise was effected whereby Piero Soderini was made gonfalonieve for life, and the Ten of War were continually re-elected; their term of office had already been extended to six months, and their duties had been narrowed down to those of a war office. It was determined that the new office should be filled by a man over fifty years of age, whose relatives should not act in the signoria; who, with his sons, should be forbidden to trade ; who should hold no other office ; who should be deprived of office if he violated the law ; and who should be paid 1,200 florins a year. The new gonfalonieve, elected by the Grand Council, was a popular man, a fluent speaker, an irreproachable citizen, whose mediocrity saved him from jealousy and foredoomed him to failure. At a time when not merely a head of the State but a strong man in the office was absolutely necessary, party rivalry, personal jealousy, and republican suspicion put at the head of affairs a man, worthy indeed, but incompetent to conduct difficult and weighty matters at a perilous crisis (I 502).

The death of Alexander VI. relieved Florence from the Borgian peril ; but Venice came nearer by taking Faenza and Rimini in the dissolution of his territories; and Southern Italy, which after the battle of the Garigliano fell to Spain, was in the possession of a power which was known to be favourable to Pisa. Meanwhile the war with Pisa dragged on, and, although Soderini was popular with the masses, owing to his exercise of rigid economy, the leading families were alienated by his contriving to fill the signoria and the colleges with young politicians, who mostly had heads 
on their shoulders or were not likely to oppose his authority, to the exclusion of people of rank and traditional position in the Republic. The defeat of the French in the South led to the hope of their expulsion from Lombardy, and, as Florence stood in the way, at the instigation of Cardinal Sforza, Spanish condottieri advanced towards the city to restore the Medici. They were, however, defeated (I505). In I506, at the suggestion of Machiavelli, a new national militia of 5,000 men was formed to put an end to the Pisan war; and at last (I509) Pisa was compelled to capitulate, though Florence had to pay over I 50,000 gold florins in fees to the monarchs of Spain and France and their servants for their non-interference.

The year I 503 saw the accession of Julius II. to the Papal throne, and the new Pope was known to be favourable to the Medici and hostile to Soderini and his republican Government. So long as Julius had Romagna to reconquer, Florence was safe ; but when Louis demanded that Florence should take his side, fearing lest a Papal army should advance, Machiavelli was sent to Paris. Florence was obliged to accede to Louis' request that a general council should be held at Pisa to depose the Pope ; the only result was to incense Julius and bring down an interdict on both cities. And directly the French were expelled it was decided at the congress of Mantua to restore the Medici. Ramon de Cardona was sent with an army to demand the deposition of Soderini and the readmission of the Medici as private citizens. Prato shut her gates, relying on her fortifications, which, however, were defended only by the ordinanza, or country militia. The walls were soon breached, the country taken by assault ; 5,00o citizens are said to have been massacred, the women violated, the churches despoiled, people supposed to have concealed wealth put to lingering torture of every kind. The terror caused by this scene of ruthless barbarity in the little town so near produced a revolution in Florence. Next day a company of young nobles, who formed a Society of the Ruccellai Garden, ostensibly devoted to the cultivation and enjoyment of the arts and graces of life, entered the Public Palace without meeting with opposition; for the city was panic-stricken, and none were concerned to defend the gonfalonieve, whose tenure of office had been signalized by little glory and much disaster. The councils were summoned, and, under a threat of slaying Soderini if he were not deposed, he was deprived of office and exiled. Cardona was then treated with. First, above all, he demanded gold, and got it; and then he required the reintroduction of the Medici into the city as private citizens. Many of the conspirators were in secret communication with the Medici. Guiliano dei Medici, the third son of Lorenzo, entered the city almost the next day ; Cardinal Giovanni, afterwards Leo X., a fortnight later, and the signoria were called upon to summon a parlamento. Few were admitted to this meeting except strangers and soldiers. All the laws cnacted since the expulsion of the Medici were abrogated. Accoppiatori, subservient followers of the Medici, were appointed to select the members of the signoria and colleges, and the office of gonfaloniere was made bimensual. The first care of the Medici, almost ruined by their long exile, was to re-establish the tyranny by the ruse of an apparent moderation ; their next, to refill their emptied purses, and pay the Spaniards who had restored them ( 15 I 2 ).

Nothing could have saved Florence : her theory of political freedom was incompatible with the exigencies of the changed and troubled times that 
had come upon Italy ; her policy was unstable ; her Government constantly changing hands; her finances unequal to the employment of a sufficiently large mercenary army; the military training of her militia insufficient to enable them to cope with experienced troops; her enemies were more numerous and powerful than ever before; her councils weakened by internal discontent and the strife of faction; her resources ruined by the war with Pisa ; her sterner virtues departed. She found herself isolated in Italy, and her isolation was not splendid, while the friends of the Medici in the city were the richest, the most powerful, and the most persistent of her factions. The old civic spirit had given way to a general feeling of distrust - distrust of the wealthy, of the efficiency of the militia, of the loyalty of the mercenaries, of the policy and good faith of the Government. Only one end was possible to such a condition, and that was the triumph of the party of the purse, the party that preferred security of trade and jobbery under the traditional leadership of the Medici to the dignity and honour of the Republic.

Yet, to the last, men like Soderini and Machiavelli burned with patriotic zeal. Michelangelo found a subject sympathetic to his nature in his magnificent David, fit expression of the defiance and hatred he felt for the foreign usurpers of republican right, and both he and Leonardo da Vinci were employed to decorate the great council chamber of the Public Palace with what were perhaps the most magnificent of their works. Public spirit was impotent, but it was not dead.

Of course, the chief foes of the Mcdici were sent into exile; but, on the whole, Cardinal Medici, who was the leading spirit of his party, behaved with singular moderation. A heavy contribution was levied on the city to pay the Spaniards, and the goods brought by them from the sack of Prato were sold in the public market-place, which did not increase the favour with which the Medici were regarded. But that family set themselves steadily to work to win golden opinions. The old trick of winning over the populace by magnificent shows and festivities was resumed; mock reforms were instituted, and the leading citizens, hoping that they would still be summoned to take their rightful share in the Government, made no sign of discontent.

Two young enthusiastic and lofty-minded youths, Paolo Boscoli and Agostino Capponi, determined, however, to imitate the example of Brutus, and rid the world of the usurpers (I 5 I3). One of them dropped a paper from his pocket containing the names of those whom he deemed would be favourable; the name of Machiavelli was on the list. Both youths were decapitated, and Machiavelli and the men mentioned in the list were cast into prison, and tortured to extract further information. Boscoli, when he was condemned, read the Bible eagerly, and tried to batter himself into a fit state of mind to meet death ; while Capponi quietly reproved him for not being content to die. "Get Brutus out of my head," cried he in despair. "I believe Capponi was a martyr, and has gone straight to paradise," said his confessor; "St. Thomas distinguishes between the case of tyrants chosen by the people and those that have planted themselves by force : against the latter conspiracy is lawful " (Archiv. Stor., vol. i., pp. 283-309). Professor Villari has pointed out, in commenting on this narrative, that Christianity had taken possession of private morality, and had affiliated itself with platonism in the minds of thinkers, but that public 
morality belonged to a separate world, of which the inspiration came from Greece and Rome. In the sixteenth century that inconsistency which characterizes the human mind in all ages was often brought into bold relief.

When Cardinal Medici took the tiara as Leo X., Florence was ruled by Lorenzo, the son of Piero dei Medici and Alfonsina Orsini. This descendant of pill-makers and usurers married one of the French Princesses, and left a daughter destined to become Queen Catherine, the curse of France. He surrounded himself with soldiers and a Court, but, dying in 1519 without legitimate male issue, Cardinal Giulio, the illegitimate son of the brother of Lorenzo "the Magnificent," ruled the State. When he became Pope Clement VII., the direct line of Cosimo was represented by two bastard descendants, Ippolito and Alessandro, respectively of the fourth and fifth generation from the Pater Patriæ. The former is supposed to have been the son of some lady of easy virtue who dwelt at Pesaro; the latter of a mulatto, the daughter of a black Neapolitan slave. Both were too young to be placed at the head of affairs. The State was really directed from Rome, Leo being represented by Cardinal Passerini. But, as is perhaps usually the case, the real ability of the House descended through a collateral branch. The brother of Cosimo, Pater Patriæ, had a grandson who married Caterina Sforza, a daughter of the famous family of Romagnan peasants, whose fortunes were founded by Attendolo the condottiere, and whose bastard son, Francesco, secured the throne of Milan. She was one of the most remarkable of the many remarkable women of the Renaissance, and her blood would appear to have increased the natural vigour of the stock. When besieged in her Romagnan castle the foe without threatened to murder her children unless she surrendered. She replied : "I am young enough to have more." Her son was the famous Giovanni, the leader of the Black Bands, one of the most capable Captains of his time; and his son, Cosimo, was destined to become the first of the Grand Dukes of Tuscany, and a ruler of remarkable sagacity and force of character. But this branch was wholly obnoxious to the bastard descendants of the Pater Patrix; there was feud between the two families, and Clarice, a daughter of the collateral branch, had married into the Strozzi family that later upheld the republican flag.

When the news of the sack of Rome (1 527) reached Florence, the Strozzi and all the more important citizens prepared to revolt. Cardinal Passerini found the situation hopeless, and rode away with Ippolito and Alessandro. The Republic was proclaimed in fact as well as in name. But the city had always tried to emulate the stable, continuous form of government enjoyed by Venice, and the reconstituted Republic limited the franchise to those who themselves, or whose ancestors, had sat in the signory, the college, or among the buoni uomini prior to I512. Those who had bought office under the Medici were thus excluded, but so were the inhabitants of Florentine territory. Thus, without the least opposition from any faction, the destinies of the State were entrusted to 2,500 inhabitants of the city, though Florentine territory probably supported little less than a million people.

De Leyva had promised his soldiery that they should use their pikes to measure Florentine silks, and it was recognised by all that the Imperial forces would certainly attack the city. Michelangelo Buonarotti came 
back like the patriotic citizen he was, and diverted his genius from the painting of pictures and the chiselling of statues to the construction of defences. There were two parties in the city-the party of the wealthy, led by Niccolo Capponi, the gonfalonieve; and the democratic party, led by a doctor of laws, one Baldassare Carducci. The aristocratic party contrived to get rid of Carducci by sending him on an embassy to France; but a certain Dante da Castiglione, an extremist, led some of the democrats in masks through the city, and smashed every emblem of Medicean predominance in order to create an irreparable breach with the Medici. They were all well known to everybody in spite of their masks, but, in face of the foe, the Government wisely took no notice. Indeed, both Bigi and Piagnoni were united under the standard of Capponi, who was himself a disciple of Savonarola, and when plague began to reappear and decimate the population, Capponi, who in spite of real ability was a devout dreamer and cultivated religious ecstasy, addressed the Greek Council with such fervour, and spoke of the chastisements of God so earnestly and so completely in the spirit of Savonarola, that it was immediately resolved that Christ should be declared perpetual King of Florence, and that an inscription to this effect should be placed on the gateway of the Public Palace. No one dared say nay, though of course there were sneers and jibes in private and the usual allegations of hypocrisy ( 1528 ) (Benedetto Varchi, Jacopo Naräi, F. dei Nerli, B. Segni, G. Cambi.). But more practical matters were not ignored; direct taxation was placed in the hands of twenty commissioners; a guard of 300 young men of the best families was appointed to defend the Public Palace ; 4,00o citizens, in sixteen companies, were to form an urban militia, and Io,ooo chosen peasants were to be organized for the defence of Florentine territory. Grave peril had once more revived ancient military spirit. Although Capponi was a religious enthusiast, he was more moderate in his views than the majority of the new Government. He strove to conciliate, and he was particularly eager to modify the resentment of the Medicean Pope. He called several Medicean partisans to the pratica - that is, to consult with the Ten of War ; this the councils disallowed, insisting on naming the pratica themselves; he also corresponded harmlessly, but secretly, with the Papal Court : the correspondence was discovered, and Capponi was deposed from office.

At this crisis news arrived of the treaty of Barcelona, whereby Charles V. abandoned Florence to the vengeance of Clement ; of the "ladies' treaty" of Cambrai, whereby Francis, the Florentine ally, renounced his protectorship, and excluded the city from the benefits of peace; of the arrival of Charles at Genoa with a Spanish army; and of the descent from the Alps of German forces to join him (I 529). The Pope commissioned the Prince of Orange, who had kept him shut up in S. Angelo, and who had been one of the sackers of Rome, to lead the same army in vengeance against the devoted city; and by the autumn of 1529 Cortona surrendered, Arezzo, which the Florentines had recovered, was evacuated, and reconstituted her Republic under the Empire; and Orange arrived before Florence. The citizens had demolished every house, garden, and wall for a mile around. Towards December Ferrante di Gonzaga appeared on the right bank of the Arno with an army of 20,000 Spaniards and Germans, and occupied Prato and Pistoja. Michelangelo had done his work well, and, notwithstanding their enormous forces, the Imperialists made no attempt to 
breach the walls; they sat down before the city, and resolved to reduce it by blockade. On the other hand, the Florentines, animated by preachers who reproduced the zeal of Savonarola, and who were filled with the passion of liberty no less than inspired by the enthusiasm of religious devotion, were eager for battle. They frequently sallied forth under the command of their condottieri Generals, Malatesta Baglioni of Perugia and Stefano Colonna of Rome, and kept the whole line of the investers alert and insecure. At night they were wont to issue forth, covered with white shirts, so as to recognise each other; and they surprised post after post of the enemy. Abandoned by the other Italian States (for Venice soon made peace with the Emperor) and by France ; threatened by the most powerful monarch of the time and the Holy Father; and face to face with all the survivors of the foreign cut-throats, whose ferocious valour made them the scourge and terror of Italy, and whose cupidity was fanned by the prospect of pillaging the richest city in the West, the Florentines none the less fought on against overwhelming odds with the courage of despair. But the small advantages they could gain made little impression on the mighty host that encompassed the city.

There was, indeed, one solitary chance of rescue. Francesco Ferrucci, a Florentine citizen, an ardent patriot, fertile in resource, intrepid in action, and trained in the Black Bands under Giovanni dei Medici, had command of the provincial troops. He had successfully brought in provisions, and recovered San Miniato and Volterra, though Empoli fell directly he left that city. He proposed to the signoria the daring plan of seducing the brigand-adventurers of the Imperial army by leading them on to another sack of Rome and frightening Clement into according peace to their country. The signoria rejected this plan as being too daring. Ferrucci then conceived another project scarcely less bold. In spite of the presence of the foe that infested all Tuscany, he led his troops to Leghorn, Pisa, the Val di Nievole, and the mountains round about Pistoja; he collected every soldier, every man possessing a grain of courage, of adventure, or of devotion to Florence, and advanced to raise the siege. No less skilful than intrepid, Ferrucci led his little troops, from July i 4 to August 2, I 530, through numerous bodies of Imperialists, in spite of their manœuvres to check, follow, and hem him in, and entered the village of Gavanina, in the mountains above Pistoja, at the head of 500 cavalry and 3,000 infantry. Orange had been enabled by the treason of Baglioni to quit the siege ; he had spent the night in a forced march, and entered the village by another gate at the same time as Ferrucci. The tocsin was sounded as Orange approached the village, to give Ferrucci warning : he harangued his followers, reminding them that they were the last hope of the Republic, and called on them to follow whithersoever he should lead. Then dismounting, he led the attack, pike in hand. A combat of foot-soldiers took place in the village, while the horse of the two armies engaged outside the walls. The Florentine horse stood firm, and Orange was shot dead. His cavalry fled, pursued by the Florentines. On the dead body of Orange the Florentine soldiery found a letter from Baglioni promising not to attack his camp. But meanwhile the Florentine rear-guard had been driven back, and was obliged to seek shelter in the village, where Ferrucci had also defeated the foe after three hours' hard fighting. Fresh landsknechte, the men that had harassed Ferrucci 
on his march, poured into the village. Ferrucci succeeded in driving out his assailants, and pursued them beyond the walls; but, when he looked back, he found the gates shut: the town had been taken. Ferrucci had already received more than one mortal blow; 2,ooo of his men lay dead on the field; he was carried to shelter. A Spanish soldier, for ransommoney, forced him to yield, and bore him bleeding to his personal enemy, Fabrizio Maramaldi, a Calabrese, who commanded the Imperial light cavalry. Maramaldi had nursed the fierce, sultry hate of the South in his breast - the hate that can only satiate itself in dramatic artistic revenge; he had his enemy divested of all armour, and then deliberately and repeatedly poignarded him. "You slay a man already dead," gasped Ferrucci. With him died the hope of the Republic.

The news quite disheartened Florence. The Arno had overflowed, and communication between the various camps was interrupted. Baglioni, whose full treachery was not yet known, was ordered to learl a sortie. That infamous Captain refused, declaring that he would save the city from its own obstinacy and temerity. There were pusillanimous people enough in Florence to support Baglioni : there are always people whose accursed love of ease will induce them to purchase peace at any price. Many of the Florentine aristocracy mistrusted popular government; there were partisans of the Medici not a few. Baglioni declared that he would resign rather than conduct a hopeless attack. The Ten took him at his word, and accepted his resignation. The villain turned on the citizen who bore his discharge and stabbed him in many places. Carducci, the gonfaloniere, ordered the militia to assemble and attack Baglioni. Only half the companies responded to the appeal. Meanwhile, Baglioni introduced Imperial troops into the bastion where he was stationed, and pointed his guns on the town (August 8, 1530). The panic-stricken citizens abandoned the defence of the walls : everyone who had anything valuable ran to hide it in the churches. The signoria sent word to Gonzaga, who had succeeded Orange, that they were willing to capitulate. The terms granted were not severe: 80,000 scudi were to be paid to the army treasury (it was not the habit of Charles to pay his troops); the Medici were to be recalled; amnesty was given to all. But it was not in Clement's character to keep the pact. On August 20 the piazza of the palace was packed with soldiers; all political suspects were driven back by the free use of steel ; 300 safe and sure men play-acted at parlamento. The sovereign people, thus assembled, clothed twelve creatures of the Medici with full authority. They deposed the signoria, the Ten of War, and the Eight Protectors. ${ }^{1}$ All who had been zealous for liberty were tortured, exiled, or slain. Within a month I 50 illustrious families were banished; before the end of the year a thousand people had felt the vengeance of the Holy Father. Every Florentine family, even those most devoted to the Medici, counted at least one member among the proscribed. Alessandro, a reputed Medici by a mulatto, was appointed chief of the Republic ; and on his return to Florence in 1531 he bore an Imperial rescript appointing him and his heirs rulers of the Republic, or, in default of issue, other of the Medici in the order of primogeniture. Alessandro was cruel, debauched, and rapacious. The death of Clement in I 534 revealed his true character. "By the interposition of God." 
wrote Condivi, "Michelangelo was away from Florence at the time." In 1535 his cousin, Cardinal Ippolito, gathered the Strozzi and other opponents of the Medicean régime around him, and sent an embassy to the Emperor to complain of his misgovernment, and that his creatures had formally changed the Government into a duchy, so contravening the terms of capitulation. Alessandro had the Cardinal and his companions poisoned. Charles was no lover of republics, and in particular of a republic that had been devoted to France : he merely amnestied the exiles, who simply refused to return, whereupon Charles gave his bastard daughter in marriage to Alessandro, and promised to protect him (1536). Alessandro's pimp-in-chief was Lorenzaccio, the eldest scion of the younger branch of the Medici, who promised to procure his young aunt for Alessandro if he would come secretly to his house, which was often placed at Alessandro's service as a brothel. Under circumstances of the most coldblooded treachery, Lorenzaccio poignarded Alessandro, hoping to succeed him as Duke, and then rode off to Filippo Strozzi, who, at the time, resided in exile at Venice. Strozzi was the richest man in Italy, and the leader of the republican party. He embraced Lorenzaccio, called him the Brutus of Florence, and promised that his two sons should marry the two sisters of this depraved murderer. Meanwhile, at Florence, Cardinal Cibo, the chief minister of Alessandro, observing the continued absence of Alessandro and Lorenzaccio, suspected the truth, but made excuses for the Duke's absence, ordered the soldiery to be ready, and ultimately discovered the Duke's body himself. When the secret, which Iorenzaccio had by no means kept to himself, leaked out, the town being thoroughly controlled by the military, the signoria met, and Guicciardini, the historian, proposed that the lordship of the State should be given to the youthful Cosimo, the son of Giovanni dei Medici, of the Black Bands. Guicciardini possessed one of the most acute, observant, and analytical minds in history ; theoretically he was a republican, and in favour of the Venetian form ; but he, like most of the men of his time, exhibited that divorce between intellect and morality which an age that had rejected old ideals and that had not yet formed new conceptions of social obligation had produced. Schooled in diplomacy, he was a master in the game: he had helped engineer the return of the Medici, had allowed himself to become their instrument. He now hoped to rule the State as the adviser of tile young Duke. By his machinations the soldiery, who still lined the street, forced the populace to shout for the Duke and the Medici, and the Senate, perforce, complied with the popular demand and elected Cosimo. But Guicciardini found the new Duke less easy to manage than he had expected. A man of ability and cold-blooded determination, this descendant of the Medici and the Sforza could also play the game. In I 569 he obtained the title of Grand Duke of Tuscany from the Pope, and his son got Imperial recognition. Seven Grand Dukes of the family followed him.

Here we may fitly take leave of Florence. She had sheathed her sword generations ago; now it was rusted in the scabbard, and she could hardly win it forth in her last stugggle. In vain did the exiles attempt to recapture the city ; Cosimo's mercenaries repelled them; the leaders were taken prisoners and put to death, and the elder Filippo Strozzo, after tortures relentlessly applied, committed suicide. Under the rule of the 
Medici Florence still enjoyed some measure of commercial prosperity; she underwent internal decay. The fine arts were patronized by the Court, but Vasari and Benvenuto Cellini were the weak successors of Fra Angelico and Fra Lippi, Botticelli and Del Sarto, Donatello and Chiberti, Brunelleschi and the mighty Buonarotti. A catalepsy which lasted three centuries fell on Florence; the canker-worm of corruption and servitude began to eat into her laurel-leaf; the heartlessness of the times and the decay of stern virtues began to paralyze her energies. Her Government exhibited, and her people felt, the blight of foreign domination. She had made the last stand but one for freedom : soon she was to see Siena fall. Well had Michelangelo expressed the feeling of all men of worth in Italy when he forbade them to awaken his marble Night, sunk in a torpor deeper than sleep.

\footnotetext{
“ Grato me è il sonno, e piu l' esser di sasso ;

Mentre che il danno e la vergogna dura

Non veder, non sentir, m' e gran ventura ;

Pero non mi destar ; deh, parla basso !"1
}

\section{PISA}

\section{Rebellion against Florence}

THE Pisans were a proud and military race. Nearly all noble Pisans had gone into exile and adopted arms in foreign service when Florence triumphed in I406; but, decayed and commercially lifeless as the city had become, almost useless as a port through the retirement of the waters, the remnant of inhabitants still nursed bitter resentment against Florence, which all the efforts of the more enlightened Medicean Government failed to assuage. When Charles VIII. descended into Tuscany, in I494, he was hailed with joy by the Pisans ; they threw the Marzocco, the Florentine lion, the ensign of their servitude, into the Arno, and boldly asserted their independence and claimed his support. It was given. He insisted, at Florence, on retaining Pisa until the end of the campaign, keeping a garrison there, while ten citizens, forming a signovia, directed the reconstructed commune. Directly Charles left Italy his venal lieutenant sold the fortress to the inhabitants. It was almost a matter of commercial life or death to Florence to recover the city, for the Tuscan littoral was no longer hers, and the northern high-road was closed by her foes; while, to the south, she had to dread revolt. Between 1499 and I505 Pisa heroically withstood three sieges and saw her lands wasted by a foe that withdrew only to recruit her forces and resume the struggle. In I495, the league formed against the French undertook to help Pisa, and Venice really did so, sending her bold, light-horse stradiots, who endangered Florentine communications and wasted her corn-fields; but, while the finances of Florence were gradually being exhausted by the contest, the Pisans, deprived of commerce and manufacture, were still the weaker

1 " Sleep is grateful to me ; still more grateful is it to be of stone; not to see, not to feel, is happiness while ruin and shame endure; therefore awake me not; speak low.", 
side. In spite of the bold resistance of the peasantry of the Apennines, in spite of secret aid received from Siena, and even from Lucca, in spite of succour sent by French, Austrian, and Spaniard in turn, with a view to their own profit from the protracted struggle, each year saw the citizens, their courage and tenacity indeed unsubdued, but less able to maintain the conflict. In 1504 they had even offered themselves to Genoa; but that city now only kept two or three armed galleys in the harbour, and, in spite of the desire of the people, the Government, undesirous of seeing the State they ruled become too powerful for them to manage, afraid of the French King, and having business relations with Florence, and, it was even said, having been bribed by that State, refused. In I 509 Pisa was again beleaguered and absolutely cut off from all supplies. Florence bribed the Ministers of France and Spain to withdraw their protection, and then agreed to fee the Spanish Ambassador and pay 50,000 gold florins to Spain and the same sum to France, plus another 50,000 florins to France by a separate treaty, the transaction to be kept secret in order not to arouse the jealousy of Spain. On these conditions the monarchies, both of which pretended to rights over Pisa on account of their defence, were ready to sell her to her foe ! (Desjardin, Négociations Diplomatiques, vol. ii., p. 293). The peasantry had sought refuge in the city; shut up within walls, they no longer exhibited the heroism with which they had defended the mountain fastness, while they were more numerous than the citizens, and were so many more mouths to feed. Pisa was completely invested : there was no longer any wine or oil, vinegar or salt, and corn sold at two gold scudi per bushel. The hour had come when a war, sustained for fourteen years and seven months with a constancy, courage, and self-sacrifice rarely observed in the annals of history, could no longer be maintained. Pisa surrendered, and, by the efforts of the Florentine gonfolonieve, Soderini, and Machiavelli, the army entered the city with great stores of provisions, which were freely distributed. Never had the world seen victory accompanied by so much humanity. All ancient privileges and forms of government were confirmed ; every commercial restriction was removed; the same court of appeal which served the Florentine was opened to the Pisan. But not merely would the pride of the Pisan aristocracy not bend; the lowest classes showed the same repugnance to submit to the shadow of foreign domination; and, in the course of half a century few of the ancient population were to be found in the city (Diplom. Pisani di Flam. del Borgo, Regist. di Cosmo I., I566). This reconquest ends the history of Pisa as an independent Republic.

\section{SIENA}

When Charles VIII. arrived in Italy, Petrucci was placed in command of a small body of mercenaries employed to maintain order; he received knighthood from the King, and on his return Charles left a French garrison in the city. Montepulciano had taken advantage of the disturbances in Florence to give herself to Siena, and when the riformatori and popolani started an insurrection, the mercenaries that had been sent thither retumed, and were only prevented from indulging in more than a skirmish 
by the intervention of the French Captain, who was shortly afterwards quietly dismissed. Florence, to avenge the loss of Montepulciano, advanced an army against Siena, accompanicd by Sienese exiles, who, however, proved unwilling to help the foes of their city very warmly, and the Florentines were compelled to retire. A plot to murder the two heads of the House of Petrucci failed, and, in I497, the balia increased the number of his mercenaries; for, although it was nominally representative of the three monti, it was really the organ of the Noveschi. Siena was far more turbulent and excitable than Florence, and Pandolfo Petrucci rose to power as much by arms as by a league of the wealthy burghers, but the parallel between his career and that of Cosimo dei Medici, none the less, remains very close. Though, unlike Cosimo, Pandolfo employed arms, he, also dominated the ring of finance, contrived, with his party, to get the balia reappointed for five years in successive elections, contented himself with the titlc of "Magnifico," and directed the external policy of the Republic through troublous times. He kept peace with Florence, but also remained in touch with the exiled Medici; he plotted in concert with Lodovico the Moor, was in touch with France, and had secret understandings with petty tyrants who might be of service as condottieri. Under the cover of the established form of government, he contrived to exercise despotic power; and, ruling a people so rash, audacious, reckless, divided, and violent, he had to adopt means which would have been repugnant to the great Florentine. Aided by a Neapolitan ex-professor of the University, a man of low birth and capable of everything, he hired the assassin's dagger to rid himself of inconvenient opponents. He had his own father-in-law, Niccolo Borghesi, set upon by six of his men, and murdered, and then, as a contemporary says, "though devoid of good faith and love, he overflowed with good words and tears" (Misc. Storica Senese, I 893, $i .7$ ) so effectually that the two families were reconciled. When Cesare Borgia was building up his great State, Pandolfo conspired with the petty tyrants to overthrow him ; and when the plotters were outwitted, seized, and strangled by Cesare, that adventurer led his army against Siena, not, as he told Machiavelli, to take the city for himself, for the King of France would not allow that, but to drive out Pandolfo, his "chief enemy" (1503). At first Siena was inclined to defend Pandolfo, but, as Cesare drew nearer, the balia lost heart and exiled him. Perhaps Cesare would have continued to hold Siena but that a rising of the barons of the Campagna required his presence in Rome, and Pandolfo, by promising the restitution of Montepulciano, gained Florentine goodwill, and suddenly appeared in the State with a small army. The King of France had requested his recall, and the balia at last begged him to come back, but with only a small number of armed men, so that he might " enjoy his sweet native country in tranquillity, such as all desire." But Pandolfo took care to make a triumphant entry at the head of a great force, "and so," he wrote to his Florentine friends, "have I returned in perfect peace to my sweet native land" (Mondolfo, P. Petrucci, Siena, I 899, p. 99). He maintained the informal dictatorship of the city until his death in $15 \mathrm{I} 2$, and was given a princely funeral at the public expense. During his rule he conducted the policy of the little State, now in so precarious a condition, with remarkable astuteness, so that the penetrative mind of Machiavelli was 
unable to read him. Machiavelli wrote to the Florentine signoria that he was as baffled as themselves, and in no better position to form a judgment at Siena than his employers at Florence. But we know that Pandolfo secretly assisted Pisa in her resistance, and balanced his friendship so as to remain on the winning side. The coffers of the State and its offices had been at his disposal, and, as his life was more than once attempted, he used to walk the streets attended by a train of the noblest Sienese gentlemen. Like many strong men, he had a weak side in the family circle, and his womenkind got him to except them from sumptuary laws, and towards the end of his days he exhibited a senile weakness for a young married peasant. His second son had been made a Cardinal by Julius II., and his eldest son, Borghese Petrucci, succeeded him. But Borghese had not his father's abilities. He deemed himself to be protected from enemies by a magic amulet; he relied on that policy of corrupting the city by spectacular display which Lorenzo dei Medici had used so successfully; he was really so incapable and arrogant and dissolute that he disgusted the people and played into the hands of his cousin, Bishop Raffaello Petrucci, Governor of the castle of S. Angelo at Rome. In I 515, by the aid of Leo X., Raffaello appeared in Sienese territory, whereupon Borghese fled, and the Bishop was accepted in his place. The new dictator was immoral and cruel, but proved himself to be a capable governor, though when he died ( 1522 ), the mob demanded that his body should be cast on a refuse-heap, and it was rescued with difficulty. The policy of the Popes was now to keep Siena and Florence in amity, and so strengthen the Papacy against the foreigner; and certain unsavoury Petrucci were kept in power. At last, in I 524, there was a general rising, and the dynasty of the Petrucci was brought to an end.

Of course, this temporary alliance of parties gave rise to the usual religious processions and thanksgivings, but the Noveschi, aided by Clement VII. and the French, threw the three monti into one, vested balia in a committee of sixteen, and appointed Alessandro Bichi, a man of spotless integrity, able, and of high purpose, to the headship of the State. But when the battle of Pavia made Charles V. arbiter of Italy, Siena paid him I 5,000 ducats to take the Republic under his protection. Directly the Imperial commissioners appeared, the bell of the Mangia was rung, and revolutionaries, called libertini, belonging to all parties in the State, under the leadership of Mario Bandini, of the monte del popolo, stabbed Bichi to death, and with very little bloodshed, proclaimed the Republic. The leaders of the insurrection were the men who had got rid of the Petrucci : from the date of their disappearance the public books are filled up under the heading, Anno I, etc., ab instaurata libertate. Fifteen, and afterwards twenty-one, "conservators of liberty" were appointed. This renewed freedom of the Republic and its protection by Spain was not at all to the liking of the Medicean Pontiff, who, in I 526 , declared war against the city and had it besieged. A devout widow, who was popularly believed to be endowed with the prophetic spirit, gave out that it was the will of our Lady that on the feast of the Immaculate Conception the city should be again given to her ; and, after due deliberation in the council, this was done with all due solemnity, the keys being formally given to the priest who officiated at the Mass, who then returned them. And it so fell out, as Vettori wrote to Machiavelli, 
that the investing army, when attacked by the besieged, broke and fled in terror, and the wonder seemed to him, though not willing to credit the miraculous, as like to Bible history, "wherein terror entered into men so that they fled before they knew not whom" (Lett. Aug. 5, 1526, in Lettere famil. ad Mach. Opere). Clement VII. soon had enough to do without troubling himself about Siena; and the very next year the city of the Blessed Virgin, relieved from external fear, renewed its street-fights, excluded the Noveschi, and instituted a government of popolani and riformatori; Siena was the key of Tuscany, and Charles V. sent a Governor and soldiers thither to restore the Noveschi; but they were only admitted to the balia in small numbers, and in I 530 tumults were renewed, and the Spanish Governor had to threaten the city in order to restore quiet.

\section{LIFE, LITERATURE, AND ART FROM THE CLOSE OF THE FOURTEENTH TO THE COMMENCEMENT OF THE SIX- TEENTH CENTURY}

\section{LIFE}

The outward life of the Italian people in the fifteenth century exhibited a far greater degree of refinement than that of their contemporaries; some measure of cleanliness began to return to the world, and cities that vied with ancient Athens in the splendour of their buildings were paved. Not all the sumptuary laws could stem the tide of luxury in living and in dress ; owing to the influence of Courts, society became splendid and life magnificent; while the moral notions of the age fell into a tumultuous and transitional condition; for causes already mentioned, the struggle of men to secure and maintain positions of command, and the increase of individualism, continued to weaken the compelling force of the family and even of the trade association, while the Great Schism and the secularization of the Papacy weakened the authority of religion.

The series of great plagues that continued during the century had much to do with the dissolution of morals; it subverted the social order, and rendered men more careless and bent on snatching at the pleasures of the moment. Religion became a mere formal habit, and the desires of men turned more than ever to the joy of life. The worst moral centres were the small despotisms, where the struggle for existence was keenest. A Princess of the great House of Este was beheaded for committing adultery with her stepson; a Prince poisoned his wife because he discovered that she was plotting to poison him; bastards were perpetually conspiring against their legitimate brothers; Sigismond Malatesta of Rimini (I4I7-I 468) had many mistresses who presented him with various children ai the same time, of whom he was the reputed father; he gave free vent to the fiercest and most degraded passions ; he is said to have wreaked his lust on the corpse of a married German lady who courted death to escape him ; he poisoned his second wife, and attempted a criminal offence on his own son; yet, from youth to death, he remained the devoted lover of the famous Isotta; she so inspired him that he became a poet, and, 
finally, he made her his wife ; after her death he erected what is, perhaps, the purest gem of the Renaissance architecture, the church of St. Francis at Rimini, to her memory, and paid her divine honours. This monster, in whom the highest and most bestial of human desires were strangely commingled, had a genuine love of art, and attracted poets and artists to his little Court; a daring soldier and an astute ruler, he was a passionate admirer of classical writers; he is but one example among a hundred rulers of similar dissolute ferocity, practical ability, artistic appreciation, and love for letters. Quite of another type was Federigo da Montefeltro, the lord of Urbino from 1442 to 1482 . A successful mercenary Captain, he made Urbino the centre of cultivated society, and the Athens of his time; and, although his means were not great, he lavished them on the poet, the artist, and the scholar, while he reared a palace that was a paradise of rare device and perfect art. His Court was a school of military education to which Princes sent their sons ; his library was filled with scholars; artists preferred his patronage to that of far richer rulers; and he went about unarmed, receiving the blessing of his peasants, for each of whom he had some kindly word. Few rulers were so urbane as Frederick; but all surrounded themselves with clever people, whatever their origin might be. Men of force of character and high intelligence alone had any chance of success : even in the republics men of wealth had to choose between being hammer and anvil ; want of scruple was necessary to success, as well as an astuteness that could dominate the State under the forms of freedom. There were few States that were not well administered from motives of self-preservation, though public offices were sold. The revenue of the Prince was immense. At the close of the previous century Gian Galeazzo Visconti received I, 200,000 florins in regular taxes, and subsidies brought his income up to 2,000,000 : he expended 300,000 florins in dykes to render Mantua and Padua defenceless, and he meditated going to the further expense of diverting the Brenta, so as to drain the Venetian lagoons, with the object of reducing Venice. Though the States were well governed, their rulers almost invariably seized or maintained power by crime. Studying the records of Courts is as revolting as reading the Newgate Calendar: there is an embarras de richesse in these archives of crime, from which a few specimens of no marked atrocity may be given as illustrations. In I434 Bernardo Varano, of Comarino, put his two brothers to death, in order that his sons might acquire their uncles' property (Chron. Eugubinium). The funeral oration of Francesco Sforza informs us that an aunt poisoned his first wife, the wealthy Duchess of Montralto, and her little danghter, in order to seize the inheritance. Cesare Borgia, who governed Romagna with marked ability, and who gained the devotion of his soldiers, according to the Venetian Ambassador, made all Rome tremble before him; he is credited with having murdered his elder brother, the Duke of Gandia, and of having got rid of everybody that stood in his way, until he found himself the sole support and reliance of his father, Pope Alexander VI., who "loved and hugely feared him." Then with the perfidy and invention of a past master in the art, he subdued the fierce, turbulent Romagnans, of whom Cardinal Juan Borgia had said that "the devils cannot be turned out by holy water." Profligate alike in public and private life, these men rarely made a mistake in the calculations of 
state-craft and policy : under the conditions of life in the higher orders of society there was atrophy of the moral sense and an undue development of the intellectual faculties. Even more remarkable than man's power of associating ideas is his faculty of dissociating them : while the brains of the fifteenth century fermented with ideas, the various mental functions pursued their separate and independent courses. The merchants of the republics and the satellites of the Court were equally subjected to conditions that favoured intellectual development; and not merely did sterling originality of every kind avail in the struggle for power which was often necessitated in the struggle for existence, but it began to be valued for its own sake. Where there were no despots, or where real despotism was disguised by republican forms, the same contradictions are everywhere to be found. Even at the beginning of the next century, in Perugia, where an emotional word could convert the blackest sinner into an emotional saint, a cruel vendetta was kept up between the rival families of Oddi and Baglioni at the very time when Perugino was painting his pictures that overflow with sentiment and serenity, and the young Raphael was nursing the central pcace and gentle wonder that peeps from the eyes of his Madonnas, his bambini, and his skies. While the Houses of Perugia are waging fiercest war and meditating the blackest plots, the leaders seek the society of a saintly nun and listen, moved, to her words of peaceful counsel, and then the exiled Oddi ravage the valleys of soft, billowy Umbria, so that they are inhabited by stags and wolves alone, and the peasants turn to a bandit's life for sustenance. Together with superb heroism in street-fights there are surprises by night ; spectators, including foreign students, gather round a dead body, and compare the grace and proportions of the slain youth to those of a Roman hero ; the mother of a dying man appears followed by sympathetic eyes, and beseeches her son to pardon his murderer; the desecrated cathedral is washed with wine and reconsecrated, and then the whole story of crime and bloodshed is recommenced. In the South, Ferrante of Naples, a master of craft and courage, though he governed in a manner that was conomically ruinous, would invite his enemies to dinner, caress them, and then send them to his prisons to die slowly and miserably: he was wont to regale his sense of power by viewing his museum of their embalmed bodies ( $P$. Jovius Hist., $i$.).

The despots were careful to marry in such a way as to increase their power, and they set the example of entire disregard of the obligations of wedded life. Pius II. tells us that when he rode to Mantua, the reigning Duke, who was a bastard, met him accompanied by seven other bastards. The sober bed of loveless marriage was seldom blessed with children of sufficient force of character to uphold the House; sons born out of wedlock, if they had sufficient boldness and ability, secured the family confidence; if personal courage were wanting, intellectual resource had to supply its place. Filippo Maria Visconti, who could not endure death to be mentioned, had wonderful penetration into character; to couple an honest man with a knave was his favourite device; he perfected a system of esiponage, and was so intellectual, and even imaginative, that he employed his leisure in studying the classics and reading the chivalrous romances of France.

Efficiency was the sole passport to society and the sole standard $47-2$ 
employed to measure the man. The great trading republics had asserted the principle that not hawking, nor hunting, nor owning landed property was the occupation of a gentleman, nor did his lineage constitute him : what a man was, made his worth, though birth and wealth were, of course, valuable adjuncts to that perfection of life towards which everyone aspired. The mercantile republics had constituted an industrial aristocracy at a time when the barbarian prejudices that linger to-day were most pronounced in other countries, and a dying Florentine merchant prayed the State to fine his sons if they did not follow some useful employment. All people of mark associated together on equal terms; the greatest scholars and wisest men were sought for to occupy secretaryships of State, or to serve as Ambassadors. In the early part of the century the learned Poggio, in his dialogue on nobility, declares that personal merit alone confers it, and despises the claim of the man who grounds it on the fact that his ancestors led the lives of brigands; he laughs at a life devoted to field-sports, which is, he says, the life of a brute, and the ideals of chivalry seem to him to be intrinsically vulgar and ignoble. A territorial nobility did, indeed, exist in North Italy; in the kingdom of Naples the foreign influence prevailed, the aristocracy was idle, and lived on the profits of their estates; but in Central Italy the feudal ideal, which still prevails in Germany and in this country, had died out. In Genoa nobles and new men were alike merchants and sailors, though caste prejudices obtained, as they did in Venice also. But, in the more cultivated Courts, personal merit was the chief passport to the best society, which was entirely constituted of men and women of ability, and, early in the next century, Baldessare Castiglione wrote his "Courtier," which Italians called "The Golden Book"; it gives a delightful picture of the Court of Guidobaldo da Montrefeltro, Duke of Urbino, and there, from the mouths of able, polished men and clever, gracious women, Castiglione elaborates, in a subtle and delicate discussion, that ideal of the true gentleman which has influenced the world for four centuries.

Great attention was paid to the education of youth. Guarino Veronese, who had studied Greek at Constantinople, returned home with a store of precious manuscripts, and was called to the Court of Ferrara. A hard worker, an excellent father, of blameless life, he kept his house full of pupils, of whom thirty became famous for their learning, and, owing to his influence, Ferrara became a centre for higher culture, and his pupils of the great House of Este famous for their support of letters. Another schoolmaster, Vittorino da Feltre, attained such a command over his passions that he remained chaste throughout his life, which he devoted to study and the education of youth. No gifted youth, however poor, was refused admission to his home; they sat side by side with Princes, and were educated "for the love of God." His system combined noble discipline of the body with noble cultivation of the mind; he took his pupils away with him to his country villa; and, not merely did parents and pupils alike respect him, but Mantua, where he resided, was visited for the sole sake of seeing him. The education of lads of ability as well as the sons of the rich and powerful was entirely in the hands of zealous and capable scholars, who regarded the classics as an avenue to selfknowledge, and honestly tried to train the pupils into perfect manhood. 
Girls were intellectually disciplined as if sex made little difference, for classical learning was too precious for such an accident to disfranchise ; hence individuality of character marks the educated woman of the $R e$ naissance no less than the man. Women became no less scholarly and cultured than men; Lucrezia Borgia had her own library, and even the courtesan was often an accomplished poetess or musician, and a woman of culture. Many women knew how to seize and hold the opportunities that the menacing mutations of the time gave, and women of beauty, intelligence, and instruction were sung by the poets, whether they were mistresses or wives. The women of the period combined the wiles and attractions of Aphrodite with the wisdom and attainments of Athene; they are typified in the enigmatic eyes and impenetrable smile of that subtlest of all delineations of character, the Mona Lisa of Leonardo da Vinci.

History shows us that no institution is so variable and adaptable as that of sex relationship; the freeing of the individual led to strange results in this regard. The emancipated woman of the Renaissance was no less intellectually evolved, no more purged of the deeper, darker passions, and as little visited by moral scruples as the emancipated man of that period. The women of a family often evinced no less personal courage and force of character than their brothers. Caterina Sforza, a natural daughter of Francesco, Duke of Milan, and widow of Girolamo Riario, son or nephew of Pope Sixtus IV., defended the citadel of Forli against an insurrection. Her husband had been murdered, and the populace dragged the dead body through the streets of the town. Caterina herself fell into the power of the mob; she asked to be allowed to visit the commander of the citadel in order to persuade him to bow to the in. evitable, and yield the fortress. She left her children with the people as hostages, but directly she was safe inside the citadel, which had been held by a man nearly as resolute as herself, she ordered the mob to be fired upon. They threatened death to her children. "If you kill them," replied the descendant of the doughty Romagnan peasant, "I still have a son at Imola, I bear another beneath my girdle, and they shall be their brothers' avengers." Other authorities quote a reply equally courageous, but less modest : they report her to have said : "I am young enough to bear more."

On the other hand, the Roman nobles, who kept bravi, secluded their women; while at the Court of Lodovico the Moor, a Court that shone like a star for the personal ability of its men and the beauty and intelligence of its women, there was such concurrent degradation of sexrelations that it was common for the husband to sell his wife's honour; the brother his sister's ; the father his daughter's ; assassination was much dreaded, and Lodovico himself would not permit strangers to approach him nearer than an appointed bar (Corio, fol. 448 ).

Verice produced many women scholars; but neither Venetian nor other Italian women appear to have entered the bottega and attained proficiency in the fine arts, probably because the emancipation movement had not reached the lowly class from which artists were recruited. ${ }^{1}$ But

1 Artists and sculptors so rarely had family names of any importance (indeed, many had none at all) that they were known to posterity by nicknames, and it is by these that they are inscribed on the roll of Fame. Alessandro Filipepi was 
Vittoria Colonna (r490-I547), the daughter of the high-constable of Naples, and a grand-daughter of the good Duke Frederick of Urbino, poured forth her passionate soul in delicate prose and sympathetic verse : there is little originality, however, in her writings, and she is chiefly known to us for the pure chivalrous friendship she established with Michelangelo and the noble verse with which that friendship inspired him. But it was not in such high intercourse only that the inequalities of sex were ignored. The same note of equal companionship that distinguished the Court, where patrons, men of letters, and artists met on a common platform. characterized ordinary social intercourse between man and woman. The lady who knew the classics talked freely and with open mind on all kinds of subjects with her male acquaintance. Modern society restricts itself to the delicate innuendo : conversation during the Renaissance was naked, unconscious, and unashamed; the world was regarded as a realm of absorbing interest, and what interested might be discussed without scruple; there was no restraining influence of religious conviction or social code, and each individual not merely did what he desired to do, but spoke about his deeds unashamedly, unless, as was not infrequent, he concealed his thoughts in the prosecution of some design. Even the peasants were not merely better off, but more intelligent and well-informed than those of other countries. It has been pointed out by more than one author that there is evidence of the continued existence of thoroughly wholesome domestic life during the periods of greatest corruption. Moreover, a time where we find women leading armies and, clad in armour, following their codottieri lovers, allowed a freedom to the spirit wherein noble natures could expand into high manifestation. What the age suffered from was the want of a synthesis. The Church had lost its force ; the form was retained, but the Papacy, now a temporal princedom, was horribly corrupt, and, except from a few, the Christian spirit had departed; the old bonds of brotherhood such as the gens, the trade associations, were loosened ; there was no real spirit of nationality; and party feuds and proscription had injured, where it had not destroyed, local patriotism ; men's minds were directed to the old world, and through it they had come to a new inheritance ; they were lords of themselves, with no tradition, authority, or inward or outward conviction to serve as a guide or standard of conduct ; men, then, had no conception of how vice becomes registered in the delicate cells of the nervous system, of how calm, unperturbed Nature inscribes man's smallest defection in the pitiless book of doom; men had neither the sense of social nor transcendental obligation; there was no true perception of the nature and claims of society; hardly any "home sickness" of the soul for what lies beyond the visible world of sense was yet awakened in the passionate perferved Italian nature, though it had awakened to the beauty of sense and the pride of life. If there was any vital religion at all, it was the sense of beauty. Intellectually active as men were in so many

apprenticed to a goldsmith named Botticelli, and was called Sandro Botticelli, or Botticelli's Sandro. Jacopo Robusti is more generally known as Tintoretto, the little dyer. Veronese, the Veronese, was Paolo Cagliari of Verona. Giorgio Barbarelli, of the little town of Castelfranco, is known to the world as Giorgione. Perugino has been substituted for Pietro Vannucci, who became a citizen of Perugia, and Raffaello Santi, or Sanzio, his pupil, has become immortal as Raphael. 
departments, there was no very serious attempt to synthesize experience. Luini, who certainly painted in Milan about the year A.D. I5OO, and whose pictures are obviously the product of sincerity and devotion, painted a picture of St. Catherine, now in the Besozzi Chapel; it is the portrait of a woman who, according to Bandello, was " over free and little honest." This woman tried to persuade one lover to kill another, and, on his refusal, returned to the man she had discarded and tried to get him to avenge her by slaying the rival she had enticed to murder him. Unable to succeed with either lover, she allured a silly Sicilian youth into her toils, and so worked on him that he murdered both. The crime was detected, and the woman, though of high rank, was beheaded; but she was beautiful, and no one was in the least shocked at the criminal being portrayed as a saint. The human mind is apt to resemble a series of water-tight compartments, a highly convenient arrangement; there are comparatively few people in whom intellection is a ferment capable of leavening the whole lump; and, in an age of universal inquiry without any cementing synthesis, all kinds of strange, inconsistent manifestations of the human spirit co-existed; the spiritual wolf lay down with the spiritual lamb, the leopard with the kid. Examples such as that of Luini might be furnished almost without end.

The many-sidedness of the men of the age strikes the modern world of specialization with astonishment. Every artist was goldsmith, sculptor, painter, and often teacher and architect. Many of the men of the Renaissance seem to have been endowed with universal genius : it was not that they were great in one thing and knew something about others, but they were really great in many departments. In the thirteenth century Dante was encyclopædic ; his friend Giotto, the shepherd lad, was equally great as sculptor, painter, and architect. In the fifteenth century it is scarcely possible to name a single man of distinction who did not excel in more than one department of human activity. Leonardo da Vinci (I452-I 519) was the finest painter of his generation, and one of the greatest of all time : he was also a sculptor, musician, architect, and a penetrating and sagacious critic of the fine arts; his insatiable mind trod the paths of science; he was an anatomist, and there was no branch of the natural sciences with which he was not familiar ; his insight enabled him to suggest a hundred explanations that rigid observation and comparison afterwards proved to be true; but, not merely was he a reasoner and a universal artist, he was also a contriver; he applied mathematics, of which he had considerable knowledge, and was a formidable man as mechanician and engineer; few men have advanced art more than he, and cautious critics say that he was the pioneer in structural and classificatory botany, the reviver of the science of hydraulics, the discoverer of the structure of the eye, the inventor of the saw still used in the great marble quarries of Carrara and of the best rope-making machine ever invented, and that he anticipated half a hundred great discoveries (vide Uzielli, Ricerche interno a L. da V., Fl., I 872). Leonardo was a bastard.

Leon Battista Alberti, who was born at the commencement and died towards the end of the fifteenth century, wrote a Latin comedy at the age of twenty, which was accepted and published by the younger Aldus as a genuine classic. He was one of the most famous architects of his age, and built that delightfully pagan church, St. Francesco, ạt Rimini ; he 
was one of the finest gymnasts of his time; he was a painter, a sculptor, acquainted with law, a trained mathematician, one of the best organists of his day, a brilliant talker, and he left treatises on sculpture, painting, and architecture, whereof the last was translated from the original Latin into his own and three other languages. He was beloved by his contemporaries as a man of an open-hearted, generous, and eminently amiable nature. He was one of the men who innocently added his quota of momentum to the quite unconscious current that fretted away mediæval landmarks and dissolved the cement of society. Man emerged, differentiated as an individual, a being with idiosyncrasies, as a private man, from the society and petty organization into which he was born.

Michelangelo Buonarotti (I475-I564) was almost equally mighty as a sculptor, painter, poet, and architect; in 1529 he was employed to direct the great engineering work of Florentine defence; he was also learned in Dante, and in speculative thinking became a Christian platonist.

The cities of Italy teemed with literary societies that appear to have had some other object than the airing of personal vanity or the pursuit of excitement. The study of the classics led to the study of man; grammatical and philological allured to philosophical inquiry; many scholars, such as Carlo Aretino, exhibited a great contempt for Christianity, and affected an admiration for paganism, but the need of a synthesis of life was felt, especially at Florence, and Pico della Mirandola (I463-I494), Marsilio Ficino (I433-I499), and others attempted to combine Plato with Christianity, and even with the Kabbalah. For these men Nature became divine, and there was some approach to the conception of the Deity as the imminent Absolute of the cosmos. Monistic doctrine became so general that, in I5I3, a Lateran Council denounced those who held the doctrine of a universal soul. The study of Greek, facilitated by the dispersion of scholars when Constantinople fell to the Turk, destroyed the old notions as to the Latin Empire, and introduced a new world for inquiry. It unveiled the profound philosophic thinking of the Hellene, which went far towards the dissolution of religious form. But the traditions of Rome always preserved the form of Catbolicism in Italy; the Italian sceptic, unlike the German, never threw off the mantle of the Church, which had become as a skin to him.

The age was one of dissolving faith, and, as is invariably the case in periods of aufklärung, belief in magic and astrology and the uncanny increased pari passu with the decrease of faith. Credulity and investigation are quite compatible in that strangely-compounded creature, man. Apollonius of the Golden Thigh flourished when paganism was decaying; the phenomena of the revival of Etruscan mysteries and crude and fantastic belief characterized the Renaissance; our own age has a strange whimsey for fantastic occultism. The drowning man clutches at straws : any sensible object that witnesses to the Unseen is sought in ages of dissolving creed. In I474 Sixtus IV. prosecuted Carmelite monks of Bologna, who asserted the harmlessness of seeking knowledge from devils. Harlots, of whom there were nearly 7,000 to be found in Rome in A.D. 1490 (Infessura apud Eccard, Script. ii., col. I997), would dig up rotten human flesh from the graveyards and give it to their lovers 
to eat as a love-charm (P. Aretino, Rag. del Zoppino). All sorts of Etruscan beliefs, which even to - day linger among the peasantry of the Maremma, came into evidence, and the unburied superstitions of classical times revisited their former habitation, like ghosts conjured. The Bull of Innocent VIII. against witchcraft was followed the next year ( 1485 ) by the burning of forty-one unhappy women in Como alone. Men of acute mind and sceptical temper, men who rejected the teaching of the Church, were often the first to accept, as fact, the most monstrous forms that even credulity could swallow: it required an Eneas Piccolomini to refuse to be cured by a professor of magic (Pii II., Comment. li.). After the publication of the Bull witches were burned who formerly had been let off by fine, according to the written law (Graziani, Arch. Stor. xvi., A.D. I445). In $\mathrm{I}_{4} 83$ the learned Poliziano read a discourse on women who could change themselves into serpents. The desire for some visible manifestation of that "Unseen Presence," which is not to be put by, is indicated by the action of the degenerate Church. A legend of unknown origin grew up that the house where the Virgin was born had been transported by angels A.D. I 295 to Loreto : Sixtus IV. issued a Bull in favour of the shrine in I49I. In the early part of the fourteenth century Dante had taught a doctrine of accommodationthat is to say, that much Scripture is pictorial, and that the Holy Spirit teaches according to human capacity; his was an age of faith, broken only by people such as the Epicureans, who were in revolt against the aggressions of the Church. This was an age of inquiry, and was marked by the acceptance of anything that would bring the supersensuous into the field of sense. The debased religious instinct was utilized by the Papacy. Pardons for murder brought in large sums, and Rome consequently swarmed with bravi for hire.

Among the causes that led to a decay of morals was the struggle for position among scholars : they had to fight their way, and many of them were stopped by nothing in their effort to secure money and reputation. Men who spend their lives in severe study are apt to seek recreation in wild orgy ; and scholars whose precocity withdrew them from the healthy sports of boyhood often indulged in extreme vice in their leisure hours. They had the temper of the half-educated journalist of to-day, and were ready to sell their souls to say a new smart thing, however unwarranted : they bespattered each other with the most odious imputations of the slums, delivered in choicest Latinity; the disgust that they caused was one of the reasons why men began to abandon humanistic culture towards the end of the period, and once again welcomed poets and authors in the vernacular.

Never was there a completer divorce between religion and morality. The darker shades in the pictures of the age left by its contemporaries are largely composed of Court scandal, repeated by disappointed placehunters. But Popes made no mystery of their debaucheries; and the Grand Turk dared to offer the Head of the Christian Church 300,000 ducats for the dead body of his brother Djem, who was in Alexander's custody, adding that the "worthy father of the Catholic Church would be thus enabled to purchase States for his children (Sanudo "de adventu Karoli."-Villari, Mach., Introd., iv., 2). Yet revivalism could still achieve a passing success with Savonarola; the spirit of 
St. Francis and St. Catherine still survived. St. Catherine Adorni (I447-I 5IO), a daughter of the fierce line of Fieschi, and the widow of a profligate, maintained that all happiness is in God alone, chose "Thy will be done " for her motto, and wrote a treatise which Cardinal Manning declared to be the utterance of one immersed in an expiation of love. The beauty of her character reached the soul even of her husband on his deathbed, and St. Catherine, "the seraph of Genoa," devoted her remaining days to meditations on the Divine love and to the care of the sick in Genoese hospitals.

Truly, the Renaissance was as a tangled forest where the most diverse and dissimilar products are nourished and intertwine, and struggle together, and sometimes stifle each other. Yet it can hardly be doubted that the natural vigour of the Italian was unabated at the close of the fifteenth century; and that, if the peninsula had been left to itself, it would have achieved some kind of organic unity and developed some stable code of conduct, some fixed object of aspiration and endeavour. As it was, the very antagonism of its petty States, the very diversity of man's outward adornment, 1 was evidence of seething ferment, of the development of individuality that had not yet found the way to accord with collective organization and associative action, of a great people yet in the making. Already in the sixteenth century we find morganatic marriages of affection taking place, and some attempt to restore legitimacy (Burckhart), while the Papacy, which had hitherto been powerful enough to prevent the unification of Italy, would perhaps have secured it by a nephew, or one of the other " four strings of the Italian lyre," Venice, Milan, or Naples would have triumphed ; if not, the Papacy would have, perhaps, still so far have predominated as to reduce the competing powers to the obedience of satellites.

Slavery had entirely disappeared in North Italy : many generations had passed away since the charge of traffic in Christian slaves could be made against Venice ; but the Popes and Kings of the South still possessed them. Pius II. mentions a negro musician who was a slave; Innocent accepted a present of roo Moors from Ferdinand of Aragon in I 488 ; in I 490 a slave was manumitted in Florence; in $150 \mathrm{I}$ the captors of Capua sold the women of the city, and Bandello speaks of the sale of a slave at Genoa. Feudal ideas became stereotyped in "the kingdom " at a time when the true aristocracy of merit and industry was established in the republics, and we learn from Massuccio (n. 19, A.D. I476) that La Cava was beggared because there everyone aspired to be a knight, a physician, or a notary. Manners grew softer; everyone tried to speak the language as it was written by the best authors, and Massimiliano Sforza expressed great disgust for the manners he had witnessed in Germany. Children were hardly ever beaten (M. Veggio, died I458, De Educ., L. i., c. 19); servants were free-spoken, and were familiarly treated as friends of the house ; but the young girl was never heard, and hardly ever seen (Bandello, ii., 44; iv. 27). Agnolo Pandolfini draws a charming picture of domestic life (Trattato del governo della Famiglia); he leads his young wife to her new home, and kneels with her before the household shrine of our Lady, and prays with her, but, be it observed,

1 By the close of the fourteenth century there was no longer any prevailing fashion of dress in Florence. 
for terrestrial, not for celestial gifts ; an artistic balance in life is his ideal ; virtue is valued solely for its grace and gaiety ; vice reprehended as disturbing the mind with desire, grief, and repentance; it makes a woman ugly; virtue adorns her. We learn from him how the peasant is never contented, he always wants his debts paid, or his daughter dowered, or a cow bought for him, requests which British sons of the soil have not yet made for themselves, and which indicate the comfortable position of the contadino.

Egoistic self-approval, and the approval of those whose good opinion was worth having, constituted the ideal of life; and out of this grew a strange perversion of the moral sense, known as honour. It gave rise to vengeance when the sexual irregularity of wife or sister became known ; it allowed of strange developments of character; for character was moulded, not on reason, but on self-love, and the opinion of a set of similarly minded men. And just as religious duty was divided into formal observance and the preservation of honour, so love developed two wholly different aspects-that of carnal enjoyment in the novel and in actual practice, and that of beatific contemplation in the imaginative and idealistic yearnings of poetry and the reflective moments of the study. Even as early as Boccaccio it is easy to see that love with a goal is identified with sensuality. The freedom accorded to woman without any struggle on her part to attain it, the unquestioning acquiescence in her equality, and the acceptance of her influence and even participation in active affairs, led to her assumption that she had a right to dispose of her person in conformity with nothing but her own whim and choice. And one scarcely ever meets with cases of real marital jealousy until the introduction of Spanish influence: men bore their horns quietly for fear of ridicule.

The enthusiasm of the Early Renaissance for recovering the lost books of antiquity was replaced, in the later Renaissance, by an enthusiasm for recovering the lost works of art. Excavation restored the Laocoon, the Venus of the Vatican, and many valuable works of antiquity, to an excited and admiring world. In 1485 an ancient sarcophagus of Julia, the daughter of Claudius, was exhumed. The face was covered with a wax mask, which was popularly supposed to be the actual face of the dead woman; her body had been preserved by some ancient process, and all Italy, enraptured, journeyed to Rome to gaze at the sacred features. The enthusiasm for learning was hardly on the wane. Libraries had grown large; they were increased by the advent of printing. In the fifteenth century Nicholas V. possessed 9,000 volumes; Niccolo Niccoli, a friend of Cosimo dei Medici, possessed 800 volumes, valued at 6,000 florins; the library of Frederick, the good Duke of Urbino, cost him 30,000 florins. Poets and scholars were crowned with laurel in their lifetime ; they were borne to the grave by majestic processions, in which the magnificent age delighted, and their tomb received more than the honours of a saint's shrine. Many men of learning had a truly Socratic enthusiasm. "What is your object in life ?" asked Niccolo Niccoli, of a wealthy youth. "To give myself a good time," replied the lad. "As soon as youth is over, of what consequence will you be ?" asked the sage. The question struck the young man, who at once secured a scholar to teach him Latin. The scholars at the.Court of 
King Alfonzo of Naples cost him 20,000 florins a year, and every petty despot, mercenary Captain, or considerable merchant spent an income on scholars that would serve to-day to rear enough pheasants for a respectable battue, or carry a family through the artificial conventionalities of a London season. At Padua a professor of law was paid I, ooo ducats a year, and a physician demanded 2,000 ducats for the teaching of physic, with the right of private practice. Filelfo asked 500 florins for sessional lectures at the University of Pisa.

\section{LiterATURE}

Both Petrarch and Boccaccio aimed rather at success as Latin than as Italian authors. A stage of scholarship followed wherein laborious students grudged themselves even sleep in order to prosecute their researches. They were dominated by the tradition of the ancient mother of the world; they had a just sense of their high calling; they gave the intellectual activity of Europe a classical bias ; they supplied a counterpoise to the Teutonic tendency to romantic unrestraint. Poggio Bracciolini scoured Europe and discovered many forgotten Latin authors; Palla Strozzi set up a search in Greece for Greek authors ; men pored over crabbed, faded characters of fusty parchments as a lover devours his mistress's face, and, unlike the lover, their enthusiasm never grew weary or cold. All Italian writers neglected the vernacular and aimed at correct latinity; at Florence alone the tongue of Dante was cultivated for its own sake, and many of the most famous Florentine scholars continued to write in the vernacular and carry into it the peculiar force, compression, and self-restraint of the ancient tongue. Men whose minds were nourished on the ancients formed literary societies, known as academies; and the Florentine academy, started by Cosimo dei Medici, was composed of three classes-the patrons; the active members, of whom were such brilliant men as Pico della Mirandola, Leon Battista Alberti, and Poliziano; and the youthful disciples. Lorenzo dei Medici studied under Greek masters, reclined at platonic banquets, and amid codices, antiques, and the best art-work of his time, polished his poems in the vernacular with the acumen of the trained classicist, but expressed the heart of the people and passed with light tread from the praise of Bacchus and Venus to the loftiest mood. The rispetti of the people, the outpourings of the peasant's beart, the poetic rill that had never left the Tuscan slopes, found in Lorenzo a polished fountain whence it broke into new and fantastic shapes, and issued reborn to the joy, not merely of a cultivated audience, but of an appreciative people. Luigi Pulci, who grew up in the Medicean circle, next produced his Morgante Maggiore; he began the line of our own Byron, as expressed in his Don Juan. Pulci took as his basis an obscure chivalrous epic of the preceding century, and rewrote it, now in the spirit of burlesque, now in that of serious earnestness, but always with unexpected caprice. He was followed by Count Matteo Boiardo, who wrote a poem of chivalry and humour, the Orlando Innamorato, based on the legends of Charlemagne. Chivalry was a strange phenomenon to the Italian mind : it suggested both ridicule and respect, and gave an opportunity for wild, fantastic treatment, and the introduction of many passions 
and every mood. Following Boiardo, Cieco of Ferrara treated similar subjects in a similar vein. The supremacy of the vernacular in literature was restored by Lorenzo dei Medici, Pulci, Boiardo, and Cieco.

The poetic line of Pulci and Boiardo found its greatest son in Lodovico Ariosto (1474-1533). His father, commander of the citadel of Reggio, put him to the uncongenial study of law, which he first forsook for literature, and then had to resume, in order to provide for his numerous brothers and sisters, Some of his work attracted the notice of Cardinal Ippolito of Este, who took him under his patronage, and gave him a miserable stipend, irregularly paid. The Cardinal's brother, the Duke of Ferrara, now employed him as Ambassador and as a kind of poetlaureate, and then as governor of a wild and distracted province of the Apennines, which he administered wisely and well. It is said that one of the banditti of the mountains captured and then released him, not because he was governor, but because he was the author of Orlando Furioso. After a time he withdrew to the debauched but cultured Court of Ferrara, leading a similar life to that of Goethe at Weimar, superintending the theatre, producing his own comedies, and perfecting his great poem. He was of a changeable but strictly honourable and selfrespecting disposition; he would neither take orders nor marry (until the end of his life), refusing to fetter himself by oaths, and he left two bastard sons by different mothers. $\mathrm{He}$ is a master of style ; vigorous, romantic, and varied in the treatment of his theme. Proud types of chivalry appear in his poem, only to be treated with outbursts of scepticism and waggish, innocent malice; he. is the most fanciful and the most vivacious of poets; even in his jests he never loses his dignity; and no work of imagination is more saturated with beauty than the Orlando. But in the fantastic world that he creates there is no grave, serious purpose : Ariosto's sole aim was to produce a perfectly delightful work of art. Ariosto and his peers express all the fleeting phases of human emotion : they are as swift in their changing moods as the brief thunder, the smiles, and tears of an April day.

There now appeared an author who has given rise to very pardonable misunderstanding, multitudinous disquisition, and interminable dispute down to our own time, Niccolò Machiavelli, the famous, or, as some would still say, the infamous, author of The Prince, the Florentine History, the Discourses, and the Art of War (I469-I 527). The education of Machiavelli, as that of Ariosto and Guicciardini, was incomplete according to the notions of his time; he had not mastery of Greek, and was not spoiled by the grammarians. Widely read, the real education he received was in the world of men; he attained a rare mastery over his native tongue, and exhibited in its use a vigour, insight, reflection, and analysis which, while these qualities were combined with a passionate admiration for the ancient world, were wholly unspoiled by too close an application to the scholar's desk. Machiavelli was employed as second Chancellor and Secretary to the Florentine Republic, and sent on several Embassies. No product of the human mind has provoked more discussion or anathema than Machiavelli's Prince and the Discourses. They became textbooks for rulers, and their principles guided the policy of Frederick the Great, the author of that indignant protest, the Anti-Machiavel. Machiavelli's very name has become a term of reproach, a synonym 
for base and injurious intrigue. Nevertheless, he founded a new science ; he was the first to examine and dissect the political life of his time; he submitted its passionate vitality, its remorseless cunning, to a process of precise, cold-blooded, undaunted vivisection. It is a mistake to say that he is immoral; he is a-moral: he looks on what is going on under his eyes, subjects the facts to analysis in the temper of pure intellect, in the spirit of the scientist examining the exquisite adaptation of the envenomed fang or the cruel claw. He notes the adjustment of means to ends, and accepts the loathsome and unclean with as little revolt as a pathologist in the dissecting-room. Political action is rarely dominated by the highest principles; even in the twentieth century a nation is hardly a society in the true sense of the term, and the "comity" of nations in "an euphuism " covering an incidence of self-interests. In Machiavelli's day subtlety, hypocrisy, deception, bad faith, cruelty, and force were the accepted armament of States; he took things as they were and laid bare the secret springs of action. There is an error in his mode of thinking, and a grave one, but it is an error which dominated human thought almost down to our own day. Just as orthodox economists were wont to regard their science as one of independent and universal laws, valid of themselves and for all time, and forgot that moral principles are apt to interfere with purely material considerations, and that they have a right to interfere, so Machiavelli discovered a science and constructed an art of politics with penetrative insight and subtle skill; but he forgot that moral principles might be involved, and that the purely intellectual adaptation of means to ends must necessarily terminate in the dissolution of society or the revolt of the moral sense. And just as the older economists failed to perceive that society is an organism with changing life existing under transient conditions, so Machiavelli fell into the error of regarding the environment and developing vitality of his own time as composed of factors immutable and permanent for all time.

None the less, he is the father of the scientific study of government and the relations of States, and he dug his foundations deep and laid them well. He is a model of scientific method. And not only was he the most profound and scientific mind of his generation; he was one of the most brilliant stars in the glorious galaxy of Italian letters. $\mathrm{He}$ is quite as remarkable for the varied vigour and purity of his concise style as for the exact observation and unerring analysis of his incisive thought. He has the keen, perceptive insight of the scientific observer, and the unerring logic of the disciplined thinker. He was another of Italy's encyclopædic men. Theoretical statesman, man of affairs, and a great historian, he was also a poet in a small way, and the author of one excellent play, the Madragola, and several gross ones. But his intellect vastly outweighed his heart. Nevertheless, one consuming passion did fire his intellect and possess his soul-his republican patriotism. His appeal for a national militia and the subtle policy he recommends to a Prince he candidly avows to have but one ultimate aim : the liberty and unity of Republican Italy was at once his inspiration and his goal.

Francesco Guicciardini ( $1483-1540$ ) is the greatest of Italian historians. For centuries his forbears had held high office in the Florentine Republic, and he might have received the scarlet hat by virtue of his ancestry and 
ability, but his father would not allow one of his five sons to enter the Church in this time of jts moral corruption. He was married, according to the custom of the time, to secure political support, and he became a statesman and diplomatist, ever working hard for the return of the Medici. Guicciardini was ambitious, crafty, calculating, and grasping by nature, and in diplomatic sleights-of-hand, he proved himself a past master of the game. In the family circle he was a cold but just father, with a strict sense of duty; in public life he was honest and trustworthy; but he was self-seeking and mean in his motives, faults all the more glaring when contrasted with the broad, luminous sweep of his fine intelligence. The predominance of his head over his heart is characteristic of the cynical, sordid, selfish age which terminated the process of individual emancipation, and marked another stage in the evolution of the modern man.

Comedy, burlesque writings, satires, and didactic works were produced in considerable number during the fifteenth and first part of the sixteenth century. But all the most famous men of the age of foreign domination first saw the light in the fifteenth century, before the descent of Charles VIII. marked the beginning of a new order. They were brought up under the influence of an Italy unenslaved by the foreigner. The Renaissance was the great age of the noblest body of literature of modern peoples : Italian letters have the great distinction of appearing not merely first in the order of time, but, in the main, of remaining first in the order of merit.

\section{Architecture}

The Gothic importation never secured the sincere affection of the Italian architect: he never lost his love for the low-pitched roof and pediment, the column and pilaster, the restful horizontal line and the dome. The Certosa of Pavia (end of fourteenth century, built by Gian Galeazzo Visconti) shows round arches used at the same time as pointed; and all kinds of experiments were made in a variety of directions at the beginning of the period of which we are now treating. Study of the works of Vitruvius aided a return to what were supposed to be ancient principles, but these were adorned with a new grace and subtle charm to which the heavy Roman artist had never attained. Vitruvius was talked about, but ancient examples were not really studied; Vitruvius was used as a lay-model whereon to hang the inventive fancy, the delicate imaginings of the individual artist. The Roman architect whom the men of the Renaissance affected to follow was hopelessly wrong in his theories, and an attempt at rigid adherence to them ultimately brought about a formal and mannered school that excluded all life and development from the art; while the fertility of Italian invention, in breaking through these artificial limits and forced orders, developed into a wild and wandering grotesqueness which violated every eanon of good taste. At first the enthusiasm for classical art led to a modification of the Gothic. In I 420. Brunelleschi added a vast dome to the cathedral of Florence, but it is octagonal and retains Gothic characteristics. His pupil, Leon Battista Alberti, insisted on the false five orders of Vitruvius, and the new styles were rapidly adopted; but, as the students of Vitruvius neither understood that misleading author nor agreed with one another in their interpretations of him, nor studied the ruins of original buildings with 
care, the result was disastrous. The Pitti Palace in Florence has a certain rugged, massive merit, and the cupolas that the new school introduced are fine; also a very imposing style for palaces grew up; but, although wealth, magnificence, and ostentation are indicated, there is usually a singular admixture of bad taste. The most charming buildings belong to the traditional period, and the most delightful characteristics of these buildings are their decorations, especially the so-called arabesques, whether the product of the chisel or the brush. These were perfected developments from the grotti of the newly-discovered Golden House of Nero and the Baths of Titus. The churches of Verona, Brescia, and Venice, the palace of Mantua and the Vatican and other buildings of Rome are full of the lovely designs of Raffaello and other masters. In spite of the reverence inspired by the ancient world, the great creative minds of the Renaissance had small respect for the work of more immediate ancestors : each generation swept away the work of the last without scruple, and any work, however noble, was ruthlessly destroyed to give place to what the self-confident taste of the moment pronounced to be an improvement.

Bramante of Casteldurante in Urbino (1444-1514) was the original designer of the rebuilding of St. Peter's. His plans far surpassed the present building, and the form of the Greek cross, which he adopted, would have given full effect to the noble dome. Much of his work is really Gothic in conception, and he skilfully combined the light grace of Northern feeling with the magnificent dignity, measure, and restraint of the classic temperament.

\section{SCUlPtURE}

Never did sculpture attain a greater perfection than in the period we are reviewing. Form became only a means to an end; the sculptor endeavoured to reproduce the real, but to reproduce it invested with dignity and in a way that would reveal "spiritual content" and express ideal conception. Ghiberti (I378-I455), a Florentine goldsmith, cast the gates of the Florentine baptistery, which Michelangelo said were worthy to become the gates of Paradise. He daringly reproduced landscape in gilded bronze, his figures in half-relief are delicately modelled and richly grouped, and every tablet bears, not merely the impress of superb genius, but of a high poetic nature charged with deep religious fervour. Donatello (I386-I466) combined realistic truth with lofty moods, and often invested his work with extreme beauty. Of his St. Mark, Michelangelo said that so noble a figure could well write a gospel; and his equestrian statue of Gattamelata, the condottiere, at Padua, vies with the great work of Verocchio at Venice. About the same time Jacopo della Quercia produced singularly rich and beautiful work at Siena, stimulated by contemporary Florentine work; he was rewarded by the honour of knighthood given him by the signoria of Siena. "Although but a sculptor," says Vasari, " he drew very well. ... He was fortunate in that his many good qualities were appreciated and acknowledged in his native land, since it rarely happens that distinguished men are universally beloved in their own country."

Luca della Robbia (I400-1482) was a sculptor remarkable for the 
tender and delicate grace of his productions. Great as was the fifteenth century in the vigour, dramatic power, and expressive grace of its sculp. ture, the singing gallery which he executed for the Florentine Duomo excels all other productions in originality, beauty, and technique. $\mathrm{He}$ improved on the already discovered process of covering terra-cotta relief with enamel, an art in which he was followed by five sons, his famous nephew Andrea, and the nephew's son, Giovanni. Andrea del Verocchio ( I 435 - I488) was goldsmith, painter, and sculptor, and equally famed in each art. His masterpiece is what is undisputedly the noblest equestrian statue in the world, the magnificent equestrian statue of the mercenary, Bartolommeo Colleoni, which he executed for the grateful Venetian employers of that General. From a host of great sculptors the names of the two Rossellini, Benedetto da Maiano and Mino da Fiesole may be selected as those of artists animated by a deep religious spirit and giving perfect expression to the ecstatic peace of the virgin soul : their works seem to dwell in disembodied air, visited by some strange, soft, translunar music.

Very different from these gentle imaginations is the Titanic force and power of Michelangelo Buonarotti (1475-1564). Great as architect, engineer, painter, and poet, he is greatest as sculptor. His style is grand, large, sublime, sometimes approaching the violent; often impetuous, impatient, and unfinished. His range of treatment is great, extending from the gentle melancholy of his Madonnas to the dignity and force of his David, from the energy of his so-called slaves to the mystic meditation of his Crepuscolo and Aurora. Buonarotti was the son of a poor but noble Florentine family, and his father had the prejudice of a certain class of Florentines against commerce of any kind : he preferred the indigence of the smaller offices of State, and vehemently opposed the entrance of Michelangelo into a goldsmith's shop, which, however, he entered, and whence he passed into a school of sculpture established by Lorenzo dei Medici. His sense of family duty and sympathy with the "gentility" which his family endeavoured to maintain under increasing pecuniary difficulty impelled him to superhuman exertions and the endurance of every kind of personal hardship, in order that he might support them, The work of this period of his life has a calm, tranquil quality, though he was from his youth of tempestuous temper, and a broken nose remained a permanent record of one of his quarrels : but when he became master of the technique of his art the furia e terribilitì of his soul entered into his works ; vehement energy found expression as it never had done before in the records of plastic art. He was employed by the Florentine State as painter and sculptor, and then received a call from Pope Julius II. to work in Rome. The two fiery natures clashed less than might be expected, but Julius was penurious, and Buonarotti suffered much from delayed payment and the intrigues of Bramante and other rivals. He worked under Julius' successors, the Medicean Popes, with no hearty goodwill, and when he found that Clement was bent on the restoration of the Medici, he sped to Florence and designed and superintended the fortifications of the city. After the submission of Florence, he was employed on the Medicean monuments, whereon he expressed in dark but majestic hints the defeat and despair of Freedom, and then let loose the sava indignatio of his soul in that immoderate and terrible work, the fresco 
of the Last Judgment in the Sistine Chapel. In his later years he was appointed as architect of St. Peter's to carry on Bramante's work, but he was hampered by having to convert the form of the building from that of the Greek to that of the Latin cross. His later life was marked by the production of impassioned sonnets, not unlike our own Shakespeare's, addressed to a youthful friend; and other verse, mystic, devotional, tender, and vehement, but concentrated. These sonnets were inspired by his female friend, Vittoria Colonna, the widowed Marchioness Pescara : they contain the secret soul, the heart and brain of Michelangelo.

\section{PAINTING}

The great art centre in Italy during the fifteenth century was Florence. The old art of missal-painting was the foundation for the frescoes and altar-pieces of Fra Angelico (1387-1455), a Dominican monk of the monastery of San Marco, which he decorated. Angelico retains the gilded background of the earlier painters, and still exhibits certain Byzantine influences; but he aims at faithful representation of the features. "Never known to be angry or reprove, save in gentleness and love," this man who refused a bishopric, prayed before he painted, and believed his brush to be directed by the Holy Spirit. His work is vital with the spirit of holy quiet and heavenly-mindedness ; but his favourite pupil, Benozzo Gozzoli (1424-I498) fell under other influences, and was keenly alive to the joy of this world. The beginnings of scientific perspective, ignored by Angelico, are first found in Paolo Ucelli (1397-I475), a pupil of Donatello; he devoted much attention to foreshortening. Antonio Pollajuolo (1429-I498) was the first artist to study anatomy by the dissection of the dead subject, and is the spiritual tather of a long line of artists rejoicing in the delineation of energetic movement and muscular activity. Luca Signorelli of Cortona (I44I-I523) combined this trend with the spirit of the classical Renaissance, and in dramatic and anatomical treatment he was the forerunner of Michelangelo. Another line of great artists begins with Massacio (I 402-I 429), who opened up a new way in giving roundness to the figures, ease to their attitudes, breadth to their draperies, and naturalness to the background. Fra Lippo Lippi (I4I2-I469), Sandro Botticelli (I447-I5I5), and Filippino Lippi (I460-I504) are perhaps the most distinguished artists of this school, which is remarkable for its portrayal of temperament, the creations of Fra Lippi being joyous and buoyant, those of Botticelli meditative and haunted by a sense of joy that has been missed or is unattainable; but all three are marked by simplicity and tenderness of feeling and allegorical content, whether the subject be religious or classical. This branch of the Florentine school came, like all the others, to deal more and more with secular subjects.

Ghirlandajo (I 449-I 494) was the first to make historical painting an opportunity for the display of portraiture; he even dared to paint a Bishop chanting prayers for the dead with spectacles on his nose, of whom Vasari says, "We only know that he is not dead, because we do not hear him." This class of painting found its highest representative in Andrea del Sarto (1487-I53I), with whom " all is silver gray, placid and perfect." Effort after technical expression was accompanied by a corresponding loss of the inner radiance of the soul in this school, and begat mannerism. Art was at first the handmaiden of religion and of 
the deeper assurances of the spirit. She was now pursued for her own sake, and the cunning of the artist became valued above the character of his inspiration.

Sienese art remained archaic in character. Perfervid Siena retained a rapt and ecstatic spirit, which expressed itself in religious pictures that for sacred association's sake continued to be produced in the old orthodox manner. Though the style became stereotyped, the artists manifested great individuality in their treatment. The school ends with Matteo dei Giovanni (1420-1495), after whom the Sienese painters fell first under Florentine influence, and then, owing to the presence of Bazzi (Il Sodona) in the city, under that of the Milanese-Lombard school.

In Umbria there were many centres of painting. Umbria was the theatre of discord and anarchy, but the shrine of Assisi, the dwellingplace of St. Francis, was a haven of peace, radiating a quiet and harmonious influence in the intervals of storm; and the mobile, earnest Umbrian nature was wont to pass from the extreme of violence to pietistic self-surrender and the mysterious charms of quietism. The smiling landscape of the soft billowy hills became a background for the portrayal of devout Madonnas and enraptured saints. The final exponent of the old religious sentiment was Perugino, a perfect craftsman and master of pietistic sentimentality. In his "Birth of the Lord," the infant Jesus smiles affectedly at the Virgin and the Virgin at the child, the angels adopt saintly attitudes, and dispose of their feet and limbs with affectation. Self-conscious perception of the beautiful is the key-note of this magnificent colourist; but in his fresco of the Crucifixion at Florence there is a gracious and quiet nobility of treatment to be found in all his very best work. He is said to have been fond of money-in his youth he had not a bed to lie on-and was credited with disbelief. That he was not really devoid of religious conviction, however heretical, is shown by his portrait, painted by himself, and now in the Uffizi at Florence, whereon he has placed a scroll lettered "Timete Deum." He was a great traveller, and studied at Florence, and also, it is possible, under another great Umbrian painter, Piero della Francesca, a native of Borgo San Sepolcro, but who studied at Florence, became master of the scientific school, and taught the great Signorelli. Perugino was the master of Raffaelo Sanzio (I483-I5IO), the son of Giovanni Sanzio, a painter of Urbino. At first he painted in the manner of Perugino, but with far superior power of grouping. His first period is marked by sweetness and grace. He proceeded to Florence, where he drew carefully from the life and produced some of his finest works, combining the results of scientific study of anatomy, perspective, and composition with exquisite gentleness and beauty, and, when the subject required it, with strong religious feeling. Later, assisted by his pupils, he painted the famous frescoes of the Vatican at Rome, and applied all the science of his day to the work. Perfect beauty of form and feature and finish of execution were achieved in these and other great works of his third period; but there is a gradual substitution of pseudo-classicism and subtle technique for simple earnestness and veracity, which heralds the decay of art. Raphael was an architect and sculptor as well as a painter, and he made vigorous representations to Pope Leo $\mathrm{X}$. on behalf of the preservation of ancient buildings Vasari (I5I3-I574), painter, architect, and biographer, says that "all harsh feelings and evil dispositions became subdued and disappeared at 
the sight of him, every vile and base thought departing from the mind before his influence. Such harmony prevailed at no other time than his own. And this happened because all were surpassed by him in friendly courtesy as well as in art; all confessed the influence of his sweet and gracious nature. Even the very animals would constantly follow his steps, and always loved him. ... Whenever any other painter, whether known to Raphael or not, requested any design or assistance of whatever kind at his hands, he would invariably leave his work to do him service. He continually kept a large number of artists employed, all of whom he assisted and instructed with an affection which was rather as that of a father to his children than merely that of an artist to artist. . . . When this noble artist died, well might painting have departed also, for when he closed his eyes she, too, was left as it were blind. . . . All who do their best to emulate his labours in art will be honoured on earth, as it is certain that all who resemble him in the rectitude of his life will receive their reward in heaven." Raphael died, exhausted by overwork, at the early age of thirty-seven years. He was never married, though the Cardinal Bibbiena designed his niece for him ; his affections were otherwise engaged; he had a mistress, whom he passionately loved, but did not marry; for marriage still remained a matter of contract whereby advantage came.

The Ferrarese school of painters came under Flemish influence owing to the stay of Roger van der Weyden at the ducal Court. Its earliest master whose works have been preserved was Cosimo Tura (1420(?)-1 498), a timber-merchant. Its leading notes are the contrast of red with green (probably due to the effects produced in the stained glass of the North), and the inventiveness and quaintness of its decorative detail and accessories.

Bologna boasted two great painters-the pathetic Francia (Francesco Raibolini) (I450-1517), a master in colour ; and his great friend, Lorenzo Costa (1460-I 535), a pupil of Tura of Ferrara. The friends occupied the same workshop, using different stories.

Verona boasted a school of painting of quite native worth. Its art is cheery, gay, and gracious.

At Padua, Squarcione, a student of the antique, adopted Andrea Mantegna (I43 I-I 506). Mantegna was " always of opinion that good antique statues were more perfect and displayed more beauty in the different parts than is exhibited by Nature "; he spent a fortune in collecting Greek and Roman antiquities, but he studied Nature as closely as art. There is a marmoreal calm and dignity about his austere figures, and an actuality that sometimes almost amounts to optical illusion. Superb compositions by this master in tempera are preserved at Hampton Court Palace.

Milan was one of the most important art centres in the fifteenth and early part of the sixteenth century. Vicenzo Foppa, of Brescia, founded the school in the middle of the fifteenth century : he was a master of perspective and foreshortening. He was followed by Ambrogio Borgognone (1455-I523), remarkable for religious peace, delicate colour, and calm dignity. Leonardo da Vinci, though trained in Florence, settled in Milan at the Court of Lodovico the Moor, for whom he carried out works of irrigation, superintended Court festivities, and designed architectural additions to the cathedral of Milan and the Certosa of Pavia. The artists of the time, like the condottieri, had little scruple in changing their alle- 
giance, and Leonardo, who seems to have been specially attracted by subtlety and dark design, subsequently followed the fortunes of Cesare Borgia, the bitter foe of Lodovico: an observing detachment from his feillows seems to have been the chief characteristic of his great mind. He is said to have spent ten years over bis "Last Supper" at Santa Maria della Grazie (Milan), now a ruin, but still commanding the same admiration of the beholder that generations of critics have experienced. His "Madonna Lisa," now in the Louvre, is marvellous as a subtle problem in psychology, and his "Virgin of the Rocks," of which the original or a replica is in our own gallery, is a masterpiece of light and shade-the Virgin, the infant Jesus, and the young St. John are in a cavern, shadowy and occult, as if the presence of Death were there also ; while beyond, in the moonlight, a dreamy river winds through jagged and difficult rocks, onward to a suggestion of infinite distance. Luini- I465(?)-I 54O(?)-was the greatest follower of $\mathrm{Da}$ Vinci, and many of his works have been ascribed to the older man. He paints as one that prayed; and there is both perfection and sympathy in his works, which are peculiarly serene and rich in colouring. Beltraffio, Solario, and Gaudenzio Ferrara are of the Milanese school, as was Giannantonio Bazzi (Il Sodona) (I479-I 549), who cracked jokes, dressed like a mountebank, turned his house into a menagerie, and appears to have been altogether a singularly indecorous person. His colouring is peculiarly rich and luscious ; his most celebrated works are in or near Siena.

The earliest Venetian paintings are religious and ascetic. The Viviani in the middle of the fifteenth century are rather behind the times, though they are the first $V$ enetian painters of note. From the first, the Venetian painters aimed at depth of colour, but there is a homeliness in their conceptions which was probably due to German influence; moreover, while they were religious, their religion is not mystical or ecstatic or visionary ; it is the religion of common-sense, that pervades life but never lifts it to heaven or reveals to it the mysteries beyond the skies. Giovanni Bellini (1426-I5I6) " united purity of religious aim with perfection of artistic power." Albrecht Dürer writes from Venice : "I have many good friends among the Italians who warn me not to eat and drink with their painters. Many also of them are my enemies ; they copy my things for the churches, picking up whatever they can. Yet they abuse my style, saying that it is not antique art, and that, therefore, it is not good. But Giam Bellini has praised me much before many gentlemen; he wishes to have something of mine; he came to me and begged me to do something for him, and is quite willing to pay for it. And everyone gives him such a good character that I feel quite an affection for him. He is very old, and is yet the best in painting." Bellini's brother Gentile (1427-1507) had such a high reputation that the Sultan Mohammed sent for him to come to Constantinople. This was contrary to his creed, which forbad the copy of any living thing, but the Moslem of the fifteenth century was " advanced" in many ways. Gentile exhibited a Herodias, whereupon the Sultan pointed out that the skin of the Baptist's head was not retracted. Gentile demurred, and the Sultan at once called in a slave, had him decapitated then and there, and proved his point. The painter fled. Vittore Carpaccio (I45O-I 522), unpretentious, quaint, devout, earnest, and simple, was an early pupil of Giovanni Bellini. Crivelli, whose earliest and latest signed pictures respectively bear the dates 1468 and 1493 , is remarkable 
for stern, hard outline, warm colour, and accessories of fruit and flower. He was knighted by Ferdinand of Naples (1490). Our National Gallery is peculiarly rich in specimens of his art. Venetian art now lost its religious simplicity and directness, and became characterized by unapproachable glory of colour, noble portraiture, and technical excellence. Giorgione (I477-I 5 I I), Palma Vecchio (I480-I 528), Tiziano Vecellio (I 477I 528), made it their first business to paint. Of great perceptive power, they were the first to see the full deep colour that dwells in shadow, and they invested landscape and man with majesty of passionate purple, serene amethyst, and pensive blue; visions at once solemn and glad, wherein the heaven becomes the very throne of God and the earth His footstool. Just as Northern Gothic aspires to the Infinite while the change to Italian Gothic reveals in jewelled mosaic and precious marble an undreamed-of glory, so pictorial art, which always sought the ideal and invested it with the sincerity of the real in the great Florentine school, changed in the Venetian into an art which clothed the real with an intensity as of the very presence of the perfect.

The Italian painters of the fifteenth century are legion, and there are few of them that do not reach a very high order of merit; while some, even as technical experts, not to speak of their rendering of deep feeling, have hardly been surpassed.

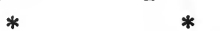

Judged by its art alone, the fifteenth century is a cycle of golden years. The great age of Scopas and Praxiteles, of Apelles and the school of Sicyon, was renewed with a new vigour derived from the romance and tenderness of the North, and deepened by the suffering love of the Christian spirit. Man strove for the highest in life as well as in art, and reached it; but in life the loosening of ancient bonds that liberated all angels that soar also unfastened all demons that lurked. Every quality of humanity, good or bad, was revealed. At first the Renaissance strikes the student as full of contradiction, strange and incomprehensible as the Sphinx, whereof the features indicate exquisite sensibility, lofty imagination, inspiration and aspiration, high intellect, "calm commemorative eyes "; and with these are associated the supple crouch and insensitive talons that mark the cruel relentless cravings of a predatory beast. The scholarly mind, alive to every hint of truth, the poetic heart responsive to each lure of beauty, the gentle soul quickened by all lofty impulse, are bound together with inconceivable treachery, unutterable lust, and secret murder. The unravelling of the riddle lies in the loosening of the human spirit from all - bonds : old restraints were lost; the ancient and the Christian types were both present, but unwelded; the ancient world came back without its civic duty; vital Christianity had disappeared, or remained unadapted to the age ; the social order had no other basis than self-interest. Hence man appeared as he is, himself Sphinx-like, the combination of unspeakable lust with Divine desire, placed in a world of unescapable exigencies. Unfettered from the codes of tradition and the bonds of accepted restraint, the human spirit attained the highest heaven, plunged into the deepest abyss : yet even its lusts were tinged with imagination, and, professional scholars excepted, the Italian always retained a delicate sensibility, and never manipulated the lewd grossness, the cold vulgarity, the coarse brutality which marks the Teuton at his worst. 


\title{
BOOK VIII
}

\author{
THE FOREIGN DOMINATION.-REVIVAL OF I'TALIAN \\ SPIRIT.-UNITED FREE ITALY, I530-I 870
}

\section{GENERAL SURVEY OF ITALIAN HISTORY.-THE CLOSE OF THE MIDDLE AGES.-SUBJUGATED ITALY.-THE RESUR- RECTION OF ITALY}

\section{From the Coronation of Charles V. (1530) to his Abdication} (I 554)

After Charles was crowned he left Italy. In his absence, Venice, as usual, had her able Ambassadors at every little Court, watching with wary, unceasing vigilance all that was going on ; she was ever ready to manipulate affairs to her own interests. Florence was full of malcontents, in spite of sentences of proscription and death : in Genoa the Spinola and Fieschi were still powerful and ready to revolt: Siena had to be kept down by armed occupation: Milan was full of sedition, caused by the miseries of bad administration and the humiliating expenses of what was really a foreign occupation : Ferrara and Mantua only obeyed from fear. Charles returned to Italy ( 1532$)$; he patched up a so-called defensive league of the Italian Powers, excepting Venice-she refused to joinand imposed on each State a contribution for the maintenance of a regular army to be entrusted to De Leyva, who commanded the garrison at Milan, thus making Italy contribute to the expenses of her enslavement. But Clement was again veering towards France; he was arranging for a marriage between his relation, Caterina dei Medici, and Henri, Duke of Orleans, the second son of the French King ; her husband was to receive certain Italian towns as her dowry. Nor was Charles able to break off the arrangements, which took effect the next year. But the death of Clement (I534) brought about the failure of the political alliance : the towns were never paid over, and Caterina brought nothing but woe to France.

The younger branch of the royal race of Paleologi that reigned in Montferrat became extinct in I533, and the House of Sforza in 1535. Charles gave Montferrat to Mantua; Milan he kept for himself. The peace between Francis and Charles had been threatened in many directions; the storm was fast gathering, and the struggle for world-empire was again to be renewed. Many Italian incidents were indicative of the inevitable resumption of war; and while Charles was in Italy, where his Viceroy, Toledo, was really re-establishing order and good government in Naples, word was brought that France had invaded Savoy. War followed with varying fortunes (1536-1537) in France, Flanders, Savoy, and Piedmont; both sides then began to find out the limits of their power; and a truce was agreed upon for ten years, Francis holding Savoy and Piedmont, which gave Charles ample time to consolidate his power in Italy. Citadels 
that were the admiration of the world, garrisoned by his troops, arose in Lombardy, where the army on a peace footing was large, and a Governor united civil and military authority in his own person. In the Two Sicilies the army was reorganized, and consisted partly of Spanish and Flemish, partly of Italian troops : by clever manipulation the clergy were balanced against Papal pretensions, the middle class were given a share in the administration, which conciliated them, and the nobles had their teeth drawn by the bestowal of Court favours. In I 530 Florence had become a dukedom : in I 537 Cosimo dei Medici, son of the leader of the "Black Bands," ascended the throne, and consolidated stable government by gradually bringing the Senate, finance, and the administration of justice under bureaucratic control; the blessings of peace and order were so welcome to a people exhausted by the turmoil of five centuries of liberty, that Cosimo was able to dispense with the support of Spanish soldiery. In I 540 Charles invested his son Philip with the duchy of Milan.

The pontificate of Alessandro Farnese, a pupil of the Roman scholar, Pomponio Leto, was marked by a fruitless effort on the part of the cultured scholars of the Renaissance to come into touch with the German Protestant thinkers. Farnese succeeded to Clement in I 534, and surrounded himself with a brilliant band of supporters. Farnese exhibited the vices as well as the virtues of the Renaissance, and a strong Catholic reaction wrecked the movement. In 1540 the order of Jesuits was approved : in I 542 the Dominican Inquisition was reorganized; in 1543 an Index Expurgatorius, which still continues to exist, was instituted: it was a list of books unlawful for a Catholic to read. Mental fetters were added by the Church to the political shackles of Charles; and the Council of Trent was opened to define articles of faith and reform the Catholic Church. But the counter-Reformation, or Catholic reaction, as it is called, did little more than destroy the art and mental energies of Italy : it never really affected the Italian conscience or reached the Italian heart; it instituted despotism in the Church and stifled Italian idealism, grace, intellectual liberty, and moral energy. On the other hand, the perpetual presence of an Italian Prince at the head of a national Church, from communion with which all Northern and nearly all advancing Europe had retired, nourished the national dream of unity which the exigencies of the time had forced into being under Julius II., and even under Alexander VI. ; the unity of which Dante and Machiavelli-strange names to conjoin-had been the spiritual fathers.

War broke out again in I 542 on a paltry pretext, such as is commonly set forth when nations struggle for power. Francis was joined by Cleves, Denmark, Sweden, and the Turk : in Italy, the Count d'Enghien advanced to Turin and defeated Del Guasto, Charles's General at Ceresole, slaying 8,00o men and taking 2,000 prisoners. But now that Italy was held by a single strong hand, this victory had no further result : even Piero Strozzi, at the head of exiles and the disaffected, could do nothing. And at the peace of Crépi Francis again renounced his rights on Milan, though the possession of Savoy, which France had taken in I 536, was a wedge thrust into the peninsula. The treaty afforded striking proof of how Charles had succeeded in consolidating his power. The wary policy pursued by Venice prevented any serious results arising from local insurrection so long as the Pope remained firm. But the Farnese were a greedy crew, 
and Paul III. was bent on their advancement: he inclined towards France.

An attempt had indeed been made, quite independently of the Pope, to re-establish the Tuscan republics, but it failed miserably. In I546 Francesco Burlamacchi, gonfalonieve of Lucca, invented the plot; and the Strozzi of Florence aided him. Burlamacchi arranged to gather the 2,000 militia of Lucca, under the pretence of reviewing them, and then to lead them over the mountain to Pisa, and excite that city to revolt; while detachments were to be despatched to Pescia, Pistoja, Florence, Siena, Bologna, and Perugia. A general insurrection, thus incited, was to be followed by the restoration of popular government and confederation of the revolting towns: Charles was busily engaged with his troubles in Germany, and was supposed not to be in a condition to do much. But the spies of Cosimo dei Medici were active ; the plot was discovered, and the trembling Senators of Lucca delivered Burlamacchi to the Governor of Milan, who had him tortured and then beheaded. ${ }^{1}$

A much more serious attempt was one fomented by the Pope and his relatives to get hold of Genoa, whose capitalists and port were the key to the Emperor's power in Italy. This formidable plot of the Fieschi, the enemies of Doria, failed, as well as several others.

Siena succeeded in expelling her Spanish garrison (1 545 ), but was compelled to readmit it (I 548). Charles took little notice of these small insurrections, but he and Gonzaga, Governor of Milan, were determined to put down the Farnese. The rule of Pierluigi Farnese in Piacenza was stern ; he forced the turbulent nobility to live in the city, and Gonzaga fomented their resentment; an insurrection took place, Pierluigi was killed, and Spanish troops immediately marched in and took possession. The Pope at once took his revenge by leaguing himself with France ; and all three Powers were busy in preparing for war. And the French contest with England (I 548) only delayed what had become inevitable. Charles claimed Parma; and Farnese threw himself on France, but received no help until peace with England was effected. Meanwhile war went on in Italy, ruined the country about Bologna and Parma, and produced no results (1550-I55I). Italy, however, was not the main theatre of war, but the Netherlands. Siena revolted (I 552), but was reduced by famine (I 555). But before this, Charles, worn out with perpetual business, anxiety, and gout, abdicated, resigning his Italian possessions to his son Philip, the King of Spain, whom he had previously invested with Naples and Milan.

1 Lucca had seen many vicissitudes of government. Become an independent commune from the death of Matilda, the usual internal discords of an Italian republic had thrown it into the hands, first of Uguccione della Faggiola (1314), then of Castruccio Castracani. Louis of Bavaria so!d it to a Genoese banker ; it was seized by John of Bohemia, and pawned by him to the Rossi of Parma, sold to Florence, abandoned to Pisa, liberated by Charles IV., and had maintained its independence as a democracy, with the usual tendency towards transformation into an oligarchy, which the attempt of Burlamacchi stimulated. In 1556 the Martiniana law excluded all families that had not shared in the sovereignty of the republic; this law copied the principle which had helped to give stability of policy to Venice. The little oligarchical state lasted until the French of the Revolution entered Italy ; they swept away its gonfaloniere, nine elders (anziani), senate of thirty-six members, and grand council of ninety, elected at last by eighty-eight families only (I797). 


\section{The LAst Struggle}

Savoy and Piedmont, the keys of Italy, still remained in French hands. The death of Paul III. ( 1555 ), followed by the reigns of two short-lived Popes, led to the election of Cardinal Caraffa, a man of fanatical temper, and determined to exterminate heresy with full Dominican thoroughness. Perfectly sincere in his religious enthusiasms, Paul IV. had founded the order of Theatines, an ascetic community, sold his goods, and given them to the poor. When he became Pope, he assumed magnificent state in order to remove the prejudices of the Roman Court, but remained as zealous as ever and as reactionary and narrow-minded. He resolved to free the Papacy from its dependency; it was he who, as a young man, had praised the equipoise of power in an Italy not yet under the heel of the foreigner as "a marvellous lute whereof Rome, Milan, Naples, and Venice are the four strings." He had hated Charles for parleying with his German heretics, he hated the foreign rule, and he had the unforgetting, irreconcilable, bitter vindictiveness that belongs to old age. France and Ferrara answered the call, Venice, as usual, holding aloof.

Philip tried to divide the Italians by concession. He gave the town of Piacenza, but not the citadel, to the Farnese; he gave Siena to Cosimo dei Medici, the Duke of Tuscany, retaining the seaports of that Republic. The Spanish troops occupied the country round Rome, and the Pope in his extremity called on the Duke of Guise, who had crossed the Alps, to leave Milan unbesieged and press on through the Campagna to Naples. The siege of Civatella, undertaken by the allied forces, was unsuccessful ; the Pope's own subjects murmured at war-taxes and the presence of the French, and the unpaid Papal troops deserted. And the defeat of the French at St. Quentin threw Paris open to the enemy, and the French army was recalled in haste ( 1557 ).

Alva, the General of Philip, could have taken Rome with ease, but the divinity that hedged the name of Pope prevented both him and his master from proceeding to extremities. Alva merely exacted the restitution of the Colonna to estates that had been transferred to relatives of the Pontiff ; and the power of Spain struck deeper root than ever. By the peace of Cateau-Cambrésis (I 559) the claim of the French to Montferrat, the Milanese, Corsica, Savoy, and Piedmont was abandoned, but they were allowed to retain Turin and certain isolated places. The little duchy which was ultimately to take the hegemony of United Italy was thus brought into prominence as a buffer-State between two great Kings. The Holy See retained its temporalities, and while it had lost the Protestant North, by the drastic counter-Reformation, it reassumed its old dominant position as Spiritual Head and Arbiter of the Catholic nations, of whom it demanded obedience as to dogma, discipline, and direction. Cosimo dei Medici had Spain in the background as a bugbear to keep Florence and Siena in order. The Duke of Parma was by family ties the devoted servant of Philip. The new Duke of Ferrara begged an Austrian Archduchess for his bride.

Paganism was conquered, but Christianity can hardly be said to have been restored. Devotion was external : it did not reach the heart of the people. The Catholic reaction killed the ideal element. The Papacy 
became a grinding tyranny in matters spiritual : the Curia copied the methods of the Spanish Prince. Criminals, bankrupts, men of high spirit who had incensed the various Governments of Italy, fled to the hills, and the common people called them bravi, and succoured and concealed them in their hour of need. Only military expeditions could now and then destroy the bands of brigands, headed by men of long descent, that infested the mountains. Italy bowed under the yoke. Venice and Genoa, the inconsiderable oligarchy of Lucca, and the little Republic of San Marino, on the Eastern spurs of the Apennines, alone remained to attest her ancient freedom.

We have now traced the general history of the peninsula from the pulverization of the Western division of the Roman Empire, through the Middle Ages, to what may be justly regarded as their termination. Divisions of time are arbitrary, but convenient; the great period that lies between the ancient and the modern world is connected at both ends by vital processes with what preceded and what followed. When the Northern barbarians poured into the enfeebled Empire, the wreckage of the Roman world was still the poor remains of culture and civilization; these did not fail to impress the imaginations of the conquerors, and attune their savage energies to gentler moods. Undisciplined children in heart, uninstructed in mind, they nevertheless were forceful in character, endowed with latent genius; from them were to spring Anselm, one of the most crucial thinkers, Dante, one of the profoundest poets of all time and a political genius of high order. No sooner has some settlement taken place than the intellect of the barbarian, stimulated and fertilized, begins to exhibit its native strength. In that first arbitrary period of the mediæval world known as the Dark Ages, Alcuin of York headed a small band that aspired to learning, and a century later Erigena, a native of Ireland or Britain, opened the avenues of thought and speculation with an independence and force that is astounding. There was, as it were, a general rising forth and budding, "a loosing of bonds with unsealings," that heralded the slow approaches of spring. Under conditions of a fertile soil, an energetic population, and relative peace, the cities of Italy grew into importance. The complicated system of relationships between the political units of society, based on the possession and delegation of land, -in other words, the feudal system, with all its mutations-and still more the opposition and unstable equipoise of Church and Empire, which gives their character to the true Middle Ages, enabled these little municipalities to obtain civic freedom and develop civic organization. Favoured by the powerlessness or inadequacy of the surviving half of the Roman world, the Byzantine Empire, communes appear first in those parts of Italy which appertained to it, in the South of Italy and the Adriatic lagoons, and later by a quite independent movement, which we have traced in detail, in Lombardy, and afterwards in Central Italy. Beginning as democracies composed of all citizens that had any sort of stake in their little locality, the growth of population and the differentiation due to commercial progress and expansion limited the usefulness of popular assemblies; and we find the wealthier burghers constituting themselves into a privileged order; they become the State, and govern by forms, 
usually designated by the loosely-defined term "republican," but to which the phrase happily suggested by Mr. J. M. Rigg, " government by confraternity," is more exactly applicable. These confraternities, harassed by units of feudal power within and without the city walls, and menaced by the lower class of burghers, nevertheless manage to establish power by playing off Church and Empire against one another, and gaining advantages from the one that happens to be the weaker at the moment; they attack each other for the command of trade, and the weaker become the subjects of the stronger. Milan, Genoa, Pisa, Venice, Florence, Bologna, take the lead; they foreshadow the change of the Middle to the Modern Age of social organization, based not alone on territory, but on wealth and power effected by the interchange of commodities. In order to obtain some degree of peaceful order and security for their manipulations, the free cities, weary of conflict with the excluded class of military aristocrats often allied with the excluded class of artizans and small tradespeople, submit to the authority of a military despot that, indeed, their martial prowess or skill ill qualify them to oppose. Sometimes security is obtained for a while by the triumph of oligarchy. During the whole of that later period of the Middle Ages, called the Renaissance, when the spirit manifested in Alcuin had penetrated into hidden classic fountains and prepared the strange alembic that gave the close of the Middle Ages - the Renaissance-its singular beauty and subtle grace, we find a struggle proceeding in the Italian States and confraternities between those two perpetual antinomies-freedom, which is seminal and dynamic, order, which is repressive and static ; freedom leading to brilliant self-realization of the human spirit, but also to perpetual unrest and political disintegration and the weakness of disunion-order giving stability to the State at the expense of the ultimate degeneration and debasement of the citizens. In the first flush of the fair promises that greet the awakened human spirit, all kinds of constitutions are tried and overthrown by the revolutions of adverse experimentalists, animated by opposite aims and interests, until the rigid hand of authority takes advantage of disorder and establishes settled command. The governmental experiments of Italy in the Middle Ages prove one and all failures; most are ephemeral. Two political institutions alone exhibit real political genius; two Governments alone knew how much liberty might be granted, what restraining force was required, and how to apply it. The Metropolitan Church, inheriting the traditions and methods of ancient Rome, consolidated itself and extended its sway. From being a government by the confraternity of the Senate, people, and clergy of Rome, which delegated its authority to a Pope, and to which that authority reverted at the Pope's death, it developed into an elcctive despotism, the election being in the hands of a Sacred College, more or less representative of Christendom, and especially of Italy, and nominated by the preceding or reigning Pontiff. The Venetian State, also, founded by Romans who fled for security from the mainland to $a$ fishing population, exhibited the gradual concentration of political power in a closed oligarchy that contrived by consummate statesmanship to weather every storm.

We have now arrived at a period that cannot be said to be mediæval. A new world and new peoples have been discovered; the opening up of new markets has shifted the pathways of tradc, and led to a growth of 
sea-power; nations have been formed, possessing national feeling and patriotism, with bureaucratic governments controlled by their Kings; the Northern peoples have revolted against an œcumenical Church, the printed book has displaced the expensive manuscript; capitalism has established itself, and the old trade associations are dying or dead; individualism is triumphant in a commerce that expands in the manipulative hands of commercial despots. In the increased complexity of political and social life there is a fuller, freer expression of individual opinion in the speculative realm in Northern Europe, a stern repression of speculation in the Catholic South; the heritage of culture departs for a while from the peninsula and passes North of the Alps.

Here we might justly end our story, but for the fact that certain of the republics still survived. Siena fell in I555; but Genoa and Lucca had copied the Venetian model ; they lived on until the end of the eighteenth century. Venice also lasted until Napoleon extinguished her. And even after the vile compact of Vienna the continuity of the republican spirit was maintained. We enter a new phase of Italian history, a phase inaugurated by the outbreak of the revolutionary spirit, sustained by increased facilities of transit and communication and world-wide competitive commerce, and intellectually characterized by the subjection of humanity to scientific examination and by the gradual recognition of man in one wide aspect, though an "insurgent son," as none the less a part of Nature. The new spirit reawakened Italian genius; the republican spirit could not be suppressed by the cold indifferentism of time-serving Cabinets or the sword and prison of the conqueror. "Austrian and priest had joined to double and tighten the cord "; but, after the heroic struggle of years and the establishment of republics of a day, the spirit of nationality was affirmed by the establishment of Rome as the capital of United Italy in r870. One little mediæval Republic, almost unnoticed on her mountain height, still survives. San Marino, enclasped by the kingdom of Italy, links the twentieth with the ninth century.

It is, therefore, desirable to give a brief account of the political currents which encircled the republics in their later history, and trace the course of Italian evolution up to the affirmation of Italian nationality.

\section{Italy under Spanish, Austrian, and Bourbon Rule}

If it be true that the nation without history is to be accounted happy, Italy must be regarded as an exception to the rule. For nearly three centuries she had no history of her own. Charles V., less as head of the Holy Roman Empire than as King of Aragon and Castille, linked her States to the destinies of Spain and made them her debased dependencies. The Papacy also linked its destinies with Spain; for Philip II. stood at the head of the Catholic powers, while England led the Protestant van : France, torn between Catholic and Huguenot, was the field of a deadly struggle between their opposed forces. The adhesion of the Papacy to Spain forged another link in the chain which fettered Italy. By the end of the sixteenth century the authority of the Church was scarcely recognised anywhere except in the two peninsulas. Thrown back on home affairs, Pope Sixtus V. (I 585-I 590) reorganized the temporal and spiritual power, and, as ancient ducal families died out one by one, the Papacy 
possessed itself of their territories and formed a compact, organized, but ill-administered State.

The persecuting attempt which the Spanish monarchs had made to unify and subject their peoples by forcing them into religious unity was copied by the Papacy. Religious intolerance sent Giordano Bruno, who dared to write on philosophy, to the stake ( 1600$)$; the quasi-independent Church of Venice was attacked by the Papacy, but the Venetian position was ably maintained by Fra Paolo Sarpi (I 552-1623), a sarcastic writer, equally admirable as a statesman, a scholar, a patriot, and a man.

When the exhaustion of Spain reduced her to a second-rate power, the Italian States found themselves like a paralyzed man, sensitive but helpless. Or, rather, Italy was like the impotent worm that has had its nervous cords gnawed through by the insect that it provides with sustenance for its brood. Spain, attacked by France, bled Italy to sustain its own declining vigour. The government of all Spanish possessions became worse, taxation grew unendurably heavy, trade declined, brigandage increased, and the pettycourts of the Italian Princes imitated the lavish pomp, expenditure, and methods of their protector. Mean while France had become strong by the overthrow of the Protestant party and the abasement of a recalcitrant nobility into humble courtiers of the King. Tax was superimposed on tax by the Spaniard to gratify the greed of Governors, and supply the sinews of war for his continued contest with France. Italy had never been wholly quiet under Spanish rule. A Dominican friar named Campanella, following the examples of Arnold of Brescia, Fra Bussolari of Padua, and Savonarola of Florence, excited an insurrection in Calabria which required an army to put it down. Suddenly, led by Palermo, city after city revolted in Sicily, but the attempt to re-establish popular government.failed (1647). All over Europe there was a revolutionary movement. Holland had freed itself from the grasp of Spain, and had established and maintained a republic; Portugal had cast off the yoke of Spain; England had risen against her King; the Catalans were in revolt; even in France there was a movement against Mazarin, the power behind the throne. At the same time as Sicily revolted, the imposition of a tax on fruit led to a revolt at Naples, headed by a fisherman, one Masaniello (Tommaso Annielo) of Amalfi, and the insurgents compelled the Government to treat. The Duke of Arcos, the Governor of Naples, gave every promise that would serve to content the people, and then had Masaniello assassinated, revoked all his perfidious promises, and on the renewal of insurrection bombarded the town. But the Spaniards were repulsed by the populace, and a republic was proclaimed. Mazarin saw and seized the opportunity; he secured the complicity of the Pope and the Dukes of Modena and Savoy, and sent help to Naples. The grateful Neapolitans, relying on French support, named the Duke of Guise head of the "royal Republic." But Gennaro Annese, an armourer, who replaced Masaniello in the movement, saw that Guise was only bent on the acquisition of the Neapolitan Crown, and that France was in league with the nobility. Annese entered into secret relations with the Spaniard, and readmitted him into the city. The civil war in France rendered that power just at this juncture impotent to act, though she still kept her eye on Italy, and from I635 to 1639 had attacked Spain in that peninsula. In 1674 Messina revolted, and drove out the Spaniard, and the French Ministers under Louis XIV. sustained the insurgents, and tried 
in vain to rouse Italy to rebel, though the war penetrated into North Italy. The important fortress of Casala round which the contest raged was destroyed by the consent of both sides (I695).

The absolute monarchs of Europe fought for the power of their respective houses without any consideration for the natural rights or interests of the peoples whom they aspired to govern. It was a reductio ad absurdum of the dynastic principle. The Austrian line in Spain became extinct in 1700 , and the Spanish succession was claimed by Charles, Archduke of Austria, and Philip, Duke of Anjou. Milan and Naples were occupied by Austria, and though the quarrel was fought out in the Low Countries, French armies invaded Italy. They were driven out by Vittorio Amadeo II. of the astute House of Savoy. The war between France and Spain became general, but at the Peace of Utrecht (1713) Charles of Austria took Milan, Mantua, Naples, and Sardinia ; Philip took Spain ; and as a reward for his services Vittorio Amadeo received the title of King with Sicily, Alessandria, and Montferrat. A little later he was obliged to exchange Sicily for Sardinia, a poorer island, but nearer to his base. Philip the Bourbon married Elizabeth Farnese, the heiress to Parma and prospective heiress to Tuscany, and reopened the war. The Quadruple Alliance was the result of this attempt. When the war of the Polish succession was ended by the treaty of Vienna, Tuscany and Parma fell to Austria, the Two Sicilies to the Bourbons, and Savoy acquired Tortona and Novara (1738). On the death of Charles VI. the wars of the Austrian succession commenced, wherein the House of Savoy became the arbiters of the situation in Italy. At the treaty of Aix-la-Chapelle Parma was converted into a Bourbon Duchy, the Bourbons were confirmed in the Two Sicilies, and Milan and Tuscany were kept by Austria, while Genoa and the Duchy of Modena were placed under French protection.

During this period Venice saw her trade gradually depart from her. Austria urged on the Uskok pirates of the Adriatic against her in order to get Istria and Dalmatia. Crete was lost to the Turk, and the decadent Venetian navy was unable to repel the pirates of Tunis, Algiers, and Morocco. Genoa, deprived of her Eastern possessions, became wealthy through her bankers, who supplied the Spanish Crown with loans, and her merchant equipped Spanish armaments. But her Rivieras and Corsica were perpetually in revolt, and in I 684 the city was bombarded by the fleet of Le Grande Monarque.

There was evidence, however, that the genius of Italy was not extinct. Though the Courts exhibited nothing but stupid and punctilious etiquette and the universal frivolity of social life in the eighteenth century became more pronounced in Italy than anywhere, though painting and sculpture lost ideality while it retained a measure of technique, Palestrina, princeps musica (I524-I 594) founded the profounder and more subjective art of modern music, and reconciled the severe demands of the counter-Reformation with the desires of art by producing glorious works which are esteemed as the perfection of Church music. Shortly after Palestrina, Italy was acknowledged to lead the world in this the most subtle of the arts, and she became the very home of opera. In science, Galileo, Torricelli, Viviani, Borelli, and others made Florence almost as renowned for the study of Nature as she had been in the fine arts; the first-named was condemned by the Holy Office to perpetual imprisonment ( 1633 ), from 
which he was only released at the intercession of the Duke of Tuscany Notwithstanding the jealousy of religion, science made headway and received support from enlightened Princes and even from cardinals. The baroque art that spoiled architecture invaded letters. Yet Muratori of Modena (1672-1750) devoted his great powers to the erection of a vast monument of learning to Italian history, and was of course accused of heresy and atheism. Venice, brought under the heel of the Papacy, did not produce another Sarpi, and everywhere thinkers had to use the greatest circumspection in the unfolding of their minds, so that the stimulating clash of opposed intellects was rarely heard.

In 1755 the patriot Paoli was successful in setting Corsica free from the misgovernment of Genoa, and the island was ceded to France just in time for Napoleon Buonaparte to be born a subject of that country. A time of repose now came to Italy, and the various paternal Governments set themselves to improve legislation and bring a land, once the leader of European civilization, nearer to the level attained by those nations of whom she had been the Alma Mater. In the south there was a medley of institutions and laws derived from Norman, Hohenstauffen, and Angevin; and the people subjected to these further endured the exactions of Spanish rule and the arrogant privilege of class. The hilly interior was a desert, the plains uninhabitable from marasma. The cities of Central Italy were depopulated, commerce had fled, the palaces were deserted; in the North the oppression of foreign Governors had introduced new abuses without removing those customs which, once of service, had in the change of time become baneful. The whole country was crippled; so far from showing any real signs of recovery from the mutilations of the sixteenth century, it appeared to be in irremediable decay. Tannuci, the minister of Charles of Naples, Dutillot in the Duchy of Parma, Francis the Duke of Tuscany, endeavoured to amend laws and restore waste lands to agriculture and revive learning, and, so far as the survival of learning was concerned, they were followed by the Popes. The ferment was beginning to agitate all Europe which engendered the French Revolution, a troubling of the human spirit not unlike that which possesses our own times. And it reached Italy. Vico, a Neapolitan philosopher (I688-I744), had already attempted a science of history, and referred the changes experienced by peoples to natural law; Denina (1731-1813) produced his famous Revolutions of Italy; Beccaria of Milan (I735-I793) investigated the relations of crime and punishment; Alfieri the poet (I749-1803) sang the passion of popular liberty, the sublimity of patriotic self-sacrifice, and the matchless merit of extirpating tyranny, in tragic drama modelled on classical studies. Liberty became an ideal; the double cord of ecclesiastical and political tyranny could not be cast off, but a change was felt to be near, and intellectual revival took the form of impassioned worship of ideal formsof liberty and truth. A whole host of thinkers investigated problems in economics ; they were led by Bandini (1677-1760), and among them were to be found remarkable men, chiefly Tuscans. Galvani the Bolognese (I737-I798), and Volta of Como (I745-I827) investigated natural facts, and founded the science of electricity. Intellectually Italy was alive ; she produced her great men as of old; it was significant that in 1778 Clement XIV. had to suppress the order of Jesuits. But the land was feeble and divided. Movements of the aristocracy and the trading class 
alarmed the most generous Princes; they fell back on the privileged class of nobles to support them, and the intellectual part of the nation eagerly watched the progress of revolution in France, and awaited the trumpet-call from that country.

\section{The French Regeneration of Italy}

In 1792 the Austrian head of the Holy Roman Empire declared war against France. Troops poured into Lombardy, and the Austrian relied on the apathy of the ignorant, unawakened peasantry. But the Grand Duke of Tuscany recognised the French Republic, Venice and Genoa remained neutral, the Freemasons in Italy were active, the " intellectuals" were everywhere ready to welcome the French. Early in 1796, Napoleon Buonaparte, a young General of Italian descent, took command of the French army destined for Italy. In a month he had forced the King of Sardinia to leave the coalition; in two months he had overrun Italy; in less than a year the Papacy begged for terms ; in a little more than a year he had finished the campaign. Aided by the results of Jacobin propaganda Northern and Central Italy became Republican. Milan was the capital of the Cisalpine Republic, a portion of which was carved out of Venetian territory; Genoa became the metropolis of a Ligurian, Bologna of a Cispadane Republic. Fearful of how matters might go on the Rhine, annoyed at risings against the French in Venetian territory, risings that were perhaps actually due to French agents provocateurs, and never an admirer of the effete Venetian oligarchy, Napoleon, utterly unscrupulous as to his means, threw Venice to Austria as a recompense. Moreover, Venice stood in the way of the predominance of France as a Mediterranean power and the vast Oriental projects of the great statesman-general; he ended the Republic, plundered her arsenal, seized her stores, and transported her art treasures to Paris. In 1797, the year of revolutionary activity, the Roman populace had risen with a view to French intervention and declared the Tiberine Republic. Early in I799, in spite of the opposition of the lazzaroni of Naples, devoted to St. Januarius and hating the French infidels, a Parthenopean Republic was declared and the overthrow of the Bourbon welcomed by the middle classes and nobles of the Neapolitan kingdom, the King taking refuge with Nelson's fleet and sailing for Sicily. But Napoleon was absent in Italy, and things invariably went wrong when the master-mind was away. The French, having to face the coalition of all Europe against them, exacted 60,000,000 francs from the Parthenopean Republic, the Austrians and Russians poured into Italy, and Suvaroff defeated the French. The priests and the ignorant rabble at once rose against the new republican Governments, and a reign of terror, most marked at Naples, inaugurated successful reaction. Napoleon returned, and the victory of Marengo (I 800 ) made him master of Italy; the Pope and Ferainand IV. were restored and French garrisons established in the most important ports of those monarchs, and the Cisalpine and Ligurian republics were reconstituted. The Cisalpine Republic gave its presidency to Buonaparte ( 1802 ) on the ground of his services and freedom from the spirit of local partisanship ; the Ligurian Republic asked him to nominate its first Doge. But in many places there were "friends of disorder," who 
rose against French predominance, and were treated with condign rigour. Made Emperor by the French, Napoleon took the Iron Crown of Lombardy at Milan (I805) which the Italian republics had offered him, and nominated his adopted son, Eugène Beauharnais, as his viceroy. Successive partitions and repartitions of Italy took place, all to the advantage of Napoleon's Generals and friends; Venice was added to the northern kingdom, the temporalities of the Papacy were absorbed, Naples was ceded to Joseph Buonaparte and afterwards to Murat, and Rome became the second city of the French Empire (I810).

Napoleon had a genuine dislike of feudalism and the old order; he was ambitious to reorganize society on the basis of the army, supported by the wealth-producing bourgeoisie; neither he nor they had real love for liberty; and the middle classes of France, as soon as they found their own position established, dropped the sounding of rhetorical bagpipes and windbags of catch-word rant. Justice according to the ideas of the bourgeoisie was established; political and "legal equality was used by Napoleon as a means to secure a military despotism, ruling equals with equal impartiality, and rendering them all equally subject to himself. Italy was soon disillusioned; yet she gained much from the French predominance: she acquired a constitution, participation in the legislature, self-taxation, the removal of all shackles on thought, education, and religion, a vague doctrine of equality, and the Code Napoléon. Italians became accustomed to submit to the administration of just and equal laws; once again they were trained in arms. The shifting of boundaries, and the dethronement of Princes, a common code and a common dependence gave them for the first time an explicit national feeling and a national aspiration that was soon to become too imperious to be kept under restraint. Thinkers looked forward to the day when, the political education of their country accomplished, she might renew for all the full liberty which some of her cities had once won and lost, and so restore the ancient glories of the Italian name.

In I8 2 Eugìne and Murat led their Italian forces to Russia. The disastrous retreat from Moscow was the beginning of Napoleon's fall. The two Kings in Italy were not on good terms. Murat was ambitious to become ruler of all the peninsula; Eugène was wroth with Murat for not standing by Napoleon; and the Italian people, hoping to get freedom from the allies that had fought against the French, turned against their rulers. Italy had suffered severely during the Napoleonic wars; her trade had been interfered with; the military qualities that her troops had evinced gave hope of freedom now that they were seasoned veterans; the interference with trade, produced by the severe blockade that the foes of France had kept up, had alienated the middle classes ; the reactionaries and ignorant populace hated French ideas. In I8I4 the Pope, Pius VII., returned to Rome, Victor Emmanuel I. to Turin, Francis IV. to Modena. The exEmpress of the French, Marie-Louise, heiress of the Bourbon House of Parma, was given the duchy of Parma; Lucca was handed over to the Bourbons, and by the end of the summer Ferdinand was installed in Florence. In I8I5 Murat was forced to abandon Naples to its former King. The Austrians reoccupied Lombardy, and created the kingdom of Lombardy and Venetia, whereof the Iron Crown was to be worn by the Austrian Emperor and the government entrusted to a Viceroy. At the Congress of Vienna five nations partitioned out Europe in such a way as 
to form a despotic authority and choke liberty and free institutions. Austria, England, France, Prussia, and Russia sat from November, I 8 I4, to June, I8I 5 ; the whole work of the congress was done by secret committees ; each power looked so sharply after its own interests that it was with difficulty that a renewal of war was prevented. Of course, Italy was sacrificed; practically the status quo ante there was affirmed; Genoa was given to Victor Emmanuel I. of Sardinia; but the insignificant little Republic of San Marino, the last survivor of the Italian communes, was left in peace.

\section{Revolutionary Italy}

Reaction was triumphant; constituted authority, scared by the French Revolution, was determined to forge a triple chain to prevent any such outburst of "fierce and drunken passion " again offering mad insult to the shrine of prerogative, the sacrosanct lustre of the crown, the stately splendour of the privileged Orders. One particular issue of the Revolution was that everyone was terrified : most people became reactionary. The waste of blood and treasure, the agony of Europe caused by the degeneration of France's attempt to compel the nations to be free into the mere anti-popular, immoral, and oppressive rule and personal aggrandizement of Napoleon, aggravated by French national aggression, alienated the friends of liberty even more than the excesses of the Terror had done : Church and State throughout Europe seized the opportunity, replaced and twisted the chain. In Italy the reforms introduced by Princes at the close of the eighteenth century were undone ; the Jesuits were called back ; education was limited as far as possible, and given into lay hands; all Liberals were closely watched ; subtle espionage went on over every family ; literature and the press were gagged; the police were all-powerful; the universities were staffed entirely by safe men. But, in spite of all, Manzoni, Berchet, Leonardi, and Silvio Pellico sang the songs of freemen, and fanned the flames of national feeling. The natural result of repression was the growth of secret societies and the advocacy of the dagger. Every Liberal movement abroad caused an insurrectionary movement in Italy. In 1820 the Spanish revolution and the proclamation of a Spanish constitution led to the mutiny of the royal army in Naples ; Lombardy prepared to throw off the Austrian shackles. Alarmed Europe rushed to extinguish the conflagration; the "Holy Alliance" of Russia, Prussia, and Austria against the liberties of Europe was on the watch. Austria sent 80,000 troops into Lombardy ; the risings, both in the North and South, were repressed, for the Holy Alliance had met at Laybach, and authorized Austria to crush out every glowing ember of rebellion in Italy. Austria accepted a congenial mission. She crushed an insurrectionary movement in Piedmont which threatened to cut off the Austrian army in Naples from its base in Northern Italy, and which would probably, if successful, like fire answering to fire, have been followed by the expulsion of the Bourbons from France. An International Congress met at Verona in I 822, whereat Metternich, the first Minister of Austria, gained his greatest triumph. The principle of absolutism was affirmed. Philanthropic England confined herself to getting the slave trade condemned, and protesting against the 
intervention of the Holy Alliance in the affairs of other nations; she was making a rapid fortune by industry ; revolutions and wars are injurious to profitable commerce; Italians were regarded, even more than most foreigners, with contemptuous pity ; it was not for free England to run risk and "dare to be strong for the rest." Some years of " resolute government" followed. Executions, imprisonment, general terrorism, led to the formation of fresh secret societies. The "Carbonari," formed of charcoal. burners of the Abruzzi, and once recruited from the lower classes, had gathered the intelligence and patriotism of the nation together ; the society numbered 700,000 men; it was now crushed and disheartened; but "White Pilgrims" organized themselves in the Papal States, "Barnabites" in Naples and Sicily: local insurrections took place, and so exasperated were the authorities that at Faenza alone, in one year, two cardinals condemned 508 persons of all ranks, including 30 nobles, for belonging to the Carbonari; 2 were executed; 200 sent to the gallows; many punished merely because they were suspected of possessing knowledge which they refused to reveal.

The revolution of July, I 830 , at Paris aroused Italy from the lethargy of despair ; it fired a carefully-prepared train of gunpowder. The Duke of Parma had been for some time in secret negotiations with the patriots, headed by Carlo Menotti, intending to use the party as a catspaw and become King of all Upper Italy : it became convenient for the Duke to betray Menotti, and he was executed. Modena, Bologna, Parma, the cities of Romagna and Umbria, proclaimed a free confederation; but the Austrian army soon quelled the movement, occupied Rome, and restored the old order. The revolution had, however, the effect of obliging the five great Powers to demand improved government in the Papal State. Promises of reform were made with the readiness with which the Turk has rendered us familiar, and proved to be as valueless. Petty insurrections stud the annals of the next fifteen years. It was evident to all Europe that the existing order could not be maintained. In 1832 Sismondi wrote : "It has been the work of the coalition to destroy all ; to place Italy under the galling yoke of Austria ; to take from her, with political liberty, civil and religious freedom, and even freedom of thought ; to corrupt her morals ; and to heap upon her the utmost degree of humiliation. Italy is unanimous in abhorring this ignominious yoke ; Italy, to break it, has done all that could be expected of her. In a struggle between an established Government and a nation, the former has all the advantages : it has in its favour rapidity of communication, certainly of information, soldiers, arsenals, fortresses, and finances. The people have only their unarmed hands and their masses, unaccustomed to act together; nevertheless, in every struggle during these fifteen years in Italy between the nation and its oppressors, the victory has remained with the people. At Naples, in Sicily, in Piedmont, in the States of the Church, at Modena and Parma, unarmed masses have seized the arms of the soldiers; men chosen by the people have taken the places of the despots in their palaces. The Italians, everywhere victorious over their own tyrants, have, it is true, been everywhere forced back under the yoke with redoubled cruelty by the league of foreign despots. Attacked before they could have given themselves a Government or formed a treasury, arsenals, or an army, by the Sovereign of another nation, who reckons not less than $30,000,000$ of subjects, they did 
not attempt a hopeless resistance, which would have deprived them of every chance in the future. Let those who demand more of them begin by doing as much themselves. Italy is crushed; but her heart still beats with the love of liberty, virtue, and glory; she is chained and covered with blood, but she still knows her strength and her future destiny; she is insulted by those for whom she has opened the way for every improvement, but she feels that she is formed to take the lead again : and Europe will know no repose till the nation which in the dark ages lighted the torch of civilization with that of liberty, shall be enabled herself to enjoy the light which she has created "' (Sismondi, Hist. It. Rep., Cab. Cyclop., Lond., I 832).

The Italian Governments, excepting the Papacy and the King of the Two Sicilies, tried to render their subjects content by the encouragement of science and the construction of railways ; and the country made substantial advance in modern civilization. Charles Albert abolished royal statute labour in Sardinia, and improved his paternal administration. The Grand Dukes of Tuscany and Lucca exhibited a spirit even more liberal and enlightened; Austria encouraged learning in Lombardy-Venetia. Commerce and population increased under this improved directorship, although their progress did not correspond to the natural fertility of the country. But the condition of the Two Sicilies remained deplorable, and that of the States of the Church was worse. Protection; the multiplication of custom-houses among the different little States; the various moneys, weights, and measures ; and the absence of sufficient means of communication, kept Italy back. The contraband trade was enormous ; crime against property was on the increase ; crime against the person remained great; to shelter a criminal was regarded as a protest against an iniquitous and tyrannical Government ; the ignorance of the masses was astonishing. In Lombardy-Venetia education was good, for the Government used the schools to bring up young Italy in doctrines of obedience. The King of Sardinia also encouraged liberal studies. Scientific congresses were used by the members to propagate liberal opinions and establish relations between the patriots of different States. Mazzini, a native of Genoa, a rebel against the enforced rule of the King of Sardinia, among the first of the great prophetic souls that gave dignity and initiative to the nineteenth century, formed a party of "Young Italy." Never was there a man endowed with more apostolic force, more conspicuous sincerity, a greater love of goodness, a deeper sense of duty and responsibility, a larger power to awaken the sleeping soul and transmit to others the pure white fire of his own heroism and sanctity. A dreamer of dreams, he yet made more practical men than himself responsive to his call to Italian unity. Italy found her great inspiring prophet in the man who had already taken an active part in insurrection and sounded his soul-stirring trumpet-call, in exile, from our own shores. Vincenzo Gioberti urged a confederation of the Italian States under the presidency of the Pope. Cesare Balbo, and a score of other men that had to be listened to, gave all their weight to the movement for the liberation of Italy. The quality in the mediæval republics of Italy which claims the lasting admiration of the world they illuminated was present in Mazzini and the thinkers of his time. This qualityindividuality of thought and character-carries with it diversity of doctrine, however. Young Italy was a house divided against itself : parties and sub-parties were too much in earnest to compromise : the.intellectuals, 
with all their fiery intensity and spiritual kinship, could not agree. "The prophetic soul of the wide world dreaming of things to come "has ever this fatal flaw : it is unpractical ; it scorns compromise.

In the Two Sicilies and in the Papal States isolated risings indicated, with the delicate accuracy of a seismometer, the political rumblings of Europe beyond the Alps. The opposition of the quadruple alliance of Austria, England, Prussia, and Russia to the views of France as to Eastern affairs gave rise to apprehensions of war; and straightway explosions of patriotism began here and there in Italy. The effervescence increased in the next few years, especially in the worst governed States, where things were so bad as to make the authorities dread any reform, stop every amelioration. In the Papal States, as the aged Gino Capponi said, " one would conclude justice to be in opposition to religion." In 1846 the Apennines were alight with signal fires without end : "Out with the barbarians " was written on every wall ; concessions had to be made by the more liberal governments; but the movement was not stayed. Presently France, the great leader of revolutionary Europe, the dauntless exponent of ideas not invariably her own, wearied of the selfishness, corruption, and trickery of the Bourbon Government, got rid of the dynasty that had been brought in by foreign bayonets (I848). It acted as flare to tow ; Lombardy and Venetia at once rose in insurrection ; republics were declared in Milan and Venice. Sicily declared her independence; Naples saw a Radical Government installed; every city in Lombardy and Venetia recovered its liberty. Carlo Alberto, the ruler of Savoy, Sardinia, and Piedmont, who had repressed Liberal movements in his own country and organized it for the inevitable war with Austria, had been a "wobbling King," dreading Austria on the one hand, the spirit of French republicanism on the other ; now he hoped the opportunity had come to assume the Iron Crown of North Italy; he declared for the insurgents : all the forces of the peninsula were hurrying to the war of liberation; even the Pope and the King of Naples had to join in the movement. High and low, rich and poor, Prince and peasant, peer and clown, workman and scholar, priest and freethinker-one and all shouted " Fuori i barbari !" as Carlo Alberto, at the head of 50,000 men, trained soldiers and volunteers, marched to front the Austrian cannon. Radetzky, the Austrian General, lost ground at first, but he contrived to compel the Papal troops to yield, overthrew Carlo Alberto at Custozza, and re-entered Milan. The commanders of Ferdinand of Naples, encouraged by the Austrian success, bombarded Messina long after it had fallen, and the French and English fleets had to put a stop to the butchery and the horrors of sack. The Pope, frightened at the revolution, turned round to the Austrian side : the Romans made him flee, and proclaimed the Republic of Rome with three dictators, chief of whom was Mazzini. A Republic was also declared at Florence, but the Florentines soon recalled their Grand Duke, on the promise that their liberties should be respected; he re-entered the city at the head of Austrian troops, and suppressed the constitution. Next year Carlo Alberto again took the field at the imperious command of his people; he lost the campaign, but he identified the House of Savoy with the cause of the nation, and laid the foundation of its present greatness.

Owing to bad generalship, the Italians lost the day at Novara, and Carlo Alberto saved his house by abdicating on the field in favour of his son, 
Victor Emmanuel II. The French and the Spaniards, responding to Papal intrigues, entered Italy. Louis, an adventurer, bearing the charmed name of Napoleon, was President of the French Republic : aiming at sovereignty, he conciliated the Catholics, and put himself in sympathy with aristocratic rulers by sending General Oudinot, under the semblance of friendship, to end the Roman Republic. Garibaldi, the knight-errant of modern times, the soldier-patriot, now appears as one of the defenders of the Republic of Mazzini ; while Cavour, the third of the great triumvirate who liberated their country, the most unpopular man in Turin, was quietly working in the spirit of Machiavelli's "Prince," supporting any measure, Liberal or Conservative, that would make for Piedmont and Italy, moulding every event and every occasion in his great purpose.

The republics of Rome and Milan had fallen; Venice still held out in her lagoons, attacked by famine, fire, pest, and the Austrian ; she engaged in a last struggle, all the more heroic because inspired by no hope, at the dictate of duty ; and she conducted it with unblenching fortitude. Venice fell : the Austrian forged the Italian chain anew : he replaced his crowned puppets on their thrones; he tried to force his own guttural speech on a people accustomed to the liquid accents of their forefathers, a tongue dignified not merely by homestead memories, but by the richest literature in Europe, the speech of those of whom our own great literature is in large measure but a rude and half-caught echo; he taxed them so as to make even the endurance of the long-suffering, insensitive, ignorant peasants of the rice-fields tum to hatred and revenge. All parties began to look towards the monarchy that for centuries had been building itself up in Alpine valleys and gathering in mile after mile of wide and fertile lands. The House of Savoy had taken its stand at last: " the House of Savoy cannot retreat!" became its rallying cry. For Cavour directed the policy of Victor Emmanuel. An honourable gentleman in private life, he had but one passion-the regeneration of Italy, and this he worked for with loving devotion, and by political manœuvring that sometimes left him in doubt whether he should consider himself a seraph or a scoundrel. He induced his master to send Sardinian troops to fight in the Crimea beside French and English ; they distinguished themselves by their bravery, and became accustomed to the tactics of the time, while Sardinia, linked with two great Powers, engaged the attentive respect of Europe. Cavour gauged the English enthusiasm for Italy at this time at its true value. He knew that she meant well, really sympathized with Italy, but would not risk a man or lose a halfpenny in Quixotic enterprise : she would only defend her own interests, or fight when at least there was commercial compensation to be obtained. He came to an understanding with Louis Napoleon, and made a secret deal with him. Then Austria was provoked until she asked for the disarmament of Piedmont as being a perpetual menace to Italian peace. The moment had arrived. The Napoleonic Government had the gauge of the nation it ruled : it knew that an appeal to the ancient spirit of generous chivalry and love of glory would prove that they were not yet extinct in the French people : their army crossed the Alps, defeated the Austrians at Magenta and Solferino (1859); and then Napoleon secretly met the Austrian Emperor and made peace ; for Prussia, pursuing her own selfish policy, and aiming at the hegemony of Germany, was massing her troops on the Rhine to attack France. The.work was 
half done. Venice was not liberated; Napoleon's promise to free Italy from the Alps to the Adriatic remained unredeemed. But he received what he had bargained for with Cavour: Savoy and Nice were the price of his services. The House of Savoy parted with the hereditary possession of centuries to become the Kings of Italy, to maintain their reputation of never drawing back on their word.

The little crowd of craven parasites that preyed on Italy had, as usual, fled into safety on the first approach of storm. Florence, Modena, and Bologna formed a league, and determined by universal suffrage to offer themselves to Victor Emmanuel ( 1860 ).

Meanwhile Garibaldi, a man with the lofty temper and noble unreason of a knight-errant, a bad General, but possessed of compelling personal force and consuming fire of enthusiasm, who had fought heroically for the Roman Republic in I 849 , who had led his volunteers in the late war, who promised his followers "vigil and hunger and thirst, but no terms with the foe," landed in Sicily, and in a few days was master of the island, of which he proclaimed himself dictator in the name of Victor Emmanuel; thence he marched on to the mainland, and occupied Naples. Cavour was in the secret of the enterprise ; he threw dust in the eyes of Europe by disavowing Garibaldi. Cavour had a difficult part to play; all moral scruples were solved for him by the application of one principle; as the trustee of Italian unity, deception, insincerity, trick counted for nothing, success for everything. A powerful kingdom was arising that aroused the hatred of defeated Austria, the suspicion of France, where self-interest contended with generous sympathy. Cavour's policy had converted a geographical expression into a nation full of hope and fire ; the balance of power was disturbed; Europe was alarmed; the young nation was surrounded by danger. England alone gave the new kingdom ungrudging support, but her support was hardly likely to pass at need from diplomacy to arms. And Garibaldi made no disguise of his intention of marching on Rome; the Republicans were ill content with the new monarchy; the inhabitants of the Two Sicilies were glad to get rid of the cruel and cowardly Bourbons, but as yet they had little or no truly national feeling ; the men of the South were unwilling to accept any settled government, and the defeated Bourbon army began to show signs of activity at Gaeta, whither Garibaldi had driven it. The Pope was supported by France, but Cavour cajoled Napoleon : he did not desire revolution, he told the Italian Parliament a little later; he wanted to end it. He got permission from the French Emperor to send troops into the Papal States ; fresh territory was added to the Crown ; and so the advance of Garibaldi on Rome was prevented, a quarrel with France and Catholic Europe avoided. The Republican idea was dear to the heart of Garibaldi ; the ideal of United Italy was still more loved and cherished. He abandoned his project, met Victor Emmanuel in the Abruzzi, hailed him " King of Italy," resigned his dictatorship, and retired into private life. Cavour announced that the possession of Rome was a question that the sword could not settle ; it must wait until it should be recognised that liberty, so far from being the foe of religion, can support it. He disavowed any design to snatch Venice from Austria by force of arms ; he assured Prussia that he aimed at a real control of the nation and at affirming the monarchical principle; he told Italy that union was the precondition of the fulfilment of her desires. 
Rome and Venetia alone remained outside the new kingdom. Within the Church itself there was a movement in favour of divorcing the temporal from the spiritual authority of the Papacy, but Pius IX. and the Curia remained inflexible. The French Government began to cool in its defence of Rome, and even withdrew a portion of its soldiery that protected the city. Suddenly Garibaldi appeared in Sicily, issued a manifesto against the monarchy, crossed to the mainland, and marched on Rome. The expedition was a miserable failure; the King sent forces to the South, and orders were given on both sides not to fire; but by some misunderstanding a few rifles were discharged, and Garibaldi was wounded and captured. France tightened her hold on Rome in order to teach the Italian Government that the destinies of the peninsula were to remain in her hands (1862). But European sympathy was now entirely with rejuvenated Italy, and in I864 Louis Napoleon had to commence the gradual withdrawal of French troops on the understanding that Italy would leave Rome alone. Florence now became the Italian capital, bringing the centre of government to the heart of the kingdom, and closer to Rome.

The example of Italy revived the old desire in Germany for national unity. Prussia had in Bismarck, her Minister, a modern Cromwell, a man of narrow but intense vision, religious confidence, rough manner, despotic nature, possessed of an appalling will that crushed through every kind of obstacle. In moral causes he had little or no belief, in big, welltrained battalions every confidence; he had learned that a boisterous affectation of blunt honesty was the most effective cover for that Machiavellian policy in which Prussia has proved herself distinguished above all European nations since the time of her other great statesman, Frederick the Great, the author of Anti-Machiavel. Catholic Austria and Protestant Prussia were rivals for the hegemony of united Germany. Austria contained Slav and Magyar populations; she reeked with discontent, and had a badly-organized army. Prussia had overridden representative government with cynical audacity, and had an enthusiastic and almost perfect army at her command. Bismarck determined to pick a quarrel with Austria, and offered Italy Venetia if she would combine with Prussia when the auspicious moment arrived. After both the leading Germanic nations had combined to despoil Denmark, Prussia turned round on Austria, and declared war against her, and crushed her with amazing rapidity. The Austrian possession of the famous quadrilateral of fortresses-Mantua, Peschiera, Verona, and Legnano-enabled troops and supplies to be poured into the heart of Northern Italy, and the Italian troops did not distinguish themselves, while the abject defeat of the Italian navy at Lissa, on the Dalmatian coast, deprived it of the hope of liberating Trieste and the Italian-speaking peoples of the Trentino. At the conclusion of peace Prussia informed Italy that the Trentino belonged to the Germanic confederation; but Venetia was added to the kingdom, and the famous Iron Crown of Lombardy, carried off in 1859, was restored (I 866).

The French garrison was now withdrawn from Rome, and Garibaldi determined to take the city. Ratazzi, now that Cavour was dead, was the Chief Minister of Italy; he tried Cavour's tactics without possessing Cavour's genius. The Italian Government did nothing to prevent volunteers from joining Garibaldi ; it hoped to keep in with Napoleon III. 
by abstaining from an overt attempt on Rome, and then profit if Garibaldi's raid proved successful. But Napoleon poured his troops into Rome, the Garibaldian army was compelled to surrender, and the Italian Government then seized Garibaldi, and confined him in Caprera (I 867). The interference of France was bitterly resented by. Italy, and this act of Napoleon was the beginning of a long estrangement between the two countries.

For a long time France had been jealous of the growing might of Prussia ; Bismarck had been busy in secret negotiations with the smaller German States; he coveted the left banks of the Rhine, occupied by a Teutonic race devoted to France. When tension was at its highest, and the German mind had been carefully coached by the semi-official press into a hatred of France, he falsified a telegram in order to induce a declaration of war. On the news of the utter defeat of the French in the FrancoGerman war of 1870 there were disturbances at Rome, and, after correct diplomatic action, an Italian army was sent to take possession of the city : it marched in without bloodshed. Here, as elsewhere, a plébiscite was taken which united Rome with Italy (1870). The Pope's person was declared to be inviolable ; he was granted a money indemnity which he has never taken; the inalienable and absolute possession of the Vatican, the Lateran, and Castel-Gondolfo ; the inviolability of his councils ; free communication with the Catholic world; the control of the theological colleges of Rome; and free nomination to Italian benefices. Cavour's last words had been, "A free Church in a free State." The intention of the Italian Government was to realize that ideal.

But the old quarrel between the civil and the ecclesiastical power, which we have followed through so many centuries, was by no means ended. It was characteristic of the Papacy that, at the very moment when it was about to lose temporal power, it summoned the largest council ever known, and, in spite of bitter opposition, that council determined that the Roman pontiff, when, in fulfilling his supreme mission of Shepherd of all Christians, he defines points of faith and morals, is directed by the Holy Spirit, incapable of error, and his decision must be accepted by the Church. By a strange irony of fate the pronouncement was made on the very day when the Franco-German War was declared, which ruined the temporal power. The Curia, however, still maintained the Bull of Boniface VIII., entitled Unam Sanctam, and held that temporal as well as spiritual power are in the hands of the Church, and that the first is exercised by means of Princes that de jure are under its discipline, and can be made and unmade by its will. The Pope and the clerical party in Italy maintain to-day that the temporal sovereignty is necessary, as the form rightly required to manifest the guardianship of the successor of St. Peter and display his independence ; they hold that the Pope who is not Sovereign is subject, and his Court is exposed to influences and ascendencies of alien aim. Italian Catholics have been ordered until quite recently to abstain from politics; the Pope remains a voluntary prisoner in the Vatican, and the Curia awaits the fall of the Italian monarchy by its own corruption or the judgment of God. Sicily and even Naples, subject to bad and corrupt government for so many centuries, feel the pressure of modern taxation, and have no strong love for the union. In Sicily the law can hardly be said to run ; an organization called the "Mafia " conducts a sort of independent 
and secret home rule; contributors to this secret society a re protected by thieves against thieves; non-contributors may seek police aid, but the criminal receives popular sympathy and concealment. It is clear to any close student of Italy that the end is not yet. A considerable country inhabited by Italian-speaking peoples still remains under Austrian rule; there is still an "Italy unredeemed." Meanwhile Rome, the ancient mother, whose immemorial eyes have witnessed the advent and the disappearance of successive civilizations, and the unceasing strife of so many shadows, with shattered visage, to outward appearance at once the colossal relic of a colossal past and the spoil of mean and restless modernity, remains still the axis of the Catholic world, the conservator of its traditions, and the chief city of the latest born among the fleeting kingdoms of this world ; like a worn rock in a waste of warring waters she awaits the further issues of change.

On an eastern spur of the Apennines another little city remains an independent republic still, a survival of the long-forgotten past. Once reached by a mule-track, a carriage-road now leads to steep, narrow, and gloomy streets, a public palace, five churches, and a museum. Its archives date from 855. In the tenth century it had walls, and governed itself as an independent municipality, described as "Plebs Santi Marini cum Castello." Two centuries later the commune purchased lands of the Montefeltro of Urbino. Situated between the rival Houses of Malatesta and Montefeltro, it had the good hap to espouse the cause of the latter, which proved to be the stronger. The Emperor Rudolph of Hapsburg, who was too occupied with Germany for serious interference in Italian affairs, and who is said to have been ignorant of the geography of the peninsula, recognised the estates of the Church, and released their inhabitants from all allegiance to the Empire (I278); but Papal sovereignty was more nominal than real, many towns like Bologna, Perugia, and Ancona being republics, and other territories, like Montefeltro, hereditary principalities. An attempt on the part of the Papacy to enforce the suzerainship of the Holy See was resisted by all Romagna except Cesena, and on San Marino being summoned to pay dues, one Palamedi, a jurisconsult of Rimini, urged that the commune was exempt, never having been under foreign domination, and the Pope's Vicar acknowledged the claim to independence. From time to time the legates of the Papacy have asserted lordship over the little city; but the attempt has never been perseveringly continued so as to command success. In I739, the little town being under an oligarchical Government that caused discontent among the masses, Cardinal Alberoni, with a small force, took possession in the name of the Holy See, but the people appealed to Clement XII., who at once gave them back their independence. The little city probably owed the preservation of its liberties in no small measure to its poverty and obscurity, though in 1463 its services to the Duke of Urbino, the Pope and the King of Naples against the Malatesta were rewarded by certain castles and the lands around. Napoleon I. preserved it as a sort of museum-model of a republic, and in 1854 , when Pius IX. was bent on adding it to the Papal States, Napoleon III. intervened and protected it. When Italy became united under the House of Savoy, by a lucky accident, one Cibrario, a citizen of San Marino, and a trusted servant of that house, was able to preserve its integrity. Here, then, we have a still living 
specimen of the old mediæval commune, rich only in its wine, oxen, and men, with an area of thirty-three square miles, and a population of about I0,000, whereof 2,000 dwell in the undressed stone houses of picturesque lanes that only a mule can traverse. There is a Great Council of life members, one-third being nobles, ${ }^{1}$ one-third burgesses, and one-third country farmers. These are nominated by the Council itself, as vacancy is occasioned by death. The Council elects another council of twelve, which, with a lawyer, forms the last Court of Appeal. There are two Captainsregent, elected each half-year, of whom one is always a noble, the other a plebeian. These have the control of an army of about I,OOO men. There is a Home Secretary, a Foreign Minister, a Minister of Finance, and a Budget. There is neither printing-press nor custom-house, but the commune receives a proportionate amount of the Italian custom-dues, and is allowed to purchase tobacco free of duty, having relinquished its right to grow its own. By this agreement questions of copyright and smuggling cannot possibly arise between the kingdom and this smallest but not least interesting of European States.

\section{MILAN}

\section{The Extinction of the Duchy}

LoDovico the Moor found himself confronted by the pretensions of Louis, Duke of Orleans, afterwards King of France, whom Charles had left behind at Asti on his triumphal march towards Naples, and thereupon contracted an alliance with the Pope, Venice, the King of Spain, and the Emperor Maximilian to maintain the independence of Italy. $\mathrm{He}$ and Venice assembled a powerful army, which they placed under the command of the Marquis of Mantua; and Charles, on his return from Naples, was

1 The term " nobility" as used in Italy is just equivalent to the term "gentry." It is an hereditary distinction that first arose from the nobility of conquest and the possession of conquered lands. All, or almost all, the older nobles were of Teutonic descent. The possession of land by a conquering people conferred nobility. Every rural squire was accounted a noble. Many of these, as we have seen, were obliged to seek the protection of neighbouring cities, and were also invited to protect them; they were compelled by the municipalities to go into residence, and they long continued to exercise within the walls that privilege of private war once the right of every freeman, and which was still the right of their order on their own lands outside. Side by side with this civic nobility the growth of commerce placed the popolani grassi, wealthy burghers who attained power, often ruled their city as Princes, and even married their children into royal Houses beyond the Alps. The notion that the Prince alone can ennoble never entered into the mind of the aristocratic commonwealths of Italy. In Venice there was no other nobility than that arising out of wealth produced by commerce. It is the proud distinction of that city to have given dignity to industry. Venice had at first no territory outside the city, and by natural selection a class appeared which, beginning as an elected governmental body, commonly recruited from distinguished families, succeeded in establishing a closed privileged class composed of all those that were descended from the ancient magistrates of the republic. 
obliged, in order to get out of Italy, to conclude terms for the release of Louis.

Lodovico contrived to get hmself confirmed in the possession of Milan by an Imperial diploma; but he had to prepare for the resentment of Louis, who had ascended the French throne, and was bent on the acquisition of Milan. He could expect no succour from the King of Naples, whose kingdom was disordered and nearly ruined by war, and who had neither sufficient troops nor money to do more than attempt to defend his own territory ; Florence continued its old policy of leaning on the French, and was busily engaged in endeavouring to recover Pisa; Venice relied on her own strength; the Pope had sold himself to France at the price of the duchy of Valentinois for his son Cesare. In I499 a French army crossed the Alps ; the ducal army was dispersed, and the Duke had to seek refuge with Maximilian. Milan fell into French hands ; but French insolence, irregularities, and oppression rendered the yoke insupportable ; there was a general ferment, and when the King of France retired to Lyons, the Milanese were eager for the return of the Duke. Lodovico advanced from the Swiss frontier at the head of 500 cavalry and 8,000 infantry; but his troops defected, and he became the captive of the French General, De la Tremouille, who had been sent to oppose him. He was conveyed to France, strictly guarded, and ended his life in that country ( 1500 ). For twelve years the Milanese remained subject to the King of France.

After the battle of Ravenna (I II2) the Emperor placed Massimiliano, one of the Sforzas, on the throne of Milan, and he maintained his position by the aid of Swiss mercenaries until the battle of Marignano ( 15 I5), when Francis I. reconquered Milan, and forced Massimiliano to retire to France on a pension of 30,000 crowns. In 1521 a secret treaty was signed between the Pope, Leo. X., and the Emperor Charles, whereby Milan was to be restored, on the expulsion of the French, to Francesco Sforza, the second son of Lodovico the Moor; and by the end of the year the Pontifical and Imperial troops entered Milan. But Francesco was no independent Sovereign; he was unable to protect his subjects from the rapacity of the Spanish and German troops, who were less his guards than his masters. The defection of Sforza to the French side now gave the Spaniards an excuse for keeping Milan, the citadel being already in their hands, and they treated the citizens with grinding cruelty. The death of Francesco, in I 535, terminated the line of Sforza. Milan became a mere Spanish dependency until, after the war of the Spanish succession, it was handed over to the tender mercies of Austria (I 7 I 4).

\section{GENOA}

\section{The Oligarchical Constitution-Ephemeral Republics}

GenoA had, by the violence of its factions, been compelled to give allegiance to external authority before the time of Simone Boccanigra. Up to I 339 she had successively acknowledged the German, the Neapolitan, and the Milanese as her lords ; the failure in 1380 of her attack on Venice had once again thrown the city into the arms of Milan; and from that time, with intervals of dependence, the State had fallen more or less into the 
power, now of France, now of Naples, now of Milan. When Louis possessed himself of Milan, Genoa fell into his possession as if it had been part of the duchy, and though communal self-government persisted, the strong hand made itself felt in the suppression of faction. But the aristocratic spirit of the French favoured the Genoese nobles, and the French Governor even exhibited some surprise that nobodies should dare presume to sign a treaty with gentlemen of quality. For generations the rivalries of the two great plebeian families of Adorno and Fregoso had given rise to revolution. Now class antagonisms speedily issued in class war. In I506 the people rose, and the French Governor had neither the ability nor the power to cope with them. The plebeians were allowed to occupy twothirds of the offices of State instead of half, as hitherto. Then the workpeople and small shopkeepers turned round on the big merchants, and got the upper hand. Louis was obliged to consent to the popolo occupying two-thirds of the magistracy; but he required that Gian Lodovico di Fieschi, the leader of the nobles, who had been forced to flee, should be reinstated in his holdings. To this, tribunes, elected by the populace, would not consent. Under Paolo da Novi, a dyer, who was elected as Doge, city after city on the coast was taken from its governor, and Monaco, held by the Grimaldi, which served as a nest for piracy, was besieged for five months, but then relieved by the Fernch. In April, I 507, Louis was obliged to advance against Genoa in person with a large army, and Julius II., himself a native of Genoa, and in favour with the people, interceded in vain. D'Amboise, the Cardinal of Rouen, aspired to the Papacy, so Julius had to retire to Rome. Louis took up a commanding position, and the advanced troops of Genoa took to flight. The next day an endeavour was made to come to terms; but warlike counsels prevailed in Genoa, and another battle took place, in which the Genoese were driven back in disorder. An unconditional surrender was demanded and acceded to ; the King entered the city, annulled its privileges, fined the Genoese 300,000 ducats, and ordered a new citadel to be built and permanently garrisoned by 2,000 men. But Louis preserved the city from outrage, though he put the new Doge to death (I 507).

In I 522 Genoa was stormed and pillaged by the Spaniards in the second Lombard campaign. Old family feuds were still in full progress, and the unhappy citizens, who had no desire to offer resistance, endured the worst barbarities. But Genoa remained in French hands, and was little oppressed, though its republican institutions were little regarded.

In 1528, Andrea Doria, whom the French monarch had first offended and still further alienated by his design of making Savona a great arsenal at the expense of Genoa, went over to the Emperor's side on the receipt of a promise of Genoese liberty. Andrea collected a fleet together, manned. by all the bold spirits of the Ligurian coast, and commanded himself, a ppointing his nephew, Filippino Doria, who had just gained a victory over the Imperialists, as his lieutenant. On September I2, I529, they presented themselves before the city, excited their countrymen to revolt, and drove out the French. On October $2 \mathrm{I}$ they captured Savona, and a few days later became masters of Castelleto. The Republic was proclaimed afresh at the moment when all freedom was nearing its end in Italy, Andrea refusing the lordship of the town which was offered him by the Emperor. From the middle of the fourteenth century the first dignity 
of the State had been reserved by law to a plebeian Ghibelline, and all factions had respected this exclusion of the nobles. Faction had, however, never ceased, and each important family, in order to increase its own power, had given its name and coat-of-arms to less important families that it undertook to protect : these families were called "Alberghi." The law that excluded nobles from the chief offices of the State was now abrogated; the names of Adorni and Fregosi were abolished, and the families of the city divided into twenty-eight Alberghi, each house containing those of noble and plebeian, of Guelph and Ghibelline descent. ${ }^{1}$ An oligarchy was thus formed of the leading families, whether patrician or plebeian, each family having its dependents. All the members were declared to be of gentle blood, and from them, in due turn, the Senate of 400 members was drawn; it was to sit for one year only, and then to be renewed. It elected another annual body of 200 members. The first body elected biennially a Doge, eight councillors, and eight procurators of the commune.

This constitution was distinctly oligarchic. A selected nu mber of people ruled the city and the entire Ligurian coast ; the masses were totally unrepresented. But the constitution lasted, with certain modifications, to the end of the Republic, and in its later days the oligarchy was frequently refreshed by the introduction of new blood. The Genoese aristocracy never became so exclusive as that of Lucca or Venice, and the constitution must be regarded as the remarkable and highly successful device of a great man.

Only a few years before the genius, fearlessness, and undaunted persistence of another great Genoese sailor had discovered a new world, and added it to the domains of Spain.

Andrea Doria had restored the name of Republic to his native country, but it was really governed by a narrow aristocracy. Nevertheless, intestinal strife, which had decreased under the later dominations, practically disappeared. The Republic, like the rest of Italy, remained under the Austrian heel; but its wealth increased owing to its bankers supplying the Spanish Crown with funds, while the Spanish armies and fleets, both for European and American service, were fitted out by Genoese. Sumptuous palaces, in debased Renaissance, arose, chiefly from the designs of Galeazzo Alessi. In I 547 Gian Luigi de' Fieschi brought down the vassals of his vast fiefs from the mountains, and was joined both by the partisans of ancient freedom, the masses, and the usual cohort of the restless spirits who desire only confusion and change. France and the Pope favoured his enterprise, which was probably dictated by nothing but anger at the loss of property and jealousy of the Doria. The only opposing force in Genoa was that of the financiers who had lent Charles vast sums. The attempt was made at dead of night, and issuing from the palace of Fieschi the conspirators contrived to seize the port, the gates, and the fleet.

The aged Andrea Doria fled, and his adopted son, Giannetto, was killed. But Fieschi, in his attempt to prevent the liberation of galley-slaves, fell overboard, and, being laden with heavy armour, was drowned. In the morning the conspirators discovered that their chief was missing, wavered,

1 This arrangement lasted forty-eight years; but in 1576 each family was allowed to resume its ancient name. 
treated with the signoria as if it, not they, had conquered, and accepted an annesty. This treaty was revoked, and Doria repelled the suggestion to put Genoa under direct Spanish control with difficulty.

Once again, in $157 \mathrm{I}$, the Spaniards endeavoured to get full possession of the city and to erect a citadel, but the attempt was frustrated. In 1576 a new body of "nobles" was admitted. In 1628 the State was again assailed by conspiracy. The "Golden Book" of families entitled to sit in the Council did not contain more than I 70, while there were 450 families in Liguria of equal pretensions who were excluded. Guilio Cesare Vacheroan extremely wealthy merchant, who adopted the prevalent Spanish manners and ideas, who was wont to walk about with a train of attendants, fill his palace with bravos, revenge himself by the assassin's dagger, and escape the law by fresh crime and intimidation - was at the head of the plot. All the great families not inscribed in the Golden Book were to unite their bravos, attack the Public Palace, kill the old nobility, and remodel the Government, which was to be placed under the protection of the House of Savoy. But the plot was discovered the evening before that intended to witness its execution. Vachero and the leaders of the conspiracy were seized and put to death.

In I684 Louis XIV. of France demanded the establishment of a depot at Savona to provide his fortress of Casal de Montferrat with salt and ammunition. The Senate refused a request which would annul their neutrality and menace their independence. The city was bombarded, and the Doge was compelled to proceed to Paris and apologize. The State was, meanwhile, becoming corrupt. Though dignity and magnificence still characterized the Doge, the narrow oligarchy copied Spanish manners, and the daggers of hired assassins alone kept them in their position by inspiring dread. Their pompous pride and prodigality required means to support it beyond their resources; they cheated the State ; every official position was for sale ; justice became venal; the subjects of the two Rivieras and Corsica were in constant revolt, and from I730 to I 768 Corsica maintained an obstinate war for freedom. At last the State made over Corsica to France in payment of a debt contracted to put down rebellion.

But though the nobles were degenerate the populace still retained their ancient spirit. In the war of the Austrian succession the Senate had allied itself with the House of Bourbon, and the Austrians, when they drove the French and Spaniards out of Lombardy, appeared before Genoa, and the Senate, not daring to arm the population, opened the gates of the city (1746). A contribution of 9,000,000 florins of the Empire was exacted, and since the city could not pay the sum all the money in the bank, all the church plate, and much private property was seized by the Austrians. The arsenals were emptied, and the Genoese, urged on by blows, were made to drag the cannon. A heavy mortar stuck fast in the ruins of a narrow street, and a sergeant raised his cane on a Genoese ; the man replied by seizing a stone and throwing it at the Austrian. A street-fight ensued, and from every roof and window the foreign soldiery were assailed with the stones of walls which were rapidly demolished, and with the tiles of houses that in a moment were unroofed. The soldiers were unable to mass themselves in the narrow lanes; they found themselves helpless, exposed to a galling fire of missiles, for the populace had no arms, and in spite of the furious firing of despair the streets were soon choked with 
Austrian dead. The Austrians tried to fire the houses, but without much success, as they were constructed of stone. The army withdrew in disorder from the city, and the populace lined the ramparts, and planted them with cannon left behind by the enemy. Deprived of arms and ammunition, and unable to get provisions on the barren Apennines, the Austrians passed over into Lombardy, and two years later the treaty of Aix-la-Chapelle secured the integrity of Genoa under the protection of France.

The waves of the revolutionary earthquake in France spread to Liguria ; a democracy of a moderate type was agreed to, but the nobles and clergy had the lowest strata of the population on their side against a purely bourgeois movement. In I797, aided by a mob of 10,000 , they rose, and this gave Buonaparte an opportunity of interfering. The Ligurian Republic was proclaimed, modified, and abolished in 1805 by the union of Genoa at the request of its Government to France. In I 814 Genoa rose against the French on the assurance of Lord William Bentinck that its independence would be preserved. But by a secret clause in the treaty of Paris, confirmed by the Congress of Vienna, the city was handed over to Sardinia. This base instance of bad faith undoubtedly fortified Mazzini, a citizen of Genoa, in his irreconcilable republicanism, and led in I850 to insurrection and the establishment of an ephemeral Republic.

\section{SIENA}

From the time when Siena placed herself under the protection of Charles V. the city became the theatre of incessant revolt. In I 535 the workpeople and small shopkeepers formed an association knowns as the "Bardotti," led by a few men of some culture, who nourished their imaginations on Livy and classic models. An abortive, ludicrous insurrection resulted, and the painter Pacchiarotti, who was one of the band, only found security by getting into a vault and lying down with a corpse. Various attempts on the part of the Noveschi and of the populace to obtain power were made in the wonted tempestuous style. In I 545 the Imperial commissioner and the Monte dei Novi were driven out, and a balia was formed of a Captain of the People and nine representatives of the other monti. The Pope supported Siena in its protest against any foreign garrison, but the exiled Noveschi got Cosimo dei Medici, Duke of Florence, to mediate, and in 1548 a garrison of Spaniards was admitted, and the troops were followed by Diego de Mendoza as Governor. Mendoza came provided with Imperial signatures, over which he superscribed what he wanted, and ordered it to be done. He commanded all arms to be given up, restored the Noveschi, and reorganized the Government, filling the offices with his own servile creatures. Then (I 550) he ordered the Siennese to build him a citadel. Even the cringing balia revolted, and the keys of the city were once again handed to Our Lady, and prayers were offered to her for the eternal oblivion of all private animosity, and the eternal preservation of concord among her devoted people. As evidence of sincere repentance for the passions of the past, or as a bribe to prevent their recurrence, the Holy 
Virgin was promised that fifty poor girls should be married and dowered yearly at the public cost. But the Emperor required a strong place in Tuscany, and had small regard for the "sweet liberty" to which his somewhat turbulent subjects clung. The castle rose, stone by stone, in spite of the "evidence of Faith, Hope, and Charity" that the Siense had given at the altar steps and the weird apparition of a wandering hermit, who, clothed in sackcloth, with a halter round his neck, a skull in one hand and a crucifix in the other, hung about the works, dismally shrieking out the text, " Except the Lord build the house, they labour in vain that build it." A vast body of the citizens of Siena conspired to oust the Spaniard; they were conjoined with men of Rome, Ferrara, and Venice, and the secret was well kept. A force of French and Italians, led by a great-grandnephew of Pius II., rode quietly up to the city one evening, and next morning the Mangia bell was rung; the citizens, even the women, rose in revolt, and fought a night and a day, until they drove out the Spaniard (1552). Every Sienese, from the highest noble to the meanest artizan, vied in the work of uprooting the new citadel, till not one stone was left on another ; the city was put under the protection of France, and the constitution of the Republic remodelled for the twentieth and last time. The Cardinal of Ferrara came as Lieutenant of France, and began to rebuild forts, but in such a way that they would command as well as defend the city; while the hermit, who had before indulged the city with predictions, again appeared, chanting crazy, doggerel satire and prophetic warning.

In r 553 an attempt made by the Spaniards to subdue the city failed owing to a recall, for the Turk had appeared off Naples. But in I554 Duke Cosimo dei Medici of Florence, in spite of his promise of neutrality, suddenly attacked Siena without any declaration of war. A gate was surprised ; but the attack failed, and the besieging army was then placed under the command of a cold-blooded and remorseless but successful adventurer, the Marquis of Marignano. Piero Strozzi, the Florentine, the determined opponent of the Empire and the House of Medici, conducted the defence with marked ability, and frequently harassed the besiegers by successful sallies; he even raided Florentine territory. But at last he was defeated in an obstinate battle during one of his expeditions, and the doom of Siena was sealed. The city was completely invested. In vain did all the charity children and a thousand maidens and the clergy precede the crucifix, followed by the whole population, entreating Heaven for help. Famine came, and I, ooo men, women, and children, " useless mouths," were sent out from the gates. Soon 700 more people, little children many of them, had also to be sent forth. Many of them were slain by the investing troops, and the rest, beaten and wounded, were driven back, bleeding, to the city. Sozzini, in his Diario says that the sight of them took away his appetite for days. Again children were sent forth ; they were stripped to their shirts and driven back. The spirit of the Sienese rose higher as the inevitable destiny drew nearer day by day ; high-born ladies worked like labourers to strengthen the defences; the mercenary troops, who grumbled at the short commons to which they were reduced, were sent out, and once again the expedient was tried of expelling the "useless mouths" ; 4,4.00 were sent out of the city. The stern Marquis refused these poor feeble wretches, even the children, food, nor allowed them to pass through the lines; he believed in " merciful 
severity " in warfare, and three-fourths of the victims died of hunger, many were mutilated by the Spaniards, stray dogs and birds picked their bones; and only a few, including the handsome Sienese maidens and the younger women, found a way of escape, for the Spaniards risked the death penalty that their commander would have exacted by taking some of these latter to their quarters.

Every peasant discovered bringing provisions to Siena was hanged; the inhabitants of all villages and fortresses that remained faithful were put to death. The coast of the Maremma was laid waste, and became the fever-stricken, desolate district that we know to-day. Incredible cruelty was exercised by the beleaguering forces. In Siena itself it became necessary to lose valuable lives in sallies, so that the women might be able to snatch a handful of grass or herbs outside the walls. Venice, the Pope, and the Madonna were appealed to in vain; the Virgin Mother was presented with the keys of the city for the last time. The city was obliged to capitulate. Montluc, the French commander, received a justly-earned ovation as he passed through the Spanish lines, and, as he tells us, though he and his soldiers had suffered the bitterest pangs of hunger, they wept at being no longer able to defend a people so determined to preserve liberty and honour (April, I 555) (Montluc, Commentaives). Many Sienese withdrew to Montalcino, and maintained a kind of Republic for yet nine years. In 1557 Siena was incorporated with Tuscany under Cosimo I., though for two centuries it had a separate administration. When fierce, quarrelsome, restless, emotional Siena fell, Venice, Genoa, Lucca, and San Marino alone remained free republics in Italy.

\section{VENICE}

THE most powerful, wealthy, and wisely administered of Italian States appeared to have been justified in her self-confidence; she had withstood the shock of the invasions; the waves had, indeed, passed over her, but she arose to all appearance as vigorous and nearly as powerful as before. The signoria alone knew how exhausted the Republic was. Menaced by the Turk on the East, and by the constant struggle of ambitious Princes on the mainland, they had yet to sustain thirty-three years of incessant warfare. The Republic made a stand to which history hardly affords a parallel. Her nobles, bred from their earliest years to devote their services to the State, displayed unceasing energy, ability, and patriotic zeal. Burdened with a Continental Empire, which, even for the sake of foodsupply, had to be maintained, with commerce decaying owing to the opening up of the Cape route to the East and the direct transit of Eastern goods to European ports, she nevertheless had to support almost perpetuai maritime and land wars with the Turk, and these wars not merely continued to diminish her resources but crippled her trade. Meanwhile, she had to re-establish the industries of the mainland wasted by war, and restore, as far as possible, her finance. Between I 537 and I 540 she lost her islands in the Archipelago ; then Cyprus was lost ( 1570 ). The Barbary pirates, too, infested the Mediterranean, and in $157 \mathrm{I}$ a treaty was signed between the Pope, Venice, and Spain whereby a fleet was sent out under 
Don John of Austria, which defeated the Turks at Lepanto. But a single national force is always stronger than an aggregation of allies delayed by divided councils and under separate commands. Wearied of waiting, and dreading the result of the war, Venice came to an understanding with the Sublime Porte, whereby she became tributary to the Sultan, and paid a war indemnity of 300,000 ducats, but she got reinstated in all her old commercial privileges.

Never had Venice manifested so much outward splendour as she did at this period. Wealth had become concentrated into fewer hands. This was the age of the great colourists. In earlier ages Venice had absorbed and transmuted Oriental and Gothic art, giving it a quality and distinction peculiarly her own. She had applied the glass manufacture, introduced by the Arabs, to the purposes of decorative art in a manner never before approached, never afterwards surpassed; she had imitated and excelled the Persian in his costly weavings; in the previous century the Aldine press had converted the new invention of printing into a fine art ; she had rescued many masterpieces of the ancient world from ruin, and her scholars were among the most famous in Europe; she had given to the world works of art by Carpaccio and Bellini which were superior in pigment to the works of the Florentines and little less deep and sincere in feeling : now she revealed in a more sensuous form of art, at the hands of Veronese and Titian, a divine surprise of colour, the glory of which has never even been approached; while her waterways continued to be busy with the rearing of pseudo-classic palaces less elevated in idea than before, but surpassingly magnificent.

As early as I3r3 Inquisitors of State had been appointed, with temporary jurisdiction. The presence of decayed noble families now led to the formal institution of the office : its members, two of whom were taken from the Ten and one from the Privy Council, were to adjudicate on the revelation of State secrets, and their decisions were merely to be reported to the Ten; and later an armed guard was afforded them. The secret proceedings of the Three have furnished an opportunity for the novelist of which he has not been slow to avail himself. They were never more than the mandatories of the Ten, and were solely concerned with State business. The Ten had jurisdiction of nearly everything, from theatrical representations and the preservation of secrets of glass-making to illicit political intrigues. Anyone might denounce a citizen by placing a paper in the mouth of the Lion of St. Mark. If the denunciation were not signed, it was placed before the Doge and three Chiefs of Council to determine whether it was of public interest : often the denunciation proved to be a mere squib against some article of dress; if the denunciation were signed, it came before the Ten. Four-fifths of the votes were required for its consideration, and these were taken by ballot five times over. Then the denunciation was entered in a book, and the defendant and witnesses examined in secret. Some questions were put in the dark, either to terrify or that the faces of the judges might not be seen by the accused. Everything was fully recorded and read over, and if half the votes taken by ballot were in favour of the accused, he was set at liberty or tried afresh. The ballot was repeated five times, and the sentence was also balloted for five times before it became irrevocable. The most terrible sentence was that of drowning in the canal Orfano, and continuity of procedure and 
precedent was secured by the presence of permanent secretaries bound to secrecy.

The Ten were quite capable of removing guilty persons by secret means. Thus, we read "that full powers be given to the Inquisitors to find a person who will prudently remove Fra Cipriano of Lucca from this life " (August 8, I 594). The man was a spy in the pay of the Turks. In I767 they ordered a dangerous enemy to the State to be poisoned in Montenegro. Undoubtedly the power of the Three gradually increased; they became an inner circle of the cabinet, and took care to become acquainted with every secret of every foreign Court, in securing which the Venetian Ambassadors had always been past masters. They recorded all their deeds, and the number of people that they secretly detained in prison was very small ; their power lay in fear, induced by the mystery of their proceedings (vide Baschet, A., Les Archives de Venise, 1870).

In 597 the cession of Ferrara to the Pope brought the Republic into antagonism with the Holy See; for the States of the Church were coterminous with the territory of the Republic. Outwardly the Pope was treated with immense respect; his legate sat beside the Doge; but in all discussions relating to the Holy See the usher invariably called out, “Fuori i papalisti !" (“ All Papalists go outside!"), and all who had any intimate relations with the Papacy or its territory had to leave the hall. Venice had always shown herself liberal, and been an asylum for dissent; she had recognised Henry of Navarre ; the Venetian clergy were subject to ordinary tribunals and excluded from all official popes, and churches and religious institutions could not be endowed without the consent of the State. The Republic held that men cannot serve two masters, and resisted the institution of an imperium in imperio. The Spaniards took care to support the Pope, and, possibly with the cognizance of Pope Paul V., an attempt was made to assassinate Fra Paolo Sarpi, the Venetian protagonist in the dispute, in whom disinterested magnanimity and purity of intention were united with clear and forceful reason, powerful expression, and pungent irony. A compromise was effected, in which the Republic got what she wanted, but the Pope's dignity was preserved.

Austria coveted Dalmatia and supported pirates of the Adriatic coast, so that no merchant fleet could set sail without a convoy, and in I6I 8 a conspiracy was discovered which had been set afoot by the Spanish Ambassador, the Marquis of Bedmar. The Doge was to be massacred, the arsenal surprised, and the city pillaged. The Ten and the Three acted with their usual secrecy, and the appearance of the dead bodies of the conspirators, who had been quietly seized and imprisoned, hanging in the square of St. Mark's, was the sole intimation given to the public of a plot which furnished Otway with the groundwork of his famous tragedy, Venice Preserved. In 1645 the Turks suddenly surprised Candia (Crete). The longest and most ruinous war ever engaged in by the Republic followed : it lasted twenty-five years, and, in spite of the valour and patriotism of Venice, the States of Europe, jealous and mutually apprehensive, looked on. The Mussulman fleet was twice destroyed, and in the single summer of 1667 thirty-two assaults were repulsed and seventeen sorties made by the Candian garrison. At last (1669), the island surrendered, after the Turks had lost over I00,000 men in the siege. In 1682 war again broke out, and Venice, allied to the Emperor 
Leopold and John Sobieski, King of Poland, reconquered the Morea, Egina, and several fortresses in Dalmatia ; but in 17 I4, in her last war with the Turk, the Morea was again lost. By this time Venetian trade was in a ruined condition; half the nobility lived on the bounty of the other half ; the effective force of the army was very different from its strength on paper; the navy was weak and antiquated, and could hardly deal with Barbary pirates; jobbery and robbery ruined the State, and even justice had become venal. The troubling of the waters that preceded the French Revolution was not unfelt in Venice : reform was in the air when the French Revolution broke out, and soon after Buonaparte marched into Italy. The Senate had refused to recognise the French Republic ; now it wanted to treat, but it was too late ; revolution broke out in the provincial cities ; Frenchmen were massacred on the mainland; and Buonaparte, afraid of what might happen on the Rhine, determined to sacrifice Venice to Austria. He wrote to the Directory on April 22, I797, suggesting that solid pacification might be secured if Austria were allowed the Venetian mainland. He wrote to Kilmaine that the Government of Venice should not be of long duration. Buonaparte had no reverence for antique institutions, no respect for effete oligarchies; he declared, "I will be a second Attila to Venice" (Camb. Mod. Hist., 1904, vol. viii., pp. 584-588). The Republic was unable to withstand the French army; she made no resistance, and on October 17, I797, one-half of her territory was handed over to Austria, one-half to the Cisalpine Republic ; the Ionian Isles went to France.

Thus perished a republic which for a thousand years had maintained its freedom and exhibited a stability of government and a devotion of its people that command universal wonder and admiration. No other country except Rome, and perhaps England, has ever exhibited political genius so remarkable; no other peoples have shown a prouder or more devoted patriotism. The Venetian was secured from invasion by position ; saved from dread of insurrection by the fortunate existence of canals intersecting the city in every direction ; even the disadvantage of being dependent on the outer world for food-supply identified in every burgher's mind the prosperous commerce and good government of the city with his own well-being. Venice set an example of a truly noble class, composed of men who were traders as well as rulers, who did their share of the world's work at a time when the peoples of the North worshipped a haughty, truculent order that for the most part merely consumed the world's productions, and deemed commerce a stain. The Venetian solved the problem of securing continuity of policy, strength of administration, and internal peace, while keeping the love of the populace for the common city, and their respect for the privileged order of rulers. If the city itself did not produce men of genius, as did Florence and some other turbulent republics, she produced men of the highest political talent and sagacity, who gave the world the remarkable spectacle, in those days, of a well-ordered and contented State, dependent territory governed with far more liberal consideration and intelligence than was exhibited by any other Italian power, and a united people.

All human ideals led to irreducible autonomies : the problem of government is among the many problems that are insoluble. Every vital constitution contains in itself the germ of its own decay and dissolution, and is subject to the disintegrating forces of changing environment. The 
conditions of her existence favoured Venice, but the stability and excellence of her institutions, the vital energy that weathered a thousand years of storm, were due, in the main, to internal factors : to the passionate force of her patriotism, and the incalculable genius of her people for the conduct of social order, the observance of duty, and the self-effacement of each and all in response to the larger demands of the community.

\section{LIFE, LITERATURE, AND ART}

\section{LIFE}

Up to the middle of the sixteenth century all kinds of labour were held in honour. The highest class in Venice, Genoa, and Florence was composed of merchants. Filippo Strozzi, brother-in-law of Leo X. and father of Marshal Strozzi and the Grand Prior of Capua, the associate of Kings, and the first of Italian citizens, was, to the end of his days, head of a bankinghouse. Possessed of an immense fortune, he none the less trained each of his seven sons to trade. But the conquerors despised all kinds of work; the Court was copied as to investment in landed property and primogeniture ; and elder and younger sons were condemned alike to lives of ignoble idleness. Empty titles and decorations became the objects of desire. The new and debased ideas adopted by the upper classes, and new manners of conventional elegance, were imitated throughout society. The withdrawal of capital and ability from commerce dealt it a cruel blow, and monopoly and bad economics completed its ruin. Luxury increased in the class that possessed stored-up wealth, while the resources of the land were diminishing; men began to live for show; they assumed a magnificence to which their wealth did not entitle them, and which, in the absence of a commercial career, they could not legitimately increase ; vanity and love of pleasure aided the frivolous misuse of life. Families that in republican times had sought power were now eager for Court honours. Rulers were for ever employed in giving themselves new titles : the young Prince became, successively, His Most Illustrious, His Excellence, His Magnificence, His Highness, His Serene Highness, His Royal Highness ; innumerable patents of knighthood, countship, marquisate, were distributed, and the folly of the Court was in fullest force. Titular distinction was, of course, claimed by one layer of society after another ; and even your cobbler had to be designated as "Most Illustrious "; to address some twopenny-halfpenny officer as merely "Chiarissimo ed eccellentissimo" was to give mortal offence: "Illustrissimo" was the correct title. Family property, unincreased by commerce, was insufficient to support the family horde; the younger and poorer members could not marry; they remained uneducated; convents overflowed with their women. Debis accumulated, and, since property was tied up, they had to be paid out of income that ought to have been spent on the land. As a consequence agriculture soon became ruined, and the peasantry, who from of old had to give half the produce to their landlord (métayer system), were starved, or took to brigand life in the hills. To get Court honours one had to intrigue ; to achieve a public career, one had to flatter and fawn, plot, and 
be base ; justice was delayed or sold ; one's honour, estate, liberty, life even, were at the mercy of secret informers and arbitrary tribunals. To help forget, to stifle thought and banish care, the pleasures of sense remained; the whole nation plunged into idle debauchery, and sowed the seeds of multiplied anxieties and fresh debasement. Fêtes and costly entertain. ments but disguised the disease and decay of the social body.

In the fifteenth century freedom of thought had been practically unchallenged. But now the Spanish monarchs strove to hammer the various nations of the Iberian peninsula into cohesive nationality. Taking advantage of the expulsion of the Moslem by the Christian, they enforced uniformity of religious profession in Spain, and attempted to do so in the Netherlands. Spanish influence was paramount at the Vatican, and the Curia, alarmed at the success of the Reformation in the North, which deprived the spiritual monarch of well-nigh half his domain, secured the definition of dogma, and put an end to liberal thinking. Paul III. secured the powerful organization of the Jesuits to suppress the free movement of the human mind, and the statesmen who engineered the spiritual police knew how to profit by their action. The Inquisition had full power; the press was gagged and placed under its control, and a word uttered or printed against the despotism of authority temporal or spiritual, meant the prison or the stake. Elsewhere the Church had received a rude awakening; the Reformation led to a counter-Reformation, marked by religious earnestness, theological learning, renewed activity, and an attempt, at least, at the removal of the more glaring abuses. It cannot be gainsaid that a genuine wave of this movement was not felt in Italy; but the Pope was a temporal Prince under the heel of Spain ; and, under a veil of puritan precision, the clergy and aristocracy descended into deeper foulness; the Italian added hypocrisy to his other vices. Perhaps the greatest argument that Roman Catholicism can urge as to the truth of its claims is that it has survived its own corruption. In I 593 the emissaries of the Inquisition were on the track of the genial and learned thinker Giordano Bruno; he was thrown into prison in Venice, brought to Rome, imprisoned for seven years, and finally burned at the stake, because he had dared to search for unity in thought, publish his conclusions, and attack the established religion. In 1616 the consulting theologians of the Holy Office declared the theory of the central position of the sun in our sidereal system and the rotation of the earth, to be untrue in philosophy, heretical, and contrary to Holy Scripture. Galileo Galilei, a good Catholic, was summoned, and officially warned not to teach these doctrines; he promised to obey, but in 1632 he published a Dialogo, in which the scientific view was re-enunciated. In 1633 he was examined under menace of torture, and recanted. Truly, as Queen Isabella confessed, it was possible for the Inquisition to do strange things " in the love of Christ and His maid-mother."

The power of the Inquisition gradually declined, and the spirit of the eighteenth century caused it to be abolished in Tuscany and Parma in I 769, and even in Sicily in I782. In I 809 Napoleon put an end to it in Rome for a time. The occupation of Rome by Vittore Emanuele again rendered the institution of the Holy Office powerless ; but it is said to have defenders still, who nourish hope of its restoration. 


\section{The "Cicisbeatura"}

A curious institution, introduced by the Spaniard, took firm root in Italy, and relics of it are said to be still discoverable in Roman society.

The influence of Provençal song and love of ladies had extended from Provence and Catalonia throughout Spain. Knightly courtesy to woman was commingled with Oriental notions of seclusion derived from the Spanish Moor. The husband was often away from home, occupied by military duty or the requirements of the Court, or on other missions. It became customary to attach a caballero as horseman in attendance, to wait on and protect the noble lady when she went abroad through a country none too secure. So honourable and distinguished a post naturally fell to a friend of the husband. Marie Henri Beyle, better known as De Stendhal, informs us in his work, De l'Amour, that by the middle of the sixteenth century it was a rule in Spain, strictly observed, that every noble or rich woman should be accompanied by a bracciere, whose arm she took. Of course, this bracciere had to be a hidalgo, and the more distinguished the House to which he belonged, the more distinction he cast on the lady and her husband whom he served. Moreover, since the proved friend is naturally more to be trusted than the mere acquaintance, it became the habit for two friends to agree to attendance on one another's wives. It became a fashionable custom, which was introduced into Italy throughout the Spanish Courts, and by the middle of the sixteenth century it became very prevalent in Italy. Indeed, it took firm root, and developed into one of the most curious institutions of social history. The soil was congenial. Various factors had prepared the way. These were: (I) The adoration of womanhood, concentrated into devotion to a single person, such as we witnessed in Dante and Petrarch, the tradition of this worship being preserved in literature and probably in life. This importation from Provence would tend to operate in Italy as it had done in Spain, directly the fashion of the bracciere was introduced. (2) Co-existing with this trend, there was also a strong tendency towards the seclusion of woman. This was derived from at least four sources-the natural sense of property, the danger of unsettled times, intercourse with the Arab, and the presence of armed retainers in the house. The Arab had dwelt in Southern Italy and Sicily; the great sea-trading republics had constant intercourse with the Moslem, as well as with the Roman Empire at Byzantium, where there was strong Oriental influence. Readers of the early Italian novels cannot have failed to notice this tendency to seclude woman. Venice, in particular, was peculiarly open to these Eastern influences, owing to her trade with the Levant; she was half Italian, half Oriental in character. The ladies of later times there had that singular vanity of the sex-a desire to make themselves appear taller than they were: high-heeled shoes became the vogue, and, according to Yriarte, the jealous husband, with small confidence in the honour of his wife or the trustworthiness of his fellow-citizens, encouraged the pretty secluded fool to increase the height of the heels until she could not walk unless supported leaning on the shoulders of one or two female domestics or of the cavalieve servente. In Rome the ceaseless struggle between the proud, fierce old nobles, the everlasting recourse to arms, became, when some degree of authority 
was restored, too often a perpetual appeal to the knife : retainers were kept armed in the lower part of the palazzo, and very often bravi of the worst description came to be employed : the women had to be kept under lock and key for protection from these ruffians; their food, even, was sent in to them through an aperture with a turnstile. A trace of this severe seclusion is still to be noted in Rome, where it is considered highly indecorous for any lady to appear at the window; if she looks out, she must remain invisible to the passer-by. When aristocratic notions became predominant in Italy, the pretensions of the old Roman nobility were enhanced, and their habits had full weight on general society. (3) The women of the Renaissance had quietly emancipated themselves from many disabilities. The newly-discovered dignity of the human soul forbade fathers to withhold classical instruction from their female children; in an age when ability was all in all, so that a natural child might found a State, the able woman naturally claimed to make her ability felt, and the claim was undisputed. Classical examples of heroines fired woman herself, and obliged man to accord her a new respect. It was no longer possible to recognise the worth of the individual soul, and treat woman as a sweet imbecile, a heaven-sent angel, or a mere servant.

Thus, just as up to the days of our own mothers very many inconsistent views of woman were bound together into one incongruous ideal, so was it in the sixteenth century. Woman was regarded as a compound of angel, fool, and servant: she was taken, as readers of the literature of the period will remember, now as one, now as the other; and no one suspected that any contradiction was involved : each aspect was emphasized as cither the nature of man or the suggestion of circumstance directed : woman was worshipped, restrained, kept in retirement, and allowed freedom all at once and in different ways. The conventional protection accorded to woman became increasingly necessary under foreign rule, and the woman of the upper class, who, half liberated during the Renaissance, still desired to live her own life in her own way, to demonstrate her power, and to exert her fascination, accepted proffered homage both as a tribute to her worth and as securing her personal safety. Men too, especially younger sons, cut off from marriage by poverty, debarred from political life by foreign domination, from duties to the land by primogeniture, from intellectual life by the counter-Reformation, and from all useful employment by prejudice, adopted the new fashion as courtly, chivalrous, romantic, and approved by the great spirits of the past ; they surrendered themselves to the new debased form of servitude to ladies ; it gratified the mystic yearnings of the spirit, amused, filled up the weary unoccupied hours, and contained possibilities of bonnes fortunes. The Court had set the fashion; in a short time it became a universal practice, and by the cighteenth century it degenerated into a conventional cloak for almost legitimatized adultery among a class wherein marriage was, as it still remains among the great Houses and impoverished nobility of Europe, a matter to be arranged on principles of interest or finance.

According to Saury, it was adopted in some cases after the first year of married life, but in other cases almost directly after marriage. Up to the time that she was given a cicisbeo, or cavalieve servente, the young married woman was spoken of as a "novice." By the eighteenth century it had become an institution very convenient for the corrupt circles of the aris- 
tocracy of that corrupt period; and Sismondi speaks of the profound demoralization of family life which followed when a nominal father was no longer assured of his own paternity. No lady of any pretension to social standing either visited her friends, or went to receptions or to public entertainments, or appeared in public, unless she was attended by her cicisbeo, and her husband was meanwhile usually occupied in dancing attendance on some other married woman. The cicisbeo became the slave of the lady, not merely by the free consent of the husband, but by the concurrence of the family; and refusal on the part of the husband would have been a grievous social solecism. The cicisbeo, the Countess de Bradi informs us, "fulfils the lady's commands or anticipates her desires, and never leaves her from mid-day until she goes to bed; but these duties are only rendered to the wife of another, and the husband leaves his own wife at home to the care of some other man. Very often such devotion is unrequited by the lady; very often the supervision is inconvenient; but it produces finished manners ; the unconstraint, bad temper, and want of self-control which married people exhibit would never be admissible." And if the cicisbeo was the actual paramour of the wife, the husband was equally bound by convention to appear not to suffer the least concern. According to Stendhal, the cicisbeo was "always the friend of the husband, and this friendship, cemented by reciprocal service, often outlived other links." The graphic pen of Madame de Staël gives us a vivid picture of this phase of Italian life in her celebrated novel, Corinne (livre vi., chap. ii.): "They went in to supper, and each cavalieve servente hastened to get himself seated beside his lady. A foreign lady came in, and, being unable to find a seat, not a single man except Lord Nesbit and the Count d'Erfeuil offered her theirs ; it was not due to want of courtesy or selfishness that not a Roman among them rose, but to the notion of honour and duty prevalent among the Roman aristocracy, and this forbade each of them to quit his lady for a single second. Some, not being able to find accommodation, stood each behind the chair of his charmer, keenly attentive to her least sign. The ladies spoke only to their cavaliers; foreigners wandered unavailingly round this circle, where nobody had a word to say to them. For Italian women are ignorant of coquetry ; they desire to please only those whom they love: there is no enticement of the soul before the capture of the heart; the most rapid overtures are sometimes followed by sincere devotion, and even by prolonged constancy. The man is blamed for infidelity far more than the woman in Italy. Three or four men, differently designated, follow the same petticoat. The lady carries these gentlemen about wherever she goes, and does not always put herself to the trouble of introducing them to the host who receives them. One is the favourite, another aspires to his position, and a third calls himself 'the sufferer' (il patito); the latter is entirely scorned, but is nevertheless allowed to play the part of useful admirer; and all these rivals live peaceably together. The common people alone have preserved the use of the poignard. There is a strange commingling of simplicity with corruption in this country, of dissembling with veracity, of good-nature with revenge, of weakness with strength, which unfolds itself to close observation; the good that is there comes from absence of vanity; the bad from the eager following of selfinterest, exhibited in pursuit of love, ambition, or money."

In the time of Napoleon, Prince Eugenius, Viceroy of Italy, tried to put 
down the cicisbeatura, and his effort was not without marked effect: he refused to receive any married lady accompanied by a gentleman who was not her husband. Nevertheless, readers of Beppo will remember that the cicisbeo was by no means extinct in Venice in Lord Byron's time ; and in one of his letters, written in 1820 , he speaks of the ladies as "extremely tenacious and jealous as furies, not permitting their lovers even to marry if they can help it, and keeping them always close to them in public, as in private, whenever they can.'

But the healthy breezes wafted across the Alps from the revolutions in France put a new spirit into the Italian nation, and the struggle for freedom and independence gradually restored masculine vigour to the men, and some such measure of feminine wholesomeness as convention yet allows to the women.

\section{LITERATURE}

The fall of the Italian States was followed by the decline of Italian letters. Rome became the centre of all the restricting influences of the Catholic reaction; and the republics that remained free-Venice and Genva-had never been remarkable for literary genius. Torquato Tasso (I 544-I 599), who ranks after Dante, Petrarch, and Ariosto as the fourth great Italian poet, grew up at the Court of Urbino in an atmosphere of hypercriticism and ultra-refinement. His father, a Bergamesque nobleman, was a gentleman of small means, given to poetry, and he selected the only career then open to gentlemen of ampler culture than wealth : he became the hanger-on of great ecclesiastics and small courts. Tasso's mother was, so his father believed, poisoned by her Neapolitan brother to get her estates. Tasso got employment as poet at the critical Court of the Este in Ferrara, where he wrote his Aminta and Gerusalemme Liberata. The years brought him little but suffering, disappointment, and disillusion. He endured madness, poveity, and imprisonment. Into the Gerusalemme Liberata he threw all his wonderful powers ; but the buoyancy of the earlier poets is replaced by settled melancholy, and the excess of conceits indicates that the period of decadence is approaching.

Indeed, the seventeenth century was vacuous ; every kind of affectation and mannered form was in vogue; matter alone was neglected, not forthcoming. Salvator Rosa, the Neapolitan painter, was also a musician and a poet. He mourned over the effeminacy of his countrymen; the wreck and desolation of the land sank deep into his soul, affected his temperament, and probably exerted an influence on his art. He and Tassoni kept alive the spirit of Italian independence.

In the eighteenth century, when the Spanish influence was more than half broken, great men again appear. Vico studied the universal laws of history ; many Italians devoted themselves to social and economic science ; many made scientific discoveries; Muratori published his great history; Goldoni, a Venetian, wrote I 50 excellent comedies of character; Alfieri sang of classical patriotism and the triumph of liberty. In the nineteenth century Leopardi, like an Atlas, bore a world of poetic sorrow and despair ; he sang a swan song of the passing of Italy.

But the return of freedom has been accompanied by every indication of a new movement, which at present is most marked in scientific, and especially in historical, research. 


\section{FIne ART}

Venice remained free, and, in spite of diminished resources, she exhibited her old patriotic spirit by employing her great artists to adorn public palaces with frescoes illustrative of her glory. Her nobility were very rich or very poor; modern conditions exalted the rich man, and his palace became more and more sumptuous, more and more adorned by art, of which the true spirit was ultimately lost in mere gorgeousness. But great spirits were abroad in the sixteenth century. Paolo Cagliari (il Veronese) (I 528-I 588), the son of an artist of Verona, painted Venetian magnificence and pride of life in a noble manner, and invested his gorgeous pigments with a delicate silver tone. Jacopo Robusti, il Tintoretto (the little dyer) (I 5 18-1594), a strikingly unequal painter, of whom his contemporaries said that he used a pencil of gold, of silver, or of iron, according to his payment, sometimes equlas Titian in colour, and vastly surpasses him in intellectual power and originality of mind. No painter ever had a greater passion for the rendering of pure light, and gave it such mystic significance. Moretto (I498-I 555), a Brescian, a great portrait painter, also gave the world altar-pieces marked by true religious feeling, and rendered his subject in cool harmonies of colour. Il Moroni of Bergamo (I 525I 578) painted "speaking portraits" in a consummate style. The three Bonifacios carried on the traditions of Titian and Palma Vecchio. In this and the next century Venetian artists abounded who have acquired imperishable fame, among the last being the famous painters of Venetian scenes, Antonio Canale (Canaletto, I697-I768) and Francesco Guardi (I 7 I 2-I 793). At Rome, Caravaggio ; at Florence, Bronzino ; at Bologna, the three Caracci, maintained technical excellence in the sixteenth century; while Antonio Allegri (Correggio) painted religious pictures wherein sensuous flesh-tones almost become the predominant note. The seventeenth century witnessed theatrical displays of emotion at Bologna by Guido Reni ; and Domenichino and Guercino, of the Bolognese school, remain great in spite of decadence, as does Sassoferrato of Rome, Carlo Dolci of Florence, and Salvator Rosa, the great landscape painter, of Naples. But all the great distinctive qualities of the great period were lost in eclecticisu and mannerism : the living spirit had departed; the skilful hand alone remained. The Divine torch was passed on to the Netherlands, and even technical power departed thither and to Spain.

\section{SCUlPTURE, ETC.}

Giovanni da Bologna (I 524-I 608), the author of the graceful "Mercury" in the Uffizzi at Florence, was a Fleming of Douai, who settled and worked in Italy. Benvenuto Cellini (1 500-I 569) was, on the whole, a poor sculptor, but a magnificent liar. As a study of the artistic temperament and the thought and manners of his time, his Memoirs (translated by Symonds) are entertaining and illuminating. His "Perseus" at Florence is his best work, and takes rank among the great works of art. In the next century Bernini, a Neapolitan, and his school exhibit progressive insensitiveness, and the energy of the school that imitated Michelangelo degenerates into 
coarse floundering. In the eighteenth century Canova made Rome the headquarters of a classic revival. The architecture of the decadence is, for the most part, dull or vulgar.

\section{Music}

At the time when the glorious Italian intellect was creating a new world in letters, painting, and sculpture, it is singular that the musical genius of the nation was scarcely aroused. The names of Italian organists are, indeed, to be found in the archives of Venice from the year I318. These men were in the service of the Republic, and played at St. Mark's ; but, although they composed, their works appear to have been improvisations only, and therefore we have no means of forming a judgment as to their talent. The birthplace of modern music was Flanders, not Italy : during the fourteenth, fifteenth, and part of the sixteenth centuries Flemish composers were remarkable for their creative genius, and it was not until the latter part of the sixteenth century that Palestrina and his great Roman school took the lead. The evolution of instruments did not then admit either of great solo-playing or of important orchestral effects, and the musical polyphonic compositions of great masters were for voices alone. Towards the end of the fifteenth century the superior musical ability of the Flemings still induced the Venetian signoria to appoint a distinguished Netherlander as Maestro di Cappella, and he was succeeded by several of his countrymen, one of whom-Adriano Willaert of Bruges-was a composer of great talent (1527). From this time Venetian composers arose who combined their own melodic utterance with that subtler, more complex gift of the North-its rich harmonies. Lombardy, as might be expected, got her musical stimulus through Flanders by way of her neighbour Venice ; and her first notable musician was Franchinus Gafurius, of Milan, who flourished at the close of the fifteenth century. There exist manuscripts of Florentine music of the fourteenth century; but the first Florentine composer of eminence arose after the extinction of the Republic: he was one Corteccia, who wrote the music for the marriage ceremony of Duke Cosimo I. (I 539).

The great centre of Italian music was Rome, and owed its birth no less than the other Italian schools to the Netherlands. Flemish musicians were employed by the Popes in the Papal chapel; but the Romans do not seem to have been stimulated into any meritorious effort of their own until long after the return of the Papacy from its long exile. The first Roman composer of distinction did not become a member of the Pontifical choir until I 5 I 7, and his works, printed at Venice, which was then the great musical publishing centre for Europe, show marked Flemish influence. The Spaniards in Rome took up the torch, but the music of religious services degenerated into exercises and the solution of stupid problems; all kinds of inappropriate and purely secular themes were introduced, and the choir usually sang a laboured canon for four or more voices, working on a canto fermo, and employing different words. In fact, it was common for all kinds of lewd, obscene, and even blasphemous ditties to be introduced into the Mass; and when the counter-Reformation began, the Council of Trent was on the point of altogether prohibiting part-singing in churches. Palestrina not only saved sacred music from its impending 
extinction, but raised vocal polyphony to its highest point by writing music that expressed the feeling naturally attaching to the words, by bringing vast learning and great constructive genius into his work, and, above all, by enduing it with spiritual content. The stimulus thus given to sacred music speedily passed on to more secular creations. Italy became the home of music and the opera: for a century she was facile princeps in this art.

Thus it will be seen that music achieved nothing memorable in Italy until liberty was practically extinct. Although other arts may flourish for a time in the Courts of Princes, they are born and nurtured in the bracing clash and contest of idea that belongs to freemen, or at least to the desire and hope of freedom ; but music, the most subjective, subtle, and elusive of the arts, least definitively articulated with the visible real, and the most expressive of the core of personal temperament, can flourish when all else is lost, and has often shown its loftiest mien under conditions that are fatal to other forms of expression. 


\section{BIBLIOGRAPHY}

A MERE list of original authorities alone would fill a volume. Nearly all of the most important State-papers, laws, charters, chronicles, documents, and works of all kinds of contemporary or first-hand character, have been published. 'The London Library contains most of these, as do the great Continental and English consulting libraries, and the British Museum Library possesses all. These original sources are contained in the following great series, some being reproduced in more than one series.

Archivio Storico Italiano (1842, etc.).

Archivio della Societa Romana di Storia Patria (1878, etc.).

Archivio Storico per le Province Napoletane (1876, etc.).

Archivio Storico Lombardo (1894, etc.).

Archivio Veneto (1871, in progress).

Atti della Società Ligure di Storia Patria.

Bullarum Romanum Cura a Tomasetti.

Calendar of State Papers, 1202-1607, vol. x. (matters relating to English affairs in the Venetian and other archives of North Italy).

Muratori, Lodovico Antonio : Annali d'Italia.

", " " Rerum Ital. Scriptores.

" $"$ " Antiquitates Italia Medii Evi.

Migne, J. P. : Patrologia Cursus Completus : Series Graca.

" ", Series Latina.

Monumenta Germania Hist. (Script. rer. Langobard, etc.).

Monumenta Historia Patria (1836-1891).

Romanin Storia Documentata di Venezia (1853, etc.).

Among the more important contemporary writers are :

Warnefred, or Paul the Deacon, contemporary of Charlemagne, lived at his Court and those of the later Lombard Kings. Towards the end of his life he retired to a monastery, and wrote a history of the Lombards up to the death of Liutprand (A.D. 774).

Liutprand was page to King Hugo, became Chancellor to Berengar, was sent as Ambassador to Constantinople, and attached himself to Otho I. He died Bishop of Cremona, A.D. 972, leaving his "Antapodoseos" (a history of the events from 887 to 949 , written with special animus against Berengar and his Queen Witta, who had disgraced him), "Historia Ottonis,". only covering the years 960-964, and " Relatio de Legatione Constantinopolitana."

Liber Pontificorum, by several hands. Anastasius, librarian, collected and edited the lives of Popes anterior to the death of Nicholas I. (867); another scholar continues the series up to 889 , and then the collection was edited by the Cardinal of Aragon up to the year ro5o.

Donizio, chaplain to Matilda, Countess of Tuscany, wrote a poem commemorating her life and virtues; there is also an anonymous biography in prose, both to be found in Muratori ("Rer. It.," lib. v.).

Otho and Radevicus of Frisingen. Otho, son of the Marquis of Austria and the sister of the Emperor Henry V., brother of Conrad III., King of the Romans, and uncle to Barbarossa, devoted the seventh volume of his history of the world to the events just anterior to his own time, as well as to an account of the first expedition of Barbarossa; he was Bishop of Frisingen, and died in 1158. 
Radevicus, a Canon of Frisingen, continued his history, but is an inferior and somewhat prejudiced writer.

Otto Morena held public office in Lodi, and was appointed judge by Barbarossa. $\mathrm{He}$ wrote a history of his times ("Historia Rerum Laudensium"), which was continued by his son Acerbus (died 1167) and an unknown author.

Radulphus Mediolensis (Sire Raul) was a Milanese, and wrote a history of Frederick I., which is valuable as giving the tale told from the point of view of the Milanese commune. Otto de Sancto Blasio and Abbas Uspergensis, contemporary German authors, are also valuable.

The unknown author of the "Vita Alexandri III." gives us an account, one would judge from its precision and details, by an eye-witness, of the war of the Lombard league.

Hugo Falcandus, the "Tacitus of Sicily," waxes too eloquent to be regarded as wholly trustworthy; he narrates the reign of William the Bad and the events of the few years after his death (I I 54-1 I69).

Nicetas, a high official of Byzantium, left an account, from the Greek point of view, of the taking of Constantinople by the Latins. The father of French history, Villehardouin, the friend of Dandolo the Doge and the Marquis Boniface, accompanied the expedition, of which he leaves an animated account. His style is strong and graphic, and quite unconsciously he reveals the spirit of crusade and of the chivalry of the time ("Conquête de Constantinople"). He wrote in French.

The age of Frederick II. is peculiarly rich in contemporary writers. The "Historia Major" of Matthew Paris gives us much information concerning the Empire. Matthew was an Englishman, as is shown by the tone in which he speaks of the French and other foreigners. He probably studied in Paris. Salimbene, a Franciscan monk, wrote a valuable chronicle. There are also chronicles published by M. Huillard-Bréholles in 1856 ("Chron. Plac. et Chron. de ret. in It. Gest."'), "Vita Greg IX., Ann. Med. I230-I402," and a work by Richard of San Germano, entitled "Chronicum Rerum per Orbem Gestarum" (I I59-1242). Peter de Vinea also left valuable letters.

Giovanni Villani (1275-1348) was a Florentine who became Prior of his city, and wrote a chronicle "in praise of our city of Florence." Part of the work, which is written in Italian, is a compilation from the "Gesta Florentinorum " of Sanzanome ; the "Chronica de Origine Civitatis," itself a compilation; "Annales Florentini Primi (IIIO-1I73); et Secundi" (IIO7-1247); and "Gesta Florentinorum," existing in various manuscripts. As a public man he exhibits exact knowledge of contemporary events, and he is clear, acute, and impassionate. His history was continued by his brother, Matteo Villani, who died of plague in I 363 ; Matteo is also a well-informed author. Filippo Villani, the son of Matteo, who in I 401 and I4O4 lectured on Dante, wrote the lives of eminent Florentines, and continued the history of the city down to the beginning of the fifteenth century.

Dino Compagni wrote a chronicle of the events in Italy of which he was an eye-witness from I280 to I312. Certain sceptical German scholars believe the work to be a forgery, however, as many of the chronicles of the period certainly are. Their view is not generally accepted. Compagni was a noble who supported the ordinances of Giano della Bella. He is democratic, patriotic, and searches for causes.

The chronicle of Marchione de' Stefani continues the Tuscan story down to I 386. He is followed by Poggio Bracciolini, an historian very little inferior to the Villani, who carries Florentine history down to the Peace of Lodi (1453); he was an eye-witness of some of the events he recounts.

Andrea Dandolo, Doge of Venice (1342-1354), an intimate friend of Petrarch, wrote chronicles of Venice. 
Andrea Gataro gives us chronicles of Padua from I3I I to I406; Piero Minerbetti, those of Florence to 1409 ; after which there is a lacuna of ten years until Neri Capponi (see below) takes up the tale. The life of Pope John XXIII. is written by Theodoric of Niem, one of his secretaries, who wrote a history of the Schism. Cristoforo da Soldo gives us an account of the siege of Brescia at which he was present (1438), while Giorgio Stella and his son Giovanni continue the invaluable records of Genoa, which date from i IOI. Leonardo Aretino, one of the Ten of War, who died in 1444, not merely left an admirable history, but commentaries on his times; they are written in Latin. Neri di Gino Capponi, one of the ablest of Florentine statesmen and Generals, who usually dictated the despatches of the Republic, gives us contemporary history up to 1453 .

Bracelli of Sarzana, Chancellor of the Republic of Genoa, gives an account, in a concise, natural style, of events of the Spanish war from 1412 to 1444 ; in these he took part. The annals of Lorenzo Buonincontro ("Ann. Miniatensis") give excellent information on Neapolitan affairs; the history of San Miniato occupies but an inconsiderable part of the work, which reviews the period I $360-1458$.

Jovianus Pontanus, author of the work entitled “ De Bello Neapolitano," was secretary to Ferdinand I., Alfonzo II., and Ferdinand II. of Naples, and employed on diplomatic missions. His history is in elegant Latin, and he describes men and places with great care, perceives the characteristics of different forms of government, and tracks events to such causes as prior revolutions; he describes with great ability.

Pope Pius II. wrote Commentaries of his own times and Epistles with an eye to the interest that posterity would take in them; he records what he knew would be valuable to future times; he explains and arranges his facts in a scientific manner, and his works are of much value to the historian.

Giovanni Simoneta was secretary to Francesco Sforza. His clear, elegant, and detailed style expounds the policy of his master and of the Italian States ; he is usually impartial, and was in a position to know what he was writing about. His history ends with the events of 1466.

Cristoforo da Soldo wrote a "History of Brescia," wherein he narrates, with minute exactness, the events which he saw as one of the magistrates of his city. But he gives too much credit to popular rumour.

The Chronicles of Bologna, nearly all written by contemporary authors, terminate with the year $147 \mathrm{I}$. These chronicles are full of the chatter of the market-place and the prices of provisions.

The annals of the church of Raynaldus, Cardinal of Pavia, finish in 1469; they contain much closely observed fact and curious details; the account of the last journey and death of Pius II. is especially interesting.

Marinus Barletius of Scutari gives a good account of his city. His histories are inflated in style, and not very trustworthy.

Giuseppe Barbaro, who traversed Scythia on an Embassy to Hussan Cassan, has left one of the most interesting narratives in literature. He was intimately acquainted with Caffa and the Black Sea, having resided on the Euxine from boyhood; he knew Tartar, and was well acquainted with all that was going on in the district. His account of the war is confused, however.

The Genoese records of Antonio Galli, which end with the events of 1478 , are written with elegance and vigour, and exhibit a great love for freedom. Corio, who wrote a history of Milan, was an eye-witness of much that he relates concerning his own time (end of fifteenth century) ; and a Corsican priest, devoted to the Duke of Ferrara, though he lived in Venice during the war of 1484 , gives many details of that campaign. The Ripalta, father and son, give an account of contemporary events in their "Annals of Piacenza" from I4OI to 1484. Domenico Malpiero gives us Venetian Annals from I457 to 1500 . 
Jacob of Volterra, Apostolic scribe, writes a "Roman Diary," which ends with the life of Sixtus IV. He gives curious details as to religious ceremonies and the Papal Court, and even inserts abstracts of Cardinals' sermons.

Marin Sanuto. ("Vite de' Duchi di Venezia") gives towards the end of his work a mere record of Venetian chatter. Sanuto was a Venetian Senator who was alive in 1520 . His work terminates in the year I493.

Machiavelli, Guicciardini, Paolo Giovio, and Jacopo Nardi, are perhaps the four most important historians of their own times. The first two writers are the fathers of really scientific history. Giovio (I483-I 552), of a noble Comasque family, became a dependant on the Medici. He is shallow, and affectedly classical, but the personal note in his writings gives them a great charm. His history of his own times is by no means entirely to be trusted.

Jacopo Nardi, an honest patriot, faced Charles V., and defended the rights of Florence. He always attempts to tell the exact truth in his history.

The "Mémoires" of Philippe de Commines and the "Lettres du Louis XII. et du Cardinal Amboise" give much valuable information as to the French invasion.

Recent books on Mediæval Italy would fill a large library. Among the most valuable are :

Gibbon, E. : Decline and Fall of the Roman Empire.

Hodgkin, Thomas, D.C.L. : Italy and her Invaders, 9 vols., 2nd ed., 1892-1896.

VILlARI, P. : Barbarian Invasion of Italy, tr. I902.

GAY, J. : L'Italie mérid. et l'Empire Byzantine, I904.

Milman, H. H. : Hist. of Latin Christianity, 9 vols., I867.

Poole, R. L. : Illustrations of History of Mediaval Thought, 1884.

Church, R. W. : The Beginning of the Middle Ages, 1894.

Bryce, Rt. Hon. J. : Holy Roman Empire, 1904.

Cherrier, C. DE: Histoire de la Lutte des Papes et des Empereurs de la Maison de Souabe, 3 vols., 2nd ed., 1858 .

Prutz, H. G. : Kaiser Friedrich I., Danzig, I87 I-I 874.

FreEMAN, ED. : Hist. Essays (Fred. 1. and II.), Series I., vol. i.

Huillard Bréholles, J. L. A. : Fred. $I I$.

Vie et Correspondence de Pierre de la Vigne.

Winkelmann, E.: Kaiser Friedrich II., I889-1897.

Vecchio, A. DEL : La Legislazione di Federico II., I 874.

Reuter, H. F. : Geschichte d. veligiösen Aufklärung in Mittelalter, 1875-1877.

Hodgson, F. : Early History of Venice, I901.

Gregorovius, F. : Hist. of Rome in the Middle Ages, tr. A. Hamilton.

FEDern, K. : Dante and his Time, I902.

VIllari, P.: Two First Centuries of Florentine History, tr. L. Villari, I894-1895.

Lanzani, F. : Storia dei Commune Italiane dalle Origine al I3I3 (1881).

Cipolla : Storia delle Signorie Italiane dal i 3 I 3 al 1530.

Yver, G. : Le Commerce et les Marchands dans l'Italie méridionale au $\mathrm{I}^{\mathrm{e}}$ et au I $4^{\mathrm{e}}$ s., 1903 .

Davidsohn, R. : Geschichte v. Flovenz, 1896 , in progress.

Perrens, F. T.: Hist. de Florence Jusqu'à la Domination des Médicis, 1877-1883.

" " Hist. of Florence, I43 I-I531, tr. H. Lynch, 1892.

Romanin, S. : Storia Documentata di Venezia, 1853-1861.

Hazlit, W. C.: The Venetian Republic, and ed., I90o.

Brown, H. : Venice, I895.

ZELLER, J. : Hist. de l'Italie, I 886.

Creighton, M.: History of the Papacy from the Great Schism to the Sack of Rome, I 887 .

Ranke, L. von: Die röm. Päpste, 1878. 
VILlARI, P. : Life and Times of Savonarola, tr. L. Villari, 3rd ed., I 899. " " Machiavelli and his Times, tr. L. Villari, I892.

Baschet : Les Archives de Venise: Histoive de la Chancellevie Sécrète, 1870. Cambridge Modern History, vol. i., c. 3, 4, 5, 6, 7, 8 ; vol. ii., c. I, 2, 3, 1902, 1903. BURCKHARDT, J.: The Civilization of the Renaissance in Italy; tr. by Middlemore, I 890.

Symonds, J. A. : Renaissance in Italy, new ed., 1897-1899.

QUiNET, E. : Révolutions d'Italie, reprinted 1895.

BARToli, A. Storia della Letteratura Italiana, I879, etc. 


\section{CHRONOLOGICAL TABLE}

A.D.

452. Retreat of the inhabitants of Venetia to the lagoons.

476. Odovacar becomes King of Italy.

489. Invasion of the Ostrogoths.

568. Invasion of the Lombards.

697. Election of the first Doge of Venice.

80o. Charlemagne crowned at Rome.

$95 \mathrm{I}$. Otho I. of Saxony receives homage of Berenger II.

961. Otho crowned at Rome.

IO00-I I 38. The Normans subdue Southern Italy.

I056. Henry IV. ascends the throne.

I077. Henry does penance at Canossa.

I073. Hildebrand becomes Pope (Gregory VII.).

I 122 . Diet of Worms.

I I 39-I I 55. Arnold of Brescia preaches liberty and reform.

I I 54. Frederick Barbarossa enters Italy.

I I 55. He takes Tortona ; is crowned at Rome.

I 58 . Second expedition of Frederick.

I I 59. Milan revolts. Siege of Crema.

I 62 . Fall of Milan; it is razed to the ground.

I 63. League of Verona, Vicenza, Padua, and Treviso to re-establish liberty.

I I66. Frederick re-enters Italy.

I 67 . The cities unite to rebuild Milan.

I 68. Frederick forced to quit Italy. The Lombards build Alexandria.

I 172 . Formation of annual elected Grand Council at Venice.

I 173 . Archbishop Christian, the Imperial Lieutenant in Tuscany.

I 74 . Christian invests and raises the siege of Ancona.

I 74-I I 75. Frederick besieges Alexandria: is forced to raise the siege.

i 176 . Frederick defeated at Legnano.

I 177 . Truce of six years signed at Venice.

I 183. Peace of Constance.

I 97-I2I6. Reign of Innocent III.

i 204. Taking of Constantinople by the Venetians.

1226. Renewal of the Lombard league.

1237. Victory of Frederick II. at Cortenuova.

I 239. Gregory IX. excommunicates Frederick II.

I24I. Victory of the Pisans at Meloria ; they arrest the prelates on their way to the Council.

1 245. The Council of Lyons condemns Frederick Ir.

1 247. Revolt of Parma against the Emperor.

I 248. The Imperial camp before Parma forced by the Guelphs. The Ghibellines drive the Guelphs out of Florence.

I 249. Victory of Bolognese at Forsalta ; Enzio, son of Frederick, captured.

1250. Death of Frederick II. Insurrection at Florence and re-establishment of liberty.

1254. Year of victory of Florence over Pistoja, Volterra, Pisa, and Siena. Fxile of the Florentine Ghibellines.

1256. Martino della Torre elected Podestà of Milan.

I 259. Defeat and death of Eccelino da Romano. 
A.D. Defeat of the Florentine Guelphs near Arbia; they leave Florence.
1260. Deferis Florence saved by Farinata degli Uberti.

r264. Filippo della Torre, lord of Milan, Como, Vercelli, and Bergamo. Urban IV. calls Charles of Anjou into Italy.

1265. Defeat and death of Manfred. Charles of Anjou becomes King of the Two Sicilies.

I 268. Conradin defeated at Tagliacozzo.

1 269-1 282. Charles of Anjou Imperial Vicar.

1 277. Napoleon della Torre vanquished by Otho Visconti. The Ghibelline nobles return to Milan.

1278. Rudolph the Emperor acknowledges the Papal right to the States of the Church.

I282. The Sicilian Vespers.

I284. Pisa defeated by Genoa off Meloria.

I 288. Death of Ugolino della Ghirardesca.

1 292. Victory of Guido di Montefeltro over the Guelphs of Florence and Lucca. The Ordinances of Justice passed at Florence.

I 297. Closure of the Grand Council at Venice.

I 3 OI. Boniface VIII. calls Charles of Valois into Tuscany. Papal Court transferred to France.

I310. Henry VII. liberates the Lombard cities from their tyrants and recalls the exiles.

I 3I I. Creation of the Council of Ten at Venice. War between Venice and Genoa. Expedition of Henry VII.

1 31 2-1329. Reign of Can Grande della Scala at Verona.

I 3 I3. Death of Henry VII.

I313-1322. Bertrand du Poïet, the Pope's legate, endeavours to secure the temporal power.

I 316. Uguccione di Faggiuola driven out of Pisa. Castruccio Castracani becomes ruler of Lucca.

I 327-1 329. Louis IV. enters Italy.

I330. John of Bohemia enters Italy.

I 333. He sells or abandons his lordships and quits Italy.

I 341. Pisa possesses herself of Lucca.

I 342. The Duke of Athens establishes himself as despot at Florence.

I343. The Florentines drive the Duke of Athens out of the city. Appearance of the great company of Guarnieri (Werner).

I345. Joan I. of Naples has her husband assassinated. The Great Plague visits Italy.

1347. Cola di Rienzi becomes Tribune of Rome; he is driven out of the city.

I 350-I 354. War of Genoa and Venice in the Levant.

I35I. The Visconti, masters of Bologna, attack Florence.

1353. Genoa gives herself to the Archbishop Visconti. Conspiracy of Marino Falieri.

I354. Genoa throws off the yoke of Visconti. Cola named Senator by the Pope ; he is assassinated.

1355. Charles IV. in Tuscany.

I 362-I 364. War between Pisa and Florence.

I 364. Giovanni Agnello declared Doge of Pisa.

I 369. Lucca regains her liberty.

I 375. Insurrection of the Papal States.

I378. Beginning of the Great Schism. War between Venice and Genoa. Insurrection of the Ciompi at Florence.

I380. Defeat of the Genoese at Chioggia. 
A.D.

1385. Gian Galeazzo Visconti puts his uncle Bernabo to death.

1387-1 388. Gian Galeazzo Visconti conquers Verona, Padua, and Treviso.

I 390. Francesco II. of Carrara, aided by Florence, retakes Padua from Visconti.

r390-1402. Genoa, Perugia, Siena, Pisa, Lucca, and Bologna lose their liberty to Visconti.

1392. Jacopo Appiano becomes tyrant of Pisa.

r 395. Gian Galeazzo Visconti becomes Duke of Milan.

1402. Gian Galeazzo dies.

1404. Francesco da Carrara conquers Verona. Venice declares war against him, and takes Verona and Vicenza.

1405. Carrara capitulates and is put to death. All the Tuscan republics throw off the yoke of Milan.

1406. Florence conquers Pisa.

1408. Ladislans of Naples takes possession of the States of the Church.

1409. Council of Pisa.

r410. The Florentine army under Braccio enters Rome.

1414. Death of Ladislaus.

I423-1425. War between Milan and Florence. Venice joins Florence.

1426. Carmagnola takes Brescia.

r432. Carmagnola executed.

1433. Cosimo de' Medici exiled by the Albizzi.

1434. Cosimo de' Medici recalled.

1435. Battle of Ponza; Alfonzo of Aragon taken prisoner by the Genoese ; he is set at liberty by the Duke of Milan, and subdues the kingdom of Naples.

144I. Francesco Sforza marries Bianca Viscont1.

1447. Re-establishment of the Republic of Milan.

1448. Sforza passes over to the Venetians.

1449. Sforza conquers a great part of Lombardy.

1450. Sforza enters Milan.

1453. Conspiracy of Stefano Porcari. Constantinople falls to the Turk.

1457. Deposition of Francesco Foscari.

1458. Death of Alfonzo of Aragon. Accession of Ferrante.

1463-1479. War of Venice with the Turks.

r464. Death of Cosimo de' Medici.

1466. Death of Francesco Sforza.

r469. Death of Pietro de' Medici.

1473. The Republic of Venice administers Cyprus.

I 476. Olgiati, Visconti, and Lampugnani kill Galeazzo Sforza.

1478. Conspiracy of the Pazzi.

1479. Revolutions at Genoa and Milan against the Duchess Sforza. Venice purchases peace of the Turk by the resignation of Scutari.

1480. Lorenzo dei Medici treats with Ferrante. The Turk at Otranto.

1489. Savonarola arrives at Florence.

1494. Charles VIII. enters Italy. Medici driven out of Florence. Revolt of Pisa.

1495. Charles achieves the kingdom of Naples. Battle of Fornovo. He returns to France.

1498. Execution of Savonarola. Louis XII. claims Milan.

r499. Venice attacked by the Turk; allied with the French against Lodovico the Moor.

I 500. Sforza besieged at Novara; he is captured.

I 50r. Treaty of Grenada.

r 502. Soderini named gonfalonieve for life. 
A.D.

I 503. The French lose Naples.

1504. The French masters of Lombardy; the Spaniards of the Two Sicilies. The Germans called into the Venetian States by Louis XII.

I 507. Insurrection against the French at Genoa.

I 508. League of Cambrai against Venice.

I 509. Pisa subdued by Florence.

I5II. The Pope forms a powerful league against the French.

I 512. Gaston de Foix is killed at Ravenna. The French are expelled. The Spaniards enter Tuscany. The Medici re-established at Florence.

I 5 I3. Alliance between Venice and France against the Germans.

I 5 I 5. Battle of Marignano. The French regain possession of the Milanese.

I 5 I6. Treaty of Noyon.

I 522. The French lose all Lombardy. Genoa pillaged by Spaniards.

I 524. Francis I. taken prisoner at Pavia.

I 525. Moroni's leagne.

I526. Francis signs the Treaty of Madrid.

I 527. The Sack of Rome. The Medici expelled from Florence.

I 528. The Republic reconstituted at Genoa.

1530. Charles receives the Imperial crown at Bologna. Capitulation of Florence.

I 545. Council of Trient opened for the definition of Catholic dogma.

I555. Capitulation of Siena.

I 556 . Lucca falls into the power of a narrow oligarchy.

1570. The Ottomans take Cyprus.

I647. Revolt of Masaniello at Naples.

1669. Candia abandoned by Venice.

I 70o. Death of Charles II. of Spain, and beginning of the wars of the Spanish succession.

I 720. The House of Savoy takes a regal title.

I738. The Treaty of Vienna settles the affairs of the duchies of Tuscany and Parma.

I740. Death of Charles VI. of Austria and commencement of the wars of the Austrian succession.

1748. Peace of Aix-la-Chapelle and redivision of Italy.

I755. Genoa cerles Corsica to France.

1796. Italian campaign of Napoleon.

1797. Treaty of Campo Formio which divides Italy into republics. Cession of Venice to Austria by the French.

I 800. Battle of Marengo.

I 805. Napoleon crowned King of Italy; Venice restored to the kingdom.

I 8 I 5. Congress of Vienna. Restoration of Austrian and Bourbon rule.

I 848. Revolution in Italy.

1 859. Campaign of Lombardy. North Italy united to Piedmont and Sardinia.

1860. Central Italy annexed by the Sardinian King. Sicily annexed.

I 86r. Vittorio Emmanuele proclaimed King of Italy.

1866. Venice united to the Italian kingdom.

I870. Rome, occupied by Vittorio Emmanuele, becomes the Capital of United Italy. 


\section{TABLE OF THE ITALIAN CARLOVINGIANS}

Charlemagne, Emperor Pepin (with Charlemagne)

\section{Bernard, his son}

Louis the Debonair, Emperor

Lothair, his son ... ..

Louis II., son of Lothair ..

Charles the Bald

Carloman, son of Louis I. of Germany

Charles the Fat, his brother
Crowned.

A.D.

Died.

800

A.D.

.. $800 \quad$.. 814

.. $78 \mathrm{I}$

.. $8 \mathrm{I}_{2}$

.. $8 \mathrm{I} 4$

.. 820

.. 849

.. 875

.. 877

. 879

TABLE OF ITALIAN KINGS FROM THE DEPOSITION OF CHARLES THE FAT TO THE REIGN OF OTHO

\begin{tabular}{|c|c|c|c|c|c|c|c|}
\hline & & & $\begin{array}{l}\text { King. } \\
\text { A.D. }\end{array}$ & & $\begin{array}{c}\text { Emperor. } \\
\text { A.D. }\end{array}$ & & $\begin{array}{r}\text { Died. } \\
\text { A.D. }\end{array}$ \\
\hline Beranger, Duke of Friuli & $\ldots$ & $\ldots$ & 888 & .. & 9I 5 & .. & 924 \\
\hline Guido, Duke of Spoleto & . & . & 889 & . & 891 & . & 894 \\
\hline Lambert, son of Guido . . & . & . & 892 & . & 892 & . & 898 \\
\hline Arnolph, King of Germany & . & . & - & .. & 896 & . & 899 \\
\hline Louis III., King of Provence & $\ldots$ & . & 900 & . & $90 \mathrm{I}$ & . & 915 \\
\hline Rudolf, King of Transjuranian B & urgundy & . & $92 \mathrm{I}$ & . & - & . & 937 \\
\hline Hugh, Count or Duke of Provenc & & . & 926 & . & - & . & 947 \\
\hline Lothair, son of Hugh $\quad$. & . & .. & $93 \mathrm{I}$ & . & 一 & . & $95^{\circ}$ \\
\hline Berenger II., Marquis of Ivrea & . & . & 950 & . & - & . & 966 \\
\hline Adalbert, son of Berenger & . & . & 950 & . & - & . & $?$ \\
\hline Otho the Great of Saxony, King & of Gern & & $95 \mathrm{I}$ & . & 962 & $\ldots$ & 973 \\
\hline
\end{tabular}

TABLE OF THE POPES AND CROWNED EMPERORS AND THEIR EXPEDITIONS INTO ITALY FROM CHARLEMAGNE TO CHARLES V

\begin{tabular}{|c|c|c|c|c|c|c|}
\hline $\begin{array}{l}\text { A.D. } \\
795\end{array}$ & $\begin{array}{l}\text { Popes. } \\
\text { Leo III. }\end{array}$ & $\begin{array}{l}\text { Emperors. } \\
\text { Charlemagne }\end{array}$ & $\cdots$ & $\cdots$ & $\cdots$ & $\begin{array}{l}\text { A.D. } \\
800\end{array}$ \\
\hline 816 & Stephen IV. & Louis I. & . & . & . & 812 \\
\hline 817 & Paschal I. & & & & & \\
\hline 824 & Eugenius II. & & & & & \\
\hline 827 & Valentinus & & & & & \\
\hline 827 & Gregory IV. & Lothair I. & . & $\cdots$ & $\cdots$ & 840 \\
\hline 844 & Sergius II. & & & & & \\
\hline 847 & Leo IV. & & & & & \\
\hline 855 & Benedict III. & Louis II. & $\cdots$ & $\cdots$ & $\cdots$ & 855 \\
\hline $\begin{array}{l}858 \\
867\end{array}$ & Nicholas I. & & & & & \\
\hline $\begin{array}{l}867 \\
872\end{array}$ & Adrian II. & & & & & \\
\hline 872 & John VIII. & \multirow{3}{*}{\multicolumn{2}{|c|}{$\begin{array}{l}\text { Charles the Bald } \\
\text { Charles the Fat }\end{array}$}} & $\begin{array}{l}\cdots \\
\ldots\end{array}$ & $\begin{array}{l}\cdots \\
\cdots\end{array}$ & $\begin{array}{l}875 \\
88 I\end{array}$ \\
\hline 882 & Martin II. & & & & & \\
\hline 884 & Adrian III. & & & & & \\
\hline
\end{tabular}




\section{TABLE OF 'THE POPES AND CROWNED EMPERORS-Continued}

\begin{tabular}{ll} 
A.D. & \multicolumn{1}{c}{ Popes. } \\
885 & Stephen V. \\
89 I & Formosus \\
896 & Boniface VI. \\
896 & Stephen V. \\
897 & Romanus \\
898 & John IX. \\
900 & Benedict IV. \\
903 & Leo V. \\
903 & Christopher \\
904 & Sergius III. \\
91 I & Anastasius III. \\
913 & Lando \\
914 & John X. \\
929 & Stephen VII \\
93 I & John XI. \\
936 & Leo VII. \\
939 & Stephen VIII. \\
941 & Martin III. \\
946 & Agapetus II. \\
955 & John XII. \\
963 & Leo VIII. \\
964 & Benedict V. \\
965 & John XIII. \\
972 & Benedict VI.
\end{tabular}

974 Boniface VII., Antipope

974 Dominus II., Antipope (?)

974 Benedict VII.

983 John XIV.

985 John XV.

996 Gregory V.

996 John XVI., Antipope

999 Sylvester II.

I003 John XVII.

1003 John XVIII.

1009 Sergius XIV.

IOI2 Benedict VIII.

IO24 John XIX.

I033 Benedict IX.

I044 Sylvester, Antipope

I045 Gregory VI.

I048 Damasus II.
Emperors.

A.D.

$\begin{array}{lllll}\text { Guido } & \ldots & \ldots & \ldots & 891\end{array}$

$\begin{array}{lllll}\text { Arnulph } & \ldots & \ldots & \ldots & 896\end{array}$

Louis III. of Provence .. $\quad$.. 9OI-9I2

$\begin{array}{lllll}\text { Berenger } & \ldots & \ldots & \ldots & 918\end{array}$

Otto I., Sovereign of Germany . . 936

$\begin{array}{llll}\text { Otho I. crowned } & \ldots & \ldots & 962\end{array}$

Enters Italy $\quad \ldots \quad \ldots \quad \ldots 961$

Returns .. $\quad$. $\quad \ldots \quad 965$

Second expedition of Otho .. 966-972

Otho II. crowned and rules

Otho II. with his father .. $\quad$. 967

967
Expedition of Otho II. . . 980-983 Otho III. " . $\quad \ldots \quad$.. 983

First expedition of Otho III. 996

Second expedition of Otho III. 997-1000

Third expedition of Otho III. 1000-1002

Henry II. . . . . $\quad$. 1004

Rival: Ardoin, Marquis of Torea

First expedition of Henry $\quad$. $\quad 1004$

Second expedition of Henry IOI3-10I4

Third expedition of Henry .. IO2I-1022

Conrad the Salic

.. 1024

First expedition of Conrad .. 1026-1027

Second expedition of Conrad 1036-1038 Henry III. ..

First expedition of Henry .. 1046 
TABLE OF THE POPES AND CROWNED EMPERORS-Continued

A.D. Popes.

I048 Leo IX.

I054 Victor II.

I057 Stephen IX.

I058 Benedict $\mathrm{X}$.

I059 Nicholas II.

106I Gregory VII.

1086 Victor III.

I087 Urban II.

I099 Pascal II.

I I 8 Gelasius II.

I I 8 Gregory, Antipope

II 9 Calixtus II.

I 2 I Celestine, Antipope

II 24 Adrian II.

II 30 Innocent II., Anaclete Antipope

I 38 Victor, Antipope

I 43 Celestine II.

I 44 Lucas II.

II45 Eugenius III.

II 53 Anastasius IV.

II 54 Adrian IV.

I I59 Alexander III.

I 59 Victor, Antipope

I 64 Paschal, Antipope

I 68 Calixtus, Antipope

II 8I Lucas III.

I 85 Urban III.

II 87 Clement III.

I 198 Innocent III.

I 216 Honorius III.

1227 Gregory IX.

I 24I Celestine IV.

I28I Martin IV.

I 285 Honorius IV.

1289 Nicholas IV.

I 292-I 294 Interregnum

I 294 Celestine V.

I 294 Boniface VIII.

I 303 Benedict IX.

I 305 Clement V.

1314-1316 Interregnum
Emperors. A D.

Second expedition of Henry I055 Henry IV. .. $\quad$.. $\quad$.. 1056

First expedition of Henry IV. 1077 $\mathrm{He}$ is crowned Emperor, Gilbert or Clement being Antipope .. $\quad$.. $\quad$.. 1084

$\begin{array}{ccccc}\text { Henry V. } & \ldots & \ldots & \ldots & \text { I I } 06 \\ \text { Crowned } & \ldots & \ldots & \ldots & \text { I I I I }\end{array}$

Lothair II. . . $\quad$. . $\quad$.. $\quad$ I I 25

Conrad III. $\ldots . \quad \ldots \quad \ldots$ I $33^{2}$

Barbarossa (Frederick I.) _. I I 52

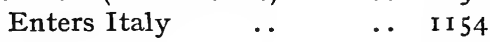

Crowned .. $\quad \ldots \quad$. $\quad$ II 55

Signs compact with towns after twenty-three years' $\begin{array}{llll}\text { resistance } & \ldots & \ldots & \text { II } 77\end{array}$

$\begin{array}{llll}\text { Barbarossa dies } & \ldots & \ldots & \text { II } 90\end{array}$

$\begin{array}{lllll}\text { Otho IV. } & \ldots & \ldots & \ldots & \text { I } 208\end{array}$

$\begin{array}{llll}\text { Frederick II. .. } & \ldots & \ldots & 1222\end{array}$

Henry VII. $\quad \ldots \quad$.. $\quad \ldots \quad$ I 308

Louis IV. $\quad . \quad 0 \quad \ldots \quad \ldots$ I3I 4

Frederick of Austria, his rival .. I 3 I 4 
TABLE OF THE POPES AND CROWNED EMPERORS-Continued

A.D. Popes.

I3I6 John XX. or XXI.

I334 Benedict XII.

I 342 Clement VI.

I 362 Urban V.

I 370 Gregory XI.

I 378 Urban VI. ; Clement, Antipope. Beginning of Great Schism

I 389 Boniface IX.

I394 Benedict, Antipope

I404 Innocent VII.

I 406 Gregory XII.

I 409 Alexander V.

I4IO John XXII. or XXIII.

I4I7 Martin V. End of Great Schism

I43I Eugenius IV.

I439 Felix V., Antipope

I 447 Nicholas V.

I455 Calixtus IV.

I 458 Pius II.

I464 Paul II.

I 47 I Sixtus IV.

I484 Innocent VIII.

I493 Alexander VI.

I 503 Pius III.

I 503 Julius II.

I 5 I 3 Leo $\mathrm{X}$.

I 522 Adrian VI.

I 523 Clement VII.

I534 Paul III.

I 550 Julius III.

I 555 Marcellus II.

I 555 Paul IV.
Emiperors.

A.D.

Charles IV. I 347

Sigismund

1410

Frederick IV. crowned at Rome .. $\quad \mathbf{I} 45^{2}$

Charles V. crowned at Bologna, not

Rome, r530.. . . . . 1519

$\begin{array}{llllll}\text { Charles dies } & \ldots & \ldots & \ldots & \text { I } 558\end{array}$ 


\section{N D E X}

Academies, 748

Adorni, the, of Genoa, 388, 389, 549, $550,553,554,555,589,640,64 \mathrm{I}$, $642,643,646,647,704,746,783$

Adrian IV., Pope, I I I, I I6, 225

Adrian VI., Pope, 686, 688, 689, 690

Agnello of Pisa, 400, 401, 402, 403

Agobbio, 405, 414, 416, 427

Agriculturalist. state of the, 244, 245

Alberghi, the, of Genoa, 783

Albizzi, the, of Florence, 225, 236, 436, $45 \mathrm{I}, 562,563,566,570,57 \mathrm{I}, 572$, $573,580,587,588,589,590,591$, $592,594,596,597,604,648$

Albornoz, Cardinal, 319, 320, 321, 325, $329,330,339,340,34 \mathrm{~L}, 356,358$, $368,429,435,487,488$

Alessandria, 1 22, I 25, I 26, I 29, I 43, I 45, I 56, I 57, I61, $216,25 \mathrm{I}, 252$, $350,35 \mathrm{I}, 356,357,358,473,505$, 5 I0, 514, 5 I 5, 5 I8, 544, 692, 704

Alexander II., Pope, 67,96

Alexander III., Pope, 46, 88, I 33, I I6, I 20, I 21 , I 22, I 27, I 28, I 31 , I 32, I 7O, I7I, I79, 225

Alexander IV., Pope, 21 8, 277

Alexander V., Pope, 467

Alexander VI., Pope, 655 et seq., 721 et seq., 738, 745, 760

Alfonzo (Alfonso) of Naples, 427, 473, $474,492,493,496,508,509,510$, 5 II, 5I7, 519, 520, 54I, 542, 544, $551,552,554,555,588,604,608$, $611,640,641,648, .668,748$

Allegory, mediæval, 30 I

Amalfi, 6, 10, 19, 20, 22, 23, 38, 39, $40,52,53,54,58,89,129$

Ancona, 58, I 10, I20, I 24, I4I, I82, $183,307,381,417,478,487,429$, 495,671

Anjou, House of, 469, 470, 472, 474, $528,575,611,617,640,641,658$, 666

Apulia, 29, 34, 35, 36, 38, 40, 52, 141 , $143,149,153,214,219,222,485$, $487,521,708,710$

Aquinas, St. Thomas, 47, I39, 300, 333,348

Architecture, 104, 105, 214, 224, 294, 798

Arezzo, 56, 98, 140, 141, 179, 198, 200, $233,274,284,289,301,347,353$, $394,405,413,414,419,422,429$, $431,438,584,593,606,725$

Ariosto, L., 796

Arnold of Brescia, 46, 79, I07, I 55 , $168,169,333,766$

Asli, 56, 82, I09, I 21 , I 25, I 56, I 57,
I78, 252,346, 356,357,360, 510, 512, 668

Assisi, 47 I, 475, 584, 67 I, 755

Astrology, 298, 579

Aversa, 35

Avignon, 41, 226, 247, 314, 319, $32 \mathrm{I}$, $327,328,329,330,331,334,342$, $366,429,440,465,467,474,496$, 576

Baglioni, the, of Perugia, 347, 67I, 681, 687, 730, 731, 739

Bank of Florence, 656

Bank of St. George at Genoa, 457, $458,555,639,644,645$

Banks, 457

Barbarossa. See Frederick I.

Bardi, the, of Florence, 242, 414, 4I6, 424

Bari, I $8,21,36,38,214,222$

Basel, Council of, $472,476,477,478$, 48 I, 613

Bassano, 530

Bayard, Chevalier, 656, 681, 691, 692

Beauty, worship of, 6 I 3

Beccaria, the family, $345,358,359$, 360, 36I, 507, 768

Bedmar's conspiracy, 789

Bellini, the painters, 757,788

Bellinzona, 507

Belluno, 21 7, 530

Benedict, St., 4, 100

Benedict VIII., Pope, 76

Benedict IX., Pope, 228

Benedict XII., Pope, 315, 327, 332, 368

Benedict XIII., Antipope, 467

Benevento, 6, 8, 6, I I, I 2, I 7, I 8, I9, 20, 2I, 24, 37, 4I, 59, 50 I

Bentivoglio, the family, 234. 3 I 8, 347, $367,368,579,606,607,608,649$, $661,672,676,680,714$

Bergamo, 56, 6I, 82, I I 7, I I 9 , I 21 , I 45, I 53, I 56, I 57, I 75, I77, 249, $252,314,349,350,355,356,357$, $473,496,507,5$ II, 514, 536, 543 , $545,546,677,709$

Black Bands, the, 693, 694, 705, 728, 730,760

Black Death, the, $338,424,425,431$, $432,443,444$

Black Guelphs, 287 et seq., 289, 290

Boccaccio, 456, 462, 463

Boccanigra, Simone, Doge of Genoa. $384,385,388$

Bologna, $7,56,62$, I I o, I I 5, I I 8, I I 9 . I $20,141,144,145,146,147,148$. $153,157,160,162,163,165,167$ 
I 75, I 76, I 79, I 80, I $81,200,205$, $21 \mathrm{I}, 217,220,221,222,230,246$, $252,259,26 \mathrm{I}, 266,277,28 \mathrm{I}, 284$, $291,292,294,300,301,306,310$, $318,322,329,353,356,357,358$, $361,364-368,383,405,409,410,413$, $420,426,427,428,435,436,439$, $441,442,446,471,475,476,485$, $495,501,505,575,576,578,579$, $582,585,606,607,608,650,660$, $661,672,673,676,680,681,682$, 706, 707, 710, 761, 764, 768, 769, $772,776,797$

Boniface VIII., Pope, 227, 228, 229, $286,288,289,330,392,402$

Boniface IX., Pope, 467, 497, 498, 578,582

Bonnivet, Marshal, 689 et seq.

Borgia, the family, $347,614,673,738$

Borgia, Cesare, 669 et seq., 725, 735, 738

Borgo S. Sepolchro, 605, 648, 755

Botticelli, painter, 653,720, 754

Boucicault, Marshal, 557, 558

Bourbon, Constable, 698

Braccio, mercenary General, 472, 474, $475,476,492,493,495,500,509$, 5 I I, 544, 584, 586, 587, 604

Bramante, architect, $752,753,754$

Brescia, 21, 50, 56, 82, I08, I I 2, I I 5 , I I 8, I I, I 2 I, I 26 , I 3 I, I 45 , I 47, I 48, I 49, I 53, I 56, I 57, I 60, I63, 177, 198, $216,232,249,254$, 29I, 307, 3I3, 3I4, 354, 355, 356, $357,473,49 \mathrm{I}, 507,5 \mathrm{II}, 5 \mathrm{I} 4,5 \mathrm{I} 7$, $536,540,543,544,545,546,56 \mathrm{I}$, $677,681,682,709,752,756,797$

Brienne, Gauthier de, Duke of Athens, $4 \mathrm{I} 8-422,442,56 \mathrm{I}$

Brindisi, 222, 709

Brunelleschi, Filippo, architect, 590, 595,603

Buonarotti, Michelangelo, 683, 727, 728 , $729,744,752,753$

Bussolari, Fra, 359, 360, 36I

Byzantine Empire, 274, 281, 282

Byzantine rule in Italy, 4, 6, 7 , 8-I 2, I 7, I 9, 2 I, 33, 34, 35, 36, 37, $38,39,40,58,59$

Byzantium. See Constantinople

Calabria, IO, I 8, 22, 40, 224, 766

Calimala (wool-dressers), rules of the, 239 et seq., 4 I 5

Calixtus III., Pope, 493, 602, 614, 665

Cambrai, League of, 678, 709, 7 10

Campanella, T., 766

Canossa, the penance at, 43

Capitalism, rise of, 237 et seq., 656

Capua, 21, 22, 34, 35, 39, 53, 54, I 38, $492,551,705$

Caracci, the, 797

Cardona, Raymond of, 307, 308, 350, $35 \mathrm{I}, 408,472$
Cardona, Raymon de, 68I et seq., 726

Carlo Alberto of Savoy, 774 et seq.

Carmagnola, 472, 481, 491, 507, 536, $537,538,550,558,589$

Caroccio, the, $34,63,64,126,127,252$

Carolingian Emperors, the, I I et seq.

Carpaccio, Vittore : 757, 788

Carraresi, the, 230, 259, 260, 321, 347, $353,354,370,376,379,381,47 \mathrm{I}$, $522,529,530,53 \mathrm{I}, 532,539,575$, 576

Castracani, Castruccio, 307, 3 II, 3 I2, $347,35 \mathrm{I}, 383,39 \mathrm{I}, 392,393,394$, $404,406,407,408,409,4 \mathrm{IO}, 4 \mathrm{II}$, 4 I 2

Cateau Cambrésis, peace of, 762

Cathari, sect of, 205

Catherine, St., of Siena, 209, 328, 440

Cavour, Count, 775 et seq.

Celestine V., Pope, 226, 227, 247

Cellini, Benvenuto, 702, 797

Cesena, I 57, 320, 493, 672, 709

Charlemagne, I I et seq., I7, 4I, 57, 73,483

Charles IV., Emperor, 32 I et seq., 330, $357,397,398,402,403,404,429$, $435,444,445,447,448,449,450$, 480,486

Charles V., Emperor, 682, 685 et seq., 689 et seq., 729, 736, 759 et seq., 765 , $781,783,785$

Charles VIII., King of France, 516 , 666 et seq., 699, 708, 7 I 2 et seq., 72I, $75 \mathrm{I}$

Charles of Anjou, 2 I 8 et seq., 225, 226, $246,268,273,274,279,281,282$, 297

Charles of Valois, 227, 228, 229, 289, $290,369,406$

Chioggia, 468, 521, 522, 523, 524, 549

Cicisbeatura, the, 793 et seq.

Ciompi, wool-workers of Florence, 236 , 450,565 et seq., 573

Cisalpine Republic, 769

Cispadane Republic, 769

Cita di Castello, I41, 485, 672, 673

Civitas, the, 60 et seq., I 58

Clement III., antipope, 48

Clement III., Pope, I 7 I

Clement IV., Pope, 220, 22 I

Clement V., Pope, 228, 229, 231, 306, $307,327,329$

Clement VI., Pope, 3I 5, 3I 7, 3I8, 319, $322,327,339,375,429,465$

Clement VII. (Robert of Geneva) : 466, 469

Clement VII. (Cardinal Medici), 690, $731,736,759$

Coleoni, Bartolommeo, 473, 496, 505, 5 I I 5 I 2,5 I6, 520,544, 545, 546, $65 \mathrm{I}, 753$

Colonies, Italian, $372,378,385,386$, $387,392,645$ 
Colonna, the House of, $172,226,228$, $246,312,331,332,334,335,337$, 339, 340, 462, 476, 477, 479, 481, $497,498,499,669,671,674,687$, $688,689,690,700,730,762$

Commerce, 104, I83, I89, I90, I93, 236 et seq., 287, 298, 370 et seq., 388 et seq, 4I 5,787

Como, 7, 56, 82, 83, 84, 105, 108, 109, I I 3, I I 5 , I I 7, I I 8 , I 2 I, I 26 , I 27, I43, I 56, I 75, 249, 250, 252, 253 , $350,351,355,357,360,362,505$, $510,670,683,745,768$

Commune, the, 60 et seq., I 56 et seq., 233 et seq.; 343 et seq.

Condottieri, 33, 328, 396, 399, 400, $402,431,433,438,439,459,482$ et seq.

Conrad II., Emperor, 33, 62, 63, 80

Conrad III., Emperor, 50, 78

Conradin, 2 I 6 et seq., 268

Conraro, Catherine, Queen of Cyprus, 635

Constance, peace of, I29, I 30

Constance, Council of, 467,480

Constantinople, 2, 3, 7, I0, I 2, 13 I 7, I9, 21, 29, 39, 89, I 22, 1 24, I 39, I40, I 82 et seq., I89, I90, 19I, 203, $22 \mathrm{I}, 222,26 \mathrm{I}, 262,274,369,38 \mathrm{I}$, $528,534,545,546,611,622,629$, $630,631,645,757$

Consuls, office of, 65, 94, 164

Coronation of Emperor, 28

Coreggio, House of, $345,395,416,417$, 512,662

Coreggio, Antonio Allegri, 797

Corsica, I7, II4, II6, I4I, I90, I9I, 193, 266, 392, 393, 551, 639, 768, 784

Cortona, 56, 400, 446, 575, 584, 585

Counter-Reformation, 767,768

Courtesans, 454

Crema, 56, 68, 82, I08, II 3, II4, I I 5 , II 7 , I $30,143,157,180,252,254$, $345,355,356,357,473,505,507$, 5II, 517, 543, 545, 677, 709

Cremona, $50,53,62,68,82,83,108$, I I 2, I I 4 , I I 5, I 16 , I I 7, I I 8 , I I 9 , I 2 I, I 22, I 29, I 3O, I 3 I, I 4I, I 42, 143, 147, I 56, I 57, I63, I65, I 75, $176,177,179,181,216,217,221$, $252,254,258,314,325,345,348$, $353,355,357,505,507,5 \mathrm{II}, 5 \mathrm{I} 4$, $518,538,542,545,593,677,683$, 688,700, 709

Crescenzio (Crescentius) (noble Roman family), 30, 3I, 75, 76

Crusade, children's, IO 3

Crusade, fourth, I8 I et seq.

Crusade, eighth, 273

Dalmatia, I7, 38, 44, 89, I 87, 375, $380,381,382,526,527,709,789$
Dames, treaty of, 706

Dandolo, the, of Venice, I 83, 375, 387

Dante Alighieri : $5,135,152,164,197$, 213, 225, 230, 231, 287, 288, 294, 289, 292, 296, 301, 303, 323, 330, $333,346,352,39 \mathrm{I}, 455,460,462$, $743,760,793,796$

Dark Ages in Italy, IOI-IO3

Decretals, false, $4 \mathrm{I}$

Divieto, law of, 433

Dolcino, Fra, 207, 208

Dominicans, I 39, I 40, 207, 458

Donatello, sculptor, 603, 720

Donati, the, of Florence : 16I, 28I, $285,286,288,289,290,29$ I

Doria, the, of Genoa, 94, 273, 373, $374,375,376,382,383,384,387$, $388,521,522,524,549,552,554$, $704,705,761,782,783$

Duccio, Sienese painter, 442

Duke, 8

Durazzo, 40, 89

Durazzo, Charles of, 497, 523, 570, $571,572,575$

Eccelino da Romano, 140, I46, I47, I49, I 52, 165, I66, I77, I 79, 248, 257,347

Education, 2 IO, 2 I I , 4I 5, 544, 740, 74 I

Eight of War, $437,439,562$

Elba, Isle of, $14 \mathrm{I}$

Election of Venetian Doge, mode of, 263

Empoli, 98, 278, 730

England, Italians in, 298

Enzio of Sardinia, 149, I 53, 190, 367

Este, House of, (Estensi), 43, 50, 84, $140,141,146,149,157,161,163$, $165,216,217,220,221,253,258$, $307,321,347,349,353,366,436$, $439,470,485,489,49 \mathrm{I}, 492,5 \mathrm{II}$, $512,529,586,611,612,672,682$, 737

Estimo, the, 589

Eugenius III., Pope, 79, I07, I68

Eugenius IV., Pope, 472, 473, 476, $477,478,479,481,492,501,597$, $598,605,613$

Exarchate, 5, 7, 10,

Facino Cano, 491

Faenza, 56, I I 3, I I 8, I 20, I 45, I 57 , $162,217,318,321,329,439,576$, $675,672,676,677,709,726$

Fagginola, Uguccione della, 390, 391, 405

Falieri, Marino, Doge of Venice, 377 . 378

Family life : 746,747

Fano: 58, 14I

Farinata degli Uberti : 164, 278, 295, 296

Farnese, the, 347,667, 760, 761, 762 
Felix V., antipope, 478, 6I 3

Feltro or Feltre, 21 7, 349, 530

Fermo, 14I, 320, 673

Ferrante of Naples, 611, 612, 616, $635,636,637,640,646,648,662$, 668,758

Ferrara, 48, 56, 63, 68, I I 8, I 33, I 47, I 53, I61, 163, 175, I76, 177, 216, $217,221,259,307,321,322,325$, $349,351,353,356,361,362,369$, $376,404,420,472,474,478,491$, $492,525,535,537,589,593,596$, $598,611,612,637,639,673,681$, $682,685,695,699,707,709,710$, $740,749,756,759,762$

Ferucci, Francesco, 730,731

Ficino, M., 603, 659, 744

Fieschi, the, of Genoa, 273, 382, 383, $552,554,589,640,644,645,647$, $746,759,761,781,783$

Fiesole, 400, 659

Financiers, 298

Flagellants, 299

Florence: 48, 56, 60, 62, 63, 70, 93, 95 et seq., I 24 , I 38 , I 40, I 4 I, I 57 , $159,160,161,162,164,177,190$, $205,214,215,220,222,230,232$, $235,236,237,238,240,24 \mathrm{I}, 242$, $243,268,275$ et seq., 295, 301, 307, $314,317,319,321,322,323,324$, $326,329,332,336,342,343,346$, $347,352,353,356,364,366,367$, $370,383,390,391,393,395,396$, 399, 400, 40I, 404 et seq., 442, 450, $45 \mathrm{I}, 452,453,454,463,464,470$, $47 \mathrm{I}, 472,473,474,475,476,477$, $48 \mathrm{I}, 486,487,493,496,505,508$, 509,5 IO, 5II, 535, 537, 538, 539, $540,541,543,544,545,549,550$, $55 \mathrm{I}, 552,555,556,557,558,559$, 560, 561 et seq., 610, 6і1, 612, 616, $622,626,628,636,637,646,647$ et seq, 667, 670, 680, 681, 682, 683, 688, 690, 698, 699, 701, 70.4, 706, 707, 709, 7I I et seq., 733, 734, 735, 736,74 ' 744, 752,753,760, 76I, $762,764,774,776,781,791,797$, 798

Florence, Council of, 478

Florence, statistics of, 4I4, 4I 5

Florentine constitution, 280 et seq., $407,412,422,423,424,433,434$, 659,7 II 7 I 7,7 I 8

Florin, value of, 276

Foix, Gaston de, 681, 682

Foligno, I4I, 438

Forli, 56, I 20, I 57, 320, 427, 488, 576, 588,672

Foscari, the, of Venice, 534, 535, 542, $546,547,548$

Fortebraccio, 477, 496, 492, 59I

Francis of Assisi, St., I 39, 205, 208, 209, 755
Franciscans, I 39, 207, 458

Francis I. of France, 684, 692 et seq., $729,78 \mathrm{I}$

Franks, I I, I 2, I 3

Frascati, I 36

Frederick I., Emperor (Barbarossa), 51, 57, 107 et seq., I4I, I 57, 162, I64, I67, I 73, I 78, I 79, I 8I, I 82, I92, $2 \mathrm{OI}, 2 \mathrm{O} 2,248,480,483$

Frederick II., Emperor, 98, I 31, I 37, I42 et seq., I64, I65, I 72, I79, 190, I9I, 197, I98, 221, 223, 224, 238, $268,275,348,367$

Fregosi, the, of Genoa, 389, 549, 550 , $553,554,555,589,639,640,641$, $643,644,645,647,704$

Friuli, 6, 25, 29, 523, 524, 533, 628, 710

Gaeta, I0, I2, 19, 22, 23, 39, I 36, 55 I, $55^{2}$

Gambacorta, the Pisan House of, 323 , $325,397,398,402,555,558,576,648$

Garibaldi, 775 et seq.

Gattemelata, 496, 540, 605

Gau, the, 60 et seq., I 58

Gelasius II., Pope, 48, 92

Genoa, 5, 6, 26, 49, 56, 63, 84, 91, 92, 93 et seq., I I 4, I 22, I 24, I 37, I 40, I 4 I, I42, I46, I48, I 50, I 57, I60, I62, I63, I81, I82, 183, I86, I87, 189, 191 et seq., 230, 232, 261, 262, $265,266,267,268,270,27$ I et seq., $276,284,291,307,322,351,357$, $360,369,371,372$ et seq., 382 et seq., $390,395,402,4 \mathrm{II}, 4 \mathrm{I} 7,425,43 \mathrm{O}$, $43 \mathrm{I}, 457,468,470,472,507,512$, $521,522,524,525,526,535,549$ et seq., $557,558,559,560,579,584$, $585,589,593,6$ II, 612, 626, 636, 639 et seq., 658, 661, 670, 680, 683, $688,698,699,704,705,740,759$. $763,764,767,769,771,781$ et seq., $787,791,796$

Gheradesca, the, 392, 395, 396, 397

Ghibellines, 50, 56, I 32 et seq., I 40, I 42, $147,148,152,153,161,162,163$, I64, I65, I72, I77, I8I, I90, I93, 194, 199, 200, 216, 218, 220, 222, $228,232,233,248,252,253,268$. $269,275,276,277,278,279,281$, $282,284,290,295,296,306,307$, $310,314,326,331,345,348,349$, $350,35 \mathrm{I}, 353,354,360,364,366$, $367,382,383,390,393,394,396$, $404,405,406,409,4 \mathrm{IO}, 4 \mathrm{II}, 4 \mathrm{II}$, $413,414,417,419,422,424,426$, $427,428,429,434,447,512,5$ I 5 , $550,562,563,6$ I I, $648,782,783$

Gimignano, San, 70, 167, 198, 278, $297,298,301,419,422$

Giovanni I., Queen of Naples, 316, $317,469,472,485$ 
Giovanna II., 470, 472, 476, 492

Golden Book of Venice, 263-265, 523 , 539

Golden Book of Genoa, 784

Gonzaga, house of the, $321,352,353$, $416,470,485,5$ I 5,5 I 6,5 I 7,6 II, $668,729,730,761$

Gregory I., Pope, 5, 6, 7

Gregory II., 59, 72

Gregory VI., 76

Gregory VII. (Hildebrand), 37, 38, 40,42 et seq., $48,67,77,92,96$, I I I, I 32, I 33, 306, 309

Gregory VIII., I 3 I

Gregory IX., I44, I48, I 72, I90, I98, 206, 247, 268, 329, 342

Gregory X., 225

Gregory XI., 440, 570

Gregory XII., 468, 584

Grimaldi, the, of Genoa, 273, 375, 376, $382,383,385,525,549,552$

Guarino (Greek scholar), 544, 740

Guelphs, 48, 56, I 32 et seq., I 40 , I 42 , I43, I47, I 49, I 53, I6I, I62, I63, I64, I65, I72, I 77, I 8I, I 98; I 99, $200,216,218,220,222,227,232$, $234,247,248,252,253,257,267$, $268,269,274,275,276,277,278$, $279,28 \mathrm{I}, 283,284,287,296,306$, $307,308,3$ IO, 3II, 3I4, 3I9, 326, $33 \mathrm{I}, 345,349,35 \mathrm{I}, 353,360,36 \mathrm{I}$, $364,367,382,383,402,404,405$, 406, 4IO, 4I3. 4I6, 4I7, 4I9, 429, $434,442,443,447,5$ I $2,515,550$, $562,563,61 \mathrm{I}, 648,683,691,783$

Hawkwood, Sir John, 325, 329, 400, $40 \mathrm{I}, 433,436,437,439,440,45 \mathrm{I}$, $47 \mathrm{I}, 490,496,572,576,577$

Henry II., Emperor, 32, 33, 76, 80

Henry III., $35,76,77$, I 33

Henry IV., 42, 77, 92, 96, 97, 98, I 33 , 309

Henry V., 48, 50, 83

Henry VI., I 29 , I 30 , I 3 I, I 36, I 37 , I 38, I 40, I 75, I 90

Henry VIII., 229, 23I, 232, 233, 253, $254,257,258,27 \mathrm{I}, 274,292,293$, $294,305,306,307,314,323,330$, $33 \mathrm{I}, 348,349,350,353,369,382$, $390,429,442,483,561$

Heresy, 199, 204 et seq., 299, 458, 61 8

Heribert, Archbishop of Milan, 33, 34, $46,62,63,81$

Hohenstaưifen, House of, 5 I, IO7-I 56 , $215-225$

Holy Roman Empire, theory of the, I 5 et seq., I 27, I 33

Honorius III., Pope, I42, I43, I 77

Honorius IV., 226, 246

Imola, 56, I 20, 488, 576, 654, 672, 709

Innocent II., Pope, 54, 55, 225
Innocent III., I 37, I 38, I 39, I40, I 4 I, I 42, I43, I 44, I45, I 72, I90, I94. $206,268,306$

Innocent IV., I $50, I_{5}$ I, I $53, I_{54}, I_{5} 6$, I $57,206,2$ I 6,2 I 8,26 I

Innocent VI., 322, 327, 339, 375, 616

Innocent VII., 498

Innocent VIII., 6I6, 6I7, 6I8, 660, 663,745

Inquisition, the, I 39, I45, 760,767

Inquisitors of State, Venetian, 788, 789

Iron crown of Lombardy, 8, I I, 22 , $24,25,26,28,29,32,143,322,481$, 770

Italian language, formation of, 99-IOI

Jesuits, 760, 768, 771,792

Jews in Italy, 298, 299

John VIII., Pope, 22

John X., 74

John XI., 74

John XII., 27, 74, 75

John XIII., 27

John XIX., 76

John XXII., 306, 307, 308, 309, 310, $311,319,327,330$

John XXIII., $467,480,585$

John of Bohemia, 31 3 et seq., 31 7,323 , $330,353,412,414,417,483$

Julius II., Pope, 647, 675 et seq., 690, $699,726,753,760,78 \mathrm{I}$

Justinian, Emperor, 4, 85, I I 3, I 79

Justinian, pandects of, 54

Knights, 457

Knights of St. John, 54, 618

Ladislaus, King of Naples, 317, 470, $47 \mathrm{I}, 497,498,499,500,559,583$, $584,585,586,66$ I

Lando, mercenary Captain, 32I, 358, $362,485,486,487,488,489,490$, $568,569,570,574$

Lannoy, Viceroy of Naples, 688, 7o r

Lanzone, 64

Lautrec, Marshal, 687, 688, 704

Learning, revival of, 460

Leghorn, 400, 550, $55 \mathrm{I}, 557,558,560$, 7 I 3,730

Leo III., Pope, I 2, I 3, 73

Leo IV., I 8

Leo VI., 57,58

Leo VIII., 75

Leo IX., 37,42

Leo X., 683 et seq., 690, 694, 699, 726, $727,728,755,781$

Leyva, de, 699, 759

Libraries, 747, 748

Life, Italian, 99, 202 et seq., 297 et seq., 452 et seq., 737 et seq., 79I et seq.

Ligurian Republic, 769,785

Literature, IOI, IO3, 2 I I et seq., 300 et seq., 460 et seq., 748 et seq., 796 
Lodi, 48, 56, 62, 80, 82, 83, Io8, Io9, I IO, I I I, I I 2 , I I 3 , I I 5 , I I 7 , I I 8 , I I9; 143, I45, I62, I63, I 75, 248, $249,252,253,254,35 \mathrm{I}, 353,355$, $356,357,505,510,517,543,546$, $648,688,692,700,704$

Lombard I,eague, the first I i, et seq.

Lombard League, the second, I44 et seq.

Lombards, 5 et seq., 20, 40, 60, 85, 99

Louis of Anjou, 58.3, 584, 585

Louis of Bavaria: 305 et seq., 330, 33I, 336, 35 I, 394, 4IO, 4I 3, 4I 7, 483

Louis IX., King of France, 178, 222

Louis XI., King of France, 642, 643, 657

Louis XII., King of France, 668 et seq., 677 et seq., 708, 725, 780, 781, 782

Louis of Hungary, $375,379,380,381$

Lucca, 56, 60, 68, 91, 92, 93, I 24, I 38, I 40, I4I, I 57, 167, 190, I92, I96, I97, 198, 230, 242, 268, 269, 274, $277,278,28 \mathrm{I}, 284,29 \mathrm{I}, 294,30 \mathrm{I}$, 307,3 II, 3I2, 3I4, 323, 324, 325, $326,329,346,347,351,353,383$, $390,391,393,395,396,398,402$, $403,404,405,406,407,409,410$, 4I $2,413,416,417,418,419,422$, $427,431,436,438,448,481,489$, $578,589,591,592,593,605,628$, $648,670,683,688,695,708,734$, $761,763,764,770,787$

Machiavelli, Niccolo, 294, 495, 501, $514,650,655,726,727,734,749$, 750,760

Malatesta, the, of Rimini, 216, 320, $32 \mathrm{I}, 353,366,400,417,418,432$, $433,447,448,449,472,485,489$, $490,49 \mathrm{I}, 493,507,5 \mathrm{I} 8,536,588$, $589,60_{5}, 616,625,672,687,689$, 737

Manfred, son of Frederick II.: 215, 216, 217, 218, 219, 238, 268, 279, 295,296

Mantua, 48, 56, I I9, I 45, I 47, I 53 , $175,177,216,217,321,322,325$, $35 \mathrm{I}, 352,356,36 \mathrm{I}, 362,376,395$, $402,416,472,474,485,535,537$, $538,540,544,577,589,628,637$, $668,678,679,682,707,709,710$, $739,740,752,759,787$

Marino, San, 673, 763, 765, 77 1, 779, 780

Marriage, 203, 454, 455

Martin IV., Pope, 22 I, 223, 226

Martin V., 474, 475, 477, 500, 536

Matilda, Countess of Tuscany, 42 et seq., 67, 68, 93, 97

Matilda, heritage of, 44, 97, I I6, I 32, I $38,14 \mathrm{I}, 194,26 \mathrm{I}, 327,678$

Maximilian, Emperor, 622, 674, 677 et seq., 780
Mazzini, 773 et seq.

Medici, the House of, $347,424,435$, $560,561,562,574,580,581,588$, $590,594,611,652,653,656,658$, $682,683,691,706,707,7$ I2, 7 I3, $7 \mathrm{I} 4,72 \mathrm{I}, 724,728,729,73 \mathrm{I}, 732$

Medici, Cosimo dei, 472, 473, 5 I 4, 542 , $544,551,591,592,593,609,612$, $647,648,649,654$

Medici, Cosimo dei, Duke of Tuscany, $732,760,761,786$

Medici, Giovanni dei, 588, 590, 687, $693,694,700,728,730$

Medici, Piero dei, the elder, 602, 603, 612,649 et seq., 665, 667

Medici, Piero dei, the younger, 7 I I et seq., 72I, 725

Medici, Lorenzo dei, 6I2, 6I6, 637, 647,652 et seq., 663, 736, 748, 753

Medici, Salvestro dei, 435, 563 et seq., 588

Medicine, art of, 299, 300, 457

Milan, 3, 18, 24, 26, 28, 33, 34, 44, 48, $50,51,56,67,68,80$ et seq., 92, 93, IO5, I08 et seq., I4I, I42, I44, I45, I47, I 48, I 53, I 55, I 56, I 57, I62, 165, I73 et seq., 203, 2 I6, 217,220 , $230,232,234,247$ et seq., 307, 322, $326,327,343$ et seq., 368, 370, 395, $400,416,425,428,436,467,473$, $476,479,481,484,492,493,502$, et seq., 540, 542, 543, 544, 556, 576 , $603,608,6$ I , 6I2, 6I 3 , 6 8 et seq., $626,628,637,641,642,644,646$, $647,648,649,658,670,684,687$, 688, 691, 698, 699, 700, 701, 704, $707,725,743,756,759,761,762$, $764,768,769,774,780$ et seq., 798

Miniato, San, 39, 56, I 38, 276, 324 , $405,435,436,494,575,577,730$

Modena, $48,56,82$, I 20, I 25 , I 33 , I 40 , I43, I47, I 56, I 57, I60, I65, I 75, I 76, I 77, I 79, I 8 I, 2 I I, 22I, 253, $29 \mathrm{I}, 293,314,352,353,366,458$, $485,596,611,628,672,680,682$, $704,710,768,772,776$

Monaco, $383,385,388$

Montepulciano, I95, 275, 446, 485, 575,609

Montferrat, $5 \mathrm{I}, 56,84$, I I I, I 2 I, I 25 , I $4 \mathrm{I}, \mathrm{I} 57,252,358,359,360,36 \mathrm{I}$, $362,383,431,432,470,474,489$, $490,5 \mathrm{II}, 5 \mathrm{I} 2,5 \mathrm{I} 4,536,544,550$, $611,628,687,688,695,699,707$, 759

Monza, I I $4,147,322,516$

Morals, Io2, 200, 203, 205, 458, 459, 745,758

Music, Io6, 767, 798, 799

Naples, 5, IO, I 2, 19, 20, 23, 35, 38, $39,53,54,55,92$, I 36, I 37, I 46, I 79 , $2 \mathrm{I} 8,232,300,326,329,338,38 \mathrm{I}$, 
$383,417,426,430,431,469,472$, $474,479,487,491,492,497,498$, $500,505,508,509,510,512,528$, $544,545,55 \mathrm{I}, 575,57 \mathrm{~S}, 609,6 \mathrm{II}$, 6 г2, 616, 622, 626, 628, 636, 643, $648,671,674,687,689,698,704$, $705,707,712,713,725,762,772$, 774,781

Napoleon Buonaparte, 769 et seq.

Narni, 438, 475, 67 I

Nicholas II., Pope, $37,38,46,77$

Nicholas III., 222, 246, 28 I

Nicholas IV., 226, 246, 368

Nicholas V., 500, 501, 502, 613, 747

Nobility, Italian, 780

Normans, 33 et seq., 52 et seq., 67, 78 , $88,89,91,92$, I 30,143, I 81 , I 82 , 223

Novara, 50, 56, 62, 82, I09, IIo, II7, I I 8, I 2 I, I 26, I 43, I $57,249,25$ I, $252,356,362,510,518,544,670$, $683,687,688,692$

Olgiati, conspiracy of the, 655

Orange, Prince of, 702 et seq.

Ordelaffi, the House of, 320, 321, 366, 438

Ordinances of Justice, 285,286

Orsini, the House of, I 4I, I72, 223, $226,227,228,246,290,33 \mathrm{I}, 332$, $337,339,466,498,669,671,673$, $674,690,7$ I I, 7 I 3,7 I 7

Orta, or Orti, 438,475

Orvieto, 63, 66, 197, 198, 205, 275, $276,277,294,319,339,356,427$, $438,474,475$

Otho I., Emperor, 14, 25, 26, 27, 28, $50,62,75,132,483$

Otho II., 28, 29, 30, 9I

Otho III., 30, 31, 32, 63, 75, 81, I 32

Otho IV., I4I, I $42,143,157,195$

Otranto, 10, 660, 663, 709

Padua, 56, 85, 89, II 8 , I I9, I45, I 47 , I 53, I60, I62, I65, I66, I77, I79, 206, 230, 257-260, 29I, 3IO, 32I, $325,347,353,354,356,365,370$, $380,381,402,404,414,436,468$, $47 \mathrm{I}, 489,52 \mathrm{I}, 531,532,542,549$, $561,576,578,678,679,710,748$, 756

Painting, 105, 303, 463, 754 et seq., 797

Palavicino, vel Pelavicino, the House of, $221,248,249,387$

Palermo, I 8, I 37, I 38, I4I, I44, I 54, 766

Parma, I8, 48, 51, 56, 62, 82, I10, II 8 , I 20, I 2 I, I 31 , I40, I4I, I 47, I 53, I 56, I 57, I62, I65, I 75, I 76, 180, I8I, 221, 25I, 314, 345, 353, $356,357,366,395,413,416,473$, $491,492,507,510,516,518,544$, $559,670,685,761,762,772$
Parte Guelfa, 280, 434, 435, 562, 564, $565,566,569,570,575,580$

Parthenopean Republic, 769

Paschal II., Pope, 47

Paul II., Pope, 61 5, 616, 626, 628

Paul III., 762, 792

Paul IV., 762

Pavia, 8, I I , 23, 24, 26, 28, 32, 33, $34,50,56,6 \mathrm{I}, 80,8 \mathrm{I}, 82,83,108$, I09, I I I, II 2 , II 7 , I I 8 , I I 9 , I 2 I, $125,127,131,14 \mathrm{I}, 142,148,153$, I $56,157,175,216,252,345,349$, $350,358,359,360,361,362,390$, $503,505,506,510,5 \mathrm{II}, 5 \mathrm{I} 4,5 \mathrm{I} 8$, $544,670,687,704,736,751,756$

Pazzi, conspiracy of the, 654 et seq. 660

Peasant, condition of the, 245

Pepoli, the House of, I $81,234,318$, $356,365-368,420,485$

Perugia, 56, I41, 198, 277, 322, 323, $336,347,405,4 \mathrm{I} 3,4 \mathrm{I} 4,426,429$, $435,436,437,438,439,446,470$, $47 \mathrm{I}, 474,475,485,486,487,489$, $495,497,575,576,578,579,584$, $587,661,671,673,676,681,687$, $702,725,739,76 \mathrm{r}$

Pescara, Marquis of, 69 i et seq.

Petrarch, 225, 235, 323, 324, 328, 333, $334,335,336,356,360,387,375$, $455,460,461,462,501,527,793$, 796

Petrucci, the House of, 234, 592, 695, 661, 662, 664, 672, 724, 734 et seq.

Peruzzi, the, 242 et seq.

Piacenza, 48, 50, 56, 82, 108, 109, I I 4, I I 5 , I I 8, I 20 , I 22, I 40, I 43 , $145,147,148,153,158,175,176$, $216,221,25 \mathrm{I}, 253,345,350,353$, $355,356,357,366,507,5$ IO, 5 I I, 5 I 2,5 I 3,5 I $8,543,544,682,685$, $695,704,761,762$

Piccinini, the, condottieri, 472,479 , $49 \mathrm{I}, 493,494,5 \mathrm{II}, 5 \mathrm{I} 2,5 \mathrm{I} 3,5 \mathrm{I} 6$, $518,520,536,538,540,541,589$, $593,60,604,605,606,607,661$, 662,663

Piedmont, 5 I, 56, 147, 148, 274, 307, $362,699,759,762,771,772,774$

Pierleoni, the House of, 77,79

Pisa, $23,29,73,56,63,84,85,90$ et seq., 97, 105, I I4, I24, I $36,137,140$, I 41 , I 49, I 57, I60, 162, I81, I82, I83, I87, I9I, I92, I93, I97, I98, $214,215,220,222,230,232,233$, $240,265,266,267,268$ et seq., 272, $274,276,277,278,281,284,289$, $29 \mathrm{I}, 3 \mathrm{OI}, 305,307,3 \mathrm{II}, 32 \mathrm{I}, 323$, $325,329,353,354,355,36 \mathrm{r}, 389$, 390 et seq., 4I4, 4I7, 4I8, 4I9, 424, $425,427,429,430,431,432,433$, $435,436,437,438,445,448,453$, $463,467,471,473,484,489,505$, 
555 ct seq., 56r, 575, 577, 579, 582, $583,585,586,592,593,609,667$, $668,670,674,680,68 \mathrm{I}, 698,7 \mathrm{I} 2$, $724,726,730,733$ et seq., 761, 764, $78 \mathrm{I}$

Pisani, the House of the, 373, 374, $375,376,382,387,463,521,522$, $523,524,525,526$

Pistoja, 56, I24, I40, I41, I60, I67, 190, 197, 198, 2 I 5, 268, 274, 278, $279,281,288,289,290,291,294$, $312,391,396,405,408,409,410$, $4 \mathrm{II}, 4 \mathrm{I} 2,422,427,578,579,594$, 596,761

Pitti, the house of, I95, COO, 602, 649, 652

Podestà, office of, I I 3 , I I 4 , I I 8 , I 62 , I63, I65, I66, I 73, I 74, I 75, I 76, I 77, I93, I96, 2 I6, 234, 250

Poïet, du, 307, 31 3, 330, 347, 357, 366, 367,4 I 3

Polenta, the House of, 235, 302, 346, $349,366,487,539,540,672$

Porcari, Stefano, $5 \mathrm{OI}, 5 \mathrm{O} 2$

Prato, I 38, 278, 290, 405, 408, 4IO, $427,436,726$

Provveditori, Venetian, 530

Raffaello (Raphael), 683, 752, 755, 756

Ravenna, 5, 7, Iо, 33, 56, 59, 63, 86, I05, I06, I 57, I 77 , 198, 235, 346, $349,487,539,540,589,672,677$, 682, 709, 7 IO

Reggio, 56, 61 , I 40, I 43, I 47, I 56, I 65, I $8 \mathrm{I}, 2 \mathrm{II}, 22 \mathrm{I}, 253,3 \mathrm{I} 4,353$, $366,436,485,559,672,682,698$

Religion, IO I et seq., 204 et seq., 299, 300, 458, 465 et seq., 474 et seq.

René of Anjou and Provence. 55 I, 554 , 6 I $7,640,642,643,658$

Renaissance, 452 et seq., 737 et seq.

Reprisals, 69, 8I, I67

Riario, the House of, $347,612,655$, 672

Rienzi, Cola di, 225, 323, 333 et seq., 462,486

Rimini, 56, 58, I 57, $217,353,417$, $427,438,467,485,486,489,576$, $605,626,672,675,676,677,687$, $689,709,726,738$

Robert of Naples, 305 et seq., 314, 326, $330,33 \mathrm{I}, 332,353,383,390,39 \mathrm{I}$, $405,409,413,416,418,464$

Romagna, I 45, 3 I 8, 329, 344, 35 I, $366,367,405,413,417,426,427$, $436,474,484,485,488,491,492$, $589,603,672,674,675,676,678$, $682,691,725,772$

Romantic love, origin of, 2 I I et seq., 455,456

Rome, 3, 4, 5, 6, 7, 10, I I, I 2, I6, I 8, $24,33,44,51,59,63,66,7$ I et seq., I02, I06, I 10, I I6, I 2 I, I4 I, I 46,
I 48, I 49, I 50, I 57, I64, I67 et seq., I95, I98, 2I 5, 2I $8,220,227,232$, 245 et seq., 323, 324, 328, 329, 330 et seq., 410, 438, 458, 465, 468, 470, $473,474,475,476,477,478,479$, $480,481,486,496$ et seq., 545, 575, $578,584,585,586,587,611,615$, $616,618,622,668,669,671,688$, $702,703,752,762,770,774,776$, $777,778,792,796,797,798$

Roncaglia, diets of, $28,32,33,5 \mathrm{I}$, I 08 , I I 3 , I 14 , I 16

Rovere, della, the House of, 347,616 . $67 \mathrm{r}, 687$

Rovere, Francesco Maria della, Duke of Urbino, 699 et seq.

Saints, 205-210, 440, $45^{8}$

Salerno, 35, 40, 54

Saracens, 1 3, I 7, I $, 19,20,21,22$, $23,24,25,29,30,32,38,39,40$, $56,87,91,92,94,95,97,144,145$, I 46, I 47, I 48, I 50, I 54, I66, I69, 204,2 I I, 2 I 8,2 I9, 223,224

Savonarola, 6I 3, 7 I4 et seq., 730, 766

Savoy, 5I, 56, 82, I 43, 23I, 232, 5 I I 516,5 I $8,519,520,526,535,536$, 544, 611, 687, 707, 759, 760, 762, 767, 774 et seq.

Scala, della, the House (Scaligeri), I $57,230,305,318,321,345,346$, $353,367,370,376,381,416,426$, $463,471,528,529,530$

Scala, della, Alberto, 353, 354

Scala, della, Can Grande, 233, 235 , $258,259,302,307,346,349,351$, $352,353,383,39 \mathrm{I}, 410,56 \mathrm{I}$

Scala, della, Mastino, 220, 313, 314 , $325,349,353,354,355,356,370$, $395,396,412,413,414,416,417$, $422,426,485$

Schism, the great, $465-478,497,500$

Scholasticism, IO3, IO4

Science, dawn of, in Italy, 303, 304

Sculpture, 214, 463, 752. et seq., 759 , 797

Sforza, the House of, $672,728,759$

Sforza, Caterina, 728 .

Sforza, Francesco, 472, 473, 474, 477 . $478,479,49 \mathrm{I}, 492,493,494,495$. 496, 508, 509 et seq., 536, 540 et seq., $548,588,592,601,602,604,605$, 609, 6I 1, 6I2, 618, 626, 640, 641 et seq., 652, 687

Sforza, Francesco, the younger, 689 , $690,706,707,738,78 \mathrm{I}$

Sforza, Galleazzo Maria, 612, 619, 645, $646,65 \mathrm{I}$

Sforza, Giovanni, 728

Sforza, Ludovico, 612, 658, 666, 668, $670,708,712,713,724,735,756$, $780,78 \mathrm{I}$

Sforza, Massimiliano, $682,683,685,78 \mathrm{I}$ 
Sforza, Muzio Attendolo, 470, 472, $474,476,491,492,495,500,508$, 604,484

Sicily, I 2, I 8, 22, 23, 32, 39, 40, 48, $52,55,94,106,122,128$, I 30, I 3 I, I 36,138, I $42,143,145,148$, I 5 I, $152,191,217,219,220,221,223$, $225,246,290,327,369,371,425$, $55 \mathrm{I}, 552,67 \mathrm{I}, 689,698,707,760$, $766,767,772,774,776$

Siena, I8, 56, 60, 68, 98 et seq., r24 I 38 , I4I, I 57, I60, I62, I90, I95, $197,198,201,202,215,220,222$, $230,234,235,242,268,275,276$, $277,278,28 \mathrm{I}, 284,289,29 \mathrm{I}, 294$ et seq., 307, 322, 323, 324, 326, 329, $336,354,365,400,404,405,410$, $413,417,421,422,425,426,427$, $428,429,430,436,437,438,44 \mathrm{I}$ et seq., 458, 463, 464, 47I, 472, 48I, $486,487,489,493,535,575,576$, $577,578,593,609,610,628,656$, $657,658,660,66$ i et seq., 670, 672, $673,683,688,695,701,708,724$, 734 et seq., 752, 755, 759, 761, 762, 765,785 et seq.

Silk-trade, 203

Sismondi, memoir of, xvii-xxv

Sixtus IV., 612, 616, 617, 654, 657, 660,744

Sixtus V., 765

Slaves, 9, I0, 27, 7 I, 167, 297, 746

Soderini, the House of, $649,653,689$, 718,725 et seq.

Spinola, the House of, 94, 272, 273, $382,383,549,552,554,640,759$

Spoleto, 6, 8, I 2, 19, 24, 56, 59, I Io, I 24, I 38, I 4 I, I 45, 307, 438, 67 I

Strozzi, the House of, $424,562,563$, $566,571,572,573,596,732,760$, $761,786,791$

Subjects, treatment of, 236,533

Taranto, 19, 21, 391

“Ten" of Venice, 788, 789

Terni, 475, 67 I

Theodoric the Goth, 4, 85, 224

"Three" of Venice, 788, 789

Tiberine Republic, 769

Tiepolo, conspiracy of, 264

Titian, 758, 797

Tivoli, 78, I 70, 496

Todi, r 41, 438

Torre, della, House of (Torriani), 165 , $230,232,233,249,250,252,253$. $254,308,347,348,350$

Torre, della, Guido, 253 ,

Torre,-della, Martino, 247, 248, 249

Torre, della, Napoleone, 234, 249, 250, 348

Torre, della, Pagano, I48, I78, I79, 2 I6, 247

Torre, della, Philip, 240, 272
Tortona, 56, 82, 108, 109, II 3, II 5 , I I 8, I 2 I, I 25, I 29, I 43, 216,307 , $350,351,356,357,366,510,515$, 5 I 8,544

Trade Associations, 58, 61, 63, 64, 66, 68, 71, 90, 195, 196, 236 et seq., 245, $279,287,424,527$

Trani, 222, 709

Trapani, I 36,425

Trémouille, De la, 670,683, 684, $78 \mathrm{I}$

Treviso, 56, I I 8 , I I 9, I 29 , I 45 , I 47 , $162,217,221,258,259,349,353$, $370,379,380,413,416,523,526$, $528,533,678,683,684,710$

Trivulzio, Marshal, 683,684

Turin, $23,56,145,358,458$

Turk, the, $371,372,381,385,533$ $611,612,622,623,624,651,658$, $660,663,679,689,706,708,745$, $757,767,786,787,790$

Tuscan League, 138, I41, 195, 197

Tusculum, 25, I 2 I, I 36

Tyrannies, general character of the Italian, 343-348

Uberti, the, $97,153,157,161,199,200$ Ugolino della Gherardesca, 267, 268, 269,284

Uguccione della Faguiola, 233, 290

Universities, foundation of, 2 IO

Urban II., Pope, 47, 48

Urban IV., Pope, 21 8, 2 I 9

Urban V., 327, 328, 342

Urban VI., 44I, 466, 469, 496, 497

Urbino, $307,427,438,576,656,673$, 682,738

Usury, 240, 298, 438, 439, $45^{8}$

Venetian rule in the East 627,628 ,

Venice, 17, 23, 30, 31, 4I, 49, 56, 59, 84,85 et seq., I06, I I 8 , I20, I28, I 40, I 46, I48, I 57, I 8 I et seq., 203 , $230,236,243,248,255,26$ I et seq., $272,322,346,353,354,357,362$, $364,367,369$ et seq.. $386,387,4 \mathrm{I} 3$, $414,423,431,463,468,47 \mathrm{I}, 473$, $474,477,486,493,505,508,509$, 5IO, 5II, 5I2, 5I3, 5I4, 5I5, 5 I6, $517,518,519,520,521$ et seq., 549 , $552,560,577,578,583,589,592$, 593, 596, 608, 609, 611, 613, 622, et seq.; 648, 649, 651, 657, 672, 674, 675,676 et seq., 682, 684, 685, 689, 692, 695, 697, 698, 699, 701, 704, 708 et seq., 724, 726, 733, 752, 759, $760,762,763,764,765,766,767$, $769,770,774,780,781,787$ et seq., $791,792,796,798$

Vercelli, I 26, I 43, I 45, I 57, 2 I0, 2 I I, $249,25 \mathrm{I}, 252,349,355,356,36 \mathrm{I}$

Verona, I $8,23,56,66$, I I0, I I8, I I9, I 26 , I 30, I 40, I 45, I 47, I 52, I 53 , I6I, 162, I65, I66, I75, I77, 206, 
$217,232,234,258,314,321,322$, $349,351,355,356,361,362,413$, $420,458,463,468,47 \mathrm{I}, 5 \mathrm{II}, 528$, $529,530,540,542,679,680,685$, $709,710,752,756$

Vicenza, 56, I I 8, I 40, I 45, I 47, I 53 , I62, I65, I 66, I 76, I 77, I 79, 2 I I, $217,230,257,258,259,355,47 \mathrm{I}$, $528,529,530,710$

Vico, 339, 340, 40I, 44I, 45I, 479, 768,796

Victor Emmanuel, 775 et seq., $79^{2}$

Villages, government in, I66, 167

Vinci, Leonardo da, 727, 743, 756, 757

Visconti, the House of, $165,230,233$, 249, 250, 305, 308, 309, 3I 3, 3I9, $32 \mathrm{I}, 322,325,326,327,329,330$, $345,350,35 \mathrm{I}, 353,359,360,36 \mathrm{I}$, $362,363,368,370,400,402,404$, $410,416,426,427,429,432,437$, 470. 484, 486, 487, 502 et seq., 5 I 3

Visconti, Azzo, 3I4, 35I, 352, 354, 409,502

Visconti, Bianca 508 ,

Visconti, Bernabo, 328, 329, 357, 358, $38 \mathrm{I}, 390,400,40 \mathrm{I}, 43 \mathrm{I}, 436,438$, $44 \mathrm{I}, 489,490,502,503$

Visconti, Filippo Maria, 47 I, 472, 473, $477,480,481,492,493,505,506$, $509,510,535,536,537,538,539$, $540,54 \mathrm{I}, 542,547,55 \mathrm{O}, 55 \mathrm{I}, 553$, $554,588,589,592,593,598,603$, $604,605,608,65 \mathrm{I}, 678,739$

Visconti, Gabriello Maria, 505, 557 , $558,582,588$

Visconti, Galeazzo, 252, 254 , 3 I I, 349, $350,35 \mathrm{I}, 355,357,36 \mathrm{I}, 368,400$, $409,4 \mathrm{II}, 432,433,502,5 \mathrm{C}_{3}$
Visconti, Gian. Galeazzo, 470, $47 \mathrm{I}$, $473,474,503-505,506,528,529$, $550,555,556,557,575,576,577$, $578,579,580,581,582,587,609$, $610,622,651,661,738$

Visconti, Gian Maria, 505, 506

Visconti, Giovanni, 319, 322, 35 I, 356, $357,368,387,502$

Visconti, Giovanni d'Oleggio, 356, 357 $396,427,428,435$

Visconti, Lodrisio, 35 I, $355,484,485$, 487

Visconti, Luchino, 356, 396, 4I 7, 502

Visconti, Marco, 351, 352, 383

Visconti, Matteo, 233, 25I, 252, 254, $262,274,307,349,350,351,357$, 502

Visconti, Otto, 222, 249, 250, 25 I-254, 348,502

Vitelleschi, Cardinal, 479, 500, 605

Viterbo, I I6, I69, 205, 220, 223, 226, 276, 319, 339, 438, 474, 497, 498, 499

Vittorino da Feltro, 5 I 5, 544, 740

Volterra, 56, 1 38, 167, 198, 2 I 5, 276, $278,282,312,324,391,396,399$, $405,419,422,430,435,590,59 \mathrm{I}$, $593,608,653,730$

Wenceslaus, Emperor, 330, 467, 47 I, $480,504,578$

Werner, Duke, 318, 396, 484, 485

White Guelphs, 287 et seq., 367,406

Witchcraft, 744,745

Women, condition of, 452 et seq., 74I, $742,747,793,794,795,796$

Zara, 89, I 84, I 85, I9 I, 375, 379, 380

THE END 
- 


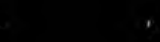




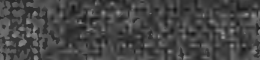

\section{(axis}

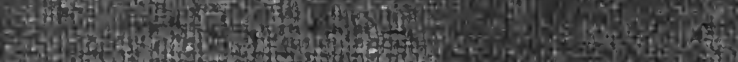

if

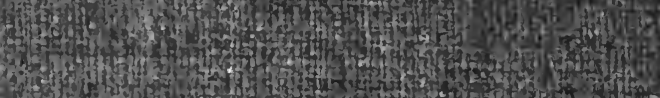

He $\mathrm{m}$ (l

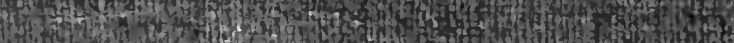

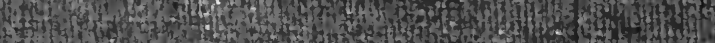

ing

4. 48 is

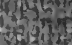

(3)

H.t.

14.

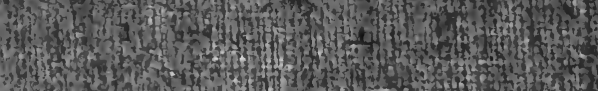

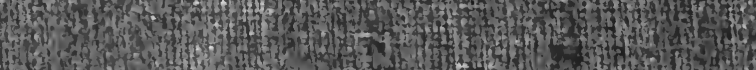

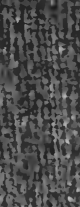

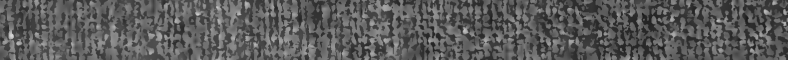

1.

IIt)

13 int

(19.

(1)

35 (5)

buth

stition

S)

With

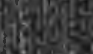

tion

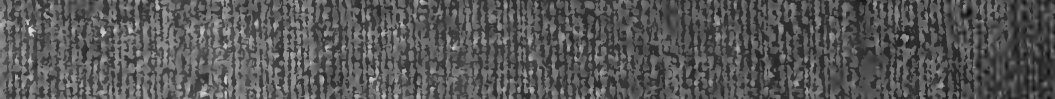

Hof

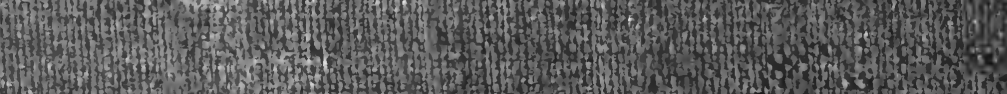

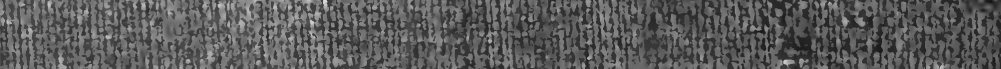
H) Why

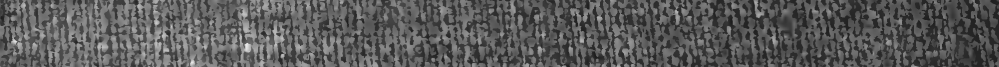
8.

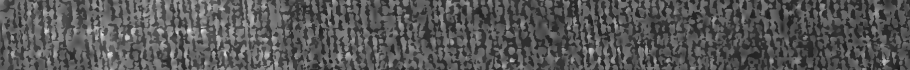
14th

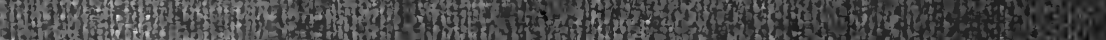

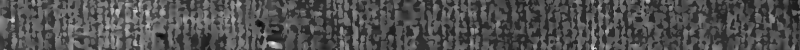
(it)

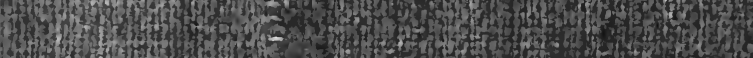
bing 